\title{
De la Revolución Productiva a la Crisis de la Merluza
}

El conflicto social en la industria pesquera marplatense

Años 1989 - 2001 


\title{
Propuesta para optar por el título de Doctor en Historia
}

\author{
Postulante:
}

\author{
Lic. Guillermo José Colombo
}

Director:

Dr. Aníbal Viguera

Doctorando en Historia

Facultad de Humanidades y Ciencias de la Educación

Universidad Nacional de La Plata

Febrero de 2014 
"Se han dado situaciones inéditas ... increíbles. Por caso, que se acabara la merluza" Palabras del ex presidente Fernando De la Rúa durante el programa televisivo Susana Giménez, 2001. 


$$
6
$$




\section{Índice}

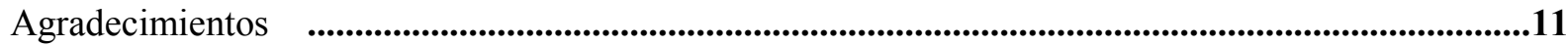

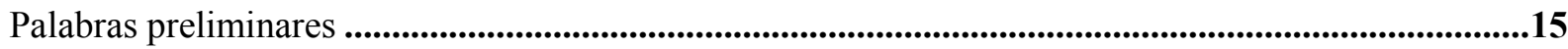

Introducción

\section{CAPITULO I}

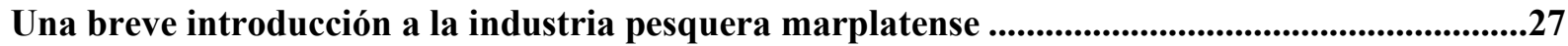

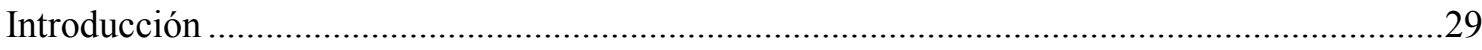

Conceptos primarios y especificidades de la flota pesquera .....................................................31

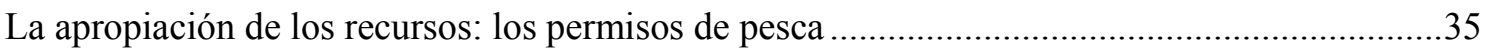

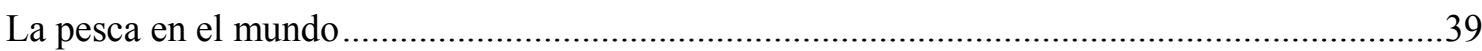

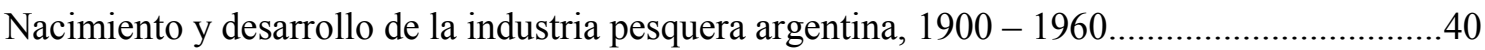

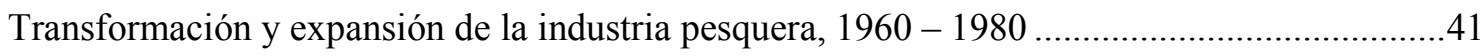

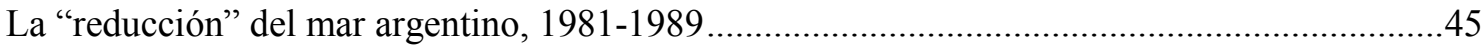

La "larga década" del '90: crisis, quiebras, reestructuración, récord de exportaciones,

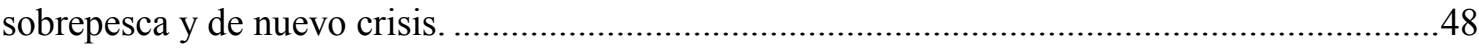

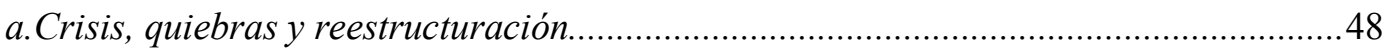

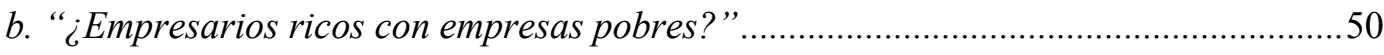

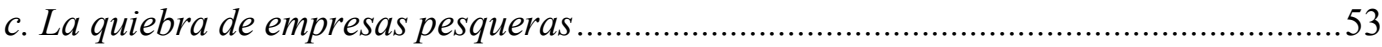

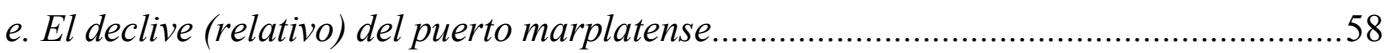

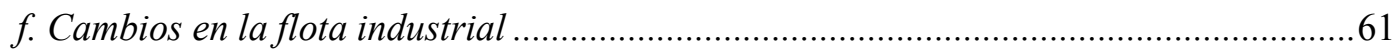

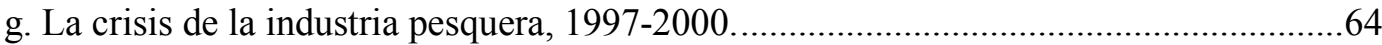

g. 1. El incremento del esfuerzo pesquero ............................................................64

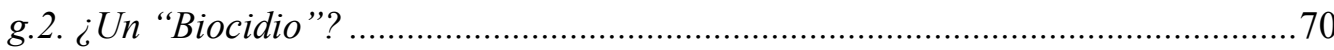

De la "Liga Pesquera" a los "Pulpos de la Pesca" .................................................................72

\section{CAPÍTULO II}

La larga década del '90: la trama política de la política pesquera .............................................81

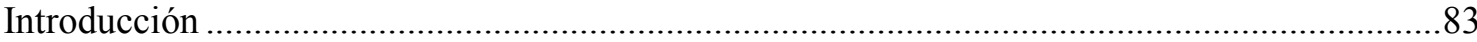

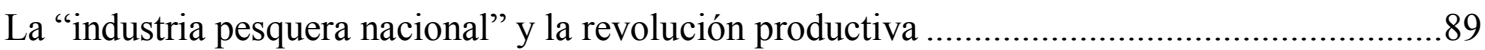

Una ley para la industria pesquera (I). Caída del radicalismo y victoria del FREJUPO..............92

La batalla por la subsecretaría: la derrota de "la industria pesquera nacional" ...........................96

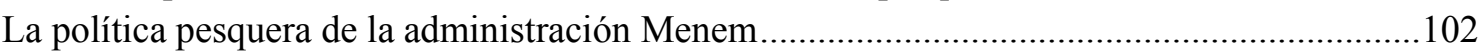

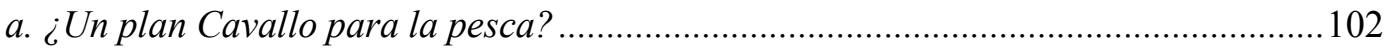

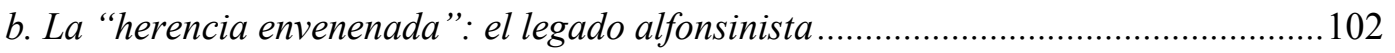

c. "Donde manda Canciller, no gobierna Subsecretario": la definición de las políticas

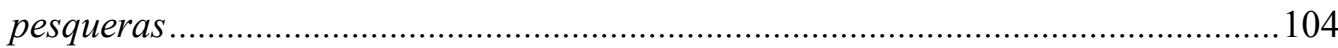

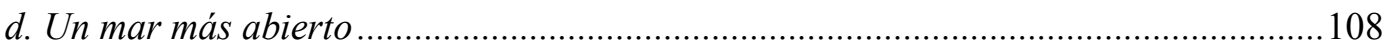

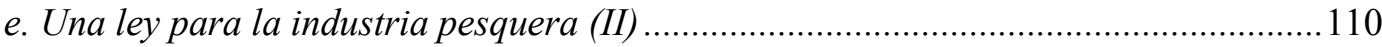

f. "El desafio de crecer": La pesca en tiempos de convertibilidad................................... 115

g. La desregulación (I): el cierre del Mercado Concentrador ........................................118 
h. La desregulación (II): “Barajar y dar de nuevo” ................................................... 122

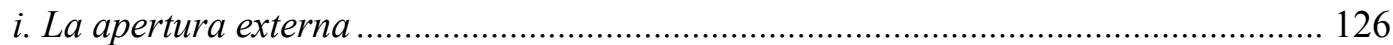

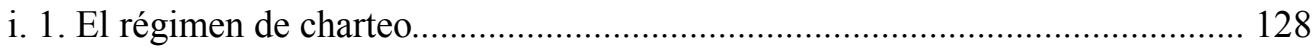

i.2. El Acuerdo con la Comunidad Económica Europea......................................... 133

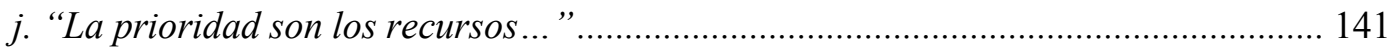

k. "Hasta que nos falló el recurso... ”: la crisis de la industria pesquera...................... 146

l. La sanción de la ley Federal de Pesca ..................................................................... 149

m. El manejo de la crisis y la disputa "fresqueros" vs. "congeladores"....................... 154

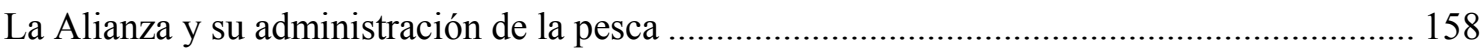

\section{CAPÍTULO III}

\section{Proceso de trabajo, relaciones salariales y conflictividad laboral en la industria pesquera}

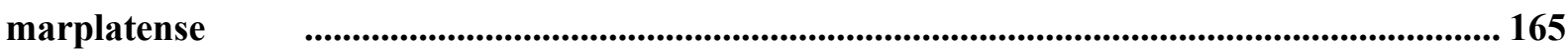

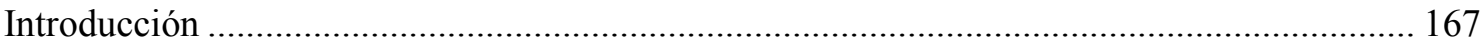

El proceso de trabajo en la actividad pesquera.................................................................. 170

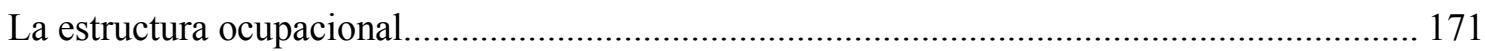

El proceso de trabajo en las plantas de fileteado............................................................... 172

"A las sombras de la noche, como si nada hubiera pasado": las plantas clandestinas............. 177

Alquimistas del trabajo: la transformación del obrero en empresario..................................... 181

Las “cooperativas” para el procesado de pescado en Mar del Plata.......................................... 184

Trabajar de fileter@.......................................................................................................... 194

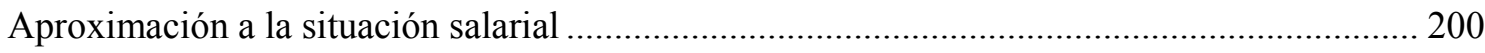

Aproximación a la conflictividad en los lugares de trabajo ................................................. 204

\section{CAPÍTULO IV}

EI SOIP, el liderazgo de Abdul Saravia y las transformaciones en la industria del pescado ..... 213

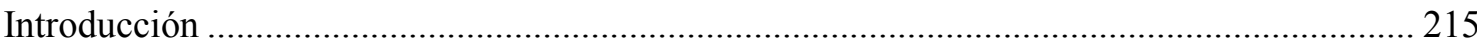

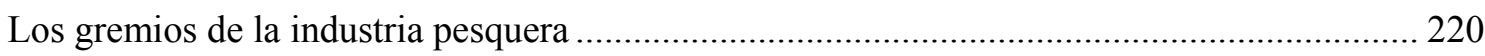

El Sindicato Obrero de la Industria del Pescado (SOIP) .................................................... 221

La estructura gremial del SOIP: aspectos formales e informales............................................ 224

La firma del Convenio Colectivo de Trabajo (1975) ............................................................ 226

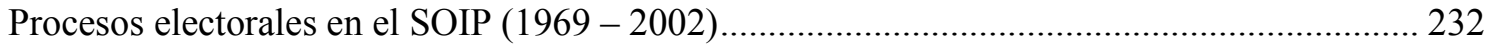

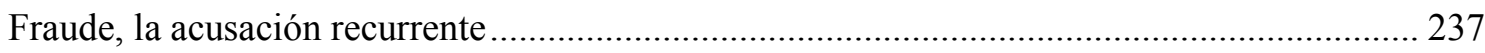

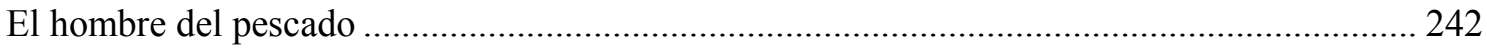

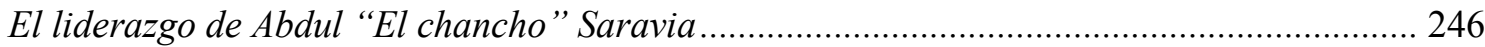

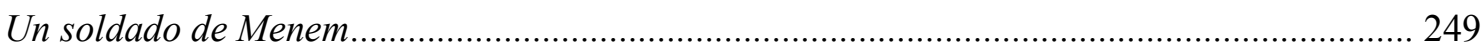

"Por defender a los trabajadores... "...................................................................................... 254

La CGT regional bajo la conducción de Saravia.................................................................. 256

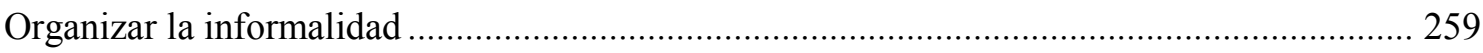

-Movimiento Obrero, Cultura y Universidad............................................................... 260

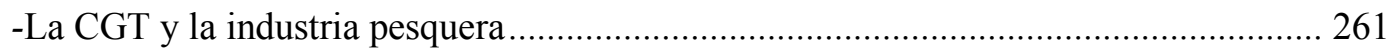

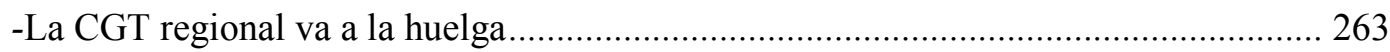

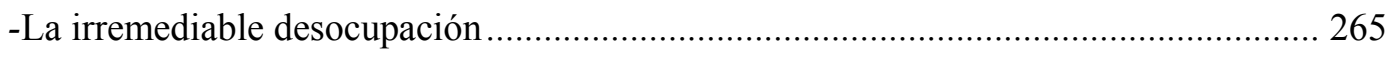




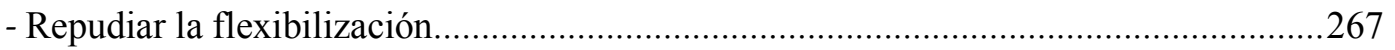

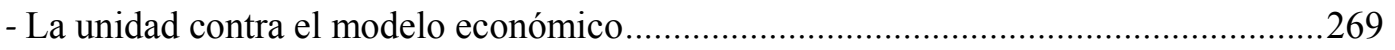

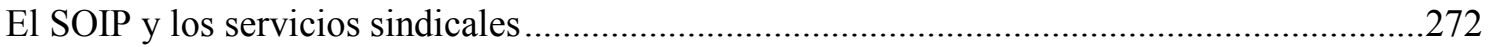

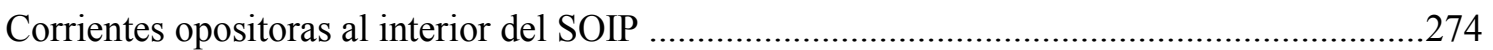

La Lista Celeste - Unión Obrera del Pescado.........................................................................277

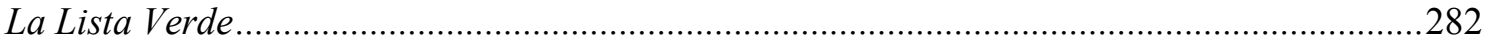

Del peronismo al trotskismo: la victoria de la Celeste ................................................................28

Sindicatos paralelos, una experiencia malograda..........................................................287

\section{CAPÍTULO V}

La dinámica de la conflictividad en la industria pesquera marplatense (1989-1996)..................289

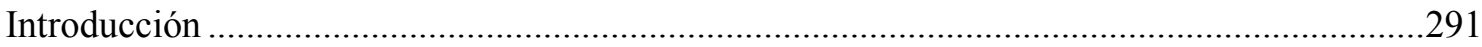

La conflictividad social en la pesca (I): los inicios del menemismo (1989-1991)....................296

Del final del alfonsinismo al gobierno de Menem ..................................................................296

Conflictos por incumplimientos en el pago de las cuotas sindicales y obra social ....................300

Conflictos por aumentos salariales y mejoras en las condiciones de trabajo ............................301

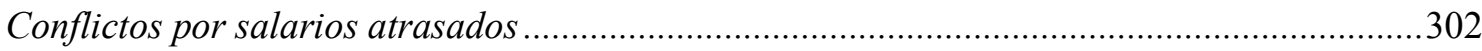

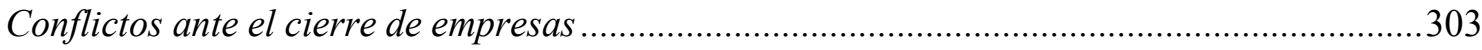

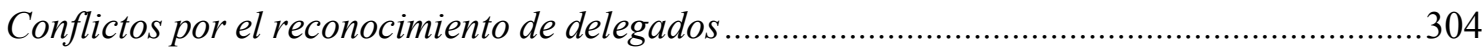

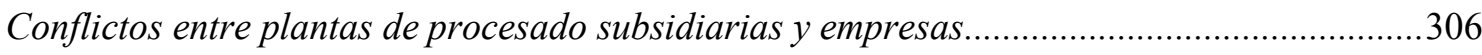

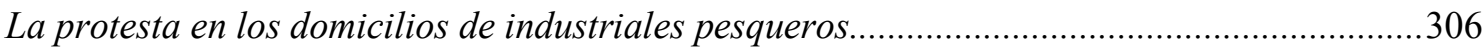

Conflictos por incluir a los gremios en la definición de las politicas pesqueras ........................307

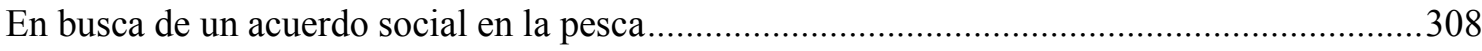

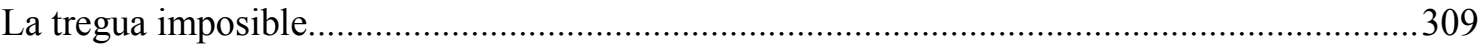

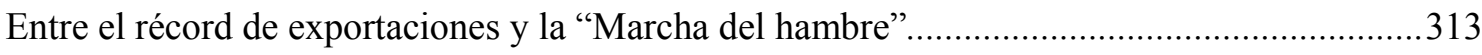

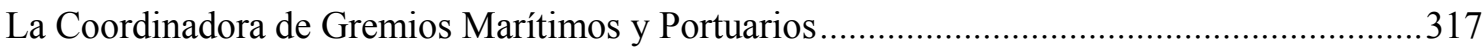

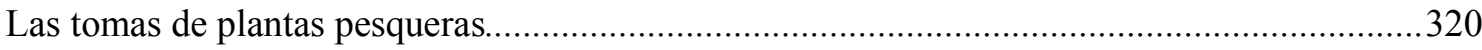

La conflictividad social en la pesca (II): los años de estabilidad (1992-1996)..........................327

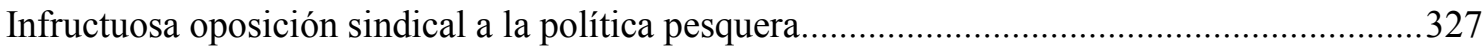

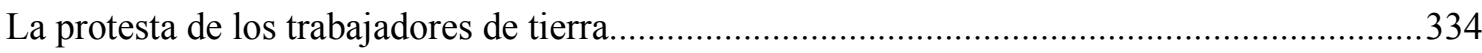

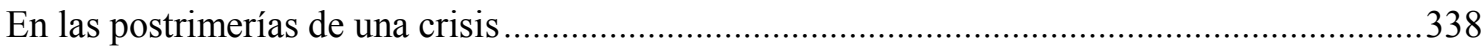

\section{CAPÍTULO VI}

La conflictividad social en la pesca (III): la "crisis de la merluza" (1997-2001)............................341

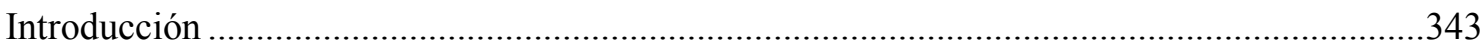

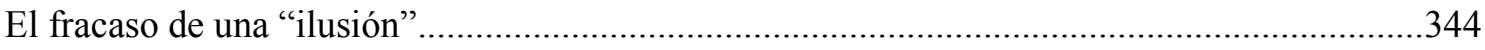

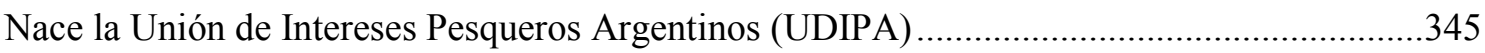

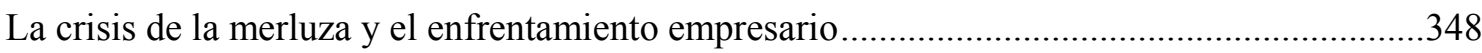

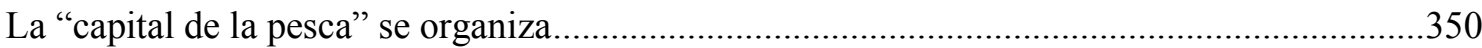

El surgimiento del Consejo de Empresarios Pesqueros Argentinos (CEPA)..............................354

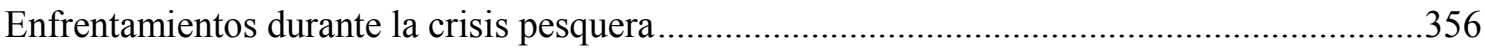

Trabajadores cooperativizados y desocupados en el escenario de la protesta............................359 
El movimiento obrero organizado en los comienzos de la crisis ........................................ 363

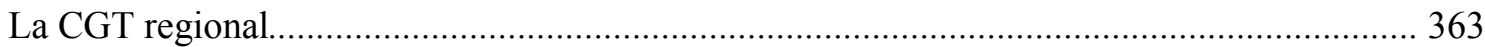

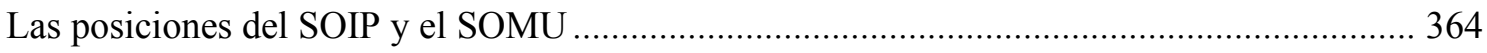

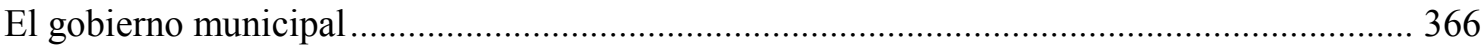

La ley de pesca y la construcción de una "convergencia" marplatense ................................... 367

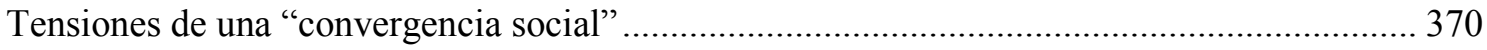

"No los une el amor...”. Los orígenes de la Multisectorial ................................................. 372

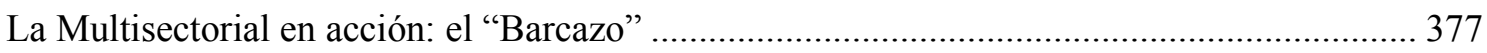

Conflictos al interior de la Multisectorial............................................................................. 382

El proyecto Mar del Plata 2000 o "De cómo permanecer juntos a pesar de todo" ................... 386

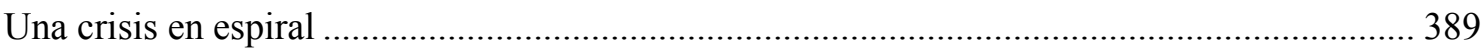

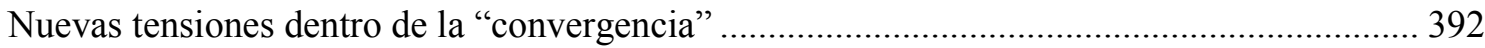

Recuperación de los stocks de merluza, nuevos vaivenes en la disputa fresqueros vs.

congeladores y movimientos en la escena gremial.............................................................. 394

\section{CAPITULO VII}

Las formas de la conflictividad. El "estallido" y la toma del SOIP............................................ 403

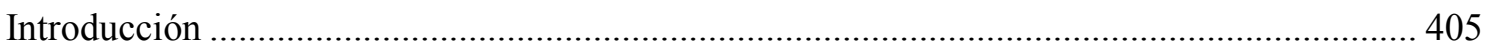

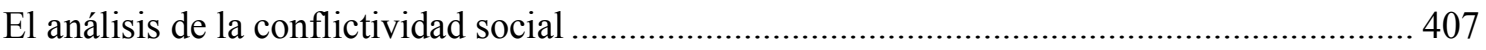

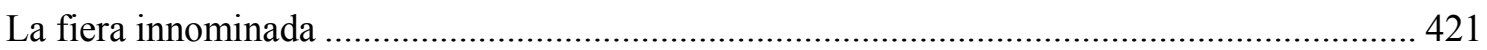

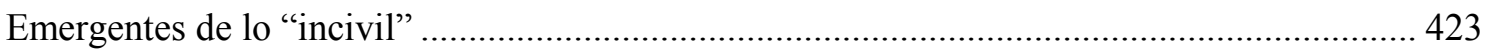

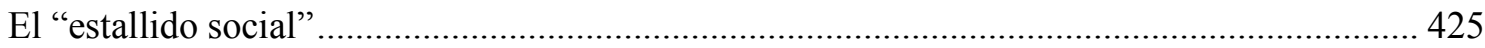

Imágenes construidas. La visión de los medios de difusión.................................................. 432

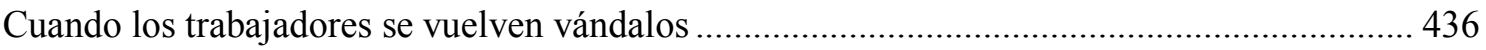

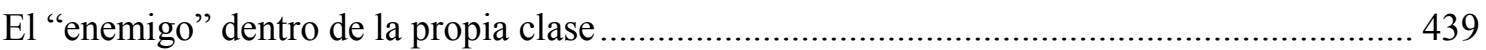

La construcción del enemigo: "los burócratas" "......................................................... 440

La toma y ocupación de la sede sindical ..................................................................... 443

CONCLUSIONES ..................................................................................................................................... 445

Anexo I

Aclaraciones metodológicas sobre los criterios de la base de datos............................................. 455

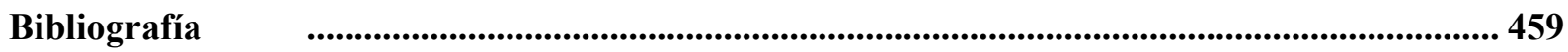

Fuentes 


\section{Agradecimientos}

Desde que empecé a trabajar con y desde las ciencias sociales fueron muchas las personas que de uno u otro modo influyeron en mí y, por lo tanto, tienen una proyección en estas páginas. Aunque, hay que decirlo una vez más, tal influjo se vincula necesariamente con alguna buena idea que aquí tal vez logré encontrarse, eximiéndoles de los posibles errores que son exclusiva responsabilidad del autor. Entre aquellas personas "influyentes" quiero destacar centralmente a los amigos y amigas con los que descubrimos y luego fuimos compartiendo, el devenir de nuestra carrera académica. Trayecto en el que aún nos seguimos apoyando en algunos casos, y en otros ya no, pero distancias actuales no borran el valor de los procesos compartidos. Silvana Ferreyra, Antonio Galarza, Gustavo Contreras, Maximiliano Camarda, Mara Pettiti, Nora Bustos, María Eugenia Alemano, Alejandro Morea y todos y todas con 1@s que transitamos dicho camino que, en la mayoría de los casos, coincidió con la militancia en la Agrupación 20 de Diciembre. Ellos y ellas fueron grandes e indispensables compañer@s. Y en un sentido más general agradezco también a todos y a todas las que atravesaron conmigo los años de militancia universitaria. Experiencia que sin duda me marcó como estudiante y como persona.

Con otros amigos y amigas, en distintas etapas, compartimos diferentes procesos de nuestras vidas. Algunos de ellos en muchos momentos tuvieron que escuchar que relegaba mi participación en algún proyecto "por estar haciendo la tesis", demorando así plazos estipulados de entrega o reduciendo mí aporte a colaboraciones esporádicas en proyectos siempre interesantes. A pesar de ello, con Cristián Serio (y con todos los amigos y amigas que forman parte de SNS Comunicación) pudimos finalizar dos documentales y tal vez, podamos ahora sí, dedicarnos con más énfasis a esa linda actividad.

También tengo que agradecer a los que siempre preguntaron por el estado del proyecto, por los avances y hasta se entusiasmaron con alguna de las historias que surgían. Con ellos renové la confianza todas las veces en que flaqueó, pude sincerar algunos dolores en los momentos tristes y compartir siempre las alegrías. Entre ellos Federico Ávalos, Rodrigo Peyrel, Juan Pablo Bottiglieri, Fernando Vissani, Federico Mastronardi y muchos más que no nombro para no hacer aún más extensas estas páginas.

Por otra parte, Gladys, Tobías, Mariana, Martín, Santiago, Francisco, Liliana e Irma son los integrantes de mi familia a quienes, por ganas, derecho y obligación, tengo que agradecer el cariño de todos los días. Cariño que siento aún más en estas épocas de vivir a más de 400 kilómetros de su compañía.

En varios años transcurridos de carrera académica fueron much@s los docentes e investigador@s que me enseñaron a pensar mejore investigar con mayor profundidad. Seguramente cometa omisiones groseras pero quisiera nombrar a aquellos que recuerdo especialmente. Aníbal Viguera, quien dirigió esta tesis, me recibió en La Plata cuando comencé a cursar el posgrado haciendo más amigable mi llegada. José Mateo, fundador del GESMar, equipo de investigación en el que me incorporé apenas comenzado mi camino en la investigación, fue un pilar para avanzar con mayor soltura, quitando rigidez y severidad a la labor investigativa, demostrando que sistematicidad y seriedad no necesariamente deben ser el vehículo de una aburrida formalidad. En el Doctorado en Historia en la FAHCE pude conocer y renovar los 
aprendizajes y saberes que portaba, interactuando con much@s docentes de distintas disciplinas. A tod@s ell@s debo también un reconocimiento. Especialmente destaco las clases, las charlas y los asados compartidos con Germán Soprano y Pablo Ghigliani.Así como la confianza de Ana Castellani para invitarme a colaborar en un libro bajo su dirección. De mi formación de grado en la UNMdP tengo un recuerdo muy grato de las clases de Julio César Melón y de Norberto Álvarez. Ellos indirectamente tienen que ver con mi gusto por el conocimiento histórico y la lectura de teoría social, así como con el hecho de que la investigación fuera una opción laboral. Luego, trabajando en la Facultad de Sociología de la UNMDP, conocí a Eduardo Chávez Molina, Astor Massetti y Victoria Salvia. Todos ellos hicieron que la labor allí fuera, y lo siga siendo, llevadera, grata y siempre dejara tiempo para dedicarme a escribir las páginas que hoy se presentan como proyecto de tesis doctoral. Particularmente con Astor Massetti discutí varias veces informalmente algunas de las ideas de esta tesis. Discusiones que generalmente resultaron ricas para plantear mejor algunos problemas y dar valor a los hallazgos.

Los años de cursada en la ciudad de La Plata fueron buenos momentos, en gran medida por ser compartidos con compañeros que pronto fueron amigos: Julieta Haydar, Paula Dinorah, Federico Vocos, Alejandro Belkin, Eleonora Bretal, Laura Rodríguez, Belén Zapata, Jorge Tripiana, Cora Díaz. Y sobre todo Felipe Venero que me abrió su casa y, siempre con un vino, se dispuso a discutir de nuestras emociones y opciones vitales, de historia y de política.

A su vez, fue central no sólo en la directa posibilidad de poder estudiar en la ciudad de La Plata, sino también en que esa estadía fuese divertida y amable, la predisposición y el cobijo que me brindaron en Villa Elisa Enrique Cortéz, Ana Carlón, Ramiro Cortéz y Lucía Cortez.

No quiero dejar de mencionar a dos personas que hoy ya no están por acá y andan vagando vaya a saber por dónde, pero que en diferentes momentos de mi vida y por distintas circunstancias fueron imprescindibles en mi manera de entender el mundo y relacionarme con él. Eduardo "Maro" Pradas logró transmitirme la idea de que estudiar a los trabajadores de la industria del pescado era un problema de investigación que, por muchos motivos, debía ser analizado en profundidad. Y también, por varios años, me contagió la pasión por hacerlo, aunque no su inteligencia e intuición para resolver los problemas que se presentaban. Pero de eso no puedo culparlo. Más acá en el tiempo, Horacio Maurette me demostró el valor de una inteligencia irónica, incisiva, rockera. Y sobre todo me enseñó que en la batalla contra los poderes, los oligopolios y los mecanismos de manipulación, siempre la risa, la confianza en el trabajo bien hechoy el compromiso colectivo resultan imprescindibles para llegar a "mear en la sopa del rey".

El apoyo y cariño de Florencia Carlón -quien por muchos años fue mi compañera de vida-, fue de enorme importancia para llevar el final de mi carrera de grado, así como el desarrollo de la investigación. A veces en días de 10, 12 y más horas de lectura y escritura. Aquel tiempo, en gran medida por haberlo pasado juntos, fue el de una hermosa cotidianeidad, donde nunca faltó una pausa para la guitarra, el canto y la risa compartida. Además de la lectura mutua de nuestras producciones y el apoyo para enfrentar los laberintos y tragos amargos que a veces la academia impone. Entonces, por las horas compartidas, pero sobre todo por el amor y la alegría con que las transitamos, va un agradecimiento fundamental. 
En mi formación como investigador, pero también como persona, es invalorable el aporte de Agustín Nieto. Siendo muy pibes, pronto much@s aprendimos de él la importancia de apasionarnos con la causa abrazada en la militancia, en el trabajo, en la investigación. Así como también aprendimos a conocer, respetar y querer a los demás, sin que en ello medien relaciones de subordinación, ni dando lugar a que "disfraces" institucionales, posiciones ocupadas o presuntuosas jerarquías importen en las relaciones humanas. Todo eso acompañado con una capacidad que aún hoy me impresiona para pensar problemas y procesar teoría.

Un agradecimiento particular para Nicolás Dorzi, que con su paciencia y buen gusto, realizó el diseño que guarda la impresión final de este trabajo.

Debo enteramente la posibilidad de estudiar a la existencia de una Universidad pública y gratuita. Así como también la cursada de un posgrado a los sistemas de becas de la UNMdP y del CONICET. Mi agradecimiento entonces debe, necesariamente, ir dirigido al pueblo de mi país, particularmente a los y las que pelean diariamente no sólo para que instituciones como éstas existan, sino también para que puedan ser mejores y acrecentar su orientación popular.

Quiero reconocer tambiéna todas las personas que entrevisté para llevar a cabo este proyecto, quienes compartieron horas de su vida, exponiendo sus experiencias y formas de entender el mundo con un desconocido que llegaba siempre con demasiadas preguntas.

Por último, quiero agradecer a los trabajadores y trabajadoras de la industria pesquera marplatense. De los días de trabajo en el sindicato, de las visitas a las plantas pesqueras, de la participación en movilizaciones, de las conversaciones personales me llevo para siempre muchos saberes y una buena dosis de humildad.

Ciudad de Buenos Aires, febrero de 2014 


\section{Palabras preliminares}

Somos, los de mi generación -qué nacimos en la década del '80-, hijos de desaparecidos. No solamente aquellos que llevan esa situación a partir del hecho físico de la desaparición de sus padres. Nos referimos a un hecho social más global. Las huellas, las heridas, las marcas que han quedado de aquellas desapariciones, almuerzan en nuestra mesa, nos acompañan en los viajes, habitan nuestros silencios, piensan parte de nuestros problemas. Las llevamos, como quien dice, puestas. Y las "sentimos" ausencias en etapas formativas.

Por cierto, la última dictadura cívico-militar no solo "desapareció" cuerpos en virtud del proceso de reorganización nacional, también "desapareció" ideas, proyectos, modos de vinculación entre las personas, espacios para la producción de saberes. Muchas zonas de la vida nacional fueron afectadas y aún padecen de fracturas duraderas. Entre aquellos lugares está la Universidad pública, sujeta entonces a modificaciones de los planes de estudio, expulsión de estudiantes y profesores y, cuando todo eso no alcanzó, el cierre liso y llano de carreras.

En Mar del Plata corrieron esa suerte Psicología, Sociología, Antropología, Ciencias Políticas y Ciencias de la Educación. La primera pudo reabrirse en la década del '80. Sociología recién en el 2007 y apenas en el 2013 vio egresar a sus primeras estudiantes del nuevo ciclo. El resto aún permanecen cerradas. El correlato, más allá de todas las otras pérdidas y dolores profundos, fue la afectación de la investigación social.

No hace mucho que estamos comenzando a recomponer ciertas relaciones con el conocimiento de lo social. La ciudad en que nací padece aún de aquellas "desapariciones" epistemológicas, del robo de su historia, sobre todo de la reciente. En tal sentido, si esta exploración consigue formar parte del proceso de reconstrucción de la historia local, habrá cumplido uno de sus objetivos. Porque, en definitiva, de lo que se trata es de conocernos a nosotros mismos, mirar dónde estamos parados y de qué procesos venimos, para saber hacia dónde queremos ir. 


\section{Introducción}

"Un periodo de crisis puede ser un excelente mirador para testimoniar acerca de la fortaleza o las falencias de una estructura económica social. Algo de esto veremos analizando someramente los posibles movimientos y estrategias que puedan manifestarse en nuestro espacio para remontar la crisis"

Carlos Assadourian

"El Puerto sigue en pie de guerra", "Desocupados del Puerto tomaron delegación", "Inician paro de 72 horas en la Pesca", "Focos de violencia tras una manifestación en la comuna", "La jornada de ayer (fue), una de las más violentas registradas en los últimos tiempos en Mar del Plata”, "Estallido Social en el Puerto", "La violencia ahondó la preocupante situación pesquera". ${ }^{1}$ Hacia finales de la década del '90 y principios del nuevo milenio, títulos de portadas como éstas dejaron de ser algo excepcional en la prensa marplatense. Es que entonces el puerto de Mar del Plata y particularmente la pesca se vieron inmersos dentro de un escenario de creciente conflictividad social. Incluso, en algunas ocasiones, la violencia material surgió como modo de acción en el marco de la beligerancia de los sectores movilizados. El más destacado de ellos fue el ataque a cinco plantas pesqueras perpetrado durante una movilización de trabajadores y trabajadoras en el mes de junio del año 2000. Llamativamente, de este modo se cerraba una década de expansión inusitada de las capturas y exportaciones pesqueras. Entonces ¿cómo es que se incrementó la conflictividad social tras prácticamente una década de crecimiento fenomenal, el más importante en la historia de la industria pesquera argentina? ¿Cuáles eran los contenidos expresados en los episodios de conflicto? ¿Y quiénes los sujetos involucrados?...

Cuando empezamos esta investigación durante el año 2005, de la cual ahora presentamos los principales resultados, los estudios acerca de la protesta social en la Argentina reciente se encontraban en su apogeo. Pues las interpretaciones acerca del fenómeno de movilización social y el ciclo de protesta de finales de la etapa de la convertibilidad proliferaron tras las jornadas de diciembre de 2001. Más allá de la gran diversidad de interpretaciones, el sentido más o menos común -asumiendo que podemos hallar tal cosa-de los trabajosapuntaba a señalar que, tras las transformaciones estructurales producidas durante la década del '90, los argentinos atravesábamos un proceso de inflexión en los "sistemas" de acción colectiva, pasando de las formas más tradicionales, como las huelgas y otras acciones vinculadas al movimiento obrero, a la emergencia de nuevos repertorios de acción ligados a movimientos de presión local de carácter disperso junto con acciones espontáneas y semi organizadas de explosión social (Svampa y Pereyra, 2005). Así,un relato "optimista" siguió al "pesimismo" propio de la década del '90 respecto de la potencia y capacidad de la movilización colectiva y la lucha popular. Recordemos que tras el desmantelamiento del modelo de industrialización por sustitución de importaciones en manos de la política económica desplegada durante la últimadictadura cívico-militar y profundizado durante la "década menemista", el "pesimismo" emergió ante la necesidad de dar cuenta de un sujeto popular que entonces era más un pobre o un excluido que un trabajador. Esto llevó a dar cuenta de una situación de

${ }^{1}$ Diario La Capital (en adelante L.C.), 12/07/1997; Diario El Atlántico (en adelante E.A.), 16/10/1997; E.A., 03/01/1998; L.C., 14/06/2000; E.A., 29/06/2000, L.C., 29/06/2000. 
carencia, destacando la incapacidad como fuerza política y/o colectiva de tales sujetos. ${ }^{2}$ En aquel contexto, la noción casteleana de desafiliación parecía explicar de modo exitoso la pérdida de lazos colectivos y los mecanismos de integración social. Los sindicatos aparecieron como cómplices o impotentes ante políticas contrarias a "los intereses" de los trabajadores. Y el peronismo, antes expresión de la identidad obrera, ahora, en su variante "neoliberal", quedaba más o menos reducido a la estructura clientelar del Partido Justicialista. En tal contexto de enunciación se llegó a pronosticar el final de la política en las calles (Romero, 2000). Sin embargo, con posterioridad a diciembre de 2001, mes que expresó el pico más alto de conflictividad pero también de dinámica de movilización de la sociedad argentina, se produjo la mudanza de aquel "pesimismo" a un renovado "optimismo" acerca de la potencia de la movilización popular. Pasó a cuestionarsela noción de desafiliación precisamente porque, centrada en una pérdida, cerraba los espacios, procesos y mecanismos propicios para la re-afiliación. Se reinterpretaron entonces los soportes que favorecían la acción de nuevos sujetos. El marco general de las explicaciones estuvo dominado por la necesidad de repensar los procesos y mecanismos de activación de sujetos que, tras las transformaciones en el patrón de acumulación capitalista, asumían un carácter más complejo y diverso, complicando la "tradicional" imagen de trabajador. Las nuevas lecturas que pretendieron dar cuenta de la potencia de la acción colectiva contenciosa encontraron espacio dentro del marco general de descrédito de la categoría clase para pensar cualquier articulación social, así como de los planteos acerca del "fin del trabajo" y del "adiós al proletariado". ${ }^{3}$ En la Argentina donde tenía lugar un nuevo ciclo de movilización estábamos en presencia de sujetos heterogéneos (tal vez la multitud), con menos vínculos con las estructuras tradicionales que "sujetaban" a los sujetos, siendo así pasibles de comportarse de manera autónoma.De este modo, el estudio de objetos y procesos de movilización, donde se pudiera dar cuenta de aquello rápidamente, conquistó la literatura sobre conflictividad social, apareciendo interesantes (y otros no tanto) trabajos sobre las tomas de tierras, la inscripción territorial (barrial) de las clases populares, la formación del movimiento de desocupados y los cortes de calles, la ocupación de fábricas por sus propios trabajadores, las puebladas, los saqueos, los cacerolazos, las asambleas, etc. Así, mientras la clase obrera, antigua protagonista más o menos indiscutida de la conflictividad social, quedaba relegada como actor, sujetos heterogéneos (múltiples) aparecieron protagonizando "novedosos" movimientos sociales portadores de renovados instrumentos y formatos de acción colectiva. En particular tres tradiciones teóricas fueron las más utilizadas como insumos para pensar esos nuevos tiempos. La sociología norteamericana de la acción colectiva; la escuela europea de los nuevos movimientos sociales; y distintas variantes de un marxismo "abierto". Muchas veces recurriendo a mixturas entre teorías favoreciendo miradas más bien eclécticas. ${ }^{4}$

\footnotetext{
${ }^{2}$ Excede nuestros objetivos pero no podemos dejar de mencionar la discusión acerca de cómo definir a la creciente masa de desocupados que arrojaba la lógica de acumulación capitalista posterior a la crisis del petróleo. Fue entonces que comenzó a plantearse la existencia de una nueva lógica de la desocupación, que dada su consolidación "estructural", ya no respondía al funcionamiento del tradicional "ejército industrial de reserva", planteándose la hipótesis acerca de la función sistémica del notrabajo en la producción de productores residuales, excedentes, descartables, desperdiciados, superfluos. Se ensayaron entonces diferentes categorías para dar cuenta de tal situación como ejército supernumerario (Castel, 1997), desagregación social (Rosanvallon, 1995), subproletariado (Antunes, 2000) o desproletarización (Wacquant, 2007).

${ }^{3}$ Un buen estado del arte al respecto puede leerse en Elley y Nield (2010). Los autores presentan, particularmente para Inglaterra y Estados Unidos, de manera clara el recorrido que llevó del momento de auge de la historia social a mediados de siglo XX al florecer de una historia cultural desde la década del '80. Proceso que fue de la mano con el pasaje de la hegemonía estructuralista en sus diferentes variantes, hacia el surgimiento y proliferación de distintas críticas provenientes del posmodernismo.

${ }^{4}$ Mencionamos las características principales de estas interpretaciones en el capítulo V.
} 
La virtud de las nuevas teorías fue que comenzaron a analizarse las dinámicas confrontativas que quizás antes pasaban desapercibidas o no eran pasibles de interrogación por parte de los investigadores. Ello, en contextos en los que partidos y sindicatos mostraban debilidades en cuanto asu eficacia como estructuras de politización y movilización, por lo que nuevos espacios fueron identificados para dar cuenta de los procesos de politización de las clases populares. De este modo, se ensancharon las preguntas y el campo de observación de las ciencias sociales que durante la década del ' 80 y comienzos de la del '90 se habían mantenido preocupadas de manera predominante por la "democracia", sobre todo en su aspecto formal - institucional y la gobernabilidad.

Decía que cuando empezamos esta investigación éste era el marco de interpretación general, existiendo solamente algunas excepciones. La tesis según la cuala un cambio en el patrón de acumulación, a las reformas estructurales, a la desindustrialización ya la desproletarización le correspondió la emergencia de un novedoso sistema de acción colectiva característico de una transformación en el sujeto principal de la conflictividad, parecía haber llegado para quedarse. Nuestra posición, entonces, a pesar de compartir algunas de las tesis ensayadas, era un poco más cauta. Nos parecía que muchas interpretaciones fueron formalizadas "al calor de los hechos", afectadas -en el peor de los casos- por modas intelectuales, sin que sus afirmaciones más contundentes estuvieran sostenidas en investigaciones sistemáticas y evidencia empírica. En cierto modo, aquella fue una época fascinada por la novedad. De continuidades y rupturas, las últimas se imponían sobre las primeras. El año 1989 se presentó como una bisagra, una nueva era. Y recién, tras aquella sombra "menemista", se veían emerger nuevas luces.A nosotros nos parecía que existía una brecha en el relato entre el "pesimismo" y el "optimismo" tanto como falta de comprobación de algunas tesis que se aceptaban como válidas. En este sentido sabemos que toda investigación está guiada por una determinada imaginación política, cuanto menos incidiendo en lo que respecta al recorte en el objeto de estudio y a la forma de su abordaje. Y la nuestra nos llevaba a, antes de aceptar lo nuevo, poner en revisión algunos de los rasgos que se consideraban perimidos. En este sentido nos preguntábamos ¿fue tan evidente y extendido el llamado proceso de desindustrialización? ¿Afectó a todas las regiones productivas y ramas de la industria por igual? ¿Tenemos que aceptar la llamada tesis de la desproletarización? ¿Su enunciación no tendrá impregnada una visión del mundo que tal vez no compartamos? Asimismo, más allá de las interpretaciones generales y de los casos más conocidos de las grandes federaciones nacionales o capitalinas ¿no habrá otras experiencias sindicales que contribuyan a completar el panorama acerca de la relación sindicatos/menemismo durante la década del '90? ¿No será pues posible observar nuevos matices, descubrir caminos alternativos de aquella relación? ¿Los sindicatos "menemistas" fueron sujetos "pasivos" ante las reformas implementadas? ¿O, como sostenían algunos trabajos (por ejemplo Etchemendy y Palermo, 1998), jugaron algún papel en su implementación, tanto resistiendo, apoyando o concertando? Al mismo tiempo, ¿estuvieron ausentes como estructuras de movilización? Y en tal sentido ¿son tan rígidas e inamovibles las fronteras que separan a trabajadores ocupados de desocupados en la participación en hechos de conflictividad? ¿Una distancia infinita, quebrada, separa a ocupados de desocupados? ¿Ningún rastro quedaba de la clase, de los trabajadores, de los sindicatos en la conflictividad social? ¿Tan novedosos resultaron los "nuevos" repertorios de acción? En definitiva ¿cuán nueva era la "nueva era"? Entre las discusiones, problemas y narrativas que presentaban aquellos análisis y la recurrencia de la conflictividad en la industria pesquera se forjó nuestro objeto de estudio. Aquellos altos niveles de conflictividad con que se despedía la década del '90, nos parecía al mismo tiempo que precisaban ser explicados (o, al menos, investigados), podían constituir un buen indicador de las 
transformaciones en la estructura productiva. En nuestro caso, dentro de una rama industrial de la economía. $^{5}$

Nos interesamos por la movilización colectiva de los trabajadores y las trabajadoras del pescado en la década del '90, puesto que nos permitía abarcar tanto el período de la "pasividad" obrera y la "complicidad" sindical, como también los procesos de beligerancia posteriores. Además, en muchos casos, la historia de los obreros y obreras dibujó el tránsito de la ocupación a la desocupación. Con la salvedad de que en este último caso, muchos trabajadores y trabajadoras desocupad@s no perdieron su identidad como obrer@s de la industria pesquera. Siendo así, en una y otra condición, partícipes de la protesta. En tal caso, los cambios y continuidades no mostraban la constitución de "novedosos sujetos" sino la transformación en las condiciones en que se desplegó la protesta de unos sujetos que experimentaban un proceso de reestructuración capitalista. En este sentido, catalogar de viejos o nuevos poco colaboraba a la comprensión de la dinámica conflictual ¿Acaso las acciones desplegadas por este colectivo obrero no tenían también su legitimidad, novedad, radicalidad, politicidad y al mismo tiempo estaban ancladas en tradiciones preexistentes?¿No expresó el accionar sindical algún contenido que nos permita pensar procesos complejos que no se reducen a la pura novedad ni a lo estrictamente tradicional? ¿No será que ese pensamiento binario tal vez oculta más que aclara los fenómenos que se pretenden explicar? Porque, interprétesebajo la mirada que se quiera, la conflictividad en la industria sucedió. En los trece años que van de 1989 a 2001, caracterizados por un crecimiento vertiginoso de las capturas y exportaciones pesqueras, encontramos que, registrados por la prensa local, se produjeron 428 episodios de protesta. Siendo el año 2000 el que mayor cantidad de hechos registró, seguido por el año 1990. De ahí la necesidad de investigar acerca de ¿qué sujetos se movilizaron?, ¿por qué lo hicieron?, ¿a quiénes señalaron como enemigos?, ¿cuáles eran las demandas y horizontes?, ¿qué repertorios utilizaron?, ¿participaron los sindicatos y sus conducciones de los procesos de movilización?, ¿qué diferencias hubo entre ellos?, ¿se desarrollaron protestas por fuera de las conducciones gremiales? A su vez, ¿cómo se desenvolvió la conflictividad con el correr de la década? ¿Cuáles fueron sus ritmos y momentos? ¿Arrojó nuevo saldos organizativos?

Para comenzar a desandar esas cuestiones presentamos un recorrido que, de manera necesaria, se remonta a la filogénesis del proceso allá por finales de la década del '80 e inicios de la del '90. Pues es preciso aquí construir una narrativa acerca del proceso en que se desenvolvió el desarrollo pesquero. Aquellos fueron años durante los cuales, en gran medida, se moría un "modelo" imaginado para la pesca,

\footnotetext{
${ }^{5}$ Una industria que además ha sido históricamente descuidada por las ciencias sociales. Mar del Plata aparece siempre asociada a la trayectoria de una ciudad turística, constituyendo el gran balneario argentino (Pastoriza en Favero y Portela, 2005). Es decir, un espacio dedicado al ocio y la diversión. La contraparte refiere a los habitantes estables y a los trabajadores. En este lugar subalterno aparece la génesis de la industria pesquera y de una comunidad de pescadores. Porque, asimismo, el puerto es una ciudad dentro de otra ciudad mayor (Ibáñez, 1988). Y a la subalternización corriente del mundo de los trabajadores, la pesca le suma la de una actividad marginalizada por la propia mirada de la sociedad argentina. Quienes de algún modo u otro se vinculan con la pesca suelen decir que Argentina ha crecido "de espaldas al mar", ignorando lo que este espacio implica en términos de potencia productiva y de territorio geopolítico (Mateo, 2008). La propia génesis de la comunidad pesquera marplatense, origen de la pesca industrial en el país, remite a una historia de conflictos y desalojos de quienes eran considerados como los hacedores de una actividad desagradable a los ojos de las clases dominantes y de su visión de lo que debía ser una villa turística. De ahí la expulsión de los primeros pescadores de los puertos naturales en que venían realizando sus tareas, ubicados en zonas cercanas al centro comercial, hacia lo que entonces eran las afueras de la ciudad. Por todo, estudiar la conflictividad social en la industria pesquera posee entonces un plus que implica un esfuerzo por otorgar visibilidad a una actividad escasamente conocida en un país predominantemente agrícolo-ganadero.
} 
al tiempo que, en su deceso, otro comenzaba a parirse. ${ }^{6}$ Con el correr de la década, tras el quiebre de numerosas empresas y el "saneamiento" de la actividad, se asistirá al crecimiento inusitado de capturas y exportaciones pesqueras, a la transformación del perfil de los grupos empresarios vueltos hegemónicos, al incremento de la importancia de otros puertos del país que no eran el "tradicional" de Mar del Plata y el declive, relativo, de éste último, a la incorporación de nuevas tecnologías en la operatoria de la pesca, etc. Procesos que fueron favorecidos y alentados por las políticas implementadas bajo el gobierno de Menem. Asimismo, hacia el final de la década, lo que en la mirada gubernamental se interpretó bajo un fuerte optimismo, comenzará a hacer evidentes algunos de sus anversos más negativos. Pues los recursos pesquerosofrecían ya para 1996 niveles alarmantes que ponían a distintas especies al borde del colapso por sobre pesca. Desde allí el gobierno buscará implementar medidas para restringir la actividad de captura.Dedicamos el capítulo I a visualizar este proceso. En él buscamos demostrar cómo la industria pesquera marplatense, que ya era una actividad fuertemente extractiva y se orientaba de manera dominante hacia el mercado externo, tras un proceso de quiebras de empresas y reestructuración, produjo un cambio en el perfil del empresariado pesquero, que sin ser absoluto, consolidó como sector hegemónico a grupos empresarios integrados que, vía asociaciones con firmas extranjeras, accedieron a la compra de tecnología y, al mismo tiempo, incrementaron la integración vertical y horizontal de su intervención en el proceso productivo. Ello no implicó la muerte de un empresariado de carácter más "tradicional", pero si su relegación hacia una posición subordinada. El contexto fue el de una expansión pesquera sin antecedentes. No obstante, buena parte de esos éxitos se sustentaron, por un lado, en la sobre pesca de los recursos del mar, dando lugar a una crisis ambiental que llevó al límite de su explotación al principal recurso pesquero del mar argentino, la merluza hubbsi. Por otro lado, apelaron a la búsqueda de incrementar la explotación de los trabajadores haciendo caer convenios colectivos y propiciando mecanismos de tercerización de la fuerza de trabajo, desligándose las empresas del vínculo laboral con sus obreros. Asimismo, el crecimiento económico alcanzado durante la década, tanto en capturas como en desembarques y exportaciones, terminó -por las propias características en que se basó tal expansión-, en una de las crisis más fuertes que enfrentó la industria pesquera marplatense. Este constituyó el escenario fundamental para comprender la conflictividad que atravesó el sector hacia finales de la década del '90.

Por otra parte, la aplicación de políticas específicas para la pesca pensamos que no derivaron de una construcción pretérita sustentada por una coalición de fuerzas, sino que fueron implementándose como resultado de una interacción política entre distintos actores, signada por la orientación general del proceso de acumulación capitalista a escala nacional y su inserción mundial. Por eso procuramos analizar el proceso político que dio lugar a la implementación de políticas pesqueras, destacando la interacción entre distintos actores sociales (empresarios, trabajadores y Estado), vínculos que en algunos momentos dieron lugar a cruentas batallas por imponer determinadas medidas o rechazar otras. Y si bien nuestro interés está centrado en la dinámica de la movilización en la rama, para comprender ese proceso de manera más acabada resulta central el estudio de los vínculos entre empresarios, Estado y movimiento obrero, ubicándolo como un espacio fundamental para pensar la implementación de políticas -pesqueras

\footnotetext{
${ }^{6}$ El entrecomillado en la categoría "modelo" busca matizar la fuerza que la categoría tiene en sí misma, así como agregar porosidad a las fronteras que dibuja. Es que el despliegue de un conjunto de políticas implementadas para la pesca, a nuestro criterio, no aconteció como una estructura pensada de antemano e impuesta tras una planificación pre-construida de parte de una coaliciónya conformada. No obstante, esas políticas estuvieron signadas por un rumbo y una orientación más o menosgeneral de la economía argentina que permiten asignarle cierta unidad. Y en la medida en que se fueron sucediendo, dieron forma a un "modelo" de desarrollo pesquero.
} 
en nuestro caso-. En este sentido, no está de más aclarar que el Estadono opera como un actor plenamente "separado" de las clases sociales, sino más bien constituye (en sus diversas agencias) un terreno de disputa desde el cual se ocupan posiciones que luego permiten formar parte del proceso de formulación de políticas que orientan la dirección, en este caso, del desarrollo pesquero en uno u otro sentido. Pensamos que un proceso de acumulación lejos está de definirse simplemente por la lógica de la competencia económica. Pretendemos demostrar aquí que el "modelo" pesquero finalmente implementado se desplegó sobre la base de la profundización de tendencias previas y, al mismo tiempo, de la derrota de un "modelo" imaginado por una coalición de fuerzas que se fue constituyendo hacia finales de la década del '90 y que, al menos en sus intenciones, buscaba un desarrollo orientado a la agregación de valor de los productos exportados y una mayor vinculación con el mercado interno. Esa derrota no fue total, pero si recibió un fuerte espaldarazo inicial desde la primera designación de funcionarios del área pesca tras el ascenso de Menem al poder. Al contrario de las esperanzas de algunos, poco a poco la política pesquera orientaba las posibilidades de desarrollo en un sentido que profundizó la vocación extractiva, favoreció la consolidación de grupos empresarios que lograban una vinculación más contundente con capitales extranjeros y el mercado mundial, al tiempo que un dominio sobre los procesos productivos de la industria. Aún así, no hubo derrotas totales, ya que si bien la orientación general de la política pesquera favorecía la consolidación de determinados sectores, no consiguió aniquilar otros formatos empresariales más "tradicionales", aunque si los obligó a aceptar las condiciones que imponía el "modelo". Con todo, en gran medida fueron estos sectores, junto con los trabajadores y trabajadoras, quienes protagonizaron una parte importante de la conflictividad de finales de la década, procurando garantizar su supervivencia promoviendo cambios en la política pesquera. De todos modos, hay que señalar que dentro de aquellos sectores "derrotados", unos fueron más derrotados que otros. Si las políticas pesqueras garantizaban cierta posibilidad de negocios para los empresarios, se imponían con mayor dureza sobre las condiciones laborales de los trabajadores y trabajadoras del sector considerados de conjunto. Este es el proceso que buscamos reconstruir en el capítulo II.

A su vez, el despliegue de políticas para la pesca junto a la orientación general que asumió el gobierno en la política económica, produjeron transformaciones en las condiciones laborales de los trabajadores y las trabajadoras de la industria pesquera. Como señalamos, se trata de un contexto de expansión de la pesca pero sustentado, entre otras características, en la precarización de la situación laboral de la clase obrera del sector a partir de la implementación de un conjunto de medidas que apuntaron a disminuir los costos del trabajo. Si bien son diversos los procesos de trabajo que afectan a la pesca, con una división especial entre aquellos que laboran sobre los buques en las tareas de marinería y quiénes lo hacen en las plantas de procesado, en este trabajo nos abocamos fundamentalmente a la situación de estos últimos, y particularmente los y las fileter@s representados por el SOIP. Por ello, en el capítulo III, presentamos las condiciones socio-laborales en que se desempeñaron las obreras y obreros de la industria del pescado. Pues serán est@s parte fundamental de la dinámica conflictual de la década. Avanzando primero en la descripción y conceptualización del proceso de trabajo realizado, dedicamos una parte importante del capítulo a presentar la forma particular que adquirió el proceso de flexibilización laboral producido de hecho en la actividad, principalmente a partir de la creación de cooperativas de trabajo y el funcionamiento de plantas clandestinas. Además, dado que los y las fileter@s constituyen el sujeto principal de nuestra interrogación, agregamos apartados en función de conocer las especificidades del tipo de trabajador/a que se constituye, presentando información acerca de los niveles salariales, las transformaciones en la consideración del "ser filetero" y la estructura ocupacional del sector. Por último, 
en otro apartado nos centramos en la conflictividad surgida al interior de los lugares de trabajo como modo de aproximarnos a los conflictos recurrentes entre el capital y el trabajo.

Con todo, y antes de presentar el análisis de la conflictividad propiamente dicha, resulta de interés conocer la situación del Sindicato Obrero de la Industria del Pescado. Entonces, si pasamos al plano de las relaciones políticas y organizacionales, podemos señalar que el SOIP es el sindicato que agrupa a los trabajadores de la industria del pescado. Como gremio cuenta con una rica tradición de combatividad y militancia sindical que dibuja una evolución desde su creación por militantes anarquistas, la posterior y tardía consolidación del peronismo, y la sorpresiva victoria en los comienzos de la década del 2000 de una corriente trotskista. Además, militantes de numerosas trayectorias político ideológicas formaron distintas agrupaciones gremiales y compitieron electoralmente. Todo eso, no obstante, no puede ocluir el sólido liderazgo protagonizado por el jefe de una corriente peronista, Abdul Saravia, quien permaneció en la conducción gremial desde 1969 hasta 1997, año de su fallecimiento. Proveniente de un "peronismo" ortodoxo, este dirigente tuvo que enfrentar el dilema de batallar entre la defensa de políticas que beneficiaran a sus representados y su lealtad al gobierno surgido en el año 1989, que transitaba un rumbo contrario a lo qué él imaginó para la pesca. En la resolución de ese dilema fueron importantes los recursos organizacionales disponibles, así como la tradición política y la manera en que concebía lo que dentro del peronismo se define como lealtad. Para adentrarnos en el universo gremial, indicaremos las principales características del convenio colectivo vigente, firmado en 1975, así como los límites y posibilidades que ofrecía el estatuto gremial para el gobierno sindical. Al mismo tiempo nos ocupamos, en el capítulo IV, de presentar la historia del SOIP, sus características como estructura formal e informal, las principales tradiciones político-ideológicas a las que dio cabida, las características del liderazgo de Abdul Saravia, las disputas electorales y, por último, el cambio de manos de la conducción gremial. Todo ello vinculándolo, como veremos, con la participación de los trabajadores y el gremio en la conflictividad social.

Finalmente, después de poner en conocimiento del lector todos los procesos mencionados, en los capítulos V, VI y VII, nos dedicamos a analizar la dinámica conflictual propiamente dicha en el transcurso de la "larga década del '90". 7 Para comprender su derrotero elaboramos una periodización en virtud del desarrollo de la protesta, vinculando la beligerancia en la pesca con los momentos particulares de la orientación del gobierno, la política económica y la conflictividad a nivel nacional. Así, la protesta desarrollada quedó dividida en tres momentos: 1) de 1989 a 1991, 2) de 1992 a 1996, 3) de 1997 a 2001. Cada período posee sus características particulares, en virtud de la lógica conflictual, los sujetos involucrados y el ritmo de la conflictividad. En el capítulo V nos ocupamos de los momentos 1 y 2 y dejamos, por su complejidad y riqueza, para el capítulo VI el análisis particular de lo que consideramos constituyó el ciclo más radicalizado de conflictividad. ${ }^{8}$ A su vez, en el capítulo VII y último, desplegamos

\footnotetext{
${ }^{7}$ Si la década del '90, como afirma Novaro (1999), nos invita a pensar en una "época", en un ciclo completo que comprende un origen, un desarrollo y una culminación, lo propio puede decirse de la pesca en estos años. Eric Hobsbawm estableció una periodización que le permitió hablar de un largo siglo XIX y un corto siglo XX. Parafraseándolo, podemos pensar para la pesca una periodización que comprenda "la larga década del '90". Porque el proceso analizado se inicia en 1989, con características heredades del período alfonsinista, y se proyecta hasta, al menos, el año 2001, tras lo cual sobrevino, luego de una sucesión de presidentes, la asunción de Eduardo Duhalde a la presidencia en el 2002 y el abandono de la convertibilidad, provocando transformaciones que dieron paso a una nueva etapa con características específicas.

${ }^{8}$ Muchos analistas de la beligerancia popular en la Argentina reciente utilizaron la categoría "ciclo de protesta", propuesta por Sydney Tarrow, la cual se refiere a "una fase de intensificación de los conflictos y la confrontación en el sistema social, que incluye una rápida difusión de la acción colectiva de los sectores más movilizados a los menos movilizados; un ritmo de innovación acelerado en las formas de confrontación; marcos nuevos o transformados para la acción colectiva; una combinación de participación organizada y no organizada; y unas secuencias de interacción intensificada entre disidentes y autoridades que
} 
la observación de las formas y contenidos de la beligerancia en la industria pesquera. A través de la información que nos brinda el procesamiento de una base de datos, buscamos elaborar una taxonomía sobre conflictividad en la pesca, mostrando los ritmos de la protesta, los sujetos y sus diferentes modos de participación, las formas que asumen las acciones y los repertorios utilizados y también los contenidos y horizontes de las demandas. Para la segunda parte de este último capítulo dejamos el examen de dos episodios centrales en la conflictividad como fueron el ataque a plantas pesqueras y la toma de la sede sindical del SOIP. Ambos ocurridos durante el mes de junio del año 2000.

Hasta allí llega entonces nuestra exploración, cerrando este último ciclo de conflictividad en el 2001.Son en definitiva los años bajo estudio los de la "hegemonía menemista" (Bonnet, 2008). Es decir, tiempos de transformaciones estructurales que completaron el alejamiento del patrón de acumulación de la industrialización sustitutiva para dar forma a un nuevo esquema denominado neoliberal o, rentísticofinanciero (Calcagno y Calcagno, 2003), de la valorización financiera (Basualdo, 2006; 2002) o con hegemonía del capital financiero (Peralta Ramos, 2006; Iñigo Carrera, 2009). El nuevo patrón de acumulación implicó una nueva forma estatal (Bonnet, 2008; Basualdo, 2006) y presentó como uno de sus rasgos principales la tendencia a la reducción de los costos laborales (Neffa, 1998). ${ }^{9}$ En paralelo, se produjo la consolidación de una forma de democracia "eficaz" en términos político-institucionales.

En cada capítulo en que lo consideramos necesario incluimos un estado del arte que nos permite insertar los problemas de investigación en marcos de consideración más generales. Así, en el capítulo uno se mencionan, por un lado, los estudios sobre la pesca en Argentina, destacando el lugar marginal que ésta actividad mantiene en la consideración de las ciencias sociales y, también, de la población en general. Se trata, además, de introducir la evolución de la rama dentro del debate en torno acerca de la tendencia del capitalismo argentino hacia la desindustrialización y si tal categoría resulta provechosa para pensar nuestro caso. En el capítulo dos se desarrollan las fortalezas y limitaciones de los estudios que consideraron la trama política (y también de aquellos que la descuidaron) para explicar las políticas pesqueras finalmente implementadas, enfatizando en la necesidad de estudiar el proceso político y las vinculaciones entre empresarios, Estado (y movimiento obrero) como elemento central. En el capítulo tres aludimos a las problemáticas destacadas por distintos analistas en relación a la importancia de estudiar los procesos de trabajo así como la conflictividad al interior del proceso productivo. En el capítulo cuatro nos adentramos en la problematización de la relación entre trabajadores/protesta/sindicatos/peronismo durante el período de "hegemonía menemista" que coincide con lo que definimos como la "larga década del "90". Por último, en el capítulo cinco presentamos las principales corrientes de interpretación sobre la protesta

pueden terminar en la reforma, la represión y, a veces, en una revolución” (Tarrow, 1997: 263 y 264). Iñigo Carrera, criticando los supuestos teóricos derivados de aquella categoría, en cuanto toma a "la gente" como sujeto (abstracto) formado por cualquier conjunto de individuos y no por clases sociales y, al mismo tiempo, no ofrece ninguna referencia sistemática a la importancia relativa de una u otras formas de lucha, propuso la noción de "ciclo de rebelión" (Iñigo Carrera, 2008; 2009). Esta categoría, a diferencia de la anterior, permite indicar una escala de lucha de la clase obrera que va desde el motín hasta la insurrección armada del pueblo. En nuestro caso, preferimos hablar de una tercera variante que definimos como "ciclo de conflictividad". Con la particularidad de aplicar la noción a lo sucedido al interior de una rama productiva, nos interesa indicar la intensificación de los conflictos, la difusión de acciones colectivas, una creciente radicalidad en los repertorios utilizados y la configuración de determinados sujetos y alianzas sociales en la propia acción. Nuestros sujetos sonlas personificaciones de relaciones sociales en la industria pesquera y no "la gente común", pero de ningún modo nos sentimos en condiciones de interpretar algo así como una escala de las luchas sociales, donde una forma superior continúe a una inferior.

${ }^{9} \mathrm{Se}$ actuó en dirección de flexibilizar la relación salarial, lo que resultaba coherente considerando la restricción monetaria impuesta por la fijación del tipo de cambio. Las políticas en lo que respecta a la relación salarial tuvieron el propósito de flexibilizar la utilización del tiempo de trabajo y reducir los costos de reclutamiento y despido, disminuir las cotizaciones de las empresas para jubilaciones y obras sociales y reducir los costos asociados con los accidentes de trabajo (Neffa, 1998) 
social en la Argentina de aquella década, procurando insertar nuestra propuesta dentro de la tradición de estudios que se ocuparon de los procesos de movilización social y acción colectiva.

Con todo, la conflictividad que padeció la industria pesquera, pensamos, por un lado se vincula a las consecuencias de la implementación del "modelo" de desarrollo pesquero finalmente desplegado. En ese sentido se produjeron las tomas de fábricas que, como veremos, respondían al quiebre de empresas a principios de la década del '90, tanto como las movilizaciones de desocupados y el resto de las acciones registradas vinculadas a los cambios y transformaciones de la industria y, también, a los vaivenes de la economía y la política nacional. Asimismo, en cuanto como afirma Juan Samaja (1996), toda estructura tiende a negar su génesis, nos planteamos analizar el origen y devenir de tal "modelo" y sus consecuencias. Por eso el orden narrativo de este trabajo comienza por ofrecer al lector o lectora el análisis de una serie de procesos que van desde la evolución de la industria pesquera en la década del '90, el desarrollo de las políticas para el sector y la trama de cómo éstas se fueron implementando, la descripción del proceso de trabajo, de las condiciones laborales y una aproximación a la conflictividad surgida en el interior de los lugares de trabajo. Posteriormente avanzamos en una breve historia del sindicato del SOIP especificando las tradiciones políticas, ideológicas y organizativas que en él se desenvolvieron. Y sólo después de este recorrido comenzamos a hablar de los episodios de acción de protesta en las calles. Pero un "modelo" de desarrollo no surge de la nada, sino que es expresión, desde nuestro punto de vista, del resultado de los enfrentamientos sociales, de la lucha, del conflicto, del antagonismo. En este sentido, existieron una serie de batallas sociales previas que, en su resultado (nunca definitivo) constituyen el elemento central para comprender el por qué se desplegó un "modelo" y no otro. Es decir que, al contrario de lo afirmado previamente, aquí es el resultado del conflicto lo que explica la instauración de un "modelo". De ese modo, nuestro análisis presupone al conflicto como el formador de territorios sociales.

Son entonces dos las puertas de entrada a nuestro objeto, conflictividad que emerge de la implementación de determinadas políticas y determinadas políticas que emergen como resultado de la conflictividad. Variantes que se separan sólo como modo de exposición pero que, en todo proceso social, se dan de manera conjunta. Señala Mateo que, dada la escasez de antecedentes historiográficos, montar una historia de la pesca y de los pescadores en Argentina resulta el armado de un puzle sin modelo a la vista. A la tarea de ese armado nos abocamos diseñando un criterio de exposición y un formato de presentación nacido, al mismo tiempo, de nuestra destreza y nuestras limitaciones. Como afirma Horacio González a todo texto "se le escapa algo" (González, 2001). Todo libro, artículo, proyecto de tesis, etc. es siempre algo inacabado, incompleto, inconsumado.En función de ello, sabemos que la construcción de conocimiento constituye una tarea necesariamente colectiva y permanente. Dada la heterogeneidad y complejidad de problemáticas que a continuación desplegamos, esperamos que futuras exploraciones puedan validar alguna de nuestras ideas, enriquecer hipótesis que aquí aparecen solamente como sospechas, agregar evidencia empírica, discutir nuestros resultados. En definitiva, alimentar todos los procesos que, en su devenir, constituyen el arte de escribir y pensar la historia. Si ello ocurre, esta investigación habrá cumplido el mayor de sus objetivos. 


\section{CAPÍTULO I}

\section{Una breve introducción a la industria pesquera marplatense}

\section{$\longrightarrow 00 \mathrm{OOOCO}$ \\ “...el modelo [pesquero] aplicado por la Argentina en los últimos 40 años, es el modelo de la 'exportación de ganado en pie' de la hacienda vacuna a fines del siglo XIX'}

César Lerena, 2009.

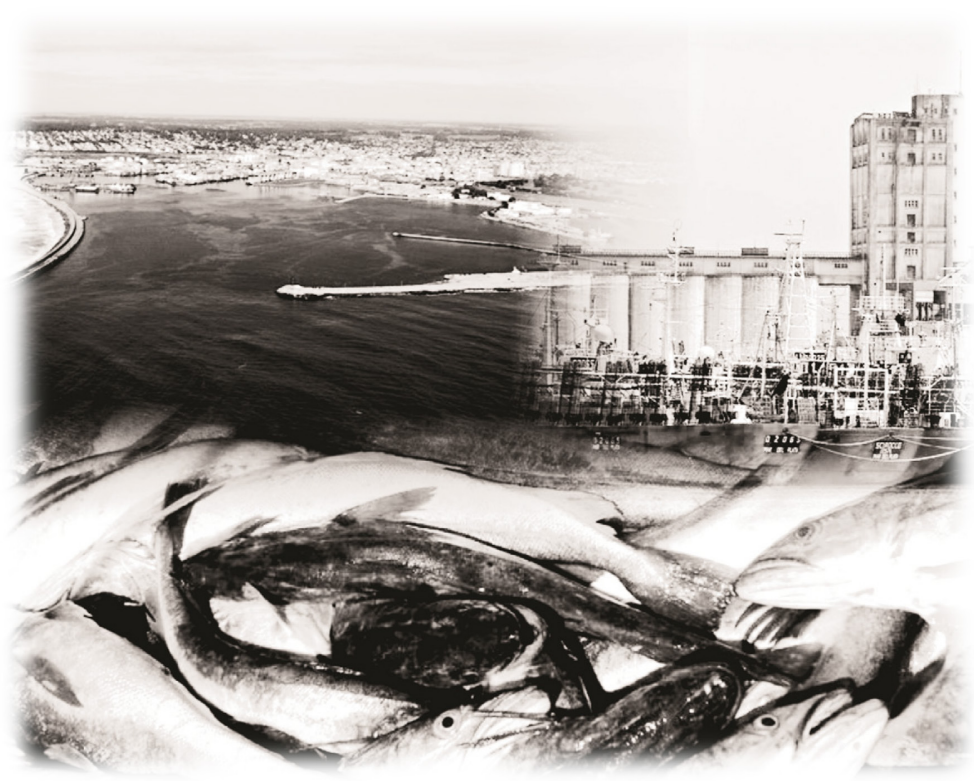




\section{Introducción}

Del mismo modo que otras actividades económicas, la industria pesquera posee características peculiares y que, aún para quienes investigamos acerca de la conflictividad social y las formas que asume la protesta obrera, no pueden soslayarse. Pues aquella peculiaridad constituye, en gran medida, el escenario sobre el que se desenvuelve la obra. Más aún cuando, como han señalado diversos autores, los argentinos hemos permanecido "de espaldas al mar" (Mateo, 2003; Dadón, 2003) y caracterizados por una fuerte "incultura marítima" (Lerena, 1989) que obliga a precisar las particularidades de una industria escasamente atendida por las ciencias sociales. Eignorada también por una gran parte de la población que, en general, desconoce el potencial pesquero, su implicancia en la economía nacional y el lugar que ocupa la industria como empleadora de fuerza de trabajo. Afirma Mateo que "la pesca en este país se ha ido desarrollando casi en secreto; un secreto que se ha visto facilitado por una cultura que concibe al fruto del mar como un producto exótico en la dieta alimentaria de los argentinos" (Mateo, 2003: 18). Dadón (2003) sugiere que este hecho no se produce por casualidad, sino más bien obedece a razones socioeconómicas, geopolíticas y culturales. Pues desde sus orígenes coloniales, la economía nacional se asentó casi exclusivamente en actividades rurales. Y es Mateo (2003) quien explica que el proceso colonizador del Río de la Plata fue excéntrico a sus costas atlánticas y, a diferencia de las zonas hoy delimitadas por Chile y Perú, no se integró a los pescadores indígenas que llevaban siglos pescando en las costas. El interés por el océano, en cuánto fuente de recursos, recién comenzó a afirmarse hacia mediados del siglo XX. César Lerena (2009), por su parte, llama la atención sobre el lugar marginal que ocupa el territorio marítimo en el imaginario nacional. Empezando por el hecho de que el Mar está demarcado en los planos y mapas con un color celeste, delimitando con nuestro continente. Aparece (casi) como si no fuera parte de nuestro territorio, sino algo que limita con él. Además es un tema muy poco abordado en las etapas de educación escolar. Y también han sido escasos nuestros conflictos marítimos, al contrario de los que sí recuerda la historia en el continente. A la pesca se la vincula más a la explotación y efectos regionales que provoca la minería y el aprovechamiento del petróleo. Sin embargo, es una industria elaboradora de productos que compiten en distintos mercados del mundo y que desde fines de la década del '80 equiparó, y hasta sobrepasó, a las carnes rojas en el rubro exportaciones. ${ }^{10}$ Se trata entonces de considerar a la pesca como rama industrial de la economía argentina.

En general, la interpretación respecto de las transformaciones en el patrón de acumulación y su relación con el desarrollo industrial encontró en los diferentes aportes del grupo liderado por Basualdo, un análisis valioso respecto de aquella evolución. ${ }^{11} \mathrm{Su}$ enfoque sostiene que los cambios en los patrones productivos luego del fin de la industrialización sustitutiva y el surgimiento de un modo de acumulación "neoliberal" favoreció la extensión de la valorización financiera así como un proceso de reprimarización de la economía nacional en desmedro de la industria manufacturera. Este proceso usualmente fue definido como desindustrialización. ${ }^{12}$ Además, grupos oligopólicos se consolidaron en la economía nacional que,

\footnotetext{
${ }^{10}$ En el año 1997 se alcanzó el record histórico en las exportaciones de pescado llegando al valor de US\$ 1.030 millones según el Instituto Nacional de Estadísticas y Censos. La cifra superaba en dicho año las exportaciones del complejo ganadero que se ubicaban en US\$ 756 millones (Rodríguez et al, 1999).

${ }^{11}$ Entre una gran cantidad de trabajos escritos bajo un marco de interpretación afín se pueden mencionar Basualdo (2006; 2002, 2000); Azpiazu, Basualdo y Schorr (2001).

${ }^{12}$ Sobre la polisemia en los usos locales de la noción de desindustrialización ver Grigera (2011).
} 
al mismo tiempo, mostró índices crecientes en las tasas de pobreza. Dentro de este nuevo patrón de acumulación, uno de los datos más relevantes será el incremento en la explotación de los trabajadores. Nos preguntamos entonces ¿qué ocurrió en la pesca? Como actividad con ventajas comparativas naturales ¿su evolución en la década permite abonar las premisas de tal explicación? ¿La experiencia de la rama se inserta dentro del fenómeno referido como desindustrialización?

La hipótesis que intentamos demostrar a lo largo de este capítulo pretende sostener que, consolidada ya como una actividad netamente extractiva y orientada hacia el mercado externo, en la década del '90 la estructura empresaria de la actividad pesquera sufrió significativastransformaciones. Al igual que otras ramas de la economía argentina, y en el marco de la apertura externa, la implementación del ajuste, el cambio de la forma de Estado y la desregulación, se produjo un "saneamiento" (en el lenguaje liberal) de la actividad que llevó al quiebre de numerosas empresas pesqueras. Tras ese proceso, las firmas supervivientes lo hicieron en base a distintos mecanismos que las llevaron a asociarse con empresas extranjeras, incrementar la integración vertical y horizontal de su intervención en el proceso productivo, fomentar la flexibilidad laboral para reducir los costos del trabajo y, finalmente, concentrar en menos manos la riqueza que genera la explotación de la actividad. ${ }^{13}$ De este modo, se consolidó un "modelo" pesquero que tendrá en las empresas integradas a su sector hegemónico modificando el escenario histórico del principal puerto pesquero del país. Asimismo, el inusitado crecimiento económico alcanzado durante la década, tanto en capturas como en desembarques y exportaciones, terminó-por las propias características en que se basó tal expansión-, en una de las crisis más fuertes que enfrentó la pesca. La misma estuvo marcada por el colapso del principal recurso pesquero nacional, la merluza hubbsi. Desde nuestra perspectiva, para describir todo este proceso resulta más explicativa la categoría de reestructuración productiva que la noción de desindustrialización. ${ }^{14}$ Por otra parte, fue en el marco de aquella crisis cuando se desenvolvió una intensa conflictividad social que implicó la movilización de todos los actores del teatro pesquero, alimentando conflictos entre grupos empresarios, tipos de flota, localidades, trabajadores, funcionarios de gobierno, etc.

En definitiva, este capítulo pretende dar a conocer precisamente los orígenes y características del libreto, los actores y el telón, como momento previo al desarrollo del drama. Como marco introductorio y contextual a las problemáticas abordas en los capítulos siguientes, y sin el cual@1 lect@r no podría comprender los aspectos esenciales que hacen al cuerpo central de esta tesis, presentamos un recorrido que transita desde los conceptos mínimos y las cuestiones específicas de la industria, para luego adentrarnos en el desarrollo histórico de la actividad durante el siglo XX poniendo énfasis en las transformaciones de mayor importancia que vivió la pesca en su devenir. Presentamos esta evolución en forma breve, para que una vez conocida su historia, podamos ingresar específicamente en el período de tiempo que abarca nuestra investigación. Al llegar a la década del '90, nos detenemos en el detalle de ciertos procesos que afectan a la industria pesquera, algunos de los cuales significaron cambios estructurales respecto al desenvolvimiento de la actividad en el pasado.

\footnotetext{
${ }^{13}$ Entre otros, Basualdo refiere al proceso de concentración y centralización del capital en la Argentina de la década del ' 90 dado el incremento significativo en la incidencia de las grandes firmas oligopólicas sobre el proceso económico en su conjunto (Basualdo, 2003).

${ }^{14}$ Nos colocamos así en una corriente que, aceptando los aportes ofrecidos por Basualdo y compañía, sostiene que algunas de sus afirmaciones deben necesariamente ser matizadas (Grigera, 2011; Pérez Álvarez, 2010).
} 


\section{Conceptosprimariosyespecificidades de la flota pesquera}

"Dentro del sector pesquero existen ciertos elementos conceptuales que resultan del todo originales, y que no se alcanzan a distinguir acabadamente a menos que el observador se aleje lo suficiente y pueda proyectar la estructura bajo estudio, no sólo a través del tiempo, sino en relación al conjunto global de la organización social. Tales elementos conceptuales, una vez aprehendidos en mérito a la interiorización de sus razones de existir, su manera de expresarse y su acabada influencia en el juego de las fuerzas productivas que componen la estructura pesquera, permitirán encontrar el sentido a las contradicciones..."

Jorge Valdez Goyeneche, 1974

La actividad pesquera se caracteriza por sufrir condicionamientos derivados de la naturaleza biológica y económica de los recursos explotados.

Entre los factores más importantes deben señalarse la propiedad común de los recursos y su forma de apropiación por los agentes económicos mediante la simple captura y la naturaleza del recurso renovable y finito. Esto no implica que las leyes que rigen las actividades económicas en general no se expresen también en el sector pesquero; sino que las características de los recursos pesqueros condicionan el carácter que la pesca asume como actividad económica (Bertolotti et al, 2002: 50).

Dada "la propiedad común de los recursos" y la apropiación "por simple captura", la acción del Estado se vuelve central en cuanto es este quién define la cantidad y precisa cuál es el sujeto que puede pescar de acuerdo con la política que cada gobierno adopte en función de lograr una explotación sustentable. La idea de "explotación sustentable" adquiere una importancia fundamental dado que el recurso, explotado "racionalmente", es de carácter renovable y podría disponerse su explotación a perpetuidad. El problema surge entonces del ordenamiento pesquero y los criterios con los cuales se delimita quién y cuánto va a pescar. Porque se trata de un recurso renovable pero finito, que puede ser extinguido mediante un esfuerzo pesquero que sobrepase la capacidad de autogeneración dentro de su medio. Esto significa que si bien los recursos pesqueros son renovables, la biomasa es limitada, de la cual sólo se puede extraer una cantidad determinada sin afectar su reproducción.

No obstante, por un lado, el desarrollo tecnológico de las artes de pesca de la mano de políticas pesqueras fundamentalmente extractivas y que algunos autores han definido como de "minería pesquera" (Cóccaro, 2000); y, por otro lado, el crecimiento desproporcionado de las flotas industriales, hicieron de las crisis de las pesquerías un fenómeno de carácter mundial. ${ }^{15}$ A principios de la década del '90 se calculaba que el 70\% de las mismas se hallaban explotadas al borde de su capacidad, sobreexplotadas o en estado de colapso. Por ello, el manejo sustentable de los recursos representa un gran desafío para los Estados (Litovsky, 2000). Esto ha motivado discusiones científicas y políticas respecto al modo en que se debe garantizar la apropiación de los recursos, que al contrario de un campo con animales, no pueden cercarse y otorgarse en propiedad al poseedor de la tierra. ${ }^{16}$

\footnotetext{
15“La pesca ha pasado, en el proceso de producción del espacio marítimo, de ser una actividad de recolección a ser una actividad de extracción 'minera' potenciando, a través del perfeccionamiento y selectividad de las técnicas de extracción, la vocación paleolítica que le quiere desarrollar el poder..." (Cóccaro et. al., 2000: 2).

${ }^{16} \mathrm{El}$ tema del funcionamiento de las leyes económicas ante recursos de propiedad común fue debatido en el mundo académico ya desde mediados del siglo XX por biólogos, geógrafos, antropólogos, economistas. y por organismos nacionales y multinacionales
} 
Dados estos rasgos, se vuelven fundamentales dos instrumentos de los que el Estado puede (y debe) hacer uso. Por una parte, las tareas de regulación y ordenamiento pesquero. Por otra, la investigación acerca de cuántos son los recursos realmente disponibles para ser pescados. En vistas del primer punto, hasta 1997 la Argentina no contó con una ley nacional de pesca. Existían regulaciones provinciales que alcanzaban la potestad de la costa marítima hasta las 12 millas. Fuera de ellas, prevaleció el criterio conocido como de "pesca olímpica" donde cualquier actor dedicado a la actividad podía pescar todo lo que quisiera y pudiera. En 1989, cuando los resultados de la falta de regulación eran más que evidentes, un estudioso señalaba "La industria pesquera argentina, cuyas exportaciones estuvieron a la altura de las carnes rojas durante los años 1987 y 1988, es un edificio cuyo cimiento es el recurso pesquero y de la buena administración del mismo dependerá su estabilidad y crecimiento" (Lerena, 1989: 34). En gran medida, el criterio subyacente en la sociedad argentina, y también en los funcionarios de gobierno, se basaba en la creencia de que los recursos del mar eran infinitos. Mientras la dimensión de la flota y el esfuerzo pesquero no sobrepasaron la capacidad de los recursos para reproducirse, no se consideró demasiado necesario ordenar la actividad.

Fue también la complicación técnica de formalizar el derecho jurídico individual un factor que colaboró con la formación de agentes económicos acostumbrados a moverse en el marco de tal inexistencia de regulación. Según Valdez Goyeneche, es el carácter comunitario de los recursos pesqueros lo que obligó a las comunidades de pescadores a buscar mecanismos que "cerraran" el acceso a la pesca, involucrando en la organización aspectos referidos al comportamiento frente a terceros que pudieran poner en peligro la explotación de los recursos. En los comienzos de la actividad, tanto las formas como los métodos de pesca y la ubicación de las concentraciones de peces, eran conocimientos que los pescadores se cuidaban muy bien de divulgar. Conducta directamente relacionada con la imposibilidad de privatización del recurso. Valdez Goyeneche comenta que:

Cuando el grupo pescador dirige sus ojos al Estado y le reclama protección y título y le son negados, está indefectiblemente librado a su propia suerte [...] Las inversiones que el pescador realiza para lograr el fruto del mar en cuya obtención muchas veces se va la vida, son riquezas tan respetables como las del leñador, sencillo campesino o rico hacendado. A éstos el Estado les da título sobre la fracción de tierra, y a aquél no sobre la fracción del mar. Son dos hombres distintos que forman comunidades diferentes y que, en el curso de los años, trasladan hábitos y reglas de juego totalmente distintos (Valdez Goyeneche, 1974: 151).

Es así que avanzado el desarrollo industrial, el empresariado del sector estaba bien poco habituado a las reglamentaciones. Refiriéndose a los años de crecimiento de la industria pesquera, el propio Valdez describía así la conformación de lo que denominaba "La Liga Pesquera": “..ésta no es sino la

de gobierno como Naciones Unidas. Gordon (1954) abría la discusión acerca de la teoría económica de los recursos de propiedad común y lo aplicaba al daño ecológico realizado por la pesca libre. El biólogo Garret Hardin (1968) retomaba el desafío. Expuso lo que denominaba "La tragedia de los comunes", describiendo la dinámica social que opera en torno al uso y conservación de un recurso de propiedad común. La idea central de su razonamiento indica que cuando los individuos comparten un recurso potencialmente agotable, en su esfuerzo por maximizar su ganancia individual, tienen incentivos para sobre-utilizarlo en detrimento de los demás, en vez de cuidar de él para aprovecharlo indefinidamente con el transcurso del tiempo. De ahí la necesidad de regulaciones. Se trataba de legislar la moderación orientando las políticas a restringir el acceso a los recursos del mar. E.P. Thompson calificó el texto de Hardin como ignorante de la Historia, que erróneamente da por sentado que las tierras comunales eran pastos abiertos para todos (cit. en Mateo, 2003). Para los economistas neoclásicos la respuesta a la "tragedia de los comunes" se encuentra en la privatización de los recursos mediante la asignación de cuotas. 
organización de los métodos por vía de reglas a respetar, que permiten la defensa de ciertos derechos" (Valdez Goyeneche, 1974: 247). Esa defensa de "derechos" implicaba la marginación de la actividad de agentes "no deseados" o posibles competidores. Durante finales de la década del '90, en el contexto de crisis de la industria pesquera, podremos ver que muchas de las disputas, tanto al interior del empresariado pesquero como entre diferentes provincias argentinas, girarán en torno a los modos de apropiación de los recursos pesqueros cuyo proceder nunca terminaba de quedar del todo aclarado. Lo veremos más en detalle en el próximo apartado.

En relación al segundo punto, el referido a la investigación, el organismo que cumple las tareas de averiguación y evaluación de los recursos en la Argentina es, desde 1977, el Instituto Nacional para la Investigación y el Desarrollo Pesquero (INIDEP) que entre otras funciones es el encargado de analizar el estado de las pesquerías e indicar el Rendimiento Máximo Sostenible. ${ }^{17}$ El RMS es el cálculo que establece cuál es el máximo que se puede capturar de pescado sin provocar la depredación del recurso. Sobre este cálculo la Subsecretaría de Pesca junto con el Consejo Federal Pesquero establecen la Captura Máxima Permisible (CMP). Es decir, dictan cuánto efectivamente se puede pescar, volumen que puede coincidir o no con la RMS. La información que produce el organismo es sensible, pues por un lado es la base de una política pesquera y, por otro, requiere de secreto porque de lo contrario brinda información de la existencia de nuestros recursos a terceros países posiblemente interesados en capturarlos. Siempre ha sido una discusión si la investigación debe subordinarse a la política o la política a la investigación. En la pesca argentina, como veremos más adelante, el criterio fue generalmente el primero.

Otro aspecto a destacar es que los argentinos tenemos un escaso hábito en el consumo de pescado. ${ }^{18}$ A diferencia de España, Japón o los países nórdicos, nuestra alimentación principal es a base de carne vacuna. Diferentes cálculos hablan de relaciones que van de un consumo per cápita de 80 kilos de carne vacuna por año contra menos de 10 kilos de pescado. ${ }^{19}$ De hecho, diferentes sectores de la pesca solicitaron insistentemente la aplicación de políticas orientadas a incrementar el consumo nacional, buscando contrarrestar la estrechez del mercado interno. Desde hace al menos 30 años alrededor del $90 \%$ de lo que se captura en nuestro mar se dedica a la exportación.

\footnotetext{
${ }^{17}$ El Instituto fue creado por Ley N ${ }^{\circ} 21.673 / 77$ años después de la firma de un convenio entre la Argentina y la Organización de las Naciones Unidas para la Agricultura y la Alimentación (FAO), institución que diolugar al Proyecto de Desarrollo Pesquero. Sus misiones y funciones son formular, ejecutar y controlar los proyectos de investigación en prospección, evaluación y desarrollo de pesquerías, de tecnologías de acuicultura, de artes de pesca, de procesos tecnológicos y en economía pesquera, conforme a las pautas y prioridades que en tal sentido establezca la autoridad de aplicación. En septiembre de 1994 fue inaugurado en Mar del Plata el nuevo edificio del INIDEP el cual fue donado por el gobierno de Japón. Si bien no hay información escrita o precisa que lo confirme, se decía en ambientes portuarios que tal donación era una contraprestación a las capturas autorizadas ilegalmente por el gobierno argentino a buques japoneses. Previo al Inidep, el Dr. Fernando Lahille fundó en 1898 el primer laboratorio costero de biología marina, ubicado en Punta Mogotes, Mar del Plata. Años más tarde, durante 1960, un grupo de investigadores y docentes de las Universidades Nacionales de Buenos Aires, La Plata y Bahía Blanca originaron el Instituto de Biología Marina. Hasta entonces las investigaciones acerca del estado de los recursos se realizaban por medio de campañas, muchas de las cuales las llevaban a cabo buques de procedencia extranjera.

${ }^{18}$ Mateo recorre la discusión acerca de las razones históricas del bajo consumo de pescado en la Argentina. Entre ellas cita la abundante oferta de carnes rojas; el desarrollo ineficiente de la industria pesquera nacional que por años no facilitó la concurrencia a los mercados minoristas de abundantes partidas de pescado; la reserva o temor basado en las condiciones en que el consumidor cree se encuentra el pescado luego del tiempo transcurrido desde su captura; el desconocimiento acerca de las ventajas que supone una dieta equilibrada y de la conveniencia de incorporar regularmente pescados y mariscos a la alimentación humana y, por último; la ausencia del Estado como promotor del consumo (Mateo, 2003).

${ }^{19}$ Según Lerena en Argentina se consumen $5 \mathrm{~kg}$ de pescado per cápita por año, en contraposición a los $25 \mathrm{~kg}$ de pollo o los 70 de carne vacuna. Australia, Canadá, Chile, Francia, Gran Bretaña, Grecia, Italia, Perú, Polonia consumen más de $15 \mathrm{~kg}$ de pescado per cápita por año. Corea, Dinamarca, España, Finlandia, Noruega, Portugal, Rusia, Suecia más de 30 kg y, más de $50 \mathrm{~kg}$, Japón.
} 
En cuanto al lugar que ocupó la pesca dentro del Estado Argentino hay que decir que recién en 1946 se creó la Dirección de Pesca y Conservación de la Fauna en el Ministerio de Agricultura y Ganadería por decreto $\mathrm{N}^{\circ}$ 22.763. Como veremos luego, eran tiempos de un cierto desarrollo de la industria volcado aún fundamentalmente al mercado interno. Es este el momento en que el país empieza a prestar atención oficial a la actividad pesquera. Sin embargo, aún así, la prioridad casi exclusiva, tanto entonces como ahora, eran la agricultura y ganadería. En materia pesquera eran más eficaces las regulaciones provinciales. De ahí que la pesca industrial en la Argentina naciera inorgánica, propia del esfuerzo individual y las coyunturas especiales y no de un programa de gobierno. Varios años después, luego del golpe cívico militar de 1976, por decreto $\mathrm{N}^{\circ} 520 / 76$ se creó la Secretaría de Intereses Marítimos. Esta vez la agencia estatal se encontraba fuera del contexto del área de Agricultura y Ganadería, ocupando una subsecretaría en el Estado Nacional. Ya la pesca perfilaba su orientación casi exclusiva al mercado externo, y el nuevo lugar ocupado era una histórica demanda del sector pesquero que reclamaba un plano de igualdad con otras actividades industriales y agropecuarias.

A partir de 1983, tras el retorno de un gobierno elegido en democracia, desapareció la secretaría de Pesca como tal y la, ahoraSubsecretaría de Pesca, pasó a depender de la Secretaría de Agricultura, Ganadería y Pesca (luego Secretaría de Agricultura, Ganadería, Pesca y Alimentación). En un país como el nuestro, de fuerte tradición agrícola-ganadero, ello implicó que la pesca se vea fagocitada por los intereses de la ganadería y agricultura. Tanto es así que el área pasó a depender de un funcionario político, el Secretario, preparado usualmente en lo agropecuario. Por ello Lerena dice que la pesca es, en la preocupación del responsable del área, la "prima pobre y fea" de su gestión (Lerena, 1989). Desde allí, será un reclamo recurrente de industriales y gremios pesqueros la creación de una Secretaría de Pesca por fuera de la órbita del complejo agrícola-ganadero. ${ }^{20}$

Llegados hasta acá, y en cuanto se mencionará recurrentemente el término caladero, conviene tener claro qué significa dicha palabra, al mismo tiempo que precisar algunas otras características de la industria pesquera. Se denomina caladero al lugar donde se acostumbra pescar debido a la abundancia de cardúmenes. Los caladeros más productivos generalmente se extienden desde la costa a lo largo de la plataforma continental, tienen cerca de 200 metros de profundidad, corrientes y temperaturas favorables y abundante vida vegetal. La Plataforma Continental Argentina es de una gran longitud, con $4.725 \mathrm{~km}^{2} \mathrm{de}$ extensión donde habitan una gran cantidad de especies ictícolas. En cuanto a las especies de mayor captura se pueden mencionar las de baja profundidad (pelágicas) y las de gran profundidad (demersales). Las primeras se encuentran en aguas cercanas a la superficie, suelen migrar con estaciones y se desplazan en grandes bancos. Tal es el caso del atún, el salmón, la anchoa, la sardina y el arenque. Las demersales frecuentan los fondos del océano y son menos gregarios, como por ejemplo el bacalao, el halibut, el lenguado, el eglefino o la platija. En Argentina, las especies de mayor captura son la merluza hubbsi, la polaca, la merluza de cola, la merluza negra, el abadejo, la anchoíta y la corvina. Entre los moluscos se destaca fundamentalmente el calamar illex y entre los crustáceos el langostino. En cuanto a las artes de pesca, estas son los equipos o métodos empleados para la captura de peces. Entre los más comunes se encuentran las redes de arrastre, los "cercos" y las específicas para determinado tipo de peces como palangres, poteras y tangones. ${ }^{21}$

\footnotetext{
${ }^{20}$ En 2009 la SAGPyA fue elevada del rango de secretaría al de Ministerio. Pasó a llamarse Ministerio de Agricultura Ganadería y Pesca. De todos modos, el área Pesca si bien fue elevada a secretaría, comparte "jurisdicción” con Agricultura y Ganadería.

${ }^{21}$ Sobre artes de pesca ver Nedelec (1984).
} 
Por último debemos mencionar los diversos tipos de flota existente. Pues los buques pesqueros pueden clasificarse de acuerdo a su tamaño y posibilidades de navegación en barcos costeros, de media altura y de altura. Del mismo modo, se denomina pesca de altura, costera o de bajura según la lejanía desde la costa con que se realiza la captura. Otra clasificación, aunque ya específica de la flota de altura y que tendrá una importancia central en esta investigación, es en base al tratamiento que se le da al pescado. Ello divide a los buques en fresqueros, congeladores y factorías. Los primeros desembarcan el pescado fresco, con hielo, para luego realizar el procesamiento en la planta industrial. Los segundos, congelan el pescado a bordo y lo mantienen y desembarcan a temperaturas inferiores a los $20^{\circ}$ bajo cero. Por último, los factorías son los que realizan el procesamiento del pescado a bordo, con la maquinaria incorporada y revisten características de verdaderas fábricas flotantes(Madaria, 1999). Los congeladores y factoría tienen mucha mayor autonomía que los fresqueros porque congelan y/o procesan su producción sin la necesidad de volver a tierra. En el buque congelador, se congela y empaca el pescado y se lo mantiene listo para enviar al mercado consumidor. Una vez en el país de destino, se descongela y trabaja, otorgándole allí el valor agregado. Los congeladores tienen una capacidad mucho mayor de captura, mientras que la industria fresquera tiene, bajo las actuales condiciones de la organización de la actividad pesquera, más posibilidades de elaborar productos de mayor valor agregado debido a su ligazón con las plantas en tierra, empleando así una mayor cantidad de mano de obra. En términos de actividad, los fresqueros deben destinar 60 días por año en el puerto para realizar las tareas de logística; mientras que los congeladores pasan sólo 42 días. Desde que los fresqueros salen del puerto, llegan al caladero y vuelven nuevamente a puerto, se calculan alrededor de 120 días de navegación por año mientras que los congeladores ocupan 21 días al año. Ello explica porqué los congeladores pueden estar entre 60 y 90 días seguidos pescando, hacen menos viajes al puerto y están permanentemente procesando sobre el cardumen. De este modo, los fresqueros tienen una pesca efectiva de 185 días al año, mientras que los congeladores tienen 302 (Litovsky, 2000). Finalmente, los buques también pueden ser denominados de acuerdo al arte de pesca utilizado, como arrastreros, cerqueros, palangreros, poteros o tangoneros. ${ }^{22}$

\section{La apropiación de los recursos: los permisos de pesca}

"La influencia que la imposibilidad de privatización de los recursos pesqueros ejerce sobre la comunidad internacional, las comunidades pesqueras nacionales y en relación de las fuerzas productivas que conforman la estructura pesquera es tan decisiva, que discutir sobre sus consecuencias en el orden económico y social obliga a un tratamiento separado". Jorge Valdez Goyeneche, 1974.

"Corre mucha plata alrededor de las decisiones pesqueras, un permiso pesquero es hoy casi, casi darle un gran negocio, un paquete de dinero a alguien [para] que lo use bien. Es decir, la responsabilidad y el peso es grande". Felipe Solá, 1989.

Una particularidad de la actividad de la pesca consiste en el modo de apropiación de los recursos pesqueros. Al contrario de, por ejemplo, el ganado bovino y la tierra para sembrar, lo que está por debajo

\footnotetext{
${ }^{22}$ Sobre los tipos de flota puede consultarse Madaria (1999) y Bertolotti et al (2001).
} 
del mar no puede ser asignado con facilidad a individuos, sino que el propietario es el pueblo de la Nación y, en su representación, el Estado. Es decir, que se trata de un recurso de propiedad común. En 1973 la ley $\mathrm{N}^{\circ}$ 20.136, al tiempo que reservaba la explotación de los recursos pesqueros a las embarcaciones con pabellón nacional, requería un previo permiso otorgado por las autoridades competentes. A partir de la creación de la Subsecretaría de Intereses Marítimos bajo la última dictadura cívico - militar y luego de la Subsecretaría de Pesca bajo la administración Alfonsín, se desarrolló este mecanismo como metodología que permitió establecer cierto "cierre" del mar, otorgando derechos a determinados agentes económicos y excluyendo a terceros. Así, las pesquerías continuaron siendo un recurso común, pero su acceso se vio limitado. Para ello se instrumentaron los Permisos de Pesca como mecanismo a cargo del Estado para asignar a los privados el derecho a realizar las tareas de pesca. Los permisos fueron de cesión gratuita, se otorgaron a los buques $\mathrm{y}$, según el decreto $\mathrm{N}^{\circ} 1533 / 82$, debían demostrar su factibilidad para ser avalados por la subsecretaría. Luego, la resolución 221/83 creó la figura de cupos, es decir, mensuró la cantidad de pescado que tenía cada permiso. En 1986, el decreto $\mathrm{N}^{\circ}$ 945/86 creó la figura del "permiso restringido" que habilitando la pesca de unas especies y excluyendo del permiso la pesca de otras. En el mismo momento se estableció el carácter definitivo de los permisos. Poco después, ante el incremento desmedido de los volúmenes de pesca, la resolución de la SAGyP ${ }^{\circ}$ 396/86 suspendió el otorgamiento de permisos de pesca de langostino y la resolución $\mathrm{N}^{\circ}$ 946/88 excluyó la captura de merluza común y de merluza austral de los proyectos de incorporación de buques. Así es como el Estado buscaba regular el esfuerzo de pesca, otorgando permisos de captura que debían guardar una relación con la estimación realizada por el INIDEP sobre los recursos disponibles en el plazo de un año. Es decir, que el control se ubicó en torno al volumen capturable. Esto se complementó con una serie de regulaciones adicionales sobre zonas o períodos de veda ${ }^{23}$ y la especificación de tecnologías permitidas y no permitidas- a emplear. ${ }^{24}$

La cuestión central a comprender es que desde el inicio mismo del otorgamiento del permiso de pesca se está definiendo la política pesquera nacional, pues este aparentemente simple instrumento administrativo puede constituirse en una herramienta de explotación "racional" del recurso, de desarrollo empresario y demanda laboral o, al contrario, en la "entrega" del recurso nacional y la quiebra del sector pesquero (Lerena, 1989). Por eso Lerena, investigador y ex funcionario, denunciaba que los permisos se otorgaban sin exigir inversión alguna a la empresa beneficiaria. Y hacia finales de la década del ' 90 entendía que la forma de asignación de permisos era obsoleta. Por ello proponía la modificación del régimen de otorgamiento de permisos con el objeto de promover la captura racional y la planificación, inversión y eficiencia empresaria, en el cual participaran los antecedentes históricos, la capacidad productiva instalada, el potencial extractivo, la ocupación de mano de obra, la exportación y la participación en el consumo interno, etc. ${ }^{25}$

Lo cierto es que las prácticas de pesca de la industria pesquera argentina siempre fueron sospechadas de padecer de fuertes irregularidades. En un extremo de la ilegalidad se encontraban las

\footnotetext{
${ }^{23}$ La veda consiste en la prohibición temporaria o permanente de toda la pesca o de alguna especie en particular. La misma se puede aplicar a todo el mar argentino o sólo sobre algún área que se desee proteger especialmente.

${ }^{24}$ Un tipo de regulación orientada a regular el esfuerzo pesquero es la que obliga al uso de determinadas redes, con un tamaño mínimo de las mallas, que permite se escapen los peces juveniles de esa especie. Sin embargo, casi ninguna tecnología permite tal nivel de selectividad y por lo general es imposible la explotación de una única especie sin afectar a las otras.

${ }^{25}$ Desde una perspectiva liberal se ha denunciado que el sistema de permisos motivó mundialmente lo que se define como "carrera por pescar", dado que por la incertidumbre general cada pescador individual procurará asegurarse cuanto antes del máximo de captura fijado por la autoridad, contradiciendo cualquier medida conservacionista (Bogo, 1994).
} 
tradicionales prácticas de pesca sin permiso que pasaban desapercibidas ante la ineficiencia de los controles estatales. Más allá de este fenómeno, y ya asociado a la sesión de permisos, hay que señalar que el modo de apropiación de los recursos generó particulares conductas, sospechadas de lo que podría definirse como corrupción, en torno al otorgamiento de permisos. Era la propia ex Directora Nacional de Pesca del gobierno de Alfonsín, la Dra. Liliana Márquez de Lupi, la que alertaba sobre valores extraoficiales para los permisos, al abrigo de lo cual se alentó un "interesante negocio no pesquero" (Lerena, 2009). Tampoco era una costumbre publicar los permisos y cuotas otorgadas con la documentación de respaldo, lo cual hubiera dado mayor transparencia al sistema. Por lo general nadie sabía a ciencia cierta quién disponía de permisos y cupos de pesca. De ahí que todo análisis debe contemplar ésta particularidad. ${ }^{26}$

Resultará una constante la mención de corrupción en la actividad pesquera buena parte de la cual nace en torno al modo de apropiación de los recursos. Y ello no mejorará en la década del '90. Fueron numerosos los sectores de la pesca que exigieron la revisión de todos los permisos de pesca, tanto a comienzos del nuevo gobierno como durante la crisis de la merluza hacia 1997. Sin más, en 1990 el diputado ucedeísta Alberto Albamonte presentó una denuncia en el Juzgado Federal de Mar del Plata apuntando a investigar "el tráfico de permisos de pesca", que involucraría a funcionarios que actuaron en la SAGyP. ${ }^{27}$ Por su parte, el empresario Federico Contessi, titular del Astillero Domingo Contessi, se quejaba de las políticas negativas para la Industria Naval, mencionando que una de ellas era la existencia de "coimas" para obtener permisos de pesca. Denunciaba que "Gente que nada tiene que ver con la pesca me pidió cinco mil, cincuenta mil, cien mil y hasta setecientos mil dólares para conseguir permisos de pesca". Y añadió que si "alguna vez se investigan los intereses que giran en torno a esta actividad, seguramente el affaire de los pollos de Mazzorin será un poroto al lado de todo esto". 28

A partir del decreto $\mathrm{N}^{\circ} 2265 / 92$ se autorizó la transferencia de permisos generando así un mercado de licencias de pesca antes inexistente al menos en términos legales. Dadas las características que en ese entonces dibujaba el escenario pesquero, el mecanismo profundizó la sobrepesca en la medida en que barcos activos vendían sus permisos y conseguían otros de remates de empresas en quiebra, u obtenían habilitación de permisos de empresas inexistentes, también se duplicaban permisos y se vendían permisos caducos o de barcos inactivos. De hecho, a inicios del año 2000 la SAGPyA encargó a la Universidad Nacional de Buenos Aires la realización de una auditoría sobre los permisos de pesca otorgados hasta el momento. El resultado denunciaba la trasferencia irregular de permisos y la evasión impositiva. ${ }^{29}$ A estos hechos se le sumó, en consideración de Héctor Salamanco, Subsecretario de Pesca entre 1997 y 1998, que en la Argentina "los controles son terriblemente ineficientes". Diferentes

\footnotetext{
${ }^{26}$ Un ejemplo lo constituye el caso de la empresa ONTRE S.A., propiedad de José María González Eiras, María A. Klein y Graciela C. Monti. El primero se desempeñó como Jefe del Gabinete de Asesores de Luis Jaimes, subsecretario de Pesca entre los años 1983 y 1989. A los pocos meses de constitución de la sociedad de ONTRE, Jaimes firmó la disposición $\mathrm{N}^{\circ} 280$ del 16/8/1988 donde se le otorgaron cuatro permisos de pesca. De este modo, se le adjudicaron permisos de pesca a una empresa vinculada a uno de los asesores del subsecretario de Pesca. No sólo eso, sino que el proyecto que solicitaba los permisos se había presentado 7 días después de que la disposición le adjudicara los mismos. Poco tiempo después, la sociedad fue comprada por la pesquera española Pescaven, adquiriendo con ella los permisos de pesca de ONTRE. De este modo, ONTRE nunca pescó pero accedió a permisos de pesca que pudo ceder rápidamente a Pescaven, quien finalmente se quedó con los permisos.

${ }^{27}$ L.C., 02/05/1990.

${ }^{28}$ L.C., $19 / 05 / 1990$.

${ }^{29}$ Una parte del Informe se publicó en la Revista Puerto, la otra cara de la pesca, № 20, Agosto de 2002, pp. 24 a 49. Según indica la misma publicación, los auditores se encontraron con todo tipo de trabas durante la etapa de realización del informe. La revista acusa que "llamativamente" el informe desapareció de la Secretaría y que nunca se atendieron a las denuncias allí formuladas.
} 
analistas, de variadas trayectorias teóricas (Lerena, 2009; Cepparo, et al, 2007; Godelman et al, 1999; Bogo, 1994), señalan que la deficiencia, tanto de la estructura de la administración como de los mecanismos de control de los recursos pesqueros tiene su origen en la carencia de una política pesquera. ${ }^{30}$ Por lo tanto, las medidas tendientes a proteger el recurso implementadas hacia finales de la década del '90, más que políticas consistentes y tendientes a dar soluciones, eran de una alta "improvisación legislativa" (Cepparo, 2007), y constituyeron paliativos y hechos de desesperación ante la evidencia del colapso, los cuales buscaban resolver las más inmediatas urgencias. El fenómeno se agravó en el marco del ajuste del Estado, debido a que se realizaron escasas inversiones en los sistemas de control y ni siquiera pudieron mantenerse por un tiempo prolongado. ${ }^{31}$ Por todo ello, un periodista podía denunciar cuando estallaba la crisis por el agotamiento de la merluza que el circuito de las habilitaciones y cupos de pesca de dudosa legalidad implicó a jueces, empresarios y funcionarios, dando lugar a un "desmanejo pesquero" (Muleiro, 2000).

Ya durante el año 1997, en el texto de la Ley Nacional de Pesca $N^{\circ} 24.922$, en su artículo 47, se establecía un nuevo sistema para otorgar propiedad de los recursos del Mar. Estas eran las Cuotas Individuales Transferibles. Las CIT implican la adopción de un criterio de otorgamiento de derechos individuales sobre determinados cupos de pesca, asignando cuotas fijas a determinadas personas, buques o grupos empresarios. Además, estas cuotas individuales eran divisibles y transferibles. A mediados de la década del '90 esta alternativa de privatización aplicada a la Argentina ya figuraba entre los deseos de investigadores de cuño liberal para lograr una explotación más racional de los recursos añadiendo incentivos para la conservación, puesto que -según decían-su adopción "solucionaba" la falla de mercado particular de la actividad. ${ }^{32}$ No obstante, este punto particular de la ley, la cual fue sancionada a poco de

\footnotetext{
30 "Las cifras sugieren fuertemente también que las tareas más propias del Estado en materia pesquera se realizan con notorias deficiencias, ya que el conocimiento de los recursos es inadecuado para los niveles de explotación alcanzados y el control sobre las capturas es deficiente, a juzgar por los niveles de pesca clandestina que se infieren de las cifras estimadas. Esto se debe, fundamentalmente, a una crónica escasez de recursos presupuestarios para afrontar gastos de operación...” (Bogo, 1994: 23). "Ese desarrollo ha mostrado un comportamiento con ciclos de avances y retrocesos provocados, en la mayoría de los casos, por la ausencia de políticas de largo plazo previamente planificadas, transparencia y seguridad jurídica, o por la recurrencia de decisiones transitorias que variaban según los lineamientos de las políticas económicas nacionales. Numerosos decretos, resoluciones y disposiciones administrativas improvisadas y discontinuas coadyuvaron a una anarquía legislativa en la que navegó todo el sector pesquero, para beneficio de unos en desmedro de otros, y no constituyeron un marco jurídico regulatorio adecuado" (Cepparo et al, 2007: 3).

${ }^{31}$ Para el control marítimo existen diferentes métodos. Por un lado, la Armada Nacional en su tarea de contribuir a la defensa nacional, es la que debe monitorear los espacios marítimos, actuando en forma disuasiva o empleando los medios en forma efectiva para proteger los intereses de la Nación. Es la Prefectura Naval la que debe controlar la actividad pesquera, ejerciendo funciones de "policía auxiliar". Esto es, controla que cada buque pesquero cuente con su permiso de pesca correspondiente, ejerce el control en el área de las 12 millas provinciales y en las 200 millas de Zona Económica Exclusiva. También controla el cumplimiento de la prohibición de pesca en las zonas de veda. A mediados de 1997 la SAGPyA puso en marcha un proyecto para crear un cuerpo de inspectores de pesca, a fin de llevar un control sobre las capturas a bordo de los buques pesqueros. Y luego la Secretaría impulsó un sistema de monitoreo satelital sobre la flota pesquera, denominado "Monpesat", que consiste en un satélite instalado en cada buque pesquero con un GPS. Ninguno de los dos, por diferentes motivos, mostró una efectividad razonable.

${ }^{32}$ Se aplicaron en Nueva Zelanda e Islandia en la totalidad de las pesquerías. Y en zonas de Canadá, Australia, Chile, Estados Unidos, Indonesia, Filipinas, Noruega y Malasia. Recordemos que desde una perspectiva liberal, bajo una política de acceso abierto a un recurso renovable, la "falla de mercado" consiste en que los agentes económicos carecen de incentivos conservacionistas dado que ante conductas de moderación en la pesca, otros agentes, que ingresan libremente, pueden apropiarse inmediatamente de la renta sin considerar las consecuencias de sobreexplotación. Por ello, en una política de acceso abierto, los agentes económicos tienen incentivos para aprovecharse de la renta inmediata, resultando incapaces de reaccionar a las señales de peligro de extinción. Una perspectiva coincidente con este análisis en Bogo (1994). También Bertolotti (2000). Una posición diferente, proclive a la manutención de regímenes de propiedad comunal de los recursos, dado que las propias comunidades se dotan a sí mismas de mecanismos regulatorios que permiten la sustentabilidad ecológica, en Feeny et al (1990). Otra mirada crítica ofrece Copes (1999).
} 
comenzar una de las crisis más fuertes que padeció la pesca, fue duramente cuestionado por sectores empresarios y gremiales, por lo que la reglamentación se vio demorada por más de una década. ${ }^{33}$

\section{La pesca en el mundo}

Durante el siglo XIX, desarrollada en las cercanías a las costas de los pueblos pesqueros, la actividad pesquera aún se basaba en la pesca artesanal. El siglo XX trajo consigo mejoras en las comunicaciones y el transporte consiguiendo un desarrollo tecnológico que permitió el nacimiento de la pesca de altura y facilitó la creación de nuevos mercados en torno a la venta de productos del mar (Holm, 1998). Con el fin de la Segunda Guerra Mundial se expandieron los volúmenes de captura al ritmo de las mejoras en las artes de pesca, la potencia de los buques y del instrumental para ubicar los cardúmenes. Además, los gobiernos de las potencias pesqueras de los países del Atlántico Norte, así como también de Japón, la entonces Unión Soviética y España, subvencionaron al sector para la construcción de buques con mayor potencia pesquera pudiendo pescar en zonas cada vez más alejadas.

Antes de proseguir, debemos señalar que la biomasa marítima no está equitativamente distribuida en los océanos. Al contrario, su distribución se corresponde con los movimientos de los vientos y las corrientes marítimas. Eso provoca la existencia de caladeros más ricos que otros. Las capturas mundiales de pescado se triplicaron durante las dos décadas posteriores a la Segunda Guerra. Esa expansión comenzó a arrojar signos de sobre pesca (Madaria, 1999). La situación provocó la intervención de las autoridades gubernamentales para regular la actividad y conservar los recursos. Ante la pesca en sus costas por naves extranjeras, Islandia fue el primer país en declarar en 1975 la Zona Económica Exclusiva (ZEE), abarcando 200 millas desde la línea de base de su territorio continental y estableciendo derechos de pesca soberanos dentro de ese espacio. ${ }^{34}$ Hacia 1982 la Convención de los Derechos del Mar otorgó a los países ribereños jurisdicción sobre la ZEE. Y a pesar de que el mar producía por aquellos años sólo del 1 al 2\% de las calorías que consumía la humanidad, mostraba un rápido crecimiento en la producción de proteínas animales (Idyll, 1983).

Para principios de los años '90s la mayoría de los recursos pesqueros estaban en el límite de su captura o sobre explotados (Holm, 1998; Litovsky, 2000).La Organización de las Naciones Unidas para la Agricultura y la Alimentación (FAO)estimabaque en 1996 la producción pesquera mundial alcanzó los 121 millones de toneladas. La entidad clasifica la producción pesquera en pesca de captura (marítima y continental) y producción acuícola (cultivo y cría de peces), suministrando los siguientes datos para aquel año:a) La pesca de captura:alcanzó los 94,6 millones de toneladas. Los países que registraron la mayor producción fueron China, Perú, Chile, Japón, Estados Unidos, Rusia e Indonesia (entre todos superaron más de la mitad del total). b) La pesca continental: la producción mundial alcanzó los 7,6 millones de

\footnotetext{
${ }^{33}$ La Ley N ${ }^{\circ} 24.922$ fue sancionada el 9 de diciembre de 1997 en un contexto bastante caótico y marcado por los enfrentamientos inter empresariales que tenían lugar durante la crisis pesquera. Hablaremos de ello en el capítulo IV. Finalmente las Cuotas Individuales Transferibles fueron reglamentadas por el Acta $N^{\circ} 48$ del Consejo Federal Pesquero y la Resolución de la Secretaría de Pesca $N^{\circ}$ 65/07 y 30/08 de los años 2007 y 2008. Luego, la Ley $N^{\circ} 26.386$, promulgada en mayo de 2008, modificó la Ley Federal N²4.922.

${ }^{34}$ Estados Unidos, Chile y Perú venían bregando por ello desde mediados de la década del '40 (Holm, 1998). Según Mateo (2003) el interés por delimitar en primer lugar las 12 millas como propiedad del país ribereño surgió en los Estados Unidos a instancia del presidente Truman en 1945, no por un interés pesquero sino por la intención de proteger las reservas de petróleo cercanas a las costas.
} 
toneladas. El principal productor fue China con 1,8 millones de toneladas. c) La acuicultura: representó el $20 \%$ de la producción pesquera mundial, siendo China y Japón los principales productores.

\section{Nacimiento y desarrollo de la industria pesquera argentina, 1900 - 1960}

La pesca comercial marítima Argentina nació en Mar del Plata, al incorporarse el litoral atlántico a la República Argentina en el último cuarto del siglo XIX, motorizada por la demanda de aquellos que disfrutaban de la villa turística y al poco tiempo por la del mercado de la ciudad de Buenos Aires (Mateo, 2004: 1). ${ }^{35}$

Esta actividad extractiva se vio relanzada en los años ' 30 s por el creciente consumo de pescado (en calidad de materia prima) que hacían los nuevos y numerosos establecimientos de elaboración de conservas. Si bien el comienzo del auge de las plantas conserveras fue producto del llamado proceso de "sustitución de importaciones" abierto en el país con la crisis del '29, fue el estallido de la Guerra Civil en España hacia la segunda mitad de la década del treinta lo que dio impulso efectivo a dicha actividad. Ésta aceleró su crecimiento, no sólo sustituyendo a España en el mercado local sino también en el mercado internacional (Mateo, 2005). Pero la pesca tuvo que esperar varias décadas hasta dar un salto cualitativo. En los años ‘40s, la Segunda Guerra Mundial y el desarrollo de la industrialización sustitutiva dieron el impulso a esa transformación, cuyas evidencias más notables fueron el logro de una nutrida flota pesquera, de una numerosa y eficiente población de pescadores de oficio y una pujante industria conservera que incentivó el incremento de los volúmenes de captura (Mateo, 2006). ${ }^{36}$

Desde su inicio y hasta nuestros días, la actividad pesquera en el país puede dividirse en dos grandes subperíodos, cada uno con características particulares. El primero, que describe su nacimiento y despliegue en la cita anterior, se desarrolló desde los inicios de la actividad hasta mediados de los años ' 60 s, teniendo preponderancia la pesca costera, al amparo del modelo sustitutivo de importaciones, con un desarrollo orientado al mercado interno, así como la generación de una incipiente industria en el procesado de anchoíta. Durante la Segunda Guerra Mundial se produjo la "coyuntura del tiburón" que significó, a través de un nicho de demanda en la exportación de aceite de hígado de tiburón utilizado como fuente vitamínica, el primer gran salto cualitativo de la pesca costera (Favero y Portela, 2005; Mateo, 2003, 2004 ; 2004, $2004^{\mathrm{c}}$; 2006; Masid y Mateo, 2008). Pasada esta euforia la actividad pesquera tanto en su faz extractiva como en su faz fabril, volvió a desarrollarse a partir de la tensa asociación entre la captura de pescadores costeros y la elaboración de los empresarios conserveros. Por estos años, la industrialización de pescado estuvo asociada, principalmente, a la elaboración de conservas de anchoíta y caballa. Así fue hasta fines de los '50s y principios de los ' $60 \mathrm{~s}$, momento en el cual la flota costera

\footnotetext{
${ }^{35}$ Sobre las costas del mar epicontinental de mayor extensión del hemisferio sur -que se extiende desde el paralelo de $33^{\circ}$ al de $55^{\circ}$ sur-, con condiciones de fertilidad óptimas para la pesca, se generó en la Argentina una única comunidad de pescadores digna de ese nombre en la ciudad de Mar del Plata (Mateo, 2003).

${ }^{36} \mathrm{Si}$ bien en su inicio la pesca se desarrolló vinculada al ocio y consumo de las clases altas, con el tiempo comenzó a ser incompatible con la idea de turismo que se manejó en aquel entonces. Los pescadores fueron desplazados hacia el barrio del Puerto, más que por una visión estratégica de la naciente actividad pesquera, persiguiendo el afán de ocultarlos ante los visitantes y eliminar un poco atractivo escenario visual y de olores que emanaba de aquella labor. En su inicio, y particularmente en la visión de "la elite", la actividad era considerada como un trabajo que hacían los pobres.
} 
empezaba a ser sobrepasada por la flota de altura y la producción conservera comenzó a perder importancia ante la producción de productos frescos y congelados (Bertolotti, 2001).

En los inicios de la década del ' 60 todavía la flota argentina estaba compuesta por embarcaciones costeras que abastecían casi exclusivamente al mercado interno. La estrechez de este destino de la producción fue una de las principales restricciones que condicionaron el crecimiento de la actividad (Pradas, 2006). La explicación de lo reducido del mercado interno en nuestro país suele relacionarse con el relativo fácil acceso a la carne vacuna como fuente de proteínas, debido a su alta disponibilidad y bajo precio relativo, que lo vuelve accesible al consumo de las clases populares. Por su parte, el consumo de productos del mar fue llevado a cabo fundamentalmente por los estratos más altos de la sociedad, siendo prácticamente un producto de lujo.

Los años '60s pueden considerarse como la transición al próximo período. Las distintas coyunturas favorables permitieron la expansión de la capacidad de captura de la flota. En 1961 se produjo un hecho trascendente en materia de procesamiento de pescado cuando se comenzaron a producir filetes frescos enfriados de pescado, especialmente merluza, en la ciudad de Mar del Plata. ${ }^{37}$ A partir de esta innovación, la industria del salado fue superada por la del congelado, al mismo tiempo que cambió la composición de la flota, la organización y tipo de trabajo al interior de las plantas pesqueras. Se incorporaron 41 embarcaciones nacionales y 15 importadas y el número de plantas procesadoras pasó de 25 en 1960 a 40 a mediados de la década. En 1963 por primera vez los volúmenes en los desembarques de la flota de altura superaron a la costera. Dicho desplazamiento fue también el de un cambio en la especie objetivo. En la pesca de anchoíta y caballa el papel preponderante lo tuvieron durante más de cuarenta años las "lanchitas amarillas”. En la pesca de merluza el rol central lo ocuparán los barcos más grandes y productivos, los buques de altura. Pero las transformaciones no culminaron ahí, antes bien, el proceso de desarrollo de esta industria fue acelerándose y pocos años después, durante los '70s, la flota sobrellevó una nueva mutación(Espoz Espoz, 1999; Mizrahi, 2001; Bertolotti et al, 2001; Masid, 2005; Pradas 2006; Nieto, 2012).

\section{Transformación y expansión de la industria pesquera, 1960 - 1980}

Hemos dicho que a partir de 1963 las capturas de la flota costera fueron superadas por las de los buques de altura, los cuales tuvieron como especie objetivo la merluza. El comienzo de un ciclo expansivo, donde adquirió importancia la reducción y exportación de harina de pescado que tuvo su auge entre 1966 y 1969 (Bertolotti et al, 2001), fue alentado por el Estado, que ahora sí intervenía en la actividad, brindando créditos a través del Banco Industrial de la República Argentina(Pradas, 2006). Además se sancionó el decreto 10.033/60 que subsidió la construcción de barcos en astilleros nacionales y el decreto 10.032/60 que permitió incorporar buques bajo el régimen de licencia arancelaria (Bertolotti et al, 2001).Sin embargo, la transformación en la flota no fue la única ni la principal. Con el cambio en la especie objetivo y los buques, también mutó la estructura fabril y el proceso de trabajo en la rama. Estos procesos se ven reflejados en las páginas del anuario estadístico pesquero:

\footnotetext{
${ }^{37}$ Hasta esta fecha el pescado se vendía entero y era el expendedor quien lo esviceraba y fileteaba.
} 
Notable capacidad se ha logrado en la industria de enfriamiento y congelación de pescados y mariscos y en las plantas elaboradoras de filetes, trozado, etc. en cuya producción se cifran grandes esperanzas...Este rubro [refrigeración y congelación de productos pesqueros] relativamente nuevo en el aspecto industrial se ha venido desarrollando con un ritmo ascendente y se espera aún una mayor demanda de productos eviscerados, trozados, etc. congelados o supercongelados, ya que constituye una forma moderna y cómoda de promover su venta... Hay muchas esperanzas fundadas en la expansión de esta nueva actividad de nuestra industria pesquera, por cuanto existe una demanda potencial grande para este tipo de productos en el extranjero en tanto compitamos en calidad y precios. $^{38}$

Para completar el escenario de la transformación en la actividad pesquera, a los cambios en la especie objetivo, los buques y el proceso de trabajo hay que sumarle una reorientación en el mercado de destino. Si previamente con la industria conservera el mercado principal era el nacional, con la industria fresquera el mercado dominante será el internacional. De esta forma quedaron grabados sus inicios en la estadística oficial:

Como brillante perspectiva dentro de la actividad pesquera nacional hay que destacar la exportación de algunas partidas de filet de merluza congelado... Es imperioso para la industria pesquera nacional la concreción de corrientes de exportación para sus productos como un medio para la consolidación económica de sus intereses... ${ }^{39}$

Pasemos ahora a ver estas mutaciones en números. Según la estadística oficial, en 1961 de las 1.333 salidas de los buques de altura 1.300 fueron dedicadas a la captura de merluza, especie que representó el 90,3 \% de las capturas de esta flota. Ese mismo año se introdujeron 7.175 toneladas de merluza en los establecimientos de fileteado y congelado existentes en el país, que entonces llegaban al número de 32. En ellos se produjeron 4.394 toneladas de merluza para comerciar, de las cuales 3.770 toneladas eran de filet de merluza. A lo largo de la década siguiente la actividad merlucera se desarrolló llegando a representar la principal actividad pesquera del país (Mateo, Nieto y Colombo, 2010).

Durante la década del '70 se produjo la expansión de la pesca. Aprovechando el proceso de deterioro de los principales caladeros extranjeros, se convirtió fundamentalmente en una industria volcada hacia el mercado mundial. Los distintos gobiernos desarrollaron incentivos de inversión que incluyeron desgravaciones impositivas, financiamiento, eliminación de aranceles a la importación de bienes de capital y subsidios a la construcción de barcos pesqueros en astilleros argentinos. De este modo, se incorporaron nuevas embarcaciones y se aumentó la capacidad de procesado en tierra. Dentro de la flota primó la compra de buques fresqueros, debido a que su precio se había reducido ante la aparición de los más poderosos barcos factoría. Dado que las principales potencias pesqueras habían prácticamente agotado sus caladeros cercanos, debieron construir buques con mayor nivel de autonomía, alcance y capacidad de almacenamiento. Ante ello, los buques fresqueros disminuyeron significativamente sus costos de venta y la legislación argentina permitió su incorporación con un régimen de licencias amparado en el decreto 440/71.Así, se incorporaron 74 buques fresqueros nuevos y usados, 6 buques procesadores congeladores y se construyeron 11 embarcaciones en astilleros nacionales. Como resultado

\footnotetext{
${ }^{38}$ Producción Pesquera, 1961, p. 81. Extraído de Mateo, Nieto y Colombo (2010)

${ }^{39}$ Ibídem, p. 3.
} 
de la expansión las capturas totales ascendieron en 1973 un 45\% con relación a 1970. Más significativo aún fue el crecimiento de las capturas de merluza que alcanzaron un 73\% más que el año base 1970 (Mizrahi, 2001). De ésta época son algunos instrumentos de política y administración pesquera de trascendental importancia en el futuro de la pesquería argentina. Entre ellos, la proclamación de la propiedad del Estado de los recursos vivos existentes en las zonas marítimas con soberanía argentina y la exclusividad de la explotación de los recursos pesqueros a las embarcaciones con pabellón argentino, con previo permiso otorgado por la autoridad competente. ${ }^{40}$ También el establecimiento de una zona común de pesca entre Argentina y Uruguay por el Tratado del Río de la Plata y su frente Marítimo. ${ }^{41}$

En la opinión de Pradas, este primer período de crecimiento prefiguró dos rasgos que perdurarían en la industria pesquera. Por un lado, un sector empresario dependiente de sus relaciones estrechas con el Estado. Esto es, siempre pendiente del reembolso a las exportaciones y a las facilidades financieras, como el subsidio al gas oíl y la manutención de un dólar elevado. Por otra parte, la integración al mercado mundial produjo una gran expansión inicial de la pesca argentina, pero también le fijó sus límites precisos por medio de los lazos de dependencia con la demanda mundial evidenciando la vulnerabilidad de un rama de la economía totalmente volcada hacia el mercado externo (Pradas, 2006). A cada retracción de ésta el sector pesquero atravesó por una crisis. Como explica un analista y marino militar:

El comportamiento de las capturas en Argentina está íntimamente relacionado con la tendencia de las exportaciones, al ser el consumo interno de productos pesqueros muy bajo, el mayor porcentaje de lo capturado tiene como destino abastecer los mercados externos. Cuando las exportaciones aumentan las capturas también lo hacen; una caída en las exportaciones (ya sea por una disminución en la demanda externa o por una situación interna desfavorable) va acompañada por una baja en las capturas. Exportaciones y capturas varían en igual dirección (Espoz Espoz, 1985).

Además, la pesca reprodujo desde entonces los problemas que presentan otros ámbitos de la economía de nuestro país. Esto es “...al no ser nuestro país formador de precios y exportar básicamente commodities y productos con escaso nivel de industrialización las coyunturas internacionales resultan factores determinantes para marcar sus periodos de prosperidad y crisis" (Rodríguez et al, 1999: 27).

Según Mizrahi (2001) a partir de 1976 Argentina dejó de ser un país con pesca para convertirse en una Nación pescadora. Se produjo el crecimiento del sector pesquero a través de un aumento significativo de las capturas y las exportaciones, con un cambio de perfil del empresariado y la incorporación de tecnología. Esta transformación debe entenderse en el contexto de convergencia de la actividad pesquera con los inicios del cambio de régimen de acumulación a escala mundial tendiente a la valorización financiera del capital que en la Argentina fue propiciado por las políticas económicas de la última dictadura cívico militar. ${ }^{42}$ Según Pradas, en Mar del Plata las Cámaras Empresarias nucleadas en la Unión del Comercio la Industria y la Producción (UCIP) ${ }^{43}$ fueron parte de una intensa actividad golpista en

\footnotetext{
${ }^{40}$ Ley $20.136 / 73$. Artículos 1 y 2.

${ }^{41}$ Sobre este tratado ver Lerena (2009).

${ }^{42}$ Este proceso significó el final definitivo del poderío de la pesca costera marítima, la cual ocupará un lugar cada vez más marginal en la composición de la flota nacional. Dice Mateo "La interrupción del estado de derecho que tuvo como herramienta a las fuerzas armadas y como resultado la represión más violenta de la historia del país fue el vehículo de instauración de otro modelo económico, el rentístico financiero. La economía basada en la apertura indiscriminada y el endeudamiento externo fue minando la economía real del país. La pesca costera no estuvo ajena a ese proceso" (Mateo, 2003: 18).

${ }^{43}$ Dada la estructura productiva marplatense, en el plano local tuvieron muy poco peso las entidades empresariales relacionadas con la producción agropecuaria (Sociedad Rural, CARBAP y Federación Agraria, principalmente). Si bien existieron (y existen
} 
contra del gobierno de Isabel Perón. Entre las iniciativas registradas se incluían la realización de documentos exigiendo un cambio en el modelo económico, así como la participación en el paro empresario de febrero de 1976. Una de las entidades asociadas erala Cámara Marplatense de Industriales del Pescado (Pradas, 2006). ${ }^{44}$ Para los industriales pesqueros el cambio significó el pasaje de créditos escasos, públicos, "atados" a programas de inversión, con tasas de interés fijas e inversiones externas de riesgo a la existencia de crédito privado abundante, prácticamente incondicional, de corto plazo (renovable), con tasas de interés variables (Cóccaro, 2000) y la posibilidad de avanzar sobre conquistas obreras a través de la vulneración del convenio colectivo de trabajo firmado en 1975 y el crecimiento de la vigilancia y disciplinamiento en el interior de las fábricas. ${ }^{45}$

El período que va de 1977 a 1979 ve una nueva expansión de la pesca frente a una demanda internacional sostenida y con precios en alza (Bertolotti et al, 2001). Entonces, las inversiones estuvieron alentadas por la nueva situación que volvió favorables los términos del intercambio. Además, la consolidación de la ZEEimplicó una mayor gravitación de los países poseedores de importantes reservas de recursos pesqueros. ${ }^{46}$ Esta constituyó la base para los acuerdos entre países con capacidad productiva pero con sus caladeros agotados y los países con recursos naturales, pero carentes de aquella capacidad. El mecanismo se convirtió en una de las formas que encontraron las potencias pesqueras para trasladar sus crisis internas (agotamiento de los caladeros, sobrecapitalización) a los países de capitalismo dependiente (Pradas, 2006; Lerena, 2009). La modalidad de incorporación de un nuevo modelo tecnológico y operativo se basó en la conformación de empresas conjuntas (joint ventures) con la participación de capitales internos y externos y la importación muy significativa de barcos procesadores (congeladores y factorías) ${ }^{47}$. Esta aparición de buques de mayor tamaño, importante equipamiento y mejoras en las capacidades de pesca se debió a la respuesta aplicada por armadores y Estados ante el agotamiento de caladeros próximos. Dado este hecho, numerosas potencias pesqueras necesitaron trasladarse allende sus mares para sostener el esfuerzo pesquero que venían realizando (Lerena, 2009). Y a partir de allí buscaron posibles caladeros donde realizar sus capturas. La legislación argentina desde 1977 vuelve a permitir la importación de buques sin aranceles. Y así como a partir de 1969 "sobraban" fresqueros en Europa y su venta en Argentina ayudó a la expansión de la explotación de la merluza, en

aún hoy) delegaciones zonales de estas entidades, las mismas no tuvieron una mayor relevancia. En todo caso, las entidades empresariales más importantes fueron precisamente las que representaban a los sectores más dinámicos del sistema productivo local: el comercio, la pesca y la construcción. En el caso de la UCIP se trata de una entidad gremial empresaria de segundo grado fundada en 1946 y que representa a distintas entidades empresariales vinculadas al comercio y la industria de Mar del Plata. Sobre la historia de la entidad ver Álvarez y Reinoso (1999). Estos autores sostienen que la UCIP es un claro ejemplo de cómo las entidades empresarias intermedias (que nuclean a pequeños y medianos empresarios) pueden desde el punto de vista gremial ejercer un alto grado de presión para el diseño de políticas económicas a nivel local y regional.

${ }^{44}$ Entre otros argumentos, UCIP justificaba su apoyo al paro empresario en una situación de grave emergencia nacional fundada en el "desamparo del ejercicio de los derechos y garantías constitucionales, legislación laboral causante de indisciplina, anarquia y baja productividad...".

${ }^{45}$ El grupo de trabajadores militantes organizados alrededor de la Comisión Memoria Portuaria menciona que personal militar ocupó en algunas plantas el rol de jefes de personal. Además, mencionan que muchos empresarios utilizaban usualmente la amenaza de llamar a la intervención de militares para solucionar algún conflicto surgido en la fábrica. Incluso señalan acuerdos salariales supervisados por personal de las Fuerzas Armadas. La Comisión, como producto de sus investigaciones, encontró además que son 40 los trabajadores desaparecidos vinculados con la actividad pesquera o naval en el Puerto de Mar del Plata (Comisión Memoria Portuaria, 2011).

${ }^{46}$ Para el año 1976 casi todos los países ribereños aplicaron las 200 millas como límite pesquero. Además se crearon la Secretaría de Pesca y la Secretaría de Estado de Intereses Marítimos del Ministerio de Economía. A su vez, se decretó una ley de promoción industrial que otorgaba reembolsos a las exportaciones de las empresas instaladas en el sur del paralelo 42 en la zona patagónica.

${ }^{47}$ Se construyeron 10 buques fresqueros en el país y se importaron 59 buques bajo régimen de licencia arancelaria, de los cuales 43 eran procesadores congeladores y 16 fresqueros. 
estos años empiezan a "exceder" los congeladores. Algunas empresas extranjeras recurrieron a la forma de asociaciones con empresas nacionales para poder penetrar las cláusulas de soberanía (Pradas, 2006). ${ }^{48}$

Entre 1975 y 1979 el valor de las exportaciones creció un $1.000 \%$ y el volumen un $330 \%$. Durante estos años, la reconversión industrial llevada a cabo por la gestión económica de Martínez de Hoz y el auge de los grupos concentrados de la economía argentina(Azpiazu, Basualdoy Khavisse, 1986) también se vio reflejada en la pesca. Se impulsó la creación de asociaciones y complejos exportadores en muchos de los cuáles tuvo intereses directos la Armada, como Alpesca (del grupo Alpargatas), Huemul (del grupo SASETRU), Argenbel ${ }^{49}$, etc. Todas las empresas ocuparon mayores aspectos dentro del proceso productivo (pesca, salado, congelado, fileteado) y se formaron empresas tipo Joint Ventures para explotar los recursos patagónicos (Pradas, 2006). ${ }^{50}$ Se alentaron estas actividades a partir de la ley $\mathrm{N}^{\circ} 21.608$ de Promoción Industrial, $\mathrm{N}^{\circ} 21.514$ de Concurso Internacional y $\mathrm{N}^{\circ} 21.382$ de Inversiones Extranjeras, otorgándose créditos y avales del BANADE para inversión y refinanciamiento de pasivos y créditos del Banco de la Nación para reembolsos a las exportaciones (Bertolotti, et al, 2001). En Mar del Plata, los grupos más fuertes combinaron plantas conserveras con frigoríficos, diversificando sus actividades productivas. Ventura abrió Esdipa, Mellino creó la conservera Mellino y el mar, Solimeno abrió una nueva planta procesadoraPoletti dio origen aEstrella de Mar (Pradas, 2006).

Por otra parte, mientras que hasta la década del '70 la provincia de Buenos Aires, y en particular la ciudad de Mar del Plata, representaban el lugar indiscutido de radicación de las fábricas y las embarcaciones, a partir de esa década los puertos de la Patagonia se transforman en espacios de asentamiento de establecimientos y barcos pesqueros. También creció la captura de otras especies como el calamar (Espoz Espoz, 1985; Mizrahi, 2001; Pradas, 2006).Las dos tendencias que exhibe la década en cuanto aparición y protagonismo de los buques factoría, así como la firma de convenios bilaterales, se acrecentaran en los ' 80 s y se difundirán en toda su magnitud en la década siguiente.

\section{La "reducción" del mar argentino, 1981-1989}

Durante los años '80sdeben destacarse dos principales que involucran a la actividad pesquera. En primer lugar, las islas Malvinas, después de la guerra y la derrota Argentina, pasaron de ser una "aparente" posesión colonial inglesa que se dedicaba a la cría de ovejas, a un enclave militar que, a través del cobro de cánones por permisos de pesca, comenzó a recibir importantes sumas de dinero. Pues inmediatamente finalizada la contienda bélica, el Reino Unido estableció una Zona de Exclusión que se extiende 150 millas marinas alrededor de las islas afectando la ZEE Argentina. En 1986 el límite se

\footnotetext{
${ }^{48}$ Según Pradas la fórmula de los Joint Ventures se manifestó como la mejor estrategia para superar las resistencias nacionalistas al capital extranjero.

${ }^{49}$ En torno de este proyecto pesquero hubo un fuerte escándalo donde se involucró a capitales belgas con el gobernador de la Provincia de Buenos Aires Ibérico Saint James, tristemente célebre por la frase "Primero mataremos a todos los subversivos, luego a sus colaboradores, después a sus simpatizantes, luego a los indiferentes y por último a los tímidos". Argenbel (que debe su nombre a la deriva de Argentina y Bélgica), a pesar de haber funcionado poco, recibió 6 millones de dólares en calidad de ayuda promocional. Finalmente presentaría su quiebra en 1985 teniendo como activo cuatro barcos (Pradas, 2006).

${ }^{50}$ Harengus es la pionera en los joint ventures y opera desde 1978. A partir de 1980 se instalan en la Patagonia Arbumasa, Pescasur, Argenova y Pescanova.
} 
amplió a 200 millas. ${ }^{51}$ De inmediato el gobierno de las islas comenzó a dar licencias a terceros países para explotar los recursos pesqueros, restringiendo la pesca de buques argentinos en la zona. ${ }^{52}$ Según un trabajo del INIDEP para 1986 el 54\% de los recursos de la zona patagónica quedaron fuera del alcance de la flota argentina. Su operatividad disminuyó drásticamente como consecuencia del conflicto, afectando seriamente a la flota de buques procesadores congeladores que en 1984 llegaron a operar al 50\% de su capacidad (Malaret, 1986, cit. en Bertolotti et al, 2001). Las cámaras de Armadores de Altura (CAABPA) y la Cámara de Procesadores de Pescado reconocieron, en 1984, el cierre de veintisiete plantas y el despido de más de dos mil trabajadores (Masid, 2005). Según Lerena (2009) los hechos políticos posteriores a la guerra de Malvinas modificaron el ecosistema, y con ello, la disponibilidad y volumen del recurso pesquero argentino. Mientras que el otorgamiento de licencias de pesca constituyó desde entonces el principal sostén económico de los isleños. ${ }^{53}$

En segundo lugar, y en lo que hace a convenios internacionales, en 1986 se firmaron los Acuerdos de Cooperación pesquera con la URSS y Bulgaria. ${ }^{54}$ Por su particularidad merecen que nos detengamos por un momento en ellos. La situación nos lleva al pasado, hacia la década previa, cuando el entonces Ministro de Economía José Ver Gelbard firmó en 1974 un acta de intención que promovió acuerdos pesqueros con la URSS, acta que no fue ratificada hasta que en los años 1976 y 1977 el gobierno de facto autorizó el ingreso de más de 30 buques congeladores y/o factorías rusos y polacos con bandera Argentina. En ese entonces la CAABPA se oponía al ingreso de barcos extranjeros sin mayor capacidad de torcer esa decisión (Lerena, 2009). Esos vínculos con la URSS en materia pesquera se profundizaron durante el gobierno de Raúl Alfonsín a través de la gestión del canciller Dante Caputo. Finalmente los convenios, conocidos como Acuerdos Marco, se firmaron en julio de 1986 con la URSS y Bulgaria y fueron aprobados en diciembre por el Congreso de la Nación. El objetivo declarado por el gobierno radical era reactivar la actividad pesquera argentina para lo cual se abría el caladero nacional a la pesca extranjera y, al mismo tiempo, se buscaba incrementar las capturas en el área de exclusión en torno a Malvinas. En aquel entonces se formaron Joint ventures entre la empresa búlgara Ribno Stopanstvo y las argentinas Galme Pesquera y Arpemar, mientras que una empresa soviética llamada Shovispan se asoció con las argentinas Bajamar, que representaba a Argenpez, Santa Elena y Estrella de Mar. La existencia de estos acuerdos desató un pugna entre el empresariado pesquero y su firma fue rechazada por aquellas empresas que quedaron fuera de ellos, dentro de las cuales se encontraba Ventura. A raíz de ello se produjo una división empresarial (Perrota, 2008). Quienes no participaron criticaron la iniciativa esgrimiendo una posición nacionalista contraria a la extranjerización de la pesca. En su último libro, Lerena señala que los acuerdos beneficiaron a unos pocos empresarios y perjudicaron a la mayoría. Por otra parte, en lugar de recibir el Estado Nacional el canon del 15\% que era el porcentual internacionalmente aceptado, sólo recibió un 3\%, mientras que el restante $12 \%$ lo cobró el gestor privado de la operación (Lerena, 2009). Además, señalaba el empresario Fernández López, si bien se estableció

\footnotetext{
${ }^{51}$ También contribuyó al "achicamiento" del mar argentino la expansión de la pesquería uruguaya tras la firma del Tratado del Río de la Plata y su Frente Marítimo efectivizada en 1974. En 1981, en la misma zona de pesca, Uruguay superó los desembarques totales y de merluza argentinos (Bertolotti et al, 2001).

${ }^{52}$ Sólo en 1987 había otorgado 204 licencias de pesca (Lerena, 1989). En 1989 fueron 335 (Lerena, 2009).

${ }^{53}$ A principios de la década del ' 90 las licencias de pesca generaban al gobierno de las islas alrededor de U\$S 40 millones de un presupuesto total de U\$S 60 millones. Ésta rama de la economía es la que permite a los isleños disponer del ingreso per cápita más alto de América.

${ }^{54}$ En 1973 se firmó el primer acuerdo de pesca con un país extranjero. El país fue Polonia, que a cambio se comprometió a construir una planta y un complejo pesquero en Puerto Deseado.
} 
una cláusula según la cual los buques extranjeros debían comprar a empresas argentinas sus insumos, ocurrió que se fijó de antemano de cuáles empresas se trataba, generando así una posición de privilegio. ${ }^{55}$

Por el lado gremial, se opusieron a los acuerdos la CGT regional Mar del Plata y los gremios pesqueros SOIP, SOMU, Patrones de Pesca. Más tarde se sumarían a la oposición el SICONARA y el SAON. ${ }^{56}$ Estos sectores gremiales, junto con los empresarios de la UCIP dispusieron un paro regional y movilización hasta el Palacio Municipal buscando hacer caer los convenios. La importancia de tal jornada se expresó en la participación de la "comunidad" marplatense en tal evento. ${ }^{57}$ Por el lado de la defensa e impulso de los Acuerdos, obviamente se expresaban la UCR y las empresas que adhirieron, pero también un consejo asesor gremial y el Partido Comunista. Éste último sostenía, en contra del paro decretado por la CGT, que "los grandes armadores - industriales han declarado la guerra a los acuerdos pesqueros firmados con Bulgaria y la Unión Soviética. La CGT regional al imponer el paro de mañana coloca a los trabajadores al servicio de los intereses de los grandes armadores". Y agregaba que el paro "resuelto a espaldas de los trabajadores, es una acción propatronal, reaccionaria y antipatriótica" "58. A su vez, Gran Bretaña presentó una protesta al gobierno argentino por la firma de los Acuerdos, a lo que el entonces Canciller Dante Caputo contestó "no vemos lo que puedan objetar los británicos, porque la Argentina firmó convenios pesqueros con los soviéticos de acuerdo a su capacidad soberana". ${ }^{59}$ Luego de esto, y como represalia, los malvinenses ampliarán su Zona Económica Exclusiva perjudicando a la Argentina. Tanto Pradas como Lerena sostienen que el balance de estos acuerdos fue "desastroso" ya que las capturas de la flota búlgara y soviética ascendieron de tal modo que se estuvo muy lejos de la conservación y racional explotación de los recursos, amén de que tampoco generó un proceso de desarrollo pesquero, ni incrementó los puestos de trabajo, ni incremento de valor agregado (Lerena, 1989; Pradas, 2006; Lerena, 2009). ${ }^{60}$

Otro cambio que trajo la década fue el comienzo de la explotación del langostino a partir del año 1982, pasó de ser hasta ese momento un recurso desconocido en la explotación comercial argentina, a

\footnotetext{
${ }^{55}$ L.C., 29/08/1989.

${ }^{56}$ Carlos Barboza (sec. General del SICONARA), Juan Manuel Rojas y Argimiro Agustín González (directivos del Centro de Patrones Fluviales de Pesca y Cabotaje Marítimo), Luis Francisco Comiso y Enzo Degregori del SAON, Eduardo Goyhenetche y Aldo Domínguez del SUPA integraban el Consejo Asesor Gremial. Carlos Barboza en calidad de vocero del Consejo, destacó que en principio "hay consenso en considerar estos acuerdos como algo positivo" dado que "pueden traer no sólo el avance de la industria pesquera, el mejoramiento de la tecnología y la entrada de capitales productivos, sino también trabajo a las plantas argentinas". Con el compromiso de las pesqueras rusas de comprar el $30 \%$ de sus capturas soviéticas en productos elaborados en el país "quizás se revierte la situación actual de subocupación, y la ocupación de la industria sea total". L.C.,16/07/1986. Luego aparecía como uno de los organizadores del paro en oposición a los Acuerdos.

${ }^{57}$ Adherían a la medida de fuerza por el arco gremial el SMATA, Pasteleros, Venturino (recolectores de residuos), judiciales, Sindicato de Choferes, SUPE, Asociación Bancaria, SAON, las 62 Organizaciones; por el arco político la Junta Comunal del Partido Demócrata Cristiano, el bloque de concejales justicialistas, la Juventud Peronista renovadora, la agrupación de Amas de Casa Marplatense, los integrantes de la lista Azul y Blanca Menem Presidente, el MAS y el Movimiento Renovador Justicialista que encabezaba el Senador provincial Roque Di Caprio.

${ }^{58}$ L.C., $13 / 10 / 1986$.

${ }^{59}$ L.C., $16 / 10 / 1986$.

${ }^{60}$ Diferente es la apreciación de Oscar Fortunato, en ese entonces Director Nacional de Pesca y participe de la firma de los acuerdos, quien argumenta que: "Lo que se hizo de los acuerdos fue una novela. Lo que demostraron es que con 18 barcos se podía pescar el mismo volumen de pescado que con toda la flota nacional. Eso daba cuenta de que algo se hacía mal. Porque si uno trabaja de manera ineficiente, para competir en el mundo, en algún momento aparecen los problemas. Este es el cambio importante. Este cambio le mostró a mucha gente. ¿¿Cómo? Yo estoy poniendo cuatro, cinco barcos, tanto tiempo, tanto combustible, tanto esto para traer lo mismo que puedo hacer con este barco. Y además este producto lo puedo reprocesar y hacerlo mucho mejor y mi fábrica trabaja. O puedo una parte reprocesarlo y una parte no'. A mucha gente se le empezó a abrir un panorama". Entrevista del autor con Oscar Fortunato gerente de CEPA y ex funcionario provincial y nacional del área pesquera (Mar del Plata, 23/04/2013).
} 
asumir el precio del llamado "oro marítimo" (Bertolotti, et al, 2001). En cuanto a la incorporación de buques a la flota nacional, fueron 78 embarcaciones. De los cuales 42 se construyeron en astilleros argentinos (4 de ellos procesadores) y 37 importados (32 procesadores congeladores y 5 fresqueros). No obstante, este aumento en la capacidad de explotación no se vio reflejado en un aumento significativo de los desembarques, que no alcanzaron a superar el máximo del período anterior (Bertolotti et al, 2001). Lo cual habla de una sobrecapitalización en el sector en relación a las capturas y rindes de la actividad. Según Pradas (2006) el alto valor internacional del langostino, agotado en Europa, fue lo que permitió "encubrir" la crisis de las empresas pesqueras durante buena parte de la década del '80, pudiendo la pesca sostenerse a pesar del la manutención de un dólar "alto" y la inflación de los costos internos.

Por último merece destacarse el proyecto de Pesca Experimental y Demostrativa que en los inicios de la década del '90 se convertirá en uno de los nuevos escándalos de la pesca. Mediante la resolución 1.111/88, donde se habilita a 12 firmas para operar con este sistema, buques de terceros países vinculados con empresas argentinas podían pescar en el mar argentino solamente en tareas de investigación. No obstante, los volúmenes que estos buques capturaron sobrepasaron ampliamente los fines investigativos. Y lo capturado se vendía en el mercado sin pagar impuestos, ni aranceles, ni agregar valor, ni generar puestos de trabajo. Varias opiniones consideraron que el sistema sólo se trataba de "una trampa" para otorgar permisos de pesca "disfrazados". Antes de alejarse del gobierno, Luis Jaimes firmó nuevas autorizaciones para el ingreso de buques, siendo alrededor de 40 barcos los que pescaban en esa situación. ${ }^{61}$ Esto motivó nuevas denuncias. Entre ellas, el titular del SOIP Abdul Saravia aseguraba que se capturaron demasiados recursos con 20 buques comerciales extranjeros. Captura que equivalía a 51 millones de dólares que no ingresaron al país y sobre los cuáles no se abonó impuesto alguno. Poco tiempo después, y por acción del juez federal de Río Gallegos Dr. Alfredo Bustos, la situación se tramitó en la justicia con el dictado de la prisión preventiva de varios funcionarios radicales. Entre ellos el secretario Luis Jaimes, el ex administrador de aduanas Juan Delconte y la ex directora nacional de pesca Liliana Márquez, disponiendo de un embargo de 40 millones de pesos de los bienes de los procesados. Fallo que fue confirmado por la Cámara Federal de Comodoro Rivadavia. Finalmente, el sistema de pesca experimental fue denunciado y se resolvió su nulidad bajo el gobierno justicialista.

La "larga década" del '90: crisis, quiebras, reestructuración, récord de exportaciones, sobrepesca y de nuevo crisis.

\section{a. Crisis, quiebras y reestructuración}

A finales de la década del '80 la pesca se veía envuelta en un cuadro complicado, dado particularmente por la caída de los precios internacionales de pescado. Roberto Tovo, entonces presidente de la CAABPA, se quejaba del tipo de cambio retrasado que conspiraba "contra cualquier politica de exportación", así como de los altos costos de los salarios de las tripulaciones y del combustible. ${ }^{62}$ Además el Plan Primavera constituyó un duro golpe para la actividad. La preocupante situación llevó a reunirse a

\footnotetext{
${ }^{61}$ L.C.,01/07/1989.

${ }^{62}$ Revista Redes, $\mathrm{N}^{\circ}$ especial, cuarto aniversario, año 1989, p. 34.
} 
los titulares de CAPECA, CAABPA y Procesadores, quienes se quejaban de la clasificación de la pesca como actividad agropecuaria, lo que además de desconocer su estructura industrial y económica -decían-, implicaba un nivel de retenciones del 15,5 por ciento para las exportaciones, la exclusión del régimen de importación de bienes de capital y del régimen de devolución de impuestos, a lo que se sumaba -para agravar el cuadro-, el incremento de los costos internos por la inflación. La Cámara de Armadores de Pesqueros Congeladores (CAPECA) envió por ello una misiva al presidente Raúl Alfonsín manifestando su queja por el encuadramiento de la actividad. ${ }^{63}$ Ya comenzado el año 1989 Homero Cánepa, entonces presidente de la Cámara Argentina de Procesadores, se quejaba: "Hoy la situación de nuestro sector es particularmente dificil porque la politica económica fijada por el gobierno nacional ha derivado en una notable pérdida de la paridad cambiaria con el dólar". Y la situación se presentaba como más grave debido a la disminución de entre un 10 o 20 por ciento de los precios de los productos pesqueros en el mercado mundial. ${ }^{64}$ Un mes después, volvía a sostener tales apreciaciones y solicitaba que la opinión de los industriales pesqueros sea escuchada por el Gobierno. También pedía que se promuevan las inversiones de quienes tienen plantas elaboradoras en tierra que aportan un "alto valor agregado" a los productos exportados. ${ }^{65}$

El año 1990, ya bajo el gobierno de Carlos Menem, mostraba que a pesar del recambio gubernamental las condiciones que arrojaban a la pesca al escenario de una crisis lejos de haberse atemperado, se habían agravado. Una nota enviada por la CAABPA al entonces titular de Economía Erman González brindaba un diagnóstico, siempre desde la mirada de los industriales pesqueros, bastante interesante. Allí informaban al Ministro, con copia al subsecretario Felipe Solá, sobre "La grave situación" que atravesaba el sector exportador pesquero. Señalaban que "la situación es debida al incremento sostenido en los costos internos de producción sin que esto fuera compensado por una variación en la paridad cambiaria efectiva". Ello "ha llevado a una distorsión en la ecuación económico financiera de las empresas, con pérdidas significativas en la rentabilidad, que amenaza con la continuidad de la actividad productiva". Detallaban los incrementos en los costos del combustible, del hielo, de la carga y descarga, del polietileno, del flete, de la tarifa eléctrica, de las cajas de cartón y el precio mayorista no agropecuario. Mientras -decían-la subida del dólar se mantiene por debajo de esas cifras y no llega a compensar. Además la "fuerte dependencia del sector externo" hace a la actividad "vulnerable a los retrasos de la paridad cambiaria que afecta en forma directa sus ingresos". E insistían en que la distorsión originada en la alteración de la relación costos - ingresos no podía:

...ser resuelta por las empresas presionando sobre un mercado [internacional] que no acepta la transferencia de las distorsiones internas de nuestra economía como el incremento de los precios en dólares de los insumos, tarifas, servicios, como también la fuerte presión impositiva que soporta el sector en el orden nacional y provincial. ${ }^{66}$

También mencionaban los perjuicios de las retenciones que oscilaban entre un 6 y un 16 por ciento dependiendo del producto. Y renovaban las quejas ya que en la devolución de impuestos internos, "erróneamente la actividad pesquera no ha sido considerada como un sector industrial", por lo que

\footnotetext{
${ }^{63}$ Revista Redes, № 38, año 1988, "Riesgo de quebranto por las medidas económicas", p. 19 a 21.

${ }^{64}$ L.C. $19 / 02 / 1989$.

${ }^{65}$ L.C., 17/03/1989.

${ }^{66}$ L.C., $26 / 07 / 1990$.
} 
solicitaban se la tenga en cuenta dentro del régimen del decreto $1.555 / 86$. Por último, se pedía el cumplimiento de devolución de IVA y la eliminación de las retenciones a las exportaciones. Por entonces, el periodista dedicado a economía Daniel Muchnik publicaba en el diario Clarín un artículo dónde recogía las preocupaciones de los industriales pesqueros. Afirmaba que:

Si bien la industria pesquera coloca en el exterior en estos momentos alrededor de 300 millones de dólares anuales, en los últimos dos meses se patentiza un especial estancamiento, motorizado por el incremento de los costos de producción, por el estancamiento de la paridad, por el aumento de la presión fiscal nacional y provincial [...] por la incidencia de los derechos de exportación, con la suspensión del pago de algunos rembolsos regionales y por la generalización del IVA. ${ }^{67}$

Dificultaba la realidad de los industriales lo que consideraban un incremento desmedido del precio del combustible. La nota de Muchnik recogía de la preocupada voz de "los perjudicados" una aparente intención oficial por reducir el sector instalado a "la mínima expresión" y autorizar, paralelamente, el ingreso de naves con bandera extranjera. La Capital se hacía eco de la situación y bajo el título "Entrarían en concurso varias firmas pesqueras" señalaba con preocupación la existencia de "Una crisis de impredecibles consecuencias [que]amenaza a la industria pesquera de nuestra ciudad, a partir de la decisión de varias de las más importantes empresas locales de presentarse en convocatoria de acreedores". Y mencionaba como principales problemas la presión de los organismos oficiales y entidades bancarias sobre esas empresas, la "crítica situación" derivada de las pérdidas determinadas por la constante baja del dólar, y el aumento de los costos, entre ellos los salariales. ${ }^{68}$

De visita por Mar del Plata el Presidente Menem se encargaba de "poner en caja" a los industriales de la pesca. Sobre la crisis en la actividad y las numerosas empresas que estaban presentándose en convocatoria de acreedores decía con irónica firmeza:

Los empresarios, inclusive los industriales de la pesca, nos han pedido hasta el cansancio esta economía de mercado. Ahora lo tienen. El precio del dólar lo fija el mercado en forma libre. Pero yo les diría a los industriales de la pesca que hagan más eficiente sus actividades, que bajen un poco más los costos y que hablen más del austral que últimamente se ha revalorizado. ${ }^{69}$

Y fue el senador Mario Cámara, quien previamente se había reunido con industriales pesqueros que apoyaban la política económica en marcha, el hombre que, aclarando que no se daría ningún tipo de subsidios, definía claramente la situación del sector:"crecerá el que está desarrollando y acepte las reglas". ${ }^{70}$ Del resto, se puede suponer que se esperaba...

\section{b. “Empresarios ricos con empresas pobres?”}

Hacia finales de 1990 y durante todo el año 1991 se sucedieron en la industria pesquera una "catarata" de cierres de empresas. Ello provocó la toma y ocupación de numerosas plantas por parte de los trabajadores que buscaban, primero continuar en sus puestos de trabajo y luego, mucho más

${ }^{67}$ El Clarin, 12/08/1990.

${ }^{68}$ L.C.,30/11/1990.

${ }^{69}$ L.C., $15 / 12 / 1990$.

${ }^{70}$ L.C., 16/12/1990. 
resignados, cuanto menos cobrar las indemnizaciones. Desde la dirigencia sindical se acusó a las empresas de "vaciamiento" y "maniobras" patronales (ver Capítulo IV).En ese marco, integrantes de la Lista Verde del SOIP, mencionando la crítica situación que vivían los obreros del pescado, señalaban:

...el grave problema laboral en el que estamos inmersos la mayoría de los trabajadores como consecuencia del cierre de más de 50 fábricas, desde el principio del año 1989 hasta mayo de 1990 y 14 establecimientos más desde agosto de 1990. Estamos soportando suspensiones injustificadas y despidos masivos, como el reciente del compañero Ramón González, quien se postulaba para secretario general de la lista Verde [...] lo que es peor todavía, es el no cobrar los haberes que legítimamente tenemos ganados con muchos sacrificios, porque muchos de estos malos empresarios se borraron y otros argumentan razones de fuerza mayor para suspendernos.

Por la gravedad de los hechos, solicitaban al Gobierno su pronta intervención para encontrar una solución a este "oscuro panorama que ya para nosotros es insostenible" dado que la situación afectaba a más de 3.000 obreros. $^{71}$

La dramática situación de los trabajadores que de un día para otro se quedaban sin trabajo llevó a Abdul Saravia, secretario general del SOIP, a exponer al presidente Carlos Menem tal situación. El dirigente gremial menciona que durante el año se dieron 2.156 despidos. Y la suma podía incrementarse a partir de las quiebras de las empresas Arpemar (450 obreros), Frigocen (300 obreros) y Delcipa (70 obreros), significando ello un alto porcentaje de desocupación respecto de la capacidad ocupacional media de la industria del pescado, que alcanzó en su apogeo a 15.000 obreros. Por eso solicitó "ante la similitud del conflicto de Acíndar, igual solución de subsidio estatal, ante la acuciante situación de los obreros desocupados por recesión económica e insensibilidad patronal". ${ }^{72} \mathrm{Al}$ día siguiente, le enviaba una nota similar al entonces gobernador de la provincia de Buenos Aires Eduardo Duhalde. ${ }^{73}$ En el mes de julio, era la pesquera San Andrés la que se presentaba a remate. Allí Saravia decía:

Nosotros estamos cada día más preocupados por las cosas que están pasando en la pesca como en el caso de este remate, en el que se vislumbra la próxima quiebra de la empresa [...] Denunciamos a los corruptos que llevan a las empresas a la convocatoria y a la quiebra; corruptos que sabemos lo que ganan a través de las exportaciones y después hunden las empresas en operaciones en que no se pagan obras sociales y en las que quedan obreros en la calle. ${ }^{74}$

Días después, presentaba su quiebra la firma Tomar. De ella dependían cerca de 500 personas. Era una planta subsidiaria de la también quebrada Mar Azul, cuyo director era Roberto Tovo, quien había sido gerente de la CAABPA. ${ }^{75}$ La problemática llegaba hasta las cumbres del poder municipal. Por un lado, los trabajadores de una empresa cerrada se movilizaban hasta la sede del Palacio de Gobierno pidiendo la intervención del Concejo Deliberante. ${ }^{76}$ Por otra, el mismo día, el intendente radical Ángel Roig, luego de haber recibido a los industriales pesqueros, se entrevistaba con la Coordinadora de

\footnotetext{
${ }^{71}$ L.C., 10/01/1991.

${ }^{72}$ L.C., $16 / 05 / 1991$.

${ }^{73}$ L.C. $17 / 05 / 1991$.

${ }^{74}$ L.C., 03/07/1991.

${ }^{75}$ L.C., 09/07/1991.

${ }^{76}$ Analizamos este ciclo de movilizaciones en el Capítulo IV.
} 
Gremios Marítimos. Allí Carlos Barboza, del SICONARA,quien también era titular del Honorable Concejo Deliberante local en calidad de concejal por el PJ,le advertía al jefe municipal que "quienes más están sufriendo la crisis son los trabajadores, ya que los empresarios paran sus fábricas pero se quedan con su capital". El dirigente denunciaba además que los obreros estaban siendo víctimas de "una maniobra" que daba por resultado la existencia de "empresarios ricos con empresas pobres". Aclaraba que "Hemos sufrido un total vaciamiento de nuestra industria pesquera, desaparecen los responsables y quedan las industrias paradas". Por ello le pedía a Roig que se agilicen las figuras jurídicas que están contempladas en dar continuidad a las empresas con la ayuda y control de los trabajadores para que, cuando se decidan las causas judiciales de venta o cuando dispongan los jueces, "estas empresas no queden en la ruina y la gente en la calle". Barboza además anunciaba que "impulsaremos un proyecto desde el cuerpo deliberativo para que la comuna pueda suspender por un tiempo prudencial el pago de los impuestos o las tasas correspondientes a los vecinos trabajadores de Mar del Plata que estén afectados por la crisis de la industria pesquera". En aquel entonces el intendente manifestó al menos buenas intenciones, argumentando que lo que él podía aportar:

...es una voluntad que haya acuerdos de partes y que esta actividad siga teniendo sede en Mar del Plata, porque ni la Provincia de Buenos Aires ni la Municipalidad se pueden permitir que en vez de ir las actividades creciendo, se produzcan cierres de fábricas, quiebras de empresas cuando la desocupación es uno de los males que más nos aflige y el problema social que acarrea a toda una comunidad, evidentemente cada día se ensancha más. ${ }^{77}$

Días después, el SOIP enviaba una carta documento a Marcelo Regúnaga, entonces Secretario de la SAGyP y, por tanto, funcionario responsable del área pesquera,informando sobre la crisis por la que atravesaban los obreros nucleados en esta organización gremial debido al incesante cierre de fábricas. Dice el texto firmado por Saravia "notifico a usted los numerosos cierres de fuentes de trabajo con posterioridad a la firma del acuerdo con las cámaras empresarias. Denuncio con ello incumplimiento(sic) mantener nivel de ocupación. Solicito que tome las medidas correspondientes". ${ }^{78}$ Mientras, Barboza cumplía con llevar al tema al Concejo Deliberante. Los ediles solicitaron que las plantas pesqueras en conflicto continúen con su labor como forma de "resolver en parte la grave situación social por la que atraviesan los trabajadores -4.000 están sin empleo-, y por otra, aportar soluciones tanto para las empresas como para la masa de acreedores". Los concejales calificaron la situación como "muy grave". Barboza informó además que "como hemos venido denunciando, los empresarios no han tenido un manejo transparente de sus negocios", reafirmando que "sobre un bien que pertenece a todo el pueblo, son ellos los que obtienen importantes ganancias". ${ }^{79}$ Dos días después, concejales de diferentes bancadas se hicieron presentes en los Tribunales locales y se entrevistaron con la presidenta de la Cámara de Apelaciones en lo Civil y Comercial, María Lettieri De la Colina, a quien le solicitaron que arbitre medidas tendientes a dar continuidad laboral a las empresas en quiebra que se encontraban en relación con la "delicada situación social" que afronta la actividad pesquera. ${ }^{80} \mathrm{Y}$ el día 25 de aquel mes el HDC aprobó por mayoría un proyecto de resolución mediante el cual se solicitó a la

\footnotetext{
${ }^{77}$ L.C., 12/07/1991.

${ }^{78}$ L.C. $15 / 07 / 1991$.

${ }^{79}$ L.C., $18 / 07 / 1991$.

${ }^{80}$ L.C., $20 / 07 / 1991$.
} 
Justicia la reapertura de las plantas pesqueras. ${ }^{81} \mathrm{Sin}$ embargo, todas esas gestiones fueron inútiles. En agosto de 1991 Saravia denunciaba lo que llamaba la "industria de la quiebra". Decía de algunos empresarios pesqueros:

Hay muchos que tienen miedo a la justicia, a propósito de la ley tributaria, y han preferido la quiebra de sus establecimientos como en el caso de Poletti o Marypez SA en donde participa Jorge y Héctor Antonio, a quienes este sindicato ha denunciado en reiteradas oportunidades. ${ }^{82}$ No sólo han quebrado empresas estafando a los obreros, sino que han aprovechado las legislaciones vigentes formando sociedades anónimas que están integradas por la mujer, los amigos, hijos y algunas amigas, entre otros socios. ${ }^{83}$

A pesar de ésta situación con las empresas, visto desde las estadísticas de capturas, desembarques y exportaciones, la pesca parecía no sufrir inconvenientes. De hecho, el nuevo ciclo de expansión pesquera terminaría en niveles récord para la actividad.

\section{c.Laquiebra de empresas pesqueras}

"Si hubiera sabido que esto era quebrar, hubiese quebrado antes"

Francisco "Paco" Ventura

Las transformaciones ocurridas en la pesca durante los años '90s se iniciaron con las quiebras de principios de la década. Previamente algunas empresas pesqueras se habían declarado en convocatoria de acreedores. No obstante, a partir de 1990eran las principales empresas pesqueras que operaban en el fresco las que se declaraban en quiebra. Se decretaron en quiebra o entraron en convocatoria de acreedores, dentro de las firmas más tradicionales, Estrella de Mar S.A., Mediterránea S.A., Ventura SAMCI, Ventura Mar del Plata S.A., Frigocen S.A., Pesquera San Andrés, Tomar S.A., Mar Azul S.A., Arpemar S.A., Bolívar S.A., Marypez S.A. y Hielo Nevada S.A.Entre los grupos que cayeron en desgracia se encontraban Arpemar y Ventura, dato significativo cuando sabemos que ambos habían sido líderes en las exportaciones en 1982 y 1986 respectivamente (Pradas, 2006). ${ }^{84}$ Desde los sectores empresariales se justificaron las quiebras por la caída de la demanda externa de pescado argentino, la presión de los costos internos, la fuerte presión fiscal y el elevado tipo de cambio. En la visión de un trabajo elaborado por economistas locales, se explica el cierre de empresas por:

\footnotetext{
${ }^{81}$ L.C., 25/07/1991.

${ }^{82}$ Gabriela Cerruti en su biografía sobre Menem (Cerruti, 1994) vincula a Saravia con Jorge Antonio. Norma Mira y "Cachito" Rodríguez, colaboradores de Saravia, sostienen que las inferencias de la biógrafa del entonces Presidente eran totalmente equivocadas, desligando completamente al sindicalista del empresario peronista. Ellos cuentan que durante la presentación del mencionado libro en Mar del Plata, Saravia se hizo presente y luego de escuchar la charla, levantó la mano e interpeló directamente a la autora del libro acerca de dichas inexactitudes. Tras lo cual compartieron una cena conversando acerca del contenido del libro. Entrevista del autor con Norma Mira, colaboradora de Saravia en el SOIP y militante del PJ (Mar del Plata, $06 / 12 / 2012)$

${ }^{83}$ L.C., 06/08/1991.

${ }^{84}$ Revista Redes, № 57, año 1991, p. 36.
} 
...la implementación de un nuevo modelo económico nacional, con una política de recaudación fiscal más estricta que elevó la presión tributaria y exigió el saneamiento de deudas previsionales e impositivas de larga data, además de la suspensión del crédito oficial para financiar déficits operativos así como el control bancario minucioso de su cartera de deudores para el cumplimiento de sus obligaciones y para el otorgamiento de nuevos créditos (Gennero et al, 1997).

Este proceso generó la caída de aquellas empresas que no pudieron adaptarse y la reconversión por parte de las que sobrevivieron, utilizando estrategias fundamentalmente de reducción de los costos laborales, pero también de integración horizontal y vertical, así como la asociación con capitales externos. ${ }^{85}$ En la interpretación que brinda Pradas (2006), las quiebras se dieron entre las empresas que habían contado con el favor oficial del Estado, que al cambiar de política económica y no brindarles apoyo crediticio para salvar sus pasivos, adoptaron como estrategia empresarial el vaciamiento, retiraron masivamente sus capitales y remataron plantas y barcos. De esta manera, no saldaron sus deudas ni con el Estado, ni con los trabajadores(al respecto ver el capítulo II).

No obstante, lo cierto es que a pesar de estas caídas,en el desarrollo de las exportaciones nacionales las quiebras pasan desapercibidas. Pues se estaba produciendo en paralelo un cambio en la industria pesquera dado por el hecho de que por primera vez en la historia de la actividad se equipararon las capturas de las flotas fresqueras y congeladoras. Según Pradas (2006) al crecimiento congelador por la incorporación de nuevos barcos, hay que sumarle la caída definitiva de las empresas puramente fresqueras. Basándonos en los volúmenes de capturas y exportaciones las quiebras en los años 1989, 1990 y 1991 pasan inadvertidas.Mientras en Mar del Plata algunas de las empresas tradicionales entraban en convocatoria de acreedores y quebraban, la tendencia nacional mostraba un continuo crecimiento tanto de capturas como de exportaciones. Éstas últimas en miles de dólares fueron de 293.123 para 1989; 323.754 en 1990; 406.532 en 1991 (Mizrahi, 2001).

Otra parte de la explicación hay que buscarla en que el año 1990 fue excelente para las empresas congeladoras del sur. Pradas menciona el demostrativo caso de Harengus. Con plantas propias en Puerto Madryn y Puerto San Julián. A sus 5 barcos propios se le suman otros 11 en joint ventures con empresas extranjeras. Con 34 millones de dólares, lideró la exportación pesquera en aquel año. Harengus es una de las primeras empresas que opera integrada y servirá como modelo para las empresas nacionales que sobrevivieron en los '90s. Ya entonces se dedicaba a la pesca con fresqueros y congeladores, además de tener diversificadas las especies y artes de pesca y lograr, mediante la asociación con empresas extranjeras, llegada a diferentes mercados compradores con rebajas arancelarias aprovechando la red comercial de la empresa asociada. Por último, de nuevo según Pradas (2006), la gestión judicial que se hizo cargo de las quiebras trabajó para facilitar la concentración de capitales en menos manos. ${ }^{86} \mathrm{Al}$

\footnotetext{
${ }^{85}$ La dificultad de adaptarse a funcionar dentro de una economía estable, con elevados requerimientos financieros derivados de las ventas a plazo, con altos costos de producción en dólares y siendo tomadoras de precios internacionales genera una situación que no permite ineficiencias internas obligando a las empresas a la búsqueda de estrategias de reestructuración frente a los profundos cambios experimentados (Gennero de Rearte, De los Santos y Graña, 1997: 56).

${ }^{86}$ La "justicia" aparece insistentemente denunciada en diferentes intervenciones respecto a su participación en lo que Muleiro (2000) definió como "desmanejo pesquero". En relación al accionar judicial en el caso concreto de dos empresas, un periodista señala "Si con los permisos hubo complicidad del poder político de turno, en la causa de la quiebra de las empresas pesqueras Argenbel primero, y Estrella de Mar después, es el poder judicial el que deliberadamente abrió grietas durante más de 23 años para mantener en vigencia lo espurio, lo inválido, lo improcedente e ilegal. Y si con los permisos truchos hubo grandes beneficiarios y cuesta encontrar víctimas, tal vez porque somos la sociedad en su conjunto la estafada con las maniobras, y
} 
respecto, un informe de la Revista Redes expresaba que "Tras una oleada de quiebras, la gestión judicial concretó ventas y alquileres que movilizaron nuevamente el parque pesquero marplatense. Sin embargo, no faltaron suspicacias ante la disparidad de criterio entre los síndicos y la infaltable presencia de los 'influyentes" "87.

\section{d.EI ciclo expansivo, 1989-1997}

Llegados a la década del '90, podemos asegurar que el desarrollo histórico de la pesca ha estado marcado por un funcionamiento cíclico que implicó fases expansivas, en las que se incrementaban las capturas, crecían las inversiones y la financiación estatal, para comenzar luego su contraparte, dominado por recaídas en crisis más o menos profundas. Esos ciclos se visualizan en el siguiente cuadro.

CuadroN $^{\circ}$ 1. Ciclos de la industria pesquera argentina, $1966-2000$

\begin{tabular}{cc}
\hline Años & Ciclo \\
\hline $1966-1967$ & Expansión \\
$1968-1969$ & Crisis \\
$1970-1974$ & Expansión \\
1975 & Crisis \\
$1977-1979$ & Expansión \\
$1980-1981$ & Crisis \\
$1982-1987$ & Expansión \\
$1988-1990$ & Crisis \\
$1991-1997$ & Expansión \\
$1998-2000$ & Crisis \\
\hline
\end{tabular}

Fuente: elaboración propia en base a Espoz Espoz (1985), Bertolotti et al (2001) y Pradas (2006)

Conocer este funcionamiento cíclico de la actividad permite entender mejor la situación producida en la década del '90. En 1989, y mientras aún persistían los factores que habían vuelto a sumergir a la pesca en el centro de una nueva crisis, el aumento del esfuerzo pesquero condujo a un crecimiento sostenido de las capturas con un máximo de 1.371.077 toneladas en el año 1997. Hemos dicho que desde la perspectiva de análisis de capturas y exportaciones las quiebras pasaron desapercibidas, asistiendo entre 1990 y 1997 a un ciclo de fuerte expansión. Pero no se trató de cualquier expansión. La década se caracterizaba por transformaciones de carácter estructural en la industria pesquera, uno de cuyos resultados fue el crecimiento colosal del esfuerzo pesquero que tuvo su correlato en el incremento de la cantidad de capturas.

porque al ser todos, no somos nadie, acá en la quiebra de estas empresas marplatenses hay rostros bien visibles donde se expone la estafa y el engaño" (Garrone, 2009)

${ }^{87}$ Revista Redes, № 60, año 1992, p. 73. "El laberinto jurídico". 


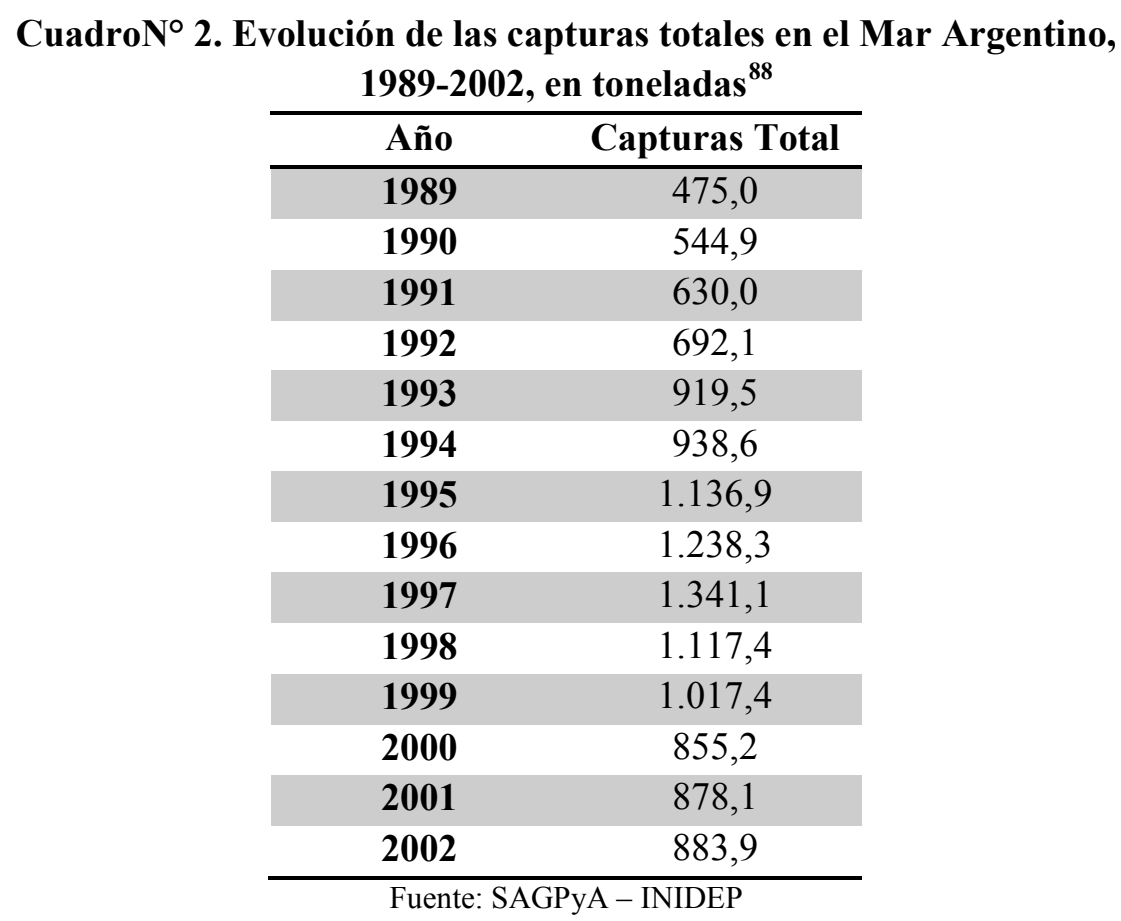

Hasta mediados de la década del '80 las capturas totales de pescado en el Mar Argentino habían llegado a un récord que rondaba las 450 mil toneladas. Como muestra el cuadro anterior, la década del '90 comienza con la superación de las 500 mil toneladas y llega casi a triplicar los volúmenes históricos hacia 1997.Un salto importante se produce entre 1992 y 1993 . Mientras que a partir de 1998 se evidencia una merma en las capturas, descenso que mantiene la tendencia a la baja hasta el año 2001. También las exportaciones muestran una evolución en el mismo sentido que las capturas.

\footnotetext{
${ }^{88}$ Debemos destacar que estas cifras arrojan el resultado de la pesca declarada. No se computan descartes a bordo, transbordos en alta mar, sustituciones de especies, ni capturas no declaradas. Además hay que señalar que el sistema estadístico oficial presenta déficits e irregularidades que hacen a las cifras efectivamente obtenidas sean de un valor estimativo. De todos modos, adoptando un criterio "conservador", según el cual el cálculo siempre es el de mínima, el margen de error juega a favor de reforzar las hipótesis aquí planteadas (Godelman et al, 1999).
} 


\section{Cuadro $N^{\circ}$ 3. Exportaciones pesqueras en Toneladas y Dólares. \\ Total Nacional, 1990-2002}

\begin{tabular}{cc}
\hline Año & Dólares \\
\hline $\mathbf{1 9 9 0}$ & 323.753 .000 \\
$\mathbf{1 9 9 1}$ & 406.531 .000 \\
$\mathbf{1 9 9 2}$ & 484.605 .000 \\
$\mathbf{1 9 9 3}$ & 636.579 .000 \\
$\mathbf{1 9 9 4}$ & 724.841 .080 \\
$\mathbf{1 9 9 5}$ & 914.270 .018 \\
$\mathbf{1 9 9 6}$ & 999.913 .073 \\
$\mathbf{1 9 9 7}$ & 1.025 .844 .244 \\
$\mathbf{1 9 9 8}$ & 881.315 .605 \\
$\mathbf{1 9 9 9}$ & 794.140 .429 \\
$\mathbf{2 0 0 0}$ & 838.086 .404 \\
$\mathbf{2 0 0 1}$ & 825.372 .429 \\
$\mathbf{2 0 0 2}$ & 711.553 .561 \\
\hline
\end{tabular}

Fuente: Revista Redes-Letter, extraído de Lerena (2009)

Este inusitado crecimiento alentaba el optimismo de algunos funcionarios del área pesca que se mostraban orgullosos por el volumen de exportaciones record. ${ }^{89}$ Sin embargo, hay que decir que las cifras que se obtenían por las exportaciones no eran el resultado de una política de desarrollo pesquero que buscara agregar valor al producto exportado, sino que se trataba del incrementó en forma desmedida el esfuerzo pesquero a través de la incorporación de una gran cantidad de buques, sobre todo congeladores, con una mayor potencia de pesca. De hecho, el valor de la tonelada exportada de pescado en 1997 era de \$1.294 dólares, cifra similar a la que se obtuvo en 1990 (\$1.269 dólares). Monto que se incrementa "artificialmente" por el alto valor de la tonelada de langostino (Lerena, 2009).Simples datos que indican que el crecimiento no se sostuvo en procesos que implicaran mayor elaboración en los productos. Veremos más adelante que esta política de "minería pesquera" (Cóccaro et al, 1999) terminará ahogando a la pesca en una de las peores crisis de su historia. Pero antes veamos otros procesos que, si bien se habían insinuado a partir del golpe cívico militar de 1976, ahora se desarrollaban en toda su magnitud. Entre ellos, el declive relativo del puerto de Mar del Plata como terminal pesquera.

\footnotetext{
${ }^{89}$ El entonces secretario de la SAGyP, Marcelo Regúnaga, anunciaba en agosto de 1991 un récord en las exportaciones. Al mismo tiempo aseguraba que como consecuencia del programa económico en marcha "se empiezan a sentar las bases para construir una industria pesquera agresiva y competitiva internacionalmente". L.C.,16/08/1991. El día anterior, trabajadores de la pesca cesantes y/o suspendidos, habían organizado la denominada "Marcha del Hambre". Sobre ella ver el capítulo IV.
} 


\title{
e.EI declive (relativo) del puerto marplatense
}

\begin{abstract}
“...nuestra realidad, la de Mar del Plata, es que estamos desapareciendo dentro de una actividad importantísima actual y de futuro como industria, y esto acarreará a la economía de la ciudad una gran desventaja comparativamente con quienes están eligiendo el sur del país". Ángel Roig. UCR. Intendente Mar del Plata, 1983-1991.
\end{abstract}

Hasta comienzos de la década del ' 70 , el 90\% de todas las actividades de pesca marítima de altura, media altura y costera tenían base en Mar del Plata (Cepparo et al, 2007). Como destacamos anteriormente, durante el gobierno de la última dictadura cívico militar se intentó dar impulso a otras regiones para que desarrollaran la actividad pesquera. La ley de promoción industrial $\mathrm{N}^{\circ} 21.608 / 77$ bajo la gestión económica de Martínez de Hoz, buscó incrementar las inversiones extranjeras y la formación de sociedades mixtas o asociaciones temporales contando con el apoyo de créditos del Banco Nacional de Desarrollo para fortalecer las actividades económicas. Entre ellas, se incluyó la pesca (Pradas, 2006). Vale recordar que este tipo de legislación que buscaba el impulso económico de la Patagonia mantenía una línea de continuidad con la discontinua pero tradicional política pública Argentina que intentaba por medio de incentivos suplir las "deficiencias" regionales que esta zona mantenía respecto del resto del país, dadas por las inclemencias del clima, las grandes distancias, el escaso poblamiento, etc. Sin embargo “...hasta 1980 una de las características principales de la evolución fue la concentración casi exclusiva en el Puerto de Mar del Plata como consecuencia de la disponibilidad, abundancia y accesibilidad de los recursos pesqueros y de la cercanía y comunicación con la ciudad de Buenos Aires" (Mizrahi, 2001: 3). Recordemos, además, que en Mar del Plata residía (y reside aún) la única fuerte comunidad pesquera de Argentina (Mateo, 2003).

En 1983 la ley $\mathrm{N}^{\circ} 23.018$ sobre reembolsos a las exportaciones realizadas por puertos patagónicos buscaba continuar el desarrollo de los puertos del Atlántico Sur. La normativa establecía que el porcentaje de los reembolsos aumentara de norte a sur patagónico, desde San Antonio Oeste hasta Ushuaia, según la localización del puerto de embarque. De allí que Santa Cruz fue una de las provincias más beneficiadas por su ubicación geográfica más austral. No obstante, la incorporación real de la Patagonia meridional correspondió más a las iniciativas privadas, comenzadas a fines del siglo XIX e incrementadas en el siglo XX que a los incentivos otorgados por el Estado argentino, dadas las limitaciones de las políticas de fomento que, en la mayoría de los casos, estaban más desarrolladas en los discursos que en las acciones concretas (Cepparo et al, 2007).Lo cierto es, y en lo que a nosotros respecta, que de esta forma comenzó a producirse el crecimiento de los puertos del Atlántico Sur que fueron favorecidos por leyes de reintegro del IVA a las exportaciones, propiciando la radicación de plantas pesqueras en las provincias de Río Negro, Chubut, Santa Cruz y Tierra del Fuego. A ello le siguió un proceso de dinamismo en las localidades costeras, donde comenzaron a instalarse actividades derivadas de la pesca, incrementándose el asentamiento de nuevos pobladores. De hecho, varias empresas instaladas en la Provincia de Buenos Aires pronto descubrieron beneficios de, en algunos casos, expandirse también a localidades del sur y, en otros, directamente radicarse allí..$^{90}$

\footnotetext{
${ }^{90} \mathrm{El}$ hecho aparece denunciado con insistencia por dirigentes gremiales. Por ejemplo Carlos Trasante del SOMU, en medio de la crisis de 1988-1990, denunciaba el "vaciamiento" de las empresas:"Se radican empresas fantasmas en el sur para pedir subsidios, que luego cierran, como acaba de ocurrir con Alpesca en Madryn que dejó 450 personas sin trabajo”. L.C.,21/07/1990. En 1991
} 
La vigencia de esta normativa se extendió hasta 1995, año en que fue prorrogada por Ley $\mathrm{N}^{\circ}$ 24.490 hasta $1999 .{ }^{91}$ Esta ley modificaba la anterior y fijaba que se mantendrían los mismos porcentajes por el término de cinco años, comenzando a disminuir a partir del 1 de enero de 2000 en un punto porcentual hasta su desaparición. Puerto Madryn, gozaría en el año 2000 del 8\%, Puerto Deseado del $11 \%$, Ushuaia del 13\%. Sin embargo, en agosto de 1996, apremiado por los efectos de la crisis del Tequila, el entonces Ministro de Economía Domingo Cavallo, a través de una circular de la Administración de Aduanas, eliminó los reembolsos para los productos pesqueros. No obstante, oportunos fallos judiciales permitieron que continúen los reembolsos para aquellas empresas que poseyeran plantas procesadoras que trabajan en la elaboración del pescado. Por otra parte, también los puertos patagónicos se vieron mayormente beneficiados que los bonaerenses por la reducción de cargas sociales implementadas por el gobierno nacional a través del decreto $\mathrm{N}^{\circ} 2609 / 93$. Mientras la reducción era de un 70\% para un barco patagónico, un barco bonaerense llegaba solamente a un 40\%. ${ }^{92}$

Un informe de la Secretaría de Programación Económica del Ministerio de Economía de la Nación indica que entre 1988 y 1993, en gran medida como consecuencia de la vigencia de la ley de reembolsos, las cuatro provincias marítimas patagónicas aumentaron sus exportaciones de productos pesqueros en $275 \%$, mientras que en el mismo período el total de las exportaciones patagónicas se incrementaba en un $141 \%$ y las exportaciones pesqueras de la provincia de Buenos Aires lo hacían sólo en un 31,6\% (Cepparo et al, 2007).En 1994, Ámbito Financiero señalaba que Mar del Plata, que llegó a desembarcar el 80\% de las capturas nacionales a finales de la década del 70', en 1986 redujo esa participación al 60\% y en 1993 a tan solo el 34,1\%. ${ }^{93}$ Para 1997 se mantenía en el 33\%. Por el contrario, Puerto Madryn que venía de un 9\% de participación en 1989 asciende en 1997 a un 25\%. ${ }^{94}$ En 1994 una nota de la Revista Redes señalaba con preocupación que "la pesca marplatense se achica peligrosamente". ${ }^{95}$ En ella, el empresario Antonio Di Leva, entonces presidente de la CAABPA, expresaba:

No hace mucho, la flota pesquera de altura tenía operando más de cien embarcaciones y hoy no pasan de cincuenta. De 30.000 personas que directa o indirectamente estaban ocupadas por la

\footnotetext{
también directivos del SOMU acusaban que mediante "maniobras desleales denunciadas oportunamente las empresas van cerrando en Mar del Plata y trasladan las mismas con otros nombres al sur del país...". L.C.,25/06/1991.

${ }^{91}$ El fomento de desarrollo de puertos patagónicos fue leído por los industriales de la provincia de Buenos Aires como una situación de inequidad. Lo declaraban abiertamente Antonio Di Leva y Homero Cánepa que mencionando un complejo panorama de la pesca marplatense, señalaban que "El sector se encuentra actualmente reducido en un 60 por ciento y las empresas que están operando en estos momentos lo hacen con un gran esfuerzo, porque tienen sustanciales desventajas comparativas con relación a las provincias patagónicas". Por ello, insistentemente pedirán ser incluidos en los regímenes de devolución de impuestos o ser favorecidos por reembolsos a las exportaciones. Los argumentos principales que esgrimían para ser considerados eran de dos órdenes. Por el lado geográfico, señalaban que no se debía tener en cuenta el puerto de partida de los buques sino el lugar donde los buques operaban, que era más o menos similar para todas las empresas. E incluso desventajoso para los bonaerenses porque las distancias que recorrían los buques hasta las zonas de pesca eran mayores que las transitadas por los patagónicos. Segundo, el pedido se fundamentaba en que el criterio para ser incluidos en los reembolsos no debía ser geográfico sino relacionado con el agregado de valor a la materia prima y la mano de obra empleada, la cual era mayor en las empresas que poseían plantas de procesado en tierra. En este último sentido, se pedía que los reembolsos fueran por productos que antes de ser exportados mantenían algún proceso de elaboración. Ver Revista Redes № 76, año 1994, p. 12, 14, 16 y 18.En junio de 1994 el ex intendente de la ciudad, y entonces diputado nacional, Ángel Roig, presentaba -sin mayor éxito- un proyecto a la cámara baja, que incluía a los puertos bonaerenses en el reembolso a las exportaciones. L.C.,08/06/1994.

${ }^{92}$ Esto motivó nuevas quejas de empresarios pesqueros bonaerenses. Revista Redes, № 76, año 1994, p. 18.

${ }^{93}$ Ámbito Financiero, 23/05/1994.

${ }^{94}$ Sobre la distribución geográfica de las capturas y desembarques pesqueros en la Argentina ver el sitio web del Ministerio de Agricultura, Ganadería y Pesca (http://www.minagri.gob.ar), Bertolotti et al (2001b), Llosa (2003), Pradas (2006), entre otros.

${ }^{95}$ Revista Redes No 76, año 1994, p. 12, 14, 16 y 18 . "Mar del Plata pelea por sobrevivir".
} 
actividad, hoy no tenemos más de 9.000. Más allá de cualquier discurso, esa es la realidad estadística de la pesca marplatense. ${ }^{96}$

No obstante tal descenso, hay que decir que la primacía de las capturas continuó siendo superior en el puerto de Mar del Plata que en el resto de los puertos pesqueros. Además, las capturas se incrementaron hasta el año 1996, reduciéndose por debajo de las 300 mil toneladas sólo en el crítico año 2000. Por ello, la caída es más relativa que absoluta.

\begin{tabular}{|c|c|c|}
\hline \multicolumn{3}{|c|}{$\begin{array}{c}\text { CuadroN }^{\circ} \text { 4. Capturas totales y Puerto de Mar del Plata } \\
\text { Años } 1989 \text { - 2002, en miles de toneladas }\end{array}$} \\
\hline Año & Capturastotales & Capturas MdP \\
\hline 1989 & 475,5 & 306,8 \\
\hline 1990 & 544,9 & 291,0 \\
\hline 1991 & 630,0 & 301,9 \\
\hline 1992 & 730,9 & 309,7 \\
\hline 1993 & 919,5 & 323,9 \\
\hline 1994 & 983,7 & 331,7 \\
\hline 1995 & $1.136,9$ & 441,1 \\
\hline 1996 & $1.238,3$ & 481,7 \\
\hline 1997 & $1.341,1$ & 442,0 \\
\hline 1998 & $1.117,4$ & 346,2 \\
\hline 1999 & $1.017,4$ & 307,1 \\
\hline 2000 & 855,2 & 260,2 \\
\hline 2001 & 878,1 & 373,3 \\
\hline 2002 & 882,9 & 392,7 \\
\hline
\end{tabular}

Fuente: Sub. de Pesca y Acuicultura. Mateo, Nieto y Colombo (2010)

Por último, debemos señalar que la caída relativa del puerto de Mar del Plata debe incluir una variable de análisis más, la cual termina de completar el cuadro de la realidad pesquera argentina durante la década del '90. Así como creció la participación de las provincias patagónicas en la pesca, este crecimiento también debe relacionarse con las transformaciones operadas en la flota nacional. Pues es precisamente en las provincias del Atlántico Sur donde se incorporaron el grueso de los buques procesadores congeladores y factoría. De este modo, las mutaciones de la década implicaron asimismo una modificación profunda en la participación en capturas y exportaciones de la flota industrial pesquera, resultando de ello una pérdida de importancia muy fuerte por parte del puerto marplatense, que quedó conformado preponderantemente por la flota fresquera y el procesado en tierra. Aunque esta situación no descartó la existencia de grupos económicos que participaron de ambos sistemas productivos y mantuvieron una doble localización, región patagónica y Mar del Plata (lo veremos en próximos apartados), es esta última ciudad la que concentró aproximadamente el 80\% de la flota fresquera.

\footnotetext{
${ }^{96}$ Revista Redes $\mathrm{N}^{\circ} 76$, op. cit... p. 12.
} 


\section{f.Cambios en la flota industrial}

En materia industrial la preponderancia del sistema productivo de pesca con fresqueros y procesamiento en tierra fue perdiendo importancia dentro de la flota que operó en el caladero argentino. El paso a un tipo de extracción con buques congeladores y factoría con procesado a bordo y mayor capacidad de bodega creció en términos absolutos. Esta transformación tuvo su impacto sobre el caladero nacional considerando las diferencias, que en su relación con la actividad pesquera, posee cada sistema. Según indican los integrantes del Grupo de Economía Pesquera del INIDEP, desde 1989 la incorporación de buques a la flota industrial estuvo dirigida a aquellos que mejoraran la eficacia de las operaciones. Como consecuencia se produjo un profundo cambio en la actividad, con la incorporación a la matricula nacional de buques congeladores con artes de pesca específicas (tangones, palangres y poteras), congeladores con procesos delimitados (elaboración de surimi) y modificación de algunos congeladores arrastreros para adoptar artes selectivas. Ello no implicó que desaparecieran los buques fresqueros y costeros. Pero sí, así como en la década del sesenta los buques fresqueros de altura superaron por primera vez a los desembarques de la flota costera constituyendo una de las más importantes transformaciones en la estructura pesquera del siglo XX,será en esta década cuando las capturas de los procesadores congeladores y factoría superen por primera vez los desembarques de los fresqueros. El siguiente gráfico nos permite identificar esta evolución.

Gráfico 1. Capturas totales de Fresqueros y Congeladores en el mar argentino. ${ }^{97}$ Años 1989 - 2002, en toneladas

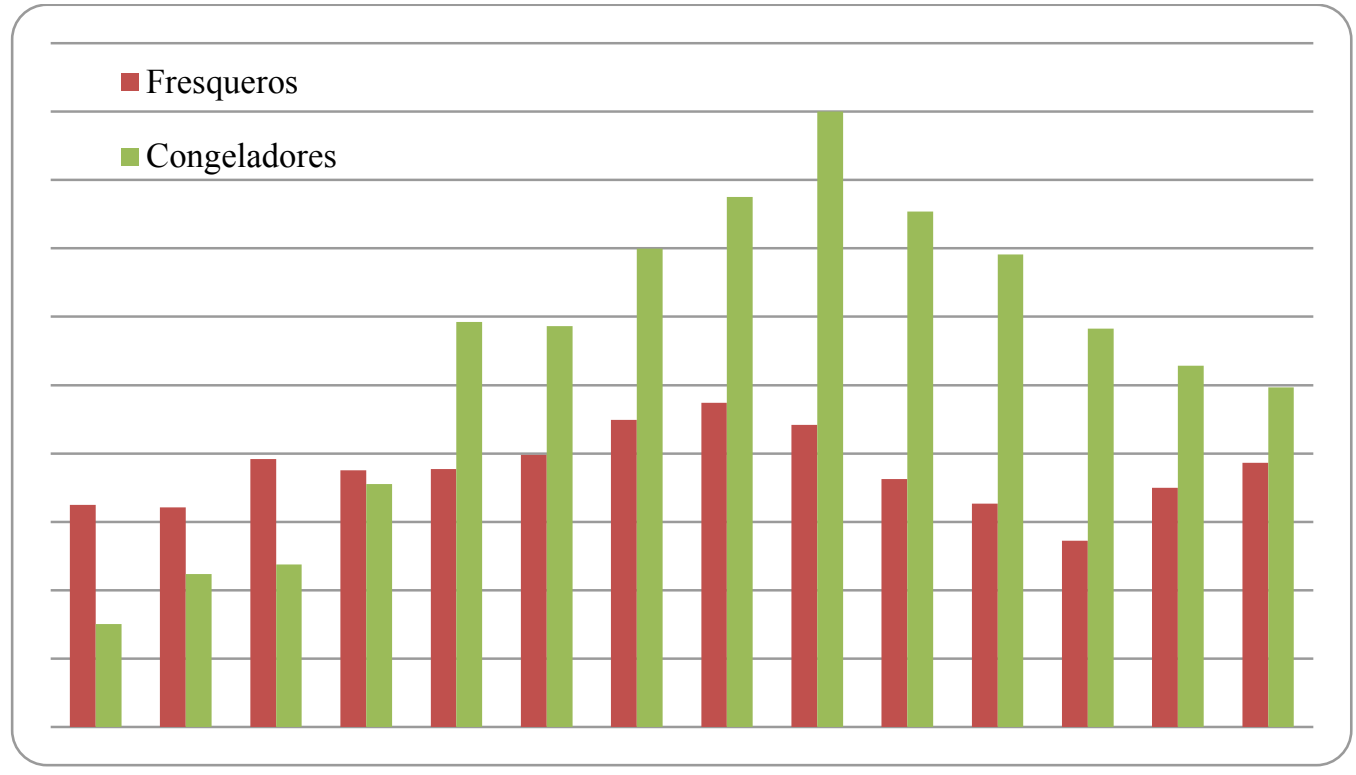

Fuente: Sub. de Pesca y Acuicultura. Mateo, Nieto y Colombo (2010)

Como muestra el gráfico precedente, los fresqueros mantuvieron sus capturas dentro de niveles cercanos a las líneas de 300 y 400 mil toneladas (disminuyendo levemente en el crítico año 2000), con un pico de 473 mil toneladas en el año 1996. Mientras que los congeladores mostraron un más contundente

\footnotetext{
${ }^{97}$ Las capturas computadas como fresqueros incluyen las de la flota de rada y ría y la flota costera.
} 
crecimiento, pasando de 150 mil toneladas en 1989 a las casi 900 mil de 1997. La cifra se ensancha en proporciones si extendemos el período de observación hacia atrás. Hasta 1977 no había prácticamente buques congeladores operando en el caladero nacional. Tras su ingreso, ya al año siguiente (1978), aparecen capturando en porcentajes poco más del 20\% del total capturado por la flota nacional (el $50 \%$ correspondía a los fresqueros puros y el restante 30\% a la flota costera). Veinte años después, en 1998, los porcentajes se habían modificado profundamente. Los congeladores capturaron poco más del $63 \%$ por ciento contra un $22 \%$ de la flota fresquera y un $15 \%$ de la flota costera (Bertolotti et al, 2001). Este salto en las capturas producidas principalmente por el accionar de la flota congeladora no sólo se corresponde con la mayor capacidad pesquera de los mismos, sino también con el incremento de la cantidad de buques congeladores operando en el mar argentino.

CuadroN ${ }^{\circ}$ 5. Buques de la flota pesquera Argentina.

Fresqueros, Congeladores procesadores y total, años 1988 - 2000

\begin{tabular}{cccc}
\hline Año & Fresqueros & $\begin{array}{c}\text { Congeladores } \\
\text { procesadores }\end{array}$ & Total buques \\
\hline $\mathbf{1 9 8 8}$ & 147 & 75 & 222 \\
$\mathbf{1 9 8 9}$ & 146 & 82 & 228 \\
$\mathbf{1 9 9 0}$ & 152 & 100 & 252 \\
$\mathbf{1 9 9 1}$ & 151 & 128 & 279 \\
$\mathbf{1 9 9 2}$ & 141 & 170 & 311 \\
$\mathbf{1 9 9 3}$ & 135 & 198 & 333 \\
$\mathbf{1 9 9 4}$ & 136 & 221 & 357 \\
$\mathbf{1 9 9 5}$ & 134 & 247 & 381 \\
$\mathbf{1 9 9 6}$ & 135 & 272 & 407 \\
$\mathbf{1 9 9 7}$ & 132 & 282 & 414 \\
$\mathbf{1 9 9 8}$ & 133 & 278 & 411 \\
$\mathbf{1 9 9 9}$ & 132 & 244 & 376 \\
$\mathbf{2 0 0 0}$ & 127 & 211 & 338 \\
\hline
\end{tabular}

Además de visualizar el crecimiento del total de buques que operaron en el caladero nacional, el cuadro 5 nos permite adivinarla relación entre las existencias de buques fresqueros y congeladores. Por una parte, se evidencia el descenso que se mantiene constante de la operatoria de buques fresqueros durante la década comprendida. Al contrario, se nota el aumento, bastante súbito por cierto, de buques congeladores procesadores que, en 1997, llegan a incrementarse casi en cuatro veces con relación al año 1988. En términos comparativos, los buques congeladores representaban el 34\% de la flota industrial en ese mismo año, mientras que en 1997 pasan a representar el 68\%, marcando así la importancia de su presencia en el caladero argentino. ${ }^{98}$ A su vez, si miramos su lugar en los desembarques de pescado vemos también esa creciente influencia.

\footnotetext{
98 A comienzos del año 1997, y luego de conocerse que las exportaciones pesqueras superaron los mil millones de dólares, Francisco Romano, titular de la Sociedad de Patrones Pescadores, relacionaba críticamente ese récord con la operatoria exclusiva
} 


\section{CuadroN ${ }^{\circ}$ 6. Desembarques de pescado por tipo de flota y total}

Años 1988 - 2000, en miles de toneladas

\begin{tabular}{cccc}
\hline Año & Fresqueros & Congeladores & Total \\
\hline $\mathbf{1 9 8 8}$ & 245,5 & 131,7 & 377,2 \\
$\mathbf{1 9 8 9}$ & 212,7 & 150,4 & 363,1 \\
$\mathbf{1 9 9 0}$ & 229,6 & 223,8 & 453,4 \\
$\mathbf{1 9 9 1}$ & 218,3 & 237,8 & 456,2 \\
$\mathbf{1 9 9 2}$ & 252,6 & 346,4 & 599,1 \\
\hline $\mathbf{1 9 9 3}$ & 265,8 & 476 & 741,8 \\
$\mathbf{1 9 9 4}$ & 263,7 & 463,6 & 727,3 \\
$\mathbf{1 9 9 5}$ & 288,2 & 616 & 904,2 \\
$\mathbf{1 9 9 6}$ & 307,8 & 682,1 & 989,9 \\
$\mathbf{1 9 9 7}$ & 286,1 & 781,2 & $1.067,30$ \\
$\mathbf{1 9 9 8}$ & 258 & 725,1 & 983,1 \\
$\mathbf{1 9 9 9}$ & 206,4 & 532,2 & 738,6 \\
$\mathbf{2 0 0 0}$ & 179,5 & 460,2 & 639,7 \\
\hline
\end{tabular}

En lo que respecta a los desembarques, podemos ver en principio que en términos generalesestos siguen el desarrollo de las capturas y exportaciones, incrementándose desde 1988 hasta 1997, cuando comienzan a decaer hasta el año 2000, final de la serie que presentamos. En una segunda instancia, se produce una diferenciación en los desembarques provenientes de la flota fresquera, los cuales se muestran más o menos constantes, mientras que el crecimiento notable le corresponde a la operatoria de la flota congeladora. Estos buques comienzan la serie por debajo de los desembarques fresqueros en 1989 (131,7 Tn de buques congeladores contra 245,5 Tn de fresqueros), realizando incrementos significativos que los ubican con un total de781,2Tn en 1997, superando ampliamente las 186,1 Tn de los fresqueros en el mismo año. Por último, la capacidad de pesca se mide en HP. Siguiendo a Godelman et al (1999), quienes aportan cifras sólo para los años 1991-1996, durante estos años la tasa de crecimiento de congeladores es de casi 28.000 HP por año, contra 3.100 anual de los buques fresqueros. Es decir que la tasa de crecimiento de la potencia pesquera durante aquellos años fue 9 veces mayor para los congeladores respecto de los fresqueros.

Hemos visto ya el crecimiento vertiginoso de las capturas y las exportaciones, el declive relativo del puerto de Mar del Plata y las transformaciones en la composición de la flota. Ahora nos queda mostrar cómo todo ese proceso desembocó en una de las principales crisis del sector pesquero argentino.

de los buques congeladores. Decía "no hay que olvidarse que ese cifra récord la han pescado los congeladores. Esto va en detrimento de la mano de obra en tierra y lo esencial para proteger el recurso, es dar mano de obra en tierra y que se pesque con los barcos convencionales. Porque si llenamos el mar de buques congeladores, aseguro que en dos años no tenemos más nada". L.C.,02/01/1997. 


\section{g. La crisis de la industria pesquera, 1997-2000.}

"La luz de alarma se encendió de pronto y como para siempre: no habia más merluza y todo lo que había sido eficacia, crecimiento y divisas se convirtió en su contrario porque empezó a escasear el pescado más popular, el que más le interesa a España, el que se consume en el débil mercado interno, el que más importa y se exporta" Vicente Muleiro, año 2000.

\section{g.1.Elincremento del esfuerzo pesquero}

En 1986 un estudio del INIDEP señalaba que "la explotación del recurso merluza común se encuentra a niveles próximos al rendimiento máximo sostenible", mientras que "existe un sobredimensionamiento de la flota pesquera habilitada para operar sobre la especie" (Verazay y Otero, 1986). Por ello la SAGPyA dispuso a partir de este momento, que a todo buque que ingresara al caladero argentino se le podría extender una licencia pero con exclusión de acceso a la merluza (Godelman, 1999). En 1989, al asumir el gobierno justicialista, se designó como interventor del INIDEP a Oscar Lazcano. Éste, a poco de ocupar el cargo, señalaba su preocupación "en cuanto a que quizá estemos excedidos en las capturas que estamos realizando". A través de la investigación del Instituto se encontraron "síntomas alarmantes" en cuanto a las reservas pesqueras de algunas especias como pescadilla, corvina y merluza. Por esto declaró que "tenemos prendida una alerta", advirtiendo que hay condiciones que nos "llevan a decir que hay que ser muy precavidos en el futuro en la explotación de estos recursos". 99

En marzo de 1990 los integrantes del Consejo Interprovincial Pesquero (delegados de Buenos Aires, Santa Cruz, Chubut, Río Negro y Tierra del Fuego), con el aval de gremios, Cámaras y legisladores nacionales alertaron que "los recursos pesqueros existentes en las 200 millas están sobre los límites de capturas permisibles". ${ }^{100}$ Señalándose como agravantes la pesca en la zona de exclusión de Malvinas y la pesca en el borde de la milla 200 por parte de potencias extranjeras. En octubre de ese año tuvieron lugar en Mar del Plata las Jornadas Internacionales de Pesca 1990, de las que participaron funcionarios gubernamentales y una comitiva de la Comunidad Europea. Una de las conclusiones fue que "En todos los mares del mundo, incluyendo el argentino, se está al borde de la sobrepesca, por lo que los países con gran litoral marítimo deben buscar opciones, antes de que el daño ecológico sea irreparable". ${ }^{101}$ Por ello el consejo era que la extracción no debía incrementarse. En noviembre el diario La Capital titulaba una nota "La depredación llega a niveles alarmantes". Allí señalaba:

La depredación en el Mar Argentino, debido a la incursión de barcos extranjeros pero también por el comportamiento de algunos pesqueros argentinos, llega actualmente a niveles más que alarmantes, según coincidieron en destacar ayer representantes de diversos sectores involucrados en la actividad, reunidos en el Instituto Nacional de Investigación y Desarrollo Pesquero. ${ }^{102}$

\footnotetext{
${ }^{99}$ L.C., 15/09/1989.

${ }^{100}$ L.C., $24 / 03 / 1990$.

${ }^{101}$ L.C., 02/10/1990.

${ }^{102}$ L.C. $27 / 11 / 1990$.
} 
En 1994 el INIDEP afirmaba que "los valores estimados para 1992 y 1993 [de las mortalidades por pesca] han alcanzado niveles tan altos que se considera improbable que la pesquería pueda mantenerse durante un tiempo prolongado" (Godelman, 1999: 14).

Sin embargo, y a pesar de tal situación, la política pesquera se orientó exclusivamente a potenciar las capturas generando un notable aumento del poder de pesca (Madaria, 1999). El propio Felipe Solá, secretario de la SAGPyA en dos períodos, afirmó que "La pesca, hasta 1997 fue manejada con el criterio del crecimiento. Toda la economía apuntaba a la competitividad y el eje eran los propios empresarios. Habia que ayudarlos a exportar, a renovar la flota..." (cit. en Muleiro, 2000: 3). Al mismo tiempo, la apertura del mar argentino a flotas extranjeras -que ya vimos a partir de la firma de los Convenios Marco con la URSS y Bulgaria a mediados de los '80s-, avanzó en esta década, impulsada en el comienzo del nuevo gobierno justicialista desde la Cancillería, bajo la titularidad de Domingo Felipe Cavallo y acompañada por todos los secretarios del área. ${ }^{103} \mathrm{En}$ este marco, fueron dos medidas concretas las que favorecieron el incremento de la flota extranjera asociada con determinadas empresas locales.

A pesar de todas las advertencias que indicaban no era conveniente el ingreso de buques al caladero nacional, en 1992 se aprobó el decreto de charteo $N^{\circ}$ 1493/92. Se trataba del alquiler de permisos de pesca a buques de terceros países para la extracción de especies excedentarias. El sistema liga a una empresa extranjera que aportaba el buque y la capacidad de pesca, con una empresa local que, como contrapartida, prestaba la bandera nacional, posibilitando así el ingreso de buques extranjeros, cobrándole a la empresa extranjera con una parte de la captura. ${ }^{104}$ Por lo general las flotas extranjeras involucradas en la operación negociaban cada año un canon que pagaban por la cesión de los permisos. Según Lerena, que como veremos en el próximo capítulo ocupó un lugar como Secretario de Estado durante los primeros años de la presidencia de Menem, la medida partía de un proyecto de su autoría que tenía por objetivo reducir en forma drástica la explotación de Calamar Ilex a los ingleses en Malvinas, previendo que embarcaciones argentinas o extranjeras pescaran el calamar que se origina en las costas de Chubut y Santa Cruz, el cual una vez adulto, migra hacia la zona de Malvinas para desovar y morir en alta mar (Lerena, 2009). ${ }^{105}$ Hasta entonces, las capturas argentinas de esa especie se mantenían en un promedio anual de 30 mil toneladas, careciendo la flota nacional de "poteros" (los buques con el arte de pesca selectivo para pescar calamar), siendo flotas extranjeras, muchas de ellas con licencias británicas, las que más pescaban. ${ }^{106}$ No obstante, en manos de la Cancillería el proyecto fue otro. Según Bogo (1994), en la práctica, el mismo devino en una suerte de aparcería sobre un recurso que es de propiedad común, fomentando la existencia de comportamientos típicamente rentísticos, así como el hecho de que muchas de las empresas originalmente mixtas se convirtieron en empresas extranjeras, luego de sacarse de encima a los socios locales. Además sucedió que, como las exportaciones pesqueras por puertos patagónicos contaban con un reembolso, estas empresas nacionales y extranjeras asociadas, terminaban cobrando ese beneficio, haciendo más lucrativo el negocio en perjuicio del Estado Nacional. Lerena denuncia que para entonces esta política de fomento patagónico se había convertido en un despropósito, dado que empresas extranjeras que no procesaban sus productos en el país recibían estos reembolsos. Decía que la situación

\footnotetext{
103 Analizamos la política pesquera y la "apertura" del mar argentino en el siguiente capítulo.

${ }^{104}$ La ley $\mathrm{N}^{\circ} 17.500$ y la ley $\mathrm{N}^{\circ} 20.136$, vigente al momento de aprobarse el charteo y el Acuerdo con la Comunidad Europea, señalaban que la pesca debía realizarse bajo pabellón nacional.

${ }^{105}$ En la visión de Lerena la importancia del proyecto no sólo era económica sino también geopolítica. Buscaba con él afectar los ingresos derivados de las licencias de pesca, los cuales sostenían buena parte de la economía de las Islas Malvinas.

${ }^{106}$ Por ejemplo, en el año 1988, mientras las capturas argentinas de Calamar alcanzaban las 21.777 Tn. las de flotas extranjeras capturadas en el Atlántico Sur llegaban a casi 600 mil Tn.
} 
era poco menos que pagarles para que vinieran a pescar y exportaran nuestros productos (Lerena, 2009). Pues por intermedio del decreto $\mathrm{N}^{\circ} 1493 / 93$, artículo 6, se sancionaba que las mercaderías capturadas por los buques extranjeros charteados por empresas argentinas debían tener el mismo tratamiento que las capturas realizadas por buques de bandera nacional. Es decir, recibir reembolsos y reintegros, que en ese entonces eran del 3\% (los reintegros) y del 11\% (los reembolsos) abonados por el tesoro nacional. ${ }^{107}$

El charteo motivó la entrada de buques factoría para la pesca de calamar, principalmente japoneses, coreanos, taiwaneses y también de otras nacionalidades. En el año 1993 ingresaron 45 barcos extranjeros pagando cada uno un canon de 120 mil dólares. ${ }^{108} \mathrm{Al}$ año siguiente ingresaron 61 buques, 74 en 1995 y 68 en 1996. Mientras las diferentes cámaras empresarias apoyaron la iniciativa, ${ }^{109}$ se instalaron como sus principales detractores los gremios marítimos y pesqueros, así como otras organizaciones de la sociedad civil. ${ }^{110}$ Veremos todo esto más en detalle en el siguiente capítulo. Aquí podemos adelantar que las críticas se dirigían a que dicho sistema, por el lado de los marineros, no preveía una dotación "razonable" de mano de obra argentina. Mientras el SOIPdenunciaba el propio sistema de pesca mediante el pago de un canon porque él mismo no generaba valor agregado ni procesos industriales que permitieran la incorporación de mano de obra nacional al proceso productivo. Un problema adicional que trajo este sistema para la pesquería argentina sucedió por la alteración de la cadena trófica, afectando la existencia de la merluza. Dado que la merluza se alimenta de calamar, si el calamar es pescado en grandes cantidades, la merluza se queda sin alimento y llega a comerse a ella misma (Lerena, 2009).

Hablamos antes de dos medidas que afectaron a la pesca. El charteo fue la primera. Veamos en qué consistió la segunda. Para ello permítaseme la referencia histórica.A fines de la década del '80 la flota congeladora española había perdido los caladeros históricos donde sustentaba su explotación. ${ }^{111} \mathrm{Ni}$ hablar de su propio caladero que desde hacía años estaba sobreexplotado. Se enfrentaba entonces al dilema de tener una gran cantidad de buques pesqueros parados, con el correlato de trabajadores sin empleo. Ante esta situación, otras potencias pesqueras subsidiaron el desguace de su flota. Pero a España, además, la apremiaba la necesidad de materia prima para abastecer su mercado interno. Y encontró una solución

\footnotetext{
${ }^{107}$ En enero de 1997 esta situación estalló como un nuevo escándalo de la industria pesquera. Pues los reembolsos por puertos patagónicos relacionados con este sistema le habían costado al Estado argentino 900 millones de dólares. La Aduana inició una investigación y la CAABPA salió de inmediato a señalar que las empresas pesqueras no habían hecho más que acogerse a los beneficios de los reembolsos y reintegros establecidos por el PEN. Por otro lado, se mencionaba en los ambientes pesqueros la presunta evasión impositiva. Se sospechaba que los pesqueros declaraban en la Aduana que introducían calamar entero y en la Subsecretaría de Pesca se declaraba que se exportaba "vaina". La diferencia entre una y otra declaración era de U\$S 2.200 por tonelada (Lerena, 2009). L.C.,06/01/1997; 07/01/1997. Ámbito Financiero, 22/11/1996; 23/12/1996.

${ }^{108}$ El hecho motivó la denuncia pública de Abdul Saravia, dado que en la zona de Malvinas Gran Bretaña cobraba por los mismos permisos 250 mil dólares. En 1994 el canon subió a 200 mil dólares.

109 A pesar del apoyo de las Cámaras, en 1996 cuando la disponibilidad de recursos ya mostraba una notoria gravedad, la CAPECA, que curiosamente asumía una posición conservacionista, solicitaba en forma urgente "interrumpir el charteo de barcos poteros". Ambito Financiero 02/12/1996.

${ }^{110}$ Una de ellas fue el Ateneo Regional de Capacitación y Estudios Sociales cuyo presidente era el Ingeniero Ernesto Godelman. Quien luego presidirá la ONG CEDEPESCA y más tarde se convertirá en asesor de pesca bajo el gobierno de la Alianza. Godelman manifestaba entonces que "tiene sus razones el Secretario Felipe Solá para ponerse nervioso por las investigaciones en curso en la Fiscalía y en la Cámara de Diputados. Si bien ahora este tema cobró notoriedad, a partir de las investigaciones de la Aduana paralela y de supuestas evasiones fiscales en empresas vinculadas a Guillermo Jacob, en verdad lo irregular es el propio mecanismo del charteo, diseñado a partir de 1993 por la Secretaría..." (cit. en Lerena, 2009: 246).

${ }^{111}$ Una mala noticia para los congeladores españoles (y también para los soviéticos) fue la independencia de Namibia en 1990. Pues la naciente República africana limitó su Zona Económica Exclusiva, obligando al retiro de las flotas extranjeras. Igualmente, los stocks de merluza sudafricana ya estaban seriamente deteriorados. El impacto que la decisión provocó sobre la flota española se puede observar en Godelman (s/f).
} 
mejor: subsidió el traslado de su flota para operar en otros caladeros. ${ }^{112}$ Acordado en el año 1992 , finalmente en mayo de 1994 entró en vigor el "Acuerdo Sobre las Relaciones en Materia Pesquera entre la Comunidad Económica Europea y Argentina”. Los orígenes, disputas y vaivenes de este acuerdo se analizan en el siguiente capítulo. Aquí sólo haremos mención a su impacto sobre el caladero nacional. Lo cierto es que en el artículo 5, inciso 3 del Acuerdo se describe el meollo de la cuestión:

La Comunidad, en el marco de su política de reestructuración de la flota, facilitará la incorporación de buques comunitarios a empresas constituidas o que se constituyan en Argentina. A este fin, la Argentina en el marco de su política de renovación tecnológica en materia pesquera, facilitará la transferencia de los permisos de pesca vigentes y expedirá los nuevos permisos que correspondan en virtud del presente acuerdo. ${ }^{113}$

Los términos del acuerdo preveían el intercambio de materia prima por el acceso a bienes de capital, mientras que se propiciaba la radicación de empresas y la constitución de sociedades mixtas y asociaciones temporales que vincularon a empresarios locales y extranjeros. Para Lerena "Estaba claro que la Unión Europea quería deshacerse de los buques españoles; a tal punto, que llegó a subvencionar hasta el 100\% de su valor a quienes los retiraban de Europa y hacian Acuerdos pesqueros extracomunitarios" (Lerena, 2009: 332). ${ }^{114}$ Con todo, el acuerdo establecía que la Comunidad facilitaría la incorporación de buques comunitarios a empresas constituidas o a constituir en la Argentina. Así, las empresas locales podían modernizar su flota y acceder -aunque en calidad de subordinadas- a mercados donde colocar sus productos aprovechando las redes comerciales de las empresas extranjeras. A cambio, permitían la transferencia de permisos de pesca de buques argentinos a las empresas mixtas o asociaciones temporales. El acuerdo comprometió anualmente 250 mil toneladas por cinco años, más un $10 \%$ autorizado de sobrepesca. Y se contempló la asignación a la Argentina de una contribución en concepto de "cooperación científica y técnica" de 33,6 millones de dólares. La Unión Europea invirtió en total 230 millones de dólares para "exportar" más de 100 barcos, la mayoría de los cuales, a pesar de que no se podían otorgar nuevos permisos, se concentró en la merluza. Si bien el Acuerdo preveía no presionar sobre la sustentabilidad de este recurso, el incremento de la pesca de merluza se realizó en buena medida trasfiriendo permisos de pesca de buques inactivos a los congeladores importados. Pues aprovechando la ola de quiebras de las empresas pesqueras en el inicio de la década se utilizaron licencias de barcos hundidos, inexistentes y quebrados, trasladando los permisos de pesca que aquellos disponían a las nuevas sociedades creadas. Entonces, a una política decidida en el sentido de incrementar el esfuerzo de pesca, hay que agregarle que por mecanismos "laterales" y "grietas" en la legislación sobre la actividad se continuó incrementando la pesca. Al decir de Muleiro "La depredación se facilitaba porque además de la inflación de permisos, es decir, la cantidad de barcos que pescaban, los controles sobre los cupos y las especies que podía pescar cada barco eran de una histórica y sospechosa ineficiencia",

\footnotetext{
${ }^{112}$ El proceso se describe con gran detalle técnico y desde una mirada crítica en Godelman et al (1999) y Godelman (s/f). Con énfasis en el trasfondo político en Lerena (2009). También puede leerse Pradas (2006).

${ }^{113}$ Ley $\mathrm{N}^{\circ} 24.315$, art. 5, inciso 3. Revista Tratados $\mathrm{N}^{\circ}$ 41, año X, Fundación Atlántica, 1994, p. 9.

${ }^{114}$ La situación ya estaba clara en 1991: "A partir de dos verdades fundamentales: la irremediable pérdida de los caladeros históricos para los buques de bandera española y la indiscutible sobredimensión de la flota, la Comunidad Europea ha decidido atajar la lenta agonía del sector pesquero congelador, fuertemente descapitalizado, con una serie de subvenciones. Las tantas veces inevitable reconversión parece ir esta vez en serio, con una aceptable dotación de recursos". Revista Redes, $\mathrm{N}^{\circ} 58$, año 1991, p. 15. "Una flota sin destino".
} 
(Muleiro, 2000: 1).Además el periodista habla de "un festival" de permisos de pesca de dudosa legalidad, que movieron cifras millonarias, incrementaron el esfuerzo de pesca y llevaron al colapso de la merluza. ${ }^{115}$ Señala Pradas que "Bajo la atenta mirada y vigilancia de Felipe Solá se desató un festival de truchadas y estafas" (Pradas, 2006).

Para Godelman (s/f) el proceso fue el de una gran transferencia de la capacidad de pesca de la CEE hacia la Argentina. Asimismo, además de un perjuicio al conjunto de la población argentina dado que se trata de un recurso de propiedad común, se produjo una pérdida de capital natural involucrado del orden de los 128 millones de dólares y un perjuicio para la flota nacional dado que, por la escasez del recurso, se necesitó de un esfuerzo de pesca mayor para obtener las capturas. Esto implicaba más combustible, más horas de navegación, mayores salarios, etc. Según Pradas (2006)el Acuerdo no fue sino un traslado subvencionado de la crisis del caladero español a la Argentina y un "salvataje" de los capitalistas pesqueros españoles que buscó evitar una ola de quiebras ante la sobredimensionada flota. ${ }^{116}$ Tanto Pradas como Godelman coinciden en que se generó un efecto dominó por el cual se transfirió la sobrecapitalización y la sobre-pesca junto con los asociados impactos socioeconómicos. Además, cómo los buques que arribaron eran congeladores que no procesaban sus productos en tierra y el acta sólo obligaba a tener un $30 \%$ de tripulación argentina, no se vieron beneficiados los trabajadores. Al contrario, fueron víctimas de los perjuicios del agotamiento de la merluza, y en el caso particular de los obreros y obreras del SOIP, porque el incremento de capturas no conllevó el procesado de las mismas en tierra. Según estimaciones del INIDEP, dadas las obligadas restricciones a la pesca establecidas por la autoridades de aplicación $^{117}$, entre octubre de 1999 y mayo de 2000 se perdieron alrededor de 4 mil puestos en las plantas procesadoras (Godelman, s/f). Además, la relación fundamental con empresas de origen español profundizó la dependencia sectorial respecto al mercado de España, origen casi excluyente de los barcos ingresados y también mercado de destino de las exportaciones. ${ }^{118}$

El Acuerdo, que finalizaba en octubre de 1998, fue denunciado por la Argentina y quedó sin efecto en el año 1999, tras cinco años de funcionamiento. El entonces senador nacional por la provincia de Chubut y miembro del Partido Justicialista, Osvaldo Sala, uno de los principales impulsores de la denuncia del Acuerdo, criticando a funcionarios de su propio partido señaló que el convenio fue "un

\footnotetext{
${ }^{115}$ Godelman et al (1999) iluminan a través de un caso particular cómo fue este proceso. Se trata de la situación del Itxas Lur, un buque comunitario de 63,3 metros de eslora, $1270 \mathrm{~m}^{3}$ de bodega y $1950 \mathrm{HP}$ de máquinas, perteneciente a la Armadora Hispano Patagónica S.A. que integraban por Argentina Pedro Moscuzza e Hijos S.A. y por España Pesquera Itxas Lur SA. Le cedieron licencias los buques Siday y Don José Moscuzza. El primero era un barco costero de 16 metros de eslora que permanecía inactivo luego de un accidente. En 1993 el armador logró la rehabilitación de su permiso y luego fue cedido al Itxas Lur. Por su parte, el Don José Moscuzza era un buque de la flota fresquera, de 37,4 metros de eslora, 310 de bodega y 750 HP cuyas capturas históricas no superaban las 3.865 toneladas. Este debió ser el cupo otorgado. Sin embargo, el cupo inicial asignado al Itxas Lur fue de 4.095 toneladas. Además, en su registro de capturas se ve que, en 1996 por ejemplo, declaró capturas de 8.728 toneladas. Es decir, se le asignó un cupo que cubría un 47 por ciento de su capacidad de captura sin prever un mecanismo de control eficaz para su cumplimiento. Además, el Itxas Lur logró hacerse de un "complemento de bodega". La Sociedad Mixta Hispano Patagónica SA adquirió la licencia del buque inactivo 12 de Octubre (por quiebra de Ventura SA) y la transfirió a su buque, el Itxas Lur, convertida en un cupo de 4.261 toneladas más. Por su parte, el Don José Moscuzza siguió pescando sin licencia ("con la anuencia de la autoridad argentina"), hasta que logró comprar una nueva licencia de un barco perteneciente a una empresa quebrada, registrando en 1997 una captura de 2.247 toneladas. Entonces, en definitiva, las 3.800 toneladas de este buque se transformaron en capturas de 10.900 toneladas: 7.100 toneladas más.

${ }^{116}$ Tras la independencia de Namibia, y la pérdida de ese caladero histórico, la flota congeladora española se encontraba ante una grave crisis, con numerosas empresas altamente endeudadas, que se enfrentaban a tres opciones: el desguace de la flota, la exportación de buques a terceros países o su aporte como capital de eventuales empresas mixtas. Revista Redes $\mathrm{N}^{\circ} 58$, op. cit.

${ }^{117}$ En el capítulo siguiente se abordan las restricciones a la pesca implementadas a partir de 1997 tras el reconocimiento de estar frente a un escenario de sobre pesca.

${ }^{118}$ Revista Redes, № 104, año 1998, "La denuncia del acuerdo con la U.E.", p.14.
} 
enorme disparate" ${ }^{\prime 119}$. Con los recursos comprometidos y la generalización de las supuestas preferencias arancelarias que tenía la Argentina, "El acuerdo con la UE ya no es negocio" ${ }^{120}$. Como consecuencia, las especies comerciales de mayor importancia, entre ellas la merluza hubbsi, fueron sobrepescadas generando una crisis de sobrepesca de gran impacto en el sector pesquero que llegó a crear incertidumbre acerca de la continuidad de la actividad. Es decir que no se cumplió con uno de las prescripciones básicas del acuerdo que establecía "promover la conservación y explotación racional de las poblaciones [de pescado] sobre bases razonables". ${ }^{121}$ Además, como destaca el documento realizado por una comisión de senadores donde se denuncia el incumplimiento del Acuerdo, tampoco puede decirse que fuera de un gran beneficio la modernización de la industria pesquera ni la reducción de aranceles en el mercado europeo que se prometían. En el primer caso, porque lo buques aportados "poseían una elevada vida útil, superando en muchos casos los veinte años", con lo que quedaba claro que no se trataba de tecnología de punta. Godelman et al (1999) señalan que la edad promedio de los buques comunitarios que llegaron a aguas argentinas era de 18 años, mientras que los de la flota nacional era de 23, lo que en sí mismo no constituyó un gran avance. ${ }^{122}$ En relación a los aranceles, para cumplimentar con el artículo I del GATT (Acuerdo General Sobre Aranceles y Comercio, según sus siglas en español), las reducciones arancelarias establecidas de manera bilateral, al no serle notificadas al organismo, debieron ser generalizadas. Poresto, las empresas mixtas constituidas al amparo del Acuerdo no tuvieron ventajas arancelarias, por ejemplo, en relación a Uruguay y Chile. Asimismo, los europeos fueron cuidadosos en marcar que la reducción arancelaria se limitaba a pescados con escasa elaboración. Cuando los productos eran rebozados o precocinados (instancias mínimas de elaboración) los aranceles se elevaban en un $100 \% .{ }^{123}$ Por todo esto se hacía evidente que se trató de un acuerdo eminentemente extractivo que en muy poco beneficiaba al desarrollo pesquero nacional. ${ }^{124}$ Veamos el impacto directo sobre el caladero de merluza.

${ }^{119}$ L.C. Mar del Plata, 22/09/1998.

${ }^{120}$ Revista Redes, $\mathrm{N}^{\circ} 101$, año 1998, "El acuerdo con la UE ya no es negocio", p. 10.

${ }^{121}$ En relación a la evidente sobrepesca, el periodista y maquinista Roberto Maturana realizó en el año 2000 una denuncia penal ante la Fiscal Liliana Mercedes Bustos en contra de la las actuaciones de la Autoridad de Aplicación del Acuerdo, mencionando cuestiones referidas a barcos supuestamente reemplazados pero que siguieron operando, barcos que fueron reemplazados pero tenían mucha menor capacidad de pesca que los ingresantes en su reemplazo, utilización de permisos de barcos siniestrados, parados y hundidos, permisos firmados por funcionarios no habilitados a tal efecto, etc. Pueden leerse las columnas de Maturana en http://www.periodicotribuna.com.ar/. Una lectura similar, según la cual buques supuestamente reemplazados continuaron pescando, la ofrecen Godelman et al (1999). Explican que "La situación más generalizada fue la de que los buques cedentes de permisos, que cumplían las normas del Acuerdo (por ejemplo, que estuvieran operativos) luego re-obtenían otro permiso, esta vez sí de alguna quiebra o de un buque parado, aunque en varias oportunidades entre una y otra operación median tiempos durante los cuales estos buques siguieron operando sin ninguna clase de permiso".

${ }^{122}$ El presidente Carlos Menem anuló una reglamentación que prohibía a la Argentina la importación de buques de más de 10 años de antigüedad. La medida se tomó ante el pedido de armadores gallegos durante una visita oficial del presidente argentino a Galicia. Milcíadez Espoz Espoz, Revista Tratados, № 41, año X, Fundación Atlántica, 1994.

${ }^{123}$ De hecho, la Comunidad se colocó en una posición de privilegio en cuanto a precios de los productos argentinos. Según las estadísticas de exportaciones del año 1997, mientras Brasil adquirió filetes a un valor promedio de U\$S 1.835 la tonelada, los europeos lo adquirieron a un valor promedio de U\$S 980.

${ }^{124}$ El senador por la UCR Hipólito Solari Yrigoyen, que se opuso a la rúbrica del acuerdo, durante la discusión en el Senado manifestó: “... la actividad pesquera argentina atraviesa una crisis estructural. Nadie debe llamarse a engaño porque en el año 92 hubo un aumento de la extracción pesquera, llegándose a las 692 mil toneladas de pesca contra 640 mil que hubo en 1991. Porque tenemos la obligación de hacer un análisis racional de estas cifras; y si lo hacemos, observaremos que el aumento se debe exclusivamente a los buques poteros de bandera extranjera y a los que trabajan con el surimi. En cambio, cayó un 7 por ciento la captura de los barcos pesqueros, que son precisamente los que llevan materia prima a las plantas radicadas en el país. De manera que estamos viendo que en donde existe la posibilidad de aumentar la industria pesquera y de poner nuevas tecnologías y más valor agregado a los productos del mar decae la producción y aumenta en cambio en los buques congeladores, que son los adaptados para transportar sus capturas a otros países para colocar en ellos el mayor valor. El procesamiento en tierra, dígase lo que se diga, resulta insoslayable para que los productos pesqueros de nuestros caladeros tengan mayor valor agregado. Mientras 


\section{g.2. ¿Un "Biocidio"?}

Para comprender la dimensión de la crisis pesquera debemos tener presente que la herramienta de política pesquera con que cuenta el Poder Ejecutivo, en manos del Secretario del área pesquera, es la determinación de la Captura Máxima Permisible (CMP). La misma está informada por la captura óptima que puede extraerse de una población de peces por año sin poner en peligro su capacidad de regeneración futura, es decir, la cifra que arroja el Rendimiento Máximo Sostenible (RMS). En Argentina la misma es elaborada por el INIDEP y elevada a la autoridad de aplicación. Se supone que la CMP debería coincidir con la RMS, aunque esto no siempre ocurre de ese modo ni en la Argentina ni en otros caladeros del mundo. La presión sobre la merluza ejercida durante la década del '90 demostró que no sólo no se ajustó al rendimiento máximo sostenible sino que incluso se superó sistemáticamente la captura máxima. Uno de los datos más graves de la situación es que la fijación de la CMP es un deber de la Autoridad de Aplicación. Sin embargo, en los años 1989, 1990 y 1991 la misma no se dictó. Es decir, que se desplegaron las negociaciones tanto del Charteo como del Acuerdo con la CEE sin delimitar realmente los stocks disponibles de merluza. Recordemos las advertenciasen cuanto a las limitaciones dicho recurso que citamos en el apartado previo.

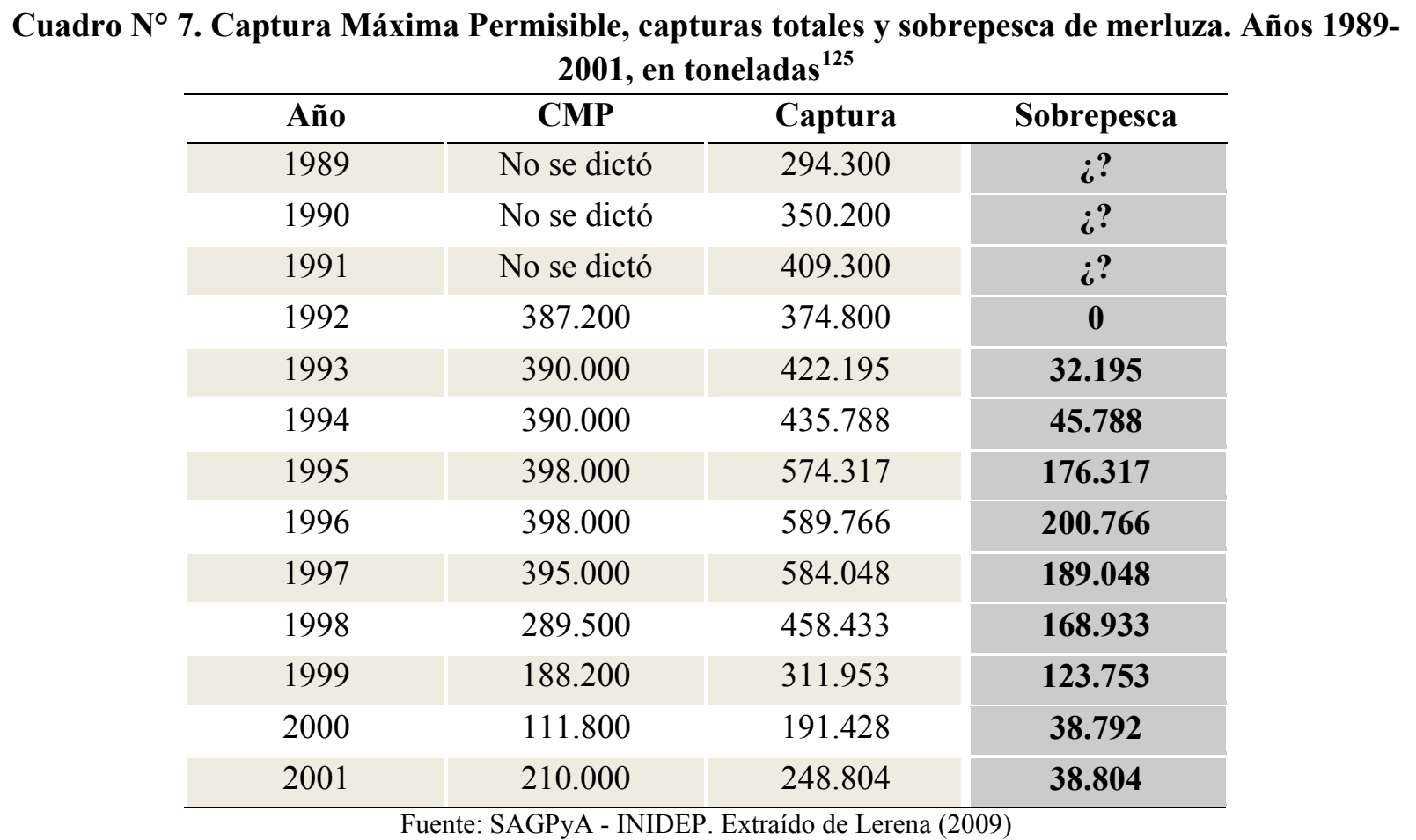

tanto, existen muchas plantas [...] que están cerrando o sufren un serio ajuste de plazas de trabajo. La política pesquera actual que está siguiendo el país privilegia lo que con un anglicismo generalizado se denomina 'commodities'. Debemos señalar que el acuerdo con la Comunidad Económica Europea se inscribe en esa realidad: menos valor agregado nacional, más producción de materia prima para terceros países" (Solari Yrigoyen, 1994: 15).

${ }^{125}$ Se computan las capturas declaradas. Algunas estimaciones sostienen que ilegalmente, por medio de diferentes mecanismos, se pescaron aproximadamente otras 200 mil toneladas solamente en los años 1996 y 1997 (Litovsky, 2000). 
Durante la década del '90 la CMP recomendada para la merluza oscilaba, hasta 1997, en las 390 mil toneladas. Como puede verse en el cuadro precedente, la cifra fue superada desde el año 1993, llegando a ser mayor a 200 mil toneladas de sobrepesca en el año 1996. La disminución en la CMP a partir del año 1998 se debió a la necesidad creciente que tuvo la SAGPyA, en ese entonces bajo la conducción de Felipe Solá, de realizar restricciones. A la sobre-pesca lisa y llana debemos sumarle aún la presión que se ejerció sobre las ejemplares juveniles (según Litovsky se estimó en un 40\% la pesca de peces de pequeña talla), que pescados en esa instancia no llegaban a reproducirse, poniendo en serio riesgo la reproducción de la merluza. Ello junto con una disminución de la talla media de los ejemplares de 44 a 40 centímetros entre 1995 y 1997 (Rodríguez et al, 1999).

Con todo, la década del '90 se caracterizó por la existencia de una sobre-capitalización dada por el sobre-dimensionamiento de la flota pesquera que excedía en tres veces la posibilidad de renovación del caladero. Por esto, la pesquería de merluza quedará en una situación cercana al colapso, dado que si se seguía incrementando la pesca el recurso podía extinguirse. Esto al menos se anunciaba desde diferentes usinas. ${ }^{126}$ Aún así, lo cierto es que en 15 años se pasó de una situación de sub-explotación a otra de sobreexplotación, lo que sumió en una nueva crisis, aunque de características inusitadas, a la industria pesquera. Por eso se le dio el nombre de "crisis de la merluza", la cual adquiría la dimensión de una crisis general de la pesca debido a que desde mediados de la década del sesenta la merluza hubbsi es uno de los pilares de la industria, al mismo tiempo que se trata de la especie que, en su procesamiento, utiliza mayor cantidad de mano de obra. Además, muchas empresas seguían una línea de captura mono-específica teniendo como especie objetivo solamente a la merluza. Lerena (2009) calificó la situación como "un biocidio" promovido desde el Estado, al mismo tiempo que se preguntaba, dada la cantidad de merluza capturada en exceso ¿qué tipo de administración y control realizaba la Autoridad de Aplicación durante la vigencia del acuerdo? Y sentenciaba que la política llevada adelante por los funcionarios de área pesquera era imposible de explicar racionalmente.

La situación de crisis llevó al gobierno a realizar paradas biológicas (vedas), junto a la implementación de otros mecanismos de control para resguardar el caladero, provocando una reducción en los cupos de merluza a ser capturada. El propio Felipe Solá detallaba que las capturas de esa especie se incrementaron por encima de los niveles autorizados. Y que disminuyó la edad de los especímenes extraídos, advirtiendo que "de no adoptarse un programa efectivo, se ingresará en la fase de colapso con consecuencias más graves y de mayor duración". ${ }^{127}$ Adjudicó la situación al "incumplimiento de todo tipo de disposiciones conservacionistas". ${ }^{128}$ Atrás quedaba el optimismo de las exportaciones récord. Ahora se buscaba brindar una imagen de mayor dureza al anunciar que cualquier incumplimiento en la reglamentación se consideraría "falta grave". ${ }^{129}$ Más tarde Solá reconocerá que durante su gestión

\footnotetext{
${ }^{126}$ Sin embargo, como afirma Cutuli (2012), los discursos que sostenían el peligro de extinción de los recursos, habituales en el discurso mediático en relación con la merluza, no encuentran asidero científico. Técnicamente, la población biológica nunca se ha encontrado en riesgo de desaparición. La crisis fue en realidad una crisis de rentabilidad, en tanto los bajos niveles de biomasa llevarían un esfuerzo pesquero por encima del rendimiento de las capturas. Lo que estaba en riesgo era la actividad económica y no la población biológica en sí misma.

${ }^{127}$ L.C.,23/07/1997.

${ }^{128}$ Resulta llamativo que ni siquiera mencionara el acuerdo y hablara de la situación de la pesca como si él no hubiera sido el funcionario a cargo del área cuando sucedió lo que denunciaba. Valdez Goyeneche sostiene que "Existe en las aventuras marinas, y especialmente en la pesca, una inclinación natural del individuo a colocarse fuera de sí mismo, yendo hacia la fantasía con cierta fruición" (1974: 150). Tal vez, de tantos años al frente del área, a Felipe Solá le haya ocurrido lo que a los pescadores.

${ }^{129}$ A tono, L.C.del 23/07/1997 titulaba su portada: "Duras medidas para salvar la merluza". Entre ellas se anunció el abandono del charteo pasando al sistema de captura a través de cuotas y la obligación de procesar el pescado en tierra.
} 
comenzó la depredación y afirmó que si bien "El Acuerdo con la Unión Europea fue positivo en general [...], se debió haber estudiado mejor la potencia de los buques que vinieron y los permisos otorgados" pues "Los congeladores depredan" (Lerena, 2009: 370). Las medidas restrictivas implementadas, que fueron tomadas en coincidencia con el inicio de un período recesivo de la economía nacional, pusieron en riesgo la economía vinculada a la pesca. ${ }^{130}$ Antes de concluir, hay que señalar que, al menos en la visión de Oscar Fortunato, aquellas cifras que causaron alarma en cierto modo se debieron a un error de medición de los investigadores del INIDEP. Según la opinión del dirigente empresario lo que sucedió no fue una disminución tan drástica de los stocks de merluza sino un cambio en el frente de desove:

Que pasa, cuando vos tenés un lugar que es el frente de desove que encontraste siempre, el frente de desove fundamental, había otros pero ese era el fundamental. Y fuiste y no lo encontraste dijiste no hay más bicho. Y en la zona te daban todos los datos mal. Pero se corrieron no sé cuantas millas, que dos años después lo encontraron y encontraron la misma fuente de desove. Pero ¿qué pasó? Las termoclinas habían cambiado, la salinidad había cambiado, las zonas habían cambiado y el frente de desove... las condiciones naturales estaban ahí no en otro lugar. No puede ser que con toda la veda que hay hoy, nosotros pesquemos la misma cantidad o más. Eso quiere decir que en el [19]99 estuvimos equivocados nosotros. En alguno de los pronósticos ambientales nos equivocamos. ${ }^{131}$

Independientemente de ello, lo cierto es que sobre la base de lo que se denominó como "la crisis de la merluza", tuvo forma una crisis social, política y económica que desembocó en un "estallido social" protagonizado por obreros y obreras del sector pesquero en junio de 2000, el momento más crítico en la ciudad de Mar del Plata. La crisis provocó disputas y alineamientos entre los distintos grupos económicos ligados al sector y el involucramiento de las fracciones obreras. El conflicto se dio entre las distintas "localizaciones" (Buenos Aires - Patagonia), entre distintos tipos de "flota" (costeros - fresqueros procesadores congeladores), entre los distintos orígenes de los "capitales" de las empresas (nacional extranjero). A su vez, también se expresó en los distintos niveles de gobierno: local, provincial y nacional, reflejándose en las reuniones del Consejo Federal Pesquero y en las discusiones en torno a la Ley de Pesca. De todo esto nos ocupamos en los capítulos siguientes. Antes de ello, y por último, veamos qué forma adoptó el perfil empresario durante este proceso y quiénes eran los grupos que pasaron a definirse como Integrados.

\section{De la "Liga Pesquera" a los "Pulpos de la Pesca"}

Valdez Goyeneche llamó "binomio pesquero" a la estructura del sector fundado en el sistema de pescado fresco. Decía que todo binomio tendía a la interrelación de sus componentes. Y aplicaba el concepto a la organización de la pesca constituida, de un lado, por unidades pesqueras, y de otro, por

\footnotetext{
${ }^{130}$ Lerena sostiene que "La veda es una herramienta adecuada para proteger especies juveniles y desovantes; pero, la veda cuando se aplica en forma sorpresiva a la captura de adultos, cuando poco tiempo antes se promovían acuerdos y pescas masivas, es una demostración evidente de pésima administración y distribución del recurso. Nadie en su sano juicio [...] podría suponerse que una actividad productiva (empresarios y trabajadores) puede graciosamente, suspender su actividad total o parcialmente hasta que el recurso se recupere, sin ocasionar un gravísimo daño social y económico, seguramente irreversible, al menos para estos actores. ¿Cómo se supone que se mantiene la actividad sin materia prima, sino es vendiendo la materia prima que se captura?" (Lerena, 2009: 369).

${ }^{131}$ Entrevista del autor con Oscar Fortunato... op. cit.
} 
instalaciones en tierra encargadas de preservar y procesar el producto. No se olvidaba de señalar la dependencia mutua de los extremos del binomio, entre uno y otro, como resultado de que el primero tenía a su cargo la captura y el segundo el procesado. Para Valdez, que era crítico de ésta estructura, la relación implicaba una "esclavitud técnica" que provocaba consecuencias especiales en la estructura económica y social de las pesquerías, terminando en una dependencia económica de uno de los dos polos. Bajo ese sistema, quienes se perjudicaban eran los pescadores, pues por la velocidad del deterioró bioquímico del pescado muerto, quedaban a merced de los compradores, quienes podían almacenar y procesar el pescado. Los diferentes intentos de organización de los pescadores en cooperativas o sociedades no hacían sino poner parches a la situación y permitir cierta mejora en la negociación, pero no terminaban con el problema de fondo. Además, por lo general, la subordinación técnica del pescador se correspondía con una dependencia financiera ya que, solía ocurrir, los gastos de alistamiento de los buques (combustible, redes, aceites, etc.) eran erogaciones demasiado elevadas para los propios pescadores, por lo que solían ser pre-financiadas por prestamistas. Usualmente, prestamista e industrial pesquero era la misma persona, que luego cobraba el préstamo con la captura del pescador y así se garantizaba de ante mano determinado precio del pescado y aprovisionamiento seguro. Es decir, casi que compraba el pescado antes de que este fuera sacado del agua. Según el autor, esta situación generaba distintos abusos por parte de los industriales que, dentro de la balanza de los términos del binomio, provocaba una inclinación claramente favorable a sus intereses, otorgándole mayor poder de movimiento y mejor posición en la confrontación.

Ahora bien, esta estructura pesquera se correspondía con el surgimiento de una organización de carácter informal que tendía a defenderla y que Valdez llamó "Liga Pesquera". Ésta era la organización de quienes ejercían el dominio en el sector pesquero, conquistando los puntos neurálgicos de la actividad. Además, por intermedio de la asociación ejercían su influencia en los campos político y social. Concretamente, decía:

Nosotros llamamos "liga pesquera" a la oligarquía pesquera que tiene en sus manos el poder de control de los elementos básicos enumerados precedentemente, y por tanto el dominio social y económico de la estructura del sector. Y entendemos por oligarquía lo que entiende Martín Alonso en su Enciclopedia del Idioma (1958), es decir, el "conjunto de algunos poderosos negociantes que se aúnan para que todos los negocios dependan de su arbitrio" (Valdez Goyeneche, 1974: 178).

La Liga no creaba al binomio pesquero sino que éste era más bien su base de existencia. Por eso cuando la Liga defendía el binomio, abogaba también por su propia existencia como organización, generando negativas consecuencias sociales, económicas y políticas. Este tipo de organización era una realidad en todas las pesquerías del mundo en que existiera el "binomio". ${ }^{132}$ Por supuesto Mar del Plata tenía su "Liga Pesquera". Ésta era la que defendía los derechos de propiedad no escritos ni individualizables fácilmente, haciendo valer sus pretensiones en el contexto económico y político. La jerga popular definía a la Liga Pesquera como "mafia", definición que según el autor no estaba exenta de una fuerte dosis de realismo. ${ }^{133}$ La marginación de agentes necesitaba, en ocasiones, del uso de la fuerza,

\footnotetext{
${ }^{132}$ Valdez Goyeneche nombra a Ecuador, Perú, México, Brasil. También Italia y Hong Kong.

133 César Lerena, por el contrario, matiza la idea de que los hábitos de los empresarios pesqueros pudiesen ligarse a comportamientos mafiosos. Sostiene que “... los empresarios pesqueros (más allá de las conductas propias de los empresarios de cualquier rubro) son verdaderamente 'nenes de pecho' al lado del sector agropecuario" (Lerena, 2009: 20).
} 
variando los mecanismos desde la destrucción del motor de una unidad pesquera, hasta la desaparición de embarcaciones pues, como sugiere Valdez, la "legitimación de la fuerza no es obra sino de los hombres"[...] "Como las limitaciones no existen, el método queda librado no sólo a las circunstancias, sino a la calidad de los integrantes, a los intereses en juego y a las 'resistencias' que se le opongan" (Valdez Goyeneche, 1974: 247). El gran enemigo del binomio y, por tanto, de la Liga, era el desarrollo técnico. Desde el momento en que se pudieran congelar las capturas a bordo, "el propietario-pescador se libera de las instalaciones en tierra y de todo el sistema basado en la existencia del binomio pesquero". Para Valdez, a partir de esta posibilidad técnica, la lucha sería entre tradición y modernidad. Y pronosticaba que las estructuras del sector pesquero fundadas en el sistema de pescado fresco se enfrentarán, sin duda, con la estructura constituida por el sistema de pescado congelado. ${ }^{134}$

Varios años después, asistimos en los años '90s a una trasformación de magnitud en la pesca. Por primera vez las capturas con buques congeladores superan a las realizadas por los fresqueros. Este cambio habilitó movimientos dentro de la estructura de la organización empresaria. Pradas (2006) señala que tras la caída del grupo "fresquero puro" en 1991 asumió la presidencia de la CAABPA Antonio Solimeno, secundado por un homogéneo grupo constituido por Alberto Valastro en la vicepresidencia y José Moscuzza como secretario de organización. Homero Cánepa era el Prosecretario y Antonio Di Leva el tesorero. Entre los tres primeros se rotaban cada año la presidencia de la Cámara, presentándose a sí mismos como "el corazón de la pesca nacional". ${ }^{135}$ Iniciada la década del '90 este grupo, junto con Mellino y Barilari, tras el vacío generado luego de las quiebras, pasó a oligopolizar la captura y aumentó la capacidad de mantenimiento del congelado en las plantas frigoríficas. En 1974, 34 empresas pesqueras tenían una capacidad frigorífica de 16 mil toneladas. Para 1990, eran 7 los grupos con aquella capacidad.

Tiempo después, y dentro del marco de la crisis que tuvo lugar entre 1997 y el año 2000, se produjo un profundo enfrentamiento entre los industriales pesqueros. La disputa, que implicó batallas de considerable magnitud, ${ }^{136}$ se conoció como el combate entre Fresqueros versus Congeladores. La prensa fue una de las principales difusoras de las disputas originadas entre los empresarios pesqueros bajo dicha fórmula discursiva. Esta imagen de la contienda elaborada en clave de una distinción por tipos de flota, si bien tiene cierto asidero con lo ocurrido, resulta sin embargo, una lectura que no permite visualizar la complejidad del fenómeno. En esa visión "simplista", por un lado se encuentra la flota fresquera, vinculada a la ciudad de Mar del Plata como ámbito principal de radicación que implica pesca en el mar y trabajo en tierra. El otro tipo de flota está comprendido por los procesadores congeladores, que operaban preponderantemente en el sur patagónico. Hacia finales de la década del ' 90 , en el puerto de Mar del Plata la relación entre fresqueros y congeladores era de 61,3\% los primeros y 38,6\% los segundos. En los puertos de las provincias del sur la relación era de $14 \%$ fresqueros y $86 \%$ procesadores congeladores. Esa simple proporción, que nos indica que Mar del Plata poseía más fresqueros que la

\footnotetext{
${ }^{134}$ En 1991 distintas cámaras pesqueras, la CAABPA entre ellas, acusaban a Valdez Goyeneche de ejercer reiterado lobby a favor de abrir el mar argentino a la pesca de flotas extranjeras a través de un proyecto de su autoría llamado Plan Neptuno. Revista Redes, № 57, año 1991, p. 12.

${ }^{135}$ La Revista Redes expresaba que con la nueva conducción “...la asamblea del nucleamiento armatorial marplatense concreta su singular homogeneidad en su conducción máxima” luego de soportar bajas por diferencias políticas, migraciones hacia el sur y, sobre todo, la quiebra de numerosas empresas. También renovaba autoridades la Cámara de Procesadores que pasaba a ser presidida por José Lorenzo (de Alberto Valastro y Cía.), con la vicepresidencia de Omar Caruso (del Frigorífico Mellino) y la secretaría en manos de Raúl Rubin (de Costa Brava). Revista Redes, N 55, año 1991, p. 14.

${ }^{136}$ Las veremos con detalle en el capítulo IV.
} 
región patagónica, nos sugiere no obstante que no podemos asociar linealmente la región con el tipo de embarcación. ¿Qué significa esto?

Para comprenderlo vayamos a los inicios de la última crisis pesquera. A mediados del año 1997 la SAGPyA anunciaba la parada biológica para disminuir la presión sobre el recurso merluza. La CAABPA y la Cámara de Procesadores de Pescado, ambas radicadas en Mar del Plata, señalaron como los responsables del colapso a los buques procesadores congeladores y solicitaron que las vedas les sean aplicadas a este tipo de flota por ser los que depredaron el caladero nacional. ${ }^{137}$ Los alineamientos en la "perla del Atlántico" se nucleaban en torno a los fresqueros. Para noviembre de 1997 las cámaras en conjunto requerían que se aseguren 300 mil toneladas de merluza para la flota fresquera debido a que la consideraban como el sistema productivo más eficiente en términos de sustentabilidad biológica y el que contrataba mayor cantidad mano de obra. También solicitaban reintegros a las exportaciones manufacturadas en tierra y distintas limitaciones a la operatoria de los congeladores. ${ }^{138}$ De esta forma, la flota fresquera lanzaba su posicionamiento respecto a un futuro donde se preveía la escasez de pescado y se iniciaba la puja inter-empresaria. La CAPECA, representante de los congeladores asentada en la Patagonia, aclaraba, tratando de contrarrestar los argumentos de los fresqueros marplatenses, que "no es uno y otro buque el que depreda" ni tampoco son culpables los barcos extranjeros, sino que el problema es la pesca irresponsable. Acusaba a los fresqueros bonaerenses, quienes si bien tenían una cantidad importante de trabajadores, los mantenían "en negro" o contratados en cooperativas. Y pugnaban por continuar pescando apelando a ser quienes poseían una flota con más tecnología y mayor eficiencia. ${ }^{139}$ Hasta aquí la imagen de la batalla según la cual se enfrentaban fresqueros versus congeladores era totalmente acertada.

Sin embargo, entre fines de 1997 y principios de 1998 se presentaba en sociedad el Concejo de Empresas Pesqueras Argentinas (CEPA) en la ciudad de Mar del Plata, bajo la presidencia de Oscar Fortunato $^{140}$. La institución se planteaba como un organismo privado de carácter científico que buscaba conocer la situación real del caladero. Los integrantes se definían como los "hombres fuertes de la pesca" y se presentaban como empresas Integradas que se dedicaban a capturar, procesar y comercializar el producto. Las firmas responsables eran Moscuzza e Hijos S.A., Giorno S.A. (Valastro), Luis Solimeno e Hijos S.A. y Santa Elena S. A. Precisamente se trataba de aquellos que habían dirigido la CAABPA durante buena parte de la década. Ahora, sin abandonar su posición en la cámara que los había cobijado hasta entonces, estas empresas se distanciaron del proyecto de los fresqueros. Afirmaban la necesidad de adecuarse a la nueva realidad del caladero, el cual debía pasar de una pesca expansiva a una regresiva. Haciendo gala de previsor, Fortunato declaraba "vemos en la pesca un panorama muy dificil y serio, estamos en un momento de crisis y cambio, de transformaciones, y para ello tenemos que estar

\footnotetext{
${ }^{137}$ Lo propio hacían las agrupaciones empresarias UCIP y la recientemente creada UDIPA y desde el lado de los trabajadores, el SOMU, la CGT Regional y hasta un grupo de desocupados.

${ }^{138}$ L.C.,05/11/1997.

${ }^{139}$ L.C., 19/09/1998.

${ }^{140}$ Oscar Fortunato había sido gerente de la empresa Arpemar y Director Nacional de Pesca durante el gobierno de Alfonsín. En el año 2003 asumirá como Subsecretario de Pesca de la Provincia de Buenos Aires. Días previos a su asunción el Diario Hoy de la ciudad de La Plata publicaba una nota que señalaba la continuidad en la existencia de intereses sectoriales enfrentados en la pesca: "Una guerra sin armas ni explosivos se ha desatado en el empresariado de la pesca comercial bonaerense [refiriéndose a la disputa fresqueros versus congeladores]. ¿El motivo central? La sucesión en la Subsecretaría de Pesca provincial. ¿El meollo profundo? Un negocio de más de 800 millones de dólares anuales que -según especulan los sectores enfrentados- podría beneficiar a uno u otro extremo de la industria pesquera, de acuerdo a quién resulte designado...". Diario Hoy, La Plata, $19 / 10 / 2003$.
} 
preparados y advertidos al respecto". En su visión, quedar ligados al sistema fresquero era una señal de atavismo de la cultura pesquera marplatense. Los tiempos habían cambiado y el desarrollo de la pesca precisaba de buques más eficientes. ${ }^{141}$ Además de, vía la integración, garantizar un paraguas de protección ante la incertidumbre propia de la industria. ${ }^{142}$

Detengámonos en estos hombres fuertes y decididos a cambiar. A falta de una investigación aún pendiente sobre la evolución y transformación del sector empresario pesquero, realizamos aquí una aproximación a las formas que adquirieron algunas empresas que adoptaron la forma de verdaderos grupos económicos. ${ }^{143}$ Comencemos con una información al alcance de la mano, pero que en su simpleza nos permite dibujar un esquema de cuál era la realidad de estas empresas. Nos referimos a la comparación a partir de datos surgidos de la Revista Redes del año 1992, ${ }^{144}$ con la información que pasada la década del '90 publicaban las empresas en sus propias páginas web. ${ }^{145}$

Luis Solimeno e Hijos S.A. era una sociedad familiar, y como su nombre lo indica, integrada por padre e hijos, con tradición en la actividad pesquera marplatense iniciada por el padre, allá por finales de la década del '30. Es en el año 1976 cuando se constituye formalmente como empresa y paralelamente construye su primera planta de procesado. En 1978 se convertirá en empresa integrada a partir de la adquisición del buque Promac, al que le siguen otros seis entre 1981 y 1991. Entre 1987 y 1990 encara la construcción de una segunda planta frigorífica y fábrica de hielo. Años después, pasada la década del ' 90 , el Grupo Solimenoya contaba con siete empresas pesqueras, radicadas en Mar del Plata y en la Patagonia. 16 barcos con una capacidad de captura aproximada de 70.000 th anuales, una capacidad de procesamiento y congelado a bordo de $25.000 \mathrm{tn}$, de mantenimiento a bordo de $5.000 \mathrm{tn}$, de procesamiento y congelado en tierra de 15.000 tn y de mantenimiento en cámaras frigoríficas en tierra de $5.000 \mathrm{tn}$. Declaraba contar con una flota pesquera diversificada que le permitía orientar los objetivos de pesca a las distintas especies. Decía ocupar 800 personas. De los 16 buques de que disponía, el 50\% eran fresqueros y el otro $50 \%$ congeladores. También desarrollaba una estrategia para el mercado interno, especialmente a través de la venta de pescado a las cadenas de supermercados.

Igualmente pertenecía al sector pesquero marplatense la familia Moscuzza. En el año 1992, la conducción de la empresa Frigorífico Moscuzza era cuarta generación de familiares asociados a la pesca. En 1959 Pedro Moscuzza construía su primera planta dedicada a la industrialización de productos pesqueros, por entonces comercializados en el mercado interno. Es en 1970 cuando realiza la primera exportación bajo su sello. En 1974 impulsa la estrategia de integración y adquiere su primer buque fresquero, el "Don José Moscuzza". En la década del '80 obtiene cuatro buques más. En 1992 construía una nueva planta pesquera. Pasada la década, el Grupo Moscuzza declaraba realizar las operaciones

\footnotetext{
141 “Hoy el producto no está acá [se refiere a la costa de Mar del Plata]. Estamos buscando mucho más abajo. Donde es imposible ir con las lanchas amarillas". Ello es un ejemplo de que se necesitaba modernizar la flota pesquera. Entrevista del autor con Oscar Fortunato... op. cit.

142 “...realmente un modelo integrado totalmente, de pie a cabeza, resiste más todos los cambios y todos los problemas que hay en una actividad exportadora, de una actividad productiva con un flujo de entrada no regulado, lo resiste mucho más que alguien que tiene un solo medio para poder moverse". Entrevista del autor con Oscar Fortunato... op. cit.

${ }^{143}$ El Grupo de Economía Pesquera del INIDEP ha estudiado la evolución de la flota y realizó importantes aportes al conocimiento del desarrollo de la actividad. También, desde luego, Valdez Goyeneche (1974), Espoz Espoz (1999), Mizrahi (2001) y más recientemente Perrota (2008). Sin embargo, aún carecemos de una investigación centrada especialmente en la forma y desarrollo de las propias empresas. La aproximación de Pradas (2006) es un excelente aporte que señala problemas y estimula algunas hipótesis, pero continúa siendo un acercamiento.

${ }^{144}$ Revista Redes, № 60, año 1992.

${ }^{145}$ Las que visitamos en agosto y septiembre de 2006. www.solimenosa.com.ar, www.moscuzza.com, $\underline{\text { www.valastro.com.ar, }}$ www.barillari.com.ar
} 
deextracción, procesado e industrialización, comercialización y distribución de frutos del mar. Orientaba su producción hacia el mercado interno y a las demandas externas. Desarrollaba sus actividades en Mar del Plata y la Patagonia. Declaraba poseer dos plantas procesadoras, dos establecimientos frigoríficos, 6 buques fresqueros, 5 buques procesadores congeladores, 4 buques congeladores y un buque potero. Ocupaba 1.100 personas.

En 1992, Alberto Valastro y Cía. S.A. ya era una empresa que integraba captura y procesado. En ese entonces declaraba poseer cinco barcos fresqueros y una "moderna" planta industrial. Catorce años más tarde el Grupo Valastro estaba integrado por Giorno S.A., Pesquera Ceres S.A. y Pesquera Géminis S.A. y empleaba a más de 500 obreros. Contaba con nueve fresqueros y tres buques factoría, una planta de procesamiento en tierra con capacidad de congelamiento de $60 \mathrm{tn} /$ día, cámaras frigoríficas con capacidad de almacenaje de más de 5.000 toneladas. Desembarcaba más de 50.000 tn de pescado por año, producía 200 tn de hielo en escamas por día. También desarrollaba el congelado a bordo. Sus actividades se desplegaban conjuntamente en Mar del Plata y la Patagonia.

Aunque no participó del CEPA, y más bien fue uno de los pilares del grupo de los fresqueros marplatenses, por su estructura hay que colocar aquí también al Grupo Antonio Barilari. El mismo abarcaba todo el proceso pesquero, desde la captura hasta la comercialización, ya sea para el mercado interno como para el externo. Contaba con tres plantas procesadoras en la ciudad de Mar del Plata, Caleta Olivia y Comodoro Rivadavia. Declaraba tener bajo relación de dependencia a 800 empleados. También el Grupo Mellino despuntaba del resto. Ya en 1992 integraba el procesado y la captura manteniendo su base en Mar del Plata, pero también desplegándose por la Patagonia a través de la Pesquera Emiliano S.A. que tenía plantas y flota propia en Rawson y Puerto Deseado. Además, recurrió temprano a la fórmula de joint venture para acceder a nuevos mercados y a tecnología de alta gama, asociándose con un grupo coreano para la pesca de calamar y un grupo japonés para la producción de surimi. Mellino también desarrolló una estrategia para el mercado interno a través de la comercialización de sus productos en dos pescaderías propias y en restaurantes, hoteles y supermercados. ${ }^{146}$

Siguiendo solamente la información que estos grupos publicaban en sus páginas web en el año 2006, vemos cómo dejaron de ser simplemente "fresqueros marplatenses", se diversificaron y concentraron, de tal forma que la división que trascendió bajo la imagen de un enfrentamiento de flotas entre "fresqueros versus congeladores" oculta más que aclara la situación compleja en que estaban insertos estos grupos. En relación a sus vínculos internacionales, ya en el primer proyecto de Charteo tenemos a todos estos grupos inscriptos y participando. ${ }^{147}$ Un par de años después aparecían como socios marplatenses de empresas españolas en el marco del acuerdo con la CEE a través de sociedades mixtas o uniones transitorias de empresas. ${ }^{148}$ Según Pradas (2006) Solimeno, Valastro, Moscuzza, Barilari y también Mellino y el Marisco, a través de su participación tanto en el charteo como en los acuerdos con la

\footnotetext{
${ }^{146}$ Revista Redes, $\mathrm{N}^{\circ} 60 \ldots$ op. cit.

${ }^{147}$ Entre otros, participaban Alberto Valastro, Pedro Moscuza e Hijos, Luis Solimeno e Hijos, Frigorífico Barillari. También Frigorífico Mellino, Frigorífico Marejada, Salerno Hnos., etc. Revista Redes Nㅜ65, año 1992, p.25. En los próximos proyectos se sumaban El Marisco, Santa Elena S.A., Pesquera Vasco Da Gamma, entre otras.

${ }^{148}$ Los primeros eran: Frigorífico Mellino S.A. (Dos proyectos, vinculado a Pescapuerta S.A. y Pescavigo S.A.). Pedro Moscuzza e Hijos S.A. (Dos proyectos, vinculado Itxas Lur S.A. y Pesquera González). Luis Solimeno e Hijos S.A. (También con dos proyectos, relacionado con Frigorífico Fandiño S.A. y Frigorífico Faldiño S.A.). También Giorno (Un proyecto, vinculado a Marítima Polux). Pesquera Santa Elena S.A., asociada con Pesquera Vaqueiro S.A. Y El Marisco S.A., en sociedad con Freiremar. Revista Redes N96, año 1997, p. 11 y 12.
} 
CEE, y tras la caída de las tradicionales Ventura, Arpemar, Mar Azul y otras, terminaron de consolidarse como empresas Integradas. Los miembros del CEPA se presentaban del siguiente modo:

Esto, planteado así, en términos musicales, hace ver claramente la complejidad en la que están inmersas las empresas que componen el CEPA. Son fresqueras? Sí, Tienen Barcos Congeladores? Si, Procesan en tierra? Si, Elaboran Mariscos? Si, Reprocesan productos en tierra? Si, Tienen sus propias redes de comercialización en el mercado interno? Si, Elaboran productos para el mercado interno? Si, Han logrado introducir productos de punta por servicio o tecnología en el mercado? Si (Boletín CEPA, 1998). ${ }^{149}$

De este modo, estas empresas se consolidaron como verdaderos grupos económicos que complican la observación de la estructura empresaria ligada a la pesca. Se localizaban tanto en el sur, como en Mar del Plata. Pescaban con fresqueros y con congeladores. Estaban asociados a empresas extranjeras y a través de esas sociedades alcanzaron a controlar los extremos del proceso económico pesquero. Es decir desde la captura hasta su comercialización final, pasando por el procesado. Se dedicaban fundamentalmente a la exportación pero también vendían en el mercado interno a través de las cadenas de supermercado. Por último, en cuanto a la fuerza de trabajo, tenían trabajadores bajo relación de dependencia, pero también operaban con cooperativas. ${ }^{150}$ En 1996 estas firmas aparecían en el ranking de las mil empresas con mayores ventas de la Argentina elaborado por la Revista Mercado. Barilari participaba de la posición 849 con $\$ 17.300 .000$. Frigorífico Mellino en la posición 907 vendía por \$16.000.000. Pedro Moscuzza e Hijos en el puesto 948 vendía por \$15.000.000. El Marisco aparecía en la posición 773 con $\$ 19.700 .000$. Luis Solimeno e Hijos en la posición 585 vendía por $\$ 28.700 .000$. El grupo Valastro asociado con Moscuzzaocupaba el puesto 613 con $\$ 26.700 .000$ en ventas. Y a través de la Unión Transitoria de Empresas Giorno-Moscuzza, el puesto 628, que vendía por 26.000.000. ${ }^{151}$

Así, la nueva realidad de la pesca veía transformarse a lo que antiguamente, y bajo la estructura pesquera del sistema de pescado fresco, se conocía como Liga Pesquera. La explicación puede hallarse en las palabras que 30 años antes escribía Valdez Goyeneche.

La 'liga pesquera', como forma de una conciencia social determinada, pertenece a la época en que el sistema de pescado fresco era único, o sea desde el nacimiento de la pesca comercial en los

\footnotetext{
${ }^{149}$ En la visión de Oscar Fortunato el CEPA representó a aquellas empresas que, reaccionando contra al atavismo tradicionalista de Mar del Plata, comprendieron el sentido del cambio que se producía en el mundo y se decidieron a acompañarlo. Dirá que "Ya a mediados del '70 ingresan barcos más grandes. Algunos congeladores que van al sur, no a Mar del Plata. A Bahía Blanca con un decreto real que permitía que los barcos salieran de España e ingresaran a Argentina conservando un pabellón español para ingresar sin impuestos la mercadería a España. Esto provoca otro cambio. Pero Mar del Plata no lo siente ese cambio. Porque siguió con el modelo fresquero porque teníamos un atavismo ahí metido de que nosotros queríamos seguir con el modelo que nos habían enseñado, el modelo fresquero. Barcos más grandes quizás, pero siempre con un proyecto fresquero. ¡El congelador no servía! [...] ¿Cuál fue el modelo que cambió en los ochenta? El modelo que cambió es que mucha gente se dio cuenta, de todos estos viajes, de todas estas cosas, que trabajando con barcos congeladores había posibilidades de realmente empezar a funcionar mejor. Empezar a funcionar con un producto que ya los mercados pedían. En lugar de tener un tiempo para llegar a puerto, el pescado que se congela en altamar, la calidad intrínseca del producto casi se conserva totalmente, afectada por la congelación nada más. Se empezaron a mover los barcos para langostino, empezó a provocarse un cambio importante...”. Entrevista del autor con Oscar Fortunato... op. cit.

${ }^{150}$ Como veremos a lo largo del capítulo III, una de las estrategias principales de supervivencia empresaria tras las quiebras de 1990 fue la implementación de estrategias de reducción del costo del trabajo, dentro de las cuáles la tercerización de la mano de obra hacia pseudo cooperativas fue pilar fundamental.

151 Barilari, Mellino, Moscuzza e Hijos y la UTE Giorno-Moscuzza solo contempla aquí las ventas por exportaciones, sin considerar las ventas en el mercado interno. Revista Mercado º 956, julio de 1997.
} 
albores de la sociedad organizada, hasta el año 1960 en que el congelamiento intensivo a bordo se hizo posible con sentido económico (Valdez Goyeneche, 1974: 248).

Surgía entonces una nueva fórmula empresaria para los nuevos tiempos. En el puerto de Mar del Plata comenzó a escucharse la definición de "Pulpos de la Pesca". ${ }^{152}$ Sin comprender estas mutaciones poco lo que puede arrojar el análisis de la conflictividad obrera en la industria pesquera.

${ }^{152}$ Eduardo Pradas (2006) retomó del lenguaje popular la calificación de "Pulpos de la Pesca" para referirse a los grupos económicos de la actividad pesquera. El concepto está puesto en función de los numerosos "tentáculos" que los grupos económicos desplegaban sobre la economía argentina. 


\section{CAPÍTULO II}

\section{La larga década del ‘90: la trama política de la política pesquera}

“...lo que pasa es que sangran por la herida. Algo que no pudieron hacer ni los gobiernos militares ni los gobiernos seudo democráticos, ni los democráticos durante estos últimos 40 años lo hizo este Gobierno, con decisión, con valentía, con coraje, y por supuesto, con una enorme dosis de talento"

Carlos Menem, diario La Capital, 05/11/1991.

Respondiendo a críticas recibidas tras anunciar la desregulación de la economía.

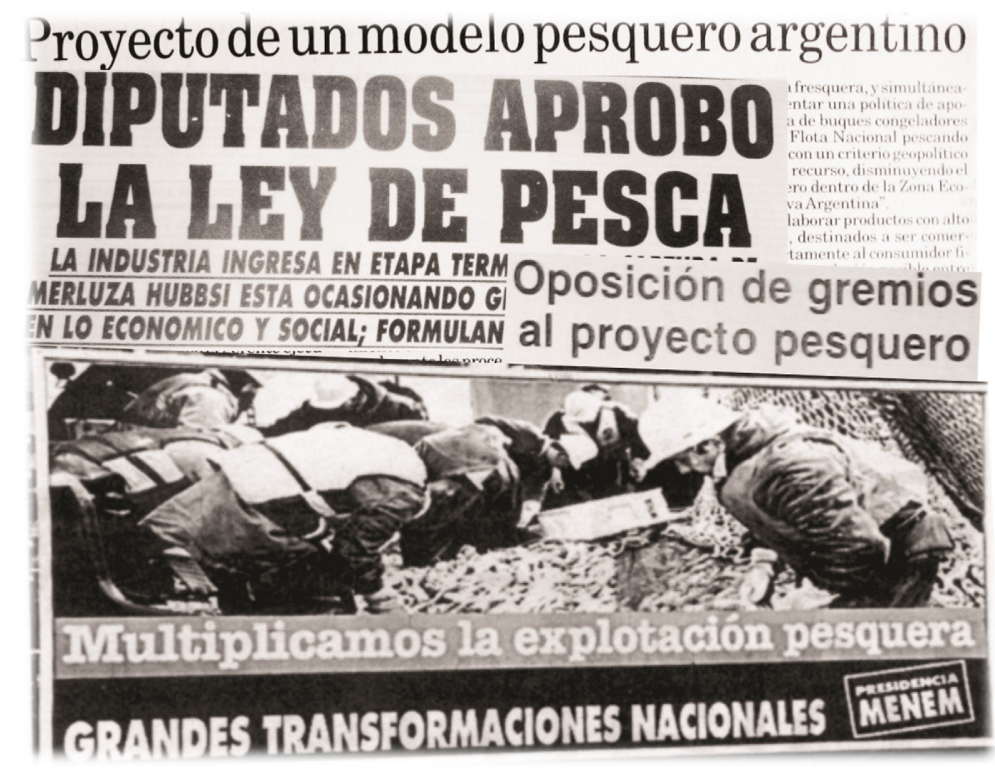




\section{Introducción}

Hemos dicho, siguiendo a Mateo (2003), que en Argentina la pesca no despertó mayormente el interés historiográfico y, podemos agregar, el de las ciencias sociales. No obstante, en los últimos años ha crecido en número no despreciable el aporte de investigaciones sobre problemáticas vinculadas con la actividad pesquera. Dejando fuera del foco de atención los trabajos que abordan procesos históricos previos a nuestro objeto de estudio, ${ }^{153}$ fueron la "crisis de la merluza" hacia finales de la década del ' 90 , la creciente conflictividad social y las condiciones de vida de los trabajadores (y particularmente de las trabajadoras) los ejes que impulsaron las diferentes pesquisas, además de los análisis de la evolución de la actividad y diagnósticos productivos. Aún así, a pesar de la aparición de estos aportes, todavía es escaso el conocimiento que tenemos sobre los procesos políticos (y las luchas que implicaron), la interacción entre actores sociales y el tipo (o los tipos) de vínculo que se desarrolló (desarrollaron) entre empresarios y Estado, factores fundamentales para analizar la orientación de las políticas pesqueras, los procesos de resistencia a esas determinaciones y los efectos sociales que provocaron. ${ }^{154}$

Así pues dentro del abanico de estudios que abordan la problemática pesquera argentina desde las ciencias sociales destacan sin duda los aportes provenientes desde las ciencias económicas. Se inscriben en esta línea los trabajos de Bertolotti et al (2001) y Mizrahi (2001). Por lo general, estos estudios nos muestran el desarrollo de políticas pesqueras y transformaciones de la industria, que más allá de sus importantes logros para el estudio de la actividad, aparecen determinadas netamente por la evolución de los mercados, donde la política (y particularmente la lucha política) se desdibuja. Cuando se hace mención a políticas estatales por lo general subyace una interpretación "inocente" del Estado, en todo caso equivocado o acertado en su definición de políticas, pero siempre como un actor, podríamos decir, que si no es neutral, si al menos debiera serlo. Este tipo de mirada oculta que también el Estado (el Estado en plural, con todas sus dependencias y extensiones) se constituye como un terreno de disputa más que como un agente neutral de los procesos sociales. Precisamente las políticas que se implementan aparecen, muchas veces, tras el resultado (nunca definitivo) de aquellas batallas. Concretamente, y en relación a la década del '90, María Inés Bertolotti, al frente del grupo de Economía Pesquera del INIDEP, ocupada en mayor medida por aspectos técnicos y operativos de la actividad, cuando menciona el contexto macroeconómico en que se desenvolvió la pesca durante la década del '90, lo ubica en el marco del desarrollo de la "globalización económica", reforzada por una "globalización financiera", sustentadas

\footnotetext{
${ }^{153}$ Podemos leer sobre la historia de la actividad pesquera Mateo (2003), Fermepin y Villemur (2004), Espoz Espoz (1999). Sobre la situación de los trabajadores y trabajadoras de la industria pesquera para las décadas del '40, '50 y '60 Nieto (2012), Ruocco (2011, 2009, 2008), Molinari (1998; 1997), Martin (1998; 1994).

${ }^{154}$ Oscar Fortunato explica la importancia de la política empresarial en la actividad: "La actividad pesquera es igual que un balneario. Exactamente igual. La diferencia que tenemos con los permisionarios de balnearios es que la inversión en el balneario no es tan alta ni de tanto riesgo. Nosotros tenemos muy fuertes inversiones y tenemos la misma seguridad que tiene un concesionario de balneario. O menos. Porque vivimos de un permiso [...] ¿Porque el barco cuánto vale sin permiso? Nada. Con permiso vale un montón. Sin permiso y en Argentina no vale nada el barco. Entonces transformamos los permisos provisorios en definitivos [Durante su gestión en el área pesca]. Y las habilitaciones tratamos de que se hiciera un sistema en la Municipalidad y el SENASA que tuvieran alguna seguridad jurídica más. Entonces toda esa situación que lleva a que vos tenés que estar en contacto siempre con el Estado, significa que estar siempre hablando con funcionarios porque tenés o problemas de pesca, de lugares donde pescar. O tenés problemas de métodos de pesca, formas de pesca. Si ponemos las cámaras o no ponemos las cámaras, si ponemos el control satelital o no ponemos el control satelital [...] Cualquier decisión de Cancillería que tenga que ver con el mar me afecta o me favorece. Cualquier decisión de la política cambiaria me destruye o me hace crecer. Cualquier decisión de la política industrial..." Entrevista del autor con Oscar Fortunato... op. cit.
} 
ambas sobre la base de tres defunciones: el comunismo, el estatismo latinoamericano y el estado benefactor. Apropiándose de las ideas de Juan Llach (1997), Bertolotti y su equipo parecen entender las transformaciones sociales de carácter mundial como un proceso que impacta sobre los estados nacionales, a lo cual el gobierno argentino respondió acompañando dichos procesos vía apertura económica y estabilidad monetaria. En dicho marco, aparecen las estrategias desarrolladas por los principales industriales pesqueros que tienen que ver con la adaptación al cambio técnico y la búsqueda de maximizar ganancias en torno a mejorar la eficiencia y la productividad, desplegar su producción y acceder a los mercados mundiales (Bertolotti et. al., 2001). La lucha social y la dinámica política no forman parte del análisis. Tampoco aparecen estos fenómenos en el trabajo de Mizrahi (2001). En el caso de Pradas (2006), desde una perspectiva marxista, el autor estudia la evolución de la estructura económica de la actividad pesquera desde 1960 hasta el año 2000. Presuponiendo la existencia de clases sociales, caracterizadas por un vínculo antagónico, focaliza el análisis en la historia de los ciclos económicos de auge, depresión y crisis de la actividad. De este modo, dicho marco le permite dilucidar los momentos de crisis y reconversión de la actividad con el objetivo de, en un próximo trabajo lamentablemente no concretado por el fallecimiento de su autor, visualizar cómo el movimiento obrero portuario respondió en cada coyuntura a los intentos de descargar las crisis sobre los trabajadores y trabajadoras. Al mismo tiempo, se ocupó de esclarecer las características y transformaciones del empresariado pesquero. Con todo, las menciones respecto a la dinámica política y a la lucha social aparecen como intuición y presupuesto del análisis, pero al concentrarse en los factores de transformación estructural, no profundiza sobre aquellos aspectos. Quien sí avanza en este sentido es César Lerena (2009), que no sólo es autor de un libro, también es actor de los hechos que narra. Lerena en forma por demás interesante por el conocimiento de primera mano que posee y las evidentes cualidades de investigador, hace referencia al trasfondo político, pero más como una enumeración de políticas erróneas o maliciosamente adoptadas, que como una interpretación de un hecho histórico a partir de alguna teoría social que lo sustente. En su examen, busca demostrar (para lo que tiene buenos argumentos) que la pesca durante la década del ' 90 , y aún hasta el día de hoy, sólo fue una moneda de cambio para los gobiernos de turno, que lejos de desarrollar un programa de crecimiento industrial, utilizaron a la industria para "mejorar" las relaciones internacionales del país con potencias extranjeras. Y ubicará lo que denominó como "biocidio", es decir la sobreexplotación de los recursos pesqueros, como desenlace de aquel proceso, donde la inexistencia de una política pesquera y la torpeza o complicidad de los funcionarios de turno con intereses "no nacionales", obtienen un peso central en las responsabilidades. Mientras que, en la visión del autor, el empresariado pesquero respondió "adaptándose" a las posibilidades de negocio que la política oficial les permitía. Perrota (2008), por su parte, menciona el despliegue de determinadas políticas para la industria de la pesca. El autor recorrió el desarrollo, expansión y crisis de la pesca comercial marplatense bajo la idea de que al cambiar el modelo de acumulación a nivel mundial y nacional a mediados de la década del setenta, como correlato de esa transformación en la pesca se consolidó un sector empresario monopólico vinculado al capital extranjero y orientado hacia el mercado mundial, aumentando su poder político y precarizando alos trabajadores. Dentro de ese proceso, el Estado no aparece como un actor pasivo, sino que actúa en materia legislativa, desregulando la actividad y aumentando el carácter privado de la extracción, producción y comercialización. Perrota avanza entonces en el análisis de las políticas pesqueras y su descripción, pero por economía de espacio y los objetivos propuestos por el autor, más que ofrecer un análisis exhaustivo de las mismas, solamente las menciona en un orden cronológico, por lo que la trama política queda desdibujada. 
La especificidad de la coyuntura de crisis de la merluza, acontecida entre los años 1997 y 2001 , motivó la realización de diferentes trabajos. Dentro de ellos, Litovsky (2000) es quien mejor desarrolla el vínculo entre incentivos políticos y sobreexplotación pesquera, adentrándose en las características de la administración estatal pesquera. Partiendo de que, dada la especificidad de operar con un recurso de acceso abierto, la literatura existente sobre recursos naturales y política ambiental puede predecir cuál será la conducta de los pescadores que se guíen por sus incentivos racionales, Litovsky intentará responder la pregunta de si el Estado tuvo "incentivos" propios que operaron en detrimento de la regulación de un espacio común. Discutiendo con las visiones más “ingenuas” según las cuales los Estados siempre poseen inventivos para regular los recursos naturales, encontrará que, al contrario, la racionalidad política posee una lógica inherente cortoplacista. Así es que los contemporáneos carecen de incentivos para resolver los conflictos dado que, en la medida que los costos de no tomar una decisión recaen en futuras gestiones, la opción será siempre la de no querer absorber los costos políticos de, por ejemplo, cerrar el caladero. En este sentido, Litovsky es quien más avanza en la relación del conflicto social, forma estatal y políticas pesqueras. Pero se centra solamente en los incentivos (o desincentivos) del Estado para regular los recursos naturales, en el período comprendido por la crisis de la merluza. En ese sentido, al ubicarse solamente en el período de la crisis, la perspectiva del cómo se llegó a la crisis, así como la génesis de las políticas pesqueras, no aparecen como el resultado de la lucha social y la dinámica política, reduciendo de ese modo, a nuestro entender, lo que se entiende por lucha política. Godelman (2001), por su parte, entiende la crisis de sobrepesca como un fenómeno producido por la sobrecapitalización en el sector que redundó en el sobredimensionamiento de la capacidad extractiva. En su visión, una serie de factores operaron como incentivos para que los actores económicos continuaran con las inversiones en la rama: las facilidades de acceso, gratuidad de la extracción, subsidios directos o indirectos, posibilidades irrestrictas de captura, falta de control y en general buena relación costo beneficio. En este aspecto, el acuerdo con la UE fue uno de los ejes centrales que motivó el sobredimensionamiento de la flota, que para peor, se dirigió principalmente a pescar merluza. Si bien puede adivinarse una crítica a las políticas implementadas, se parte de los resultados que arrojaron la implementación del acuerdo pesquero y la política de mar abierto, pero no se menciona el proceso de luchas previo ni tampoco la interacción entre actores que da lugar a que esas políticas efectivamente pudieran implementarse. También Villalobos (s/f) se refirió a la depredación de la merluza. En su análisis partió de la afirmación de que la pesca comercial en la Argentina se caracterizó históricamente por un nivel de esfuerzo pesquero que no constituía ningún peligro para la biomasa hasta llegar a la década del '90, cuando abruptamente se pasó a un estado de sobrepesca. Pretende dar cuenta de esta situación desde la perspectiva de la economía de bienestar que mide la relación beneficio - costo, buscando proyectar cuáles eran los costos y beneficios de generar una política alternativa de manejo sustentable de los recursos naturales extinguibles así como también del "no hacer". Al contrario de Litovsky que analizó cuáles eran los incentivos para que pasara lo que efectivamente pasó, Villalobos calculó las pérdidas que pudieron haberse evitado si se hubiera seguido una política diferente, a partir del respeto de las tasas máximas de captura. ${ }^{155}$ Su perspectiva supone imaginar un analista situado en 1990 frente a dos opciones de políticas diferentes para regular los recursos. Dentro de la primera opción, las capturas no superan las máximas permitidas; mientras que la segunda opción es la que se adoptó (llevando a la sobrepesca). Esto

\footnotetext{
${ }^{155}$ Este tipo de análisis puede utilizarse para calcular alguna tasa con el valor de la pérdida que provocaron los responsables de extinguir un recurso y, en ese caso, solicitar compensaciones.
} 
le permite esbozar cuánto se hubiera ahorrado la sociedad si no se hubieran desplegado políticas de desastroso manejo pesquero. Pero no esboza una explicación del por qué se adoptaron efectivamente esas políticas y, una vez más, no se analizan las mismas como resultado de un proceso político.

En cuanto a trabajos centrados en la conflictividad y las condiciones de trabajo en la industria pesquera, Yurkievich (2012) aborda el conflicto social desde una perspectiva geográfica, procurando otorgar un peso específico a la espacialidad en la configuración de las formaciones sociales y económicas. Si bien se plantea como objetivo dar cuenta del discurrir político, económico y espacial de la pesca comercial marítima argentina durante el período 1991-2007, la trama política y los enfrentamientos no aparecen como un elemento de investigación. En su análisis las políticas efectivamente implementadas en la industria pesquera, apelando a las fuentes teóricas del regulacionismo, se explican por la transformación estructural del sistema de regulación que pasó de la industrialización sustitutiva al postfordismo (o neoliberalismo). Gennero de Rearte et al (1997), centrados en las nuevas modalidades de organización del trabajo, estudian el surgimiento de las cooperativas de fileteado de pescado a partir de la necesidad de las empresas de adaptarse a la nueva lógica de acumulación tras la crisis del modelo de desarrollo fordista. En su visión, en cuanto se perfila un nuevo modelo de acumulación cambian también los marcos regulatorios (del trabajo en este caso) que, para los trabajadores, significó un desequilibrio en el poder de negociación. Siendo un trabajo fundamental para estudiar el proceso de cooperativización, no forman parte de la argumentación ni del análisis la conflictividad social ni la trama política. Igualmente un informe elaborado, en colaboración con los doctores José Mateo y Agustín Nieto, por el autor de esta tesis (Mateo, Nieto y Colombo, 2010) sobre la "precarización" laboral de los trabajadores de la industria pesquera, desarrolla la implementación de políticas tendientes a la flexibilización de la fuerza de trabajo como resultado de la transformación del patrón de acumulación capitalista. Si bien se atiende a la conflictividad desarrollada no se avanza en el estudio de la dinámica de la disputa política. También Cutuli (2012) se ocupó de las condiciones de trabajo en la industria pesquera, concretamente del proceso de flexibilización laboral padecido por las trabajadoras de la industria pesquera marplatense, desde una analítica que conjuga los estudios del trabajo incorporándole una mirada centrada en las relaciones de género. ${ }^{156}$ Pero no se ocupa, pues no forma parte de su interés analítico, de pasar revista de la dinámica política que llevó a la implementación de determinadas políticas pesqueras. Lo mismo vale para los estudios anclados en el conflicto social como formador de territorios sociales (Nieto, 2010; Colombo 2010a; 2010b; 2008; Nieto y Colombo, 2009; 2008), los cuales avanzaron en la conflictividad social en la pesca, que obviamente implica una politicidad, pero no se ocuparon de lo que llamamos la trama política de las políticas económicas.

A estos trabajos podríamos agregar una serie de estudios que realizan aportes fundamentales, dado que antes de ellos era poco lo que se conocía sobre los fenómenos que se exponen, como los trabajos de Cepparo sobre la valorización del espacio pesquero patagónico a partir de los incentivos de las políticas públicas (Cepparo et al, 2007a; 2007b), el diagnóstico de Rodríguez coord. (1999) sobre el sector pesquero marplatense, y el análisis de Cóccaro et. al (2000) sobre el pasaje de la pesca de ser una

\footnotetext{
${ }^{156}$ En tanto los cambios que se producen en los procesos de trabajo así como las formas de lucha y protesta obrera no resultan inocuas respecto a cuestiones de género, debemos señalar allí una limitación en las aportaciones de esta tesis. Sin embargo, dejando claro esta limitación de la que no pretendemos exculparnos, nuestro estudio avanza en sentidos que consideramos en nada se oponen a pensar algunas dinámicas en clave de género. Al contrario, estudios producidos desde esa perspectiva sin duda pueden enriquecer y colaborar a complejizar el tipo de investigación que aquí presentamos.
} 
actividad de recolección a una de extracción "minera". En todos ellos, la dinámica política no ocupa un lugar de importancia.

Con todo, en líneas generales los estudios disponibles sobre la actividad pesquera no se han ocupado del desarrollo de lo que definimos como la trama política. Consideramos que este proceso debe ser entendido a partir del despliegue de un nuevo patrón de acumulación capitalista denominado recurrentemente como neoliberal o rentístico-financiero (Calcagno y Calcagno, 2003), de la valorización financiera (Basualdo, 2002; 2006) o con hegemonía del capital financiero (Peralta Ramos, 2006; Iñigo Carrera, 2009), basado en la precarización de las condiciones de vida y trabajo de una importante franja social (Novick et al, 1989; Beccaria y Orsatti, 1989; Salvia y Tissera, 2000; Lindemboim, 2004) así como en el desarrollo del proceso de centralización y concentración de capitales dando lugar a la consolidación de grandes grupos económicos (Vilas, 1974; Asborno, 1988; Basualdo, 2006; Peralta Ramos, 2007) y la profundización del proceso de transnacionalización de la economía argentina (Kosacoff y Porta, 1998; Chudnovsky y López, 2001; Briner y Schorr, 2002; Jozami y Lefrancois, 2004). Pero también razonamos que el análisis del proceso debe comprender, como sostienen distintos autores para el caso global de la reforma económica en la Argentina (Beltrán, 2007; Viguera, 2000), que el resultado de las políticas pesqueras efectivamente implementadas no se trató de la imposición de los intereses de una coalición previamente conformada que presionó sobre las agencias estatales, y que ya era portadora de un proyecto acabado. Sino más bien fue la tramitación de lo que llamamos proceso político, lo que fue dando forma a los hechos y delimitando un perfil. En este sentido podemos pensar a la trama política como el territorio donde se expresan los diferentes actores en pugna que, al mismo tiempo, influyen sobre las agencias estatales. Por supuesto, se trata de un territorio separado de la conflictividad solo en el análisis, en cuanto nos permite una mayor claridad expositiva. A su vez, el proceso político aparece vinculado a diferentes factores como las tendencias de la economía mundial, las jerarquías internacionales entre países (las pensemos o no en términos de dependencia), las formas institucionales y reglas jurídicas, el tipo de relación de los actores con el Estado, etc. Pero pensamos que la idea de trama política puede funcionar como explicación del territorio donde esos múltiples factores interrelacionados y puestos en acción darán lugar a la conformación de proyectos y coaliciones $\mathrm{y}$, en definitiva, a las políticas finalmente implementadas. ${ }^{157}$

En el caso de la actividad pesquera, el proceso de consolidación de determinados agentes productivos se afianzó sobre la base de una derrota de otros proyectos (nunca terminados y cerrados) que también pugnaban por ocupar un lugar. Que estos movimientos no hubieren triunfado o que, como en nuestro caso podamos decir no fueran más que una ilusión, ello no los arroja fuera de la historia. Y no sólo se trata de "recuperar" ese proyecto porque su sola existencia merece conocerse. Ignorarlo terminaría por hacernos mal comprender todo un proceso histórico que implicó luchas y pugnas y, tal vez, hacernos caer en una visión teleológica que explique lo que finalmente ocurrió como un resultado inevitable y no como resultante de procesos históricos. Aquí, en particular, procuraremos ver el nacimiento del proyecto pesquero esbozado por un grupo de empresarios fresqueros, varios gremios marítimo-portuarios y

\footnotetext{
${ }^{157}$ El derrotero de las reformas económicas muestra que fueron modelándose en un proceso de permanente interacción y negociación entre el gobierno y los empresarios (Beltrán, 2011). Agreguemos también que la negociación y disputa implicó al movimiento obrero (Etchemendy y Palermo, 1998). Aunque en este punto e instalados en este terreno de la trama política, en el marco de las relaciones sociales capitalistas, los empresarios adquieren una notoria centralidad, detentando un poder estructural superior al resto de las clases sociales, en la medida en que son quienes detentan los resortes de la acumulación capitalista (Offe y Wiesenthal, 1980)
} 
diferentes funcionarios de disímiles partidos políticos, así como la consolidación de una fuerza social que intento materializarlo. A su vez, si bien las políticas implementadas avanzaron en el sentido de una profundización de la apertura externa, la transnacionalización de los agentes económicos y la vocación "minera" extractiva de la industria, hubo hechos de resistencia expresados en acciones o, cuanto menos, en acciones discursivas. Y es precisamente con todo este bagaje de enfrentamientos previos que se llegó a la coyuntura crítica de los años 1997-2000 cuando conflictos que permanecían soterrados se expresaron de manera más clara y contundente.

Con todo, uno de los objetivos que nos planteamos en este capítulo es dar a conocer el proceso de gestación de "la revolución productiva" en la pesca (así nombraron el proyecto los actores que buscaron implementarlo), mostrando su desarrollo, las batallas que brindaron sus principales sostenedores y los resultados que el proceso fue arrojando en su propio devenir, que se dibujará favorable a un proyecto diferente hegemonizado por los "Pulpos de la Pesca" y capitales extranjeros, dando por tierra con los sueños de empresarios "fresqueros" y dirigentes gremiales. Para avanzar en ello, procuramos entonces desandar la trama política de esos acontecimientos que fueron sucediendo escalonadamente, para, en el caso del "proyecto fresquero", ser sepultado por quien, a priori, se presentaba como su principal articulador. Una vez conocido ese proceso, transitamos por la década del ' 90 desarrollando las políticas pesqueras que efectivamente se implementaron, buscando señalar a sus promotores y detractores. En este camino, procuramos volver la mirada sobre los vínculos entre empresarios, Estado y gobierno, junto con las respuestas que brindó el movimiento obrero. Pensamos que este proceso actúa como condicionante de las políticas económicas implementadas para el sector e invita a analizar el tipo de intervención estatal a partir de la trama de relaciones que afectan a empresarios y organismos estatales y que incluyen prácticas institucionalizadas de presión sobre el aparato estatal, de influencia directa (lobby), de colusión, de colonización y hasta de corrupción. Además, esta lectura supone que los resultados (positivos o negativos) de los agentes privados que funcionan en un contexto económico definido por estas características, lejos están de sustentarse en la "libertad" de la competencia económica, sino que se originan a partir de la forma en que el Estado garantiza, o al menos estimula, determinados procesos de acumulación. Lo que nos sitúa ante un rasgo capital del desenvolvimiento económico argentino y que refiere al proceso de difusión de "ámbitos privilegiados de acumulación" (Castellani coord., 2012). Haya o no constituido la pesca un APA, lo cierto es que cualquier investigación que se plantee analizar el desarrollo de la actividad, para poder avanzar en el conocimiento de los procesos acontecidos, deberá tener en cuenta la relación entre empresarios, Estado y trabajadores.

De este modo, la disputa de actores sociales y su capacidad de influencia sobre el aparato del Estado será el eje ordenador que nos permitirá transitar la implementación de políticas para la pesca que, en definitiva, llevaron a un profundo deterioro en las condiciones de vida y trabajo de los obreros y obreras del sector que tuvo como telón de fondo la crisis de los recursos naturales. Contexto sobre el que se desarrolló una intensa conflictividad social que analizaremos oportunamente en el capítulo IV.Finalizando las palabras preliminares, decimos que se trata en este capítulo de enunciar cronológicamente determinados problemas que intentan vincular la formación de coaliciones y las acciones que despliegan sus integrantes, con la forma de Estado y las políticas de gobierno, para luego sí poder avanzar sobre la conflictividad social y la situación de los trabajadores y trabajadoras. 


\section{La "industria pesquera nacional" y la revolución productiva}

En julio de 1988 Carlos Menem ya había vencido al entonces gobernador de Buenos Aires y figura de la renovación, Antonio Cafiero, en lo que fue la primera interna de la historia del Partido Justicialista con voto directo de afiliados y, de ese modo, se constituía en el candidato presidencial por el justicialismo para las elecciones de 1989 (Bonnet, 2007). En lo que a nosotros nos compete, interesa destacar que dentro del grupo que formó parte del diseño de la plataforma de campaña electoral del futuro presidente participó en calidad de asesor en temas de política pesquera el veterinario César Augusto Lerena. Éste provenía de las filas del PJ habiendo coordinado la Comisión de Pesca dentro de los equipos técnicos de Ítalo Luder durante la campaña presidencial del año 1983. Contaba con un vasto curriculum como docente, funcionario del Servicio Nacional de Sanidad Animal (SENASA), ex gerente de la pesquera Ventura Mar del Plata S.A., e integrante de las comisiones directivas de las Cámaras de Armadores; de Procesadores; e Industriales de la Pesca. Por aquellos años presidía el Centro de Estudios de la Pesca (CESPE) y el Colegio de Veterinarios de la Provincia de Buenos Aires.

Por otro lado, entre varios apoyos en la ciudad de Mar del Plata, la candidatura de Menem tenía el sostén del entonces secretario general del Sindicato Obrero de la Industria del Pescado (SOIP) y luego de la CGT regional, Abdul "El Chancho" Saravia. Éste trabóamistad con Menem durante los años en que el riojano recayó en la ciudad de Mar del Plata tras la prisión y destierro impuesto durante la última dictadura cívico-militar, luego de que como condición de su libertad condicional se lo obligara a no volver a La Rioja (Cerruti, 1993). ${ }^{158}$ El personaje del caudillo había fascinado al sindicalista, que desde un temprano 1984 creyó en la posibilidad de que Menem llegaría a la presidencia. ${ }^{159}$ En el año 1986 cuando se conformó Federalismo y Liberación. Línea Nacional. Rojo Punzó para impulsar la candidatura presidencial de Menem, Saravia fue uno de los hombres fuertes de la agrupación en la provincia de Buenos Aires, ocupando por varios años el cargo de presidente, además de desempeñarse como consejero provincial del PJ representando al Partido de General Pueyrredón, integrar las 62 Organizaciones Peronistas de Mar del Plata y ser luego uno de los promotores del FREJUPO local. ${ }^{160}$

Pero vayamos unos años atrás y veamos un episodio que cimentó los vínculos entre Lerena y Saravia. En octubre de 1986 se produjo un paro regional contra la firma de los Acuerdos Marco ${ }^{161}$ liderado por la CGT local bajo el impulso de Saravia. Apoyaban la medida de fuerza los industriales pesqueros vinculados con UCIP. En cambio, expresaron su adhesión a los acuerdos las empresas Estrella de Mar, Bajamar, Antártida Pesquera Industrial, Pescasur, Pesquera Santa Cruz, Santa Elena y Pionera (Lerena, 2009). El escenario planteaba así una disputa inter empresaria. El énfasis en la soberanía nacional, el apoyo a la candidatura presidencial de Menem y su antagonismo con las empresas que

\footnotetext{
158 Junto a Saravia, el empresario José Greco, dueño de FRIGOCEN, fue otro de los protectores de Carlos Menem durante su detención. Luego éste, junto con Francisco "Paco" Ventura, Luciano Zucatosta de Ventura S.A. y Norberto Otero de Hielo Nevada fueron algunos de los empresarios pesqueros que apoyaron la candidatura de Menem.

${ }^{159}$ Por ejemplo en el año 1985 el SOIP convocaba a "todos los Compañero/as y grupo familiar de la Industria del Pescado" a la entrega de Diplomas y certificados de los trabajadores y trabajadoras egresad@s de la Escuela de Capacitación Sindical "22 de Agosto". En lo que se presentaba como una cena de compañerismo se resaltaba la presencia del gobernador de la Provincia de La Rioja Dr. Carlos Saúl Menem, así como también la de Saúl Ubaldini. Invitación entrega de diplomas, Comisión de Organización, SOIP, 27/12/1985. Archivo de prensa diario La Capital.

${ }^{160}$ En el próximo capítulo brindamos mayores datos biográficos sobre este personaje central en la pesca marplatense.

${ }^{161}$ Se trata de los acuerdos mencionados en el Capítulo I.
} 
apoyaron los acuerdos constituyó el marco propicio para que se conformara una "alianza social" "162 entre los grupos empresarios de la pesca y varios sindicatos, que se ratificó mediante la elaboración de un documento producido en conjunto en el año 1988, donde a la par industriales y gremialistas delinearon algunos cursos de acción como:

...asuntos referidos a la preservación del recuso, los tratados internacionales, la necesidad de una ley nacional de pesca, la creación de una secretaría nacional, la aplicación de normas que protejan la salud, higiene y condiciones de trabajo, la reducción de las capturas en la Zona Común del Tratado del Río de la Plata, el repudio al otorgamiento de permisos de pesca en la zona de exclusión de Malvinas, el control de las capturas clandestinas, el tratamiento cambiario y arancelario de la industria, lo que está demostrando claramente el grado de entendimiento... (Saravia en Lerena, 1989: 107).

En 1989 la relación entre Saravia, Lerena y Menem quedó plasmada públicamente con la aparición del libro La Industria Pesquera Argentina: reafirmación o decadencia, cuyo autor era el mismo Lerena. Contaba con los aportes de Menem en la elaboración del "Prólogo" y de Saravia en el capítulo "El pacto social pesquero". En el prólogo, y atendiendo al contexto de elaboración que implica el intento de seducción del electorado y la competencia política, Carlos Menem plasmaba las medidas que proponía implementar para la pesca en caso de alcanzar la presidencia de la Nación:

Estamos convencidos que con las herramientas necesarias, la producción de este sector permitirá cuadruplicar el consumo interno de este vital alimento proveedor de proteínas del más alto valor biológico, y quintuplicar el ingreso de divisas al país mediante las exportaciones de productos pesqueros. El aumento del valor agregado a los productos, el incremento del consumo nacional, las exportaciones de especies no tradicionales, la captura argentina en zonas adyacentes al mar territorial argentino y la consecuente ampliación de la producción de harinas, conservas y aceites, habrán de generar recursos directos del orden de los mil cuatrocientos puestos de trabajo, que el Justicialismo aspira a concretar, movilizando las fuerzas de la producción en programas concretos, apoyados por el dictado de las normas necesarias para favorecer esta revolución productiva (Menem en Lerena, 1989: 9. El énfasis es nuestro).

Y remataba "No dudamos tampoco que la pesca se constituirá en un protagonista activo en el impostergable objetivo de la integración latinoamericana, partícipe necesario en la recuperación pacífica de las Islas Malvinas". El libro presentaba como propuestas para el desarrollo pesquero la expansión del mercado interno a través de la educación de los consumidores, el otorgamiento de subsidios a las empresas y la creación de puestos de trabajo. Además proponía una política cambiaria que mantuviera una ecuación positiva entre el dólar de exportación y los costos internos de producción; una política monetaria que contemplara la financiación de la producción y exportación; inversiones destinadas a la modernización tecnológica y una política fiscal que privilegiara las exportaciones con alto valor

\footnotetext{
${ }^{162}$ Entrecomillamos la categoría puesto que amerita una advertencia. La utilizamos de manera más laxa que la noción de alianza de clases, y a la vez, con mayor énfasis que la categoría de compromisos inestables, puesto que la coincidencia de industriales y trabajadores será una constante en oposición a un tercer antagonista, y eso es lo que delinea un tipo de alianza pero, al mismo tiempo, mostrará altos momentos de antagonismo interno y diferencia programática.
} 
agregado. En cuanto a las relaciones trabajo - capital propugnaba por un pacto social que sería rubricado con los gremios del sector, mediante el cual las partes se comprometían:

...por un período determinado a no realizar ningún tipo de medidas de acción directa sin previamente presentar y debatir en una mesa de concertación creada al efecto los problemas que pudieran motivar disputas entre las mismas, sin perjuicio del reclamo ante la autoridad competente de no encontrarse solución al diferendo...

Como contrapartida de mantener la "paz social" en pos de alcanzar "el crecimiento productivo y el fortalecimiento del hombre trabajador" se proponía garantizar un incremento inicial de los salarios. ${ }^{163}$ Por otra parte, en el texto Lerena se ocupaba de indicar cuál era el rol del Estado Nacional y los Estados provinciales, definía mecanismos de regulación y el modo de apropiación de los recursos y se manifestaba contrario a la pesca extranjera sin una ordenación precisa, cuestionando los Acuerdos Marco (con la URSS y Bulgaria) que, en opinión del autor, arrojaron "resultados lamentables" (Lerena, 1989).El propio Lerena destacará años más tarde que su libro se trataba de la publicación de "la política pesquera industria nacional" (Lerena, 2009). Es importante señalar que el autor no descartaba la inversión extranjera, y al contrario, veía entre las funciones del gobierno del Estado la promoción y el fomento de las sociedades mixtas entre empresas locales y foráneas, aunque aclaraba que se debían tomar las precauciones indispensables para que esas sociedades se constituyeran con empresarios "argentinos de probada idoneidad en la temática" (Lerena, 1989). Con lo cual, por un lado, mostraba un clima favorable para la incorporación de capitales externos $\mathrm{y}$, por otro, indirectamente señalaba la existencia -cuanto menos potencial- de empresarios que, desde su perspectiva, no eran "idóneos" y por ello no debía considerárselos como miembros en los proyectos de asociaciones mixtas. Según Pradas (2006) la propuesta de Lerena fue el primer y único "intento intelectual orgánico del empresariado fresquero" por diseñar un proyecto de política pesquera integral. ${ }^{164}$ Por último, el texto que disertaba sobre otros aspectos que hacen a la industria pesquera, sugería además un proyecto de Ley Nacional de Pesca, el cual se presentaba para iniciar la discusión tendiente a la generación de una norma reguladora de la actividad.

\footnotetext{
${ }^{163}$ Ver Lerena (1989). También L.C.,13/06/1989. En relación a la “paz social”, la CAABPA y los Procesadores explicaban que "La industria pesquera argentina se desarrolló en un marco de permanentes conflictos laborales como consecuencia del gran número de gremios que tienen injerencia dentro del proceso productivo en todas sus etapas... sólo es posible aspirar a una reactivación de la actividad pesquera, con un período de paz social sin conflictos laborales, que permita restablecer los niveles de producción necesarios" (Revista Redes, N³7, 1988 cit. en Perrota, 2008: 72).

${ }^{164}$ También la revista Pesca Argentina, financiada por empresarios pesqueros, oficiaba como tribuna del proyecto de política pesquera de "los fresqueros" marplatenses.
} 


\title{
Una ley para la industria pesquera(I). Caída del radicalismo y victoria del FREJUPO
}

\author{
"Desde la presidencia de Nicolás Avellaneda, \\ pasaron más de cien años sin darse un marco legal para la explotación pesquera". \\ Felipe Ludueña, Senador del PJ por Santa Cruz. La Capital, 05/12/1991.
}

Aún promediando la década del '90 la Argentina carecía de una ley nacional de pesca. A comienzos de 1989 hubo intentos más definidos por dar sanción a una norma que ordenara la actividad originando entonces diferentes discusiones. El dictado de una ley pretendía regular, entre otras cosas, el modo de acceso de los agentes privados a los recursos marítimos. Como vimos en el capítulo I, hasta mediados de los años '70s prevaleció el criterio de "pesca olímpica” según el cual más o menos cualquier interesado/a podía pescar todo lo que quisiera. Subyacía entonces la creencia de que los recursos del mar argentino eran prácticamente infinitos. Luego se implementó el sistema de permisos de pesca y recién en el año 1997 se sancionó una ley nacional. ${ }^{165}$ Pero volvamos por ahora a los primeros intentos de promulgar una normativa en el período que nos ocupa.

Los debates en torno a la nueva legislación se daban en el contexto mundial que expresaba un agotamiento del modelo de acumulación por sustitución de importaciones en los países de América Latina (Boesner, 1996). ${ }^{166}$ En Argentina es a partir de 1987 cuando comienza a introducirse en la agenda pública la cuestión de las reformas estructurales y la apertura económica (Viguera, 2000). Desde el año anterior, en el marco de las tratativas con la URSS y Bulgaria por los Acuerdos Marco, el entonces subsecretario de pesca del gobierno radical presentó un proyecto de ley de pesca que, entre otros puntos, autorizaba la pesca con buques extranjeros mediante la firma de acuerdos internacionales (Lerena, 2009). En 1988, el senador de la UCR Solari Yrigoyen presentaba otro proyecto que recogía la posibilidad de que buques extranjeros pescaran en caladeros nacionales. Ese contexto era el que servía para la activación de la Coordinadora de Gremios Marítimos, ${ }^{167}$ que se declaró en estado de alerta y movilización en oposición a la apertura del mar argentino, retomando las banderas que la habían movilizado en 1986. La entidad quería una norma, pero se oponía a la apertura del caladero a flotas extranjeras. Por eso presentaba su propio proyecto de ley que, en palabras de su representante legal, Dr. Gustavo Demarchi:

Es el único proyecto que abarca todos los ámbitos: la investigación, la producción, la extracción, las relaciones laborales que se generan dentro de la actividad pesquera -tanto en la extracción, en la producción como en el transporte-, que apunta a la calidad del producto, a la

\footnotetext{
${ }^{165}$ La misma establecía el sistema de cuotas individuales transferibles como mecanismo de acceso a los recursos, permitiendo de este modo su privatización. Pero las disputas en torno al mecanismo que otorgaba el acceso a los recursos no acabaron con la sanción de la ley. Al contrario, este aspecto constituyó el eje de los nuevos conflictos.

${ }^{166}$ Previamente, data de 1974 un proyecto de ley de Pesca presentado a la Cámara de Diputados de la Nación que entre otras cuestiones creaba una Corporación Nacional de Pesca Marítima la cual sería el organismo estatal encargado de ejecutar la política pesquera. Archivo DIPPBA, Mesa B, Factor gremial, Carpeta 57, Legajo 33.

${ }^{167}$ Integraban entonces la Coordinadora Abdul Saravia (SOIP), Carlos Barboza y Edelmiro Gavilán (SICONARA), Héctor Máximo y Julio Di Gerónimo (Centro de Capitanes y Patrones Fluviales de Pesca y Cabotaje) y Carlos Villarreal (SAON). Aparecen también Roberto Comaschi (sec. Adjundo de la CGT regional) y los asesores Dr. Gustavo Demarchi y Dr. Eduardo Bonoris. Estos últimos integraban además el CESPE que dirigía César Lerena.
} 
promoción del consumo interno, a la posibilidad de sumar valor agregado al pescado extraído del $\operatorname{mar} . .{ }^{168}$

Poco después, senadores radicales y peronistas acordaron un proyecto de ley que integraba la propuesta de Solari Yrigoyen con otra del senador del PJ Edgardo Murguía y permitía, a través de su artículo 24, el acceso a la actividad por parte de buques extranjeros a partir de tratados internacionales que aseguraran ventajas recíprocas. También se estipulaba interponer ciertas restricciones a la operatoria de buques factoría, los cuales estaban obligados a desembarcar las capturas en puertos argentinos y un $10 \%$ de su personal debía ser de nacionalidad argentina. ${ }^{169}$ Además, decretaba la creación de la Secretaría de Pesca dependiente directamente del Ministerio de Economía, separándose así de la cartera de Agricultura y Ganadería y dejando el rango de Subsecretaría. ${ }^{170}$

En ese entonces, la Coordinadora de Gremios Marítimos cuestionaba varios artículos del proyecto de ley y ratificaba el estado de alerta y movilización. Los sindicalistas denunciaban que el proyecto "entrega nuestra riqueza icticola", atacaban a los radicales y justicialistas firmantes y buscaban solidaridad en el reclamo apelando a la "comunidad marplatense" integrada por las "fuerzas de la producción y a todos los sectores de la ciudad" y "partidos políticos, legisladores y candidatos". ${ }^{171}$ Un comunicado del SOIP, que rechazaba "terminantemente" la iniciativa calificándola de "entreguista", declaraba que "el proyecto de ley debe contar con el respaldo del sector gremial y empresarios de la industria pesquera y naval, que hasta la fecha ha formulado serias criticas a aspectos de fondo de la citada legislación" para lo cual debía consultarse a la ciudad de Mar del Plata. El gremio se identificaba con lo que denominaba era "el proyecto nacional mayoritario" de los empresarios pesqueros y unánime en los gremios marítimos. ${ }^{172}$ Esta identificación de la comunidad pesquera marplatense con la pesca "verdaderamente nacional" se repetirá en las batallas que enfrentó el sector pesquero local. El punto principal de desacuerdo radicaba en la posibilidad de que buques extranjeros pescasen en el Mar Argentino. Contra ello, citaba como antecedente negativo la firma de los Acuerdos Marco. Además, se cuestionaba la promoción de la exportación de pescado sin elaboración en tierra. Para Saravia el proyecto:

\footnotetext{
${ }^{168}$ L.C.,02/10/1988.La figura de Gustavo Demarchi merece que nos detengamos unos instantes en su trayectoria, puesto que se trata de un polémico abogado que tuvo un fuerte peso en el PJ local. Candidato a intendente de Mar del Plata en 1983, fue acusado por su actuación como fiscal entre los años 1974 y 1977, ya que se sospecha tuvo vinculación no sólo con grupos como la CNU (organización investigada por haber cometido diversos asesinatos políticos) sino también con sectores del ámbito castrense. Secretario general del Sindicato de Abogados Peronistas de Mar del Plata a comienzos de la década del '70, ejerció primero la representación legal de las 62 Organizaciones Peronistas y luego de la CGT regional. Recientemente fue detenido en una cárcel en Colombia y extraditado a la Argentina donde está siendo juzgado. Demarchi se desempeñó por muchos años como abogado asesor del SOIP y, según señalan algunos militantes de la industria del pescado, fue también el líder de la Juventud Sindical que funcionaba dentro del sindicato. Es cuanto menos curioso que si bien Demarchi, asociado a lo que se conoce como "la derecha" peronista, fue asesor del sindicato, años antes, el gremio contaba con el asesoramiento del Dr. Norberto Centeno, prestigioso abogado laboralista vinculado al peronismo local, especialista en Derecho del Trabajo y autor del proyecto en base al cual se redactó el Régimen de Contrato de Trabajo. Este abogado primero se había desempeñado como asesor del STIA y luego del SOIP, la CGT regional y otros gremios. Centeno fue detenido-desaparecido el 7 de julio de 1977 apareciendo su cuerpo sin vida cuatro días más tarde. En el mismo episodio, en un lapso de tres días, fueron asesinados otros abogados y el hecho pasó a conocerse como la "Noche de las Corbatas".

${ }^{169}$ L.C., 4/01/1989.

${ }^{170}$ Firmaban el dictamen, entre otros, Faustino Mazzuco, Antonio Berhongaray, José Oenoud, Juan Trilla, Fernando De la Rúa y Luis Brasesco, por la UCR. Carlos Juárez, Liliana Gurdulich de Correa y Antonio Benítez, por el PJ.

${ }^{171}$ L.C., $7 / 01 / 1989$

${ }^{172}$ L.C., $7 / 01 / 1989$.
} 
...atenta contra la industria nacional y promueve la exportación de pescado sin elaborar por buques extranjeros, pretendiendo ratificar legalmente en el congreso de la Nación un pacto de hecho promovido por [Dante] Caputo, [Luis] Jaimes, CAPECA y estos senadores, cuya política instrumentada desde el gobierno ha significado la mayor extracción del recurso pesquero de las dos últimas décadas por parte de embarcaciones extranjeras... [y sentenciaba] El gremio que presido se habrá de oponer activamente a estas iniciativas que tienen apoyo en el minúsculo grupo de empresarios congeladores -CAPECA- que oportunamente apoyaron los Acuerdos Marco y persisten en una actitud que significará el vaciamiento del caladero argentino y la consecuente desaparición de la industria radicada en tierra. ${ }^{173}$

Dos meses antes de esta declaración, la Coordinadora de Gremios enviaba su propio proyecto de ley al Senado de la Nación por intermedio del senador Eduardo Menem. ${ }^{174}$

Por esos días, la entonces asesora del Senado de la Nación en materia pesquera y posterior integrante del FREJUPO, Alicia Muzio ${ }^{175}$, declaraba que "vamos a propiciar una revisión legislativa para que no se renueven los acuerdos marcos pesqueros, que han sido nefastos en lo ecológico, lo social y lo económico". ${ }^{176}$ Junto a los sindicatos, también Cesar Lerena participó de gestiones en contra del anteproyecto de ley de pesca. Durante una reunión con el senador nacional Julio Amoedo, organizada por Saravia, Lerena señaló "estamos en contra de los acuerdos marco de pesca, pero no porque no nos interese la inversión extranjera. Estos acuerdos no implican inversión extranjera sino que sólo se trata de retirar recursos pesqueros del mar territorial argentino pagando un mísero canon". ${ }^{177}$ Aclaraba que la llegada de capitales externos debía servir para el desarrollo de la pesca nacional, lo cual no se produciría bajo el sistema de pesca contra canon sin procesamiento de los productos en tierra. También adhería a la postura contraria a los acuerdos con otros países apelando a la idea de "soberanía nacional" el tandilense y entonces vicegobernador justicialista bonaerense, Luis María Macaya. ${ }^{178}$ Un mes antes, el propio gobernador Antonio Cafiero pedía al gobierno nacional "priorizar el crecimiento de la actividad, a través del sector pesquero nacional y no favorecer más las licencias de pesca para las flotas extranjeras", al mismo tiempo denunciaba que la política cambiaria vigente afectaba al sector, fundamentalmente exportador, "ya que usa al tipo de cambio como variable de ajuste de todo el sistema. Todo esto impide el acceso de nuestros productos pesqueros a los mercados internacionales". ${ }^{179}$ En marzo Lerena envía a las autoridades del PJ un proyecto titulado "Bases para el crecimiento pesquero" cuya finalidad era su incorporación en la plataforma electoral del menemismo. ${ }^{180}$ Para el mes de abril, una nota aparecida $L a$ Capital titulada "La propuesta de Carlos Menem para el sector pesca" reproducía, sin mencionar su origen, todas las ideas de Lerena. ${ }^{181}$

${ }^{173}$ L.C., 27/03/1989.

${ }^{174}$ L.C., 14/01/1989.

${ }^{175}$ Luego de la victoria del FREJUPO se anunciaba su designación en la Dirección Nacional de Pesca Marítima. Pero su nombramiento fue cuestionado por quien entonces conducía el área y terminó asumiendo el cargo el capitán Adolfo César Philippeux. Éste era reconocido dentro del justicialismo por haber participado del levantamiento dirigido por Juan José Valle contra el gobierno de la autodenominada Revolución Libertadora en el año 1956.

${ }^{176}$ L.C.,30/01/1989.

${ }^{177}$ L.C.,31/01/1989.

${ }^{178}$ L.C., $04 / 02 / 1989$.

${ }^{179}$ L.C., 08/01/1989.

${ }^{180}$ L.C.,01/03/1989

${ }^{181}$ L.C., 26/04/1989. 
Por su parte, el candidato a presidente por la UCR, Eduardo Angeloz, presentaba también algunos lineamientos de política pesquera, los cuáles enfatizaban en aspectos que podemos calificar como de compromiso. Se comprometía a "ejercer la soberanía en el mar argentino", "fomentar el desarrollo de tecnologías de captura" y "favorecer el fortalecimiento del sector productivo". La propuesta era más interesante cuando incorporaba alguna de las demandas de los industriales pesqueros orientadas a una política pesquera más en línea con la liberalización de la actividad, como eran la necesidad de desregulación, la eliminación de aranceles para la importación de barcos que la industria nacional no estaba en condiciones de producir y el establecimiento de líneas de crédito para el reequipamiento que ofrecían organismos multilaterales. ${ }^{182}$

Más allá de los proyectos de ley presentados hasta ese momento y de la inclusión de una agenda pesquera por parte del candidato del radicalismo, en mayo de 1989 el FREJUPO obtuvo la victoria electoral. Menem alcanzaba así el anhelado acceso al Ejecutivo Nacional, Saravia saludaba al nuevo gobierno y la pesca, a pesar de los padecimientos financieros, anunciaba exportaciones record. ${ }^{183}$ Para entonces, Lerena venía realizando intervenciones públicas en la prensa marplatense apareciendo como experto en materia pesquera. ${ }^{184}$ Opinaba sobre todos los temas y disparaba sus principales críticas a la política de apertura de los mares a flotas extranjeras encarada por la cancillería, criticando en especial a su titular Dante Caputo, a quien en varias oportunidades invitó a debatir públicamente acerca de geopolítica y cuestiones pesqueras, invitaciones siempre rechazadas por el entonces canciller. ${ }^{185} \mathrm{El}$ veterinario decía con motivo de la presentación de su libro La Industria Pesquera....

Yo sigo insistiendo en que la política de la Cancillería y específicamente del licenciado Caputo, ha sido nefasta no solamente para los intereses sectoriales de la pesca sino para los intereses de la Nación... [y continuaba] ...yo le preguntaría al señor Caputo si la Argentina hubiese dado a extranjeros un millón de hectáreas o un millón de kilómetros como dio de mar argentino, en lugar de ser mar hubiese sido tierra, cuál hubiera sido la reacción de la civilidad... ${ }^{186}$

En mayo la licenciada Alicia Muzio ya era la coordinadora de la Comisión Nacional de Pesca del victorioso FREJUPO. Entonces, mientras anunciaba la necesidad de elaborar una política pesquera nacional, denunciaba la "incoherencia" de las medidas implementadas en materia pesquera por el gobierno radical:

La falta de una política pesquera convirtió a este sector [el de la pesca] en una actividad meramente extractiva y de comercialización fomentando además las relaciones con países del Mercado Común Europeo, aliados de Gran Bretaña. El justicialismo entiende que la política pesquera tiene varios puntos fundamentales como la extracción, industrialización, comercialización, distribución y consumo. Y que se debe privilegiar la relación con Latinoamérica, en especial con

\footnotetext{
${ }^{182}$ L.C., 06/03/1989.

${ }^{183}$ L.C., 18/05/1989; 19/05/1989.

${ }^{184}$ Ver L.C.,09/04/1989, 21/04/1989, 04/05/1989, 07/05/1989.

${ }^{185}$ Uno de los telegramas que Lerena envió a Caputo invitándolo a una discusión pública decía "La riqueza pesquera está siendo devastada impunemente por buques extranjeros, con y sin acuerdos, vulnerando nuestra soberanía, llevando a esta industria productiva hacia la decadencia industrial y la desocupación obrera. Para que los argentinos conozcamos su política, lo invito a debatir sobre pesca y geopolítica en el medio de difusión nacional que usted quiera". L.C.,21/04/1990.

${ }^{186}$ L.C.,07/05/1989.
} 
aquellos países que fueron solidarios con la Argentina cuando se presentó el conflicto con los ingleses por las Malvinas. ${ }^{187}$

De este modo, señalaba una orientación industrialista de la política pesquera que llevaría adelante el justicialismo y, al mismo tiempo, indicaba que el peronismo comprendía en la pesca una actividad estratégica en términos geopolíticos, contraria a la tradicional incultura marítima y escasa valoración de la actividad. Además, anunciaba el lanzamiento de un proyecto para la pesca que llamaba, ampulosamente, el Plan Pesquero Nacional. Así, con el justicialismo en la conducción del país, Lerena contaba con mejores armas para discutir una ley de pesca favorable a su ideario e, imaginamos, se sentía el hombre que llevaría a cabo el ansiado proyecto pesquero nacional. Y Saravia, junto a gremios y diferentes empresarios pesqueros marplatenses, estaban allí para acompañarlo.

\section{La batalla por la subsecretaría: la derrota de "la industria pesquera nacional"}

Después de la colaboración de Menem y Lerena en el libro de este último -recordemos que se había impreso en abril de 1989-, para el mes de junio de aquel año, medios periodísticos marplatenses anunciaban la "inminente designación como subsecretario de Pesca de la Nación" de César Lerena. Aseguraban que el Presidente le había ofrecido el cargo "lo que fue aceptado de buen grado por el doctor Lerena que ha venido preparándose desde hace tiempo para las eventuales funciones de gobierno". ${ }^{188}$ Días más tarde, una nota titulada "Lerena será el titular de Pesca" ratificaba lo antedicho. ${ }^{189}$ Sin embargo Felipe Solá, entonces un joven Ingeniero Agrónomo que había sido secretario de Jorge Luis Taiana ${ }^{190}$ y Ministro de Asuntos Agrarios de la Provincia de Buenos Aires durante la gobernación de Antonio Cafiero, se hizo cargo de la Secretaría de Agricultura, Ganadería y Pesca de la Nación (SAGyP). Y con él, Luis Otero, quien fuera titular del área pesca en la provincia de Buenos Aires, pasará a ocupar la subsecretaría de Pesca Nacional.

La noticia caía como un balde de agua helada en distintos sectores de la pesca marplatense. La Capital titulaba "Crea malestar la no designación de Lerena" ${ }^{191}$. La nota indicaba que la situación generó inocultable fastidio en Mar del Plata, tanto en el empresariado pesquero como en la Coordinadora de Gremios Marítimos. Un cronista del propio diario atribuía la "no designación" a las internas entre el "cafierismo" y el "menemismo", postulando a Solá como un hombre de Cafiero, quien procuraba no perder autonomía frente al avance arrollador del riojano. ${ }^{192}$ Días más tarde se aclaraba que el asunto no se resumía a una interna solamente política:

En el fondo no existe solamente una cuestión política, que está bien presente con grave incidencia, sino una concepción (que puede acarrear, si no se equilibran bien los intereses, graves perjuicios para la pesca de Mar del Plata) de orden económico que parece dividir las aguas en dos

\footnotetext{
${ }^{187}$ L.C.,22/05/1989.

${ }^{188}$ L.C., $11 / 06 / 1989$.

${ }^{189}$ L.C., $13 / 06 / 1989$.

${ }^{190}$ Ex ministro de salud del presidente Héctor Cámpora y médico de Juan Domingo Perón.

${ }^{191}$ L.C., $17 / 06 / 1989$.

${ }^{192}$ L.C., $18 / 06 / 1989$.
} 
campos hasta ahora antagónicos; la pesca con plantas en tierra y la pesca de buques factorías o sea con elaboración en alta mar. La una con eje en Mar del Plata y la otra en el sector patagónico.

Aparecía así mencionado el conflicto entre dos tipos de flota (fresqueros versus congeladores) que tenía, a su vez, una expresión geográfica, dado que en el Puerto de Mar del Plata operaban de forma mayoritaria buques fresqueros, mientras que en la Patagonia argentina principalmente se radicaron los buques congeladores y factoría. ${ }^{193}$ Lo que hasta ese momento no había aflorado plenamente en la escena pública era el enfrentamiento larvado entre diferentes empresarios que integraban la misma cámara, todos radicados en Mar del Plata. Hasta entonces, parecía que el conjunto del empresariado marplatense se sentía perjudicado por la ausencia de Lerena en la secretaría. No obstante, a través de una solicitada del 18 de junio firmada por Roberto Tovo, presidente de la CAABPA y por Homero Cánepa, presidente de la Cámara Argentina de Procesadores de Pescado, los industriales señalaban haber "recibido con singular beneplácito la designación del Dr. Luis César Otero como Subsecretario de Pesca de la Nación". ${ }^{194}$ Días más tarde, declaraban en el mismo sentido el vicepresidente de la CAABPA Antonio Solimeno, los vocales José Moscuzza y Juan Carlos Marzoni y el vicepresidente de los Procesadores Alberto Valastro, así como Juan Zadjman y Alejandro Ocampo de las firmas Arpemar y Alpesca. Tovo y Zadjman, junto con Heriberto Volpato, se habían reunido previamente con el flamante presidente Menem para exponerle "sus inquietudes básicas en materia de desarrollo y protección de la actividad", al mismo tiempo que entregaron un documento donde el objetivo básico de la expansión pesquera consistía en "duplicar en los próximos cuatro años el volumen actual de las exportaciones". ${ }^{195}$

Adrián Freijo, titular de prensa de la gobernación de la Rioja y quien fuera enviado por Menem para supervisar la situación en Mar del Plata, luego de entrevistarse con empresarios pesqueros señalaba que "cuando se trasladó tenía entendido que la posición de rechazo a la designación de Otero era unánime en la ciudad, pero que de los contactos mantenidos en esta jornada su impresión había variado", por lo cual suponía que la ratificación de Otero como subsecretario "parece inmodificable". 196 No coincidía con esa postura la UCIP, que apoyaba a Lerena. De hecho, su entonces gerente ejecutivo, Eduardo Benedetti, fue recibido por Menem en La Rioja para hablar de la situación del empresariado pesquero marplatense. ${ }^{197}$ Mientras que por su parte, los gremios marítimos agrupados en la Coordinadora ratificaban su oposición a la designación de Otero y su inclinación por Lerena, argumentando que dada la importancia de Mar del Plata en la pesca nacional el subsecretario debía ser un marplatense. Pero entonces las divisiones no sólo se producían en el empresariado, sino que también se fracturaba una virtual alianza más abarcadora en los gremios vinculados con la industria de la Pesca, dado que los sindicatos del Hielo y de Conductores Navales apoyaban la designación de Otero.

La disputa continuó a través de diferentes comunicados y apariciones públicas. La UCIP declaraba representar al "sector sano de la actividad pesquera" en oposición a las empresas que se habían beneficiado de los acuerdos con la URSS y Bulgaria y que estaban comprometidos en maniobras poco claras de pesca con buques destinados a la investigación. ${ }^{198}$ Cerca de 50 firmas -que en el transcurrir del

\footnotetext{
${ }^{193}$ Explicamos la diferenciación de la flota en el capítulo I.

${ }^{194}$ L.C., 18/06/1989.

${ }^{195}$ L.C., 03/06/1989.

${ }^{196}$ L.C., 21/06/1989.

${ }^{197}$ L.C. $, 21 / 06 / 1989,22 / 06 / 1989$.

${ }^{198}$ L.C.,22/06/1989. Se referían a las denuncias sobre la captura ilegal de pescado para su comercialización por parte de buques que solo tenían permiso de pesca para investigación. Mencionamos esto en el capítulo I.
} 
tiempo llegaron a ser casi 100- en representación del mismo número de empresas pesqueras se reunieron en una nota de adhesión a la nominación de Lerena y en desacuerdo con la posición esgrimida por parte de la dirigencia de las cámaras de Armadores y de Procesadores, evidenciando la división en el empresariado pesquero marplatense. La solicitada se titulaba "Cinco empresas no son la Pesca". ${ }^{199}$ Mientras que la agrupación Federalismo y Liberación, bajo la presidencia de Saravia, exponía a través de una solicitada:

Federalismo y Liberación entiende que mas allá de un juego de funcionarios se trata o de continuar con la política de los acuerdos marco nefastos para Argentina o de promover la reactivación de la industria pesquera con profundo sentido nacional a través de un hombre que ha acreditado sobrados conocimientos sobre el tema como el doctor César Augusto Lerena. ${ }^{200}$

En otra solicitada posterior se aportaba una suerte de mapa que denunciaba vinculaciones entre empresarios y funcionarios del área pesca. Acusaba al presidente de la CAABPA de haber participado de un "permiso de investigación" sin la debida licitación en sociedad con un buque de bandera inglesa, proveyendo pescado a un programa de la Provincia de Buenos Aires bajo la gestión de Luis Otero. ${ }^{201}$ Asimismo se acusaba a Oscar Fortunato, ex gerente de la empresa Arpemar y entonces Director Nacional de Pesca, de haber participado con su empresa de los Acuerdos Marco con la URSS y Bulgaria, así como también a Juan Zadjman y Piero Traballoni -vinculados a la empresa GALME, subsidiaria de Arpemar-. A estas alturas, el principal diario marplatense señalaba que la ratificación de Otero "tambaleaba" producto de la presión de los decepcionados fresqueros y que, incluso, los sucesos hacían peligrar la continuidad del propio Solá. ${ }^{202}$ Mientras, se sumaba el apoyo del PJ del distrito General Pueyrredón a Lerena mediante una solicitada firmada por su presidente Buenaventura González, quien argumentaba:

Hoy la situación se plantea entre dos posiciones extremas: los que defendemos la soberanía y el patrimonio nacional, a través de la captura por naves argentinas, la industrialización en tierra de los productos que implique la plena ocupación de los obreros argentinos (POSICIÓN ENCABEZADA POR LOS GREMIOS MARÍTIMOS Y EMPRESAS CON SENTIDO NACIONAL, A LA CUAL ADHERIMOS); y por otro lado, la posición "continuista" de quienes sostienen que nuestros recursos pesqueros son UN PATRIMONIO "PRIVATIZABLE", que puede entregarse a la explotación por parte de buques extranjeros sin contraprestación alguna en beneficio del país y con tan sólo el rédito particular de unas pocas empresas. ${ }^{203}$

Pese a la lucha llevada a cabo para torcer la designación de Otero, finalmente Lerena, la Coordinadora, los empresarios "fresqueros" y el PJ local, perdieron la crucial pulseada. La derrota se explica en buena medida por la división en el empresariado pesquero y los propios gremios, existiendo un sector favorable a Otero. Al mismo tiempo, debe sumarse un factor no pesquero pero fundamental para el nombramiento de los funcionarios del área. Felipe Solá había conseguido en su favor la adhesión del grueso de las entidades ruralistas para ocupar el cargo de Secretario de la SAGyP, por lo que su capacidad

${ }^{199}$ L.C.,22/06/1989.

${ }^{200}$ L.C., $22 / 06 / 1989$.

${ }^{201}$ L.C.,22/06/1989. También se denunciaba que Luis Otero fue designado como asesor apoderado del SOMU a partir de la intervención sufrida por el gremio luego del golpe de 1976.

${ }^{202}$ L.C., 23/06/1989.

${ }^{203}$ L.C., 23/06/1989. El énfasis es de la fuente. 
de designar a los subsecretarios bajo su mando fue ratificada. Por su parte, ya dentro de la actividad pesquera, el propio Luis Otero había conseguido para sí mismo apoyos empresariales de peso, con lo cual contaba con sustento propio para ejercer el cargo. La noticia se la trasmitiría el propio Carlos Menem a una delegación marplatense integrada por los empresarios José Greco y Eduardo Benedetti, junto al líder del SOIP, Abdul Saravia.

El premio consuelo, ante la negativa de desairar a Solá, fue la designación de Lerena como asesor presidencial, por lo cual "funcionará institucionalmente al lado del Presidente de la República" según las palabras del propio Menem. ${ }^{204}$ Así, el veterinario ocupó un lugar dentro del gobierno como secretario de Estado entre los años 1989 y 1991. Lerena explica "En realidad yo me había metido como una cuña para introducir el tema pesca en algún lado, que luego tuviera que ver con la estructura habitual del gobierno: la secretaría de agricultura, ganadería y pesca; pero trabaja [sic] con los equipos de Carlos Menem y Alberto Kohan (FEPAC) en la coordinación de los temas de pesca" (Lerena, 2009:19).

Aquellos primeros años estaban signados por la alianza entre el gobierno y el grupo Bunge y Born, con la manutención del dólar alto y otros aspectos que ilusionaron a los empresarios "fresqueros" (Pradas, 2006). Quienes, tras haber sido derrotados en la batalla principal, buscarían recuperarse a través de ofensivas menos directas. En ese tiempo, Lerena presentó diversas notas y proyectos tendientes a influir en la política pesquera, sin que sus propuestas obtuvieran respuestas satisfactorias (Lerena, 2009). De a poco iría advirtiendo la contundencia de la derrota. Con el ascenso de Domingo Cavallo al Ministerio de Economía y la implementación del Plan de Convertibilidad, la política cambiaria, monetaria y fiscal que se consolidó fue exactamente la contraria a la postulada por Lerena. Al contrario de quien fue calificado por Menem como "uno de los especialistas más destacados en el ámbito[pesquero]"205, quien fue ganando peso dentro de la estructura del gobierno fue el abogado Carlos Vladimiro Corach, ${ }^{206}$ quien hasta el momento se desempeñaba como representante legal de distintas empresas pesqueras y era asesor de CAPECA. Corach había expresado públicamente su apoyo a la designación de Luis Otero. ${ }^{207}$ Un dato de interés es que el funcionario de la "servilleta" compartía el estudio jurídico con el Dr. José María González Eirás, quien se desempeñó como jefe de asesores del gabinete de ministros de la subsecretaría

\footnotetext{
${ }^{204}$ L.C., $29 / 06 / 1989$.

${ }^{205}$ L.C.,29/06/1989. Expresiones de Carlos Menem refiriéndose a César Lerena.

${ }^{206}$ Corach había sido concejal metropolitano durante el gobierno de Frondizi en las épocas en que militaba en las filas de la Unión Cívica Radical Intransigente. Luego sería apoderado del PJ y miembro de la renovación peronista en la década del ochenta. Tras la asunción de Menem fue Subsecretario general de la Presidencia, encargado de la Secretaría Legal y Técnica y Ministro del Interior durante la segunda presidencia del riojano (Corach, 2011). La imagen de Carlos Corach como personaje influyente en la pesca circula en las calles del puerto marplatense. Incluso su visita a la ciudad generó episodios de acción colectiva contenciosa. Por ejemplo, en enero de 1998, en el contexto de un paro que aglutinó al grueso de los trabajadores marítimos, una movilización se dirigió hasta las puertas del Hotel Hermitage, lugar desde donde se emitían, para su televisación, los tradicionales almuerzos de Mirtha Legrand. Al día siguiente estaba previsto que se hospedara en el hotel el ministro Corach para luego participar del almuerzo. Sin embargo, los trabajadores se movilizaron hasta el lugar repudiando la presencia del funcionario. Luego repartieron volantes que señalaban “...los pescadores pedimos disculpas a los turistas y ciudadanos de Mar del Plata por las molestias que ocasionábamos para repudiar la presencia del ministro de Interior con chapa de señor Carlos W. Corach, que es el personaje de consulta de los empresarios de la pesca, es quien manipula al secretario de Estado y Cámaras empresarias que poseen el dinero para las campañas políticas en desmedro de todos los recursos de todos los argentinos y los trabadores de la pesca...". Finalmente se suspendió la visita del entonces Ministro del Interior. Por ello los trabajadores y trabajadoras podían afirmar luego: "Queríamos que el ministro Corach se encontrara incómodo en Mar del Plata; no vino y el objetivo está cumplido”. L.C.,16/01/1998.

${ }^{207}$ L.C.,22/06/1989. En su autobiografía política, que como dijera J.L. Borges en relación a la redactada por Torres de Villarroel "tiene más de naipe de tahúr que de intimidad del corazón", Corach alude lateralmente a sus vinculaciones con la actividad pesquera. Menciona que en el momento de producirse el atentado contra la AMIA él se encontraba en una reunión en la sede de la CAPECA. Además cita un viaje al Japón al que lo enviaron empresarios pesqueros (Corach, 2011).
} 
de Pesca de la Nación cuando la cartera estaba a cargo del radical Luis Jaimes, funcionario muy poco estimado en la consideración de un amplio grupo de empresarios y gremios pesqueros marplatenses. ${ }^{208}$

Luis Otero, mientras se encontraba desempeñando funciones como Subsecretario de Pesca e Intereses Marítimos de la Provincia de Buenos Aires, manifestó públicamente mediante un documento fuertemente crítico de la política pesquera del radicalismo, su oposición a la renovación de acuerdos pesqueros con la URSS y Bulgaria o la incorporación de buques extranjeros al caladero nacional.

Como lo hemos manifestado en muchas ocasiones y más aún en la actual crítica situación en que se encuentra el Atlántico Sur, no es posible que ni siquiera se piense en nuevos convenios pesqueros con Bulgaria o bajo otras formas, se introduzcan nuevamente en nuestra zona económica exclusiva más buques con pabellón extranjero o se recurra a la ficción de enarbolar la bandera nacional, bajo la apariencia de un joint venture u otro figura jurídica, asociados a grupos siempre dispuestos a realizar sus negocios, aunque ello contradiga los intereses del país o vaya en detrimento de nuestra pujante industria nacional pesquera. ${ }^{209}$

Además, solicitaba proyectos que fomentaran la expansión de empresas radicadas en el país, inversiones reales, producción con mayor valor agregado "debiendo desestimarse la tentación de viabilizar negocios circunstanciales que solamente benefician a unos pocos en detrimento del conjunto". ${ }^{210}$ No obstante, luego de asumir en la Subsecretaría nacional, pronto lo veremos renovando los convenios con la $\mathrm{URSS}^{211}$ y viajando a España para promover acuerdos pesqueros con la entonces Comunidad Económica Europea (CEE) ${ }^{212}$.

Con todo, la política pesquera posteriormente adoptada -como veremos a continuación- daba por tierra con las esperanzas de César Lerena y, con él, las ilusiones de los “tradicionales fresqueros". Por el contrario, la orientación económica favorecía la consolidación de otros agentes económicos. De hecho, durante este proceso numerosas empresas pesqueras presentaron quiebra y abandonaron el mercado. Para quienes quedaron, la reconfiguración profundizó la división entre el empresariado pesquero, plasmada en los fracasos de varios intentos federativos que buscaban agrupar a las cámaras, ${ }^{213}$ división que cristalizará hacia finales de la década y en el contexto de la "crisis de la merluza" motivará enconados conflictos. Como cierre momentáneo de ese enfrentamiento nos sirve una solicitada de página completa publicada en La Capital en julio de 1989, titulada "Los sectores representativos de la industria pesquera ante una instrumentada campaña difamatoria", en la cual directivos de las diferentes cámaras

\footnotetext{
${ }^{208}$ En una entrevista con Norma Mira, quien estuvo por mucho tiempo al lado de Saravia militando en el PJ local en la rama femenina, nos comentó que Carlos Menem le habría pedido a Saravia que consiga un millón de dólares para la campaña presidencial. Ante el pedido, el titular del SOIP le respondió que “¿de dónde iba a sacar esa suma?”. Y el candidato justicialista contestó “de las empresas pesqueras ¿de dónde va a ser?”. Saravia le habría indicado que él ponía a disposición todo su esfuerzo militante pero que no estaba en condiciones de reunir esa suma de dinero. Días después -siempre según Mira- le comunicaron que otra persona consiguió la suma requerida. Ese no era otro más que Carlos Corach. Entrevista del autor con Norma Mira... op. cit. ${ }^{209}$ L.C. $23 / 05 / 1989$.

${ }^{210}$ L.C. $23 / 05 / 1989$.

${ }^{211}$ Por este "cambio de posición" del funcionario, y no sin ironía, Lerena, retomando conceptos que atribuye al empresario Joaquín Fernández López, decía de Otero "Este muchacho es raro" (Lerena, 2009: 333).

${ }^{212}$ La CEE se creó en 1957 con el objetivo de consolidar un mercado común europeo. En sus inicios estaba integrada por seis países: República Federal Alemana, Francia, Luxemburgo, Bélgica, Holanda e Italia. En 1981 ingresa Grecia y en 1986 España y Portugal. Luego de la Cumbre de Maastricht (Holanda) en 1991 se consolidó la Unión Europea.

${ }^{213}$ Revista Redes, №61, 1992; N80, 1995.
} 
pesqueras ${ }^{214}$ denunciaban una campaña difamatoria en su perjuicio que estaría "capitaneada" por Abdul Saravia. ${ }^{215}$ Paralelamente, ese mismo día, el mismo periódico publicaba la noticia acerca de la presentación de cinco denuncias a instancias de Gustavo Demarchi, César Lerena, Eduardo Benedetti, Abdul Saravia y Pablo Ortié " a fin de determinar la existencia de ilícitos, negligencias, irregularidades administrativas, incumplimiento de deberes de funcionario público, etc., en asuntos referidos a la explotación pesquera y defensa nacional" que involucraban a funcionarios del gobierno radical, a empresarios de la pesca y asesores vinculados a la actividad. Entre los empresarios denunciados estaban Roberto Tobo, Alfredo Pott, Piero Traballoni y Juan Zadjman. ${ }^{216}$

La batalla por la subsecretaría había terminado en la derrota del grupo de empresarios "fresqueros" marplatenses y de la Coordinadora de Gremios Marítimos. El acontecimiento comenzaba a evidenciar la profunda división al interior de la CAABPA iniciada a partir de los Acuerdos Marco, y dada ahora fundamentalmente- entre quienes ocupaban los cargos de dirección y el resto de sus integrantes. Sin embargo, tras la designación de Lerena como Secretario de Estado, quienes se consideraban como "la pesca nacional" no bajaron los brazos y comenzaron el camino de las ofensivas parciales. El estado de situación le permitía a un anónimo escritor deLa Capital decir:

Una cadena a la que sólo le está faltando la anulación de los acuerdos marco, pero que registra ya entre sus más preciados eslabones la derogación de la resolución [1]111 de investigación pesquera $^{217}$-incluyendo la designación de César Lerena como asesor presidencial, la de José Ibáñez como titular del Mercado Nacional de Concentración Pesquera y el procesamiento de algunos ex funcionarios-, es la obtenida por un grupo de dirigentes y entidades marplatenses que han resuelto dejar de lado intereses sectoriales o particulares para pelear todos por la pesca marplatense. ${ }^{218}$

La columna expresa la disputa en términos de "pesca marplatense" vs. un enemigo potencial que se coloca por fuera de Mar del Plata. El periódico sirve en este caso como lugar de encuentro y publicación de esa fuerza social que se arrogaba, en su pertrecho, con la identidad de representar a toda una ciudad. Por su parte, José Ibáñez, hermano del petrolero Diego Ibáñez, era un amigo personal de Saravia y un hombre nacido en el puerto de Mar del Plata. Mientras, la decisión de derogar la resolución 1.111 por parte de Solá fue saludada por los sectores que no habían podido llegar a la subsecretaría del área, así como también por parte de la UCIP. El mismo Saravia era quien había radicado la denuncia en contra del programa de Pesca Experimental de los funcionarios radicales (del área Pesca y del INIDEP), representado por los abogados Demarchi y Bonoris. Por último, según Norma Mira, Corach había llamado a Saravia para que éste se integrara en alguna función vinculada a la pesca, pero el titular del SOIP por resquemores con quien luego sería Ministro del Interior, habría rechazado la oferta, creyendo de

\footnotetext{
214 De la CAABPA Roberto Tovo, de Procesadores Homero Cánepa, de CAPECA Alfredo Pott, de la Cámara Argentina de Industriales de Pescado Miguel Dobarro) junto a diversas empresas asociadas (entre las que se encontraban Moscuzza e hijos, Pennisi Natalio, Pesquera Mar Azul, Piergentili Luis, Solimeno Luis e Hijos, Valastro Alberto y Cía., Pescamar, Mellino, Arpemar, Barilari Antonio, Centauro, Estrella de Mar, etc.)

${ }^{215}$ El diario L.C.del día 12/07/1989 publica una contestación a dicha solicitada del empresario José Denegri, negando haber prestado su nombre para la primer solicitada agraviante contra Saravia.

${ }^{216}$ L.C.,08/07/1989. Días después, Saravia respondía a la solicitada en su contra con otro texto en el cual ratificaba las denuncias y señalaba que "Nuestro accionar lejos de ser agraviante e irresponsable está basado en hechos concretos y reconoce como fundamento las opiniones científicas...". L.C.,11/07/1989.

${ }^{217}$ Se refiere al proyecto de Pesca Experimental y Demostrativa, al que hemos hecho mención en el apartado sobre la década del '80, en el capítulo I.

${ }^{218}$ L.C.,06/08/1989.
} 
todos modos que en la gestión de Menem no era otro sino él mismo, y su aliado Lerena, quienes tendrían el mayor peso en la definición de la política pesquera. ${ }^{219}$ De ser así, se equivocaba.

\section{La política pesquera de la administración Menem}

\section{a. ¿Un plan Cavallo para la pesca?}

Si hemos dedicado las páginas anteriores a reseñar la derrota de Lerena y Saravia, y tras ellos del empresariado fresquero y la Coordinadora de Gremios en la batalla por ocupar la Subsecretaría de Pesca, es porque ubicamos allí el comienzo de lo que fue la orientación de la política pesquera durante la década del '90. La fuerza social que impulsaba el proyecto fresquero, a pesar de los estrechos lazos que mantenía con Carlos Menem y de haber militado su llegada a la presidencia, se veía apartada del poder y de la toma de decisiones. A partir de allí, las medidas que se tomaron, coincidiendo además con una política nacional de desregulación, apertura externa y ajuste estatal, se desplegaron sobre la base de aquella derrota. Y así como hacia finales de la década del '70 la pesca ratificó su vocación exportadora de commodities, en los años '90 profundizó ese rasgo, no sin antes atravesar por un proceso que llevó a numerosas empresas a la quiebra, posibilitando una nueva reestructuración empresaria que más tarde facilitó la concentración de la actividad pesquera. Paralelamente, se produjo la incorporación de nuevas tecnologías y formatos productivos junto a un cambio en las localizaciones principales donde se desarrolló la actividad. Además, por estos años se consolidó la apertura externa y la extranjerización de la flota, al tiempo que se fomentaron relaciones laborales tendientes a la flexibilización y el abaratamiento del costo de la fuerza de trabajo. En todo ese proceso, la industria alcanzará niveles récord de capturas y exportaciones. Pero el costo de tal expansión se evidenció tras un duro "final de fiesta" que dio inicio a un profunda crisis entre 1997 y el año 2000, durante la cual se sobreexplotó el principal recurso pesquero del Mar Argentino, la merluza hubbsi. Veamos la genealogía y el desarrollo de ese proceso.

\section{b. La "herencia envenenada": el legado alfonsinista}

La política pesquera implementada durante la década del ' 80 dejó un legado que preocupaba tanto a empresarios como a dirigentes sindicales. La situación era tal que en el imaginario de muchos de los actores de la pesca no era para nada exagerada la voluntad del Partido de los Trabajadores y el Pueblo que abogaba por "impedir el continuismo alfonsinista en la pesca" que se traducía, en la opinión de la organización, en convenios pesqueros perjudiciales para Argentina, pesca ilegal, otorgamiento arbitrario de permisos de pesca e introducción de buques extranjeros con fines distintos a los declarados. ${ }^{220}$ Para un amplio grupo de empresas y sindicatos, el término del gobierno radical hacía a de la posibilidad de dar término a lo que veían como una profunda injusticia en materia de políticas pesqueras, producto de la inoperancia y la corrupción. Era precisamente el nuevo gobierno justicialista el que permitiría ajustar cuentas con aquella tradición.

${ }^{219}$ Entrevista del autor con Norma Mira... op cit.

${ }^{220}$ L.C., 02/07/1989. 
Entre muchos de los aspectos que se cuestionaban de la administración radical, se encontraba el programa conocido como de Pesca Experimental y Demostrativa. Hemos hablado de este proyecto en el capítulo I. Recordemos aquí que antes de alejarse del gobierno, el Subsecretario de Pesca radical Luis Jaimes, firmó nuevas autorizaciones para el ingreso de buques pesqueros, siendo alrededor de 40 buques los que se encontraban pescando en tal situación. ${ }^{221}$ Ante ello el SOIP interpuso un recurso de amparo que respondió favorablemente el juez federal de Mar del Plata Julio Pettigiani, disponiendo "no innovar" en materia de permisos de investigación pesquera ordenando a la SAGyP que se abstenga de otorgar autorizaciones especiales para desarrollar tales proyectos. Saravia, por aquel entonces envalentonado tras la victoria electoral de su amigo, publicaba una solicitada que retomaba las palabras de Menem ante la Asamblea Legislativa y titulaba "En la Pesca también 'la corrupción es traición a la patria". Allí denunciaba que:

Bajo pretexto de un "Programa de Investigación" de los recursos pesqueros se esconde una explotación comercial clandestina, evasora de impuestos y depredadora de las riquezas del mar argentino, maniobra que se encuentra agravada por la participación de buques extranjeros en combinación con algunas empresas pesqueras radicadas en el país.

Luego indicaba que para los objetivos de investigación se requería como máximo 2 buques y 80 kilos de calamar. En contraposición:

...la Subsecretaría de Pesca del Gobierno Radical saliente, implementó un programa comercial encubierto de explotación del calamar con poteras por el cual se capturaron 51 millones de kilos con 20 buques comerciales extranjeros contratados por algunas empresas pesqueras que, cuesta afirmar que sean argentinas. Captura que equivale a 51 millones de dólares que no ingresaron al país, y sobre los cuáles no se abonó impuesto alguno [...] Lejos de rectificar tremendo despojo el Gobierno de Alfonsín pretendió implementar un nuevo "Programa de Investigación" que en realidad encubre la denunciada explotación comercial clandestina. ${ }^{222}$

Más tarde, un escrito dirigido al titular de la Fiscalía Nacional de Investigaciones Administrativas, del que la mención de la fuente sólo indica se trata de un "especialista local sobre temas de la industria pesquera" (imagínanos que se trataba del abogado Gustavo Demarchi en representación de César Lerena) se preguntaba si “¿Hubo negligencia, irregularidad administrativa, simple equivocación o corrupción en el Programa de Buques de Investigación o de Pesca Experimental y Demostrativa del INIDEP, de la Subsecretaría de Pesca de la Nación?" y reclamaba que se determinara el grado de responsabilidad que les cabría en las maniobras denunciadas:

...al ex canciller Dante Caputo, a la ex canciller Ruiz Cerruti, al ex secretario de Pesca Ernesto Figueras, al ex secretario de la misma área Lucio Reca, al ex presidente del Banco Central José Luis Machinea, al ex administrador de Aduanas Juan Carlos Delconte, al subsecretario de Pesca Luis Jaimes, a la directora nacional de Pesca Liliana Márquez de Lupi, al jefe del gabinete de asesores de la Subsecretaría de Pesca José María González Eirás, al director del INIDEP Antonio Malaret, al presidente de la Cámara de Armadores de Pesqueros Congeladores de la Argentina (CAPECA)

\footnotetext{
${ }^{221}$ L.C., 01/07/1989.

${ }^{222}$ L.C., $11 / 07 / 1989$.
} 
Alfredo Pott, al asesor legal de esta institución Carlos Corach, al presidente de Mar Azul S.A. y actual presidente de la Cámara de Armadores Pesqueros de Altura Roberto Tovo, a la subdirectora nacional de Pesca Elsa Calima de Borci, al estudio jurídico y económico Carlos V. Corach, José María González Eirás y Asociados y a todos aquellos que pudieran tener relación directa o indirecta con el citado programa. ${ }^{223}$

Según las denuncias, la defraudación al fisco ascendía a la suma de 600 millones de dólares anuales. ${ }^{224}$ La situación terminó cuando la SAGyP declaró la nulidad de la resolución 1.111. Luis Otero, entonces subsecretario de Pesca de la Nación, manifestó que la instrumentación efectuada por la anterior conducción en el área pesquera del sistema de investigación permitido por la ley $\mathrm{N}^{\circ} 20.489$ "desvirtuó totalmente la finalidad perseguida en dicha norma" pues "llama la atención la captura sin discreción que se iba a efectuar y la total libertad de comercializar la misma sin ingresar divisas al país"225. Esta primera medida volvió a ilusionar a gremios y algunos empresarios en cuanto implicaba el comenzar a deshacerse de una "herencia envenenada" dejada por el gobierno saliente.

c."Donde manda Canciller, no gobierna Subsecretario": la definición de las políticas pesqueras

Luego de asumir la conducción de la SAGyP, y en ocasión de poner en funciones a Jorge Ibáñez al frente del Mercado de Concentración Nacional Pesquera, Felipe Solá brindó un discurso, en el cual planteaba algunas líneas de acción respecto de la actividad pesquera. Decía "vamos a poner orden donde hay desorden. Vamos a trabajar en medio de ese desorden que hemos encontrado en el área pesquera, trabajaremos para ir ordenando uno a uno los problemas y tomaremos todas las medidas que sean necesarias...”. Previamente anunció las dificultades recibidas para semejante empresa pues:

Esta actividad pesquera nacional, arrolladora, que crece año a año, es una actividad nueva. Como tal estamos cruzados por corrientes muy encontradas, todavía no está asentado un pensamiento pesquero nacional. Todavía hay tantas opiniones como empresas hay en la pesca. Cuesta mucho concertar, cuesta mucho ponerse de acuerdo, cuesta mucho pensar en el interés del conjunto, en el interés de todos y dejar en la mesa el interés de un grupo o sector.

Anunciaba así la inexistencia de un pensamiento pesquero unívoco, mostraba lo dificultoso que sería conducir el área pesquera en función de los múltiples intereses en juego y, al mismo tiempo, evitaba pronunciar una posición propia. Concluía de un modo sincero en cuanto a lo que sucedía en la actividad, pero su "ingenuidad" resultaba temeraria, "Corre mucha plata alrededor de las decisiones pesqueras, un permiso pesquero es hoy casi, casi darle un gran negocio, un paquete de dinero a alguien que lo use bien. Es decir, la responsabilidad y el peso es grande"226.

Hemos dicho que el lugar de subsecretario de Pesca lo ocupó, tras el desaire a Lerena, Luis Otero luego de su paso como funcionario del mismo sector en la provincia de Buenos Aires. Insistimos con el hecho de que desempeñando dicha tarea este funcionario mantuvo una postura proclive a la mayor

${ }^{223}$ L.C., $21 / 07 / 1989$.

${ }^{224}$ L.C., $29 / 07 / 1989$.

${ }^{225}$ L.C., $03 / 08 / 1989$

${ }^{226}$ L.C., $26 / 08 / 1989$. 
industrialización, a la agregación de valor en la elaboración de productos y al ordenamiento mediante una ley. ${ }^{227}$ Tal es así que Otero desarrollaba fuertes críticas al gobierno radical por su política pesquera. ${ }^{228} \mathrm{~A}$ su llegada a la dependencia nacional anunciaba "Vamos a priorizar el crecimiento del área a través de la industria nacional que está instalada en el pais, porque es la que ha realizado esfuerzos para que la actividad crezca hasta la realidad que es hoy"229. Y comunicaba, criticando proyectos como el de pesca experimental del gobierno anterior, que se "fijarán reglas de juego claras y permanentes que alienten las inversiones nacionales y extranjeras" para "devolver la credibilidad que hemos perdido al no alentarse la radicación de capitales y tecnología en el país que signifiquen más buques, más plantas industriales, con el mayor valor agregado posible y adecuadas estructuras portuarias". ${ }^{230}$ El tono ya no era el mismo de las declaraciones de antaño. En septiembre vencían los plazos para la renovación o denuncia del convenio pesquero con la URSS. El acuerdo con Bulgaria había expirado en el mes de julio. Recordemos que al mismo se habían opuesto los gremios marítimos y pesqueros, la CGT regional y varios empresarios fresqueros. El PTP, en calidad de integrante del FREJUPO, solicitaba a Menem la denuncia del convenio argumentando que "dicho convenio es otra herencia de la política anti popular y antinacional del gobierno alfonsinista. Contribuyó a la depredación de nuestra riqueza pesquera afectando las fuentes de trabajo de miles de trabajadores, y socavó nuestra soberanía"231. Días más tarde, Felipe Solá pedía una prórroga para tomar una decisión. Y, adelantando que no era firme la voluntad de denunciarlos acuerdos, como se sospechaba haría el gobierno justicialista, aseguraba que "en caso de que continúen, lo hagan de una forma totalmente diferente a lo que ha ocurrido hasta el momento". Y a modo de justificación por la decisión que aún no se había tomado, agregaba:

En primer lugar, hay que decir que los acuerdos marco no definen el problema de la pesca argentina, en total hay 17 barcos. Es decir que se le está dando al tema una resonancia excesivamente grande. Creo que aquí en Mar del Plata hay una especial sensibilidad al problema porque Mar del Plata se sintió perjudicada por la implementación de los acuerdos marco. Pero también es menester decir que esto no decide el futuro de la pesca argentina. Me parece que lo que se quiere es ver si la política argentina va a defender la radicación de capitales en tierra y poner en igualdad de condiciones a las empresas nacionales con las empresas extranjeras o no, y esas dos premisas son las que nos mueven a nosotros a denunciar o modificar la implementación de los acuerdos marco. ${ }^{232}$

\footnotetext{
${ }^{227}$ L.C. $23 / 04 / 1989$.

${ }^{228}$ L.C., $23 / 05 / 1989$.

${ }^{229}$ L.C., $02 / 08 / 1989$.

${ }^{230}$ L.C., 03/08/1989.

${ }^{231}$ L.C., $05 / 09 / 1989$.

${ }^{232}$ L.C.,16/09/1989. Bonnet (2009) llama "distanciamiento cínico" al estilo discursivo menemista, que se caracterizaba por la formulación de declaraciones en las cuales los problemas más graves resultaban completamente banalizados. Por ejemplo, días después de anunciar la desregulación de la economía, Menem decía "en la Argentina no trabaja el que no quiere, ya que en un tiempito vamos a tener que ocupar mano de obra de afuera del país...". Si seguimos a Bonnet, podemos arriesgar que la variante "Solá" de tal postura tenía sus particularidades. Tal vez sea ésta declaración la que inaugure una forma de intervención pública, que ya juzgará el lector, pero que adelantamos caracterizó las declaraciones de Felipe Solá, generalmente elípticas y confusas. En este caso la cuestión mostraba que si la decisión del gobierno era, como afirmaba Solá, defender la radicación de capitales en tierra y poner en igualdad de condiciones a las empresas nacionales con las empresas extranjeras, el convenio debía denunciarse, a pesar de que el funcionario buscara a través de la retórica ocultar lo evidente. Buques extranjeros que pescan, procesan y venden sus productos en sus propios países y compiten en el mercado mundial con las empresas nacionales ¿cómo podían beneficiar un proceso de industrialización nacional? A no ser que ese cambio que anunciaba, de continuar los acuerdos, obligara, por ejemplo, a procesar lo pescado por dichos buques en las plantas en tierra, transfiriera tecnología, etc. Pero ello implicaba el reconocimiento de que el convenio en sí mismo había fracasado, no había cumplido sus objetivos, y por lo tanto había que denunciarlo. O cuanto menos iniciar una renegociación. Volveremos sobre este aspecto.
} 
En cuanto hablamos de un acuerdo bilateral donde se afectan relaciones exteriores de la Nación, correspondía la intervención de la cancillería. Cómo seguramente sepa nuestro lector/a informado/a, en el nuevo gobierno justicialista el Ministerio de Relaciones Exteriores y Culto lo ocupó Domingo Felipe Cavallo. Quién, más temprano que tarde, mostraría sus credenciales. Desde su ingreso al gobierno la perspectiva del contador fue buscar un mejor entendimiento con las principales potencias del mundo. Una de ellas era Inglaterra con quien la Argentina aún mantenía sus relaciones afectadas tras la guerra y la derrota de Malvinas. A poco de asumir, Cavallo declaró su deseo de "normalizar totalmente nuestra relación con el Reino Unido" indicando que:

...el tema Malvinas estará siempre presente en quienes conduzcamos la política exterior argentina, porque indudablemente se trata de una prioridad nacional. Lo discutible es cuál es la mejor forma de defender nuestros derechos soberanos. Nosotros entendemos que no es otra cosa que buscar la negociación y el diálogo, tratando de restablecer una relación entre los argentinos y los malvinenses del tipo de la que existió hasta la guerra de $1982 .{ }^{233}$

En lo que se refiere a pesca, pronto se conoció un proyecto de ley cuya autoría pertenecía a la Cancillería. La norma insistía con la propuesta de "abrir" el mar argentino a las flotas extranjeras buscando algún tipo de acuerdo con terceros países. Un convenio con empresas foráneas no sólo se buscaba en virtud de temas estrictamente pesqueros, sino que la intención era, a través de un acuerdo, mejorar las relaciones con Inglaterra y con la Unión Europea en general. Según Lerena (2009) la actividad pesquera le serviría a Cavallo para este y otros proyectos más ambiciosos en igual sentido. Así es como, sin que desde la SAGPyA se tuviera en claro qué política pesquera implementar, fue en la búsqueda de extender relaciones con las potencias europeas que la Cancillería fue definiendo las principales políticas para la rama. Es decir, que las políticas implementadas nacían de las necesidades de Cancillería y no como producto de la orientación pesquera. Por ello dirá Lerena que la pesca se convirtió en la gran moneda de cambio (Lerena, 2009).

Aunque se anunciaban algunas modificaciones, una de las primeras resoluciones en la que intervino la Cancillería fue declarando la renegociación de los cuestionados Acuerdos Marco con la URSS. Cavallo se mostraba firme señalando que esos convenios debían ser adaptados a la nueva política pesquera buscando la participación de empresas argentinas, el abastecimiento en puertos nacionales de los buques soviéticos y el mayor procesamiento del pescado capturado en territorio argentino. Como adivinaba que la propuesta generaba resistencias, ensayó una defensa algo estridente. El entonces Canciller, ante acusaciones de depredación y del incumplimiento de normas que esgrimían diferentes sectores de la pesca, negó que se hubieran detectado irregularidades de parte de la URSS en las cláusulas que establecía el convenio, pero destacó que "no hay mecanismos para que la Argentina verifique el cumplimiento de las condiciones pactadas" $" 234$. El argumento era, al menos, llamativo. Sostenía que no fueron cometidas irregularidades, pero de haberse producido, tampoco se contaba con los elementos para poder descubrirlas. Finalmente en el mes de noviembre el gobierno, a través de su subsecretario de pesca, renegoció los acuerdos en Moscú. Ante esto La Capital publicó en su tapa una nota titulada "Es 'escandaloso' un acuerdo con la URSS" ${ }^{235}$. El cuerpo del texto aseguraba que a pesar de la satisfacción

${ }^{233}$ L.C., $14 / 08 / 1989$.

${ }^{234}$ L.C., $19 / 09 / 1989$.

${ }^{235}$ L.C., 08/11/1989. 
expresada por Otero tras la ratificación de lo convenido, trascendió que el presidente Menem "habría recibido un pormenorizado informe" que se opone a lo expresado por el subsecretario. En él se denunciaba que Otero "negoció sin acuerdo del gobierno y bajo la presión de una empresa pesquera privada" que se beneficiaría especialmente con el convenio, llamando la atención la inferioridad numérica de representantes argentinos en comparación con los soviéticos en el acto de la firma de esta renegociación. La denuncia más fuerte radicaba en que del canon acordado, buena parte estaba dirigido a una sola empresa argentina cuyo representante estaba presente en la negociación. Además, se establecía que la cuota de pescado a ser procesado en tierra estaba destinada a una sola empresa de Punta Quilla, no pudiendo participar empresas de la Provincia de Buenos Aires. En diciembre, el senador nacional justicialista Pedro Molina aseguró que los Acuerdos Marco de la pesca "no le han dado ventajas al país" y advirtió que "hay una gran exportación unida a una depredación más que inconveniente". ${ }^{236}$ También se oponían a la ratificación de estos acuerdos desde una usina liberal como la UCEDé los diputados nacionales Héctor Siracusano ${ }^{237}$ y Adelina Dalesio de Viola ${ }^{238}$. Ésta última los calificó como "nefastos". Por su parte, también el SOIP denunciaba el acuerdo agregando otros elementos de crítica. Revelaba que barcos de la URSS "tiraron 300 mil toneladas de merluza al mar para poder seguir pescando el langostino". Al respecto Saravia expresó que no hay control y que se estaba produciendo una depredación. Y aclaró la posición del gremio, que una vez más lo ponía en disidencia con las políticas que para la pesca impulsaba el gobierno de Menem. Saravia argumentaba:

El SOIP siempre estuvo en desacuerdo con los acuerdos marco, ya paramos en 1986 y no fuimos oídos. Se nos están cerrando cada día más fábricas, las tripulaciones son fábricas flotantes donde hacen la producción. Además se cometen estragos y con el tiempo nos vamos a quedar sin pescados. $^{239}$

Finalmente, una vez más desde la cada vez más importante Cancillería se anunciaba la finalización de la renegociación de los convenios con la URSS, asegurando que la misma era "muy conveniente para los intereses de nuestro país". Cavallo aclaró que se convino en extender los convenios por el transcurso de un año, pero con un canon a cargo de los soviéticos del 12\% en lugar del 3\% convenido durante la gestión radical. Además, la URSS tendría obligación de compra ya no únicamente con las empresas elegidas por ellos. En cuanto a la posibilidad de atender convenios similares con otros países interesados, el Ministro se presentaba más bien cauto, pero a la vez confiado en la aprobación del proyecto de ley elaborado en su área, diciendo que "eso sólo será factible en el marco de una nueva legislación sobre pesca que deberá discutir el Congreso" dado que la idea del gobierno era "en primer lugar satisfacer las necesidades de pesca que tienen los buques de bandera argentina, y si queda un excedente, temporalmente se podría otorgar licencias a otros países si es que esa legislación lo autoriza". ${ }^{240}$

Pero esa cautela no es la que exhibía en otros ámbitos, ni lo que caracterizaba las ideas ni la personalidad del ministro. Por eso Gustavo Demarchi salía al cruce de lo que se sospechaba "se estaba tramitando" al interior de la Cancillería. Primero acusó a Cavallo de falsear lo recientemente convenido

\footnotetext{
${ }^{236}$ L.C., $16 / 12 / 1989$.

${ }^{237}$ L.C. $29 / 11 / 1989$.

${ }^{238}$ L.C., $15 / 02 / 1989$.

${ }^{239}$ L.C., $16 / 02 / 1990$.

${ }^{240}$ L.C.,20/03/1990.
} 
cuando el canciller dijo que la URSS elevó el canon. Demarchi, que pensaba que lo correcto era la anulación de los convenios, mostraba que el aumento del canon tenía condicionantes y que uno de ellos era el abaratamiento de los costos, como también el aumento del cupo de pesca, ampliación de la zona de pesca, etc. Es decir, que implicaba concesiones por parte de la Argentina. Demarchi acusa además una continuidad en la Cancillería con respecto a la gestión de Dante Caputo en el desarrollo de una política de "mar abierto" que pone "en serio peligro el recurso pesquero". Pues se "visualiza la intención de implementar una política de 'mar abierto' que tiene como objetivo lograr ser considerados correctamente entre los países centrales, lograr un concepto de país abierto, de país permisivo", pero advirtió que ello atrae otro fin que se trasunta "Nosotros estamos frente a un recurso que es renovable pero también es agotable y acá habría un egoísmo generacional de tomar ese recurso adquiriendo la mayor cantidad de beneficios económicos, pero produciendo el agotamiento futuro, apropiándose esta generación del recurso en lugar de usarlo prudentemente". En contra de lo que consideraba una "intervención" de Cancillería en el área pesquera expresaba que "el recurso ictícola es propiedad del estado nacional y de las provincias, qué tiene que hacer la Cancillería que trata las relaciones del país hacia afuera. Esto es un antecedente peligroso y el avance de la Cancillería en este tema, puede traer graves daños a un recurso que es propio". ${ }^{241}$

d. Un mar más abierto

"Estoy temiendo que todos los barcos que están sobrando en el mundo vengan ahora de aluvión a la Argentina para distorsionar lo que hay." Joaquín Fernández López, director de CONARPESA, 29/08/1989.

Cómo vimos, las primeras discusiones en torno de la sanción de la Ley de Pesca giraban fundamentalmente en torno de la apertura del mar argentino a la pesca de flotas extranjeras. El debate se originaba acerca del modo en que pretendían ingresar dichas flotas y del tratamiento que se realizaría de la materia prima. Esto es ¿el pescado se exportaría directamente sin elaboración? o, en cambio, ¿mediaría proceso de agregado de valor con la consiguiente creación de puestos de trabajo? Hasta ese momento, los acuerdos firmados con terceros países se inclinaron por la primera de las fórmulas. Fue ese el formato de lo convenido con la URSS y Bulgaria. Incluso entre quienes no tenían una posición contraria a la apertura una cuestión que preocupaba particularmente eran las condiciones que estaban padeciendo las principales potencias pesqueras con sus barcos parados y con varios caladeros agotados producto de la pesca indiscriminada. Recordemos que según la Organización de las Naciones Unidas para la Alimentación y la Agricultura (FAO) para mediados de la década del '90 el 70\% de las pesquerías del mundo se hallaba explotada al borde de su capacidad, sobre explotada o en estado de colapso (Litovsky, 2000). Y el temor era que aquellas potencias trasladaran su capacidad de pesca a zonas donde, si bien aún no existían grandes problemas, tampoco podían sustentar un desmedido esfuerzo de pesca.

Aquella alarma no carecía de sustento. Pues, tras la batalla por ocupar la subsecretaría, en octubre de 1989, desde el gobierno se declaraba públicamente la intención de profundizar la apertura del Mar

${ }^{241}$ L.C., 18/04/1990. 
Argentino y posibilitar la pesca de terceros países buscando un desarrollo de la actividad pesquera. El ungido subsecretario Luis Otero, antes enemigo de este tipo de apertura, revelaba ahora que "España, Italia y Francia, entre otros países, están demostrando su interés en invertir en nuestro país [...]La pesca está en la óptica de esos capitales, y es entonces la hora de armonizar todos los intereses a los efectos de que esa perspectiva se transforme en una realidad alentadora de nuestra reactivación". ${ }^{242}$ Pocos días después ratificaba lo dicho "La Argentina se propone reconvertir su industria pesquera, abriendo el sector a mayores inversiones extranjeras en plantas y embarcaciones, y procura acuerdos con la Comunidad Económica Europea para la explotación controlada de recursos ictícolas", asegurando que el gobierno "tiene la firme decisión política de impulsar negociaciones con la CEE"243.

Ante iniciativas como esta Lerena, todavía asesor, insistía en la posibilidad de que se llevaran a cabo, pero advertía acerca de la necesidad de proteger los recursos y de que tales iniciativas sólo podían adquirir un sentido en el marco de un plan pesquero nacional. Además era bastante más cauto que Otero porque "el ofrecimiento de caladeros argentinos a cambio de sociedades mixtas, expresado en términos generales, no constituye de por sí un mecanismo suficiente de desarrollo ni una garantía de generación de empleos". ${ }^{244}$ Para ello, argumentaba, se debían contemplar inversiones de carácter productivo que guardaran relación con el esfuerzo pesquero a emprender. Este era uno de los grandes temas, dado que según sospechaban en ciertos espacios, los diagnósticos del INIDEP no eran sólidos y por ello no se conocía a ciencia cierta cuál era la cantidad de recursos efectivamente disponible. Como expresaba Joaquín Fernández López, el miedo radicaba en la profundización de una pesca meramente extractiva que buscara incrementar las capturas y exportaciones sin atender criterios de sustentabilidad biológica de los recursos. Por ello pedía "Que la revolución productiva no se convierta en revolución destructiva". ${ }^{245}$

Por el lado empresarial, cómo veremos más adelante, las cámaras pesqueras ya no portaban el nacionalismo y antiimperialismo que alguna vez sostuvieron allá por la década del '70. Ahora señalaban los momentos difíciles por los que atravesaba la actividad, las dificultades dadas por la falta de capital, la ausencia de créditos y las barreras para el acceso a tecnología, mientras que, contrariamente, los buques extranjeros se beneficiaban de la pesca ilegal de los recursos nacionales en la zona adyacente a las Islas Malvinas. La CAABPA, en un lenguaje más "aggiornado", se presentaba como representante de las empresas "que se resisten al estancamiento y progresan". Por ello mismo necesitaban un cambio, pues:

No se puede seguir mirando para adentro y para atrás. La pesca argentina debe crecer y para ello necesita buques, tecnología y capital, necesita ampliar la flota, ocupar la plataforma continental en toda su extensión, e incrementar su producción y sus exportaciones a los niveles que permitan el recurso y la necesaria ecuación económica. ${ }^{246}$

Dos meses después, la CAABPA y los Procesadores, hegemonizadas por los grupos Moscuzza, Solimeno y Valastro, enviaban una nota al ministro Cavallo, a quien luego de pedir que la pesca sea declarada actividad de interés nacional, recomendaban que la futura ley de pesca se oriente al crecimiento y desarrollo de la actividad, explotación y reserva de recursos, apertura a flotas extranjeras,

\footnotetext{
${ }^{242}$ L.C., 11/10/1989.

${ }^{243}$ L.C. $19 / 10 / 1989$.

${ }^{244}$ L.C., $11 / 11 / 1989$.

${ }^{245}$ L.C., $29 / 08 / 1989$.

${ }^{246}$ L.C.,21/07/1989. La nota se titulaba "Los Armadores frente a la Revolución Productiva".
} 
desregulación, incentivos a la exportación y facilidades para la importación de bienes de capital y participación del sector empresario en las cuestiones fundamentales de la actividad, entre otros aspectos. Interesaba particularmente la incorporación de nuevos buques pesqueros, la importación libre de aranceles y el sistema de charteo. Al tiempo que pedían por la reserva de los recursos para buques de pabellón nacional. ${ }^{247}$ Los industriales de la pesca se mostraban favorables a una apertura "controlada" siempre y cuando ello favoreciera su posición a través de algún vínculo con las empresas extranjeras. Al pedir la reserva del pabellón nacional buscaban asegurar separa sí el lugar de socios locales de los capitales externos, los cuales precisarían llevar la bandera nacional para realizar las tareas de pesca.

e. Una ley para la industria pesquera (II)

"Hoy vivimos otra crisis, una crisis que va más allá de las discutidas cuestiones de una ley de pesca que no sale nunca, que se traba a cada momento, que hay más de un proyecto y que cuando está a punto de salir aparece otro más, como buscando de presentar algún obstáculo para que la ley no salga y que va también mucho más allá de lo que puedan ser los intereses empresariales o los intereses sindicales". Ángel Roig, UCR, ex intendente de Mar del Plata, julio de 1991.

A finales de 1989 y comienzos de 1990 se renovaron las intenciones de sancionar una ley nacional de pesca, retomando la iniciativa de los últimos años del gobierno de Alfonsín. Para ello se presentaron diferentes proyectos. Los diputados nacionales demoprogresistas Alberto Natale y Enrique Muttis presentaron un proyecto de ley que tenía como objetivo básico propender a una intensa explotación de las riquezas bioacuáticas del mar argentino, dentro del marco de una "estricta política de preservación de las especies y del reconocimiento del dominio sobre estas riquezas de las provincias ribereñas a dicho mar". ${ }^{248}$ El proyecto planteaba la creación de un Consejo Federal Pesquero y un Consejo Asesor Pesquero y la revalorización del INIDEP para lograr una responsable evaluación científica. También César Lerena, todavía asesor del presidente Menem, buscaba propiciar una ley que, recordemos, ya había adelantado a modo de borrador en su libro La Industria Pesquera.... Para impulsarla convocó en la ciudad de Mar del Plata a las "Primeras Jornadas sobre Problemática Pesquera". Allí, luego de escucharse voces críticas a la renovación de los acuerdos marco con la URSS, se discutió sobre un proyecto de ley. ${ }^{249}$ A la hora de las conclusiones se resaltó la importancia de contar con una norma de carácter nacional que exprese un proyecto pesquero, la necesidad de constituir un Consejo Federal Pesquero así como de mayor investigación, además de la elevación del rango de Subsecretaría a Secretaría y la extensión del Mar Territorial Argentino hasta las 200 millas, discutiendo con la terminología de la CONVEMAR. ${ }^{250}$ Meses

\footnotetext{
${ }^{247}$ L.C.,09/09/1989.

${ }^{248}$ L.C.,31/10/1989.

${ }^{249}$ L.C., $16 / 12 / 1989$.

${ }^{250}$ L.C.,17/12/1989. La Convención de las Naciones Unidas sobre el Derecho del Mar (CONVEMAR) es considerada uno de los tratados multilaterales más importantes de la historia, desde la aprobación de la Carta de las Naciones Unidas, siendo calificada como la "Constitución de los océanos". Fue aprobada en abril de 1982 en Nueva York (Estados Unidos) y abierta a su firma el 10 de diciembre de 1982, en Bahía Montego (Jamaica). Recién entró en vigor el 16 de noviembre de 1994. Entre otros aspectos, la Convención establece que el Mar Territorial de cada país llega hasta las 12 millas. El resto, hasta llegar a la milla 200, es una Zona Económica Exclusiva, lo que le otorga una jerarquía menor. La legislación argentina hasta ese momento proclamaba un Mar Territorial de 200 millas.
} 
después Lerena presentará su proyecto de ley reelaborado en función de lo discutido en aquellas jornadas. $^{251}$

También el SOIP buscaba participar de las discusiones sobre el ordenamiento de la actividad procurando que el movimiento obrero obtuviera un espacio en las deliberaciones. Por ello Saravia envió una nota al presidente de la comisión de pesca del Senado de la Nación Luis Rubeo, poniéndose a disposición "a los fines de tratar de elaborar un proyecto de ley de Pesca, juntamente con todos los sectores empresariales, gremiales y del Estado para defender el patrimonio nacional". ${ }^{252}$ Por su lado el entonces Consejo Interprovincial de Pesca insistía en la necesidad de que la nueva ley de pesca ratifique la vigencia de la ley $\mathrm{N}^{\circ} 20.136$ que establece la reserva del pabellón nacional con exclusividad de la captura ictícola dentro del mar argentino ante el temor de una apertura externa indiscriminada,.

Por su parte, tanto la CAABPA como la cámara de Procesadores enviaban una nota al ministro Cavallo dando a conocer su posición sobre distintos temas de política pesquera. Subrayaban que "la industria pesquera no ha tenido nunca una ley de pesca que representara un camino orientativo para el crecimiento del sector, además [de]un ordenamiento jurídico para la actividad. Es por ello imprescindible que la futura ley de pesca declare la actividad pesquera como de interés nacional". Recomendaban además que la ley se oriente al crecimiento y desarrollo de la actividad, a la explotación y reserva de los recursos, apertura a flotas extranjeras, desregulación, desarrollo de incentivos a la importación y exportación de bienes de capital y la participación del sector empresario. La entidad pedía que la ley recree un marco jurídico con reglas de juego claras y de largo plazo que incentive las inversiones de capital de riesgo en barcos pesqueros y, fundamentalmente, en plantas industriales en tierra. También solicitaban por la explotación racional de los recursos ictícolas, además del otorgamiento de facilidades para la incorporación de nuevos barcos, la importación libre de aranceles y, siempre, la reserva de los recursos para buques de pabellón nacional. ${ }^{253} \mathrm{~A}$ su vez requerían la puesta en marcha de un proceso de industrialización que agregue valor a la materia prima, utilizando la mayor cantidad de mano de obra posible. ${ }^{254}$ En el $26^{\circ}$ aniversario de la CAABPA el gerente Roberto Baltar clamaba por un lugar para la pesca dentro de la revolución productiva. Después de señalar a la industria pesquera como un sector fuerte pero desatendido que aún así logró exportar con éxito, expresaba que:

....alertamos a las autoridades competentes sobre el peligro de un retraso en el tipo de cambio el cual se vislumbra en el corto plazo que afectará nuestros ingresos como netos exportadores, o en los súbitos aumentos de insumos críticos para el sector, tales como el combustible [...] y las tarifas de Servicios Públicos, que incrementan nuestros costos... ${ }^{255}$

El mayor "enemigo" de estos sectores pesqueros era el proyecto que Adolfo Gass presentó en el Senado, el cual planteaba establecer las nuevas líneas de base a partir de las cuales delimitar el Mar Territorial argentino hasta las 12 millas marinas y la Zona Económica Exclusiva hasta las 200 millas marinas. El tema se vinculaba con la reforma del Código Aduanero y con una nueva ley de pesca, adecuando el lenguaje a los términos de la CONVEMAR. El peligro giraba en torno a qué se permitiría

\footnotetext{
${ }^{251}$ L.C., 26/05/1990.

${ }^{252}$ L.C., $12 / 01 / 1990$.

${ }^{253}$ L.C., 09/09/1989.

${ }^{254}$ L.C.,09/10/1990.

${ }^{255}$ L.C.,09/10/1989.
} 
hacer dentro de la ZEE. Los críticos, entre ellos Lerena, señalaban que tomar esta medida achicaba el territorio del país. Mientras que gremios y cámaras temían que fuera la puerta de entrada para que buques extranjeros pescaran dentro de las 200 millas sin que lo recolectado fuera considerado producto nacional. El Código Aduanero que pretendía ser reformado, en su artículo 585 sostenía que:

...la extracción efectuada desde el mar territorial argentino o desde el lecho o subsuelo marinos sometidos a la soberanía nacional, de mercadería originaria o procedente de los mismos con destino al extranjero o a un área franca, se considera como si se tratare de una exportación para consumo efectuada desde el territorio aduanero general. ${ }^{256}$

Ese código fue el que habilitó a dictar prisión preventiva a la ex Canciller Susana Ruiz Cerruti y al ex Subsecretario de Pesca Luis Jaimes, al considerar que una medida suya permitió que no se cobraran derechos de pesca sobre cientos de toneladas de calamar pescados entre las millas 12 y 200. Por aquel entonces también la Cancillería presentó su proyecto de ley. Un artículo de La Capital reconocía los temores de los sectores pesqueros: "El primer llamado de atención para las entidades vinculadas con derechos legítimos a la pesca es que la Cancillería aparezca manejando el tema".

De particular desconfianza para los marplatenses es advertir que el proyecto de la Cancillería, que está siendo activado con la pretensión de constituirse en ley, privilegia la extracción sobre la industrialización [...] Consecuentemente no promueve la incorporación de valor agregado al producto capturado. $^{257}$

Nuestro cronista pasa revista a los principales puntos que oponen a "la comunidad pesquera marplatense" respecto el texto de ley. Los cuestionamientos se originaban en la quita de poder al Parlamento, el centralismo que promueve al darle poder de veto al Estado Nacional en el Consejo Federal Pesquero, la eliminación de la cláusula de que el 75\% del personal embarcado debe ser de nacionalidad argentina, la subestimación de la tarea científica al no considerar obligatorios los dictámenes del INIDEP, la promoción del otorgamiento ilimitado de permisos de pesca, y el aspecto más controvertido, la reserva que realizaba la Cancillería respecto de la facultad de otorgar permisos de pesca para investigar. En realidad, según declararán luego los propios funcionarios, se había tomado el proyecto base del senador Hipólito Solari Yrigoyen modificando y/o añadiendo algunos incisos, particularmente tres o cuatro vinculados con las Islas Malvinas, que era el tema central para la Cancillería. ${ }^{258}$ Solari Yrigoyen, senador por la UCR, decía que el proyecto "se inspira en el mío al punto de reproducir textualmente 56 artículos. Sin embargo, cambia su filosofía" porque plantea un sistema de licencia que "ha caducado en el mundo". Y aclaraba su punto de vista diciendo:

Esto no significa rechazar la inversión extranjera, sino precisar que quienes están interesados en venir, lo hagan sabiendo del compromiso de construir plantas, dar trabajo a obreros argentinos e incorporar valor agregado a los productos en nuestra propia tierra. No quiero que se lleven nuestro

${ }^{256}$ L.C., 29/03/1990.

${ }^{257}$ L.C., $22 / 03 / 1990$.

${ }^{258}$ L.C., $12 / 05 / 1990$. 
pescado, lo valoricen en sus países de origen, y luego compitan con nuestras propias exportaciones en terceros mercados. ${ }^{259}$

Concluía que el proyecto de Cancillería se trataba de un grave error por "el sesgo de apertura sin condiciones para el aprovechamiento de nuestros recursos". ${ }^{260}$

Por su parte, el SOMU y el SOIP no tardaron en manifestar su "más enérgica oposición" a tal proyecto. El SOIP se refirió al texto como "extranjerizante, no productivo y atentatorio de la necesaria preservación del recurso". En un documento que denota una fuerte preocupación, el sindicato explica que al ser atribuida la competencia al Ministerio de Relaciones Exteriores se "pone en duda la titularidad plena y soberana de la Argentina respecto del recurso", al tiempo que "autoriza y promueve la captura por embarcaciones extranjeras derogando la ley 20.136 que reserva la captura al pabellón". Además, se apunta que con el sistema de canon, que disponía implementar el proyecto en cuestión, "lo único que hace el Estado es vender pescado sin promover la industrialización del mismo a través de mano de obra que agrega valor al producto exportado". En términos geopolíticos denunciaba que "Se estaría reconociendo derechos a Gran Bretaña a tener alrededor de Malvinas una Zona Económica Exclusiva contigua a la Argentina”. Y señalaba que por el artículo 33 se otorgaba la posibilidad de relativizar y desvirtuar la necesaria ocupación del $75 \%$ de argentinos entre los embarcados y se posibilitaba atentar contra la preservación del recurso al no obligar a respetar los dictámenes del INIDEP. Por si todo ello fuera poco se apuntaba además que el proyecto de la Cancillería promovía "el otorgamiento irresponsable e ilimitado" de permisos de pesca que podía traer aparejado prolongados períodos de veda con inactividad en la industria pesquera nacional y consiguientemente desocupación temporal a los obreros embarcados y de tierra. A su vez, se quejaba el gremio de que el proyecto desconocía la importancia de las fuerzas organizadas del trabajo y la producción al reducir su participación a un Consejo Asesor de un Consejo Federal que carecía de facultades decisorias, donde las provincias quedaban en minoría frente a la Nación. Por último, acusaba al plan de atentar contra la defensa nacional al sustraerle al Comando en Jefe de la Armada el control de la actividad investigativa de buques extranjeros derivando esa función a la Cancillería. Por todo eso, el SOIP se disponía a iniciar todas las gestiones posibles para forzar la no sanción de semejante ley. ${ }^{261}$ Más tarde, los gremios marítimos pedirán por carta al secretario de Planeamiento de la Presidencia de la Nación, entonces el Dr. Moisés Ikonikoff, la convocatoria de una mesa de concertación pesquera integrada por gremios y empresarios, junto con representantes de las provincias del litoral marítimo argentino a efectos de delinear las políticas pesqueras $\mathrm{y}$, consecuentemente, formular un anteproyecto de Ley Federal de Pesca. ${ }^{262}$

Por el lado del empresariado pesquero marplatense también llegaban críticas. La Cámara de Armadores Pesqueros (suponemos se refiere a la CAABPA) criticó el proyecto de ley impulsado por la Cancillería por entender que "parece claramente destinado a facilitar las gestiones del acuerdo con Gran

\footnotetext{
${ }^{259}$ L.C., $12 / 08 / 1990$.

${ }^{260}$ La Nación, 04/06/1990.

${ }^{261}$ L.C., 23/04/1990.

${ }^{262}$ L.C.,16/05/1990. Los gremios que firmaban la carta eran el SOIP, Asociación Argentina de Capitanes y Patrones de Pesca, Centro de Patrones Fluviales y Cabotaje Marítimo, SICONARA, SAON y UPCN. También la Asociación de Embarcaciones de Pesca Costera y la Sociedad de Patrones Pescadores.
} 
Bretaña, en un modo poco usual". ${ }^{263}$ La entidad señalaba que la iniciativa "significa una involución, ya que no sale la Argentina pesquera al mundo, sino el mundo viene a ella en términos de intercambio político, no económico". Y señalaba que "no parecen evidentes los beneficios concretos del régimen que se propone, debido a que la apertura, vía discrecionalidad administrativa, genera graves consecuencias sobre la competitividad de la industria nacional" 264 . La UCIP también expresó su rechazó quejándose además por que la reunión convocada para debatir la ley -y a la que no fue invitada la entidad-, se realizó en la sede de un banco extranjero (el Banco de Nueva York). ${ }^{265}$ Lo mismo expresaba la Coordinadora de Gremios que "destaca el carácter dependiente y sectario de este proyecto al ser convocadas las fuerzas empresarias a una reunión informativa en el Banco de Nueva York, excluyendo de esa convocatoria a las organizaciones gremiales vinculadas a la pesca". ${ }^{266}$

Las múltiples oposiciones tuvieron efecto y la Cancillería, mientras culpaba por el "error" de organizar una reunión en la sede del mencionado Banco al subsecretario del Ministerio de Relaciones Exteriores, Abel Danone, retiró su proyecto de ley. Con todo, cuando el Parlamento se disponía a tratar la demorada norma de pesca se habían presentado al menos seis proyectos: 1) el de Cancillería (retirado); 2) el de los Senadores Solari Yrigoyen y Eduardo Murguía; 3) el que presentaba la SAGyP (ahora des jerarquizada en subsecretaría) con las firmas de Felipe Solá y Luis Otero, 4) el del asesor presidencial César Lerena; 5) el del diputado socialista Estévez Boero; 6) el del demoprogresista Alberto Natale. Ante la heterogeneidad y multiplicidad de proyectos un cronista afirmaba:

Esa multiplicidad de iniciativas está demostrando en principio que aún, no obstante el potencial económico de nuestros recursos ictícolas y la necesidad de encuadrar orgánicamente todos los aspectos relacionados básicamente con la captura, procesamiento y comercialización, no han podido hilvanarse para estructurar una actitud uniforme del país en esta materia, especialmente en temática tan delicada como ésta donde deben armonizarse los intereses nacionales con cuestiones relacionadas, por ejemplo, a la delimitación territorial del Mar Argentino, y a la oportunidad, forma y modo de operar de flotas extranjeras. ${ }^{267}$

En septiembre de 1990 Luis Otero dejaba sus funciones como asesor de pesca, escalafón en la que quedó instalado luego de la des jerarquización del área. Lo reemplazó el justicialista Edgardo Murguía, quien fue senador por Santa Cruz entre 1983 y 1989 y elaboró previamente su propio proyecto de ley de pesca. ${ }^{268}$ De su mano aparecían como colaboradores Eduardo Pucci, Fernando Gutiérrez y Roberto Baltar. ${ }^{269}$ El nuevo funcionario relacionó su presencia en el cargo con la necesidad de promover la

\footnotetext{
${ }^{263}$ Arturo Crosetti, senador provincial por el Partido Intransigente, realizaba un critica similar cuando afirmaba que "Esta manera compulsiva de elevar el proyecto parece haber sido determinada por la urgencia de acordar políticas al respecto con Gran Bretaña, y no por un estudio riguroso de las condiciones que presenta el espacio marítimo del Atlántico Sur...”, L.C.,24/12/1990.

${ }^{264}$ L.C., 28/04/1989.

${ }^{265}$ L.C., $29 / 04 / 1989$

${ }^{266}$ L.C., 08/05/1989.

${ }^{267}$ L.C., $12 / 08 / 1990$

${ }^{268}$ Vicente Muleiro vincula a Murguía con Carlos Corach. Indica que cuando este último asumió como Ministro del Interior, Murguía fue llamado para cumplir la función de Coordinación de dicho Ministerio (Muleiro, 2000). César Lerena lo ubica como uno de los Senadores que promovió los convenios con la URSS y Bulgaria. Por otra parte, años después, Murguía fue procesado bajo la figura de peculado por maniobras con facturas y recibos mellizos de trabajos de la imprenta del Congreso (Lerena, 2009).

${ }^{269}$ Eduardo Pucci será luego subsecretario de Pesca, presidente de CAPECA y posteriormente del CEPA. En 1997 se lo vinculó con maniobras irregulares en la dotación de permisos de calamar. La Nación, 12/06/1997. Fernando Gutiérrez ocupará luego la subsecretaría de Pesca. El Lic. Roberto Baltar había sido gerente de la CAABPA y Director Nacional de Pesca.
} 
actividad pesquera. ${ }^{270}$ Afirmó su compromiso con la rama, el cual pasaba por sancionar una ley de pesca: "nuestra idea es llegar a un proyecto consensuado que cuente con el apoyo de los distintos sectores gremiales, empresarios y de la comercialización de la pesca". Además, ratificando la continuidad en la búsqueda de inversiones extranjeras, indicaba que se buscarán "todos los medios" económicos para incrementar los valores de exportación que se impulsarán con la CEE. ${ }^{271}$ Aseguró además que "habrá rapidez en las decisiones" en lo relativo a los otorgamientos de permisos de pesca; prometió "mano dura" para aquellos empresarios que no sean leales con el país; y expresó que "la pesca, como negocio que es, debe servir para que el país genere nuevas fuentes de trabajo y se logre lo que aspiramos todos: la puesta en marcha de la reactivación productiva". ${ }^{272}$ No obstante las declaradas intenciones de Murguía, la ley tuvo que esperar hasta el año 1997 para ser sancionada. Y varios años más para su reglamentación definitiva. De todos modos, lo que el Ministro de Relaciones Exteriores y futuro "padre de la convertibilidad", no podía lograr en la sanción de una ley nacional, lo promovió por otras vías a partir de su llegada a la cartera de Economía. ${ }^{273}$

f.“El desafío de crecer”: La pesca en tiempos de convertibilidad

En el año 1991 Felipe Solá se alejó de la secretaría para ocupar una banca de diputado. Entonces, Cavallo aprovechó la oportunidad para ubicar a un hombre de su confianza en la SAGyP (todavía subsecretaría tras las des jerarquización). Se trataba del Ingeniero Agrónomo Marcelo Regúnaga, quien años después volverá a la secretaría también de la mano del ex ministro de Economía durante la presidencia de Fernando De la Rúa. Regúnaga nombró como Interventor del INIDEP a Fernando Giorgiadis. Éste último, al asumir en su nuevo cargo, planteaba que "es un compromiso del gobierno conciliar una política de ajuste y al mismo tiempo una de crecimiento, en este caso para el sector pesquero". ${ }^{274}$ Y prometió que "desde ahora, la pesca será negocio". Regúnaga contaba con el Lic. Fernando Gutiérrez como asesor, a quien luego nombrará como Subsecretario de Pesca (al mismo momento que el área recuperaba el rango de subsecretaría). Gutiérrez, como vimos, había oficiado como asesor de Cavallo en la Cancillería. Se trataba de un empresario textil cuya empresa, que fabricaba camperas, había presentado quiebra. ${ }^{275}$ Según la Revista Redes, Gutiérrez era un hombre que respondía directamente a Cavallo, con vínculos que lo relacionaban a Guillermo Seita y Jorge Lara. El primero fue

\footnotetext{
${ }^{270}$ L.C.,21/09/1990.

${ }^{271}$ L.C., $02 / 10 / 1990$.

${ }^{272}$ L.C.,03/10/1990.

273 Ángel Roig acusó al propio ejecutivo por la demora en la sanción de una Ley de Pesca. Expresó "Un tramo de la demora también corresponde al señor [Fernando] Gutiérrez [entonces ya subsecretario de Pesca], quien hizo saber a las autoridades de la Comisión de Industria que era necesario introducir algunas reformas al proyecto de ley y a sus efectos, se tomó un largo plazo largamente excedido a su promesa de envío [...] Tanta 'demora' sirvió al Poder Ejecutivo para dictar resoluciones y avanzar en acuerdos internacionales, sin el resguardo y marco jurídico que significa una ley sancionada por el Congreso de la Nación”. L.C.,05/01/1994.

${ }^{274}$ L.C., 20/04/1991.

${ }^{275}$ Gutiérrez poco después formará la Fundación Sudeste en Mar del Plata y desde allí buscará fomentar su candidatura a Intendente dentro del PJ. Finalmente perderá en las internas con el juez Pettigiani. Como contribuyente de la Fundación figuraba el empresario pesquero Guillermo Jacob, conocido como el "rey del calamar", sindicado como uno de los principales beneficiarios de las políticas pesqueras de los últimos 30 años. Además Gutiérrez fue uno de los hombres designados por Menem y Cavallo para conformar la Comisión de Pesca del Atlántico Sur, que integraban nuestro país y Gran Bretaña, para buscar consenso en la definición de políticas pesqueras correspondientes al área de las islas Malvinas.
} 
uno de los operadores políticos del Ministro de Economía y Lara luego sería nombrado como responsable liquidador del Mercado Concentrador Pesquero. Según el cronista, Gutiérrez permitiría desde el área pesca fomentar los convenios con potencias extranjeras como la CEE y el Japón, que tanto interesaban a Domingo Cavallo. ${ }^{276}$

Los nuevos funcionarios iniciaban sus actividades en el marco de la Ley de Convertibilidad. La misma, al mantener la paridad cambiaria, perjudicaba a un sector fundamentalmente exportador como es la pesca. Por ello, los incentivos otorgados a los industriales debían provenir de otros lados. De la mano de la política macroeconómica que siguió el gobierno argentino, uno de los alicientes ofrecidos se vinculó con la posibilidad de incrementar la competitividad de las empresas a través de mecanismos de reducción de los costos laborales. Iniciando ese camino el gobierno sancionó la Ley de Empleo y comenzó a transitar la discusión más profunda sobre la flexibilización laboral. Pero veremos esto en el capítulo siguiente. Ahora exploraremos otro conjunto de medidas fiscales tomadas por el gobierno, las cuales, en parte, respondían a las demandas de los empresarios de la pesca.

Marcelo Regúnaga reconocía como insuficientes las políticas hasta el momento implementadas y anunció reducciones impositivas en derechos de exportación y en los aranceles de importación de buques con el objetivo de llevarlos a cero. A la vez, prometió trasparencia en los procesos de administración. ${ }^{277}$ Pero también advirtió a los industriales: "los beneficios que otorgue el Estado están condicionados al cumplimiento estricto de las obligaciones fiscales". Decía esto en el contexto en que aquellos estaban siendo investigados por evasión a la Ley Penal Tributaria. Por aquel entonces, las cámaras pesqueras buscaban alcanzar lo que definían como un pacto fiscal. La CAABPA y los Procesadores anunciaban discusiones en tal sentido con el gobierno nacional, luego de auto elogiarse del siguiente modo:

En nuestra trayectoria hemos demostrado un gran dinamismo, a tal punto que el nuestro es el único sector que ha crecido en los últimos años a pesar de las características recesivas de toda la economía argentina. $\mathrm{Y}$ esto se debe a su relación con el mercado internacional, que ha intensificado su demanda, y a la respuesta de los empresarios, que aún con políticas pesqueras adversas, aceptamos el desafío de crecer.

El pacto se basaría en dos aspectos. Uno hacía a temas fiscales como la inclusión de los productos pesqueros en el régimen de devolución de impuestos, lo que significaría el reconocimiento como industria para el sector (hasta el momento la pesca se incluía en el mismo rango que la agricultura), la reducción de la base de cálculo del impuesto a los activos, un precio de retención para el gas oíl, la eliminación de retenciones a las exportaciones, la eliminación de aranceles de importación de bienes de capital, repuestos, maquinarias e insumos y la regularización de la entrega de Bocrex ${ }^{278}$ para recomponer el "atraso cambiario". De política pesquera solicitaban la remoción del art. 42 del proyecto de ley de pesca del PEN, agilizar el tratamiento de la Ley de Puertos que permitiera privatizar los servicios portuarios y solicitaban la privatización del Mercado Concentrador. ${ }^{279}$ En Mar del Plata, pedían al intendente Ángel Roig algunas consideraciones respecto de las tasas municipales del servicio de Obras Sanitarias. ${ }^{280}$

\footnotetext{
${ }^{276}$ Revista Redes, № 59, año 1991.

${ }^{277}$ L.C.,29/04/1991.

${ }^{278}$ Se trataba del pago de reintegros, reembolsos o devolución de tributos mediante la entrega de Bonos de Crédito.

${ }^{279}$ L.C., 13/04/1991.

${ }^{280}$ L.C.,22/04/1991. Más adelante, la Cámara de Procesadores enviaba un informe al intendente municipal referente al estado de emergencia que atravesaba la actividad pesquera. Los industriales buscaban concretamente que se los eximiera del pago de tasas
} 
Tras los requerimientos de los empresarios pesqueros, en el mes de mayo el gobierno y varias cámaras del sector pesquero llegaron a un entendimiento bajo el título Acuerdo Fiscal para el Crecimiento y el Desarrollo Pesquero Argentino. Por medio de éste los precios al consumidor de las distintas especies de pescado registrarían rebajas de entre el 25 y el $30 \%$, al tiempo que los industriales se comprometían a alcanzar un "crecimiento sectorial previsible con un 30 por ciento de incremento en el valor de sus exportaciones". Además prometían realizar inversiones en la explotación de recursos en Tierra del Fuego. De este modo, se acordó que se respetarían las medidas de conservación y zonas de veda que impusiera la autoridad de aplicación, así como mantener el nivel de ocupación y cumplir estrictamente con las obligaciones fiscales y previsionales. Curiosamente, lo que los industriales pesqueros debían cumplir por ley ahora necesitaba ratificarse a partir de un pacto. El gobierno, por su parte, cumpliendo un viejo anhelo de los armadores pesqueros, se comprometía a eliminar los aranceles de importación para buques y otros bienes de capital. Incorporaría a la industria pesquera al régimen de devolución de impuestos del decreto $\mathrm{N}^{\circ}$ 1555/86 (considerándola así actividad industrial), y garantizaba agilizar la devolución del IVA, la liquidación de reembolsos y programas especiales de exportación y entrega de los Bocrex. El acuerdo fue firmado por Regúnaga, Enrique Díaz de CAPECA, José Luis Lorenzo de Procesadores, Antonio Solimeno de la CAABPA, Ricardo Iñurrieta por la CAPIP, Francisco Romano por la Sociedad de Patrones Pescadores y Cayetano Arcidiácono por la Asociación de Embarcaciones de Pesca Costera. Por último, además del compromiso de estudiar la privatización del Mercado Concentrador, el gobierno daba su palabra en cuanto a proyectar modificaciones al convenio colectivo para los trabajadores portuarios y realizar un análisis de la flexibilización laboral y el régimen de accidentes de trabajo buscando disminuir los "costos del trabajo". 281

A pesar de lo acordado, para el mes de junio la situación de la pesca era ciertamente caótica. A la quiebra y cierre de plantas, las ocupaciones de edificios, denuncias sindicales y la movilización de trabajadores desocupados, se sumaba un nuevo escándalo protagonizado por industriales pesqueros, cuando numerosos empresarios fueron apresados por cometer infracciones a la Ley Penal Tributaria. El pronto pago de las fianzas para quedar en libertad generó la indignación de dirigentes sindicales que no comprendían por qué no se realizaban los aportes de las cuotas sindicales y obras sociales, mientras que rápidamente se encontraban fondos para sacar a los empresarios de prisión. No obstante, a pesar de los padecimientos de algunos de sus actores, la situación vista desde las estadísticas demostraba una fase expansiva. La paradójica circunstancia se mostraba en un periódico del día 25 de junio, el cual ¡en la misma página! se anunciaba: "Se registró un récord en las exportaciones pesqueras" y, a su lado, "Fueron despedidos sesenta empleados". ${ }^{282}$ En lo que será un rasgo de toda la década, la pesca mostraba que crecimiento económico (medido en incremento de capturas y exportaciones) y generación de empleo eran dos cuestiones que no necesariamente marchaban juntas.

En ese contexto, los industriales pesqueros buscaron propiciar una tregua de 180 días entre empresarios y gremios, sin medidas de fuerza, durante los cuales se discutirían nuevas condiciones de trabajo. La apuesta era abaratar la mano de obra buscando que los sindicatos tolerasen la situación, prometiendo que ello frenaría los cierres de plantas y los despidos. Por eso se reunieron con el delegado

e impuestos municipales durante el período 1991 y 1992, así como disponer el pago en cuotas de deudas anteriores. También pedían el apoyo del intendente para que ese pedido se trasladase a las autoridades provinciales. L.C.,20/09/1991.

${ }^{281}$ L.C., 04/05/1991.

${ }^{282}$ L.C.,25/06/1991. 
del Ministerio de Trabajo y con el intendente Roig. ${ }^{283}$ Pero dicho pacto no era más que una ilusión, dado que las empresas pesqueras seguían cerrando sus puertas. Abdul Saravia, impotente, denunciaba lo que llamaba la industria de la quiebra. Mientras que trabajadores desempleados realizaban la "Marcha del Hambre”. Marcelo Regúnaga, por su parte, se entusiasmaba con los números que arrojaban las exportaciones y explicaba la situación bajo los siguientes conceptos:

En Argentina, en general, la mayor parte de las actividades económicas están viviendo un período de transición. La pesca no escapa a este caso, y se enfrenta en estos momentos a una caída estacional de los precios internacionales que de alguna manera está generando ciertos inconvenientes en la actividad. En el caso de Mar del Plata se está registrando un proceso de reajuste empresario que viene de arrastre y que lamentablemente está afectando a algunas empresas [...] Nosotros pensamos que como consecuencia del programa económico que se está desarrollando se empiezan a sentar las bases para construir una industria pesquera agresiva y competitiva internacionalmente [...] Además, hay un proceso normal de ajustes que se va dando en la economía donde se verifica la competencia. Aquí hay firmas que están creciendo y otras que están quebrando, de manera que algo también tiene que ver en esto la conducción empresaria. ${ }^{284}$

En la visión oficial, se estaba produciendo un necesario saneamiento de la actividad producto de las políticas económicas implementadas y el cambio de reglas de juego. Las empresas sobrevivían o sucumbían según marcaba el ritmo de la "libre" competencia. Los costos sociales de ello, eran, por cierto, males necesarios.

\section{g. La desregulación (I): el cierre del Mercado Concentrador}

A finales del año 1990 el gobierno dispuso la disminución en los aranceles de importación de los buques pesqueros usados. La medida, beneficiosa para los armadores pesqueros, perjudicaba directamente la industria naval nacional. Así lo hacía saber la Asociación de Importadores y Exportadores de la República Argentina que le reclamaba a Erman González, entonces Ministro de Economía:

Fijar un arancel del 5 por ciento para la importación de barcos nuevos o usados de hasta 5 años de edad y del 10 por ciento para la antigüedades mayores significa abrir las compuertas al ingreso de unidades de importación usadas en detrimento de los astilleros argentinos, como si estuviese buscando su desaparición, eliminando fuentes de trabajo en estos momentos tan necesarias en el país.

Esta queja iba en contra de lo que demandaban los propios industriales pesqueros, quienes habían solicitado la rebaja de aranceles para la importación de buques. En este sentido, incluso antes del arribo de Menem a la presidencia podían observarse las disidencias cada vez mayores entre los industriales pesqueros que buscaban liberar la incorporación de buques y los empresarios navales que solicitaban medidas de carácter proteccionista. ${ }^{285}$

\footnotetext{
${ }^{283}$ L.C., 11/07/1991.

${ }^{284}$ L.C., 16/08/1991.

${ }^{285}$ L.C.,31/03/1989. Años después, el empresario naval Domingo Contessi señalaba "jamás sospechamos que la aplicación de políticas tan contradictorias llegarían a poner en peligro no sólo al sector naval, sino también a la pesca". Mientras "se restringían
} 
El nuevo rumbo que marcaba el gobierno se profundizó en el año siguiente. En 1991 el presidente Menem anunció medidas des regulatorias de la economía para "continuar con la transformación de raíz de nuestro sistema económico y social" terminando con un "Estado prebendario, asfixiante y arbitrario que trabó la vida productiva nacional". La desregulación afectaba diferentes aspectos de la economía nacional, entre ellos, facilitaba la liquidación de entes reguladores, nuevas medidas fiscales, mercado de capitales, seguridad social y libertad en las negociaciones colectivas. En comercio exterior se suprimían todas las restricciones, cupos y otras limitaciones cuantitativas a las importaciones y a las exportaciones para mercaderías. En cuanto a entes reguladores, se disolvían las juntas nacionales de granos y carnes, el Mercado de Concentración Pesquera y otras instituciones. ${ }^{286}$ La decisión se tomaba por decreto porque, en palabras del Presidente, "la Argentina no puede esperar". ${ }^{287}$ En Mar del Plata, el titular del Mercado Concentrador José Ibáñez aseguraba estar desinformado, conociendo el hecho por versiones periodísticas. Según un anónimo cronista las medidas sumieron en el desconcierto a los noventa empleados del lugar. La novedad tomaba al Mercado de camino hacia la creación de un ente autárquico, sobre el cual se ensayaba un convenio entre las autoridades, los usuarios y los gremios del sector. Ibáñez expresó "el presidente Menem nos depara una sorpresa cada día". ${ }^{288}$

Antes de seguir en la descripción de la política pesquera veamos el rol que cumplía el Mercado. Su función se relacionaba con la venta de pescado en el mercado interno. El organismo fue creado en 1980 a través de la ley $\mathrm{N}^{\circ} 22.260$ con el objetivo, entre otros, de abastecer y abaratar los productos pesqueros. Subsanando antiguos inconvenientes en cuanto a la comercialización de pescado que padecían principalmente los pescadores de lanchas costeras, el organismo se ocupaba precisamente de concentrar las ventas de pescado en el mercado interno, rematando a la baja y negociando directamente con los grandes consumidores. ${ }^{289}$ Hacia finales de la década del '80 expertos en temas pesqueros, incluido César Lerena, realizaban numerosas críticas al organismo, el cual no cumplía con casi ninguno de los objetivos que se proponía. No obstante ello, dicho especialista le asignaba un rol preponderante al convertirlo, en caso de implementarse su proyecto, en el brazo ejecutor de un Programa de Consumo Nacional de Pescado (Lerena, 1989).

Pero no fue esa la suerte corrida por la entidad en los comienzos de la gestión Menem. Saravia había presionado para colocar allí a un hombre que le brindaba confianza y pertenecía a la vida portuaria marplatense. Se trató de José Ibáñez, hermano del petrolero Diego Ibáñez. El primero nació en el puerto de Mar del Plata, fue interventor del SOIP en la década del '60 y mantenía una relación de amistad con titular de los obreros del pescado. El día de su asunción, Federalismo y Liberación saluda con entusiasmo la designación. ${ }^{290}$ Mientras que en su discurso, Ibáñez finalizó “...quiero agradecer por su gestión al titular del SOIP, Abdul Saravia y a toda la comunidad pesquera le pido su colaboración para llevar con

[los permisos de pesca] a los pocos barcos nuevos que se construían en el país, se permitió y fomentó la importación de buques congeladores y factorías más grande que haya sufrido caladero alguno en el mundo [...] Si en lugar de importar uno solo de los tantos buques congeladores de gran porte que ingresaron en los últimos años, se nos hubiera permitido construir barcos fresqueros por igual esfuerzo de pesca, se le habría garantizado trabajo continuado a nuestro astillero por unos cinco años por cada barco. A la vez que se habrían generado muchos más empleos y brindado esperanzas de desarrollo a un sector tradicional de la pesca argentina”. L.C.,02/02/1997.

${ }^{286}$ L.C., $01 / 11 / 1991$.

${ }^{287}$ L.C., 02/11/1991.

${ }^{288}$ L.C.,01/11/1991. Más tarde Ibáñez declaró "sentirse afectado personalmente, pues luego de dos años de trabajo con la finalidad de blanquear el sistema y luego de muchos logros, tanto poner el pecho, uno se pregunta ¿para qué?”. L.C.,05/11/1991.

${ }^{289} \mathrm{Al}$ respecto ver Mateo (2003).

${ }^{290}$ L.C.,25/08/1989. 
éxito mi gestión". ${ }^{291} \mathrm{Al}$ frente del mercado Ibáñez realizó algunas medidas pero muy pronto los funcionarios de pesca comenzaron a instalar la idea de la necesidad de privatizarlo. El propio Luis Otero, recordemos que se desempeñó como subsecretario de pesca de la administración Menem, fue el encargado de presentar a sindicatos y empresarios el proyecto de privatización. Luego de lo cual indicó que el empresariado se mostraba de acuerdo con la medida. ${ }^{292} \mathrm{Al}$ contrario, la iniciativa privatizadora fue fuertemente criticada por Saravia, quien expresó su "total rechazo".

En una asamblea realizada el lunes con los 250 delegados se rechazó la posibilidad de privatización del Mercado Nacional de Concentración Pesquera por entender que este Mercado tiene una recaudación de 200 millones de australes por mes con un 40 por ciento de gastos por estructura. Hay que privatizar lo que da déficit al Estado, y además, este proyecto no le da participación a los trabajadores. Acá cuatro o cinco pulpos grandes van a querer sacar ventaja con este plan y nosotros estamos en contra obviamente. ${ }^{293}$

Finalizaba con un grito de resistencia "Vamos a seguir golpeando, trabajando, y yo prefiero morir parado antes que morir arrodillado por la entrega de un patrimonio que es de todos los argentinos". Hombre de acción, Saravia no se quedaba solo con declaraciones rimbombantes. Días más tarde el SOIP enviaba cartas a todos los funcionarios con poder de decisión, entre ellos a Felipe Solá, reiterando su "firme oposición" a la propuesta de privatización. En ella insistía en el desacuerdo gremial con lo que consideraba "la entrega del patrimonio nacional, formalizar un monopolio pesquero". Acusaba a los funcionarios del área pues "el negocio que ofrecen el ingeniero Solá y el doctor César Otero es un negocio redondo" ya que "conforman el directorio y la sociedad, los privados no ponen nada, el Estado les consigue el crédito para arreglar el Puerto y el crédito lo pagan con las habituales ganancias que hasta hoy da el mercado y que nadie puede afirmar que seguirán existiendo". Sentenciaba que la privatización no reduciría los precios ni distribuiría mejor el pescado. ${ }^{294} E 1$ dirigente obrero seguirá, en diferentes intervenciones, en la tesitura de explicar que el mercado es "una de las pocas empresas del Estado que brinda beneficios directos al Tesoro de la Nación". ${ }^{295}$

En marzo, Erman González anunció la reducción de gastos públicos por 2.000 millones de dólares. Las medidas incluían la eliminación de 56 secretarías de Estado y la reducción de 112 a 32 de las subsecretarías. Afectaba también al Mercado Concentrador puesto que recortaba las horas extras del personal. Tal recorte no atendía las particularidades de la actividad pesquera en cuanto los barcos no poseen un horario fijo de arribo y por ello los trabajadores del mercado debían trabajar en horarios amplios. Poco después, el secretario Legal y Técnico de la Nación, Dr. Raúl Granillo Ocampo, le comunicaba a Felipe Solá la necesidad de proceder "al más breve plazo" posible a la privatización del Mercado. ${ }^{296}$ Saravia, que no terminaba de resignarse, emitía entonces un comunicado apelando a cierto criterio de lo que él consideraba justo y razonable. Decía:

${ }^{291}$ L.C.,26/08/1989

${ }^{292}$ L.C., $16 / 02 / 1990$.

${ }^{293}$ L.C., $16 / 02 / 1990$.

${ }^{294}$ L.C. $26 / 02 / 1990$.

${ }^{295}$ L.C., 03/03/1990; 14/03/1990.

${ }^{296}$ L.C., 07/12/1990. 
Esta organización [el SOIP] que fue la que luchó a brazo partido ante el funcionario de turno en la Subsecretaría de Pesca de la Nación para que se designara al frente del Mercado a un hombre de Mar del Plata y con conocimiento del tema pesquero e imparcialidad en su gestión, enfrentando a las cámaras empresarias que tenían ya a su nombre "colocado"; él existe, fue coronado con la designación del señor José Ibáñez, quien en un año de gestión ha demostrado su capacidad para administrar y sanear el organismo pese a las constantes limitaciones impuestas por las autoridades económicas [...] Llama la atención la premura con que ha sido lanzada la versión de la privatización. ${ }^{297}$

Pero ni la resistencia, ni la amistad con el presidente lograban torcer el rumbo de una política general dirigida en otro sentido, incluso más implacable de lo que Saravia imaginaba. A su modo, bien lo interpreta el Ministro de Asuntos Agrarios de la Provincia de Buenos Aires José María Vernet, quien anunciaba en 1990 que "Lo que está ocurriendo en el país es que está eclosionando un viejo modelo. Acá hay un modelo productivo, un modelo de creación de la riqueza, de relaciones sociales y de organización del Estado que no funciona más". El funcionario comparó los cambios que se producían en la Argentina con los registrados en Europa Oriental "porque aquí también nos decidimos a cambiar y, como también ocurre en esos países, aquí los cambios no serán baratos". ${ }^{298}$

A los 18 meses de iniciada su gestión, José Ibáñez solicitaba encarecidamente una definición de las autoridades nacionales respecto al futuro del Mercado Concentrador. ${ }^{299}$ Por su parte, los integrantes de la mesa directiva de la Asociación Mutual del Mercado Nacional de Concentración Pesquera elevaron un anteproyecto alternativo al presentado por Otero que, para no llegar a la privatización, apuntaba a la cogestión del Estado y el personal del mercado con un consejo de asesores conformado por diferentes sectores portuarios. Tal proyecto es el que se discutía cuando los tomó por sorpresa la desregulación. Y finalmente el organismo no fue privatizado. En una decisión inimaginable para los hombres que llevaban años relacionados con la industria del pescado como Saravia, se resolvió directamente su disolución y remate. Al momento del cierre el mercado comercializaba tan sólo el $20 \%$ de la captura nacional. Según la Revista Redes “... la escasa repercusión del episodio es el mejor indicador para medir la importancia del mercado en las transacciones pesqueras". 300 "Escasa repercusión" es un término injusto, cuanto menos para los trabajadores del mercado y para los sindicatos que, como el SOIP, habían procurado insistentemente evitar la privatización. Incluso bastante tiempo después, la idea de reflotar un Mercado Concentrador, aunque infructuosamente, volverá a ser impulsada por los dirigentes gremiales. Por su parte, Regúnaga designó a Jorge Lara para el cargo de interventor liquidador del mercado en reemplazo de Ibáñez. Lara era alguien de "absoluta confianza" del secretario según indica nuestra fuente. ${ }^{301} \mathrm{Se}$ terminaba así otro de los pilares del proyecto de Saravia. Haber peleado para que la dirección del organismo la cumpliera un hombre del Puerto, partícipe de una "visión nacional" de la pesca, no sirvió de nada. Mientras el árbol de la "otrora industria nacional" se secaba, crujía y poco después comenzaba a arder, la apertura externa y la profundización de la desregulación humedecían las raíces de otro proyecto pesquero, cada vez más vigoroso y verde, como las praderas donde crecían sus flores. Tal vez no fuera dulce el aroma que éstas desprendían. Pero poco importaba. Porque sí era enérgico, casi unánime. Como las flores malsanas de Baudelaire, los perfumes corrompidos, potentes y triunfantes que exhalan en su

\footnotetext{
${ }^{297}$ L.C., 08/12/1990.

${ }^{298}$ L.C., $17 / 02 / 1990$.

${ }^{299}$ L.C.,26/02/1991.

${ }^{300}$ Revista Redes, №59, año 1992.

${ }^{301}$ L.C.,08/11/1991.
} 
expansión las cosas infinitas, se instalaban en la órbita de la industria de la pesca. Aún hoy podemos discernir su diáfano aroma.

\section{h. La desregulación (II): "Barajar y dar de nuevo"}

El "sistema" portuario argentino al igual que el trazado de líneas ferroviarias, ambos estrechamente relacionados, se conformó al calor de la integración de la economía argentina al mercado mundial como exportadora de productos agropecuarios. Así como el ferrocarril se necesitaba para trasladar la producción agropecuaria a los centros urbanos, particularmente Buenos Aires, los puertos de ultramar se

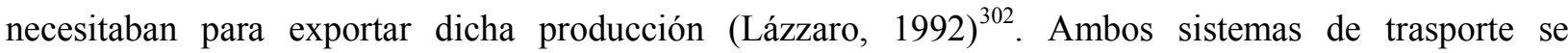
consolidaron en la zona pampeana, siendo el sector exportador -fundamentalmente en manos de capitales extranjeros- el que delineó su infraestructura en función de las necesidades de exportación. En ese contexto, muchos puertos fueron construidos y explotados por capitales extranjeros mientras que en otros tuvo participación el Estado Nacional. En el caso del Puerto de Mar del Plata su construcción (realizada entre 1911 y 1922) ${ }^{303}$ respondió a las necesidades agroexportadoras y su infraestructura se pensó bajo esos parámetros. ${ }^{304} \mathrm{Su}$ construcción, impulsada por una licitación nacional, comenzó desde cero y en un espacio que requería un puerto artificial en su totalidad (Mateo, 2003). ${ }^{305} \mathrm{~A}$ pesar de ello, terminó siendo el puerto pesquero más importante del país. A mediados de la década del '40, el peronismo igual que había hecho con el sistema ferroviario, estatizó el manejo y la administración portuaria. Esa situación perduró hasta la década del '90. Viviana Burijson (2003), aclarando que su fuente de información son fundamentalmente entrevistas, ofrece un panorama de la administración portuaria para la década del ' 80 , donde el grueso de los inconvenientes se explican por el manejo estatal que interponía "barreras regulatorias" que incrementaban artificialmente los costos operativos de las terminales portuarias. Más allá de las interpretaciones, lo cierto es que en el año 1991, en el marco de la desregulación de diferentes actividades, la idea de descentralizar y privatizar los puertos comienza a expresarse con énfasis. Tal medida fue solicitada, entre otros actores, por industriales pesqueros que deseaban abaratar costos de preparación y alistamiento de los buques. Además, era cada vez más fuerte la corriente de ideas que denunciaba la ineficacia de las administraciones estatales en diferentes áreas, entre ellas la administración portuaria. En el caso del puerto de Mar del Plata, Luis Otero, que ahora se desempeñaba como coordinador de la Comisión Provincial de Reactivación Portuaria, manifestaba a principios de 1991 refiriéndose al posible traspaso del puerto de la administración nacional a la provincial: "se escuchará la

\footnotetext{
${ }^{302}$ Lázzaro entrecomilla la palabra sistema porque a lo largo de su estudio demuestra que la Argentina careció de algo así como un sistema portuario nacional, entendido como una dinámica portuaria caracterizada por una situación de interacción entre puertos orientada hacia el objetivo específico de la actividad portuaria. Más bien, aquí la tendencia fue hacia una competencia recíproca y ruinosa entre los puertos.

${ }^{303}$ Mar del Plata tenía diferentes antecedentes respecto de la construcción de puertos. El primero de ellos, cuya existencia correspondía a mediados del siglo XIX, se vinculó al saladero propiedad de Coelho de Meyrelles. Sobre este tema ver (Mateo, 2003; Favero y Portela, 2005).

${ }^{304}$ Un comunicado del gobierno nacional señalaba que “...el desarrollo de la producción exportable impone la necesidad de aumentar el número de puertos de aguas hondas" (cit. en Favero y Portela, 2005: 16).

${ }^{305}$ Los pescadores fueron desalojados del puerto natural donde se habían afincado y obligados a trasladarse porque su actividad, a los ojos del gobierno conservador de la ciudad, no era compatible con el perfil de villa turística para disfrute de una elite. Al respecto ver Mateo (2003).
} 
voz de todos los que tienen que ver con el quehacer portuario". En su discurso ya se podía apreciar la filosofía imperante, tendiente a descentralizar y privatizar los puertos. Decía Otero:

La provincia lo que va a hacer es establecer un sistema por el cual va a convocar a concesiones de áreas portuarias determinadas, con la obligación de los privados de realizar determinadas inversiones para mejorar su infraestructura [...] Porque seamos sinceros: ni la nación ni las provincias están en condiciones de mantener o mejorar la infraestructura actual de los puertos. Aquí se requieren capitales para cambiar... ${ }^{306}$

En diciembre de 1991, tras la re jerarquización del área, se hizo cargo de la Subsecretaría de Pesca Fernando Gutiérrez mientras que Roberto Baltar asumió la Dirección Nacional de Pesca. El primero manifestó en su discurso de asunción:

Es necesario que la participación del sector privado crezca, sin afectar el interés del Estado, y siempre conforme a la política económica que viene marcando con éxito el ministro Domingo Cavallo [...] Yo pondré énfasis en la desregulación de todos los costos de la actividad pesquera, al igual que con la investigación a través del Instituto Nacional de Investigación y Desarrollo Pesquero. ${ }^{307}$

El año 1991 fue duro tanto para la pesca como para otras actividades económicas. Aún así la pesca tuvo un buen rendimiento en relación con las exportaciones. Realizando un balance, el presidente de la cámara de procesadores indicó que era grande el esfuerzo que exigía el reordenamiento económico del país. Desde la perspectiva empresaria, la hiperinflación y "el atraso cambiario" provocaban un continuo desfasaje en la ecuación precios-costos. Se sumaban como problemas la retracción en la demanda internacional y la caída de los precios. En ese contexto, el Acuerdo para el Desarrollo Pesquero mediante el cual se incorporó a la industria pesquera en el régimen de devolución de impuestos se transformó en una buena noticia, sumada a, siempre desde la mirada del empresariado, la desregulación del Mercado Concentrador. Por ello José Lorenzo terminaba diciendo que el año 1992 parecía presentarse como el de la definitiva consolidación de una verdadera política pesquera en el país. ${ }^{308}$ En marzo de 1992 Fernando Gutiérrez señalaba:

1991 fue un año récord para la actividad pesquera [...] Se han aumentado en casi un $22 \%$ las exportaciones; se ha aumentado la captura en ochenta mil toneladas. Esto habla a las claras que la pesca es una de las actividades industriales que sigue creciendo en el país y que nosotros tenemos que ayudar a desregularizar...

\footnotetext{
${ }^{306}$ L.C.,02/01/1991.

${ }^{307}$ L.C.,16/12/1991. Señaló además que se mantenían los contactos con la CEE para firmar un acuerdo tendiente a "la renovación de la flota pesquera argentina”. A los pocos días el Senado de la Nación daba media sanción al proyecto de Ley de Pesca impulsado por el PEN. La iniciativa terminó siendo apoyada por el bloque justicialista y resistida, entre otros, por el radical Solari Yrigoyen. Entre otras cuestiones la nueva normativa preveía el sistema de charteo, aranceles cero para los insumos de la actividad y tratamiento impositivo con precios de exportación. Además, permitía los tratados internacionales para fomentar la pesca de buques de bandera extranjera previa Ley del Congreso aceptándolo. Si bien, como dijimos arriba, la Ley no fue sancionada, si se podía adivinar el espíritu y las políticas para la pesca, las cuales, prescindiendo del marco jurídico, se dirigieron por ese sendero.

${ }^{308}$ Revista Redes, № 60, año 1992. "Una crisis de modalidades distintas”, José Lorenzo, p. 33.
} 
El objetivo -decía- era pasar de las 600 mil toneladas capturadas por la flota que operaba en el caladero nacional al millón. Y, desde su visión, para ello había que profundizar la desregulación y fomentar convenios internacionales. ${ }^{309}$ Poco después un documento emitido desde la Subsecretaría de Pesca señalaba la intención de desregular para "desarticular el entramado de regulaciones que distorsionaban el funcionamiento del sistema, procurando adecuar el costo argentino a niveles internacionales que posibiliten la natural competitividad de la industria local'. Por eso la desregulación se pretendía que llegará a nuevos rubros tales como el costo energético, fletes, ordenamiento portuario, actualización, simplificación y flexibilización de la normativa laboral. ${ }^{310}$

En fin, a mediados del año 1992 el Poder Ejecutivo Nacional, mediante el decreto $\mathrm{N}^{\circ}$ 817, procedió a la Desregulación Portuaria, Marítima y Pesquera, estableciendo la libre contratación de puertos y buques y modificando el régimen jurídico vigente que hasta ese momento exigió la captura con buques nacionales, el cual había asegurado un alto grado de protección económica a los pescadores locales según las leyes $\mathrm{N}^{\circ} 20.136 / 73$ y N $\mathrm{N}^{\circ} 20.489 .{ }^{311}$ Los considerandos del decreto, que se inscribía en el marco de la reforma del Estado en marcha, estaban poblados de terminología liberal que insistía en la necesidad de promover la libre concurrencia en el mercado para la formación de precios, el abaratamiento de costos empresarios, la no intervención estatal y la tendencia a una mayor apertura económica. ${ }^{312}$ La filosofía imperante decía buscar eliminar todos los mecanismos que atenten contra la libertad y la fluidez de los mercados. Entre otros aspectos el decreto disolvía la Administración General de Puertos Sociedad del Estado, la cual pertenecía a la órbita nacional y delegaba la administración pesquera en las provincias, habilitando (y alentando) la posibilidad de privatizar los servicios portuarios. Además, aduciendo "limitaciones a la libertad de contratación entre las partes" y generando "la formación de gravosos sobrecostos", se daban de baja los convenios colectivos de trabajo de las tripulaciones de buques a favor de "la libertad de contratación". ${ }^{313}$ En el mismo sentido, se terminaba con la obligación de contratar un $75 \%$ de ciudadanos argentinos para las tareas de marinería y maestranza, derecho que desde 1973 había garantizado la ley de Navegación $\mathrm{N}^{\circ} 20.094 .{ }^{314}$ Este hecho motivó la reacción en forma de acciones de protesta y denuncias por parte de las tripulaciones marineras. En el capítulo IV se analiza este proceso. Citemos aquí la manifestación conjunta del SOMU, la Asociación Argentina de Capitanes y Patrones de Pesca y el SICONARA denunciando "la presencia de personal extranjero a bordo de los buques pesqueros que se incorporan a la matrícula nacional con la plena aprobación de las autoridades

\footnotetext{
${ }^{309}$ L.C., 29/03/1992.

${ }^{310}$ L.C., 03/05/1992.

${ }^{311}$ Con el criterio de proteger la industria nacional pesquera la ley $N^{\circ} 20.136 / 73$ disponía que los recursos del mar argentino solo podían ser explotados por buques con pabellón argentino.

312 Decreto $\mathrm{N}^{\circ} 817$ de 1992. Disponible en línea http://infoleg.mecon.gov.ar/infolegInternet/anexos/5000-
} 9999/8845/norma.htm. Visitado el 12 de abril de 2012 .

${ }^{313} \mathrm{El}$ artículo 35 especificaba que "Transitoriamente y hasta tanto se formalicen los nuevos convenios a los que se refiere el artículo siguiente, dejarán de tener efectos aquellas cláusulas convencionales, actas, acuerdos, o todo acto normativo que establezcan condiciones laborales distorsivas de la productividad o que impidan o dificulten el normal ejercicio de dirección y administración empresaria". Artículo 35, capítulo V sobre Regímenes Laborales, Decreto N 817/92. Poder Ejecutivo Nacional. Entre otros aspectos, también eliminaba la obligación de contratar delegados de personal arriba del buque. Por último, comprometía al Ministerio de Trabajo a convocar, luego de diez días de vigencia de la normativa, a las comisiones negociadoras de los convenios colectivos de trabajo. Es decir, primero atacaba las conquistas obreras y luego volvía a repartir las cartas en un marco bastante más favorable para la negociación por parte de los empresarios.

${ }^{314}$ El artículo $N^{\circ} 143$ de la Ley de Navegación de 1973 decía que "El Setenta y Cinco por Ciento (75\%) del personal de maestranza y marinería del buque debe estar constituido por argentinos. En lo posible habiendo tripulantes argentinos en disponibilidad, la tripulación deberá ser completada con ellos”. La vigencia de este artículo de la ley fue restituido en el año 2004 a través del decreto $\mathrm{N}^{\circ} 1010$. 
nacionales del área". Los firmantes no comprendían "cómo, sin contar con estudios concretos que avalan estas maniobras" se les "concede el uso de nuestro pabellón" a buques extranjeros y "permisos de pesca que se niegan a buques construidos en grada nacional". Y expresaban con desasosiego que "estamos presenciando la entrega de la explotación de los recursos marítimos, el despojo a los argentinos de sus fuentes de trabajo, en nombre de la modernización, la desregulación y la transparencia", no existiendo revolución productiva "con la familia marinera desamparada, hambreada, despojada de su recurso natural de supervivencia". ${ }^{315}$ También se conocía el rechazo hecho público por parte de la CGT regional. $^{316}$ El propio Gutiérrez declaraba tiempo más tarde que el decreto $\mathrm{N}^{\circ} 817$ que desreguló el transporte fluvial y marítimo "fue importante porque entre otros puntos bajó costos de la estiba. Fundamentalmente creo que es un avance dentro de los nuevos convenios colectivos de trabajo que tienen que regir en la Argentina estabilizada que vivimos hoy" ${ }^{317}$.

Por el contrario, la nueva iniciativa contaba con el apoyo de la recientemente creada Federación de la Industria Pesquera Argentina (FIPA) ${ }^{318}$. A poco de conocer el decreto, el flamante presidente de la entidad, Enrique Díaz, ante la consulta acerca de la sanción del decreto desregulador, declaraba "Como una industria netamente exportadora y en función de la paridad cambiaria en vigencia, la expectativa de la pesca respecto a una eventual mejora de sus ingresos está vinculada al rubro costos. Toda decisión que implique reducirlos será bienvenida". ${ }^{319}$ También la CAABPA y los Procesadores, por su cuenta, brindaron apoyo al decreto de desregulación. Argumentaron "una primer lectura deja una impresión sumamente positiva respecto de las posibilidades que dicha norma abre a la concreción de profundas reformas estructurales tendientes a insertar la Pesca Argentina en un contexto competitivo internacional". La medida entusiasmó también a Alberto Valastro (CAABPA) y Carlos Domine (Procesadores) dado que:

...la puesta en práctica de las nuevas medidas dispuestas por el gobierno nacional, originará una disminución de los costos operativos y una adecuación de las modalidades de trabajo que conllevará a una mayor eficiencia y productividad del sector. Creemos que en tanto medie una pronta aplicación de las mismas, se posibilitará la reactivación del Sector Industrial Pesquero, el cual está atravesando una profunda crisis. ${ }^{320}$

Finalmente, continuando con la política desregulatoria, en junio de 1992 el Congreso sancionó la ley $\mathrm{N}^{\circ} 24.093$, la cual transfería los puertos a los Estados Provinciales y/o a la actividad privada, salvo el puerto de Buenos Aires que permanecería en la órbita del entonces municipio porteño.

\footnotetext{
${ }^{315}$ L.C., 18/03/1992.

${ }^{316}$ L.C., 01/06/1992.

${ }^{317}$ L.C., 31/12/1992.

318 Se trataba del intento federativo de las cámaras armadoras y procesadoras de buques pesqueros de la Argentina. Desarrollamos sus características en el capítulo IV.

${ }^{319}$ Revista Redes, № 62, año 1992, p. 6.

${ }^{320}$ L.C., 01/06/1992.
} 


\section{i. La apertura externa}

Hacia mediados del año 1992 la conducción del Ministerio de Economía buscaba diseñar políticas que, al mismo tiempo que fomentaran las exportaciones, continuaran demoliendo los lineamientos del viejo modelo sustitutivo. Entre ellas se trataba de eliminar lo que consideraban privilegios artificiales, entre las que se colocaban los regímenes de promoción industrial. En ese marco, que implicaba la elaboración de medidas para impulsar al sector exportador, Cavallo anunció un aumento en los reintegros a las exportaciones pesqueras. La medida respondía a otra de las reiteradas demandas de los industriales pesqueros. Después de algunas correcciones, la escala llevó a un 7,5\% el rubro filetes, 5\% para langostinos, 7,5\% surimi, 2,5\% calamar entero. Sin embargo, y como contraparte, el gobierno a través del decreto 2000/92 suprimió lo que quedaba del régimen de promoción industrial afectando particularmente a las empresas pesqueras radicadas en la Patagonia. Tanto era así que los anuncios más que entusiasmar a los empresarios alentaron las críticas por parte de CAPECA y un apoyo nada eufórico por parte de la CAABPA, pues esta última entendía que los incrementos recibidos serían absorbidos por los mayores costos de los insumos.

En ese contexto, el entonces subsecretario de Pesca Fernando Gutiérrez, declaró que "la crisis pesquera pasó". Pero no era esa la opinión de las principales cámaras de armadores. Por el lado de CAPECA se denunciaba la existencia de una crisis de mercado dada por la recesión que transitaba la economía de los principales países compradores de las exportaciones pesqueras argentinas y el impacto de ese fenómeno en los precios. Por ejemplo, la merluza había bajado en un año un $40 \%$ su valor. Además, la peseta y la lira habían sufrido un deterioro en relación al dólar, lo cual indirectamente representaba una caída en los niveles de ingreso de los exportadores. Complicaba el escenario la situación local que mantenía el tipo de cambio fijo, el incremento de tarifas, de transporte, comunicaciones, "costos financieros" y de intervención bancaria, así como la falta de financiación, aumento de la presión fiscal y de cargas previsionales. Todo esto posicionaba a las empresas en camino de una suspensión de pagos. ${ }^{321}$ Para compensar esa situación pedían que los reintegros se elevaran a un promedio de entre 8 y $10 \%$.

Por su parte la CAABPA también presentaba un panorama inquietante. Si bien reconocía que la estabilidad monetaria les había permitido a sus empresas reducir algunos costos y detectar ineficiencias, y que la desregulación y los reintegros ayudaban a mejorar la situación, se quejaba de dos problemas que afectaban a sus asociados. Uno era interno y el otro externo. El primero tenía que ver con los altos costos en términos internacionales de la mano de obra, intensiva en la industria, y las cargas sociales que la gravaban, así como el costo de algunos insumos y servicios privados y públicos como las tarifas telefónicas, la energía, los repuestos, el equipamiento de los barcos y los costos portuarios. ${ }^{322} \mathrm{E}$ l segundo problema se relacionaba con la revaluación del dólar y del peso frente a las monedas de los países compradores lo que afectaba los precios de venta de los productos a exportar. ${ }^{323}$ En esta situación, en octubre de 1993 los industriales pesqueros marplatenses representados por la CAABPA y Procesadores se

\footnotetext{
${ }^{321}$ Revista Redes, № 65, año 1992, p. 6, 7 y 10. "El Estado salió ganando".

${ }^{322}$ En el diagnóstico coincidían con el establishment económico argentino que reafirmó su confianza en el ministro Domingo Cavallo y el Plan de Convertibilidad, aunque advertían la necesidad de bajar el costo argentino, flexibilizar las leyes laborales y ampliar el crédito productivo, entre otros cambios. Esa era la respuesta a una encuesta sobre economía argentina que brindaron Roque Maccarone (Asociación de Bancos Argentinos), Manuel Herrera (Unión Industrial Argentina), Leónida Gasoni (Confederación Intercooperativa Agropecuaria), César Tortorella (Confederación de la Industria), Carlos de la Vega (Cámara de Comercio), José Manuel Castillo (CGE), Jorge Althabe (CRA) y Daniel Artana (FIEL). L.C.,01/10/1992.

${ }^{323}$ Revista Redes, N 67 , año 1993, p. 45, 46 y 48.
} 
presentaron ante el Ministerio de Trabajo de la Nación con la intención de ampararse en los artículos 98 al 105 de la ley $\mathrm{N}^{\circ} 24.013$ que en su capítulo $6^{\circ}$ señala que en ciertos casos las industrias se pueden acoger al procedimiento preventivo de crisis empresaria, lo cual significa que, legalmente, puede desligarse de su plantel básico del personal con el 50\% de las indemnizaciones. Con esta acción los armadores buscaban presionar al gobierno buscando lograr ventajas impositivas y/o rebajas arancelarias. ${ }^{324}$ Pero la petición fue rechazada por el Ministerio. No obstante, y como contraparte, el gobierno ofreció, por un lado, la posibilidad de abaratar los costos de la fuerza de trabajo (como veremos en el capítulo siguiente). Por otro, fomentó la ligazón de los empresarios pesqueros "nacionales" con empresas extranjeras, permitiendo a los primeros acceder a bienes de capital para su explotación sin requerir el desembolso de erogaciones abultadas, así como la posibilidad de alcanzar una reinserción en los mercados tradicionales mediante alguna rebaja arancelaria. Todo ello bajo un signo de expansión de capturas, que redundó en un gran incremento de las exportaciones. Los mecanismos para implementar estas iniciativas fueron el charteo y el acuerdo con la CEE.

Antes de abocarnos a desarrollar tales instrumentos, digamos que hemos mencionado al pasar que la CAABPA, en diferentes ocasiones, se opuso a distintas políticas pesqueras de apertura del Mar Argentino a la pesca de buques extranjeros, argumentado la defensa de la soberanía nacional. En la década del '70 un boletín perteneciente a la cámara se titulaba "Colonos de las fronteras de la patria en el mar’. Allí los industriales pesqueros sostenían:

Nunca hemos ocultado que nuestra opinión sea comprometida. Estamos en contra de los buques extranjeros (importados o factorías) porque afectan nuestros intereses vitalmente: desvalorizan nuestras inversiones, exterminan los recursos naturales y compiten con nuestras exportaciones (cit. en Pradas, 2006: 63).

Más acá en el tiempo, oponiéndose a las negociaciones que se mantenían con el gobierno uruguayo por la zona común de pesca, la entidad decía "Queremos dejar bien establecida la oposición de los armadores pesqueros y procesadores argentinos a cualquier concesión de nuestra politica exterior que involucre al sector pesquero" "325. No obstante, la década del '90 mostrará una evolución con menores reparos respecto del aporte de capitales externos. Ya hemos visto cómo hacían mención al fomento de algún tipo de vínculo con terceros países. Según la visión de Lerena, para esta altura y luego del éxito de la participación de unas pocas empresas en los convenios Marco con la URSS y Bulgaria, se difundió entre los industriales la idea de no quedarse fuera de algún negocio semejante (Lerena, 2009). Entonces, la visión negativa de la apertura externa ya no era tan sólida como en el pasado, sobre todo cuando convertirse en socios de grandes empresas pesqueras extranjeras permitiría a los empresarios acceder a nueva tecnología y garantizarles acceso a los mercados europeos. ${ }^{326}$ Veamos entonces la situación a partir de la implementación del charteo y de los acuerdos con la Comunidad Económica Europea.

\footnotetext{
${ }^{324}$ L.C.,21/10/1993.

${ }^{325}$ L.C., $22 / 03 / 1989$

${ }^{326}$ Aunque mayoritaria, tal opinión no era unánime dentro de los industriales. Por ejemplo, directivos de la empresa Centauro S.A. daban a conocer un comunicado donde se preguntaban sobre "qué consecuencias tendrán los acuerdos firmados con la Comunidad Europea y si no serán los mismos futuros causales de despidos debido a la pérdida de mercados y a la sustitución de las plantas por la acción de los buques congeladores que comenzarán a operar”. L.C.,30/10/1993.
} 


\section{i. 1. El régimen de charteo}

Según afirma César Lerena, el proyecto posteriormente implementado como charteo nació de una idea suya para la explotación del calamar y otros recursos migratorios, buscando exclusivamente afectar la fuente de ingresos de los ingleses en Malvinas. Su iniciativa preveía el procesamiento del calamar en plantas en tierra y la adecuación de las flotas extranjeras al régimen impositivo y aduanero nacional. De nuevo, tal descripción coincidía con la aceptación de la pesca extranjera pero bajo la orientación determinada por un plan pesquero que no sólo pretendía fomentar el desarrollo de la pesca sino también cumplimentar ciertos objetivos geopolíticos en relación a la situación Argentina con las Islas Malvinas. Pero, para tristeza de quien se presenta como su ideólogo, el plan se transformó, en manos de Cavallo, en un simple método de captura contra pago de un canon sin obligación de procesar el pescado en tierra, lo cual fue aprovechado fundamentalmente por flotas asiáticas. De este modo, fracasó su objetivo en cuanto al desarrollo pesquero. Pero, además, tampoco alcanzó el propósito geopolítico de afectar la principal fuente de ingresos de los kelpers dado que para asegurar la disponibilidad de ese molusco en el área adyacente de Malvinas el volumen de captura finalmente se acordó con Gran Bretaña (Lerena, 2009). Fue en octubre de 1992 cuando el gobierno lanzó el nuevo régimen de captura del calamar, asumiendo el argumento de que se trababa de una estrategia para disputarle a los kelpers la supremacía comercial en la pesca de ese molusco. A través del decreto $\mathrm{N}^{\circ} 1.493$ se creó un registro de buques extranjeros que podían ser "charteados" por empresas constituidas en la Argentina. El secretario Regúnaga señaló en el momento del lanzamiento de la medida que los objetivos de la pesca nacional apuntaban a establecer acuerdos con la CEE y con Japón en la concesión de permisos y en el otorgamiento de franquicias para la incorporación de nuevas unidades de pesca. El charteo apuntaba a atraer a los buques japoneses, coreanos, taiwaneses y españoles que desde 1987 eran clientes de los kelpers, cuyos ingresos por la venta de licencias de pesca financiaban entonces hasta el 64\% del presupuesto de las Islas. El PEN esperaba contrastar esto con el ingreso de alrededor de 150 buques. ${ }^{327}$ Eran 56 proyectos, con 112 barcos implicados, los que se habían anotado en su lanzamiento en 1992. Pero tras negociaciones con Gran Bretaña, la Argentina decidió reducir el límite a 45 barcos. Al año siguiente se chartearon 61 buques, 73 en 1995 y 68 en 1996. Las principales empresas extranjeras que participaron eran japonesas, coreanas y taiwanesas. El proyecto contó con el apoyo de la mayoría de los empresarios marplatenses, quienes pronto se inscribieron para participar de sus beneficios. Recordemos que el mecanismo ligaba a empresas extranjeras con las nacionales. Unas ponían los buques y pescaban y las otras cedían los permisos y el pabellón nacional.

En 1993 la CAABPA señalaba como "muy positiva" la política pesquera instrumentada por las autoridades del área, destacando la posibilidad que brinda el charteo de buques como herramienta para acceder a un bien de capital para su explotación sin requerir el desembolso de cifras que el sector no podía costear. $^{328}$ De la primera convocatoria en 1992 participaron las empresas marplatenses Giorno (Alberto Valastro), Pedro Moscuzza e Hijos, Luis Solimeno, Frigorífico Mellino, Frigorífico Barilari, pero también otras como Romfioc donde tenía participación Francisco Romano de la Sociedad de Patrones de Pesca. Con todo, el protagonismo lo asumía nuevamente Guillermo Jacob, considerado el "Rey del Calamar". Dice la Revista Redes “...vuelve a sorprender el protagonismo alcanzado por el presidente de Bajamar. En 1986 fue también Guillermo Jacob la cabeza visible del acuerdo firmado con

${ }^{327}$ L.C.,13/10/1992.

${ }^{328}$ Revista Redes, № 67, año 1993, p. 46. 
la ex URSS, un episodio que, como el actual, exigió aceitados contactos políticos" ${ }^{329}$.Curiosamente, eran ahora las empresas pesqueras del sur del país las que hacían conocer su descontento con respecto al ingreso de barcos extranjeros alquilados por armadores argentinos, beneficiando y poniendo en pie de igualdad a las grandes y pequeñas empresas pesqueras. Ya en 1992 CAPECA y CAPIP se quejaban de que "la incorporación de 50 buques extranjeros deprimiría los precios del mercado; los cincuenta buques extranjeros no computarán el costo argentino y las divisas que recibirá el estado argentino serán inferiores al reembolso que deberá efectuar" (cit. en Lerena, 2009: 245).

Por su parte, Fernando Gutiérrez ("quien mucho tuvo que ver para iniciar esta operación") destacaba que "el charteo está consensuado con las mayorías de las empresas y pensamos que las cantidades de solicitudes que se han presentado no es el reflejo de las que se darán. Nosotros tenemos una política de conservación del recurso, en la cual se estimarán cuántos permisos de charteo se darán". Con respecto a la posición de CAPECA y CAPIC decía que "no refleja la posición que escucho de todos los armadores, puede haber -como en todo cambio-, intereses mayores de uno u otro sector. Pero creemos que tanto el acuerdo con la CEE como el charteo es beneficioso para todo el sector pesquero". $\mathrm{Y}$ dado que una de las principales quejas de los empresarios argentinos se refería a la competencia desleal, destacando que las empresas extranjeras no computarían "el costo argentino", Gutiérrez explicaba que "nosotros hemos comenzado un proceso de regulación durante todo el año, que nos ha llevado a bajar sistemáticamente el costo argentino. Creo que la pesca está incluida dentro del programa global de política económica del gobierno, la cual toda la puesta del plan nuestro es bajar esos costos".

En Mar del Plata, la medida incluso era reivindicada por los más pequeños de los industriales de la pesca, quienes también se anotaban en los beneficios del charteo. Al respecto, la Sociedad de Patrones Pescadores destacaba:

...los que no están de acuerdo son las grandes empresas porque sangran por la herida. Lo que hizo el subsecretario de Pesca es buscar una equidad entre los grandes y los chicos. Nosotros los marplatenses vemos al charteo como una cosa justa, por eso repudiamos totalmente las declaraciones de las empresas porque a la pesca costera nunca la toman en cuenta. Estas personas son las que se han beneficiado con las exenciones impositivas y los créditos sin invertir nunca nada en el país. ${ }^{330}$

Un año después de su implementación, Gutiérrez se refería al charteo señalando "fue un éxito de la politica pesquera argentina y un hecho geopolítico muy importante" señalando que en "el año "90 se pescaba 20.000 toneladas de calamar y ahora hemos pescado 200.000 toneladas este año". Aunque aclaraba que el sistema necesitaba ajustes, se mostraba partidario de extender los permisos de pesca a barcos extranjeros "a lo máximo que el recurso dé". 331

En cuanto a los gremios locales, sus posiciones fueron críticas de la fórmula de charteo, sobre todo a partir de que empezaron a visualizarse las consecuencias de su implementación. El arribo de buques de procedencia asiática no generó puestos de trabajo para las tripulaciones locales. Contra ello iban radicadas

\footnotetext{
${ }^{329}$ Revista Redes, N ${ }^{\circ} 65$, año 1992, p. 24 y 25 . Incluso la prensa se hacía eco de la presencia de este empresario y de, lo que a todas luces era polémico, la participación de empresas que habían pescado (y lo continuarían haciendo) en la zona de Malvinas bajo licencia inglesa. "De los 23 charteos elegidos, por lo menos 14 se concretaron de la mano de Guillermo Jacob, presidente de Bajamar, y tendrán como contrapartida poteros de la cooperativa KSJ que conduce el japonés Matsutomi” históricamente uno de los mayores operadores en la zona de Malvinas. L.C.,22/01/1993.

${ }^{330}$ L.C.,08/12/1992.

${ }^{331}$ L.C.,06/01/1994.
} 
las primeras denuncias. Entre ellas, se destacan las de los oficiales de pesca argentinos. Primero estaban quienes se quedaban sin trabajo. Juan José Velich, entonces secretario general de la Asociación Argentina de Capitanes y Patrones de Pesca decía "De un año a esta parte hay un avasallamiento total a la ley de navegación porque se habilitó masivamente como oficiales de pesca (patrones y maquinistas) a extranjeros pese a que existen muchos oficiales argentinos habilitados y en disponibilidad'. Respecto la pesca con extranjeros explicaba que "Por comentarios sabemos que habría presiones de Cancillería que por su politica exterior alienta a que se facilitan estas habilitaciones". Y advertía que:

...cuando se habilita a un extranjero como oficial de un buque argentino se le da autoridad argentina a bordo, que no debiera tenerla. Y es así que una vez en zona de pesca pueden comunicarse con sus connacionales que están fuera de las 200 millas, manejando todo el movimiento de nuestra flota pesquera y nuestra flota de seguridad. Es así que reiteradamente los buques extranjeros que están fuera de las 200 millas ingresan a pescar cuando son de la misma empresa de los barcos que están en el mar argentino gracias al charteo.

En relación a quienes sí obtenían trabajo, Velich denunciaba que debido a la integración de extranjeros en las tripulaciones, en especial asiáticos, "hay innumerables casos de insubordinación y de riesgo para la seguridad en el buque" porque aquellos marineros desconocen la autoridad de los oficiales argentinos arriba del barco con actos de "negligencia y temeridad" que repercuten en riesgos para la vida de todos los pescadores. ${ }^{332}$ Dos años después de implementado el sistema, el secretario general del SOMU, Domingo Novero, lo criticaba directamente. Decía que la fórmula del charteo "ha dejado 2.000 compañeros en la calle al no embarcar a ningún argentino". Y realizaba una cuenta "cada barco ha hecho una producción de casi 1.000 .000 de dólares, a cada empresa nacional le ha correspondido 180.000 dólares, sin crear nuevas fuentes de trabajo" dado "que a las empresas argentina se la da un reembolso del 18 por ciento". ${ }^{333}$ También Saravia, por el lado del SOIP, manifestaba su oposición. El argumento básico consistía en que mientras empresas extranjeras realizaban la pesca de un recurso de propiedad común, y empresas nacionales recibían una parte del "botín", ese incremento de capturas que tanto entusiasmaba a los funcionarios como Gutiérrez en nada beneficiaba a los trabajadores de las plantas en tierra. Por esta fecha, Saravia ya era el secretario general de la CGT local. Seguramente por su influjo, la entidad emitía un comunicado donde se mostraba "altamente contrariada" con el régimen de charteo de pesca que rige en nuestro país, ordenado por el decreto $\mathrm{N}^{\circ} 1493 / 92$, "herramienta legal que permite a barcos extranjeros pescar en aguas argentinas sin ocupar personal local, llevándose el recurso sumado a un inmenso capital sin procesar". La entidad graficaba que en 1993 ingresaron por ese régimen 45 barcos extranjeros pagando cada uno 120.000 dólares por tres años de permiso de pesca, totalizando una suma de USS 5.400 .000 por todo concepto. Valga comparar que por una temporada de pesca de calamar en la zona de las Islas Malvinas los "ingleses usurpadores" cobran U\$S 250.000 de canon. " $A$ raíz de esto, el país perdió en 199330 millones de dólares". Y como en 1994 entraron 72 barcos, las pérdidas por cobrar un canon menor que el aceptado en Malvinas ascendieron a los 50 millones de pesos. En 1995, calculaba la entidad obrera, esos índices serán mayores. Concluyendo:

\footnotetext{
${ }^{332}$ Los oficiales de pesca denunciaban agresiones físicas, la superación de los volúmenes de pesca permitidos que incluso podían provocar una vuelta de campana al barco, y otros conflictos graves cuando se trabaja en mar abierto, poniendo en riesgo la vida de los operarios. L.C.,19/06/1993.

${ }^{333}$ L.C., $13 / 08 / 1994$.
} 
...los extranjeros se llevaron productos sin elaborar por un valor en bruto de más de mil millones de pesos, dinero producto de nuestros mares que ni queda en la (sic) ni es reinvertido en el país. Todo este paquete genera pérdidas millonarias porque el Estado pagó y seguirá pagando para que se lleven el producto, el cual no paga impuestos en el país ni genera los empleos necesarios. ${ }^{334}$

De los pocos tripulantes que accedieron a trabajar en aquellos buques, muchos se encontraron con profundas diferencias culturales respecto de los marineros asiáticos. Estas desigualdades a veces asumían extremos dramáticos. En los diarios de la época, así como en declaraciones de dirigentes gremiales, es común encontrar denuncias de que en tales barcos se violaban sistemáticamente no sólo las condiciones de trabajo más elementales, sino también los derechos humanos. "La forma de trabajo es primitiva. Sin limpieza". En algunos barcos se mantiene a la gente en "estado de esclavitud" 335 . En relación con ello, la Cámara Federal de Mar del Plata dispuso la interdicción de salida y prohibición de navegar de varios buques pesqueros que fueron denunciados por violaciones a las condiciones de trabajo a bordo. ${ }^{336}$ Tiempo después, Pablo Ortié del SOMU entregó un informe de 709 hojas de antecedentes de malos tratos en ese tipo de buques. ${ }^{337}$ Otra denuncia recurrente residía en la sospecha de que, además de los buques extranjeros que pescaban con el permiso de charteo, existían otros buques que aprovechaban ese marco para realizar una pesca ilegal. En los periódicos aparecen menciones a supuestos buques "mellizos". Es decir, que se disfrazaba un buque ilegal por otro legal, sin que los controles pudieran detectarlos o diferenciar uno de otro. ${ }^{338}$ Con todo, hacia 1994 comenzaron los primeros síntomas acerca del impacto de esta política sobre la población de calamares. Y en mayo de aquel año, Felipe Solá se vio en la necesidad de establecer una veda para la pesca de calamar por el transcurso de 60 días. $^{339}$

Con todo, a pesar de que en palabras del subsecretario Fernando Gutiérrez, la crisis pesquera ya había pasado, la situación no era cómoda para las empresas pesqueras marplatenses y menos aún para los trabajadores del sector. Eso al menos expresaban los principales dirigentes de las organizaciones empresarias y sindicales. A poco de asumir Fernando Mellino la titularidad de la CAABPA, la entidad elaboró un documento de prensa en el cual se aludía a una coyuntura negativa para las empresas pesqueras. En primer lugar, mencionaba las "condiciones adversas" de los últimos años dadas fundamentalmente por dificultades externas. Se refería a la situación de un mercado foráneo con precios en baja y devaluaciones en Europa, con varias economías en recesión, lo cual afectaba notoriamente a la

\footnotetext{
${ }^{334}$ L.C., 23/04/1995.

${ }^{335}$ L.C., $19 / 06 / 1993$.

${ }^{336}$ Se trataba de los buques Man Sheng, Man Fu, Reyes del Mar, Depamas 51, Sincomar Uno, Marnovia II y Estrella II. L.C.,16/12/1993. El texto donde constaba la denuncia señalaba, entre otras cuestiones, que "Reseñan los testigos insuficiencia de comidas, media bolsa de arroz, una cucharada grande de caldo, cebolla frita y repollo, una cucharada grande de perro (en la cámara de frío constataron la presencia de doce perros congelados), todo ello hervido: los tripulantes extranjeros eran azotados con una caña de bambú, la que servía de bastón de mando; trabajan descalzos, el calamar era envasado en el piso laborando ellos 'en cuclillas', no tenían ropa adecuada para trabajar con 15 grados bajo cero...".

${ }^{337}$ L.C.,30/05/1995.

${ }^{338}$ L.C., 09/06/1994.

${ }^{339}$ L.C.,25/05/1994. Al respecto, Carlos Barboza del SICONARA expresaba con dureza "esto marca el comienzo de una demostración de que la pesca está en manos de una banda que ha regalado recursos". Afirmaba ello porque no podía comprender cómo se alentaban acuerdos internacionales mientras en paralelo se prohibía la pesca por peligro de sobre pesca. L.C.,26/05/1994. Por su parte, el biólogo Enrique Balech tampoco comprendía la situación al advertir que se "salta de un proyecto de superpesca a la prohibición total, demostrando una tremenda e imprudente improvisación que incluye la firma de compromisos internacionales". L.C.,29/05/1994. Por el contrario, sin advertir tal incongruencia tanto Felipe Solá, como la CAABPA y los Procesadores felicitaban la medida, argumentando que se tomaba bajo informes del INIDEP. L.C.,01/06/1994.
} 
demanda. En cuanto a los factores internos explicaba que la convertibilidad, con el tipo de cambio fijo, puso de manifiesto una serie de ineficiencias "algunas originadas en la propia organización empresaria y otras que vienen dadas por la inadecuada legislación laboral, el altísimo impuesto al trabajo... ", 340 así como la desalentadora tributación sobre los ingresos brutos, sobre los activos productivos y sobre la energía eléctrica aplicada a la producción. No obstante, a pesar de la coyuntura compleja, Mellino se mostraba no solo optimista sino también altamente satisfecho por la gestión de Gutiérrez.

Estamos convencidos [...] que la sana comprensión encontrada en el señor Fernando Gutiérrez [...] alienta a los empresarios del sector pesquero marplatense a seguir bregando por la producción y apostando al engrandecimiento de las empresas, vía nuevas inversiones en modernización y tecnificación de las unidades productivas. ${ }^{341}$

Parte de ese optimismo y apoyo se basaba en la participación de las empresas más importantes que integraban la CAABPA en las negociaciones por los acuerdos con la CEE y las posibilidades que ellos brindaban. Interesaba particularmente a los industriales conseguir una rebaja de aranceles de importación por parte de la Comunidad para los productos argentinos (que los llevarían del 15\% al 5\%), así como también la posibilidad de renovar unidades productivas. Asimismo, en el año 1993 se llevó adelante el Pacto Fiscal (a partir del decreto $\mathrm{N}^{\circ} 2609$ ) mediante el cual se redujeron los aportes patronales que debían abonar los industriales pesqueros. Atendiendo al insistente reclamo de la desproporción de los costos internos, en particular lo que llamaban "impuesto al trabajo", el gobierno promovió un descuento de los aportes previsionales que alcanzaban una reducción del $40 \%$ para el sector bonaerense y del $80 \%$ para el sector patagónico. ${ }^{342}$

Por el lado de los dirigentes sindicales, la coyuntura se presentaba en términos más crudos. Juan Domingo Novero explicaba que "La actividad pesquera está padeciendo momentos dramáticos". A diferencia de los empresarios, el secretario general del SOMU local indicaba "el absoluto rechazo" a la política que en materia pesquera llevaba adelante el gobierno nacional, cuyos coletazos han generado una desocupación que actualmente ronda el $80 \%$. La principal causa de esa situación radicaba para el dirigente "en el dólar que ha quedado quieto, mientras los insumos, desde el plan de convertibilidad hasta ahora, han aumentado un 60 por ciento". Explicaba que el sector industrial estaba trabajando a pérdida por la caída de los precios internacionales, por lo que las exportaciones eran mínimas y tenían una menor rentabilidad. Y se quejaba porque "los únicos costos que aqui se han bajado son los laborales". La solución que veía Novero no salía de apoyos fiscales a los mismos empresarios. Sostenía como necesario "que se le dé mayores reembolsos a las empresas, para que puedan así paliar esta crítica situación ante el parate del dólar". Además, explicaba la dificultad en que se encontraba la conducción sindical para exigir mejoras laborales, señalando que lograr un convenio colectivo de trabajo "no está alejado del pensamiento gremial” pero, así y todo, interrogaba “¿Cómo podemos sentarnos a dialogar con ellos [los empresarios] si están fundidos? ¿Para qué nos vamos a sentar a pedirles? Es una realidad. Si en este

\footnotetext{
${ }^{340}$ Revista Redes, $\mathrm{N}^{\circ}$ 70, año 1993. "Mellino y su evaluación de la coyuntura”, p. 6. La negrita es nuestra. Participaba de la opinión el propio Gutiérrez que declaró "la pesca es una actividad intensiva en la que las cargas tienen gran impacto en los costos y creemos que la reforma laboral será una buena salida para la disminución de estos costos". L.C.,21/07/1993.

${ }^{341}$ Revista Redes, $\mathrm{N}^{\circ} 70$, Ibídem...

${ }^{342}$ Por supuesto esa "discriminación” entre Buenos Aires y la Patagonia fue cuestionada por la CAABPA.Revista Redes $\mathrm{N}^{\circ} 76$, año 1994.
} 
momento pedimos aumento se funden las pocas que quedan, o quiebran, o se van". ${ }^{343}$ También Abdul Saravia expresaba su preocupación. Durante el plenario nacional de secretarios generales regionales de la CGT, el dirigente denunció la desocupación existente en Mar del Plata, la cual en buena medida se originaba en la pesca, y al mismo tiempo, cuestionó la formación reciente de lo que consideraba cooperativas "truchas" que "han sido inventadas por los empresarios para afectar los derechos de los trabajadores de la pesca, vigilancia, del campo y de la maestranza, entre otros sectores" ${ }^{344}$. Sobre la situación de la pesca explicó las dificultades derivadas de la desregulación marítima-portuaria, además de los perjuicios que para el personal en tierra provocaron el charteo y los Acuerdos Marco. En Mar del Plata, los dirigentes de la CGT elaboraron un comunicado con las conclusiones del plenario de secretarios generales sobre la situación económica general. Allí reprocharon el modelo económico que "hasta ahora no ha logrado definir los perfiles industriales de un país moderno". Expresaban, en un texto que enunciaba la tensión entre el Saravia "menemista" y sus ideas respecto del desarrollo del país, que "El verdadero rostro de la crisis nacional no es financiero, sino productivo: este modelo económico no genera recursos genuinos para hacer frente a las obligaciones de una deuda, externa e interna, que, pese a todos los sacrificios, no ha cesado de aumentar". Y finalizaba diciendo que "se torna absolutamente inaceptable el traslado del aumento del IVA al costo de una canasta familiar que ya resulta inalcanzable para el bolsillo del trabajador" 345 .

\section{i.2. El Acuerdo con la Comunidad Económica Europea}

La firma de los acuerdos con la CEE constituye un punto central de la política pesquera bajo la administración Menem. Ya hemos hecho referencia sobre algunas de sus características en el capítulo I. Pero aún no nos hemos detenido en el proceso mediante el cual se rubricó y se llevó a cabo. Para empezar, recordemos que a fines de la década del '80 la flota congeladora española había perdido definitivamente los caladeros históricos donde sustentaba su explotación (Pradas, 2006). Por ello se encontraba con una flota propia ampliamente sobredimensionada. Ya en 1991 la Revista española Alimarket realizaba un informe en el que hablaba de los congeladores españoles como "Una flota sin destino". ${ }^{346}$ Muchas empresas estaban fuertemente endeudadas y no tenían dónde ir a pescar. ${ }^{347}$ Esa situación, que estallaba en la frente de la Comunidad Europea, motivó la decisión de implementar una serie de subvenciones para "atacar la lenta agonía del sector pesquero congelador"348. En 1989 Ramón

\footnotetext{
${ }^{343}$ L.C., 13/08/1994.

${ }^{344}$ Desarrollamos en el siguiente capítulo la problemática de la formación de "pseudo" cooperativas.

${ }^{345}$ L.C., 07/04/1995.

${ }^{346}$ Revista Redes, № 58, año 1991. "Una flota sin destino", p. 15.

${ }^{347}$ En la opinión del senador por la UCR Solari Yrigoyen "Fue entonces que la Comunidad Económica Europea tuvo que salir en auxilio de la flota española. En primer lugar, aprobó un plan de subsidios para los barcos de esa nacionalidad, diez de los cuales fueron beneficiarios de algunas iniciativas concretas. Se trataba de barcos desactivados por falta de países ribereños que permitieran la pesca. Pero el subsidio de la Comunidad Económica Europea no bastó. Fue así que hubo que buscar nuevas formas de auxilio, sobre todo porque existió una gran presión por parte de los banqueros. Esos barcos inactivos en los puertos españoles debieron ser hipotecados o prendados a efectos de su mantenimiento;y precisamente los impulsores de este acuerdo entre la Comunidad Económica Europea y la Argentina -nadie puede negarlo- han sido los banqueros [...] El endeudamiento del sector pesquero español con sus acreedores es tan grande que ha puesto en riesgo al área financiera de esa nación. Armadores españoles deben a los banqueros unos treinta mil millones de pesetas. Mediante el acuerdo firmado con la Argentina, gran parte de los créditos que se conceden será destinada al pago de hipotecas (Solari Yrigoyen, 1994: 22 y 23). La negrita nos pertenece.

${ }^{348}$ Revista Redes, № $58 \ldots$ Ibídem.
} 
de Miguel, representante de la Dirección de Pesca de la CEE, viajó a la Argentina, Chile y Uruguay con la misión de colocar la flota pesquera comunitaria que se encontraba paralizada. Y a fines de 1990 será el presidente de la Xunta de Galicia y líder del Partido Popular, Manuel Fraga Iribarne, quien arribe al país con el objetivo de analizar la factibilidad de constituir empresas pesqueras mixtas para la explotación de las riquezas ictícolas en el litoral marítimo del Atlántico Sur. ${ }^{349}$ Previamente, las potencias pesqueras que pescaban en caladeros de terceros países pagaban un canon como contraparte de la obtención de licencias. Pero dicho mecanismo había caído en descrédito en los países que tenían caladeros en condiciones de ser explotados, los cuales comenzaron a exigir inversiones directas y asociaciones con capitales propios. De ahí que la CEE buscó subvencionar la formación de sociedades mixtas con terceros países y, como segunda opción, la exportación definitiva de buques o simplemente su desguace. Finalmente invertirá alrededor de 230 millones de dólares para deshacerse de su flota, y de paso, acceder a nuevos caladeros de pesca. Alimarket sentenciaba "La Comunidad, por fin, parece haberse quitado de encima un 'pequeño' problema con sólo rascarse el bolsillo"350.

Por otro lado, estaban los países como Argentina que aún contaban con caladeros cuya capacidad permitía su explotación. Desde mediados de la década del ' 80 se buscaba en nuestro país alcanzar un convenio pesquero con la CEE. Durante el gobierno radical, antes que los propios acuerdos con la URSS y Bulgaria, la subsecretaría de Pesca y la Cancillería (cuyos funcionarios eran Luis Jaimes y Dante Caputo respectivamente) pensaban acordar con algún país miembro de la CEE. ${ }^{351}$ Poco después, ya durante el gobierno justicialista, tanto en 1989 como en 1990 crecía en el horizonte la posibilidad de "abrir" el Mar Argentino permitiendo la pesca de buques extranjeros. Recordemos que la discusión consistía, más que hacerlo o no hacerlo, en cómo llevar a cabo esa posibilidad. En aquel entonces, el propio Luis Otero viajó a España para promover un acuerdo. ${ }^{352} \mathrm{Y}$ en junio de 1992 fue Manuel Arnal, representante pesquero de la CEE, apodado el "Sr. Pesca", quien realizó una visita a la Argentina buscando alguna fórmula de acuerdo que permitiera a sus barcos operar en el Mar Argentino. Sabiendo que cualquier entendimiento generaría resistencias locales, Arnal se sintió en la necesidad de garantizar que los stocks de pescado no sufrirían daño alguno:

...los europeos no propondríamos nunca un acuerdo en el que el gobierno argentino saliese perdiendo, nunca lo ha hecho la Comunidad y menos con la Argentina. Buscamos un acuerdo en el que las dos partes salgan ganando. Creo que el equilibrio es posible, si la Argentina cede algo y la Comunidad también cede algo. ${ }^{353}$

Finalmente el acuerdo se concretó en Bruselas en 1992, durante la gestión de Fernando Gutiérrez como titular de pesca y de Guido Di Tella en Cancillería. El Parlamento europeo lo aprobó en junio de

\footnotetext{
${ }^{349}$ L.C.,26/11/1990.

${ }^{350}$ Revista Redes, $\mathrm{N}^{\circ} 58 \ldots$ Ibídem, p. 18.

${ }^{351}$ Luis Jaimes había expresado "España fue uno de los primeros países a los cuales nosotros convocamos para firmar un convenio pesquero en el año 1985". Revista Industria Pesquera, 1986. Cit. en Lerena (2009). Fue el conflicto por Malvinas el que impidió llegar a un acuerdo. Por eso fueron países no vinculados a la CEE, como la URSS y Bulgaria, los que respondieron a la convocatoria argentina.

${ }^{352}$ Previamente, Domingo Cavallo firmó en 1991 un “Acuerdo para la Promoción y la Protección Recíproca de Inversiones" entre Argentina y España. En el mes de mayo de 1992, Cavallo viajó a España para participar de un seminario sobre privatizaciones y oportunidades de inversión en la Argentina. Desde Madrid, el Ministro señaló que deseaba que España "invierta e incremente sus relaciones económicas con la Argentina". L.C.,04/05/1992.

${ }^{353}$ L.C., 28/06/1992.
} 
1993 y el Consejo de la Unión Europea lo adoptó, con la abstención de Inglaterra, en septiembre de aquel año. En este mismo año finalizó el convenio de Argentina con la URSS. Y en abril de 1994 por Ley del Congreso Nacional Argentino $\mathrm{N}^{\circ} 24.315$ fue aprobado y promulgado en el mes de mayo el Acuerdo Pesquero. ${ }^{354}$ En palabras del Felipe Solá el acuerdo permitiría democratizar el mar, al tiempo que debía considerarse como una de las victorias diplomáticas más resonantes de la Argentina en los últimos años (Solari Yrigoyen, 1994).

Ya hemos visto cuáles fueron sus consecuencias en relación al incremento del esfuerzo pesquero, así como su incidencia en la trasformación de la estructura de los grupos empresarios de la pesca (capítulo I). Digamos ahora que el acuerdo declaraba, entre sus objetivos, "desarrollar una cooperación económica más estrecha en el sector de la pesca maritima" con el objeto de proveer "un acceso estable a nuevas posibilidades de pesca" para la flota europea, contribuir "al objetivo de la renovación y reconversión de la flota argentina y la reestructuración de las flotas de la Comunidad" y promover "la explotación racional de los recursos de largo plazo" ${ }^{\text {"35. }}$. Y preveía la promoción de tres tipos de vínculo entre empresas nacionales y extranjeras: 1) sociedades mixtas, ${ }^{356}$ 2) radicación de empresas ${ }^{357}$ y, 3) constitución de asociaciones temporales ${ }^{358}$. De los tres tipos de vínculos, sólo se produjeron las variantes uno y tres. Como señalamos en el capítulo I, el eje fue el intercambio de materia prima por la posibilidad de renovación de la flota pesquera. Desde la perspectiva de la Comunidad el entendimiento era especialmente positivo dado que, de un modo u otro, debían deshacerse de sus buques. El vínculo también arrojaba beneficios para las empresas nacionales que participaron en él. ${ }^{359}$ Seguramente por ello, en marzo de 1993 viajó a Vigo una nutrida delegación de empresarios pesqueros acompañando a Fernando Gutiérrez, buscando posicionarse ante la firma del acuerdo. Espoz Espoz se refiere a esos hechos como un "idilio primaveral" entre armadores locales y españoles. ${ }^{360}$

\footnotetext{
${ }^{354}$ En comisión el acuerdo fue aprobado con el voto de 13 justicialistas y el ucedeísta José María Ibarbia, con la oposición del radicalismo, el MODIN (que encabezaba Aldo Rico) y el Partido Intransigente. El senador Solari Yrigoyen expresó "de las cláusulas positivas y negativas del acuerdo, desgraciadamente llegamos a la conclusión que las negativas son muy superiores a las positivas, lo que nos lleva a aconsejar el rechazo". L.C.,12/12/1994. Yrigoyen, en nombre de la UCR, veía posible un acuerdo con la CEE pero rechazaba los términos de éste acuerdo en particular pues consideraba que las ventajas que anunciaban los funcionarios estatales respecto del mismo eran solamente "una fantasía" (Solari Yrigoyen, 1993).

${ }^{355}$ Ley N ${ }^{\circ} 24.315$ en Revista Tratados N 41, año X, Fundación Atlántica, 1994, p. 8 a 21.

356 "Por sociedad mixta se entiende una sociedad de derecho privado constituida por uno o varios armadores comunitarios y una o más personas físicas o jurídicas argentinas, vinculadas por un contrato de sociedad mixta con el fin de explotar y en su caso transformar los recursos pesqueros argentinos dentro de una perspectiva de un abastecimiento prioritario del mercado de la Comunidad". Ley $\mathrm{N}^{\circ} 24.315$, art. 2, inciso E.

357 "Por radicación de empresas se entiende una sociedad de derechos privados constituida en la Argentina cuyo capital sea originario de uno o más Estados Miembros de la Comunidad y cuyo objeto social sea el de explotar y en su caso transformarlos recursos pesqueros argentinos en la perspectiva de un abastecimiento prioritario del mercado de la Comunidad". Ley $\mathrm{N}^{\circ} 24.315$, art. 2, inciso F.

358 "Por asociación temporal de empresas se entiende la relación contractual durante un período limitado, entre armadores de uno o más Estados Miembros de la Comunidad y armadores de la Argentina con el fin de explotar y aprovechar conjuntamente los recursos pesqueros argentinos de uno o más buques comunitarios, dentro de una perspectiva de abastecimiento prioritario del mercado de la Comunidad". Ley $\mathrm{N}^{\circ} 24.315$, art. 2, inciso B.

${ }^{359}$ Lerena, que en todo su libro jamás responsabiliza a los empresarios pesqueros por las políticas cuestionables en las que participaban, señala que "la ocasión hace al ladrón" dado que el sector empresario estaba exportando a pérdida los últimos dos años con un bajo precio internacional para los productos pesqueros. Además, sus buques pesqueros estaban vetustos, mientras que a los españoles les “sobraban” buques de gran porte (Lerena, 2009).

${ }^{360}$ Espoz Espoz, Milcíadez, Revista Tratados N 41, año X, Fundación Atlántica, 1994, p. 6. Acompañaron a Gutiérrez, Enrique Díaz (FIPA), Alberto Valastro (CAABPA), Néstor Sánchez Real (CAPECA), Carlos Dominé (Cámara de Procesadores) y una delegación que entre otros incluyó a Fernando Mellino, Oscar Salerno, Alfredo Pott, Antonio Di Leva, Franco Barilari y Antonio Solimeno. Revista Redes $\mathrm{N}^{\circ}$ 68, año 1993.
} 
Analizando mínimamente sus rasgos, podemos señalar que el acuerdo demostraba cómo la Argentina se vinculaba con "El Primer Mundo" durante la década del '90. César Lerena (2009) menciona que previo a este acuerdo existió uno de similares características firmado por la Comunidad con la República de Gambia. Éste se ejecutó "bajo la soberanía o jurisdicción de la República Africana de Gambia" según el texto del entendimiento. Llamativamente, en el acuerdo firmado con Argentina se omitieron las palabras soberanía y jurisdicción y sólo se fundó en "los principios, normas y modalidades de cooperación, en lo referente a la conservación, explotación y la transformación de los recursos pesqueros". La ausencia de aquellos conceptos se habría debido a las presiones inglesas para limitar la soberanía y jurisdicción Argentina. El acuerdo, fundamentalmente extractivo, entre sus aspectos más controvertidos mostraba la intención de evitar toda interferencia en la pesca de los ingleses y las licencias que ellos otorgaban en Malvinas y espacios marítimos circundantes. Además, el artículo 9 obligaba a la Argentina, en el caso de tener que adoptar medidas de conservación que afectaren las actividades pesqueras de los buques que faenaban en virtud del acuerdo, a consultar a las partes y aplicar cualquier decisión a toda la flota nacional, no pudiendo discriminar a los buques extranjeros. Por último, hay que destacar cuál era el país con el que se acordaba. España era una de las principales potencias pesqueras que tenía antecedentes en la depredación de otros mares. Con sus caladeros sobrepescados, los hispanos contaban con una poderosa flota congeladora que debía buscar recursos en aguas lejanas. Esa situación la llevó incluso a pescar al borde de las 200 millas de los mares de otros países, provocando una gran tensión con un conjunto de naciones, principalmente Canadá, que promovían una legislación que protegía los recursos migratorios. Es decir, que los recursos que nacían en el mar de un país determinado siguieran perteneciendo a la misma nación aunque traspasaran las 200 millas. ${ }^{361}$ Entre los países que sostenían esta posición se encontraba el gobierno argentino. Hacia el año 1995, y cuando los índices de sobre explotación eran cada vez más notorios, la Argentina retomó la idea de extender sus aguas jurisdiccionales dada la pesca intensiva que se realizaba muy cerca de las 200 millas. A esto se opuso fervientemente España, pues numerosos buques españoles se encontraban operando en esa zona. ${ }^{362} \mathrm{Sin}$ embargo, el acuerdo no hacía mención a esta situación que implicaba una diferencia muy profunda en cuanto a derecho internacional se refiere. De hecho, en la visión del vicecanciller Fernando Petrella, la relación con la Unión Europea favorecía “acelerar la inserción de Argentina en el mundo, en particular

\footnotetext{
${ }^{361}$ La CONVEMAR definió el territorio de las ZEE dentro de las 200 millas como propio de cada país ribereño. El problema se origina con los recursos migratorios que nacen dentro de esa zona, pero que migran por fuera de ella. Estos son los que permiten a las potencias pesqueras, que cuentan precisamente por ello (y por haber agotado sus propios caladeros) con flotas que pescan a grandes distancias, permanecer en el límite de las 200 millas y pescar esos recursos transzonales. Esta situación motivó que un conjunto de países entre los que se cuenta Argentina y Canadá buscaran prohibir la pesca de esos recursos por terceros países. No hace falta aclarar que las potencias pesqueras se opusieron fervientemente. Entre ellas, España, Japón y la Unión Soviética. Canadá pertenecía al grupo de países que conformaba la Conferencia Internacional sobre especies pesqueras transzonales y altamente migratorias, cuya presidencia mantenía la nación de Fidji. Por otra parte, el conflicto entre Canadá y España se llamó la guerra del fletan negro y se estuvo cerca de un conflicto armado cuando buques canadienses, tras múltiples advertencias, traspasaron sus 200 millas, cortaron redes y apresaron a los barcos españoles que se encontraban pescando.

${ }^{362}$ L.C.,05/05/1995. El Ministro de asuntos exteriores español, Javier Solana, declaró que las pretensiones argentinas plantearían "problemas serios" a su país y "por eso tenemos que luchar para que esa decisión no se lleve a cabo". Explico que "de cada diez toneladas que pesca [España], desgraciadamente, sólo puede pescar en sus aguas unas dos toneladas, por lo tanto tenemos que pescar las restantes ocho toneladas fuera de nuestro territorio [...] Esto quiere decir que tenemos un problema muy importante para mantener los niveles de captura de pesca y tenemos que tener unas buenas relaciones internacionales, porque hay otros países que nos tienen que permitir, mediante acuerdos, pescar en sus aguas". También se mostraron muy preocupados los armadores españoles de Vigo. Reinaldo Iglesias, gerente adjunto de la Cooperativa de Armadores de Vigo, la más importante de España, declaró que de prosperar la pretensión argentina "la situación de nuestros congeladores sería más que preocupante, ya que en estos momentos faenan en aquellas aguas entre 50 y 60 congeladores gallegos".
} 
con Europa, mejorando la exportación del pescado" 363 .La consecución del acuerdo fue favorecida, en primer lugar, por la ocupación de la Subsecretaría de Pesca en manos de uno de los hombres de Cavallo, Fernando Gutiérrez, quien participó desde 1989 en negociaciones con Inglaterra por la pesca en la zona de Malvinas. En 1992 este funcionario declaraba el valor positivo de los acuerdos señalando que:

...van a beneficiar a toda la pesca en general y tendrán una incidencia mayor porque prevén una renovación de flota y rebajas arancelarias para los productos con valor agregado, lo que va a dar trabajo intensivo en las plantas basadas en tierra. Tenemos esperanzas de que nuestros productos pesqueros sean competitivos, para lo cual hay que reducir los aranceles. ${ }^{364}$

Además, la desregulación del mismo año estableció la libre contratación de puertos y buques, y con ello, la libre elección de banderas de conveniencia. Al mismo tiempo, se anuló la proporción de $75 \%$ de tripulación argentina para la pesca en aguas nacionales, con lo cual los buques españoles podían traer sus propios trabajadores. Para Lerena (2009) las razones del acuerdo se encontraban más en la búsqueda por mejorar las relaciones con Inglaterra, y con ella con las de toda la Comunidad, que en razones pesqueras. Pues los acuerdos abrían las puertas de un posible tratado de cooperación entre el gobierno argentino y la Comunidad. En la visión del veterinario, desde el punto de vista del desarrollo pesquero, era inadmisible un acuerdo con la Unión Europea. En primer lugar, porque los países que integraban la unión se caracterizaban por depredar mares y la flota española participaba del grupo de naciones que pescaban clandestinamente en aguas argentinas. ${ }^{365}$ En segundo lugar, desde un punto de vista soberano y geopolítico, porque en el proyecto de constitución de la unidad europea se incluía como espacio propio a las Islas Malvinas y la Antártida. De hecho, en 1993 la CEE aprobó un proyecto conjunto de Portugal con las Malvinas, lo cual significaba darle el reconocimiento de "tercer país" a las Islas, desinteresándose de la disputa territorial existente entre la Argentina e Inglaterra. Además, tampoco podía descuidarse que España fue una de las principales potencias pesqueras opositoras a las pretensiones Argentinas que, con otro conjunto de países, solicitaba una legislación especial para las especies migratorias.

Más allá de cualquier consideración, la bibliografía existente sobre el tema coincide en señalar que casi ninguno de los objetivos propuestos inicialmente en los considerandos del acuerdo se cumplieron (Godelman et al, 1999; Rodríguez et al, 1999; Pradas, 2006; Lerena, 2009). Particularmente, en gran medida la responsabilidad de la sobre explotación de los recursos del mar argentino se debió a la incorporación que se registró por esta vía de buques con capacidad de pesca (HP) mucho mayor a las previamente existentes. ${ }^{366}$ Con estos autores coincide el texto de denuncia del acuerdo, presentado por senadores nacionales, mediante el cual finalmente se terminó el vínculo con la CEE en 1999. ${ }^{367}$

En cuanto a los apoyos y críticas al interior del sector pesquero, la CAABPA en 1989 advertía al Subsecretario de Pesca que cualquier tratado con España no debía incluir merluza o langostino (dos de las

\footnotetext{
${ }^{363}$ L.C., $13 / 05 / 1995$.

${ }^{364}$ L.C.,13/10/1992.

${ }^{365} \mathrm{La}$ FAO calculaba que la pesca clandestina de la flota española en aguas argentinas rondaba las 100 mil toneladas por año (Lerena, 2009). El acuerdo ni siquiera puso límites a todos los buques españoles que siguieron pescando en el área adyacente de la ZEE Argentina y alrededor de Malvinas.

${ }^{366}$ El mismo año de aplicación del acuerdo, 1994, Milcíadez Espoz Espoz se preguntaba “¿soportaran los recursos los incrementos de capturas?". Revista Tratados, № 41, año X, Fundación Atlántica, 1994, p. 7.

${ }^{367}$ Oscar Fortunato piensa plenamente diferente. Según él más que una sobre pesca lo que hubo fue un cambio en el frente de desove de los peces, mientras que el acuerdo fue positivo en la medida que permitió incorporar tecnología. Entrevista del autor con Oscar Fortunato... op. cit.
} 
especies finalmente más afectadas) y no debía otorgar licencias de pesca, sino promover inversiones efectivas en buques y plantas procesadoras en tierra. Sin embargo, uno de los impulsores españoles del acuerdo, Manuel Arnal (el "Sr. Pesca"), se encargó de explicar que el acuerdo no incrementaría el volumen de pesca sino que se procedería a una sustitución de flota y que no se otorgarían nuevas licencias. Con ese panorama ya para 1992 las entidades empresarias veían con mejores ojos un acuerdo siempre que implicara una cooperación más real entre empresas de uno y otro país. ${ }^{368}$ Es curioso que la CAABPA hacia 1994 continuara pidiendo por una política pesquera que ampliara los horizontes de la industria pesquera que procesaba en tierra. En ese marco reclamaba que se reorientaran los reembolsos a las exportaciones hacia la elaboración de productos en tierra en lugar de una discriminación geográfica. Ante esa situación es interesante un diálogo que reproduce la Revista Redes:

R.R.: Aunque legítimo, el argumento no deja de ser curioso porque el acuerdo con la Unión Europea, por ejemplo, se orienta en la dirección inversa...

Antonio Di Leva: No se sorprenda. Si hay armadores marplatenses interesados en algún barco congelador, es por exigencias de la coyuntura antes que por vocación industrial. ${ }^{369}$

Así es como por "exigencias de la coyuntura" la CAABPA dio su aval y participó de los acuerdos. ${ }^{370}$ Sin esos reparos hacia los buques congeladores, y luego de una oposición inicial sobre todo a la entrega de licencias de pesca, finalmente la CAPECA también apoyo su firma. Lo mismo hizo la Cámara Argentina de Industriales de Pescado. ${ }^{371}$

Por el contrario todos los sindicatos del sector pesquero manifestaron su oposición. Respondiendo a declaraciones de Gutiérrez tendientes a publicitar el acuerdo ${ }^{372}$ el SOMU, SICONARA, SUPA, SOIP, SAON, Patrones de Pesca Fluvial y Capitanes y Patrones de Pesca se declararon en estado de alerta, sumando una señal más de preocupación después de la desregulación. En un documento con las firmas de esas entidades sindicales se destaca que los comentarios vertidos por el:

...subsecretario de Pesca de la Nación, nos llevan a denunciar que el otorgamiento indiscriminado de permisos para que operen buques de bandera extranjera en aguas jurisdiccionales argentinas constituye un acto de entrega del patrimonio y soberanía nacionales, al permitirse la extracción del recurso ictícola sin límites ni control, lo cual constituirá una depredación que provocará la desocupación de 50.000 trabajadores de Mar del Plata que dependen de la actividad pesquera, con

\footnotetext{
${ }^{368}$ L.C., 22/08/1992.

${ }^{369}$ Revista Redes, № 76, año 1994, p. 18.

${ }^{370}$ Veinte años atrás, en julio de 1974, la CAABPA emitía un documento en relación al convenio pesquero que desde el Ministerio de Economía se buscaba implementar con Polonia. En aquel contexto, la entidad empresaria entendía que las sociedades mixtas con empresas polacas eran un "virtual quinta columna" destinada a sabotear el esfuerzo pesquero de la industria nacional. Pero los tiempos habían cambiado, como también la economía internacional y la propia estructura de las empresas pesqueras, por lo que ya no había más lugar para estas expresiones de nacionalismo económico. CAABPA: “Convenio Pesquero con Polonia. Observaciones” en Archivo DIPPBA, Mesa B, Factor gremial, Carpeta 57, Legajo 33, Folio 165, $15 / 07 / 1974$.

${ }^{371}$ L.C.,11/11/1993. La entidad representaba al sector de conserva y salado y se mostraba favorable al acuerdo porque "en virtud de éste, ya se ha realizado una ampliación del cupo para el ingreso de nuestros productos, y una importante rebaja de aranceles comunitarios".

${ }^{372}$ L.C., 25/06/1992.
} 
incidencia a todo el grupo familiar (250.000 personas) y con efecto inmediato en el resto del quehacer económico de la ciudad. ${ }^{373}$

Con ironía, concluían trasmitiendo alarma: "A corto plazo tendremos una nueva atracción turística para mostrar: el puerto fantasma de la ciudad de Mar del Plata". Por ello realizaban un llamado a "las fuerzas vivas de la comunidad marplatense" para organizarse en la defensa de la actividad local. Más tarde, los gremios marítimos preocupados por la creciente desocupación que vivían los trabajadores expresaran que la Subsecretaría de Pesca "propicia la entrega del recurso ictícola a intereses extranjeros" a través de los permisos otorgados para la pesca del calamar a "gran cantidad de buques (poteros) con personal extranjero". Tal situación se ve agravada por los anuncios de convenios con la CEE, dado que "Después de escuchar por largo tiempo de los investigadores, que nuestros recursos están al borde del agotamiento, hoy nos enteramos que sobran ciento veinte mil toneladas anuales [de merluza] para regalar". ${ }^{374} \mathrm{Y}$ también desde el área de pesca de la provincia de Buenos Aires, Carlos Brown se mostró contrario al acuerdo. ${ }^{375}$

En marzo de 1993 la situación ameritaba que La Capital agrupara una serie de notas sobre pesca bajo el título "Crisis en la Pesca". Allí, entre otros, Carlos Barboza transmitía la claridad que tenían los gremios respecto de los acuerdos con la CEE. Después de asegurar que tras el decreto $\mathrm{N}^{\circ} 817$ se sucederían una serie de conflictos seguros en la pesca marplatense, anunciaba que "Los acuerdos favorecerán a las empresas quebradas españolas que al poder acceder a nuestros caladeros, garantizarán los subsidios que otorgue la Comunidad para su recuperación. Es decir, vamos a pagar con nuestros recursos ictícolas y fuentes de trabajo las falencias europeas, como asi sus proyectos hegemónicos" ${ }^{376}$. También la CGT local y el SOMU renovaran sus críticas del decreto $\mathrm{N}^{\circ} 817$. Dirigentes de este último gremio denunciaron que la "política de pesca que se está llevando adelante no es negocio para el país, sino para los funcionarios". Y además especificaron que de los acuerdos participarían sectores acotados de la pesca, pues “...van a venir 50 barcos y acá son más o menos 7 empresas grandes, con 35 barcos, que van a monopolizar todo; el resto de la flota no va a tener acuerdo con la comunidad". $\mathrm{Y}$ se preguntaban “ ¿Son nuestro principal cliente y los dejan que vengan a buscar ellos mismos el pescado, con su gente y sus barcos?”. Luego, representantes de gremios marítimos se reunieron en la CGT y decidieron solicitar en forma inmediata audiencias con el intendente municipal, con el obispo diocesano, con la secretaría de Trabajo, local y nacional, además de otros organismos para manifestar la "preocupación existente por la ocupación de tripulantes extranjeros en lugar de argentinos en los barcos que pescan en nuestro mar" ${ }^{377}$. Poco después el diario La Capital titulaba una nota "Preocupación obrera

\footnotetext{
${ }^{373}$ L.C.,27/06/1992. Poco después, el Centro de Patrones de Pesca Fluviales y de Cabotaje Marítimo de Mar del Plata señalaba "teniendo en cuenta que hay tanta gente sin trabajo en nuestro país, nos preguntamos si es justo que extranjeros que no hablan nuestro idioma ocupen esos puestos”. L.C.,15/01/1993.

${ }^{374}$ L.C.,24/02/1993.

${ }^{375}$ L.C.,28/11/1993. Brown expresó “La provincia no conoce esos acuerdos y no ha participado en su celebración”, aclarando que "Hemos detectado una afectación de la pesca y de lo relacionada con ella, especialmente en Mar del Plata, ya que el tipo de permisos que se otorgan va en contra del sector naviero, de los que actualmente tienen permisos de pesca y fundamentalmente de la industria, porque los buques que van a operar a partir de la firma de los acuerdos, son buques-factoría. Y se han otorgado a barcos de la CE permisos para la pesca de merluza que les están negados a los barcos argentinos, con el agravante de que no sólo se perjudica la pesca sino también la industria astillera [...] Por eso vemos que el convenio no beneficia a nuestro territorio, y en esto tenemos el acompañamiento de la CGT y gremios vinculados a la actividad pesquera en Mar del Plata, como también de las cámaras empresarias, lo que nos fortalece en nuestro accionar". No sabemos a qué cámaras empresarias se refiere.

${ }^{376}$ L.C., 25/03/1993.

${ }^{377}$ L.C., 27/03/1993
} 
ante el convenio con la CEE". El texto comienza señalando que "Para los distintos sindicatos ligados a la actividad pesquera el acuerdo logrado con la Comunidad Económica Europea [...] 'no es beneficioso', ni para el sector obrero, ni para las empresas nacionales" ${ }^{378}$. Para el SOMU la aprobación del acuerdo traería a corto plazo mayor desocupación en la pesca. ${ }^{379}$ Mientras que Carlos Barboza señaló que con este convenio la Argentina resignaba afirmación soberana del mar que rodea a Malvinas. También corría el peligro de que cientos de barcos vinieran adepredar nuestra riqueza ictícola, perdiendo el país el control sobre la pesca y, encima, enfrentandola competencia en sus mercados tradicionales.

[Veía] con mucha preocupación que el acuerdo se hace sin ninguna base científica; es decir un estudio confiable que diga que se puede capturar tal cantidad de peces. ¿Cómo es esto... si ya con anterioridad se decía que estábamos en sobrepesca, por ejemplo con la merluza común? No entiendo cómo si los buques de bandera nacional no tienen por esta razón permiso para la pesca irrestricta, se actúa en sentido contrario en este acuerdo con la Comunidad.

Por último explicaba que "Hay ideas equivocadas. Esos barcos extranjeros congelarán todo a bordo. Nuestras plantas en tierra no van a trabajar, porque procesarán todo arriba y lo exportarán directamente. ${ }^{380}$ Es igual que con los acuerdos marcos". Por último se preocupaba por la capacidad de control de los buques que lleguen a pescar y por la posibilidad "de que se formen empresas fantasmas" ${ }^{381}$.

Al contrario, un amplio grupo de empresarios pesqueros se disponían a viajar con el subsecretario Fernando Gutiérrez a España para negociar su participación en los acuerdos. ${ }^{382}$ Desde Europa Gutiérrez dirá que "Hemos dicho hasta el cansancio que lo que más nos importa es preservar el recurso, jugar en forma limpia y seguir apostando al crecimiento del sector con transparencia". Mientras, Antonio Di Leva (CAABPA) expresaba que "El saldo es muy importante porque se han abierto grandes perspectivas fundamentalmente para la renovación de nuestra flota". Díaz, deCAPECA, decía que "Hay un cambio positivo y vamos a poder capitalizar este acuerdo para permitir un desarrollo genuino y a largo plazo de la industria pesquera nacional ${ }^{383}$. Para Gutiérrez el acuerdo se trataba de un doble triunfo que afectaba a la política y al comercio:

En lo político quedó claro que la Comunidad se fija en nuestro país, como un país estable, como un país que puede tener un crecimiento considerable; y en lo comercial, se abre una gran perspectiva para la industria pesquera nacional, en cuanto a que en los acuerdos hay una importante

\footnotetext{
${ }^{378}$ L.C., $15 / 07 / 1994$.

${ }^{379}$ L.C., 21/05/1994

${ }^{380}$ Consultado acerca de la posibilidad de que las empresas que participen del Acuerdo procesen el pescado en plantas en tierra, Felipe Solá había manifestado "nosotros somos partidarios de no obligar a una empresa a tener radicación en tierra; en todo caso hay que obligarla a pagar sus impuestos y darle arraigo en el país. Porque es la empresa en definitiva la que va a decidir cómo invertir el capital, si va a poner la planta en transporte, si va a alquilar una planta, por ejemplo. Nosotros no les podemos decir a los empresarios dónde tienen que invertir". L.C.,22/04/1994.

${ }^{381}$ L.C.,22/09/1993.

${ }^{382}$ L.C., $25 / 03 / 1993$

${ }^{383}$ L.C.,31/03/1993. Curiosamente, nuestro cronista finalizaba con euforia: "Rara vez un alcalde recibe en el aeropuerto a una delegación empresarial. Sin embargo, en Vigo, la presencia de Carlos Alberto González Príncipe en la estación aérea dándole la bienvenida al subsecretario de Pesca y a los miembros de la comitiva, evidenció que el viaje había despertado expectativas y que en definitiva, también para los españoles resultaba de importancia".
} 
rebaja en los aranceles, se va a poder traer algunos barcos, en fin, creo que las expectativas son enormes... ${ }^{384}$

Días más tarde era el propio Felipe Solá quien se entusiasmaba con las posibilidades que brindaba el acuerdo para incrementar la explotación pesquera. ${ }^{385} \mathrm{Al}$ cual consideró como "muy beneficioso para la Argentina" haciendo hincapié en que el mismo "tiene el apoyo de las cuatro grandes cámaras pesqueras que hay en el país" ${ }^{386}$. De la oposición de los gremios no decía una palabra.

\section{j. "La prioridad son los recursos..."}

El año 1995 comenzaba con un moderado optimismo por parte de los integrantes de la CAABPA. La crisis de 1991, y su prolongación hasta 1994, parecía haber menguado en sus efectos. Atrás había quedado la quiebra de firmas. Además, producto de la asociación con empresas europeas, se garantizaron mercados más o menos estables. Por su parte, las cooperativas de trabajo estaban dando buenos resultados en el abaratamiento del "costo del trabajo". Asimismo, la rebaja de aportes patronales colaboraba con la disminución de dicho costo. Mientras, el charteo permitía ingresos extras sin mayores esfuerzos y las capturas y exportaciones continuaban en ascenso. Tal vez por ello, el cronista Luciano Filler podía esperanzarse con una repotenciación del liderazgo pesquero marplatense. ${ }^{387}$ En dicho contexto, la desjerarquización del área pesca, que dejó de ser una Subsecretaría para convertirse en Dirección Nacional a comienzos de aquel año, pasó casi desapercibida. En cuanto al gobierno del área, luego de haber cumplido la misión de formalizar los acuerdos con la UE, Fernando Gutiérrez presentó su renuncia para instalarse en la lucha política por la intendencia de la ciudad de Mar del Plata. Lo reemplazó Eduardo Pucci quien, como vimos, era otro de los colaboradores de Eduardo Murguía.

No obstante estos buenos augurios, algunas señales de alarma comenzaban a encenderse. En mayo de 1994 la UCIP, cámara empresaria en la que participaban algunas empresas pesqueras, publicó un estudio donde aseguraba que "La situación pesquera local es grave, y la tendencia hace temer la paulatina desaparición de la industria local" lo que surgía al analizar la tendencia de las estadísticas sobre producción, captura y mano de obra empleada. El informe invitaba a que, aún cuando las estadísticas daban al puerto de nuestra ciudad como el principal del país, había que reflexionar sobre las tendencias. Expresaba que el $65 \%$ de las plantas de procesado estaban inactivas; el 50\% de la flota pesquera local paralizada; los precios internacionales de la merluza habían caído un 29\% desde 1981. Además, denunciaban que la industria marplatense se encontraba "arbitrariamente discriminada" en relación con sus pares de puertos patagónicos según las siguientes pautas: a) la existencia de un reembolso patagónico que varía desde un $7 \%$ al $12 \%$ según lo establece la Ley $\mathrm{N}^{\circ} 23.018$, y b) el decreto $\mathrm{N}^{\circ} 2.609$ del 22 de diciembre de 1993 que dispuso la reducción de las contribuciones patronales, que eran en Mar del Plata del orden del 40\%, en tanto que en las provincias patagónicas se otorgó entre un 55\% y el 70\%. Mencionaba también el descenso en el volumen de capturas proporcional, según el cual la provincia de Buenos Aires pasó de representar el 86\% de las capturas en 1986 al 53\% en 1992. A su vez,

\footnotetext{
${ }^{384}$ L.C., 21/09/1993.

${ }^{385}$ L.C., $25 / 09 / 1993$

${ }^{386}$ L.C., $17 / 03 / 1994$.

${ }^{387}$ Revista Redes, № 87, año 1995. "Un activo escenario en el puerto líder". P. 45 a 52.
} 
remarcaba la disminución en la ocupación de mano de obra embarcada, pues entre 1989 y 1993 se perdieron el 38,1\% de plazas de trabajo. Por otra parte, la mano de obra en el sector pesquero de plantas elaboradoras ocupaba en 1989 quince mil puestos de trabajo y ahora se reducía a no más de 9.500 incluida en forma estimada la mano de obra cooperativa. ${ }^{388}$

Así es como algunos sectores vinculados a la pesca, sin desconocer el crecimiento de la actividad, comenzaron a enunciar las tendencias que avizoraban negativas. A ello se le agregaba un problema más profundo. Resonaba, entre los más precavidos, la pregunta de si ¿soportaran los recursos tal nivel de actividad? Uno de estos previsores era el director editorial de la Revista Redes, Julio Torres. En una nota titulada "La prioridad son los recursos" Torres retomaba el diagnóstico realizado por la FAO según el cual la crisis de los recursos se advertía en todo el mundo. Y la conclusión arribaba de un modo fatal: "no alcanza el pescado para tantos barcos" $" 389$. Por ello sentenciaba, retomando dichos del presidente de CAPECA, que el camino de crecer aumentando las capturas había llegado a su fin. Debían aparecer otras alternativas. También la CGT local alertaba a la opinión pública sobre la depredación de los recursos ictícolas, haciendo hincapié en la ausencia de un eficaz aparato de control que permitiera la protección de las especies. Y acusaba a Felipe Solá y Fernando Georgiadis por la política pesquera. Abdul Saravia firmó una nota denominada "En defensa de la soberanía y los recursos naturales del Mar Argentino", en la que argumentó:

...la extensa sobreexplotación depredadora de la flota extranjera es posibilitada por falta de apoyo a una política protectora naval adecuada, que permita mayor presencia de nuestra Marina y Prefectura para impedir el robo y la depredación frente a las flotas que acumulan más de 200 barcos y que invaden y penetran profundamente en el Mar Argentino, violando nuestra soberanía, hoy insuficientemente custodiada por un par de guardias.

Reclamaba además que desde el Parlamento se sancionaran leyes punitorias para las embarcaciones que violaren las fronteras y que "roban nuestros recursos", pues "con la anuencia de funcionarios que tienen la obligación de defender los recursos pesqueros y los tratados internacionales, se violan estos tratados y se depredan los recursos pesqueros". ${ }^{390}$ Saravia aprovechaba la oportunidad para introducir la discusión acerca de una reorientación en el modelo pesquero en favor de la industrialización de la producción, elaborando productos con mayor valor agregado. ${ }^{391}$ De hecho, el dirigente creó dentro del SOIP una comisión de estudios para la reactivación del sector pesquero. Desde allí promocionaba los beneficios de industrializar la materia prima, detallando que "genera divisas, produce ahorro interno $y$ puestos de trabajo", mientras que cuando se exportan las materias primas (pescado entero) no sólo se reduce el ingreso de divisas sino que "dejamos de dar trabajo a nuestra gente y dejamos de generar ahorro interno, que es la base real del crecimiento de cualquier economía". Para Saravia la industrialización de la materia prima era la base de la ocupación de mano de obra, el polo de crecimiento y desarrollo del sector. ${ }^{392}$ Además, una orientación semejante permitiría exportar con altos valores

\footnotetext{
${ }^{388}$ L.C., $16 / 05 / 1993$.

${ }^{389}$ Revista Redes, № 87, año 1995. "La prioridad son los recursos". P. 21.

${ }^{390}$ L.C., $19 / 05 / 1995$.

391 Enumeraba como posibles productos la elaboración de "porciones rebozadas, empanadas, palitos de pescado, hamburguesas, etcétera, con empaque final y llegando a mercados minoristas internacionales". Con ello se multiplicaría por tres el valor de las exportaciones, además de incrementar los puestos de trabajo. L.C.,03/01/1995.

${ }^{392}$ L.C., 26/03/1995.
} 
reduciendo los volúmenes de pesca. Dado que cada vez más las autoridades eran conscientes de la necesidad de reorientar el modelo pesquero la discusión sobre el camino a seguir se hacía interesante.

En cierto modo, la postura de Saravia tenía algunos puntos de contacto con las nuevas pretensiones de los empresarios pesqueros. El día 23 de septiembre de 1994 los industriales pudieron reunirse con el Ministro de Economía. El diario La Capital titulaba ampulosamente "Una etapa nueva para la pesca" y como subtítulo "Importantes anuncios realizó el ministro Cavallo en Mar del Plata". La nueva etapa, según Cavallo y Solá, estaría orientada a fortalecer las exportaciones de productos pesqueros con mayor valor agregado, dado que como resultado de la política pesquera llevada adelante por el gobierno nacional las capturas y exportaciones crecieron inusitadamente llevando a los recursos al límite de su explotación. El empresario Homero Cánepa explicaba que "se acabaron los negocios de grandes volúmenes [...] Lo que hay que hacer no es exportar como se hace actualmente, para que se reprocese en otros paises, sino elaborar y exportar los productos listos para el consumidor final" ${ }^{393}$. Tras la reunión, los principales anuncios eran: 1) se buscarán nuevos acuerdos sobre pesca con Japón, Corea y Taiwán; 2) para aprovechar el pescado argentino las empresas extranjeras deben radicarse en el país y abrir sus mercados; 3) licitación internacional del satélite con el que será monitoreada la flota pesquera; 4) nueva estructura de reintegros a la exportación de productores elaboradores de la pesca; 5) ajuste en los regímenes de charteo; 6) se autoriza la importación sin aranceles de bienes de capital. Por todo ello, un cronista sostenía que "los históricos reclamos" de los industriales pesqueros fueron escuchados. ${ }^{394}$

Al día siguiente la crónica indicaba que "Tras el encuentro con el ministro Domingo Cavallo, la satisfacción de los empresarios locales ligados a la pesca era mayúscula. Lograron concretar una serie de reclamos del sector, verdaderamente históricos" ${ }^{395}$. Entre otras cuestiones, los industriales radicados en Mar del Plata se entusiasmaban con la posibilidad de ingresar en algún tipo de sistema de devolución de impuestos. El director de Pesca, Roberto Baltar expresó que "el tema de la devolución de impuestos va a ser de una gran ayuda para el sector, para el producto que se exporta y eso va a mejorar bastante los precios de ingreso de los productos"396. Y agregó que se trata "de una señal importante porque al ser diferenciados los aranceles, va a permitir al sector que hace los productos de mayor valor agregado tener un ingreso adicional y va a inducir a la reconversión del sector en función de este tipo de productos, los que interesan al país".

Sin embargo, las promesas realizadas a los industriales del pescado no se cumplirían. Ya en enero de 1995 éstos se quejaban de la escala de reintegros vigente. Argumentaban que no se privilegiaron los productos con mayor valor agregado y que la elaboración de los rangos no partió de la Subsecretaría de Pesca sino de la cartera de Economía. Les prometieron retornos de alrededor del 18\% y en realidad los efectivamente implementados no superaban el 10\%, agravado por la rebaja de reintegros en las exportaciones dentro de los países del Mercosur. ${ }^{397}$ Al día siguiente, Felipe Solá se reunía con los empresarios de la pesca y les informaba acerca del estado de situación. Los efectos de la llamada crisis del Tequila alcanzaban a la economía argentina. Allí advirtió que la crisis económica que atravesaba el país incidía en forma negativa en la actividad pesquera, manifestando que la misma dejaría secuelas. El

\footnotetext{
${ }^{393}$ L.C.,27/09/1994.

${ }^{394}$ L.C. $23 / 09 / 1994$.

${ }^{395}$ L.C., 24/09/1994.

${ }^{396}$ L.C. $27 / 09 / 1994$.

${ }^{397}$ L.C.,11/03/1995. Se referían particularmente a la exportación de merluza a Brasil, país que a pesar de integrar el Mercosur, en algunas de sus regiones continuaba cobrando aranceles de importación a los productos argentinos.
} 
primero de los síntomas de esta situación era la suspensión de los reembolsos que "están detenidos y seguirán estándolo, hasta que el Congreso apruebe el paquete fiscal" ${ }^{398}$. Al mismo tiempo, el secretario, que sorprendentemente manifestó como superado el problema de la desocupación (i!), expresó su preocupación por la sobrepesca de determinadas especies. Ante esto, los industriales señalaron que la situación del sector pesquero exportador argentino se había agravado sustancialmente y que "las cosas han cambiado, hoy estamos peor que a fines de 1994"399. Poco después, Homero Cánepa expresaba su desilusión porque ninguno de los reclamos de los industriales marplatenses fue tenido en cuenta. ${ }^{400} \mathrm{Y}$ tanto la CAABPA como los Procesadores señalaban su hondo malestar por ello. ${ }^{401}$ Pasaban así del optimismo inicial a la desilusión.

De todos modos, vale aclarar, no puede dejarse confundir la posición de los gremios pesqueros, como el SOIP, con la de los industriales. Estos últimos estaban particularmente interesados en recibir reembolsos a las exportaciones de productos con mayor valor agregado. Pero esa fórmula no apuntaba a modificar el modelo pesquero, sino tan sólo a que se reconociera que el fileteado y envasado de pescado realizado en plantas en tierra, que obviamente ellos poseían, fuera reconocido como el más conveniente proceso de trabajo, frente al congelado y procesado a bordo. Pero de ningún modo aparece en su horizonte un perfil industrialista como el que mencionaba Saravia, ni tampoco una alternativa que orientara el desarrollo hacia el mercado interno.

Para empeorar las cosas, por aquel tiempo se incrementó la pesca de buques extranjeros en la zona adyacente de las 200 millas, fundamentalmente españoles. Esto es, de la misma nacionalidad con la que la Argentina estableció un acuerdo de pesca. El propio Felipe Solá denunció que en el límite de las 200 millas del mar argentino hay 250 buques pesqueros de distintos países que están "depredando" los recursos ictícolas. ${ }^{402}$ Mientras que el entonces ministro de Defensa Oscar Camilión expresaba su preocupación por la "creciente depredación" pesquera más allá de las 200 millas y no descartaba un conflicto diplomático con los países que operan en esas aguas internacionales. ${ }^{403}$ Con el acuerdo de por medio, la situación resultaba algo paradójica. El jefe de la Armada, Almirante Enrique Molina Pico, decía que la invasión de embarcaciones extranjeras es "una real agresión a todos los argentinos" "404. Mientras que el entonces canciller Guido Di Tella, sin abundar en argumentos, afirmó que Argentina no aceptará la depredación pesquera pues "Los recursos marinos son un objetivo fundamental" ${ }^{405}$. Luego decía que "El tema de la pesca se ha vuelto extremadamente importante" y anticipaba que la Argentina "cuidará el recurso y vamos a tomar una posición extremadamente conservacionista" para evitar la pesca indiscriminada. ${ }^{406}$ Felipe Solá anunciaba que "vamos a agotar instancias para llegar a un sistema de control y preservación de las especies" ${ }^{\text {407. }}$.

\footnotetext{
${ }^{398}$ L.C.,12/03/1995. Si bien la CAABPA se quejaba por no ser incorporados a un régimen de reembolsos según el agregado de valor a los productos, la suspensión de los reembolsos afectó particularmente a las empresas pesqueras patagónicas, que ya venían recibiéndolos y dejaron de hacerlo, por lo que CAPeCA presentó innumerables reclamos.

${ }^{399}$ L.C.,31/03/1995.

${ }^{400}$ L.C., 23/07/1995

${ }^{401}$ L.C., 11/08/1995.

${ }^{402}$ L.C., 13/06/1995.

${ }^{403}$ L.C., 06/06/1995.

${ }^{404}$ L.C., 18/05/1995.

${ }^{405}$ L.C., 18/05/1995.

${ }^{406}$ L.C., 19/05/1995.

${ }^{407}$ L.C., 04/08/1995.
} 
Por aquel entonces, la CEPAL presentaba un informe en el cual indicaba que "El auge de las exportaciones pesqueras latinoamericanas, que se inició en la década de los años '70, parece estar limitado por la excesiva explotación de los recursos". Por eso "Se hace cada vez más necesario regular la extracción, en especial de aquellas especies cuya capacidad de reproducción está amenazada" ${ }^{408}$. $\mathrm{Al}$ mismo tiempo, los industriales pesqueros insistían en que la totalidad de las especies comerciales dentro de la ZEE se encontraban en el máximo de captura permisible. Por lo que consideraban que la única manera de aumentar las exportaciones debía basarse en productos de mayor valor agregado. Llevaron ese planteo a la reunión con el flamante Subsecretario de Pesca, Eduardo Pucci. ${ }^{409}$

El día 13 de junio, Felipe Solá volvió a prohibir la pesca de calamar al sur del paralelo 44, en una medida que regía hasta el 1 de febrero de 1996. Sin embargo, nada entorpecía el optimismo de las autoridades de pesca. El nuevo Director Nacional de Pesca y titular del INIDEP, Fernando Georgiadis, expresaba que "Las proyecciones de las exportaciones ictícolas para 1996 son de 900 millones de pesos, lo que convierte a este rubro en el cuarto o quinto en cuanto a las ventas argentinas hacia el exterior" ${ }^{410}$. Pero el funcionario no hacía referencia a las características de esas exportaciones que seguían basándose en el incremento de pescado capturado y no en el agregado de valor. Solá continuaba con su optimismo cuando anunció que las exportaciones pesqueras durante el primer semestre de 1995 alcanzaron los 440 millones de pesos, valor que representaba un incremento del 2\% frente a los 431 millones exportados en 1994. En relación con los nuevos tiempos, aseguró que "los principales objetivos de la actual política pesquera buscan la conservación de los recursos, optimizando su utilización económica mediante la incorporación de valor agregado y generando mayor empleo de mano de obra argentina". Además dijo que el volumen exportado disminuyó $23 \%$ lo que, desde su perspectiva, indicaría un importante crecimiento del valor agregado de los productos comercializados en el exterior. ${ }^{411}$ En realidad las cifras no indicaban eso, sino simplemente un nuevo incremento coyuntural del precio internacional. Y aunque Solá anunciara que "nuestro objetivo es no aumentar la captura, y en cambio aumentar sí el valor agregado, aumentar sí verticalmente la cantidad de puestos de trabajo en tierra en relación a lo que se podría pensar que es la actividad en el mar" ${ }^{412}$, ninguna de las políticas pesqueras implementadas se dirigía en ese sentido. En otra de sus declaraciones el funcionario señaló que "la pesca argentina está en pleno proceso de modernización", aunque no aclaraba qué entendía por tal concepto. Sí tomó la decisión de recrear mediante la resolución $\mathrm{N}^{\circ} 318$ de la SAGPyA, cumpliendo con un pedido de las provincias con litoral marítimo, un Consejo Federal Pesquero con el objetivo de establecer un ámbito de discusión estable sobre la política pesquera argentina con las provincias del litoral marítimo. Lo integraban, por las provincias, los máximos responsables del área pesquera de cada una; por la Nación, el subsecretario de Pesca, el Director de Pesca y un asesor de la SAGPyA. El objetivo era "analizar y discutir la problemática del sector pesquero y armonizar las políticas vinculadas al mismo" ${ }^{413}$. Más tarde, este organismo se formalizará a partir de su inclusión en la Ley Federal de Pesca.

\footnotetext{
${ }^{408}$ L.C.,06/01/1995.

${ }^{409}$ L.C., $23 / 12 / 1995$.

${ }^{410}$ L.C.,30/06/1995. Un informe elaborado por la Universidad Nacional de Mar del Plata en el año 1996, que tomaba como base datos correspondientes a los nueve primeros meses del año 1995, indicaba que en ese tiempo, y en relación al año anterior, se acumuló una caída del 3\% en el índice de Producción Industrial del Partido de General Pueyrredón. Los sectores pesquero y químico eran los únicos que registraban una evolución favorable del 9,7 y 3,4 respectivamente.

${ }^{411}$ L.C. $27 / 09 / 1995$.

${ }^{412}$ L.C., $02 / 06 / 1996$.

${ }^{413}$ L.C., 13/06/1996.
} 
k. "Hasta que nos falló el recurso...”: la crisis de la industria pesquera

"Es que la fiesta terminó, y para probarlo están los restos que quedaron en el mar. Algunos se divirtieron y otros no, aunque en este punto todos parecen tener una dolorosa resaca" Revista Redes, № 97, 1997.

Ya hemos mencionado las numerosas advertencias de diferentes actores respecto a los crecientes niveles de sobrepesca. El gran incremento de buques y esfuerzo pesquero, que en la mirada de funcionarios optimistas se traducía en declaraciones acerca del crecimiento de capturas y exportaciones, hizo llegar a los recursos, en particular la merluza hubbsi, al límite de su capacidad de explotación. Todas las advertencias previas, todas las declaraciones que temían se llegara a una situación de colapso de los recursos, se volvían en el año 1997 una realidad contundente. Lo confirmaba un informe de la Revista Redes $\mathrm{N}^{\circ}$ 93, que retomando cifras producidas por el INIDEP, informaba acerca de "un crecimiento notable de la captura con problemas sobre el stock (de la merluza), caída de la biomasa total, reducción de las tallas y con alta incidencia en la captura de especies juveniles". Incluso entonces, desde la secretaría de Recursos Naturales y Desarrollo Sustentable, cuya titular era María Julia Alsogaray, se dio a conocer un documento denunciando que "se está pescando en exceso". Y mencionaba que "la política netamente extractiva se aleja de manera significativa del criterio de uso sustentable de los recursos", mientras que "Esta situación se ve agravada por la falta de un marco jurídico adecuado, lo cual conlleva un riesgo evidente para la integridad de los ecosistemas marinos a corto plazo" 414 .

En ese contexto, y ahora vuelto todo un conservacionista, Felipe Solá expresaba la necesidad de sancionar de inmediato una ley para regular la actividad pesquera. Entre otras razones, argumentaba que la ZEE "está prácticamente con una gran mayoría de peces que han dejado de ser excedentarios", lo que exige "rever todo el modelo de permisos de pesca, y para eso es necesario una ley, porque genera un respaldo jurídico que evita la problemática de tomar medidas desde el gobierno federal, que terminan siendo objetadas" ${ }^{415}$. Para entonces ya era muy claro que no se podía continuar con la estrategia de incrementar el esfuerzo de pesca sin poner en serio riesgo la reproducción de los recursos, en particular, de la merluza hubbsi. La situación de sobre pesca le había estallado en las manos y por ello Solá buscaba instrumentar, mientras se avanzaba en la discusión en torno de la futura ley, un acuerdo con las cámaras pesqueras para lograr una reducción concertada de los volúmenes de pesca (al menos de un 20\%). ${ }^{416}$ Para ello se reunió con los miembros de las cuatro cámaras más significativas: Pablo Silveyra de CAPIP, Antonio Di Leva de Procesadores de Pescado, Enrique Díaz de CAPECA y José Moscuzza de la CAABPA. Solá aseguró que "la captura total en la Argentina ha llegado a su nivel máximo posible, por lo cual, el futuro de la pesca pasa por distintas formas de procesamiento y captura de mercados externos, $y$ en menor medida de mercado interno, para lograr un aumento del valor del producto final, nuevos productos y mercados". Entre los temas discutidos, se destacaba el pedido de elaborar una política tendiente a premiar a la industria que favoreciera la elaboración de productos con un mayor valor agregado, por ejemplo, a partir de recibir mayores reintegros. Se analizó también la cuestión de la flexibilidad laboral y la creación de cooperativas de trabajo. Los empresarios se mostraban satisfechos por la implementación de estas últimas dado que el cambio en el nivel de procesamiento de pescado generó

${ }^{414}$ L.C.,02/04/1997.

${ }^{415}$ L.C., 12/01/1997.

${ }^{416}$ Revista Redes, № 95, año 1997, p. de 6 a 10. 
un gran aumento de la productividad. Según la fuente periodística, un industrial acotó que "en los últimos años, con menos recursos se ha logrado facturar más y concretamente se puede hacer a través del régimen laboral que imprime el trabajo con cooperativas". Por eso será un pedido insistente de los industriales pesqueros marplatenses mantener en forma estable y clara las disposiciones que promovían nuevos sistemas de contratación de la mano de obra. ${ }^{417} \mathrm{Y}$ la discusión giró en torno a cómo llevar la captura de merluza al nivel necesario para asegurar el recurso en los próximos años. ${ }^{418}$ Ante las demoras en la sanción de la ley, en la visión de los firmantes, resultaba impostergable un acuerdo que garantizara la sostenibilidad de los recursos con un adecuado dimensionamiento industrial. Poco después, la SAGPyA conseguía firmar un compromiso de los representantes de las cámaras para la conservación de la merluza hubbsi. Se estableció una reducción en la explotación anual de dicho recurso para llegar a niveles que hicieran compatible la actividad industrial con la conservación y el respeto de la CMP. El acuerdo habilitaba a la SAGPyA a establecer una reducción en los días de pesca contemplando el impacto de la medida en la situación de las empresas según el personal ocupado, las inversiones realizadas hasta el presente y el valor agregado que se le añadía en el proceso productivo. Se estableció el sistema de vedas móviles a fin de proteger las áreas en las que la promoción de ejemplares juveniles resultare elevada. También se previó crear una comisión permanente de asesoramiento del secretario integrada por los presidentes de las cámaras y el INIDEP bajo la presidencia del subsecretario de Pesca. Asimismo las cámaras empresariales y la Secretaría procurarían que las empresas evitaran el uso de los permisos de pesca emergentes de quiebras o medidas judiciales como forma de impedir el aumento del esfuerzo pesquero. Y Solá, finalmente, prometió que el gobierno buscaría propiciar los reintegros a las exportaciones de productos con valor agregado. ${ }^{419}$

En ese contexto, comenzaron a crecer los cuestionamientos a la política oficial. Desde la UCR Néstor Saggese criticó el sesgo economicista de las apreciaciones oficiales que hasta hacía poco tiempo habían sostenido los funcionarios del gobierno, así como los festejos por el récord de las exportaciones pesqueras, manifestando su preocupación acerca de que "el caladero argentino está siendo sometido a un esfuerzo de pesca prolongado que pone cercanos los límites del agotamiento y explica reacciones sino tardías, de dudosa eficacia".

...es hora de señalar impericias y responsabilidades, como en el caso del secretario Solá en la conducción de la SAGPyA, quien ha confesado públicamente al anunciar el acuerdo de reducción de capturas que "...se ha tomado conciencia tardía que los recursos requieren estricta conservación" lamentando que la ausencia de marcos legales no hubieran controlado a tiempo la situación. Reconociendo "...no haber estudiado mejor la potencia de los buques que vinieron (de la CEE) y los permisos otorgados" 420 .

\footnotetext{
${ }^{417}$ Dentro de diferentes propuestas de los industriales, tanto la CAABPA como los Procesadores llevaron a la mesa de discusión la necesidad de debatir la situación laboral. La CAABPA pedía "Procurar una solución al tema del empleo, a partir de la actual situación de la actividad, previendo el establecimiento de una nueva reglamentación laboral y normas de flexibilización laboral". La Cámara de Procesadores, por su parte, solicitaba "La búsqueda de una solución al tema laboral vinculado con las plantas en tierra, a través de la clarificación de las cooperativas de trabajo”. Revista Redes, N 95, año 1997, p. 8.

${ }^{418}$ L.C., $19 / 04 / 1997$.

${ }^{419}$ L.C., $16 / 05 / 1997$.

${ }^{420}$ L.C., 13/06/1997.
} 
También Greenpeace Argentina criticó el acuerdo sobre reducción del esfuerzo pesquero alcanzado entre las cámaras pesqueras y la SAGPyA, afirmando que no constituía una herramienta para detener la persistente disminución de ese recurso. Advertía que si la intención era disminuir en un $20 \%$ el esfuerzo pesquero, esto ubicaría a las capturas en 472 mil toneladas, cifra que aún continuaba superando la CMP. ${ }^{421}$ La organización ecologista denunció luego que la Argentina registraba un nivel de sobrepesca de merluza de casi el 100 por ciento sobre el máximo estimado por el INIDEP. Y volvió a responsabilizar a Felipe Solá, quien autorizó la pesca de 395 mil toneladas anuales a pesar de que el INIDEP había sugerido fijar la CMP en 360 mil. Por eso, exigió que el gobierno tome medidas inmediatas. ${ }^{422}$ De hecho, organizó una jornada de protesta en la concurrida esquina porteña de Florida y Córdoba donde construyó un puesto con un gran cartel que rezaba Pescadería Don Felipe, donde acusaban directamente a Solá por la sobre pesca. ${ }^{423}$ Por su parte, el nuevo titular de la Comisión de Pesca del Senado de la Nación, el chubutense Osvaldo Sala, redactó un documento que tituló "la actual política pesquera no le conviene al país". ${ }^{424}$ Estas eran solo algunas de las apreciaciones críticas de las políticas oficiales.

Fue en julio de 1997 cuando Felipe Solá, mediante una conferencia de prensa, anunció públicamente la situación de crisis que atravesaba la pesca e indicó las medidas que se tomarían para "salvarla". Entre ellas, se extendería la zona y el período de veda para la pesca de merluza además de promover un incremento de las sanciones para las empresas que violaren las nuevas reglas. El funcionario adjudicó la sobrepesca al incumplimiento de todo tipo de disposiciones conservacionistas como la reducción del tamaño de malla, la captura de ejemplares por debajo de la talla mínima y el descarte de grandes cantidades de pescado. Señaló además la falta de estímulos para la preservación, la debilidad del marco legal y la carencia de una ley de pesca. Por ello declaró la necesidad de crear un cuerpo de inspectores. Al mismo tiempo que, para paliar las consecuencias laborales de tales medidas, anunció la conformación de un equipo de trabajo que seguiría la evolución del empleo. En el corto plazo, estimaba la reserva de un cupo de 30 mil toneladas de merluza para ser capturada por la flota costera del puerto de Mar del Plata. Con respecto a la pesca de calamar, señaló que se tendería a abandonar el sistema de charteo para dar paso a la cuotificación con elaboración en tierra y con mano de obra argentina. Asimismo, se cobrarían derechos de explotación para que los empresarios costeen la pesca. También se estudiaría un sistema de financiamiento particular para la reconversión de las flotas pesqueras. ${ }^{425}$ Días más tarde, el recientemente creado Consejo Federal Pesquero ratificó el cumplimiento de las medidas. Entonces ya había asumido la Subsecretaría de Pesca Héctor Salamanco, quien deslindó responsabilidades de su cargo así como del INIDEP en lo que ya se denominaba como "crisis de la merluza”. El funcionario al asumir expresó “... hoy las pesquerías de Argentina se encuentran en una fase difícil, fase de ajuste $y$ administración fina" ${ }^{\text {"26 }}$. Eludiendo cualquier responsabilidad de los administradores, no relacionó las políticas implementadas previamente con el origen de esas fases. Y sostuvo que la situación de agotamiento la sufrían todos los caladeros del mundo y las medidas "fracasan

\footnotetext{
${ }^{421}$ L.C.,15/06/1997. Emiliano Ezcurra, coordinador de la campaña de Biodiversidad, afirmó que "La merluza hubbsi se ha venido explotando irracionalmente desde hace 10 años y los responsables en el gobierno no se han preocupado debidamente de proteger el recurso marino que más divisas aporta al país. El acuerdo entre el gobierno nacional y las cámaras es pedirle al lobo que cuide a las ovejas".

${ }^{422}$ L.C.,26/06/1997.

${ }^{423}$ Revista Redes, № 96, año 1997, “¿En las vísperas del paro biológico?”, p. 6.

${ }^{424}$ Revista Redes, $\mathrm{N}^{\circ} 96 \ldots$ op. cit.

${ }^{425}$ L.C., 23/07/1997.

${ }^{426}$ Revista Redes, № $96 \ldots$ op. cit.
} 
en un régimen donde hay propiedad común. El pez que está en el agua es de todos". Salamanco, apoyado en la tesis de la "tragedia de los comunes" de Garret Hardin proponía aplicar un sistema de cuotas que permitiera privatizar los recursos del mar, cuyo mecanismo principal sería el de la implementación de cuotas de captura individuales y transferibles.

De este modo, desde los organismos gubernamentales que se ocupaban de la pesca se pretendía tomar cartas en el asunto de la crisis pesquera. Ello ocurría al ser evidente la reducción del stock de merluza. Al mismo tiempo, se anunciaban cambios para definir un nuevo rumbo en la política pesquera, que debía pasar de una fase de pesca expansiva o una restrictiva. La transformación se planteaba bajo la presión que significaba que el pescado se terminaba y sobre una estructura pesquera que, a pesar de sus limitaciones y falencias, se venía desarrollando en aquel marco de pesca expansiva. Eran, pues, más los comensales invitados que el menú disponible. Además, en el contexto de ajuste del Estado y de una crisis recesiva que comenzaba a adquirir cada vez mayor peso en la economía nacional, desde el gobierno no se vislumbraba ensayar alguna política de subsidios mientras se prohibía el desarrollo de la pesca. Entonces, al tener que reducir los volúmenes de pesca de manera abrupta ¿qué sectores se perjudicarían? Esta situación marcará el conjunto de los movimientos que se produjeron dentro de las acciones colectivas de los actores de la escena portuaria, las que se analizan en el capítulo IV. Al tiempo que las implicancias de esa pregunta se trasladaron a la disputa por definir los contenidos de la ley de pesca.

1. La sanción de la ley Federal de Pesca

"Tardamos tanto en tener una Ley de Pesca porque los intereses son muy cuantiosos, muy importantes y presionan sobre los legisladores de manera muy efectiva en algunos casos".

Diputado Héctor Lence, PJ.

"La Ley de Pesca que la Argentina necesita no va a hacer milagros, no va a definir un problema de fondo. La razón profunda de la crisis del sector pesquero es que no hay política industrial en la República Argentina" Diputado Rafael Flores, FREPASO.

Ya hemos visto los intentos fracasados por consensuar una Ley Nacional de Pesca hacia finales de la década del '80 y principios de los años '90. Será recién bajo la presión de los informes que evidenciaban una creciente sobrepesca cuando nuevamente se ponga en el centro de la escena pública la necesidad de sancionar dicha reglamentación. Haciendo una autocrítica Felipe Solá declaraba:

En el '93, '94 nosotros no teníamos conciencia de la necesidad de un instrumento jurídico como la que tenemos ahora; por lo tanto, no tuvimos la misma premura en conseguir esa ley. Se hizo absolutamente imprescindible tener una ley de Pesca cuando se llegó a la conclusión de que estábamos superando el límite de la captura máxima permisible, por ejemplo, en el caso de la merluza hubbsi. Mientras esto no ocurría no teníamos la convicción. ${ }^{427}$

\footnotetext{
${ }^{427}$ Revista Redes, № 95, año 1997, “Autocrítica de Solá”, p. 14.
} 
En septiembre de 1996 ingresaron a ambas cámaras de la Nación 16 proyectos sobre Ley Nacional de Pesca. ${ }^{428}$ Cuál sería el uso de los recursos y cómo se otorgarían los permisos de pesca eran los interrogantes primordiales. La discusión giraba en torno al perfil industrial de la actividad (y no sólo extractivo), el porcentaje de mano de obra argentina y qué entidad tendría el Consejo Federal Pesquero en la definición de la política pesquera. ${ }^{429}$

Un proyecto presentado por el Senador Felipe Ludueña, al que acompañaban César Mac Karthy, Juan Ignacio Melgarejo y Leopoldo Moreau, obtuvo media sanción en el Senado. Dicho proyecto " $h a$ provocado una honda y profunda preocupación en todo el sector pesquero" expresó el entonces presidente de la CAABPA, Antonio Solimeno. ${ }^{430}$ Entre otros motivos, la preocupación giraba en torno a la instrumentación de "corredores marítimos" que permitían el acceso a puertos nacionales por parte de flotas extranjeras. También se opuso la CGT regional, señalando que el proyecto:

...no ha sido consultado con los distintos sectores de la pesca, dando como resultado la falta de protección al recurso ictícola nacional, el perjuicio a las fuentes de trabajo en tierra, libera los acuerdos de charteo, no incluye la participación de los sectores de la pesca en el Consejo Federal Pesquero y otorga demasiado poder al secretario de Pesca y Alimentación de la Nación.

Además, el proyecto "no respeta los legitimos derechos de los obreros maritimos y portuarios y le resta seguridad jurídica a las empresas instaladas en el país y con amplia trayectoria". Mostrando dureza, dado que veían peligrar las fuentes de trabajo de "los compañeros marítimos y portuarios como los intereses pesqueros argentinos", la CGT se declaraba en estado de alerta permanente y reclamaba una vez más participación gremial en las decisiones de política pesquera. ${ }^{431}$ Pablo Vacante, representante de la provincia de Buenos Aires y miembro del PJ, por su parte, sostenía que dicho proyecto de Ley contempla "aspectos que no favorecen la posición de la Provincia de Buenos Aires en este sentido, ni los intereses generales, en cuanto a la sustentabilidad del recurso, la empresa y la mano de obra nacional" ${ }^{432}$. Lo propio hacían Francisco Romano, José Benvenuto ${ }^{433}$ y Abdul Saravia. ${ }^{434}$ Este último, desde el SOIP, emitió un comunicado de fuerte contenido crítico respecto de la actuación de los funcionarios del área pesca, los empresarios y el modelo pesquero en general. En él decía que se repudia "enérgicamente la media sanción que tiene la Ley de Pesca, presentada en esta oportunidad por el senador Ludueña de Santa Cruz, ya que la misma enfoca la problemática pesquera en forma parcial y beneficia en demasía a ciertos sectores patagónicos en detrimento del resto de la colectividad pesquera nacional". Por su interés, y porque tal vez fue el último documento elaborado por Saravia, citamos el texto en extenso:

[Dicha ley]...no contempla el adecuado control del recurso, ya que impulsa el desarrollo de la flota congeladora que aceleradamente está diezmando nuestros caladeros [...] Cabría preguntarse

\footnotetext{
${ }^{428}$ Por razones de economía narrativa no podemos aquí examinar cada proyecto. Para un análisis de varios de los diferentes proyectos de ley de pesca presentados entre 1986 y 1997 ver Lerena (2009).

${ }^{429}$ L.C.,21/09/1996.

${ }^{430}$ Revista Redes, № 93, año 1996, "La despedida del '96”, p. 6. También expresaron su repudio la Sociedad de Patrones Pescadores y la Asociación de Pesca Costera.

${ }^{431}$ L.C., 23/12/1996.

${ }^{432}$ L.C., $23 / 12 / 1996$

${ }^{433}$ L.C.,02/01/1997.

${ }^{434}$ L.C., $07 / 01 / 1997$.
} 
cuáles son los oscuros intereses que llevarán a que se impulsen iniciativas tan funestas para el futuro de la pesca [...] En primer lugar están los funcionarios de más alto rango en la toma de decisiones, a saber el ingeniero Felipe Solá, el Dr. Pucci, el Dr. Fernando Georgiadis, quienes misteriosamente se desentienden del drama de los pescadores argentinos y de la conservación del recurso, ya que si tomaran cartas en el asunto no seguirían otorgando indiscriminadamente permisos de pesca a supercongeladores extranjeros, en vez de desarrollar los excelentes productos navales elaborados en nuestra ciudad [...] Los empresarios se callan la boca, ya que han establecido en Mar del Plata la pesca por medio de estos destructores de los caladeros, que abandonaron otros puertos europeos por el dramático daño que realizaron en la ecología marina [...] Ellos saben positivamente el daño que hacen, pero no les importa ya que una vez que agoten el recurso estarán con sus arcas repletas de dinero y el pescador tradicional y artesanal no tendrán para comer [...] En definitiva este manejo de la promulgación de la Ley de Pesca fue elaborado por gente que no es del sector, que sólo entiende y atiende a intereses personales y parciales, ya que en forma absolutamente inconsulta armaron su negocio $[\ldots]$ ¿qué hacen nuestros diputados y senadores marplatenses que no se ponen a la cabeza de los reclamos de los obreros de la pesca? ¿Quién los habrá votado, los empresarios, los poseedores de chatarra importada o los verdaderos dueños del recurso que son los habitantes de este bendito suelo? [...] Como dijo el general Perón... la única verdad es la realidad y la nuestra es muy negra. ${ }^{435}$

En ese contexto Felipe Solá manifestó que "Hay dos proyectos de ley, uno originado en el Senado, que tiene media sanción, y otro consensuado en Diputados, de José Luis Castillo, y el pensamiento oficial está mucho más cerca del modelo que propone este último". También dijo que la ley fundamentalmente debía contemplar tres aspectos: la conservación de los recursos, ${ }^{436}$ la generación de empleo nacional y el valor agregado a los productos capturados. Reconoció que "Si bien hemos crecido en cuanto al volumen y las exportaciones, no lo hemos hecho en la generación de empleo de la manera que la expectativa de la población esperaba". Y volvía a confesar que la ZEE "está prácticamente con una gran mayoría de peces que han dejado de ser excedentarios", lo que exige "rever todo el modelo de permisos de pesca, y para eso es necesario una ley, porque genera un respaldo jurídico que evita la problemática de tomar medidas desde el gobierno federal, que terminan siendo objetadas". En un mensaje claro para los bonaerenses, manifestó que "el traslado progresivo de recursos hacia el sur, lo que va derivando inversiones hacia aquellas zonas, no lo podemos contrarrestar con una política de reembolsos, porque sería hacer una política contra natura". En la opinión del entonces secretario, en cuanto la industria radicada en la zona patagónica compite utilizando tecnología de menor costo, se desprende que la tendencia favorece a los buques congeladores. Aunque destacó a los empresarios que trabajaban con los dos sistemas. ${ }^{437}$

Estas declaraciones generaban la respuesta de diferentes espacios políticos. Entre ellos, el Ateneo Regional de Capacitación y Estudios Sociales, del cual estaba al frente el Ing. Ernesto Godelman, expresaba que "llama la atención la frescura con que notifica y habla aspectos críticos de la política pesquera. Pareciera que este Felipe Solá no es el mismo que condujo el área durante el último lustro", pues "el gran esfuerzo de pesca que se ha abatido sobre las especies comerciales, llevando algunas al borde del colapso, es responsabilidad directa de quien hoy habla de la necesidad de una ley para

\footnotetext{
${ }^{435}$ L.C.,07/01/1997.

436 “La obligación primaria de la autoridad federal es la conservación del recurso, asegurarlo para todos los argentinos y para las generaciones futuras". Por ello proponía imponer multas más onerosas para quienes pescasen ilegalmente.

${ }^{437}$ L.C., 12/01/1997.
} 
conservar el recurso". ${ }^{438}$ La misma institución organizaba el encuentro "El puerto de Mar del Plata: crisis y propuestas". Allí un grupo de empresarios, trabajadores y sindicalistas trazaron un preocupante cuadro de la actividad pesquera, donde se resaltó la sobrepesca a cargo de buques factoría, la depredación, la reducción de las capturas, la desocupación y la falta de una política pesquera clara. Las conclusiones eran alarmantes:

- Las condiciones macroeconómicas privilegian la sobrepesca y la participación de buques factoría por encima de las embarcaciones fresqueras nacionales.

- No se generan empleos en tierra debido a los acuerdos con la Unión Europea.

- La captura local reunió el 68 por ciento a nivel nacional; hoy, sólo el 38 por ciento.

- No existe política pesquera nacional, comenzando la depredación con los convenios marco de los años ' 80 .

- Se han perdido en los últimos 6 años 6.000 puestos de trabajo.

- 9 de los 12 caladeros mundiales están agotados.

- Corre peligro el recurso nacional.

- Un buque factoría captura en el Mar Argentino 15.000 toneladas por mes con una tripulación de 79 personas. Un fresquero nacional ocupa 400 personas.

- Merluza: en el '95 se pescaron 570.000 toneladas; en el '96 610.000 toneladas. Si no se limita, el recurso entrará en crisis.

- Desconocido número de embarcaciones extranjeras están pescando en el límite argentino. Fallan los controles.

- La política de reembolsos favorece a los puertos patagónicos y perjudica a Mar del Plata. Es escasa la acción de concejales y legisladores. ${ }^{439}$

Ante este panorama, desde el Concejo Deliberante local se ensayaba una respuesta convocando para el día 14 a una audiencia pública especial para tratar específicamente la situación general del sector pesquero marplatense, la necesidad de una ley de pesca y el establecimiento de una política de explotación sostenible de los recursos vivos del mar, para lo cual se convocó a funcionarios e instituciones involucradas en la problemática. ${ }^{440}$ El titular del HCD local, Oscar Pagni, expresaba:

${ }^{438}$ L.C., 19/01/1997. Hablando específicamente del sistema de charteo, El Ateneo expresaba: "nos llama la atención que, en su defensa, el secretario de Pesca, eluda mencionar la Resolución 963/3, firmada por él, que prácticamente obligaba a los empresarios a entrar en un sistema de pesca cuya única posibilidad de ganancia estaba en los reintegros y reembolsos del Estado".

${ }^{439}$ L.C.,02/02/1997.

${ }^{440}$ En la ciudad este tipo de convocatoria organizada por el poder legislativo del gobierno comunal tenía diversos e históricos antecedentes. Uno de ellos fue el encuentro multisectorial llevado a cabo en el Concejo Deliberante en agosto de 1975. La CGT Regional había realizado la convocatoria buscando establecer coincidencias de las fuerzas obreras, empresarias y autoridades comunales, tendientes a lograr en el plano local medidas que atemperaran la crisis que afectaba a la economía del país y sus consecuencias. Participaron de la misma el intendente de la ciudad, el delegado regional de la CGT, representantes de las 62 Organizaciones, la Cámara Marplatense de la Industria de la Pesca, el Centro de Constructores y Anexos, la UCIP y representantes de los diferentes bloques del Concejo, quienes aprobaron un documento estableciendo compromisos comunes para los sectores obreros y empresariales a fin de amenguar los efectos de la desocupación a partir de la mutua colaboración (Tomasone, 2006). 
Las erráticas y absurdas políticas oficiales respecto al tema pesca, están destruyendo la industria pesquera marplatense [...] Mientras que la pesca argentina obtiene récords de capturas y exportaciones Mar del Plata tiene niveles de desocupación tremendos, y esto sucede por el desmesurado incremento de la actividad de barcos poteros, congeladores y factorías que procesan todo en alta mar, arrastrando a la desesperación y el cierre a las industrias en tierra y a cientos de trabajadores marplatenses a la calle. ${ }^{441}$

En aquella reunión quedaron expresados todas las posiciones e intereses que luego se desplegaron durante el período que va de 1997 a 2001, dominado por la crisis de la merluza. A partir de este momento podemos señalar que la ciudad de Mar del Plata se erigió como corporación económica bajo el desarrollo de un programa de acción que, construyendo una imagen de la ciudad como víctima de las políticas oficiales, aglutinaba a unos actores de la pesca local al mismo tiempo en que marginaba a otros (hablaremos de ello en el capítulo IV). Los restantes proyectos de ley existentes irían quedando en un lugar marginal dentro de la discusión, que llevó a polarizar el debate en dos proyectos. Finalmente se consensuó el rechazo a la Ley de Pesca presentada por el senador Ludueña y el apoyo generalizado al proyecto desplegado por el diputado José Luis Castillo. ${ }^{442}$

En definitiva, en el mes de abril Felipe Solá reiteraba que era "altamente necesaria" una Ley de Pesca que regulara la actividad. La regulación debía sancionarse en un contexto conflictivo, dado que se estaban discutiendo los mecanismos para alcanzar la reducción de las capturas. Finalmente en el mes de noviembre la ley se encontraba en el Congreso de la Nación pronta a ser tratada. Como veremos en el capítulo IV, diferentes actores de la pesca marplatense se nuclearon en oposición a un artículo de la ley, el $\mathrm{N}^{\circ} 27$, que era el que disponía el modo de apropiación de los recursos pesqueros. La normativa postulaba el sistema de Cuotas Individuales de Captura Transferibles que se asignarían a cada barco o empresa en función de cinco parámetros: los antecedentes de captura (el promedio de capturas realizadas en los últimos 8 años hasta diciembre de 1996), la mano de obra empleada, la producción, las inversiones realizadas y las infracciones recibidas. Pero las empresas locales que adquirieron buques congeladores fueron las de mayor crecimiento en volúmenes de pesca en aquellos años, y probablemente, las que realizaron significativas inversiones. ${ }^{443}$ Desde el sector fresquero, los gremios y la intendencia de Mar del Plata se visualizó dicho mecanismo distribuidor de cuotas de captura como el triunfo institucional del sector congelador. Eduardo Porta, secretario de la UCIP, señalaba que la CAPECA jugó el papel de "ángel negro" en la redacción de esa ley. ${ }^{444}$ Por ello iniciaron un proceso de movilización que incluyó una marcha del sector pesquero marplatense a Capital Federal y terminó cuando pudieron lograr introducir modificaciones en aquel criterio. El 20 de noviembre y ante un Congreso cercado por temor a la movilización de los pescadores marplatenses, se aprobó la ley, aunque con la modificación del artículo 27. En este sentido, se introdujeron puntos más afines a las pretensiones de los fresqueros para la asignación de cupos de pesca, como el procesado en tierra, el empleo de mano de obra argentina y se

\footnotetext{
${ }^{441}$ L.C., 08/02/1997.

${ }^{442}$ L.C.,07/05/1997. Otro proyecto era, por ejemplo, el presentado por el diputado nacional Néstor Saggese el cual pretendía modificar sustancialmente el régimen de pesca, sustituyéndolo por otro con perfil más industrial, con cupos de captura, fuertes incentivos a las plantas en tierra, uso prioritario para buques nacionales y más severos controles.

${ }^{443}$ Además se sospechaba que la flota fresquera durante años había sub-declarado capturas, al tiempo que mantenía muchos de sus empleados "en negro", con lo cual los criterios de cuotificación no generaban demasiado entusiasmo, dado que se les otorgarían menores volúmenes de lo que realmente pescaban (Litovsky, 2000).

${ }^{444}$ E.A., 12/11/1997.
} 
prohibió la transferencia de cuotas de los fresqueros hacia los congeladores. Además, el CFP se reservó un cupo de pesca para destinarlo a una situación de crisis social como la que entonces vivía la pesca marplatense.

La Ley Federal de Pesca $N^{\circ} 24.922$ fue sancionada en diciembre de 1997 y publicada en el boletín oficial en enero del año siguiente. ${ }^{445}$ Son muchas las definiciones que promovió, entre ellas se reconoció la jurisdicción provincial hasta las 12 millas y desde allí la jurisdicción nacional en la ZEE, ${ }^{446}$ el carácter industrial de la actividad, se creó la Secretaría de Pesca en el ámbito del Ministerio de Economía y Obras y Servicios Públicos de la Nación, ${ }^{447}$ el Consejo Federal Pesquero ${ }^{448}$, una Comisión Asesora ${ }^{449}$ honoraria, el ejercicio de la pesca quedaba sujeto al pago de un derecho único de extracción por especie y modalidad de pesca (anteriormente los permisos eran gratuitos) y el Fondo Nacional Pesquero. Previendo 90 días para definir su reglamentación desde el momento de su sanción, tuvo que esperar varios años para que sus especificaciones respecto al modo de apropiación de los recursos pudieran implementarse.

\section{m. El manejo de la crisis y la disputa "fresqueros" vs. "congeladores"}

En el contexto de crisis de la merluza, y tras la sanción de la Ley Federal de Pesca, la discusión acerca de cuál resultaba el mejor modo de distribuir los recursos que, como hemos dicho, no alcanzaban para todos los que estaban desarrollando la pesca, guió las conductas de los actores de la escena pesquera. Los criterios se superponían. La oposición de la "convergencia marplatense" ${ }^{450}$ logró que el artículo 27 de la ley no se reglamentara y, por ende, no se asignaran las cuotas. Pero ello no solucionó los problemas de escasez de recursos. Es por eso que a partir de 1998, y ya en plenas funciones del Consejo Federal Pesquero, se tuvieron que implementar diferentes medidas coyunturales tendiendo tanto a la restricción de la pesca, como a la sanción de una nueva ley (la de Emergencia Pesquera), que atendiendo la particularidad de la situación se crisis, creaba un modo de distribución de los recursos que chocaba con lo dispuesto por la Ley de Pesca. Un rápido recorrido por la administración pesquera de aquellos tiempos, que abarca el final de la administración menemista y los inicios de la Presidencia de Fernando De la Rúa,

\footnotetext{
${ }^{445}$ Ley N ${ }^{\circ}$ 24.922, Régimen Federal de Pesca, Honorable Congreso de la Nación Argentina, año 1997. El artículo I manifestaba "La Nación Argentina fomentará el ejercicio de la pesca marítima en procura del máximo desarrollo compatible con el aprovechamiento racional de los recursos vivos marinos. Promoverá la protección efectiva de los intereses nacionales relacionados con la pesca y promocionará la sustentabilidad de la actividad pesquera, fomentando la conservación a largo plazo de los recursos, favoreciendo el desarrollo de procesos industriales ambientalmente apropiados que promuevan la obtención del máximo valor agregado y el mayor empleo de mano de obra argentina".

${ }^{446}$ Para César Lerena este aspecto retrocedía el derecho soberano de la Argentina sobre su mar territorial. El cambio de término de Mar Argentino a Zona Económica Exclusiva aceptaba los términos de la CONVEMAR y, desde el punto de vista del veterinario, consolidaba la posición de Gran Bretaña (Lerena, 2009).

${ }^{447}$ Mediante el decreto $N^{\circ}$ 6/98, a instancias de Felipe Solá, el Gobierno promovió el veto a la creación de la Secretaría de Pesca. De haberse creado tal dependencia el mencionado funcionario hubiera perdido el dominio sobre la actividad pesquera.

${ }^{448}$ Tenía por misión establecer la política pesquera nacional. Estaba integrado por a) Un representante por cada una de las provincias con litoral marítimo; b) El Secretario de Pesca; c) Un representante por la Secretaría de Recursos Naturales y Desarrollo Sustentable; d) Un representante del Ministerio de Relaciones Exteriores, Comercio Internacional y Culto; e) Dos representantes designados por el PEN.

${ }^{449}$ La cual estaba integrada por representantes de las distintas asociaciones gremiales empresarias y de trabajadores de la actividad pesquera.

${ }^{450}$ Por "convergencia marplatense" nos referimos a la alianza social que luego se institucionalizaría a partir de la Multisectorial en Defensa de la Pesca Argentina, integrada fundamentalmente por empresarios fresqueros, gremios y el ejecutivo marplatense, quienes buscaron volcar la política de gobierno y la distribución de cuotas de captura en su favor. Veremos en el capítulo IV los pormenores de esta convergencia.
} 
nos presenta un cuadro de implementación de vedas, resoluciones, paradas biológicas, etc. ${ }^{451}$ Muchas de estas medidas tuvieron que dar marcha atrás, o funcionaron por un tiempo y luego se abandonaron. En general la iniciativa estatal, "influida por el periodo pre-electoral, tendió más a satisfacer las demandas sectoriales que ha intentar dar una solución de fondo al problema" (Litovsky, 2000: 40). En la visión de este autor, que asume una mirada algo más solidaria respecto del sector congelador y de la CAPECA en particular, la cuotificación no se aplicó por tratarse de un sector poco habituado a reglamentaciones. De ahí el "boicot" emprendido contra los criterios que establecía la ley particularmente a cargo de los fresqueros marplatenses. Aunque el grueso de responsabilidad, en la visión de Litovsky, recae en la lógica de los incentivos políticos que promovían intereses de corto plazo que no toleraban la absorción de los costos de implementar una veda. ${ }^{452}$ Desde la perspectiva de César Lerena, esta situación demostraba una inexistente política en materia de administración pesquera que incentivara la conservación. Las medidas no provenían de un manejo preventivo que estableciera vedas anuales para asegurar la preservación de los recursos, sino de pautas reactivas ante la urgencia de una situación que estallaba en las manos de los administradores de turno. Por eso señalaba el veterinario que, siendo las vedas excelentes herramientas "preventivas" que la Autoridad de Aplicación utiliza en determinadas estaciones vinculadas a la reproducción, al desove o al cuidado de juveniles, aplicadas en forma reactiva no hicieron sino demostrar una pésima administración que producía cambios sorpresivos en los planes de producción de empresarios y compromisos comerciales, a la par de desocupación en el sector (Lerena, 2009).

Lo cierto es que la disputa cruzada entre tipos de flota (fresqueros versus congeladores) se trasladó tanto al interior de la propia Subsecretaría de Pesca ${ }^{453}$ como dentro del CFP, organismo encargado de definir la política pesquera. Dentro de este consejo, el representante de la provincia de Buenos Aires, asumiendo la defensa del sistema fresquero, chocaba continuamente con la opinión de los representantes patagónicos que respondían a una visión más afín a los congeladores. De ahí que la disputa también adquirió matices regionales, expresados al interior del propio órgano de gobierno de la actividad. Por ello Litovsky (2000) dirá que el organismo padecía de parálisis política. ${ }^{454}$

Luego de un año de haber buscado el consenso para reducir el volumen de captura en el conjunto del sector pesquero, la cuestión había vuelto al inicio y el CFP fracasaba en consensuar cualquier

\footnotetext{
451 1) Resolución $N^{\circ}$ 4/98, Estado de Emergencia (01/07/1998); 2) Disposición $N^{\circ}$ 131/98, Veda Biológica (20/07/1998); 3) Resolución N 96/98, Parada de Buques (14/10/1998); 4) Resolución Nº 190/98, Veda Biológica (10/11/1998); 5) Resolución N 591/99, Emergencia Pesquera (01/06/1999); 6) Ley N²5.109, Emergencia Pesquera (24/06/1999); 7) Resolución N 354/99, Parada biológica (31/08/1999); 8) Resolución $\mathrm{N}^{\circ}$ 24/99, Emergencia Pesquera (30/12/1999); 9) Resolución $\mathrm{N}^{\circ}$ 189/99, Emergencia Pesquera (30/12/1999); 10) Resolución No 241/00, Emergencia Pesquera (18/05/2000); 11) Resolución N²65/00, Veda total arrastre (09/06/2000); 12) Resolución $N^{\circ}$ 52/00, Parada Biológica (08/02/2000); 13) Resolución N 145/00, Parada Biológica (31/03/2000).

${ }^{452}$ Litovsky aporta un dato interesante cuando señala que "En Canadá, con el colapso del bacalao en 1992, el gobierno declaró una veda, pero además destinó dos mil millones de dólares para hacer frente a la crisis social que generó el colapso, que en ese caso ascendía a 40.000 desempleados. En la Argentina, el anuncio del cierre del caladero no estuvo acompañado por un plan de reestructuración, ni por fondos económicos que acompañaran la decisión y le confirieran un carácter estratégico, ni por ninguna otra medida que significara una preocupación por el futuro del sector pesquero. En este contexto, aumentó aún más la racionalidad de los actores privados para oponerse a estas medidas aisladas" (Litovsky, 2000: 46).

453 "Los pasillos de la SAGPyA, mientras tanto, evidencian una disputa de poder por los espacios pesqueros". Revista Redes $\mathrm{N}^{\circ}$ 104, año 1998, "Límite de 300.000 toneladas para la captura de merluza", p. 6.

454، "La SAGPyA se mostró vinculada a los compromisos sectoriales, no pudiendo sostener una posición firme frente a éstos. La Secretaría de Recursos Naturales y Desarrollo Sustentable, la agencia menos comprometida con el tema y sin los costos políticos derivados de sus decisiones, tuvo la posición más orientada en favor del establecimiento de medidas conservacionistas. El Ministerio de Relaciones Exteriores mantuvo una posición neutral y las provincias se enfrentaron entre sí, principalmente organizadas en torno a dos polos: la provincia de Buenos Aires y la Patagonia. De esta manera, el debate fresqueros/congeladores se reprodujo en el seno del CFP" (Litovsky, 2000: 34).
} 
mecanismo de reducción. En cuanto a la estructura de gobierno del área, hacia finales del año 1998, Héctor Salamanco dejó su lugar de Subsecretario a Eduardo Auguste, mientras que Gumersindo Alonso se hizo cargo de la SAGPyA tras la partida de Solá para lanzar su candidatura a vicegobernador. Auguste había sido titular de CAPECA, y ahora tenía un sus manos la obligación de establecer un criterio de reducción de capturas junto con el CFP, lo que generó una profunda resistencia de la "convergencia marplatense" (ver capítulo IV). ${ }^{455}$ Auguste intentó confeccionar un programa orientado, según sus palabras, al equilibrio entre los tipos de flota, quitándole "dramatismo" al conflicto entre fresqueros y congeladores. Desde la ciudad de Mar del Plata expresó:

Ésta discusión empezó en el año 1978, y después convivimos siempre bien hasta que nos falló el recurso. Ahora inventar que la culpa es de aquel o del otro no sirve. Hay una gran capacidad de flota, se ha pescado mucho, pero si sabemos cuidar el recurso vamos a poder pescar todos y volver a convivir bien. ${ }^{456}$

El nuevo subsecretario se definía como uno de los hombres clave del presidente Menem. Oponiéndose a las demandas de los empresarios "fresqueros" y gremios marplatenses, indicó que no realizaría ningún tipo de diferenciación entre las flotas pesqueras, revelando que "cuando hay recursos pescan todos y cuando no, no pesca ninguno" 457 . Decía:

...todos los barcos que se dedican a la merluza, pescan con el mismo sistema de arrastre. La veda será para todos por igual, son las órdenes que tengo. La balanza será por igual y no habrá diferencias entre congeladores y fresqueros. Si debe hacerse un sacrificio lo harán todos [...] no creo que el mal que se ha hecho al caladero se cure tan rápido. Habrá paradas en diciembre y enero próximos de 30 días, tanto para fresqueros como para congeladores. Y cada empresa decidirá cómo fracciona y cumple con sus barcos esta veda. ${ }^{458}$

De este modo, el funcionario planteaba un escenario de padecimientos compartidos. Lejos de considerar que eso era justo, los fresqueros marplatenses se preparaban para un nuevo combate. Sin embargo, y a pesar de las oposiciones generadas entre la "convergencia marplatense", Auguste, rebajando sus pretensiones, logró la firma de un Acta de Coincidencias entre todos los sectores empresariales incluyendo a los fresqueros, que entre otras medidas, declaraba las vedas de 10 días para fresqueros y 30 para congeladores, dos veces en el año. ${ }^{459}$ Para el senador Osvaldo Sala (PJ) el acuerdo fue un golpe mortal contra la merluza. ${ }^{460}$ El propio Felipe Solá, desde su nuevo lugar en la arena política como

\footnotetext{
${ }^{455}$ Auguste era visto por los fresqueros marplatenses como el representante de los congeladores en el comando del área pesquera. Y sus gestos no eran nada simpáticos para los críticos de la política pesquera llevada hasta el momento. Por ejemplo, Héctor Salamanco, junto al CFP, se habían pronunciado a favor de denunciar el acuerdo con la UE, posición que se comunicó formalmente a la Cancillería. Al contrario Eduardo Auguste se encargo de retirar dicha comunicación y dentro de su gestión pretendió una renovación de aquellos acuerdos. Tal empresa se frustró cuando desde la propia Cámara de Senadores se promovió la denuncia y finalización de los mismos.

${ }^{456}$ L.C., $2 / 09 / 1998$.

${ }^{457}$ E.A., 3/09/1998.

${ }^{458}$ E.A., 3/09/1998.

${ }^{459}$ Según el cronista de la Revista Redes "El documento, además, reparte excepciones y toneladas con un criterio que alimenta las sospechas a propósito de los mecanismos utilizados para asegurarse la respuesta sectorial". Revista Redes, № 103, año 1998, "Un acta de coincidencias?", p. 7.

${ }^{460}$ L.C.,22/09/1998.
} 
candidato a vicegobernador por la provincia de Buenos Aires, se diferenció de las medidas implementadas por Auguste, señalando que se debía cumplir la ley y llevar adelante una política que genere puestos de trabajo y conserve el recurso. ${ }^{461} \mathrm{Y}$ el diputado, también justicialista, José Luis Castillo manifestó que "esa acta es una repartija del mar, entre todos los sectores que quieren ir a rapiñar hasta que se acabe el recurso"462. Lo cierto es que las medidas dispuestas por el nuevo subsecretario no fueron suficientes para frenar la sobrepesca. Y por ello anunció en diciembre, que para el año próximo, se produciría una reducción de 120 mil toneladas en la captura de merluza (sobre las 420 mil capturadas en 1998) y la prohibición de que los buques congeladores, que no poseyeran plantas en tierra realizaran su actividad sobre el paralelo 48 y dentro de las 180 millas marinas. A pesar de que se le ponían algunas restricciones a la operatoria de los congeladores la medida fue duramente cuestionada por los fresqueros marplatenses, que tras movilizarse nuevamente a Capital Federal, consiguieron la sanción de la Ley $\mathrm{N}^{\circ}$ 25.109 de Emergencia Pesquera (el proceso de movilización se analiza en el capítulo IV). Esta ley, amparada en la difícil situación social de la comunidad pesquera marplatense, declaraba la emergencia de la merluza hubbsi, planteaba levantar la veda para los fresqueros y obligaba a los congeladores a pescar al sur del paralelo 48, en la provincia de Santa Cruz. Y en el primer artículo del decreto que reglamentó la ley, el presidente Menem estableció la dotación de 50 mil toneladas de merluza por encima del límite de la CMP. La medida carecía de todo tipo de justificación conservacionista y generó opiniones encontradas y conflictos al interior del CFP que, sin embargo, terminó refrendando el otorgamiento. ${ }^{463}$

Finalizando el gobierno de Carlos Menen, en reemplazo de Gumersindo Alonso, asumió la conducción de la SAGPyA Ricardo Novo. Durante su gestión, se intentó volver a sancionar una veda "equitativa" en la reducción de los volúmenes de pesca, la cual fue rechazada por la "convergencia marplatense". Después continuaron los intentos por aplicar algún tipo de veda y las resistencias, particularmente generadas en Mar del Plata. Incluso el propio presidente Menem, ante el pedido formulado por esposas de pescadores, solicitaba al CFP que no se cerrara el caladero. ${ }^{464}$ Por otra parte, a partir de un decreto de necesidad y urgencia se prorrogó por cuatro años el régimen de charteo. Y luego no habría tiempo para mucho más. Jorge Cajal, designado primero como interventor en el INIDEP y luego como subsecretario de Pesca, explicó que utilizaría su gestión en el gobierno para encaminar el sector pesquero de manera que hay "una continuidad no traumática con el próximo gobierno" ${ }^{465}$. Poco después exponía el dilema: “...el futuro es crítico y uno tiene que sopesar el tema biológico, que está indicando que hay que cerrar el caladero, y lo social y económico, que dice que el cierre del caladero puede traer conflictos" ${ }^{\prime 46}$. Llegaba luego el turno de La Alianza en la conducción del país y en la definición de una política pesquera.

\footnotetext{
${ }^{461}$ L.C., 25/09/1998.

${ }^{462}$ Revista Redes, №103, año 1998, “A la capa”, s/p.

463 “...las milagrosas 50.000 toneladas sólo buscan descomprimir la coyuntura y ganar tiempo hasta fin de año". Mientras, los congeladores de empresas con plantas en tierra, a pesar de la Ley de Emergencia, continuaron pescando al norte del paralelo 48 mediante recursos de amparo y otras medidas judiciales. Revista Redes N108, año 1999, "Milagro en el Atlántico Sur", p. 7.

${ }^{464} \mathrm{La}$ situación expresaba todo el drama que vivían las familias de trabajadores y trabajadores vinculadas con la industria pesquera. Al arribo del presidente Menem al Hotel Sheraton de Mar del Plata, un grupo de mujeres lo interceptó para pedirle que no se cerrara el caladero.

${ }^{465}$ L.C., $21 / 08 / 1999$.

${ }^{466}$ L.C.,09/10/1999.
} 


\section{La Alianza y su administración de la pesca}

"La señal que el gobierno envió durante 1999, era que no tenían la menor idea de qué hacer ante el colapso inminente"

Alejandro Litovsky, 2000

“...sólo Cristo podría resolver el problema multiplicando los peces. Y ni Berongharay ni Cabirón son Cristo, no pueden multiplicar la merluza..."

Ricardo Alfonsín, diputado provincial por La Alianza, 2000

Hemos visto cómo se desplegó la política pesquera durante la administración Menem. Repasemos. El proyecto de carácter industrial, con un mayor proceso en la elaboración de productos basado en la pesca con fresqueros y el procesado en las plantas en tierra, y con una perspectiva de desarrollo del mercado interno, sintetizado en el plan elaborado por César Lerena, pronto quedó sepultado por el desarrollo de otras políticas. En principio, más que un conjunto de ideas acabado sobre qué hacer con la actividad pesquera, pensamos que el conjunto de medidas se fueron aplicando sobre la marcha, determinadas por una orientación general de la política económica del gobierno tendiente a la apertura externa en el marco de la crisis fiscal del Estado. Lo cierto es que el gobierno buscó mejorar las perspectivas exportadoras en un contexto de paridad cambiaria y potenciar vínculos con las potencias internacionales. El resultado ya lo conocemos. En cuanto al gobierno de La Alianza, recibía una pesada herencia de problemas irresueltos. En lo específicamente pesquero, es difícil señalar que haya existido una política pesquera. De entrada, el margen de maniobra del nuevo gobierno era francamente escaso. ${ }^{467}$ Un espiral de crisis corroía cualquier capacidad de iniciativa, sobre todo si en la intensión de los nuevos gobernantes no se incluía la de realizar cambios profundos. Mientras, se multiplicaban los conflictos determinados por la escasez de recursos.

Dos eran las ventajas del gobierno aliancista. Por un lado contaba con una legislación pesquera y el funcionamiento de un organismo como el Consejo Federal Pesquero, pudiendo fomentar que la carga de decisiones no recayera solamente en la figura del subsecretario del área. En el contexto de crisis y con nuevas instancias institucionales, la existencia de un CFP podía significar el final de políticas unilaterales del subsecretario de pesca o de cualquier otra área del Estado (como hemos visto sucedió con la Cancillería durante la gestión de Cavallo). Aunque la ventaja se reducía porque, como hemos señalado, los conflictos corroían la propia capacidad del CFP de definir una política pesquera. Recordemos que se encontraba paralizado el mecanismo de asignación de cuotas de captura $y$, precisamente, era el desacuerdo en la forma de repartir los recursos lo que alentaba la conflictividad. En la práctica, un Consejo inmovilizado no era de gran ayuda y, en todo caso, hasta podía generar un nivel más de tensión en su relación con el Subsecretario de Pesca. El punto a favor de la nueva gestión en relación a los

\footnotetext{
${ }^{467}$ Recordemos que recibía como herencia de la última etapa menemista una buena cantidad de problemas entre los que se destacaban la inestabilidad de los flujos de inversión externa (originada tanto en factores internacionales como en la desconfianza respecto de la solidez de la economía argentina y la capacidad de repago de su deuda), débil crecimiento de las exportaciones, ciclos recesivos pronunciados, altos índices de pobreza y de desocupación (que no bajaban del 14\% desde 1995), fuertes tensiones entre la nación y las provincias en torno a la distribución de los recursos de coparticipación, el manejo del déficit y el endeudamiento, dificultades del gobierno nacional para contar con mayorías en el Congreso (Novaro, 2001).
} 
recursos era la denuncia y finalización del acuerdo con la UE. Lo que redundaba en una existencia menor de buques operando en el caladero nacional. Sin embargo, esta ventaja "biológica" repercutió en los intereses de la flota pesquera nacional, debido a que la UE como reacción al "abrupto" final del entendimiento, y a pesar de que se encontraba desarrollando una política más bien aperturista debido al déficit de productos pesqueros que mantenía, incrementó los aranceles de importación para los productos provenientes de la Argentina. ${ }^{468}$

Sin embargo, lo que estaba claro al iniciarse el nuevo gobierno es que se encontraba de lleno con una crisis pesquera, una álgida conflictividad social, un CFP que tras un año y medio de funcionamiento estaba preso de una parálisis, un escaso respaldo para las decisiones que se adoptaren, una nueva trasgresión al límite de captura sugerido por el INIDEP y un estado financiero que, a priori, no permitía iniciar un necesario proceso de contención social en caso de aplicarse una verdadera restricción de las capturas. ${ }^{469}$ Para entonces la situación de los trabajadores y las trabajadoras, particularmente quienes se desempeñaban en las plantas de fileteado, era poco menos que dramática. En ese contexto surgió la Unión Obrera del Pescado (hablamos con detalle de esta organización en el capítulo IV) y con ella el reclamo de un subsidio de 500 pesos por trabajador/a ante la situación de desempleo que afectaba a la pesca. Dicho reclamo era respaldado por la organización no gubernamental CEDEPESCA, que manifestó la necesidad de que el Estado destine al sector pesquero un subsidio, señalando que si bien el flamante gobierno de Fernando De la Rúa "no es responsable" de la actual situación, si "está obligado a resolverla". La entidad argumentaba "Los trabajadores tienen derecho a exigirle al Estado que, así como ahora comenzará a cuidar los recursos naturales, cuide también los recursos humanos [...] ese cuidado tiene un nombre: subsidios. No existe otra posibilidad". En tanto se precisaba un subsidio de 500 pesos por mes que afectaría a 8 mil trabajadores, la cifra sería de 50 millones de pesos por año. ${ }^{470}$

La llegada de La Alianza al poder implicó una reestructuración de la administración pesquera. Antonio Berongharay fue designado a cargo de la SAGPyA. ${ }^{471}$ Mientras que la Subsecretaría retrocedió al

\footnotetext{
${ }^{468}$ A su vez, la UE interrumpió el envío de fondos previsto en el acuerdo, suspendiendo el pago cuando faltaba abonar alrededor de 6 millones de dólares.

${ }^{469}$ Por aquellos días el gobierno buscó concretar un crédito con el Banco Mundial que le permitiera contar con fondos para subvencionar una reestructuración de la pesca. La cuestión fue planteada por el Director Nacional de Pesca luego de sancionar una parada biológica. El funcionario anunció que la medida de restricción de la pesca sería acompañada por una red de contención social con el fin de atenuar el impacto económico que provocará la veda. "Nosotros somos conscientes del impacto social que esto va a provocar y por eso hoy mantuvimos una reunión en el Ministerio de Trabajo para analizar la implementación de medidas para aumentar la contención social que se está llevando a cabo en Mar del Plata". Entre las distintas iniciativas de contención social, se analizaba la posibilidad de otorgar subsidios, “aunque también se está considerando la opción de tomar un crédito del Banco Mundial por 50 millones de pesos". Una parte de este préstamo se destinaría a "ayudar a los trabajadores y otra para tratar de lograr una solución de fondo, sobre la base de la reconversión de la flota y la industria". Uno de los objetivos de la reconversión sería modificar los buques para cambiar de especie objetivo. L.C.,08/04/2000. Sin embargo, aquella opción no llegó a concretarse. Previamente, en junio de 1999 el senador Osvaldo Sala había presentado un proyecto de ley que ante la grave situación del sector pesquero, buscaba propiciar la contención social y la reconversión pesquera. En el proyecto se autorizaba al gobierno nacional a tomar créditos por la suma de hasta 600 millones de dólares para repartir, 300 millones para subsidios por desempleo y capacitación, 100 millones para la creación de partidas presupuestarias destinadas a la reconversión industrial, 200 millones para la compra de permisos de pesca vigentes a fin de reducir el esfuerzo pesquero sobre el recurso.

${ }^{470}$ L.C.,11/01/2000. Explicaba CEDEPESCA que "Si estos 50 millones no se gastan en forma ordenada, se gastarán de todas formas a través de asistencia social, atención médica, remendando parches, apagando incendios. Se gastan para reforzar la esperanza o se gastan para tapar la desesperación".

${ }^{471}$ También la subsecretaría de Pesca de la provincia de Buenos Aires cambiaba de manos. A Sergio Lorusso lo reemplazó el armador Francisco Romano.
} 
rango de Dirección Nacional de Pesca, cuyo titular pasó a ser Juan Carlos Cabirón ${ }^{472}$. Berhongaray, que por la disolución de la Subsecretaría de Pesca se convertía claramente en el encargado más directo del área, había expresado a su llegada al gobierno que si bien estaban realizando informes para determinar la cantidad de recurso disponible, el panorama era sombrío. ${ }^{473}$ Además, criticó enérgicamente al gobierno anterior, acusándolo de haber cometido abusos y actuado con nula transparencia, lo que provocó la crisis del caladero. Y denunció que sus antecesores "concedieron autorizaciones de pesca con una importante cuota de corrupción" ${ }^{474}$. Una de las primeras medidas de la nueva gestión, mediante el decreto $\mathrm{N}^{\circ} 189$, fue la renovación de la declaración de la Emergencia Pesquera "mientras se mantengan las causas que la motivan" $"$. La resolución eludía la instancia de discusión en el CFP, dejando en un incierto lugar el funcionamiento del organismo. Aquel gesto fue leído como una toma de postura a favor del sistema fresquero, pues recordemos que la Emergencia establecía limitaciones para la operatoria de buques congeladores, y por eso se opusieron el CEPA, CAPECA, CAPIP y CALAPA (Cámara Langostinera Patagónica), quienes recurrieron a recursos de amparo para continuar pescando. ${ }^{476}$ Como consecuencia, continuaba una presión desmedida sobre el recurso merluza. Convertido en el primer mandatario que visitó la Fiesta Nacional de los Pescadores realizada en Mar del Plata, Fernando De la Rúa realizó declaraciones que se dirigieron a criticar la política pesquera del gobierno anterior y a sostener una posición de carácter nacionalista respecto del aprovechamiento de los recursos pesqueros. Concretamente De la Rúa lamentó "convenios internacionales que entregaron nuestro mar y sometieron a la industria naval, llevando a la dificultad y a la crisis a nuestros astilleros. Hay una consigna muy clara que surge de este encuentro, y es la necesidad de defender el trabajo de los argentinos y la riqueza argentina para los argentinos" ${ }^{\prime 77}$. Mientras, las nuevas campañas del INIDEP arrojaban malas noticias para la gestión aliancista: los stocks de merluza disponible no cesaban de disminuir. En la Semana Santa, Juan Carlos Cabirón renunció. Según La Nación porque "no quiere ensuciarse y terminar con problemas legales" ${ }^{478}$. Luego, en el marco de la profundización del ajuste estatal, eran los pescadores quienes recibían un negativo mensaje al enterarse de que por la resolución $\mathrm{N}^{\circ} 257$ el Ministerio de Economía recortaba los reintegros a las exportaciones, al mismo tiempo que aumentaba el precio del combustible. A Cabirón le sucedió Horacio Rieznik, ingeniero industrial que se había desempeñado como director de Alpesca, la pesquera del grupo Alpargatas. Tras su asunción, el funcionario habló de "formular un plan estratégico de mediano y largo plazo", además de mencionar la necesidad de una reconversión que "permita lograr más dinero por menos volumen", y el estímulo de la acuicultura. ${ }^{479}$ Se buscó implementar un sistema más

\footnotetext{
472 J.C. Cabirón no tenía mayores antecedentes en el área pesquera. En su curriculum contaba con dos intendencias en la ciudad de Bahía Blanca y al momento de asumir en la Dirección de Pesca se desempeñaba como legislador bonaerense.

${ }^{473}$ L.C., 17/12/1999.

${ }^{474}$ L.C., $03 / 01 / 2000$.

${ }^{475}$ Revista Redes, $\mathrm{N}^{\circ} 111$, año 1999, "Los primeros pasos”, p. 6.

${ }^{476}$ Por ejemplo, Ernesto Azpillaga de CALAPA señaló: "Por un esquema histórico, los pescadores de Mar del Plata poseen la hegemonía de la actividad, pero por comodidad nunca quisieron invertir más allá de su ciudad y ahora que la merluza se acabó quieren cargarse con la nuestra". Y consideró que no debían realizar discriminaciones por tipo de flota, dado que "Toda la flota argentina cometió errores, hay que sincerar las cosas". La Nación, 06/06/2000, "Pesca: sigue el descontento", en línea: http://www.lanacion.com.ar/19695-pesca-sigue-el-descontento, visitada el 4 de abril de 2012.

${ }^{477}$ Revista Redes, $\mathrm{N}^{\circ} 111$, año 1999, "De la Rúa pescador", p. 7.

${ }^{478}$ Revista Redes, $\mathrm{N}^{\circ} 112$, año 1999, "En terapia intensiva”, p. 22. El funcionario adujo agotamiento laboral, sumado a presiones. Y denunció un "entorno de corrupción" en el manejo pesquero.

${ }^{479}$ Revista Redes, N 113 , año 2000, "Bienvenido", p. 6.
} 
eficiente de control de capturas, poniendo en funcionamiento el MONPESAT ${ }^{480}$ e incorporando el mayor número de embarques de observadores científicos del INIDEP (Godelman et al, 2004). De todos modos, el gobierno no pudo avanzar en el sistema de cuotificación que preveía la Ley de Pesca.

A pesar de los mayores controles los informes del INIDEP continuaban desairando cualquier posibilidad de continuar con el ritmo de pesca, por lo que la Secretaría se vio en le necesidad de volver a declarar una veda en el mes de febrero del año 2000. La decisión se tomó dado que en poco menos de un mes y medio se superaron las 24 mil toneladas de merluza fijadas para tres meses. La reacción de la "convergencia marplatense" fue inmediata y comenzaron las gestiones y movimientos para hacer retroceder la medida, la cual no incluía ningún tipo de programa de contención social que la pudiera sostener y acompañar. La iniciativa permitía reconstruir la Multisectorial en Defensa de la Pesca Argentina, que finalmente logró una reducción de los días en que los buques fresqueros debían permanecer parados. ${ }^{481}$ Pero, dado que no mermaba el esfuerzo pesquero, la situación crítica de los recursos se mantenía invariante. Entonces de nuevo en abril el gobierno se vio en la necesidad de declarar otra parada biológica, que nuevamente fue combatida por la Multisectorial que realizó su tercera movilización a Capital Federal (analizamos este proceso en el capítulo IV). Berhongaray, por su parte, cada vez que podía reiteraba la responsabilidad del gobierno de Menem en la depredación de la merluza y explicaba que "hemos distribuido la pesca dándole preferencia a los barcos más pequeños, denominados 'fresqueros' aquellos que más actividad económica generan y más mano de obra ocupan, y que en su mayoría están en Mar del Plata"482.

Pero no sólo la situación pesquera complicaba la situación del gobierno, sino más bien una crisis global envolvía a La Alianza que sólo atinaba a profundizar las políticas de ajuste. ${ }^{483}$ Tras poco más de un año de gestión de gobierno aliancista, tanto el CEPA como la CAABPA y los Procesadores, organizaron cada uno reuniones de camaradería festejando el fin de año. ${ }^{484}$ Desde cada una de ellas, los empresarios pesqueros realizaron balances de gestión. Por el lado del CEPA, Oscar Fortunato brindó un discurso marcadamente crítico. "La inseguridad jurídica reina en la actividad pesquera argentina" y "La imprevisibilidad impera en las decisiones administrativas". Se quejó de las restricciones a la operatoria de buques congeladores, así como de los costos financieros, de los insumos y los impuestos, a los que consideró distorsivos. Como era de esperar, contrario fue el mensaje de la CAABPA y los Procesadores. Aún cuando hizo mención a que fue "sin lugar a dudas el año más difícil en toda la actividad pesquera" citando el paro de actividades de más de 100 días que dejó en situación comprometida al sector, Ricardo Angeleri elogió la gestión gubernamental tanto municipal, como de la SAGPyA y la conducción del

\footnotetext{
${ }^{480}$ Este servicio de monitoreo satelital volvió cortarse por falta de pago a la empresa proveedora a comienzos del año 2002 . Y desde mayo de 2001 no hubieron más embarques de observadores por falta de presupuesto.

${ }^{481}$ La veda había sido declarada por 30 días y solamente se realizó durante 12 días.

${ }^{482}$ L.C.,06/05/2000. En relación a las críticas respecto del gobierno anterior señaló "La situación de la pesca en todo el mar argentino es muy grave, producto de diez años de depredación y corrupción, donde la principal especie ictícola, la merluza, ha sido colapsada y está en franco camino a desaparecer, si es que no tomamos una serie de medidas de protección de aquí a dos años". Más tarde el propio Berhongaray informó que presentó denuncias penales en contra de todos los funcionarios que para él estuvieron vinculados en la depredación de la merluza.

${ }^{483}$ La "crisis argentina" se compuso por un conjunto de crisis que ocurrieron al mismo tiempo: crisis económica (agravamiento de la recesión), crisis financiera (huida de capitales, explosión del riesgo país, corrida bancaria), crisis social (aumento del desempleo y crecimiento de la pobreza) y varias crisis políticas (renuncias del vicepresidente, varios ministros y finalmente la caída del gobierno) (Gervasoni, 2002).

${ }^{484}$ Para esta altura, las empresas Moscuzza, Solimeno y Valastro, recordemos, se habían alejado de la conducción de la CAABPA para sostener sus propias posiciones desde el CEPA. Por ello, la posición de la CAABPA fue por estos años la de los fresqueros marplatenses, particularmente enemistados con aquellos tres grupos empresarios.
} 
Ejecutivo Nacional, mencionando también al senador Leopoldo Moreau y hasta al gobernador justicialista Carlos Ruckauf. Y, por supuesto, saludaba la decisión de prorrogar la Emergencia Económica que permitía continuar la pesca con los fresqueros. ${ }^{485}$ En su balance, Ricardo Angeleri decía: "El año que estamos despidiendo ha sido sin lugar a dudas el más dificil en toda la historia de la actividad". Se trato de "un período que se ha caracterizado por incertidumbre, marchas, contramarchas, paradas biológicas, recambio de funcionarios, restricciones y un paro de actividades de más de 100 días que dejó en situación hartamente comprometida al sector" y que "no será fácil de olvidar" ${ }^{486}$.

Para septiembre del año 2000 se alcanzaron las 110 mil toneladas de captura establecidas como CMP para todo el año. Por ello, y de nuevo arbitrariamente, la SAGPyA dispuso habilitar la pesca de 30 mil toneladas más de merluza. La medida provocó la reaparición de "ruidos" entre las flotas pesqueras. Los fresqueros volvían a quejarse, esta vez porque la decisión no excluía a los congeladores. Y el año finalizó con un intento del ahora asesor de la Dirección Nacional de Pesca, Ernesto Godelman, de establecer un sistema de manejo pesquero que buscaba regular los volúmenes de pesca reglamentando la cantidad de cajones que cada buque podía ingresar a puerto, sistema que logró generar nada menos que el rechazo en conjunto de todas las cámaras pesqueras de Mar del Plata. ${ }^{487}$

Ya en el año 2001 el caladero dio algunas señales que indicaban una posible recuperación. Berhongaray se entusiasmaba con la posibilidad de elevar el límite de captura de las 110 mil toneladas a casi el doble. Rieznik anunció que se esperaba una captura de 150 mil toneladas de merluza, bajo un sistema doble de distribución de los recursos pesqueros. En la primera mitad del año 2001 se pescaría tradicionalmente, mientras que el segundo semestre comenzaría a implementarse el proceso de cuotificación. Sin embargo, tal cuotificación no se produjo. Tampoco, por la resistencia de todos los sectores pesqueros, avanzaría la intención de cobrar un derecho de extracción por pesca. Y la situación económica general se encerraba en una creciente crisis recesiva. ${ }^{488}$ Para la Revista Redes ya era alarmante la ausencia de políticas pesqueras que mostraba la administración delarruísta. ${ }^{489}$ Encima en marzo se desjerarquizaba la SAGPyA, pasando a ser una subsecretaría dentro de la Secretaría de Producción. En el mismo momento se le pidió la renuncia a Berhongaray. Ante ello, la CAABPA pasó del apoyo más o menos decidido a la fuerte crítica. En palabras de Ricardo Angeleri, con la degradación del área no existen dudas sobre cuál "es el rol que piensa asignarle a partir de ahora el gobierno a toda la producción". En la opinión del empresario, las recientes medidas demostraban que éste es un tema que no les interesa ni les importa desjerarquizar. A su entender "el único sector privilegiado [por el gobierno] en este momento es el financiero" ${ }^{\$ 90}$. Al mismo tiempo, el gobierno renovaba acuerdos de charteo para la

\footnotetext{
${ }^{485}$ Revista Redes, № 116, año 2001, "Fin de año en Mar del Plata", p. 34.

${ }^{486}$ L.C.,24/12/2000.

${ }^{487}$ El intendente Aprile expresó en esa oportunidad que "Las absurdas resoluciones de Rieznik lograron lo que parecía imposible: que se juntaran congeladores y fresqueros para protestar en conjunto".

${ }^{488}$ En diciembre del año 2000 la UCIP elaboró un comunicado donde planteaba la situación de las empresas locales, víctimas de una "profunda recesión". En él expresaba su "honda preocupación por la profundización de la incertidumbre de los sectores productivos, cada vez menos competitivos y empobrecidos, la creciente desigualdad y el inminente peligro de la degradación social, a raíz de una crisis económica sin precedentes y un gobierno incapaz de resolverla, inserto en una más grave crisis política que no puede superar". L.C.,10/12/2000. Días más tarde se conocía que el índice de desocupación en la ciudad llegaba al 20,8\%, lo que colocaba a Mar del Plata en el primer puesto de las ciudades con mayor índice de desempleo del país. Con estos índices, el Intendente Elio Aprile reconoció que la inactividad pesquera fue de uno de los principales motivos de la alta tasa de desempleo. Concretamente aseguró que "no nos debiera sorprender, con 100 días de la pesca parada no podría lograrse otro resultado en este incremento de la desocupación”. L.C.,16/12/2000.

${ }^{489}$ Revista Redes, $\mathrm{N}^{\circ} 117$, año 2001, "Vivir en la cornisa", p. 6.

${ }^{490}$ L.C., $11 / 03 / 2001$.
} 
captura del calamar, bajo las críticas de gremios y al apoyo de empresarios. Poco después Cavallo volvería al ministerio de Economía y de su mano, Marcelo Regúnaga a la SAGPyA (ahora nuevamente rejerarquizada). Con un alto grado de confrontación con este último, Julio Melgarejo ocupaba la Subsecretaría de Pesca. En abril se habilitaba un corredor marítimo de 30 millas entre la milla 170 y la milla 200 denominado Área Especial de Pesca en el Atlántico Sur. Mediante él, los congeladores podían pescar cualquier especie, salvo merluza, pero se aceptaba la pesca incidental de este recurso. Lo que generó el rechazo de los fresqueros.

Pero ya no había tiempo para mucho más. Sólo algunos intentos por elaborar un plan de competitividad; reclamos de los industriales pesqueros por el atraso cambiario y los altos aranceles de países como Venezuela, México y también la Unión Europea para importar productos; críticas por el elevado precio del combustible; a lo que se sumaban las tensiones recurrentes entre los tipos de flota. ${ }^{491}$ Además, los cortocircuitos entre el secretario de la SAGPyA y el subsecretario de Pesca, dado que el primero, con la oposición del segundo, volvió a renovar un convenio de charteo con pesqueros japoneses (proyecto del que finalmente se dio marcha atrás). ${ }^{492}$ Mientras, crecían los niveles de conflictividad social. En ese marco, la gestión aliancista se evaporaba tras la movilización popular de diciembre de 2001 que no sólo implicó la expulsión de un gobierno elegido tan sólo dos años antes, sino también la pérdida de varias vidas humanas. ${ }^{493}$ El año 2002 vendría con cambios para la industria pesquera, dominados por el proceso devaluacionista y una cierta recuperación de los stocks de pescado. Pero eso ya forma parte de otra historia.

En 1989 César Lerena editaba La Industria Pesquera Argentina: reafirmación o decadencia. Allí realizaba, como vimos, un diagnóstico de la actividad e identificaba líneas de acción para el desarrollo futuro. Él, junto a buena parte del empresariado fresquero y al sindicato del SOIP, colaboró de forma estrecha para llevar a Carlos Menem a la presidencia. Con la victoria del FREJUPO el camino de la "reafirmación" parecía asomar. Abdul Saravia, por aquellos días, se sentía orgulloso. De nuevo, luego del Proceso de Reorganización Nacional y de una gestión radical que deploraba, el proyecto industrial pesquero que el sindicalista identificaba con el desarrollo nacional pasaría a la ofensiva de la mano del peronismo en el gobierno. Por eso se permitía, a los pocos días de la victoria de Menem, denunciar la corrupción del gobierno radical y enfrentar a empresarios que consideraba antinacionales, al mismo tiempo que se preparaba para impulsar el Proyecto Nacional Pesquero. Y no era otro que César Lerena quien conduciría una política pesquera verdaderamente nacional. Pero aquello, visto lo que ocurrió después, parece el sueño de algún trasnochado. Veinte años más tarde, en el 2009, Lerena publicaba un nuevo libro sobre la industria pesquera. Al abrir el texto, en la página 5, se ve una foto de Felipe Solá ${ }^{494}$,

\footnotetext{
${ }^{491}$ Lo que incluyó una fuerte desazón de los fresqueros marplatenses ante la sanción del decreto $\mathrm{N}^{\circ} 25.45$ que reinstalaba los reintegros a las exportaciones realizadas al sur del Río Salado.

492 Melgarejo llegó a declarar que sospechaba que detrás de este tipo de acuerdos pueden existir "favores especiales" a "funcionarios". L.C.,28/10/2001.

${ }^{493}$ Algunos de los textos que se refieren a ese proceso enfocados desde la conflictividad y la protesta social son Astarita (2002), Auyero (2002), Colectivo Situaciones (2002), Delamata (2002), Fradkin (2002), Lobato y Suriano (2003), Zibechi (2003), Svampa y Pereyra (2003), Iñigo Carrera y Cotarelo (2004) y Shuster et al (2006).

${ }^{494}$ A quien Lerena menciona como "el más destacado desleal".
} 
debajo de la cual se cita una frase pronunciada por el ex funcionario: "En mi gestión comenzó la depredación".

En Reafirmación o Decadencia... Carlos Menem iniciaba el texto firmando el prólogo. Aquí también es el riojano quien tiene un lugar privilegiado. Lerena decide comenzar el libro reproduciendo el texto de su renuncia indeclinable a la Secretaría de Estado, Asesoría de la Presidencia, en diciembre de 1990. El destinatario de la renuncia era precisamente el presidente Menem. A tan sólo dos años de la victoria del FREJUPO, la letra de la renuncia denunciaba la explotación irracional de los recursos, la falta de una política de desarrollo industrial, la subordinación y dependencia a los objetivos de la Cancillería. Dirá que "la actividad pesquera sufrió la intervención de la Cancillería", y el "...accionar de la Cancillería confirma la convicción de que la pesca es una moneda devaluada de cambio en el manejo de Cavallo de los intereses internacionales". En relación a la estructura de toma de decisiones indicaba que "La Pesca es, en la preocupación del responsable del área, la prima pobre y fea de su gestión" (Lerena, 2009:15). Y argumentaba que la orientación de la política pesquera fue "contraria al interés nacional" al volcarse solamente hacia actividades extractivas no industriales y a la explotación de los recursos por parte de embarcaciones extranjeras. Por último indicaba que la "aplicación de 'políticas de economía de mercado' en la pesca, se tradujeron en la Argentina, en la apertura del mar a las flotas extranjeras. Un despropósito en un país que tiene flota e industria propia" (Lerena, 2009: 22).

En definitiva, aquel recurso de propiedad común, que administraba el Estado y que en las expectativas de Lerena y de tantos otros debía fomentar un proceso de desarrollo industrial, generando puestos de trabajo y participando de la recuperación de la soberanía marítima, terminaba la década en el marco de una profunda crisis de sobre pesca, afectando las condiciones de vida y trabajo de los obreros y obreras de la rama (cuando no expulsándolos directamente como trabajadores) y con altísimos niveles de conflictividad social. 


\section{CAPÍTULO III}

Proceso de trabajo, relaciones salariales y conflictividad laboral

en la industria pesquera marplatense

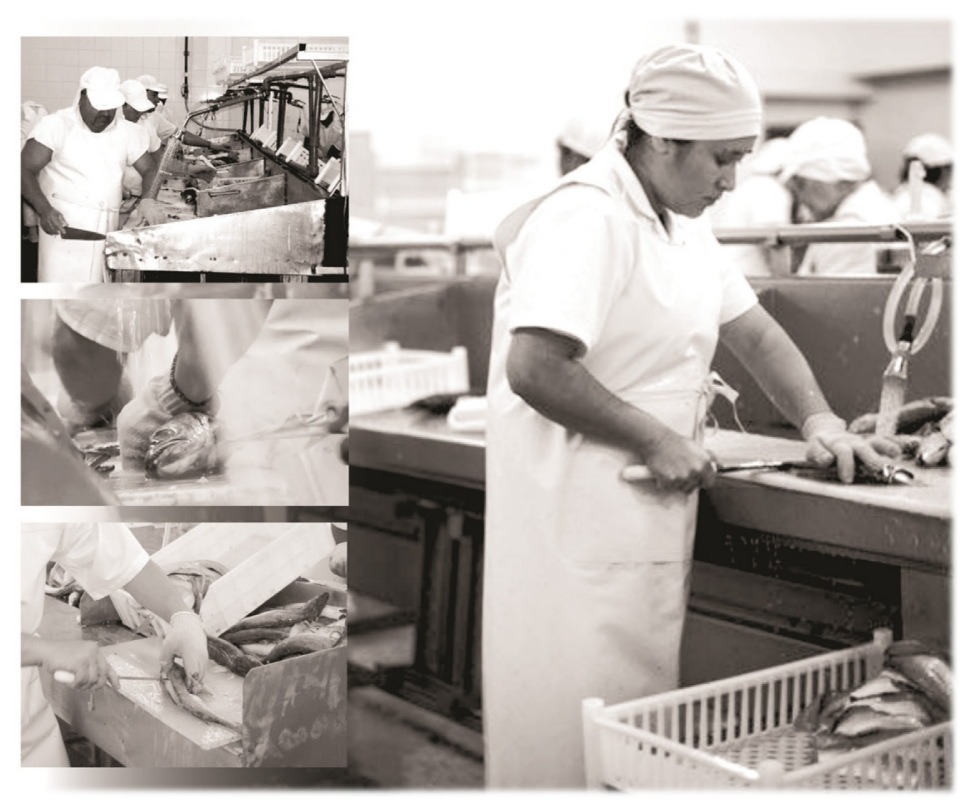




\section{Introducción}

En el proceso productivo, desde la perspectiva del capital, los trabajadores y trabajadoras son considerados como factores de producción o mercancías de las cuáles se deben extraer beneficios. Pero, como sabemos, se trata de una mercancía "peculiar" que nunca se somete completamente a aquel proceso. Si por un lado el obrero (y la obrera) garantizan el funcionamiento del proceso productivo, lo hacen portando un conjunto de nociones y valores que se expresan en, al mismo tiempo que en parte se producen desde, el espacio de trabajo. Esta es una de las razones por las que el estudio del proceso de trabajo ${ }^{495}$ se "ha convertido en una herramienta conceptual y metodológica imprescindible para los historiadores que quieren comprender las actitudes, comportamientos y valores obreros en las fábricas" (Dicósimo, 2009). En principio, y como contrapartida de las interpretaciones en su tiempo dominantes y que tendían a acentuar que la insatisfacción laboral estaba desapareciendo como problema social hacia mediados del siglo XX, desde una perspectiva marxista Harry Braverman en su texto clásico Trabajo y capital monopolista (1975) se dirigió a recuperar la perspectiva de Marx en el análisis del proceso de producción, considerando necesario estudiar fenómenos como la reducción del trabajo cualificado, las estrategias patronales para controlar a los trabajadores y la extensión y carácter de la resistencia de éstos a dichas estrategias (García Calavia, 1999). Para Braverman el capital monopolista llevaba a la creciente degradación del trabajo y a la tendencia a la baja en las cualificaciones, tendiendo a la progresiva simplificación de la actividad laboral. Poco después, con Burawoy (1989[1979]) los procesos de carácter más estructural dejaron paso a la indagación sobre los mecanismos de generación de consentimiento en los espacios productivos. ${ }^{496}$ Es decir la pregunta acerca de cómo participaban los trabajadores en su propio sometimiento. Pues solamente apelando a mecanismos de coerción no era posible garantizar el funcionamiento eficaz de la realización laboral, por lo que ponía el eje en el tándem consentimiento/conflicto. ${ }^{497}$ Burawoy entendió que a través de lo que definió como "el juego de arreglárselas" los intereses de los trabajadores se individualizaban y convergían con los de la gerencia, a través de distintos mecanismos mediante los cuales el trabajador se acomodaba dentro de las estructuras de producción capitalistas. Postulando el surgimiento del conflicto laboral como intrínseco al vínculo capital - trabajo, las discusiones quedaban marcadas en torno a sí el antagonismo podía ser armonizado, podía eludirse o si era disfuncional. En Argentina, el Ceil Piette ha realizado diversas contribuciones al estudio de los procesos de trabajo. En particular Julio C. Neffa buscó reflexionar sobre la relación existente entre los procesos de producción, de salarización y de acumulación del capital (Neffa, 1990). Asimismo, reconociéndose en la herencia de Braverman, con mayores o menores relaciones críticas hacia este autor, tanto desde el PIMSA como desde el CEICS se enfatizó el análisis del proceso de trabajo, apuntando a reconsiderar el valor explicativo de categorías tales como cooperación simple, manufactura y

\footnotetext{
495 "El proceso de trabajo es el acto específico donde la actividad del hombre efectúa, con la ayuda de sus medios de trabajo, una modificación voluntaria de los objetos y materias primas de acuerdo con un objetivo. La materia prima cambia así de forma y deviene un producto o bien que tiene un valor de uso" (Neffa, 1990: 22). Este autor considera que la noción de proceso de trabajo sigue siendo clave para explicar y entender la evolución del régimen de acumulación de capital.

${ }^{496}$ Un estado del arte puede leerse en el citado texto de García Calvia.

${ }^{497}$ En oposición a lo que definía como concepción tradicional, es decir, aquella noción según la cual son las actitudes, creencias, teorías (conciencia) adquiridas en el seno de la familia, la escuela, la iglesia, etc., las que determinan las relaciones y actividades del proceso productivo, la tesis principal de Burawoy sugiere que el consentimiento necesario para el encubrimiento y el aseguramiento de la plusvalía se genera en el lugar de la producción y no en un ámbito externo al centro del trabajo.
} 
gran industria para ilustrar diferentes momentos del desarrollo capitalista en reemplazo de los conceptos de fordismo o taylorismo (Kabat, 2009; 2005; 2001; Fernández, 2000; 1999; Aquino et al, 1998; Manzano, 1996). En particular se intentó pensar, desde el estudio de los procesos de trabajo, la evolución del desarrollo del capitalismo en la industria argentina. Diferente es la mirada que desde la tradición de investigación del PEHESA se dirigió a indagar los espacios de trabajo. Para los investigadores pertenecientes a este grupo, el objeto en cuestión valía la pena no por el hecho de que al analista le interesaravolverse un ingeniero industrial dispuesto a estudiar cada uno de los movimientos que el trabajador realiza con sus manos, herramientas y máquinas, sino porque se trata de integrar esos procesos dentro de una lectura comprensiva de la dimensión laboral (Lobato, 2007). La cual, entre otros aspectos, interprete los valores y representaciones de los trabajadores. La importancia de ello radica, por ejemplo, en la posibilidad de conocer los circuitos donde se acuñan y difunden categorías que resultan centrales para garantizar los procesos de acumulación de capital tales como eficiencia, racionalidad, modernización y progreso (Suriano, 2006).

Por nuestra parte, nos interesó en este bloque problemático introducirnos en el estudio del proceso de trabajo con el objetivo de conocer un poco más acerca de la experiencia de vida de los trabajadores y las trabajadoras en las fábricas, así como el modo en que ellos (y ellas) elaboraron esas experiencias, particularmente en el espacio de trabajo. En la presentación de nuestra investigación hemos desarrollado, en el capítulo I, la evolución de la industria pesquera procurando dar cuenta específicamente de las transformaciones ocurridas durante la década del '90 dominada por una inédita expansión de las capturas y exportaciones y un cambio en el perfil del empresariado hegemónico dentro de la actividad. En el capítulo II procuramos demostrar cómo se desplegaron las políticas para la pesca y cuál fue el sentido que éstas adquirieron. En este capítulo buscamos presentar cómo impactaron aquellos procesos en las condiciones de trabajo de los obreros y obreras de la industria. Para avanzar en ello, en primer término describimos las características principales del proceso de trabajo. Pues consideramos que antes de adentrarnos en la vida gremial, en las tradiciones políticas y en la dinámica de la protesta obrera, debemos conocer qué tipo de labor desarrollaba nuestro principal sujeto de análisis. Pretendemos por ello poner a consideración del lector o lectora el trabajo realizado por los obreros y obreras de la industria del pescado, pensando que las horas allí pasadas por los sujetos que trabajan, hicieron, en buena medida, a su experiencia como sujetos. ${ }^{498}$ Esto es, buscando enriquecer el contenido de esta investigación, introducimos como elemento de análisis la experiencia de la cotidianeidad laboral a partir de examinar la presentación del proceso de trabajo, las características del trabajar como fileter@, las formas que asumió la relación salarial y la conflictividad en el espacio productivo. En este aspecto, buscamos señalar las características del proceso de trabajo en la industria del pescado, los límites que encuentra el capital para avanzar sobre el factor subjetivo de la relación, y al mismo tiempo, describir los procesos que dan cuenta de cómo la organización del trabajo está supeditada al mando patronal. Pero también intentamos dar cuenta de la resistencia obrera al despotismo patronal y a los conflictos surgidos al interior de las plantas, procurando al mismo tiempo rastrear los posibles elementos que nos permitan vislumbrar una cultura obrera y sus características principales en un momento histórico particular. Damos cuenta de ello

\footnotetext{
${ }^{498}$ Nicolás Iñigo Carrera realiza una fuerte crítica al concepto frecuentemente utilizado de "mundo del trabajo" para referir a los trabajadores, pues dicho concepto reduce la persona del trabajador tan sólo a las horas que trabaja. De este modo, quienes apelan al uso de aquella categoría tratan a los sujetos del mismo modo que lo hace el capital, es decir, se los concibe sólo como un atributo de éste (Iñigo Carrera, 2009; 2006). No obstante compartir dicha posición, pensamos que no puede desatenderse el proceso de trabajo como espacio (uno más y de significativa importancia) donde se constituye el sujeto trabajador.
} 
mediante entrevistas, sentencias de los Tribunales del Trabajo, informes oficiales y fuentes editas, con el objetivo de representar de forma más completa y rica las experiencias de quienes encontraremos, en los próximos capítulos, participando de la conflictividad social.

En la industria pesquera de la década del '90, el marco sobre el que se desenvolvió la cotidianeidad laboral refiere a un proceso de reorganización capitalista que, al tiempo que mostraba (al menos hasta 1997) una fase expansiva y de crecimiento en la actividad, entre otros aspectos, apuntó a la explotación más intensiva de la fuerza de trabajo en un contexto de retracción del mercado laboral, de fragmentación de la lucha obrera y de políticas que tendieron a abaratar los costos de la mano de obra fomentando relaciones salariales precarias. ${ }^{499}$ Ante ello, nos preguntamos por cómo impactaron esos procesos en la cotidianeidad laboral al interior de las plantas elaboradoras de pescado y cómo fueron procesados y significados por los propios trabajadores y trabajadoras. Si bien realizamos referencias generales a los obreros marineros, nos centraremos en la situación de los trabajadores y trabajadoras de la industria del pescado, es decir, aquellos y aquellas que laboraban en las plantas radicadas en tierra y que pertenecen a la esfera de incumbencia del SOIP. ${ }^{500}$ La razón de ello reside no sólo en que se trata del contingente obrero industrial de mayor envergadura en la ciudad de Mar del Plata, sino también porque su situación fue particularmente afectada por las tendencias que adoptó la política pesquera durante la larga década del '90, así como por las transformaciones en la industria. Uno de sus efectos fue que la pesca, mientras alcanzaba exportaciones récord, paralelamente ingresaba en una de sus crisis de mayor profundidad.

Sin procurar brindar respuestas definitivas, pero esperando sirva de insumo para las reflexiones más generales que este trabajo busca generar, nos preguntamos ¿cómo opera el proceso de trabajo en la industria del pescado? Para luego conocer ¿qué modificaciones surgieron en los años bajo estudio? Al mismo tiempo ¿qué tipo de trabajador se configura en la industria? ¿Qué pasa con el cuerpo que trabaja? ¿Y con su subjetividad? Y ¿cuáles eran sus condiciones de vida y de trabajo? ¿En qué medida la fase expansiva que atravesó la industria pesquera durante la década del '90 impactó en su situación? ¿Fueron beneficiados de algún modo por el crecimiento de los volúmenes exportables de pescado? Dado que fueron estos los años de avance de la "desregulación” y del impulso a la flexibilidad laboral ¿cómo afectaron esas políticas a la población obrera del pescado? Al respecto, buscamos desarrollar extensamente el proceso de formación de cooperativas en la industria del pescado puesto que se volvió de particular importancia en la transformación de la relación laboral de buena parte de la fuerza de trabajo. Lo cual, a su vez, repercutirá en las características que asumió la movilización obrera contenciosa. Además, incluso hoy en día aquella condición de precariedad continúa siendo una de las problemáticas principales por las que atraviesa la industria pesquera argentina. Por otra parte, y en cuanto nunca un proceso disciplinatorio es total y completo existiendo siempre resquicios para la resistencia, vale interrogar acerca de si ¿expresaron los trabajadores malestar y/o oposición individual y/o colectiva en el espacio de trabajo y/o hacia aquellas políticas? ¿De qué manera? ¿En qué medida influyó negativamente en esa resistencia el contexto de disciplinamiento social dominado por el creciente desempleo? Desplegado este contenido problemático, vayamos a conocer el proceso de trabajo en la pesca.

\footnotetext{
${ }^{499}$ Este fenómeno no fue privativo de la pesca. Pues la extensión del desempleo, la subocupación y la precarización del empleo (se incrementaron los índices de trabajo 'en negro' y los períodos de prueba) no sólo ocurrió en contextos de recesión de la economía Argentina, sino también inclusive en algunos años de crecimiento sostenido (Panigo y Torija Zane, 2004).

${ }^{500}$ Por las particularidades que asume el trabajo realizado sobre los barcos, el proceso mismo de trabajo, las condiciones laborales, la organización sindical, entre otros varios factores, su análisis requiere otra investigación y otra propuesta de tesis que escapa a nuestras posibilidades. Ojalá sirvan las referencias laterales que aquí incluimos sobre dicho tema para alentar futuras exploraciones.
} 


\section{El proceso de trabajo en la actividad pesquera}

El proceso laboral en la industria pesquera requiere tres etapas definidas: la captura, el procesamiento y la comercialización (Madaria, 1999). Hemos visto que en la evolución histórica de la industria se recorre un camino que va desde la pesca costera, cuyo proceso de trabajo más importante es la elaboración de conservas de pescado, a la pesca industrial con buques fresqueros, que se corresponde con la elaboración del filete en plantas en tierra. ${ }^{501}$ Más reciente es la expansión del uso de los buques congeladores y factoría que procesan el pescado dentro del propio barco. Lo cierto es que en una empresa "tipo" argentina, dedicada a la captura de la especie merluza hubbsi con buques fresqueros-arrastreros y planta de procesamiento en tierra, la duración de las mareas (tiempo en que el barco se encuentra en el mar pescando) durante la alta temporada, es de 2 a 6 días, de acuerdo a la cercanía y a la existencia del recurso. En baja temporada la marea puede durar alrededor de 10 días. Cada buque cuenta con una tripulación de entre 18 y 22 personas que están integradas, jerárquicamente, por un capitán o "patrón de pesca", un segundo patrón, un primer y segundo pescador y por los marineros y aprendices. En el sector de máquinas se encuentra el jefe de máquinas (de jerarquía similar al patrón de pesca), un segundo y un tercero. El capitán es quien decide la zona de pesca, es el responsable de la embarcación y su salario suele ser proporcional al volumen de pescado capturado. Además de los instrumentos tecnológicos que permiten la detección de la especie, suele ser útil la experiencia de la tripulación que conoce en qué lugar encontrar el pescado de acuerdo a la época. Una vez localizado el cardumen, se sumergen las redes en el mar, se realiza una maniobra por la cual se arrastra al pescado, se embolsa y se eleva por una rampa ubicada en la popa. Luego, se coloca en el pozo de pescado. Allí es distribuido en cajones de alrededor de 30 kilogramos cada uno, provistos de hielo para mantener fresca la materia prima. La capacidad de cada barco fresquero es de 3.500 a 4.500 cajones, es decir, entre 100 y 150 toneladas de pescado.

Junto a la captura de la especie principal, en este caso la merluza hubbsi, se suelen capturar otras especies al azar, lo que se denomina "pesca incidental" o "acompañante". Esta captura no sólo es permitida sino que, además, es obligatorio descargarlas en tierra pues, de lo contrario, estaría indicando que son arrojadas al mar (el llamado "descarte"). El descarte está prohibido no sólo para las especies acompañantes sino también para los ejemplares de la propia especie principal cuyo tamaño no satisface la expectativa de los pescadores. Ésta, como otras reglamentaciones, tiende a proteger el desarrollo biológico de la especie impidiendo la captura de ejemplares juveniles. Cada barco se comunica periódicamente con la planta industrial o cuando alguna novedad lo determine oportuno. En base a ello, la planta puede programar el trabajo y conoce el tiempo y la cantidad de materia prima que tendrá disponible. De todos modos, es esta una actividad sujeta a la incertidumbre y, en tal sentido, particular:

... tiene una dinámica muy difícil de entender. Te doy un solo dato. Cuando vos haces cualquier proyecto industrial que hagas -porque esto es una industria- una de las primeras cosas que aseguras en el proyecto es que donde te vayas a instalar hay un flujo de materia prima seguro y constante o al menos que pueda crecer [...] En la actividad pesquera el flujo de materia prima que es una base del diseño de todo el proyecto es lo que es una incertidumbre. Esta es una realidad [...] el

\footnotetext{
${ }^{501}$ Sobre el proceso de trabajo en la industria conservera marplatense puede leerse Nieto (2012), Molinari (1998) y, para el caso de la anchoíta, Bertolotti y Manca (1986). Otro de los productos más comunes que genera la actividad pesquera es la harina de pescado, producida a partir de los residuos de la planta industrial o de los buques. La harina de pescado se utiliza para consumo animal (como alimento balanceado) o industrial (como fertilizante). Al respecto consultar (Madaria, 1999).
} 
barco uno sabe cuando sale y tiene una idea de cuando entra pero si en el medio tuvo tres días de temporal, sonamos. [...] o se rompió o paso algo. La realidad concreta es que nosotros manejamos mucha más incertidumbre que otras actividades industriales. Es más, un barco salió a pescar algo y pescó ese algo, esa dada especie que salió pero además pescó otras cuatro, otras cinco que no tenía programado que iba a entrar porque ese día las encontró. Bueno, uno tiene que tener adecuada la fábrica para que cuando llegue se pueda trabajar esas otras especies que no estaban consideradas. ${ }^{502}$

Más allá de estos aspectos que refieren al necesario manejo de la incertidumbre en cuanto a la provisión de materia prima, al finalizar cada marea el capitán formula un "parte de pesca"en el que detalla la especie, la cantidad capturada y otros datos de la jornada de pesca. De esa manera, la empresa conoce lo que el barco pescó, cuántos días tuvo el pescado a bordo y, por otra parte, los organismos nacionales y provinciales se basan en esos informes para realizar un control sobre las capturas. Escuetamente, ese es el camino que sigue el pescado antes de ingresar a las plantas de procesado.

\section{La estructura ocupacional}

La ciudad de Mar del Plata es conocida por ser uno de los principales destinos turísticos de la Argentina (Sebreli, 1970; Torre y Pastoriza, 2002). Sin embargo, desde mediados de los años '30 y hasta la actualidad, también es el principal centro industrial - pesquero del país (Bertolotti et al, 2002; Mateo, 2005; Pradas, 2006). Ha sido, no obstante, la tradicional visión que relacionó a la ciudad con el ocio la que ha colaborado en desdibujar su perfil industrial y obrero. Más aún cuando la industria en cuestión, como ya hemos dicho, no ocupó un gran espacio en la consideración de quienes definieron agendas públicas en la sociedad. Con todo, debemos destacar que la industria de la pesca es una de las actividades productivas de mayor significancia en el Partido de General Pueyrredón. ${ }^{503}$ En su conjunto, la actividad extractiva (sector primario) e industrial (sector secundario), representaban hacia mediados de la década del '90 la cantidad de \$197.803.659 dentro del Producto Bruto Geográfico, ocupando alrededor de 11.600 personas de manera directa, solamente contabilizando a marineros pescadores y trabajadores de las plantas en tierra (Bertolotti et al, 2002). ${ }^{504}$ A ello deben sumarse las actividades económicas indirectamente relacionadas. Además dicha industria contaba con 110 empresas reconocidas en funcionamiento, más las cooperativas con lo cual la cifra ascendía a, por lo menos, 175 establecimientos (Gennero de Rearte et al, 1998).

En cuanto al trabajo en las plantas elaboradoras de pescado, conocemos ya que desde mediados de la década del ' 60 , cuando comenzó a producirse el filete de pescado, su procesamiento se convirtió en uno de los trabajos industriales de mayor importancia enMar del Plata. A comienzos de la década de 1980 el

\footnotetext{
${ }^{502}$ Entrevista del autor con Oscar Fortunato, gerente de CEPA y ex funcionario provincial y nacional del área pesquera (Mar del Plata, 23/04/2013).

${ }^{503}$ El Partido de General Pueyrredón, cuya cabecera es la ciudad de Mar del Plata, es uno de los 135 partidos en que se divide la Provincia de Buenos Aires.

${ }^{504}$ De este modo la Pesca (sectores primario y secundario) representaba hacia 1993 alrededor del 6\% del total del PBG del Partido de General Pueyrredón. Mientras que abarcaba el 51\% del PBG del sector primario y el 22\% del sector secundario (Gennero de Rearte y Ferraro, 2002).
} 
SOIP declaraba representar el total de 16.400 trabajadores y trabajadoras. ${ }^{505}$ Años después, dentro de la década bajo estudio, la estructura ocupacional del sector evidenciaba una merma importante:

\begin{tabular}{lc}
\hline \multicolumn{2}{c}{$\begin{array}{c}\text { Cuadro } \mathbf{N}^{\circ} \text { 8: Trabajadores de la industria del } \\
\text { pescado - Mar del Plata -Año }\end{array}$} \\
\hline Fileteado & 2.921 \\
\hline Congelado & 816 \\
\hline Fileteado y congelado & 2.916 \\
\hline Conserva & 550 \\
\hline Salado & 950 \\
\hline Fábrica de Hielo & 37 \\
\hline Fábrica de Harina & 151 \\
\hline Total & $\mathbf{8 . 3 4 1}$ \\
\hline Fuente: “Censo de mano de obra ocupada y capacidad industrial \\
instalada. Partido de General Pueyrredón”, Milciadez Espoz Espoz y \\
otros, CITEP-INTI, Fundación Atlántica, 1996.
\end{tabular}

Esos poco más de ocho mil trabajadores correspondían a las plantas de procesado, abarcando tanto los sub sectores del Filet, Harina y Conserva y son nuestro principal sujeto de análisis, especialmente el sector del Filet. Para entonces hay que señalar también la disminución notable en el nivel de afiliación, cuando en 1994 solamente eran 3.221 los trabajadores y trabajadoras afiliados al sindicato. ${ }^{506}$

\section{El proceso de trabajo en las plantas de fileteado}

Una vez capturado, el pescado destinado a tal fin, pasa a ser procesado en las plantas de fileteado que están en tierra. Esta actividad es la que mayor cantidad de mano de obra ocupa, alrededor de 6 mil trabajadores y trabajadoras, quienes además son los sujetos principales de la conflictividad que abordaremos en el capítulo siguiente. Las empresas de mayor envergadura, como eran Solimeno, Moscuzza, Valastro, pero también otras más como Ventura y Arpemar contaban con el dominio de dos de los circuitos básicos de la producción pesquera; esto es, la captura (a través de buques) y el procesado de pescado (en plantas en tierra fundamentalmente, pero también algunas de ellas en buques congeladores). A su vez, existían fábricas fazoneras que asumían el rol de intermediarias. Es decir, que se ocupaban solamente del procesado de pescado sin poseer buques. Por ello debían adquirir el pescado por su cuenta o trabajar como subsidiaria de alguna empresa mayor que les brindara la materia prima, siendo ellas quienes la procesaban para luego devolverla ya elaborada. ¿Pero cómo es el trabajo dentro de las plantas de procesado de pescado?

Después de las tareas de pesca y del arribo de los barcos a puerto, el pescado es descargado y se lo traslada hasta las plantas de procesado por medio de cajones de plástico (antes eran de madera) en

\footnotetext{
${ }^{505}$ L.C.,27/06/1982.

${ }^{506}$ Para encontrar una respuesta en torno de la reducción del 50\% de la mano de obra en el lapso de diez años es preciso realizar una investigación exhaustiva acerca del desenvolvimiento de la pesca en la década del ' 80 , teniendo en consideración el cierre de plantas pesqueras, el traslado de algunas empresas hacia el sur, junto con otros fenómenos que escapan a nuestras posibilidades.
} 
camiones que cuentan con equipos de enfriamiento que mantienen congelada la materia prima. Por lo general, la voz de mando en la producción la llevaba el jefe de planta o el capataz quien indica, en las plantas que se procesaban diferentes tipos de pescado, que especie de pescado se procesa en cada momento, organizando la rotación de especies. Podía ocurrir que este rol lo asumieran trabajadores, pero esto era menos común. Lo cierto es que una vez que el pescado llega al sector descarga, es almacenado en cámaras de enfriado a bajo $0^{\circ}$ hasta su procesamiento o llevado directamente a unas tolvas donde se lo deposita. Después de ello es trasladado por peones hasta el lugar donde será procesado. Si el procesado lo realizan máquinas, que las hay de diferentes tipos (descabezadoras, descuereadoras, fileteadoras), el pescado es llevado hasta ellas, donde un operador lo toma en forma manual y lo introduce en la descabezadora. Ya descabezado el pescado puede ser conducido en forma mecánica por una cinta transportadora o en forma manual en cajones hasta la máquina fileteadora. El trabajo consiste en este punto en colocar el pescado sobre una guía, donde es transportado a la sierra que lo divide por el vientre y lo separa en dos filetes. Bajo esta forma es depositado en cajones para alimentar a las "cuereadoras". En general para el fileteado se utilizan las Baader 51 que son máquinas con cuchillas fijas que permiten separar el cuero. Esto mismo puede hacerse por intermedio de máquinas, que mediante la acción de un cilindro refrigerado por gas freón, congela el cuero mientras que la cuchilla lo quita. Desde aquí, el filete pasa a la sección de revisado y "emprolijado". Ésta última tarea se realiza en forma manual, con la ayuda de un cuchillo. ${ }^{507}$ De todos modos, la incorporación de tecnología no pudo reemplazar el uso de mano de obra intensiva. La razón reside en que las máquinas de fileteado de pescado desperdician demasiado, descartando y cortando partes que una mano educada para tal fin puede aprovechar.

Habían intentado traer las máquinas, alguna para cuerear, otras para cortar. Pero yo ni las conocí. No las conocí porque supuestamente las probaron y no anduvieron. Porque los tipos lo que les interesa es que les rinda en cantidades de pescado elaborado. Y una cosa es trabajarlo con la mano y otra cosa es una máquina que te corta donde va la cuchilla. El filetero busca el hueso y saca bien [...] Siempre el promedio que te pedían era el $42 \%$ de rinde. En un kilo de merluza tenés que sacar 420 gramos de filete. ${ }^{508}$

Una máquina no podía garantizar ese porcentaje. El capataz Walter Flores cuenta su experiencia trabajando en Arpemar:

Arpemar tuvo cinco líneas de Baader. Está buenísimo porque te ahorras el dinero de un montón de gente. Es lo único, pero no pasas el 38\%. Muy, muy fino el 38\%. Mientras estuvieron los alemanes daban el 38\%. Cuando se fueron los alemanes ya la cosa cambió. Nosotros teníamos cinco máquinas y cinco alemanes. Uno en cada máquina. Nosotros terminamos el último turno a las diez de la noche. Eran la una de la mañana y los alemanes estaban engrasando, ajustándole el tornillito y lavándola con agua dulce. Al otro día venían. Habían arrancado a las cinco de la mañana y los alemanes estaban ahí paraditos a las cinco de la mañana. Cuando se fueron los alemanes les regalaron las cajas de

\footnotetext{
${ }^{507}$ Ministerio de Trabajo y Seguridad Social y P.I.A.C.C.T - O.I.T., 1986.

508 Segunda entrevista del autor con Ricardo "Polaco" Muñoz, militante y ex trabajador de la industria del Pescado (Mar del Plata, 05/06/2013).
} 
herramientas a los argentinos... [Y las máquinas] se fueron deteriorando por el descuido y terminaron una millonada de dólares arrumbadas en un galpón de la calle Ayolas. ${ }^{509}$

Por ello, lo más común es que el fileteado se realice en forma manual. En este caso, los peones trasladan los cajones desde las "tolvas" hasta el lugar donde se encuentran los trabajadores y trabajadoras que elaboran el filete y lo vuelcan sobre la mesa de trabajo, ayudados generalmente por el filetero o filetera. En ocasiones es el propio filetero/a quien debe volcar el cajón. El filetero/a trabaja de pie frente a una mesa, algunas veces también pueden hacerlo parado sobre algún tipo de estructura o elemento que los mantiene separados del piso, el que, por lo general, está mojado por el continuo paso de agua que se utiliza para limpiar el pescado. El filetero/a utiliza una cuchilla grande, aproximadamente de 20 centímetros, una tabla generalmente de acrílico (antiguamente de madera) donde corta el pescado y un guante con el cual lo sostiene. El pescado viene congelado o enfriado.

La elaboración de filete consiste en cortar el pescado quitándole la cabeza, la espina dorsal y las tripas, en un movimiento que va desde la cabeza a la cola, logrando dos filetes por cada unidad cortada. Se hunde la punta del cuchillo debajo de la cabeza del pescado con presión hacia adelante, para luego llegar hasta el centro del pescado y luego baja por el vientre seccionándolo. Con otra operación en el lomo se quita la aleta dorsal y la cola. Luego se saca la cabeza, vísceras y espinazo, pasándose a cortar los dos filetes de cada pescado. El estilo y tipo de corte depende de la especie procesada. Existen fileteros especializados en el corte de determinada especie, como también fileteros llamados "banquineros" que cortan cualquier tipo de pescado. Los desechos se tiran habitualmente sobre el cajón en el cual aquel venía y paralelamente se apilan los filetes. Terminado el cajón, se le quita la piel (el "cuero") del pescado y se lo coloca en una bandeja que, llena, alcanza los 17, 18 o 19 kilos. Todo este proceso se realiza con un incesante contacto con hielo y abundante agua. Los peones llevan las bandejas hasta la balanza de pesaje, actividad generalmente desarrollada por individuos que realizan esa tarea específica y son por ello conocidos como "pesadores". Luego se lleva hasta el lugar donde están las empaquetadoras o envasadora para envasarlo. La tarea de fileteado consiste en una operación monótona y repetitiva:

La operación de fileteado es efectuada con gran rapidez, produciendo el operario una serie de movimientos vivos y de corto recorrido. El cuerpo recto, volcando sobre su mayor peso sobre la pierna derecha, mientras la cabeza permanece inclinada observando fija y atentamente la labor de las manos. La mano derecha (en el caso en que el trabajador o la trabajadora es diestro o diestra) hace una repetición mecánica de movimientos habiendo observado cuatro movimientos principales del brazo derecho con accionamiento de hombro, codo y principalmente muñeca, que se producen aproximadamente de 250 a 500 veces por hora [...], alternados con movimientos complementarios del mismo fileteo, lavado, vuelco del cajón sobre la mesa, arrojar a la caja de residuos cabeza, vísceras y espinazo. ${ }^{510}$

Por último, se realiza el empaquetado y envasado. El mismo depende de la especie, la calidad del pescado y el destino al que se envíe. Generalmente mujeres, las empaquetadoras o envasadoras seleccionan el pescado (y según la variedad que exige determinada modalidad de trabajo), lo apilan sobre

\footnotetext{
${ }^{509}$ Entrevista del autor con Walter Flores, Técnico en Industria y Alimentación en orientación pesquera y capataz de la firma Di Constanzo (Mar del Plata, 07/06/2013).

${ }^{510}$ Sr. Carlos Depaolo, Jefe de Policía del Trabajo, delegación Mar del Plata del Ministerio de Trabajo y Seguridad Social; cit. en Ministerio de Trabajo... op. cit.
} 
bandejas separándolo con polietileno para ser trasladado, ya sea por autoelevador o manualmente al área de placas (congelamiento por contacto), o a los túneles (enfriado por aire). En las placas, que funcionan con circulación de amoníaco líquido, se deja la mercadería aproximadamente dos horas, para luego sacar las placas en forma manual. En los túneles la mercadería permanece aproximadamente cuatro horas. Posteriormente los productos son desmoldados y envasados para su estibaje en las cámaras a $-25^{\circ} \mathrm{C} \mathrm{y} \mathrm{-}$ $30^{\circ} \mathrm{C}$. El estibaje se realiza en forma manual. ${ }^{511}$ A comienzos de la década del ' 90 algunas empresas introdujeron el girofreezer que permitía eliminar el envasado interfoliado. Antes de él:

Se le llevaba el pescado al filetero. Corta el filetero. Se pone en una bandeja, se lava y se pesa. Lo dejás al costado, lo agarra la envasadora y envasa. Pone el pescado en una cinta. La sacan de la cinta y la ponen en una pila de bandejas para entrar a congelación. Espera un período de tiempo y se congela. Hay que descargar la placa después de dos horas o el túnel después de dos horas. Hay que ponerlo en otro carrito para que lo saquen de la bandeja. Lo pongan adentro de la caja, lo pongan en una bolsa, cierren la caja y lo manden a cámara.

La modificación producida por el ingreso de cualquier túnel continuo, como el girofreezer, consistía en que si bien continuaba cortando el filetero, ahora: "Se lava el pescado. Se empieza a colocar arriba de una mesa, se pone en una cinta transportadora, entra en girofreezer y sale congelado. Va a una máquina que dice que kilaje querés. Cerrás, ponés adentro de la caja y listo" ${ }^{\text {"12. }}$. De este modo se ahorra tiempo de trabajo en el estibaje. Como fuere, en este punto el pescado ya está listo para venderse. Los criterios de presentación pueden variar en cuanto el destino que tenga la materia prima en relación con el mercado interno o externo, dependiendo a su vez de la calidad del pescado.

Junto a esta modalidad de procesado en las plantas convive el trabajo de los buques factoría que realizan todo el procesamiento a bordo, generalmente con esvicerado, descuereado y fileteado mecánico (no se puede llevar demasiados fileteros en un buque), con la posibilidad de descargar directamente en puerto el producto final ya envasado para la comercialización. También existe la posibilidad de congelar el pescado a bordo, descargar en puerto y realizar el procesamiento en la planta industrial. Las distintas modalidades varían de acuerdo a la especie, a la calidad del producto que se desea obtener, al valor agregado que se incorpora o a la conveniencia económica del productor. Pero no nos ocupamos aquí de esta modalidad productiva.

Pasando del terreno de la descripción a una primera conceptualización, podemos afirmar que el proceso de trabajo en la industria del pescado conserva elementos del régimen de manufactura dada la importancia del trabajo con herramientas manuales, trasladándose los obreros al lugar de trabajo con sus propias herramientas y donde el factor subjetivo conserva un valor nada desdeñable. En este sentido, la disgregación y desarticulación del trabajo encuentra un límite en la medida en que la maquinaria resulta aún poco eficaz en su uso. ${ }^{513}$ Este "saber hacer" que conservan consigo los obreros y obreras, implica un conocimiento particular que lo asemeja a un oficio y que se aprende por canales informales. ${ }^{514} \mathrm{Se}$ trata de

\footnotetext{
${ }^{511}$ Ministerio de Trabajo... op. cit.

${ }^{512}$ Entrevista del autor con Oscar Fortunato... op. cit.

${ }^{513}$ Recordemos que una de las características propias del régimen de gran industria es la subordinación del factor subjetivo (obrero colectivo) al factor objetivo (maquinaria) dentro del proceso de trabajo, donde el primero sólo se convierte en un apéndice del segundo, luego de que le ha sido expropiado su saber.

${ }^{514}$ En algunas referencias de trabajadores se mencionan escuelas de aprendizaje donde se enseñaba a elaborar filete radicadas tanto en la Facultad de Ingeniería como en el SOIP. La destreza básica para ser "filetero o filetera" se dominaba en alrededor d
} 
una labor que implica cierta especialización, la cual se desarrolla con herramientas manuales (cuchillos) y que se va perfeccionando a lo largo del tiempo con la práctica. ${ }^{515}$ Según el último convenio colectivo de trabajo un aprendiz demora alrededor de 15 días en aprender los rudimentos de la actividad. El tipo de trabajo de los fileter@s se diferencia de, por ejemplo, los marineros. Estos últimos deben pasar por un período largo de aprendizaje ( 2 años) adquiriendo una formación técnica específica, otorgada por una autoridad competente, precisando de la obtención de una libreta habilitante para poder ejercer la actividad. ${ }^{516}$ Entonces, podemos conjeturar que ser fileter@ se acerca a la calificación obtenida tras un aprendizaje que se basa en la rutina repetitiva y en la imitación adquiriendo rasgos de un oficio, pero no termina de ser tal cosa en la medida en que su aprendizaje no requiere atravesar por un proceso demasiado extenso. Aún así, su labor tiene mayor complejidad que la tarea del peón o de quien fuera un apéndice de la máquina de la gran industria. Y mantiene un lugar trascendente dentro de una planta porque los fileteros son el primer eslabón en el procesado de pescado. De su labor dependen peones, planilleros, pesadores y envasadoras. ${ }^{517}$

Por todo lo dicho podemos pensar que en el proceso de trabajo de la industria del pescado se entremezclan elementos de manufactura y gran industria. ${ }^{518}$ Posiblemente en los buques congeladores, donde sí se utilizan máquinas para el procesado de pescado, la actividad adquiera ya definitivamente los contornos de la gran industria. No obstante, el trabajo en plantas en tierra continuó siendo fundamental. ${ }^{519}$ En tal sentido, es complejo extraer alguna conclusión respecto de la tendencia hacia la consolidación de un régimen de gran industria como si pueden hacerlo analistas de otras ramas de la economía. ${ }^{520}$ No obstante, la actividad está completamente subordinada a la planificación y organización por parte del empresario. Con la particularidad de que, por las características del tipo de labor y la forma de retribución, el obrero puede regular los ritmos y tiempos de trabajo que, en mayor o menor medida, dependen de su voluntad. Por ello, el empresario dispuso de un sistema de planificación con eje en el pago por productividad, el cual induce a los trabajadores a acelerar los ritmos de trabajo para alcanzar

una semana o 15 días de práctica, aunque la pericia en el trabajo requería algún tiempo mayor. Sobre todo a la hora de filetear diferentes clases de pescado. Sin embargo, el grueso de los aprendizajes se realizaba por la enseñanza de un familiar o amigo, mirando como trabajaban otros y otras o por la simple práctica. "Y yo veía a la chica que fileteaba más que yo y más rápido, ella cortaba y yo le cuereaba....y aprendí con ella y con una semana me largue sola, yo iba haciendo y ella me corregía". Entrevista realizada por David Santos a Ana Mazzela, filetera, 60 años (Mar del Plata, 2009).

${ }^{515}$ Consultado por cómo aprendió la actividad un trabajador nos cuenta: “¿De filetear?....y bueno estaba en la fabrica yo estaba trabajando de peón o camarista...en ese tiempo....este...los fileteros iban a tomar cuarto, yo me quedaba y empezaba a cortar en la mesa, y ahí aprendí...y después cuando no había trabajo o estaban echando a la gente que estaba efectiva, yo un día como no había trabajo, para mí en lo que yo trabajaba, le pedí que me dieran la mesa para cortar pescado, ya más o menos sabia y bueno...me trajeron, ya más o menos sabia, así que sabía algo, y me dieron y así empecé a trabajar de filetero. Por mirar y practicar; nadie me enseño yo agarraba el cuchillo y ponía a cortar”. Entrevista realizada por David Santos a Natividor Sosa, filetero, 59 años (Mar del Plata, 2009).

${ }^{516}$ Esto es así al menos en términos legales y formales. Sin embargo, son conocidos diferentes casos de pescadores sin libreta o que obtuvieron la libreta sin pasar por los dos años de preparación.

${ }^{517}$ En la visión de un capataz esto se traduce del siguiente modo: "El filetero es el tipo más jodido adentro de la planta, porque se cree que es el único en la planta. Entonces se cree que si él no trabaja entonces no trabaja nadie en el resto del frigorífico. Está todo parado si él no trabaja. Entonces él se ve con derecho a parar cuando cree que algo no le gusta y para a todo el resto. Si no quiere trabajar no trabajan y el resto no puede trabajar porque la envasadora si no cortan ellos no trabajan y pierden plata. El filetero es un tipo muy especial en todo orden". Entrevista del autor con Walter Flores... op. cit.

${ }_{518}$ Sobre el tema ver Marx (2003). Entre varios textos que resumen la cuestión puede leerse Neffa (1990).

519 "Me parece que estos desarrollos deben ser interpretados como el hecho de que, en muchos casos, estamos en presencia más bien de un 'apilamiento' y de una articulación de formas diferentes, antes que de una sucesión necesaria de 'modelos tipo' de organización del trabajo, cada uno de los cuales se supondría más eficiente que el precedente” (Coriat, 1990: III).

${ }^{520}$ Por ejemplo, desde el PIMSA Fabián Fernández analizó, en diferentes trabajos, las transformaciones del proceso de trabajo en el caso de la industria automotriz (Fernández, 2000; 1999). 
salarios adecuados. Marx señalaba respecto a la forma de retribución salarial a destajo que: "Esta forma de pago brinda al capitalista una medida rigurosamente precisa de la intensidad del trabajo" donde:

...el interés personal del obrero estriba en emplear su fuerza de trabajo de la manera más intensa posible, lo que facilita al capitalista la elevación del grado normal de la intensidad. El obrero, asimismo, está personalmente interesado en prolongar la jornada laboral para que de esta manera aumente su jornal o su salario semanal (Marx, 2003: 675-676). ${ }^{521}$

En cuanto a las relaciones entre los propios trabajadores, un sistema de retribución semejante no se basa en el esfuerzo colectivo, sino en un esfuerzo individual. En este sentido Burawoy (1989) afirmaba que la constitución del trabajador como individuo en competencia y conflicto con otros individuos vela su común pertenencia a una clase de agentes productivos que venden su fuerza de trabajo a cambio de un salario. Y en gran medida, ese proceso contribuye a la generación de consentimiento dentro de la fábrica. En primer término porque un trabajador gana más dinero cuando corta a mayor velocidad. También sucede que cierta noción de prestigio se mide a partir de la velocidad y calidad con que se filetee el pescado. Un trabajador o una trabajadora lentos pueden recibir como contrapartida el desprecio y la burla de sus propios compañeros. Por otra parte, muchas veces las personas más veloces poseen algún tipo de reconocimiento especial por parte de la dirección de la empresa. De este modo, tanto por la búsqueda por obtener mayor cantidad de salario, como por el reconocimiento de los pares y la obtención de premios, la velocidad se convierte en un valor dentro de la cultura de trabajo al interior del espacio productivo.

A lo largo de este proyecto de tesis doctoral hemos hecho mención a la conformación de cooperativas de trabajo en la industria pesquera. Conocido entonces el proceso de trabajo y la actividad que desarrollan los fileteros y las fileteras llegó el momento de abocarnos a presentar dicho fenómeno, central en la dinámica de acumulación capitalista en la pesca marplatense durante la década del ' 90 .

\section{"A las sombras de la noche, como si nada hubiera pasado": las plantas clandestinas}

Desde su nacimiento la actividad del fileteado realizada por los trabajadores y las trabajadoras del pescado fue complementaria a otras tareas más tradicionales fundamentalmente relacionadas con la elaboración de conservas. En aquel entonces y aún cuando comenzó a constituirse como actividad autónoma, su desarrollo se realizó por fuera del amparo legal de la relación de dependencia de trabajadores con sus empleadores. Es así que desde el nacimiento de la actividad de fileteado, el tipo de labor emergió con un perfil de precariedad en las condiciones de trabajo. Fue en ese contexto donde se enmarcó el intento del SOIP por revertir aquella situación durante el año 1958 cuando firmó un CCT específico para el sector. Pese a las esperanzas despertadas, el convenio nunca logró instrumentarse plenamente en el conjunto de la geografía fabril (Nieto, 2012). Luego, poco a poco el desarrollo de la actividad se fue dando sobre la primacía de la merluza como especie objetivo, la cual se elaboraba en tierra, lo que dio lugar a la creciente aparición de plantas de procesado dentro de un espacio que mostró la coexistencia de pequeños establecimientos artesanales y plantas fabriles de mediano y gran tamaño.

\footnotetext{
${ }^{521}$ En este sentido, el mínimo de kilos exigido por las empresas solía rondar los 161 kilos de pescado procesado, cifra que se alcanzaba con facilidad, siendo el propio obrero el más interesado en superar esa marca.
} 
Por un lado, surgieron plantas a instancias de las empresas que poseían buques con lo cual podían garantizar tanto la captura como el procesado. Por otro, otras plantas ofrecían el servicio del procesado de pescado. Eran establecimientos donde alguna persona generalmente con experiencia en el oficio oficiaba de contratista, poniendo la instalación y contratando la mano de obra, a la que una empresa madre derivaba materia prima. Este mecanismo de tercerización ahorraba una parte importante de los problemas de contratación y de organización del trabajo a aquellas empresas de mayor tamaño. ${ }^{522}$ Los dueños de estas plantas procesadoras dieron forma a la Asociación de Procesadores de Pescado. ${ }^{523}$ En paralelo a estas plantas "legales" históricamente en la industria de la pesca funcionaron las façoneras, también llamadas "cuevas" o "covachas", que eran establecimientos satélites clandestinos que disponían de instalaciones y mano de obra para realizar el procesamiento del pescado, mientras que seguían siendo empresas de mayor envergadura las que suministraban los insumos, la materia prima y, en algunos casos, también asistencia técnica. La razón de su existencia la explica con sencillez Pradas: "Siempre existió como tendencia porque la patronal nunca pudo regular eficientemente la captura de la materia prima, entonces cuando tenía algún excedente con respecto a capacidad de proceso instalada en las plantas, recurría a una 'cueva' (planta en desuso) donde se trabajaba a changa, en negro y pago al finalizar la jornada" (Pradas, 2006: 54). ${ }^{524}$ Esta situación de clandestinidad fue (y lo es aún hoy) una constante en la industria pesquera y por ello objeto de controles, tanto del Servicio Nacional de Sanidad Animal (SENASA) como de la Administración Federal de Ingresos Públicos (AFIP). ${ }^{525}$

Hacia finales de la década del ' 80 y comienzos de la del '90 era la Asociación de Procesadores de Pescado la que multiplicaba las denuncias respecto de las plantas clandestinas de procesamiento de pescado dado que su funcionamiento resultaba una competencia desleal con aquellas fábricas façoneras que mantenían a sus empleados bajo relación de dependencia. Por ejemplo, en el contexto de cierres de plantas pesqueras en el año 1990 y ante la situación definida por la no entrega de materia prima a las plantas procesadoras “independientes”, la Asociación manifestaba:

Si los frigoríficos no entregan materia prima a las plantas, éstas no pueden pagar a sus operarios. Se genera así una cadena, donde los únicos que resultan gananciosos son los propietarios de plantas clandestinas, ya que los operarios de estas plantas no pueden hacer ningún reclamo legal y trabajan por lo que les pagan. ${ }^{526}$

\footnotetext{
${ }^{522}$ Benjamín Coriat describe el funcionamiento del sistema a destajo o ajuste a tanto alzado como una de las fuerzas más eficaces utilizadas por los fabricantes para tratar de circunscribir el oficio. En su descripción un destajista era un subcontratista de mano de obra que, con las materias primas y la maquinaria proporcionada por los patrones, hacía ejecutar trabajos a él confiados con la ayuda de obreros que él mismo contrataba y pagados por él por día o pieza sin intervención del patrón. De este modo, el destajista se erigía como organizador del trabajo y contratista de mano de obra, liberando de estas tareas a "la empresa". Cómo hombre de oficio, el destajista estaba en condiciones de cumplir con más eficacia que el patrón dos funciones esenciales: el reclutamiento y la organización y vigilancia del trabajo (Coriat, 1997).

${ }^{523}$ La Asociación de Procesadores de Pescado no debe confundirse con la Cámara Argentina de Procesadores de Pescado. La principal diferencia es que ésta última, cómo sus titulares generalmente también eran armadores, confluirá con la CAABPA funcionando de hecho sus oficinas en el mismo espacio físico que la mencionada cámara de armadores.

${ }^{524}$ El grado de informalidad de alguno de estos lugares donde se procesaba pescado queda ilustrado en el siguiente relato que realiza Oscar Fortunato: "Mi primer trabajo en la Junta Nacional de Carnes fue subirme a una camioneta F100 a buscar plantas clandestinas. En una cancha de bochas encontré una planta. Y hasta debajo de una parra encontré una planta con un señor lisiado que era el que la regenteaba. Y así te puedo contar 20 historias". Entrevista del autor con Oscar Fortunato... op. cit.

${ }^{525}$ Por ejemplo en 1973, trabajadores se referían al problema de las plantas clandestinas "las que aumentan sin que nadie haga nada". L.C.,29/03/1973.

${ }^{526}$ L.C., 17/01/1990.
} 
También el SOIP denunciaba la situación. Luego de la victoria de Carlos Menem, Abdul Saravia esperanzado con las perspectivas que emanaban del nuevo gobierno calificaba como "Piratas del Pescado" a los establecimientos "que continúan trabajando en las sombras de la noche como si nada hubiera pasado" $" 527$. Pero más allá de las denuncias de estas "cuevas", el dirigente sindical pretendía dejar en evidencia a las plantas proveedoras de materia prima, las que sí tenían sus papeles en regla, pero regulaban sus excedentes de producción enviando el pescado para procesar en tales establecimientos que operaban ilegalmente con trabajadores no registrados. Al respecto, a través de un comunicado, Saravia denunciaba que:

...uno de los representantes o responsables de la provisión de la materia prima a estas 'covachas' es José Di Iorio, quien trasgrediendo normas vigentes desde su establecimiento, en San Salvador 3.200, intenta ejercer un negocio en la total clandestinidad e insensible a la cobertura médico asistencial que debe prestarse a todo el personal.

Luego de informar acerca de la implementación de una campaña para erradicar las actividades clandestinas en el sector, el titular del SOIP aseguraba que:

...es necesario continuar con esta lucha, que periódicamente aparece ante la indiferencia de la delegación municipal del Puerto, la que a través de sus inspecciones solamente atina a dar días de plazo para que estos infractores se presenten ante el Juez de Faltas otorgando de esta manera más oxígeno a estos seudo-empresarios que en muchos casos hacen trabajar en casas de familia, con todos los riesgos de contaminación que eso significa para el vecindario. ${ }^{528}$

Ante las denuncias sindicales, el entonces delegado municipal del Puerto, Jorge Iácono, se defendió señalando que "no hay indiferencia con respecto al problema de las plantas clandestinas de fileteado". Mientras que el titular del Departamento de Habilitación de dicha delegación, Edgardo D’Avila, explicó que "en lo que va del año 1989, se han realizado (en el área de la Delegación), 55 constataciones de plantas de fileteado clandestinas". Además expresaba las dificultades existentes para el control, dado que a veces "cuando vamos a realizar un acta de infracción, chocamos contra la oposición de los propios trabajadores que se desempeñan en esos lugares y que, desde sus puntos de vista, defienden su trabajo". ${ }^{52}$ Y declaraba también la complejidad de la cuestión dado que era imposible calcular cuántas plantas clandestinas funcionaban en la ciudad, pues algunas estaban en casas particulares y se iban cambiando de lugar. "Una planta que un día estaba en esta cuadra, la semana próxima está en la otra y a veces resulta muy difícil de detectar". ${ }^{530}$ Días después informaba acerca de la detección de alrededor de 50 posibles plantas de fileteado irregular, el labrado de 19 actas de infracción y 7 clausuras. ${ }^{531}$

\footnotetext{
${ }^{527}$ L.C., 20/09/1989.

${ }^{528}$ L.C.,20/09/1989.

${ }^{529}$ Esta situación aparece reflejada en la prensa cuando un grupo de obreros denunció que a raíz de la clausura municipal de una planta ubicada en la calle Guanahani 3555, 24 familias marplatenses se quedaron sin trabajo. Aunque se trataba de una planta clandestina, vale aclarar, la clausura llegaba por el incumplimiento a las normas de uso de suelo y no por la explotación no regulada que allí se realizaba de la fuerza de trabajo. L.C.,01/07/1990.

${ }^{530}$ L.C., $21 / 09 / 1989$.

${ }^{531}$ L.C.,05/10/1989. Durante la primera quincena de octubre, la delegación Municipal del Puerto informaba sobre la realización de 70 inspecciones en lugares en donde podían funcionar plantas clandestinas de fileteado de pescado, labrando 20 actas de constatación y clausurando tres locales. L.C.,18/10/1989. También la Asociación de Procesadores continuaba denunciando las
} 
También sucedía que en alguna planta de funcionamiento legal determinado grupo de obreros y obreras laboraban sin estar registrados. Por ejemplo, en el marco de la toma del frigorífico Ferrier llevada a cabo por sus trabajadores (analizamos el hecho más adelante), Saravia declaraba que existían fábricas infractoras que no pagaban las cuotas de obra social y sindical, acostumbrando a ocupar personas a la manera de la "changa", es decir, eludiendo los aportes que corresponden por ley. Y denunciaba que era fácil reconocer el fenómeno por el anuncio de "pago al finalizar", cosa que estaba prohibida. ${ }^{532}$ Como respuesta, el gremio incentivaba continuar realizando inspecciones, contando ahora con la colaboración de la delegación del Ministerio de Trabajo de la Nación. Esta delegación, en la última ronda de inspección realizada en el mes de enero había encontrado personal trabajando "a changa" en distintos establecimientos fabriles. Por ejemplo en la fábrica Manuel Francisco Milillo, donde trabajaban 25 obreros. La estrategia sindical era informar de las inspecciones, darles publicidad y publicar los nombres de los responsables. ${ }^{533} \mathrm{~A} 1$ mismo tiempo, el SOIP se encargaba de elaborar listas de plantas clandestinas durante las inspecciones y luego las denunciaba en la prensa. También solicitaba a diferentes entidades que colaborasen con la erradicación de dicho "flagelo". Por ejemplo, a la Delegación Municipal del Puerto le pedía que proceda a clausurar establecimientos "que se encuentran trabajando al margen de la ley, evadiendo los entes oficiales, previsionales, sociales, aportes y contribuciones legales en vigencia". Y a continuación brindaba las direcciones de las plantas "Padre Dutto 771, Calle 104 y 25 (frente a Alem), Calle 100 y 25 (esq. Taller), José Martí 815...".534 En julio de 1990, desde el SENASA, Jorge Raed explicó que en Mar del Plata estaban funcionando diariamente 250 plantas clandestinas, 145 de las cuales fueron constatadas por la Municipalidad, sin tener ninguna habilitación. Resaltando que contaba con el apoyo gremial del SOIP para buscar solución al tema, advirtió que existían plantas clandestinas de fileteado de pescado que funcionaban en un garaje o hasta al aire libre en tablones. Y "ese pescado muchas veces ingresa a las plantas para ser exportado". Al mismo tiempo aclaró que desde el Servicio de Sanidad Animal "No se van a cerrar las plantas, sino que las mismas se van a quedar sin materia prima porque no va a estar certificado el producto que reciban". 535

Es interesante remarcar la complejidad de la situación. Por un lado estaban las plantas clandestinas, las cuales podían ir desde establecimientos donde laboraban una veintena de trabajadores, hasta garajes o patios de casas, donde unos pocos obreros u obreras fileteaban el pescado. Pero estas "plantas" que funcionaban en la ilegalidad no existían completamente separadas de las plantas formales. Más aún, como podemos inferir de las fuentes, era habitual que empresas "legales" recurrieran en ocasiones en que lo necesitaran a desviar parte de su producción a aquellas plantas clandestinas. Pero no sólo eso, sino también, estas empresas a veces contrataban parte de su personal, por lo general con carácter temporario, sin registrarlo como trabajador en relación de dependencia. En diciembre de 1990 era el SOIP el que daba a conocer una lista de empresas, algunas de ellas de las más importantes, denunciadas al Ministerio de

plantas de procesamiento clandestino evasoras del pago de cargas sociales. L.C.,22/10/1989; 07/11/1989. Miembros de la entidad llegaron a entrevistarse con el subsecretario de Pesca Luis Otero, a quien entregaron una nómina de lo que llamaban el "Club de dadores de materia prima" para su elaboración clandestina, buscando se penalice a quienes proveían la materia prima. L.C.,12/11/1989.

${ }^{532}$ L.C., 18/01/1990.

${ }^{533}$ L.C., 31/01/1990.

${ }^{534}$ L.C., 18/05/1990.

${ }^{535}$ L.C.,21/07/1990. 
Trabajo por haberse comprobado la contratación de personal en condiciones de trabajo al margen de la legislación laboral. ${ }^{536}$

A comienzos de 1991, y mientras numerosas empresas pesqueras se presentaban en convocatoria de acreedores y cerraban sus puertas, continuaban las inspecciones realizadas por la Delegación Municipal del Puerto detectando plantas pesqueras que funcionaban sin habilitación. En el mes de mayo de 1991 el ente municipal clausuró 19 plantas clandestinas. Quien entonces se desempeñaba como delegado Municipal del Puerto, Ricardo Maglieri, prefirió no llamar plantas clandestinas a los sitios clausurados "No pueden llamarse plantas a lugares como galpones, garajes, quinchos de viviendas e incluso talleres mecánicos, donde hemos detectado el procesamiento de pescado". La finalidad de los procedimientos se daba más por una cuestión sanitaria que por un control laboral. Maglieri demostraba su preocupación señalando que "si queremos ser exportadores de pescado y fundamentalmente preservar la salud de la población, no podemos permitir que funcionen estos lugares de fileteado clandestino". 537 No obstante estas medidas, un cronista, bajo el seudónimo de Sebastián Fish, podía afirmar:

Mucha prensa tuvieron las clausuras de plantas clandestinas de fileteado en la zona portuaria. La demostración de autoridad se tradujo en la colocación de fajas y sin que eso se sepa oficialmente, en la aplicación de algunas multas. Sin embargo, apenas cesó el ruido de los operativos, los muchachos de las clandestinas retiraron las fajas y cuchillo en mano volvieron al fileteado como si nada hubiera pasado. Una simple recorrida por el lugar permitirá a los funcionarios comprobar que los operativos apenas si fueron considerados un tirón de orejas. ${ }^{538}$

\section{Alquimistas del trabajo: la transformación del obrero en empresario ${ }^{539}$}

En Argentina las cooperativas (incluyendo las de trabajo) se rigen por medio de la Ley $\mathrm{N}^{\circ}$ 20.337/73 que las define como "entidades fundadas en el esfuerzo propio y la ayuda mutua para organizar y prestar servicios". A su vez, la Ley $N^{\circ} 25.877 / 97$, en lo relativo a las cooperativas de trabajo,

${ }^{536}$ L.C.,06/12/1990. Las firmas mencionadas de trabajar “en negro” eran Pesquera San Andrés, Pesquera San Nicolás, Loba Pesquera, Valastro Alberto y Cía. S.A., Ventura Mar del Plata (Yagan), Pesquera Alondra, Pescamar, Solimeno Luis e Hijos, Larno Hnos., Salerno, Golfo, Frigocen, Pesquera Atlántico Norte, Fiolo Prestifilipo, Lorinto, Marejada, Pesquera Mar Azul, Rúa Angel Hnos., Rúa Hnos. S.A., Barilari Antonio, Pesquera Beamor, Bonarde, Vasco Da Gamma, Tour, El Progreso Marplatense, Pesquera Príncipe, Pesquera Rodríguez, La Pesca, Aballay Pedro Ángelo, Centauro, Marycar, Compemsa y Leomar S.A. luego se mencionan las firmas con personal a changa y sin registración contable: Frigorífico Santa María, San Cono, Bonarbe II, Rosi (Tarpal), Cegemar, Fiolo y Prestifilipo, algas Pesquera, Mariscal Eduardo, Ferrero Vicente, Lauro Francisco, Príncipe I y II, San Marcos, Dispez, Sumai, Marexport, Mapaz, Cuberan, Lemos y Roda, Balamar, Pesquera Don José, Di Yorio, Pesquera Juancito, Lemar, Fénix, Balero (el Refugio), Pesquera Azopardo, Feliz Quintana, Coral del Norte, Filpesca, San Basilio, san Matías, Alas Pesquera, Acuario, Cafiero y Polio, Omar Posadas, Pescadería Costa Azul, Algas Pesquera, planta de fileteado de Gianelli al 870, Alfredo Tivolo, planta de Hernandarias 3366, Pescamar, Planta de Magnasco 1360, planta El Hormigón, planta de Don Orione 909, planta de José Martí al 2828, planta de José Martí al 2835, Spina Hnos., Dos Océanos, Juan Todisco, Satumar y Pesquera Puerto Nuevo.

${ }^{537}$ L.C., $03 / 05 / 1991$.

${ }^{538}$ L.C., 10/06/1991.

${ }^{539}$ Aquella transfiguración emanaba desde la cúspide del poder presidencial. Recordemos sin más las palabras del ex presidente Carlos Menem cuando luego de anunciar los Programas de Propiedad Participada tras la privatización de diferentes empresas del Estado, hacia el año 1991 dijo: "He expresado en muchas oportunidades que quería también una patria, un país, una Argentina con menos proletarios y más propietarios, y esto se está dando actualmente. Este acto importa convertir en propietarios a quienes durante muchos años, y a través de varias generaciones, trabajaron incansablemente para ir encontrando un lugar en el contexto de la comunidad organizada...” (cit. en Fair, 2008: 6). 
ratifica la prohibición de actuar como intermediarios (en tanto agencias de colocación y/o empresas de servicios eventuales) en la contratación de personal. Según esta ley, si se constatara que el 'socio' en realidad es un trabajador en relación de dependencia encubierto y que se utiliza en forma fraudulenta la figura de la cooperativa, se procederá a su juzgamiento y sanción. La ley, si bien pretendía atacar el fenómeno, no hacía sino demostrar su existencia. Y de la disputa entre el derecho y el hecho, este último mostraba su fortaleza. Sin embargo, a medida que este fenómeno iba creciendo su ropaje legal no lograba cubrirlo por completo y se descubría como un eufemismo. Entonces no tardaron en hacerse oír las voces que denuncian su ilegitimidad e ilegalidad. Desde Portalcoop (Portal de cooperativas y mutuales), el Vicepresidente del Colegio de Graduados en Cooperativismo y Mutualismo consideraba lamentable que dentro del sector cooperativo se encuentren: "entidades que en su práctica cotidiana muestran una separación y una gran brecha entre el pensamiento y la acción cooperativa". Muchas se constituyen "sólo por algunas conveniencias impositivas o para evadir obligaciones de la previsión social, siendo utilizadas como herramientas de flexibilidad laboral por parte de la patronal para redoblar la explotación sobre los obreros, mediante engaños, enmascarando fraudulentamente una relación laboral de dependencia". Es común que a éstas se las denominen 'seudocooperativas' o 'cooperativas truchas' debido a que:

...son pura apariencia y no tienen nada más que el nombre de cooperativa. Son creadas desde la patronal, cubriendo con testaferros, amigos y/o parientes los cargos en los consejos de administración y en la sindicatura. Cuando la forma cooperativa es utilizada como pantalla, es decir, utilizan sólo el nombre, los trabajadores, supuestos asociados suelen llamar 'dueño(s) o patrón(es) de la cooperativa', a la(s) persona(s) que la(s) maneja(n) y los explotan (Fontela, 2008).

En el proceso de desarrollo de cooperativas la paradoja radica en el hecho de que lo que otrora fuera una herramienta de resistencia y lucha obrera en contra de la explotación del capital, mutó hacia principios de la década del '90 convirtiéndose en un instrumento para incrementar la explotación obrera en manos capitalistas, pasando a integrar el listado de las formas y mecanismos de precarización laboral. Como señalan Neffa et al:

Históricamente, este tipo de cooperativas fue creado en el siglo XIX por los obreros de oficio para organizar las empresas de tipo no capitalista, donde predominara una relación igualitaria y solidaria entre sus miembros, que trabajan sin relación de dependencia y sin estar sometidos a la subordinación. Se trata de unidades económicas en las que jurídicamente sus integrantes son socios cooperarios en lugar de asalariados; por lo tanto no correspondería que sus relaciones dentro de la firma sean reguladas por el derecho del trabajo y de la seguridad social (Neffa et al, 2008: 98).

De esta manera, irónicamente las cooperativas que surgieron como un modo asociativo regido por los principios de solidaridad y de gestión democrática se transformaron en un andamiaje jurídico-legal y en una forma de organizar el trabajo con el objetivo de reducir los "costos salariales". Sabe el capitalista que para formar valor es necesario gastar trabajo de manera útil. Y ese gasto, en su proceder, puede alentar la explotación obrera, deteriorando las condiciones de vida y trabajo de la población. Aunque no necesariamente fue así como lo asimilaron los propios trabajadores. Por definición el empleo en estas seudocooperativas está precarizado. Por lo general "los socios" no están registrados, no reciben aportes jubilatorios, ni poseen obra social, ni seguro de vida ni aseguradora de riesgo de trabajo (ART). Y en caso 
de tener algunas de estas prerrogativas se debe a que están inscriptos como monotributistas y son ellos mismos quienes las costean. Aunque tampoco la realidad es tan clara, dado que existen cooperativas donde los responsables de las mismas se hacen cargo de dichas cargas sociales, sin dejar de mantener a los obreros como monotributistas. Los "socios" tampoco tienen representación gremial. Si bien desde 1992 se encuentra vigente una resolución del Ex Instituto Nacional de Acción Cooperativa (actual Instituto Nacional de Asociativismo y Economía Social) que establece que estas cooperativas deben prestar a sus asociados los beneficios de la seguridad social, otorgar prestaciones dinerarias correspondientes a enfermedades o accidentes laborales y brindar un sistema de obra social; muchas de las cooperativas desconocieron estas obligaciones $\mathrm{y}$, debido a la insuficiencia o dificultades de aplicaciones de los controles y las sanciones, continúan en funcionamiento (Neffa et al, 2008).

La existencia de cooperativas fraudulentas no es una realidad privativa de Argentina. Colombia parece ser un caso paradigmático ${ }^{540} \mathrm{Su}$ propagación alcanza escala planetaria, aunque su terreno privilegiado son los países del hasta hace poco llamado “Tercer Mundo". La cuestión se relaciona con:

...las políticas de adelgazamiento del aparato estatal, que han tenido efectos nocivos en términos de desempleo y subempleo, porque además del impacto directo que implica el despido de trabajadores del sector público, la flexibilización del mercado de trabajo se ha traducido en una proliferación inusitada de cooperativas de trabajo, forma eufemística por medio de la cual los empresarios le hacen el quite a las obligaciones laborales que tendrían con los trabajadores en un escenario más humano. Así, se mostrará... que las nuevas formas de contratación han llevado a un deterioro en las condiciones laborales evidentes en el auge del outsourcing, la subcontratación y la desprotección en lo relacionado con la seguridad social (Ramírez Rojas y Guevara Fletcher, 2006: 99-100).

En nuestro país las seudo-cooperativas de trabajo se extienden por todo el territorio nacional, tanto en el ámbito urbano como en el rural. Sin embargo, este universo es heterogéneo y los trabajadores más perjudicados son aquellos vinculados a las ramas industriales con alta estacionalidad. Dentro de estos últimos se destacan las ramas agroindustriales. Esta modalidad de tercerización, que se enmarca en una aparente legalidad, representa uno de los aspectos más extremos de la llamada precarización laboral. Donde, a través de una alquimia de la relación laboral, el trabajador se convierte en 'asociado'. Socio que carece de los beneficios cristalizados en la legislación laboral y los convenios colectivos, no cuenta con aportes previsionales, estabilidad laboral, beneficios asistenciales, protección ante accidentes, enfermedades y, en general, percibe un salario por debajo del establecido por el Convenio Colectivo de Trabajo(Bendini y Gallegos, 2002).Esta modalidad de precarización de la relación laboral, que estaba latente en nuestro país, se expandió abruptamente a partir de 1990, década en la cual la mayoría de las

\footnotetext{
${ }^{540}$ Para América Latina véase Ermida Uriarte y Colotuzzo (2009). Según Álvarez “...en la actualidad las cooperativas de trabajo asociado en Colombia se encuentran en un estado de alerta debido a la proliferación de pseudo-cooperativas que utilizan esta figura jurídica, para realizar prácticas laborales y de contratación contrarias al espíritu cooperativo, y que en definitiva generan tercerización, deslaborización, precarización de las condiciones salariales y de la seguridad social de los trabajadores asociados" (Álvarez, 2007: 2). Por otra parte, en un estudio de caso sobre la transnacional Unión Fenosa, el Tribunal de los Pueblos a las Transnacionales Europeas y su actuación en América Latina y Caribe (TPTEALT) considera que el proceso de subcontratación y flexibilización laboral se instrumentó haciendo que "los puestos vacantes, tras los retiros y despidos" no fuesen cubiertos "con la incorporación de nuevo personal, sino que se ha subcontratado a empresas contratistas, cooperativas de trabajo asociado y pequeñas y medianas empresas. El resultado es que el grado de externalización de un trabajo puede llegar hasta tres o cuatro niveles de subcontratación, y lleva aparejado que, a medida que la relación con la empresa resulta más lejana, disminuye la responsabilidad que se le puede atribuir a Unión Fenosa en cuanto al control sobre las condiciones laborales, los accidentes y la precariedad" (TPTEALT, 2008: 27).
} 
'cooperativas' que prestan servicios laborales a terceros cometían fraude laboral (Ibarlucía, 1997). El desarrollo de estas cooperativas fraudulentas fue (y es) significativo en los sectores agroindustriales, particularmente los frutihortícolas de San Pedro (provincia de Buenos Aires), Tucumán, Mendoza, Neuquén y Rio Negro. En el caso de la industria pesquera, con sus especificidades locales, el fenómeno de pseudo cooperativas de trabajo que prestan servicio de fileteado está presente en países que van desde la India hasta Argentina, pasando por Sudáfrica, Marruecos, Perú y Chile.

\section{Las “cooperativas" para el procesado de pescado en Mar del Plata}

"El origen de estas cooperativas de trabajo que se han hecho conocidas bajo la denominación de 'truchas'o 'pseudo cooperativas', no es otro que el espíritu corrupto de algunos empresarios del sector que no encuentran otra fuente de aumento de sus ingresos económicos que no sea la explotación de los obreros que allí trabajan"

Abdul Saravia, 1995

Hemos visto ya que las plantas clandestinas, así como el trabajo informal, eran una realidad que acompañó a la actividad de fileteado de pescado desde su nacimiento. A su vez, también data desde su inicio la búsqueda por parte del empresariado por dar forma a una modalidad de trabajo que excluyera la responsabilidad propia respecto del personal contratado. Para ello trataron de instrumentar la conformación de sociedades obreras autónomas, las cuales no guardaban ninguna relación de dependencia con las industrias motrices, brindando solamente el servicio de trabajo. Es así que a principios de la década del '60, por ejemplo, la Pescadería Atlántida perteneciente a lo que luego sería el grupo Moscuzza propuso (a modo más imperativo que consultivo) a "sus" obreros la conformación de una sociedad “autónoma" llamada SOFI (Sociedad de Obreros Fileteros). ${ }^{541}$ De este modo, los industriales eludían la responsabilidad respecto del personal contratado y podían ajustar la necesidad de fuerza de trabajo a la disponibilidad de pescado volcando los costos de aquellos vaivenes sobre los propios trabajadores.

El sistema de "sociedad" o "coparticipación" instaurado por la patronal, no solo era estratégico para ajustar rápidamente y sin costo la demanda de mano de obra con las oscilaciones de la materia prima y la demanda de filet. También era un excelente sistema para eludir los costos de las enfermedades y accidentes laborales que no fueron exóticos en el medioambiente de las plantas de fileteado. En esas circunstancias lxs fileterxs tenían que tener cuidado de no enfermarse o accidentarse, pues no solo la empresa se desentendería de los costos de la atención médica a la vez que los días no trabajados por enfermedad y accidente no serían abonados, sino que corrían el riesgo de perder el puesto de trabajo (Nieto, 2012: 525).

Esta modalidad permitía contratar y despedir prácticamente sin trabas, convirtiendo a los obreros en "trabajadores autónomos". Sólo la resistencia y organización de los obreros y obreras, sumado a un cambio en la "justicia" que se volvió receptiva a las solicitudes laborales, permitió vulnerar el intento de hacer extensiva esta modalidad de trabajo, particularmente cuando se generalizaron las demandas en los

541 'La propuesta patronal consistía en la formación de grupos de fileteros y fileteras en "sociedad o coparticipación", entidad "autónoma" que ofrecía sus "servicios" de fileteado a las firmas pesqueras' (Nieto, 2012: 541). En ocasiones, se presentaba esta modalidad de trabajo como obligatoria para conservar el empleo. 
Tribunales del Trabajo. Primero se produjo un huelga de más de 30 días de duración en contra de las condiciones laborales imperantes (Nieto, 2012). Y desde los propios Tribunales de Trabajo se reconoció que aquellos y aquellas trabajadores y trabajadoras que presentaban demandas en realidad mantenían una relación de dependencia con las plantas denunciadas. La cuestión no era menor, ya que resolvía que los trabajadores y las trabajadoras eran obreros y no "cuentapropistas" como quería definirlos la parte empresarial y, por tanto, tenían derecho a denunciar a estos últimos. Esto motivó, entre otras cuestiones, que los arbitrarios despidos de la patronal pesquera cada vez le resultaren más onerosos. Y, por tal motivo, se constituyó en una traba contra el despotismo patronal. ${ }^{542}$ Sin embargo la informalidad en el trabajo de fileteado, más que llegar a su fin, continuó siendo un territorio de disputa ya que los empresarios no abandonaron nunca la práctica de procesar una parte de la materia prima en plantas clandestinas, las cuales fueron continuamente denunciadas por los trabajadores. Así como tampoco los obreros dejaron de dotar de mano de obra a esta iniciativa. A veces eran obreros "distintos" y, en otras ocasiones, trabajadores en relación de dependencia podían laborar en otras partes sin aquella registración.

El 23 de febrero de 1973 el SOIP declaraba un paro y movilizaba a los trabajadores en contra de las plantas clandestinas, las cuales no respetaban "los convenios laborales, ni en salarios ni en asignaciones familiares". Aquella movilización terminaba en una cruenta represión policial. ${ }^{543}$ Pero, lo que era un fenómeno ilegal y realizado de manera oculta, una "avivada de los empresarios pesqueros" (Pradas, 2006), se convirtió en los inicios de la década del '90, en el marco de las reformas estructurales, los cambios en el Estado y las transformaciones de la relación salarial, en una política generalizada. Se buscaba reducir los costos de producción y mejorar la competitividad al disponer de una amplia plantilla de trabajadores eventuales, sin que ello implicara algún tipo de responsabilidad o sujeción para las empresas. Es así como a partir del año 1991 nacen en la industria del pescado las cooperativas de trabajo para la elaboración del filete. Con ellas, los empresarios pesqueros lograban cumplir un viejo anhelo.

Antes de ingresar en su descripción vale la pena mencionar que en agosto de 1991 un grupo de trabajadores pertenecientes a la Comisión Pro-Reactivación de la Actividad de la Pesca se reunía con el entonces intendente interino y luego Intendente por dos períodos consecutivos, Elio Aprile (UCR) y con el director de Acción Cooperativa de la Comuna, Enrique Marín Vega. A ellos les consultaban acerca de la posibilidad de formar una cooperativa de trabajo que, según su visión, aportaría soluciones a la situación de desocupación que estaban padeciendo los trabajadores y permitiría poner en funcionamiento las empresas que se encontraban en convocatoria de acreedores o con pedidos de quiebra. ${ }^{544}$ La iniciativa, en este caso, partía de la voluntad obrera ante la angustia que generaba el cierre de empresas y la cada vez más extendida desocupación.

Sin embargo, es precisamente en el marco del nuevo modelo de acumulación, sustentado en la paridad cambiaria, donde la búsqueda de mayor competitividad por parte de las empresas se basó, por un lado, en incorporación de tecnología y en la integración de las diferentes actividades, y por otro, fundamentalmente, en mecanismos de reestructuración de la organización del trabajo, generando incrementos de productividad y disminución de costos. En tal contexto, la iniciativa cambió de manos. En el año 1992 el SOIP denunciaba junto con los obreros de una empresa pesquera actos de "extorsión" por parte del presidente de un establecimiento pesquero para lograr "la renuncia voluntaria y así crear una

\footnotetext{
${ }^{542}$ Para conocer el nacimiento y evolución de los Tribunales del Trabajo en Mar del Plata, particularmente en relación a las demandas de los obreros y obreras del pescado, véase Nieto (2012).

${ }^{543}$ Archivo DIPPBA, Mesa B, Factor gremial, Carpeta 57, Legajo 17, Folio 147-148, 23/02/1973.

${ }^{544}$ L.C.,06/08/1991.
} 
'cooperativa de trabajo"'. El gremio advertía que el propietario pretendía crear una cooperativa que él mismo presidiría. Los trabajadores manifestaban que el empresario:

...está extorsionando a los trabajadores para que presenten la renuncia voluntaria a cambio de un 25 por ciento de las indemnizaciones, lo que sería pagado en cuotas que llegan hasta el año [...] El objetivo del señor Cioffi [titular de la empresa] es sumarse a los otros patrones que quebraron y/o cerraron sus empresas para convertirse en cooperativistas, una figura legal que es propicia para evadir todo tipo de aportes [debido a que] con suma facilidad tramitan ante el INAC la correspondiente inscripción y posterior matriculación. ${ }^{545}$

Y como el ente oficial "no posee inspectores para la posterior verificación, las mismas no funcionan de acuerdo a lo previsto por las leyes vigentes". Luego denunciaban que "a Alfonso Cioffi no le bastó con quedarse con los aportes de los trabajadores de su anterior empresa", sino que "siendo cooperativista dejaría de pagar los accidentes de trabajo, las asignaciones familiares, feriados, vacaciones, aguinaldo y por último la garantía horaria de acuerdo al CCT $N^{\circ} 161 / 75^{\prime}$. Este caso particular participaba de la situación general de la industria pesquera marplatense después de las quiebras de empresas afectadas por el cambio de orientación en la política pesquera nacional. Ante tal situación “...la mayor parte de las empresas han adoptado estrategias de 'competitividad costo' basadas en la competitividad salarial". ${ }^{546} \mathrm{Y}$ dado "que la participación de la mano de obra en el costo total es aproximadamente el 33\%, ella es la forma más directa de lograr mejoras en la competitividad en el corto plazo" (Gennero de Rearte et al, 1997: 57). De esto se desprende que la desintegración vertical en cooperativas de trabajo del proceso de fileteado (la tarea más intensiva en el uso de trabajo), fuese una estrategia clara de competitividad salarial. Al respecto, los:

...problemas de costos [de las empresas] constituirían una de las causas de la precarización del empleo del personal de las plantas fileteadoras. La necesidad de las empresas locales de mantenerse competitivas frente a los buques procesadores, y la permisiva legislación laboral aprobada a mediados de los '90 dieron lugar al surgimiento de seudo-cooperativas de trabajo que, al tiempo que reemplazan una relación laboral directa fueron la vía para ajustar costos en el marco de la convertibilidad pesodólar uno a uno (Godelman, s/f: 8 y 9).

El Censo Pesquero realizado en 1996 cataloga a estas cooperativas bajo el rubro "Procesado y fileteado fresco" ${ }^{547}$. De un total para la región bonaerense de 175 establecimientos pesqueros, 66 asumieron la forma de cooperativa. Buena parte de estas cooperativas carecía de plantas propias y funcionaba dentro de las plantas de procesamiento de las empresas que contrataban sus servicios de mano de obra. La transformación de la forma organizativa se dio entre mediados de 1991 y comienzos de 1992, cuando muchos obreros fueron despedidos u obligados a renunciar y posteriormente se los volvió a incorporar pero en calidad de "socios" de las cooperativas. Algunos trabajadores fueron indemnizados,

\footnotetext{
545 L.C.,28/08/1992.

${ }^{546} \mathrm{La}$ competitividad costo está integrada por el costo laboral que incluye los salarios directos e indirectos más las cargas asociadas a ellos, que junto con la productividad del trabajo constituye la competitividad salarial (Gennero de Rearte et al, 1997).

${ }^{547}$ El censo expresaba "En 1987 existía la modalidad del fasón, que eran plantas pesqueras de pequeño tamaño que fileteaban el pescado y lo vendían a las plantas del rubro procesado, fileteado y congelado, que continuaban con su elaboración. A partir de 1996, y por una cuestión de disminución de costos laborales de las grandes empresas, surgen las cooperativas de trabajo".
} 
pero muchos otros mantienen aún al día de hoy juicios con las empresas que presentaron quiebra. Así es que la cooperativización y el "trabajo en negro" se convirtieron en una de las principales estrategias de crecimiento impulsadas por los industriales pesqueros.

En una verdadera cooperativa, los socios compran la materia prima, procesan el pescado y luego lo venden, se eliminan los costos operativos y la diferencia se reparte entre todos. Este tipo de régimen societario legal se basa en el esfuerzo común, ayuda mutua y fin común. En la práctica, el mismo fue utilizado en forma 'fraudulenta' dado que en el proceso productivo el filetero aporta la mano de obra pero la materia prima y la comercialización están a cargo del dueño, produciéndose de esta manera la distorsión del principio cooperativo. La empresa no figura dentro de la cooperativa pero conforma un comité de administración digitado por el propio empresario. Esta última aparece como contratando el servicio de mano de obra de la cooperativa y como proveedora de la materia prima, pagando a cambio del trabajo un monto determinado, que varía de acuerdo a la variedad de pescado procesado (Rodríguez et al, 1999: 47).

En casi todos los casos no eran los trabajadores quienes se ocupaban del armado de la cooperativa, sino que eran los empresarios, personas que trabajaban para ellos, o gente de manera independiente, quienes conformaban el diseño de la cooperativa, perfilaban el consejo de administración, ponían los abogados, el contador y hasta el nombre y, recién luego de todo ello, le "ofrecían" a los trabajadores inscribirse en ella. También los empresarios incurrían en promesas acerca de que pondrían a disposición de la cooperativa los bienes de su empresa, llegado el caso de ser necesario, venderle edificios e instrumentos de producción. Según las entrevistas realizadas, muchos trabajadores creyeron que aquella ocasión sería propicia para convertirse ellos mismos en dueños. Y el drama era tan espeso que, en ocasiones, cuando algún obrero u obrera no quería formar parte de una cooperativa, los mismos compañeros llegaron a expulsarlo/a de la fábrica. ${ }^{548}$

Es en agosto de 1991 cuando encontramos la primera denuncia respecto de la creación de cooperativas realizada por Abdul Saravia. El titular del SOIP denunció la actividad de tres cooperativas pesqueras porque "éstas son supuestas cooperativas ya que están encubriendo a empresarios, que son los que las manejarian. Esas cooperativas de trabajo serían Filecoop Ltda., 'Venceremos' -estas dos funcionan en la planta Santa Cruz-y la Cotrafil, creada por la empresa Ostramar S.A.". Con respecto a la primera señalaba que "esa planta que alquila sus instalaciones a la cooperativa, le saca el 20\% del bruto de la producción”. Mientras que:

...los obreros desarrollan jornadas diarias de entre 13 y 15 horas, en algunos casos el pago es de 20 mil australes la hora. Otro caso es que trabajan 4 mujeres cobrando entre todas 350 mil australes por tonelada. Además el pago es con fecha diferida a la que se trabajó y sufre un descuento, en algunos casos argumentando que es para abonar la cuota de la O.S.(obra social) -que desde ya no la pagan-, en caso de accidente y si no le quitan en concepto de gas para poder utilizar la cocina o para poder tomar algo. Además tienen la modalidad de llamar al obrero por radio, pidiendo envasadoras

\footnotetext{
548 "Si vos no querés trabajar, dejame trabajar a mi" era el argumento de los trabajadores que se corporativizaban contra aquellos que no querían hacerlo. Segunda entrevista del autor con Elda Taborda, filetera y militante del Partido Comunista (Mar del Plata, 11/02/2011).
} 
con equipo. Las toman por 3 o 4 días, las despiden señalándoles que las volverán a llamar de la misma manera, es decir por radio. ${ }^{549}$

Saravia también informaba que la "cooperativa" Venceremos (de curioso nombre) echó a una empleada por reclamar los derechos del CCT, y luego también echaron a su marido. Además declaraba que el "pago es irrisorio". El dirigente gremial explicaba que la "cooperativa" de trabajo Cotrafil, que trabajaba con la empresa Ostramar S.A. no se encontraba en regla según las inspecciones y allanamientos que se hicieron. Asimismo la cooperativa no estaba autorizada por el Instituto Nacional de Cooperativas. El titular del SOIP mencionaba también la cooperativa Clandepez vinculada a Estrella de Mar y MaryPez. Estas eran fábricas importantes del puerto local. Tiempo después, denunciaba "la proliferación de pseudas cooperativas de trabajo" ante la Gerencia de Contralor e Inspección del Ministerio de Economía. ${ }^{550} \mathrm{Y}$ explicaba:

...los integrantes de las cooperativas y gestores de las mismas son empresarios que han quebrado sus empresas en algunos casos con administraciones fraudulentas e intermediarios de intereses de los armadores (dueños de barcos) quienes no aportan los impuestos correspondientes por la captura de la materia prima. ${ }^{551}$

Pero dejemos por un momento la visión que del fenómeno tenían los dirigentes sindicales y pasemos a conocer la del empresariado pesquero marplatense. Según las expresiones de los propios industriales, las empresas que sobrevivieron a la paridad cambiaria "lo consiguieron a base de mejorar su eficiencia antes que sus costos". Así lo entendía, al menos, Luis Solimeno, que colocaba a las cooperativas como una mejora en la eficiencia y no como un mecanismo de abaratamiento del costo de la fuerza de trabajo. A pesar de ello, reconocía en 1994, cuando era presidente de la Cámara de Procesadores de Pescado, que "A partir de la constitución de cooperativas con el personal, se mejoró notablemente el rendimiento, se atenuó el ausentismo que había llegado a fluctuar en un 25\% y hoy existen productos que de no ser por las cooperativas no podrían elaborarse". ${ }^{552}$ La cuestión del ausentismo es también para Oscar Fortunato el problema central que permite resolver la organización cooperativa. ${ }^{553}$ Por otra parte, los proveedores de materia prima contaban con la posibilidad de elegir la cooperativa a la cual otorgaban el pescado para su procesamiento. Esto los colocaba en una situación de mando y a las cooperativas fazoneras en una situación de clara subordinación. Pues estas últimas dependían de la cesión de pescado y por tal motivo competían entre sí, muchas veces ofreciendo el servicio de procesado por un menor costo. Cuestión que repercutía directamente en los salarios de los trabajadores/socios de las cooperativas. En el año 1994 un grupo de trabajadores, vinculado con el Partido

\footnotetext{
${ }^{549}$ L.C.,20/08/1991.

${ }^{550} \mathrm{La}$ formación de cooperativas si bien afectó profundamente a los trabajadores de tierra vinculados al SOIP, también impactó en la situación de otros trabajadores y gremios pesqueros. Tal es así que el Centro de Patrones y Capitanes de Pesca y el SOMU denunciaban la situación vivida por trabajadores de los dos remolcadores de la estación marítima marplatense. La firma responsable, Caresincro S.A., única prestataria del servicio en el puerto, dejó suspendida a la decena de personas que no aceptaron la "sugerencia" de que se integraran en una cooperativa a fin de participar del rescate económico de la empresa y cambiar el vínculo laboral. L.C.,09/10/1992.

${ }^{551}$ L.C.,03/09/1991.

${ }^{552}$ Revista Redes, № 76, año 1994, p. 18.

553 Fortunato, crítico de las cooperativas fraudulentas, menciona la ventaja que si pueden aportar cooperativas legalmente constituidas. Entrevista del autor con Oscar Fortunato... op. cit.
} 
Comunista, intentaron constituir una cooperativa nacida desde la iniciativa obrera a la que dieron por nombre Nueva Esperanza. Sin embargo, la empresa pronto se vio frustrada porque los empresarios pesqueros, según declaran estos trabajadores, no les vendían pescado para procesar. Finalmente el proyecto se desvaneció luego de menos de un año de intentar convertirse en proveedores de filetes para comedores, colegios y hospitales. ${ }^{554}$

En el año 1996 los empresarios procuraban conseguir definitivamente "la estabilidad jurídica de las cooperativas de trabajo legalmente constituidas, que permitieron mejorar ostensiblemente la productividad de la mano de obra y obtener un óptimo aprovechamiento del recurso pesquero"555. Sin embargo, para los economistas, era claro que:

...la elección del sistema cooperativo en la descentralización (realizada por los empresarios) no responde a los principios intrínsecos del mismo, sino a un sistema que no tributa impuesto a los Ingresos Brutos ni Ganancias, genera un crédito fiscal a la empresa subcontratante por el servicio facturado por la cooperativa, elimina los riesgos inherentes a la incorporación de personal en relación de dependencia trasladando los mismos a los socios de las cooperativas, flexibilizando de hecho la contratación y creando una organización productiva que induce importantes incrementos en productividad (Gennero de Rearte et al, 1997: 58).

Este proceso, si bien fue más intenso en Mar del Plata, comprendió también a las empresas pesqueras patagónicas. Según los datos del último censo del sector, mientras en la Patagonia el personal cooperativizado representaba el 18\% (749) del total de operarios (4.153), en Mar del Plata alcanzaba el 42\% (3.303 sobre 7.932 operarios). Hay que tener en cuenta que estos números son valores mínimos ya que, por un lado, el censo no pudo captar la totalidad de las cooperativas fraudulentas ni las unidades productivas donde se trabaja "en negro". Por otro lado, los 3.303 puestos de trabajo en cooperativas representan eso, puestos de trabajo, y no necesariamente personas, pues un mismo puesto podía ser ocupado por 2, 3 o 4 individuos distintos a lo largo de una semana o quincena.

Gennero de Rearte et al (1997) mencionan cierta heterogeneidad en la existencia de las "cooperativas" a partir de sus distintas formas de relación con el frigorífico madre: 1) cooperativas que trabajan dentro del espacio físico del frigorífico en una relación permanente y de exclusividad; 2) cooperativas que trabajan fuera del frigorífico, son dirigidas en general por ex façoneras, donde la infraestructura puede ser propiedad del frigorífico, del fazoneras o de una sociedad creada a tal efecto; 3 ) plantas que prestan sus servicios por medio de contratos de corta duración, manteniendo la exclusividad durante ese período pero pudiendo cambiar de empresa en un nuevo contrato; 4) plantas clandestinas, cuyo número es difícil precisar, pues son estructuras precarias donde todo el trabajo es al margen de la legislación laboral e impositiva.

$\mathrm{Si}$ volvemos a la perspectiva del trabajador "El pase es muy rápido y el obrero no llega a comprender plenamente la nueva situación, pues sigue trabajando en el mismo establecimiento recibiendo materia prima del mismo frigorifico" (Gennero de Rearte et al, 1997: 58). Una trabajadora y militante del gremio explica:

\footnotetext{
${ }^{554}$ Segunda entrevista del autor con Elda Taborda... op. cit.

${ }^{555}$ L.C., 12/02/1996.
} 
Cuando cierran todas las fábricas, por falta de higiene, seguridad y no sé cuántas cosas encontraron, nosotros quedamos en la calle y la única alternativa era trabajar en cooperativas. La desesperación de muchos compañeros hizo que cambiaran la indemnización correspondiente, por el ingreso a cooperativa que proponían los patrones. ${ }^{556}$ Supuestamente no iba a haber más patrones, íbamos a ganar un montón de plata, un grupo de compañeros nos dedicamos a caminar todo el puerto y a explicarle a los compañeros de qué se trataba, que cuando el patrón ofrece algo nunca es para beneficiarnos, que los beneficios se ganan con la lucha, estuvimos mucho tiempo en contra de las cooperativas, hasta que de a poco tuvimos que ir ingresando en las cooperativas; la gente no tenía un margen para estar tanto tiempo sin trabajar. Muchísimos compañeros renunciaron a su indemnización, otros fueron a juicio. Era cooperativa o nada. ${ }^{557}$

Otro trabajador cuenta, con dramatismo, cómo fue su experiencia:

Nosotros esta casa la levantamos con ella [se refiere a su compañera de vida] trabajando, pero nosotros tuvimos mala suerte, agarramos la peor época. Pasa que en 1992 que estábamos re bien, se les antoja en la fábrica decir que este sistema no funciona, que viene el de cooperativa. A todos calentándonos los oídos, yo era un poquito más visionario yo nunca quise las cooperativas, yo era el más viejo, tenia dieciocho años ahí adentro; y yo no quería las cooperativas. Entonces un día se casa mi sobrina en Olavarría, teníamos auto estábamos re bien. Yo con los patrones tenía una relación muy buena, yo era el ejemplo de la fábrica cuando había quilombo. Los primeros en entrar, los últimos en salir, y los que nunca protestaban. Entonces le digo al dueño: "mire Don Antonio, se casa una sobrina en Olavarría y me han invitado al casamiento y si no voy...".Y el dueño me dice, "tomate el tiempo que quieras Julio".... "¿seguro?....Mire me tomo una semana”. Y fui a Olavarría y cuando vuelvo a la semana me encontré unos compañeros que me dicen que la fábrica está cerrada, pusieron seguridad... no te dejan entrar más. Y yo les digo... eh no puede ser... pusieron seguridad y los que no querían entrar al sistema de cooperativa afuera. La empresa era Azaro Mar, el dueño es Antonio y Pedro Azaro, ahí están los sobres firmados por ellos. Le hicimos juicio. Se declararon insolventes y no cobramos un peso, nada... ¡El ejemplo de la fábrica! -dice Ana María esposa de Julio-. Ni el seguro de desempleo pudimos cobrar, nosotros igual que todos los demás. Y la abogada nos vendió como perros... sabemos todos que él y el hermano eran dueños absolutos de esa fábrica. De apoco fue desapareciendo todo, los camiones, los autos... ${ }^{558}$

Demostrando que la experiencia no era una cuestión puramente individual, una situación similar describe Mirta Canosa:

...después me largue a hacer filete. Trabajé hasta el 90 el $91 \ldots$ que empezó el tema de las cooperativas. Hasta ahí trabaja efectiva siempre, tenía mi aguinaldo, mis vacaciones, mi seguro si me enfermaba. Cuando tuve a los chicos [pude tomarme] los días de licencia y todo...Y en el 91 que firmaron las cooperativas se termino todo, fue una gran diferencia, porque los que estaban en planta San Diego efectivos, ahí nos subieron a un camión nos dejaron en el correo y nos dijeron que

\footnotetext{
556 Muchos trabajadores que ingresaron a una cooperativa entregaron el dinero que les correspondía como pago de la indemnización por su despido para que formara parte de los activos de capital de la cooperativa.

${ }^{557}$ Primera entrevista del autor con Elda Taborda, filetera y militante del PC (Mar del Plata, 2005).

${ }^{558}$ Entrevista realizada por David Santos a Julio Lela (padre), filetero, 64 años (Mar del Plata, 2009).
} 
"manden el telegrama de renuncia y siguen trabajando todos como cooperativas o quedan todos en la calle". Y bueno, había que trabajar, los chicos eran chicos, había que trabajar. ${ }^{559}$

De esta manera, como afirma un informe de la revista Puerto:

Las formas elegidas por los empresarios para desligarse de sus obreros y arrastrarlos hacia las cooperativas de trabajo, fueron variadas y contuvieron desde la seducción hasta la extorsión lisa y llana. Así se les hacía creer a los trabajadores que al abandonar la relación de dependencia para constituirse como autónomos, dejarían de ser simples fileteros para florecer como pequeños empresarios o, directamente, se los amenazaba con dejarlos cesantes si no aceptaban formar parte de alguna cooperativa (Nahúm, 2003b: 5). ${ }^{560}$

Crédulos por obtener una mejora en las condiciones de vida u obligados por los empresarios, es así como, con la implementación del sistema de cooperativas de trabajo, los obreros y las obreras perdieron el pago de garantía horaria, bono alimentario, sueldo anual complementario, salario familiar, vacaciones, feriados y ausencias por enfermedad. En términos de ingresos monetarios directos la situación no era igual en todas las cooperativas, variando entre ellas considerablemente y según la capacidad de negociación de cada filetero, además de su habilidad y velocidad en el trabajo. No obstante, se supone que en un principio las diferencias salariales con los trabajadores registrados no eran demasiado notorias (Gennero de Rearte et al, 1997). Sin embargo, la explotación aumentó en términos del incremento del número de horas trabajadas, crecimiento en la intensidad del ritmo de trabajo, inestabilidad laboral, pérdida de participación en el sistema previsional y de seguridad social, así como otros beneficios sociales quebrantados (vacaciones, aguinaldo, seguro de trabajo, etc.). Además, como consecuencia indirecta, hoy la industria pesquera presiona con mayor exigencia a los fileteros respecto del rinde que deben obtener del pescado procesado. Si en la década del ' 70 el rinde promedio solicitado era del $42 \%$, poco a poco fue incrementándose al 45,46 y hasta el $47 \%{ }^{561}$

Asimismo, a nivel global, los trabajadores se vieron perjudicados por la pérdida de relaciones políticas, dado que "los y las cooperativizado/as" perdieron el vínculo con el sindicato. Y este es un "logro" nada despreciable para los industriales pesqueros porque de este modo consiguieron, a partir de consolidar una relación laboral diferente, instalar una división profunda entre los trabajadores que realizan la misma actividad. No es difícil imaginar la diferencia existente en cuanto a un sujeto que mantiene seguridad laboral y previsibilidad respecto del futuro, con otro (u otra) que diariamente debe velar por su fuente de trabajo, aceptando condiciones laborales más precarias y sin posibilidad de planificación, perdiendo incluso su ligazón a una organización obrera que mantenía determinados lazos

\footnotetext{
${ }^{559}$ Entrevista realizada por David Santos a Mirta Canosa, envasadora, filetera, 53 años (Mar del Plata, 2009).

${ }^{560}$ Los trabajadores denunciaban todo tipo de estrategias por parte de los empresarios para obligar a los obreros y obreras a inscribirse en cooperativa. Algo relativamente común era que una planta cerrara temporariamente, planteando luego que sólo podría reabrir sus puertas si los trabajadores adoptaban la organización cooperativa. "Cuando ya habían cerrado muchas fábricas con el tema de que el Mercado Común Europeo no les aceptaba las condiciones de las fábricas y todo eso, eran clausuradas por SENASA... [Los empresarios] se agarraban [argumentaban] "van a abrir las persianas solamente si ustedes se ponen como cooperativa y piden que se reabra esta fábrica'". Segunda entrevista del autor con Elda Taborda... op. cit. De este modo, el cinismo de la situación llevaba a que sean los propios trabajadores quienes tuvieran que pedir la formación de una cooperativa para poder continuar siendo explotados $(i !)$.

561 “ $50 \%$ es un muy buen rinde. La media es $45 \%$. La media real sería $42 \%$. 45\% es el promedio que se pide. En 1989 se pedía el $42 \%$ en invierno y el $40 \%$ en verano. Con las cooperativas fueron depurándolo. Con las cooperativas se empezó a aumentar, aumentar, aumentar. A pedir el 45\%, el 47\%, dame todo". Entrevista del autor con Walter Flores... op. cit.
} 
entre sus representados y otorgaba sentidos de pertenencia. En coyunturas de crisis, la precarización se transformó en situación de indefensión y vulnerabilidad, dado que un amplio contingente obrero quedó desempleado o trabajando muy pocas horas semanales. ${ }^{562}$

Robert Castel ha utilizado la idea de desafiliación para señalar la nueva cuestión social del capitalismo de finales de siglo XX, que arrojó a un amplio número de personas fuera de las actividades productivas con el consecuente aislamiento relacional produciendo, de ese modo, exclusión social (Castel, 1997). ${ }^{563}$ Mientras que Merklen (2005), utilizando las metáforas en torno a la lógica del agricultor y del cazador, describió el pasaje de las conductas individuales desde una situación de previsibilidad y planificación de la propia vida a las estrategias de supervivencia de los individuos sometidos a la pobreza. En relación con esto, Patricia Comparada, filetera, ex dirigente sindical y militante del Partido Obrero, definía la cotidianidad del trabajador que está "en negro":

El que tiene la suerte de tener una mesa fija, a las ocho de la noche escucha la radio y sabe a qué hora va a entrar; al que no, lo llaman a trabajar a la hora que llega el pescado a la planta. La jornada dura hasta que se termine el pescado, pueden ser cinco o quince horas, a veces son llamados a trabajar a las tres de la mañana para tirar dos cajones y en dos horas estar en su casa de vuelta, no saben nunca cómo organizar el día después. No pueden hacer planes si tienen que llevar a un chico al médico, si tienen que acompañar a un hijo a la escuela, a las reuniones de padres tienen que mandar a otra persona porque las madres no pueden abandonar sus mesas de trabajo. La vida del trabajador en negro es eso, es nunca tener horario, no poder organizar nunca tu vida. ${ }^{564}$

Por estas y otras razones, a poco de asumir como secretario general de la CGT local, Abdul Saravia emitió una carta documento dirigida al Instituto Nacional de Acción Cooperativa solicitándole negar cualquier tipo de inscripción o matrícula referida a la integración de "cooperativas de trabajo" en todos los rubros y/o actividades laborales "que involucren mano de obra obrera". La nota aseguraba que "éste es el sistema de moda utilizado para que el obrero-empresario (ambos una misma persona), encubiertos bajo la figura jurídica de Cooperativa de Trabajo, logren seguir obteniendo ganancias ilegales, marginando a los obreros y utilizando la crisis por la que atravesó el país...". 565 Continuaba

\footnotetext{
${ }^{562}$ Ta situación reconoce toda una historia. “A la irregularidad en el ingreso de pescado se le sumaba su carácter altamente perecedero. Todo lo que entraba debía ser procesado sin demora. Estas características incentivaban en la patronal pesquera el deseo de un mercado interno de trabajo ajustable de forma inmediata y sin costos a las oscilaciones propias de la actividad. Fue por esto que los principales aspiraron a mantener solamente una pequeña porción de 'trabajadores permanentes', principalmente capataces y peonxs, instaurando para lxs fileterxs el trabajo ocasional y 'desregulado' (es decir, regulado íntegramente por los intereses y horizontes patronales)" (Nieto, 2012: 538).

${ }^{563}$ Silvia Sigal (en Merklen, 2005) advirtió la necesidad de distinguir las categorías de desafiliación y desafiliados. Desafiliación es un concepto útil para dar cuenta de un proceso histórico, pero desafiliados lo es menos para un análisis sociológico sincrónico. De la marginalidad o desafiliación pueden inferirse el sufrimiento, la pérdida de autonomía o la vulnerabilidad de las personas; pero poco o nada nos dicen esas categorías sobre la emergencia de nuevas formas de acción colectiva. La experiencia argentina caracterizada por un ciclo de movilización donde primordialmente participaron sujetos "desafiliados" mostraría que existen otros modos de reafiliación, como por ejemplo, la inscripción territorial.

${ }^{564}$ Revista Puerto, N ${ }^{\circ} 36,2005$, p. 44. Tal vez por ello "Sin horario" fue el nombre del cortometraje realizado por trabajadores y trabajadoras del Pescado y el Proyecto Audiovisual Comunitario Trabajo en el año 2007.

${ }^{565}$ L.C.,18/01/1992. La importancia de la figura de Saravia es para mí clave. Por ello, en el próximo capítulo, dedicamos varias páginas a conocer quién era este dirigente sindical. Por ahora basta señalar que más allá de estas críticas al sistema cooperativo, Saravia no dejó de ser un convencido "menemista". Incluso a pesar de la marginación en la que lo colocaba la ruta seguida por Carlos Menem, el dirigente del SOIP al mencionar la crisis continuaba “...de la cual estamos saliendo mediante la reestructuración del Estado público y privado, implementada por el Gobierno nacional al cual le brindamos todo nuestro apoyo". A pesar de todas estas denuncias, hoy en día es común escuchar en el puerto que el SOIP fue cómplice en el proceso de
} 
manifestando la posición gremial con suma claridad "nos oponemos enérgicamente a la creación de Cooperativas de Trabajo, creadas para que seudoempresarios utilicen a los obreros con el único objetivo de cercenar los derechos de los trabajadores, que fueron logrados mediante años de lucha, marginación $y$ muerte". Además se quejaba de la distancia que este tipo de modalidad de trabajo generaba entre los trabajadores y los sindicatos. Por eso manifestaba el "Repudio a la desafiliación que sufren las organizaciones sindicales por parte de los obreros-empresario, manipulados éstos por seudoempresarios para defender sus pingues ganancias". Y advertía a los obreros de las cooperativas que pudieran sentirse amparados por ese sistema que "la única herramienta que tienen los obreros para ser respetados y reconocidos como tales, es que los gremios que nuclean a la Confederación implementen un plan de lucha para defender los derechos de la masa obrera". Tiempo después, bastante resignado, Saravia decía:

...es vergonzoso ver y escuchar en los medios de información que el Ministerio de Trabajo de la Nación anuncia campañas para detectar trabajos en negro y evasión. Nos molesta sobremanera el hecho de engañar sin escrúpulos a los trabajadores [...] Es de público conocimiento que este gremio ha denunciado la evasión y el fraude laboral que se realiza en el puerto de Mar del Plata. Es por ello que no entendemos por qué motivo el Ministerio de Trabajo de la Nación permite que las pseudocooperativas de trabajo, las cuales en reiteradas oportunidades hemos denunciado con documentación a través de la Subsecretaría de Trabajo, hoy siguen trabajando [...] Es intolerable escuchar tan burda mentira cuando todos sabemos que las empresas son las que utilizan permanentemente los obreros en negro sin registración contable, evadiendo todo tipo de aportes y contribuciones legales en vigencia. También sabemos que algunos empresarios fueron infraccionados por la DGI pero sin embargo con la documentación en mano tampoco hacen nada. ${ }^{566}$

En cuanto al funcionamiento político administrativo al interior de las cooperativas, los trabajadores y trabajadoras que laboraban dentro de ellas indican que en la mayor parte de las mismas no se realizaban asambleas ni elecciones democráticas de las autoridades, siendo en general los miembros del Consejo de Administración, elegidos en acuerdo con el empresariado, los encargados de organizar la cooperativa. Esto explicaba José San Martín, quien fue secretario general de la CGT local y delegado regional del Ministerio de Trabajo de Buenos Aires. Con su intervención damos por finalizado este apartado.

Los empresarios arman todo este tipo de cooperativas, que a ellos no les gusta que les digan truchas, pero que producen fraude laboral, con gente que no es socia de la cooperativa, que no vota en asamblea, que no reparte las ganancias, que no tiene acceso a las decisiones ni tienen libros contables certificados por el consejo profesional correspondiente. Todo eso no existe. Nada de lo legal existe, lo que hay es un recibo donde le pagan al trabajador doscientos o trescientos mangos; eso es fraude laboral, está claro [...] En el puerto, los más castigados son los fileteros. Pero no son los únicos: el otro día inspeccionamos a las empresas que hacen harina de pescado y las de cajones, y te aseguro que es lamentable en las condiciones que están trabajando esos pobres tipos. Hay que ver cómo laburan, en las condiciones que trabajan: ni guantes, ni botas, ni nada. Y lo peor es que cada vez que vamos a hacer un reclamo por los trabajadores, tenemos a los señores de la Prefectura para cagarnos a palos [...] Todos estos señores están utilizando a la gente mediante un fraude laboral por el cual la explotan; esto está claro. Ahora no sólo hay que hacer que estos señores blanqueen a la gente, sino que también

formación de cooperativas. Por ello en el próximo capítulo mencionamos los discursos, con sus argumentaciones, que señalan dicha complicidad.

${ }^{566}$ L.C., $15 / 06 / 1996$. 
hay que mostrarles cuánta gente ha quedado estropeada con este sistema cooperativo: gente que se ha cortado un pie, un dedo, una mano, que se ha accidentado trabajando... están todos tirados ahí, se terminó la relación con el empresario, no tienen ninguna cobertura social y los señores empresarios ni se enteran. ${ }^{567}$

\section{Trabajar de fileter@}

Poco tiempo atrás, la tarea del fileteado mantenía un arraigo importante en Mar del Plata y existía una suerte de identidad del filetero o filetera. Era frecuente escuchar las frases de "Todos los barrios de Mar del Plata tienen un filetero", "Si el filetero no trabaja, se para Mar del Plata". ${ }^{568}$ Las historias ocupacionales señalan que los trabajadores, en tiempos de apogeo de la actividad y expansión de la industria fueron obreros bien remunerados que podían ahorrar, obtener fácilmente créditos, acceder a la vivienda, etc.

Durante esa época [se refiere al año 1975] era furor la industria pesquera, nada que ver lo que es actualmente. Vos entrabas a una fábrica, no te gustaban las condiciones de trabajo y te ibas a otro lugar a pesar de estar bajo relación de dependencia, con todo lo que esto incluye [...] No solamente había trabajo, sino que el pago era suficiente como para mantener a una familia y satisfacer sus necesidades básicas, con el agregado de tener trabajo fijo, obra social, aportes jubilatorios, y pertenecer al gremio de la pesca. ${ }^{569}$

Trabajar de fileter@ durante del tiempo de una industria en expansión garantizaba un puesto de trabajo relativamente fácil dada la necesidad de los industriales de procesar el pescado rápidamente, una vez que este era descargado. ${ }^{570}$ Entonces era común que los trabajadores y las trabajadoras se iniciaran laboralmente en alguna actividad relacionada y luego aprendieran el fileteado.

Los mismos compañeros te enseñaban en ese tiempo. Te dejaban pescado cortado y en la hora del cuarto, a la tarde, al mediodía... Porque antes se trabajaba de 6 de la mañana a 11 y de una de la tarde a tres y media se tiraba el último cajón. Se terminaba a las cuatro más o menos. Y se cumplían las dos horas de descanso. Entonces se terminaba de comer y me decían. Te dejo pescado, si querés practicar, practica. Lo más difícil es que te salga bien cuerearlo. ${ }^{571}$

Iniciarse en el fileteado permitía alcanzar un salario mayor que el que obtenían otros obreros de la planta: "El filetero por ahí primero fue un peón que fue practicando en sus horas libres. En los cuartos se fue quedando y practicando para aprender, para ganar más ¿Por qué? Para ascender en la escala. El ascenso de la gente es ser filetero. Pero no por un ascenso jerárquico, es por un ascenso económico" ${ }^{272}$. Muchas familias trabajaban juntas y no era extraña la presencia de niños y niñas que laboraban en la

\footnotetext{
${ }^{567}$ Revista Puerto, la otra cara de la pesca, año 2003.

${ }^{568}$ Ministerio de Trabajo... op. cit.

${ }^{569}$ Leiva Ramos, Miguel: "Fileteros marplatenses", en Revista Puerto No 17, noviembre 2001, p. 4 a 10.

570 "Había mucho trabajo en el pescado, no había problemas. Porque te echaban de una planta y te ibas a otra. En seguida, al otro día. Si eras filetero más todavía". Segunda entrevista del autor con Ricardo "Polaco" Muñoz... op. cit.

${ }^{571}$ Segunda entrevista del autor con Ricardo "Polaco" Muñoz... op. cit.

${ }^{572}$ Entrevista del autor con Walter Flores... op. cit.
} 
industria. El trabajo de niños no necesariamente estaba mal visto, aunque en algunas ocasiones, el empleo infantil funcionaba fuera de cualquier norma vigente y sí era rechazado por el gremio del pescado. ${ }^{573}$ Pero no era infrecuente que las mujeres trabajadoras llevaran a sus hijos a las plantas, tanto para tenerlos cerca y poderlos cuidar, como para, a partir del trabajo de ellos, incrementar los ingresos familiares. ${ }^{574}$ Por lo general, se trataba de familias numerosas de más de cuatro hijos. Años más tarde, la situación presentaba un cambio. La crisis que la industria pesquera enfrentó en los comienzos de la década del '80 (Espoz Espoz, 1985; Bertolotti, 2001) arrojó una primera ola de despidos y rebajas salariales que perjudicaron a los trabajadores del sector (Pradas, 2006). Ya en 1986, un informe daba cuenta del cambio de situación:

...desde hace unos años la paralización de muchas industrias, la incorporación al mercado laboral de contingentes migratorios del norte del país, la reducción del tamaño de la materia prima, produjeron una disminución en los ingresos de estos trabajadores con la consiguiente desvalorización de la fuerza de trabajo. ${ }^{575}$

Algunos trabajadores se alejaron para siempre de la industria. Otros tomaron como opción la migración temporaria o total hacia los puertos del sur, que demandaban fuerza de trabajo ante la creciente radicación de empresas en aquellas latitudes. No obstante, el cambio más drástico se produjo en la década del '90. Durante estos años la tendencia hacia la desvalorización de la fuerza de trabajo se profundizó, particularmente a partir del armado de pseudo cooperativas para el procesado de pescado. Para muchos trabajadores y trabajadoras fue este el contexto que marcó negativamente su trayectoria laboral, ante el impacto que generó el nuevo sistema de trabajo.

Entrevistadora:-Volviendo un poco al puerto, ¿Qué hechos o problemáticas te marcaron?

Sonia:- $Y$ el trabajo en negro, que lamentablemente lo tuvimos que agarrar porque no habia otra cosa, la pseudo cooperativa como le dicen.... Y vos te la tenés que comer...porque son las cosas así...

E.:-¿¿En qué momento empieza el trabajo en negro?

Sonia:-En los noventa...que ahi cerraron mis jefes, quedamos en la calle y tuve que agarrar lo que viniera...

E.:-¿Y cómo era trabajar en las cooperativas? ¿Qué diferencias notas con tu trabajo de ahora?

Sonia:-El trabajo y la tarea son lo mismo, lo que pasa que [en la cooperativa] son más horas, mas exigencias... ${ }^{576}$

De este modo, en los casi 25 años que van desde 1975 al año 2000, el/la filetero/a, al mismo tiempo que padece una desvalorización de su labor, va perdiendo el prestigio social asociado a su profesión. Y si bien todavía no había desaparecido, era menos visible aquella valoración de antaño del "ser filetero". Este

\footnotetext{
${ }^{573}$ Por ejemplo, en enero de 1975 una inspección realizada en conjunto por la comisión directiva del SOIP y la delegación local del Ministerio de Trabajo constataba en una planta procesadora de pescado la ocupación de menores de edad, de entre 10 y 13 años, para labores que se desarrollaban en horario nocturno. L.C.,18/01/1975.

${ }^{574}$ Elda señala que comenzó a trabajar a la edad de 12 años en 1967. Su hermano a los 10 años. Segunda entrevista del autor con Elda Taborda... op. cit.

${ }^{575}$ Ministerio de Trabajo... op. cit. p. 77.

${ }^{576}$ Entrevista realizada por María Schulze a Sonia, envasadora, filetera y operaria de control de calidad (Mar del Plata, 2009).
} 
pasaje contribuye al quiebre del significado del trabajo como medio de ascenso social. ${ }^{577}$ Tiempo después, en el año 2009, Cutuli (2012) demuestra cómo las trabajadoras en situación de precariedad laboral que transitaban por un angustioso presente, miraban un pasado idealizado, tanto por los altos salarios, la posibilidad de hacer uso de créditos, las buenas prestaciones de salud y las diferentes conquistas sociales que mantenían (como el boleto obrero) ${ }^{578}$, así como por las posibilidades de independencia económica y participación en el espacio público que les brindaba trabajar. ${ }^{579}$ En este, y otros sentidos, es importante la dimensión de género en el proceso de trabajo, la cual nosotros no estudiamos específicamente. ${ }^{580}$ Sobre el tema puede consultarse (Cutuli, 2012; Ruocco, 2011; Molinari, 1998; Martín, 1998).

Los trabajadores y trabajadoras en general pertenecían a un nivel educativo donde primaban las personas que tenían el colegio primario completo, seguidas por las de primario incompleto y secundario incompleto. 581 "La mayoría de los trabajadores del pescado [...] o somos analfabetos o semianalfabetos. No somos gente de estudio los trabajadores del pescado [...] Son muy pocos los compañeros, pero muy poquititos, contaditos con las manos los que han terminado la [escuela] secundaria". ${ }^{582}$ Este bajo nivel de formación fue evaluado como una gran limitante para la reinserción de trabajadores desocupados en los momentos de crisis de la pesca. ${ }^{583}$

En cuanto a las condiciones medioambientales de trabajo es importante aclarar que estas se diferenciaban en la industria del pescado según los obrero/as laboraran bajo relación de dependencia o en las cooperativas. Recordemos que en la década del ' 90 la heterogeneidad en las formas de las relaciones laborales con las que se realizó el fileteado de pescado reconocía, al menos, tres estamentos: a) en relación de dependencia con el convenio colectivo de trabajo firmado en 1975; b) en las cooperativas de

\footnotetext{
${ }^{577}$ Por estos años el mismo proceso se da en otras ramas de la economía argentina. Para un estudio sobre el otrora poderoso sector metalúrgico ver Manzano (2002).

${ }^{578}$ El llamado "boleto obrero" consistía en el derecho con que contaban trabajadores y trabajadoras quienes con el mismo boleto con el que se dirigían hacia su lugar de trabajo podían también retornar hacia sus casas.

579 “....mi marido se casó conmigo y de los trece años que hacía filet, esto venía... se ganaba muy bien, se trabajaba ocho horas, ehh... estaba muy protegido el filetero... ehh protegido en todos los sentidos porque vos ibas a Dan Antonio [que] era una casa de muebles, por ejemplo te nombro algo, y vos decías yo trabajo, soy filetera, 'si, tomá, ponete, llevá'. Era una cosa que el filetero estaba allá arriba, aún de lo que yo te digo que era degradante por, por el olor, por el frio, ehh... y sin embargo estaba bien protegido. Después, después no se qué pasó ehh... esos paros grandes que hubo varios paros grandes y se empezaron a abrir cooperativas y clandestinas porque por esto que te digo yo de los patios y de los galpones clandestinos sin agua, te ponían un tarro de agua así (con las manos indica el tamaño del tarro) y con eso tenías que trabajar ehh... ehh... después ya se empezó como a desbaratar todo". Entrevista realizada por Guillermina Laitano a Beatriz, filetera, 57 años (Mar del Plata, 2009).

${ }^{580}$ Por ejemplo, una trabajadora explica el entrecruzamiento entre pago por productividad y relaciones de género: “...hay una competencia por hacer mas porque es todo por kilo, que llegaba un camión de pescado, y... el peón le llevaba el mejor al amigo al compañero y las mujeres júltimas!, entonces que, perdías tiempo, no agarrabas un buen cajón, porque el más grande es el que te rinde mas, ser mujer era terrible ahí adentro, entonces tenías que tener unos que te dije así (hace el gesto con las manos) agarrar el gancho, ir al camión, traerte tú cajón y tirártelo vos a la mesa, como muchas veces llevarte la bandeja, que pesa 25 kilos más o menos, a la balanza porque si vos estas ipeón, peón, peón! Perdés tiempo...”. Entrevista realizada por Guillermina Laitano a Beatriz... op. cit.

${ }^{581}$ EspozEspoz, Milcíades, Zugarramurdi y otros: Industria Pesquera 1994 - 1996 Censo de mano obra y capacidad industrial, FUNDACIÓN ATLÁNTICA, Mar del Plata, 1997.

582 Segunda entrevista del autor con Elda Taborda... op. cit.

${ }^{583}$ Curioso es que en algunos discursos académicos estas características aparecen como atributos de las personas que trabajan: "En general, el recurso humano de nivel operativo ocupado en el sector, tanto en las plantas en tierra como en los buques, pertenece a una clase social de bajos recursos económicos que además tiene un nivel sociocultural bajo. Estas características, que se traducen en costumbres y hábitos de presentación, orden y limpieza descuidados, se convierten en verdaderos obstáculos a la hora de procesar y empacar el producto para presentaciones con moderada o alta exigencia. Resulta difícil lograr que los operarios se involucren con una filosofía de calidad, limpieza y cuidado en el tratamiento de la materia prima y del producto final que deben manipular" (Bertolotti et al, 2002: 59).
} 
trabajo (con sus diferencias); c) directamente en "negro", sin ningún tipo de regulación. ${ }^{584}$ Vale aclarar que esta clasificación es provisoria, que no se trata de compartimentos estancos y homogéneos y que con frecuencia sus fronteras eran más o menos permeables y permitían la circulación de obreros de un sector a otro. En las primeras, el contexto que hacía a las condiciones de trabajo estaba normado y favorecía la "estabilidad" material y mental de los obreros. Aunque la situación variaba de planta en planta, la obtención de un salario mínimo garantizado permitía disponer a los trabajadores de un sueldo todos los meses. También se accedía a otro tipo de remuneraciones que debían ser abonadas por las empresas, como por ejemplo el salario por hijo en edad escolar. A su vez, las condiciones de trabajo solían ser mejores dado que contaban con instalaciones adecuadas: mesas de trabajo, ${ }^{585}$ comedores, vestuarios. Sin embargo, al igual que en los otros sectores, los trabajadores eran presionados por el trabajo a destajo que genera auto-explotación. Aún así, en gran medida el espacio de trabajo bajo relación de dependencia garantizaba el acceso a lo que Burawoy (1989) definió como "ciudadanía industrial". De todos modos, los obreros cuentan que en muchas ocasiones aquel "estar en blanco" era en realidad un tanto ficticio, dado que era común que las patronales descontaran los aportes jubilatorios y las cuotas sindicales de los salarios, pero nunca los abonaran. ${ }^{586}$ Del mismo modo, también era habitual la práctica de abonar una parte del salario "en blanco" y otra parte "en negro", eludiendo de este modo determinadas cargas sociales. ${ }^{587}$ Por su parte, los obreros de las cooperativas (con las variantes de un sector heterogéneo) carecían de regulaciones y estaban expuestos a una situación de alta precariedad y vulnerabilidad. También dependiendo de la relación jurídico-legal es que se extendía la jornada laboral de los obreros y obreras. Aquellos que laboraban bajo el convenio 161/75 trabajaban ocho horas (obligatorias por día, siendo las excedentes horas extras). Carecían de regulación aquellos que trabajaban en cooperativas o directamente en negro, aunque por lo general se daban regulaciones de hecho. Las jornadas podían durar 9, 10 u 11 horas, llegando algunas veces hasta 12.En general se trabajaba de lunes a sábado. Muy pocas veces los domingos, aunque algunos entrevistados mencionan que en ocasiones especiales eran llamados también ese día. Cuando se laboraba ese día estando "en blanco" la paga era doble. En las cooperativas y "en negro" esta distribución horaria semanal raramente era estable. El trabajo dependía directamente de las capturas y de la derivación que realizaban los dueños del pescado. En coyunturas de crisis la disminución de ingreso de pescado afectaba la distribución semanal de horas trabajadas. Tal es así que durante la "crisis de la merluza" se sucedieron denuncias acerca de las pocas horas trabajadas. ${ }^{588}$

\footnotetext{
${ }^{584}$ En el año 2006 surgió una nueva relación salarial a partir de la elaboración de un anexo para pequeñas y medianas empresas que presenta condiciones de trabajo diferentes a las definidas en el convenio de 1975.

${ }^{585}$ Las mesas de trabajo son importantes para los trabajadores porque se genera una relación entre ellos y su espacio físico de trabajo. Cada uno trabajaba siempre, de ser posible, en la mesa que le correspondía. Con la formación de cooperativas, el incremento de la desocupación y el descenso de las horas trabajadas, muchos trabajadores y trabajadoras fueron perdiendo esa relación con su espacio cotidiano de trabajo.

586 “Un día me dijo el capataz 'Te querés quedar, te pongo efectivo'. En ese momento era ficticio también. Porque obviamente te daban recibo. Pero era ficticio aunque te decían en relación de dependencia, porque nunca te aportaban. Ahí estuve dos años trabajando. Te descontaban, te retenían y no te aportaban. Ni lo que te descontaban a vos, ni lo que les correspondía a ellos". Segunda entrevista del autor con Ricardo "Polaco" Muñoz... op. cit.

587 "Los fazoneros más ratones te hacían recibos re truchos, donde te figuraba solamente los 3.200 kilos que te dice la garantía. 3.200 kilos a tanto, cobraba tanto. Y el resto lo pagaban en negro. Encima de no aportarte también se daban esas cuestiones. Te robaban por otro lado también. Esto era común en casi todas las plantas". Segunda entrevista del autor con Ricardo "Polaco" Muñoz... op. cit.

${ }^{588}$ Durante la realización de una olla popular, Patricia Más representante de la organización de los Obreros Autoconvocados por la Reactivación de la Industria Pesquera decía: "hace un par de años trabajábamos 50 horas semanales, el año pasado fueron un promedio de 15 semanales. Hoy por hoy, hay semanas en que no llegamos a trabajar cuatro horas. Nosotros como trabajamos por producción, es decir cuanto más se hace más se gana, ahora no llegamos a los sueldos más miserables que puedan existir en todo
} 
Los trabajadores de la industria descansan generalmente tras un período de trabajo. Pero aquel variaba de acuerdo al tipo de relación laboral en la que se encontraba el trabajador. Los trabajadores amparados en el convenio tenían horario fijo de trabajo y si voluntariamente trabajaban a deshora, la misma se contabilizaba como hora extra. Para mediados de la década del '70 era usual que se ingresara en las plantas a las seis de la mañana y se trabajara hasta las cuatro, cinco o seis de la tarde. En este tiempo, existían tres descansos: uno de veinte minutos a la mañana, otro de quince a la tarde y la hora u hora y media del mediodía donde se paraba para almorzar. Mientras que cada planta tenía su comedor como lugar destinado a pasar aquel tiempo. La cuestión era un poco diferente en las plantas denominadas "cuevas" y/o en las cooperativas. Los tiempos se calculaban en un descanso de 15 minutos tras 3 horas de trabajo. Con las cooperativas desapareció el horario de entrada fijo y la hora extra. ${ }^{589}$ De este modo, el horario de trabajo se flexibilizó dependiendo de las necesidades de la empresa. ${ }^{590}$ Por otra parte, para los que trabajaban bajo el convenio de 1975, el uniforme y las herramientas de labor eran pagados usualmente por el empresario. En cooperativas, el trabajador pagaba por la ropa y las herramientas (generalmente las compraba el patrón y luego la descontaba del salario). El sistema de convocatoria de los trabajadores de las cooperativas y los "changas" 591 se realizaba a través de la radio. Desde las 20 horas, a través de dos frecuencias del dial, se anunciaban los horarios de entrada y cuántos trabajadores se solicitaban. También era frecuente el dirigirse hasta la puerta de las fábricas con anticipación esperando la llegada del encargado. Algunos entrevistados señalaron que esta espera a veces se prolongaba por varias horas en la vereda, en horarios nocturnos y con las frías temperaturas que acostumbran realizar en Mar del Plata. De ninguna manera esto garantizaba el puesto de trabajo. ${ }^{592}$

Por lo general eran las redes primarias o secundarias las que intervenían orientando las decisiones del mercado de trabajo. Así, en los relatos de obreras y obreros de la pesca, generalmente un amigo o familiar es el que aparece facilitando el acceso al nuevo puesto de trabajo. ${ }^{53}$ Por otra parte, según los convenios colectivos, el día del obrero del pescado se pagaba doble. Esto también perdieron los trabajadores no registrados, que más allá de la pérdida monetaria que significa, veían borrados espacios y

el mundo... para llevar a nuestros hogares mensualmente e intentar la aventura cruel de sobrevivir en familia con esto".E.A., $12 / 07 / 1997$

589 "Y cuando estábamos todos legal, trabajábamos ocho horas por día, y a veces los sábados también. Entrábamos de seis a nueve y media que ya se terminaba. Nosotros nos quedábamos a hacer extra, los dueños de la fábrica decían que no era obligación, pero nosotros siempre nos quedábamos, porque nosotros siempre estuvimos atrás del maldito peso. Y nosotros nos quedábamos hasta al medio día...y a veces los domingos íbamos también. Pero siempre nos cobrábamos el domingo era el cien por cien, entonces nos convenía a nosotros trabajar, y después bueno con la cooperativa quedamos todos peor, porque el precio es el mismo, la cooperativa viste, a parte no tenés feriado...no tiene nada, se terminaron las horas extras se termino todo". Entrevista realizada por David Santos a Julio Lela... op. cit.

590 “....en el [año 19]92, vos entrabas a las seis de la mañana, el horario más temprano era a las cinco de la mañana y después empezaron a entrar a las dos de la noche...una de la mañana, dos de la mañana...” Entrevista realizada por David Santos a Julio Lela (hijo), filetero, 32 años (Mar del Plata, 2009).

${ }^{591}$ Se trata de aquellas personas contratadas por períodos breves para hacerse cargo de algún sobrante de pescado. Las personas que laboraban en calidad de "changas" no poseían ningún tipo de prerrogativa laboral, pagándoseles al finalizar la jornada que dependía también de la cantidad de pescado existente para procesar.

592 "Nosotros escuchamos la radio, ahora con las cooperativas...pasan el informe pesquero...pedidos no te pide nadie, pero si alguno tiene conocidos... siempre alguno por ahí falta. Escucho la radio a las ocho de la noche, y los pocos que trabajan...algunos están entrando a las dos de la mañana, a la una...te enteras a las ocho y a las dos tenés que estar laburando, el informativo es de ocho a ocho y media, cortan por si llama otra fábrica, otra planta...y de ocho y media a nueve, y ahí te enteras [...] Y garantía de quedar ninguna...y yo ya estoy cansado de patear el puerto, si no conozco ya ni voy porque sabes las veces que fui a la mañana ya de gusto y vuelvo". Entrevista realizada por David Santos a Julio Lela (padre)... op. cit.

593 "Me llevo un muchacho amigo, un compañero que trabajaba ahí, me llevo para una planta de harina, yo no quería ni verlo al pescado". Entrevista realizada por David Santos a Natividor Sosa... op. cit. 
tiempos de sociabilidad y de identidad obrera. A su vez, afectando a las mujeres trabajadoras, desde 1992 fue eliminado del convenio colectivo el día de la mujer, el cual consistía en un franco al mes que las mujeres podían utilizar para realizar controles de salud, programar reuniones escolares para el seguimiento de la educación de sus hijos o cualquier otro asunto a realizar en horario de trabajo. Por supuesto que no existía tal día franco en las seudo cooperativas, al menos nada que estuviera normado. Otro aspecto que señalan los trabajadores y trabajadoras de la industria del pescado en relación a la pérdida de derechos de la mujer trabajadora es que para mediados de la década del ' 70 se conquistó una discriminación positiva según la cual las mujeres no debían levantar ni tirar cajones de pescado, ese trabajo tenían que realizarlo los peones. Aunque no siempre se daba de hecho, la cuestión estaba normada. Hoy en día, una suerte de "igualdad negativa" se fue instaurando en la industria obligando, no en la mayoría pero sí en muchos casos, también a las mujeres a levantar pesados cajones. ${ }^{594}$

Entre las reivindicaciones de los trabajadores, un reclamo histórico fue la lucha por el reconocimiento de la insalubridad de la tarea, pidiendo la reducción de las horas trabajadas y la jubilación anticipada. La insalubridad estaría dada tanto por las bajas temperaturas como por la postura en que se trabaja. En el convenio de 1975 la insalubridad fue reconocida por los empresarios del pescado. Aunque no se logró la reducción de la jornada laboral sino que finalmente se negoció el pago de un plus por insalubridad, volviendo la salud y la esperanza de vida un bien negociable (Tomasone, 2006). El trabajo repetitivo del filetero configura una corporalidad particular y expone los cuerpos a distintas enfermedades físicas (músculo esqueléticas y otras relacionadas con las bajas temperaturas sufridas) y padecimientos psíquicos y mentales (Mateo, Nieto y Colombo, 2010). Ya en 1975, el Dr. Adolfo León Monteverde comentaba que la actividad que efectuaban los obreros de la industria del pescado era la actividad más insalubre de la que él tenía conocimiento, pues quienes allí trabajaban debían someterse a amplias jornadas y a constantes variaciones de temperatura y humedad. ${ }^{595}$ Además, en algunos casos los trabajadores y trabajadoras debían trabajar en un suelo cubierto de hasta 10 centímetros de niebla amoniacal y transportar pescado congelado a $18^{\circ}$ bajo cero hasta las ollas en permanente ebullición. Las consecuencias eran enfermedades tales como la tuberculosis, afecciones bronco-pulmonares, estados sinusales y reumatismo, el cual incapacitaba a corto plazo, en forma parcial y permanente. ${ }^{596}$ También se destacaba la observación de numerosos casos de accidentes laborales provocados por los pisos

\footnotetext{
${ }^{594}$ Segunda entrevista del autor con Ricardo "Polaco" Muñoz... op. cit. Entrevista del autor con Gabriela, envasadora (Mar del Plata, 06/06/2013).

${ }^{595}$ Valorando ventajas y desventajas de trabajar como filetero Ricardo Muñoz expresa: "Las ventajas de trabajar como filetero es que si vos trabajás todos los días, con un buen pescado, tenés una diferencia, ganás más que en otros gremios. Si estuviera todo normal. Con el pescado normal, no con el que pescan hoy. Tenés posibilidad de hacer alguna diferencia. Y después las contras es que te hace pelota. Te hace pelota todas las articulaciones, la vista también te quita. Yo tengo cortando el tendón largo de este brazo, tengo poca fuerza". Segunda entrevista del autor con Ricardo "Polaco" Muñoz... op. cit.

596 "Es muy jodido trabajar en la fábrica. El tema es, para empezar, la salud. Te vas estropeando de a poquito la salud. El frío, los huesos, el agua, el hielo. Más trabajando en el fresco. Por ahí en el salado no. Yo ahora estoy trabajando en el fresco y trabajé 12 años en el salado. En el salado hace frío pero no tanto como en el fresco. En el fresco trabajas con las cámaras ahí. Mucho frío, muchas horas. Las enfermedades más comunes son principios de bronquitis, neumonía. Las gripes mal curadas. Porque por ahí no te podés tomar siete días. Nosotros si no trabajamos, no ganamos. Entonces si vos te tomás siete días te pagan por enfermedad 40, 50 pesos. No hacés nada. Tenés que poner la olla. No hacés nada. Yo terminé, de tantos resfríos mal curados, con una sinusitis. Y con el tiempo artrosis, reuma, todo eso. Y los huesos... Calcula la mayoría de las envasadoras llega un momento que trabajás con tanto hielo que se te congelan las manos en el invierno. Y tenés que irte a buscar los baldes de agua caliente. Eso te hace re mal. Pero es la única forma de seguir trabajando. El lugar más frío es el fresco. Porque vos trabajas con el hielo, las cámaras. Yo de elegir, a mi no me gusta este trabajo. Yo hace 18 años que lo hago. Pero lo hago porque no me quedó otra. Es un trabajo muy sacrificado". Entrevista del autor con Gabriela... op cit.
} 
resbaladizos; enfermedades de la piel; trabajo excesivamente rudo para las mujeres y exposiciones a muy bajas temperaturas por tiempo prolongado (Tomasone, 2006). ${ }^{597}$

Por otra parte, en contextos de crisis, cuando se padecía una menor oferta de trabajo e incertidumbre laboral, una de las respuestas de los obreros y obreras fue la combinación de este trabajo con otras actividades estacionales. Por lo general, servicio doméstico las mujeres y construcción y gastronomía en el caso de los hombres (Cutuli, 2012). ${ }^{598}$ En cuanto a aspectos negativos o estigmatizantes, varias de las personas entrevistadas destacaron la situación de discriminación al trabajar de fileteros, sobre todo al compartir lugares comunes como el colectivo donde, por el fuerte olor a pescado que se impregnaba en el cuerpo y la ropa, el resto de los pasajeros los miraban con desdén. ${ }^{599}$

\section{Aproximación a la situación salarial}

Las relaciones salariales en la industria del fileteado de pescado se basaban fundamentalmente en el pago a destajo. Es decir, por productividad. Sobre esta base desarrollaban las actividades los fileteros/as. Mientras que peones y envasadoras eran remunerad@s en virtud de las horas trabajadas. Por lo generall@s fileter@s eran la categoría mejor pagada. ${ }^{600} \mathrm{El}$ destajo se calculaba por kilo fileteado de pescado. El precio del kilo difería según la especie que se estuviera procesando. Y una gran diferencia se producía entre los más veloces y los más lentos. Mientras que un filetero promedio podía procesar entre 180 y 220 cajones de pescado por día, uno muy veloz prácticamente podía llegar al doble, incrementando de este modo de manera sustancial sus ingresos.

Los fileteros varían lo que ganan según su capacidad. No todos cortan igual. Todos aprenden a cortar igual pero no todos terminan cortando igual. Muchos se hacen rápidos y cortando bien y otros se hacen rápidos y cortando mal. Y otros no toman velocidad nunca y cortan bien. Y otros no toman velocidad nunca y cortan mal. ${ }^{601}$

Por otra parte, los salarios diferían según la condición laboral de los trabajadores. Es decir, dependiendo si se estaba al amparo del CCT, en cooperativa o directamente "en negro". Quienes laboraban bajo el convenio colectivo de Trabajo contaban con una "garantía de trabajo" consistente en el pago de un canon por parte del empresario que garantizaba, hubiera o no materia prima para procesar, una remuneración al obrero por una cantidad de kilaje mínimo de pescado. Es decir que funcionaba como un

\footnotetext{
597 "Es el día de hoy que yo me levanto me hago así [1leva sus manos hacía la nuca] no me puedo peinar ¡yo tengo artrosis! ¡Todos tienen artrosis, problemas de huesos... ¡todos terminan igual!”. Entrevista realizada por Guillermina Laitano a Beatriz... op. cit. “...enfermedades de huesos las tengo todas, que empecé con un reuma después el reuma se hizo artritis, después la artritis se hizo artrosis, después la artrosis se hizo osteoporosis”. Entrevista realizada por David Santos a Mirta Canosa... op. cit.

${ }^{598}$ Ricardo Muñoz cuenta que alternaba su trabajo entre la industria del pescado y la construcción. Segunda entrevista del autor con Ricardo "Polaco" Muñoz... op. cit.

599 “....si yo realmente digo si tengo que volver... y no sé qué haría para no volver [hace una pausa] no se qué haría para no volver [lo acentúa]... porque es, es, es feo, es sucio eh frío es... es terrible. Subir al colectivo y que la gente, por más que te laves, vos ahh que la gente piensa.... ¡ay! No sabes, yo sufrí tanto...”. Entrevista realizada por Guillermina Laitano a Beatriz... op. cit. .

600 "Un filetero gana más, pero mucho más que una envasadora [...] el filetero cuando te hizo cuatro horas de trabajo, por ahí te hizo lo que la envasadora te hizo en cuatro días. El filetero está muy bien pago. A pesar de que la envasadora es la que se queda más tiempo". Entrevista del autor con Gabriela... op. cit.

${ }^{601}$ Entrevista del autor con Walter Flores... op. cit.
} 
salario mínimo. Para quienes laboraban en las cooperativas, esta garantía no estaba normada y por ende, dependía de las negociaciones particulares entre trabajadores y los responsables de la cooperativa, así como de las coyunturas de expansión o crisis de la industria, pudiendo ser brindada o no. Peor suerte corrían los denominados "changarines", quienes no contaban con nada parecido a este tipo de garantías salariales. Perolas fronteras no eran estancas. Sucedía que un trabajador de cooperativa fuera, en paralelo, "changarin" en otra planta o por un período breve de tiempo en cualquier lugar donde fuese llamado. Debe tenerse en cuenta también que, al igual que en otros rubros, también en la pesca existía el pago no declarado ("en negro") de una parte de los salarios de los trabajadores. Por ejemplo abonándosele a los trabajadores sumas mínimas, que no contemplaban los incrementos por productividad, ni las horas extraordinarias. ${ }^{602} \mathrm{Al}$ respecto el SOIP presentó numerosas denuncias. ${ }^{603}$

Como vimos, entre los relatos de los trabajadores y trabajadoras es común escuchar la diferencia existente entre un pasado donde los salarios en la industria eran más bien elevados, en contraste con lo sucedido durante la década del ' 90 , cuando los salarios tendieron a la baja y permanecieron prácticamente estancados. Por ejemplo Beatriz explicaba que “...se ganaba muy bien en el filet, pero muy bien... Entrevistadora:- ¿De qué tiempo estamos hablando? Beatriz: Y del... del año 71, 72"604. Lo mismo sucedía en la industria de la conserva, donde las remuneraciones no sólo alcanzaban a cubrir necesidades "básicas", sino además "equipar la casa", comprar vestimenta habitualmente, "darle gustos a los hijos" (Molinari, 1998).La situación fue diferente ya en la década del '90. Son varias las fuentes de información que podemos utilizar para aproximarnos a los niveles salariales de los trabajadores de la industria pesquera. Comencemos por un acta del SOIP según la cual los valores a partir del 01/04/1991 para la rama filet eran los siguientes:

Cuadro $N^{\circ}$ 9. Valores salariales rama filete A partir de 01/04/1991 ${ }^{605}$

\begin{tabular}{ccccc}
\hline Categoría & Básico & Presentismo & B. Producción & Total \\
\hline Envasadora & 0.85 & 0.08 & 0.17 & 1.10 hora \\
Peones & 0.85 & 0.08 & 0.18 & 1.11 hora \\
Camaristas & 1.13 & 0.11 & 0.24 & 1.48 hora \\
Fileteros/as & 0,048 & 0,0039 & 0,0064 & 0,058 kilo \\
\hline
\end{tabular}

De este modo, centrándonos en el salario de fileteros/as, a los valores de 0,058 por kilo, procesando la cantidad de pescado de 180 kilos (un nivel bajo de procesado) los trabajadores y las trabajadoras obtenían $\$ 10,44$ por día, sin contemplar la antigüedad, alrededor de $\$ 270$ mensuales. Contabilizando otros ítems, junto con el cálculo de algunos kilos más de procesado, los salarios rondaban entre \$400 y \$500. Por otro lado, un informe nos indica un promedio de la estimación de las remuneraciones para el personal contratado y cooperativo, según el cual el salario de los fileteros y fileteras para mediados de la década

\footnotetext{
${ }^{602}$ Este es uno de los puntos denunciados por la filetera Elvira Renee Camps contra las Firmas Dispez S.R.L. y Ventura Mar del Plata, siendo el resultado de la sentencia favorable a la trabajadora. "CAMPS ELVIRA RENEE contra DISPEZ S.R.L y Otro sobre cobro de haberes e indemnizaciones”, Expediente N 33040, Tribunal del Trabajo N I, Provincia de Buenos Aires, 1993.

${ }^{603}$ L.C., 05/02/1992.

${ }^{604}$ Entrevista realizada por Guillermina Laitano a Beatriz... op. cit.

${ }^{605}$ Estos jornales corresponden a salarios básicos. Se debe contemplar también la antigüedad.
} 
del '90 era, sumando todos los aspectos salariales, de \$604 mensuales (Bertolotti y Pagani, 2001). Según Rodríguez et al (1999) los números son algo menores y más coincidentes con los datos del cuadro. Los salarios rondaban los \$300 más un bono de presentismo de alrededor de $\$ 100 .{ }^{606}$ Recordemos que para mediados del año 1995 la canasta básica familiar en la Argentina estaba calculada en \$533 (Lacabana coord., 1997). Por su parte, en los rubros conservas, harinas y salado, el salario promedio era menor, oscilando entre los \$300 y \$500 (Bertolotti y Pagani, 2001). ${ }^{607} \mathrm{Al}$ mismo tiempo hay que señalar que tanto las conservas como el salado presentaron históricamente una alta estacionalidad de la producción, hecho que hace variar los salarios según la época del año.

Tras la llegada de Menem al poder, y a partir del decreto $\mathrm{N}^{\circ} 1334 / 91$, la definición del nuevo gobierno fue que solamente se incrementaran los salarios en correspondencia con un incremento de la productividad, al mismo tiempo que se interrumpieron las negociaciones colectivas de trabajo, debilitando de este modo una de las herramientas centrales del poder de negociación sindical para regular el salario de los trabajadores. En aquel entonces, el Ministro de Trabajo Rodolfo Díaz dejaba aclarado que no se permitiría el regreso a "prácticas indexatorias" en materia salarial y que los aumentos debían pactarse por largo tiempo en función de la productividad y sin que se trasladasen a los precios. ${ }^{608} \mathrm{En}$ este contexto el SOIP acordó a partir de abril de 1992 el pago de un adicional por productividad. ${ }^{609}$ A su vez, para quienes laboraban de manera registrada, se incluían en las remuneraciones "premio" por presentismo. Este premio solía constituir una parte importante del salario que oscilaba entre el 20 y $30 \%$. Esta cláusula, incorporada en el convenio fue discutida entre los trabajadores. ${ }^{610}$ El interés de los industriales por implementarla radicaba en los altos niveles de ausentismo que la actividad presentaba. ${ }^{611}$

No obstante, estas cifras deben leerse sólo como estimaciones, debido a que el salario de los fileteros varía en relación a su productividad, que se ve condicionada tanto por su propia velocidad ${ }^{612}$, como por el ingreso de pescado que llega en las plantas. Además, existía como práctica informal el arreglo particular entre un trabajador y el patrón, lo cual hace aún más heterogénea la cuestión.

No existe el incremento salarial personal. Pero en ciertos lugares existe bajo la mesa. Voy yo, hablo. Hablamos vos y yo. Yo soy el mejor. Yo soy el único que te da el 52\% [de rinde]. Todos te dan el $48 \%$ cuando mucho. Yo te doy el $52 \%$. No te voy a hacer un quilombo para que me pagués la garantía y todo más, pero fijate siempre tirame un mango más a mí, porque yo... mi pescado es que el

\footnotetext{
${ }^{606}$ Tomando casos individuales encontramos, por ejemplo, la más alta remuneración obtenida durante mayo de 1992 por Daniel García, ascendía a la suma de 700 pesos. "GARCÍA Daniel Oreste c/ J.C.B. PRODUAR", Expte. N 36.621, Tribunal del Trabajo N I, Mar del Plata, Sentencias, año 1993.

${ }^{607}$ Como comparación del nivel salarial, sabemos que para 1992 el SMATA informa acerca de los salarios para los trabajadores de estaciones de servicio: el encargado cobraba un básico de $\$ 396,50$ más $\$ 19,82$ (5\% por productividad), más $\$ 59,47$ (15\% por presentismo). Mientras que un principal cobraba $\$ 305$, más $\$ 15,25$, más $\$ 45,75$. L.C.,03/02/1992.

${ }^{608}$ L.C., 16/07/1991.

${ }^{609}$ El incentivo a la producción radicaba en un plus pagado según la cantidad de kilos realizada por hora, en un rango que iba, para los filet estirados, de los 180 kilos a lo que correspondía un valor mensual de $\$ 21,23$ hasta los 280 kilos, correspondiéndole al trabajador/a $\$ 60,14$.

${ }^{610}$ Incluida en el artículo 16 del CCT 161/75, la norma terminó siendo derogada ante las distintas interpretaciones que de la misma realizaban los sindicatos y empresarios. Finalmente, se incorporó al salario un premio de $25 \%$ de incremento salarial por presentismo. Para conocer este proceso con mayor detalle ver Tomasone (2006).

${ }^{611}$ En el año 1975 la CAABPA y la Cámara de Procesadores de Pescado emitían una solicitada donde denunciaban que en la actividad pesquera se registraban los índices porcentuales más elevados de ausentismo y paros del país, ocasionando pérdidas constantes e irrecuperables que afectaban tanto al país, como a la industria y a los trabajadores. L.C.,15/08/1975.

612 "Si, si yo era muy trabajadora, muy ligera y ganaba más porque el ligero gana más". Entrevista realizada por Guillermina Laitano a Beatriz... op. cit.
} 
mostras cuando querés vender, con mis cajas armás la parte de arriba de todas tus cajas. En 9 horas te corto quince cajones. Encima de los 15 cajones te doy el 50 por ciento. ${ }^{613}$

A su vez, en los últimos años de la década, afectaba al nivel salarial no sólo la merma en el ingreso de pescado en las plantas, sino también el tamaño de los peces procesados. Pues como resultado de la intensidad con que fue explotada la merluza, lo cual implicó que dicha especie redujera su tamaño, se vio afectado el salario de fileteros y fileteras. María Demateis, dirigente sindical, explicaba: "Vos estás trabajando y ganas por la cantidad de kilos que hacés. Entonces, si a vos te viene un pescado asi de chiquito, que es lo que viene, no tardás veinte minutos, tardás una hora para hacer 18 kilos, a 0,18 centavos que te pagan, los que pagan muy bien, significa 3,60 la hora"614. En este contexto, era habitual que los trabajadores exigieran se les abonara un salario mayor por kilo procesado cuando el pescado era de tamaño pequeño. ${ }^{615}$

Una encuesta realizada por la consultora CISI en el año 1999 mostraba que el nivel de ingresos en la actividad pesquera marplatense, incluidos marineros y trabajadores de la industria en promedio de pesos/dólares era de:

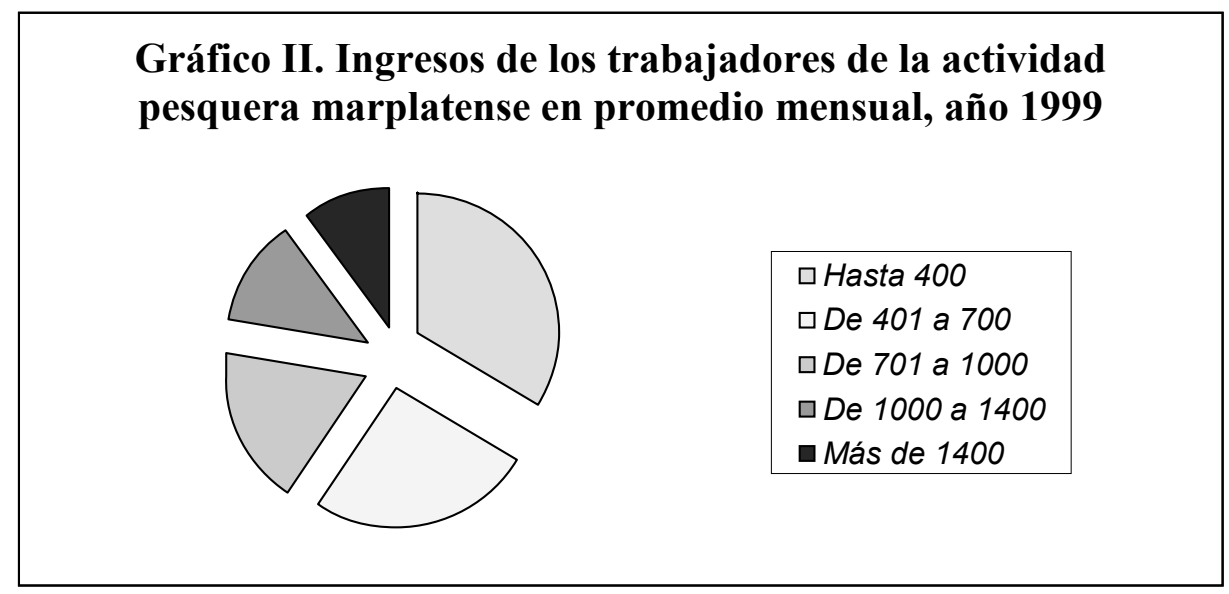

Fuente: CISI, 1999

El gráfico precedente demuestra que el grueso de los trabajadores y trabajadoras se encontraban entre los dos rangos más bajos de los ingresos salariales de la industria. Esto es, entre los rangos de $\$ 0$

\footnotetext{
${ }^{613}$ Entrevista del autor con Walter Flores... op. cit.

${ }^{614}$ Revista Puerto, 2002, p. 61. "Este... se respetaba al filetero porque el filetero era... [piensa] como te puedo decir... era una pieza muy importante dentro de la fábrica del pescado. Era el que laboraba el pescado. Entonces decíamos no, este valor no va, por ejemplo, pero porque... el pescado es chico. Porque no permitíamos lo que hoy se permite. No permitíamos la masacre que están haciendo en el mar... No hacíamos el pescado chico, hacíamos un cierto tamaño. Medíamos las merluzas en el azulejo. Dos azulejos era la medida de la merluza que nosotros... ya, pasando esa medida la cortábamos, de esa medida ya no, era un crimen lo que se cometía. Entonces no le permitíamos al marinero, al dueño de los barcos que pescara pescado chico ¿entendés?Entonces que pasaba, se utilizaban redes más grandes, con bocas mas grandes cosa que las merluzas chiquitas se escaparan”. Entrevista realizada por Cristián Tibaldi a filetera (Mar del Plata, 2009).

615 “... yo ponía la cara. Hablaba con el capataz para que nos dé mayor precio. Esa es una de las cosas que yo digo. Nosotros, a veces, somos depredadores también. Porque voluntario o involuntario... nosotros teníamos que negarnos a hacer el pescado. Nosotros qué decíamos: si me pagás tanto te lo hago igual. Obviamente si es más chico el pescado rinde menos, pero te compensaba con el precio. Así ayudás a la depredación. Vos tenés que negarte para que no lo pesquen”. Segunda entrevista del autor con Ricardo "Polaco" Muñoz... op cit.
} 
hasta $\$ 400$ y de $\$ 400$ a $\$ 700$. Si a este dato le agregamos el tipo de trabajo desarrollado encontraremos también que la división salarial se manifestaba entre marineros y trabajadores de la industria, siendo los primeros los mejor remunerados.

\section{Cuadro $N^{\circ} 10$. Comparación de ingresos en la actividad pesquera marplatense. Personal de las plantas en tierra y embarcado. Promedio de pesos/dólares, año 1999}

\begin{tabular}{|ccc|}
\hline Nivel salarial & $\begin{array}{c}\text { Personal de las } \\
\text { plantas en tierra }\end{array}$ & Personal embarcado \\
\hline Hasta 400 & $49,30 \%$ & $1,50 \%$ \\
\hline De 401 hasta 700 & $35,50 \%$ & $6,10 \%$ \\
De 701 hasta 1000 & $13,60 \%$ & $27,30 \%$ \\
De 1001 hasta 1400 & $1,60 \%$ & $34,50 \%$ \\
Más de 1400 & $0,00 \%$ & $30,60 \%$ \\
\hline
\end{tabular}

Por otra parte, sobre todo para quienes trabajaban en una precaria relación salarial, las coyunturas de crisis repercutían fuertemente en las condiciones salariales. Tal es así que durante el período de la crisis de la merluza se presentaba la situación de los obreros y obreras como desesperante. Patricia Más, entonces desocupada y quien en los últimos años trabajó en una cooperativa, decía:

...supimos estar entre los empleados mejor pagos de Mar del Plata; pero el nuestro es un trabajo de esfuerzo y sacrificio, ahora, muchísimos compañeros no llegan a ganar más de cien pesos mensuales. Incluso, muchos compañeros no sacan ni para redondear las cargas sociales que deben pagar en las cooperativas. Cargas que rondan mensualmente los 150 pesos. La opción es no pagar a la DGI o dejar sin comer a nuestros hijos por las obligaciones que nos han impuesto.

\section{Aproximación a la conflictividad en los lugares de trabajo}

El mercado de trabajo no constituye un ente estático. Al contrario, está sujeto a la dinámica de los enfrentamientos. En los años estudiados aquí asistimos a un momento de repliegue del movimiento obrero organizado y de los territorios conquistados por la clase trabajadora. Tras la "derrota" década del ' 70 y el tránsito por los años ' 80 , la década que se avecinó, y que cristalizaba el cambio en el modelo de acumulación iniciado a partir de la última dictadura cívico-militar, retrotrajo la participación de la clase obrera en la riqueza social del país, al mismo tiempo que debilitó en líneas generales la organización obrera tanto a nivel fabril como en las condiciones de existencia de los sindicatos. Esta situación general impactó de un modo particular en las condiciones de trabajo y organizacionales de fileteros y fileteras que comenzaron a desarrollar sus tareas en crecientes condiciones de precariedad e

\footnotetext{
${ }^{616}$ La bibliografía sobre el tema discurre entre la tesis de la derrota de la clase obrera sostenida por Delich (1982) hasta quienes se ocupan de analizar las formas de resistencia y lucha de los trabajadores destacando su lugar en el proceso de acumulación de fuerzas como Pozzi (1988). Otros trabajos sobre la temática que pueden consultarse son los de Di Cósimo (2006), Palomino (2005), Falcón (1996), Almeyra (1980),
} 
informalidad, retrotrayendo de este modo su condición a la existente cuando se produjo el nacimiento de la actividad. El aspecto más significativo fue la segmentación en el mercado de trabajo que afectó a trabajadores que realizaban el mismo tipo de trabajo, generando así, al menos, dos condiciones laborales diferenciadas entre, los "estables" y los “inestables". Así, por un lado, con la formación de las cooperativas, las relaciones laborales se reconfiguraron al incluir a los trabajadores como socios. ${ }^{617}$ Por otro lado, la división entre "estables" e "inestables" repercutió en los modos y organización de las acciones de protesta, siendo los últimos mucho más activos en el escenario conflictual que los primeros, sosteniendo demandas particulares que afectaban a su condición. Además, aquellos trabajadores precarizados padecieron también de la situación general de desempleo que afectaba al país y que golpeaba particularmente a la industria pesquera, fundamentalmente en la coyuntura de la "crisis de la merluza" a partir de 1997. En este contexto, la frontera entre inestable y desocupado ganó en porosidad y cada vez en mayor número, los (y las) primeros (as) fueron incrementado el volumen de la segunda categoría. Este fue el telón de fondo de la protesta obrera en las calles. Pero también lo fue de la conflictividad al interior de las plantas en la cotidianeidad laboral. Por ello, antes de analizar la lucha de calles, dedicamos algunos párrafos a la conflictividad laboral surgida dentro del propio proceso productivo.

En principio hay que señalar que el espacio fabril es un lugar de encuentro en las relaciones de explotación, determinadas por la dominación capitalista. Sin ese contexto, no puede apreciarse el tipo de relación que allí se produce (Hyman, 1978). Ello implica una serie de procesos anteriores al propio lugar de trabajo. El primero radica en que los empleos se negocian en el mercado de trabajo, donde el futuro trabajador debe encontrar un empresario que quiera pagarle un salario a cambio de la utilización de su fuerza de trabajo. La ficción de un contrato libre entre iguales sede a la desigualdad de poder que marca desde el inicio la relación. El empleador que contrata, adquiere también obediencia. Una vez que el obrero u obrera consigue el puesto de trabajo se transforma, en el espacio de trabajo, en una mercancía. De ahí en más, y como tal, se los (y las) trata como un factor de producción. ${ }^{618}$ El salario, que en su incremento permite una mejor calidad de vida al obrero, desde la perspectiva del capitalista es un costo que disminuye sus beneficios. De ahí las presiones de uno para incrementarlo y el otro para reducirlo. Para el empresario también existe alguna noción acerca de lo que es un nivel razonable de esfuerzo que se espera que el trabajador cumpla. Sin embargo, está claro que una vez dentro del espacio productivo, el dominio del empleador lejos está de ser total. Sabemos que los trabajadores (y trabajadoras) constituyen una mercancía "peculiar". Su tiempo de trabajo, vendido al capitalista, no puede nunca dejar de ser

\footnotetext{
${ }^{617}$ En ese contexto cada trabajador o trabajadora poseía mayor "libertad" en las decisiones sobre su trabajo. Por ello algunas prácticas no eran castigadas, quedando en la decisión de los propios obreros qué actitud adoptar respecto de la conservación de la limpieza, el horario de ingreso, los métodos de trabajo, el ausentismo, etc. De ahí que muchos obreros que trabajaron en cooperativas, cuando luego del año 2006 pudieron acceder a trabajar bajo relación de dependencia, sintieron el mayor nivel de disciplinamiento. Entrevista del autor con Mariano, delegado de la empresa Centauro (Mar del Plata, abril 2011).

${ }^{618}$ Marx ya planteó claramente la cuestión: "El obrero trabaja bajo el control del capitalista, a quien pertenece el trabajo de aquél [...] el producto es propiedad del capitalista, no del productor directo, del obrero. El capitalista paga, por ejemplo, el valor diario de la fuerza de trabajo. Por consiguiente le pertenece su uso durante un día, como le pertenecería el de cualquier otra mercancía por ejemplo un caballo que alquilara por el término de un día. Al comprador de la mercancía le pertenece el uso de la misma, y, de hecho, el poseedor de la fuerza de trabajo sólo al entregar su trabajo entrega el valor de uso vendido por él. Desde el momento en que el obrero pisa el taller del capitalista, el valor de uso de su fuerza de trabajo, y por tanto su uso, el trabajo, pertenece al capitalista. Mediante la compra de la fuerza de trabajo, el capitalista ha incorporado la actividad laboral misma, como fermento vivo, a los elementos muertos que componen el producto y que también le pertenecen. Desde su punto de vista el proceso laboral no es más que el consumo de la mercancía fuerza de trabajo, comprada por él, y a la que sin embargo sólo puede consumir si le adiciona medios de producción. El proceso de trabajo es un proceso entre cosas que el capitalista ha comprado, entre cosas que le pertenecen. De ahí que también le pertenezca el producto de ese proceso...” (Marx: 2003).
} 
tiempo de vida propio. Y así como la lucha y la negociación salarial se convierten en una relación constante por determinar el precio al que se vende la fuerza de trabajo, también se produce una lucha de poder por definir lo que Hyman (1978) llamó "frontera de control" en cuanto a las condiciones en que se produce la explotación. Pues si bien subordinados, los trabajadores y trabajadoras cuentan con espacios y mecanismos para discutir la linealidad de ese poder, o al menos imponer algunos límites. Mientras que en el espacio productivo se juegan aspectos "no materiales" como nociones divergentes de "justicia", "necesidad”, "derecho", "bienestar" (Thompson, 1989). Tal es así que, al igual que para la década del "60, en los años '90 la cotidianeidad laboral se enfrentaba diariamente a procesos de lucha, negociación y renegociación, a partir de los cuales obreros y patrones buscaban imponer los sentidos que cada uno portaban de justicia sobre la jornada laboral, intensidad del esfuerzo, precio razonable de la fuerza de trabajo, condiciones laborales, etc. Es así como en el proceso de trabajo pueden verse las tendencias tanto a la división del colectivo obrero como los intentos por superarla.

Uno de los principales motivos de queja por parte del empresariado pesquero a lo largo de la historia de la actividad fue el alto índice de ausentismo. Viejo problema del capitalismo, que siempre muestra una brecha en su deseo de fabricar cuerpos que trabajan. ${ }^{619}$ Nieto menciona al ausentismo como una práctica de resistencia recurrente por parte de los trabajadores ya desde la década del '60 (Nieto, 2012). Y el fenómeno aparece en los Tribunales del Trabajo como uno de los principales motivos que aducen los industriales pesqueros para interrumpir el vínculo laboral. ${ }^{620}$ Oscar Fortunato comenta que las empresas mantenían un nivel de “ $30 \%$ de ausentismo! 30\% de ausentismo significa que para hacer la misma producción vos tenés que tener 130 personas contratadas para hacer una producción de 100. Esto no lo soporta nadie en el mundo. Está claro. Hay que encontrar un sistema que solucione esto" ${ }^{621}$. El ausentismo era habitual los días sábados o luego del día de pago. También, desde la mirada empresarial, se producía un exceso de supuestos enfermos que se ausentaban del trabajo. Por eso las empresas implementaron la visita a las casas de los trabajadores enfermos por parte de un médico de la empresa. ${ }^{622}$ En este aspecto, un entrevistado relacionó la pérdida del convenio de 1975, entre otros factores, con la irresponsabilidad de los mismos trabajadores:

El convenio de 75 es el mejor convenio que hubo. Pero también es culpa de la gente el haberlo perdido. Porque vos no podés tener 100 fileteros y tener 20 en el seguro. Ninguna empresa soporta 20 tipos en el seguro. Hoy menos que antes. Antes se soportaba, hoy no se soporta. Encima yo he visto gente cortarse a propósito para irse al seguro. ¿Por qué? Porque vos ganabas una quincena de 3 mil pesos de hoy, te cortabas y vos cobrabas la quincena siguiente que vos estabas en el seguro lo mismo

\footnotetext{
${ }^{619}$ La "holgazanería obrera sistemática", denunciaba el propio Frederick Taylor, era el último obstáculo importante que se alzaba contra el desarrollo de la acumulación de capital. Como el capital compraba tiempo de trabajo, la holgazanería era considerada una forma de "hurto".

${ }^{620}$ Entre otros, las recurrentes faltas -a su criterio- injustificadas del trabajador José Andino, llevaron al empresario Otto Rodríguez a romper el vínculo laboral. Pero lo justificado o injustificado de aquella medida era también objeto de controversia entre empleado y empleador. Contrario a la opinión de "su" patrón, Andino denunciaba haberse ausentado por padecer de una enfermedad causada en el trabajo. "ANDINO JOSE LUIS contra RODRIGUEZ OTTO ASMAN sobre Indemnización por despido", Expediente N 34921, Tribunales del Trabajo № I, Provincia de Buenos Aires, año 1993.

${ }^{621}$ Entrevista del autor con Oscar Fortunato... op. cit.

${ }^{622}$ Incluso los propios trabajadores reconocían el "abuso" que algunos obreros hacían de la posibilidad de faltar al trabajo: "Es un 50 y un 50. El patrón en ese sentido tiene razón [...] estaba el grupo, que estaba en el convenio y por ahí te mandaban certificado médico, una semana. Venían a trabajar dos días, otra semana... certificado médico. Hasta que empezaron a mandar el médico a la casa. Así y todo siguen faltando. [...] Yo ahí entiendo al empresario, ahí si tiene razón el patrón. Porque ya te abusas. Hay gente que no. Hay gente que sigue cumpliendo..." Entrevista del autor con Gabriela... op. cit.
} 
que la quincena anterior. Entonces mucha gente metía la mano en el balde, sacaba, le pegaba con el cuchillo y se abría el dedo. No sentía el dolor. Cuando sentía el dolor ya te lo habían cosido, ya estaba en la casa calentito, tomando mate. ${ }^{623}$

Este era el caso más extremo, el autodaño que se producían algunos trabajadores para que el seguro médico les otorgue días de franco, cobrando de todos modos el salario, sin asistir a laborar. La existencia de esta práctica la reconocen los trabajadores:

Y algunos se cortaban [...] Eso de meter el dedo en el hielo y después cortarse. Es más algunos jodiendo se cortaron el dedo [...] Había muchos que también eran mañeros. Yo me acuerdo de una chica que tenía problemas en una muñeca. Y la vaga íbamos al consultorio ahí y antes de llegar al consultorio se sentaba en cualquier lado, se sacaba el zapato y se pegaba en la vena y el brazo se le hinchaba. Se golpeaba el tendón y se le hinchaba la mano como loco.

Aunque desde la mirada obrera, eso no era un fenómeno demasiado extendido: “...algunos se cortaban, pero no eran muchos tampoco [...]Eso pasaba, pero eran pocos. No eran tantos que pasaba eso [...] Éramos 40 y de esos habrá habido cinco, tres. No era que era la mayoría. Pero siempre los empresarios se quejaban por eso". ${ }^{624}$

Desde la perspectiva de los industriales en gran medida el problema se solucionó con las cooperativas. Puesto que al carecer de garantía horaria y de licencias por enfermedad, los trabajadores procuraban laborar todo lo posible porque de eso dependía su salario. Además, en un contexto donde sobraba la mano de obra era posible convocar a trabajadores de modo intermitente, sin tener que abonarles los períodos en que no se posee materia prima para procesar. Sin embargo, es interesante destacar que si bien desde un punto de vista empresario el ausentismo fue "solucionado", no fue así desde la perspectiva obrera. El ausentismo continuó, pero la diferencia es que los empresarios dejaron de pagar sus costos. Existía ausentismo "obligado" cuando por escasez de materia prima los trabajadores laboran pocos días en la semana. También era una forma del ausentismo, sobre todo en los jóvenes, cuando dentro de sus prácticas cotidianas muchas veces trabajan por la paga diaria, faltando otros días y regresando cuando algún motivo los impulsara a buscar nuevamente dinero. ${ }^{625}$ Con todo, es claro que desde una mirada patronal el ausentismo constituyó un serio problema cuando se debían enfrentar sus costos. Desde la perspectiva obrera, lo que en verdad refleja es una aversión al tipo de trabajo, originado por causas que debieran indagarse, pero que sin duda habla de un fenómeno extendido.

Dentro de los conflictos mencionados por los obreros y obreras destacan los reclamos por aumento de salario y por la hora de entrada a la fábrica. Respecto de esta última, los empresarios muchas veces procuraron que fuera directamente en la hora en que el pescado llegaba a planta -habitualmente alrededor de las tres de la mañana-, mientras que los trabajadores intentaron ingresar más tarde, generalmente alrededor de las cinco de la mañana. Por otra parte, entre los elementos con los que los obreros presionaban a la patronal y utilizaban como estrategia para incrementar sus salarios, existía la práctica de

\footnotetext{
${ }^{623}$ Entrevista del autor con Walter Flores... op. cit.

${ }^{624}$ Segunda entrevista del autor con Ricardo "Polaco" Muñoz... op. cit.

625 "El ausentismo existe igual. La irresponsabilidad de la gente existe cada vez más. La gente cobra los viernes, el sábado tenés la mitad del personal. El lunes es otro día difícil. A mitad de semana por ahí zafas. Pero es así, la gente... Nadie la pudo solucionar en ningún lado. Para mí es cultural. No tiene... no, no es... Porque vos tenés gente que no te falta nunca. Pero nunca”. Entrevista del autor con Walter Flores... op. cit.
} 
realizar la mitad de la tarea y, antes de iniciar la otra mitad y dada la necesidad de que se realice con premura porque el pescado se pudre rápidamente, renegociaban los términos contractuales y el monto salarial. Por ejemplo, cuando se les pedía que realizaran un corte especial para pescados pequeños, como cortar sólo la cabeza y la cola, le cortaban solo la cola y luego pedían al empresario que les pagara más por cortarle también la cabeza. ${ }^{626}$

Otro conflicto habitual dentro de las plantas y donde colisionaban los intereses de empresarios y trabajadores se relacionaba con la provisión de la materia prima. En primer lugar por el tamaño, porque cuando el pescado era pequeño, los obreros procuraban que se les pagara más por filetearlo, dado que "gastaban" mayor tiempo en elaborar filetes. Estos, al ser los peces de tamaño reducido, hacen que al finalizar la jornada el kilaje logrado sea menor que en los casos en que los peces son grandes. Lo mismo sucedía cuando el pescado llegaba "pasado" o podrido, pues los obreros y obreras desperdiciaban mucho al intentar procesarlo, o en el peor de los casos, podían sufrir cortes al manipular el producto en mal estado. Ello provocaba que tuvieran que recortar demasiado al pescado, con un cuidado extremo, lo que redundaba en una pérdida global de tiempo de trabajo. ${ }^{627}$

Un mecanismo que en cierto modo cuestiona la disciplina fabril en el contexto de la explotación capitalista al interior de las plantas era el "hurto" de pescado. Desde los comienzos de la actividad las empresas contemplaban en sus balances un ítem con un porcentaje de mercancías, materia prima y herramientas "hurtadas" por sus empleados (Nieto, 2012). A veces esto estaba controlado férreamente, pudiendo coincidir con un permiso de la patronal para que los obreros y obreras se llevasen pescado para consumo individual (alrededor de un kilo por semana). En otros espacios había mayores controles y no se permitía el retiro de pescado. El robo no sólo era para consumo individual sino también para la venta fuera de la planta o el regalo a familiares y amigos. En general era más fácil robar pescado que no fuera merluza porque tenía menos controles. ${ }^{628} \mathrm{Y}$ muchas veces la acción debía ser concertada no sólo con algún sereno o guardia, lo cual era más fácil, sino también con los mismos capataces u otra categoría del personal jerárquico.

Por otra parte, a través de la observación de las sentencias del Tribunal del Trabajo $\mathrm{N}^{\circ} \mathrm{I}$ de la Provincia de Buenos Aires, pudimos rastrear otros modos de conflictividad en la industria pesquera. ${ }^{629}$ Uno de los conflictos principales refiere a la desigual interpretación acerca de lo que constituyen causas justificadas de despido. Esto es, sobre la legitimidad o no de poner fin a la relación laboral. Son muchas las demandas que proliferaron en la década del ' 90 por despidos injustificados y despidos indirectos, buscando poner un límite al despotismo patronal. ${ }^{630}$ En ese sentido, los Tribunales del Trabajo parecen haber podido poner cierto freno a aquellas actitudes realizando sentencias la mayor de las veces a favor de la parte accionadora de la demanda, obligando a la parte demandada a realizar un resarcimiento económico. También surgían diferendos respecto de la condición de enfermo o no de un trabajador, aducida muchas veces por la patronal como causal de despido. Aparece de modo recurrente en las

\footnotetext{
${ }^{626}$ Entrevista del autor con "El negro", filetero que laboró en plantas clandestinas y cooperativas (Mar del Plata, marzo 2010).

${ }^{627}$ Entrevista de autor con Amalia, filetera de cooperativa (Mar del Plata, marzo 2010); con Ana, filetera de cooperativa (Mar del Plata, marzo 2010); segunda con Ricardo "Polaco" Muñoz... op. cit.

${ }^{628}$ Entrevista del autor a "El negro"... op. cit.

${ }^{629}$ No está de más destacar que la particularidad de la fuente nos ofrece datos de la conflictividad una vez que el disenso llega a ser judicializable. Así mismo, la resolución sólo se expresa a partir de una sanción económica dispuesta por los jueces del trabajo. Sanción que recae sobre el accionado si este es encontrado en infracción.

${ }^{630}$ Despido indirecto es aquel por el cual el empleador nunca notifica el despido al empleado, pero tampoco lo convoca a presentarse al trabajo. Ante tal situación, el empleado se considera a sí mismo despedido.
} 
demandas iniciadas por los trabajadores de la industria pesquera hacia sus patrones el hecho de que estos últimos interrumpieran el vínculo laboral desconociendo o directamente rechazando el carácter de "enfermo" que aducían trabajadores y trabajadoras para ausentarse en sus tareas. Por ejemplo esta es la razón que aduce la Pesquera Don Romeo para finalizar el vínculo laboral con su empleada Norma Baiz. Baiz, por su parte, señalaba haber probado que padecía de neumonía. A juzgar por el resultado de la sentencia, favorable a la empleada, la patronal carecía de fundamento para descreer de la enfermedad y por ello era obligada a abonar todos los ítems de la indemnización por despido injustificado. ${ }^{631}$ En otras circunstancias, la discusión refería al "grado" de incapacidad de un enfermo o de quien padeció un accidente de trabajo. Tal es el caso de Carmen Díaz, quien a los pocos días de ingresar a trabajar en la fábrica Tomar S.A. sufrió un accidente que la incapacitó para desempeñar las tareas de envasadora, según la junta médica en un $12 \%$. Sin embargo, desde la perspectiva de la trabajadora, esa incapacidad llegaba al 35\%, lo cual fue ratificado por la sentencia de los jueces del Tribunal, obligando a la empresa a abonar una diferencia salarial. ${ }^{632}$ Una situación similar se produjo entre Héctor Taboada y Tomar S.A. Esta última -considera el expediente de la sentencia-, "No desconoce [...] que el actor hubiera sufrido los accidentes referidos precedentemente y que la incapacidad parcial y permanente es de un $12 \%$ [...] Lo que objeta la accionada es el porcentaje de incapacidad reclamado por el actor (50\%)..."633.

Es ilustrativa la demanda que el peón Ángel Chávez, quien poseía diez años de antigüedad, realizó contra Ángel Rúa por el cobro de indemnización por despido. ${ }^{634}$ Chávez fue despedido por incurrir en faltas sin justificar y realizar pedidos de órdenes médicas sin hallarse enfermo. Respecto de la aparente enfermedad de Chávez, en ocasión de presentarse éste ante el Instituto de Medicina del Trabajo el día 19 de julio de 1989 solicitando orden médica para no ir a trabajar, dicho organismo certificó que el obrero no tenía síntoma alguno que le impidiera realizar sus tareas normalmente. A pesar de lo cual Chávez se ausentó de su trabajo y por ello la empresa procedió al despido. Sin embargo, Chávez adujo que tras retirarse de aquel instituto se dirigió hacia la OSPIP (obra social del SOIP) donde el médico que lo atendió le prescribió un día de reposo. Y por ello consideraba legítima su inasistencia. De este modo, puede observarse como cada extremo de las relaciones de trabajo legitimaba su accionar en un organismo considerado propio. El Instituto para la patronal y la OSPIP para el trabajador. ${ }^{635}$

En cuanto a sabotajes y descenso en el ritmo de producción, nuestros informantes prácticamente no nos han relatado que ello sucediera salvo en casos excepcionales. Uno de ellos se produjo en una época previa a la que nosotros estudiamos, durante la última dictadura militar. Trabajadores de la firma Mellino se encontraban pidiendo un incremento salarial, el cual la empresa se negaba a otorgar. En aquel entonces los obreros disminuyeron la intensidad de la producción, demorando el tiempo en que procesaban el pescado. En aquel contexto, fueron subidos a un camión militar y detenidos durante todo un día. ${ }^{636}$ Más acá en el tiempo, se menciona de modo recurrente como elemento que intercede en el mercado de trabajo,

\footnotetext{
631 "BAIZ GLORIA BLANCA contra PESQUERA DON ROMEO S.A. sobre Haberes e indemnizaciones", Expediente N 33607, Tribunal del Trabajo N 1, Provincia de Buenos Aires, año 1993.

632 "DIAZ CARMEN BEATRIZ contra TOMAR S.A. sobre Haberes y accidente de trabajo", Expediente N $^{\circ} 34795$, Tribunal del Trabajo $N^{\circ}$ I, Provincia de Buenos Aires, año 1993.

633 "TABOADA HÉCTOR EDUARDO contra TOMAR S.A. sobre Indemnización por incapacidad parcial y permanente", Expediente $N^{\circ}$ 33402, Tribunal del Trabajo N I, Provincia de Buenos Aires, año 1993.

634 "CHAVEZ ANGEL ADALBERTO contra RUA ANGEL ADOLFO sobre indemnización por despido", Expediente N 33446, Tribunal Del Trabajo N I, Provincia de Buenos Aireas, 1993.

${ }^{635}$ El resultado de la demanda fue favorable al demandante, debiéndosele abonar una suma de dinero en concepto de indemnización por despido y falta de preaviso, salarios, etc.

${ }^{636}$ Entrevista del autor con Ricardo "Polaco" Muñoz... op. cit.
} 
la existencia de "listas negras" con los nombres del personal señalado como "conflictivo" o "problemático", ante lo cual estos no eran contratados por ninguna planta pesquera. De este modo, una parte de la clase trabajadora, aquella que poseía experiencia en lucha gremial, podía ser relegada sin permitirle ingresar a trabajar. Así, la patronal podía "recortar" la experiencia de lucha de la clase. Según indicaron algunos entrevistados las listas negras comenzaron a aparecer a partir de 1984. También denunciaron la complicidad de la conducción sindical en la confección de tales listas, perjudicando la participación electoral de los activistas opositores. La existencia de esas listas fue constantemente negada tanto por la parte empresarial como por la conducción sindical del SOIP.

Pero no todo era conflicto entre patrones y trabajador@s. También las relaciones asumían variantes de paternalismo industrial, tanto interno a los procesos de trabajo en las fábricas como aquellos externos que se definían por otorgar determinados beneficios a los trabajadores en la búsqueda por lograr la "construcción" de un "obrero soñado". ${ }^{637}$ En la industria pesquera, por un lado encontramos relaciones que incluían vínculos personalizados, como los pedidos especiales para que los trabajadores se queden hasta terminar el pescado, ingresen antes a laborar, realicen el corte de una especie no convencional, etc.; por otro, préstamo de las instalaciones de las fábricas para organizar fiestas o eventos a los empleados, adelantamientos de salario, premios salariales no reglados, etc. ${ }^{638}$ Una particularidad de la actividad es que muchos de los que se convertían en patrones habían sido anteriormente pescadores que participaban de una cultura compartida del trabajo. ${ }^{639} \mathrm{Y}$ los trabajadores solían ver que algunos de sus patrones "se mataban laburando". Era común también como práctica empresarial compensar la buena conducta o la afinidad de un trabajador otorgándole recompensas como horas extras, llamarlo los días en que se pescara más, asignarle el procesado de un pescado de mayor precio. A su vez, estas dádivas podían realizarse en forma anticipada y recurrente generando la idea de que se le hace "un favor" al trabajador. De este modo, el obrero u obrera se siente que debe un favor, una retribución a la empresa: "Entonces ¿qué pasa? Te piden quedarte dos horas más y te tenés que quedar" 640 .

Por otra parte, en lo que respecta a los conflictos entre los propios trabajadores, en numerosas oportunidades y en virtud de la organización del trabajo, el conflicto entre dirección y trabajadores no necesariamente se expresaba entre ambos extremos de la producción, sino que muchas veces se trasformaba en competitividad y luchas dentro del propio grupo obrero (Burawoy 1989 [1979]). Según Stuart Klein "El comportamiento de cohesión suele ser inviable en condiciones de gran presión de trabajo, por cuanto la estructura retributiva impuesta por la dirección obliga a cada trabajador a trabajar con la máxima rapidez de que es capaz" (Klein, cit. en Burawoy, 1989: 93). Y esto era así particularmente bajo condiciones de trabajo a destajo. En la industria pesquera se producían disputas entre trabajadores cuando alguno no quería tomar los descansos estipulados que, en general en las plantas

\footnotetext{
${ }^{637}$ Sobre el fenómeno del paternalismo patronal ver, entre otros, Sierra Álvarez (1990).

638 "E:- ¿Hacían actividades? M:-¡Si si! ¡La fiesta de fin de año! E2:- ¿Eso por la cantidad de horas que estaban adentro? M:-Si, si- Aparte en aquel tiempo los patrones eran tus amigos! Eran muy buena gente también! E:-¿Cómo era eso que hacían las comuniones, los bautismos? M:- Si, si y porque yo tenía la comunión de mi hija y si "acá tenés la fabrica, límpienla bien, acomoden las mesas de otra manera" y en la bacha de hielo ahí poníamos toda la bebida y hacíamos ehh eran hermosas fiestas, ehh yo bauticé ehh no, tomó la comunión Paola y bauticé ¡hasta Yamila! Hasta Yamila en la fábrica de pescado, en Ortiz de Zarate y Hacha". Entrevista realizada por Guillermina Laitano a Beatriz... op. cit.

639 "Muchos eran los gringos que hicieron plata... o sea venían de gente que no venía de cuna de oro, sino que eran gente que venían del trabajo". Segunda entrevista del autor con Ricardo "Polaco" Muñoz... op. cit.

640 "El tema de los favores. Qué es lo que yo trato que no haya. Es lo que no me gusta hacer porque no me gusta que me reprochen porque yo hice tal cosa por vos. La empresa te maneja y a vos no te queda otra. Tenés que bajar la cabeza”. Entrevista del autor con Gabriela... op. cit.
} 
clandestinas, eran de tres momentos de 15 minutos a lo largo de la jornada laboral. El hijo de una entrevistada, también filetero, no tomaba los descansos porque prefería continuar trabajando y eso era motivo de crítica por parte de los otros trabajadores. ${ }^{641}$ También hemos encontrado quejas respecto del individualismo preponderante en la industria, según el cual cada uno se preocupaba sólo por sus intereses, particularmente por incrementar su productividad como causa del trabajo a destajo. Un trabajador y militante de la industria pesquera explica:

Está sociedad está muy individual y la industria del pescado es más individualista todavía. Siempre fue muy individualista la industria. Cómo trabajamos viste a destajo, cada uno hace lo que... entonces siempre fuimos un poco medio mezquinos... digo... a ver cómo... cómo le sacó ventaja al otro, le robo el cajón que tiene pescado más grande para... para tener más ganancia yo. Siempre fue medio así viste. Pero bueno... hoy en día está peor obviamente, la situación es más jodida y los compañeros están jodidos también.

Una forma de ese individualismo se expresaba en no respetar el orden con que debían procesarse los cajones de pescado. Esto es, cuando un filetero -posiblemente advertido por algún peón- divisaba un cajón con pescado de mejor tamaño, buscaba por todos los medios quedarse con ese cajón que, por orden del mismo proceso productivo, le correspondía a otro compañero. Estas formas del "individualismo" se visibilizaban también en contextos de medidas de fuerza, cuando una parte participaba de los reclamos, mientras que los otros proseguían con su trabajo. El extremo de tal falta de solidaridad sucedía entre los obreros que trabajaban bajo relación de dependencia y quienes lo hacían en cooperativas. Los primeros en general fueron renuentes durante gran parte de la década del ' 90 a participar en medidas de acción directa que expresaran solidaridad respecto de los obreros de las cooperativas.

Entonces es como... como que ellos... "Nosotros no nos metemos, nosotros estamos trabajando, nosotros estamos en relación de dependencia". Y no les importa por ahí que le pasa al conjunto, las cosas que nos vienen pasando, por supuesto. No hay esa solidaridad entre los trabajadores, que tendría que haber. ${ }^{642}$

Ocurría también una división según la categoría laboral, expresándose en ocasiones conflictos entre peones, fileteros y envasadoras, donde muchas veces cada categoría acciona por separado frente a un reclamo a la patronal.

En la empresa lo fundamental son los fileteros. No hay fileteros... no pueden trabajar las envasadoras ni nada. ¿Qué pasa? El filetero... se arreglan ellos. Ellos se arreglan. Ellos hacen una reunión, ellos arreglan todo. El filetero no te dice, bueno paramos el filetero y para la envasadora y vamos a pelearla juntos. No. Ellos arreglan ellos. Entonces cuando nosotros nos enteramos que se arreglaron ellos, vamos nosotros y nos arreglamos nosotros. No te queda otra [...] Cada uno tira para su lado. ${ }^{643}$

\footnotetext{
${ }^{641}$ Entrevista del autor con Ana... op. cit.

${ }^{642}$ Primera entrevista del autor con Ricardo el "Polaco" Muñoz, ex filetero (Mar del Plata, abril 2009).

${ }^{643}$ Entrevista del autor con Gabriela... op. cit.
} 
Pero no sólo se producían relaciones de competencia entre los obreros, sino que surgían relaciones solidarias, muchas veces a través de prácticas informales. Una de ellas, que se menciona como práctica extendida, tiene lugar en la propia actividad del fileteado de pescado, la cual tiende a individualizar los intereses de quien realiza el trabajo inhabilitando las posibilidades de cooperación. Sin embargo, a veces cuando quedaban unos pocos trabajadores que aún no habían terminado, otro/as se quedaban trabajando, fileteando para completar el cajón de los retrasados y retrasadas, y así irse todos juntos a la misma hora ${ }^{644}$ Por lo general, ese tipo de ayuda se daba entre grupos que mantenían alguna afinidad. Otra práctica habitual era la realización de colectas cuando algún trabajador tenía algún problema familiar o accidente. $^{645}$ También entre las envasadoras existía, planificada por ellas mismas, la coordinación y organización de la producción, trabajando en conjunto y dividiendo entre las partícipes el total de lo producido en lugar de hacerlo individualmente. Esto se produjo, por ejemplo, cuando a un grupo de envasadoras les pidieron un corte especial y reaccionaron colectivamente ante la inexperiencia de alguna de ellas:

Entonces ¿qué hicimos? Eran 20 cajones para nosotras. Éramos tres, y las tres hicimos todo. Y a lo último se pesó todo junto y se dividió en tres. Por ejemplo yo, que yo no soy tan rápida. Yo hice 52 kilos. ¿Por qué? Porque la división de todo lo que hicimos dio 52 para cada una [...] Para mí era nuevo hacer vaina, entonces las chicas dijeron bueno entonces yo corto, la otra sacaba la aleta y yo lo pelaba. Entonces se va trabajando así las tres. Terminamos las tres y ninguna nos matamos. Y al final, obvio, el que es más rápido pierde... ${ }^{646}$

Y hasta acá avanzamos en las relaciones de conflictividad al interior de las plantas, así como los vínculos de competencia y solidaridad entre trabajadores y trabajadoras. En los capítulos V, VI y VII estudiamos las formas y horizontes de la conflictividad en las calles. Pero antes de ello, nos introducimos en la historia del SOIP y sus tradiciones político-ideológicas.

${ }^{644}$ Entrevista del autor con "El negro"... op. cit.

${ }^{645}$ Segunda entrevista del autor con Ricardo "Polaco" Muñoz... op. cit.

${ }^{646}$ Entrevista del autor con Gabriela... op. cit. 


\section{CAPÍTULO IV}

El SOIP, el liderazgo de Abdul Saravia y las transformaciones

en la industria del pescado

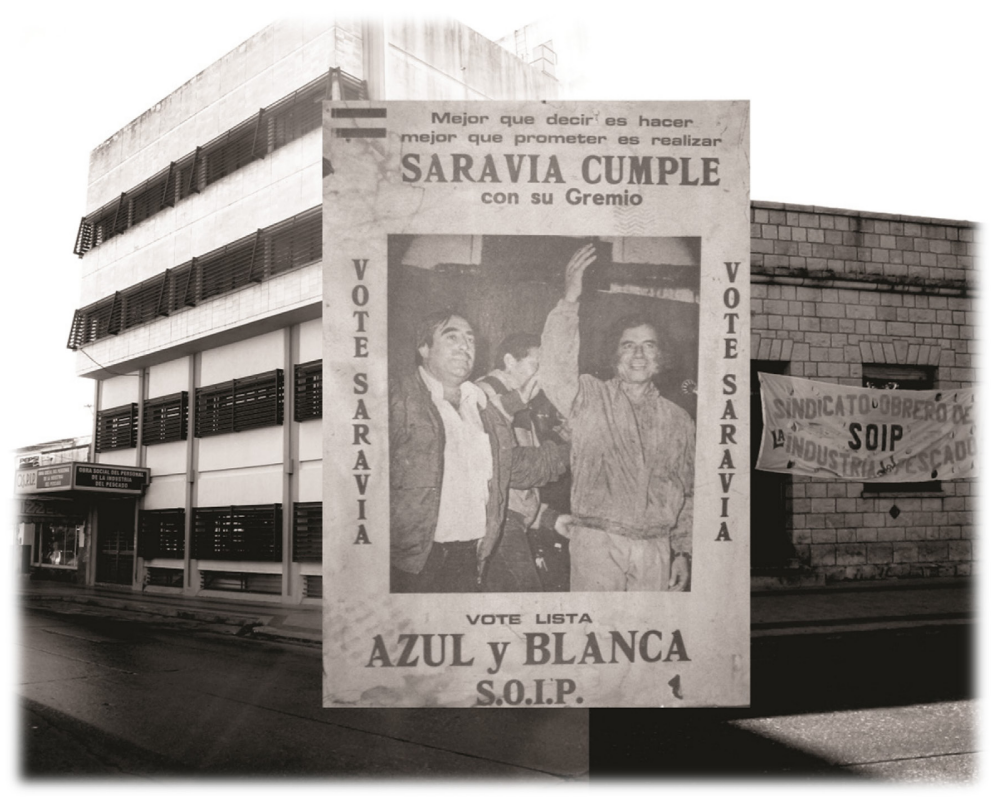




\section{Introducción}

"El ocaso de la patria metalúrgica" se titula un capítulo del libro que, sobre las transformaciones del peronismo, escribieron Danilo Martuccelli y Maristella Svampa en 1997. El nombre buscaba dar cuenta de un fenómeno que comenzaba a redefinir las coordenadas de la conflictividad en la Argentina. Las transformaciones producidas en el régimen de acumulación desde mediados de la década del '70 y que, entre otros aspectos, significaron el final de una estrategia de desarrollo mercado internista así como también la conclusión de un tipo de vinculación entre sindicatos, Estado y Partido Justicialista, desde una mirada que pronto se extendería, redundaban en la pérdida de centralidad de la conflictividad en clave laboral y, con ella, de la hegemonía de la huelga como repertorio de acción, además del quiebre o, cuanto menos, el debilitamiento del poder sindical (Lobato y Suriano, 2002; Cafassi, 2002). Estos y otros autores dirán que desde mediados de la década del '70 los sujetos de la protesta y las formas de llevarla a cabo se volvieron mucho más heterogéneos tras la aparición de movimientos reivindicativos como el de los derechos humanos, el derecho al aborto, el feminismo, comunidades indígenas, movimiento gay, movimiento de desocupados, etc. La mutación era considerable. Pues desde los inicios del siglo XX y luego bajo el funcionamiento del modelo de industrialización por sustitución de importaciones, se fue consolidando un fuerte movimiento obrero en la vida del país. Fortaleza radicada en la presencia sindical al interior de las empresas, una elevada tasa de afiliación y, luego de la década del '40, la participación de la mayoría de los gremios en la vida política como "columna vertebral" del peronismo. Que a su vez operaba como ideología política e identitaria de los trabajadores. ${ }^{647} \mathrm{Sin}$ embargo, las condiciones impuestas tras la aplicación de políticas usualmente llamadas "neoliberales" iniciadas a mediados de la década del ' 70 y profundizadas en la del ' 90 , habrían horadado aquella experiencia. Si en algún momento un campo de estudios políticos sobre el sindicalismo se planteó la dificultad de llevar a cabo una política de ajuste basada en los principios neoliberales bajo un régimen democrático, ahora la literatura enfatizaba en la importancia explicativa de las particularidades del nuevo régimen de acumulación y sus consecuencias en el mercado de trabajo, determinadas por la desindustrialización, la desocupación, la precarización del empleo y el disciplinamiento laboral como mecanismos de corrosión del poder social de los trabajadores y de las organizaciones sindicales (Lozano, 1995). ${ }^{648}$ En este tiempo se habría resuelto favor del capital el empate distributivo que caracterizó a la Argentina (Acuña, 1995; 1993). Mientras que los trabajadores no pudieron articular una resistencia efectiva ante las transformaciones que perjudicaban sus intereses. Aquel periodo estuvo marcado por la caída general en los niveles de conflictividad (Etchemendy, 2011; Palomino, 2005; McGuire, 1997; Orlansky, 1997) y la tendencia a la fragmentación y heterogeneidad de las luchas (Piva, 2006; 2001). De este modo, en la década del '90, como producto de la política económica y de las reformas laborales, se produjo la erosión del mercado de trabajo, afectando el poder estructural y organizacional de los gremios, dando por resultado "la crisis del sindicalismo" (Fernández, 2002; 1997) y hasta "el quiebre del modelo sindical" (Palomino, 2005).

Así, en la década del '90 la temática de la impotencia obrera ante las transformaciones globales y las políticas "neoliberales" ocupó el mayor espacio dentro de las ciencias sociales preocupadas por el mundo sindical. En las ciencias políticas la pregunta se dirigía a la convivencia de la política neoliberal

\footnotetext{
${ }^{647}$ Los sindicatos como columna vertebral de la protesta social reivindicativa dirá Cafassi (2002).

${ }^{648}$ El análisis de Lozano se sumaba al diagnóstico acerca de la transformación estructural de la clase obrera argentina que la volvía in-incorporable organizativamente bajo los moldes del modelo sindical tradicional. Tal diagnóstico acompañará la creación y consolidación de la Central de Trabajadores de la Argentina.
} 
con los gobiernos llamados neopopulistas (Matsushita, 1999). Lo que entonces se debía explicar era la "pasividad" o la "ineficacia" de la resistencia. La "tolerancia social" (Gerchunoff y Torre, 1996) o "tolerancia popular frente al ajuste económico" (Navarro, 1995). El nuevo contexto de desenvolvimiento de la clase trabajadora se definía por un proceso de desestructuración de la sociedad salarial, el cual en su desarrollo provocó una ola de desafiliación (Castel, 1997). En Argentina, tanto la represión ejercida desde el Estado durante la última dictadura cívico militar, como el proceso hiperinflacionario sirvieron como mecanismo disciplinador. Generando miedo del gobierno y miedo del caos (Battistini, 2007). Ello fue reforzando la fragmentación social, dando por resultado la exacerbación del individualismo negativo (Castel, 1997), la ruptura de lazos colectivos y una fragmentación individualizante (Battistini, 2007), la pérdida de relaciones de solidaridad (Izaguirre, 1994), una cultura basada en la competencia, el éxito rápido, el deseo de lucro, el consumo banal y suntuario, etc. En definitiva, la implantación de una nueva cultura social (Battistini, 2004). ${ }^{649}$ Además se fue perdiendo la cultura obrera y los contornos de lo que era una identidad social (Stratta y Barrera, 2009). Mientras que los tradicionales soportes políticos de las clases populares no pudieron articular respuestas al avance regresivo.

En general, salvo excepciones, la preocupación se centró en los padecimientos de los sindicatos que, desacoplados del Estado y sometidos a los efectos de la desestructuración del universo laboral, vieron disminuir su fuerza social y disolver su capacidad de iniciativa política (Lozano, 1995). Dejaron prácticamente de pesar en las decisiones del Estado, perdieron sus funciones de protección social, no pudieron defender los empleos y fueron incapaces de dar respuesta a quienes quedaban fuera de las relaciones salariales (Merklen, 2005). ${ }^{650}$ Delamata (2004) afirmó que la retirada del Estado árbitro y regulador, restó eficacia al repertorio tradicional de reclamo colectivo sindical, consistente en presionar y negociar a través del Estado mejoras económicas o actualización de derechos. Al mismo tiempo, el disciplinamiento social impuesto por los altos niveles de desocupación y empleo precario entre la población que conservó su empleó desincentivó la participación en estrategias ofensivas. "Bajo estas circunstancias, el rol de las corporaciones sindicales como referentes específicos del reclamo económico y laboral se diluyó...” (Delamata, 2004: 12). ${ }^{651}$ Incluso retrocedieron las instancias de representación sindical en los lugares de trabajo, asistiendo a un proceso de desmantelamiento de las mismas (Basualdo, 2010). El gobierno de Menem les había dado el golpe de gracia a los sindicatos en todos sus frentes. Haciendo retroceder a los gremios como actores corporativos luego del espacio político que estos ocuparon en la gestión de Alfonsín. Con la rápida puesta en marcha de un modelo aperturista, el ajuste del Estado, las privatizaciones y el impulso a la flexibilización laboral por parte de un gobierno peronista, los sindicatos se mostraron incapaces de dar una respuesta eficaz a esas transformaciones (Merklen, 2005; Fernández, 1997; Martucelli y Svampa, 1997). ${ }^{652}$ En ese contexto, alejados del "pesimismo" sindical,

\footnotetext{
${ }^{649}$ Para los sectores en mejores condiciones relativas se promovió el individualismo centrado en su propia estabilidad laboral y capacidad de consumo. Para los trabajadores precarizados y empobrecidos se trató de instalar la resignación y el miedo, presentando el ajuste excluyente como la única solución posible y la lucha social como un anacronismo (Stratta y Barrera, 2009).

${ }^{650}$ Para Merklen, de ese proceso emergería una nueva politicidad de las clases populares vinculada fundamentalmente a su inscripción territorial.

${ }^{651}$ También se postuló la decadencia sindical por ser los gremios instituciones tradicionales y parte de la estructura burocrática de la sociedad que tendería a ser reemplazado por organizaciones de carácter más informal, menos rígidas y más horizontales (Zibechi, 2003).

${ }^{652}$ El embate se produjo a partir de determinadas medidas de gobierno como: la ley nacional de empleo; la privatización de empresas públicas que suspendió derechos adquiridos de los trabajadores; el decreto de desregulación que incentivó la descentralización de la negociación colectiva; la reforma de las obras sociales; la disposición de aumentos solamente en base a la
} 
otros autores buscaron contar la experiencia de construcción de un sindicalismo alternativo como el caso de la CTA (Duhalde, 2009; Armelino, 2005).

Paralelamente a estos procesos, en las ciencias sociales fueron apareciendo los discursos sobre la disolución de las clases, la pérdida de relevancia de la conflictividad laboral, las crisis de las organizaciones sindicales $\mathrm{y}$, en el caso particular de nuestro país, se cuestionó la articulación/identificación entre trabajadores y su filiación ideológica mayoritaria, el peronismo (Santella, 2006). Con todo, Caracterizó a la literatura sobre lucha social en la Argentina una mirada "pesimista" sobre el alcance y la potencia esas luchas. La apatía política (apatía electoral a la vez que desencanto de las posibilidades de transformación) se instauró en el seno de la sociedad (Bonasso, 1999). ${ }^{653}$ Para quienes no hablaban de apatía sino de transformación de lo político, se trataba de un claro momento de reflujo en la lucha popular (Martuccelli y Svampa, 1997). En general, los trabajos fueron a buscar una explicación de aquella pasividad o ineficacia de la resistencia. Se describió el pasaje del trabajador a la figura del pobre. Los discursos hablaban desde la negatividad y las movilizaciones de las clases populares fueron presentadas como si oscilaran entre la defensa de las conquistas del pasado, la incomprensión de lo que les pasaba o la anomia. Enmarcado por el "pesimismo", algunos historiadores podían, incluso, enunciar la tendencia al "ocaso de la política en las calles" (Romero, 2000). Mientras que un interesante texto sobre las transformaciones de las identidades social-populares reunía un conjunto de trabajos de los cuales ninguno tomaba por objeto de estudio una experiencia sindical (Svampa, 2000). ${ }^{654}$

En ese contexto, pocos fueron los estudios como los de Etchemendy (2011) y Etchemendy y Palermo (1998) que demostraron, a pesar del debilitamiento, el peso corporativo del que aún disponían los sindicatos, lo cual obligó al gobierno a concertar las reformas implementadas y a otorgar compensaciones, siendo esto lo que permitió la existencia de bajos niveles de conflictividad a diferencia de, por ejemplo, el caso español. También Murillo $(2008 ; 2000)$ analizó la importancia de la interacción entre sindicatos y gobierno para comprender las respuestas a las reformas, así como la negociación del proceso de reformas estructurales de la CGT con el gobierno de Menem a fin de garantizar la pervivencia de las estructuras organizativas (Murillo, 1997; 1996). ${ }^{655}$ Las investigaciones de Nicolás Iñigo Carrera, por su parte, apuntaban a demostrar justamente lo contrario de la desaparición de la clase obrera, esto es el proceso de creciente proletarización de la sociedad argentina, así como el lugar todavía principal de los trabajadores asalariados ocupados en las luchas sociales y políticas (Iñigo Carrera, 2007; 2001). ${ }^{656}$

Otro aspecto también se imponía en la reflexión: la "re-peronización” de las clases populares. ¿Si el peronismo había muerto, por qué los electores votaban por el justicialismo? (Martucelli y Svampa, 1997). El menemismo en el gobierno, al cual accedió con promesas de corte "populista" y en la clave del lenguaje peronista clásico, orientó su programa hacia políticas económicas neoliberales. El "problema" estaba planteado entonces entre la aplicación de éste tipo de políticas y las bases sociales del partido

productividad y con ello la liquidación de la negociación colectiva; la flexibilización laboral y la eliminación de asignaciones familiares a partir de determinado tope salarial.

653 "El sedimento de desesperanza que deja el menemismo en este imaginario es indecible" (Cafassi, 2002: 40).

${ }^{654}$ Los capítulos analizaban el fenómeno del empobrecimiento, el tránsito de la clase media a la nueva pobreza, la sociabilidad y cultura en los asentamientos del Gran Buenos Aires, la desestructuración de identidades de trabajadores industriales, el pentecostalismo y la religiosidad, el clientelismo y los valores domésticos.

${ }^{655}$ A ello Murillo denominó estrategia de supervivencia organizativa frente a otras posibles reacciones sindicales frente a políticas liberales como podían ser la resistencia o la subordinación.

${ }^{656}$ Una breve intervención de Matsushita también señala que a pesar de apoyar algunas reformas, el sindicalismo no asumió una actitud ni tan pasiva ni tan colaboracionista, conciliando algunas políticas laborales pero oponiéndose también a muchas otras (Matsushita, 1999). 
peronista que se caracterizaban por ser el sustento de políticas obreristas, estatistas y nacionalistas. Esto es, se planteaba una paradoja histórica, en el sentido de que un peronismo de base obrera y popular finalmente aplicó políticas neoliberales y conservadoras (Ostiguy, 1997). La paradoja fue llevada al plano explicativo por Sidicaro (2002), Gerchunoff y Torre (1996) quienes sostuvieron que los trabajadores pudieron ser convencidos de la necesidad del ajuste y de las reformas precisamente porque el argumento les era formulado desde el partido que representaba sus intereses. Por su parte, Peter Ranis (1992, cit. en Santella, 2006) incursionó en el consenso de los trabajadores hacia las políticas neoliberales, partiendo de una crítica a la teoría de la conciencia de clase, según la cual ésta se definiría por un complejo de intereses y deseos que incluyen intereses económicos y demandas de libertad individual y personal, así como el progreso dentro del capitalismo. En este sentido, la explicación buscó mirar los procesos de adscripción identitaria. La filiación a la tradición peronista ya no se explicaba por el lugar ocupado en el "mundo del trabajo" o en la organización de la producción, sino por el proceso de formación de la identidad y la relación con las redes extendidas por el aparato peronista. De este modo, se produjo en la bibliografía un desplazamiento del dúo trabajadores/sindicatos hacia los pobres/desocupados y sus relaciones de reproducción/supervivencia. Entonces, tras la desindicalización del PJ (Gutiérrez, 2001) el clientelismo pasaba a ocupar un lugar central en la explicación de la vinculación del peronismo con los sectores populares (Auyero, 2001). En una Argentina "postindustrial" las redes territoriales de tipo clientelar remplazaron a las organizaciones sindicales como "columna vertebral" del peronismo. Ello permitía explicar con mayor facilidad la mutación programática del PJ (Levitsky, 2005). En cierto modo, se podía pensar que lo que efectivamente ocurrió en esta década fue la retirada del peronismo de las bases del conflicto social (Farinetti, 2007).

Por todo esto, cuando al calor de la conflictividad recrudecida sobre el final de la década se multiplicaban los estudios sobre protesta social, movimiento de desocupados, puebladas, asambleas, etc., en el momento en que se mencionaban los sindicatos, estos se presentaban como cómplices de las políticas neoliberales, y en el mejor de los casos, impotentes en la organización de la resistencia, perdiendo su lugar hegemónico como canalizadores de la beligerancia popular. ${ }^{657}$ Lo cierto es que con aquellos diagnósticos acerca de la pérdida de centralidad del conflicto en clave laboral, de los trabajadores como sujetos y de los sindicatos como canalizadores de las demandas, muchos analistas se desinteresaron por la vida gremial durante la década del $90 .{ }^{658} \mathrm{Si}$ bien algunas investigaciones arrojaron luz sobre los caminos emprendidos por la CGT durante el proceso de ajuste y el surgimiento de polos sindicales alternativos como el MTA, la CTA y la CCC (Gómez, 2009; Fernández, 2002), en tanto los

\footnotetext{
657 “...los sindicatos agrupados en la otrora poderosa CGT no sólo no acompañaron a sus afiliados sino que, en casi todos los casos, avalaron activamente el programa de reformas estructurales" (Svampa y Pereyra, 2003: 15). "La adaptación de los sindicatos peronistas a las transformaciones económicas y la desregulación del mundo laboral, tanto como a los nuevos contornos organizacionales del partido, se produjo con velocidad" (Delamata, 2004: 19). El menemismo redujo el peso de los sindicatos en la vida política con su ofensiva hacia el trabajo con la flexibilización laboral y las privatizaciones. Aprovechó además el desconcierto de la burocracia sindical respecto de su propia identidad política tradicional (Cafassi, 2002). Otros analistas destacaron los cambios en el protagonismo en la protesta de los diferentes sindicatos, señalando la pérdida de importancia de los gremios industriales frente a los de servicios y estatales (Lobato y Suriano, 2002). Donde los primeros quedaron prácticamente al margen del conflicto social, al menos como actor colectivo, mientras que fueron los gremios estatales nacionales y provinciales los verdaderos protagonistas de la protesta (Fradkin, 2002).

${ }^{658}$ El estudio de la revitalización sindical posterior al año 2003 crecerá algunos años después impulsado particularmente por el texto "Golpeados pero de pie..." de Etchemendy y Collier (2007).
} 
trabajadores, pero sobretodo los sindicatos habían perdido su estrella, ya no ocuparon un lugar de importancia en el análisis social. ${ }^{659}$

Introduciéndonos en los debates sobre las respuestas sindicales a las transformaciones producidas en el patrón de acumulación, en este capítulo buscamos comprender cuál fue el accionar del SOIP. En cuanto el sindicato se había consolidado desde una lógica a mitad de camino entre lo que se define como participacionismo y vandorismo, nos preguntamos sobre cómo enfrentó las mutaciones en el modelo de desarrollo pesquero, en el vínculo con el Estado y en el nuevo contexto de una economía aperturista. ${ }^{660}$ Estos cambios ¿dejaron su impronta en la dinámica sindical? ¿cómo impactaron en la organización interna del gremio? Siendo un sindicato con una tradición combativa, tanto bajo el liderazgo anarquista como bajo el peronista ¿cuál fue la política sindical llevada a cabo por la conducción gremial en la década del '90? ¿avaló el proceso de reformas estructurales o, al contrario, lo rechazó? En el caso de haber participado ¿recibió el sindicato algún tipo de compensación para apoyar el proceso de ajuste? ¿qué actitud adoptó ante la instauración de pseudo cooperativas para el procesado de pescado? Para conocer estas cuestiones se hace necesario presentar de qué tradición sindical provenía, cuál era el estilo de liderazgo, cuáles los recursos organizacionales con los que contaba. Pero no se trata de quedarse con la actitud de la conducción, pues influenciadas por las transformaciones en el modelo de acumulación ¿se generaron movimientos internos alternativos? ¿se incrementó la competencia sindical?

En pos de buscar dar respuestas a estos interrogantes es que realizamos un recorrido por la historia del SOIP, presentamos algunos elementos de la estructura sindical como el estatuto y el CCT bajo el cual se laboraba en la actividad, para luego repasar los procesos electorales por los que transitó el gremio. Estos aspectos nos permiten continuar conociendo las tradiciones organizativas e ideológico - políticas preponderantes así como vislumbrar con qué recursos organizacionales contaban los dirigentes para hacer

${ }^{659}$ La línea de trabajos tal vez más fértil se dedicó a analizar las diferentes respuestas sindicales a los procesos de ajuste, construyendo tipologías acerca de la lógica de intervención. Martuccelli y Svampa (1997) observaron dos grandes divisiones entre sindicatos: 1) los que desde la crítica o adaptación parcial desarrollaron una práctica sociopolítica basada en los moldes nacionales y populares y que atravesaron una profunda crisis; 2) los que a través de diferentes estrategias intentaron dar forma a otro modelo sindical, adaptándose a la nueva situación económica, desarrollando vínculos privilegiados con el gobierno y reformulando desde ahí sus marcos de acción; o partiendo de una crítica general al viejo modelo de representación, con el objeto de consolidar un nuevo modelo sindical. Fernández (2002) elaboró un esquema con cuatro tendencias que tuvieron lugar a partir de los años setenta dentro del sindicalismo Argentino: 1) la tendencia participacionista, subordinada al Estado y cooperativa con el sector capitalista hegemónico; 2) la tendencia vandorista o negociadora, con estrecha vinculación con el peronismo; 3) la tendencia confrontacionista, que dirigió las principales luchas obreras de hostigamiento al bloque dominante y, 4) la tendencia clasista, ajena al sindicalismo peronista. Durante la década del ' 90 las dos primeras tendencias fueron convergiendo en la postura del líder de la CGT, Rodolfo Daer. Por su parte, la tendencia confrontacionista quedó encarnada en la tradición que responde a Hugo Moyano, que intentó viabilizar un programa político opuesto al modelo neoliberal. Por último, la tendencia clasista o renovadora se nutrió de la convergencia de nuevas organizaciones gremiales y de renovadas prácticas sindicales que fueron rompiendo con el modelo justicialista de vinculación del Estado con el movimiento obrero. En esta descripción podría ubicarse la CTA o la CCC. Algo similar es la descripción realizada por Gómez (2009), quien tras criticar el excesivo énfasis de la literatura en la importancia explicativa del régimen de acumulación y sus consecuencias en el mercado de trabajo, como los determinantes estructurales de los cambios en el sindicalismo, puesto que "El sesgo homogeneizante implícito en las explicaciones de este tipo impide captar muchas veces cómo los procesos estructurales son asimilados de manera diversa a partir de trayectorias históricas previas" (Gómez, 2009), propuso una tipología con las diferentes respuestas sindicales. Entre las distintas formas de estructurar la acción sindical define al participacionismo, vandorismo, sindicalismo combativo, clasismo y nuevo sindicalismo social y estudia cómo cambiaron estas estrategias a partir de las reformas neoliberales.

${ }^{660}$ Aunque tal vez parezca ocioso, pensamos que aquí hay que hacer lugar a las críticas desplegadas por Hyman, entre otros, hacia aquellas miradas puramente institucionales de los sindicatos que tropiezan ante afirmaciones del estilo "El sindicato ha llegado a un acuerdo con la empresa". Pues un sindicato no se reduce a la entidad física, ni a quienes trabajan en ella sino que implica las acciones del conjunto de población obrera que abarca. Por ello no hay que caer en cosificaciones que llevan a considerar abstracciones impersonales (sindicatos) comportándose como agentes sociales. Se trata no sólo de ver a los sindicatos en cuanto organizaciones sino también a los trabajadores, sus problemas y aspiraciones (Hyman, 1978). 
frente a los desafíos que imponía el devenir de un nuevo modelo de desarrollo pesquero en el marco de la transformación en el patrón de acumulación del capitalismo argentino. ${ }^{661}$ Destacamos también un fenómeno que aparece de modo persistente para quien estudie la historia de los procesos electorales del SOIP: la denuncia de fraude. Posteriormente desarrollamos las características del liderazgo de Abdul Saravia al frente del sindicato (y también de la CGT regional) porque su figura constituye un referente ineludible en la historia del gremio tras 28 años de conducción prácticamente ininterrumpida. Entre otras cuestiones interesantes, su liderazgo plantea la paradoja de que nos encontramos frente a un líder sindical menemista pero opositor a las políticas que para la pesca se desplegaban desde el gobierno. Al mismo tiempo que la trayectoria de la conducción gremial, analizamos la existencia y desarrollo de corrientes opositoras, algunas de las cuáles buscaban construir otro modelo sindical cercano a las orientaciones del clasismo. Una de esas listas, la Celeste, en el año 2002 logró reemplazar a la vieja conducción gremial, tras 33 años de hegemonía. La particularidad de este gremio es que así como los peronistas desplazaron a los anarquistas a mediados de la década del ' 60 , ahora militantes trotskistas reemplazaban a los peronistas en uno de los gremios industriales de mayor peso y tradición de la ciudad de Mar del Plata.

\section{Los gremios de la industria pesquera}

En la actividad pesquera existen seis gremios principales distribuidos según su participación en el proceso productivo que va desde la captura hasta la elaboración final del producto. Los sindicatos abarcan al personal de los buques pesqueros en sus diferentes jerarquías, a los trabajadores del sector portuario propiamente dicho y al personal de la industria del pescado. Los dos sindicatos mayoritarios son, al menos desde mediados de la década del '40, el SOIP y el SOMU. En relación con este último, los marineros cuentan con una larga historia de organización sindical, que encuentra sus orígenes hacia principios del siglo XX desde la conformación de la Sociedad de Resistencia de Marineros y Foguistas en el año 1903; la posterior formación de la Liga Obrera Naval en 1907 y la Federación Obrera Marítima hacia 1910. Los trabajadores de esta actividad siempre contaron con una fuerte organización sindical aunque sus siglas hayan ido cambiando. Hacia 1947 está variación de siglas se estabiliza con el surgimiento del Sindicato de Obreros Marítimos Unificado que representa a marineros provenientes de diferentes ramas de la economía. En Mar del Plata, los trabajadores marítimos son fundamentalmente marineros pescadores. Pero la historia de los marineros es particular porque en los primeros años estos eran, en general, propietarios de sus embarcaciones. Se organizaron principalmente en torno a su

661 "Ir a la prensa" para dar a conocer a la comunidad una noticia que se consideraba de importancia dentro del pensamiento de la conducción del SOIP era una actividad cuidada ya desde las primeras conducciones del gremio (Nieto, 2012). Este legado permanece vivo en la práctica de Saravia y también en los opositores gremiales. De allí que podamos reconstruir diferentes aspectos de la vida gremial analizando la prensa. Por el lado de Saravia, de manera recurrente visitaba oficinas o enviaba telegramas a los principales diarios de la ciudad por diferentes motivos: situación del gremio, aumentos obtenidos, aclarando su posicionamiento respecto de algún conflicto, anunciando obras, informando acerca de eventos sociales, recordando un aniversario del gremio, incluso saludando a instituciones como el Ejército o la Iglesia y apoyando o cuestionando la designación de algún funcionario. Además, usualmente aparece en la prensa de la época el llamado a elecciones de delegados del SOIP, así como los nombramientos de quienes resultaren electos, siendo el único gremio local que publicitaba de manera constante estos eventos. Además, Saravia trabajaba su relación con la prensa, por ejemplo, realizando agasajos y reuniones donde se valoraba la tarea del periodismo local. Agradeciendo también con cenas y eventos la difusión que los diarios brindaban de las actividades del gremio. Por su parte, los opositores gremiales, por lo general debían su aparición en la prensa a la presentación de su lista, publicitar algún conflicto en el gremio o lanzar críticas a la comisión directiva. 
identidad étnica y realizaban la explotación pesquera con mano de obra familiar. La organización gremial no tuvo el carácter sindical, sino que se trató de una cooperación de carácter mutualista para alcanzar una mejor posición en la venta de pescado en contra de los intermediarios a través de la Corporación Pesquera de Ayuda Mutua a instancias de sectores de la iglesia católica. Poco después, la expansión de la industria pesquera trajo aparejada la incorporación de buques con mayor capacidad de pesca, los cuales requerían más número de obreros. Esta situación fue dando fin a la explotación familiar de la mano de obra, creando un nuevo mercado de trabajo. Así, durante el primer gobierno peronista, surgió la seccional local del SOMU. Desde aquel momento al día de hoy, esta organización sindical se mantuvo vigente en la representación de los trabajadores marítimos de la ciudad de Mar del Plata, aunque mermando notablemente su cantidad de afiliados a partir de la formación del SIMAPE en el año 2000 (nos referimos a ella en próximos capítulos). Según datos aportados por la seccional Mar del Plata del SOMU, en el año 1999 el sindicato contaba con alrededor de 2.000 afiliados, todos de sexo masculino, sin existir personal en cooperativas (Rodríguez et al, 1999). El Centro de Patrones de Fluviales de Pesca y de Cabotaje Marítimo es una asociación profesional de Primer Grado, adherida a la Federación Marítima Portuaria y de la Industria Naval de la República Argentina, la Confederación Argentina de Trabajadores del Transporte y en el ámbito internacional a la Federación Internacional de Trabajadores del Transporte. Representa a todos los trabajadores que desarrollan su actividad laboral como Capitán, Primer Oficial o Segundo Oficial en los ámbitos Fluviales, Pesqueros o de Cabotaje Marítimo o bien como Patrón Motorista de Zona Especial en las embarcaciones que navegan ríos, mares y lagos. Los orígenes de esta organización nos llevan a 1933 donde, bajo la conducción del Secretario General José Vanoli, surge en primera instancia con el nombre de Asociación Profesional y Mutual de Patrones de Lanchas. Su sede central se encuentra en la Capital Federal y la personería se consiguió en 1959 a través de la resolución 278 que otorgó la Personería Gremial N 321. La Asociación Argentina de Capitanes, Pilotos y Patrones de Pesca Surgió en 1983 como una escisión del Centro de Patrones organizada netamente por trabajadores de la industria pesquera. También es una organización de primer grado de carácter nacional. Su sede está en Mar del Plata y obtuvo su personería gremial ( $\left.{ }^{\circ} 1442\right)$ en el año 1992. En 1958 el Sindicato de Conductores a Vapor y Combustión Interna de la República Argentina y el Centro Naval de Conductores se fusionaron conformando el Sindicato de Conductores Fusionados. En 1980 este gremio resolvió pasar a llamarse Sindicato de Conductores Navales de la República Argentina (SICONARA) agrupando y representando a los trabajadores profesionales de la navegación que poseen las categorías de conductores de máquinas y motoristas navales. Su sede central se encuentra en Capital Federal y funciona con la personería gremial $\mathrm{N}^{\circ}$ 319. El Sindicato Unido de Portuarios Argentinos agrupa a los trabajadores de la estiba comprendiendo las tareas de carga y descarga. Posee personería gremial desde el año 1978 pero su primera conducción se organizó en 1984. Nucleaba alrededor de 550 trabajadores a mediados de la década del '90. Todos los sindicatos, junto con el SOIP, están enrolados en la CGT y son los que pronto veremos participar en la protesta obrera.

\section{EI Sindicato Obrero de la Industria del Pescado (SOIP)}

Sabemos que la estructura sindical argentina, consolidada sobre todo a partir de los gobiernos peronistas, se caracterizó por el manejo centralizado de la conducción nacional, que es la que dispone, entre otras cuestiones, de los fondos sindicales. La legislación favoreció la consolidación de liderazgos 
nacionales fuertes, generalmente en desmedro de las delegaciones locales que, en caso de disidencia, podían ser intervenidas. En varias ocasiones surgían por ende diferencias entre las dirigencias locales y las nacionales. Esto afectará a la industria pesquera cuando, por ejemplo, la conducción local del SOMU (marineros) se enfrente a la dirección nacional. El caso del SOIP es particular, porque es un sindicato nacional que solamente tiene presencia en la provincia de Buenos Aires. Por esto es al mismo tiempo local y nacional. Es decir que la conducción que define la política y el perfil del gremio está radicada en Mar del Plata. Los intentos por expandirse hacia el sur y abarcar a quienes trabajaban en plantas de procesado, pero que representaba el STIA, jamás prosperaron. Esta realidad lo redujo a convertirse de hecho en un sindicato local con un peso muy reducido en la dinámica sindical nacional, dado además por representar a trabajadores de una industria que ocupa poco lugar en la agenda pública de gobiernos tanto como de la ciudadanía. En cierto modo, aquella limitación significó también una potencialidad cuando el sindicato se hizo fuerte a partir de consolidarse tras la identidad de representar a la comunidad pesquera marplatense.

Lo cierto es que después de varios intentos fracasados de organización, y con el claro predominio de la actividad de elaboración de conservas, en 1942 las obreras y obreros del pescado lograron crear y consolidar el SOIP. Hasta 1948 el gremio estuvo dirigido por anarquistas, pero desde aquel año hasta 1955 la dirección -bajo otro sello organizacional- ${ }^{662}$ quedó en manos de militantes gremiales peronistas, para luego volver a ser retomado por anarquistas cuando por acción de la "revolución libertadora" comandos civiles integrados, entre otros, por socialistas y anarquistas, coparon todos los locales sindicales de la ciudad, entre ellos el SOIP, desplazando a las conducciones peronistas. Si bien en muchos de estos gremios la militancia peronista se reactivó dando lugar al fenómeno conocido como la "resistencia peronista", en el caso del SOIP la conducción se mantuvo en manos de dirigentes anarquistas hasta 1966.Paralelamente, desde finales de la década del '50 comenzaba a iniciarse una transformación en la industria pesquera que poco tiempo después repercutirá en la influencia de las corrientes políticoideológicas al interior del gremio. Tal transformación se definía por la creciente importancia de la elaboración de filete en desmedro de la fabricación de conservas de pescado. Esta mutación fue produciendo la construcción de una nueva figura de trabajador/a: el filetero y la filetera. Siendo una actividad iniciada al margen de regulaciones legales, con un alto nivel de precariedad, la labor de los trabajadores y las trabajadoras del filete estaba sujeta a la arbitrariedad y mando patronal. Jornadas de amplias horas de trabajo sin computar horas extras, semanas en que se laboraba de lunes a lunes, malas condiciones medio ambientales de trabajo y bajos salarios fueron los principales motivos de reclamación de una población obrera en formación. Este marco fue el caldo indispensable para los primeros ensayos de agrupamiento en ese sector de la actividad. El movimiento iniciado por la elección de hecho de delegados en distintas plantas, cristalizó en un sindicato de activa pero corta vida, el Sindicato de Obreros Fileteros de Pescado y Afines, que unos meses después se integró como rama en el STIA (Nieto, 2012). En los comienzos los empresarios ejercieron despidos como método para descabezar la organización gremial. En ese afán eran varios los instrumentos con que estos contaban para mantener disciplinada a la fuerza de trabajo. El despido liso y llano era uno de ellos, pasando por la amenaza de, o la reducción de materia prima que acercaban a los trabajadores "díscolos", al tiempo que premiaban a los obreros y obreras más dispuestos. En ese contexto, la conducción anarquista del SOIP buscó pactar un convenio

${ }^{662}$ En esos años el SOIP pasó a ser la Sociedad de Obreros de la Industria del Pescado y Afines. Y a partir de 1950 fue una rama del sindicato de la alimentación. 
colectivo de trabajo con los industriales pesqueros para regular la actividad. Pero en su gran mayoría la población de obreros y obreras del filete, donde ya predominaba la militancia de origen peronista y comunista, rechazaron la iniciativa y poco tiempo después, tras fuertes disputas, organizaron la toma de la sede del SOIP en repudio a tal convenio. ${ }^{663}$

Finalmente en 1966 bajo el gobierno de la autodenominada "revolución argentina", el gremio fue intervenido y puesto bajo la dirección de José Ibáñez, hermano del petrolero Diego Ibáñez, quien en 1989, como hemos visto, ocupará la titularidad del Mercado Nacional de Concentración Pesquera. En 1969 se produjo una nueva intervención y un renovado llamado a elecciones. Se presentaron tres listas, pero terminó participando solamente una, la Lista Unificada Naranja. La "Naranja", encabezada por Abdul Saravia, ganó la conducción del gremio. Este nuevo liderazgo peronista dentro de la actividad marcó una transformación fundamental en la composición de afiliados al sindicato. El hecho acompañaba la evolución de la industria, esto es, comenzaba a mostrar la preeminencia de los trabajadores fileteros y fileteras por sobre los de la industria conservera. Curiosamente Saravia, que provenía del sector de elaboración de conservas siendo delegado de la Campagnola, fue el dirigente sindical que representó poco después la hegemonía del filet. Los cambios no solo conmovieron la dimensión cupular de la organización obrera, también afectaron al conjunto de los obreros y obreras del pescado. Era el final de la preeminencia anarquista. Estos hechos crearon las condiciones de posibilidad de la emergencia y coagulación de la militancia sindical peronista como fuerza social obrera hegemónica en el gremio del pescado. Cuanto menos hasta finales de la década del ' 90.

Si bien la emergencia de la figura de filetero data de finales de los años '50 y la militancia peronista en el gremio existió desde mediados de los '40, fue en los '60 que la producción de pescado fresco comenzó a disputarle el dominio de la actividad a la conserva. Esta transformación en la industria encontró relativamente mejor posicionados a los peronistas que a los anarquistas, pues estos últimos mantenían sus esfuerzos recreando su hegemonía en la rama conservera y en cierta manera descuidaron su inserción en un espacio que consideraron marginal como el de los establecimientos de fileteado. Circunstancias que supieron aprovechar muy bien los militantes gremiales peronistas, aliados en ese entonces con comunistas, quienes se encontraban al asecho de toda oportunidad abierta por una nueva coyuntura para conquistar el sindicato. Nieto (2012) ubica aquí un cambio en la cultura sindical en la industria del pescado dado, por un lado, por la aparición definitiva de los fileteros eclipsando otras subramas de la actividad y hegemonizando el sindicato. Por otro, por la instalación de la toma como repertorio de protesta válido tanto para la lucha por mejorar salarios, condiciones de vida y protestar contra el despido de compañeros, como para dirimir las disputas intra-gremiales. Además, por estos años los obreros y obreras del pescado cambiaron otro aspecto de su cultura sindical presente desde 1942: el proceso de elección de sus dirigentes. Entre 1942 y 1966 las elecciones se realizaban por medio de asambleas generales donde se proponían nombres para los distintos cargos y pasaban a ser votados de inmediato, al principio a mano alzada después escribiendo el nombre en un papel, pero siempre en el marco de una asamblea. A partir de aquel año los militantes peronistas y comunistas plantearon la necesidad de elecciones libres, secretas y por listas. Reclamo que se concretó una vez concluida la intervención del gremio en 1969.

\footnotetext{
${ }^{663}$ La toma de la sede sindical del SOIP por parte de los militantes gremiales peronistas en el año 1966, que en ese entonces funcionaba en la Casa del Pueblo, fue un momento central en el cambio de conducción gremial. Un análisis de esta toma en Nieto (2012). A partir de entonces, la acción de ocupar el edificio gremial se instaló dentro de los instrumentos de lucha a los que acudieron los obreros y obreras de la industria del pescado como repertorio de protesta para dirimir antagonismos sindicales.
} 


\section{La estructura gremial del SOIP: aspectos formales e informales}

Los sindicatos, en tanto figuraciones de poder, producen cristalizaciones cíclicas que pueden ser leídas como testimonios de las correlaciones de fuerzas, tanto hacia su interior como en relación a otras figuraciones, algunas de ellas más generales como las leyes de asociaciones profesionales y las convenciones colectivas de trabajo donde interviene el Estado. Ejemplo de estas cristalizaciones son los estatutos y los convenios colectivos de trabajo, cada uno con sus particularidades. Si bien los estatutos y los CCT no determinan prácticas organizacionales de los obreros y militantes sindicales, quienes se someten a la guía de los principios prácticos (Bourdieu, 2007), tampoco prescinden por completo de dichas normas y ello por varias razones. Muchos de los procedimientos internos del sindicato están pautados formalmente por normas que se encuentran por encima de dicha organización, como la ley de asociaciones profesionales. Por otra parte, muchos de los artículos estatutarios son el producto de la correlación de fuerzas interna a la organización sindical, siendo esos artículos el resultado de prolongados procesos de discusión y negociación. Otro elemento que nos habla de la no prescindencia de dichas normas es la cíclica actualización de las mismas, siendo estas siempre provisorias. Este estatus provisorio no sólo se revela en los momentos de actualización sino también en los lapsos de vigencia de cada uno, cuando las prácticas organizacionales flexibilizan su articulado o lo desconocen selectivamente. Reiteradas veces, durante estos lapsos, el estatuto, al igual que el CCT, es presentado para "el afuera" como monolítico e incuestionable, mientras que "hacia adentro" su interpretación y aplicación es disputada. Los estatutos y convenios suelen constituir "recursos organizacionales" que los sindicatos bregan por mantener. Esto vuelve interesante la mirada sobre estas normas que pretenden regir la vida organizacional de sus integrantes.

La estructura organizacional del SOIP se basa el estatuto de 1990, el cual aún hoy permanece vigente y el Convenio Colectivo de Trabajo $\mathrm{N}^{\circ} 161 / 75 .{ }^{664}$ Uno de los primeros aspectos que define el estatuto es la incumbencia, esto es, el universo de trabajadores y trabajadoras a representar. Esas fronteras se trazan excluyendo a ciertas figuras asalariadas, como capataces, gerentes, administrativos. ${ }^{665}$ De esta forma el universo de potenciales asociados refiere exclusivamente a los obreros y obreras que intervienen en cualquier manipulación concerniente a productos de la pesca: fileteros/as, empaquetadoras/es, envasadoras/es, peones/as, pesadores/as, etc. Desde su fundación, una preocupación central de los dirigentes anarquistas, producto de una experiencia adquirida a partir de fracasos previos, era el miedo a la disolución de la entidad que tanto les había costado forjar. Por ello, desde un principio buscaron desarrollar una fuerte presencia del sindicato a partir de extender la representación hacia los propios lugares de trabajo, ampliando las fronteras gremiales hasta el mismo lugar de producción. Desde entonces funcionaron comisiones de fábrica y una extensa red de delegados por planta. Su existencia y funcionamiento aparecieron como reivindicaciones ya en el primer pliego de condiciones finalmente aceptado por los patrones pesqueros (Nieto, 2012). Estas instancias de representación sindical en los propios lugares de trabajo permitían además hacer cumplir los CCT. La gran cantidad de fábricas y la

\footnotetext{
${ }^{664}$ Desde su inscripción como asociación sindical en 1958 el SOIP modificó sus estatutos en cuatro momentos: 1962, 1972,1982 y 1990. Es decir, que el último estatuto de la actividad se redactó con posterioridad a la ley y decreto reglamentario sobre asociaciones sindicales de 1988.

${ }^{665}$ Los trabajadores que ocuparon estos cargos más directamente vinculados con la patronal eran (y son) afiliados al sindicato de Empleados de Comercio. La diferente pertenencia gremial permitía a los mandos medios ocuparse de las tareas que quedaban pendientes cuando, por ejemplo, el SOIP convocaba a un paro. De este modo garantizaban con este personal jerárquico un mínimo de funcionalidad de las plantas.
} 
intransigencia patronal habían enseñado a esta comunidad obrera que no bastaba con lograr la sanción legal de un convenio y su homologación, sino que había que hacerlo cumplir planta por planta. Con el tiempo, la figura organizacional elemental del sindicato, la cual le permite desarrollar una activación territorial, fue la de delegado de personal. Desde la propia formación del SOIP, la función de las comisiones de control y, luego de 1948, ya reconocida por Convenio Colectivo de Trabajo, la función del delegado gremial fue central en el día a día de la tarea sindical. Una de las tareas primordiales que tenían era hacer cumplir en los lugares de trabajo los acuerdos alcanzados para el conjunto de la rama. Desde los anarquistas se cuenta la práctica de la recorrida por las fábricas, asambleas, reuniones de personal. ${ }^{666}$ Lo interesante de estas prácticas es que permanecieron independientemente de la corriente política que condujera el gremio. Los peronistas incorporaron además la reunión periódica con la delegación del Departamento de Trabajo, así como se adecuaron más al crecimiento burocrático de las organizaciones instaurando el cargo rentado. ${ }^{667}$ La figura del delegado, con sus obligaciones y atribuciones, está contemplada en el estatuto y en el CCT y no es menor el lugar que cada uno de ellos le dedica. ${ }^{668}$

Un aspecto importante es que son los delegados quienes controlan las balanzas donde se pesa el pescado producido a destajo, mediante pesas certificadas provistas por el sindicato. La cuestión no es menor. Pues existen dos maneras de medir los salarios: el tiempo o la producción. Si en las primeras las herramientas indispensables son el reloj y el cronómetro; en los trabajos donde se abona por producción la herramienta central es la balanza. Como hemos relatado en el capítulo sobre el proceso de trabajo, la producción de cada filetero o filetera se pesaba en una balanza que indicaba la cantidad de pescado que cada trabajador o trabajadora había realizado ese día. Ese peso, luego de una quincena, era el que informaba acerca de cuál sería el salario de los trabajadores. Pero una balanza, que es nada más que un objeto o un instrumento, en el marco de las relaciones sociales capitalistas también se convierte en una suerte de árbitro que regula el pago del salario y, por tanto, un pilar esencial de la relación obreropatronal. Por ello, se vuelve un rol de suma importancia el hecho de calibrar la balanza, quién lo hace y qué posibilidades tienen los trabajadores y trabajadoras de controlar la precisión de dicho instrumento. ${ }^{669}$ Pues un mal funcionamiento de la balanza podría generar complicaciones a la hora de precisar los salarios. Esta situación trajo no pocos conflictos obrero - patronales. Y por ello, la organización obrera buscó llevar un contralor de la balanza entre sus atribuciones. ${ }^{670}$

\footnotetext{
666 “Aquella situación llevó al sindicato a tener una agitada y cotidiana actividad militante, actividad que implicó desde micronegociaciones a la paralización de actividades en los lugares de trabajo. En la resolución de estas fricciones cotidianas, las comisiones internas y lxs delegadxs de fábrica jugaron un papel para nada desdeñable" (Nieto, 2012: 149).

${ }^{667}$ Mirando los diarios de todos los días, correspondientes a los 13 años que van desde 1989 a 2002, hemos advertido que el SOIP informaba todas las semanas acerca de la realización de elecciones de delegados. Esta asiduidad informativa no la publicaba ningún otro sindicato. Esto no quita que durante la "larga década del 90" la cantidad de delegados descendiera paulatinamente, de la mano del surgimiento de las plantas clandestinas y las cooperativas de trabajo, debilitando uno de los aspectos centrales de la organización obrera.

${ }^{668}$ No siempre fue así. En el estatuto de 1972 la figura del delegado está ausente.

669 "Como había ocurrido con el control del tiempo en los talleres de la Inglaterra decimonónica, en las plantas de fileteado marplatense un gran número de patronos intentaron expropiar a lxs trabajadorxs de todo conocimiento sobre el control del buen funcionamiento de la balanza" (Nieto, 2012: 518).

${ }^{670}$ Ya en el CCT de la rama filet cuyo artículo $9^{\circ}$, inciso d) punto 4- establecía que "El filetero tendrá derecho a controlar las pesadas que le corresponden debiendo la empresa tomar disposiciones que faciliten el control de las mismas". Una década después, demostrando las condiciones del aprendizaje obrero y una mejora en la correlación de fuerzas para la fuerza laboral al interior de las plantas, los fileteros y las fileteras en el artículo $6^{\circ}$, inciso e) del CCT 161/75 lograron convenir que "Las balanzas estarán perfectamente equilibradas y sujetas al control de los Delegados de planta, mediante pesas certificadas que serán provistas por el Sindicato Obrero de la Industria del Pescado".
} 
El estatuto establece una rígida verticalidad en la dinámica intrasindical, donde la CD del SOIP condiciona fuertemente el accionar de los delegados, mientras que éstos poco y nada pueden hacer para condicionar a la cúpula del SOIP. Como veremos más adelante, esta situación estatutaria no se corresponde por completo con la vida organizacional práctica del SOIP. En contraposición al poder de decisión que tiene en el interior de la organización sindical según estatuto, en los lugares de trabajo el delegado domina la situación, condicionando fuertemente el poder de decisión del mando capitalista. El papel de los delegados no culmina aquí. Según el estatuto, la totalidad de los y las delegadas componen el Cuerpo de Delegados. Este cuerpo es de carácter consultivo. Al igual que en el caso de la figura del delegado, el estatuto parece establecer una rígida verticalidad en la dinámica intrasindical. Lo cierto es que las personas que cumplían un rol como delegados resultaban fundamentales participando en la negociación colectiva cotidiana, buscando disminuir las tensiones entre los dos polos del proceso productivo. Velaban por el cumplimiento del convenio, o al menos las normas consuetudinarias, imponiendo un límite a la arbitrariedad del capitalista, pero también intervenían para que el proceso productivo funcionara más o menos adecuadamente, regulando el trabajo de los obreros y obreras. En este sentido, asumieron el doble rol de ser, por un lado, una instancia fundamental de poder obrero en los lugares de trabajo, pero también (cuanto menos en la cotidianeidad no alterada por algún conflicto) permitiendo negociaciones menos conflictivas con la patronal, asegurando el discurrir de la jornada laboral y el funcionamiento de la producción. Aún así, en cierto modo, la presencia de los delegados en las plantas se constituyó como expresión del poder que poco a poco fueron forjando los trabajadores de la industria institucionalizado en el propio espacio productivo.

\section{La firma del Convenio Colectivo de Trabajo (1975)}

La firma del convenio $\mathrm{N}^{\circ}$ 161/75 marcó un punto de inflexión en la historia del SOIP y fue vivido por los trabajadores como una victoria, mientras que, al contrario, el empresariado fue más bien reacio a tolerarlo. ${ }^{671}$ Estos últimos tuvieron pronto su "revancha" luego del golpe cívico militar de marzo de 1976, que permitió "relajar" algunas de las normas del convenio. ${ }^{672} \mathrm{Al}$ mismo tiempo que la existencia de plantas clandestinas de procesado permitía la obtención de mano de obra no afectada por el convenio. De todos modos, las condiciones de pleno empleo y desarrollo de la industria, que permanecieron en vigencia hasta principios de la década del ' 80 , favorecieron el cumplimiento de las condiciones que establecía el convenio. Será pues en la década del '90 cuando los empresarios, a partir de la formación de

\footnotetext{
${ }^{671}$ En los últimos años han surgido nuevas investigaciones acerca de las relaciones entre empresarios y el gobierno de la última dictadura cívico - militar, las que han permitido arrojar luz acerca de aquellos vínculos (Basualdo, 2006; Simonasi, 2004). En la industria pesquera local todavía constituye una deuda pendiente realizar una pesquisa en tal sentido. Por el momento contamos con la elaboración de un libro de autoría colectiva realizado por la Comisión Memoria Portuaria. Allí se mencionan como prácticas recurrentes las amenazas de llamar al "601" ante cualquier movimiento reivindicativo. Se trataba del Grupo de Artillería de Defensa Área 601 que mantenía la jefatura de la subzona 15 dentro del sistema represivo. También se relata la presencia de personal uniformado ocupando puestos de jefes de personal, así como también la existencia de traslados de delegados en camiones del Ejército (Comisión Memoria Portuaria, 2011). Además, integrantes de la conducción del SOIP, entre ellos el propio Abdul Saravia, fueron apresados por varios meses.

${ }^{672}$ Por ejemplo, el derecho al pago del día del obrero del pescado, que además debía darse como día libre fue eliminado de la práctica de las relaciones laborales. Recién en 1989 Saravia informaba acerca de la recuperación de tal derecho señalando que "este año se logró que nos pagaran nuestro día, conquista que se había perdido con el gobierno militar". L.C.,27/11/1989. Por otra parte, a poco de andar el período democrático, en 1984 integrantes de la agrupación Puerto para Todos pedían por la estricta aplicación del CCT, manifestando que tal cuestión "no ocurre en la actualidad". L.C.,14/07/1984.
} 
cooperativas, puedan en gran medida esquivar lo normado. El mecanismo fue la fragmentación del mercado de trabajo, donde unos obreros y obreras realizaban sus tareas amparados en el convenio, ${ }^{673}$ dada la vigencia de la ultraactividad, mientras que otros lo hacían bajo la forma de cooperativas. ${ }^{674}$ Para finales de la década y principios de la nueva, en las movilizaciones protagonizadas por trabajadores y trabajadoras de las cooperativas, aparece como primera reivindicación la registración laboral bajo el CCT de 1975. Será este un reclamo sentido y con gran predicamento entre los trabajadores. Por todo ello, merece la pena que brevemente repasemos el contexto en que lograba rubricarse el convenio, así como las características principales que normaba.

Recordemos que el nacimiento de la actividad de fileteado de pescado estuvo marcado, como indicamos más arriba, por condiciones de precariedad laboral. Fue en 1958 cuando el SOIP incluyó la sección filet dentro de su órbita. En ese mismo año firmó un convenio exclusivo para el sector, aunque no logró hacerlo extensivo a toda la geografía fabril. En 1961, cuando la actividad se encontraba en expansión, el SOIP volvió a ensayar un nuevo intento por imponer la registración laboral de los fileteros y fileteras y su regulación a partir de un nuevo CCT. La negativa patronal llevó a una huelga de 20 días del sector que se levantó tras haber conseguido la conformación de una mesa de negociación entre el gremio y la patronal bajo la mediación del Ministerio de Trabajo. Días después se firmó el nuevo CCT. Aunque, al igual que con el anterior, la letra del convenio no lograba imponerse en la vida fabril, más aún cuando era rechazado por una gran cantidad de trabajadores y trabajadoras. Además, muchos establecimientos comenzaron a despedir a los obreros y obreras involucradas en la medida de fuerza previa (Nieto, 2012). Este proceso se dio en el marco de fuertes disputas inter sindicales entre el SOIP y el STIA por la personería gremial de la labor de fileteado. Desde esta experiencia hasta mediados de la década del ' 70 se sucedieron las firmas de dos convenios colectivos de trabajo (1966 y 1972) que acompañaban el cada vez mayor crecimiento del fileteado de la mano de un proceso de expansión de la industria pesquera que se orientaba al mercado externo.

A partir de la década del '70 la estructura pesquera argentina se había consolidado sobre la base de la integración al mercado mundial a través de la exportación de pescado enfriado y la captura con buques fresqueros. Este proceso derivó en la instalación de grandes plantas de congelado, conserva y fileteado en tierra. Las mismas se radicaron en su mayoría en el puerto de Mar del Plata que concentraba y centralizaba alrededor del $90 \%$ de la producción pesquera del país. A la vez se conformó un importante contingente de obreros y obreras en tierra. Tal expansión sufrió un freno en los años 1974 y 1975, cuando la crisis económica de orden mundial impactaba sobre la Argentina, mientras se agudizaba la crisis política y las tensiones entres las diferentes fuerzas sociales, en un escenario que se completaba con el despliegue de la violencia como forma de la política. Por aquel entonces, tras el deceso de Juan Perón y bajo el gobierno de Isabel, se desarrolló un movimiento reivindicativo que incluyó un proceso de huelgas, negociaciones paritarias y la reacción generalizada del movimiento obrero en contra del llamado "Rodrigazo". ${ }^{675} \mathrm{La}$ industria pesquera marplatense no fue ajena a todos estos procesos.

\footnotetext{
${ }^{673}$ Salvo la planta "14 de Julio" perteneciente a Antonio Di Leva e inaugurada en el año 1992, donde se había confeccionado un convenio de empresa.

${ }^{674}$ Respondiendo a una demanda empresarial, en 1996 el entonces Ministro Caro Figueroa buscaba hacer caer paulatinamente aquella clausula de la ultraactividad. Concretamente decía que el principio de la ultraactividad "fue un retroceso en la democratización del mundo del trabajo". Al mismo tiempo que señalaba "Queremos negociación por empresa, y que haya más convenios colectivos descentralizados. [La medida] "va a profundizar el proceso de democratización sindical". L.C.,04/10/1996.

${ }^{675}$ Sobre el "Rodrigazo" ver, entre otros, Restivo y Dellatorre (2005).
} 
En 1974 las exportaciones pesqueras sufrieron un descenso general. El año 1975 se presentaba con cierres de plantas y suspensiones. En julio el diario La Capital planteaba en su editorial que "Se agudiza la crisis de la Industria Pesquera Nacional". Allí se indicaba una pronunciada caída de las capturas debido a los problemas surgidos en los mercados internacionales para la comercialización de los productos del mar y a la escasa demanda interna, teniendo como consecuencia altas tasas de capacidad ociosa y desempleo. La Federación Argentina de la Industria Pesquera, que nucleaba a las cuatro cámaras empresariales concernientes a extracción, fileteado, conservería y fabricación de harina de Mar del Plata, manifestaba su inquietud advirtiendo que "Vamos hacia la quiebra". Y aducía que la gran expansión de la industria desde el año 1970 se había detenido en 1974 a raíz del descenso de los precios del pescado en el mercado mundial y, en paralelo, el incremento de los costos operativos internos de las empresas (Tomasone, 2006). En paralelo, en las fábricas que hicieron punta y se desarrollaron con la exportación, en especial en las del grupo Ventura, Polo Sur y San Andrés, se vivía un importante proceso de lucha que buscaba imponer la "garantía de trabajo" (un salario mínimo garantizado). Esa lucha surgía de la necesidad de que la patronal sostuviera un salario mínimo en los momentos en que se interrumpía por motivos externos la producción pesquera. Sobre aquel trasfondo nacional y las particularidades de cómo afectaba la crisis de la demanda internacional a la pesca, los trabajadores y trabajadoras de la industria pesquera, al igual que el conjunto del movimiento obrero se dispuso a discutir las condiciones salariales y de trabajo en el marco del desarrollo de las paritarias a nivel nacional. ${ }^{676}$

En febrero de 1975 empresarios y sindicatos fueron convocados para que a partir de marzo comenzaran a discutir los salarios y las condiciones de trabajo en sus respectivas industrias. En el mes de junio debían conocerse los resultados (Cotarelo y Fernández, 1997; Torre, 1989). Los meses de junio, julio y agosto fueron los de mayor conflictividad social en la rama, coincidiendo con el momento de la crisis pesquera. Finalmente, en el mes de junio fueron suscriptos los nuevos convenios laborales a nivel nacional y también a nivel local. El SOIP suscribía los propios para las ramas de harina, conserva y filet el 27 de junio, él mismo día en que se producía la movilización de la CGT que buscaba la homologación final de los convenios colectivos surgidos en paritarias. En Mar del Plata, el gremio del pescado tenía un lugar "significativo" en la movilización obrera logrando congregar a trabajadores y representantes de las diferentes tendencias políticas.

El CCT, que establecía una mejora salarial de $89 \%$ para fileteros y $104 \%$ para peones y envasadores, fue rubricado. Pero, al igual que durante otras experiencias gremiales, la letra del convenio era discutida por los empresarios luego en la cotidianeidad sindical. Una interpretación divergente de algunos puntos del convenio enfrentó a obreros y patrones. Según Pradas, la huelga por la derogación del premio de asistencia nació desde abajo con la toma y ocupación de plantas. ${ }^{677}$ Y mientras Saravia llamó a

\footnotetext{
${ }^{676}$ No está de más mencionar que la negociación paritaria funcionaba como una escuela y espacio de formación para los trabajadores, pues cada delegado formaba una comisión de asesoramiento donde, muchas veces, se habilitaba la participación de trabajadores y trabajadoras jóvenes para que hicieran sus primeras experiencias gremiales. Entrevista del autor con Elda Taborda... op. cit.

${ }^{677}$ Los premios por asistencia estaban considerados en el nuevo convenio colectivo de trabajo en el artículo $16^{\circ}$, el cual establecía: "Se instituye un premio por asistencia para los fileteros/as, envasadores/as, peones en general y todo otro personal que se encuentre encuadrado en el presente convenio. Dicho premio consistirá en un incremento mensual según el siguiente detalle: 100 por 100 de asistencia: $25 \%$ del salario mensual; $90 \%$ de asistencia: $20 \%$ del salario mensual; $85 \%$ de asistencia: $15 \%$ del salario mensual. Se reconocerán como válidas únicamente las inasistencias motivadas por fallecimiento de familiares directos, a saber: padres, madres, hijos y esposo/a del trabajador/a beneficiario de dicho premio, sin excepción.". El meollo del asunto consistía en que los días no trabajados por enfermedades y/o accidentes, comprobados por las empresas, estaban justificados debidamente en el artículo $22^{\circ}$ el cual establecía que serían debidamente remunerados de acuerdo con las reglamentaciones
} 
la acción concertada de empresarios y trabajadores, poco después debió declarar la huelga indefinida contra el Art. 16 (Pradas, s/f). ${ }^{678}$ La dirigencia del SOIP denunciaba, entre otras cuestiones, que no se estaban registrando los pagos de premios por asistencia sin computar ausencias o enfermedades, lo cual había obligado desde el lunes anterior a asumir una medida de fuerza que implicaba la inactividad en las plantas de industrialización. Poco después el gremio encabezaba una movilización desde las calles del puerto hasta el centro de Mar del Plata. Las consignas remitían al cumplimiento de los pagos por asistencia y en contra del cierre de las fuentes de trabajo. El hecho continuaba con el proceso dominado por el desarrollo de movilizaciones, asambleas en plantas, asambleas interfabriles, incesantes reuniones en el sindicato y en las plazas, concentraciones, piquetes de huelga, tomas de plantas, huelgas y enfrentamientos entre diferentes corrientes sindicales. ${ }^{679} \mathrm{En}$ total sumaron diez días de huelga, que finalizaron con la victoria obrera, logrando que se eliminara el artículo cuestionado y se compensaran los días caídos. En este contexto los empresarios nucleados en la CAABPA y la Cámara de Procesadores denunciaron a las dirigencias sindicales por interpretar arbitrariamente las cláusulas del convenio manifestando que el sector empresarial vivía en un clima de desaliento, violencia, ocupación de plantas, amenazas directas o indirectas, dos atentados con bombas, una balacera y el recuerdo de dos asesinatos (Tomasone, 2006). ${ }^{680}$ Finalmente, el artículo 16 fue derogado y el premio por presentismo se incluyó como un $25 \%$ de incremento total de salario final en caso de asistencia perfecta, disminuyendo aquel porcentaje en relación a los días de ausencia.

En relación a las características del convenio, lo primero que debemos destacar en comparación con otros de la rama, es que con el desplazamiento de la industria conservera frente al dominio productivo del fresco y la elaboración de filetes, las relaciones laborales sufrieron cambios. Dentro de ellos, lo más característico fue que después de 25 años de convenios que prohibían explícitamente el trabajo a destajo, en 1966 se firmó uno para la rama filete donde aquello quedaba legitimado. Eso se relaciona con el comienzo de la elaboración de filetes frescos enfriados de merluza. Así, mientras que en las décadas del '50 y ' 60 muchas de las luchas obreras giraron en torno del rechazo del trabajo a destajo (Nieto, 2012), ya en 1975 tal modalidad aparece plenamente aceptada. Y tanto a principios de 1989 como a finales de la década del '90 ni las posturas más radicales lo cuestionaran.

Una de las principales reivindicaciones de los trabajadores del pescado finalmente plasmada en el CCT era el pago de una garantía horaria. Precisamente, ello apuntaba a discutir, en parte, sobre quién recaería el peso de las crisis de la industria y los vaivenes en la disponibilidad de pescado. Los

laborales, lo cual servía de argumento para que los trabajadores los reclamaran como jornadas trabajadas, más aún si se consideraban a las condiciones laborales como las causantes de tales enfermedades y/o accidentes.

${ }^{678}$ Según Pradas, que asume la visión de la burocracia sindical como aliada al Estado y la patronal, se trataba de un artículo que el propio Saravia había firmado días antes. Entonces fue la presión de "las bases" lo que obligó al dirigente a convocar a la huelga. Mejor aún, es "La prédica y la agitación de los delegados de base [que] tomó cuerpo y se transformó en acción en cuanto se cobraron los sueldos de julio con los descuentos del premio por asistencia" (Pradas, s/f: 6). Desde nuestro punto de vista, la cuestión no se resume a una "vendida" de la letra del convenio por parte del dirigente del SOIP, quien se vería luego presionado a llamar a una huelga. Más bien entendemos que el desarrollo de esta huelga se desata por las diferencias obrero-patronales en torno a la interpretación de la letra del convenio.

${ }^{679}$ En el convenio colectivo de trabajo $N^{\circ} 161 / 75$ “....se plasmó lo que tantas asambleas multitudinarias lograron consolidar como sentido común en los obreros. No fue una concesión sino el logro de una lucha elaborada con tomas de plantas, piquetes, paros; participación activa de muchos, obstinación persistente" (Comisión Memoria Portuaria, 2011: 9).

${ }^{680}$ El 8 de enero de 1974 fue secuestrado el empresario Francisco Paco Ventura. Y liberado 23 días después, previo pago de un rescate. Las Fuerzas Armadas Peronistas (FAP) se adjudicaron el hecho. El 14 de diciembre del mismo año fue asesinado el empresario pesquero Antonio Dos Santos Larangeira a manos del Ejército Revolucionario del Pueblo. El empresario había cerrado una de sus plantas y dejado sin trabajo a un amplio número de trabajadores, lo que motivó el "pedido" del ERP de que los reincorporará. Ante el incumplimiento, se produjo la ejecución. Al respecto ver Yurkievich (2012). 
empresarios continuaban en su deseo de disponer a su libre arbitrio de la mano de obra a la que buscaban contratar o despedir sin restricciones según las oscilaciones del mercado internacional y las capturas de pescado. Por el contrario, el contingente obrero que se había incrementado en gran cantidad desde la expansión de la actividad pesquera, pugnaba por lograr un salario mínimo garantizado que los "salvara" de los padecimientos de aquellos movimientos procurando que las consecuencias de la crisis no recayeran totalmente sobre sus espaldas. En agosto de 1975 los empresarios a través de la FAIP se manifestaban en contra de aquellas reclamaciones obreras. ${ }^{681} \mathrm{Sin}$ embargo, la letra del CCT establecía una "garantía de trabajo" extendida a todo el gremio que sería de 140 cajones mensuales de 23 kilos cada uno en el caso de fileteros/as y de 184 horas mensuales para peones, envasadoras y empaque. ${ }^{682}$ Otras reivindicaciones que se lograron instalar a partir de la firma del CCT fueron:

- La fijación de un horario de entrada del personal, que debía realizarse entre las 6 y las 9 horas. Esta fijación horaria ponía cierto coto a las prácticas de los industriales pesqueros que, según el horario nunca fijo de ingreso de materia prima para procesar, llamaban en cualquier horario a los trabajadores y trabajadores. Muchas veces en horas de la madrugada.

- Horas extraordinarias. Se las contabilizaba en base a la hora de ingreso fijada en la planilla horaria. Y se abonaban un 50\% más y un 100\% más los días sábados después del mediodía y todo el día domingo. Años antes era habitual que fileteros y fileteras trabajaran más de ocho horas diarias, llegándose en algunos casos a trabajar hasta $14 \mathrm{hs}$., sin que se les reconociera en ningún momento horas extras.

- Se establecían las condiciones de la mesa de trabajo y la tabla sobre la cual trabajadores y trabajadoras realizarían el fileteado.

- El tamaño de la merluza a procesar no podría ser inferior al que determinara la Autoridad competente. De este modo, fileteros/as podían negarse a procesar un pescado de tamaño más pequeño que incidía negativamente en el volumen de su salario.

- La empresa debía brindar información clara y visible sobre la planilla de producción de cada trabajador.

- La empresa debía garantizar el salario de los delegados, cuando estos se ausentaran de su tarea por motivos gremiales.

- Un descanso por turno (de 15 minutos tras cuatro horas de trabajo) computado como jornada laboral y pagado, por tanto, por el empresario.

- Se debía otorgar un trato preferencial a mujeres (no podían levantar determinado peso), y también a mujeres embarazadas. Además se instauraban las licencias con goce de sueldo a fin de rendir exámenes de enseñanza primaria, secundaria o universitaria. Así como licencias por nacimiento o fallecimiento de familiares.

- La empresa proveería los equipos de trabajo o, en su defecto, abonaría una compensación a cada trabajador.

- Se prohibía la ocupación de personal transitorio o "changuista".

- Se debía garantizar la existencia de un peón cada 8 trabajadores.

- Se estipulaba como obligación empresaria tener instalaciones adecuadas como baños, duchas y comedores con cocinas y heladeras.

- Los obreros/as percibirían un plus por antigüedad elaborando un escalafón que incrementaba el monto según los años trabajados.

\footnotetext{
${ }^{681}$ L.C.,08/08/1975.

${ }^{682}$ Convenio Colectivo de Trabajo No 161/75. Artículo 17.
} 
- Se reconocía el día del aprendiz y el día del obrero del pescado, debiéndose otorgar el día franco pago por la empresa.

- Se garantizaban vacaciones anuales.

La plasmación de determinadas conquistas obreras en el CCT, así como también la contrapartida de respetar ciertas normas, constituía una suerte de cristalización de las relaciones de fuerza obreropatronales. En tal sentido, la letra del convenio expresaba el poder social conquistado por los trabajadores en un contexto histórico particular, con una industria pesquera que si bien atravesaba por una nueva crisis, había sido precedida por una gran expansión. Pero esa "cristalización” no era definitiva ni mucho menos. Las condiciones laborales se rediscutían constantemente y, en todo caso, el CCT servía como recurso organizacional de los trabajadores, el cual buscaron mantener en todo lo que pudieron. Recién con la formación de las cooperativas de trabajo, el gremio, y el conjunto de trabajadores de la rama, recibirán un golpe que incluso aún hoy no han podido revertir. Ya a principios de la década del '90, así como la estrategia sindical fue mantener la letra del convenio y negarse a participar en negociaciones paritarias en un contexto que consideraban adverso, los empresarios buscaron vulnerar el convenio sin atacarlo directamente, sino tras el ardid de las cooperativas. ${ }^{683}$

Con todo, durante la década del ' 90 estuvieron vigentes el convenio colectivo de trabajo firmado en 1975 y el estatuto aprobado en 1990. En aquel contexto desfavorable, ambos se transformaron en recursos organizativos de sustancial importancia para el SOIP. En el repliegue sindical el estatuto y el convenio fueron usados como "trincheras" para la defensa de la organización. Más allá de la dificultad para hacer cumplir cada uno de sus artículos, fueron defendidos integralmente esperando para su modificación un contexto favorable. Figuras como la del delegado y el cuerpo de delegados en los lugares de trabajo y en la vida sindical, que seguían vigentes en la letra del estatuto y el CCT, decayeron tanto en número como en activación. Una organización de delegados fuerte requería una situación favorable en términos de empleo. El cierre de fábricas, los despidos, la instrumentación empresarial de la estrategia precarizadora vía cooperativas de trabajo fraudulentas y relaciones laborales no formales, se conjugaron para menguar el poder asociativo y de activación de los obreros. Esto conllevó la reducción del número de delegados de planta y de la cantidad de reuniones del cuerpo de delegados por año. ${ }^{684}$ Esta situación no implicó la desactivación completa de los obreros, sino su debilidad y fragmentación, en particular por la segmentación del mercado de trabajo y de la representación gremial.

\footnotetext{
${ }^{683}$ Incluso en el año 2013 una trabajadora nos explica cómo, bajo la nueva coyuntura, el convenio colectivo de 1975 no sólo abarca a pocas personas dentro de la industria del pescado, sino también puede llegar a convertirse en un obstáculo para trabajar en la actividad: "Yo estoy en gris porque tengo un recibo dibujado, el cual yo cobro salario por ella [señala a su hija], tengo una obra social y una jubilación por cuatro o cinco horas de trabajo. ¿Me entendés? Es un recibo dibujado. El cual yo tengo mis beneficios, pero yo compro en negro. Hay un grupo de gente, que son muy poquitas, que están el en convenio del 75 [...] Yo estuve un tiempo en el convenio del 75. Pero vos cuando te metés en el convenio del 75 ya el jefe, el empresario no te quiere. ¿Por qué? Porque vos trabajás en blanco. Ellos tienen que aportar un montón por vos y tienen que respetar tus ocho horas de trabajo, tu feriado, todo. ¿No? No te hacen hacer horas extras porque obviamente a ellos no les conviene. Entonces la hora extra la hace la que está en gris, que no se la pagan. Entonces yo estuve un tiempo en el convenio del 75, pero ¿qué pasó? A él [empresario] le conviene que haya menos gente en el convenio. Cuando empezaron a ir mal las cosas ellos cortaban las horas de trabajo. Te pagaban garantía horaria. Al pagarte garantía horaria no cobrás nada la quincena. O sea, muy poco. Entonces iba la gente a salirse del convenio porque no te iba a alcanzar. Entonces llegó una oportunidad que tuve que pedir que me sacaran del convenio". Entrevista del autor con Gabriela... op. cit.

${ }^{684}$ Para mediados de la década del '80 existían alrededor de 120 delegados. L.C.,01/02/1986. Finalizando la década del '90 se estima que el número apenas llegaba a la cantidad de 20.
} 


\section{Procesos electorales en el SOIP (1969-2002)}

La participación obrera en la vida sindical no se reduce a los actos eleccionarios. Sin embargo estos pueden ser un buen punto de partida para su análisis. Su revisión nos habla no solo de la participación electoral, sino también de las tendencias políticas dentro del gremio, que a su vez pueden vincularse aunque no de un modo directo claro está- con las transformaciones en la industria y su impacto en las formas de la competencia sindical. Recordemos que desde 1969 hasta 1997, año de su muerte, Abdul Saravia se mantuvo como el líder del SOIP. Si alguna cosa sabía hacer este dirigente sindical era ganar elecciones gremiales. Luego de su fallecimiento, el grupo que lo acompañó se disgregó y finalmente perdió la conducción. De este modo, su muerte marcó el comienzo del fin de una experiencia de conducción gremial que duró más de 30 años, abarcando el proceso de "despegue" de la industria de procesado de pescado orientado al mercado externo hasta su crisis a fines de la década del ' 90 .

La llegada de Saravia a la titularidad del gremio se produjo en 1969, tras el llamado a elecciones por parte de la intervención, tras lo cual obtuvo la victoria la Lista Unificada Naranja. De los comicios habían participado dos listas, pero la Lista Blanca, en medio del proceso electivo y habiendo obtenido solamente dos votos, se apartó de las elecciones. La "Naranja", dentro de un pequeño padrón de 320 inscriptos, obtuvo la victoria con 138 votos sobre un total de 144 emitidos. ${ }^{685}$ Resulta llamativo la baja cantidad de afiliados en condiciones de votar, situación que fue denunciada por la lista Blanca al momento de su retiro. Pues argumentó que antes de la intervención existían más de dos mil afiliados en condiciones de votar y luego quedó solamente aquella escueta cantidad. Por otra parte, la victoria de la Lista Naranja también marcaba la transformación en la industria pesquera, cuando los principales dirigentes, con la sola excepción de Saravia, provenían de la elaboración de filet y ya no de la conserva.

Tras dos años de caminar juntos se produjo en el gremio una división en la conducción cuyos principales referentes eran Abdul Saravia y Corino Díaz. Ambos peronistas, mantenían vínculos diferentes dentro del "movimiento", dado que el primero estaba vinculado a la delegación local de la CGT mientras el segundo se relacionaba con sectores opositores encabezados por los sindicatos de la carne y la construcción. Públicamente, el enfrentamiento se originó cuando el segundo acusó a Saravia de un dudoso manejo de los fondos de la obra social. Tal situación llevó a la división en dos listas. Mientras Díaz permaneció con la identidad de la Lista Naranja, Saravia pasó a integrar la Lista Azul y Blanca ${ }^{686}$. Para el período 1971-1973, obtenía la victoria la lista Azul y Blanca con una cifra cercana a los 500 votos sobre 860 emitidos. La situación hablaba de cierto equilibrio en el apoyo de la masa trabajadora y de los

\footnotetext{
${ }^{685}$ Archivo DIPPBA, Mesa B, Factor gremial, Carpeta 57, Legajo 17, Folios 101-104, 23/10/1969. Observando la composición de la lista victoriosa podemos advertir una cuestión de interés. La Naranja estuvo integrada por 13 miembros de los cuales solamente uno era nacido en Mar del Plata, demostrando la fuerte presencia de migrantes en la industria del pescado. Los restantes seis provenían de localidades del interior de Buenos Aires y de otras provincias del país. Abdul Saravia, el flamante secretario general, era oriundo de la localidad vecina de Balcarce y en 1965 tenía veintiocho años. El Pro-secretario, Corino Díaz, nació en la provincia de La Pampa y tenía para ese entonces 38 años. El Tesorero, Benjamín Sánchez, también era nacido en Balcarce y tenía 46, Juan Carlos Acevedo, el Pro-tesorero, era oriundo de la localidad bonaerense de Nicanor Otamendi, el Secretario de Notas, Orlando Rico, era el único marplatense y tenía 22 años, Ramón González, Secretario de Organización, era nacido en Gualeguay (Entre Ríos) y tenía 28 años, el Secretario de Publicación, Ricardo Ferreyra, había nacido en la provincia de Santa Fe y tenía 31 años, la Primera Vocal, Ingle A. Vivian de Apaolasa, nacida en Italia, el Segundo Vocal, Rafael José Torres, oriundo de Santa Fe, el Tercer Vocal, Enrique Oraldo Icardo, nació en Gualeguay, el Cuarto Vocal, Carlos Darguibel, nació en Necochea (Buenos Aires), la Primera Vocal Suplente, Susana Iris Fogoaga de Oberts, nació en La Dulce (Buenos Aires), la Segunda Vocal suplente, Mariana O. Bertolli de Loaldi, nació en Zárate (Buenos Aires).

${ }^{686}$ Según la fuente de inteligencia de la policía provincial, la Lista Azul y Blanca tenía una tendencia "izquierdista", pero Saravia logró desplazar a la conducción y quedarse con el nombre. Tras eso, los “izquierdistas” se nuclearon en la Lista Granate.
} 
delegados de fábrica tanto a Saravia como a Díaz. Luego de tensiones por el reconocimiento de la victoria, y tras distintas presentaciones legales, se concedió el triunfo a la lista encabezada por Saravia. Esta elección ya no contaba con una lista de tradición anarquista dentro del gremio.

En las elecciones de 1973 eran tres las listas que disputaban la conducción de los obreros del pescado. Abdul Saravia, representando al "peronismo ortodoxo" con la Lista Azul y Blanca se disponía a revalidar su conducción. ${ }^{687}$ Corino Díaz, vinculado ahora directamente con la derecha peronista, volvía a insistir representando a la Lista Naranja. Mientras que las fuerzas de izquierda lograban conformar su representación a través de la Lista Verde, relacionada al PST, cuyo candidato a ocupar la conducción sindical era Julio Manza. ${ }^{68}$ En estas elecciones ya aparecen mesas receptoras de votos en diferentes establecimientos, además de la sede gremial. La cantidad de trabajadores en condiciones de votar pegó un amplio salto al calor del crecimiento de la industria. Sobre un total de 7.050 empadronados, votaron 2.743. Los resultados fueron: 1) Lista Azul y Blanca, 2.205 votos; 2) Lista Verde, 311; 3) Lista Naranja, 162; 4) En blanco, 33; 5) Anulados, $32 .{ }^{689}$ El caudal de votos arrojaba que un gran número de trabajadores y trabajadoras no participaron de la elección (4.307), al mismo tiempo que demostraba la fortaleza de la lista comandada por Saravia, así como un crecimiento de las fuerzas de izquierda representadas en la "Verde" que ocuparon el segundo lugar. El tercer lugar en que quedó la Lista Naranja la arrojaba a un territorio cada vez más marginal. ${ }^{690}$

Sorpresivamente, y a pesar de que en la memoria popular se atribuye una fuerte influencia de las distintas fuerzas de izquierda en la industria del pescado, en 1975 solamente dos listas competirán por alcanzar la conducción gremial. Y nuevamente en el enfrentamiento se encontrarán Saravia conduciendo la Lista Azul y Blanca, y Corino Díaz al frente de la Lista Naranja, sin que la izquierda logre conformar una lista convalidada por la junta electoral. Al día de las elecciones, la Lista Azul y Blanca llegaba con el aval de 1.500 afiliados, mientras que la Lista Naranja lograba reunir 250 firmas. ${ }^{691}$ Las elecciones se realizaron en una "absoluto orden y sin que se registraran incidentes de ningún tipo" en un clima pleno de "democracia sindical", según se encarga de destacar el cronista deLa Capital. Entonces estaban en condiciones de sufragar 4.300 afiliados. La Lista Azul y Blanca obtuvo 3.357 de los votos emitidos, mientras que la Naranja alcanzó solamente $585 .{ }^{692}$ De ese modo, Saravia era nuevamente reelegido.

A poco del golpe cívico-militar, varios integrantes de la comisión directiva, entre los que se encontraban Abdul Saravia y Luis Ronner, fueron apresados. Durante un tiempo el sindicato permaneció bajo la conducción de Néstor Lucero, quien se desempeñaba como secretario adjunto de la entidad. Luego, Saravia volvería a hacerse cargo de la conducción, no sin mediar un enfrentamiento con Lucero,

\footnotetext{
${ }^{687}$ Los servicios de inteligencia de la Policía de la Provincia de Buenos Aires definían a la lista encabezada por Saravia, curiosamente, como portadora de "cierta inclinación izquierdista". Mientras que vinculaban a la lista Naranja directamente con la derecha peronista. Archivo DIPPBA, Mesa B, Factor gremial, Carpeta 57, Legajo 17, Folio 170, 17/10/1973.

${ }^{688}$ Julio Mártires Manza nació en Corrientes el 17 de julio de 1939. Llegó a Mar del Plata en 1962 y comenzó a trabajar como filetero en distintas plantas como Dispesa y Fadeco. Con el tiempo fue elegido delegado gremial, empezó a militar en el PST y pasó a formar parte de la Agrupación Clasista del Pescado, siendo candidato a Secretario General en las elecciones del SOIP por la lista Granate y por la Lista Verde. El 7 de enero de 1979 fue secuestrado y posteriormente desaparecido.

${ }^{689}$ Archivo DIPPBA, Mesa B, Factor gremial, Carpeta 57, Legajo 17, Folio 175, 19/10/1973.

${ }^{690}$ Más allá de la pérdida de representatividad, el bajo caudal de votos se debió a que desde las 11 de la mañana los integrantes de la Lista Naranja decidieron retirarse de las elecciones.

${ }^{691}$ L.C.,21/10/1975. En el diario aparece un comunicado de la Alianza Libertadora Nacionalista brindando "su total e incondicional apoyo a la Lista Azul y Blanca, del SOIP, encabezada por Abdul Saravia, y su rechazo a todo tipo de presiones que pretendan ejercer sobre los comicios a efectuarse".

${ }^{692}$ L.C.,23/10.1975.
} 
quien pretendía quedarse en la titularidad del gremio. ${ }^{693}$ Así, la vieja CD permaneció al frente del sindicato con mandatos prorrogados. Recién en 1982 Saravia anunció la aprobación de los estatutos por el Ministerio de Trabajo de la Nación de acuerdo con la ley $\mathrm{N}^{\circ} 22.105$. Ello permitió la regularización de la vida institucional del SOIP y la designación de una Junta Electoral para realizar el llamado a elecciones. ${ }^{694}$ Entonces el sindicato contaba con un padrón sorprendente de 16.400 afiliados. Y Saravia señalaba que "Nuestro gremio goza actualmente de una virtual ocupación plena, luego de sufrir momentos dificiles". ${ }^{695}$

Finalmente, unos meses después de derrotada la llama Ley Mucci que el gobierno de Alfonsín pretendía sancionar para modificar la estructura del sindicalismo, las elecciones se realizaron en julio de 1984 luego de 9 años de suspendidas. Hizo en estos años su aparición la Lista Celeste ("Unión Obreros del Pescado"), vinculada al peronismo de izquierda y al Partido Comunista. Entonces pugnaban por la victoria tres listas. La Azul y Blanca de Saravia, la Celeste conducida por Daniel Cabrera y la Rosa liderada por José Luis Flores. En relación a las 16 mil personas de 1982, el padrón mostraba una reducción significativa, cuando solamente 6.610 trabajadores y trabajadoras estaban autorizados a sufragar. ${ }^{696} Y$ por primera vez en las elecciones gremiales votaban los jubilados de la entidad. Finalmente la lista Azul y Blanca se impuso por ajustado margen al obtener 2.722 votos frente a 2.433 de la lista Celeste. Muy por detrás se ubicó la lista Rosa (agrupación "Puerto para todos") con 288 sufragios. Ello sobre un total de 5.941 votos emitidos.

Al igual que en las elecciones previas, también en 1986 Saravia fue reelecto. El padrón volvía a mostrar un descenso. Estaba compuesto ahora por 6.095 afiliados y tres era las listas en pugna. La oficialista Azul y Blanca; la Celeste, que entonces desplazó a los sectores comunistas de los lugares de conducción y estaba comanda por peronistas de izquierda, siendo Armando García el candidato a Secretario General; y la Blanca, también peronista, presidida por Aníbal Lemmo. Según la información de la prensa, esta vez el oficialismo se imponía por amplia ventaja: lista Azul y Blanca 2.400 votos; lista Celeste 1.103; lista Blanca 703; votos impugnados 101. Las elecciones de 1988 llevaron dividida a la lista Celeste, que ahora quedaba integrada por militantes gremiales de izquierda vinculados al Partido Comunista. Producto de la escisión, se formó la lista Verde representando a un grupo de trabajadores de militancia peronista y que anteriormente habían formado parte de la Celeste. El resultado arrojó una nueva victoria de la Lista Azul y Blanca alcanzando 3.967 votos. El resultado constituye el mayor caudal de votos obtenido en la historia de la lista. Segunda quedó la Lista Celeste con 1.295 y tercera la Lista Verde que alcanzó los 963 votos.

Para 1990, nuevamente fueron tres las listas que compitieron por la conducción sindical. La Azul y Blanca, la Lista Verde, ambas de tradición peronista y la Lista Celeste con mayoría de trabajadores comunistas. La situación política concreta nacional favorecía a la Lista Azul y Blanca y en menor medida a la Verde. La victoria electoral de Menem, a quien Saravia apoyó fervientemente, le trajo al dirigente sindical una renovada influencia política. Además, el triunfo del justicialismo reposicionaba al peronismo como tendencia dentro del sindicato, mientras que la caída del muro de Berlín y la disolución de la URSS indirectamente impactaban de manera negativa en las posibilidades de la tercera lista, dado que su horizonte político ideológico exponía un fracaso. Estaban en condiciones de sufragar 8.596 afiliados,

\footnotetext{
${ }^{693}$ Entrevista del autor con Norma Mira... op cit.

${ }^{694}$ L.C.,27/06/1982.

${ }^{695}$ L.C., 27/06/1982.

${ }^{696}$ L.C., $21 / 07 / 1984$.
} 
además de los jubilados, para lo cual se instalaron 195 urnas. Los resultados fueron: Azul y Blanca 3.482 votos; Lista Verde 2.649; Lista Celeste 515. ${ }^{697}$ Tanto la lista oficial como la Verde realizaron una muy buena elección, superando esta última por primera vez a la Celeste, siendo bastante pobres los guarismos obtenidos por ésta. Luego de ello la Celeste se enfrentará a una creciente dispersión, sin poder aprovechar el descontento creciente que en la industria pesquera producían las consecuencias del cambio de orientación en la política pesquera, que arrojaba como resultado las quiebras de empresas, el cierre de plantas y el despido de trabajadores.

En 1990 se reformaron los estatutos adecuándolos a la ley de asociaciones profesionales de $1988 \mathrm{y}$, por ello, las elecciones pasaron a ser cada cuatro años, además de ampliar la cantidad de candidatos en 14 miembros, pasando de 22 a 36 la composición de la comisión directiva. La ampliación en la cantidad de personas en la CD implicaba tener que presentar un número más amplio de candidatos en las listas dado que se debían ocupar más cargos. Estos cambios favorecían a la dirigencia oficialista del SOIP y complicaban a los opositores. Abdul Saravia era ya secretario general de la CGT local. Los años transcurridos entre una y otra elección afectaron profundamente a la pesca. Si por un lado se vivió una nueva fase expansiva, por otro, los despidos tras las quiebras de empresas, así como la formación de cooperativas modificaron la situación del mercado de trabajo segmentándolo. Ello afectó al padrón electoral del sindicato que se vio reducido a un total de 3.221 afiliados. Nuevamente eran tres las listas que previamente competirían: la Azul y Blanca encabezada por Abdul Saravia y Carlos Darguibel; la Celeste, dirigida por Rosana Burges y Oscar Baez; y la Verde liderada por Ramón González y Enrique Medina. Sin embargo, la pérdida de puestos de trabajo bajo relación de dependencia afectaba la posibilidad de juntar la cantidad de trabajadores y trabajadoras necesarios para formar las listas. El problema era grave para las listas opositoras. Tal fue así que finalmente, tras un conflicto con la junta electora, la Celeste y la Verde debieron retirarse del proceso electoral. ${ }^{698}$ A pesar del pedido de estas de que se aplazaran las elecciones, la junta se apresuró en aclarar que los comicios "se realizaran como estaba previsto" con la participación de una sola lista. Ante ello, las listas opositoras presentaron denuncias y convocaron a los trabajadores a no participar del proceso electoral. No obstante, la conducción de Abdul Saravia fue ratificada, votando un total de 1.100 afiliados (el 34\% del padrón).

Las elecciones de 1998 tenían algunas particularidades. La primera era que, tras su muerte, Saravia ya no estaba en la conducción gremial. En segunda instancia, se desarrollaban en medio de la crisis de la merluza y de una creciente movilización de los trabajadores desocupados. En ese contexto, la Lista Azul y Blanca sufrió su primera escisión tras perder a Luis Ronner, que ahora se presentaba en la conducción de la Lista Granate. ${ }^{699}$ Mientras que un delegado de La Campagnola y ex integrante del oficialismo,

\footnotetext{
${ }^{697}$ L.C., 19/06/1990.

${ }^{698}$ El conflicto se produjo luego de que fuera presentada ante el juzgado en lo Correccional y Criminal del Dr. Rodolfo Guimarey una denuncia por "falsificación de firmas y abuso de confianza" contra las listas Celeste y Verde. Los procesos se iniciaron cuando dos de las candidatas de estas agrupaciones, Gladys Sosa (de la Celeste) y Fátima Susana Delgado (de la Verde) afirmaron no haber dado su consentimiento para ser incluidas en los listados. La Junta según parece igualmente aceptó a los reemplazantes de las denunciantes. Sin embargo, las listas opositoras decidieron retirarse.

${ }^{699}$ A Luis Ronner le decían "el loco". Era, según parece, un hombre de acción. En calidad de secretario gremial, acompañó a Saravia durante la mayor parte de su gestión y compartió incluso los años de prisión bajo la dictadura. Un episodio lo muestra de modo sugerente. En febrero de 1990 el consejo directivo del Colegio de Abogados patrocinaba una denuncia contra el dirigente gremial por lo que consideraban "un gravísimo atentado al libre ejercicio profesional, al honor, a la dignidad profesional, atentatoria a la seguridad e integridad personal" de un abogado local. El abogado Capdeville, apoderado de una veintena de obreros de la planta de fileteado Gohermar denunció que Ronner, con siete acompañantes, le propinó en una reunión epítetos de grueso calibre y amenazas de muerte que avaló con la extracción "de un revolver que blandió impunemente". Mediante empujones y puntapiés, Ronner le habría arrebatado una carpeta donde Capdeville llevaba las cartas-poder extendidas por los
} 
Rolando Frías, se presentaba a la cabeza de la Lista Amarilla. Como continuidad del oficialismo, la titularidad recayó en Carlos Darguibel, a quien acompañaba Adrián Casariego. Mientras que la Celeste y la Verde habían coincidido en la Alianza Celeste-Verde, articulando nuevamente al peronismo con fuerzas de izquierda. Ésta última llevaba como candidato a secretario general a Ramón González (peronista) y secretaria adjunta a Patricia Comparada (militante del Partido Obrero). Sin embargo, aquel año la junta electoral sólo oficializó a la Azul y Blanca, aduciendo que las otras listas no cumplían con los términos del estatuto. ${ }^{700}$ Ante ello, las listas opositoras presentaron diferentes recursos ante la propia Junta así como frente al Ministerio de Trabajo. Y este organismo procedió a suspender las elecciones, las cuáles jamás se realizaron. Por aquellos días los opositores gremiales consideraban que los obreros y obreras desocupadas tenían el derecho de votar. ${ }^{701}$ Finalmente, la vieja CD, con Darguibel a la cabeza, fue nombrada como custodio de los bienes del sindicato y, a pesar de que no podían ejercer las funciones gremiales, lo hicieron de hecho hasta el año 2002.

Con todo, durante los ocho años que en el gremio no se realizaron elecciones se fueron acumulando agravios. El trabajo precarizado, la formación de cooperativas, el estancamiento de los salarios, la pérdida de relaciones políticas y, hacia el final de la década, la merma en el trabajo y la desocupación, contrastaban con el notorio incremento del crecimiento pesquero. En 1997 no solo murió el legendario líder sindical del SOIP, también comenzaron a emerger las consecuencias de la sobreexplotación del recurso pesquero y el fantasma de una creciente desocupación. Fue en ese año que empezaron a ser cotidianos los piquetes de trabajadores precarizados y desocupados en el puerto. Comenzó en aquel tiempo una nueva crisis que se fue profundizando con el correr de los años. Esta situación hizo eclosión en junio de 2000, con el desarrollo de piquetes, quema de fábricas y una nueva toma de la sede sindical por parte de los trabajadores precarizados. Este grupo de obreros, junto a los militantes de la Lista Celeste (Unión Obreros del Pescado), conformaron una Comisión Provisoria del SOIP con el objeto de llamar a elecciones para normalizar el gremio, pues estos obreros y obreras pretendían "recuperar" el sindicato como herramienta para combatir la precarización y el trabajo en negro. No tuvieron éxito en desplazar de ese modo a la comisión directiva, pero sí fueron instalando su influencia dentro del gremio. Así se llegó a las elecciones del año 2002. En este año, tras 31 años de dominio de la Lista Azul y Blanca, y 33 de hegemonía peronista en la conducción gremial, luego de un proceso de impugnaciones y aplazamientos,

obreros que representaba, a la vez que lo conminaba a abandonar el asunto, porque "el conflicto con la empresa Mellino lo solucionaba el sindicato". Ronner habría intimado a Capdeville a "abrirse" del asunto porque de lo contrario lo iba a "reventar". L.C.,14/02/1990. Por su parte, Ronner se defendía efectuando duras consideraciones contra el Colegio de Abogados y denunció que en la empresa "Gohermar, desde hace años, tiene obreros en su planta a los que les dibujan los recibos salariales evadiendo impunemente las normas establecidas por el Estado". Y explicaba que "Gohermar es una empresa que trabaja para la PROPESA desde hace unos cuantos años. El dueño de la planta es el presidente de la Asociación de Procesadores de Pescado, Germán Olmedo, y siempre que hubo problemas con el personal se han solucionado a través del Sindicato de Obreros de la Industria del Pescado. Nos llama poderosamente la atención que ahora, tras todos estos años, sea el mismo patrón el que efectúe los reclamos de sus propios obreros". Y acusaba a Olmedo de fogonear innecesariamente el conflicto y de haberle pagado a personas que no eran de la empresa para ir a protestar frente a la casa de Mellino. L.C., 18/02/1990.

700 Consultado por la suspensión de las listas opositoras, Carlos Darguibel expresó "no hay nada raro. Las listas, desgraciadamente no reúnen las condiciones necesarias de acuerdo a la ley". Sobre el motivo por el que fueron rechazadas puntualizó que se trata de "gente que estuvo trabajando en una empresa, la han despedido y se han quedado sin relación de dependencia. La ley es clarita: hay que tener dos años de antigüedad y tiene que estar bajo relación de dependencia para participar de la lista”. E.A., 13/06/1998.

${ }^{701}$ Rolando Frías decía "Queremos que se expresen este año todos los trabajadores tanto los que están bajo patrón como los desocupados, condición que sabemos perfectamente no es por culpa del trabajador. Queremos tener elecciones abiertas para todos". Sus palabras son interesantes porque provenían de alguien que en tiempos remotos había acompañado a la conducción gremial. E.A., 26/07/1998. 
una lista vinculada a la izquierda triunfó en los comicios. Un hecho fundamental en tal proceso fue la división del oficialismo, que afrontó las elecciones separado en varias listas. En total se presentaron cinco listas, votando 1.336 afiliados. La Lista Celeste llevaba a Samuel Salas como candidato a secretario general, mientras lo propio hacía la Lista Blanca con Adrián Casariego, la lista Granate con Luis Ronner, la Lista Azul y Blanca con Carlos Darguibel y la Lista Amarilla con Carlos Ávila. Los resultados fueron los siguientes: Lista Celeste, 377; Lista Blanca, 324; Lista Granate, 264; Lista Azul y Blanca, 234; Lista Amarilla, 84. La nueva conducción gremial asumía con el $28 \%$ de los votos de poco más de 1.300 emitidos, en una industria que empleaba, aproximadamente, entre 6 mil y 8 mil trabajadores. El cambio de dirección gremial, se daba en el marco nacional de la devaluación y los primeros vestigios de un "modelo" anti-neoliberal.

\section{Fraude, la acusación recurrente}

Suele ser habitual en los procesos electorales sindicales encontrarse con denuncias de fraude. Es decir, acusaciones respecto de que se ha cometido algún tipo de irregularidad en el proceso electivo, anomalía que desvirtúa la voluntad de los afiliados, buscando impedir, anular o modificar los resultados electorales. Los mecanismos para obstaculizar o impedir la victoria del adversario y, al mismo tiempo, favorecer la propia son diversos. En general, en una primera distinción, se pueden reconocer dos tipos. Por un lado aparecen maniobras más o menos legales que tienden a dificultar la presentación de la competencia sindical partiendo de la formación de juntas electorales amigas, que permiten tener un cierto control sobre el proceso electoral, como también la aplicación de cláusulas más restrictivas para formalizar listas y la implementación estricta de cláusulas prohibitivas de convenios o estatutos. También se utilizan mecanismos para atentar contra la efectividad de la oposición como obligar al despliegue de gran cantidad de fiscales para el control de la elección multiplicando la disposición de sitios de votación o la demora en la entrega de los padrones. En general estos mecanismos se dan en el período previo a las elecciones. Por otro lado, ya fuera de cualquier legalidad, puede aparecer la alteración de padrones o la falsificación de recibos de sueldo para ingresar mayor cantidad de votantes incluyendo, a veces, votos de los no afiliados, junto a acciones realizadas durante las propias elecciones como cambios de urnas, trampas en los conteos, etc. ${ }^{702} \mathrm{~A}$ pesar de la recurrencia e importancia de estos fenómenos en la vida gremial, consideramos que no han sido mayormente estudiados dentro de la bibliografía sobre movimiento obrero. El vacío se produce en dos órdenes. Abarca tanto al estudio concreto del tipo de prácticas al que acuden las direcciones gremiales, y en algún caso también los opositores, como a las derivas e implicancias que genera en la disputa gremial la denuncia de que se ha producido fraude.

No resulta ilógico que buena parte de las conducciones gremiales recurran a diferentes prácticas que persiguen el objetivo de mejorar su desempeño electoral frente a las listas opositoras. De ahí que existan estas prácticas y que deban ser miradas. Aunque, si bien en peor posición para realizarlas, tampoco estas prácticas son privativas de quienes ejercen el mando. Lo cierto es que conviene al menos tenerlas en cuenta. Tal vez su estudio resulte de difícil acceso, pero sin duda debemos incluir estas

\footnotetext{
${ }^{702}$ La confección de padrones adulterados y el escamoteo a brindarlos a las listas opositoras, según nos han referido algunos/as de nuestros/as entrevistados/as opositores, era una práctica recurrente de la conducción Saravista. "Jamás entregaron los padrones a las listas opositoras... podías ir al sindicato a mirarlos, pero no te daban copia [...] o sea que ellos manejaban los padrones, agregaban a quien le parecía, sacaban a quien le parecía”. Entrevista del autor con Elda Taborda... op cit.
} 
prácticas operando dentro de la disputa gremial y no simplemente como algo desviado o patológico que no debiera ocurrir. Al mismo tiempo, resulta interesante pensar la noción de fraude a partir de lo que su denuncia favorece. La imputación de fraude apunta a impugnar el conjunto de una elección. Porque lo que pone en consideración, haya existido realmente o no, es señalar, por un lado, una frontera y, por otro, una suerte de crítica a todo el proceso electoral. Una frontera porque la idea de fraude se opone a cualquier legitimidad. No se apunta a "una" de esas prácticas posiblemente realizadas por la conducción sindical, sino que invalida todo el proceso electoral. No hay grados en tales prácticas. El fraude lo invade todo. Exista o no, se compruebe o no, la denuncia de fraude habilita a considerar que la conducción gremial ganó las elecciones de manera ilegítima. Es decir, no las ganó. Y esto nos pone ante la crítica y sus efectos. La denuncia, por un lado, mantiene los vínculos (imaginados o no) de las listas denunciantes con la base afiliada. Sin fraude, el resultado electoral hubiese sido otro. Posiblemente, los denunciantes hubieran ganado. Por otra parte, resulta útil en la disputa política porque discursivamente -al menosapunta a restar legitimidad al ganador. Tal es así que una cosa son las prácticas que buscan de un modo u otro distorsionar unas elecciones "libres" y otra cosa es poder, desde la oposición a los resultados de las elecciones o al propio proceso electoral, instalar entre los trabajadores y trabajadoras del gremio que se ha cometido fraude. Aún así, las posibilidades de comprobar una denuncia semejante y que los organismos responsables la atiendan es prácticamente inexistente, salvo que el propio gobierno (o Estado) esté particularmente interesado en un cambio de conducción gremial. Pero veamos qué sucedió en el SOIP.

En nuestro caso, la acusación de que la dirección cometió fraude resultó recurrente en todos (¡sí, todos!) los procesos eleccionarios del SOIP desde, al menos, 1969 hasta incluso el día de hoy. ${ }^{703}$ En el año 1966 la toma de la sede sindical propició la intervención del gremio. Recién en 1969 volvió a llamarse elecciones. En aquel entonces fue la Lista Blanca la que decidió abandonar el proceso electoral debido a irregularidades. ${ }^{704}$ Entre otras cosas denunciaban que cuando fueron intervenidos dejaron un padrón con 3.700 afiliados en condiciones de votar y en las elecciones presentes sólo eran 300 las personas habilitadas. Por ello, entre otras razones, deslizaban la animosidad por parte de la intervención para otorgar la victoria a la Lista Unificada Naranja, lo que hablaba de una connivencia entre organismos del Estado y la lista finalmente victoriosa. En 1971 la Lista Naranja, ahora comandada por Díaz y opositora a Saravia, presentaba una impugnación que no sería atendida por la justicia electoral. ${ }^{705}$ Poco después caracterizaba lisa y llanamente como fraudulento e ilegitimo al proceso electoral. Lo curioso es que en esta elección la propia junta electoral declaró, una vez finalizado, la nulidad del proceso electoral. ${ }^{706}$ De nuevo en 1973, y previo a la realización de las elecciones, la Lista Naranja anunciaba que

\footnotetext{
${ }^{703}$ Las últimas elecciones del gremio se realizaron en el año 2010. En el marco de una jornada polémica, donde se denunció quema y rotura de urnas, obtuvo la victoria la Lista Negra y Blanca que llevó a Cristina Ledesma a la secretaría general, siendo la primera mujer en la historia del gremio en ocupar ese lugar. Ver "Elecciones en el SOIP: aún sin ganador", 11/09/2010. Revista Puerto, la otra cara de la pesca. En línea: http://revistapuerto.com.ar/RP Noticia Detalle.php?id=1255. Visitada el 31/10/2012. También en el año 2006, cuando obtuvo la victoria la Lista Celeste, integrantes de las listas opositoras denunciaron fraude.

${ }^{704}$ La Lista Blanca, integrada por los grupos anarquistas que dirigieron previamente el sindicato, emitió un comunicando denunciando el accionar de la intervención y anunciando que se retiraba del comicio debido a las irregularidades del acto eleccionario. Archivo DIPPBA, Mesa B, Factor gremial, Carpeta 57, Legajo 17, Folio 103, 19/10/1969.

${ }^{705}$ Entonces Saravia, luego de que el Ministerio de Trabajo por resolución de la Dirección de Asociaciones Profesionales desestimó la impugnación de nulidad expresaba "No nos explicamos cómo la misma junta electoral que organizó y dirigió las elecciones, y que certificó con el acta y con otro documento el resultado conocido, viene a hablar luego de anormalidades, irregularidades, etc., al producirse la impugnación". L.C.,22/11/1972.

${ }^{706}$ L.C.,17/05/1972. En la asamblea de designación, Corino Díaz había logrado imponer por mayor cantidad de votos la terna propuesta por él para ocupar la Junta Electoral. Sin embargo, el poder de la junta no fue suficiente para desandar la victoria de Saravia, avalada finalmente por el Ministerio de Trabajo.
} 
se realizaría fraude. En esta ocasión denunciaban un conjunto de irregularidades en la confección de los padrones, que además no les habían sido entregados a las listas opositoras. Por eso, acusaban, la CD "se apresta a consumar el más escandaloso fraude". ${ }^{707}$ Ante ello solicitaron al Ministerio de Trabajo la suspensión de las elecciones y la designación de un delegado electoral para que confeccione los padrones. $\mathrm{Y}$ anunciaban que de no atenderse sus reclamos no participarían de las elecciones. A su vez, convocaron a un paro en el SOIP en repudio a la comisión directiva.

En el recuerdo de algunos entrevistados, las victorias de Saravia se explican principalmente por el recurso del fraude. Por ejemplo la campaña desarrollada por la Lista Celeste en 1984 incluyó pintadas por las calles del puerto que rezaban "Si no hay fraude, gana la Celeste". ${ }^{708}$ Daniel Cabrera, candidato a secretario general por la Celeste, explicaba que "Lo que sucede es que realmente hay temor de que se produzcan hechos fraudulentos en el acto eleccionario, sobre todo teniendo en cuenta que la junta electoral que fiscalizará los comicios fue designada por la actual dirigencia. Además, ya estamos encontrando irregularidades en los padrones". El propio día del recuento de los votos se vivieron momentos de tensión por la demora en el conteo de sufragios. Luego de los resultados, y a pesar de que Cabrera se abrazó con Saravia, ${ }^{709}$ posteriormente integrantes de la lista Celeste denunciaron la existencia de fraude. Saravia respondió denunciando que "la agrupación perdedora empleó la injuria como método". Y luego declaró estar sufriendo una campaña de desprestigio. ${ }^{710}$ Elda, integrante de la lista, explica la cuestión según su punto de vista:

Ya estaba el fraude en el sindicato... que Saravia te hacía aparecer urnas del cementerio parque. Siempre hizo todo ese tipo de trampas. [Refiriéndose a las elecciones de 1975] en realidad con la gente que trabajaba ganó la Lista Naranja, ganó la Lista Naranja. Pero viste... aparecían urnas, el Ministerio de Trabajo las aprobaba y así es como se quedaba Saravia con el sindicato. A nosotros nos pasó en el año 1984 lo mismo. Que la lista Celeste robó, robó [en el sentido de que ganó por un amplio margen] con la gente que estaba trabajando, pero después empezaron a traer urnas de Batán, del Hospital Regional... Y en realidad nos gana por 180 votos. Nada. Con todo el fraude, todo el fraude... ${ }^{711}$

Aquellas eran las elecciones del año 1984, donde hemos visto que la lista Azul y Blanca de Saravia obtuvo una vez más la victoria. ${ }^{712}$ En 1990 tanto la lista Verde como la Celeste denunciaban un posible fraude en las futuras elecciones. Por parte de "La Verde" se mencionaban presiones a delegados, así como maniobras con los padrones. ${ }^{713}$ Por su parte, a través de un comunicado los integrantes de la Celeste expresaban:

....ante el proceso electoral que tiene lugar en el gremio, [La lista Celeste] denuncia ante la opinión marplatense y los trabajadores del pescado en particular, que un nuevo fraude está preparando

\footnotetext{
${ }^{707}$ Archivo DIPPBA, Mesa B, Factor gremial, Carpeta 57, Legajo 17, Folio 170, 17/10/1972.

${ }^{708}$ L.C., 15/07/1984.

${ }^{709}$ L.C. $22 / 07 / 1984$.

${ }^{710}$ L.C., 16/10/1984.

${ }^{711}$ Entrevista del autor con Elda Taborda... op cit. Elda señala que el estatuto del SOIP habilita a votar con el recibo de sueldo. Menciona que a raíz de esta condición, los empresarios emitían recibos de sueldo "falsos" para personas que luego votaban, denunciando de este modo una connivencia obrero - patronal.

${ }^{712}$ L.C., $21 / 07 / 1984$.

${ }^{713}$ L.C.,07/07/1990.
} 
Saravia. Por ejemplo, la constitución de la Junta Electoral fue conformada por la actual dirección, sin ninguna participación de la oposición. Los padrones no han sido entregados a las agrupaciones participantes; no se ha informado el número de votantes que están en condiciones de sufragar, y en la convocatoria a elecciones se determinan fábricas que ya no existen...

A su vez, la abogada y dirigente justicialista Dra. Norma Godoy patrocinando a la Lista Verde concretó una presentación ante el Juzgado en lo Criminal $\mathrm{N}^{\circ} 4$. El recurso de amparo se realizó invocando serias irregularidades en los procedimientos preelectorales, "maniobra que amenazaban derechos de los simpatizantes de las listas opositoras". El Dr. Hooft declaró su incompetencia en el caso, resolviendo enviar las actuaciones a la Justicia Federal, por lo cual el juez Eduardo Pettigiani debió definir sobre el recurso. En este contexto no tendrían suerte los presentantes del recurso y el juez desestimaría la presentación. ${ }^{714}$ De todos modos, las tres listas habían firmado un documento, previo a la elección, en el que señalaban que no existía tal impugnación. Ello no impidió que la Lista Verde se dirigiera a la prensa para comunicar lo que consideraban había sido un fraude en las elecciones del SOIP, siendo ellos, en realidad, los legítimos ganadores:

Es curioso pensar que en 1984 la industria del pescado estaba trabajando entre un 80 a un $85 \%$ en su potencial productivo. En esa oportunidad el padrón real de afiliados en condiciones de emitir el voto era de 6.600. Hoy después de seis años, Saravia y la junta electoral comunican que se encontrarían en condiciones de votar entre 8.500 y 9.000 afiliados y si tomamos en cuenta que en el último año se cerraron alrededor de 70 establecimientos, lo que significa un caudal aproximado de más de 3.000 afiliados sin aportes y existen 250 plantas infractoras [...] ¿dónde están los votos legales que Saravia dice que tiene? ${ }^{715}$

Además denunciaban que se votó con credenciales emitidas por la propia junta electoral y que el padrón no se depuró de fallecidos. "Resumiendo todas las anormalidades entendemos que en nuestro gremio en condiciones de emitir el voto estarían entre 4.500 y 5.000 afiliados y si tomamos en cuenta los votos de la lista "Verde", la elección fue legítimamente nuestra".

Previo a las elecciones de 1994, la lista Verde presentaba su plataforma en la prensa. El candidato a Secretario General, Ramón González expresaba "Somos la agrupación Lista Verde del pescado triunfante en el comicio de 1990 y que fuimos arrebatados por el fraude de la dirigencia sindical del SOIP"716. En esas elecciones, también participarían la Lista Celeste y la Azul y Blanca. Finalmente ésta última quedó como única participante del acto eleccionario al haber sido retiradas de la puja las listas Celeste y Verde.

\footnotetext{
${ }^{714}$ L.C.,18/07/1990; 19/07/1990. Eduardo Pettigiani comenzó a desempeñarse en la Administración Pública Nacional a los 17 años como empleado del Banco de la Nación Argentina y en 1973, luego de concluir la carrera de Derecho, se desempeñó como abogado auxiliar y titular en Azul y Mar del Plata, respectivamente. En el ámbito judicial, fue designado Juez Federal en la ciudad de Mar del Plata (hay quien dice durante el gobierno de la última dictadura cívico militar) y nueve años más tarde fue camarista Federal. Declinó a este último cargo tras haber sido convocado para integrar el gabinete de Eduardo Duhalde, como Secretario de Seguridad de la Provincia de Buenos Aires. Pettigiani renunciaría a la secretaría en 1994. Al año siguiente intentó alcanzar la intendencia marplatense como candidato justicialista, perdiendo en manos del radical Elio Aprile. Luego de ello Duhalde lo recomendó para integrar la Suprema Corte de Justicia de la Provincia, cargo para el que fue aceptado. Desde 1996 integra el máximo Tribunal de Justicia provincial, ejerciendo la presidencia durante el período 2002/2003 y concomitantemente la del Consejo de la Magistratura y la de la Junta Electoral provincial. Pettigiani aparece vinculado a Saravia. Participando de la fiesta de cumpleaños del líder del SOIP y participando en distintos eventos y fiestas realizados por el sindicato.

${ }^{715}$ L.C.,22/07/1990.

${ }^{716}$ L.C., 03/06/1994.
} 
Los integrantes de éstas últimas solicitaron la postergación de los comicios alegando que están "plagados de irregularidades que las configuran en un verdadero fraude". Pedían que se suspendan las elecciones y se convoquen "dentro de 90 días" cuando haya "una Junta Electoral electa por la asamblea general del gremio, integrada por un representante de cada lista interviniente, con padrones depurados, agrupados por fábrica, jubilados y definitivos". El reclamo apuntaba a democratizar la forma de elección de la junta electoral. Cómo vimos, este es un punto central de los reclamos de la oposición, dado el manejo arbitrario que le permite a la conducción nombrar a quiénes son los encargados de instrumentar el proceso electoral. De hecho en el año 2002, cuando la lista Azul y Blanca perdió las elecciones, la designación de la junta electoral corrió a cargo de un interventor enviado por el Ministerio de Trabajo. Pero el estatuto del SOIP marcaba que era la CD la que elegía la junta. Ello hacía que los integrantes de las listas opositoras no tuvieran participación en el armado de las elecciones y, por ejemplo, no intervinieran en la confección de los padrones. ${ }^{717}$ Además la junta era la que nombraba a los presidentes de mesa que llevaban el control de los comicios en las propias fábricas.

Por otra parte, el proceso de despidos y cooperativización de la mano de obra produjo que muchos de los activistas de las listas opositoras se quedaran sin trabajo o pasaran a trabajar sin relación de dependencia, lo cual los alejaba de la posibilidad de competir electoralmente. Al mismo tiempo, diferentes voces denunciaban que Saravia no podía ser candidato, dado que entonces estaba procesado por una causa en su contra. ${ }^{718}$ De lo cual Saravia se defendía argumentando que había apelado a la Suprema Corte de Justicia.

En 1998, nuevamente, de cuatro listas que pensaban participar, finalmente la junta electoral sólo reconoció a la oficialista Azul y Blanca. En la opinión de la junta, ésta era la única que recogía los requisitos establecidos por el estatuto, particularmente en relación a que los candidatos debían desempeñarse bajo relación de dependencia. Ante ello, representantes de la alianza Celeste - Verde denunciaron la proscripción de todas las listas opositoras. Los delegados Mamerto Verón y Ramón González dijeron que "la junta electoral acusa, en virtud de un decreto de asociaciones profesionales que el tiempo de presentación de las listas es de 30 días hábiles, pero nosotros presentamos la lista en tiempo y forma". Y opinaron que el motivo de esta impugnación por parte del oficialismo es que "ellos saben que nosotros les podemos ganar la conducción del gremio". Informaron además que se encontraban realizando un plan de lucha "tanto por medio de la justicia penal, como en el Ministerio de Trabajo y vamos a movilizar a todos los compañeros del gremio para lograr el objetivo, que es la oficialización de nuestra lista". Por último comentaron que en las elecciones de 1994 "nosotros impugnamos parte de las mesas ante escribano público y actualmente no tienen una legalidad ante el Ministerio de Trabajo, por eso creemos que son dirigentes truchos". ${ }^{719}$ Luego, obreros y obreras del pescado simpatizantes de las listas opositoras se movilizaron para repudiar el rechazo de la presentación de listas opositoras a la actual

\footnotetext{
${ }^{717}$ Representantes de la Lista Verde denunciaron la existencia de padrones "inflados": "hicimos un padrón que arroja un total de 1.500 a 1.600 afiliados y con los jubilados sumarían unos 1.800, mientras que Saravia nos presentó un padrón de 3.300 a 4.000 afiliados". L.C.,19/07/1994.

${ }^{718}$ Los mismos representantes de la Lista Verde afirmaron que "Aparte de que las elecciones son fraudulentas, Saravia no puede ser candidato porque independientemente del fraude está condenado penalmente; el estatuto, ley nacional y toda la ley penal no le permite ser candidato". L.C.,19/07/1994. Analizamos esta causa contra Saravia en un próximo apartado.

${ }^{719}$ L.C., 16/06/1998.
} 
conducción y denunciaron fraude electoral. ${ }^{720}$ También Ronner, ahora al frente de la Lista Granate, denunciaba fraude. ${ }^{721}$ Finalmente las elecciones del año 1998 se suspendieron y jamás se realizaron.

En el año 2002, previo a la realización de las elecciones, integrantes de la lista Verde denunciaron serias irregularidades en la junta electoral que debía calificar a los candidatos para el acto eleccionario. La junta había impugnado a los dos principales candidatos de dicha lista por considerar que no tenían relación de dependencia, lo cual era cierto. Sin embargo, los integrantes de la lista denunciaron que:

...hay 4.700 trabajadores en negro. Ellos lo saben pero no hacen nada. Las pseudocooperativas funcionan así porque ellos lo han permitido. Son cómplices de todo esto. Más todavía, algunos de los candidatos de las listas oficiales tienen varias causas penales en la justicia, están sospechados de jubilaciones truchas y el gremio fue allanado por la justicia. ${ }^{722}$

No discutían sobre su condición de ocupación, pero sentían el derecho de participar de las elecciones aunque no estuvieran trabajando bajo relación de dependencia. Ante los conflictos suscitados y dado que la conducción que nombró la junta electoral no estaba en condiciones de hacerlo puesto que sólo estaba al frente del gremio en calidad de "custodio de los bienes" (recordemos no se habían realizado elecciones en 1998), las elecciones fueron aplazadas. Para instrumentarlas fue nombrado por el Ministerio de Trabajo Carlos Solá como interventor, quien finalmente impulsó la convocatoria a elecciones. De no hacerlo, expresó: "el sindicato puede tender, no sé si a la desaparición, pero sí a una intervención judicial o a un problema más serio, dejando desprotegidos a todos los afiliados". ${ }^{23}$ Previo a ello, se efectuaron arduas negociaciones con el objeto de terminar con una acefalia de cuatro años, buscando acuerdos de presentación que relajaran las normas del estatuto. Finalmente las cuatro listas autorizadas para participar de la elección aceptaron de manera excepcional la participación de Luis Ronner, que era jubilado, como candidato por la Granate. Bajo este acuerdo pudieron llevarse a cabo los comicios, sin que pudieran participar los obreros que no tenían la relación de dependencia.

\section{El hombre del pescado}

Cuando inicié esta investigación habían pasado varios años del fallecimiento de Abdul Saravia. Aún así, su nombre todavía resonaba en las calles de Mar del Plata. Buena parte de la militancia de izquierda utilizaba el enunciado de "burocracia saravista" para referirse a los dirigentes sindicales que continuaron a Saravia en la conducción del gremio. El nombre de éste era, entre quienes empecé a entrevistar, el sinónimo de un fenómeno extendido en la Argentina. Pues tanto anarquistas, como peronistas y comunistas, cuando fueron oposición, acusaron a las conducciones sindicales de burócratas. A ello refiere Ladeuix (2013), para quien Saravia quedó relacionado en la memoria colectiva de la ciudad como el representante típico de la llamada "burocracia sindical". De ser tal cosa lo acusaron muchas veces los opositores gremiales, acudiendo a diferentes calificativos que operaban en la construcción moral del antagonismo político. Esto es, el "burócrata" no sólo es un dirigente con otra tradición política y

\footnotetext{
${ }^{720}$ L.C., $18 / 06 / 1998$.

${ }^{721}$ L.C., $24 / 06 / 1998$.

${ }^{722}$ L.C., $04 / 02 / 2002$.

${ }^{723}$ L.C., 05/03/2002.
} 
diferente programa de acción, sino que también suele ser representado como un "traidor", "vendido", "delincuente". ${ }^{724} Y$ a en la década del "70, el grupo liderado por Corino Díaz se refería a la conducción del SOIP como "ENTREGADORES, VENDIDOS, OBSECUENTES, INOPERANTES Y VIVIDORES". ${ }^{725}$ En fechas más recientes, similares calificativos desplegaban otros oponentes:

Porque era traidor ${ }^{726}$, nos empezó a vender tanta lucha que les costó el convenio del $75 \ldots$ él le empezó a vender artículos sueltos... Cuando nos quisimos acordar [...] el fue vendiendo artículo por artículo. Vendió la media hora de espera, vendió el artículo 16 del convenio que era el premio al presentismo, que era el $25 \%$ del premio al presentismo. ${ }^{727}$

A la acusación de haber "vendido" el convenio otros le suman la colaboración de la dirigencia del SOIP en el proceso de formación de cooperativas:

...yo creo que... el que inició este tema de las cooperativas si bien fueron los grandes empresarios, fueron amparados por el sindicato, por el SOIP [...] nuestros dirigentes iban a las fabricas y nos decían "porque estar en las cooperativas no es malo, es bueno, van a ser como patrones" [...] Hubo luchas, hubo luchas pero muy pocas, habíamos perdido mucha fuerza porque el SOIP no nos amparaba, el SOIP nos empujaba a las cooperativas. Nuestro sindicato se vendió. ${ }^{728}$

Incluso mandos medios de la actividad pesquera vinculan hoy al sindicato con la formación de las cooperativas, cuanto menos, por inacción:

Yo sé cómo se hicieron las cooperativas. En el 92 los que entregaron fue el sindicato, el sindicato entregó. Hizo cooperativas cuando Menem necesitaba que el puerto... que los empresarios ganaran, porque los empresarios no ganaban porque se seguía manteniendo el uno a uno y a los empresarios no les servía. Entonces ¿qué era mejor? No pagar cargas sociales. Y la mejor manera de no pagar cargas sociales era la cooperativa [...] El sindicato participó del proceso de las cooperativas. El sindicato apoyó eso. Si no, no lo podrían haber hecho nunca. Porque como era el sindicato nunca podrían haber creado las cooperativas sin la participación del sindicato. Te lo pueden contar a vos, se lo pueden contar al otro. Pero uno que estuvo adentro y lo vivió de todas formas. A mí nadie me va a venir a decir... yo no vi nunca el sobre, pero a mí nadie nunca me va a venir a decir que el sindicato no colaboró en la creación de las cooperativas. Mentira. Colaboró. Y recibió la plata que debía recibir. Saravia ya estaba muy enfermo, no era el mismo Abdul Saravia... Pero con la fuerza que tenía el

\footnotetext{
${ }^{724}$ Sobre la construcción moral del antagonista político ver Colombo (2011).

${ }^{725}$ Archivo DIPPBA, Mesa B, Factor gremial, Carpeta 57, Legajo 17, Folio 133, 03/05/1972

${ }^{726}$ El calificativo de traidor es una constante en las disputas gremiales. Podemos ver que ello tenía tradición en el SOIP. Por ejemplo, comunistas y peronistas acusaban de ello a la gestión anarquista al momento en que esta firmó el primer convenio colectivo de la rama filete. En la visión de estas fuerzas la actitud de la dirección del SOIP era "lisa y llanamente una traición" y así debía ser presentada. En sus palabras: "la firma de dicho convenio significa [una traición] a los intereses de los compañeros, traición cometida por el señor Roberto Crocitto, Secretario del Sindicato autónomo, títere de los industriales del filet". Al mismo tiempo, el dirigente comunista Raúl Mastronardi, mediante una solicitada, le decía al secretario general del SOIP "si el Convenio que Ud. termina de firmar para el gremio del filet no fuera por sí mismo una TRAICION y una INFAMIA, su solicitada dirigida a los compañeros lo completa" (Nieto, 2012: 567).

${ }^{727}$ Entrevista del autor con Elda Taborda... op cit.

${ }^{728}$ Entrevista realizada por Cristian Tibaldi op cit.
} 
sindicato, con lo que era el SOIP... Le hubiera sacado la gente a la calle, le hubieran parado todo. Le hubiera parado el puerto el sindicato para que no se creara una cooperativa. ${ }^{729}$

Y aún hoy, esa visión de la conducción de Saravia planteada en términos de burocracia en buena medida es compartida por algunos investigadores:

Desde hacía más de tres décadas existía una elite, encabezada por Abdul Saravia, que concentraba el poder y que excluía a los demás integrantes de dicha organización y a sus bases de la toma de decisiones. Este grupo se "perpetuaba en el poder" tal como lo explica Michels, (2006), en su Ley de Hierro de la oligarquía, siendo el fraude electoral, la compra de votos y la sumisión política a la estructura sindical justicialista elementos corrientes en aquellos años. La burocratización del SOIP, la cooperación de Saravia hacia el proceso desafiliador y el desamparo en el cual quedaron sumidos los trabajadores cooperativizados, fueron los blancos principales de la crítica efectuada por la oposición (Yurkievich, 2012: 270). ${ }^{730}$

No nos corresponde a nosotros juzgar este hecho ni formular juicios de valor respecto de tales opiniones. Si vale la pena insistir en la complejidad que asume el fenómeno, marcando que esas imágenes críticas contrastan con el hecho de que, tras las quiebras de empresas, la primera denuncia pública acerca de la aparición de estas falsas cooperativas corresponde a una imputación del propio Saravia. ${ }^{731}$

La crítica más interesante a la conducción sindical la realizaba contemporáneamente la Lista Verde, atacando el modelo sindical que Saravia encarnaba. Para los militantes de aquella lista "Las cooperativas son consecuencia en gran parte de la política de autoritarismo llevada a cabo por el señor Saravia y algunos industriales evasores y estafadores". Pues "La evidencia está en las negociaciones de salarios y condiciones de trabajo hechas a espaldas de los trabajadores, no haciendo jamás asambleas generales ni reconociendo los resultados de las urnas". ${ }^{732}$ Estos trabajadores consideraban que el SOIP estaba en “desintegración” y que Saravia no hacía nada para salvarlo. Ante ello, pedían la realización de una asamblea general con la participación de trabajadores ocupados y desocupados. Y el pedido es por demás interesante, no solo porque es la primera vez que, al menos desde la prensa gráfica, se hace mención a la situación que padecía el SOIP con un gran número de trabajadores que al haber perdido el trabajo no podían participar de la vida de la entidad gremial. Sino también porque implica una discusión en torno al modo de organización del propio sindicato. De este modo, la crítica no se reduce a un aspecto moral. Lo

\footnotetext{
${ }^{729}$ Entrevista del autor con Walter Flores... op cit.

${ }^{730}$ Recurrente entre las interpretaciones de la "burocracia sindical", la explicación transita factores que explican la permanencia de un liderazgo de 30 años desde la más pura negatividad. Entre varias cuestiones que se podrían discutir, aclarando nuestra perspectiva, sirve la observación realizada hace años por Hyman "...enfocar el problema del gobierno y la administración de un sindicato como si fueran 'organizaciones formales' arrancadas de su contexto social, es ignorar el impacto del entorno institucional de poder con el que los sindicatos interactúan constantemente. Al dejar de lado la significación de determinantes estructurales más amplios, entonces se atribuyen con facilidad los fallos de la democracia a características personales de los miembros o de los dirigentes: 'apatía' por una parte, 'corrupción' o 'arribismo' por otra. Sin embargo, permanecer en ese nivel de análisis más que explicar es moralizar” (Hyman, 1978: 84).

731 L.C.,20/08/1991. Esas denuncias no terminaron ahí. Prosiguieron en numerosas ocasiones, cargando contra distintas cooperativas y diferentes personas implicadas. Por ejemplo, el SOIP advierte sobre la "proliferación de seudocooperativas de trabajo, encubiertas por supuestos gestores con parentesco gubernamental, que estarían trabajando en la zona Puerto" informando que las mismas violan "toda norma y leyes vigentes que reglamentan la actividad y la relación laboral". L.C.,15/09/1991. También denuncia ante la Gerencia de Contralor e Inspección del Ministerio de Economía "la proliferación de pseudas cooperativas de trabajo". L.C.,03/10/1991.

${ }^{732}$ L.C., $25 / 10 / 1992$
} 
que estaba perimido, para los trabajadores y las trabajadoras militantes de la lista Verde, era el modelo sindical que Saravia representaba.

Con todo, las primeras ideas que fui generando mientras avanzaba en el conocimiento de los hechos me llevaron a compartir todas estas apreciaciones. Pensaba entonces que la categoría burocracia sindical resultaba explicativa y que Saravia había sido, pues, un burócrata. Pero el tiempo y el desarrollo de la investigación me hicieron cuestionar aquellas primeras impresiones. De nuevo, no se trata aquí de emitir juicios de valor de una figura denostada por la oposición sindical y ensalzada por sus seguidores, sino más bien procurar comprender la riqueza de un fenómeno social. Por un lado, el análisis de la historia de la lucha de los trabajadores de la industria del pescado me demostraba, cuanto menos, que la conducción del SOIP había participado en numerosas acciones de lucha en defensa de los intereses de los trabajadores. Y esa participación no podía reducirse a la "presión de las bases", expresión usualmente utilizada cuando una conducción gremial "burocrática" participa o convoca a una medida de fuerza. Además, producto de mi experiencia de trabajo en el archivo de prensa del SOIP y de los continuos intercambios de opiniones que allí pude sostener con dirigentes de la nueva conducción sindical, comencé a entender que la noción de burocracia, si bien ilumina algunas características de las conducciones sindicales, también, a veces, termina ocluyendo un conjunto de procesos que hacen a la situación de la clase trabajadora argentina, al manejo gremial, a las tradiciones políticas, a las formas de representación obrera y, en definitiva, a la vida sindical (Colombo, 2011; 2010b). ${ }^{733}$ Todo ello teniendo en cuenta la particularidad de la etapa analizada, caracterizada por una transformación del capitalismo, no sólo en Argentina, sino a escala mundial. El que, como interesante y anticipadamente sugiere Burawoy (1983), pasa de una etapa donde el capital otorgaba concesiones a la clase trabajadora para el mantenimiento de su dominación a una nueva etapa que el autor denomina "despotismo hegemónico". Aquí la relación de fuerzas se invierte. Son los trabajadores quienes deben resignar intereses ante los empresarios, dado que se enfrentan en la amenaza permanente de perder sus empleos.

En cuanto a Saravia, de algún modo su figura, su estilo de conducción, su trayectoria sindical, sus aliados e, incluso, el programa que fomentaba para el desarrollo de la industria pesquera, lo convierten en un personaje, cuanto menos, de sumo interés. Por lo demás, todos nuestros entrevistados, amigos pero también enemigos, reconocían la "inteligencia", "astucia" y "capacidad de liderazgo" de aquel hombre oriundo de la ciudad de Balcarce que nunca completó sus estudios primarios. ${ }^{734}$ No tanto por sus características personales, sino porque su persona constituye una suerte de diatriba de la historia de la pesca marplatense y del movimiento obrero local, nos pareció oportuno incluir en esta tesis algunas referencias a su figura. ${ }^{735}$ Más que ubicarlo categorialmente en algo que usualmente definimos como "burocracia sindical", donde claramente podemos situar su existencia y, tal vez, su accionar utilizando

\footnotetext{
${ }^{733}$ El uso y abuso de la categoría burocracia sindical fue objeto de un dossier de la revista Nuevo Topo. Revista de Historia y Pensamiento Crítico, Nro. 7, 2010, en la cual, entre otros trabajos, se incluye un aporte propio.

${ }^{734}$ Vale señalar que sus amigos y colaboradores suelen destacar que el dirigente no se enriqueció, como si lo hicieron otros, a costa del sindicato: "Saravia murió en la casa que era del papá y de la mamá, nunca se compró una casa. Era un hombre re bohemio. Nunca le interesó para nada lo material. Por eso cuando dicen que era coimero a nosotros nos da bronca, porque nosotros fuimos los que más estuvimos con él". Entrevista del autor con Norma Mira... op. cit.

Cuestión que no niegan algunos de sus más fuertes detractores: "Más o menos es así... no murió rico como es ahora Moyano...". Entrevista del autor con Elda Taborda op cit.

${ }^{735}$ Un dato de color es que Saravia construyó un museo peronista, llamado Eva Perón, en la ciudad de Mar del Plata. Entre otros objetos mostraba allí un reloj de pared que Juan Domingo Perón le obsequió a Carlos Menem, quien a su vez, se lo entregó a Saravia. La particularidad era que en lugar de un tradicional Cucú que anunciaba la hora se escuchaba la marcha peronista.
} 
prácticamente cualquiera de las definiciones disponibles, nos interesa el personaje por lo que condensa. ${ }^{736}$ Cuasi analfabeto, peronista "de nacimiento", justificador de la lucha antisubversiva, preso durante la última dictadura cívico militar, católico, admirador profundo de J.D. Perón y de Carlos Menem, Saravia fue uno de los pocos dirigentes gremiales que mantuvo una visión integral acerca del lugar que el SOIP tenía en el desarrollo pesquero argentino. Su figura pertenece a una dirigencia sindical que puede no gustarnos, pero cuando los juicios de valor entorpecen demasiado nuestra comprensión nos perdemos de entender fenómenos complejos y ricos que, desde nuestra mirada, hacen tanto a la formación de la clase trabajadora argentina como a sus representantes gremiales. La presencia cotidiana del dirigente en casi todos los conflictos, sus enfrentamientos con sectores de las derechas y las izquierdas, su "estilo" de conducción gremial, su visión de la soberanía nacional, del desarrollo económico argentino y del lugar que la pesca ocupaba en ese escenario, su relación cotidiana y permanente con "las bases", hacen de Abdul Saravia un dirigente digno de estudio y consideración. ${ }^{737}$

\section{El liderazgo de Abdul "El chancho" Saravia}

"Mejor que decir es hacer, mejor que prometer es realizar" J.D.Perón (Lema de la plataforma gremial de la Lista Azul y Blanca)

Abdul Saravia nació en la ciudad de Balcarce en el año 1937. Se conoce que, tras su llegada a la ciudad de Mar del Plata, trabajo como cadi en el Golf Club y también en la fábrica de ladrillos que su padre tenía en la localidad de Batán. Ingresó a la actividad pesquera siendo menor de edad -algo común en la época- en 1955, como trabajador de la conserva en la empresa La Campagnola. Desde aquella época destacaba su fama de reclamador por los derechos laborales. Allí comenzará, como delegado, su carrera gremial. En el año 1966 participa de la toma del SOIP y ya en 1969 asciende a secretario general del gremio. La Lista Unificada Naranja, ganadora en los comicios, estaba integrada por una nueva camada de militantes gremiales peronistas que habían participado de los conflictos de los fileteros y fileteras del período 1960-1966. En gran medida se trataba de un "peronismo tardío" dentro del sindicato (Pastoriza, 1993). A partir de allí el liderazgo de Saravia se constituyó primero en la rama conserva, de dónde él provenía, sin dejar de extenderse hacia la rama filet, de creciente importancia dentro el gremio. Su llegada

\footnotetext{
${ }^{736} \mathrm{Su}$ liderazgo se relaciona a aquello que se definió como "caciquismo popular" donde el poder del dirigente dentro de la maquinaria formal (agreguemos también informal) de toma de decisiones en el sindicato está firmemente afianzado, donde generalmente los mecanismos institucionales de control para arriba son de significación limitada, mientras que la "dominación" se legitima cultivando una identificación personal y la lealtad de los afiliados. Aunque el mayor error de estas visiones institucionalistas es que en su análisis no se preguntan cómo y por qué se generan precisamente esa identificación y esa lealtad. En este sentido, resulta bien interesante la descripción sobre los líderes sindicales del yute en la India que realiza Dipesh Chakrabarty (1997) los cuales asentaban su liderazgo en la construcción de autoridad y poder que era personal, lo cual más que indicar ausencia de disciplina o entrenamiento sindical revelaba la presencia de sistemas alternativos de poder y autoridad. Demasiado apegados a nociones como la de "burocracia sindical" aquellos fenómenos generalmente "informales" de construcción de poder y liderazgo se escapan de la consideración.

${ }^{737}$ A unos meses de su muerte un cronista resaltaba "Nadie puede ocultar que la muerte de Abdul Saravia, cabeza visible del sindicato por largos años, con una trayectoria que fluctuaba entre el combate frontal en defensa de los intereses del gremio y sus inocultables amistades con lo más sobresaliente del poder político nacional -como caso, su estrecha amistad con el presidente Carlos Menem-, dejó al SOIP como desguarnecido”. En ese mismo espacio, los dirigentes Carlos Darguibel y Sergio Gaitán señalaban que "El SOIP está muy identificado con Saravia; eso no lo podemos ocultar; sería inútil no reconocerlo. Van a pasar muchos años y el SOIP va a seguir siendo identificado por su imagen, su lucha y la combatividad que tuvo". L.C.,14/12/1997.
} 
a la conducción gremial prácticamente coincide con el período de "despegue" de la pesca como actividad industrial exportadora, así como con la mutación que dio paso a la hegemonía del filet por sobre la conserva. Esta transformación también fue acompañada por el fin del predominio anarquista y la consolidación del peronismo como corriente hegemónica dentro del sindicato. No obstante, fue un hombre de la conserva el que condujo ese proceso. De aquí en más Saravia permaneció al frente del sindicato, interrumpiendo esas funciones solamente cuando fue encarcelado tras el golpe de marzo de 1976. Liberado en 1978, Saravia volvió a ocupar la conducción gremial. Renovó su liderazgo durante la década del '80 y también la del '90. En 1992 llegó, además, a la secretaría general de la CGT regional cargo que ocupó hasta 1996. Finalmente, como anticipando, su muerte en febrero de 1997 se produjo justo en el momento previo a que la pesca ingresara en una de las crisis más fuertes de su historia.

Saravia pensaba que la defensa de los intereses de los trabajadores no podían hacerla los partidos liberales sino la organización sindical concebida a través de una doctrina nacional y popular. Y esto era para él el peronismo. Solía utilizar la frase de J.D. Perón respecto de que sólo la organización vence al tiempo. Y varias de sus apreciaciones iban en el sentido de que en el gremio no se hacía política, sino que se defendía a los trabajadores. Con ese argumento desplegaba críticas a la oposición gremial vinculada con algún partido político. ${ }^{738}$ Adhería a cierta noción de comunidad organizada, donde el Estado funciona como árbitro regulando la relación, potencialmente conflictiva, entre trabajadores y patrones. En este esquema, las arbitrariedades patronales eran fuertemente cuestionadas. Contra ello, Saravia apuntaba a la acción concertada, "inteligente", entre obreros y patrones. Encargado de un capítulo del libro de César Lerena, La industria pesquera ¿reafirmación o decadencia?, Saravia propone un pacto social para campear la crisis que vivía la actividad pesquera hacia finales de la década del ' 80 . Mediante éste comprometía a los empresarios a aumentar salarios y cumplir las obligaciones de aportes sindicales y de obra social, mientras que los obreros se comprometían a no realizar medidas de fuerza ni reclamar mayores salarios durante un tiempo. Saravia era además un dirigente sindical peronista formado en épocas de proscripción del peronismo. Desde su asunción en el gremio, se vinculó al armado sindical de quien conducía la CGT regional, el dirigente del FOETRA local Nelson Rizzo quien a su vez se encontraba alineado tras la conducción nacional de Rucci y Paladino. ${ }^{739}$ En calidad de secretario regional de la central sindical, Rizzo tuvo que enfrentar principalmente los cuestionamientos provenientes del Peronismo de Base a raíz de sus vínculos con los grupos que actuaron en el asesinato de Silvia Filler. ${ }^{740}$ Sin embargo, la profundización de los vínculos de la CGT regional con "la derecha peronista" se produciría luego del desplazamiento de Rizzo a manos de Marcelino Mansilla proveniente del gremio de la Construcción. ${ }^{741}$ El SOIP, que apoyaba a Rizzo, no asistió a la asamblea donde se eligió la nueva

\footnotetext{
${ }^{738}$ Elda Taborda, afiliada al PC, menciona que uno de los cuestionamientos más corrientes que sufrían por parte de Saravia era que en realidad ellos estaban haciendo política. La acusación hace recordar al conocido pasaje de la novela No habrá más penas ni olvidos de Osvaldo Soriano.

${ }^{739}$ Como sugiere Ladeuix (2013) el derrotero del movimiento obrero marplatense a partir de la caída del peronismo y en particular la experiencia de la resistencia sindical y de la construcción de poderosos gremios durante los años fuertes del vandorismo se presenta como un verdadero vacío historiográfico. En ese sentido, y si bien con un objeto de estudio centrado en un período posterior, se encuentran interesantes aportes sobre la CGT regional y los sindicatos más importantes de la ciudad para aquellos años en el citado texto de Ladeuix. Para el caso del SOIP, contamos con la investigación de Nieto (2012).

${ }^{740}$ Silvia Filler era una joven de 18 años estudiante de la Facultad de Arquitectura de la Universidad -en ese entonces- Provincial de Mar del Plata. Durante la realización de una asamblea en el mes de diciembre de 1971 un disparo en la cabeza terminó con su vida luego de que un grupo parapolicial identificado como CNU ingresará al lugar donde se realizaba la reunión accionando sus armas de fuego.

${ }^{741}$ Caracterizado como un traidor a la clase obrera, el 27 de agosto de 1973 Mancilla fue asesinado por el comando BelloniFrondizi de las FAP.
} 
conducción y desconoció la legitimidad de la convocatoria. En ese tiempo, Saravia era secretario adjunto de las 62Organizaciones Peronistas.

De este modo, podía advertirse una división entre las 62 Organizaciones que entonces representaban a un peronismo que podemos definir como "ortodoxo" y la delegación de la CGT regional que ahora albergaba a los sectores más vinculados con la "derecha" peronista. ${ }^{742}$ Además, conduciendo algunos sindicatos menores, pero sobre todo con presencia a partir de diferentes agrupaciones, estaban las tendencias de izquierda. Dentro de este esquema, la conducción del SOIP estaba más cerca de aquel peronismo ortodoxo. Quien entonces poseía una relación más estrecha con la "derecha" peronista era Corino Díaz. Este dirigente, que acompaño a Saravia como secretario adjunto del gremio entre 1969 y 1971, será el principal opositor durante la década del '70. A Díaz se lo vinculaba con Marcelino Mansilla, a quien a su vez se le atribuyen relaciones con el CNU y otras organizaciones de la "derecha" peronista. $^{743}$

Con el regreso del peronismo al gobierno el SOIP vivirá su etapa de esplendor. En aquellos años logrará construir una guardería infantil, un sanatorio, la sede gremial y comenzar a planificar la construcción de un ambicioso complejo de viviendas. En este marco, la conducción sindical cambiaba de estrategia pasando de un estilo más vandorista, de golpear y negociar, a uno más participacionista, donde su vínculo con el partido de gobierno favorecía la realización de obras y el fomento de los servicios sindicales. Pero ello sin dejar de acudir a medidas de fuerza y episodios de acción directa cuando la situación lo ameritaba, como por ejemplo, en el antes y durante de la firma del convenio colectivo de trabajo.Al momento de inauguración del sanatorio del sindicato Saravia expresó "Para lograr lo que buscamos en función de organización gremial, no necesitamos tirar bombas. Esto, y lo que he anunciado, lo demuestra". Concluyendo esas palabras expresó la adhesión y el apoyo al gobierno que entonces presidía María Estela Martínez de Perón "cueste lo que cueste y caiga quien caiga". ${ }^{744}$

Luego del golpe de 1976 el SOIP fue intervenido, aunque rápidamente se devolvió la conducción a las viejas autoridades, quedando bajo la responsabilidad de Néstor Lucero, quien era secretario adjunto. Durante el operativo en el gremio las fuerzas represivas encontraron armas en la sede sindical. Saravia, junto a Ronner, Carlos Darguibel y otros integrantes de la CD, fueron encarcelados. ${ }^{745}$ Existen diferentes versiones sobre el tiempo en que Saravia permaneció preso. Hay quienes dicen que solo fueron pocos meses y otros que permaneció detenido hasta tres años. También distintos relatos acerca de dónde estuvieron detenidos. Como la versión que afirma que compartió prisión con Lorenzo Miguel y Carlos Menem en el buque 33 orientales y luego en el Penal de Magdalena. Otros dicen que aquello no es más que un mito. Lo cierto es que los dirigentes permanecieron alrededor de 2 años presos en la Base Naval y el Gada 601 de Mar del Plata y luego en el penal de Olmos. ${ }^{746}$ Saravia aparece libre hacia fines de 1978 y desde allí vuelve a hacerse cargo del SOIP. Cuentan sus colaboradores que en la gestión del sindicato y, particularmente por temas vinculados a la obra social que permanecía intervenida, el dirigente debía

\footnotetext{
${ }^{742}$ Al momento de la muerte de Perón, en julio 1974, Saravia expresó: "La estirpe de genuina argentinidad de Eva Perón acentuó con su martirologio el sentido de solidaridad que acrisolaba su espíritu. Hoy el teniente general Perón es quien nos ofrece su vida, como respuesta necesaria a quienes pretenden con la violencia la desunión de los argentinos".

${ }^{743}$ Archivo DIPPBA, Mesa B, Factor gremial, Carpeta 57, Legajo 17, Folio 163, 28/05/1973.

${ }^{744}$ L.C., 11/11/1974.

${ }^{745}$ Según nos cuenta Carlos Darguibel no era que hubiera armas del sindicato, sino que las armas eran las de cada uno. "Todos andábamos armados en esa época”. Entrevista del autor con Carlos Darguibel, ex secretario adjunto del SOIP (Mar del Plata, $18 / 02 / 12)$.

${ }^{746}$ Algunas versiones sugieren que Saravia durante su cautiverio denunció a activistas del gremio del pescado, señalando así su colaboración con el funcionamiento del sistema represivo. Pero no conocemos causas en la justicia al respecto.
} 
reunirse con funcionarios del gobierno cívico-militar. ${ }^{747}$ Entre los militares, con quien más vínculo tuvo fue con Emilio Massera, pues recordemos que la Marina se encargaba del área pesca. Críticos del dirigente gremial lo llamaban "El pescadito de oro de Massera" indicando que Saravia "trabajaba" para el represor. ${ }^{748}$ No es esta la visión de sus colaboradores, quienes sostienen que Saravia "usó" a Massera para conseguir "cosas" para los afiliados del SOIP. Lo cierto es que el ex Almirante tentó a Saravia para incorporarlo al proyecto de constitución del Partido para la Democracia Social. ${ }^{749}$ Este pedido habría sido rechazado por Saravia, manifestando su pertenencia al peronismo. ${ }^{750}$

\section{Un soldado de Menem}

Saravia estaba afiliado al PJ local. Fue Consejero Provincial en representación del Partido de General Pueyrredón y participó activamente como militante de la organización en la década del ‘ 80 y la del '90. Al mismo tiempo, hemos indicado en capítulos previos que el dirigente fue uno de los hombres fuertes de la organización Federalismo y Liberación Línea Nacional Rojo Punzó, que impulsó desde 1986 la candidatura de Carlos Menem a la jefatura de la Nación. Saravia llevó la presidencia de la agrupación en la provincia de Buenos Aires. ${ }^{751}$ La misma funcionó como una fuente de apoyo al menemismo durante sus primeros años de gobierno. También el SOIP participó de la conformación de la seccional local de la Mesa de Enlace Gremial junto con otros gremios marplatenses. Mesa que en septiembre de 1990 decidió el cambio de denominación por el de "Mesa Sindical Menem Presidente". Desde allí se ratificó el apoyo incondicional a la gestión política, económica y social que llevaba a cabo el presidente de la Nación. ${ }^{752} \mathrm{~A}$ través de un documento explicaban que "se ha puesto en marcha un programa que significa el mayor y más profundo esfuerzo para los argentinos" y "no existe otro para salvar a la Nación”:

No es el tiempo para los "logreros", ni los resentidos, ni los incapaces. Es sí el tiempo de los que quieren y anhelan participar en la empresa grande y generosa de construir una Argentina nueva [porque] el crecimiento genuino, la reactivación verdadera y una mejor calidad de vida, surgirán del esfuerzo fecundo en el trabajo [...] Este es nuestro compromiso: aportar nuestro esfuerzo y exhibir nuestra confianza en el hombre que nos la pidiera y que día a día demuestra a través de sus actos que es posible pensar en un futuro mejor, para felicidad del pueblo y la grandeza de la patria. ${ }^{753}$

\footnotetext{
${ }^{747}$ Cuentan que Saravia se presentaba en las reuniones, aún en pleno invierno, solamente vistiendo una camisa. "Se lo hacía a propósito a los militares, por los descamisados". Entrevista del autor con Norma Mira... op cit.

${ }^{748}$ Durante un programa de televisión donde aparecía el mismo Massera se regalaban pescaditos de oro. De allí la asociación.

${ }^{749}$ Recordemos que el represor Emilio Massera soñaba con ser presidente de la Nación. Su proyecto comenzó a expresarse con cuestionamientos a la política económica desplegada por José Martínez de Hoz. Con un perfil pretendidamente socialdemócrata, se fue gestando con el uso forzado de experiencias de militantes detenidos-desaparecidos, contactos con sectores del peronismo ortodoxo y la derecha, con la propia Isabel Perón, entonces detenida, y con el lanzamiento del diario Convicción. Más tarde, cuando la derrota de Malvinas obligó al régimen a negociar una salida con los partidos políticos, ese plan de Massera se encarnó en el Partido para la Democracia Social.

750 "Y cuando Massera se postuló lo vino a ver y Saravia le dijo 'Te equivocaste hermano, yo soy peronista, yo no voy a trabajar para vos. Te equivocaste, conmigo te equivocaste"'. Luego de que uno de sus hijos fuera asesinado en 1986, Abdul Saravia recibió, entre otras salutaciones de pésame, una del puño de Emilio Massera. Entrevista del autor con Norma Mira, op. cit.

${ }^{751}$ Norma Mira fue secretaria de prensa de la entidad.

${ }^{752}$ Participaban 28 organizaciones locales, entre ellas, el SOIP, SICONARA y SAON.

${ }^{753}$ L.C., 16/09/1990.
} 
Desde Federalismo... se convocó al acto que del 17 de noviembre de 1989 en Plaza de Mayo, en conmemoración de un nuevo aniversario del retorno al país del General Perón, el cual sirvió para que el presidente Menem hablara. Al momento de convocar, la organización declaraba que "observa atentamente la evolución de la situación económico-social de nuestro país, ratificando la confianza depositada en el doctor Carlos Saúl Menem para superar la crisis que padece el pueblo argentino"754. Aquel fue el acto en que el presidente señaló:

...vengo a convocarlos para librar la batalla contra quienes pretenden sabotear nuestra esperanza, contra quienes buscan estafar nuestros cambios, contra los que buscan apostar al fracaso, a la Argentina de la decadencia, al país de la frustración [...] algunos compañeros no entienden el camino elegido por el gobierno; soy plenamente consciente de las dudas y las reservas de muchos militantes $[\ldots]$ no debemos ser esclavos de nuestras ideologías porque las doctrinas tienen que servir a los hombres y no los hombres a las doctrinas. ${ }^{755}$

A su vez, el $5^{\text {to }}$ Congreso de Federalismo... de la V Sección Electoral incluía a la organización dentro del nucleamiento de reciente formación llamado "Menem Conducción”, que buscaba al mismo tiempo posicionarse al interior del menemismo y disputar en la interna justicialista de la provincia de Buenos Aires contra el sector que aún respondía a Antonio Cafiero. Mediante un documento señalaba:

$1^{\circ}$ ) Apoyo irrestricto a todo lo actuado por el presidente doctor Carlos Menem sin obsecuencias ni traiciones; $2^{\circ}$ ) Manifestar la satisfacción por los resultados obtenidos en el lanzamiento de "Menem Conducción" en Mar del Plata, donde "Federalismo y Liberación" se constituye en el pilar fundamental del trabajo orgánico realizado en las distintas comisiones... ${ }^{756}$

En mayo de 1990 representantes de la agrupación por la $5^{\text {ta }}$ Sección Electoral declararon personas no gratas en la sección a los integrantes del denominado "Grupo de los Ocho", identificados con el "seudo-dirigente Moisés Fontela" (diputado, representante por Castelli), por su "sistemática y nociva oposición al proyecto de todos los argentinos que lidera nuestro conductor Carlos Menem”. Y repudiaron la:

...lamentable actitud que se observa como movimiento preelectoral de algunos personajes de la política interna, que intentan anticiparse a los tiempos buscando alcanzar objetivos puramente burocráticos, a costa del abandono de las tareas de apoyo a la gestión presidencial que es lo primordial en esta etapa tan difícil que transita la Argentina. ${ }^{757}$

Por otra parte, en abril de 1990 Saravia cumplía 53 años. Y su fiesta tendría como invitado de honor al presidente de la República. Flanqueado por Menem, el dirigente del SOIP planteó en un discurso los momentos difíciles que estaba viviendo el país, pese a lo cual "seguimos apoyando incondicionalmente al gobierno" abogando por un "gran Pacto Social entre los trabajadores, el Estado y los empresarios para tener una patria justa, libre y soberana". Dijo también que era necesario "terminar

${ }^{754}$ L.C., $14 / 11 / 1989$

${ }^{755}$ L.C., 18/11/1989.

${ }^{756}$ L.C., 20/12/1989.

${ }^{757}$ L.C., 15/05/1990. 
con la corrupción" y privatizar las empresas estatales que arrojaban déficit, no así las que producen superávit, en directa referencia al Mercado Concentrador. En cuanto a la pesca, hizo hincapié en la necesidad de defender las 200 millas "para que no nos lleven toda nuestra pesca". Por último prometió que en las malas "vamos a seguir al lado del presidente porque somos los soldados de Carlos Menem". ${ }^{758}$

Desde su participación política Saravia brindaba un apoyo incondicional a la gestión presidencial. Pero es necesario hacer algunas precisiones en cuanto a lo específicamente gremial y también en relación a sus ideas sobre el desarrollo pesquero. Para ello, veamos previamente cómo algunos autores definieron a los sindicatos que apoyaron inicialmente la gestión presidencial de Menem. Gómez (2009) afirma que:

Algo poco destacado por los estudios del sindicalismo contemporáneo es que los líderes del nucleamiento participacionista por excelencia, "Los 15", habían anticipado con notable perspicacia el advenimiento de un escenario de agotamiento del modelo sindical anterior. Ya en 1988 estos dirigentes se incorporaban directamente al mundo de discusión empresarial y pensaban en un "pacto de crecimiento no distributivo". Llegaron a formular la idea de que la misión del sindicalismo era "forzar que los empresarios inviertan". Esto rompe completamente con las orientaciones gremiales preexistentes reconociendo de hecho la preeminencia de los intereses del capital. Por tanto, podría decirse que las ideas de reestructuración económica dentro del peronismo no fueron en realidad "sorprendentes" desviaciones ideológicas de Menem sino que ya habían sido elaboradas previamente con notable claridad dentro de un sector del sindicalismo. Triaca (plásticos), Andreoni y Cavalieri (comercio) y Rodríguez (mecánicos), mostraban esta versión de "vanguardia posmuro de Berlín" que tenía una visión compartida con Menem respecto de la necesidad de recrear un "bloque de recomposición del capitalismo argentino" mediante privatizaciones, apertura de la economía y achicamiento del Estado cuyas consecuencias no alcanzaban directamente a sus sectores (Gómez, 2009: 114-115).

De este modo, vemos que existían dirigentes gremiales "menemistas" incluso antes de Menem. Saravia era menemista, pero su lealtad al líder riojano era completamente diferente de la que estos sindicatos profesaban. Cuentan sus colaboradores que el dirigente del SOIP conoció a Menem cuando este aún era gobernador de La Rioja y desde allí sintió una profunda admiración. ${ }^{759}$ Aquella relación crecería cuando el ex presidente se encontraba en Tandil bajo libertad vigilada y luego se trasladó a Mar

\footnotetext{
${ }^{758}$ L.C.,12/04/1990. Ni los integrantes de la otrora potente Renovación justicialista, ni el propio Antonio Cafiero habían sido convidados a participar. En la consideración de un cronista anónimo del L.C.,el festejo no había sido inocente: "Es que para muy pocos distraídos puede pasar desapercibido, teniendo ya la visión global de estos tres ajetreados días políticos en el balneario y en la sierra, que de lo que se trataba era de dar claros y contundentes signos de apoyo a los que se han constituido, luego de la riesgosa manifestación -hoy triunfal- del 6 de abril, en los dos más sólidos y fieles puntales de la "línea menemista" en la provincia de Buenos Aires. Fue algo así como el testimonio de agradecimiento o más bien de retribución por los riesgos que tanto Barrionuevo como Macaya vienen corriendo en el apoyo irrestricto a la política económica y social del gobierno nacional [...] El cumpleaños de Abdul era un pretexto válido para cerrar esta operación política de cuño internista en el justicialismo con resonancias en lo local, seccional, provincial y sindical y fue hábilmente urdida por Barrionuevo...”. L.C.,15/04/1990.

${ }^{759}$ Matsushita menciona que la colaboración de los gremialistas hacia la figura de un presidente del propio partido no debe reducirse sólo a razones partidistas. También los lazos personales de amistad que vinculaban a dirigentes con Menem constituyen un elemento suficiente para explicar la moderación de los líderes obreros (Matsushita, 1999:170). Tal observación parece ajustarse al caso de Abdul Saravia.
} 
del Plata. Saravia fue uno de los varios que ayudaron a Menem en aquel momento, enviándole comida y hasta colaborando con los gastos de una operación de su hija Zulemita. ${ }^{760}$

Para Saravia la llegada de Menem al poder era la que permitiría fomentar un proceso de desarrollo nacional de la pesca. El dirigente ya había participado de la confección de un anteproyecto de Ley de Pesca elaborado por la Coordinadora de Gremios Marítimos bajo el asesoramiento de Gustavo Demarchi y Eduardo Bonoris. ${ }^{761}$ Con César Lerena al frente del área, su llegada a determinados empresarios pesqueros y el apoyo sindical que podía proporcionar el propio Saravia, podía ensayarse la implementación de un proyecto pesquero que, como sostenía Lerena, apuntara a la expansión del mercado interno a través de la educación de los consumidores, al fortalecimiento de las empresas vía subsidios para que mejoren sus capacidades técnicas, al agregado de valor a los productos exportados a partir del trabajo realizado en las plantas en tierra y, con ello, construir más puestos de trabajo. Además, se buscaría jerarquizar el área pesquera dentro del gobierno. Por otra parte, la pesca también serviría para desplegar una política soberana en relación a la ocupación del territorio marítimo nacional. En la ilusión de Saravia, la categoría de revolución productiva en la industria pesquera abarcaba todos esos contenidos.

Resulta llamativo ver que en distintos hechos de acción directa realizados por el SOIP a principios de la década del '90, los trabajadores enarbolaban pancartas y fotos de Menem. Ello ocurre, por ejemplo, durante la toma de la planta Surmai en febrero de 1990. Como veremos en futuros capítulos, los reclamos principales eran el pago de la garantía horaria, de la cuota sindical, de la obra social, asignaciones familiares y licencias por maternidad. ${ }^{762}$ De algún modo, Saravia consideraba que el proyecto de Menem significaba más trabajo y mejores condiciones laborales, encarnando nociones de justicia y bienestar para la clase obrera. Ante el incumplimiento patronal y el cierre de plantas, producto tanto de la crisis que arrastraba la pesca, pero también de las políticas del nuevo gobierno, Saravia respondía protagonizando medidas de acción directa. Y no le parecía una contradicción, más bien todo lo contrario, enarbolar en ellas la figura del caudillo riojano. Sin embargo, ni la política pesquera ni la política laboral se dirigieron hacia donde Saravia quería. Ante ello es interesante mostrar cuál fue la reacción del SOIP.

Gómez (2009) y Fernández (2002) construyeron tipologías de intervención sindical dentro de la tradición gremial argentina. Ligeramente disímiles ambos mencionan, según su lógica de participación, las tendencias participacionista, vandorista, combativa o de liberación y clasista. Más allá de que este tipo de construcción, útil para delinear los alineamientos gremiales resulta menos rica para estudiar las prácticas sindicales, a grandes rasgos podemos insertar la lógica de intervención sindical del SOIP durante el liderazgo de Saravia a mitad de camino entre lo que se define como participacionista y vandorista. De la primera tenía el privilegio de la estrategia política de alineamiento negociado con los poderes fácticos que le permitía obtener ventajas corporativas y beneficios organizacionales. Así lo muestra durante el gobierno de Isabel Perón y de su buena relación con el entonces gobernador Victorio Calabró, que le permitió obtener ayudas financieras a través del Instituto Nacional de Obras Sociales. También durante el gobierno cívico-militar el SOIP logró la construcción de un complejo habitacional. Ahora bien, esa inclinación a la negociación en el sistema político, bajo las muy disímiles realidades entre un gobierno que apoyaba fervientemente y otro que toleraba por imperio de las circunstancias, no implicó

\footnotetext{
760 "No le hablaras mal de Menem. El se distanció de Barrionuevo cuando Menem se separó de él. El fue amigo, Menem no. Cuando venía Menem no había mujer, no había sindicato, no había familia. Era devoción lo que él tenía. Y no sé por qué. Porque nunca lo ayudó. No lo ayudó con el gremio, no lo ayudó con las casas”. Entrevista del autor con Norma Mira... op. cit.

${ }^{761}$ L.C., $02 / 10 / 1988$.

${ }^{762}$ L.C., $16 / 02 / 1990$.
} 
la renuncia a la movilización colectiva. Por ejemplo durante el contexto de la firma del CCT de 1975. En ese sentido, la participación del SOIP en la dinámica gremial resultaba de tipo vandorista, con énfasis en las capacidades organizativas del aparato sindical e identitarias del peronismo, y los obreros del pescado, como factor de cohesión frente a otros actores así como en el desarrollo de un potencial de movilización y gestión, de lucha y negociación. Gómez agrega que el vandorismo maduró en la década del ' 60 siguiendo la estrategia de movilizar capacidades organizativas para obtener ventajas y concesiones de unas burguesías industriales fragmentadas y de un Estado deslegitimado políticamente por la proscripción del peronismo. Su lógica de acción permitía maximizar ventajas organizativas y reivindicativas utilizando la capacidad de acción colectiva de la clase obrera de las industrias con mayor peso estructural. Se trataba de una lucha en el plano de las relaciones de fuerza sin amenazar las estructuras de dominación social ni el proceso de acumulación. Pero con el ascenso de Menem al gobierno:

...era claro que el escenario propuesto por las políticas menemistas secundadas por el participacionismo tendía a deshacer los pilares sobre los que descansaba la eficacia del sistema de acción sindical vandorista. La negociación dura, el no otorgar cheques en blanco al gobierno, perdía toda perspectiva frente al fortalecimiento y cohesión de las fracciones de la burguesía, la reducción de capacidades estructurales de la clase por el desempleo y la precarización, la fuerte legitimación electoral del gobierno, el propio aislamiento dentro del peronismo, y el desprestigio dirigencial ante la opinión pública (Gómez, 2009: 25-26).

En el SOIP sucede lo siguiente. Por un lado, Saravia se asocia a las variantes del participacionismo, declarando apoyar de manera irrestricta las políticas del gobierno. Pero ni lo que quedaba de tradición en una lógica de intervención vandorista ni la deriva de las transformaciones en la industria pesquera le permitía reinsertar al sindicato en las nuevas reglas de juego. Asimismo, tampoco negoció la obtención de beneficiosos o concesiones por parte del gobierno. ${ }^{763}$ Cómo otros sindicatos de tradición "vandorista", no renegó del recurso a la acción colectiva, tanto para rechazar las consecuencias de la crisis pesquera y la reestructuración capitalista en la industria, como en la intención de influir en el sistema político, pero todo ello sin apuntar a la figura del presidente. Así, mientras apoyaba la gestión menemista, por otra parte se volvía un fuerte crítico de la política pesquera, oponiéndose al cierre de plantas, a la formación de cooperativas, a la extranjerización de la pesca, al cierre del Mercado concentrador, a la designación de los funcionarios nombrados para el área, al crecimiento del sector congelador y, más tarde ya al frente de la CGT, a la crisis de las economías regionales y al proceso de flexibilización laboral. ${ }^{764}$ De este modo Saravia procuró enfrentarse al dilema de apoyar un proceso político que por las políticas que desplegaba afectó, en gran medida, los intereses de los trabajadores que representaba.

Sin embargo el accionar sindical fue prácticamente inútil en su intento por torcer el rumbo de la política pesquera, tanto sea a través de la movilización de sus recursos como en los intentos por influir a

\footnotetext{
${ }^{763}$ En este sentido, tampoco el análisis desplegado por Murillo (2008) nos brinda demasiadas herramientas para analizar la dinámica del SOIP y la posición de su líder. Pues, si por un lado coopera en el sistema político (y político gremial), por otro, resulta ser un antagonista de la política pesquera, aunque sin lograr mayor éxito.

${ }^{764}$ La paradójica situación de la conducción gremial queda demostrada en un hecho curioso. En diciembre del año 1990 Saravia compartió la Nochebuena con los obreros que permanecían ocupando una fábrica. Al día siguiente, viajó a Capital Federal para participar de un brindis en la residencia de Olivos donde 150 dirigentes sindicales, entre los que se encontraban Diego Ibáñez, Lorenzo Miguel y Luis Barrionuevo, se reunieron con el Presidente Carlos Menem. L.C.,27/12/1990. De este modo, mientras las consecuencias de un modelo pesquero afectaban a los trabajadores y Saravia se comprometía con sus luchas, por otro continuaba brindando apoyo a la gestión presidencial.
} 
través de sus vínculos en el sistema político. En aquellos años el SOIP tuvo que ver cómo alrededor de la mitad de la mano de obra perdía la relación de dependencia con las empresas, achicando el padrón de afiliados drásticamente. Al mismo tiempo, a duras penas la obra social sindical pudo mantenerse por intermedio de subsidios y préstamos que apenas llegaban a cubrir los gastos, reduciendo cada vez más sus prestaciones, mientras que las deudas más grandes nunca fueron abonadas por muchos empresarios que, para colmo, presentaron quiebra. Por otra parte, también impotente se mostró el SOIP respecto de la representación política de aquellos trabajadores que perdían la relación de dependencia e incluso de quienes quedaban desocupados, no logrando generar ningún mecanismo que los incorpore a la vida sindical. Su respuesta se limitó al repudio y denuncia de la situación, pero sin lograr ninguna instancia de rearticulación. ${ }^{765} \mathrm{~A}$ su favor debemos decir que en gran medida fue una característica del grueso del sindicalismo, formado en un modelo sindical diferente, el que no pudo originar respuestas a este proceso. Así, de la mano de las transformaciones en la industria y las políticas del gobierno en materia laboral, el SOIP irá perdiendo poder estructural y político en las configuraciones gremiales de Mar del Plata. El comienzo de la crisis pesquera, tras la muerte de Saravia, relegará al sindicato a una posición cada vez más marginal dentro de las alianzas políticas que dieron forma, por ejemplo, a la Multisectorial Pesquera, pasando a ser el SOMU el sindicato de mayor peso en la dinámica de la protesta. Será justamente a partir de su trabajo político entre el sector de cooperativizados y desocupados del SOIP donde la oposición gremial construirá los pilares de su base de poder.

\section{"Por defender a los trabajadores..."}

En el año 1991 Saravia, junto a Luis Ronner y el delegado Juan Paso, fueron procesados al ser considerados incursos en los delitos de "usurpación" y "coacción”. La acusación remitía a la ocupación de una planta pesquera, medida de la que los dirigentes sindicales habían participado. Según Pedro Hooft, juez de la causa, los obreros de la firmaBarilari procedieron a la toma "instigados" por la conducción gremial. La sanción provenía de considerar que los mencionados dirigentes turbaron el derecho al goce de la propiedad a los dueños de la pesquera al impedir, entre el 7 y el 15 de marzo de 1991, se cargaran contenedores con pescado congelado destinado a las exportaciones debido a que los operarios de la firma se hallaban en conflicto por falta de pagos. Saravia, Ronner y Paso fueron condenados a un año y medio de prisión en suspenso por los delitos de "usurpación de propiedad, coacción y coacción en concurso real con desobediencias". Saravia, refiriéndose a este hecho expresó: "Yo en la Dictadura Militar estuve detenido un mes en el Ejército acá en Mar del Plata, estuve detenido cinco meses en el Destacamento 9

\footnotetext{
765 "Saravia fue un dirigente que creo yo, si lo ponemos en la balanza hoy entre los que están y los que estuvieron antes que estos, yo creo que de uno a diez yo lo pondría en siete, en ocho. Porque teníamos cierta independencia como trabajadores, se respetaba la ley de contrato de trabajo, se respetaban nuestros derechos, si bien había plantas que trabajaban en negro eran las menos, y casi siempre el trabajador estaba más respaldado. Y después bueno, a nivel social teníamos una buena obra social, teníamos atención médica [...] Pero después en el año '90 cuando viene el gobierno de Menem vienen todas estas situaciones que hoy todavía las estamos pagando, se cambian las leyes laborales, se cambian un montón de leyes, la ley de accidentes y bueno nosotros nos empezamos a ver un tanto desprotegidos [...] y muchas veces los dirigentes, creo yo, se adecúan a los gobiernos de turno en lugar de cumplir con el rol que le encomienda el trabajador que es defender los derechos y no importa quién esté en el gobierno. El [Saravia] era un ferviente seguidor de Menem, apoyaba la política de Menem. Yo creo que en ese sentido los trabajadores fuimos traicionados. $\mathrm{Y}$ en esto de las cooperativas este fue, producto de una política de un sindicato que no supo defender lo que a nosotros nos correspondía como trabajadores [...] Creo que gran parte de la responsabilidad de esta situación la tuvo Saravia". Entrevista del autor con Alberto "Beto" Rosa, filetero y ex militante de la JTP, Mar del Plata, 02/02/2010.
} 
de Julio y once meses en el Penal 9 de La Plata, sin causa y sin proceso. Ahora para mí es un honor que me hayan dado una pena por defender a los compañeros". Aprovechó para denunciar las malas condiciones laborales y los abusos patronales en varias plantas pesqueras porque "hay problemas de capataces que le pegan a los compañeros, hay explotación de mujeres que las hacen entrar a cualquier hora de la madrugada, se están abusando de los derechos de los trabajadores y se paga en negro". " La sentencia, además de desnudar la criminalización de la protesta social en que incurría "la justicia" local, resolvía una sanción deshonrosa, y en tanto tal, desprendía visiones de clase. Tras un fallo firmado por Carlos Haller y Daniel Laborde como castigo los dirigentes fueron sentenciados a cursar materias de la carrera de Derecho en la Universidad Nacional de Mar del Plata durante dos años. Se suponía que los gremialistas deberían instruirse en leyes para conocer cuáles eran sus deberes como representantes de los trabajadores. Los magistrados se arrogaban el derecho de fallar acerca de cómo debería comportarse un dirigente sindical, cuáles eran conductas apropiadas y cuáles desviadas. Ante ello, entre otras entidades que expresaron su solidaridad con Abdul Saravia, ${ }^{767}$ la mesa directiva y el plenario de secretarios generales de la CGT local enunció en un comunicado de prensa "su sorpresa e indignación" por el fallo judicial. El documento aclaraba:

...cuando los patrones, empresarios o funcionarios corruptos provocan daños en los sectores del trabajo creando situaciones de insubsistencia, nadie los obliga a concurrir a la Universidad para ser buenos empresarios, buenos patrones o buenos funcionarios. El fallo esconde una dosis extravagante de paradoja e ironía. Nada ni nadie obstaculizará la acción del movimiento obrero en defensa de los legítimos intereses de los trabajadores. ${ }^{768}$

Por su parte, Saravia expresó "Si una vez recurrido el fallo la Justicia considera que soy un burro y que tengo que ir a la universidad voy a ir, pero que nadie se olvide que en Mar del Plata hay un 40\% de desocupación, que en mi gremio especificamente sube al 60\%, y que yo seguiré yendo al frente para bancar a los trabajadores". Consideraba el dirigente que en su función de representante gremial hizo lo correcto: "Hace dos meses tomé una fábrica que no pagaba nada y no me importaba que me metieran preso porque las cárceles se hicieron para los delincuentes y yo soy un tipo honesto que va para adelante". Y afirmó que "la volvería a tomar mil veces". Además de injusta, la resolución ignoraba que Saravia concurría a la Universidad desde hacía dos años, cuando formó junto con las autoridades de la UNMDP la cátedra sobre movimiento obrero. Finalmente Saravia, Ronner y Paso apelaron la sentencia judicial y obtuvieron un resultado favorable poco después de la muerte del líder del SOIP.

\footnotetext{
${ }^{766}$ L.C.,24/04/1994.

${ }^{767}$ Entre ellas, la seccional Puerto de la Asociación del Personal de Dirección de Ferrocarriles Argentinos y Administración General de Puertos Sociedad de Estado y la delegación Puerto de la Unión Ferroviaria. "Abdul Saravia hace prevalecer en todos sus actos la defensa de los legítimos intereses de los trabajadores, que son los de la Nación misma, sobre los particulares y sectoriales [...] en estos momentos se pretenden, con maniobras jurídicas, desprestigiar el accionar honrado y limpio de un verdadero representante de la clase trabajadora". L.C.,26/04/1991.

${ }^{768}$ L.C.,30/06/1994.
} 


\section{La CGT regional bajo la conducción de Saravia}

En 1992 Saravia alcanza la conducción de la CGT local. Su llegada le imprimió un perfil particular a la entidad. Su influjo llegaba por dos aspectos, uno local y otro nacional. Por un lado, se trataba de uno de los viejos líderes peronistas, líder de uno de los gremios más fuertes de la ciudad. Asimismo, el gremio no poseía ataduras nacionales, respondiendo plenamente a una lógica local. En cuanto a la órbita nacional, su alineamiento con el gobierno de Menem lo dotaba de prestigio y de una cercanía envidiable respecto del primer mandatario. En el nivel de relaciones políticas Saravia era "El" amigo del Presidente. $\mathrm{Su}$ vínculo directo con Menem ilusionaba a diferentes sectores respecto de la llegada que el dirigente del pescado mantendría con la cúpula del gobierno nacional. Sin embargo, a pesar de calificarse como un profundo menemista, el proyecto político-laboral que Saravia tenía para el movimiento obrero marplatense de ningún modo podía coincidir con las políticas de ajuste, reforma del Estado y flexibilización laboral que impulsaba el gobierno. Sin embargo, Saravia alcazaba el cargo tras vincularse con el grupo de sindicatos menemistas. ${ }^{769}$ Desde la "Mesa Sindical Menem Presidente" había ratificado el apoyo incondicional a la gestión política, económica y social que lleva a cabo el presidente de la Nación. ${ }^{770}$ No obstante, es interesante ver el accionar de Saravia al frente de la entidad. Pues si bien su lealtad al presidente era inquebrantable, también estaba atento a las consecuencias que comenzaba a exhibir la implementación de las políticas neoliberales.

Es así que, como otras delegaciones locales de la CGT, la de Mar del Plata comienza a adoptar un perfil crítico. Esto merece que nos detengamos en la situación general de las delegaciones regionales, antes de continuar con la situación de Saravia. Sabemos que las centrales sindicales regionales de la CGT funcionaban como delegaciones con escaso margen de autonomía, siempre dependientes de las resoluciones de la conducción nacional. Asimismo, funcionaron muchos años sin que sus atribuciones estuvieran delimitadas en la estructura orgánica de la entidad. Recién en 1987 se establecieron disposiciones concretas sobre sus funciones a través de la "Reglamentación para las Delegaciones Regionales de la CGT" aprobada por el Comité Confederal el 8 de enero de 1987 (Sangrilli, 2009). Si bien no existen muchos estudios sobre el rol de las delegaciones locales, en una breve intervención Béliz señala que durante la década del ' 80 las delegaciones realizaron propuestas más audaces y combativas, formularon fuertes críticas a funcionarios del gobierno y exigieron un mayor peso en las decisiones. Así fueron creciendo en cantidad y adquiriendo cada vez más importancia. En 1976 existían alrededor de 86 y diez años más tarde ya eran 130. Esta situación habría surgido como producto de la política llevada adelante desde el Ministerio de Trabajo, que buscó dispersar y atomizar la conformación de la organización obrera. También las propias divisiones entre CGT Brasil y Azopardo tuvieron su correlato en el interior del país, con delegaciones enfrentándose y disputándose un mismo terreno de negociaciones (Béliz, cit. en Sangrili, 2009). Fue Saúl Ubaldini quien en desventaja dentro de la CGT proviniendo de un gremio pequeño en cantidad de afiliados potenció desde su liderazgo los plenarios de delegados regionales. De ese modo otorgó mayor protagonismo a las delegaciones regionales. Sangrilli (2009) demuestra la dinámica adquirida por la CGT regional Mar del Plata en el período de la transición democrática, proceso que fue de la mano del ferviente apoyo al liderazgo ubaldinista. Paralelamente, las crisis provinciales potenciadas durante la década del noventa habilitaron la creciente combatividad de

${ }^{769}$ L.C.,02/09/1990.

${ }^{770}$ L.C., 16/09/1990. 
estas instancias locales de organización obrera, las cuales muchas veces no se condecían con las tendencias dialoguistas que primaron en distintos períodos de la confederación de trabajadores, particularmente a partir de la jefatura de Antonio Cassia una vez reunificada la entidad. No obstante, los líderes de las delegaciones locales siempre dependían de los sindicatos madre, estando tensionados por las realidades locales y los mandatos nacionales de sus gremios. Ese no era el caso de Saravia.

El secretario general del SOIP llegaba a la CGT en un contexto complejo: a) producto de las transformaciones en la economía, si bien se lograba la tan mentada estabilidad, comenzaban a sentirse algunas consecuencias dadas particularmente por el crecimiento del desempleo; b) ese proceso afectaba profundamente a Mar del Plata, la que pronto se instaló como una de las ciudades con mayores índices de desocupación; c) la situación de los sindicatos como representantes de los trabajadores, que a la vez que sufrían una derrota tras otra a manos del gobierno, irían cayendo en sus más amplios niveles de descrédito; ${ }^{771}$ d) una CGT local escindida a partir de la formación de la CGT Azopardo y luego la formalización de una nueva entidad obrera: la CTA. Logrando el apoyo de algunos sectores gremiales y la enemistad de otros, lo cierto es que hacia finales de 1991 un plenario de gremios de la CGT local convocaba a la confección de un padrón de gremios con vistas al plenario normalizador de la CGT Regional. Poco después se constituiría la junta electoral bajo la presidencia de Nicasio Astrada (UOM), Dante Morelli (Sindicato de la Madera) y Ceferino Luna (Alimentación). ${ }^{772}$ De esta manera, si por un lado aparecía indeterminado el futuro de los gremios -sobre todo estatales- que habían conformado la CGT Azopardo local, a partir de la incorporación de Astrada al proceso electoral, se consolidaba el acercamiento de las “62" a la CGT regional. Además, en las deliberaciones sobre el perfil de la renovada conducción se perfilaba la idea de que la CGT podía cobrar vigor si se transformaba en protagonista de temas locales. ${ }^{773}$ Finalmente una sola lista, la Celeste y Blanca, encabezada por Abdul Saravia se presentaba para las elecciones y resultaba electa. ${ }^{774}$ La nueva conducción había logrado conjugar el apoyo de los sindicatos más fuertes: Construcción, SMATA, Carne, UTA y Camioneros.

Lo cierto es que con Saravia al frente, la CGT regional obtuvo un renovado vigor. Su primera acción fue la denuncia de las cooperativas que consideraba "truchas". A poco de asumir, el líder del SOIP manifestó la existencia de "supuestas" cooperativas de trabajo que en realidad constituyen un fraude laboral. En enero de 1992 envió una carta documento al presidente del Instituto Nacional de Acción Cooperativa, Lic. Juan Herrera, solicitándole negar cualquier tipo de inscripción o matrícula referida a la integración de "cooperativas de trabajo" en todos los rubros y/o actividad laborales "que involucren mano de obra obrera". La nota explicaba que "éste es el sistema de moda utilizado para que el obreroempresario (ambos una misma persona), encubiertos bajo la figura jurídica de Cooperativa de Trabajo, logren seguir obteniendo ganancias ilegales, marginando a los obreros y utilizando la crisis por la que

\footnotetext{
${ }^{771}$ La situación era tal que un columnista de la prensa sobre temas sindicales llegó a sostener "Los dirigentes sindicales recordarán a 1991 como un año sombrío y nefasto", como el año de "la muerte del modelo sindical tradicional". Luis Di Nardo, L.C.,05/01/1991. Paralelamente se conocían algunas encuestas que señalaban al sindicalismo como el sector de acción pública peor observado de la Argentina, teniendo una referencia positiva sólo de una franja que oscilaba entre el 7 y el 9 por ciento de la población. L.C.,13/07/1992.

772 L.C., 20/12/1991.

${ }^{773}$ L.C.,22/12/1991.

774 Acompañaban a Saravia como Adjunto Carlos Trujillo (construcción), Administrativo Mario Santiago (panaderos), Organización Carlos Poletti (Municipales), Gremial Aníbal Flores (UTA), Prensa Héctor Martínez (Camioneros), Hacienda Aníbal Aielli (Seguros), Actas Pedro Lacuadra Montiel (Carne), Acción Social Carlos Theiler (SMATA), Vivienda Fredy Delfino (SUTERyH.) y Cultura Daniel Di Bártolo (SADOP). El sindicalista Ángel Barreiro había presentado una lista solicitando una prórroga de los plazos de presentación, solicitud que fue rechazada por la junta electoral. L.C.,28/12/1991.
} 
atravesó el país...". Para Saravia las cooperativas de trabajo fueron "creadas para que seudoempresarios utilicen a los obreros con el único objetivo de cercenar los derechos de los trabajadores, que fueron logrados mediante años de lucha". ${ }^{775}$ Días más tarde una delegación de la CGT local se dirigía al Ministerio de Trabajo para discutir la misma problemática. Allí Saravia calificó de "cooperativas truchas" a las instaladas en el puerto de la ciudad, diferenciándolas de las cooperativas legítimas. ${ }^{776}$

En enero de 1992 Saravia elaboró un documento en el cual manifestó su oposición a la desregulación de las obras sociales. El texto señalaba que "Toda reforma al sistema de obras sociales debe ser acordada con los legítimos representantes de los trabajadores que son sus dueños". Pues "no se puede de un golpe liberalizar la salud ni imponer modelos comerciales dentro de un sistema que, aunque casi olvidado es uno de los pocos que se rige por la solidaridad de quienes se agrupan por afinidad de oficio o de trabajos para defender el único capital que tiene para aportar a la grandeza de la Patria: su salud". Luego se quejaba porque "nadie dice qué se hará con los fondos que ingresan y que son aportados por los trabajadores. ¿Por qué no se fortalecen las arcas de los hospitales públicos? No hay claridad en los planteos del gobierno sobre este tema". Además cuestionaba el funcionamiento de lo que antes fue el INOS y entonces era el ANSSAL. ${ }^{777}$

Esta cerrada oposición de la CGT local a los intentos por desregular las obras sociales coincidía con la posición también contraria que mantuvo en un principio la CGT San Martin. ${ }^{778}$ Más tarde, el gobierno logrará una negociación que permitió la competencia entre obras sociales sindicales y privadas. Apoyaron la iniciativa los dirigentes de la CGT más ligados al menemismo y la UOM, con la fuerte crítica de la CGT Azopardo. ${ }^{779}$

Saravia también desarrolló una intensa actividad que llevaba a la entidad sindical a sostener vínculos con diferentes actores de la política y vida pública marplatense. Reuniones con la cúpula de la Iglesia local, con el Intendente de la ciudad a quien se le solicitó la creación de una subsecretaría de Pesca Municipal $^{780}$, con el Partido Justicialista local ${ }^{781}$, con el bloque de concejales del PJ ${ }^{782}$, la UCIP y otras entidades. Tampoco se privaba de promover personas para puestos públicos o criticar públicamente a aquellas con quienes no coincidía. En una de esas ocasiones, una organización que se presentaba como Juventud Peronista criticó a Saravia por entrometerse en designaciones de las que él no debía participar, al mismo tiempo que le sugerían que prestara atención a los padecimientos dentro de su gremio. ${ }^{783}$ Ante ello la dirección de la CGT local ratificó su programa político gremial y su metodología de trabajo. Allí

\footnotetext{
${ }^{775}$ L.C., $18 / 01 / 1992$.

${ }^{776}$ L.C.,28/01/1992. Las denuncias fueron recurrentes y se pueden seguir en la prensa escrita.

777 “...pasó a transformarse en un gran recaudador de fondos que, según el funcionario de turno que la administre, reparte subsidios de acuerdo a simpatías propias o del poder político. La burocracia y el oficio creados con la fortuna que significa la recaudación mensual de la ANSSAL trae como consecuencias abusos, producto de los cuales hoy se la intenta disolver". L.C.,08/01/1992."

${ }^{778}$ L.C., 10/01/1992.

${ }^{779}$ L.C., $22 / 01 / 1992$.

${ }^{780}$ L.C.,23/04/1992.

${ }^{781}$ L.C., 16/04/1992.

782 L.C.,18/03/1994

${ }^{783}$ L.C.,29/06/1992. El texto decía "cada vez que un ministro hace algún cambio o nombramiento en Mar del Plata, [Abdul Saravia] sale a oponerse". Ante ello "La Juventud Peronista le agradecería al 'compañero' Saravia que se ponga a la altura de las circunstancias. Que antes de ponerse a defender funcionarios 'ñoquis', que mire un poco su Sindicato, ya que tiene más de 180 fábricas cerradas y 4.000 obreros desocupados y 1.500 súper-explotados sin aumento desde varios años. Que deje de perseguir a los obreros que se han organizado en Cooperativas de Trabajo. Como ya es sabido en el Puerto, Abdul Saravia 'sugiere' a los dueños del pescado a quien se le da materia prima y a quién no. Les pedimos a los dirigentes de la CGT que encuadren a su secretario por el bien de todos los trabajadores de Mar del Plata".
} 
Saravia aprovechó para explicar que "la salud, los jubilados, la pesca y tantos otros asuntos son de interés para la gente, y la CGT ya había anunciado su vocación de debatir mucho más que la grilla salarial, y ser artífices y protagonistas de la situación política, social y económica de la ciudad y la Nación". Y finalizaba con lo que él consideraba debía ser el rol sindical "La acción gremial es construcción política, y la conducción exige ser parte y asumir posiciones". ${ }^{784}$ En el mismo sentido, también se declaraba proclive a la participación en cargos políticos de los dirigentes sindicales. En una oportunidad, y previo a la reelección de Carlos Menem, cuando la CGT reclamaba por lugares para los dirigentes sindicales dentro de las listas, expresó “...consideramos que los dirigentes gremiales también tenemos que hacer política y queremos cubrir cargos de concejales, diputados y senadores para estar al servicio de los trabajadores" ${ }^{785}$.

En mayo de 1992, tras un plenario de delegados, se decidió normalizar las regionales locales de la CGT que mantenían algún tipo de conflicto. Este era el caso de Mar del Plata donde se buscaba incorporar a mayor cantidad de gremios dentro de la entidad obrera. Las elecciones se realizaron el día 29 y, siendo la única postulante, la lista encabezada por Saravia denominadaAzul y Blanca por la Justicia Social obtuvo la victoria. El líder del SOIP ahora compartía la conducción con Pascual Torres de UOCRA (en un doble comando). No participaron bancarios, judiciales, ATE y SUTEBA. ${ }^{786}$ Al día siguiente, la entidad local declaró a la CGT en "estado de conflicto" precisando que tal medida fue adoptada "en adhesión a las disposiciones emanadas del Comité Central Confederal de la CGT". Al mismo tiempo, indicaba que la organización decidió "ratificar la vocación de unidad del movimiento obrero como exclusiva garantía de cohesión y solidaridad frente al avance de una política socio-económica que margina a los trabajadores de las grandes decisiones nacionales". ${ }^{787}$ Se refería particularmente a la gestión de Rodolfo Díaz en el Ministerio de Trabajo. Este funcionario era el blanco principal de las críticas, dado que aparecía como el impulsor de la pretensión de atar los incrementos salariales a la productividad, así como del intento por desregularizar las obras sociales, la búsqueda de propiciar sindicatos por empresas, entre otras medidas consideras gravosas para el movimiento obrero.

\section{- Organizar la informalidad}

Una política por demás interesante realizada por Saravia fue la búsqueda de otorgar determinado nivel de organización a trabajadores de sectores informales de la economía y apoyar sus reclamos. De esta manera, el dirigente del SOIP pretendió devolver su pertenencia al colectivo de la clase obrera, a través de la organización, a sectores desplazados de la economía formal. ${ }^{788}$ En abril de 1994 "cartoneros" y "botelleros", con sus carros, efectuaron una vistosa movilización por las calles céntricas de Mar del Plata y se concentraron luego frente al edificio municipal. El reclamo se realizaba porque una resolución

\footnotetext{
${ }^{784}$ L.C.,09/07/1992.

${ }^{785}$ L.C., $19 / 09 / 1994$.

${ }^{786}$ L.C., 31/05/1992.

${ }^{787}$ L.C.,01/06/1992.

788 "Una experiencia muy fuerte de los noventa que fue de la mano de las políticas neoliberales la exclusión social y la pérdida del trabajo. ¿Esos trabajadores adónde iban a parar? Iban a parar a la informalidad. Petiseros eran la informalidad, cuida coches era informalidad, trapito era informalidad. Abdul organizó la informalidad. Le dio sentido de pertenencia a la clase trabajadora a aquellos sectores que se habían perdido por el fruto de una política”. Entrevista del autor con Daniel Di Bártolo, ex secretario de Prensa de la CGT local (Mar del Plata, 11/05/2012).
} 
municipal les prohibió transitar con sus carros por determinadas calles, ante lo cual no podían recolectar los cartones y botellas en las zonas céntricas, posiblemente las de más utilidad para aquellos trabajadores. Tal decisión afectaba aproximadamente a dos mil familias que vivían de esa actividad. Abdul Saravia organizó una reunión entre los trabajadores y funcionarios municipales. Y encabezó la protesta. Luego de la cual arribó a la reunión con funcionarios. Y demostró su apoyo conduciendo uno de los carros. ${ }^{789} \mathrm{En}$ otra ocasión participó directamente como el impulsor de la organización de los trabajadores. Ese fue el caso de los comerciantes de frutas de la vía pública a quienes instó a conformar el Sindicato de Vendedores de Frutas "Santa Evita". Otro ámbito laboral tradicionalmente informal era el de los cuidadores de vehículos estacionados en la vía pública a quienes se conoce con el nombre de "trapitos" o “cuida coches". En 1994, bajo el impulso de Abdul Saravia, se constituyó un gremio denominado Sindicato de Cuidadores de Mar del Plata agrupando alrededor de 500 trabajadores. ${ }^{790}$

Saravia también apoyó la movilización y manifestación frente al edificio de la Municipalidad de todos los petiseros (dueños de caballos en alquiler) del barrio Alto Camet con el fin de encontrar una solución al conflicto que mantenían con un funcionario municipal -Fernando Arroyo-, quien les prohibió trabajar en el predio debido a que no poseían el correspondiente permiso de suelo. Por ello realizaron una "cabalgata" de protesta que estuvo encabezada por Saravia. Éste, montado en su poni Juan Domingo, recorrió la avenida Luro hasta llegar al palacio municipal. ${ }^{791}$ Tiempo después, en la sede de la CGT local, se reunían los representantes de los gremios de Recuperación de Materia Prima Industrial en Desuso y Depósito, de la Asociación de Trabajadores Cuidadores de Autos, de la Asociación Marplatense de Alquiler de Caballos y Ponis y del Sindicato de Vendedores de Fruta con el secretario de Obras y Servicios Públicos, licenciado Guillermo Saisi, el subsecretario de Inspección General, doctor Carlos Arroyo y el propio Saravia. Allí se acordó que al término de quince días todos los gremios estarían organizados con sus respectivos permisos municipales para trabajar. ${ }^{792}$

\section{- Movimiento Obrero, Cultura y Universidad}

Durante la gestión de Saravia, en octubre de 1992, se puso en marcha la Cátedra Abierta del Movimiento de los Trabajadores en la Argentina que cumplió una totalidad de 10 encuentros en un período de un año. La actividad se conformó a partir de un convenio de cooperación entre la Universidad Nacional de Mar del Plata y la CGT firmado por el rector radical Jorge Petrillo y el propio Saravia. En dicho acuerdo la Universidad y la CGT se comprometían a desarrollar de manera conjunta "aportes en el área de la capacitación, la investigación, extensión y cualquier otra actividad especifica o docente que resulte de interés común para el desarrollo potencial de ambas instituciones...". 793 Las gestiones fueron iniciadas por Daniel Di Bártolo en ese entonces secretario de prensa de la CGT local. ${ }^{794}$ El vínculo entre

\footnotetext{
${ }^{789}$ L.C., 24/04/1992.

${ }^{790}$ L.C., 04/11/1994.

${ }^{791}$ L.C., $19 / 09 / 1994$.

${ }^{792}$ L.C., $16 / 11 / 1994$

${ }^{793}$ L.C., 15/07/1992.

${ }^{794}$ Se llamó Cátedra Abierta del Movimiento de los Trabajadores porque el nombre buscaba dar cuenta del cambio que percibía un grupo de dirigentes gremiales en torno de la conformación de la clase obrera argentina, la cual mostraba la tendencia al crecimiento del sector servicios y de los excluidos sin trabajo frente al clásico obrero industrial. No era la cátedra abierta de la
} 
la entidad obrera y la Universidad local habilitaba a que la CGT expresara su profunda preocupación por la situación económica-financiera de la UNMdP, exigiendo una urgente solución. Saravia pidió mayor presupuesto universitario y reafirmó su postura en defensa de la educación pública y del derecho de los trabajadores y sus familias a acceder a los diversos niveles del sistema educativo. En ese contexto, la UNMDP fue declarada en estado de emergencia económica, indicando el riesgo de no continuar con sus servicios. ${ }^{795}$ Por otra parte, en la misma época se inauguró una biblioteca en el SOIP. La intención de su formación se encuadraba "en el proyecto de la CGT de ir abriendo bibliotecas en las distintas sedes gremiales para contribuir asi a la formación de quienes no tienen demasiadas posibilidades de comprar los materiales nuevos" ${ }^{\text {"796 }}$. Además se editó una revista que lamentablemente solo vio salir dos números. Decían los dirigentes que "El movimiento obrero se propone, a través de esta publicación, abrir un intercambio de opiniones y debate sobre los grandes temas que en la actualidad afectan a los trabajadores", en particular abordando problemáticas locales. ${ }^{797}$

\section{- La CGT y la industria pesquera}

En la conducción de la CGT Saravia continuó con la oposición al proceso de formación de cooperativas de trabajo fraudulentas. Una reunión en la central de trabajadores nucleó a representantes de Capitanes y Patrones de Pesca, Conductores Navales, SAON, SOMU y SOIP. Allí Saravia denostó la presencia "trucha" de cooperativas clandestinas y dio a conocer la nómina de las empresas "irregulares". ${ }^{798}$ La situación afectaba a todos los gremios del pescado. Es interesante el hecho de que aparecían como irregulares algunas de las principales empresas pesqueras como "Alberto Valastro, Pedro Moscuzza (h), Mellino, Marisco, Loba Pesquera y Salerno Hnos." que "pretenden que los empleados paguen de sus bolsillos los aportes previsionales y las obras sociales". Sobre el caso específico del SOIP dijo que "estas mismas firmas están exigiendo a las plantas façoneras, extorsionándolas para que formen estas cooperativas truchas fraudulentas, pues en caso contrario no les venden pescado". 799

Otra búsqueda de la entidad fue la reactivación de la pesca, para lo cual elaboró distintos proyectos. Uno de ellos consistía en propiciar la comercialización entre pequeños y medianos procesadores y las municipalidades de la provincia de Buenos Aires para recuperar el mercado interno y activar a las plantas afectadas por la crisis. ${ }^{800}$ También propuso "controlar la captura en barcos factorías", ${ }^{801}$ y retirar los permisos de pesca inactivos para otorgárselos a la industria capaz de elaborar. Por otra parte, expresando su apoyo a diferentes gremios en lucha, entre los que se encontraban los trabajadores de la pesca "que sufren un repudiable despojo a través de la veda del calamar", dijo en

CGT. Era la cátedra abierta de un movimiento que incluía distintos sectores del trabajo. Entrevista del autor con Daniel Di Bártolo... op. cit.

${ }^{795}$ L.C. $23 / 10 / 1992$.

${ }^{796}$ L.C.,26/07/1994.

${ }^{797}$ L.C., 06/11/1994.

${ }^{798}$ En la foto del periódico se ve a Saravia sentado en su escritorio, donde se ubica un portarretrato con la foto del presidente Menen. Se ve también un cuadro de Menem con la banda presidencial pegado en la pared justo detrás de la espalda de Saravia.

${ }^{799}$ L.C., 13/09/1992.

${ }^{800}$ L.C., $14 / 10 / 1992$.

${ }^{801}$ L.C.,01/02/1993. Agregaba el documento que "Es de mucha importancia para asegurar la transparencia de la actuación del señor secretario de Ganadería y Pesca, la eliminación del negocio ilícito de venta de permisos de pesca que permite a personas sin escrúpulos y de operadores de influencia obtener ingresos de montos incalculables". 
relación a esta situación que "la disminución del recurso se debe a políticas erróneas al aplicar licencias de pesca a buques extranjeros, esto produjo la sobrepesca y la disminución del recurso". Por ello pedía se declare la prohibición de la pesca en Mar Argentino a todo buque de bandera extranjeray que se institucionalice la participación obrera en la definición de la política pesquera. ${ }^{802}$

También la entidad se mostró proclive a la creación de una dependencia de pesca en el ámbito municipal, así como, dada la importancia de las cifras que moviliza la rama, la creación de una Secretaría de Pesca Nacional por fuera de la órbita de Agricultura y Ganadería. ${ }^{803}$ Exigirá también constantemente la reapertura del Mercado Nacional de Concentración Pesquera. ${ }^{804}$ Con todo, la CGT local mantenía esperanzas respecto de lo que llamaba la reactivación de la pesca. Depositaba buena parte de su optimismo en la aplicación del denominado Plan Quinquenal Pesquero "con lo que se crearán 30.000 nuevos puestos de trabajo por año, proceso que se iniciará de inmediato con la aplicación, desde la Secretaría de Pesca de la Nación, de políticas de preservación, explotación e industrialización racional de los recursos ictícolas" ${ }^{805}$. De hecho, Jorge Sustas, asesor de la CGT, explicaba que la elaboración en fábricas argentinas del pescado destinado a la exportación podría cuadruplicar el nivel de la mano de obra ocupada. Pues "Vender el producto ya terminado significaría un gran incremento en cuanto a la divisa, pero también a la mano de obra". ${ }^{806}$ Eran tiempos en que los funcionaros comenzaron a hablar de una política de preservación de los recursos y potenciación de la industria que aportaba valor agregado (ver Capítulo II, apartado "La prioridad son los recursos"). Pero esas declaraciones no tenían aún un correlato en el plano de los hechos. La CGT regional, en representación de los gremios marítimos y portuarios, redactó un texto denominado "Declaración de la Clase Trabajadora Pesquera". Allí daba a conocer el plan de acción que llevaría adelante "con miras a revertir este proceso de desintegración que hoy lamentablemente nos toca vivir", debido a "desaciertos de nuestros funcionarios de turno, por empresarios que llevaron a la quiebra a sus empresas empobrecidas, y por desacuerdos entre los propios dirigentes". Sostenía que "no acepta la entrega del Mar Argentino a las flotas extranjeras". Entre otros reclamos se pedía al Ministerio de Trabajo "la inmediata convocatoria a las comisiones negociadoras de los convenios colectivos", así como la sanción de una ley de pesca. ${ }^{807}$

El otro gran problema de la época, la desocupación, afectaba particularmente a la pesca y de ello se hacía eco la entidad sindical. Las denuncias crecían, de la mano de una imputación de las causas que se ubicaban en la política económica implementada por el gobierno, sobre todo por la habilitación de la pesca con trabajadores extranjeros. Por ejemplo en 1996 Saravia pedía que "los barcos extranjeros cumplan con los convenios marco, ya que si pescan en nuestras aguas y se llevan nuestros pescados, que los mismos se procesen en nuestras tierras. Pero no se respeta ningún convenio, porque procesan el pescado en altamar, en los buques factorías". Esto influye para "agravar la gran desocupación que sufre nuestro sector". Luego se reunían los dirigentes gremiales de actividades portuarias y marítimas para tratar específicamente el tema de la desocupación que estaba sufriendo el sector, y porque "esos puestos

\footnotetext{
${ }^{802}$ L.C., 03/06/1994.

${ }^{803}$ L.C.,31/10/1994.

${ }^{804}$ L.C., $15 / 06 / 1995$.

${ }^{805}$ L.C., $18 / 06 / 1995$.

${ }^{806}$ L.C.,20/08/1995.Argumentaba la entidad que "Los países que más consumen productos pesqueros adquieren en la Argentina la materia prima y la elaboran en su territorio dando empleo a más de 120.000 personas". En el mismo documento reiteraba la necesidad de volver a poner en funcionamiento al Mercado Nacional de Concentración Pesquera y denunciaban a las empresas que manufacturaban y comercializaban pescado de manera clandestina, porque incrementaban la explotación de los obreros y provocaban en materia de evasión impositiva una pérdida al Estado de 80 millones de dólares. L.C.,15/01/1996.

${ }^{807}$ L.C.,04/12/1995.
} 
de trabajo los ocupan extranjeros sin ningún tipo de control" ${ }^{\prime 808}$. Por este motivo, Saravia anunció la posibilidad de decretar un paro en el puerto local. Al mismo tiempo se resolvió ir a ver a Ubaldini y enviar una nota a Carlos Menem para informarle de tal situación. Pero todos estos proyectos, en el marco de la política pesquera del gobierno, no pasaron de ser meras ilusiones.

\section{- La CGT regional va a la huelga}

Si bien la CGT local, bajo el liderazgo de Saravia nunca rompió con Menem, se enfrentaba con una situación socio-laboral de los residentes en Mar del Plata que propiciaba una tendencia cada vez mayor hacia la confrontación, sobre todo contra la política económica. ${ }^{809}$ Los avances de los planes oficiales de flexibilización llevaron incluso a incrementar la oposición de la CGT nacional, cuando Oscar Lescano y José Pedraza se mostraron críticos de los proyectos de flexibilización que "barren con toda la protección legal" de los trabajadores. El propio Lescano adjudicó esa iniciativa al "capitalismo salvaje y los monetaristas" y criticó la política económica del gobierno sosteniendo que "no sirve la estabilidad con 10.000 millones de dólares en el banco, mientras aumenta la desocupación”. Paralelamente las regionales de la entidad obrera le exigían al Comité Confederal la ejecución de un plan de acción contra la desocupación y los bajos salarios. ${ }^{810}$ Entre otras cuestiones debía derogarse el decreto 1334 que coartaba la negociación salarial y reducía los aumentos a los índices de productividad, lo que en la práctica dejaba prácticamente congelados los salarios. ${ }^{811}$ Además solicitaban a la conducción central el cuidado de la unidad del movimiento obrero pues "las divisiones sólo benefician los intereses de los poderosos y profundizan los efectos del ajuste sobre los más débiles”. La posición cegetista se daba a conocer a raíz de la falta de acuerdo en la estructura nacional. En la visión de la regional, el consenso interno era la única manera de "enfrentar la influencia nefasta del neoliberalismo". 812

En este contexto, la CGT resolvió la aplicación de un plan de lucha nacional incluyendo el primer paro organizado contra la política económica del gobierno. ${ }^{813}$ La CGT rebelde señaló que "acompañara el plan de acción del movimiento obrero". Desde la delegación local se ratificó la huelga convocada por la CGT nacional. El petitorio incluía:

\footnotetext{
${ }^{808}$ L.C.,28/02/1996.

${ }^{809}$ Daniel Di Bártolo explica que: “Abdul era un peronista de Perón y Eva Perón. Un tipo sencillo, un hombre humilde. Para él su referente era su amigo que además era el presidente de la Nación. O sea que imaginate lo que significaba. Ahora Abdul era un hombre de pueblo, sencillo pero sumamente inteligente [...] Jamás Saravia me condicionó o censuró una expresión de mis comunicados de prensa. Y yo escribía no en base a la opinión de Saravia o la opinión de Di Bártolo sino a la opinión yo diría de un sindicalismo que migró de ser amigo de Menem a ser confrontador de Menem. En un momento determinado mi gremio es parte de la creación del MTA. De la mano de uno de los tipos que más ayudó a Menem y después obviamente lo confrontó como fue el Bocha Palacios (UTA). Nosotros con Moyano, con UTA y Ubaldini creamos el Movimiento de los Trabajadores Argentinos. Y el MTA era crítico a la CGT oficialista. Y yo estaba en la regional. O sea que ahí tenía un tema de incompatibilización. ¿Cómo resolví yo estos temas? Los resolví a partir del discurso de la regional [...] El discurso fue de tono crítico hacia el menemismo cuando migró al neoliberalismo. Ese fue el posicionamiento que nosotros adoptamos. O sea. Abdul era Menem. Nunca dejó de ser Menem, pero era Menem de un peronismo histórico. Pero tampoco censuró un posicionamiento contrario a las políticas neoliberales [...] Él nunca le puso frenos a la lucha contra la flexibilización laboral". Entrevista del autor con Daniel Di Bártolo... op. cit.

${ }^{810}$ L.C.,20/10/1992.

${ }^{811}$ L.C., 18/10/1992.

${ }^{812}$ L.C., 17/10/1992.

${ }^{813}$ L.C.,22/10/1992.
} 
1) Aumento de emergencia a jubilados y pensionados; 2) Derogación del Decreto 1334/91 y sanción del Proyecto de Convenciones Colectivas de Trabajo; 4) Rechazo del proyecto de flexibilización laboral y 5) Derogación del Decreto 1803/92 que priva de los derechos de la ley de contrato de trabajo a los trabajadores de empresas privatizadas o a privatizar y del decreto 817/92 que deroga los convenios colectivos de los trabajadores marítimos y portuarios. ${ }^{814}$

Desde el gobierno nacional se atacó duramente la medida de fuerza. El propio Menem había declarado que "podrán hacer uno, diez, veinte, mil paros, pero no vamos cambiar este modelo". ${ }^{815}$ También el PJ se manifestó en oposición a la medida. Aún así, finalmente el día 9 de noviembre se produjo la huelga, de la cual participó, entre otros gremios de la rama, el SOIP. ${ }^{816}$ Menem calificó la medida de fuerza como un fracaso.

El año 1993 tomó a la central local alineada en una postura crítica de la política económica. Ya en el mes de enero la mesa directiva emitió un documento donde denunció "la falta de respuesta a los acuciantes problemas de los trabajadores". El comunicado señalaba que el "decreto de productividad ha impedido la negociación libre en materia salarial, mientras los precios aumentaron, los sueldos están virtualmente congelados y la recesión aumenta". Declaró también su oposición a la jubilación privada, la que "aparece como un 'meganegocio' para los grupos de banqueros y empresarios". ${ }^{817} \mathrm{En}$ el mes de marzo se declaraba en estado de alerta y movilización ante la innumerable cantidad de conflictos irresueltos que afrontaban diversos sindicatos de la ciudad. La entidad brindaba su apoyo irrestricto a los panaderos, choferes, bancarios, metalúrgicos, municipales, docentes y trabajadores marítimo-portuarios, cuyas organizaciones sindicales se encontraban en conflicto con las patronales, el gobierno o como consecuencia de los planes de ajuste. ${ }^{818}$ En abril anunciaba la necesidad de rediscutir los salarios. ${ }^{819}$

Esta participación, con acciones contrarias a la política económica de gobierno, no le impedía a Saravia expresar que "haremos nuevamente otro gobierno con la reforma de la Constitución y la reelección de nuestro presidente ${ }^{\$ 20}$. Y en noviembre participaba de la solicitada convocando a votar por el sí ante la consulta por la reforma constitucional. ${ }^{821}$ Pero sí se permitía objetarla pretendida reforma laboral. La mesa directiva de la CGT expresó su rechazo a todo tipo de reforma "que no contemple los derechos de los trabajadores conquistados en la lucha del movimiento obrero por la justicia social". Y repudió "la falta de consulta a las estructuras del movimiento obrero para lanzar al ruedo un debate sobre intereses genuinos de los trabajadores y sus familias" denunciando la "insensibilidad del ministro Rodríguez" ${ }^{\prime 22}$.En marzo de 1994 la mesa directiva y el plenario de secretarios generales de la CGT regional resolvieron por unanimidad el rechazo del proyecto de reforma laboral impulsado por el gobierno y el inicio de una campaña de movilización destinada a resistir la iniciativa y proponer un proyecto alternativo.

${ }^{814}$ L.C.,03/11/1992.

${ }^{815}$ L.C.,04/11/1992.

${ }^{816}$ L.C., 10/11/1992.

${ }^{817}$ L.C., 03/01/1992.

${ }^{818}$ L.C., 20/03/1993.

${ }^{819}$ L.C., 10/04/1993.

${ }^{820}$ L.C., 12/04/1993.

${ }^{821}$ L.C., 04/11/1993.

${ }^{822}$ L.C.,09/05/1993. 
Resulta inaceptable la Reforma Laboral elaborada por el Ministerio de Trabajo e inspirada en experiencias externas que han fracasado y que suelen ignorar las pautas jurídicas, culturales y sociales de los trabajadores argentinos, ni tampoco aquellas inspiradas en concepciones que nos consideren como un insumo más del proceso productivo [...] En aras de bajar los costos laborales, se intenta extender la jornada de trabajo hasta 10 horas diarias. El despido libre que rige en nuestro país morigerado tan sólo por el pago de una indemnización, sufre la disminución de tan precaria protección por la rebaja de los montos indemnizatorios [...] Los exclusivos beneficiados por el proyecto son los empresarios, por ello defendieron hasta el cansancio su postura a través de los representantes de la Unión Industrial Argentina. ${ }^{823}$

A finales de 1994 la entidad se embarcaba también en la lucha contra la reforma al sistema de salud que se pretendía encarar desde el Ministerio de Economía. Ante ello, la mesa directiva de la CGT local resolvió impulsar una campaña de firmas "en defensa del derecho a la salud" contra la quita de los aportes patronales a las Obras Sociales. Los dirigentes expresaron que "no estamos dispuestos a asistir pasivamente a la destrucción de un sistema basado en la solidaridad y en la dignidad del hombre" ${ }^{\text {. }}$.

\section{- La irremediable desocupación}

Hacia finales del año 1993 el desempleo comenzaba a ser un factor evidente en las nuevas formas que asumía el capitalismo argentino. Según Saravia, en Mar del Plata la desocupación rondaba el alarmante nivel del 40 por ciento. El dirigente aclaraba que en el último año "es demasiada la gente que se acerca a la CGT a pedir trabajo, donde tratamos de darle destino, pero también vemos en el Ministerio de Trabajo la cantidad de compañeros que están cobrando desempleo". Sobre todo era preocupante la situación del empleo en la industria pesquera, en sectores del campo, de la construcción y de la industria textil. También la Iglesia Católica, preocupada por las consecuencias sociales del ajuste, se mostraba alarmada por el nivel de desempleo. ${ }^{825}$ Mientras comenzaba a visualizarse el problema como un rasgo estructural. ${ }^{826}$ Ante esta realidad, en el discurso del líder del SOIP se produjo una inflexión indicando un espacio para mostrar cierto antagonismo con la conducción presidencial: "Nosotros apoyamos al gobierno provincial del doctor Duhalde y, como todos saben, a nuestro presidente, y aunque muchas veces nos encontramos con problemas dificiles de resolver, las conversaciones son cordiales. Eso sí, los compañeros saben muy bien que no somos obsecuentes". Si la situación socioeconómica de los trabajadores marplatenses lo exigía, parecía decir Saravia, él y la CGT estarían en la oposición a la política gubernamental, puesto que "Los cargos son de honores y los puestos son de lucha". ${ }^{827}$ Más tarde, recordando a los mártires de Chicago ("quienes levantaron la esperanza por un mundo mejor y una sociedad justa") Saravia expresó que "Mar del Plata vive una gran crisis de desempleo que lleva a un sinnúmero de personas a deambular sin trabajo o con una subocupación muy por debajo de las

\footnotetext{
${ }^{823}$ L.C., 03/03/1994.

${ }^{824}$ L.C., 22/12/1994.

825 "A la Iglesia le preocupa profundamente el nivel de desocupación que hay" declaraba el obispo José María Arancedo durante el acto central por la fiesta de San Cayetano. L.C.,08/08/1994.

${ }^{826}$ Por ejemplo el sociólogo Abel Ayala explicaba que en la ciudad "La desocupación ya no es algo estacional sino que se está transformando en un problema estructural". L.C.,03/09/1994.

${ }^{827}$ L.C.,30/12/1993.
} 
necesidades básicas". ${ }^{828}$ Días después impulsaba la convocatoria a un plenario de delegados regionales de la CGT con el objetivo de analizar las "gravísimas consecuencias" de las políticas implementadas por el gobierno. ${ }^{829}$ A estas alturas, Saravia reflexionaba respecto de la lucha contra la desocupación "si no sirve aplicar el sindicalismo moderno vamos a volver al de antes, el del bombo" ${ }^{830}$.

En diciembre de 1994 la CGT regional se reunía con la intendenta interina Maryla Trápani, con el objetivo se informarle acerca de los principales problemas de los trabajadores marplatenses. El punto número uno era, claramente, la desocupación y subocupación. ${ }^{831}$ En segundo lugar mencionaban la proliferación de seudo cooperativas de trabajo. En 1995, tras los efectos de la crisis del Tequila, la desocupación no hacía más que incrementarse. El ministro Caro Figueroa admitió en el Congreso que la tasa de desocupación seguiría aumentando. Mientras que el monseñor Justo Laguna reclamó entonces al gobierno medidas prácticas para revertir la desocupación porque "va a producir una verdadera conmoción social" ${ }^{\prime 32}$. En ese contexto la CGT regional realizó un "dramático" llamado a las autoridades y legisladores nacionales, provinciales y municipales para que promuevan algún tipo de solución a la desesperante situación de la desocupación en la ciudad. ${ }^{833}$ Poco después, el propio Caro Figueroa reveló que prácticamente se duplicó la cantidad de despidos y suspensiones de empleados entre marzo y mayo de este año. Y aclaró que "lo más grave en el último año" es que "ya la desocupación no es solamente el resultado de más personas buscando empleo, sino que se suman muchos trabajadores que tenían empleo anterior y lo perdieron". La conclusión daba por tierra con todos los argumentos optimistas que previamente había ensayado el gobierno. ${ }^{834}$ Lo afirmaba ahora un funcionario: "En el último año la economía argentina empezó a destruir empleo". Claro que la solución que preveía era la reforma del sistema laboral puesto que "Hay que disminuir los impuestos al trabajo porque ningún país puede mantener las cargos sociales que tiene la Argentina" ${ }^{35}$. Más directamente, la UIA proponía "bajar transitoriamente los salarios" de los trabajadores "para poder parar los despidos". Además, esto "ya se está aplicando" en numerosas empresas del país. ${ }^{836}$

En nuestra ciudad, la grave situación social motivó el anunció del intendente saliente, Mario Russak, del lanzamiento del Plan de Contención Alimentaria que planeaba distribuir alimentos en diferentes barrios. En palabras de Russak se trataba de "un paliativo, una asistencia social concreta a la situación de recesión que está atravesando en este momento el plan económico" ${ }^{837}$. En 1995, y en gran medida a contramano de los padecimientos de muchos trabajadores en relación a las consecuencias de las políticas económicas, la llegada de Antonio Cassia a la CGT marcó el momento de mayor cercanía de la entidad sindical con el gobierno nacional. Paralelamente, tal situación alentaba el surgimiento de otras entidades que asumían una perspectiva definitivamente crítica en torno de las políticas económicas

\footnotetext{
${ }^{828}$ L.C., 30/04/1994.

${ }^{829}$ L.C., $25 / 05 / 1994$.

${ }^{830}$ L.C., 19/09/1994.

831 "De acuerdo a las informaciones que disponemos, aproximadamente 45.000 personas en Mar del Plata están sin trabajo y/o no están ocupadas suficientemente, razón por la cual el 20\% de la población se encuentra bajo la línea de pobreza”. L.C.,26/12/1994. ${ }^{832}$ L.C., $14 / 06 / 1995$.

${ }^{833}$ L.C., 05/07/1995.

${ }^{834}$ Recordemos que Cavallo señaló que los índices de desempleo no necesariamente eran malas noticias porque se producían por un fuerte aumento en la voluntad de trabajar de las mujeres y los jóvenes, dado que la buena situación económica impulsa a mucha gente a incorporarse al mercado de trabajo.

${ }^{835}$ L.C., $11 / 07 / 1995$.

${ }^{836}$ L.C., $23 / 07 / 1995$.

${ }^{837}$ L.C.,27/07/1995.
} 
implementadas. Precisamente era el entendimiento de la CGT con el gobierno lo que generaba un espacio mayor para desplazar a nuevos lugares a quienes se instalaban en el terreno de la oposición. En ese marco, el MTA y el CTA, tras la realización de la Marcha Federal, convocaron a una huelga en contra de la política económica del gobierno, la cual no fue respaldada por la CGT. Mientras el MTA y la CTA preparaban el paro, Corach, secretario Legal y Técnico de la presidencia, ratificó que la medida de fuerza sería declarada ilegal, particularmente porque la convocatoria se realizaba por organizaciones sindicales que no tenían personería gremial. Caro Figueroa anunció entonces que el gobierno sancionaría a los sindicatos y trabajadores que adhieran. El hecho impactaba en las regionales de la entidad obrera, puesto que por las realidades locales, el grueso de los sindicatos adheridos a la entidad compartía las demandas expresadas en la medida de protesta. Sin embargo, al no haber sido declarado el paro por los cuerpos orgánicos de la CGT, muchas delegaciones locales se veían tensionadas entre el alineamiento político de la entidad nacional y la presión local. Así, la comisión directiva del SOIP informó que dispuso no adherir a la medida de fuerza anunciada. Explicaba que adoptó dicha decisión a partir de que la medida no fue resuelta por los cuerpos orgánicos de la CGT nacional. Al contrario, el sindicato de camioneros local ya dentro del MTA, decidió adherir a la huelga en rechazo de la política socio-económica. El secretario general Héctor Martínez y el adjunto Oscar Contarino se mostraron extrañados por las críticas que realizara Abdul Saravia "a esta justa demanda, ya que él parece olvidarse que el pavoroso problema de la desocupación (uno de los puntos del reclamo) ha impactado en su propio gremio con mayor contundencia que en otros de la ciudad". Expresaron "Nos llama mucho la atención que un hombre tan combativo como Saravia, hoy sea complaciente no sólo con el nefasto plan económico del gobierno, sino también brindando su apoyo a la CGT Nacional de Antonio Cassia". ${ }^{838}$

\section{- Repudiar la flexibilización}

Desde mediados del año 1994 el gobierno nacional impulsaba un nuevo estatuto para las Pymes que buscaba cambiar las relaciones de trabajo para fomentar el empleo sobre la base de aumentar los períodos de prueba, reducir las indemnizaciones, extender la jornada laboral y hasta reducir salarios. Volvía de este modo a plantear el tema de la flexibilización laboral. Ante esta situación, la CGT nacional buscó negociar los términos del estatuto procurando introducir algunos cambios favorables a los trabajadores. ${ }^{839}$ La CTA y Saúl Ubaldini rechazaron fervientemente la medida. La posición de la CGT regional fue más cercana a la de estos últimos. Durante un plenario de secretarios generales y de la mesa directiva se aprobó por unanimidad "rechazar y repudiar" el proyecto de "flexibilización laboral impulsado para las PYMES" calificándolo de "inconstitucional, inconsulto y negociado a espaldas de los trabajadores". Los dirigentes de gremios marplatenses recordaron que:

...esta fue la primera regional cegetista del interior en oponerse a la flexibilización y desde el mes de mayo de 1994 viene reclamando ante el Consejo Directivo Central de la CGT, la convocatoria al Plenario de Regionales para debatir este candente tema que amenaza con dejar en la absoluta indefensión a más del $80 \%$ de los trabajadores argentinos.

\footnotetext{
${ }^{838}$ L.C.,01/08/1994.

${ }^{839}$ Como el acuerdo por convenio colectivo de las condiciones laborales o la disminución de una plantilla de 150 a 40 trabajadores para que una empresa sea considerada Pyme.
} 
Por ello se envió una carta documento a la CGT central exigiéndole que "se abstenga de firmar ningún tipo de acuerdo con los empresarios y el gobierno sobre relaciones laborales". Además criticaron al organismo nacional porque "muy poco consultan a las regionales sobre los pasos a dar". Saravia afirmó que "no es cierto que la flexibilización garantice la creación de puestos de trabajo". Por todo ello se facultó a la mesa directiva a organizar una movilización en rechazo del proyecto flexibilizador. ${ }^{840}$

Finalmente, la ley que flexibilizaba las condiciones de contratación y trabajo para las Pymes fue aprobada en marzo de 1995. Esta medida produjo un nuevo giro dentro de la CGT. José Rodríguez, del SMATA, renunció a su cargo en la conducción nacional. Mientras que se expandían las críticas al, para estas alturas, ultra oficialista Antonio Cassia. En ese contexto, la CGT local volvía a distanciarse de la política económica del gobierno en virtud de las consecuencias que ésta arrojaba. En abril se pidió a la central obrera nacional que declare el estado de alerta y movilización en todo el país en demanda de "trabajo para la gente". Los dirigentes locales explicaban que "En el centro de nuestras preocupaciones está el desempleo y el subdesempleo que en Mar del Plata ha alcanzado a más de 45.000 personas que implican un 20 por ciento de la población local con las necesidades básicas insatisfechas". Y trazaban, nuevamente, un crudo panorama de la situación local:

...la crisis marítimo-portuaria con sus coletazos en la industria del pescado, la falta de reactivación en la construcción y sus actividades conexas, el cierre de fábricas, la caída del comercio minorista, el intento de privatización de los casinos nacionales, la ruptura de la cadena de pagos, son aristas conflictivas de la problemática social que hoy vivimos los marplatenses y que exige respuestas inmediatas [...] La CGT Regional Mar del Plata, como todo el interior del país no ha sido escuchada a la hora de las grandes definiciones. Obras Sociales, Reforma Laboral, Accidentes de Trabajo, son capítulos de una historia donde los trabajadores organizados que estamos en contacto diario con el afiliado hemos sido mudos testigos de negociaciones inconsultas.

En relación con el "nuevo estatuto para las PyMES", lo consideraron no sólo anti constitucional sino además anti obrero. Y finalizaban el documento pidiendo que:

...el Plenario de Delegados Regionales se expida en contra de todos los proyectos que cercenan los derechos sociales del trabajo, que declaren el estado de alerta y movilización en todo el país en demanda de trabajo para la gente, y genere un programa de encuentros con las fuerzas sociales, políticas, económicas, culturales y eclesiales de la Nación para promover un estado de justicia social. $^{841}$

Días después los delegados regionales de la CGT reclamaron la renuncia de los ministros de Trabajo y de Economía y exigieron al gobierno "un cambio de política" en medio de fuertes críticas al ajuste económico y denuncias por la "grave" situación social de los trabajadores. Además se declararon en estado de alerta y movilización y denunciaron que la crisis financiera y el ajuste económico "proyecta

\footnotetext{
${ }^{840}$ L.C.,19/01/1994. La CGT regional proponía la aplicación selectiva de la flexibilización solo para aquel empresario que realmente generase empleo. Y esta podía considerarse para los nuevos empleos, pero no para el conjunto de los trabajadores porque se perderían conquistas y antigüedad laboral. En ese contexto, se denunció que empresas de más de 150 empleados se estaban dividiendo para poder aplicar el estatuto de PyMES.

${ }^{841}$ L.C.,04/04/1995.
} 
sus peores sombras sobre los que menos tienen". Incluso el propio Cassia no descartó la posibilidad de decidir medidas de fuerza ante la "dramática situación social de los trabajadores". Mientras, en ese contexto, comenzó a impulsarse una renovación de la cúpula del movimiento sindical. ${ }^{842}$ Por el lado de la delegación local, al regreso del plenario nacional. Ésta emitió un comunicado que la alejaba definitivamente de la política económica implementada por el gobierno. Del modelo económico decía que "hasta ahora no ha logrado definir los perfiles industriales de un país moderno". Pues "El verdadero rostro de la crisis nacional no es financiero, sino productivo: este modelo económico no genera recursos genuinos para hacer frente a las obligaciones de una deuda, externa e interna, que, pese a todos los sacrificios, no ha cesado de aumentar". Al mismo tiempo cuestionaba el incremento del IVA dado que "se torna absolutamente inaceptable el traslado del aumento del IVA al costo de una canasta familiar que ya resulta inalcanzable para el bolsillo del trabajador" ${ }^{\prime 43}$. Poco después, la entidad local expresaba su apoyo y solidaridad con los trabajadores reprimidos en Tierra del Fuego. ${ }^{844}$ Pero a pesar de esta situación, la CGT local mantenía su organicidad respecto de las decisiones de la CGT nacional. Por ello no participó del paro nacional de 24 horas dispuesto por el CTA y el MTA. Aunque sí lo hicieron varios gremios locales vinculados con estas entidades. De la pesca y marítimos, llamaron a la huelga el Centro de Patrones de Pesca, SOMU, SICONARA y SAON.

El año 1995 prometía tiempos espinosos. Los efectos de la crisis del Tequila impactaban en la economía argentina. El propio Menem, reelecto, anunciaba la llegada de meses difíciles. ${ }^{845}$ Antonio Cassia renunciaba a la CGT tras señalar que su objetivo se había cumplido porque Menem fue reelecto. Lo reemplazó Gerardo Martínez quien se pronunció por una central obrera "independiente y autónoma" del gobierno y los partidos políticos y sostuvo que "no hay ningún impedimento", si es necesario, para realizar un paro contra la política económica. ${ }^{846}$ La entidad obrera buscaba de esta manera adquirir un perfil más combativo. De todos modos ni los gremios del MTA ni Lorenzo Miguel participaron en la elección de la nueva conducción. Sí volvía a la entidad Saúl Ubaldini para ocupar la secretaría de Interior. Este pronto viajara hacia Mar del Plata para entrevistarse con Saravia.

\section{- La unidad contra el modelo económico}

Hemos visto como la CGT regional, a pesar de su cada vez mayor oposición a la política económica, permanecía orgánica a las decisiones nacionales de la confederación. Pero es interesante que, a pesar de su organicidad y su filiación en el menemismo, durante la gestión de Saravia la CGT confluyó con la CTA y el MTA, coincidiendo no sólo en declaraciones sino también en acciones concretas de

\footnotetext{
${ }^{842}$ L.C., 05/04/1995.

${ }^{843}$ L.C., 07/04/1995.

${ }^{844}$ L.C.,15/04/1995. Se trataba de la represión a los trabajadores metalúrgicos de Tierra del Fuego, jornada durante la cual fue asesinado el obrero Víctor Choque. Al contrario, desde la CGT Nacional, Cassia denunció la "politización” de los conflictos y la influencia de la extrema izquierda que fomentaba los desbordes sociales. Por su parte, el CTA y el MTA exigieron la renuncia del gobernador de Tierra del Fuego y convocaron a un paro nacional de 24 horas. L.C.,16/04/1995; 18/04/1995; 20/04/1995.

${ }^{845}$ L.C.,06/06/1995.

${ }^{846}$ L.C.,02/07/1995. Martínez también afirmó que la CGT "no va a tolerar que el sector empresario siga utilizando a los trabajadores como variable de ajuste, y si no tenemos una solución a la desocupación", los empresarios van a "encontrar a la CGT en la vereda de enfrente y dispuestos a confrontar". Reclamó al gobierno "poner la economía al servicio del hombre" advirtiendo que "hoy está al servicio de los mercados". L.C.,05/07/1995.
} 
lucha. ${ }^{847}$ Ya en 1995, CGT local y CTA, junto al FREPASO, se opusieron a la cesantía de trabajadores de Luz y Fuerza cuando los nuevos dueños pretendían encarar la privatización de la empresa de energía eléctrica. ${ }^{848}$ Días después de aquello, Saravia anunciaba el inicio de contactos entre la CGT, la CTA y el MTA con la intención de unificar al movimiento obrero local. El dirigente expresó "La mesa central de la CGT de Mar del Plata ha resuelto recibirlos [al MTA y CTA], porque queremos lograr la unión de todos los trabajadores, que no se pudo hacer en Buenos Aires, pero si en Mar del Plata". Se trataba de la búsqueda por coordinar acciones en conjunto frente a la crisis, aunque advertía que existían diferencias señalando que no se puede pegar una unidad con engrudo, para que al poco tiempo se despegue. ${ }^{849} \mathrm{De}$ este modo se constituyó la Mesa de Enlace Gremial Marplatense, la cual convocó a un paro con consignas básicas que permitían la unidad. Estas eran "contra la desocupación; por la reincorporación de los cesantes de la ESEBA; por la reactivación del aparato productivo" ${ }^{850}$. Finalmente el 21 de julio se 11 evó a cabo la movilización conjunta de las tres entidades sindicales, junto a organizaciones vecinales, partidos políticos y otras organizaciones de la sociedad civil, congregando alrededor de 7 mil personas. Abdul Saravia, por una "dolencia física" no pudo estar presente. La crónica decía: "Una verdadera multitud marchó [...] desde la avenida Luro y Olazábal hacia el edificio de la Municipalidad local en protesta contra el grave problema de desocupación". Luego se refería a los manifestantes, quienes se movilizaron: "en una cantidad que aparece como inédita en la historia de las movilizaciones realizadas en una ciudad como la nuestra que -por lo menos hasta ayer-, aparecía como 'fría' en relación a lo que sucedía en otros puntos del país". La marcha, que se desarrolló con normalidad, estuvo signada por los cánticos de protesta contra el gobierno nacional y sobre todo contra Cavallo y su política económica. ${ }^{851}$ En agosto de 1995 la CGT local decretó el estado de alerta y movilización en defensa de las fuentes laborales y en solidaridad con los desocupados y despedidos. En plenario de secretarios generales responsabilizó "al ministro Cavallo y al modelo económico por la grave situación que atraviesan los trabajadores" "852 . Pidió por la reactivación de la industria, el otorgamiento de créditos para las PyMES y la realización de obras públicas. Por otra parte, la entidad rechazó las pretensiones del gobierno de rebajar aportes patronales, realizar recortes salariales y flexibilizar el trabajo como supuestas salidas al desempleo. Por último, se invitó a los trabajadores a la marcha hacia San Cayetano en pedido de pan, paz y trabajo. Luego se sumaron a la convocatoria la CTA y el MTA. La consigna "Basta de despidos y trabajo para todos" unificaba nuevamente a los gremios. El día 7 de agosto se llevó a cabo la procesión a San Cayetano, la

\footnotetext{
${ }^{847}$ Esta acción concuerda con la afirmación acerca de que durante 1996 se produce una unidad de acción a nivel nacional de los cuadros sindicales de la CGT, CTA, MTA, CCC, 62OP que convocan y adhieren a las huelgas generales (Iñigo Carrera y Cotarelo, 2000).

${ }^{848}$ El sindicato local de Luz y Fuerza, enemistado con la Federación Nacional, fue uno de los puntales del CTA en Mar del Plata. L.C.,06/07/1995.

${ }^{849}$ L.C., $14 / 07 / 1995$.

${ }^{850}$ L.C., $19 / 07 / 1995$

${ }^{851}$ L.C.,22/07/1995. Según la crónica, las entidades presentes fueron (posiblemente hayan sido más) Luz y Fuerza, Asociación Bancaria, UTEDyC, Instituto Movilizador de Fondos Cooperativos, Sindicato de Camioneros, UTA, SUTEBA, Sindicato de Locutores, Sindicato de Prensa, Sindicato de Maestranza, Asociación de Empleados Casinos; Agrupación Radical de Empleados de Casinos, Sindicato de Empleados de Comercio, Partido Solidaridad, Alianza Sur, ATE, Agrupación Verde del Pescado, Lista Blanca del Peronismo, Sindicato de Trabajadores Municipales, Frente Grande, FREPASO, Sindicato del Gas, Movimiento Vecinal Marplatense, UOM, Mesa de enlace de Jubilados y Pensionados del CTA.

${ }^{852}$ L.C., 02/08/1995. Mediante un documento señalaban que "hoy en Mar del Plata los desocupados y subocupados son casi 50 mil. Frente a esta realidad no caben discursos ni promesas, sólo son válidas las respuestas concretas. Ante la dramática situación del empleo en la ciudad y la falta de perspectiva a corto plazo, la mesa directiva y el plenario de secretarios generales resuelve declarar el movimiento obrero local en estado de alerta y movilización en defensa de las fuentes laborales y en solidaridad con los compañeros desocupados y despedidos".
} 
cual fue, según el diario, multitudinaria. El monseñor José María Arancedo, obispo de Mar del Plata, consideró que se trató de "un llamado a toda la comunidad-de modo particular a la dirigencia política-, a la solidaridad real; solidaridad que tiene que manifestarse en equidad, que no crezca el número de excluidos, sino que vaya bajando". En el mismo momento se produjo la concentración de la CGT, el MTA y el CTA. ${ }^{853}$

Al día siguiente, la CGT nacional convocó a un cese de tareas y movilización para el 6 de septiembre en reclamo de cambios en la política económica del gobierno. De inmediato la CGT regional adhirió a la medida e invitó a participar al MTA y el CTA. ${ }^{854}$ Días después, en plenario de delegados, con la presencia del MTA, se aprobó por unanimidad acatar el paro y proponer una movilización a Buenos Aires. Se decidió también trasladar a las autoridades de la CGT nacional la voluntad de los gremios locales de propender a la unidad de los trabajadores, mostrando como antecedente la cohesión lograda en esta ciudad. ${ }^{855}$ La gota que rebalsó el vaso fue el decreto que redujo los aportes patronales para las obras sociales. El documento acordado por las entidades locales insistía en la crítica hacia el modelo económico que "excluye a las mayorías nacionales; prioriza la moneda y el mercado sobre el trabajo y la industria nacional, llevando al cierre de fábricas, colapso de pequeñas y medianas empresas y concentración económica en manos de pocos empresarios y banqueros" ${ }^{856}$ El 6 de septiembre se produjo el paro. Esta vez incluyendo al SOIP, todos los gremios marítimos y portuarios participaron de la medida de fuerza que contó con un $80 \%$ de adhesión. ${ }^{857}$ En el plano nacional, el único orador fue Gerardo Martínez. Dado que en su discurso atacó la política económica pero evitó mencionar al presidente Menem, el MTA y el CTA se retiraron de la Plaza de Mayo.

Con todo, lo cierto es que luego de la reelección de Carlos Menem, la situación socio-económica no hizo más que desmejorar. La lucha contra la desocupación y la flexibilidad laboral encontró hermanadas a las distintas corrientes sindicales. Hacia finales del año 1995 la CGT y las 62 OP locales, con las firmas de Abdul Saravia y Nicasio Astrada, elaboraron un documento sobre la situación laboral que desbordaba el tono de decepción luego de seis años de gobierno menemista, del que los firmantes se sentían parte.

La clase trabajadora ve con asombro e incredulidad como en el transcurso de los últimos años, quienes pusieron su sacrificio para cristalizar lo que nos prometieron, solo 'supimos conseguir' mayor desempleo, mayor pobreza, y mayor concentración de la riqueza en manos de unos pocos; situación que sólo afecta al sector trabajador, sino también a parte del empresariado industrial argentino. ${ }^{858}$

Para estas alturas, la enarbolada estabilidad ya no resolvía los problemas de las grandes mayorías y el modelo económico demostraba sus dramáticas consecuencias. En 1996, y a pesar de los deseos de Saravia de continuar en la conducción de la entidad gremial, fue reemplazado por el dirigente casinero Daniel Rodríguez, acompañado por Héctor Martínez, del MTA, como adjunto. La cercanía de Saravia con

\footnotetext{
${ }^{853}$ L.C., 08/08/1995.

${ }^{854}$ L.C., $10 / 08 / 1995$.

${ }^{855}$ L.C. $23 / 08 / 1995$.

${ }^{856}$ También instaba a "modificar el modelo económico; revisar la deuda externa; fomentar una política industrialista; y crear las condiciones óptimas para reactivar el aparato productivo" considerando que son las necesidades actuales para "desarrollar un modelo de país socialmente justo, económicamente libre y políticamente soberano”. L.C.,01/09/1995.

${ }^{857}$ L.C., 07/09/1995.

${ }^{858}$ L.C., $17 / 11 / 1995$.
} 
Menem, valorada antes como un signo positivo, se volvía ahora, tras las consecuencias del modelo económico implementado, su principal defecto. La CGT local buscaba ahora constituirse en un polo de marcado carácter opositor. ${ }^{859}$ No le valía de mucho su disposición, siempre tensionada entre lealtades, a continuar en el "puesto de lucha".

\section{EI SOIP y los servicios sindicales}

Como muchos gremios, una de las características del modo de intervención sindical fue la apelación a estrategias integradoras y de ciudadanización de los trabajadores dentro de la propia órbita gremial, lo que al mismo tiempo reforzaba la identidad en tanto trabajadores. En ello eran un gran aporte los servicios que ofrecía el sindicato, así como la recurrencia a prácticas ritualizadas de festejos y eventos donde se reunían trabajadores y trabajadoras. Algunas de esas prácticas provenían de la tradición anarquista. Dentro del ámbito de las fiestas, los anarquistas festejaban el día del obrero del pescado realizando un picnic, veladas teatrales y celebraciones particulares. La costumbre continuó incluso durante la gestión de Saravia con modificaciones propias de la nueva cultura política. Lo cierto es que año tras año, los días 10 u 11 de diciembre se celebraba el día del Obrero del Pescado por lo general con un picnic que incluía una serie de celebraciones, a las cuales solían asistir más de 4 mil personas, participando de juegos (carrera de embolsados, carrera de peludo en carretilla), rifas, bailes y el otorgamiento de premios. Aquellas reuniones se realizaban en el Complejo Polideportivo Juan Domingo Perón. ${ }^{860}$ Dado que también el deporte era una preocupación en el gremio, se construyó ese polideportivo con cuatro canchas de fútbol para mayores, tres para menores, dos canchas de bochas, una cancha de tenis, una cancha de voleibol yuna pista de atletismo.

Desde 1948 data la elección de la Reina del Pescado. Allí trabajadoras competían por el podio y, paralelamente, se producía la elección del más feo de la industria del Pescado. Esta tradición también pervivió durante la gestión de Saravia, siendo uno de los momentos más esperados del año en el gremio. Espacio que se aprovechaba para invitar a distintas personalidades o funcionarios del poder local, como por ejemplo, el Juez Julio Pettigiani quien alguna vez oficio de juez en la elección. Tras la muerte de Saravia todos estos festejos decayeron. Lo que habla también de una pérdida de espacios de sociabilidad y de vinculación de los trabajadores y trabajadoras. Por otro lado, se consolidaron a partir de mediados de los setenta buena parte de los servicios que el gremio proveía a sus afiliados. Por ejemplo el Instituto Jardín Maternal Eva Perón fue inaugurado en el año 1975 con el aporte de 20 millones de pesos cedidos al gremio por el gobierno de la provincia de Buenos Aires, en ese entonces, a cargo de Victorio Calabró. ${ }^{861}$ También en el pensamiento del líder del SOIP aparecía la necesidad de formación y capacitación de los trabajadores y fundamentalmente de los delegados y delegadas en diferentes aspectos y materias que afectaban su vida y trabajo. Por eso fomentó el desarrollo de la Escuela de Capacitación Sindical, Cultural y Deportiva "22 de Agosto", la cual llevaba el nombre de la fecha en que se fundó el

\footnotetext{
${ }^{859}$ Entrevista del autor con Daniel Di Bartolo op. cit...

${ }^{860}$ L.C.,11/12/1989; 13/12/1994.

${ }^{861}$ L.C.,22/02/1975. Saravia explicaba que la creación apuntaba a que "los obreros de nuestro gremio puedan ir a trabajar tranquilos porque sus hijos son atendidos por el sindicato en esta gran guardería”. L.C.,01/09/1975.
} 
SOIP ${ }^{862}$ Otra de las áreas donde la conducción gremial buscó expandir los servicios brindados fue la salud. En ese sentido, en octubre de 1975 se puso en función una Unidad Sanatorial Móvil que contaba "con todos los elementos necesarios para efectuar relevamientos sanitarios como así para brindar asistencia en todo tipo de emergencias y urgencias médicas". La CD del SOIP recibía el vehículo con "la alegría del deber cumplido para con los obreros del pescado, beneficiarios directos de esta nueva conquista" y también se ponía al servicio del "pueblo todo de Mar del Plata que tenga necesidad, fundamentalmente de aquellos sectores marginados en sus posibilidades a los que el SOIP reconoce como pueblo de Perón..." ${ }^{863}$. Otro de los importantes logros consistió en la construcción de un policlínico de alta tecnología. El mismo comenzó a edificarse a finales del año 1974 con el aporte del Instituto Nacional de Obras Sociales. ${ }^{864}$ Luego se ampliaron sus instalaciones y se compró una ambulancia. ${ }^{865}$ En 1982 la obra social del SOIP contaba con 65.000 beneficiarios. ${ }^{866}$ En 1984, antes de las elecciones, Saravia enumeraba entre los logros de su gestión la construcción de un "moderno sanatorio". ${ }^{867}$ Luego,el policlínico fue perdiendo áreas y capacidades al calor del descenso en el número de afiliados. A finales de la década del '90, por las deudas contraídas, la obra social se encontraba embargada.

La gestión de Saravia también adquirió las tierras y construyó una nueva sede sindical, esta vez en el puerto de la ciudad, anexada al policlínico de la obra social del SOIP. Entonces el gremio tenía, según su secretario general, 9.500 afiliados. ${ }^{868}$ Veinticinco años después, en el año 2000, la sede del SOIP estuvo a punto de ser rematada judicialmente por una deuda que el sindicato mantenía con un abogado. ${ }^{869}$ Por otra parte, a mediados de los años ' 80 s se construyó el comedor para jubilados y pensionados. Varios días a la semana el propio Saravia comía allí, compartiendo el almuerzo con los trabajadores y trabajadoras retirados. Otra de las iniciativas de Saravia fue la construcción del complejo habitacional del SOIP “José Ignacio Rucci”. La idea era construir una serie de viviendas para los afiliados al gremio por lo que el sindicato adquirió un predio de 33 hectáreas en una zona relativamente cercana al puerto y que, vía un plan de financiación, permitiría a los trabajadores y trabajadoras poseer sus propias residencias. Presentado en 1975, planeaba construir 2 mil departamentos de cuatro ambientes cada uno. ${ }^{870} \mathrm{El}$ complejo finalmente comenzó a construirse a finales de la década del '70 a través de la Sociedad Civil Complejo Habitacional SOIP. ${ }^{871}$ Los nombres de los monoblocks hablaban de la identidad del conductor

\footnotetext{
${ }^{862}$ La importancia de esta institución es resaltada por un dirigente gremial opositor a Saravia "Lo que yo valoro de Saravia es que él tenía una escuela de capacitación. Había una escuela de capacitación. Y yo en esa escuela vi muchos compañeros que eran de la oposición y estaban en la escuela de capacitación. Porque más allá de la idea política si a mí me están enseñando como me debo defender yo debe aprovechar eso. Y si hay cosas que no conozco debo ir para aprenderla". Entrevista del autor con Alberto "Beto" Rosa... op. cit.

${ }^{863}$ L.C., $14 / 10 / 1975$.

${ }^{864}$ L.C.,11/11/1974. "Fue inaugurado ayer el sanatorio del SOIP".

${ }^{865}$ L.C., $15 / 09 / 1979$.

${ }^{866}$ L.C., $27 / 06 / 1982$.

${ }^{867}$ El policlínico constaba de "planta baja y tres pisos, más un amplio subsuelo. Consultorios externos, áreas de internación con trece habitaciones con baños privados de dos camas cada una y otras 8 de tres camas con baño privado. Sala de terapia intensiva, de partos; nursery; sala de recuperación para recién nacidos; dos quirófanos, sala de preparación para cirugía compuesta con cuatro camas; sala de esterilización accionada a electricidad y gas, ecógrafo, banco de sangre y plasma, cocinas, hornos, radiología, odontología, etcétera".

${ }^{868}$ L.C.,07/10/1974.

${ }^{869}$ L.C.,25/03/2000. La deuda se originó hacia finales de la década del ' 80 cuando a instancias de Abdul Saravia el SOIP inició y ganó un juicio contra el INIDEP por la pesca ilegal de vieyra. El abogado que llevó la causa reclamó el pago de los honorarios al SOIP que inicialmente fueron de 25 mil pesos, pero en el año 2000 ascendían a 210 mil. El día del remate, algunos trabajadores se movilizaron para manifestar su oposición. Finalmente el remate no se hizo dado que no se presentaron tampoco oferentes.

${ }^{870}$ L.C. $20 / 04 / 1975$

${ }^{871}$ L.C.,26/09/1979.
} 
del SOIP:Vicente Leônidas Saadi, Pedro Giachino, Nestor Saravia, Carlos Menem Junior. Sin embargo, el ambicioso proyecto traerá numerosos dolores de cabeza a la conducción gremial y mayormente a los habitantes del complejo, particularmente después del proceso hiperinflacionario, puesto que obligó a reestructurar los pagos y demoró las obras. Por ello serán recurrentes las manifestaciones de vecinos del complejo SOIP en contra del Consejo de Administración e incluso de la propia persona de Saravia. ${ }^{872}$ Inclusive llegaron a formalizar una agrupación llamada "Unión de los Estafados del Faraónico Fracasado Plan Habitacional del SOIP", ${ }^{873}$

\section{Corrientes opositoras al interior del SOIP}

A diferencia del SOMU, y aunque la conducción permaneció por muchos años dentro del sector vinculado a Saravia, el SOIP se caracterizó por una importante historia de competencia sindical. Hemos visto ya que la principal oposición a Saravia durante la década del '70 nació del seno del peronismo. Corino Díaz, antiguo compañero de conducción, agrupó las críticas y encabezó la oposición. Desde 1971 hasta 1973 se registraron varios enfrentamientos entre los dos grupos, los cuales fueron desde pedidos de impugnación de las elecciones sindicales hasta episodios de violencia armada, pasando por golpes de puño y el incidente de la toma y ocupación de la sede sindical. Por ejemplo, días previos a la elección de 1971, mientras integrantes de la Lista Naranja se encontraban pegando afiches, fueron agredidos con armas de fuego desde el interior de cinco vehículos. En ese episodio Díaz fue lesionado en su pierna derecha, por lo que tuvo que ser internado. Los atacantes pertenecían, presuntamente, a la lista Azul y Blanca. Tiempo después, el auto de Corino Díaz estacionado en la puerta de su domicilio recibía otro ataque con armas de fuego. ${ }^{874}$ En el mes de mayo Díaz, junto a un grupo de afiliados, ocupaba la sede del SOIP. ${ }^{875}$ Desde allí emitía un comunicado donde directamente denunciaba la presencia de "matones a sueldo" en el SOIP sostenidos por la conducción gremial. ${ }^{876} \mathrm{La}$ intención del grupo, que consideraba fraudulenta la victoria de Saravia, era que se propiciara un nuevo llamado a elecciones, donde buscaría desplazar a la conducción saravista. ${ }^{877}$ Luego de la ocupación de la sede gremial, Díaz y su grupo fueron

${ }^{872}$ Ver L.C.,31/08/1989; 06/12/1989; 09/12/1989; 26/06/1990; 05/03/1991. El día 12 de agosto, por ejemplo, vecinos del barrio SOIP se manifestaban frente a Tribunales quejándose de la prolongación de las cuotas que se debían abonar. En la foto del periódico que da cuenta de la protesta se puede ver una pancarta con la consigna "Saravia en contra de la Justicia Social". L.C.,13/08/1992.

${ }^{873}$ L.C., 14/08/1992.

${ }^{874}$ Archivo DIPPBA, Mesa B, Factor gremial, Carpeta 57, Legajo 17, Folio 136, 13/01/1972.

${ }^{875}$ La ocupación se produjo el 3 de mayo de 1972 protagonizada por alrededor de 20 personas armadas. Durante la misma se efectuaron no menos de cinco disparos. L.C.,04/05/1972. Días después la sede del SOIP era víctima de un atentado cuando una bomba estallaba en su puerta. Desde la conducción del gremio apuntaron directamente contra Corino Díaz "La comisión directiva del Sindicato de la Industria del Pescado, en reunión extraordinaria convocada como consecuencia del cobarde atentado de que fuera objeto la sede de la entidad, y considerando que el mismo obedece a la campaña promovida desde hace tiempo por elementos desplazados de la conducción que pretenden por la violencia anarquizar la organización con el único fin de obtener legalmente y con padrinazgos espurios el manejo del sindicato...". L.C.,17/05/1972.

${ }^{876}$ Archivo DIPPBA, Mesa B, Factor gremial, Carpeta 57, Legajo 17, Folio 133, 03/05/1972.

${ }^{877}$ Corino Díaz recordaba la llegada al gremio mediante una toma contra el entonces dirigente anarquista Roberto Croccito. En relación a la nueva toma, defendía la acción diciendo "La toma fue decidida por la mayoría del gremio, harto de la inconducta de la comisión directiva, después de meses de peticiones y gestiones para modificar la actitud entreguista de estos mal llamados dirigentes". Y se quejaba del mal funcionamiento de la asamblea del gremio por culpa de la CD. Entendía que Saravia sólo se imponía en ella a través de maniobras y la presencia de barras y pistoleros. Después de calificar de entreguista a Saravia enumeraba los males de la conducción que "no resuelve los problemas individuales de cada uno de los grupos obreros de distintos establecimientos, permite el funcionamiento de plantas clandestinas, no convoca a elecciones para renovar los cuerpos 
expulsados del sindicato. Al año siguiente, el secretario de Organización del SOIP sufría una balacera sobre su domicilio. ${ }^{878} \mathrm{La}$ violencia armada se daba en el SOIP entre fuerzas peronistas que lejos estaban de posiciones "izquierdistas" "779. Lo interesante de estas disputas, que conocemos a través de los referentes de ambos grupos, es que no se limitaban ni a acciones armadas ni al nivel cupular, sino que muchas veces implicaban la movilización de trabajadores y trabajadoras. Por ejemplo, el 30 de abril de 1973 se produjo un paro del que participaron alrededor de 2.000 personas. La medida se realizó tras un escándalo suscitado en la asamblea de trabajadores, luego de aceptarse la formación de una comisión verificadora de fondos. Se produjeron golpes de puño y se sacaron a relucir armas de fuego. Al mes siguiente, ante el despido de un trabajador, la fracción disidente llamó a realizar otro paro, cuya convocatoria fue rechazada por la conducción. No obstante, la medida de fuerza convocó alrededor de 3.000 obreros y obreras. ${ }^{880}$

Por otro lado, al calor del impacto del "Cordobazo" fueron creciendo en Mar del Plata, como en el resto del país, las corrientes "clasistas" dentro de los sindicatos. En ese marco, la presencia de agrupaciones y fuerzas de izquierda se produjo también dentro del sindicato industrial que, en ese entonces, poseía el mayor número de afiliados de la ciudad. ${ }^{881}$ Las tendencias "combativas" estaban representadas por pequeños agrupamientos y organizaciones que contaban, en su mayoría, con delegados en las plantas pesqueras. Las diferentes corrientes que intervenían estaban relacionadas con el peronismo de base (Agrupación 26 de Julio), el PC (Movimiento Unificador del Pescado), el PCR (Agrupación $1^{\text {ro }}$ de Mayo), la Unión Obrera Local (viejo nucleamiento anarquista), el PCML (Agrupación Lista Bordó) y el PST (Agrupación Clasista de los Trabajadores del Pescado) principalmente. Posteriormente surgió el Movimiento Sindical de Base orientado por el PRT - ERP y la Agrupación Evita que formaría, ya en 1973, parte de la JTP (Ladeuix, 2013; Yurkievich, 2012). ${ }^{882}$ En 1973 la izquierda logró presentar una lista propia liderada por Julio Manza, militante del PST. Desde allí, fue más o menos constante el enfrentamiento de la conducción con "los zurdos". A veces asumirá una forma discursiva, otra con golpes de puño y en ocasiones bajo el imperio de las armas. Según Ladeuix (2013) Saravia lograría sortear los conflictos del ' 70 recurriendo en más de una ocasión a prácticas violentas. Por ejemplo, en agosto de 1973, delegados y trabajadores de la planta Galeote que se encontraban en huelga denunciaron las continuas actitudes gansteriles de las que hacían responsables a los directivos del sindicato y "sus matones a sueldo". Dirán: "Estábamos cumpliendo la segunda jornada de huelga y los mismos integrantes de la comisión directiva del SOIP con un grupo de matones, que son ajenos al gremio, se

\footnotetext{
de delegados aunque los mandatos estén vencidos y simplemente porque sabe que serán reelectos los mismos, que no lo apoyan, no se atiende los reclamos y se amenaza a los delegados que se niegan a respaldarla". L.C.,07/05/1972.

${ }^{878}$ Archivo DIPPBA, Mesa B, Factor gremial, Carpeta 57, Legajo 17, Folio 165, 08/06/1973.

${ }^{879}$ La Lista Azul y Blanca respondía advirtiendo "No aceptamos la violencia como expresión de democracia sindical, pero entendemos que de no adoptar los poderes públicos las medidas necesarias para ponerle fin habremos de asumir las actitudes que corresponden en defensa de nuestros derechos".

${ }^{880}$ Archivo DIPPBA, Mesa B, Factor gremial, Carpeta 57, Legajo 17, Folio 155, 13/01/1972.

${ }^{881}$ Según Ladeuix (2013) la composición gremial marplatense a comienzos de la década del ‘70, si bien distaba de ser propia de una ciudad altamente industrializada, tuvo características particulares: un marcado peso de los sindicatos relacionados a las actividades pesqueras y de la construcción. El SOIP alcanzaría a tener más de 12.000 afiliados a mediados de la década.

${ }^{882}$ Es difícil mensurar la influencia que tenían estas corrientes en la vida gremial. Pues si bien su peso electoral no era significativo, no podemos reducir los observables a los mecanismos y procesos institucionales. Un dato revelador es que cada corriente poseía, al menos, un delegado. Asimismo, su participación en acciones gremiales también era evidente. Por su puesto es importante su presencia en las movilizaciones durante la firma del convenio colectivo de trabajo en 1975. También, previamente, participaron del paro convocado por los disidentes del SOIP relacionados al grupo de Corino Díaz.
} 
lanzaron a romper la huelga". ${ }^{883}$ Denunciaban también la presencia de personas ajenas al gremio. Durante una medida de fuerza llegaron hombres a bordo de varios autos y atacaron a golpes a los trabajadores. En aquellos días era común que los trabajadores y trabajadoras vinculados con las agrupaciones de las izquierdas se nuclearan en la Plaza Manuel Belgrano, rebautizada como Plaza de los Fileteros. Allí se realizaban reuniones y asambleas buscando obtener algún grado de coordinación entre las distintas fuerzas. Tanto en la memoria de los militantes, como también de personas vinculadas a Saravia, se cuentan varios enfrentamientos entre los grupos gremiales opuestos ${ }^{884}$ Con todo, lo cierto es que un grupo de personas vinculadas al sindicato y que cumplía tareas de amedrentamiento funcionaba dentro de las herramientas que el estilo de conducción -y las circunstancias- volvían válidos para dirimir la pugna gremial y que, visiblemente, resultaban bastante eficaces. ${ }^{885} \mathrm{Su}$ uso no se limitaba a los enfrentamientos contra las corrientes que mantenían orientaciones políticas diferentes (como las corrientes relacionadas con el llamado "clasismo") sino también con adversarios surgidos en el mismo seno de la conducción sindical. Incluso, podía llegar a servir para amedrentar a empresarios codiciosos que desconocieran o se negaran a otorgar algún beneficio a los trabajadores.

Luego del golpe de marzo de 1976, el SOIP fue intervenido y parte de la conducción gremial fue encarcelada. Pero la intervención duró poco y el sindicato fue devuelto a la Comisión Directiva. Al frente del gremio quedó Néstor Lucero hasta el regreso de Saravia, quien volvió a liderar el SOIP con mandato prorrogado. Durante aquellos años del Proceso, la represión al movimiento obrero implicó particularmente que las organizaciones "clasistas" fueran duramente perseguidas por la dictadura, provocando desapariciones, asesinatos, cárcel o exilio. Pero si bien se produjo este proceso de eliminación y detención de los cuadros obreros y se buscó desarticular las prerrogativas conquistadas a partir del CCT de 1975, la economía pesquera en el corto plazo vivió unos años de crecimiento. Así, la renovada expansión de la actividad industrial pesquera a partir de 1977 produjo que la pesca volviera a constituirse en un centro de absorción de mano de obra. Por aquellos años fue significativa la inmigración recibiendo la ciudad trabajadores y trabajadoras provenientes de localidades vecinas así como también de otras provincias como Santiago del Estero y el litoral. Además, arribó a la ciudad una importante camada de trabajadores y trabajadoras perseguidos por las dictaduras chilena y uruguaya, sujetos que portaban una experiencia sindical y/o política previa (Pradas, s/f). Durante los años de dictadura la militancia y el activismo obrero, si bien sufrieron un fuerte impacto, no desaparecieron completamente, existiendo procesos conflictivos tanto subterráneos como públicos. ${ }^{886}$ Por ejemplo, en 1980 un panfleto aparece en

\footnotetext{
${ }^{883}$ L.C.,07/08/1973. También El Atlántico publicó la información "Un numeroso grupo de obreros de la planta de fileteado Galeote y de otros establecimientos fueron baleados por individuos que, aunque oficialmente no fueron identificados, testigos insisten en haber reconocido a varios dirigentes del Sindicato Obrero de la Industria del Pescado”.E.A., 07/08/1973.

884، "Lo que recuerdo de aquel tiempo es que se hacía una asamblea en la Plaza de los Fileteros, en Juramento y Ortiz de Zárate y se armaba una de tiros ahí que... ese era el lugar, la cita de todos los trabajadores del Puerto". Entrevista del autor con Alberto "Beto" Rosa... op. cit. Quien, de todos modos, luego integrará por un breve tiempo la lista de Saravia en 1984.

${ }^{885}$ En cierto modo, estas prácticas con una menor asiduidad tal vez por el cambio en el contexto, se mantuvieron. Elda Taborda señala que durante la primera movilización de la CGT en contra de la última dictadura sufrieron un ataque de "la patota del SOIP" con Saravia a la cabeza. Allí uno de los hijos de Saravia habría apuñaló al militante/trabajador Alejandro Lantzev. Por otra parte, en 1990 la Lista Verde denunciaba haber sufrido un atentado en contra de su local, al cual le habrían disparado 8 balazos. Integrantes de la lista denunciaron que "se ha desatado una campaña de intimidación y amenazas contra los afiliados y dirigentes de la Lista Verde por parte de la conducción oficial del gremio”. L.C.,11/08/1990.

${ }^{886}$ A pesar del clima represivo y del retroceso generalizado de la actividad gremial, ésta no desapareció por completo. Para el período 1976-1983 hemos encontrado que se sucedieron episodios como la realización de asambleas, distribución de panfletos, pintadas, reclamos por mejoras salariales, ocupación de una planta pesquera por deudas salariales. Ver Archivo DIPPBA, Mesa B, Factor gremial, Carpeta 57, Legajo 17 “SOIP”. Entrevistados también mencionaron una toma de la sede sindical del SOIP
} 
las calles del puerto titulado "A los obreros de la Industria del Pescado", el cual criticaba fuertemente la política económica impulsada por Martínez de Hoz y estaba firmado por "Obreros Comunistas de la industria del pescado". ${ }^{87}$ En concreto, por aquellos años era evidente que existían organizaciones pequeñas que se reunían clandestinamente, integradas por trabajadores que habían tenido alguna militancia en organizaciones de izquierda en el periodo pre-dictatorial. De esa experiencia surgirán algunos integrantes de la Lista Celeste.

\section{La Lista Celeste - Unión Obrera del Pescado}

Como afirma Pradas (s/f) la historia de este agrupamiento obrero hunde sus raíces en las organizaciones de izquierda y "clasistas" que participaron de la vida gremial y política del SOIP durante la década del '70. Transitado el auto llamado Proceso de Reorganización Nacional, la recuperación democrática marcó un hecho inédito en la historia argentina, pues por primera vez el radicalismo le ganaba en elecciones libres al peronismo. Como sabemos, al asumir Raúl Alfonsín a la presidencia buscó, entre otras cuestiones, producir una modificación de la estructura sindical argentina. Aquel intento, posteriormente fracasado, implicó también una fuerte crítica a las conducciones gremiales peronistas, la cual sirvió para que en todo el país cobraran aliento corrientes sindicales opositoras que se alineaban detrás del pedido de una mayor democratización sindical. En Mar del Plata se produjo una oleada de listas opositoras en diferentes gremios. En el SOIP, ante el proceso electoral que se avecinaba, y como modo de disputarle la conducción a Saravia, diferentes agrupaciones opositoras con activistas provenientes de la izquierda peronista y de la izquierda marxista se unieron para competir electoralmente, manteniendo cada agrupación su independencia. En este contexto surgió la Unión Obrera del Pescado - Lista Celeste unificando a varias agrupaciones opositoras, siendo las cuatro principales: la agrupación 11 de Marzo (vinculada al Partido Intransigente), el Movimiento 2 de Abril (PC) ${ }^{888}$, Agrupación 22 de Agosto (Peronismo de Base) y la Juventud Peronista del Puerto. ${ }^{889}$

Previo a las elecciones de 1984 Edgardo Gabin, Rafael Valdez y Román Cáceres, integrantes entonces de la Celeste, respondían públicamente desdiciendo los dichos de una presunta campaña abierta para tachar de izquierdista a la agrupación. Lo curioso es que estos trabajadores militantes se sentían en la necesidad de aclarar que no eran tal cosa. Luego de mencionar que la Celeste se armó mediante un frente integrado por diferentes agrupaciones "en su inmensa mayoría integrada por justicialistas, salvo la 2 de Abril que es un movimiento aperturista donde se encuentran radicales, hombres y mujeres del Partido Intransigente, pero desconocemos que haya militantes del Movimiento Al Socialismo, por ejemplo" ${ }^{890}$ En cuanto a los objetivos al llegar al gremio exponían que:

durante el año 1979, aunque no hemos encontrado registro de ella. Mientras que, aunque "vigilado", el sindicato pudo continuar con sus tareas de representación de los trabajadores.

${ }^{887}$ Archivo DIPPBA, Mesa B, Factor gremial, Carpeta 57, Legajo 17, Folios 216 a 220.

${ }^{888}$ El día del desembarco de las tropas argentinas en Malvinas un grupo de trabajadores se reunió y decidió ponerle a su agrupación el nombre Movimiento 2 de Abril - Trabajadores del Pescado. Allí estuvieron Carlos Rosales, Alejandro Lantzev, Luis Cabrera, Miguel Pereyra y su hermano. Según Elda Taborda la agrupación llegó a tener 700 adherentes. Muchos militantes de izquierda provenientes de otras tradiciones se vincularon de manera independiente con el Movimiento. Entre sus consignas de máxima figuraba la conformación de la Empresa Nacional de Pesca, donde el Estado controlaría los recursos pesqueros.

${ }^{889}$ Elda Taborda menciona además la participación de otras agrupaciones como "Puerto Para Todos", "Agrupación 26 de junio". Algunas de las agrupaciones eran muy pequeñas, organizando a trabajadores y trabajadoras por fábrica.

${ }^{890}$ L.C., 01/07/1984. 
En lo inmediato lucharemos por un acuerdo de emergencia, como primer paso para una recuperación del poder adquisitivo que hemos perdido en los últimos años. De manera que el trabajador del pescado pueda acceder a un nivel de vida digno con ocho horas de trabajo [...] también exigiremos el cumplimiento de todos los puntos de los convenios colectivos y de la ley de contrato de trabajo, lo que nos permitirá modificar sustancialmente las condiciones de trabajo imperantes en la actualidad. $^{891}$

En la plataforma se incluía el pedido de convocatoria a paritarias para impulsar mejoras en las condiciones de trabajo. Junto a ello, planteaban la necesidad de crear instancias sindicales para la educación de los trabajadores, dado que "un obrero culto es garantía para la defensa de nuestros derechos" y por ello propugnaban la formación de apoyo escolar, guarderías infantiles y una escuela nocturna para adultos. Cuestionaban a la dirigencia la creación de un plan de viviendas que no podían pagar los afiliados, así como los contenidos que se daban en la escuela de capacitación sindical que "no enseña al trabajador a defender sus derechos". ${ }^{892} \mathrm{Y}$ se comprometían a poner en funcionamiento la clínica así como luchar por la reducción de los años necesarios para acceder a la jubilación "dadas las condiciones penosas de nuestras tareas". También se planteaba impulsar la organización federativa de todos los obreros del pescado del país y se apuntaba a modificar las prácticas sindicales, buscando que el sindicato fuera manejado por la asamblea constituida por todos los trabajadores y no solamente por la dirigencia. Poco después acusaban a la dirección gremial de no haber encarado una lucha eficaz en contra del cierre de empresas y los problemas de la industria. ${ }^{893}$

Luego de la derrota electoral el frente consolidado se quebró y emergieron las divergencias de los diferentes grupos que llevarán a una escisión primero y luego a la dispersión de la Lista Celeste en 1990. Según Pradas (s/f) las diferencias más notorias se produjeron entre los sectores peronistas y la izquierda comunista. Tras un balance referido a que la elección se perdió por la excesiva influencia del PC dentro de un gremio de trabajadores con fuerte presencia peronista, los peronistas iniciaron un proceso de "peronización" de la Lista Celeste. Para las elecciones de 1986 se mantuvo la presentación conjunta a condición de que los principales cargos los conservaran dirigentes peronistas. Así se presentó como candidato a secretario general Armando García y como secretario adjunto Ricardo "El Polaco" Muñoz, mientras que el tercer lugar era para Elda Taborda, esta sí militante del PC. Pero el punto mayor de disidencia se mostró en ocasión de la firma de los Acuerdos Marco con la URSS y Bulgaria. El PC planteaba el apoyo a una decisión autónoma de la política exterior argentina y abiertamente apoyó la iniciativa. Distinta era la visión que de ellos mantenía el sector peronista. Cuando la conducción del SOIP, con la adhesión de la CGT, convocó a un paro contra la firma de aquellos convenios, la situación golpeó a la Lista que como tal no emitió una posición. Pero el sector peronista participó del paro y movilización por considerarlo una medida antiimperialista defensora de la soberanía nacional.

Ya en las elecciones de 1988 el grupo peronista que había integrado la lista se presentó de manera autónoma, con los colores Celeste y Blanco, pero tal pretensión fue impugnada porque esos colores formaban parte de otras listas. Es así que asumirá el color Verde. Aquí comienza entonces la historia de otra de las agrupaciones obreras del SOIP, de la cual hablaremos más adelante. En aquel año la Celeste estaba encabezada por Rubén Roldán, mientras que Mamerto Verón (padre) era candidato a secretario

${ }^{891}$ L.C.,01/07/1984.

${ }^{892}$ L.C., $15 / 07 / 1984$

${ }^{893}$ L.C., $21 / 07 / 1985$. 
adjunto e integraban también la lista Elda Taborda, Elsa Vera, Mamerto Verón (hijo), Rubén Godoy y Rubén Peralta. Todos ellos, salvo Roldán, vinculados en mayor o menor grado al PC. El resultado de las elecciones arrojó un segundo puesto para la lista Celeste, detrás de la Azul y Blanca de Saravia, pero delante de la Lista Verde.

En el año 1989, luego del ataque del Movimiento Todos por la Patria al Cuartel de la Tablada, Elda Taborda y Alejandro Lemtzev se sintieron en la necesidad de "defenderse" ante lo que denunciaban eran acusaciones de la conducción del SOIP respecto de la participación de integrantes de la Lista Celeste en el aquella acción. El episodio ilustra las profundas divisiones político-ideológicas en el sindicato del pescado. Los dirigentes acusaban de "maccartista" a la conducción gremial, repudiando "la actitud de las autoridades del SOIP que quieren involucrarnos en los hechos producidos en La Tablada, hechos que nosotros mismos repudiamos por la metodología empleada". Carlos Darguibel, secretario adjunto del gremio, había afirmado que "no fueron resueltos ni totalmente aniquilados los grupos que en la década del '70 pretendieron asolar nuestra Nación...". Los denunciantes indicaron el "El nuestro es un gremio que tiene muchos desaparecidos y de ellos el sindicato nunca dijo nada". Y señalaban que:

Darghebel (sic) en su documento también dice que en abril de 1987, Saravia denunció la presencia de terroristas entre los trabajadores que mantuvieron un conflicto con las empresas Yagán y Propesa y aquí si hubo terrorismo fue por parte del propio SOIP y de su patota armada. Por otra parte el gestor de estos conflictos fue Ronner, que presionó a la empresa (Yagán) para que despidiera a los delegados que no eran de su sindicato. La mejor prueba de esto es que Saravia y Ronner son testigos a favor de la empresa en el juicio colectivo que por despido están realizando los trabajadores [...] Los generadores de la violencia en el gremio del pescado son los bajos salarios, la salvaje explotación de los trabajadores, el desempleo, las listas negras ${ }^{894}$ y la persecución ideológica.

Finalizaban diciendo "Vamos a seguir luchando aunque Saravia y su patota nos acuse de subversivos" ${ }^{895}$ Por su parte, la CD del SOIP daba a conocer como respuesta un comunicado. En él ratificaban las acusaciones respecto de los vínculos de los integrantes de la Lista Celeste con aquel episodio. Decían entre otras cosas:

Hoy, cuando los hechos nos revelan que un integrante de la Lista Celeste del SOMU integró el grupo terrorista que atacó La Tablada, lista que tiene su correlato en el SOIP a través de estos dirigentes que hoy atacan a la organización gremial, confirma su militancia en contra de la Nación [...] las denuncias formuladas por Abdul Saravia sobre la infiltración por parte del E.R.P. y Montoneros dentro de los gremios pesqueros no estaban desacertadas.

\footnotetext{
${ }^{894}$ En varias oportunidades la oposición gremial de izquierda, tanto la peronista como la no peronista, mencionó la existencia de listas negras. Por ejemplo, Cabrera denunciaba en 1984 la existencia de tales listas "que condenan a los compañeros a deambular de planta en planta para obtener su sustento, o a no hallar trabajo en el gremio, por el solo hecho de levantar la voz en defensa de los derechos del obrero". L.C.,15/07/1984. Para Ricardo Muñoz desde 1986 empezó la penuria para conseguir trabajo en una empresa grande y desde ahí trabajo en fazoneras pequeñas. Señala que en aquel año, siendo candidato a secretario adjunto por la Lista Celeste, aún así, lo echaron de la planta donde trabajaba. Mencionan además una connivencia patronal - sindical tanto en los despidos como en la tolerancia de la situación que llevaba a muchos trabajadores a no conseguir trabajo. Entrevista del autor a Ricardo "Polaco" Muñoz... op. cit.

${ }^{895}$ L.C., 01/02/1989.
} 
El documento, cuando menciona los hechos de La Tablada se refiere a "los delincuentes" Miguel Luque, del gremio de Conductores Navales y Pedro Luque, del gremio del SOMU, ambos integrantes de la Lista Celeste (en marineros). Estas dos personas fueron asesinadas en el copamiento de la Tablada. El documento de la CD del SOIP señalaba que "...los dirigentes de ese grupo en lugar de atacar a los dirigentes del SOIP deberían explicar a los trabajadores del pescado y a la población en general qué participación tuvieron en los hechos mencionados y su relación con estos delincuentes y asesinos abatidos...". Finalmente advertía que "...estas circunstancias determinan que el SOIP continuará luchando no sólo por las reivindicaciones obreras sino también por la defensa de los intereses de la Nación, con la doctrina peronista y el ejemplo de Rucci y los defensores de La Tablada y la Bandera Argentina como arma". Además aprovechaban para rebatir otros puntos de la crítica que los dirigentes de la Celeste dirigían hacia esta agrupación, haciéndose presentes en la redacción del diario La Capital los dirigentes Saravia y Ronner.

...con respecto a las listas negras, eso lo utilizan como bandera para hacerse las víctimas y más cuando hay un proceso eleccionario. Ya en una oportunidad nosotros invitamos a los que hacen esas acusaciones a proporcionar nombres, cosa que nunca hicieron, como tampoco concurrir a las asambleas para formular propuestas positivas. Esos señores siempre fueron perdedores en el gremio y prueba de ello es que en las últimas elecciones la lista Azul y Blanca sacó más votos que las dos opositoras juntas. Por eso sólo hacen la protesta a través de la noche y en la oscuridad, pero no dan la cara y el pecho como hacemos los valientes.

Los comienzos de la década del '90 fueron años de máxima dispersión para la Lista Celeste. Previamente, tras un conflicto en la planta de Yagan Pesquera, una de las máximas dirigentes, Elda Taborda fue despedida y ya nunca más recuperaría la relación de dependencia que le permitía votar y ser votada en elecciones. Luego, la ola de quiebras, cierre de plantas y despidos, afectó sensiblemente a estos activistas. En paralelo, la caída del Muro de Berlín y la disolución de la URSS, junto a la creciente influencia del neoliberalismo, arrojaba a los márgenes de la discusión política a las tendencias que reivindicaban el socialismo como alternativa al modo de producción capitalista. Aún así, la Celeste seguirá procurando influir en el gremio. Un volante llamaba a votarla subrayando solamente como virtud que lista no tenía compromisos partidarios ni patronales. ${ }^{896}$ Para 1990 los volantes remarcaban la pésima situación económica de la clase obrera, con "salarios miserables". También señalaban que la obra social no funcionaba. Y acusaban a Saravia, en repetidas ocasiones, de demagogo. Además ya para entonces tenían una caracterización del gobierno menemista como conservador y reaccionario. ${ }^{897}$ Otro comunicado invitaba a recuperar "nuestro sindicato, para que sea realmente democrático, pluralista y combativo". También se hacía referencia a la defensa de las fuentes de trabajo que día a día se perdían ante "la pasividad" de la dirigencia. Además se apuntaba a modificar las prácticas sindicales. Por ejemplo, proponían que los salarios no sean arreglados entre patrones y la conducción sindical, sino discutidos por "asamblea libre y soberana con todos los trabajadores". Como método de acción sindical se esperaba "la democracia y participación de todos los afiliados". ${ }^{898}$ En aquel entonces la UOP elaboró un proyecto en

\footnotetext{
${ }^{896}$ Volante Lista Celeste "Compañeros del S.O.I.P - Lista Celeste".

897 "Compañeros, queremos un gremio unido y solidario con todos los trabajadores que hoy luchan contra la política de hambre, entrega del patrimonio nacional y represión de este gobierno conservador, cuyos socios principales son los enemigos del pueblo, como la familia Alsogaray". Unión Obrera del Pescado - Lista Celeste, "Por la Justicia Social", Mar del Plata, Marzo 1990.

${ }^{898}$ Comunicado de la Lista Celeste, Mar del Plata, 2 de julio de 1990.
} 
el cual manifestaba la política gremial desarrollada en caso de llegar a la conducción del gremio. Los primeros seis puntos se dirigían a lograr una democratización de las prácticas sindicales buscando consolidar otro modelo de sindicalismo.

1) Cambiar el sistema actual del gremio democratizándolo dando plena participación a todos sus afiliados, a través de las asambleas generales o por fábrica, que deben realizarse una vez por mes, a fin de que las mismas transparenten la gestión de la Comisión Directiva,

2) Modificar el actual estatuto para dar cabida en la dirección del gremio a las agrupaciones participantes en las elecciones, en forma proporcional al caudal de adherentes,

3) Modificar el mandato de cuatro a dos años de la Comisión Directiva,

4) Modificar las actuales atribuciones del secretario general para que sea la Comisión Directiva en su conjunto la que tenga la dirección efectiva del Sindicato,

5) Revocación del mandato de los delegados y miembros de la Comisión Directiva cuando no cumplieren el mandato dado en asambleas llamadas a tal fin, acepte. ${ }^{899}$

6) Las paritarias deberán quedar sujetas a lo que el gremio mediante asambleas de fábrica

Después continuaban un conjunto de reivindicaciones gremiales y finalizaba asumiéndose partícipes de un proyecto de liberación nacional y social. Sin embargo, como dijimos, los comienzos de la década del '90, con el cambio en las políticas para la pesca, las quiebras, los despidos, la formación de cooperativas, serán más bien adversos para el activismo de izquierda. La instauración del modelo de desarrollo pesquero predominante, caracterizado por su "vocación extractiva" bajo la hegemonía de los "Pulpos pesqueros", junto con la formación de las pseudo cooperativas, produjo una fuerte crisis el interior de la Lista Celeste que no podrá participar en las elecciones de 1994 por no alcanzar el número necesario de trabajadores bajo relación de dependencia. No obstante, a partir de la segunda mitad de la década del '90, cuando comienzan a sentirse las primeras manifestaciones de lo que será luego "la crisis de la merluza", la activación de la militancia de izquierda se reforzó, particularmente a partir de la organización del descontento de los trabajadores de las cooperativas, quienes veían reducidas las horas de trabajo cuando no comenzaban directamente a formar el contingente de desocupados. En ese contexto, fue la UOP una de las principales organizaciones que irá ganando protagonismo a partir de su presencia en las protestas callejeras. En 1994 Mamerto Verón (hijo) había abandonado sus vínculos con el PC y, buscando continuar en la organización de los trabajadores del pescado al tiempo que una línea política más general, se acercó al Partido Obrero. A partir de la incorporación de Verón, la UOP fue hegemonizada por el PO. ${ }^{900}$ Mamerto Verón (hijo) era sin dudas su principal referente, además de Patricia Comparada, María Inés Dematteis y luego, Luis “Tete" Verón (hermano de Mamerto).${ }^{901}$ Como resultado

\footnotetext{
899 "Proyecto de la agrupación de la Lista Celeste a aplicarse en caso de llegar a la dirección del Sindicato", Unión Obrera del Pescado - Lista Celeste, Mar del Plata, 1990.

${ }^{900}$ Mamerto Verón (hijo) nació en una pequeña localidad santafesina de Fortín Olmos. Hijo de un hachero con tradición de organización sindical, de orígenes muy humildes, trabajó de adolescente en estancias rurales y en la zafra del algodón. A los 17 años arribó a la ciudad de Mar del Plata, donde ya vivía una de sus hermanas, y finalmente se quedó. Pronto comenzó a trabajar en la industria del pescado.

${ }^{901}$ Protagonista de este proceso fue también Eduardo "Maro" Pradas, trabajador del Correo Argentino y militante del Partido Obrero. El libro de su autoría Una aproximación... (Pradas, 2006), citado aquí en diferentes pasajes, fue de hecho pensado como herramienta de militancia gremial y política para facilitar la caracterización de la industria pesquera y de las tareas que la nueva conducción sindical debería priorizar.
} 
de este proceso, la Lista Celeste se alzó con la conducción del gremio. Pero antes de analizar el proceso que llevó a dicha lista al frente del SOIP, veamos el desarrollo de la Lista Verde.

\section{La Lista Verde}

Hemos visto que la Lista Verde emerge, impulsada por el sector de activistas peronistas, luego de la división de la Lista Celeste. Retomaba el color de la vieja lista encabezada por militantes del PST, pero sólo porque no podía utilizar otros colores. Como lista participa de dos procesos electorales, en $1988^{902}$ y en 1990, ya bajo la candidatura de Ramón González. En las elecciones de 1994 la lista fue impugnada y no pudo competir electoralmente. En cuanto a sus posturas ante el desarrollo pesquero, asumió una posición de corte nacionalista y de defensa del sistema fresquero, bastante coincidente con las posiciones de Saravia y su grupo. Por el lado partidario, los integrantes de la Lista Verde participaron de las internas del PJ nacional, declarando en 1988 su apoyo a la dupla Cafiero - De la Sota. También de las internas del PJ local, contando con el apoyo de la Dr. Norma Godoy y luego sosteniendo la candidatura del cavallista Fernando Gutiérrez. En 1990, la preocupación de su máximo dirigente se centrará en la crisis laboral que atravesaba la pesca. Ramón González dirá que:

...se tratará por todos los medios que se reactive la fuente de trabajo. Para ello se buscará la fórmula y agotará todas las instancias, en función de un acercamiento con los diferentes sectores de la actividad y también con autoridades y funcionarios municipales, provinciales y nacionales, poniendo plena conciencia para lograr la tan ansiada solución a esta grave crisis laboral.

También anunciaba la lucha por la sanción de una ley nacional de pesca "con un proyecto que apunte a la legítima defensa de nuestra soberanía sobre las 200 millas". Además pedía que se reactivara la pequeña y mediana empresa. En aquel año la lista mantuvo un enfrentamiento con la Celeste por el uso del color, ya que los integrantes de la "Verde" querían competir bajo los colores "Verde - Celeste", deseo al que se opusieron fuertemente los integrantes de la Lista Celeste y que, posteriormente, fue desestimado por la Junta Electoral. Acusaban de inoperante a la dirigencia del SOIP "ante la crítica situación que azota a la industria pesquera marplatense". Mediante un documento firmado por Alberto Rosa, Miriam Gómez y Ramón González aseguraban que:

Lo sucedido con la empresa 'Estrella de Mar' es patético reflejo de la falta de resolución ante el grave problema de la decadente y mediocre dirigencia, con evasiones de aportes a la obra social, con vaciamiento de empresa, una cantidad considerable de trabajadores en la calle y como si fuese poco sin cobrar lo que legalmente les corresponde. El panorama es cada día más sombrío con alrededor de cinco mil obreros desocupados y subocupados, dando muestras claras que esto es ya insostenible, con una industria pesquera al borde del abismo. Repudiamos la lucha estéril por mejoras salariales, poniendo en riesgo la estabilidad laboral para lograr un magro $10 \%$ de aumento. ${ }^{903}$

\footnotetext{
902 Este año Elbio Fernández encabezaba la Lista, secundado por Alberto "Beto" Rosa y antiguos activistas de la Lista Celeste como Edgardo Gabbin, Enrique Medina, Ricardo Muñoz, Carlos Rosales y Ramón González.

${ }^{903}$ L.C.,30/09/1990.
} 
Los cierres de empresas pesqueras estaban afectando duramente a los trabajadores y, de hecho, en aquellos días el líder de la agrupación, Ramón González, perderá la relación de dependencia. ${ }^{904}$ Por otra parte, para la agrupación, las cooperativas surgidas con posterioridad a este proceso eran:

...consecuencia en gran parte de la política de autoritarismo llevada a cabo por el señor Saravia y algunos industriales evasores y estafadores [...] La evidencia está en las negociaciones de salarios y condiciones de trabajo hechas a espaldas de los trabajadores, no haciendo jamás asambleas generales ni reconociendo los resultados de las urnas.

También denunciaron la existencia de listas negras de "opositores", mientras que grandes empresarios que aparecen como enemigos de Saravia fueron en realidad amigos en otra época. Pero la crítica más contundente se refería a la inoperancia de la conducción del SOIP. Argumentaban que el sindicato se encontraba "en una total desintegración" y que Saravia no proponía nada para salvarlo. Como alternativa, solicitaban la convocatoria a una asamblea general de la que participen tanto trabajadores ocupados como desocupados. ${ }^{905}$

Este grupo obrero intentó aprovechar distintas situaciones para afectar a la conducción de Saravia. Una de ellas fue respecto a la experiencia del complejo habitacional del SOIP. Apoyando los reclamos de los vecinos, dirán que a Saravia "se le terminó el hilo del carretel", esperando que "de una vez por todas la Justicia tome cartas en el asunto y vuelque la balanza a favor de los que reclaman desde hace ya mucho tiempo". Denunciaban que "como trabajadores de este sector sufrimos durante muchos años la discriminación y la salvaje persecución por parte de la supuesta conducción del SOIP, vemos con total estupor cómo se pretende burlar a la Justicia con maniobras muy poco limpias por parte de Saravia y compañia". Y agregaba que:

...como trabajadores vimos con impotencia cómo Saravia dio lugar a una industria superexplotada y un gremio semidestruido, cómo nos estafaba con el fraude en las últimas elecciones. Hoy también pretende estafar la dignidad y la confianza de muchas familias que apostaron a la vivienda propia, es por eso que no podemos callarnos por esta vergonzosa situación, que pone en peligro nuestro patrimonio que, tras sacrificados años de trabajo con nuestros aportes pudimos construir. Nos referimos a nuestro sindicato y Obra Social. ${ }^{906}$

Tiempo después, un comunicado firmado por Ramón González y Ana María Juárez, con la adhesión de los "Estafados sin Vivienda" y los "Estafados con Uso de Vivienda", calificaba a Saravia de "estafador en lo moral y económico", entre otras duras consideraciones. ${ }^{907} \mathrm{El}$ otro intento surgía en el año 1994. En este año electivo, la propuesta de la Lista Verde se centraba en "la reactivación de la industria; la seguridad en la relación laboral con beneficio y justicia social y resguardando nuestra legislación

\footnotetext{
${ }^{904}$ Ante ello remitían una carta al presidente Carlos Menem para informarle del "grave problema laboral en el que estamos inmersos la mayoría de los trabajadores como consecuencia del cierre de más de 50 fábricas, desde el principio del año 1989 hasta mayo de 1990 y 14 establecimientos más desde agosto de 1990. Estamos soportando suspensiones injustificadas y despidos masivos, como el reciente del compañero Ramón González, quien se postulaba para secretario general de la lista Verde [...] lo que es peor todavía, es el no cobrar los haberes que legítimamente tenemos ganados con muchos sacrificios, porque muchos de estos malos empresarios se borraron y otros argumentan razones de fuerza mayor para suspendernos". L.C.,10/01/1991.

905 L.C.,25/10/1992.

${ }^{906}$ L.C., $13 / 09 / 1993$.

${ }^{907}$ L.C.,07/04/1995.
} 
laboral". González, nuevamente liderando la lista, expresó: "lucharemos para conservar y mejorar nuestra jubilación estatal, por un aumento salarial inmediato, por respeto al trabajador por parte de algunos elementos antisociales. También pedimos que se respete el derecho legal de la efectividad y si así no sucediese que se indemnice con el 100\% efectivo de acuerdo a la ley". ${ }^{908}$ La pretensión era que Saravia no pudiera presentarse como candidato en las elecciones debido a que pesaba sobre él un procesamiento. Lo curioso es que ese procesamiento del dirigente gremial era por la toma y ocupación de Barilari. Es decir, por una acción de lucha. Pero todo argumento era útil para buscar correr de en medio a quien, con el uso de distintos ardides, lograba mantenerse al frente del gremio. Sin embargo, quienes no pudieron participar de las elecciones, como vimos, fueron las listas Verde y Celeste, imponiéndose nuevamente la oficialista Azul y Blanca, que fue la única competidora. Allí se termina la historia de esta agrupación durante el periodo bajo estudio. Pero no de alguno de sus militantes que continuaron activos, participando de la lucha gremial y la lucha de calles.

\section{Del peronismo al trotskismo: la victoria de la Celeste}

En el año 1994 la conducción del SOIP ganó las elecciones siendo la única lista en competencia. Desde entonces, hasta el año 2002, no se realizaron elecciones gremiales dado que las correspondientes a 1998 fueron suspendidas. En ese entonces se dio lugar a las impugnaciones que las corrientes opositoras realizaron a los procedimientos de la CD y la junta electoral. Desde aquel año el sindicato, por resolución ministerial, quedó bajo la custodia de la vieja CD, con Juan Carlos Darguibel como titular tras la muerte de Saravia. De esta forma, a una crisis económica de la actividad se le sumaba una crisis de representación gremial. En ese contexto, se imponían redefiniciones sociales y políticas. La extensión del desempleo y subempleo en la industria del pescado provocó el surgimiento de nuevas organizaciones y la redefinición de otras ya existentes. Esa reinterpretación correspondió a la UOP. ${ }^{909}$ En gran medida porque sus principales dirigentes trabajaban en cooperativas y padecían ahora el desempleo, pero también porque esa realidad particular afectaba también a una gran parte de la población obrera del pescado, la organización pasó a representar fundamentalmente a los cooperativizados, sub ocupados y desocupados, pretendiendo, a través de la lucha reivindicativa, redefinir los horizontes políticos inmediatos de estos segmentos. La participación de los activistas de la UOP en las protestas callejeras fue cada vez más significativa dentro de un proceso de "piqueterización" de la protesta obrera. ${ }^{910}$ Mientras que la conducción sindical, que había perdido a su máximo referente, desatendió la situación de los trabajadores que crecientemente quedaban desocupados, fue allí donde la UOP dirigió sus esfuerzos organizativos. Posteriormente, se logró producir una confluencia entre los trabajadores desocupados y precarizados con un sector de trabajadores en blanco. Un esquema de creciente conflictividad callejera en la industria, con un número cada vez mayor de desocupados y subocupados, fue el contexto ideal para que aquellos grupos más en sintonía con el proceso de "piqueterización" de la

\footnotetext{
${ }^{908}$ L.C.,03/06/1994.

${ }^{909}$ Varias eran las agrupaciones y corrientes político - sindicales que tenían trabajo político en el Puerto. Sin embargo, pronto emergieron como las dos experiencias más significativas, la UOP y los obreros Autoconvocados de la Industria del Pescado. Desarrollamos aspectos de la UOP aquí. Y en siguientes capítulos nos referimos al posicionamiento de los Autoconvocados.

${ }^{910}$ Entendemos por piqueterización de la protesta un proceso que arroja a los trabajadores a protestar cada vez más en las calles, acudiendo a repertorios como cortes de tránsito, movilizaciones, manifestaciones, muchas de las cuales se realizan por fuera de las conducciones gremiales. Además, decaen los conflictos de "baja intensidad" como las declaraciones al tiempo que se despliegan acciones más radicalizadas.
} 
protesta social pudieran canalizar los reclamos. Hacia 1997 la agrupación declaraba su rechazo a "la política flexibilizadora y el ajuste de los '90" y planteaba entre sus principales reivindicaciones: la vigencia del convenio de 1975, la entrega de un subsidio a los desocupados en la medida en que el gobierno era responsable de la desocupación y la reactivación del trabajo en las plantas pesqueras. ${ }^{911}$

Esas fueron las tres demandas principales que acompañaron el desarrollo de la Celeste. Tres años más tarde un nuevo hito en el proceso de lucha social tendrá lugar hacia junio del año 2000 cuando este grupo, junto a activistas de otras corrientes, emparentándose con la historia del antagonismo gremial en el SOIP, ocupe la sede sindical denunciando a la CD por no representar adecuadamente a los trabajadores, solicitándole que adhiera al paro que entonces llevaban a cabo los marineros del SOMU. Durante la toma pidieron que se realizaran nuevas elecciones (analizamos este hecho en el último capítulo). Desde ese año y hasta el 2002, su participación fue creciendo de la mano del alza en la conflictividad social. Hacia fines de 2001, con el motivo de impulsar el llamado a elecciones, el Ministerio de Trabajo de la Nación nombró un interventor en el SOIP para normalizar el gremio. ${ }^{912}$ Los comicios se realizaron en marzo del año 2002. El desafío para la UOP consistía en ¿cómo competir en las elecciones cuando estatutariamente, por no ser trabajadores en relación de dependencia, no podían participar? La estrategia desarrollada radicó en llevar como candidatos a un conjunto de trabajadores con poca experiencia gremial pero que cumplían los requisitos para poder presentarse en las elecciones. Esto es, estaban "en blanco". Samuel Salas fue el candidato a secretario general. La particularidad que presentó aquella lista fue su configuración, pues se conformó con los 36 candidatos reglados por el estatuto y doce asesores, uno para cada secretaría. Ésta última figura era anti-estatutaria. Sin embargo, una vez en la conducción, el pulso de la dinámica interna del sindicato fue marcado por el grupo de asesores. Los más destacados en su actividad militante eran entonces integrantes de la UOP y del PO: Patricia Comparada, María Dematteis y los hermanos, Luis y Mamerto Verón. ${ }^{913}$ El dato electoral sorprendente lo constituyó la victoria de la Lista Celeste que derrotó a la antigua conducción por un pequeño pero logrado margen de votos. A poco de asumir, la dirigencia redactó un acta en la que resolvió conformar una comisión de asistencia ejecutiva, incluyendo así a los asesores en la estructura gremial. La figura tendría la facultad de ejecutar y hacer cumplir las órdenes directas de la CD y los secretarios. ${ }^{914}$ Samuel Salas, nuevo secretario general, entonces declaró:

El SOIP tiene que recuperarse, volver a lo que era antes. Necesitamos que los compañeros confíen en sus dirigentes, porque todos estamos pasando por las mismas necesidades [...] La única forma que tenemos de que la gente regrese al sindicato es blanqueando el trabajo de cada obrero, que

\footnotetext{
${ }^{911}$ L.C., 14/07/1997.

${ }^{912}$ E.A., 10/01/2002.

${ }^{913}$ Un volante de la Lista Celeste rezaba "Nosotros que no podemos ser candidatos y no podemos votar y no conseguimos recibos de sueldo porque no transamos nunca con la patronal, hemos armado la lista Celeste junto a trabajadores y trabajadoras que se merecen toda nuestra confianza y provienen de 21 fábricas diferentes ¿A quién vas a votar? Pensalo... ¿A Casariego o Darguibel? A los que hace 10 o 12 años que están en el sindicato y que nos han llevado junto a la patronal a una situación de hambre y superexplotación a todos los trabajadores y las trabajadoras de la industria." (cit. en Yurkievich, 2012: 280).

${ }^{914}$ L.C.,22/03/2002. La incorporación de los trabajadores de las cooperativas y militantes de la UOP era objetada por un sector de los delegados del SOIP. Uno de ellos, Sergio Barreiro, expresó que "nosotros defendemos y apoyamos a la actual comisión directiva, pero no a los que no se hallen en relación de dependencia". Precisando que, en estos casos, "ellos no fueron votados por los afiliados". Detrás de esta consideración legal, se instalaban diferencias políticas, ya que todos los que ingresaron al gremio como asesores provenían del personal cooperativo y pertenecían a la UOP. Respondiendo a estas acusaciones, Samuel Salas dijo que "los afiliados ya sabían, incluso durante la campaña, que la conducción estaría en manos de los efectivos, pero también los cooperativizados". Al mismo tiempo, recalcó que "la intención es unir a todos y luchar por la efectividad de todos. Esto será lo que tratará la comisión directiva”. L.C.,22/03/2002.
} 
las empresas vuelvan a aportar al sindicato y la obra social. Nuestro planteo es afiliar masivamente a todos para hacernos fuertes. ${ }^{915}$

Otras propuestas de la lista eran: aumento salarial, cumplir el convenio colectivo para acabar con el trabajo en negro, efectivizar a los trabajadores cooperativos y "changas" y recuperar la obra social. ${ }^{916} \mathrm{El}$ triunfo señaló un hecho particular dentro del escenario sindical marplatense al llevar a la dirección de uno de los gremios industriales más importantes de la ciudad una lista identificada con el clasismo. La victoria sorprendió incluso a los propios ganadores, porque según ellos mismos reconocían, su mayor influencia política estaba entre los cooperativizados. En un artículo de la Prensa Obrera, diario del PO, se señalaba con entusiasmo "Lejos de tratarse de una interna gremial, la recuperación del sindicato obrero más importante de la zona será una palanca para la transformación del cuadro político del sindicalismo local" (cit. en Yurkievich, 2012). La nueva conducción tenía por delante un desafío para nada sencillo. Gobernaba el gremio solamente habiendo obtenido un $28 \%$ del total de votos emitidos. Mientras que, al mismo tiempo, debía responder ante los miles de trabajadores de las cooperativas. A su vez, las cuentas sindicales estaban embargadas por las deudas que mantenía la obra social, con lo cual el gremio no recibía prácticamente fondos de los aportes de los trabajadores. Se encontró con una estructura sindical que había sobrevivido al menemismo pero con grandes problemas. Edilicia y financieramente el sindicato estaba en ruinas y su obra social tenía deudas millonarias. El cuerpo de delegados estaba desarticulado y existía una escaza presencia de delegados en las plantas. Disponía si de la vigencia de la letra del convenio del ' 75 y el estatuto de 1990. Bajo el marco de estas normativas y lo que había sobrevivido de la estructura sindical, la nueva dirección emprendió la reorganización del gremio, procurando revitalizar y renovar el cuerpo de delegados. Revitalizar, porque no todas las fábricas del sector tenían delegado, ni el cuerpo de delegados se reunía asiduamente. Renovar, porque la lista Celeste contaba en el 2002 solo con 2 delegados propios sobre un total de 20. Al mismo tiempo intentó buscar un mecanismo de integración de los trabajadores cooperativizados a la estructura gremial. Para ello impulsó la elección de delegados en las cooperativas con el objetivo de lograr representación gremial en esos espacios de trabajo. Con altibajos, la reactivación y renovación del cuerpo de delegados poco a poco se fue concretando.

Con todo, en cierto modo, el resultado de las elecciones del año 2002 en el SOIP permite pensar en cierto quiebre, en el plano de la política de los efectos de la segmentación del mercado de trabajo a partir del establecimiento de lazos de solidaridad que se fueron tejiendo entre los trabajadores precarizados y los trabajadores registrados. Por ello resulta interesante analizar la evolución posterior de este grupo, una vez que inició la gestión gremial, describiendo un desarrollo que mostró el lanzamiento de huelgas generales, la búsqueda de alcanzar el "blanqueo" de las relaciones laborales "en negro" y una posterior división de la conducción que llevó al alejamiento de Patricia Comparada y María Dematteis de la comisión directiva junto con la expulsión de los hermanos Verón del PO. Sin embargo eso ya es producto de otra historia y quedará su exploración como materia de futuras investigaciones. ${ }^{917}$

${ }^{915}$ E.A.,s-f/02/2002.

916 “„Atenti, compañeros!”, volante de la lista Celeste, Mar del Plata, s/d fecha.

${ }^{917}$ Algo de ello hemos explorado en Colombo (2010). También puede leerse Yurkievich (2012). 


\section{Sindicatos paralelos, una experiencia malograda}

Quizá la marca más profunda que imprimieron los activistas gremiales anarquistas en el gremio del pescado fue la de consolidar una organización sindical de corte local que hizo fracasar todo intento de disolución en una estructura más amplia, como por ejemplo, la alimentación (Nieto, 2012). En los marcos del SOIP se fraguó entonces una identidad obrera. Esa identidad nunca fue la de ser un/a obrero/a o trabajador/a de la alimentación, sino la de ser obreros u obreras del pescado. Y esta identificación aún hoy sigue siendo irreductible. Sólo cuando los militantes gremiales peronistas "descubrieron" y "respetaron" aquella identidad en la década del ' 60 , lograron construir una hegemonía duradera en el gremio.

Una expresión de la persistencia de aquella identificación entre el SOIP y los trabajadores de la industria pesquera fue el continuo fracaso de quiénes buscaron consolidar una organización obrera alternativa. Ejemplo de ello fue la experiencia de militantes sindicales vinculados al Partido Comunista y a la CTA que promovieron la creación de un nuevo sindicato buscando agrupar a los trabajadores de las cooperativas y los desocupados. La cuestión respondía al hecho de que una gran parte de los obreros y obreras del pescado en la década del ' 90 perdieron la relación salarial estable y, por lo tanto, la posibilidad de participar de la vida sindical. La iniciativa tenía lugar en el año 2000 a los pocos días de haber sido tomada nuevamente la sede del SOIP. Primero estos trabajadores y trabajadoras buscaron habilitar el pago de aportes sindicales voluntarios y de ese modo integrar la tradicional organización gremial. Pero, como esto iba en contra de la letra del estatuto, la norma sirvió como argumento de la conducción sindical para rechazar la iniciativa. Sólo después de ese fracaso nacía la propuesta de generar un nuevo sindicato, pues se pensaba que no había posibilidad de reinsertarse efectivamente en el gremio. Así, en julio de 2000 quedó constituido a través de una asamblea general en la sede del Sindicato Luz y Fuerza, el Sindicato de Trabajadores del Pescado y afines de la República Argentina (SIPES). La nueva organización convocó a afiliarse "a los obreros y empleados que presten servicios en empresas o establecimientos de la industria del pescado, en todas las formas de la manufactura, elaboración y/o procesamiento de los productos y subproductos de la pesca, cualquiera sea la forma jurídica bajo la cual se encontraren registrados los empleadores". ${ }^{918}$ La entidad se constituyó como un sindicato de primer grado con representación en todo ámbito nacional y se propuso tener autonomía "de los empresarios, el Estado y los partidos políticos"919. Pero esta alternativa, que pretendía representar aquellos trabajadores cooperativizados y desocupados que la conducción del SOIP había descuidado, no tuvo demasiado éxito y más temprano que tarde pasó al olvido. La identidad que vinculaba a los trabajadores y trabajadoras de la industria del pescado fue, una vez más, más poderosa. En cuanto a la hegemonía ideológico-política del peronismo entre los trabajadores de la rama, recién en el año 2002, como vimos, una lista de otra tradición político ideológica (trotskista) ganó las elecciones.

\footnotetext{
${ }^{918}$ La CD provisoria está encabezada por Daniel Alaniz, como secretario general; secretario adjunto, Dórico Bentos; secretario gremial, Elda Taborda; de Finanzas, Mirta Sueiro; de Organización, Cristina Santillán y de Prensa y Difusión, Oscar Pérez.

${ }^{919}$ L.C., 16/07/2000.
} 


\section{CAPÍtULO V}

La dinámica de la conflictividad en la industria pesquera marplatense (1989-1996)

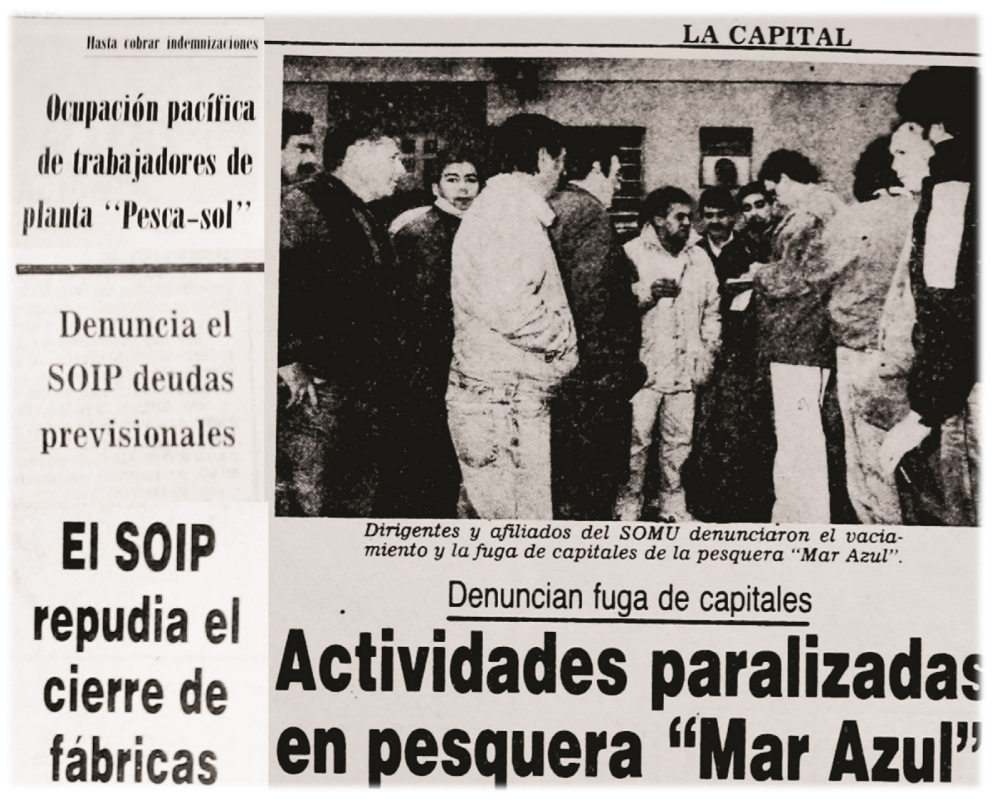




\section{Introducción}

“Mucho se ha escrito durante los últimos años sobre la beligerancia popular en el país, pero es poco lo que se ha investigado" Javier Auyero, 2002

En el año 2002 Javier Auyero presentó un pequeño libro titulado La protesta, retratos de la beligerancia popular en la argentina democrática (Auyero, 2002). ${ }^{920}$ Un año antes, el sociólogo había publicado su investigación sobre el clientelismo, el peronismo y lo que llamó "la política de los pobres" (Auyero, 2001). Con tan solo doce meses de diferencia, su nuevo objeto de estudio no era tan distinto, pero sí diferente. El análisis acerca del funcionamiento de las redes de resolución de problemas de los pobres dejaba paso al examen de la acción colectiva contenciosa. Las formas de la política "popular" continuaba siendo el tema, pero ya no enfocando cierta subordinación a estructuras partidarias, sino intentando dar cuenta de los mecanismos de activación de la beligerancia. En ese sentido sí, como vimos en el capítulo IV, el mayor número de trabajos sobre conflictividad social en la Argentina se dirigió en la década del '90 a analizar la "pasividad" obrera y sindical ante la ofensiva neoliberal, paralelamente, al ritmo en que fueron creciendo las protestas en diferentes provincias del país, así como la multiplicación de los cortes de calles y la progresiva presencia del movimiento piquetero en la provincia de Buenos Aires, junto a otras manifestaciones que antagonizaban con las políticas emanadas desde el gobierno; todo eso provocó que poco a poco fueran germinando estudios de carácter "optimista" respecto al resurgimiento de la conflictividad y la capacidad popular de resistencia y transformación. Finalmente, luego de los hechos producidos durante la rebelión de diciembre de 2001, la tendencia que exhibían aquellos trabajos se expandió con celeridad. De esta forma, las temáticas vinculadas a la consolidación "democrática" (en cuanto estructura institucional y formal), a la gobernabilidad y al "adecuado" funcionamiento de un sistema de partidos, hegemónicas durante la década del ochenta, dejó pasó tras la crisis del neoliberalismo y la emergencia y extensión de la protesta social, a los interrogantes sobre conflictividad (Santella, 2010). Producto de ello asistimos a un intenso proceso de edición y publicación de ensayos e investigaciones que buscaban dar cuenta del renovado protagonismo popular en la dinámica conflictual. Esta revitalización pronto indicó un doble desplazamiento. Tanto en el orden de los procesos, como en el de las interpretaciones.

La primera cuestión, y a pesar de la heterogeneidad de los nuevos aportes, refiere a la aparición de una suerte de nuevo paradigma interpretativo, al cual podemos adjudicarle cierta unidad no tanto por lo que los textos tenían en común, sino más bien por lo que rechazaban. De este modo, el grueso de las aproximaciones daba cuenta de un estado prácticamente terminal de la categoría de clase social y, junto con ella, del marxismo "clásico" (por llamarlo de algún modo) y de las perspectivas estructuralistas. Ahora las principales referencias teóricas provenían de la escuela europea que enfatizaba la formación y construcción de identidades a partir de la acción, preocupada por la identificación de los nuevos movimientos sociales, así como de la sociología norteamericana que ponía el eje en la movilización de

\footnotetext{
${ }^{920}$ Previamente ya había publicado un texto acerca del "santiagueñazo" de 1993 (Auyero, 2000).
} 
recursos organizacionales y en la estructura de oportunidades políticas. ${ }^{921}$ Si los primeros, desde una perspectiva que se anclaba en el pos marxismo, se encontraban preocupados por los cambios estructurales en el sistema capitalista y la aparición de distintos movimientos de protesta que se alejaban de los esquemas clásicos de combatividad laboral e implicaban la construcción de una novedosa identidad colectiva emplazada en la acción; ${ }^{922}$ los segundos daban importancia a los actores racionales y a los recursos organizacionales. ${ }^{923}$ De todos modos, la más de las veces, los trabajos locales utilizaron una mixtura más o menos libre entre ambas opciones. Curioso resulta que se produjo una suerte de collage entre dos escuelas que fueron rivales. La primera al estudiar la constitución de la identidad en los procesos políticos que remite al campo de la subjetividad y la segunda a partir de la acción colectiva como instrumental (Massetti, 2004). Una tercera variante que completó el panorama, también muchas veces apelando a la utilización de categorías provenientes de las otras corrientes, fue una suerte de marxismo abierto que realizaba una relectura de Marx centrada en los aportes de Tony Negri y John Holloway, junto a otros autores críticos de la "ortodoxia" marxista, asignando una fuerte importancia a la noción de autonomía, en desmedro de la antigua influencia leninista en el pensamiento de izquierda. Lo común en todos los análisis fue la esperanza generada por los nuevos movimientos sociales respecto de la renovación de las prácticas políticas. La excepción en la literatura sobre protesta fueron los trabajos del PIMSA que continuaba con una tradición de interpretación marxista "clásica", orientada por Marx y Engels obviamente, pero también por Gramsci y Lenin. Apelando a una fuerte reconstrucción empírica, los integrantes del programa de investigación buscaban delimitar el grado de construcción de una fuerza social de oposición política. Más que un sujeto pos proletario buscaron demostrar las nuevas tácticas de la lucha obrera vinculada a un nuevo contexto surgido históricamente en la correlación de fuerzas. ${ }^{924}$

De la mano de este cambio interpretativo surgieron nuevos conceptos y categorías, mientras que otros fueron relegados. La creciente alza en la conflictividad social, que con oscilaciones siguió al santiagueñazo de 1993, mostraba para el grueso de los analistas que el papel de los sindicatos y las reivindicaciones de tipo laboral perdían su antigua preponderancia. Ya no eran los clásicos trabajadores, representados por sindicatos y utilizando sus principales herramientas de reclamación quienes hegemonizaban el escenario de la protesta. Al contrario, ésta emergió a través de nuevas formas de lucha y con distintos actores involucrados. En general, los estudiosos coincidieron en señalar que la centralidad de la huelga como método de lucha duró hasta el momento de la aplicación de las políticas neoliberales que modificaron el rol del Estado, promovieron la desindustrialización y produjeron una intensa desproletarización, provocando la desestructuración de la sociedad del trabajo, a raíz de lo cual perdieron vigencia las "viejas" formas de organización y de protesta obrera. ${ }^{925}$ Los cortes de calles y rutas fueron desplazando a la huelga de su anterior hegemonía. ${ }^{926}$ Desde algunas interpretaciones lo que antes era

\footnotetext{
921 Ya durante el período de transición democrática apareció en la agenda académica y política la temática de los nuevos movimientos sociales (Jelin, 1987; Calderón, 1986). El concepto buscaba identificar actores que cobraban una visibilidad inédita y, sobre todo, despertaban expectativas (Viguera, 2009).

${ }_{922}$ Alberto Melucci, Claus Offe y el francés Alain Touraine han sido tal vez los autores más destacados.

${ }^{923}$ Predominaron autores como Oberschall, Mc Carthy y los más influyentes, Sidney Tarrow y Charles Tilly.

${ }^{924}$ Cotarelo (2000; 2000b), Iñigo Carrera (2009; 2007; 2000), Iñigo Carrera y Cotarelo $(2005 ; 2004 ; 2003 ; 2002 ; 2001 ; 2000$; 1999; 1998), Iñigo Carrera y Donaire (2003); Klachko (2000), Kindgard, Federico y Elizabeth Gómez (1999).

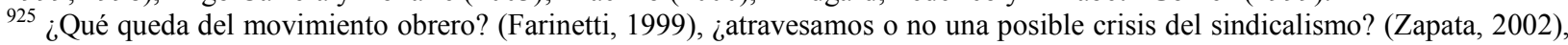
¿las organizaciones sindicales siguen siendo la vía adecuada para estructurar las demandas obreras? ¿Otros movimientos sociales podrán ocupar su lugar? (Battistini, 2002).

${ }^{926}$ En el contexto de mundialización capitalista ya no se cortaba la producción sino la circulación (Colectivo Situaciones, 2002; Lucita, 2001).
} 
dominado por reclamos laborales dejaba paso a una lucha de carácter defensivo originada por la pérdida de derechos sociales (Giarraca, 2002).O mejorse trataba de una reclamación por la obtención de nuevos derechos y una renovada ciudadanía (Pereyra, 2008; Schuster et al, 2006; Scribano y Schuster, 2001). Lo cierto es que los obreros integrados ya no ocuparon un lugar central en los estudios de la protesta. ${ }^{927}$ Asumían el protagonismo los "excluidos del modelo" (desocupados, cartoneros, beneficiarios de planes sociales, vagabundos y mendigos) con novedosos repertorios de confrontación. Y de este modo, las protestas tomaban un carácter más episódico, las demandas adquirieron mayor complejidad y los sujetos fueron más heterogéneos (Lobato y Suriano, 2003).

En este contexto la noción de lucha de clases perdía poder explicativo, mientras florecieron las categorías de protesta social, acción colectiva, beligerancia popular, nuevos movimientos sociales, repertorios, ciclo de protesta, estructura de oportunidades políticas, etc. ${ }^{928}$ A nivel general la "protesta" desplazó, como categoría que permitía interpretar la clave del proceso social, a la noción de lucha de clases. ${ }^{929}$ Dado que la protesta ya no era eminentemente laboral y se había heterogeneizado, el nuevo concepto utilizado permitía dar cuenta de esa transformación haciendo posible entender bajo su signo las acciones vinculadas con el movimiento de derechos humanos, los reclamos de los trabajadores desocupados, el feminismo, las demandas de los pueblos originarios, la movilización de los ahorristas de clase media, las acciones en defensa de la tierra, el reclamo de soberanía alimentaria, etc. El peso de la categoría era tal que los historiadores preocupados por el tema no sólo la aplicaban a partir de las transformaciones socioeconómicas de los últimos tiempos, sino que también la proyectaron como "categoría útil" para pensar la conflictividad en el pasado (Lobato y Suriano, 2003). Además, para algunos pensadores, el rechazo de cualquier determinismo estructural permitía centrar la mirada en aquellas acciones caracterizadas por constituirse en prácticas autoafirmativas (Zibechi, 2003), con un renovado protagonismo social donde la heterogeneidad y des-anclaje permitían hablar del sujeto multitud (Colectivo Situaciones, 2002).Muchos análisis plantearon la emergencia de una nueva politicidad global asociada a variantes de una "nueva izquierda" donde se unificaron la emergencia del movimiento piquetero en Argentina, el movimiento sin tierra en Brasil, el zapatismo en México, las luchas campesinas en Bolivia (Bialakowsky, Costa y Patrouilleau, 2009).También Auyero, desde otra perspectiva e influenciado por la obra de Charles Tilly, rechazaba cualquier lectura reduccionista que vinculara la lógica de la acción a la posición en la estructura productiva o al padecimiento de un agravio. En el medio, aquella decisión se procesaba en la dimensión de la cultura política. Allí es donde debía buscarse la explicación de la acción (Auyero, 2002). Parte de los análisis más provechosos ubicaron la clave de interpretación en la inscripción territorial de las clases populares y las formas de su politización o re politización donde se hizo habitual la reproducción del planteo de la CTA según el cual "la nueva fábrica es el barrio", construyéndose éste en uno de los espacios privilegiados de re-colectivización(Merklen, 2005; De la Mata, 2004; 2002). Sin duda el foco de atracción principal lo constituyó el "milagro sociológico" (Svampa y Pereyra, 2005). Es decir, el estudio del movimiento piquetero en tanto

\footnotetext{
927 ¿Asistimos a la crisis de la acción laboral tradicional, junto al crecimiento del protagonismo de los obreros precarizados? (Delamata, 2002).

${ }^{928}$ Un buen indicador constituyen los temas abordados durante el Primer Congreso sobre movimientos sociales y acción colectiva realizado en marzo de 2009. Allí, para hablar de movimientos sociales, hubo una marcada preponderancia de citas teóricas de Tarrow, Tilly y Melucci. Del primero se tomaron sobre todo los conceptos de ciclo de protesta y estructura de oportunidades políticas, de Tilly la noción de repertorio, mientras que de Melucci se apeló a la noción de identidad (Massetti, 2010).

${ }^{929}$ Aníbal Viguera sostiene que tal vez no exista una dicotomía irreductible entre las visiones de los nuevos movimientos sociales y la noción de lucha de clases (Viguera, 2009).
} 
organización de trabajadores desocupados ligado a una dinámica barrial (Pacheco, 2010; Svampa y Pereyra, 2005; Delamata,2004; Massetti, 2004b; Isman, 2004; Blanco, 2002). También las puebladas (Auyero, 2002; 2002b; 2000, Cotarelo, 1999; Arias Bucciarelli, Favaro e Iurno, 1999; Laufer y Spiguel, 1999, Dargoltz, 1994), el fenómeno de los saqueos (Auyero, 2006; Fradkin, 2002; A.A.V.V., 1999), las fábricas recuperadas por sus trabajadores (Rebón, 2005; Fajn et al, 2003; Magnani, 2003), las jornadas de diciembre de 2001 (Pérez, 2008; Astarita, 2002; Negri y Cocco, 2003), las asambleas y cacerolazos (Fernández et al, 2008; A.A.V.V., 2002), junto con los ensayos de interpretación más generales que abarcaron algunos de estos aspectos en particular o todos ellos. Y que podemos resumir en la idea de un nuevo protagonismo popular (Zibechi, 2003; Colectivo Situaciones, 2002; Cafassi, 2002) ${ }^{930}$ Si bien como afirma Auyero, muchos aportes se realizaron al "calor de los hechos" sin investigaciones profundas que dieran sustento a las afirmaciones realizadas y las categorías utilizadas volviendo efímeras ideas y nociones que se pretendían potentes, también es cierto que, como sugiere Massetti (2010), la virtud de las nuevas teorías es que permitieron mirar las dinámicas confrontativas en contextos en que partidos y sindicatos perdían la hegemonía en cuanto estructuras de politización y movilización. En este aspecto, interesantes aportes se hicieron para "des-institucionalizar" los estudios de la política y ensanchar los horizontes de una política democrática, al mismo tiempo que romper rigideces normativas respecto a los sujetos sociales (y cómo estos deberían comportarse) y sacudir algo del polvo en que se encontraban los análisis sobre la movilización popular.

De todos modos, a nuestro parecer, se produjo entre las tesis vinculadas con "la pasividad" del movimiento obrero de mediados de los '90 y el "optimismo" posterior anclado en la aparición de nuevos movimientos sociales y en la dinámica de la acción colectiva, una suerte de hiato interpretativo en el conocimiento del proceso histórico. La "desproletarización" consecuencia de la desindustrialización, la "retirada" del Estado, los cambios en al patrón de acumulación, es decir las consecuencias sociales de la implementación del "neoliberalismo", usualmente tomados como puntos de partida de los diferentes análisis, provocó que demasiado pronto se anunciara la presencia de una "nueva era" donde la conflictividad tendía cada vez menos a expresarse en clave de las relaciones capital - trabajo. Si algo de ello ocurrió, pues también es absurdo sostener que nada ha cambiado tras las transformaciones en el capitalismo global, eso no implicaba hacer un corte tan rígido respecto del pasado donde lo válido solamente fue lo "novedoso". En este sentido nos manifestamos críticos de los análisis que buscaron construir polaridades dicotómicas como viejo versus nuevo, nuevos movimientos sociales vs. partidos y sindicatos, trabajadores vs. desocupados, nueva política vs. vieja política, nuevos actores vs. viejos actores, nuevos repertorios de acción vs. viejos repertorios de acción, etc. ¿O acaso no existen relaciones, vínculos, proximidades entre un fenómeno y otro? Aún cuando en cierto modo expresaban parte de sus falencias ¿no estimularon los partidos la creación de movimientos sociales? ¿No ocurrió que militantes de partidos políticos fueran al mismo tiempo militantes barriales y formaron movimientos sociales? ¿Es tan enorme y definitiva la frontera que separa a un trabajador de un desocupado? ¿Esto es así siempre? ¿No alternan los "nuevos" repertorios de acción con los "viejos"? Y así podríamos continuar...

\footnotetext{
${ }^{930}$ Vinculados a la heterogénea producción sobre protesta social en la Argentina citamos solamente los textos a los que hemos accedido y que, directa o indirectamente, algún elemento de su lectura influyó en el desarrollo de este proyecto de tesis doctoral. Sin duda se nos escapan una gran cantidad de textos, sobre todo en formato de artículos de revistas, ponencias e, incluso, algunos libros. Sin embargo, pensamos que incluir aquí un listado definitivo o sumamente extenso de estos trabajos en nada contribuye a mejorar nuestra argumentación y resultaría, seguramente, bastante tedioso para el lector o lectora.
} 
Nos parece un camino más provechoso preguntarnos precisamente por la experiencia histórica del proceso vivido en la década del ' 90 . Para conocer en profundidad una de esas experiencias, en ese sentido desde una mirada no tan pretenciosa, nuestro deseo es el de avanzar sobre el conocimiento del devenir de los sujetos vinculados a una rama productiva, la industria pesquera, y un territorio específico, la ciudad de Mar del Plata. Esperando, eso sí, que un estudio particular colaboré en iluminar experiencias pasibles de ser pensadas para otras ramas y otras regiones. De este modo ¿cómo fueron experimentadas por los trabajadores y las trabajadoras de la industria del pescado las transformaciones que trajo la década del '90? ¿Cuál fue su reacción ante los cambios en la actividad? Nuestro caso resulta algo particular dado que poco y nada se conoce de la industria pesquera y de los sujetos vinculados con esta actividad. Entonces, en poco más de diez años de historia transcurridos durante la larga década del ' 90 ¿qué fue de la otrora combativa y luchadora tradición de los trabajadores? ¿Fueron víctimas pasivas de las transformaciones en la industria o emprendieron acciones tendientes a revertir los procesos que se desenvolvían perjudicándolos? ¿Aceptaron o rechazaron la precarización, la reestructuración productiva, la terciarización? En aquel contexto de fragmentación individualizante de los lazos sociales ¿existieron luchas y procesos de resistencia? A su vez, en el período posterior sí, como sostienen la mayoría de los trabajos sobre protesta social, a nivel general las conducciones sindicales y también la CGT fueron perdiendo protagonismo en la dinámica conflictual participando de las políticas implementadas por el gobierno en algún caso y otras veces buscando negociar en pos de defender determinadas prerrogativas de las organizaciones sindicales ¿qué sucedió con los trabajadores del pescado? ¿Participaron los sindicatos y sus conducciones de la protesta? ¿O las acciones se dieron por fuera de las estructuras gremiales? ¿En el interior de los sindicatos se vivieron fisuras o disidencias? ¿Cuáles fueron los sectores más movilizados? ¿Qué contenidos y horizontes expresaron las demandas? ¿Bajo qué forma se realizaron? ¿Se conformaron alianzas sociales en la acción? ¿Qué resultados arrojaron? Con estos y otros interrogantes nuestra inquietud en este capítulo se centró en procurar visualizar cómo reaccionaron los trabajadores y las trabajadoras ante las transformaciones en la industria. En ese sentido, se trata de trabajadores efectivamente partícipes de la protesta social. Conociendo que en el final de la década del '90 se vivió una profunda conflictividad que involucró a buena parte de la "comunidad" pesquera marplatense, el caso se vuelve de interés para, al menos, matizar las nociones más radicales respecto del alejamiento de los trabajadores del escenario conflictual. Mejor aún, lo que buscábamos mostrar es qué sucedió con ese segmento de la clase obrera, anteriormente integrada, representada por un sindicato poderoso y protagonista de las luchas sociales. La otrora combativa clase obrera portuaria, si ya no se movilizaba ¿por qué no lo hacía? Y si, como sabemos, se movilizó ¿por qué lo hizo y bajo qué formas organizativas? De ahí que en este capítulo y en los dos siguientes, busquemos aportar información respecto de la dinámica conflictual en la industria pesquera particularmente atendiendo a qué sujetos se movilizaron, con qué objetivos, demandas y horizontes, a quiénes señalaron como enemigos y a quiénes como amigos, qué respuestas obtuvieron, qué tipo de repertorio utilizaron al reclamar, cuál fue la actuación de los poderes del Estado y cuáles los saldos organizativos resultantes. También intentaremos vislumbrar la conformación de alianzas o compromisos inestables expresados en la acción, que dieron forma a protestas donde la ciudad, defendiendo intereses conjuntos opuestos a otra localidad, actuó como corporación económica. Lo cual no impidió la emergencia de conflictos en la clave de trabajo versus capital. Nos interesa ver cuál de estas formas prevaleció, qué grupos sociales participaron de aquellos compromisos y quiénes no lo hicieron. Además, procuramos observar qué sujeto y qué tipo de hecho predominaron en el balance global de las protestas ocurridas y si estas últimas fueron de carácter disruptivo o transitaron por 
los canales normalizados del reclamar. Para introducir a nuestros lectores y lectoras en la conflictividad ocurrida en la industria pesquera en la "larga década del '90", empecemos por dividir la misma en tres momentos disímiles:

1) 1989-1991. Abarca el final del gobierno de Alfonsín y el comienzo de la administración Menem. Período marcado por la quiebra de empresas pesqueras acompañado de un proceso de toma de plantas. Y, posteriormente, el surgimiento de las primeras movilizaciones de desocupados.

2) 1992-1996. Se trata del momento donde primó la estabilidad posterior a la implementación del Plan de Convertibilidad, donde se consolidó el sistema de trabajo de las pseudo cooperativas. En este período encontramos el más bajo nivel de actividad de protesta.

3) 1997-2001. Aquí ubicamos el ciclo de rebelión más importante, cuyo pico puede ubicarse en el "estallido social" de junio de 2000. Fue durante estos últimos cuatro años cuando se produjeron crecientes enfrentamientos y lucha de calles que movilizaron a todos los actores de la industria pesquera.

Con todo, en este capítulo nos dedicamos a los dos primeros momentos, buscando integrar la situación de la pesca como actividad económica y las políticas implementadas para la rama, con las reacciones de los trabajadores y los principales objetivos que manifestaron en la lucha. Si bien nuestra atención prioritaria refiere a los hechos protagonizados por los trabajadores del SOIP, mencionamos también los conflictos de otros gremios vinculados a la actividad pesquera para, de este modo, tener un mayor conocimiento de los procesos padecidos por el conjunto de los trabajadores de la rama, generalmente dependiente de una misma patronal y, al mismo tiempo, visualizar las respuestas que brindaron los diferentes sectores y organizaciones. A diferencia del ciclo posterior, cuando la dinámica conflictual arrojó a empresarios y gobierno local a ser partícipes de episodios de protesta, antes de 1997 las acciones estuvieron marcadas por la conflictividad prácticamente exclusiva de los trabajadores y trabajadoras. Dejamos el tercer período para el capítulo siguiente puesto que, por su riqueza y complejidad, precisa de un espacio propio de exposición.

\section{La conflictividad social en la pesca (I): los inicios del menemismo (1989-1991).}

\section{Del final del alfonsinismo al gobierno de Menem}

Los tres años que van desde el final del alfonsinismo y el fracaso del Plan Primavera hasta la consolidación de la Convertibilidad y del nuevo equipo económico del gobierno de Menem, fueron de una profunda reestructuración en la industria pesquera. Hemos visto el desarrollo de este proceso tanto en los aspectos económicos (capítulo I) como en lo que refiere a la trama política (capítulo II). Es momento de analizar el proceso desde la perspectiva de los trabajadores y trabajadoras y su lucha. En estos años, al mismo tiempo que se forjaban grandes alteraciones en el funcionamiento de la industria, cerraban numerosas fábricas y se producían despidos. Crecía también la conflictividad obrera con un horizonte defensivo que, si bien no era único, si era el predominante. En los 3 años que van entre 1989 y 1991 sobrevinieron 130 acciones de protesta, es decir, un promedio de una acción cada 8 días y medio. Se sucedieron manifestaciones, movilizaciones y tomas de fábricas reclamando mantener fuentes de trabajo, 
cobrar salarios atrasados y denunciando incumplimientos en el pago indemnizaciones. ${ }^{931}$ Otro grave problema, esta vez repercutiendo en la estructura financiera de los gremios, fue el incumplimiento de las patronales del pago de cuotas sindicales y de obras sociales. ${ }^{932}$ Ante todo ello, veremos que el conjunto de los gremios pesqueros se vieron activados durante esta etapa de mutaciones.

Recordemos que el Plan Primavera consideró a la pesca como actividad primaria no industrial, lo cual la excluyó del pago de reembolsos. Además la situación cambiaria perjudicaba a los sectores empresarios pesqueros, acompañada por una baja de los precios internacionales del pescado. ${ }^{933}$ Sobre esa realidad se sucedían los padecimientos de trabajadores y sus organizaciones gremiales. Uno de los problemas de la época fue el recurrente atraso en el pago de salarios. El 9 de enero Abdul Saravia denunciaba ante la Subsecretaría de Trabajo de la Provincia de Buenos Aires a varias empresas por no haber cumplido con los haberes correspondientes al sueldo anual complementario del segundo semestre de $1988 .{ }^{934}$ Otra de las situaciones dadas fue la falta de pago de los aportes de obra social y cuota sindical. Ello llevó al Sindicato del Hielo a declararse en estado de asamblea permanente. ${ }^{935}$ El SOMU local lanzaba un paro ante la suspensión de la obra social por el incumplimiento de pagos a los prestatarios de servicios. Mientras el SAON denunciaba que se hacía difícil sostener las prestaciones de la obra social. Por ello en el mes de agosto decretó un paro con permanencia en los lugares de trabajo pidiendo que se cumplieran las condiciones generales que establecía el convenio. ${ }^{936}$

Sin duda la mayor de las dificultades, vinculada con las anteriores, radicó en el cierre de plantas pesqueras, proceso generado a comienzos de la década del '80, pero que se volvió más contundente durante estos años. Como respuesta comenzó entonces un ciclo de toma de plantas por parte de los trabajadores del sector. Por ejemplo, los obreros y obreras agrupados en el sindicato del Hielo ocuparon la planta Pesca Sol denunciando que los empresarios la estaban "desmantelando". ${ }^{937}$ Tras diez días de ocupación, mientras todavía se encontraban esperando que se presentara alguna persona con poder de decisión, el secretario del gremio, Manuel Martínez, expresó que la planta estaba "inserta dentro de otra fábrica y cuando se produce el conflicto no aparecen los dueños". El hecho también mostraba las condiciones de la industria, donde una razón social, Pesca Sol en este caso, funcionaba en el interior de otra firma, de la cual no se nos dice su nombre. Pero lo cierto es que ni sindicato ni trabajadores podían recurrir a un interlocutor claro puesto que nadie se hacía cargo del personal. En aquel entonces el reclamo

\footnotetext{
${ }^{931}$ La década del '80 presenció también numerosas tomas de plantas que se pueden rastrear en la prensa de la época. Por ejemplo en 1984 era tomada la planta San Andrés. L.C.,09/11/1984. También en mayo de 1988 Saravia señalaba que permanecían ocupadas tres plantas procesadoras por falta de materia prima e informaba acerca del funcionamiento de una olla popular en la sede del SOIP donde se proporcionaba alimento a unas 600 personas sin trabajo. L.C.,13/05/1988.

${ }^{932}$ Esta situación data de principios de los años '80. En 1982 el SOIP denunciaba que "Aproximadamente mil trabajadores de nuestro sector se encuentran a merced de malos empresarios que, aprovechando la actual situación, evaden aportes a las cajas de jubilación y a las obras sociales. Como consecuencia de lo dicho el obrero no computa el trabajo realizado a los fines de la jubilación y carece de la cobertura de la obra social respectiva”. L.C.,18/12/1982. En 1984 el gremio mantenía acciones judiciales contra más de setenta empresas por el atraso en los pagos de retenciones, aportes de obra social y cuota sindical. L.C., 19/10/1984.

933 L.C.,19/02/1989. La crisis socioeconómica nacional se expresaba localmente. Los periódicos de la época muestran las continuas movilizaciones que enarbolaban consignas contra el hambre. Y la situación no hizo más que empeorar a raíz de la hiperinflación.

${ }^{934}$ Las firmas eran Germán Olmedo, Estrella de Mar, Marypez, Frigorífico Pescaso, Antonio D’Antonio, El Langostino, Frigocen, San Cayetano, Barilari, Abreumar, Pesquera Atlántida, Rúa Hnos., Pesquera Don Salvador, Taboas S.A. y Salerno Hnos. L.C.,10/01/1989.

${ }^{935}$ L.C.,29/01/1989. Y denunciaban a Pesca Sol, Ventura, Yagán Pesquera, Polo Sur, Estrella de Mar, Marypez y Hielo Nevada.

${ }^{936}$ L.C., $29 / 04 / 1989$.

${ }^{937}$ L.C.,28/02/1989.
} 
de los trabajadores y trabajadoras traslucía la situación de incertidumbre que vivían: "Pedimos la puesta en marcha de este establecimiento que se encuentra en perfectas condiciones, de no ser así, la reubicación del personal en otras fábricas, sino la indemnización que corresponde de acuerdo a la Ley de Contrato de Trabajo". Es decir, pedían algo, cualquier resolución. ${ }^{938}$ En relación con esto, solicitaban una reunión con la Cámara de Procesadores para que conjuntamente se analice el cierre de plantas. Buscaban conocer de ese modo si, como proclamaban, era sincero el deseo de los empresarios por cumplir el pacto social. El pedido daba cuenta del cierre de fábricas como fenómeno extendido. El SOIP, por su parte, se sumaba al estado de alerta agregandouna denuncia. En la visión de Saravia las quiebras y posteriores cierres de plantas no se producían por causas "razonables", sino que se debían a estrategias patronales contrarias a lógicas productivistas. Señaló que se trataba de "maniobras patronales lesivas a los intereses del gremio, la ciudad y la economía nacional" producto de "inescrupulosos empresarios de la industria del pescado", pues "resulta sugestivo que estos cierres se producen cuando las perspectivas económicas de exportación del producto tienden a mejorar ostensiblemente". 939

Pero los tiempos parecían cambiar tras la victoria de la fórmula Menem-Duhalde. Para la totalidad de los gremios pesqueros la vuelta del peronismo al poder significaba la posibilidad de modificar la realidad de la industria pesquera en favor de los trabajadores. Por ello el SOIP emitía un comunicado saludando a los ganadores. En medio de la crisis, los dirigentes se encontraban bajo el yugo de la situación económica pero, al mismo tiempo, reconocían tener por fin un gobierno propio que, confiaban, resolvería la situación. El 20 de mayo los trabajadores del pescado lograban, en el contexto de crisis general y solamente luego de que el gobierno anunciara un aumento de tarifas, el incremento de un $100 \%$ para las ramas filet, conserva y harina. ${ }^{940}$ Pero la inflación continuaba creciendo. Ante ello, durante los pocos días de gestión de Miguel Roig en el Ministerio de Economía, se anunció un plan económico que, entre otros aspectos, decretaba el pago de 8 mil australes no remunerativos para trabajadores estatales y privados, además de poner precios máximos. En la industria pesquera, el SOIP tuvo que convocar a una movilización el día 18 de julio ante el incumplimiento de este decreto por parte de varias empresas. El dirigente Luis Ronner denunciaba que algunas empresas no respetaban la garantía horaria y sólo pagaban por lo realizado, mientras que otras adeudaban hasta 3 años a la obra social. A esta situación general se sumaban conflictos puntuales. En septiembre el sindicato se declaraba en estado de alerta dada "la grave situación" por la que atraviesan gran parte de los afiliados del gremio en su encuadramiento rama conservara y enviaba una comunicación informativa a la delegación local del Ministerio de Trabajo. El problema estaba dado porque las lanchas pesqueras no habían salido a pescar anchoíta, ante lo cual las plantas de procesado no recibían materia prima para procesar. Eso perjudicaba a los trabajadores estables,

\footnotetext{
${ }^{938}$ L.C.,05/03/1989. En la foto que publica el diario puede verse a los trabajadores en la puerta de la fábrica junto a una bandera con la leyenda "No al cierre de plantas".

${ }^{939}$ L.C.,08/04/1989. El documento detalla que han cerrado Pescasol S.A. con 80 trabajadores despedidos, Marypez S.A. con 83 trabajadores despedidos, y El Langostino, del Grupo Antonio Poletti con 70 trabajadores despedidos. A estos casos se suman a las fábricas cerradas en los últimos cuatro años como consecuencia de declaraciones de quiebras judiciales: Copemar, Integral de Harina, Ciudad Feliz, Pesca Andes, Argenbel, Sangyu, Pesquera San Cayetano, Turegano y Pesquera San Antonio como asimismo las empresas que cerraron por otros motivos económicos como Escobar Hnos., Protemar, Pesquera Argentina, Del Mar, Arpemar 1 y 2, Veracruz, San Justo 2 y 3, Nazaria, Ferrier, Denegri 1 y 2, Carioca, Dan Mar, Sancahuano, Costa Azul, San Mateo, Gavemar, Agua Azul, Golfo Nuevo, Pesquera San Francisco, Vigo Mar, Anchoar, Ferro Mar, La Báltica, Roja Mar y San Ignacio, y el reciente cierre del sector de fileteado de la empresa Polo Sur S.A, con el despido de 29 obreros. Explica el SOIP que "algunos de estos establecimientos fueron reabiertos bajo la identificación de otras razones sociales, con lo que crearon condiciones objetivas de achicamiento del sector con graves perjuicios sociales y económicos que trascienden el ámbito del gremio para proyectarse a toda la ciudad de Mar del Plata”. También L.C.,18/04/1989.

${ }_{940}$ L.C., $21 / 05 / 1989$.
} 
que recibían menos salario, y más aún a los temporales, que directamente no habían sido llamados a trabajar. ${ }^{941} \mathrm{Al}$ año siguiente, en el mes de marzo, el SOIP comunicaba a los afiliados que conjuntamente con los haberes correspondientes a la segunda quincena de febrero se debía recibir la suma de A 150.000 establecida por el decreto $370 / 90 .{ }^{942}$

No obstante las ilusiones de los gremios marítimos y portuarios, y a pesar de aquellos primeros aumentos salariales, en octubre de 1989 Menem se encargaba de anunciar una política de sacrificios, sobre todo para los trabajadores. Como suplemento aclaraba que "paros, huelgas y reclamos" no iban a torcer la política salarial que "es inflexible", ${ }^{943}$ y que apuntaría a la flexibilidad laboral, a la parálisis de las paritarias y al aumento de salarios únicamente sujeto al incremento de la productividad. Al mismo tiempo, se puso un tope al incremento de salarios de estatales de un $20 \%$, lo cual rechazaban gremios y también la CGT Azopardo. En aquella oportunidad el Ejecutivo utilizó el miedo para "poner en caja" a los trabajadores, advirtiendo que es una decisión de los obreros reclamar en las negociaciones paritarias incrementos nominales que "harían peligrar sus fuentes de trabajo". ${ }^{944}$ Poco después ratificaba que no le temblaría la mano, no toleraría huelgas y que "el gobierno se mantendrá firme en su rumbo". 945

En la industria pesquera los tiempos de reestructuración no sólo no disminuyeron los conflictos, sino que más bien los multiplicaron. Para los industriales pesqueros era una época en que las políticas implementadas en relación al movimiento obrero les permitirían buscar mecanismos para lograr incrementar la explotación de la fuerza de trabajo. Por ejemplo, ya en los comienzos del año 1990, el Ministerio de Trabajo convocó a conciliación obligatoria ante un conflicto entre el SOIP y la pesquera Alpesca. Ante ello el gremio, que se había declarado en estado de alerta y movilización, puso en claro su decisión de no aceptar ninguna suspensión y/o despido "arbitrario". Y denunció que "la empresa pretende implantar condiciones de trabajo que no están pactadas y que no reconocemos...", así como denunció que mantenía deudas con la obra social y la cuota sindical. Por el lado empresarial, el apoderado de la firma pesquera Horacio Giacoboni, cuestionaba la posición del gremio expresando que "pretender desconocer la reducción deliberada del ritmo normal de trabajo en clara actitud de medida de fuerza, no solamente constituye una violación a sus obligaciones laborales, sino que es un boicot a la producción...". ${ }^{946}$ Las plantas eran Cerrito y Posadas y entre ambas comprendían alrededor del significativo número de casi mil operarios. La intención de los empresarios era que se aceleraran los ritmos de producción, lo cual implicaba trabajar a mayor velocidad. Cosa que los trabajadores rechazaban. Saravia señalaba "el personal sigue trabajando normalmente como dice el convenio, pero ellos (la empresa) quieren que el trabajo de 12 horas lo hagan en 8, cosa que no aceptamos". También denunció el despido de una obrera embarazada y el cambio de secciones arbitrario de los trabajadores. ${ }^{947}$

\footnotetext{
${ }^{941}$ L.C., 01/10/1989.

942 L.C., 08/03/1990.

${ }^{943}$ L.C., $22 / 10 / 1989$.

${ }^{944}$ L.C., 26/10/1989.

${ }^{945}$ L.C., 09/11/1989.

${ }^{946}$ L.C., 24/01/1990.

${ }^{947}$ L.C., 30/01/1990.
} 


\section{Conflictos por incumplimientos en el pago de las cuotas sindicales y obra social}

En el marco de la crisis hiperinflacionaria y del proceso de reestructuración pesquera que terminó en la quiebra de varias firmas, numerosas empresas suspendieron los aportes a la obra social y las cuotas sindicales. El hecho afectaba fuertemente las finanzas de los gremios que, ante la necesidad de activos, debían recurrir a los préstamos y subsidios otorgados por ANSSAL, quedando a disposición de quién se encargara de administrar aquellos recursos. Por ello una de las demandas recurrentes de los sindicatos será la de que las empresas efectivicen aquellos pagos. Sin más, en el mes de octubre de 1989 el Sindicato del Hielo volvía a declarar el estado de alerta ante la negativa por parte de la Cámara de Frigoríficos y Fábricas de Hielo de presentarse en la Comisión Paritaria Permanente. ${ }^{948}$ El gremio denunciaba los padecimientos financieros de los trabajadores y de la estructura sindical y señalaba en relación a las complicaciones del sindicato, que "...la situación tiende a agravarse, por un lado a causa de los aumentos no remunerativos que no aportan descuentos ni sindicales ni de obra social, asentando más el empobrecimiento de estas estructuras". Por ello denunciaban la insensibilidad de algunos empresarios que retenían en forma indebida los dineros que los trabajadores aportaban al sindicato y a la obra social. ${ }^{949}$ También el SOMU declaraba un paro, siendo uno de los más cortos de la historia del gremio, puesto que fue levantado a pocas horas de haber comenzado. Se reclamaba el pago de los aportes sindicales, particularmente en lo referente a la obra social. Decretado el paro, el $85 \%$ de las empresas se acercaron hasta la sede del gremio a conversar, arreglando su situación. A medida que las empresas iban pagando se autorizaba la salida de los barcos. El hecho habla de la importancia que adquiría la posición estratégica (Womack, 2007) de los marineros pescadores, que por su lugar en la estructura productiva pesquera tenían la capacidad de impedir la salida de los buques pesqueros. ${ }^{950}$ De todos modos, la fortaleza que les otorgaba a estos trabajadores el proceso productivo no servía de mucho cuando entre las causas de los incumplimientos se encontraba la quiebra y el cierre de plantas.

Pues esta realidad se sumaba a la hora del no pago por parte de muchos empresarios pesqueros de los aportes a la obra social y los descuentos correspondientes alos sindicatos. Ante ello, no eran muchas las herramientas que podían desplegar las conducciones sindicales. En el caso del SOIP, una de las amenazas esgrimidas por Saravia fue que denunciaría ante el fuero federal los casos de evasión comprobada. El dirigente expresaba: "solicitaremos en caso de incumplimiento comprobado la plena aplicación de la ley penal tributaria 23.771 sancionada el 7 de febrero de este año, en cuyo artículo tercero se encuadran quienes evaden esta obligación total o parcialmente". Destacaba que la norma castigaba con prisión a los responsables del incumplimiento, además de imponer elevadas multas. ${ }^{951} \mathrm{~A}$ estas alturas la evasión de aportes patronales ponía en peligro la situación de las obras sociales. Tiempo después, como veremos, las denuncias tenían algún efecto y varios empresarios eran procesados.

\footnotetext{
${ }^{948}$ L.C., $18 / 10 / 1989$.

${ }^{949}$ L.C., $22 / 10 / 1989$.

${ }^{950}$ L.C., 06/05/1990.

${ }^{951}$ L.C.,27/09/1990.
} 


\section{Conflictos por aumentos salariales y mejoras en las condiciones de trabajo}

Si bien menores, durante estos años se sucedieron algunos conflictos en reclamo de incrementos salariales. Por ejemplo a finales de 1989 el SAON buscaba un aumento de sueldo para los trabajadores navales. Ante la negativa patronal se declaraba en estado de alerta y asamblea permanente. Luis Comiso, líder de la entidad, expresaba "una vez más queda reflejada la actitud y soberbia de los señores empresarios ante la negativa de ajustar los magros salarios que venimos percibiendo los trabajadores navales". ${ }^{952}$ En febrero el gremio volvió a anunciar el estado de alerta y movilización debido a que los empresarios persistían en la negativa de otorgar un incremento salarial luego de los aumentos de precios y del nivel de vida. ${ }^{953}$ Recordemos que aún se vivía en un período altamente inflacionario. Cuando los industriales incrementaron el monto inicial ofrecido comenzó por fin la senda de un acuerdo. Comiso comentaba "nuestra predisposición es que el conflicto no se agrave", reconociendo que por esa razón aceptaban el aumento aunque les resultaba insuficiente. Y añadía "El país está inmerso en una crisis muy seria y de nuestra parte no queremos añadir un ingrediente para el malestar generalizado, ya que confiamos en la democracia, pero nuestros reclamos han sido justos..."954. Sin embargo, luego del principio de acuerdo, las condiciones laborales llevaron nuevamente al SAON a emprender un paro con movilización en reclamo de mayor seguridad, higiene y salubridad. "Este es un viejo problema que de una vez por todas debe solucionarse. Dos compañeros nuestros han muerto, hay otro, Teófilo Lledo, que se encuentra en terapia intensiva, todo por accidentes laborales que quizás se hubieran podido evitar". ${ }^{955}$ Días después retornaba el gremio al paro ante el incumplimiento de la CAABPA de un incremento salarial acordado en forma verbal entre el sindicato y la entidad. ${ }^{956} \mathrm{Y}$ en junio anunciaba un paro de 48 horas "ante la persistente mora empresarial en el pago de los aportes y el constante deterioro que viene sufriendo en virtud de la caída de los salarios de los trabajadores, se hace insostenible mantener las prestaciones médico asistenciales..." A esto se sumaban los intereses que cobraban los proveedores por no abonar las facturas en término. ${ }^{957}$ La medida de fuerza era parcial y sólo abarcaba a las empresas que se encontraban atrasadas con esos pagos. El paro se realizó con presencia en los lugares de trabajo, pero sin que los obreros desarrollaran tarea alguna. La finalización de la medida de fuerza tomaba al gremio en estado de alerta. La empresa Estrella de Mar despedía a 30 trabajadores. ${ }^{958}$ Ante la intervención del Ministerio de Trabajo, la firma los reincorporó. Pero tiempo después se presentó en quiebra y cerró sus puertas definitivamente. En septiembre de 1990 el SAON volvía al paro "ante la falta del incremento salarial correspondiente a los meses de julio, agosto y setiembre" como así también a "la falta de pagos de los aportes sociales, sindicales y mutuales del mes de agosto". ${ }^{959}$ Esta vez las negociaciones subían de tono. El día 9 la Cámara de la Industria Naval publicaba una solicitada titulada "No a los matones del $S A O N$ ". En la misma desestimaban los pedidos de incremento salarial que realizó el sindicato,

\footnotetext{
${ }^{952}$ L.C., 09/12/1989.

${ }^{953}$ L.C. $22 / 02 / 1990$.

${ }^{954}$ L.C. $24 / 07 / 1990$.

${ }^{955}$ L.C.,03/05/1990. Al día siguiente el concejal justicialista José Luis Pérez denunció que fue agredido por los trabajadores del SAON, sufriendo la fractura de dos dedos y daños en su automóvil. Mientras que el secretario de Acción Social del gremio, Enzo de Gregoris, señaló que fue el edil quien inició las agresiones. L.C.,04/05/1990.

${ }^{956}$ L.C.,28/05/1990.

${ }^{957}$ L.C., $08 / 06 / 1990$.

${ }^{958}$ L.C., $13 / 06 / 1990$.

${ }^{959}$ L.C.,08/09/1990.
} 
denunciaban que fueron amenazados y que los operarios no concurren al trabajo por miedo. ${ }^{960} \mathrm{La}$ respuesta sindical no demoró. Los dirigentes declararon que "Esta entidad jamás ha adoptado prácticas de esta naturaleza". Si aceptaban la existencia de tensiones, de las cuales responsabilizaban al apoderado legal de la cámara. ${ }^{961}$

El SOIP, por su parte, al no haber llegado a un acuerdo con la parte empresaria, anunció que iniciaría un plan de lucha consistente en la aplicación de la cláusula convencional de que "a igual trabajo igual salario". Todavía no se resignaba a abandonar la lucha por los salarios y por mantener negociaciones que abarcaran al conjunto de la rama. Por ello el sindicato presentó un acta en el Ministerio de Trabajo con la solicitud de que realicen inspecciones a distintos establecimientos asociados a las cámaras para constatar que "se han dado aumentos en forma individual por empresa y más adelante agregaremos la respectiva lista de las que trabajan en negro, no pagando las obligaciones sociales y previsionales, para que se aplique con todo rigor la ley tributaria". En paralelo se requería a las empresas que "suspendan todos los despidos arbitrarios y salvajes". ${ }^{962}$ A los pocos días convocaba a una movilización, previa consulta en reunión del cuerpo de delegados, al Ministerio de Trabajo para acompañar las gestiones del sindicato con las cámaras por un aumento salarial del 15\% para septiembre y $7,7 \%$ para octubre. Valores que no eran aceptados por las entidades patronales. ${ }^{963}$

\section{Conflictos por salarios atrasados}

Más corrientes que los anteriores fueron los conflictos surgidos por el reclamo acerca del cobro de salarios atrasados. A mediados de la década del '90 el SOIP se ponía en estado de alerta y movilización por lo que calificaba "mal cumplimiento" del pago del aguinaldo correspondiente al primer semestre de ese año y segunda quincena de haberes con asignaciones familiares del mes de junio. La comisión directiva, en conjunto con el cuerpo de delegados, declararon el trabajo a reglamento en las empresas que no cumplieran con la ley. Una lista proporcionada por el sindicato daba cuenta que de las 187 plantas registradas solo 41 pagaron de conformidad a lo que entendía el SOIP debían ser las liquidaciones. Ese mismo día, trabajadores del gremio se movilizaron por las calles del puerto y luego llegaron hasta la puerta de La Capital como forma de exteriorizar su desagrado por la situación que denunciaban. En la foto se puede ver un nutrido grupo de trabajadores junto al dirigente Luis Ronner. Los manifestantes portaban carteles con fotos de Saravia junto a Menem. ${ }^{964}$ Una de las empresas en conflicto era Arpemar. Por ello el Ministerio de Trabajo convocó a los pocos días a una audiencia entre empresarios y sindicatos, donde finalmente se llegó a un acuerdo cuando la empresa se comprometió a ir efectivizando los pagos de sueldos retrasados. Los empresarios explicaban los retrasos en los pagos afirmando que no podían pagar por el bajo valor del dólar y por la escasa captura. ${ }^{965}$ La ironía se producía cuando los empresarios, que

\footnotetext{
${ }^{960}$ L.C.,09/09/1990.

${ }^{961}$ L.C., $11 / 09 / 1990$.

962 L.C.,03/11/1990.

963 L.C., 10/11/1990.

964 L.C.,08/07/1990.

965 Por estos días enviaban una carta a Erman González, entonces ministro de Economía, anunciando los padecimientos de la actividad pesquera dados fundamentalmente por el incremento de los costos internos de producción en un contexto de retraso de la paridad cambiaria.
} 
conocían la situación y habían tomado la decisión de cerrar sus puertas, aún no lo comunicaban ni al Ministerio de Trabajo ni a los sindicatos. Lo cual nos pone ante una realidad dramática.

\section{Conflictos ante el cierre de empresas}

Hemos visto algunos conflictos en torno al incumplimiento en el pago de cuotas sindicales y obra social. Entre otras razones, dicho proceso se vinculaba con la presentación en convocatoria de acreedores y el cierre de algunas empresas, lo que hacía que se discontinuaran los pagos. En el caso de los marineros, la firma Estrella de Mar adeudaba los salarios de junio a los trabajadores de dos buques factoría. También Arpemar, Frigocen y Aurora Austral debían salarios. Otras empresas libraron cheques que, al intento de cobrarlos por parte de los trabajadores, fueron rechazados. Por todo ello el SOMU amenazó con un paro si no se llegaba a algún tipo de acuerdo. Carlos Trasante, secretario general, fue categórico al describir la situación denunciando que "las empresas no están pagando las obras sociales ni depositan los aportes y algunas están vaciando sus instalaciones. Se radican empresas fantasmas en el sur para pedir subsidios, que luego cierran, como acaba de ocurrir con Alpesca en Madryn que dejó 450 personas sin trabajo". Finalizó "No puede ser que todas las divisas que genera la pesca acaben depositadas en bancos del exterior y no se cumpla con trabajadores que desde hace muchos años además de poner el hombro no han hecho ningún paro de actividades desde hace muchisimo tiempo". ${ }^{966}$

Un caso paradigmático de empresas pesqueras que cerraban sus puertas fue el de Estrella de Mar. La incertidumbre respecto del futuro de dicha empresa convocó a sindicatos y empresarios a participar de varias reuniones. ${ }^{967}$ Una de ellas tuvo lugar en la delegación regional del Ministerio de Trabajo, donde se reunieron los dirigentes Abdul Saravia (SOIP), Carlos Trasante y Pablo Ortié (SOMU) y Luis Comiso (SAON) con representantes de la empresa. La finalidad era elaborar un acta en conjunto donde se expusieran las irregularidades que venía sufriendo el personal de los tres gremios, dados los masivos despidos y el retraso salarial. Del SOIP se contaban 150 despidos, 140 del SOMU, 100 del SAON. Además 500 personas no cobraban sus salarios. Saravia expresaba:

Tenemos deudas, todos estos gremios con las obras sociales, porque la empresa no paga, como tampoco paga las cuotas sindicales. Nos obligan a pedirles subsidios al ANSAL y mientras tanto los compañeros no pueden atender a sus familias. Debemos en la farmacia, a los laboratorios... la situación es inhumana, porque mientras más de quinientos trabajadores sufren, el señor Jorge Antonio, que de la actividad no sabe nada, un pirata y sinvergüenza está paseando en París. Y su hijo, titular de "Mar y Pesca" hace padecer la misma situación a sus trabajadores. Acá hay una ley tributaria que debe ser cumplida. De lo contrario habrá que actuar contra estos delincuentes y llevarlos a la cárcel como se merece. $^{968}$

Pero de nada sirvieron las negociaciones y acuerdos cuando estaba decidido el final de las operaciones de la empresa. Luego del cierre, los empresarios buscaron abonar indemnizaciones reducidas en un 50\% aduciendo la situación crítica que llevó a la quiebra, cosa que rechazaban los trabajadores. El

\footnotetext{
${ }^{966}$ L.C.,21/07/1990.

${ }^{967}$ L.C., 26/07/1990.

${ }^{968}$ L.C., 18/09/1990.
} 
responsable de la entidad, Oscar Poletti, luego fue procesado y encarcelado por administración fraudulenta. ${ }^{969}$ Frente a las oficinas de Estrella de Mar también se manifestaron los trabajadores de los barcos Neptune y Urán, propiedad de dicha firma, quienes revelaban que el conflicto con la empresa continuaba porque les adeudaba "los sueldos de julio, agosto y septiembre" a 150 tripulantes. 970

Los dirigentes del SOMU, por otra parte, no podían descansar de los conflictos y se veían obligados a lanzar otra amenaza de paro, pero esta vez de los afiliados de la pesca de media altura. Dirigentes explicaron que "Hay una violación total del convenio colectivo de trabajo" y denunciaron que "están echando a trabajadores, como en los casos de los buques Orión I ${ }^{\circ}$ y Tifón, sin el pago de las indemnizaciones correspondientes". ${ }^{971}$ Hacia octubre de 1990 la reestructuración que atravesaba la industria pesquera se hacía sentir en la situación de los trabajadores. En buena medida, se produjo un retroceso fundamental. Pues sin ni siquiera poder mantener las fuentes de trabajo de muchos de sus representados se hacía más difícil para los dirigentes sindicales sostener reclamos por incrementos salariales. Nuevamente en la delegación regional del Ministerio de Trabajo de la Nación se reunieron gremialistas con el titular de la delegación, Vicente Gazzanego, para hacerle saber la difícil situación por la que estaba pasando el sector a raíz de los masivos despidos producidos en Arpemar-Promasa y Valastro. Los gremios presentes eran el SUPA, SOMU, SOIP, SAON, Empleados de Comercio, Centro de Patrones y Capitanes de Pesca y SICONARA. Los dirigentes descartaron la posibilidad de un paro. Julio Di Gerónimo expresó "Nuestra intención es trabajar en conjunto para sacar adelante todo el problema que hay en el Puerto y, también en el país. No vamos a solicitar aumentos de sueldos, no queremos mejores remuneraciones, lo que queremos hacer es preservar el derecho de trabajador". Se contabilizaba entonces que la empresa Arpemar-Promasa había despedido a 80 trabajadores del SOIP, 25 de Empleados de Comercio, 14 de façoneras sin representación y mantenía dos barcos parados con obreros del SOMU. Por su parte Valastro había echado a 35 obreros estibadores afiliados al SUPA. ${ }^{972}$

\section{Conflictos por el reconocimiento de delegados}

Hemos visto ya la importancia que la figura del delegado mantenía en la estructura del gremio SOIP. Pero este aspecto estaba también sujeto a la dinámica cotidiana del antagonismo entre el trabajo y el capital. Tal es así que el reconocimiento y protección de delegados motivó varios conflictos entre el SOIP y distintas empresas. Por ejemplo en febrero de 1989 el sindicato declaraba el estado de alerta y movilización ante el intento de la empresa COOMARPES de despedir a dos candidatos a delegados de personal violando lo dispuesto por la ley $\mathrm{N}^{\circ} 23.551$ y el decreto reglamentario $\mathrm{N}^{\circ} 167 / 88 .{ }^{973}$ Producto de las gestiones del sindicato y mediante conciliación obligatoria dictada por el Ministerio de Trabajo, los

\footnotetext{
969 El SOIP denunció en numerosas oportunidades a Oscar Poletti por despedir trabajadores. El propietario de la firma, se sostenía, era Jorge Antonio. Éste último siempre dijo que no se dedicaba al rubro y que la empresa era en realidad de su hijo.

${ }^{970}$ L.C.,29/10/1990. Los trabajadores denunciaban que "ese señor" (en relación a Jorge Antonio) se jacta en los programas del periodista Bernardo Neustadt de estar con "la revolución productiva" pero en realidad "lo que hace es abrir y cerrar empresas dejando a la gente en la calle y, lo que es peor, sin pagarles sueldos ni indemnizaciones". A los marineros les informaron que aquellos barcos no saldrían más a navegar. Ante ello, los obreros manifestaron "no entendemos lo que pasa. Es una empresa floreciente, que exporta mucho, y sin embargo la gente no cobra".

${ }^{971}$ L.C.,26/07/1990.

972 L.C., 03/11/1990.

${ }^{973}$ L.C.,29/02/1989. Los trabajadores eran Mario Hugo Ocampo y Oscar Alfredo Ferreira.
} 
obreros fueron reincorporados. ${ }^{974}$ En marzo de 1990 la lucha por el reconocimiento de un delegado provocó la realización de una manifestación frente a la delegación del Ministerio de Trabajo. La acción fue llevada a cabo por parte de "una bulliciosa delegación del cuerpo de delegados del SOIP" reclamando por el reconocimiento de uno de los delegados, Juan Carlos Beltrán, quien no era aceptado como tal por la patronal de la planta procesadora Pesquera Nerano. Realizando una arbitraria lectura de la norma, la empresa alegaba que su plantel de personal no alcanzaba el número de dependientes mínimos provisto por la ley laboral para la designación de un delegado. Los manifestantes mantenían cortado el tránsito para dar lectura a la resolución por la cual se intimó a la empresa a reconocer a Beltrán. Pasadas un par de horas la movilización se dirigió hasta la pesquera San Andrés que amenazaba con despedir a un delegado gremial que fue detenido en una causa ajena a su actividad laboral. ${ }^{975}$

Otro conflicto que involucró a la figura de los delegados se dio en una de las plantas de Solimeno. IndamiraJuárez y Orlando Dunrao, delegados de fábrica, enterados de que se produjo un incendio de casas en la villa en que residían, abandonaron la planta y corrieron hasta aquel lugar con la perspectiva de enterarse cuáles eran los daños y brindar algún tipo de ayuda. Ante ello, al día siguiente fueron suspendidos. Enterado de tal circunstancia Saravia, el SOIP convocó a un paro en la empresa mencionada -que duró una hora y media-pidiendo por el levantamiento de la suspensión, lo cual finalmente sucedió. ${ }^{976}$ Por otra parte, en abril de 1991 Federico Diffel, candidato a delegado de la empresa Famas SRL, fue despedido. Ante ello el SOIP, que para estas alturas ya estaba sumido en una vorágine de conflictos, presentó una denuncia el Ministerio de Trabajo. ${ }^{977}$ La fuente no brinda respuesta sobre el resultado de esta acción. Ya en 1994 se desata otro conflicto en torno al reconocimiento de Guillermo Díaz como delegado de personal de la firma Ardapez S.A. Mientras la firma no lo reconocía, el SOIP se declaraba en estado de alerta y movilización. Díaz denunció malos tratos de parte de los propietarios. Y tras realizar una denuncia en la comisaría, al volver a la planta, le impidieron el acceso, suspendiéndolo y desde ahí no lo dejaron ingresar al establecimiento ni siquiera para retirar sus pertenencias. Saravia señaló que " $L a$ empresa no puede suspender ni despedir a un delegado gremial si no es por caso justificado". El SOIP presentó entonces una carta documento en la Subsecretaría de Trabajo de la provincia, donde se pidió para todos los trabajadores de la empresa que se pague el sueldo en horario de trabajo y no fuera de él, que se respete la distribución de las tareas de acuerdo a la categoría de cada trabajador, y a su vez, se intimó a la empresa a que blanquee las remuneraciones que estaba pagando "en negro". También se incluían reclamos por despidos injustificados de tres trabajador@s, dos de ellas mujeres embarazadas. ${ }^{978}$

Poco después el SOIP informó que rechazaba la impugnación del acto eleccionario para la designación de delegados en Pesquera Atlántico Norte. El gremio inició trámites administrativos ante el Ministerio de Trabajo de la Nación y expresó su "repudio al Sr. Gerente y propietario de dicha empresa, Enrique Madoia, conocido en el sector de la industria pesquera como 'El Cabezón' y testaferro de José 'Pototo' Moscuzza, quienes han intentado en reiteradas oportunidades convertir el establecimiento de marras en una Cooperativa de Trabajo para perjudicar a los trabajadores en sus derechos" ${ }^{\text {"79 }}$.

\footnotetext{
${ }^{974}$ L.C.,04/03/1989.

975 L.C.,31/03/1990. Durante esa misma jornada de protesta ante una invitación del secretario general del SMATA, Carlos Theiler, los manifestantes se movilizaron hacia Indultlántica para solidarizarse con los trabajadores metalúrgicos que mantenían tomada esa planta.

${ }^{976}$ L.C., 20/09/1990.

${ }^{977}$ L.C., 06/04/1991.

${ }^{978}$ L.C., $19 / 04 / 1994$.

${ }^{979}$ L.C.,03/06/1994.
} 


\section{Conflictos entre plantas de procesado subsidiarias y empresas}

Dentro del esquema de funcionamiento del procesado de pescado era común que una empresa madre derivara parte de su materia prima hacia alguna planta de fileteado donde se produjera el fileteado y luego fuera la primera empresa la encargada de la venta. La Asociación de Procesadores de Pescado era la entidad que nucleaba a esas plantas de fazonado. Pero ocurría que esas empresas a las que se derivaba parte del pescado, a veces eran legales y otras veces plantas clandestinas, existiendo cierto vacío en cuanto a quién efectivamente contrataba al personal. En relación a las quiebras y cierres de plantas sucedía que algunas de estas plantas que faenaban para empresas más grandes cerraban sus puertas por falta de abastecimiento y dejaban en la calle a los trabajadores y trabajadoras. En numerosos casos los responsables de las plantas intermedias no se presentaban ante los obreros y obreras y, est@s, recurrían entonces a la planta madre para iniciar un reclamo. Ante la reiteración de estas situaciones la conducción del SOIP buscó rescatar la vincularidad de las empresas, citando el artículo $\mathrm{N}^{\circ} 30$ de la ley de Contrato de Trabajo por el cual la dadora de materia prima debía hacerse responsable del destino de los trabajadores cuando no aparecían los responsables de la planta façonera. Esto ocurrió en octubre de 1990 cuando Saravia denunció al grupo económico "El Marisco". El dirigente sostuvo que éste debería responsabilizarse de los obreros que prestaban servicios en Femar, atento a que "el mismo ha cerrado sus puertas dejando a todo el personal sin trabajo y sin percibir salario alguno". ${ }^{980}$ En otras ocasiones era la propia planta façonera la que iniciaba el reclamo. Un conflicto que se materializó en la toma de una planta fue la denuncia que llevaron adelante directivos de Gohermar SRL, quienes informaron que venían trabajando para el Frigorífico Propesa pero desde un tiempo ya no lo hacían debido a que la citada empresa no les proveía la materia prima necesaria. El titular de la planta, Germán Olmedo, comentó que:

...sin decirnos nada dejaron de enviarnos el pescado, de esta manera hay 30 operarios que están parados [...] Por el momento la gente ha decidido quedarse en la fábrica hasta que haya una solución, lo único que queremos es seguir trabajando como lo veníamos haciendo hasta hace dos meses atrás y desde hace cinco años con este frigorífico. ${ }^{981}$

Olmedo era integrante de la Asociación de Procesadores de Pescado. Tiempo después denunciaba haber sido burlado en su buena fe cuando la empresa Mellino, que se había comprometido a convertirse en la abastecedora, "decidió la suspensión definitiva de [la entrega de]materia prima". No sólo eso, sino que además se adeudaba diferencias salariales al personal, el incremento del 77\% asignado por el SOIP, las garantías de producción de un mes, las sumas fijas otorgadas por el gobierno y las vacaciones. ${ }^{982}$

\section{La protesta en los domicilios de industriales pesqueros}

Un repertorio de protesta que generaba enconadas quejas de los industriales pesqueros era la protesta frente a los domicilios de los patrones. Generalmente este repertorio funcionaba más como

\footnotetext{
${ }^{980}$ L.C., 03/10/1990.

${ }^{981}$ L.C., $26 / 08 / 1989$.

${ }^{982}$ L.C.,23/12/1989. Por su parte, la planta Abamar SRL despidió a 16 trabajadores aduciendo como causa la falta de entrega de materia prima. Con ese justificativo apelaba a abonar el 50\% de la indemnización.
} 
amenaza que como realidad. Por ejemplo, si bien fuera de este momento, en las protestas de junio de 2000 cuando se incrementaban los niveles de violencia y conflictividad social, los trabajadores barajaron la posibilidad de manifestarse frente a los domicilios de los empresarios. De inmediato, las fuerzas policiales protegieron aquellas residencias. Otras veces, ante tal amenaza, los patrones accedían a las demandas obreras. De todos modos imaginamos que si la amenaza era efectiva y generaba la airada reacción empresarial era porque contaba con hechos que el pasado permitía imaginar como posibles. Uno de esos episodios ocurrió cuando la Asociación de Procesadores de Pescado movilizó a los trabajadores de una planta subsidiaria de Mellino. Ésta empresa negaba dicha vinculación. Al asistir los trabajadores a la morada del empresario y permanecer algunas horas en la puerta manifestándose, el industrial finalmente salió de su casa y abonó una parte de los salarios adeudados. Al pagarles ratificaba que la denuncia no carecía de fundamento. Este reclamo tenía mayor peso dado que se efectuó el día de Navidad. ${ }^{983}$ Sin embargo, cómo sólo les había abonado una parte del salario, días después los obreros y obreras instalaron una olla popular frente a la casa del industrial. En la foto del periódico se ve una pancarta señalando "Queremos comer". ${ }^{984}$ En otra oportunidad fue el SOIP el que movilizó a sus afiliados a reclamar frente al domicilio de José Greco y la oficina de un representante de Estrella de Mar.

\section{Conflictos por incluir a los gremios en la definición de las políticas pesqueras}

No solamente por reivindicaciones salariales se movilizaban los gremios pesqueros. Eran frecuentes también las movilizaciones rechazando alguna definición política nacional en materia pesquera. Veremos en el próximo apartado que la Coordinadora de Gremios servía como núcleo aglutinador para que se produjeran estas medidas de fuerza. Pero también los sindicatos por su cuenta, y en particular el SOIP, se movilizaban en esa dirección. Por ejemplo ello ocurrió en febrero de 1990 en repudio al tratamiento en el Senado del proyecto de reducción de las 200 millas marinas. Al mismo tiempo era común que el sindicato enviara notas, cartas documento, etc. a diputados, senadores y funcionarios de gobierno, por lo general del PJ, buscando apoyo para la definición de políticas pesqueras. En esas cartas se expresaban preocupaciones, críticas a las políticas implementadas, etc. El gremio envió cartas documento a todos los diputados y senadores nacionales, declaró el estado de alerta y movilización ante la posible aprobación de la normativa y amenazó con que "realizaremos paros de todo el gremio". En una ocasión se movilizaron los afiliados en cuatro micros recorriendo diferentes lugares de la ciudad. La carta documento expresaba que "este sindicato, interpretando el sentir de los trabajadores que viven de y por los recursos pesqueros, se opone a cualquier iniciativa que signifique reducir nuestro Mar Territorial de 200 millas marinas" ${ }^{\prime 85}$. Recibía también el apoyo de la CGT regional. ${ }^{986}$

\footnotetext{
${ }^{983}$ L.C., $17 / 01 / 2012$

${ }^{984}$ L.C., $21 / 01 / 1990$.

${ }^{985}$ L.C.,24/02/1990. La foto utilizada por la prensa deja ver un importante número de personas movilizadas con bombos y carteles con las figuras de Menem y Evita.

${ }^{986}$ L.C., 25/02/1990.
} 


\section{En busca de un acuerdo social en la pesca}

Terminaba el año 1990 y en la sede del Ministerio de Trabajo los sectores de la producción y el trabajo vinculados a la industria pesquera llegaron a convenir un acuerdo social con la finalidad de regular la actividad portuaria. Convocados por Gazzanego participaron la Cámara de la Industria Naval, la Cámara de Industriales del Pescado, la CAABPA y, por los gremios, el SOIP, el SAON, el SOMU, el Centro de Patrones y Capitanes de Pesca y Empleados de Comercio. Se firmó entonces un documento: "vista la grave situación que afecta a trabajadores y empresarios del sector, y siendo necesario movilizar ideas y acciones tendientes a modificar con urgencia la situación de incertidumbre que, de continuar, alteraría la paz social de la ciudad" observando cómo metas imprescindibles para las partes "resguardar las fuentes de producción y trabajo, convienen en celebrar sin dilaciones un acuerdo social para la actividad". No era más que una declaración de buena voluntad donde las partes se comprometían a elevar propuestas y volver a reunirse. El principio de un pre acuerdo buscaba el compromiso del sector empresarial de no producir suspensiones ni despidos por el término de 60 días, en ese caso los trabajadores se comprometían a no iniciar medidas de fuerza. ${ }^{987}$

El primero de los sindicatos que rechazó la propuesta fue el SAON, dado que el gremio buscaba incluir la cuestión salarial entre los puntos a discutir. El sindicato naval se declaró en estado de alerta ante la reiterada negativa de la patronal a realizar un incremento en los sueldos. El requisito de la patronal para alcanzar una tregua era que los gremios no hicieran paros ni pedidos de aumento salarial. Comisso expresó: "Este tipo de acuerdo social no nos parece viable", puesto que "En los últimos meses se produjeron 110 despidos en distintas empresas, y los obreros no fueron indemnizados. Esto, sumado a las malas condiciones de trabajo, la reducción de horas extras y los bajos sueldos que venimos soportando, hacen imposible arribar a un acuerdo". ${ }^{988}$ Las diferencias llevaron a un cuarto intermedio en las deliberaciones de empresarios y sindicatos.

La situación se volvió aún más compleja luego de que la firma Barilari suspendió por 75 días a 224 operarios. Al día siguiente se firmó un acta que logró paralizar dicha suspensión. En los justificandos de la medida se mencionaba la difícil situación social del país y el estado de movilización gremial. Aún así, el segundo gremio que denunció la imposibilidad de un pacto fue el SOIP. Saravia manifestó "su renunciamiento al tipo de pacto social que se venía manteniendo a través del Ministerio de Trabajo de la Nación, puesto que todo lo actuado por las empresas agrupadas en el sector están produciendo despidos y suspensiones en forma indiscriminada". Por ello no se cancelaba el plan de lucha que elaboró el gremio para lograr "la recomposición salarial correspondiente al índice de inflación del mes de septiembre para ser percibido en octubre y la inflación de ese mes ajustada a noviembre". 989

Pero en la pulseada eran los gremios y los trabajadores los que perdían. El mes de noviembre terminaba cada vez con mayores signos negativos para ambos. Luis Comisso manifestaba la continuidad del estado de alerta de su gremio dado que medio centenar de obreros habían sido suspendidos en los últimos días: "Estas actitudes destruyen la moral de los compañeros", "hay pesqueras que están presentándose en convocatoria para, a través del concurso, eludir el pago de obligaciones a trabajadores y proveedores". ${ }^{990}$ Por su parte el SOIP denunció a varias empresas por incumplimiento

${ }^{987}$ L.C., $14 / 11 / 1990$

${ }^{988}$ L.C., $21 / 11 / 1990$

${ }^{989}$ L.C., $23 / 11 / 1990$.

${ }^{990}$ L.C., $28 / 11 / 1990$. 
salarial. ${ }^{991}$ Entre ellas, la planta Alondra había enviado telegramas de suspensión para todo el personal aduciendo "fuerza mayor" en la disminución de trabajo. A nombre de la comisión directiva, Sergio Gaitán escribía en un comunicado:

Esta organización gremial repudia enérgicamente a los empresarios que se aprovechan de la coyuntura, para quebrar o cerrar por distintos motivos y así poder crear sociedades anómicas [sic], que les permitirían justificar los desfalcos realizados con distintas entidades bancarias para blanquear capitales [...] Así se han gestado empresarios ricos con empresas pobres, y un ejemplo es Estrella de Mar. ${ }^{992}$

Reclamaba además por inspecciones y verificaciones a cargo de los organismos públicos. En diciembre se produjo una nueva manifestación del SOMU frente a las oficinas de la empresa "Mediterránea". Los trabajadores protestaban por el atraso en "el pago de salarios y muchos otros más beneficios sociales". Trasante decía "No se han pagado los sueldos desde hace tres meses, tampoco los francos y lo que corresponde a los accidentados. Que me digan quien puede vivir tres meses sin cobrar". Y endurecían sus críticas:

Solamente queremos preguntarle al señor Carlos Kalenzuc, que ha desaparecido, donde está la plata de los trabajadores, porque aquí se está jugando con el hambre de la gente [...] ¿quién entrega los permisos de pesca a estos delincuentes? [...] ahora van a traer barcos de España, harán trabajar a los pescadores argentinos y luego van a hacer la misma maniobra que ahora, desapareciendo con el dinero de los salarios. ${ }^{993}$

La Nochebuena del año 1990 estuvo marcada por el cierre de plantas, los despidos y la movilización de los trabajadores. El día 26 el SOIP encabezaba una movilización hasta una de las plantas de la empresa Estrella de Mar reclamando salarios adeudados. Los obreros encendieron una fogata en la calle. Luego de las negociaciones, los empresarios se comprometieron a abonar antes de fin de año. ${ }^{994}$ Mientras que las empresas Estrella de Mar y El progreso marplatense permanecían tomadas por los trabajadores. Éstos pasaron la Nochebuena y la Navidad en el interior de las plantas.

\section{La tregua imposible}

A pesar de las intenciones (sinceras o no) de los diferentes actores de la escena pesquera, parados en el centro de una reestructuración y en un cambio en la orientación industrial del país, cualquier tipo de tregua estaba destinada al fracaso. Pues la realidad de la actividad y, sobre todo de los trabajadores, era cada día más difícil. El incumplimiento salarial, los perjuicios a sus organizaciones, el cierre de plantas, no traían sino padecimientos a la situación de los obreros y obreras. En enero de 1991 el SOIP daba a conocer que venció el plazo estipulado por la ley para el pago de la primera quincena de enero, existiendo

\footnotetext{
${ }_{991}$ Pesquera Alondra, Pesquera San Andrés, las dos plantas de Produart, Pesquera Necomar, Frigorífico San Luis, Pesquera Príncipe, Arpemar, Promesa Feliccetti, Filolo Prestifilipo, Estrella de Mar.

992 L.C., 29/11/1990.

${ }^{993}$ L.C., $19 / 12 / 1990$.

${ }^{994}$ L.C.,27/12/1990.
} 
numerosos establecimientos que aún no habían pagado. ${ }^{995}$ También el SOMU, Patrones Pescadores y el SICONARA se veían envueltos en un nuevo conflicto al declarar los remolcadores del servicio portuario un paro que tenía como demanda que se cumplieran los aumentos salariales autorizados por el gobierno. Por esta razón, los barcos estaban entrando y saliendo bajo la exclusiva responsabilidad de los capitanes. El conflicto abarcaba a dos remolcadores de empresas privadas en los que trabajaban 22 personas. ${ }^{996}$ En febrero tanto el SOIP como el SAON se reunían con las cámaras empresarias en la delegación del Ministerio de Trabajo buscando volver a discutir un posible incremento salarial. Los empresarios ofrecieron la suma de 500 mil australes de incremento para todos los obreros y obreras por igual. El SAON la rechazó por exigua. En tanto que empleados de diversas plantas pesqueras continuaban con conflictos, el Ministerio de Trabajo dispuso la conciliación obligatoria. La seccional local del SAON la desoyó y convocó a un paro de 72 horas. ${ }^{997}$ El SOIP, por su parte, aceptó la propuesta patronal. Sin embargo, poco después Saravia y otros dirigentes denunciaban la existencia de plantas que no estaban abonando ni si quiera ese incremento mínimo. Ante ello, la Asociación de Procesadores de Pescado confesaba coincidir con el reclamo del SOIP, pero señalaba que los dadores de materia prima "parece que desconocieran los incrementos que se han operado" y se quejaban porque estaba ingresando menor cantidad de materia prima a las plantas. La situación era aún más grave, según decían para sus agremiados, por la existencia de la garantía horaria establecida en la convención colectiva de trabajo que les obligaba a pagarles a los obreros y obreras aunque no recibieran materia prima. ${ }^{998}$

Por el lado del SOMU, al sindicato de marineros le tocó protagonizar un conflicto que marcará claramente cuál fue la intervención del nuevo gobierno en los asuntos del trabajo y el capital. Pues en medio de discusiones paritarias donde los marineros buscaban mejorar sus condiciones de trabajo y mientras se complicaba arribar a un acuerdo, finalmente el Ministerio de Trabajo produjo el laudo 1057/90, el cual era definitivamente favorable a la parte empresarial. El prosecretario del SOMU, Juan González, afirmó que "Se han dejado de lado todas las actas de acuerdo y hasta el convenio del 75. En definitiva, se le quitaron conquistas a los obreros, en items como la hora de espera para la zarpada, enfermedad, nueva modalidad de accidentes de trabajo". La respuesta consistió en la amenaza de convocar a un paro por tiempo indeterminado. ${ }^{999}$ Se sumaba además el reclamo por el incumplimiento de un incremento salarial. Durante una asamblea de afiliados y mientras se mantenía el paro, Trasanteexpresaba la difícil situación:

...quiero dejar bien en claro que esta conducción ha trabajado durante dos años y medio sin tomar medidas de fuerza directa. Con esto nos están obligando a ir al paro, a tomar medidas de fuerza que no queremos porque la situación económica del país es desesperante y la del sector también. No podemos permitir que si no teníamos nada nos quiten lo poco que nos queda. Nadie quiere parar, nosotros queremos la fuente de trabajo, pero lo que pasa es que tenemos que defender -por lo menoslas conquistas que teníamos antes de este laudo. ${ }^{1000}$

\footnotetext{
995 L.C.,24/01/1991.

996 L.C., 25/01/1991.

${ }^{997}$ L.C., $27 / 02 / 1991$.

${ }^{998}$ L.C., 22/02/1991.

${ }^{999}$ L.C., 07/03/1991.

${ }^{1000}$ L.C., 12/03/1991.
} 
Poco después, el SOMU redactaba un comunicado de prensa con respecto del laudo dictado. En él expresaba:

Ahora se intenta volver a un régimen arcaico que somete al marinero pescador a la voluntad y arbitrio de los armadores, tanto en lo que se refiere a la navegación como a lo laboral, a semejanza de la 'milicia civil' imperante en la época de las naves a vela, dejando de lado conquistas, tanto del sector como de todos los compañeros trabajadores.

El gremio solicitaba que los empresarios "reconozcan que es inconstitucional y arbitrario aplicar un laudo que desconoce y rebaja las condiciones actuales de trabajo" poniendo fin "a una paritaria donde la parte obrera intentaba mejorar las condiciones de trabajo, seguridad e higiene a bordo de los buques pesqueros de altura". ${ }^{1001}$ El SOMU declaró entonces paro en los buques de altura. La medida comenzaba el día 20 y se prolongaba al menos hasta el martes 23, a la espera de ese día realizar una asamblea y decidir los pasos a seguir. Al momento de realizarse la reunión obrera se conocía que el laudo cuestionado quedaría sin efecto, retomándose el laudo de 1975 y recomenzarían las discusiones con la CAABPA. En ese momento los trabajadores lograron revertir la situación. Sin embargo, poco después, la sanción del decreto $N^{\circ} 817 / 92$ terminó definiendo la situación en desmedro de las condiciones laborales de los marineros. ${ }^{1002}$ Por otro lado, una nueva manifestación involucraba a trabajadores del pescado. Se trataba del personal de la planta pesquera La Florentina, quienes se manifestaban frente a la puerta de la fábrica dado que hacía dos semanas carecían de trabajo y se les adeudaba la segunda quincena de febrero y los reajustes correspondientes, los 400.000 australes de suma fija, bonos, salario familiar, ayuda escolar. Además denunciaban que los dueños los hacían ir todos los días con la promesa de pagarles pero hasta el momento no lo habían hecho. Interesante es que por primera vez en el transcurso de una manifestación recogida por la prensa (al menos en lo que nosotros pudimos encontrar), se realiza una crítica a la conducción del SOIP. Los trabajadores manifestaron que "el SOIP tampoco nos hace caso. Varias veces les pedimos que vinieran a ayudarnos pero nadie del sindicato se preocupó por nosotros". ${ }^{1003}$ Días después, la información disponible presenta a la planta tomada por sus trabajadores, ahora con la solidaridad del SOIP, que denunciaba que la empresa no sólo le debía a los trabajadores sino también "está debiendo a la caja de jubilaciones 700 millones de australes correspondientes a 1990, más los aportes a la obra social y sindicato desde julio de ese año". ${ }^{1004}$

En el mes mayo de 1991 se producía una nueva medida de protesta cuando los obreros de la planta Mar Azul, que empleaba 180 trabajadores, se manifestaron en la puerta de la empresa esperando la aparición de directivos que atendieran a sus reclamos por el pago sueldos atrasados. ${ }^{1005}$ En junio la empresa cumplía 60 días sin trabajar y se producía una nueva concentración frente a su puerta. Uno de los trabajadores señalaba:

...aquí hay fuga de capitales, un vaciamiento. Existen deudas previsionales e incluso a la obra social, pese a que la empresa, en noviembre tuvo una ganancia de un millón de dólares. Hoy dicen que no tienen plata. Se llevaron un velero a España, el gerente tiene dos casas, el dueño de la empresa,

\footnotetext{
${ }^{1001}$ L.C., 10/04/1991.

1002 L.C., 26/04/1991.

1003 L.C., 14/03/1991.

${ }^{1004}$ L.C., 24/03/1991.

1005 L.C., 11/05/1991.
} 
Roberto Tovo, tiene un colegio de una manzana en Alberti y General Paz, reciben créditos del Banco Nacional de Desarrollo o del Provincia. Esta es, en definitiva, la gente que no quiere pagarnos. ${ }^{1006}$

Y se sucedían los conflictos mes a mes. En una nueva concentración que tuvo lugar el día 13 de junio dirigentes del SOMU y del SICONARA señalaron "Esta empresa el año pasado estuvo pagando el 50 por ciento de los sueldos en negro, y lo que más duele es que nosotros hemos hecho propuestas concretas para reactivar la empresa". ${ }^{1007}$ Vale la pena reproducir, dada la posibilidad de contar con una fuente única, fragmentos de la carta que la esposa de un pescador le enviaba a quien era entonces la esposa de Roberto Tovo (presidente de la Cámara de Armadores):

Ser esposa de un tripulante pescador no es cosa fácil. Quizás usted no comprenda lo que se siente al ser padre y madre a la vez. La ausencia del compañero en el parto del hijo, en el cumpleaños, o como aquella noche imborrable cuando el padre debió salir a navegar para poder pagar los gastos de nuestro hijo internado [...] Patricia Stewar de Tovo; usted vive de Mar Azul, igual que nosotros, pero hay una diferencia: usted sigue comiendo todos los días, sigue vistiendo a sus hijos, mantiene sus coches; vive en una casa suntuosa y paga su tarjeta. Nosotros no señora, primero porque nunca tuvimos su nivel, y segundo porque no pudimos mantener lo poco que teníamos. ¡Hasta las cosas que más queríamos tuvimos que vender! ${ }^{1008}$

Ante la grave situación general de los trabajadores de la pesca el SOIP atinaba a enviarle cartas a Menem y al entonces vicepresidente Duhalde reclamándole soluciones por los ya casi 3 mil trabajadores despedidos, solicitando una solución al estilo Acindar. ${ }^{1009}$ También el senador nacional Pedro Molina ingresaba a la Cámara Alta un proyecto en el cual le solicita al PEN que se arbitren "las medidas tendientes a morigerar las graves consecuencias socioeconómicas" derivadas de los "numerosos despidos operados durante el corriente año en la industria pesquera". ${ }^{1010}$ En la interpretación de los gremios, insistimos, lo que sucedía se trataba de "maniobras" por parte de los empresarios pesqueros, quienes en lugar de consolidar una lógica productiva elegían realizar diferentes operaciones que les arrojaran mejores beneficios, despreocupándose por el destino de sus empresas y de los propios trabajadores. Con tal diagnóstico el SOMU demoró la salida de dos buques. Señalaba la dirigencia de la entidad que el motivo se fundamentaba porque:

...en maniobras desleales denunciadas oportunamente las empresas van cerrando en Mar del Plata y trasladan las mismas con otros nombres al sur del país, o simplemente se llevan las ganancias arrancadas de nuestro mar al exterior del país, no cumplen con sus obligaciones fiscales y mucho menos con las laborales [...] esta conducción, que creyó en el trabajo solidario para salvar al sector y flexibilizó dando a las empresas todas las oportunidades para que no cierren, hoy ve con disgusto que es una maniobra para enriquecerse más.

${ }^{1006}$ L.C.,06/06/1991.

${ }^{1007}$ L.C., 14/06/1991.

${ }^{1008}$ L.C., $14 / 06 / 1991$.

${ }^{1009}$ L.C., 16/05/1991; 17/05/1991. Se refería a la garantía salarial que el Estado brindaba a los obreros despedidos de ACINDAR a través de subsidios.

${ }^{1010}$ L.C., $13 / 06 / 1991$. 
Finalizaban el documento aclarando la situación a afiliados y posibles críticos de la conducción gremial: "No se pecó de ingenuos, sino que no había otra salida".

\section{Entre el récord de exportaciones y la "Marcha del hambre"}

No obstante todos estos padecimientos de los trabajadores, la Subsecretaría de Pesca anunciaba un récord de exportaciones pesqueras. Incluso es, cuanto menos curioso, que en la misma página de la prensa en que se realizaba este anuncio, otra nota indicaba que "Fueron despedidos sesenta empleados" de la empresa Mellino. ${ }^{1011}$ Paralelamente, alrededor del 50\% de la flota pesquera de altura estaba paralizada debido a que el SOMU seguía en paro con el objetivo de tener a sus afiliados en tierra para discutir la situación de la pesca. La asamblea tenía lugar los días 24 y 25 de junio. Allí se reunieron alrededor de 600 asambleístas, se sucedieron algunos cuestionamientos a la dirigencia del SOMU y se pidió al Ministerio de Trabajo la reincorporación de los despedidos. ${ }^{1012}$ En paralelo, las cámaras de Armadores y de Procesadores ofrecieron nuevamente a los gremios llegar a una tregua social por 180 días, para reactivar el sector pesquero marplatense. ${ }^{1013}$ Mientras, los marineros seguían movilizados puesto que se había retrotraído el laudo ministerial. Aprovechando su estadía en tierra, algunos de ellos que cuestionaban a la conducción sindical, se movilizaron hasta el Ministerio de Trabajo argumentado que "Estamos aquí para garantizar que la dirigencia actúe y obtenga los resultados que tiene que obtener para que nosotros podamos seguir trabajando en las condiciones que toda persona tiene que trabajar". Había "muchísimos trabajadores del sector".

Nosotros lo único que queremos es preservar las fuentes de trabajo, pero con respeto a las condiciones de trabajo. Estamos trabajando en forma inhumana y los contratos y acuerdos que se firmaron en su oportunidad no fueron respetados, incluso porque ni los mismos dirigentes de nuestro gremio velaron por esos derechos [...] También queremos que se blanqueen los pagos y acordar el precio del pescado pero sin 'negros', queremos blanquear la situación. ${ }^{1014}$

En esa situación, el Ministerio de Trabajo optó por declarar una conciliación obligatoria. Consultado sobre los resultados de la reunión y ante la pregunta ¿qué puede pasar con aquellas empresas que presentaron quiebra? Gazzanego expresó "Este es el problema. La inteligencia de cada dirigente sindical debe entender si éstos son momentos para reclamar salarios o para hablar de condiciones de trabajo". Los empresarios, por su parte, se quejaban del paro de actividades, señalando que mantenían los buques alistados para zarpar pero no podían hacerlo por la medida de fuerza. Esto, pensamos, continúa demostrando la posición estratégica de los marineros, dado que su lugar en el proceso de trabajo les otorgaba una capacidad de presión distinta a la de otras labores. Finalmente, tras la firma de un acta, los trabajadores levantaron la medida de fuerza y acataron la conciliación, salvo en las empresas Mellino y Tomar, donde persistieron los conflictos. ${ }^{1015}$

\footnotetext{
${ }^{1011}$ L.C., 25/06/1991.

1012 L.C.,25/06/1991; 26/06/1991.

1013 L.C.,26/06/1991.

1014 L.C.,27/06/1991.

1015 L.C.,28/06/1991.
} 
En julio de 1991 era el SOIP el que volvía a la acción directa. El motivo era el cierre indiscriminado de plantas pesqueras. Una de ellas era la pesquera San Andrés que en otros tiempos albergó a más de 200 trabajadores. El día de su remate una manifestación de los obreros del pescado se dirigió hasta el Colegio de Martilleros, lugar donde se realizaba la subasta. Una vez allí, un grupo ingresó al edificio portando pancartas que repudiaban la existencia de empresarios ricos con empresas pobres. Mientras tres mujeres que habían trabajado en la planta lloraban desconsoladamente sentadas en la primera fila, Abdul Saravia subió al estrado y dijo "Les decimos a los nuevos propietarios que queremos la revolución productiva para que no se cierren más fábricas". Mencionó los conflictos, las quiebras y cierres de empresas. Y habló de los obreros que tenían una antigüedad de 20 o 25 años en San Andrés. Una pancarta decía "Cárcel para los ladrones". Saravia también habló de la necesidad de cambiar la justicia diciendo que "hay empresarios delincuentes que dejaron un tendal, que no han pagado" y comentaba que gracias a la ley penal tributaria "algunos fueron presos, pero pudieron pagar la eximición de prisión, varias veces millonaria, y sin embargo no abonan la quincena de los trabajadores. Vamos a denunciar a todos los corruptos". Pidió por "empresarios serios". Dirigiéndose al doctor Omoldi, representante de los compradores, demandó "que la empresa continúe trabajando. Tenemos una nueva empresa y les decimos que vamos a colaborar". Y cerró su discurso refiriéndose, en el medio de una ovación -y en obvia alusión a su procesamiento- "si me tienen que meter preso por defender a los compañeros no tendré problemas en estar tras las rejas todos los días que quieran". Además "invitó" a Omoldi para que dijera algunas palabras. Este se limitó a señalar "vamos a esperar el trámite judicial que finalizará en 60 días", mientras que el titular del SOIP confiaba que antes de los dos meses puedan levantarse las persianas de la empresa. Por último, Saravia pidió aplausos para el martillero y para el personal policial. $^{1016}$

Pero no era feliz el final de esta historia. Pasado el tiempo, y a la espera del pago de salarios adeudados, los trabajadores y trabajadoras decidieron ocupar la fábrica. Pero sin poder conseguir su objetivo, finalmente fueron desalojados. Nos ocupamos de ello en el próximo apartado. Aquí nos detenemos brevemente en la movilización que protagonizaron estos trabajadores el día 29 de agosto, que tiene la particularidad de realizarse ya no sobre la puerta de las planta, sino nuevamente en el domicilio de uno de los empresarios. Encabezados por Saravia, los trabajadores se movilizaron en micros hasta la casa de José Greco. Luego, como la situación de la empresa MaryPez del grupo Estrella de Mar era similar, se dirigieron a la oficina de un tal Carlos Mata que tenía vínculos con dicha empresa, controlando los bienes de Poletti y Antonio. El dirigente explicó que "estamos reclamando los haberes del mes de agosto, asignaciones familiares, bonos alimentarios, accidentes, enfermedades inculpables". En la casa de José Greco las ventanas y cortinas estaban totalmente cerradas. Saravia dijo "Se ha escondido o fugado, ya que hace unos días andaba por acá”. Y advirtió que si en las próximas horas no abonan lo reclamado pondrá una olla popular frente a la casa y frente a la oficina de Mata. ${ }^{1017}$ Bien mirado el panorama, los hechos no parecieron desmentir las denuncias sindicales respecto de las "maniobras" patronales contrarias a una lógica productiva. Víctimas de tales ardides eran también los trabajadores del SAON, quienes

${ }^{1016}$ L.C.,04/07/1991.

1017 L.C.,30/08/1991. Además Saravia se refirió a la situación de la empresa Coral del Norte destacando que "le adeudan al personal parte de los haberes de julio y agosto. Esta empresa pertenece a los hermanos Leeb, que se encuentran en el sur trabajando con un barco. Aquí en Mar del Plata dejaron a la fábrica y a los obreros a la buena de Dios, sin nada. Solamente le dejaron al capataz de la fábrica la llave para que abriera y siguieran trabajando, pero no lo pueden hacer porque no tienen pescado para procesar". 
encabezados por Carlos Santillán, en ese entonces interventor de la entidad, se hicieron presentes en el Juzgado Civil y Comercial N²para interiorizarse acerca de la situación de la empresa Ventura. Allí les informaron que la firma "había pedido su propia quiebra con autorización de seguir desempeñando sus tareas en la zona sur". La firma mantenía diferentes deudas con el personal. Un trabajador se mostró indignado:

...nosotros conocíamos la situación de la empresa, poníamos el hombro porque nos decían que íbamos a cobrar y que en la empresa no pasaba nada extraño. Trabajamos dentro de las peores condiciones, horas extras pues nos decían y prometían que cuando termináramos de arreglar los barcos y estos salieran a navegar nos iban a pagar lo adeudado. Los barcos volvieron y todavía no hemos visto un peso, encima nos encontramos con esta novedad. Como queda visto, a los empresarios de la pesca de Mar del Plata no les interesa para nada su personal, ya que hicimos todo lo posible para que la empresa funcione y nos pagan con esta moneda.

El diario menciona que los trabajadores se encontraban en un desconcierto total "ya que ningún responsable se hizo presente para decirnos lo que pasaba". Un obrero expresó: "Alguien dijo que estábamos en la Argentina de la Revolución Productiva, quiero saber dónde queda para ir, porque lo que es en el Puerto de Mar del Plata eso no existe; al contrario, estamos inmersos dentro de una importante recesión". ${ }^{1018}$ En julio el SOMU se declaraba nuevamente en estado de alerta y movilización debido a la interrupción de la obra social y de los servicios de farmacia. Más allá de la medida de fuerza, aparece aquí una enemistad que diez años más tarde cobrará toda su dimensión. Pues el secretario adjunto del SOMU local, Juan Domingo "El Gato" Novero responsabilizó por la situación al interventor del SOMU nacional, Omar Enrique "El Caballo" Suarez: "Suárez y la ANSSAL son los responsables de esta medida". Y anunciaba que "De seguir asi vamos a tener que tomar medidas drásticas que incluso obligarían a romper la conciliación obligatoria." 1019

El día 11 de aquel mes la Coordinadora de Gremios Marítimos era recibida por el Intendente Ángel Roig, ante quien denunciaba los padecimientos de los trabajadores y las "maniobras" de empresarios. ${ }^{1020}$ Paralelamente, se produjo una concentración de trabajadores frente al Palacio Municipal. Se trataba de los obreros de la recientemente cerrada empresa Tomar, quienes se movilizaban solicitando el apoyo de los concejales ante la situación de que al menos 450 personas habían quedado en la calle. El delegado Luis Sepúlveda señalaba:

...al síndico le decimos que nosotros queremos trabajar. La actitud de todos los implicados es volver a trabajar. Nosotros también pedimos en el Concejo que por favor esto termine, porque en Mar del Plata la pesca se acaba de a poco. Acá nadie da la cara, los obreros no tenemos quién nos defienda, por eso los trabajadores de Tomar nos estamos defendiendo por nuestros propios medios... ${ }^{1021}$

La movilización surgía por fuera de la dirigencia del SOIP, siendo la primera acción de verdadera magnitud en la que no aparece la dirigencia gremial. Dada la cantidad de personas en la misma situación Sepúlveda convocaba a participar de la lucha a:

1018 L.C., 13/07/1991.

1019 L.C.,09/07/1991.

${ }^{1020}$ Analizamos su composición y objetivos en próximos apartados.

${ }^{1021}$ Luis Sepúlveda tendrá una errática trayectoria de la que nos ocupamos en próximas páginas. 
...todos los trabajadores que están en las mismas condiciones que nosotros, nos juntemos y nos acompañen en esta lucha porque es de todos. Queremos que todos los trabajadores de esas empresas se acerquen a conversar para buscar alguna solución porque sino el Puerto se acaba. Tenemos que luchar porque nos beneficia a todos, y si es necesario, todo el pueblo marplatense que trabaja en el sector de la pesca salga a manifestar a la calle y no dejen que los únicos que protestemos seamos los de Tomar. ${ }^{1022}$

El día 22 trabajadores del pescado que se encontraban despedidos, cesanteados, suspendidos o con incertidumbre sobre su situación laboral ante el cierre de empresas, se concentraron en la intersección de las calles Edison y 12 de Octubre. Desde allí se movilizaron hasta el Concejo Deliberante. La crónica titulaba "Ruidosa manifestación contra el cierre de pesqueras". No sabemos la cantidad de personas involucradas pero se trataba de "un numeroso grupo de trabajadores de la pesca". Entregaron un petitorio a los ediles exigiendo la intervención de las autoridades municipales. Aclararon los manifestantes: "este no es un movimiento político, ni gremial, no tiene ningún tipo de color. Esta movilización no tiene más banderas que la de mantener una fuente de trabajo que hoy tiene paralizada a más de cinco mil personas, pero que pueden ser muchas más si no sabemos defendernos, pero todos juntos". ${ }^{1023}$ Dos días después, representantes de los trabajadores pudieron presenciar la deliberación del Concejo ocupando "la barra", donde se aprobó por mayoría el proyecto de resolución por el cual se solicitó a los magistrados la reapertura de las plantas pesqueras paralizadas. Pero aquello no pasaba de ser una declaración de buenas intenciones sin capacidad de incidir en la situación real de la pesca.

En agosto estos trabajadores conseguían un mayor grado de organización al realizar una nueva movilización otra vez desde el puerto de la ciudad hasta el Concejo Deliberante. Esta vez la medida de protesta tenía un nombre, "Marcha del Hambre"; una organización convocante, la Comisión Pro Reactivación de la Pesca; y algun@s líderes como Ricardo Muñoz, Luis Sepúlveda, Felisa Hernández, Juan Nogueira, Susana Escobar, Martín Muñoz y Patricia Torres. Los acompañaban "un centenar de personas con bombos, pancartas y carteles". La movilización expresaba un antagonismo con la conducción sindical. Algunos de los movilizados habían integrado la Lista Verde. L@s manifestantes aclaraban que la organización de la protesta se realizaba a espaldas de la dirigencia sindical porque "los dirigentes de la pesca se han escabullido". El contexto de cierre de plantas comenzaba a generar un espacio mayor para la crítica a Saravia y su grupo, quienes a pesar de sus acciones, declaraciones y relaciones políticas, se mostraban impotentes para contrarrestar el proceso de reestructuración que vivía la pesca y la economía argentina en general. Las elecciones gremiales mostraron el crecimiento de la oposición sindical, aunque no pudieron quitar de la conducción a Saravia. Volviendo a la movilización, una vez en el Concejo los manifestantes entregaron un petitorio a los ediles. Según este "Aspiramos a que se respete nuestra libertad constitucional de trabajar, producir, y el precepto bíblico de ganarás el pan con el sudor de tu frente y que se haga realidad a través de nuestro esfuerzo, sumado al de todos los que se esmeran en lograr la ansiada revolución productiva, arribar al país que merecemos". ${ }^{1024}$ Todavía se utilizaba la noción de revolución productiva como un valor. Lo que sucedía en la pesca era lo contrario a lo que aquella categoría contenía implícito. La "Marcha del Hambre" protagonizada por un grupo de

1022 L.C., 12/07/1991.

1023 L.C., 23/07/1991.

${ }^{1024}$ L.C., 16/08/1991. 
trabajadores y trabajadoras constituyó uno de los emergentes de la reestructuración pesquera. Mientras estos se movilizaban a partir del "hambre", la pesca continuaba anunciando exportaciones récord.

\section{La Coordinadora de Gremios Marítimos y Portuarios}

La formación de una Coordinadora de Gremios respondió a un interés de los trabajadores marítimos y pesqueros de alcanzar una unidad mayor a la de sus sindicatos aislados. La iniciativa estaba potenciada por pertenecer los trabajadores y trabajadoras a una misma rama de la economía, por verse afectados ante las mismas medidas de política económica y por tratar con una misma patronal. Además, colaboraba con la mutua consulta sindical la proximidad y concentración geográfica que brinda el puerto de Mar del Plata. Se trataba de un organismo con alto grado de informalidad, pero que permitía articular en determinadas coyunturas las diferentes voluntades para la acción. La conformación de la Coordinadora no siempre fue estable, ya que algunos gremios fluctuaron entre su participación y su alejamiento, generado por disidencias. Un aspecto por demás interesante de la entidad, es que la misma generalmente se activó cuando alguna política nacional afectó los intereses de conjunto del sector pesquero. Y en esa activación, no permaneció resguardada defiendo intereses gremiales de sus representados, sino que trascendió esos límites y buscó intervenir en la definición de políticas nacionales, a veces con mayor suerte, y otras anotándose fuertes derrotas, lo que no quita la importancia de la iniciativa.

En cuanto a sus antecedentes históricos, una Comisión Intersindical Marítima integrada por el SOMU, el Centro de Patrones Pescadores y el Sindicato de Conductores Fusionados se conformó en 1965 durante el contexto de una huelga llevada adelante por trabajadores y trabajadores que faenaban filet (Nieto, 2012). Para nuestro análisis, la primera acción en la que se ven los gremios mancomunados es la oposición a los Acuerdos Marco de 1986, siendo ellos el motor de la convocatoria al paro regional decretado por la CGT local. A su vez, en 1988 y 1989 la Coordinadora decretó el estado de alerta y movilización ante las discusiones en las Cámaras Alta y Baja del Parlamento de proyectos de ley de pesca que autorizaban el ingreso de buques extranjeros a nuestro caladero. Al mismo tiempo, demostrando que su existencia no se limitaba a reclamos meramente reactivos, presentaba un proyecto propio de ley de pesca. En otras oportunidades, la Coordinadora destacó la actividad realizada por la Armada Argentina cuando ésta detuvo buques de bandera extranjera pescado en nuestras costas. ${ }^{1025}$ Este asunto no era menor dado que la señal de apoyo se realizaba justo en el momento en que la Armada, a través del jefe del Estado Mayor, contraalmirante Jorge Osvaldo Ferrer, solicitaba mayores recursos para controlar la actividad pesquera ilegal. ${ }^{1026}$

En enero de 1989 Pablo Ortié, secretario general del SOMU que siguió a Trasante, participó de la Coordinadora. Por ese entonces, el nucleamiento de gremios discutía la orientación de la política pesquera, criticando las intenciones de la Cancillería de ratificar la CONVEMAR. ${ }^{1027}$ Paralelamente, solicitaba audiencias con las autoridades del área de Puertos y Pesca con el objetivo de obtener soluciones ante los padecimientos de los trabajadores. ${ }^{1028}$ Las acciones tendientes a influir en la política pesquera que encaraba la Coordinadora la llevaron a protagonizar nuevos enfrentamientos con las autoridades del área

${ }^{1025}$ L.C., $19 / 10 / 1989$.

${ }^{1026}$ L.C., $18 / 10 / 1989$.

${ }^{1027}$ L.C., 15/09/1989.

${ }^{1028}$ L.C., 17/09/1989. 
pesca. Para el mes de octubre de 1989 la entidad gremial se declaraba en estado de alerta y movilización, y solicitaba una urgente entrevista con Menem a propósito de la decisión adoptada por Luis Otero de invitar sólo a dos gremios (el Centro de Patrones y Capitanes y el SOMU) a la reunión de la Comisión Consultiva de Planificación y Gestión. ${ }^{1029}$ Acusaban a Otero de sostener una actitud divisionista, indicando que no permitirían ese tipo de comportamiento de las autoridades pesqueras "porque esto no puede ser una reiteración de la política radical". Y profundizaban su crítica al supuesto continuismo en las políticas pesqueras señalando que:

...esta actitud pone nuevamente de manifiesto la incoherente y maliciosa conducta de los funcionarios del sector y muy especialmente del doctor Otero y el licenciado Lazcano, quienes continúan empeñados en una política nefasta ya conocida, de funcionarios ignotos, ineptos y de dudosa honestidad, hoy procesados penalmente como Jaimes y Malaret.

Mientras, se reunían con César Lerena procurando coordinar el trabajo "a fin de poder implementar desde Mar del Plata una politica adecuada al quehacer pesquero". ${ }^{1030}$

En marzo de 1990 los gremios que integraban la Coordinadora eran el SUPA, SAON, UPCN, SOIP, SOMU, Centro de Patrones Fluviales y de Cabotaje. A través de un comunicado ratificaban su oposición a la sanción del proyecto de ley del senador Adolfo Gass que pretendía reducir el Mar Argentino y su plataforma continental, mientras que manifestaban su "más encendido apoyo a los senadores nacionales Pedro Molina y César Mac Carthy por la patriótica oposición que llevan a cabo respecto de esta insólita iniciativa". Luego enumeraban las innumerables pérdidas económicas y de soberanía que implicaría dicha reducción. ${ }^{1031}$ También desde la Coordinadora los gremios se opondrían a la ley elaborada por la Cancillería. Destacaban "el carácter dependiente y sectario de este proyecto al ser convocadas las fuerzas empresarias a una reunión informativa en el Banco de Nueva York, excluyendo de esa convocatoria a las organizaciones gremiales vinculadas a la pesca", lo que beneficiaba a empresas extranjeras. Además cuestionaban la insistencia por la firma de tratados internacionales "completándose el loteo de nuestro mar para vender pescado sin valor agregado, mediante licitaciones internacionales". ${ }^{1032}$ Finalizaban diciendo que "este proyecto constituye una ofensa sin precedentes a nuestros soldados muertos en Malvinas, ya que de su texto sólo se advierte una concreta finalidad de consentir las exigencias británicas en el Atlántico Sur a costa de nuestros derechos, riquezas y dignidad nacional..."

Esa voluntad por influir en la política pesquera obligaba a los gremios a un ejercicio cotidiano de presión y control, particularmente atentos a la designación de funcionarios. En mayo de 1990 y por "carecer de idoneidad y requisitos legales para conducir los destinos del organismo", la Coordinadora de Gremios rechazó categóricamente la posibilidad de que Renato Hugo De la Rosa sea designado titular del INIDEP pretendiendo imponerlo el ex subsecretario de Pesca Luis Otero. ${ }^{1033}$ Aún así, no conseguirían su objetivo y De la Rosa asumiría en el mes de junio. La Coordinadora Marítima, también llamada

${ }^{1029}$ L.C.,26/10/1989. La fuente menciona también al SAON. Suponemos que en lugar del SOMU, era el SAON el sindicato invitado, pero no tenemos mayores precisiones. Por otra parte, la Coordinadora cuestionaba también a Otero por convocar a una reunión en Rawson en lugar de hacerlo en Mar del Plata.

${ }^{1030}$ L.C.,31/10/1989.

${ }^{1031}$ L.C.,06/03/1990.

1032 L.C.,08/05/1990.

${ }^{1033}$ L.C.,20/05/1990. Se refería a que De la Rosa no poseía un título universitario relacionado con las ciencias del Mar. 
Intersindical, volvería a activarse en noviembre de 1990, ante la creciente presentación a concurso de empresas pesqueras, el atraso salarial, las suspensiones y despidos de trabajadores. En ese contexto se declaraba en estado de alerta "ante la grave situación socioeconómica del sector pesquero". En un comunicado emitido por la entidad, Saravia declaraba que:

...el crecimiento de conflictos que se agravan diariamente, que se generalizan creando una total incertidumbre en los trabajadores, nos mueve a no querer asistir pasivamente sin el real protagonismo a las fuentes de trabajo [...] los señores empresarios argumentan que la actividad ha dejado de ser rentable, a raíz de que el tipo de cambio del dólar favorece la exportación, ocasionando únicamente pérdidas. Los componentes de la intersindical marítima portuaria, luego de analizar detenidamente los factores que se conjugan para agravar la situación, están en condiciones de plantear desde sus organizaciones, el debate abierto que posibilite soluciones viables para el sector. ${ }^{1034}$

Por último, a pesar de las fallidas experiencias que venían manteniendo en relación a un posible pacto social, las entidades sindicales solicitaban a través del Ministerio de Trabajo una urgente reunión entre los empresarios y los representantes de los trabajadores, planteando conformar una comisión tripartita (Ministerio, empresarios y sindicatos) a efectos de evitar conflictos, mantener reuniones periódicas, estudiar planes alternativos y solicitar la concreción de un programa de emergencia. Al día siguiente, la Coordinadora le solicitaba al obispo diocesano de nuestra ciudad, monseñor Rómulo García, y al intendente municipal, Ángel Roig, que intervengan en la búsqueda concertada de una solución. ${ }^{1035} \mathrm{~A}$ los pocos días se producía un nuevo intento de acercamiento entre sindicatos y empresarios. Participaron de la reunión las cámaras empresarias, los sindicatos y la CGT. La Intersindical proponía:

...formar una comisión que peticione ante las autoridades nacionales condiciones y mejoras a la situación de ajuste a que se ven sometidas las empresas para que este sector tan importante para la vida de Mar del Plata que directa e indirectamente involucra a casi 300 mil personas en actividad no sufra los embates de este ajuste.

La propuesta buscaba "evitar la presentación en convocatoria o el cierre de los establecimientos", solicitando algún tipo de rescate o intervención estatal. El delegado del Ministerio, Gazzanego, manifestó que las gestiones buscan "evitar que el ajuste sea de tales características que dé lugar a convulsiones de tipo social en Mar del Plata”. Especificó que en:

...estos momentos los empresarios están soportando presiones por parte de la Dirección General Impositiva para la actualización de sus créditos que son varias veces millonarios en dólares, así como lo que se debe a los bancos por préstamos tomados el año pasado. Todo esto hace que las empresas vean distorsionado su funcionamiento y el sector sindical está dispuesto a peticionar ante las autoridades nacionales para que se tenga algún tipo de consideración, para que el poder político de la Nación acuda en auxilio del sector empresario en un momento de crisis. Aquí no se trata de subvencionar ni que el Estado regale nada, sino de considerar la situación de excepcionalidad que vive en este momento la tarea del puerto. ${ }^{1036}$

\footnotetext{
1034 L.C.,01/12/1990.

1035 L.C., 06/12/1990.

1036 L.C., 12/12/1990.
} 
Sin que se produjera la intervención estatal, para mediados del año 1991, Pesquera San Andrés, Mar Azul y Tomar, en un lapso menor al de un mes, cerraban sus puertas y se sumaban a otras muchas empresas que hicieron lo propio despidiendo a un buen número de trabajadores. Es en este contexto en el cual la Coordinadora de Gremios, que ya había reincorporado a Carlos Barboza entre sus filas, se entrevistaba con el intendente Ángel Roig. Barboza solicitó al jefe comunal que los acompañe en su reclamo y dijo "quienes más están sufriendo la crisis son los trabajadores, ya que los empresarios paran sus fábricas pero se quedan con su capital". Señaló que están sufriendo "una maniobra" que llaman "empresarios ricos con empresas pobres", dado que "Hemos sufrido un total vaciamiento de nuestra industria pesquera, desaparecen los responsables y quedan las industrias paradas." "1037

Pero así como señalamos cierta intermitencia en la composición de la Coordinadora, también es cierto que la relación entre los gremios no siempre fue de cooperación, pues más de una vez se han visto enfrentados, incluso en acciones de pelea callejera. Esto ocurrió, por ejemplo en un conflicto que tuvo como protagonistas al SOMU y al SOIP que, si bien anterior a nuestro período, merece destacarse. En julio de 1988 el gremio de marineros había decretado un paro a raíz de un conflicto que mantenía con la empresa Estrella de Mar, impidiendo la zarpada de buques tras un accidente que sufrió el buque María Liliana. Luego de una varadura la tripulación se negó a reembarcar hasta tanto no se realizara una inspección oficial de los daños. Entonces la empresa decidió el despido de los 18 tripulantes. Si confiamos en la fuente periodística, luego de negociaciones la empresa habría decidido reincorporar a 15 trabajadores buscando alguna forma de indemnización para los tres restantes. Cosa que no convenció al gremio y adoptó la medida de fuerza que perjudicaba no sólo a los buques de la empresa implicada, sino a todos los que se disponían a zarpar. Pero el SOIP no apoyó la medida y decidió movilizar hasta donde se encontraba la concentración de marineros. El dirigente Ronner, al quedar cara a cara con los conductores del SOMU, expresó "no paren los barcos porque nos dejan sin trabajo a nosotros, y no vamos a permitir que vuelvan a ser nuestros afiliados los que paguen los conflictos de otros gremios". Mientras, la respuesta de uno de los dirigentes del SOMU fue: "no queremos que nadie se perjudique, pero no podemos quedarnos de brazos cruzados mientras despiden a nuestra gente". Hubo insultos y reclamos de ambos lados. Luego se produjeron empujones, manotones y forcejeos hasta que intervino Prefectura. ${ }^{1038}$ La tensión se resolvió días después con la zarpada de los buques.

\section{Las tomas de plantas pesqueras}

Un fenómeno extendido durante estos años, del cual hemos dado algunos indicios en el apartado anterior, fue la toma de establecimientos pesqueros, a veces impidiendo la continuidad laboral en la fábrica, y otras, la mayoría, en el contexto de quiebras y cierres procurando generar un impacto en la opinión pública a través de los medios de difusión. El repertorio de protesta tenía historia entre los fileteros. Hacia mediados de la década del ' 60 se sucedieron tomas de plantas a modo de rebelión contra un convenio colectivo, el cual desconocieron los fileteros y fileteras, firmado en aquel entonces por la conducción anarquista del SOIP (Nieto, 2012). Algunas de aquellas tomas se enmarcaron en el plan de lucha de la CGT, mientras que otras fueron específicas de la industria. Se presentaban en carácter de

${ }^{1037}$ L.C., 12/07/1991.

${ }^{1038}$ L.C.,23/07/1988. 
"espontáneas", con demandas que apuntaban a mejorar los salarios, las condiciones laborales o manifestando solidaridad con trabajadores despedidos. También quedó instalado en el instrumental obrero la opción de la toma como método de dirimir las disputas intra-sindicales. Entonces un joven Abdul Saravia vivió aquellos episodios, siendo protagonista de la toma de la sede del SOIP. Ya en la década del '90, Saravia entendía de movimiento obrero y de pesca, pero más sabía de lealtad. ${ }^{1039}$ Cuando se cumplieron seis meses de iniciado el gobierno de Menem, a pesar de estar atravesando el proceso de cierre de plantas pesqueras, el SOIP realizó una movilización para recibir al presidente en ocasión de una nueva visita de éste a Mar del Plata. ${ }^{1040}$ Pero la realidad del gremio no permitía demasiado tiempo para festejos y alegría. Por su magnitud, la proliferación de tomas de plantas fue uno de los muy pocos hechos que llamaron la atención de los Servicios de Inteligencia de la Policía de Buenos Aires, según se sabe, bastante diezmados hacia principios de la década del ' $90 .{ }^{1041}$ Lo cierto es que el año 1990 se inauguraba con la toma de la planta de procesado Ferrier debido a que se adeudaba a los sesenta empleados el sueldo de diciembre, el sueldo anual complementario y los decretos 1505,1564 y 1566 . Saravia se ponía a la cabeza de estos reclamos y anunciaba una ética muy presente en su modo de reclamar, según la cual dejaba ver parte de su sentido de justicia. Decía en relación a las deudas que mantenía la empresa, la cual también estaba endeudada con la obra social "Esta es una actitud reiterada de los responsables de esta empresa, que ahora están veraneando en Punta del Este, mientras los obreros no tienen para comer". ${ }^{1042}$ El dirigente sindical aseguraba que la intención de los trabajadores "es permanecer aqui hasta que los propietarios paguen lo que deben". ${ }^{1043} \mathrm{Al}$ día siguiente instalaban una olla popular. Es interesante destacar que la empresa estaba cerrada desde hacía un año, pero desde entonces abonaba la garantía horaria a los obreros dado que no existían razones de fuerza mayor para la inactividad de la firma y la ley obligaba a las patronales a abonar esos salarios mínimos.

Mientras todavía estaba fresca la toma de Ferrier, se produjo la del frigorífico Wenders, donde trabajaban 37 personas. Presente en la planta, Saravia explicaba que la empresa adeudaba el pago de la segunda quincena de enero, el ajuste de la primera de ese mismo mes y asignaciones familiares. Además, despidieron a dos operarios. Como era ya común, la empresa tampoco realizaba los aportes correspondientes a la obra social ni a la cuota sindical. Se reclamaba la reincorporación de los despedidos como primera instancia, pero con resignación aparecía en el horizonte, más realista, la demanda del pago de indemnizaciones: "Nuestro gremio se encuentra en estado de alerta y movilización, especialmente por el abuso de las patronales y de piratas improvisados que ponen fábricas y desaparecen por periodos y dejan el tendal de compañeros en la calle", denunciaba Saravia, a la vez que amenazaba "Vamos a seguir tomando las fábricas que no paguen los montos correspondientes a la obra social". ${ }^{1044}$ Muy pocos días después se cumplía la amenaza gremial cuando la planta de fileteado Surmai fue ocupada por sus 27 trabajadores y trabajadoras. Entre los reclamos la fuente menciona el retraso en el pago de la cuota sindical y de la obra social, asignaciones familiares y licencias por maternidad, así como la falta de

\footnotetext{
${ }^{1039}$ Sobre el lugar fundamental de dicha categoría como articulador dentro del peronismo ver Balbi (2008).

${ }^{1040}$ L.C.,26/01/1990.

${ }^{1041}$ Archivo Comisión por la Memoria, Ex DIPBA, B. C 57. L 17, Factor Gremial, SOIP.

1042 En varias oportunidades Saravia apelaba en su discurso, para legitimar alguna medida de fuerza, a la desigualdad de situaciones que ante el cierre de plantas vivían las patronales y los trabajadores. Los primeros pudiendo veranear en lugares caros, mientras los obreros y obreras padecían el hambre.

${ }^{1043}$ L.C.,12/01/1990. En la foto se ven a los trabajadores con gorras del SOIP.

${ }^{1044}$ L.C., 10/02/1990.
} 
instalaciones adecuadas. ${ }^{1045}$ En junio volvía a ocuparse el frigorífico Ferrier. Se trataba ahora de 60 trabajadores que denunciaban la falta de pago como una situación reiterada en la firma mientras que las gestiones iniciadas por el SOIP no dieron ningún resultado. Los obreros indicaron "la patronal nos adeuda la última quincena de abril y todo el mes de mayo, además de debernos también las vacaciones, el aguinaldo y varias diferencias del año pasado, por lo que aqui vivimos en situación de permanente conflicto". Explicaban que la decisión de tomar la fábrica surgió después de varias reuniones ya que "no queríamos llegar a esto. Pero no tuvimos otra solución... los señores que supuestamente estaban a cargo del personal, de apellido Susta y Ponce, desaparecieron hace quince días y el propietario, Ricardo Ordoñez, también titular de 'Bajamar', tampoco contesta nuestros reclamos...". Aseguraron haber dado intervención al Ministerio de Trabajo pero la única solución que ofreció fue la de enviar telegramas a los responsables, pero con "con telegramas no comemos...".

Aquí hay muchos problemas graves, tenemos por ejemplo un compañero padre de nueve hijos a los que ya no les puede dar de comer, a otros compañeros ya les cortaron la luz en sus casas; la mayoría ha tenido que salir a buscar alguna changa -si la consigue con suerte- para aportar algo en su casa. Mientras tanto el señor Miguel Susta está parando en un appart-hotel de esta ciudad donde abona por día lo que nosotros prácticamente ganamos por mes... y no nos pagan. ${ }^{1046}$

En julio el SOIP informaba que se encontraban tomados por el personal varios establecimientos de procesamiento de pescado en reclamo por la falta de pago de haberes. Se hallaban tomados Arpemar I, II, y III y Arpemar (planta de harina y lavadero de cajones), Coral de Norte y Pensacola. Todos adeudan la segunda quincena del mes de junio y sueldo anual complementario correspondiente al primer semestre de 1990. Ferrier adeudaba retroactividad, vacaciones atrasadas, mes de junio y sueldo anual complementario. Frigocen y San Andrés adeudaban aguinaldo. ${ }^{1047}$ En agosto, 104 operarios tomaron una planta de la pesquera Estrella de Mar en demanda del pago de aguinaldo, primera y segunda quincena de julio y primera quincena de agosto. El delegado de los trabajadores, Héctor Figueroa, informaba:

La situación se va agravando a medida que transcurren los días, pues los compañeros no pueden pasar más necesidades. Muchos de ellos están vendiendo parte de sus artículos del hogar para poder darle de comer a sus familias, mientras los empresarios deciden la conformación de un verdadero paro empresario aduciendo que no tienen trabajo. ${ }^{1048}$

La empresa no volvería a abrir sus puertas y los trabajadores fueron despedidos. En ese contexto, la CD del SOIP emitió una declaración en la que "repudia y rechaza los despidos efectuados por la empresa Estrella de Mar S. A.". Acusaban al responsable de la firma, asegurando que "toda la realidad conoce la trayectoria de Oscar Poletti y que no es la primera vez que realiza despidos masivos en contra de nuestros afiliados". El SOIP informaba que rechazaba:

${ }^{1045}$ L.C.,16/02/1990. En la foto que publica el Diario se pueden ver a los trabajadores con sus familias. En ella los chicos sostienen carteles con las caras de Eva Perón, Juan D. Perón y Carlos Menem.

${ }^{1046}$ L.C., 07/06/1990.

${ }^{1047}$ L.C., $12 / 07 / 1990$.

1048 L.C.,22/07/1990. El diario señala que los trabajadores pertenecen al SAON. Sin embargo, dado que es una planta de procesado podemos suponer que el grueso de los trabajadores eran afiliados al SOIP y el cronista posiblemente confundió la pertenencia. 
...todos los telegramas por improcedentes y exigirá el pago de todos los haberes correspondientes para cada trabajador, de acuerdo a la Ley de Contrato de Trabajo art. 245 y no permitirá que mencionando falsas circunstancias deje a todo el personal en la calle abonando el 50 por ciento de las indemnizaciones, agotando todas las instancias ante las autoridades del Ministerio de Trabajo de la Nación.

Al mismo momento, el SOIP anunciaba un viaje de Saravia a Capital Federal para entrevistarse con Jorge Antonio. ${ }^{1049} \mathrm{Al}$ mes siguiente llegaban a un acuerdo entre las partes, comprometiéndose la empresa a pagar en dos cuotas lo adeudado. ${ }^{1050} \mathrm{En}$ octubre los trabajadores de planta y taller naval procedieron a ocupar otra planta de Estrella de Mar. Ahora se trataba de obreros afiliados al SAON, gremio que denunció en un crítico comunicado, la situación por la que estaban atravesando los trabajadores, quienes desde hacía mucho tiempo vivían permanentes dificultades económicas. Por ello expresaban:

...su total repudio por los hechos que vienen sucediéndose en la empresa Estrella de Mar, donde los responsables son Héctor Antonio y Oscar Poletti, empresarios que no aportan para el país, despiden trabajadores y no les pagan, hacen trabajar a otros y tampoco les abonan los salarios, acuerdan con el Ministerio de Trabajo de la Nación y no cumplen lo pactado.

Se preguntaban:“¿Qué quieren estos empresarios de los trabajadores? Pretenden continuar robándole a los trabajadores y al país todo, porque estos señores no aportan jubilación, obra social, CASFIC, sindicato y mutual". Y justificaban la medida de acción directa expresando que "Ante la situación planteada, los trabajadores decimos basta a la corrupción; basta a los que explotan a los trabajadores. Por eso hoy en defensa de nuestros derechos ocupamos la planta y el taller naval. Lo único que pretendemos es cobrar y ser respetados". Mencionaban también la existencia de conflictos por falta de pago en otras plantas navales. ${ }^{1051}$

El año finalizaba con la presentación de varias empresas pesqueras en convocatoria de acreedores. Paralelamente, trabajadores tomaban la planta Frigocen solicitando el cobro de haberes atrasados. Mientras, el SOMU, que había propiciado la toma de tres empresas (Ocean Sur, Maripez y Huemul), amenazaba con ocupar también Arpemar y Mar Azul en el marco del reclamo que mantenía con varias empresas del sector que "no venden el pescado que tienen porque dicen que el precio actual es bajo y por consecuencia, los barcos no salen a pescar, privando del trabajo a nuestra gente". ${ }^{1052}$ Por estos días, el entonces secretario adjunto del SOMU nacional, Enrique "Caballo" Suarez, reconoció que 1.500 trabajadores del gremio en Mar del Plata estaban viviendo dificultades salariales a raíz del "incumplimiento de empresarios que son delincuentes de guantes blancos". ${ }^{1053}$ Poco después la planta Maxpax era ocupada por sus 34 operarios, quienes tomaron la medida esperando el pago de las indemnizaciones ante la ruptura de los contratos laborales. ${ }^{1054} \mathrm{El}$ día 20 el SOIP informaba que permanecían tomadas Maxpax, Estrella de Mar y le sumaba la planta el Progreso Marplatense. La primera por el no pago de indemnizaciones a los trabajadores, la segunda por salarios adeudados y la tercera por

\footnotetext{
1049 L.C., 16/09/1990.

${ }^{1050}$ L.C., $10 / 10 / 1990$.

1051 L.C.,03/10/1990.

1052 L.C., 13/12/1990.

1053 L.C., 14/12/1990.

1054 L.C., 17/12/1990.
} 
tener "personal a changa" violando el convenio colectivo de trabajo. Las tres adeudaban los aportes correspondientes a la cuota sindical y obra social. El sindicato permanecía en asamblea permanente. Mientras 32 trabajadores del SAON tomaban el taller naval de Arpemar. Les habían informado que se cerrarían las puertas de la empresa sin darles mayores explicaciones y debiéndoles los haberes de noviembre, diciembre y el medio aguinaldo. Los obreros anunciaron que pasarían las fiestas en el taller "en resguardo de las fuentes de trabajo". ${ }^{1055}$

Hemos señalado anteriormente que Abdul Saravia pasó la Nochebuena con los trabajadores que permanecían ocupando la planta El Progreso Marplatense. Al iniciarse el nuevo año, la planta procesadora Aquadring II era tomada. La crónica se titula, ilustrativamente, "Empresarios de la pesca abandonan a trabajadores". Los delegados del personal Marcos Stábile y Luis Lambert, acompañados por el capataz, Juan Sosa, explicaban la situación:

Desde hace dos meses venimos denunciando los problemas de esta empresa, cuyos propietarios han desaparecido de la escena, y nos adeudan las quincenas que insumen dos meses de haberes, aguinaldo y la compensación del bono ayuda, así como las vacaciones correspondientes, y para colmo ahora nos enteramos que estos señores se han presentado en convocatoria de acreedores, creando insertidumbre (sic) entre los sesenta trabajadores que aquí nos desempeñamos.

En lo que ya era un drama reiterado, los obreros repetían "queremos hacer pública la denuncia de que los empresarios al menos desde el 8 de diciembre han desaparecido".

...estamos seguros de estar en presencia de una quiebra, aunque nada se nos ha informado y se nos ha dejado librados a nuestra propia suerte. Tuvimos que pasar el fin de año sin un peso, con el solo alivio de una canasta que por el motivo de las jornadas navideñas nos hizo llegar el SOIP, pero desde entonces nadie ha dado respuesta a nuestros reclamos.

Lo que generaba mayor indignación entre los trabajadores eran los "rumores" que señalaban que todo se trataba de maniobras empresariales. "Tenemos entendido, sin embargo, de que en el lapso que estuvieron operando aqui efectuaron buenos negocios, y se señala que han transferido al exterior sus utilidades, y hasta se menciona que han efectuado depósitos en el Uruguay". "1056 En febrero una nueva planta era ocupada. 44 trabajadores reclamaban el pago de deudas salariales y bonificaciones incumplidas. ${ }^{1057}$

El recurso extendido de la toma de fábrica colaboraba con la visibilidad de los reclamos y obligaba en cierto modo a la prensa a hacerse eco de tales acontecimientos. Sin embargo, no era un repertorio demasiado eficaz frente a firmas pesqueras que estaban en proceso de quiebra y a punto de cerrar sus puertas. Era más bien una reacción posible, aprehendida, una ocupación del tiempo y algo que permitía a trabajadores y trabajadoras sentirse luchando, pero lejos estaba de funcionar en el sentido de revertir el proceso de cierre de plantas, ni tan siquiera, frenarlo. En algunos casos, los obreros y obreras lograron cobrar parte de los salarios adeudados y la reincorporación pero por escasos periodos de tiempo. Y no mucho más. En este contexto, un medio utilizado por empresarios pesqueros que se mantenían aún en la

1055 L.C.,21/12/1990; 23/12/1990.

1056 L.C.,10/01/1990. Las fotos que aparecen desnudan el drama: "Planta Tomada", "Los chicos nos piden pan, leche", "Paguen". Se puede leer en carteles y pancartas que portaban los obreros y obreras.

${ }^{1057}$ L.C., 18/02/1990. 
actividad para disciplinar a la mano de obra fue la amenaza de cierre, método que funcionaba amedrentando a los obreros. Tal es el caso de una planta de la pesquera Barilari, la cual estaba tomada porque 12 trabajadores fueron despedidos. Ante la postergación de esta situación la empresa anunció el cierre y la cesantía de todos los empleados. Juan José Paso, delegado, indicó que los obreros se encontraban en estado de asamblea permanente a la espera del pago de deudas. Se le adeudaba cerca de dos millones de australes a cada uno en concepto de bonos y presentismo, al tiempo que se denunció que María Elena Vargas fue golpeada por el jefe de personal. Paso explicó que tampoco les querían pagar los 400 mil australes de enero e incluso que había gente a la cual ni siquiera le abonaron la última quincena. Eran 130 personas las que allí trabajaban. ${ }^{1058}$ El reclamo de los trabajadores se producía en una diferencia de criterio con la patronal dada por una situación excepcional. Cuando el año anterior la empresa declaró que suspendería a su personal, el SOIP intervino y negoció que se levantara la suspensión con la condición de que se le abone a los trabajadores la garantía horaria entre los meses de noviembre de 1990 y enero de 1991. La discusión residía en los pagos adicionales que se detallaban en el convenio, así como aumentos producidos durante esa fecha, los cuales la empresa se negaba a abonar. Mientras continuaba la toma, personas enviadas por la empresa intentaron cargar mercadería en una camioneta, lo que fue impedido por los obreros y dirigentes sindicales que allí estaban. Por esta acción, Saravia, junto a Luis Ronner y al delegado Paso, serán procesados por delitos de "usurpación” y "coacción”.

Pero el recurso a llevar la conflictividad laboral a la justicia en nuestro caso no fue únicamente utilizado por la patronal. También el SOIP, sintiéndose con legitimidad para reclamar, inició acciones legales contra la empresa Barilari, denunciando que:

...en las declaraciones juradas desde el mes de enero de 1988, mes a mes, correspondientes a los aportes y retenciones que acompaña los pagos que efectúa a la Dirección Nacional de Recaudación Previsional y a la obra social del SOIP, se incluyen liquidaciones que no revelan el verdadero monto de las remuneraciones que efectivamente se pagan al personal, siendo estas notoriamente superiores con las que el denunciado evade esos pagos. ${ }^{1059}$

Y no sólo la empresa Barilari. Por los motivos de una denuncia donde se incluían a distintas firmas pesqueras, varios empresarios fueron apresados por evasión impositiva, en un hecho que conmocionó al puerto marplatense por la envergadura de los personajes que, ahora se descubría, infringían la ley y eran puestos en prisión. El entonces juez federal Eduardo Pettigiani, recordemos de buena relación con Saravia, explicaba que:

...este es un tema muy complejo que surge a raíz de la aplicación de la ley 23.771 , la Ley Penal Tributaria, que establece distintas penalidades para diversos ilícitos tributarios, como la falta de aportes previsionales, doble contabilidad, pagos en 'negro', etc., es decir una serie de conductas que lamentablemente son bastante comunes en nuestro país. ${ }^{1060}$

Por "trascendidos" en la prensa se supo que varios empresarios pesqueros viajaron a Capital Federal para entrevistarse con "altas autoridades" para expresarles su preocupación y solicitar cierta

\footnotetext{
${ }^{1058}$ L.C.,09/03/1991.

1059 L.C., 14/03/1991.

${ }^{1060}$ L.C.,20/03/1991.
} 
"flexibilidad" en los operativos contra la evasión fiscal. Se conoció que algunas de las empresas comprometidas eran Arpemar, Ventura, Mediterránea, Cerosol, Color del Norte, Ventura Mar del Plata y Bolívar. Constadas las irregularidades, la pena que era de prisión, se volvía excarcelable tras el pago del doble de lo que se debía. En junio más de una docena de empresarios pesqueros locales fueron detenidos imputados de omitir aportes previsionales por montos millonarios. ${ }^{1061}$ La evasión fiscal por parte de las empresas en conjunto no era menor a los cinco millones de dólares. Por otra parte, como hecho colateral, cientos de empresarios y contribuyentes se presentaron ante los organismos recaudadores a fin de regularizar sus situaciones saldando sus deudas. ${ }^{1062}$

En abril Saravia expresó "No cejaremos en nuestra lucha por los derechos de los trabajadores, avasallados por empresas que no contemplan más que sus propios intereses" al referirse a los múltiples conflictos gremiales que afrontaba el sector pesquero. La situación no ofrecía tregua. Continuaba tomada la pesquera Barilari. Los trabajadores permanecían dentro de la planta en estado de asamblea permanente. Rechazaron las cartas documento enviadas por la patronal comunicando el despido de los obreros. La empresa les ofreció indemnizaciones bastante menores de lo que, según los obreros, les correspondían. Se le sumaba la toma de una nueva planta de Estrella de Mar llevada a cabo por trabajadores que pretendían que los empresarios no quitaran de la empresa materia prima y maquinarias. Además la ocupación de Frigocen que involucraba a 250 obreros y obreras. A estos se les adeudaba el mes de marzo. Pero la empresa se declaró en quiebra. La toma se decidió en una asamblea conjunta del SOIP, Empleados de Comercio y el gremio del Hielo. En un documento elaborado por dirigentes y trabajadores se anunciaba:

...vamos a permanecer en el interior del establecimiento en asamblea permanente ejerciendo los derechos que la Constitución Nacional les otorga inequívocamente en el artículo 14 bis y normas concordantes hasta tanto se efectivice el pago, solicitando asimismo las (sic) continuación de la fuente de trabajo y cumpliendo con el mandato del señor presidente de la Nación sobre la Revolución Productiva.

Además, declaraban que "vamos a instalar en la planta ollas populares con la intención de que el juez, que a cuatrocientos kilómetros de distancia decretó el quebranto de la empresa, concurra a este lugar para observar de qué manera la gente necesita este trabajo para comer". ${ }^{1063}$ Días después Saravia buscaba "una solución para la cesantía de cientos de compañeros" y declaraba que los "trabajadores no aceptamos el ofrecimiento patronal de pagar indemnizaciones violando la ley 20.744. Las empresas quieren pagar la mitad de lo que corresponde, y además en tres cuotas". ${ }^{1064}$ Aproximadamente por el lapso de un mes permaneció ocupada la pesquera San Andrés. A comienzos de agosto de 1991 el juez Reinaldo Fortunato ordenó su desalojo. Alrededor de 50 trabajadores y trabajadores permanecían en la planta pesquera como medida de presión para que los dueños, uno de los cuales era José Greco, les abonaran los salarios adeudados. Sin embargo, la decisión judicial era terminante y al arribar al lugar la

${ }^{1061}$ L.C., 12/06/1991. Los detenidos en esta oportunidad fueron Roberto Tovo, Carlos Ares, Antonio Kercia, Carmen Greco, Rubén Lev, Cecilia Lillo, Clara Ghys, Oscar Basualdo, Ana María Basualdo, Carlos Choco y Mariano Santa María. Tovo había sido presidente de la CAABPA y Ares de la Cámara de Procesadores de Pescado. El primero abonó 80 mil dólares como fianza para salir de prisión.

1062 L.C., 15/06/1991.

1063 L.C.,06/04/1991.

1064 L.C.,06/05/1991. 
síndico Susana Dilon se produjeron fuertes discusiones entre Saravia y quien se dirigía a terminar de ejecutar el remate. Ante la negativa de los trabajadores a retirarse se produjo un "espectacular despliegue policial" para respaldar la presencia de la juez. Finalmente los trabajadores y trabajadoras se retiraron en forma pacífica algunos de ellos llorando. Antes de retirarse Saravia declaró "mientras acá esta toda la policía para decirnos que nos vayamos, mañana se sumarán otros 100 desocupados a los 3.000 que ha dejado hasta el momento el cierre de plantas pesqueras. Y con esto viene la pobreza, con la pobreza la desesperación y después viene la delincuencia". ${ }^{1065}$

\section{La conflictividad social en la pesca (II): los años de estabilidad (1992-1996).}

Tras la implementación del plan de Convertibilidad pronto se lograron reducir los índices de inflación, retornaron los depósitos a los bancos, reapareció el crédito interno y externo y se recompuso el consumo, todo lo cual marcó una nueva etapa de estabilidad económica. ${ }^{1066}$ Además, en sí misma, la convertibilidad operó como el orden contrapuesto al caos hiperinflacionario (Bonnet, 2008). Ello expandió el poder de compra de los trabajadores y la clase media. Apareció así, fruto de la estabilidad, la reactivación (Bonnet, 2008; Fair, 2008; Piva, 2006; Basualdo, 2003; Gerchunoff y Torre, 1996; Acuña, 1995; 1993). En ese contexto y pasada la ola de quiebras, junto a lo más duro de la crisis pesquera, la conflictividad tendió a reducirse, manteniéndose dentro de los canales institucionales. Durante los cinco años que van desde 1992 hasta 1996 registramos 59 episodios de conflicto, bajando la intensidad en la recurrencia de las acciones a un promedio de un hecho por mes (contra los ocho y medio del período anterior). En general estos hechos se vincularon con la profundización de la apertura externa y la desregulación implementada por el gobierno.

\section{Infructuosa oposición sindical a la política pesquera}

Con el respaldo de la drástica reducción de la inflación, la política económica diseñada por Domingo Cavallo encontraba terreno para avanzar. En tal escenario, se profundizó la apertura externa, el ajuste del Estado, las privatizaciones y, en una medida que impactaba fuertemente en la pesca, la desregulación. Fue el decreto N817 del año 1992 el que generó una airada protesta por parte de los sindicatos de marineros. Inmediatamente después de su anuncio, el SOMU, la Asociación de Capitanes y el SICONARA expresaron su profunda preocupación porque el decreto permitía la libre contratación de personal independientemente de su nacionalidad. Lo propio hacía la CGT local. A la vez, causaba estupor el hecho de que la medida implicaba la caída de los convenios colectivos de trabajo que afectaban a 21 gremios. Por ello, al mes siguiente, la protesta alcanzó carácter nacional logrando la activación de una organización marinera de ese alcance. Es así que la Intersindical de Gremios Marítimos, integrada por 14 sindicatos, convocó a una movilización a la Plaza de Mayo. La misma se produjo el día 2 de junio. ${ }^{1067}$ Además se convocó a un paro de 24 horas y se elevó una denuncia a la OIT. En Mar del Plata, el día 4 de

\footnotetext{
1065 L.C.,09/08/1991.

1066 Según Palermo el plan de Convertibilidad constituyó un punto de inflexión en la medida en que logró establecer un núcleo de gobernabilidad firme, por primera vez desde 1989, basado en el logro de un piso de autonomía institucional (Palermo, 1999).

${ }^{1067}$ L.C., 02/06/1992.
} 
junio se reunieron los representantes de la actividad portuaria (sindicatos, cámaras y asociaciones) y establecieron un plazo de treinta días para encontrar una manera de adecuar las disposiciones convencionales y condiciones laborales vigentes a lo establecido por el decreto $\mathrm{N}^{\circ} 817 .{ }^{1068}$ Allí, tanto el representante del SUPA como del SICONARA expresaron su rechazo. Mientras que la CAABPA y la Sociedad de Patrones lo consideraron beneficioso. Al día siguiente, el SICONARA local se declaró en estado de alerta permanente mientras continuaran las negociaciones. Barboza manifestó que el decreto "no tiene nada a favor de los trabajadores". ${ }^{1069} \mathrm{Y}$ en su desesperación envió una carta al gobernador Duhalde pidiendo su intervención. En ella decía:

...el decreto 817/92 que firmaron el presidente de la Nación, del ministro de Economía y al ministro de Trabajo de la Nación, no sólo deroga legislación laboral vigente y respaldada por la Constitución Nacional, sino que deja en el desamparo a los trabajadores marítimos afectados al sector pesquero, otorgando al sector empresario la cierta posibilidad de embarcar personal extranjero en lugar del argentino.

Le advertía al gobernador que "Esta aplicación del mencionado decreto aumentara la desocupación en el sector, agravando las tensiones sociales en la provincia de Buenos Aires". ${ }^{1070}$ Sin embargo, desde el Ministerio de Trabajo de la Nación se intimó, mediante una conciliación obligatoria, a toda la actividad marítima y portuaria a atenerse al decreto en el término de cinco días. Ante ello, los sindicatos llamaron a asambleas de afiliados, donde se notaba que aún estaban afectados por el gran retroceso que implicaba tal normativa. En ese sentido, Barboza no podía salir de su asombro y declaraba: "nuestra gente no acepta la nueva reglamentación puesto que permite a los empresarios variar a su antojo la cantidad de tripulantes que baja, cambiar cuando desea la tripulación hasta por gente extranjera e, incluso, cambiar de bandera. Todo esto lo interpretamos nosotros como un estado de desamparo total..."1071. En aquel entonces algunos trabajadores aceptaron el ofrecimiento de retiro voluntario. Ese fue el caso de muchos estibadores del puerto de Buenos Aires. La administración buscaba pasar de 3.200 empleados a 1.500. ${ }^{1072}$ Ya en 1993, el SOMU, la Asociación Argentina de Capitanes y Patrones de Pesca y el SICONARA decidieron constituirse en sesión permanente "para iniciar todo tipo de gestiones para defensa de la fuente de trabajo del personal argentino". Indirectamente, tanto el charteo como el anuncio de posibles acuerdos con la CEE impactaban en el trabajo de las tripulaciones. Por eso los sindicatos afectados buscaban unificarse "ante la situación planteada en el sector y que se agudiza día a día por el aumento de la desocupación de los trabajadores maritimos, en beneficio del personal extranjero y ante la falta de respuesta del gobierno nacional en general y en particular de los funcionarios del área pesca". ${ }^{1073}$ Similares declaraciones realizaban días después, cuando criticaron severamente la aplicación del decreto 817/92, pues "sólo sirvió para despojar a los trabajadores" de la protección de sus fuentes laborales. Dijeron que la política pesquera oficial está llevando a que "se

1068 L.C.,05/06/1992.

1069 L.C.,06/06/1992.

${ }^{1070}$ L.C.,08/06/1992.

1071 L.C., 26/07/1992.

1072 L.C.,02/08/1992.

1073 L.C.,07/02/1993. 
incremente la desocupación" en la zona y ello "asegura para nuestra comunidad una suma de conflictos sociales que tendrá que soportar" ${ }^{1074}$.

Por estos días Fernando Gutiérrez, recordemos Subsecretario de Pesca, anunciaba con euforia un nuevo récord en la exportación de productos pesqueros. Paralelamente, Juan Novero, nuevo titular del SOMU local advertía "Así como el subsecretario de Pesca de la Nación puede afirmar con orgullo que se ha producido un récord en materia de capturas pesqueras, nosotros con toda la bronca, podemos decir que también se ha registrado un récord en materia de desocupación" ${ }^{1075}$. El dirigente marítimo expresaba desde su óptica cuál era el drama de los trabajadores:

El gran problema surge de la presencia de los barcos extranjeros. La Subsecretaría de Pesca ha entregado permisos en gran cantidad, y así hoy tenemos más de 45 barcos poteros a los que habrá que sumarles los del acuerdo de la Comunidad Económica Europea. Ya están entrando estas embarcaciones y hasta el señor Francisco Javier Romano, presidente de los Patrones de Pesca, tiene dos poteros. En un momento dijeron que se respetaría la presencia de tripulantes argentinos en un 50 por ciento, pero a partir del decreto 817 ni siquiera se embarca a personal de este país. Hace casi dos años era de un 50 por ciento la tripulación argentina pero ahora ya estamos con 200 barcos extranjeros, y 15 mil desocupados del SOMU en todo el país. Nos preguntamos qué réditos le deja al país todo esto. Tenemos 3.000 extranjeros trabajando, y sin ir más lejos, en estos momentos, en el puerto de Mar del Plata hay barcos extranjeros y no hay ningún argentino embarcado [...] acompañamos este proceso de renovación del país [pero] tampoco es posible que nos quedemos sin fuentes de trabajo. En Mar del Plata son 1.200 los desocupados de nuestro gremio. Nos han mentido siempre y una vez más estamos viviendo una política de entrega.

Luego el SOMU se declaraba en estado de alerta ante el manejo en torno a las quiebras por parte de los síndicos y la situación de los trabajadores de las empresas quebradas, los cuales no habían sido aún indemnizados mientras llegaban marineros extranjeros para trabajar en buques de la flota nacional. ${ }^{1076} \mathrm{En}$ abril la CGT regional y los gremios marítimos se reunieron con el Intendente de la ciudad. Previamente lo habían hecho con Monseñor José María Arancedo. ${ }^{1077}$ Buscaban transmitir su preocupación por la situación posibilitada a partir del decreto $\mathrm{N}^{\circ} 817$ y la cantidad de trabajadores extranjeros que operarían en los buques. Los gremios solicitaron la creación de un ente municipal que regule la actividad de los barcos y pidieron la implementación de dos medidas principales: 1) se reincorpore a los desocupados de la pesca y 2) se impida a los capitanes de barcos extranjeros contratar personal antes de haber cubierto sus vacantes con los desocupados de Mar del Plata. Por último, la CGT anunció un viaje a Capital Federal para reunirse en el Ministerio de Trabajo y la solicitud de la convocatoria a convenciones colectivas de trabajo con carácter urgente para iniciar "la necesaria rediscusión de los salarios" en todos los gremios del sector. ${ }^{1078}$ Ninguna de todas esas demandas fue atendida.

También el acuerdo con la CEE había generó la oposición gremial. Todos los sindicatos vinculados a la pesca se declararon en estado de alerta ante su firma. ${ }^{1079}$ Ya hemos mencionado la preocupación de los dirigentes sindicales respecto a las características del acuerdo, particularmente porque la llegada de

\footnotetext{
1074 L.C.,24/02/1993.

1075 L.C.,01/03/1993.

1076 L.C., 13/03/1993; 20/03/1993.

1077 L.C.,08/04/1993.

1078 L.C., 10/04/1993.

1079 L.C.,27/06/1992.
} 
buques no contemplaba la contratación de mano de obra argentina y porque se trataba de buques congeladores que no procesaban el pescado en tierra. Esa preocupación era la antítesis del entusiasmo que mostraba la conducción de la subsecretaría de Pesca. En septiembre de 1993 los gremios marítimos y portuarios se reunieron en la sede de la CGT local para analizar los resultados de una reunión mantenida con Felipe Solá y Fernando Gutiérrez para tratar el acuerdo con la CEE. En dicho encuentro los gremios solicitaron al menos un $40 \%$ de tripulación argentina en los buques afectados al convenio. Se acordó la creación de un consejo asesor de control de gestión, el otorgamiento de permisos de pesca para barcos en actividad, un cupo total de pesca para las cuatro especies principales hasta 250.000 toneladas, ingreso de barcos extranjeros en un máximo de 50. Los funcionarios se comprometieron a lanzar alguna propuesta para incentivar el consumo interno de pescado fresco con miras a la reactivación del mercado. ${ }^{1080}$ No obstante, a los pocos días la CGT local dispuso la declaración del estado de alerta y movilización debido a que muchos buques pesqueros realizaban trasbordos de materia prima en alta mar, provocando graves perjuicios a los trabajadores de tierra. ${ }^{1081}$ Mientras varios gremios estimaban la presencia de niveles alarmantes de desocupación en Mar del Plata, cuya fuente principal era la pesca. ${ }^{1082}$

A nivel nacional, en julio de 1994 el MTA y la CTA confluyeron, tras la realización de la Marcha Federal, en la convocatoria a un paro general en contra de la política económica del gobierno. Por su parte, la CGT dirigida entonces por Antonio Cassia se opuso a la medida, señalando su posición de diálogo con el gobierno nacional. Mientras, desde el propio gobierno se apelaba a la generación de miedo y se prometían sanciones para aquellos gremios y trabajadores que participaran de la medida. Finalmente el paro se llevó a cabo el día 2 de agosto y mantuvo un acatamiento dispar según la prensa. La posición ante el paro dividió a los gremios marítimos y pesqueros marplatenses. De un lado, participaron de la medida de fuerza el SOMU, SICONARA, Asociación de Marineros Pescadores y el Centro de Capitanes y Patrones de Pesca. Del otro lado, se opuso a la medida el SOIP. Y, por supuesto, tampoco contó con la convocatoria de la CGT regional. El propio Saravia había expresado que no convocaría a un paro por no haberse resuelto en los órganos responsables de la entidad obrera. ${ }^{1083}$ Tras la medida de fuerza, mientras los organizadores estimaron un acatamiento del 70\%, desde el Ejecutivo Nacional se continuó con la tendencia a reducir a la mínima expresión la importancia de acciones como esta. El propio Carlos Menem manifestó que el paro fracasó "del mismo modo que fracasó la Marcha Federal” y lamentó que quienes adhirieron a la medida de fuerza "pierdan un día de salario y el presentismo", "Todo para qué, para nada, porque mañana las cosas van a seguir igual". También cuestionaron el alcance de la medida los dirigentes Antonio Cassia y José Pedraza. ${ }^{1084} \mathrm{Y}$ en el sentido del desprestigio de las medidas de fuerza, el diario La Capital publicó una encuesta según la cual "la gente" opinaba que los paros no servían. ${ }^{1085}$ Diferente era la apreciación de Carlos "El perro" Santillán, para quien, tras la medida, "ha nacido una nueva dirigencia sindical" ${ }^{1086}$.

\footnotetext{
${ }^{1080}$ L.C., 28/09/1993.

${ }^{1081}$ L.C., 23/11/1993.

1082 L.C., $17 / 11 / 1993$.

1083 L.C.,03/07/1994.

1084 L.C.,03/08/1994.

${ }^{1085}$ L.C., 05/08/1994.

${ }^{1086}$ L.C.,03/08/1994.
} 
Lo cierto es que despidos ${ }^{1087}$ y atraso en el pago salarial ${ }^{1088}$ fueron dos de los conflictos que tuvieron al SOMU como protagonista. Pero la desocupación imperante en el puerto comenzaba a ocupar el centro de la conflictividad. La extranjerización de la flota, y con ella de la mano de obra, se percibía como uno de los mayores culpables. Por eso los gremios convocaron a una manifestación contra la llegada de cuatro barcos chinos cuyas tripulaciones estaban integradas exclusivamente por nativos de ese país. ${ }^{1089}$ Participaron el SOMU, SUPA, el Centro de Patrones de Pesca y la Asociación de Marineros Pescadores. Según la crónica "Momentos de tensión se vivieron durante gran parte de la mañana de ayer en el amarradero de las cuatro naves orientales, debido a la desesperación por la falta de trabajo en varios gremios relacionados con la actividad portuaria" ${ }^{1090}$. Allí, un Domingo Novero muy molesto expresó "se plantea esta situación cuando tenemos 300 marineros que están en la calle, no tienen qué darle de comer a su familia" 1091.

Por eso el año 1995 comenzaba para el SOMU con la denuncia a través de una carta remitida a Felipe Solá sobre la situación de "los trabajadores de la pesca argentinos desocupados" por la "invasión de mano de obra semiesclava extranjera". En ella señalaban lo que veían como una clara contradicción "Por un lado el Gobierno está haciendo esfuerzos denodados para paliar la desocupación y, por el otro lado, funcionarios del mismo gobierno firman disposiciones que permiten ingresar al país mano de obra semiesclava, casi sin restricciones y que agravaría la plaga de la desocupación argentina" ${ }^{1092}$. Tiempo después la preocupación del dirigente incluso se volvía regional, cuando procuró la defensa de los marineros marplatenses debido a que se estaba embarcando "a mucha gente del sur y norte del país, pero la gente nuestra sigue sin trabajar". ${ }^{1093}$ Poco después, el gremio declaraba el estado de alerta buscando llamar la atención de la CAAPBA y las autoridades del área pesquera. Al mismo tiempo buscaba algún mecanismo para incorporar a los desocupados al circuito productivo. Por ejemplo, pensó en la alternativa de un reparto de las horas de trabajo, ampliando los francos del personal estable y alternando con el trabajo de los desocupados. ${ }^{1094}$

La problemática, lejos de disminuir, se acrecentó en el año siguiente. Novero explicaba que un pescador costero percibe un promedio de 800 pesos mensuales, mientras que uno de altura supera los 1.200. En cambio, a los extranjeros, no se les paga más de 200 o 300 pesos, además de no abonárseles las cargas sociales. ${ }^{1095}$ "Este negocio redondo para ciertos industriales ha hecho que ahora el total de extranjeros sea de aproximadamente 6.000 en un número total de casi 20.000 pescadores, que hay en todo el país. Los países que más aportan trabajadores de la pesca son Chile, Perú, China, Rusia y

${ }^{1087}$ L.C.,08/02/1992. La firma Romano y Poletti dejaba sin trabajo a cinco marineros del buque Lucía Luisa cuando los mismos exigían que se respete la convención colectiva de trabajo.

${ }^{1088}$ L.C.,26/08/1993. 35 tripulantes del buque Tehuelche se opusieron a la decisión de un capitán que quería obligarlos a pescar merluza sin tener permiso para ello. En ese contexto la empresa contratante se negó a abonarles los salarios que les adeudaba.

1089 L.C.,04/11/1994.

${ }^{1090}$ Los cuatro barcos asiáticos habían llegado producto de un acuerdo de la SAGPyA con los industriales extranjeros, donde se les permitía a los pesqueros de nacionalidad china pescar especies costeras. Carecemos de mayor información acerca de las características de este acuerdo.

${ }^{1091}$ L.C.,05/11/1994. El propio Novero explicaba que "ahora han venido cuatro barcos, pero se esperan veinte más" y lo que más le preocupaba es que "no quieren llevar tripulantes argentinos, ya que a los chinos les pagan nada más que cien dólares, plata que en la Argentina no alcanza ni para una semana"

1092 L.C., $18 / 01 / 1995$.

1093 L.C., $27 / 09 / 1995$.

1094 L.C.,05/10/1995.

${ }^{1095}$ Y por ello culpaba directamente a la política pesquera del gobierno nacional. Porque "les dio todas las oportunidades a los extranjeros para que vengan a trabajar acá. Mientras que la banquina está abarrotada de gente que quiere trabajar, los extranjeros lo hacen por doscientos pesos por mes. Y con ese dinero, en la Argentina no se vive”. L.C.,09/01/1996. 
Bielorrusia" 1096 . También por fuera de la conducción del SOMU trabajadores pescadores juntaban firmas para conocer la cantidad de obreros desocupados. Así, un grupo de pescadores de quienes no se menciona filiación política, pero si sabemos por sus propias declaraciones que se reunían diariamente en los muelles del puerto para discutir una solución al problema del desempleo, recolectaron 300 firmas de trabajadores en estado de desempleo. Explicaban que "Para nuestra defensa juntamos firmas, porque no pedimos nada raro: queremos trabajar con las condiciones que exige la Prefectura, que sea para todos iguales" en relación a la pesca con buques extranjeros. Criticaron a la conducción del SOMU y a los funcionarios provinciales que "no hacen cumplir como deben la Ley de Inmigración que asegura en cada barco extranjero un 50\% de tripulación local". Jorge Giménez exigió que "algún ente oficial venga a devolvernos los puestos de trabajo que nos corresponden" y agregó que "el sindicato no nos contiene, ni siquiera se arrima a nosotros, queremos sentir que alguien nos defiende" ${ }^{1097}$. En tal contexto, el SOMU reaccionó poniéndose al frente del reclamo. Se declaró en estado de alerta y Novero expresó que "acá hay empresas de Mar del Plata que llevan el 4 por ciento de tripulantes argentinos y 30 chinos" y denunció que "las empresas no nos reciben" 1098.

Además de la desocupación cada vez más grave, el otro punto de antagonismo fue la instrumentación de toda una política desregulatoria en materia laboral. Al decreto $\mathrm{N}^{\circ} 817$, se sumó en 1993 el decreto $\mathrm{N}^{\circ} 2.104$ mediante el cual los pescadores tradicionales de las lanchas amarillas dejaron de gozar de los beneficios sociales al pasar a la categoría de autónomos, perdiendo la relación de dependencia. Contra ello marineros locales se movilizaron hasta la banquina del puerto. Se trataba de representantes locales de la Asociación de Marineros Pescadores de la R. A. Néstor María, secretario general de la asociación, señalaba en aquel entonces que "éste es peor que el decreto 817, pues nos deja afuera de todo marco legal, pues ahora quedamos como obreros independientes, ya que la empresa no se hace responsable de los trabajadores al no tener relación de dependencia". Destacó que por lo pronto ahora eran los propios trabajadores quienes deberían pagar el seguro de trabajo y hacerse cargo de la obra social. Por su parte, Julio Di Gerónimo del Centro de Capitanes y Patrones de Pesca acusaba al gobierno nacional "como es costumbre, manejan la pesca desde 400 kilómetros y toman medidas sin importarles el sector". " ${ }^{1099}$ Tiempo después era el SOMU quien se declaraba en estado de alerta debido a la situación del personal de la flota costera, solicitando a los trabajadores del sector que se movilizaran en defensa de sus derechos. Se refería al encuadramiento de los trabajadores como autónomos, un pedido de la Sociedad de Patrones y la Asociación de Embarcaciones a la que se opuso el sindicato, sosteniendo que los pescadores costeros eran trabajadores en relación de dependencia. Argumentaba Novero que como autónomos los trabajadores tienen que pagarle a la DGI todos los meses lo cual es una enorme injusticia. ${ }^{100}$

También Carlos Barboza del SICONARA fustigó los últimos decretos gubernamentales que cercenaban "el libre trabajo de los hombres ligados a la pesca" y criticó la nueva categorización de autónomos para los obreros del sector costero. "Así, de un plumazo, sin consultar a nadie, solamente a los empresarios, todos los trabajadores son declarados autónomos, desconociéndoles antigüedad y quedando desprotegidos y sin resguardo jurídico, de obra social y previsional, alrededor de cien compañeros". Agregaba este nuevo decreto a una lista de males provocados luego del decreto $\mathrm{N}^{\circ} 1772$

${ }^{1096}$ L.C., 11/01/1996.

${ }^{1097}$ L.C., $22 / 02 / 1996$.

1098 L.C.,07/03/1996.

1099 L.C., 18/12/1993.

${ }^{1100}$ L.C., 18/04/1995. 
que indujo al cambio de la bandera nacional a bordo de buques mercantes y luego el mencionado decreto No817. El dirigente de los conductores navales expresó que "Con esta desregulación el Gobierno intenta bajar los costos operativos, pero casualmente estos costos operativos se reflejan en la variable de ajuste permanente, que es el salario de los trabajadores y la permanencia de las fuentes de trabajo". Denunció que la falta de actividad y de rentabilidad ha hecho disminuir notablemente el padrón del sindicato. De los 1.520 afiliados activos con que contaba el SICONARA, solo se registran en 1996 alrededor de 240. Ante ello expresaba la impotencia gremial por la falta de respuestas por parte tanto del Ministerio de Trabajo de la Nación, de la Provincia (que adujeron no era su competencia) y de la Justicia, donde se presentaron tres recursos de amparo que no fueron respondidos. Finalizaba Barboza: "En principio, vemos que se nos cierran todos los caminos. La política que fija Domingo Cavallo y la aplica el presidente, afecta directamente al orden institucional y desprotege a los trabajadores". ${ }^{1101}$ Ante ello, los gremios marítimos buscaron consolidar una unidad que permitiera organizar la oposición. Barboza explicó que la búsqueda de unidad se daba porque la situación que estaban viviendo era "más dramática que nunca", a pesar de lo cual "tenemos grandes esperanzas, pues en el día de ayer hemos concretado una reunión los cinco secretarios generales de las entidades que representan al personal embarcado y hemos concretado los primeros pasos para la unidad definitiva de todos los gremios". ${ }^{1102}$ Y señaló la posibilidad cierta de, en un tiempo no muy lejano, "una sola organización que represente a todos los trabajadores" y que "los nuclee en una federación". ${ }^{1103}$ Pero la iniciativa no trascendió más allá de las buenas intenciones.

Una problemática que afectó sobre todo a los capitanes como producto de la implementación del charteo fue la des jerarquización de su trabajo en los buques. Pues de estar acostumbrados a tomar todas las decisiones de pesca, pasaron simplemente a comandar naves y tener que subordinarse a las decisiones de los capitanes que arribaban con las flotas extranjeras. Por ello, en octubre de 1995, alrededor de 200 capitanes de pesca se reunieron en asamblea extraordinaria. La particularidad fue que la convocatoria se hizo en alta mar, planeándose la convergencia en Mar del Plata. El tema era expuesto por los trabajadores, asistiendo los dirigentes tan solo en calidad de oyentes. ${ }^{1104}$ En aquella oportunidad uno de los capitanes manifestó que "el objetivo es aunar criterios para dignificar y rejerarquizar la profesión. Hoy los capitanes no somos más que 'material de recambio' en la polifacética gama de barcos extranjeros que vienen a pescar con pabellón argentino". Se quejaba de que les dieran un trato como simples marineros, sin dejarles participar de las tareas de pesca y del planeamiento de la actividad. Las alteraciones se produjeron a partir de los decretos $\mathrm{N}^{\circ} 1493$ sobre charteo y $\mathrm{N}^{\circ} 817 .{ }^{1105}$ Luego de un par de días de deliberaciones, quedó conformada en Mar del Plata la Coordinadora Nacional de Capitanes, Patrones y Oficiales de Pesca que por primera vez logró agrupar a los centros de Capitanes de Ultramar, de Patrones de Pesca y a la Asociación de Capitanes de Pesca. ${ }^{1106}$ El capitán Máximo Sánchez señaló que luego de la desregulación alrededor del 40 por ciento del personal de buques era extranjero. También mencionó los malos tratos recibidos por muchos capitanes y se discutió acerca de la depredación, tema que comenzaba

\footnotetext{
${ }^{1101}$ L.C., 22/04/1994.

${ }^{1102}$ Las entidades eran la Sociedad de Capitanes y Patrones, Centro de Capitanes, SOMU, la Asociación de Marineros Pescadores y el SICONARA.

1103 L.C., $17 / 11 / 1994$.

${ }^{1104}$ Los capitanes expresaron que "fueron las bases las que convocaron a sus dirigentes para ponerse de acuerdo, algo que, hasta el momento, era una cosa atípica, porque por viejas enemistades es que habíamos llegado a esta situación”

${ }^{1105}$ L.C., $11 / 10 / 1995$.

1106 También la desocupación se presentó como uno de los motores de aglutinamiento de los capitanes. En su opinión la misma era originada "por la política gubernamental de desregulación, que permitió la entrada de personal extranjero en las embarcaciones".
} 
a incorporarse en la agenda de las discusiones pesqueras. Alberto Altamirano destacó que estas situaciones "no sólo ocurre[n] afuera de las 200 millas, sino que adentro del Mar Argentino, y nosotros que somos los que estamos en los buques, hemos visto más de una forma de depredación". ${ }^{1107}$

\section{La protesta de los trabajadores de tierra}

Las batallas que brindó el SOIP durante estos años estuvieron dominadas por 1) luchas salariales, 2) la defensa de los trabajadores sin trabajo y 3) múltiples denuncias contra la consolidación de cooperativas de trabajo. En cuanto al primer punto, en la rama conserva fracasaron las tratativas salariales del gremio con la Cámara de Procesadores, por lo que el sindicato se dispuso a decretar el estado de alerta, convocando de manera urgente al cuerpo de delegados. ${ }^{1108}$ Un año después, 1@s 40 trabajador@s temporarios de la planta de procesamiento Oromar, encabezados por Abdul Saravia, tomaron la pesquera en reclamo de sueldos adeudados. ${ }^{1109}$ Más grande fue la movilización de 267 trabajadores y trabajadoras de la firma La Campagnola al Ministerio de Trabajo reclamando por diferencias de salarios de los últimos dos años. Tras una reunión con los empresarios, obreros y obreras llegaron a un acuerdo. ${ }^{1110}$ Luego, la situación de los obreros y obreras de la firma Dispesa S.A. llevó al SOIP a declararse en estado de alerta y asamblea permanente. Aquell@s atravesaban difíciles momentos debido a que se "les adeudan los haberes desde el mes de enero de 1994, el decreto reglamentario 1777/89 (bonos alimentarios), asignaciones familiares del mismo período, vacaciones no gozadas de 1993 y el sueldo anual complementario del segundo semestre de 1993". Mostrando la continuidad de las problemáticas respecto del período previo, Saravia denunció además que dicha empresa mantiene una deuda con el SOIP de $\$ 13.200$ en concepto de aportes de obra social y cuota sindical. ${ }^{111}$ En otra ocasión, las medidas de lucha también incluyeron la instalación de carpas. Por ejemplo se instaló una frente a la empresa de Conservas de Pescado TOURS, pues esta mantenía deudas con su personal. Tras negociaciones, finalmente los salarios fueron abonados. ${ }^{1112}$

Respecto al segundo aspecto, el SOIP reclamaba insistentemente que los jueces apuraran las liquidaciones de empresas para que así los trabajadores pudieran cobrar sus indemnizaciones. ${ }^{113}$ En estos años, que evidenciaron un descenso en la conflictividad abierta y colectiva, muchas demandas de los trabajadores se tramitaron en la justicia. El crecimiento de las demandas llevó a diferentes sectores a pedir la creación de nuevas tribunas del trabajo en el ámbito provincial. La CGT local y el colegio de abogados firmaron en 1992 una resolución conjunta solicitando a la gobernación de la provincia de Buenos Aires "tenga a bien arbitrar todos los medios a su alcance a los efectos de la inmediata puesta en marcha y funcionamiento del tribunal de trabajo $N^{\circ} 3$ con asiento en la ciudad de Mar del Plata". La razón que justificaba el pedido la expresaba Saravia, quien manifestaba que las sentencias en juicio laboral "están tardando muchísimo" y esas demoras afectan "a la parte obrera ya que hay muchos reclamos de miles de

${ }^{1107}$ L.C., $13 / 10 / 1995$.

${ }^{1108}$ L.C., $05 / 04 / 1992$.

${ }^{1109}$ L.C., $23 / 12 / 1993$.

${ }_{1110}^{110}$ L.C.,06/05/1994. Además denunciaron: "nos obligan a que nosotros entremos en la jubilación privada".

${ }^{1111}$ L.C., $09 / 07 / 1994$.

${ }^{1112}$ L.C., $18 / 02 / 1996$.

${ }^{1113}$ L.C.,26/06/1992. 
compañeros que están en la calle por quiebras y otras cuestiones y no pueden cobrar"1114. Tras las quiebras, el SOIP prestó asesoramiento e invitó a los trabajadores a que realicen las demandas correspondientes en los Tribunales. ${ }^{1115}$ En algunas ocasiones los trabajadores y trabajadoras denunciaron haber sido estafados por los abogados que debían defenderlos. ${ }^{116}$

Ya para mediados de la década del '90 era rutina la movilización de trabajadores de la industria del pescado reclamando frente al Palacio de Tribunales. ${ }^{111}$ Buscaban que les pagaran las indemnizaciones que les correspondían con el dinero recaudado en los juicios de quiebra. ${ }^{1118}$ Como impulsores de las protestas aparecían los ex delegados Luis Sepúlveda y Elba Gloria Garay, acompañados en diversas oportunidades por el marinero Domingo Novero. También el periódico menciona los apoyos de las Listas Verde y Celeste, opositoras a la conducción del SOIP. ${ }^{119}$ Según los propios trabajadores desocupados el número de personas afectadas por esta situación eran "más de 4.500" que al perder sus empleos en su mayoría quedaron en la calle y sólo algunos lograron subemplearse, realizando "changas, por las que cobran muy poco dinero, sin contar con obra social ni otra cobertura". Aclaraban que desde "1991, venimos realizando gestiones para que nos informen qué hicieron los síndicos con el dinero recaudado de las quiebras". Aclaraban que al decretarse la quiebra de las firmas recurrieron a las vías legales para obtener el pronto pago de lo que se les adeudaba. Entonces "esperamos la subasta de las instalaciones y los bienes de estas fábricas". Pero les informaron que las sumas de dinero existentes en las cuentas de las empresas eran insuficientes y fueron destinadas al pago de los gastos de los juicios. Lo que reclamaban es que "después de decretarse las quiebras, la mayoría de las plantas fueron dadas en alquiler por montos de importancia. Por eso solicitamos que ese dinero se destine a pagarnos a nosotros". ${ }^{1120}$

En relación al tercer punto hemos visto ya en el capítulo III cómo se sucedieron las denuncias y planteos del sindicato. Sin embargo, el rechazo de la organización gremial al sistema de cooperativas continuó. En 1993 fueron los trabajadores de la empresa Mellino, junto con la conducción sindical, quienes denunciaron las pretensiones de los industriales pesqueros. Explicaron que "la empresa Mellino pretende la formación de cooperativas de trabajo, pero no con la claridad que debería, perjudicando de esta manera al obrero cuando los mismos se niegan a participar del citado proyecto". Pues "La empresa accede a cederles la planta por espacio de seis meses sin cobrar alquiler de la misma y se compromete a proveer pescado por dicho período. En caso de no acceder vienen las presiones, que consisten en

\footnotetext{
${ }^{1114}$ L.C.,05/02/1992.

${ }^{1115}$ L.C., 16/05/1992. El apadrinamiento del SOIP a este tipo de acciones venía desde antes. Ya en 1984 Saravia se permitía citar un fallo que responsabilizaba al dador de materia prima en un contexto en el que los trabajadores se encontraron sin trabajo. Se refería a la sentencia "Carini c/Pesquera Lourdes y Frig. Mellino S.A. s/cobro de indemnizaciones", de la cual decía "juicio iniciado y patrocinado por la iniciativa de la actual conducción del SOIP por intermedio de sus abogados”. L.C.,19/10/1984.

${ }^{1116}$ Por ejemplo cuando 75 obreros y obreras de las empresas pesqueras Miguelez, Aquatrading y Celeco solicitaron la intervención del Colegio de Abogados para que se investigue el desempeño del Dr. Francisco LópezGómez. Pues luego de dos años de contratar sus servicios para que les tramitara los juicios de despido, no obtuvieron respuesta. Y cuando reclamaron ante el Tribunal de Trabajo donde supuestamente se habría dado curso a sus demandas, comprobaron que no existe ningún expediente. En el caso de los obreros de la planta Miguelez, sospechaban que dicha fábrica fue a remate, siendo comprada por sus antiguos dueños, mientras que el abogado mencionado habría recibido dinero de la firma para no avanzar con los juicios. L.C.,26/03/1994. ${ }^{1117}$ L.C.,07/05/1997. El cronista señala que "La presencia de estos otrora obreros de firmas dedicadas a la manufactura de pescado ha pasado a convertirse en un hecho incorporado a la cotidianeidad de la sede tribunalicia. Jornada tras jornada se puede apreciar cómo los trabajadores y su familia -que han pasado a integrar el ejército de desocupados- van llegando, algunos en caravana por las calles adyacentes, y se ubican serenamente frente a las escalinatas del edificio".

1118 Entre ellas Mar Azul, Estrella de Mar, Maripez, Tomar, Eruomar, Arpemar, Mareexport, Produar, Agua Azul, Corinto, Pescamar, San Salvador, Yagan Pesquera, Frigocen, San Andrés, Taboas, Ferrero, Polo Sur, Ventura, Río Monte, Mellino.

1119 L.C., 21/04/1996.

${ }^{1120}$ L.C., 20/04/1996.
} 
suspensiones y en despidos". El SOIP denunció casos similares ante la subsecretaría de Trabajo y el Ministerio de Trabajo, sin mayores resultados. ${ }^{1121}$ Algún tiempo después en la esquina de Edison y Guanahani, a metros de la ex planta Dispesa, ahora Sur Trade, un grupo de trabajadores levantó la denominada "Carpa de la Justicia" como expresión de repudio a las cooperativas "truchas" y las empresas que "explotan a los obreros al margen de toda legislación laboral". Sur Trade había negado la entrada a seis obreros y obreras que como otros 80 trabajaban para la Cooperativa Los Acantilados. Quienes instalaron la carpa explicaron que:

La necesidad de un salario nos llevó a prestar servicios para esta Cooperativa, pero no bien se nos ocurrió reclamar por la obra social, el seguro de vida y las descargas previsionales prometidas, nos encontramos que si bien nos descontaban no se hacían los depósitos. Más aún, al indagar en los organismos correspondientes nos encontramos con que Los Acantilados es una cooperativa 'trucha', no inscripta ni reconocida, que vive de la explotación de los trabajadores, y que Sur Trade, además, no efectivizó las descargas jubilatorias. Es así, ahora, que nos encontramos con deudas acumuladas de CUIT que pesan sobre nuestro patrimonio particular, al punto que dos compañeros tienen la amenaza de remate de sus casas por parte de la DGI.

Explicaron también que "Sur Trade hace seis meses que efectúa los descuentos previsionales pero no los deposita" y expresando una crítica a la conducción gremial: "se han hecho las presentaciones correspondientes al SOIP y la CGT, sin que los dirigentes hasta ahora se hayan ocupado del tema, demostrando con ello la falta de sensibilidad para con los trabajadores afectados". Tras la denuncia ante el Ministerio de Trabajo, según los manifestantes, lo único que ocurrió fue la firma de un acta. Mientras ellos esperaban "una tarea a conciencia, que fuera de acuerdo al tenor de la denuncia, es decir haciendo las constataciones con los ochenta compañeros que son explotados igual que nosotros". Allí anunciaron una asamblea para evaluar la situación y señalaron que había al menos otras 50 cooperativas "truchas" relacionadas con la pesca. ${ }^{1122}$ De este modo se expresaba ya una protesta en oposicióna la conducción gremial. Antagonismo que irá creciendo, sobre todo a partir del ciclo posterior, cuando ya no esté Saravia al frente del sindicato. Previo a ello, Saravia acusaba recibo de las críticas:

Es lamentable ver cómo personas y obreros del pescado son dejadas en la calle, pero también es lamentable que en su desesperación nos adjudiquen responsabilidades que no nos competen [...] Esta entidad gremial, junto con la CGT regional somos quienes más hemos luchado, denunciado e inspeccionado a estas seudocooperativas a lo largo de cuatro años [...] No es responsabilidad del SOIP que tanto INAC como IPAC sean incompetentes y permitan utilizar el nombre de cooperativas a personas que explotan a los trabajadores. Nosotros hemos realizado denuncias con respecto a la seudocooperativa Los Acantilados y estamos a la espera que los entes nombrados se dignen inspeccionar. ${ }^{1123}$

\footnotetext{
${ }^{1121}$ L.C.,20/02/1993. También se habían realizado denuncias ante la ANSSES, DGI, Delegación Municipal del Puerto, Ministerio de Asuntos Agrarios de la Provincia, el IPAC, la Dirección de Acción Cooperativa. En la nota periodística Saravia menciona directamente la figura del Dr. Fernando Rivera como el ideólogo de lo que llamó "el falso cooperativismo" y de la quiebra de varias empresas locales.

1122 L.C., 19/10/1995.

1123 L.C.,24/10/1995.
} 
Otro conflicto de valioso interés para observar la complejidad del fenómeno de las cooperativas sucedió en la empresa pesquera Argenpesca. Argumentando que los trabajadores que desarrollaban sus tareas allí "no están registrados, trabajan en negro", representantes del SOIP se presentaron buscando presionar para lograr la registración laboral de estas personas. Por su parte, los directivos de la empresa Jorge Giovanelli y Guillermo Aufrac aclararon que "todo está en orden, trabajamos con la cooperativa 'Mares del Sur limitada' y está todo controlado". Los sindicalistas pretendían que los obreros pasen a trabajar en relación de dependencia, mientras que la parte empresaria adujo que "la única manera de trabajar es a través de este sistema" refiriéndose a las cooperativas. Sin llegar a un acuerdo con los empresarios, los sindicalistas decidieronquedarse "en la planta hasta llegar a alguna solución". Denunciaron que "la pseudo-cooperativa 'Mares del Sur' tiene labrada un acta, por la Subsecretaría de Trabajo local, por trabajar con obreros no registrados". Los empresarios rechazaron acusaciones esgrimiendo que "los obreros tienen seguro que cubre accidentes, incapacidad y muerte y, por supuesto, la obra social. Además tenemos todos los pagos al día, comprobables a través de una auditoría contable". El SOIP, por su parte, calificó a los empresarios de "explotadores", al igual que otras empresas que actúan de la misma manera, como "Moscuzza, El Marisco, Vasco Da Gama, Mellino Frigorífico, A. Mellino y Salerno". Y denunciaron, además, que la empresa debía 600 mil dólares a la obra social del sindicato. ${ }^{1124}$ Hasta aquí el hecho no presenta mayor complejidad. El sindicato demanda registración laboral que el empresariado niega apelando a la legalidad de las cooperativas de trabajo. Lo interesante surge después, cuando los trabajadores y trabajadoras de la planta Argenpesca, presionados o no por la patronal, desvincularon públicamente a la firma de la situación denunciada por el SOIP. Aclararon que "el sindicato se metió" pero que ellos no mantenían conflictos con la empresa. Declararon ante el diario $L a$ Capital que el conflicto surgió "con la Cooperativa Mares del Sur" pero aclararon que "nadie trabaja en negro y todos cobramos como corresponde". Explicaron que "todo lo dicho por la gente del SOIP es falso", afirmando que "cobramos religiosamente los viernes, además tenemos todo en orden, pagamos la obra social, los seguros de vida y la jubilación". Dijeron que el conflicto surgió de "un problema interno, con la cooperativa, que se nos fue de las manos". ${ }^{1125}$ De este modo, se vuelve visible el grado de inserción que tenía el sistema cooperativo en la realidad portuaria, y en cierto modo, revela la aceptación de tal situación por un grupo de trabajadores.

Distinta era la realidad de los 35 trabajadores y trabajadoras de Argenfish, cuya situación reflejó otra de las caras del problema de las cooperativas. El conflicto cobró visibilidad a partir de que dirigentes del SOIP, con un grupo de trabajadores que se encontraban desde hacía una semana en la puerta de la empresa, tomaron las oficinas de la firma luego de una reunión con los gerentes en la cual no se arribó a ninguna solución. El gerente administrativo, Jorge Golec, manifestó: "No tenemos ningún tipo de relación con ellos, ya que pertenecían a una cooperativa que nosotros contratamos y cumplimos con los requisitos que habiamos pactado". Los trabajadores, por su parte, expresaron "nos dicen que teníamos relación comercial con ellos, pero aclaramos que nosotros no somos cooperativistas". "Trabajamos para esta empresa en una supuesta cooperativa, que no es tal porque es todo trucho ya que ni matrícula tiene, no somos asociados a ella ni tenemos nada firmado". ${ }^{1126}$ Finalmente, los trabajadores consiguieron un pago

\footnotetext{
${ }^{1124}$ L.C.,29/02/1996.

${ }^{1125}$ L.C.,06/03/1996. Los trabajadores eran Carmen Pacheco, Fani Jakov, Raquel Palomino, Ana Marmori, María Valdez, Carlos Díaz, Marcelo Arrieta, Cristian Firmani, Lucía Canda y Mabel Pérez.

${ }^{1126}$ L.C.,11/08/1996. El gerente Jorge Golec explica, desde su punto de vista, la situación. En el período que fue de marzo a junio "crecieron las ventas al exterior de pescado de distintas especies. En nuestra fábrica tenemos trabajando, desde que está operando
} 
de 400 pesos cada uno, tras de lo cual depusieron su actitud. En octubre de 1996 un grupo de trabajadores "en negro" y desocupados del pescado se organizan colectivamente para protestar, detrás de lo que comienzan llamando simplemente como una comisión, ya con una lectura fina del rol que cumplían las seudo cooperativas en la industria del pescado. Estos obreros y obreras se juntaban habitualmente en las calles del puerto, buscando discutir alguna salida a la situación de desocupación que estaban padeciendo. La larga cita de un comunicado resulta ilustrativa del modo que estos trabajadores, por fuera de la conducción gremial, entendían la cuestión:

...entre 3.000 y 4.000 trabajadores del sector nos encontramos sufriendo las consecuencias del trabajo en negro con su secuela de inestabilidad, inseguridad jurídica y previsional, sin convenio, expuestos a jornadas y ritmos de superexplotación. A través de un proceso de tercerización las cada vez más grandes patronales del pescado (como lo indica el incesante aumento de las exportaciones), estos empresarios han arrasado con todos los límites que impone la legislación laboral. [Para ello] se han valido de la cooperativización forzosa y fraudulenta para llevar adelante una maniobra deliberada de trabajo semi-esclavo, una gran evasión impositiva y llevando adelante un caso de masivo fraude laboral en Mar del Plata [...] Los empresarios gozan de la posibilidad de imponernos estas condiciones, amparados por la alta tasa de desocupación, y en la desesperación por procurar el sustento para nuestras familias. Pero aquí no termina nuestro sacrificio porque la misma maniobra que permite evadir su responsabilidad previsional, descarga sobre nuestras espaldas la pesada carga del pago de la 'jubilación como autónomos' (CUIT), que sumado al seguro y a la obra social, ronda los $\$ 150$ mensuales. Estos son los tristes y miserables fundamentos que explican el 'fervor cooperativista' de las patronales [...] Una baja en los precios por kilogramo o por hora, jornadas de hasta 14 horas (de trabajo insalubre), sin horarios fijos, pérdida absoluta de la relación laboral y el pago asfixiante de $\$ 150$ mensuales se llevan el 50\% de un mes con discontinuidad laboral, últimamente muy común en el gremio. ${ }^{1127}$

\section{En las postrimerías de una crisis}

En agosto de 1996 los gremios marítimos anunciaron una nueva movilización en desacuerdo con la política pesquera. Dentro de una larga lista de reclamos se destacaba la desocupación. Entre otras medidas esperaban se termine con el charteo que afecta, según ellos, directamente a las fuentes de trabajo. ${ }^{1128} \mathrm{El}$ desempleo perjudicaba principalmente a los trabajadores del pescado pero también a los marineros. Por

\footnotetext{
'Naviera Argenfish', a una cooperativa que se llama 'Meropez' y como en ese tiempo hubo mucha demanda, para poder cumplir con los compromisos salimos al mercado a buscar otra cooperativa que pudiese procesar la materia prima nuestra, a manera de complemento de lo que hacíamos aquí". Así fue que enviaron entre marzo y junio a la cooperativa "Nueva Estrella" para procesar merluza, la que "fileteaban tras el acuerdo que convinimos con Pedro Ferreira, el titular de la cooperativa. El facturaba, nosotros pagábamos todos los días viernes y tenemos los comprobantes a disposición de quien quiera". Pero al llegar al mes de junio "la situación desmejoró notablemente la producción de merluza, por lo que nuestras ventas bajaron considerablemente. Ya no tuvimos que recurrir a una tercera empresa, pues con la cooperativa que trabajábamos dentro de nuestra planta era suficiente para atender la demanda, que había disminuido al 50\%, incluso hubo días en que no trabajaban por no haber materia prima”. Golec cuenta que le explicaron la situación a Pedro Ferreira pero luego aparecieron pedidos de gente exigiendo que les paguen lo que se les debe. Para la empresa la relación con Nueva Estrella siempre fue comercial. "Entonces entendemos que no les debemos nada desde el momento que no tenemos el producto para mandarles, y qué tipo de relación pueden tener con nosotros, si contratamos a dicha cooperativa".

${ }_{1127}$ L.C., $12 / 10 / 1996$.

${ }^{1128}$ L.C., $17 / 08 / 1996$.
} 
ello el SOMU se reunía con el intendente Aprile para informarle acerca de la cada vez más crítica situación laboral por la que atravesaban los trabajadores marítimos. Muchas familias no podían pagar los impuestos, sufrían cortes de luz y gas y se enfrentaban a juicios de desalojo por falta de pago del alquiler, estando a punto de perder sus viviendas. ${ }^{1129}$

A finales del mes de octubre la CGT regional y los gremios portuarios se declaraban en estado de alerta y movilización dado que no se resolvían los problemas de los trabajadores. Novero advirtió que en los próximos días se pasaría a la acción. Los pescadores dijeron no soportar más la situación. Días atrás denunciaron que "más de 300 marineros locales", con libreta y autorización de embarque se hallaban sin trabajo, mientras que "en el puerto existen más de 3.000 cédulas irregulares que permiten el embarque de extranjeros, mujeres y desocupados. Estos últimos son trasladados en micros desde el litoral norte del país". Denunciaron las violaciones a la ley de salubridad e higiene. Calculaban que trece buques factorías funcionaban con tripulación no marplatense, embarcando unos 500 trabajadores en forma ilegal. Daniel Rodríguez, entonces secretario general de la CGT reemplazante de Abdul Saravia, expresó que "Los tiempos no dan para más, hay que encontrar soluciones a corto plazo porque es obvio que los tiempos de los funcionarios no son los tiempos de la gente". Y anunció que la CGT va a acompañar cualquier medida que tomen los gremios. Por su parte, los sindicatos marítimos emitieron un documento indicando que " $\mathrm{el}$ pago en negro y la violación a la ley de cooperativas es moneda corriente en el puerto"1130. Más tarde el SOMU realizaba un piquete en la banquina demorando la salida del buque Mister Big, reclamando empleo de personal documentado. Novero expresó que la actitud de este empresario que opta por personal sin documentación es la de muchos industriales. ${ }^{1131}$ Así se cerraba el año 1996. Donde ya estaban a la vista los emergentes de una situación que estallará poco tiempo después.

El año 1997 se inauguraba con la toma de la fábrica Indupesa por parte de 17 operari@s que reclamaban ser reconocid@s como trabajadores eventuales, en un conflicto que desnudaba los niveles de despotismo patronal a que daba lugar la situación de la industria pesquera. ${ }^{1132}$ Por otra parte, los trabajadores y trabajadoras desocupad@s que aún no habían cobrado sus indemnizaciones y se manifestaban periódicamente frente al edificio de Tribunales, intentaron ocupar los pisos superiores del edificio pero fueron persuadidos de deponer tal actitud. Asimismo surgía por esta época un nuevo conflicto entre trabajadores cooperativizados y una empresa pesquera. El día 11 se produjo una manifestación y quema de neumáticos frente a una planta de Barilari. En paralelo, se instaló una carpa frente a la puerta. Se trataba de cinco empleados del área descarga que reclamaban el pago de

\footnotetext{
${ }^{1129}$ Expusieron al Intendente que "el fondo del problema son las condiciones en las que hoy se está manejando el Puerto y muchos empresarios, ya que hay empresas que pagan totalmente fuera de término con los trastornos que ello significa, pero además incumplen el convenio firmado entre el SOMU y los armadores por el cual por cada tres meses embarcados corresponden veintisiete días de franco [...] Pero lo más grave es la permanente situación de discriminación que vivimos los trabajadores del puerto [...] las empresas no toman personal con más de 40 años [y] muchas de estas empresas prefieren contratar a trabajadores de otros orígenes antes que a marplatenses".

${ }^{1130}$ L.C., $29 / 10 / 1996$.

${ }^{1131}$ L.C., 04/11/1996.

1132 L.C.,23/01/1997. Rolando Frías, integrante de la CD del SOIP, explicaba que "dentro del convenio colectivo está contemplada la rama de los trabajadores 'eventuales', o sea, los que las empresas toman en momentos de mucho trabajo. A estas obreras ni siquiera se les reconoció esa categoría; fueron tomadas 'a prueba' con contratos que tampoco la firma cumple, de modo que cuando reclamaron los bonos de asistencia alimentaria que les corresponden por convenio, el señor Pennisi en represalia las despidió, aclarándoles que si insistían en lo del bono no tendrían más trabajo". Obreras de la planta expresaron que las despidieron sin previo aviso y que "Alejandro Pennisi vino a presionarnos con un escribano, un tal Grecco, quien nos trató de muy mala manera y nos dijo que le fuéramos a reclamar a Menem [...] O trabajan o se van, fue lo que nos dijo Pennisi, quien no está dispuesto a tomarnos como eventuales y quien no nos quiere dar el bono de asistencia alimentaria".
} 
indemnizaciones tras ser despedidos. ${ }^{1133}$ Patricio Alesandroni, gerente delegado de la Cooperativa de Trabajo Puerto Nuevo aclaró que las personas que dicen ser empleados de Barilari, en realidad son asociadas a esa cooperativa. Desarrollaban tareas con la firma Barilari con quien la cooperativa tiene un contrato de prestación de servicios. Por ello, no tenían relación alguna con la firma sino con la cooperativa. Al contrario, los trabajadores respondían que a pesar de trabajar en forma cooperativa lo hacían para la empresa Barilari y por ello reclamaban que se los reincorpore o se les paguen las indemnizaciones. Al mismo tiempo, desnudaban la situación de precariedad en la que se encontraban pues "no tenemos representatividad gremial. Somos huérfanos, nadie nos cubre, ni siquiera las leyes laborales, por lo tanto tenemos que juntarnos y hacer la presión nosotros con otros compañeros de otras empresas que están en nuestra situación". Dijeron que hay 180 cooperativas y "todos tenemos este tipo de problema". Si no firmaban el ingreso a la cooperativa no se les permitía trabajar en ningún lado, por lo que consideraban era una extorsión "Porque de esta manera los empresarios evaden las cargas sociales". El hecho era ya una cosa común en el puerto de Mar del Plata si no fuera porque a partir de este momento los trabajadores comenzaron a mencionar, más allá de las condiciones laborales y el despotismo patronal, las pocas horas que estaban laborando por semana. De este modo expresaron lo que luego se conocería como "la crisis de la merluza", pues lasobre pesca de la merluza generó la multiplicación de conflictos en la medida en que faltaba la materia prima de las plantas pesqueras y se reducía el trabajo.

${ }^{1133}$ L.C., 12/03/1997. 


\title{
CAPÍTULO VI
}

La conflictividad social en la pesca (III): la "crisis de la merluza" (1997-2001)

\begin{abstract}
$\longrightarrow 00$
"La crisis de escasez en la que se encuentra la merluza hubbsi, ha catalizado y puesto sobre la superficie una enorme cantidad de conflictos que, en última instancia, conducen a un salvaje canibalismo interflota (fresqueros vs. congeladores), interempresarial (grandes vs. chicos; empresas de capital nacional vs. empresas de capital extranjero), intersectorial (sindicatos vs. empresas), intrasindical (sindicatos de a bordo vs. sindicatos de tierra), interregional (Mar del Plata vs. Patagonia), interinstitucional (administraciones provinciales vs. administraciones nacionales) e intrasectorial (investigación vs. administración, sector privado vs. sector público)"
\end{abstract}

Revista Redes, №107, 1999

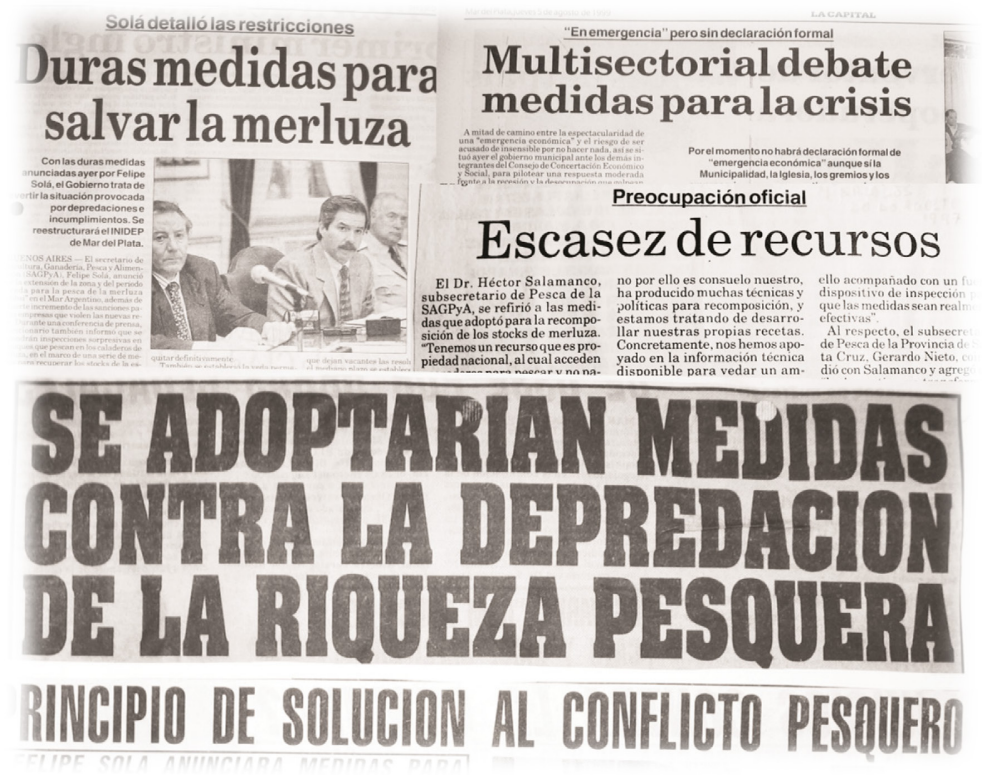




\section{Introducción}

La conflictividad emergente expresada en declaraciones, tomas de planta y movilizaciones analizadas en el capítulo previo, mostraba en gran medida algunas de las consecuencias del modelo pesquero adoptado. La gran expansión de la década se sustentó en el arribo de buques pesqueros extranjeros, con tripulaciones propias, principalmente mediante el sistema de charteo y el acuerdo con la CEE. Por ello para marineros, capitanes y conductores navales, el crecimiento bajo el signo de la política aperturista en materia pesquera significó una pérdida global de lugares de trabajo. A su vez, el grueso de ese pescado tampoco se procesaba en las plantas en tierra, con lo cual no existían beneficios para los trabajadores de la industria del pescado. Al mismo tiempo, otra de las características de la época fue el arribo de buques procesadores y factoría. Esto también repercutió en la situación dado que disminuyó las posibilidades de trabajo. Además, para abaratar los costos operativos de las empresas, la instalación de pseudo cooperativas de trabajo impactó negativamente en las condiciones de explotación de la fuerza de trabajo, presa ahora de inseguridad laboral e inestabilidad. Por último, el incremento del esfuerzo pesquero, que llevó al país a exportar niveles récord para la actividad, redundó en el fenómeno de la sobre pesca de los recursos, particularmente de la merluza hubbsi. Los efectos de ese proceso, si bien se expresaron previamente, comenzaron a cobrar toda su dimensión en el contexto de la llamada crisis de la merluza. En el transcurso de estos años, el dato más significativo estuvo dado por una aguda separación en los intereses de los empresarios, provocando la transformación de la tradicional estructura de la organización empresaria al producirse disidencias al interior de la CAABPA. Surgiendo así nuevas cámaras y organizaciones que plantearan sus demandas particulares, muchas de las cuales antagonizaron con los otros segmentos empresariales. Y este es, a nuestro entender, uno de los puntos centrales del análisis del ciclo de conflictividad. Pues si bien existían disidencias en el empresariado pesquero, primero respecto al ingreso de buques congeladores y luego tras la firma de los Acuerdo Marco, hasta entonces primó generalmente el entendimiento. Y sobre todo se generó un consenso hacia finales de los ' $80 \mathrm{y}$ comienzos de la administración Menem respecto de la necesidad de implementar reformas orientadas a la reactivación de la pesca, la posibilidad de incorporar tecnología y mejorar la inserción exportadora de la industria. Este consenso "parcial" mostrará su ocaso hacia finales de la década. ${ }^{1134}$ Por eso, si a comienzos de la década del ' 90 prácticamente no observamos acciones de protesta llevadas adelante por el empresariado pesquero, en el final de la década su presencia en el escenario conflictual se vuelve fundamental. Paralelamente, asistiremos a la participación creciente de la protesta de los trabajadores precarizados, subocupados y desocupados de la rama, al mismo tiempo que la consolidación de una “convergencia marplatense" buscó la defensa de la ciudad en tanto corporación económica. Todas estas cuestiones comenzaron a vislumbrase en el año 1996 y se expresaron con toda claridad en el año siguiente. La protesta y conflictividad social deben entenderse en ese marco. Son también estos los años donde el régimen de la Convertibilidad ingresará en su crisis terminal. En la pesca, la cantidad de acciones beligerantes registradas se incrementó, pues entre 1997 y 2001 se produjeron 242 acciones,

\footnotetext{
${ }^{1134}$ Esta situación se corresponde con el acontecer nacional donde el escenario de la organización empresarial mostraba en la antesala de la crisis del 2001 un escenario francamente diferente al de 1989-1990. Mientras que en la década del '80 el empresariado había logrado, a través de sus principales asociaciones, encontrar fuertes consensos respecto de lo que era deseable, en 2001 no fue posible sortear la conflictividad que arrojaba las diferentes posiciones respecto de la posible salida de la crisis entre quienes pretendían la continuidad de la convertibilidad, los que buscaban profundizarla a partir de la dolarización y aquellos que reclamaban por una devaluación (Beltrán, 2011).
} 
alcanzando una frecuencia de un conflicto cada 7 días y medio. Con todo, y para conocer la dinámica de la conflictividad en este período, es necesario comenzar por comprender la situación del empresariado.

\section{El fracaso de una "ilusión"}

En gran medida a lo largo de la historia de la actividad, el alineamiento empresario del sector pesquero se produjo en función del tipo de flota del que se era dueño. La Cámara Argentina de Armadores de Buques Pesqueros de Altura (CAABPA) agrupó desde su creación a los fresqueros. De más reciente nacimiento, promediando la década del '70, la Cámara de Armadores de Pesqueros Congeladores de la Argentina (CAPECA), como lo indica su nombre, congregó a los congeladores. Una radicada en Mar del Plata y la otra en la Patagonia. La relación entre ambas tuvo un duro comienzo dada la cerrada oposición marplatense al ingreso de congeladores en la pesca nacional. Un nuevo momento de enfrentamiento se produjo en oportunidad de firmarse los convenios de pesca con la URSS y Bulgaria en 1986. Sin embargo, a comienzos de la década del "90 comenzaba a vivirse un "razonable" clima de convivencia. Según indica la Revista Redes había razones "estructurales" para que ello ocurriera, dado que la propia evolución de la industria contribuyó a diluir las rígidas fronteras del pasado. Pues para esas alturas no eran pocos los armadores que tenían congeladores y fresqueros en sus flotas, mientras que la inversión extranjera les brindó un nuevo protagonismo a los armadores foráneos, abundando las sociedades mixtas. En ese contexto "La Patagonia ya no es un escenario remoto para el empresario bonaerense, y la silueta de más de un congelador matiza a diario el paisaje portuario de Mar del Plata". Esas nuevas realidades ilusionaban a los optimistas que buscaban consolidar la Federación de la Industria Pesquera Argentina logrando agrupar al conjunto de las cámaras pesqueras. ${ }^{1135}$ El esperado asociacionismo se anunciaba con entusiasmo en el mes de mayo de 1992, presentándose como un "paso decisivo para la consolidación de su presencia institucional”. La CAABPA, la CAPECA, la Cámara de Procesadores y la Cámara Argentina Patagónica de Industrias Pesqueras (CAPIP ${ }^{1136}$ ) decidían dejar sus diferencias de lado y conformaban, bajo la presidencia de Enrique Díaz, la Federación de la Industria Pesquera Argentina (FIPA). ${ }^{1137} \mathrm{Su}$ flamante presidente anunció que el propósito era "aunar esfuerzos para promover el crecimiento ordenado y sostenido del sector pesquero nacional" y "promover inversiones genuinas y de riesgo, y desalentar el oportunismo, persiguiendo un crecimiento de la producción compatible con la necesaria conservación del recurso". ${ }^{1138}$ Además se buscaba, a partir de una organización de peso, integrar a la industria pesquera a las organizaciones empresarias de superior nivel gremial, asumiendo su representación en las mismas. Sin embargo, a pesar del optimismo, este proyecto asociativo mantuvo un errático funcionamiento mientras la industria pesquera creció en volúmenes de captura y exportaciones, pero finalmente fracasó cuando aquel ciclo llegó a su fin. La crisis de la merluza a partir de 1997 y la discusión frente a la sanción de la nueva ley federal de pesca impulsaron a cada entidad a pugnar por sus propios intereses, rompiendo la frágil unidad e incluso

\footnotetext{
${ }^{1135}$ Revista Redes, № 61, año 1992, p. 20. “Cámaras ¿Rumbo a la Federación?”

${ }^{1136}$ La Cámara Argentina Patagónica de Industrias Pesqueras se creó precisamente para, defendiendo un interés regional, agrupar a las empresas pesqueras patagónicas.

${ }^{1137}$ Revista Redes, № 62, año 1992, p. 6, 7 y 8. Se acordó en el acta constitutiva que la presidencia la ejercerían en forma anual y rotativa los representantes de las cámaras fundacionales. En el primer período Enrique Díaz (CAPECA) era el presidente. Alberto Valastro (CAABPA) vicepresidente. Eduardo Auguste (CAPIP) secretario y Carlos Domine (Procesadores) tesorero.

${ }^{1138}$ Revista Redes, $\mathrm{N}^{\circ} 62$, op. cit. p. 6.
} 
generando novedosos realineamientos, varios de ellos bajo exclusivos criterios regionales, producto de los cuales emergieron nuevas entidades.

En Mar del Plata por ejemplo, ante diferentes situaciones percibidas como injustas que sufrían los industriales pesqueros locales respecto de sus pares patagónicos, ya en 1994 desde la UCIP se convocó a una reunión del empresariado pesquero local. El planteo llevado por la entidad empresaria local sugería que "ante la ausencia de una política pesquera nacional, se debe articular un frente común de la ciudad para defender dicha actividad". ${ }^{1139}$ Tiempo después el senador Mario Cámara se comprometió a integrar el frente común. ${ }^{1140} \mathrm{El}$ eje deberían ser las empresas que contaban con plantas en tierra, radicadas en Mar del Plata. Por ello, fracasado el intento federativo nacional, a comienzos del año 1995 se ensayaba un intento federativo local. Se constituía, entre las diferentes cámaras empresarias marplatenses, la Federación Argentina de la Industria Pesquera. La integraban la CAABPA, Procesadores, Industriales del Pescado, Asociación de Embarcaciones de Pesca Costera y la Sociedad de Patrones Pescadores. ${ }^{1141}$ Pero tampoco el eje antagónico de Mar del Plata versus Patagonia logró unificar al sector empresario local. El modelo de desarrollo pesquero había generado mayores divisiones entre los empresarios de la ciudad, tanto por su tipo de flota como por su situación ante la posesión de permisos de pesca. Y ello no se pudo zanjar mediante un entendimiento institucional. El primer dato significativo en ese sentido es la aparición de una nueva cámara pesquera local.

\section{Nace la Unión de Intereses Pesqueros Argentinos (UDIPA)}

UDIPA nació en el año 1996, en el cual comenzaban a aparecer con mayor visibilidad las consecuencias del modelo de desarrollo pesquero. Firmaban el documento de presentación de la entidad el empresario naval Domingo Contessi, José Ramaci (presidente) y Graciela Piergentilli (vicepresidente) ${ }^{1142}$, quienes declaraban como objetivo principal "la defensa de los intereses pesqueros auténticamente argentinos" "1143. Explicaban que la entidad "nació a partir de la inquietud de numerosas empresas vinculadas a la pesca, que ven seriamente comprometido su futuro, y que compartían problemas en común". El diagnóstico que las mancomunaba sostenía que "La industria pesquera vive hoy una crisis muy seria que la ha alejado de sus raices, y amenaza con perjudicar a un amplio sector productivo, especialmente aquél ligado con la pesca de los barcos fresqueros, el procesado en tierra, y todas las actividades industriales y de servicios conexas". Quienes integraban UDIPA pensaban que "ha llegado el momento de aunar esfuerzos para efectuar propuestas serias tendientes a lograr un cambio de rumbo" ". Poco después declaraban como finalidad bregar por "los intereses de la pesca nacional, de las empresas argentinas, y de las fuentes de trabajo genuinas generadas en el país". Integraban la entidad alrededor de 50 empresas, agrupando no sólo a pesqueras sino también a cooperativas de estibaje, entidades de transporte, distribuidoras de combustibles, talleres navales, fábricas de hielo, agencias marítimas y fábrica de redes, entre otras. Uno de los problemas principales que señalaban era la

\footnotetext{
${ }^{1139}$ L.C., 02/06/1994.

${ }^{1140}$ L.C., 26/08/1994.

${ }^{1141}$ L.C.,11/03/1995. La primer comisión directiva estaba presidida por Antonio Di Leva y vice presidida por Miguel Dobarro. Antonio Solimeno era el secretario, Cayetano Arcidiácono el tesorero y Javier Romano el primer vocal.

1142 Graciela Piergentilli también ocupaba el cargo de prosecretaria de la UCIP.

${ }^{1143}$ La negrita nos pertenece.

${ }^{1144}$ L.C.,04/03/1996.
} 
depredación de las especies en general y de la merluza en particular. Además, calificaban como una "injusta situación” la de los barcos fresqueros argentinos con permisos de pesca restringidos para las principales especies comerciales "cuando existen enormes buques ingresados posteriormente del extranjero, que no poseen restricciones". ${ }^{1145}$ Será este un punto clave, ya que muchos de los barcos que integraban la entidad pescaban sin los debidos permisos. En su primer informe, UDIPA denunciaba directamente el accionar de los buques factoría, demostrando su incidencia creciente en la pesca dentro del mar argentino en desmedro del accionar de los fresqueros. ${ }^{1146}$ En otra oportunidad, Graciela Piergentili explicaba que:

En el caso del sector pesquero es difícil explicar la crisis ante un sector que ha crecido a la luz de la política actual. Crecieron las exportaciones, las capturas, pero ese crecimiento se ha dado a favor de la gran empresa, de la empresa extranjera y del procesamiento a bordo. Eso hace que las pequeñas y medianas empresas con instalaciones en tierra, que son las que representan a la entidad a la que pertenezco, estén viviendo una situación de crisis [...] Es difícil competir a nivel de precios con la producción a bordo, porque los niveles salariales que pagan las empresas extranjeras y las nacionales son muy distintos. ${ }^{1147}$

En el contexto de discusión en torno a la nueva ley de pesca, UDIPA elaboró un comunicado en el que reclamaba por una política pesquera que privilegie los barcos tripulados por argentinos, fresqueros que procesen en tierra y que generen empleos durante su construcción. Exponía que en la pesca la inversión extranjera no se traducía en generación de empleo. Días antes, Felipe Solá había deslizado que si el uso de buques congeladores se expandía era porque éstos eran más eficientes para desarrollar las tareas de pesca. UDIPA reaccionaba contra ese argumento explicando que:

Las empresas extranjeras que se radicaron en nuestro país trajeron barcos usados que ya habían sido expulsados por depredar en otros caladeros, no tuvieron que pagar aranceles ni impuestos para importarlos y tampoco emplearon a pescadores argentinos porque el Dec. 817/92 les permitió trabajar con sus tripulaciones extranjeras [...] Las capturas que realizan tampoco sirven para generar nuevos empleos en tierra, porque todos los barcos importados son congeladores o factorías y cuando llegan a puerto sólo tienen que acodarse al buque mercante para transbordar la carga y exportarla. Luego, esos productos deberán competir por los mismos mercados con los elaborados en tierra por mano de obra y capitales argentinos [...] Como si esto fuera poco, la situación se agrava aún más porque nuestro generoso Estado también les debe pagar a esas empresas foráneas los correspondientes reintegros por exportaciones [...] Es decir que nos invaden, nos quitan fuentes de trabajo, depredan el caladero y, aparte les pagamos un premio.

Además denunciaba que en el modelo pesquero existe:

...una evidente discriminación para con las empresas argentinas. Con sólo analizar la cantidad de permisos de pesca que se otorgan a partir de 1990 a las empresas de capital extranjero en

1145 L.C., 10/03/1996.

${ }^{1146}$ L.C.,07/04/1996.

${ }^{1147}$ L.C., 27/10/1996. 
comparación con las nacionales veremos que es así [...] el poderío económico de ciertos grupos extranjeros tiene mucho que ver en esto.

UDIPA consideraba que Argentina tenía que poner un límite a las inversiones golondrinas porque "cuando el caladero se agote y ya no quede más recursos que extraer, se irán a otras costas y nos dejarán un tendal de problemas sin resolver". Por último razonaban que "la apertura económica no debe significar un renunciamiento a beneficios y puestos de trabajo para los argentinos" $" 1148$. Tiempo después aparecía un informe de la revista Redes que ratificaba, a través de información del INIDEP, que eran ciertas todas las preocupaciones en cuanto a la situación de los recursos. Entonces UDIPA precisaba su diagnóstico y proponía alternativas. Aseguraba que el incremento de pesca se debía "exclusivamente al aumento en el esfuerzo de pesca, como producto del increible crecimiento que se ha producido en la flota pesquera durante los últimos años". Para la novel entidad era:

...indudable que la política de apertura económica ha hecho estragos en materia pesquera. Tal es así que durante los últimos años no sólo se ha fomentado importación de barcos congeladores y factorías, sino también la radicación de empresas de capital extranjero que los operan. Las consecuencias de estas políticas sobre la industria argentina preexistente y sobre el propio recurso pesquero, son una asignatura pendiente.

Como posibles soluciones proponían dividir la captura máxima permisible por tipos de flota, asegurando a los barcos fresqueros operados por tripulaciones argentinas una captura global similar a las descargas históricas, de manera que no se perdieran puestos de trabajo embarcados y en tierra. ${ }^{1149}$ También, pasados tres años de su puesta en acción, la entidad manifestó su oposición a los acuerdos pesqueros celebrados con la $\mathrm{CEE}$, a los que consideró como una "nueva entrega del mar argentino" y los calificó de importación camuflada. Denunciaba que "bajo un acuerdo de segunda generación se escondía la incorporación subsidiada de buques congeladores gallegos" que depredaron otros caladeros. Especificaban que ninguno de los objetivos por los cuales se firmó el acuerdo se cumplió. ${ }^{1150}$ En el marco de índices de sobrepesca alarmantes, en mayo de 1997 la SAGPyA y las cámaras más importantes de la industria pesquera alcanzaban un acuerdo en torno de la reducción consensuada de las capturas de merluza hubbsi (ver capítulo II). A esa reunión no fue invitada UDIPA, por lo que manifestó su repudio. Frente a ello, la entidad se reunió en Mar del Plata en la sede de UCIPpara discutir el acuerdo entre Solá y las cámaras, procurando "volver a pedir el apoyo del resto de los sectores económicos de la ciudad". Pensaba la entidad que antes de reducir la actividad de los buques fresqueros primero se debía revisar la actividad de los barcos congeladores. Apuntaban a que éstos "son los causantes de la depredación por la tecnología de pesca que aplican". El documento redactado, cuyo título era "Principios que debe contener la futura ley de pesca", apuntaba a influir en los contenidos de la nueva legislación pesquera. Pedían también que se prioricen los barcos que generan trabajo en tierra y cuya materia prima es procesada e industrializada en plantas; los buques de empresas de capital nacional tripulados por argentinos; los barcos de firmas con antecedentes y especialmente aquellos construidos en el país. En cuanto a lo laboral exigían el $75 \%$ de tripulación argentina. Y asumiendo una posición patronal, contrapuesta al punto de

\footnotetext{
1148 L.C., $14 / 01 / 1997$.

1149 L.C., 02/02/1997.

${ }^{1150}$ L.C.,04/03/1997.
} 
vista sindical, pedían por el reconocimiento de otras formas de organización laboral tales como "sistema a la parte" y cooperativas de trabajo, así como la firma de nuevos convenios colectivos de trabajo en reemplazo de los vigentes desde $1975 .{ }^{1151}$ Por otra parte, se manifestaron en contra de que el criterio de distribución de los recursos en base a la necesaria reducción sea digitado "sólo por unos pocos".

En Mar del Plata la crisis está instalada desde hace tiempo. No son compatibles los actuales volúmenes de captura y exportaciones con una desocupación récord del sector pesquero local [...] La culpa la tiene esta política pesquera que favoreció un profundo cambio en la estructura de producción, el cual finalmente llegó a esta ciudad gracias al convenio con la Unión Europea. Así estamos pasando de traer pescado fresco y procesado en tierra, a elaborar todo a bordo de buques congeladores que depredan y desaprovechan la materia prima. ${ }^{1152}$

En defensa del sistema fresquero, el procesado en tierra, Mar del Plata como principal puerto pesquero y lo que consideraban como industria realmente nacional, se posicionaba UDIPA. Su aparición ponía en escena nuevos elementos de lo que sería, a partir del segundo semestre de 1997, el enfrentamiento empresario en el marco de la crisis de la merluza.

\section{La crisis de la merluza y el enfrentamiento empresario}

“¿Quién ganará finalmente la pulseada que, hasta el momento, parece inclinarse levemente hacia los fresqueros? El tiempo lo dirá"

T. K., La Capital, 30 de noviembre de 1997

En el año 1997 ya no se pudo eludir el impacto de la sobrepesca de la merluza, obligando al gobierno a reaccionar. En este contexto se adoptaron medidas para contraer las capturas. En primer lugar se intentó generar un consenso de reducción con las diferentes cámaras empresarias (ver Capítulo II). Pero la necesidad de disminuir de manera drástica los niveles de explotación de los recursos complicaba la posibilidad de alcanzar cualquier tipo de criterio mancomunado. La crisis de la merluza terminaba con la ilusión de crear una federación de cámaras pesqueras. Más aún, un fuerte conflicto se instaló entre los diferentes sectores empresarios en torno a una cuestión muy simple. Ante la evidente necesidad de reducir las capturas ¿quién pagaría esa disminución? O dicho de otra manera ¿quién dejaría de pescar? Con este panorama, cada agrupamiento empresarial pretendió influir a través de distintas acciones sobre las políticas de gobierno, procurando hacer recaer la crisis de sobrepesca sobre algún otro sector, generando un antagonismo abierto en el empresariado pesquero que se vio expresado en las dificultades por sancionar una ley de pesca y, luego de aprobada, por implementarla efectivamente.

La disputa se inició en torno a la obtención de las cuotas de captura efectivamente disponibles. Como vimos en el capítulo I, entre 1992 y 1997 la Captura Máxima Permisible (CMP) de merluza se

${ }^{1151}$ L.C., $17 / 05 / 1997$.

1152 L.C., 14/06/1997. 
mantuvo cercana a las 390.000 toneladas. Sin embargo, se venían pescando alrededor de $600.000 \mathrm{tn}$, superando los límites permitidos en 210.000 tn. Ante la evidencia de la depredación la autoridad de aplicación expresó la necesidad de reforzar los controles para hacer cumplir la CMP. Pero respetar la cantidad normada implicaba entonces una merma general en los volúmenes disponibles para ser pescados. En 1996, con una CMP de 398 mil toneladas de merluza, la flota fresquera había pescado 270 mil toneladas y la flota congeladora 300 mil. Para mediados de 1997, la flota fresquera había pescado 90 mil toneladas y la congeladora $120 \mathrm{mil}$. Es decir que ambas flotas en conjunto pescaron durante la primera mitad del año 210 mil toneladas. La CMP se había establecido nuevamente en 390 mil toneladas. Es decir que quedaban para pescar 180 mil toneladas de merluza. Para ambas flotas, esas 180 mil tn representaban poder alcanzar el nivel de pesca del año previo. Pero las dos flotas pescando juntas rebasarían ampliamente dicha cifra. Por lo tanto, había dos posibilidades ¿o algún tipo de flota dejaba de pescar? ¿o se encontraba algún parámetro para reducir las capturas de ambas? Esta segunda opción, más consensualista, hacía inviable económicamente -según los empresarios pesqueros- el mantenimiento de la actividad de cada flota por separado. Por eso, no era una opción disponible. Ante ello comenzaron los enfrentamientos dentro del empresariado. La disputa fue planteada en la prensa bajo la polarización de los tipos de flota. Esto es"fresqueros" versus "congeladores". Esa polaridad ilumina alguno de los ejes por los que transitó el conflicto, pero oculta otros. Aprovechemos ahora esa manera de presentar el conflicto para avanzar sobre las iluminaciones, para luego complejizar un poco más la cuestión.

Ya hemos visto como UDIPA se posicionaba frente al modelo pesquero exigiendo se privilegie a fresqueros y plantas en tierra, apelando a un discurso de soberanía nacional. En este tiempo, esta posición también ganaba a la CAABPA y a la Cámara de Procesadores. Con lo cual quedaba delimitado cierto perfil marplatense del empresariado pesquero. El enemigo aparecía en la Patagonia, poseía congeladores y lo representaba la CAPECA. En la batalla por los cupos de pesca, a grandes rasgos, unos recurrirían al peso de la tradición, de la generación de empleo, de lo nacional. Los otros a la mayor eficiencia, tecnificación y adecuación a la modernidad pesquera. A las puertas de la crisis, cada bloque generó un programa de respuesta orientado a la definición de una política pesquera nacional, señalando un culpable de la depredación y generando propuestas de desarrollo sustentable. El programa de "los fresqueros" marplatenses giraba en torno a la defensa de una cuota de 300 mil toneladas de merluza para ser pescada con los buques fresqueros y procesada en tierra. Responsabilizaban por la sobrepesca a los buques factorías-congeladores y pedían por ello su expulsión del mar argentino. La vocera de UDIPA, Graciela Piergentilli, al definir los problemas de la industria pesquera a partir de 1989, atacaba al mismo tiempo la extranjerización y el arribo de buques congeladores:

...cuando de alguna manera, por necesidad de aumentar las exportaciones argentinas, se toma la decisión de abrir el caladero a las flotas extranjeras. Fue en ese momento cuando se da un aumento excesivo con la flota que explota el Mar argentino. En general son grandes empresas internacionales, que van en barcos de factoría, es decir que procesan los pescados arriba del barco. ${ }^{153}$

De este modo, culpaba por la sobre pesca a la política pesquera aperturista que favoreció el ingreso de flotas extranjeras al caladero nacional, las cuales mantenían una tecnología "depredatoria".

${ }^{1153}$ L.C.,31/10/1997. 
En noviembre de 1997, mes en que se trataba la aprobación de la ley de pesca, la CAABPA y la Cámara de Procesadores emitieron un comunicado sobre la crítica situación por la que atravesaba el sector pesquero en Mar del Plata. Allí proponían una serie de medidas tendientes a resolver la crisis. Las más importantes eran: 1) Disponer en forma inmediata de una parada biológica, antes que termine el año en curso, de 15 días para la flota fresquera y de 60 días para la flota de congeladores y factoría; 2) a partir del año 1998, se deberá garantizar a las flotas pesqueras [fresqueras] un cupo global de 300.000 toneladas anuales de merluza hubbsi, para asegurar el normal abastecimiento de materia prima a las plantas en tierra; 4)prohibir la pesca de buques factoría y congeladores en todos los golfos del litoral marítimo argentino; 5) establecer una clara diferenciación en la escala de reintegros a las exportaciones entre los productos elaborados en tierra y a bordo; 6) eliminar los reembolsos por puertos patagónicos a los productos elaborados a bordo de congeladores y factoría; 7) formar un fondo para subsidiar el retiro de buques pesqueros de la ZEE Argentina. ${ }^{1154}$ De este modo, las cámaras pesqueras con asiento en Mar del Plata exigían un cambio de rumbo en el desarrollo pesquero, al mismo tiempo que definían un programa para la pesca que garantizaba, básicamente, la continuidad de la actividad para "los fresqueros", junto al procesamiento en tierra y, al mismo tiempo, excluía a los buques congeladores y factoría de las tareas de pesca. Los empresarios Barilari y Di Leva, representando a la CAABPA, señalaban que "hoy es la autoridad de aplicación la que debe cambiar la política del sector pesquero caso contrario será la única responsable del futuro de las plantas procesadoras y de las miles de familias que dependen de esta industria en Mar del Plata y su zona de influencia" "1155. Su posición mostraba un creciente consenso en Mar del Plata en torno al programa a llevar a cabo, el cual implicaba la defensa del sistema fresquero con elaboración en tierra.

Del otro lado quedaban los congeladores y las empresas patagónicas. CAPECA y CAPIP, ante la definición de criterios para reducir las capturas, procedieron a rechazar cualquier "discriminación" por tipo de flota que utilizara el mismo arte de pesca y reivindicaron el carácter industrial del procesamiento de productos sobre buques factoría. De este modo se preparaban para la batalla. Su capacidad de influir en la política oficial, manejando un discurso técnicamente acorde a los postulados neoliberales que asumía el gobierno en general, particularmente en relación a los mecanismos para asignar recursos pesqueros, la colocaban en una posición de poder nada despreciable para influir sobre el texto de la futura ley de pesca. Norma que finalmente incluyó el sistema de asignación de cuotas individuales transferibles para distribuir los recursos. Al contrario, los "fresqueros" marplatenses buscaban consolidar su poder apelando a su identidad de pescadores "tradicionales". De este modo se fue constituyendo el escenario para la batalla.

\section{La "capital de la pesca" se organiza}

El período que va de 1997 a 2001 estuvo dominado por la crisis de la merluza. La disminución de los stocks de pescado disponible, producto de la política pesquera implementada, marcó un límite al esfuerzo pesquero, el cual a su vez impactó en la situación de todos los actores involucrados en la pesca. Con ese marco, comenzó a perfilarse una posición de Mar del Plata como corporación económica. Esto es, la organización de la defensa de la actividad pesquera local como corporación de intereses conjuntos

${ }^{1154}$ L.C.,5/11/1997. La negrita nos pertenece.

${ }^{1155}$ L.C.,5/11/1997. 
de empresarios y trabajadores pesqueros marplatenses, apoyados en el gobierno de la ciudad y los "vecinos", en contra de un enemigo común externo que afectaba sus intereses económicocorporativos. ${ }^{1156} \mathrm{El}$ primer acontecimiento de visible importancia que marcó el inicio de este proceso fue la audiencia pública convocada por el HCD local con motivo de la crisis de la pesca y la futura sanción de la ley de pesca. La convocatoria incluía tres puntos 1) situación general del sector pesquero marplatense, 2) necesidad de una ley de pesca y 3) establecimiento de una política de explotación sostenible de los recursos vivos del mar. ${ }^{1157}$ Para la misma se invitó a funcionarios responsables del área pesca, así como también a diputados y senadores nacionales y provinciales. Mientras que por la ciudad se hicieron presentes, además de los concejales, representantes de las cámaras pesqueras y dirigentes sindicales. La apertura corrió a cargo del Intendente de la ciudad que, luego de resaltar la importancia de la pesca para Mar del Plata e indicando la grave situación que atravesaba mucha gente "que sufría y esperaba soluciones inmediatas", expresó:

Deseo apelar a la prudencia de todos los sectores involucrados en la cuestión de la pesca para que trabajemos fuertemente sobre los aspectos en los que estamos en coincidencia y que dejemos para otro momento aquellos aspectos en que -naturalmente tal vez- podamos tener divergencias. ${ }^{1158}$

Sabiendo los antagonismos existentes, el Intendente Aprile priorizaba consolidar aquello en lo que existiera acuerdo, buscando el reclamo monolítico de la ciudad por los contenidos de la ley de pesca. El cronista del diario La Capital parece apelar a la misma sensibilidad del intendente, mencionando la existencia de disidencias pero enfatizando en las coincidencias. Éstas últimas giraron en torno al diagnóstico sobre la sobrepesca y la ausencia de controles, ${ }^{1159}$ la necesidad de funcionamiento del Consejo Federal de Pesca y el incremento del valor agregado a los productos procesados en tierra. Se consensuó el rechazo a la ley de pesca presentada por el senador Ludueña y el apoyo generalizado al proyecto presentado por el diputado José Luis Castillo y se aprobaron dos consignas tendientes a revalidar el peso de Mar del Plata en la pesca nacional: "Igualdad de condiciones para el puerto de Mar del Plata con los demás del país y que no haya ley sin consenso de esta ciudad'. La CGT y UDIPA comunicaron la existencia de un documento elaborado por ambas entidades, que entre otras cuestiones solicitaba:

- No a la renovación ni a la ampliación del Acuerdo con la Unión Europea y exigir el cumplimiento de su letra y espíritu durante la vigencia del mismo.

- Derogar el régimen de charteo -Decreto 1493/92- y permitir la pesca de calamar con buques fresqueros -arrastreros- para promover el empleo de mano de obra en tierra y disminuir el esfuerzo sobre otras especies.

- Implementar reembolsos por mayor valor agregado para los productos elaborados por las plantas en tierra.

- Establecer que el caladero sea explotado exclusivamente por barcos argentinos operados por trabajadores argentinos.

\footnotetext{
${ }^{1156}$ Sobre la noción de corporación económica ver Aufang (1989).

${ }^{1157}$ Audiencia pública, 14/07/1997, Honorable Concejo Deliberante de la ciudad de Mar del Plata.

${ }_{1158}$ Audiencia pública, 14/07/1997... op. cit. p. 3.

1159 En su exposición José Benvenutto, titular de la Asociación Argentina de Capitanes, Pilotos y Patrones de Pesca, hizo mención a un informe del INIDEP, según el cual la biomasa total de merluza se había reducido de 2.400 .000 a 1.800 .000 , es decir un 25\%, entre 1986 y 1996 . Mientras que los ejemplares con capacidad de reproducción se redujeron de 1.900 .000 a 1.000.000 entre los mismos años. Audiencia pública, 14/07/1997... op. cit. p. 6.
} 
- Salarios, medio ambiente y condiciones de trabajo dignas para los trabajadores vinculados al sector.

- Instaurar un régimen de administración del recurso donde tengan prioridad de acceso: los barcos que procesan sus capturas en tierra, los barcos de empresas de capital nacional y tripulados por argentinos, los barcos de empresas con antecedentes en el sector, los barcos construidos en el país.

- Inmediato llamado a paritarias con participación de todos los sectores involucrados para dar solución definitiva al alto índice de litigiosidad laboral actual y a las nuevas modalidades de trabajo.

El documento mostraba un nuevo entendimiento entre organizaciones que representaban al trabajo y el capital. Y así como se expresó una posición conjunta entre UDIPA y CGT, por otro lado, se hicieron visibles las tensiones entre los industriales pesqueros. La discusión se producía entre quienes contaban con permisos de pesca legalizados, como los adheridos a la CAABPA y Procesadores, y los que poseían las embarcaciones pero adolecían de la cantidad necesaria de permisos, como UDIPA. Más importante aún fue la disidencia entre quienes poseían solamente fresqueros y grupos que aparecían trabajando tanto con fresqueros como con congeladores, reconociendo que un stock de inversión más grande y una mejor posición ante la crisis pesquera pertenecía a estos últimos empresarios, nucleados entonces tras la figura de Antonio Solimeno. El industrial fue interrumpido y silbado por quienes aparecían ocupando "la barra" del recinto del HCD cuando relativizó la importancia de la crisis pesquera y manifestó la satisfactoria situación por la que atravesaban las empresas (aunque fueran algunas de ellas) que integraban la CAABPA y la Cámara de Procesadores. ${ }^{160}$ Una posición crítica del manejo pesquero atravesó diferentes alocuciones siendo el concejal Carlos Baldino (FREPASO) quien apuntó directamente contra la gestión de Felipe Solá. Además de empresarios, dirigentes sindicales y funcionarios, participaron de la audiencia un amplio grupo de trabajadores desocupados y cooperativizados, organizados detrás de la agrupación Obreros Autoconvocados de la Industria del Pescado. Según la crónica de La Capital, la organización aparecía portando "los reclamos de uno de los sectores, a la vista el más marginado de todos"1161.

A partir de este acontecimiento podemos comenzar a esbozar el proceso mediante el cual la ciudad de Mar del Plata se organiza como corporación económica. Los contenidos que marcarán esa alianza social en torno a la defensa de los intereses del "pueblo marplatense" estarán dominados por la crítica a la política pesquera nacional y en particular a la operatoria de los buques congeladores y procesadores. Esa posición comenzaba a excluir al grupo de empresarios pesqueros marplatenses que operaban con ambos tipos de flota. En la prensa local se pueden encontrar a partir del año 1997 múltiples críticas a los buques congeladores. Por ejemplo, el titular del HCD local, Oscar Pagni, con motivo de convocar a la audiencia pública expresó que:

Las erráticas y absurdas políticas oficiales respecto al tema pesca, están destruyendo la industria pesquera marplatense [...] Mientras que la pesca argentina obtiene récords de capturas y exportaciones Mar del Plata tiene niveles de desocupación tremendos, y esto sucede por el desmesurado incremento de la actividad de barcos poteros, congeladores y factorías que procesan todo

${ }^{1160}$ Audiencia pública, 14/07/1997... op. cit. p. 19.

${ }^{1161}$ L.C., 15/02/1997. Analizamos sus características en un próximo apartado. 
en alta mar, arrastrando a la desesperación y el cierre a las industrias en tierra y a cientos de trabajadores marplatenses a la calle. ${ }^{1162}$

También el diputado provincial por el Frepaso, Carlos Nivio, aseguraba que la crisis del sector pesquero se debía a la "errática política nacional" y a la pérdida de participación "de los capitales marplatenses". Esto se produjo por "la intensa actividad de barcos congeladores y factorías que han transformado a nuestras plantas en meras cámaras de mantenimiento con la consecuente pérdida de fuentes de trabajo". Calificaba de "contradictoria" la situación del sector pesquero, ya que si bien se obtuvo "récord de capturas", la desocupación "es la más alta" de todas las áreas productivas de la ciudad. ${ }^{1163}$ Una postura similar sostenía el Ateneo Regional de Capacitación y Estudios Sociales. ${ }^{1164}$

De este modo, los fresqueros marplatenses impulsaban su ofensiva buscando agrupar a casi toda la ciudad. En cuanto a los gremios pesqueros, la muerte de Abdul Saravia dejó al SOIP sin su máximo líder y un gran vacío en la representación de los trabajadores. A su vez, Carlos Barboza, del SICONARA, por este tiempo se retiró de la vida gremial. En ese contexto, asumió un lugar cada vez más trascendente Domingo Novero del SOMU. Éste decía en relación a la sobrepesca:

....si no cuidamos el recurso, en cuatro o cinco años nos quedamos sin pescado [...] La merluza ya es difícil de encontrarla y viene cada vez más chica y todos saben que si es muy pequeña, se la tira al mar [...] Esto hace que las campañas de los barcos sean cada vez más largas porque para llenar las bodegas se necesitan mayor número de lances de red.

Por esto consideraba que de aplicarse medidas restrictivas de pesca se debía discriminar entre flotas: "A nuestro criterio, los factorías tendrían que quedarse en puerto dos meses y los fresqueros solamente un mes, porque mucha gente trabaja en tierra con el pescado que traen". ${ }^{1165}$ También por aquellos días formalizaba su aparición la ONG denominada Centro en Defensa del Puerto y de la Pesca Nacional (CEDESCA) cuyo titular era Ernesto Godelman. La entidad realizaba diferentes aportes al estudio de la realidad pesquera argentina, al mismo tiempo que tomaba posición y señalaba posibles cursos de acción. El diagnóstico tras el cual se presentaba sostenía:

...en los últimos diez años las políticas pesqueras han modificado totalmente la situación económica, social y laboral del sector, y desde entonces la introducción indiscriminada de buques congeladores y factoría en las pesquerías argentinas, benefició el crecimiento de algunas especies comerciales hasta el momento inexplotadas en la zona patagónica, pero distorsionó toda la estructura socio-económica montada principalmente alrededor de la extracción y procesamiento de la merluza hubbsi [...] La agonía en la que ha entrado el sector de la economía vinculado al pescado fresco se traduce en políticas empresarias de supervivencia, con bajísimo nivel de inversiones [...] Esta disminución del trabajo y de los ingresos, repercute en toda la economía portuense y marplatense, ya que al haber menos circulante, todo el circuito económico se resiente.

\footnotetext{
1162 L.C.,08/02/1997.

1163 L.C., 16/02/1997.

1164 L.C., 21/02/1997.

1165 L.C., 17/04/1997.
} 
La organización también planteaba una fuerte crítica a la política pesquera nacional. Decía: "Nosotros no estamos de acuerdo con la depredación del recurso, y sabemos que hay poderosos intereses que se han beneficiado con el otorgamiento de permisos indiscriminados, y que estos intereses tienen personeros con nombre y apellido, llámense Carlos Corach, Felipe Solá o Fernando Gutiérrez". Al momento de anunciar la necesidad de medidas restrictivas de la pesca planteaban como objetivo:

...consensuar con los sectores interesados y aplicar en forma urgente medidas para disminuir el esfuerzo de pesca de los buques congeladores y factoría, prohibir la presencia de personal a bordo de buques de bandera nacional que no cuenten con residencia permanente en la República Argentina y convocar a reuniones tripartitas (Estado, obreros y empresarios), para elaborar un plan progresivo de recomposición de la estabilidad laboral que acompañe el proceso de recomposición económica del sector. ${ }^{1166}$

De este modo, se agrupaba la ciudad de Mar del Plata, integrando a empresarios pesqueros "fresqueros", gremios, gobierno comunal y organizaciones no gubernamentales. Sólo un pequeño grupo de empresarios locales quedaba fuera de este entendimiento.

\section{El surgimiento del Consejo de Empresarios Pesqueros Argentinos (CEPA)}

Hemos visto como, por fuera de la CAABPA, UDIPA surgía como organización empresaria que sostenía la defensa del sistema fresquero y la elaboración de pescado en las plantas en tierra. Pero este no es el único movimiento del empresariado pesquero durante la crisis. En este punto debemos resaltar que estamos ante los aspectos que la polaridad "fresqueros vs. congeladores" oculta mucho más de lo que aclara. Pues alejados de esa dualidad los "grandes" de la pesca marplatense, dentro de cuyo calificativo se encontraban los grupos empresarios Moscuzza, Solimeno y Giorno (Valastro), se alejaron de la conducción de la CAABPA (sin abandonar la entidad) y conformaron en 1996 el Consejo de Empresarios Pesqueros Argentinos (CEPA). No se trataba de una nueva cámara pesquera, sino más bien de una institución que buscaba dar a conocer el posicionamiento respecto al futuro de la pesca de las empresas que lo integraban, aportando investigaciones acerca de la realidad pesquera y promoviendo determinadas líneas de acción. Se trataba de demostrar "quiénes somos, qué somos, qué queremos hacer"1167. Las empresas que integraban el CEPA a través del acuerdo con la CEE incorporaron buques congeladores a su flota. Ya en 1995, una nota de la revista Redes destacaba como el dato más significativo de la performance de ese año del puerto de Mar del Plata el rol creciente de los buques congeladores en los desembarques. Habían pasado de un total de desembarques de 6.403 toneladas en 1987 a 86.273 en 1995. ${ }^{1168}$ Es decir, de representar un 2\% de los desembarques treparon hasta un 20\%. Así, mientras UDIPA surgió criticando la operatoria de buques congeladores, diferentes grupos empresarios marplatenses decidieron hacerse con ese tipo de buques. ${ }^{1169}$ Paralelamente, hemos visto ya, crecía por

1166 L.C.,22/06/1997.

${ }^{1167}$ Entrevista del autor con Oscar Fortunato... op. cit.

${ }^{1168}$ Revista Redes, № 88, año 1996, p. 45.

1169 Oscar Fortunato aclara la perspectiva de estos industriales pesqueros: “El modelo del '90 ¿cuál es? Gente que nunca había entrado... porque en el sur había barcos congeladores, en el sur era casi todo congeladores. Mar del Plata no. Pero la vidriera es 
aquellos años la conciencia acerca de la necesidad de comenzar a proteger los recursos pesqueros. Y si UDIPA por su lado disparaba contra los congeladores, por el contrario, Antonio Solimeno cuando aún era presidente de la CAABPA, mencionando la necesidad de preservar los recursos, destacaba como uno de los problemas a atacar la captura concretada por barcos sin permiso de pesca. ${ }^{1170}$ Es decir, apuntaba contra varios de los representados por UDIPA. De ahí en más, la situación al interior de la CAABPA no hizo sino comenzar a dividir las aguas entre las empresas Integradas y las que se mantenían en base al sistema fresquero. Y con más convidados que menú disponible, la situación estalló en el marco de la crisis de la merluza, en el momento de discutir la definición de la ley de pesca, particularmente en cuanto al criterio para acceder a los recursos del mar. Según la Revista Redes:

...ante la perspectiva de un mecanismo que puede decidir la suerte de muchos, no sorprende que cada uno intente perder lo menos posible en el reparto, y un primer escenario de esa pulseada han sido las cámaras que nuclean al sector. En Mar del Plata, por ejemplo, hizo eclosión el larvado conflicto entre los armadores que aprovecharon la oportunidad del acuerdo con la Unión Europea para incorporar buques congeladores, y aquellos con un perfil empresario en el que prevalece el manejo de pescado fresco y su procesamiento en tierra. ${ }^{1171}$

Dentro de la CAABPA, los fresqueros lograron prevalecer en el pronunciamiento institucional realizando una ofensiva contra los congeladores, profundizando así las grietas que separaban a los empresarios pesqueros marplatenses. En este marco, en febrero de 1998 el diario La Capital publicaba una nota sobre el surgimiento del CEPA. La entidad "nuclea a hombres fuertes del sector que no sólo apuntan a su interés en lo comercial, sino que a partir de este emprendimiento incorpora su inquietud por saber cuál es el marco natural en que realizan la explotación". Los integrantes son responsables de firmas como "Pedro Moscuzza e hijos S.A.", "Giorno S.A:", "Luis Solimeno e hijos S.A.” y "Santa Elena S.A.”. Son empresas integradas que se dedican a capturar, procesar y comercializar el producto. Oscar Fortunato presidía la comisión directiva, integrada también por Antonio Solimeno. Ellos afirmaban la necesidad de adecuarse a las nuevas realidades del caladero, el cual debería pasar de una pesca expansiva a una regresiva. Fortunato señaló que "vemos en la pesca un panorama muy dificil y serio, estamos en un momento de crisis y cambio, de transformaciones, y para ello tenemos que estar preparados y advertidos al respecto" $" 1172$. Ante la crisis de la actividad pesquera, eran estos últimos los que se encontraban mejor posicionados por su tamaño, integración y capacidad, para reconvertirse hacia otras actividades. ${ }^{1173}$

\footnotetext{
Mar del Plata. En el sur no lo ve nadie porque no va nadie al sur. En el sur pasaban un montón de cosas que Mar del Plata creía que no pasaban. Pero pasaban. Estaban. Había un modelo distinto. Que después le fue mal por otras causas, ese es otro problema. Pero la realidad es que el lugar de la cultura de la actividad que está acá no vio rápido el cambio que venía. Cuando lo vio dijo no. Apareció un proyecto que era de acuerdo con la Comunidad que barcos de un valor importante se podían conseguir y muy bien financiados y a muy buenos precios para traerlos... se trajeron los barcos y son la flota que tenemos ahora". Entrevista del autor con Oscar Fortunato... op. cit.

${ }_{1170}$ Revista Redes, N 93 , año 1996, p. 6.

${ }^{1171}$ Revista Redes, № 98, año 1997, "Cuotas. El debate que viene", p. 6.

1172 L.C.,22/02/1998.

${ }^{1173}$ Con la certeza de un eventual reparto de recursos que no alcanzaría para todos continuaron los conflictos y realineamientos empresarios. Cambios de conducción (como en el caso de la CAABPA) o surgimientos de nuevas cámaras u organizaciones similares (UDIPA, CEPA) se multiplicaban. Por ejemplo, Pedro Silveira (ALPESCA) dejó la titularidad de la CAPIP y asumió en la CAABPA tras el desplazamiento de Solimeno y Moscuzza. También se creó con sede en Comodoro Rivadavia la Cámara de Empresas Procesadoras y Pesqueras Fresqueras del Golfo San Jorge (CA.E.P.P.FRE).
} 


\section{Enfrentamientos durante la crisis pesquera}

“...la Naturaleza es inexorable y las señales que manda con cada lance de merluza no parecen ser ambiguas. Efectivamente, la torta no parece alcanzar para todos y es comprensible que, aún con los argumentos más disparatados, cada uno trate de defender lo suyo"

Revista Redes, № 97, 1997

En abril de 1998 la Subsecretaría de Pesca estudiaba la implementación de algún criterio para reducir las capturas de merluza. Ante tal situación, los empresarios "fresqueros" locales se reunieron con el intendente Elio Aprile. Alberto Castro Aran, de la Cámara de Procesadores, expresó su preocupación por la eventual reducción: "suponemos vamos a entrar en un proceso de ajuste, además de mencionar los perjuicios que esto puede traer para la ciudad tanto en la producción como en los niveles de ocupación". Y continuó:

...ahora estamos en un $60 \%$ del nivel histórico de producción y la política de ajuste va a depender de la política que se implemente desde el gobierno nacional. Si orienta la política hacia una extracción y elaboración a bordo exclusivamente creemos que ninguna empresa va a poder pasar estos años de ajuste [...] las empresas pueden seguir esforzándose como para que la ciudad no sienta este nivel de ajuste, pero si la política es netamente extractiva y de procesado a bordo, la ciudad seguramente tendrá que seguir sufriendo las consecuencias de esta política nacional. Todo eso se lo planteamos al intendente para aunar esfuerzos y lograr con su apoyo que se cumpla la Ley Federal de Pesca que en su artículo primero indica que no se desvirtúe en la práctica la política general pesquera del país. ${ }^{1174}$

El empresario Castro Arán reconocía la inevitable disminución de la actividad, pero indicaba que las empresas marplatenses podrían hacerle frente siempre y cuando la política pesquera nacional cambiara de rumbo. Esta no era, sin embargo, la posición del CEPA. La entidad señalaba como variables de la crisis pesquera: el bajo stock del recurso merluza común y la sobreinversión en flota en relación a los recursos existentes, los altos costos internos de insumos y servicios, la política fiscal y tributaria, los aranceles que gravan inversiones de capital que generan mano de obra y la escasez de crédito y el alto valor de los intereses bancarios. Para solucionar estos problemas proponía:

...fijar una política de promoción a la producción y a las exportaciones pesqueras que atienda al reintegro de los impuestos generados por los productos de exportación, eliminación de impuestos distorsivos, que además involucre una reducción en el valor de las tasas que se pagan por servicios aún en manos de los estados nacional, municipal y provincial, y también debe contener una acción clara y concreta de reducción de aranceles para la importación de máquinas y equipos fundamentales para la necesaria reconversión de las empresas pesqueras. Como culminación de esta política se deberían establecer tasas preferenciales de crédito. ${ }^{175}$

\footnotetext{
1174 L.C., 19/04/1998.

${ }^{1175}$ Informe del CEPA, 29/11/1999, Archivo INIDEP.
} 
A su vez, con el objetivo de:

...provocar una administración clara, sana y responsable del caladero argentino, exigimos la inmediata aplicación de la Ley Federal de Pesca en todos sus aspectos, tanto laborales como en la asignación de cuotas individuales transferibles de captura, así como también en lo relativo a la pesca responsable y conservación del caladero sin discriminaciones.

Además, criticaban que aquellas empresas que "hoy reclaman ampliamente desde lo social" haciendo clara referencia a los sectores "fresqueros", no tuvieron ningún cuidado en abandonar fábricas y presionar sobre los recursos en zonas biológicamente comprometidas para obtener mayores utilidades. Y agregaban:

Estamos convencidos de que la actual crisis pesquera -originada en una crisis de recurso y por una situación de política internacional, financiera e impositiva- deben salir fortalecidas todas las empresas pesqueras integradas por ser éstas la verdadera columna vertebral de la Industria Pesquera Argentina. Cuando decimos empresas integradas nos referimos a empresas que capturan con barcos fresqueros y congeladores, además de procesar en sus plantas en tierra. ${ }^{1176}$

Así, tanto el CEPA como la CAABPA apoyaban discursivamente el texto de la Ley Federal de Pesca, pero cada entidad le asignaba su propio significado. Para la CAABPA había que priorizar el espíritu del capítulo I de la Ley, el cual señalaba:

La Nación Argentina fomentará el ejercicio de la pesca marítima en procura del máximo desarrollo compatible con el aprovechamiento racional de los recursos vivos marinos. Promoverá la protección efectiva de los intereses nacionales relacionados con la pesca y promocionará la sustentabilidad de la actividad pesquera, fomentando la conservación a largo plazo de los recursos, favoreciendo el desarrollo de procesos industriales ambientalmente apropiados que promuevan la obtención del máximo valor agregado y el mayor empleo de mano de obra argentina. ${ }^{1177}$

Por supuesto que la CAABPA consideraba que el sistema que mejor respetaba este "espíritu" era el de la pesca con fresqueros y el procesado en tierra. Por el contrario, el CEPA ponía el énfasis en los artículos del primer texto de la ley que se vinculaban a la implementación de las Cuotas Individuales Transferibles, al mismo tiempo que consideraban la integración como el sistema productivo más eficiente en términos económicos. La CAABPA y la Cámara de Procesadores no tardaron en responder a las acusaciones que les habían dirigido los integrantes del CEPA.

Son sorprendentes las declaraciones de los integrantes del CEPA, cuando señalan que ellos vieron hace mucho tiempo que la pesca cambiaba, y que por ello comenzaron a traer barcos congeladores y factorías. En primer lugar, digamos que apostaron a un cambio a contramano de las

\footnotetext{
${ }^{1176}$ L.C.,6/02/1999. La negrita es de la fuente.

${ }^{1177}$ Ley $N^{\circ} 24.922$, año 1997, artículo I.
} 
tendencias mundiales, ya que todos los países dan prioridad a los barcos fresqueros que proveen a plantas en tierra para que exploten recursos de su Zona Económica Exclusiva. ${ }^{1178}$

Este cambio:

...se generó a través del acuerdo con la Unión Europea, el cual fue incumplido en forma flagrante por este grupo de empresas, ya que en el lugar de reemplazar barcos y no aumentar el esfuerzo de pesca sobre la especie merluza, hicieron triangulaciones y violaciones a la letra y el espíritu del acuerdo que les permitieron traer los barcos congeladores, cobrar los subsidios comunitarios y no desafectar ningún barco de la flota. ${ }^{1179}$

Apuntaban que "Asi fue como solamente cuatro grupos empresarios del CEPA aumentaron en casi 75.000 toneladas sus capturas de 1997 con respecto a las de 1991" "1180.

De este modo, cada bloque se apoyaba en el contenido de la ley de pesca pero interpretándola a su modo y según las conveniencias del caso. Por su parte Daniel Badens, presidente de CAPeCA, decía respecto a la depredación de la merluza que "no es uno u otro buque el que depreda" ni tampoco son culpables los barcos extranjeros, sino que se debe a una pesca irresponsable, al mismo tiempo que señalaba la posición de la cámara bajo su representación, postulando que no se debía denunciar el acuerdo con la CEE, sino renovarlo bajo nuevas condiciones. Con relación al conflicto de la cuotificación expresaba:

Se hacen mal las comparaciones. Se compara un fresquero con la planta en tierra, y se olvida que el congelador tiene marineros pescando y una planta en el buque procesando. Habría que sacar bien los números de cuánto es la industria en tierra y a bordo, como también la rentabilidad que arrojan. Mal vale comparar social o laboralmente tener en tierra una cantidad inmensa de trabajadores en tierra mal pagados, en negro o contratados en cooperativas, contra la comparación de un congelador, donde posiblemente haya menos gente en planta, pero rentables, estables, que paga sus sueldos y su seguridad social. ${ }^{1181}$

Así la CAPECA enrostraba a la CAABPA la situación laboral en que mantenía a buena parte de su fuerza de trabajo. Lo cierto es que durante todo el proceso de protesta se mantuvo constante el conflicto al interior de la burguesía pesquera. La división fue fundamental en las características que asumió el ciclo de conflictividad desarrollado en el puerto de Mar del Plata, favoreciendo distintas alianzas sociales. En este proceso debemos tener en cuenta que los más preparados para enfrentar una reconversión industrial y afrontar una pesca restrictiva dentro del empresariado marplatense eran los grupos integrados. Cuanto menos esto era así de no modificarse radicalmente la política pesquera. Pero, el grupo fresquero, peor posicionado a priori, adquirió mayor capacidad de presión política integrando una alianza con la participación de los gremios de la pesca, la intendencia municipal y la gobernación de la provincia de Buenos Aires. En este sentido, se conformó desde mediados de 1997 una "alianza marplatense" en la que estaban integrados los empresarios fresqueros junto con los gremios de la ciudad y que contaba con el

${ }^{1178}$ L.C., 07/02/1999.

1179 L.C.,07/02/1999.

${ }^{1180}$ L.C.,07/02/1999.

${ }^{1181}$ L.C., $19 / 09 / 1998$. 
apoyo del intendente Elio Aprile. Con el tiempo tomará la forma institucional de una Multisectorial de la Pesca Marplatense. Pero antes de adentrarnos en la constitución de esa alianza social, veamos qué sucedía en el otro extremo de la relación capital trabajo, puesto que allí también la crisis generaba movimientos. Será en estos años cuando asistamos a la emergencia definitiva de los trabajadores de las cooperativas como sujetos de la protesta, quienes en el período que va de 1997 a 2000 tendrán el mayor protagonismo en el desarrollo de la protesta social en el puerto marplatense.

\section{Trabajadores cooperativizados y desocupados en el escenario de la protesta}

Hemos visto a lo largo del capítulo I cómo se produjo el declive relativo del puerto de Mar del Plata a nivel nacional perdiendo lugares como exportador de productos pesqueros frente a los puertos patagónicos. En particular, si bien algunos grupos empresarios locales pasaron a trabajar con una combinación de flota fresquera y congeladora, el arribo de estos últimos buques se vinculó mayormente con el litoral patagónico argentino. En la medida en que el crecimiento y la expansión pesquera se asociaron principalmente con el arribo de aquellos barcos procesadores, mientras que fresqueros mantuvieron sus capturas consideradas históricas, la expansión no redundó en una mayor oferta de trabajo para los obreros de las plantas en tierra. Asimismo, y luego de las quiebras de varias plantas, buena parte de la fuerza de trabajo comenzó a desarrollar su actividad bajo el sistema de pseudo cooperativas. Mientras la expansión pesquera seguía su curso, estos factores, si bien generaron procesos de protesta social y denuncias, no ocuparon un lugar central en la conflictividad, que de hecho mermó entre los años 1992 y 1996. Pero, al iniciarse la crisis pesquera, con la consecuencia de una disminución drástica del ingreso de pescado a las plantas, la rebaja de las horas de trabajo por semana -cuando no directamente la desocupación-, aparecieron como el reverso amargo de la expansión pesquera. En este contexto, emergieron cada vez con mayor importancia los trabajadores de las cooperativas y los desocupados en el escenario de la protesta social. Si entre 1989 y 1991 el proceso estuvo dominado por la toma de establecimientos ante los cierres de plantas pesqueras; entre 1992 y 1996 los niveles de conflictividad descendieron mientras se multiplican las cooperativas; será fundamentalmente a partir del mes de julio de 1997 cuando el personal cooperativizado y desocupado ocupe las calles del puerto marplatense y se convierta en el principal protagonista de la lucha social, al menos en cuanto a su presencia en la cantidad de hechos de acción directa. En este contexto se volvió más notoria la institucionalización de agrupamientos que expresaban las demandas de estos obreros y obreras.

En agosto de 1996 y tras realizar una movilización, mencionamos en el apartado anterior la aparición pública de una organización de trabajadores de las cooperativas denominada Obreros Autoconvocados de la Industria del Pescado. Su principal referente era Carlos Rosales, quien el 29 de agosto del mismo año ocupaba la banca abierta del HCD y desde allí narraba la apremiante situación de los trabajadores de las cooperativas, al mismo tiempo que proponía líneas de acción para revertirla. ${ }^{182}$ Rosales señalaba "Mar del Plata necesita que el 50\% de la pesca entre a la ciudad, que ese 50\% se elabore aqui y salga con mano de obra y valor agregado argentinos y que se retiren el 50\% de los buques". Y, por supuesto, que el pescado se elabore en las plantas en tierra. Además, se quejaba del rol de la Comuna y del HCD en relación a la escasa importancia que se le daba al tema de la pesca.

\footnotetext{
${ }^{1182}$ Audiencia Pública, 29/08/1996, Honorable Concejo Deliberante de la ciudad de Mar del Plata.
} 
Nosotros no tiramos bombas ni prendemos fuego nada; solamente queremos que nos devuelvan la industria porque trabajar es lo que sabemos hacer. Nosotros no queremos la indignidad de que nos den una bolsa de comida, no le pedimos a nadie una bolsa de comida; queremos que los representantes del pueblo, en los que depositamos nuestra confianza, nos devuelvan el trabajo.

Sobre la situación de los trabajadores y la creciente desocupación decía:

Nosotros estamos destruidos económica y moralmente [...] estamos desesperados, nos están quitando la esperanza y las ganas de vivir [...] Quisiera que alguno de ustedes, como cuando van a buscar los votos, recorran el Puerto y verán que en una fábrica que llama a las cinco de la mañana pidiendo dos fileteros, hay una cola de sesenta o setenta compañeros discutiendo por una mesa, por un puesto de trabajo.

Definiendo una posición respecto a la prioridad del trabajo en plantas en tierra, Rosales solicitó que en caso de que se tenga que implementar algún tipo de veda, ésta se le aplique a los buques extranjeros o a los barcos que participan del charteo. Por otra parte, en cuanto a su posición dentro del gremio, explicó que "No tenemos representatividad gremial porque desde 1990 que nos obligaron a cooperativizarnos en un contubernio de los empresarios, parte del gobierno y el sindicato" ${ }^{1183}$.En febrero de 1997 cuando el HCD se reunió en una nueva audiencia para tratar la situación de la pesca marplatense y posicionarse frente a la discusión de la futura ley de pesca, los trabajadores de las cooperativas asistieron ocupando "la barra". En esa ocasión, Rosales nuevamente hizo uso de la palabra. Al presentar la situación de los obreros y obreras del pescado expresó:

...nosotros somos parias ya que no tenemos sindicato que nos represente. Nosotros somos personal cooperativizado, a nosotros nos cooperativizaron y nos entró la flexibilización laboral allá por los años `90, cuando entra todo este sistema de cooperativización a Mar del Plata, donde antes a los empresarios -según algunos números- le costaba cincuenta centavos el kilo de filet -producto terminado- y hoy le cuesta veintiséis centavos gracias a la flexibilidad porque ahora somos socios en las pérdidas [...] Del año '80 al '89 trabajábamos 50 horas semanales; ahora estamos trabajando $12 \mathrm{o}$ 15 horas semanales. Eso representa un 50\% menos de ingresos que tenemos porque nosotros somos trabajadores a destajo, no tenemos sueldo fijo. Antes teníamos garantía horaria, ahora con el sistema de cooperativización no tenemos obra social. No tenemos aguinaldo, no tenemos seguro, no tenemos vacaciones, no tenemos nada. ${ }^{184}$

Veían en la reactivación del puerto de Mar del Plata una posible solución. Decía Rosales "Nosotros consideramos que para que Mar del Plata vuelva a tener pleno empleo debe entrar el 50\% de la pesca a Mar del Plata, se debe elaborar en tierra, con valor agregado, como decían los empresarios para que ellos también tengan lo suyo" "1185. El 9 de julio de 1997 tuvo lugar un corte de calle en el puerto marplatense, con instalación de una olla popular, medida en la que participaron, según los periódicos, más de 100 obreros. Según el diario El Atlántico los trabajadores señalaron "Nos estamos muriendo de

1183 Audiencia Pública, 29/08/1996... op. cit.

${ }^{1184}$ Audiencia Pública, 14/07/1997... op. cit.

${ }^{1185}$ Audiencia pública, 14/07/1997... op. cit. p. 21. 
hambre, queremos trabajar" ${ }^{1186}$. Entre los organizadores aparecían los Obreros Autoconvocados de la Industria del Pescado. También en esa ocasión la Unión Obrera del Pescado, con posiciones disímiles respecto de los Autoconvocados, participaron del corte de calle. El propio diario La Capital señalaba:

Debido a las diferencias planteadas entre los manifestantes la asamblea de ayer no produjo ningún comunicado, esto se debió a que algunos de los presentes estaban de acuerdo en exigir un subsidio de $\$ 500$ hasta que se normalice la situación laboral y otros no. En un momento de la asamblea, los grupos antagónicos amenazaron con dirimir la diferencia a golpes. ${ }^{1187}$

Los denominados Autoconvocados, que lideraban trabajadores de tradición política peronista, definieron un programa básico en torno al pedido de reactivación del puerto local, la definición de una política pesquera nacional y la intervención de las autoridades municipales. La responsabilidad de la sobrepesca recaía, al igual que la postura de los "fresqueros", sobre los "congeladores". En este sentido, Patricia Más, representante del grupo, expresaba:

...hoy por hoy un barco congelador con 50 personas a bordo, les está robando el trabajo a mil obreros entre empleos directos e indirectos en tierra. Por cada barco, nos quitan mil puestos de trabajo. Tenemos 150 congeladores en aguas jurisdiccionales, por lo que nos están quitando en tierra más de 50 mil puestos de trabajo a los argentinos, en todas las provincias costeras [...] los congeladores son los grandes culpables de la enorme depredación del recurso vivo, especialmente la merluza. ${ }^{1188}$

A su vez, dejaba en claro las prioridades cuando afirmaba "primero debemos pelear por el pescado en puerto y después comenzaremos a hablar de cómo estamos trabajando" y "hay que salvar la industria y el procesado en tierra". Esta jerarquía de los reclamos los desvinculaba de los planteos de la UOP que asumían una postura, en principio, de mayor radicalidad respecto a la denuncia de las condiciones de trabajo, en particular las imperantes en las cooperativas. Al respecto, Más y su grupo sostuvieron "Nosotros no somos piqueteros, somos fileteros. Existe una gran diferencia en quienes salen a hacer un piquete y quienes nos reunimos para un reclamo justo como el derecho a trabajar [...] el objetivo es la reactivación del puerto. No queremos subsidios, queremos trabajo" ${ }^{1189}$. Así se distanciaban del pedido de subsidio por una parte, y por otra, de la identificación con el movimiento piquetero, asimilación que el grupo liderado por la UOP alzaría como estandarte de lucha. Los Obreros Autoconvocados fijaron como prioridad la entrada al puerto de materia prima, la elaboración y procesamiento del pescado en tierra y la revisión de los permisos pesqueros de los últimos años. Hasta aquí, sus consignas eran perfectamente compatibles con las demandas de los empresarios fresqueros.

Por su parte, la UOP era la agrupación que se presentaba a elecciones mediante la Lista Celeste, tradicionalmente vinculada al Partido Comunista, pero que para estas alturas ya se encontraba hegemonizada por la línea definida por el Partido Obrero. Recibían con desahucio las reformas anunciadas por Felipe Sola:

\footnotetext{
${ }^{1186}$ E.A., 10/07/1997.

${ }^{1187}$ L.C., 10/07/1997.

${ }^{1188}$ E.A., 12/07/1997. El resaltado es del autor.

${ }^{1189}$ L.C., 15/07/1997.
} 
Vamos a pasar más miseria todavía, hace más de cinco años que la gente del puerto decía que nos íbamos a quedar sin pescado, el propio Felipe Solá decía el año pasado que no había sobrepesca. Pero los informes del INIDEP decían otra cosa, ¿cómo él no lo sabía?, ¿por qué no cuidó a tiempo el recurso? [...] estas medidas signifiquen menos cajones al año descargados en Mar del Plata para su procesado. Hay unas 200 cooperativas en la ciudad y para que haya trabajo cada una absorbe no menos de 400 cajones por día. Si falta pescado, la mano de obra se verá totalmente perjudicada, así como la economía general de Mar del Plata. ${ }^{1190}$

En su programa alentaba un ideario de corte más "clasista" apuntando, en primer lugar, hacia las condiciones de trabajo:

Ante la evidente falta de respuesta a nuestros justos reclamos, los obreros del pescado hemos decidido ser nuestros propios representantes y unir nuestra voz en el siguiente petitorio: 1) Por el derecho al trabajo con pleno empleo; pago de la garantía horaria; el bono alimentario, los salarios familiares; vigencia del convenio colectivo de 1975; 2) El gobierno, responsable de la desocupación y el subempleo, debe otorgar un subsidio para el compañero parado; 3) Por la defensa de la riqueza ictícola; por la reactivación del trabajo en la industria pesquera en tierra... ${ }^{1191}$

De esta manera, entre los trabajadores de las cooperativas y desocupados la división en cuanto a los caminos a recorrer se expresaba en torno a dos consignas inmediatas. La primera remitía al subsidio que, ante la imposibilidad de trabajar, pedía la UOP, mientras que el sector liderado por Rosales y Más exigían únicamente trabajo. Por otra parte, los primeros demandan la regulación de la situación salarial, mientras que los segundos la aplazaban en pos de la reactivación del puerto. Estos últimos culpaban de la crisis a los grupos más concentrados, posibilitando de hecho una alianza con el bloque fresquero. Por el contrario, los primeros apuntaban a las cooperativas consideradas "truchas", de las cuales se servían ambos bloques empresariales. Uno y otro grupo cuestionaban a la dirigencia del SOIP, pero los segundos lo hacían más enconadamente. Se constituyó así una división que superficialmente puede ser presentada entre "duros" y "blandos", pero que encarnaba diferentes apreciaciones tanto de las relaciones de fuerza existentes, como diferentes tradiciones de lucha. ${ }^{1192}$

En el mes de julio del año 1997 ambos sectores mantendrán cortes de calle, pero cada uno en un lugar distinto. Los Autoconvocados en Edison y 12 de Octubre. La UOP a escasos cien metros, en Magallanes y Edison. Al respecto el diario El Atlántico publicó una nota destacando precisamente las diferencias existentes entre ambos grupos. Los "blandos" plantean "no atacar a las empresas que están bajando el pescado a tierra y consensuar con políticos y empresarios para lograr la deseada reactivación, y no encarar la lucha sobre la ciudad sino que el objetivo es apuntar al Gobierno de la Nación como 'único responsable de esta situación"”. Según el cronista estos últimos "No son partidarios de subsidios ni de ayuda social, sino de 'puestos de trabajo dignos y estables para que el obrero no tenga

${ }^{1190}$ L.C., $24 / 07 / 1997$.

${ }^{1191}$ L.C., 14/07/1997.

${ }^{1192}$ La prensa local definió a los dos sectores a partir de la clasificación entre "duros" y "blandos", la misma fórmula con que también se refería por aquella época a las distintas corrientes dentro del movimiento piquetero. En este caso, los Autoconvocados eran, siempre desde la mirada periodística, los "blandos", mientras que la UOP representaba a los "duros". Desde nuestro punto de vista esta analítica solo es útil en la medida en que diferencia dos sectores con posiciones diferentes en el contexto de la crisis pesquera. Sin embargo, no apelamos a ella porque consideramos que en ningún modo resulta eficaz para caracterizar los contenidos de las demandas así como los formatos de las acciones de cada sector. 
necesidad de mendigar ni de seguir viviendo en la miseria". El mismo periódico señalaba que, a diferencia de los Autoconvocados, el otro sector ha "reclamado subsidios y alimentos para los desocupados, y llevan adelante la lucha apuntando a Menem, a las cooperativas 'truchas', y pegándole a los dirigentes gremiales del SOIP"1193. Con todo, mientras "la capital" de la pesca se organizaba como corporación económica contra el enemigo congelador incluso integrando a sectores de los desocupados y trabajadores de las cooperativas, las protestas de éstos irán creciendo de manera autónoma hasta alcanzar su pico máximo en el año 2000. Antes de estudiar qué sentido adquirieron esas protestas, sigamos el desarrollo de la conflictividad en el marco de la crisis pesquera.

\section{EI movimiento obrero organizado en los comienzos de la crisis}

\section{La CGT regional}

La crisis de la industria pesquera se produjo mientras la CGT regional estuvo liderada por el dirigente casinero Daniel Rodríguez, teniendo como secretario adjunto al camionero Héctor Martínez, quien respondía al MTA. Hemos mencionado ya algunas de las características que asumió la entidad respecto de la lucha contra la flexibilización laboral y la creciente oposición a lo que definía como un "modelo neoliberal". En cuanto a su relación con la situación de los trabajadores marítimos y portuarios, la central será una de las organizaciones que buscará articular la lucha de Mar del Plata como corporación económica tras la defensa del sistema fresquero y el procesado en tierra. En este sentido se ubicó el documento elaborado en conjunto con UDIPA en febrero de 1997. Por otra parte, desde el corte de calle del 9 de julio de 1997, la central obrera manifestó su solidaridad con los reclamos de los trabajadores cooperativizados. Elaboró un comunicado titulado "Los desocupados del puerto tienen razón" en el cual señalaba que el conflicto "es la consecuencia de decisiones políticas que nunca atendieron la urgente necesidad de cuidar el recurso ictícola ni de defender la falta de trabajo de la gente", al mismo tiempo que defendía la medida de acción argumentando que "No dudamos en pronunciarnos en apoyo al pedido del grupo de familias que, cansadas de promesas incumplidas y reuniones estériles, han tomado posición en esa esquina de tanta significación para nuestro puerto" ${ }^{1194}$. El documento apuntaba contra los acuerdos con la $\mathrm{CEE}$, las potencias pesqueras multinacionales y los grandes grupos económicos. Al mismo tiempo solicitaba a las autoridades la modificación de la política pesquera en favor de la industria nacional. También incluía otras reivindicaciones como la implementación del plan Barrios en el puerto, ayuda a los desocupados, el llamado a que el Instituto Provincial de Acción Cooperativa intervenga para inspeccionar el funcionamiento de las cooperativas. ${ }^{195}$ Además, anunciaba la creación de una comisión de seguimiento del proceso de cambios en la política pesquera integrada por funcionarios municipales y la CGT. Y pedían la sanción de una ley que contemple la utilización de mano de obra argentina. Por último denunciaban a los congeladores por sobreexplotar el recurso. Dentro de la CGT Domingo Novero, líder

\footnotetext{
${ }^{1193}$ E.A., s-d/07/1997.

${ }^{1194}$ L.C., 13/07/1997.

${ }^{1195}$ Días después, y apuntando a erradicar el fraude laboral en el puerto, comenzará a tener vigencia un Plan elaborado en forma conjunta por el IPAC, la Dirección Municipal de Acción Cooperativa y la CGT. Vilanova, titular de IPAC, señalaba que "con la misma firmeza con la que alentamos y reivindicamos las verdaderas expresiones cooperativas, estamos dispuestos a desenmascarar a aquellas que, denominándose así, no respeten los principios cooperativos ni los derechos de los trabajadores". L.C.,20/07/1997.
} 
del SOMU local, se desempeñaba como secretario de Pesca e Intereses Marítimos y Portuarios. Él expresa bien la posición de la entidad obrera local a lo largo del conflicto “...defender a Mar del Plata a toda costa. Queremos que los recursos sean para los fresqueros que históricamente han trabajado y que el mayor cupo que se asigne a la pesca de merluza sea para los fresqueros marplatenses". ${ }^{1196}$

\section{Las posiciones del SOIP y el SOMU}

Sabemos que los dos principales gremios de la industria pesquera son el SOIP y el SOMU. Por eso debemos mostrar cuál fue su posición frente a la crisis pesquera. Mirado desde la cúpula, la conducción del SOMU fue la que más protagonizó medidas de protesta, contrastando tal accionar con la dirección del SOIP. Las acciones de los marineros se orientaron hacia la defensa del sistema fresquero y el ingreso de pescado al puerto marplatense pero introduciendo siempre reclamos tendientes a mejorar las condiciones salariales de los trabajadores. Las acciones discurrieron entre lo institucional y lo disruptivo. Con motivo de la oposición al primer texto de la Ley de Pesca, el SOMU estableció sus reivindicaciones principales: descarga de materia prima en puerto, $100 \%$ de mano de obra argentina, las cuotas no pueden ni deben ser trasferibles (oposición al artículo 29), repudio de los acuerdos con la CEE, participación de los gremios con voz y voto en el Consejo Federal Pesquero. Además, ante el creciente desempleo de marineros, el sindicato presionó para que los inspectores contratados por la SAGPyA fuesen marineros afiliados al SOMU. ${ }^{1197}$ Por su parte, la nueva realidad del caladero tomó al SOIP sin su máximo referente. Abdul Saravia falleció en febrero de 1997. Después de su deceso, pasó a liderar el gremio Carlos Darguibel, quien por muchos años secundó a Saravia y, sin embargo en su gestión, no pudo garantizar la unidad de criterio que si logró imponer el viejo líder. La posición del gremio estaba dominada por la defensa del sistema fresquero y el procesado en tierra: ${ }^{1198}$ “...dejó aclarado que mantendrá su objetivo, que es la lucha por la veda a los buques factoría y congeladores que tanto afectan al sector, haciendo prevalecer la mano de obra argentina en tierra, la ley de pesca que proteja a la riqueza ictícola nacional y en contra de las supuestas cooperativas que trabajan sin legislación" ${ }^{\prime 199}$. En este sentido, como veremos, la posición fue similar a la del SOMU. Sin embargo, su presencia en acciones de protesta, tanto institucionalizadas (paros) como desinstitucionalizadas (movilizaciones o escraches en domicilios de empresarios), fue mucho menor a las realizadas por el SOMU. Y cuando el SOMU peleaba por incrementos salariales, el SOIP se limitó a intentar defender los puestos de trabajo. Aún más, la conducción gremial mostró cierta impotencia ante la realidad de la crisis pesquera. El sindicato, ya menguado por la pérdida de relaciones políticas tras la implementación de las cooperativas, y sin la presencia de su máximo referente, mantuvo posiciones más bien "conservadoras" en tanto participación en la lucha social. De hecho, en varias oportunidades el gremio se diferenció abiertamente de las medidas

\footnotetext{
1196 L.C.,06/05/1998.

${ }^{1197}$ E.A., 26/11/1997. Novero expresaba con angustia “...con la pérdida de puestos de trabajo y de poder adquisitivo, con aumento de la productividad y reducción de nuestros derechos, hemos financiado la etapa de reestructuración pesquera que ahora está muriendo y tuvo como apogeo los acuerdos con la CEE. Gracias a estos acuerdos padecemos la depredación de buques congeladores y factoría y cientos de ex afiliados activos del SOMU trabajan hoy en lavaderos de estacionamientos de servicio o son peones de taxímetros".

1198 Esto no impidió que tiempo después se manifestara a favor de la creación de un corredor marítimo para que operen los congeladores, siempre y cuando procesaran parte del pescado capturado en las plantas en tierra.

${ }^{1199}$ L.C.,s/f.
} 
que disponía el SOMU, argumentando razones como el cobro del presentismo y el resguardo del personal de las plantas en tierra. A su vez, mientras se multiplicaban las protestas de los trabajadores cooperativizados y desocupados, la conducción gremial no dispuso de una política para contemplar las demandas de este sector. Precisamente será desde allí donde surgirán las principales críticas que más tarde produjeron el recambio de la conducción gremial. Si bien la denuncia de las cooperativas fraudulentas fue una constante, las acciones del gremio se mantuvieron dentro de los canales institucionales, primando el recurso de presentar cartas a distintos organismos del Estado, pero sin participar de acciones directas o protestas que tuvieran como finalidad la eliminación de dicha modalidad de trabajo. Este aspecto fue el más cuestionado por la oposición que surgió al interior del gremio y por los fileteros cooperativizados.

La reivindicación principal del SOIP en aquel contexto consistió en el ingreso a puerto y procesado en tierra de la materia prima, lo que permitía mantener las fuentes laborales. Darguibel aclaraba la postura del gremio en defensa del trabajo en las plantas en tierra. Decía "pedimos que cuando cuotifiquen las capturas por el Consejo Federal Pesquero y se reglamente la Ley Federal Pesquera, se respete la historia a nivel de procesamiento y no de captura":

...pretendemos que el nivel de reprocesado en tierra se mantenga. En Mar del Plata existen 8.000 familias directamente relacionadas con este movimiento y en forma indirecta son 25.000 los puestos de trabajo vinculados con la pesca. Una detención de la industria por falta de abastecimiento de materia prima, provocaría un fuerte revés en la economía de toda la ciudad y agravaría al máximo posible la actual situación del alto índice de desempleo [...] si las medidas que se tomen de aquí para adelante no son equilibradas y no priorizan las fuentes de trabajo de los argentinos, los puertos pesqueros especialmente el de Mar del Plata, enfrentarán una crisis social incontenible [...] La única forma de sostener el equilibrio laboral dentro de la industria pesquera marplatense, es permitiendo y asegurando que la flota de fresqueros mantenga sus niveles históricos de capturas. En caso de no poder ser así y para evitar problemas laborales masivos, el SOIP, solicita que las autoridades de aplicación en Pesca y el Consejo Federal Pesquero, dispongan que los buques congeladores y factorías descarguen más del $50 \%$ de sus capturas en tierra, tenemos el derecho soberano de exigir que el procesado se haga en tierra, en beneficio de los trabajadores argentinos. ${ }^{1200}$

La prioridad de la dirigencia era el procesado en tierra de la materia prima. Preferían la operatoria con buques fresqueros, pero en caso de que no se limitara la pesca de los congeladores, pretendían que el gobierno exigiera que el $50 \%$ de las capturas se descarguen en tierra. La prioridad era el trabajo en las plantas y no uno u otro sistema productivo. En cuanto al resto de los gremios, más allá de diferencias coyunturales, la posición fue coincidente por la manifestada por el SOMU y el SOIP. Junto a los sindicatos mencionados, otros sectores de la pesca y el gobierno comunal, tanto el SICONARA, como el SUPA coincidieron en un documento titulado "La Industria Pesquera de Mar del Plata y los recursos del mar argentino". Entre otras cuestiones se pedía "Aplicar estrictamente la Ley de Navegación para asegurar los cupos de personal argentino en el enrolamiento de tripulantes, sin excepciones"; "Prohibir la pesca de barcos congeladores o factorías en los golfos del litoral maritimo"; "Disponer la obligación de descargar en puerto". De este modo los sindicatos vinculados a la pesca marplatense se disponían a

\footnotetext{
${ }^{1200}$ E.A., 13/05/1998.
} 
enfrentar la crisis apoyando a los fresqueros y defendiendo el procesado en tierra. Faltaba un solo integrante para conformar toda una alianza social.

\section{El gobierno municipal}

El gobierno municipal fue otro de los actores del proceso. Hemos visto ya como desde el poder legislativo comunal se organizaron eventos con el objetivo de mancomunar posiciones por parte de la comunidad marplatense como la reunión de febrero de 1997. Con respecto al poder ejecutivo, luego de recibir fuertes críticas por su inacción respecto de la crisis pesquera, particularmente por rechazar la creación de una Subsecretaría de Pesca municipal, desde la comuna marplatense, gobernada por el Partido Radical, se desarrolló un programa de acción con relación a la crisis pesquera. Desde julio de 1997 el gobierno comunal se manifestó solidario con los desocupados, coincidiendo en la necesidad de que se reactive el puerto local. Uno de los funcionarios de mayor presencia en los hechos fue el secretario de producción Darío Sócrate. ${ }^{1201}$ Durante una reunión que sostuvo con los integrantes de Obreros Autoconvocados, señaló la posición del ejecutivo municipal:

...no sólo vamos a estar para acompañar, sino para participar y dar el mensaje oficial, y vamos a ir a apoyar este tipo de planteos, que tienen que ver básicamente desde nuestro lugar con dos cuestiones: la primera de ellas que es con la conservación del recurso y la segunda, tratar de defender todo lo que tenga que ver con los puestos de trabajo en tierra. ${ }^{1202}$

En noviembre de 1997, mes en que se trató la ley de pesca, Sócrate renovó el apoyo del Intendente a la defensa de la reactivación del puerto local.

Frente a la necesidad de la conservación del recurso marino y de la implementación del trabajo en tierra que pone a esta ley de pesca en uno de los temas más importantes para la ciudad, el intendente municipal ha manifestado su voluntad de acompañar a todos los sectores de Mar del Plata, que por primera vez en la historia, han señalado un discurso único en defensa del trabajo para los marplatenses y para los argentinos en general. ${ }^{1203}$

De este modo, la comuna marplatense expresaba no sólo su apoyo a las protestas de los pescadores, sino que también anunciaba la existencia de un discurso único en la ciudad, que sería resumido en el programa de la posteriormente conformada Multisectorial Pesquera. En este sentido el ejecutivo local se consolidó como un fuerte sostén de la alianza pesquera marplatense, participando al igual que los gremios y los empresarios fresqueros de la defensa de Mar del Plata en tanto corporación económica. Esta actitud

\footnotetext{
${ }^{1201}$ Durante una entrevista que le realizáramos a Darío Sócrate, el ex funcionario señaló que durante aquellos años ocupando la secretaría de Producción, el intendente Aprile le pidió que se dedique solamente al tema pesca. Entrevista del autor a Darío Sócrate, ex gerente de la CAABPA y ex Secretario de Producción de la Comuna (Mar del Plata, 03/07/2007).

${ }^{1202}$ L.C., 30/07/1997.

${ }^{1203}$ L.C., 13/11/1997.
} 
le será recriminada por los empresarios vinculados con el CEPA. Por otra parte, a pesar de recibir en más de una oportunidad y de dialogar con los trabajadores cooperativizados/desempleados, fueron escasas las medidas que pudieran aliviar la situación de aquellos. Sólo después de un amplio espectro de protestas desarrolladas por los obreros de la pesca se dispuso el reparto de bolsones de comida que provenían de fondos provinciales y se implementó una rebaja en los impuestos municipales para garantizar los servicios básicos a los desempleados.

\section{La ley de pesca y la construcción de una "convergencia" marplatense}

Las posiciones de los actores marplatenses se fueron nucleando en torno al programa de defensa de la flota fresquera y el procesado en tierra, ante lo cual sirvieron de impulso los anuncios de Felipe Solá en agosto de 1997 y que, al menos en el plano discursivo, indicaban la existencia de una voluntad de cambio en la política pesquera. Para estas alturas, Héctor Salamanco había reemplazado a Eduardo Pucci en el cargo de subsecretario de Pesca. ${ }^{1204} \mathrm{Su}$ llegada se producía en el contexto de una crisis, por lo cual entendía el funcionario que la pesca pasaba ahora por una fase difícil y de ajuste. A su arribo, Salamanco debió implementar un nuevo mecanismo para reducir la pesca. Pasado el acuerdo de reducción de mayo, ahora procuraba implementar una reducción en los días de faena que, en la mirada de diferentes actores, era inviable. Por ello se generó un creciente malestar en el sector pesquero. ${ }^{1205}$ En ese contexto en Mar del Plata se terminó de producir la "convergencia" de diferentes sectores de la pesca. ${ }^{1206}$ Como espacio articulador funcionó una instancia provincial, esto es el Concejo Provincial Pesquero, donde los sectores de la pesca lograron una postura común que dejaba fuera a las empresas que pronto formarían el CEPA. Dicha convergencia se expresó en un documento elaborado en conjunto titulado "La Industria Pesquera de Mar del Plata y los recursos del mar argentino". ${ }^{1207}$ Desde la letra del texto se exigía:

1) Garantizar a la flota pesquera en actividad el acceso a un cupo global de merluza que al menos sea similar a las capturas históricas, como forma de garantizar aprovisionamiento de materia prima a las plantas en tierra, 2) No prorrogar el acuerdo con la Unión Europea más allá de 1999, 3) Aplicar estrictamente la Ley de Navegación para asegurar los cupos de personal argentino en el enrolamiento de tripulantes, sin excepciones, 4) Prohibir la pesca de barcos congeladores o factorías en los golfos del litoral marítimo, y permitir que los buques fresqueros puedan pescar calamar con red de arrastre, 5) Establecer un sistema de reembolsos para productos exportados desde los puertos de la

\footnotetext{
${ }^{1204}$ Héctor Salamanco era un veterinario que fue agregado agrícola en Bruselas y por ello testigo privilegiado del proceso de instrumentación del acuerdo con la CEE.

${ }^{1205}$ Revista Redes, N 97, año 1997, p. 7.

${ }^{1206}$ Ya durante la crisis de la pesca en los años 1974 y 1975, tanto los empresarios como los gremios buscaron lograr algún tipo de articulación para luchar en conjunto contra la introducción de buques factoría y contra la penetración de capital extranjero. Sin embargo, en aquel tiempo la profundización del conflicto entre las clases imposibilitó cualquier tipo de entendimiento, extendiéndose las batallas en relación a la firma del CCT (Tomasone, 2006).

${ }^{1207}$ Llevaba las firmas del Intendente Aprile, el responsable provincial del Consejo Asesor Pesquero, Sergio Lorusso, Daniel Rodríguez (CGT), Edelmiro Gavilán (SICONARA), Juan Novero (SOMU), Juan Ferreira (SUPA), Carlos Darguibel (SOIP), Alberto Moreira de la UCIP, José Ramasi (UDIPA), Cayetano Arcidiácono, José Albano, Miguel Desbarro (Cámara de Industriales del Pescado), Pablo Vacante y Susana Salerno (legisladores justicialistas) y los titulares de firmas Frigorífico del Sudeste, Cafiero y Pollio, Centauro, 14 de Julio, Ostramar, Loba Pesquera, Frigorífico Marejada, Salerno Hermanos.
} 
Provincia, equiparándolos con el que beneficia a los puertos patagónicos, 6) Disponer la obligación de descargar en puerto. ${ }^{1208}$

De este modo se plasmaba un acuerdo que defendía el sistema fresquero, el procesado de materia prima en tierra y garantizaba el trabajo para los argentinos. Sin embargo, no todo era concordia. Existían diferencias claras entre los sectores del trabajo y el capital respecto a las formas de explotación laboral y por ello el documento no hace mención a la relación laboral de los trabajadores. ${ }^{1209}$ Sin embargo, la construcción de una corporación económica con intereses comunes y enfrentada a un enemigo mayor, primaba entonces por sobre relaciones sociales desiguales y jerárquicas al interior de la propia "comunidad". Este primer acuerdo entre los distintos sectores terminó de tomar forma en torno a la futura ley de pesca, cuando se manifestó con mayor énfasis el conflicto pesquero subyacente. El 12 de noviembre, el Congreso Nacional debía tratar la aprobación de la ley. El día anterior se produjo una movilización convocada por el SOIP hacia el INIDEP y la Municipalidad. La intención era entregar un petitorio al intendente Aprile en donde se le pedía que abrazara la causa de la defensa de la actividad en tierra y que no se permitiera la depredación. Los reclamos eran: 1) Representación gremial con voz y voto en el Consejo Federal Pesquero, 2) No a la Sobrepesca, 3) No a la evasión en alta mar, 4) Materia prima argentina para mano de obra argentina, 5) Reglamentación del artículo 29 que tenga como prioridad las empresas nacionales o reelaboren la materia prima en tierra y 6) No a la renovación de convenios con barcos factoría. La movilización contó con el beneplácito de un amplio sector del empresariado local y del propio intendente. El punto principal de acuerdo fue el ataque al artículo 29, en donde se permitía la libre transferencia de cupos de pesca. Eduardo Porta, de UCIP, señalaba que:

El cuello de botella es que los barcos chicos al no tener rentabilidad, estarán obligados a la transferencia de sus cuotas de extracción. De modo que la captura se concentrará en pocas manos. En Islandia hay empresas que han monopolizado hasta el $20 \%$ de las capturas nacionales anuales. Y la depredación es mayor todavía. No se protege el recurso ni se evita la depredación. Se eliminan los barcos chicos, que actúan a modo de contralor de todo el sistema. ${ }^{1210}$

Sin embargo existía una diferencia entre la postura empresarial, que propiciaba que las transferencias de los cupos fueran libres pero impidiendo solamente el traspaso de permisos de barcos fresqueros a congeladores y la posición de los gremios que solicitaban que las cuotas fueran directamente intransferibles. Según Novero: "Si las cuotas son transferibles, la industria pesquera será absorbida por dos o tres monopolios extranjeros, y van a vender nuestros productos al exterior. De ser transferible van a quedar de 50 a 100 barcos varados en Mar del Plata" 1211 .

Con todo, la oposición al artículo 29 logró comulgar en la ciudad a la UCIP, la Sociedad de Patrones Pescadores, UDIPA, la Asociación de Pesca Costera, SOMU, SUPA, la Asociación Argentina de Capitanes y Patrones de Pesca, SICONARA, CEDEPESCA, los Obreros Autoconvocados por la Reactivación del Puerto y la CGT local. Mediante una conferencia de prensa conjunta estas entidades

${ }^{1208}$ L.C., 19/09/1997.

${ }^{1209}$ Además de las cooperativas para los trabajadores de tierra, un nuevo decreto del Ejecutivo, el $\mathrm{N}^{\circ}$ 701/97, modificó el régimen laboral en el sector de buques costeros remunerados a la parte. La norma declaraba autónomos a los marineros pescadores que laboraban en las lanchas. Ello generó una intensa oposición de los gremios marítimos y de la CGT regional.

${ }^{1210}$ E.A., 12/11/1997.

1211 L.C., 18/11/1997. 
volvieron a criticar el cuestionado artículo, argumentando que de aplicarse, se concentrará la actividad y se favorecerá a los buques factoría y congeladores. Al día siguiente se produjo la primera movilización (fueron tres en total) del sector pesquero marplatense hacia la Capital reclamando la derogación del polémico artículo. Según El Atlántico:

La Ley Federal de Pesca, que se tratará en diputados, ha logrado movilizar y unificar criterios en sectores empresarios y gremiales, tanto marplatenses como de puertos patagónicos y sureños bonaerenses. Las protestas individuales fueron suspendidas en el día de ayer, para sumar esfuerzos contra el Art. 29 de la nueva legislación; artículo que permitiría la libre transferencia, es decir compra-venta, de las cuotificaciones pesqueras futuras. ${ }^{1212}$

Por su parte, el gobierno de la comuna expresaba en palabras de Darío Sócrate su compromiso con los pescadores marplatenses sosteniendo "Lo que se plantea desde Mar del Plata, incluyendo a todos los sectores, es que debe necesariamente contemplarse una división entre lo que van a pescar aquellas flotas que tienen que ver con el trabajo en tierra y los barcos congeladores o factoría"1213. Finalmente, el tratamiento de la ley quedó paralizado durante una semana porque los legisladores oficialistas pidieron un tiempo para analizar el contenido de los reclamos. Posteriormente, el 20 de noviembre y ante un Congreso cercado por temor a la movilización de los pescadores marplatenses, se aprobó la ley aunque con la modificación del artículo 29. En este sentido, se introdujeron variables más afines a las pretensiones de los buques fresqueros para los cupos de pesca, como el procesado en tierra, las inversiones en el país, la mano de obra argentina y se prohibió la transferencia de cuotas de los fresqueros hacia los congeladores. Además, el CFP se reservó un cupo de pesca para destinarlo a una situación de crisis social como por ejemplo la que vivía la pesca marplatense. De este modo, la presión ejercida por la alianza social conformada en torno a la defensa de la pesca marplatense logró obtener un cambio de sentido en la ley de pesca. Quién mejor definió el alcance de la nueva ley, tal como lo veía esta convergencia marplatense, fue Ernesto Godelman:

Si el proyecto de ley, tal como estaba hace dos semanas, podía calificarse sin ninguna duda como un intento final por liquidar la actividad pesquera marplatense, el instrumento legal que ayer recibió media sanción podría definirse por lo menos como un nuevo campo de batalla por la supervivencia y el desarrollo de la estructura productiva y social vinculada al pescado fresco. ${ }^{1214}$

Precisamente, se trató de un nuevo campo de batalla, después de una victoria parcial, que solamente anunciaba la llegada de nuevos enfrentamientos.

\footnotetext{
${ }^{1212}$ E.A., 12/11/1997. El énfasis es de la fuente.

${ }^{1213}$ L.C., $13 / 11 / 1997$.

1214 L.C.,24/11/1997.
} 


\section{Tensiones de una "convergencia social"}

En diciembre de 1997 los gremios pesqueros se reunieron en asamblea para debatir una postura de conjunto respecto de la crisis pesquera. Los sindicatos no querían que sus reivindicaciones se vieran diluidas dentro de la expresión más general de la convergencia marplatense. Entre las entidades convocantes figuraban el SOMU, el SOIP, el SUPA, el Centro de Patrones Pescadores, el SICONARA y la Asociación de Capitanes de Pesca. Los dirigentes de las entidades confluyeron en un diagnóstico de los problemas a tratar:

...hasta el día de hoy tratamos de mantener diálogos para mejorar la situación de todos los sectores de todas las cámaras. Pero el cuadro de situación actual es que hay desocupación, hay sueldos en negro, no hay aumento salarial desde ' 91 , el precio de la merluza sigue estancado en 0,14 centavos de dólar y las cámaras empresarias siguen manejando el mercado. ${ }^{1215}$

Al mismo tiempo, hacían pública la mayor preocupación por el lado de los trabajadores “...tenemos vedas y restricciones que son para mejorar el recurso pero quién paga estos costos, porque habrá gente que no podrá trabajar..." ${ }^{1216}$. En la asamblea, los participantes elaboraron un petitorio que incluía las siguientes reivindicaciones: relación de dependencia en todas las lanchas y buques costeros a la parte; No al fraude laboral. No a la evasión fiscal. No a las cooperativas de trabajo en lanchas y buques pesqueros y plantas procesadoras en tierra; $100 \%$ tripulación argentina en todos los buques de pabellón nacional y los que operen en ZEE; buques congeladores y poteros deben operar al Sur de los 47 grados latitud Sur; no a los trasbordos en rada. Descarga obligatoria en muelles y puertos; no a la privatización del Puerto local; instalación del Mercado Provincial de Concentración Pesquera; participación de los gremios con voz y voto en el CFP; pacto social para proteger al pescador y trabajador de la pesca por las consecuencias derivadas de la implementación de las vedas, entre otras. ${ }^{1217}$ Los términos del petitorio incluían reclamos netamente sindicales que el conjunto de los empresarios no estaba dispuesto a cumplir. Días más tarde, un informe del diario La Capital daba cuenta del cambio de situación:

...el conflicto definitivamente tomó un matiz laboral, cuando inicialmente ambos protagonistas habían impulsado un documento conjunto para superar la crisis del recurso y doblegar la competencia desleal que presupone la explotación de los buques congeladores y factoría. Todo pareció encarrilado hasta que en la asamblea del 2 de enero los trabajadores en el Mercado concentrador resuelven parar la flota hasta obtener una respuesta favorable a sus reclamos. Desde entonces lo que fue un pedido a las autoridades oficiales terminó como un enfrentamiento sobre el cual hoy sólo se impone la inexistencia de diálogo. ${ }^{1218}$

De este modo, tras el relativo éxito de la movilización a Capital Federal, los trabajadores de todos los gremios buscaban juntos alcanzar determinadas mejoras en las condiciones de trabajo. El 3 de enero

${ }^{1215}$ L.C., $17 / 12 / 1997$.

${ }^{1216}$ L.C., $17 / 12 / 1997$.

${ }^{1217}$ Volante "Convocatoria a Asamblea", diciembre 1997.

${ }^{1218}$ L.C., 09/01/1998. 
los sindicatos, con la única e importante excepción del SOIP, decretaron un paro hasta tanto no se atendieran los puntos requeridos, particularmente la actualización del precio de la merluza para los pescadores marineros. A raíz de esta medida se expresaron divisiones verticales (entre clases) y horizontales (al interior de las clases). En el primer sentido, las reivindicaciones en clave clasista por las condiciones de vida chocaron con el programa general de la "convergencia" que propugnaba un consenso en torno a la defensa del sistema fresquero. Esto dividió a trabajadores de empresarios. Los segundos consideraron que el paro era "a contramano" porque mientras la flota fresquera se encontraba parada, los congeladores continuaban pescando. Para los empresarios las condiciones laborales solo podían tratarse una vez que el trabajo se hubiese reiniciado: "hablamos con los barcos en el agua". Al mismo tiempo, aseguraban que muchos de los pedidos realizados por los obreros correspondían al Ministerio de Trabajo y no al empresariado. ${ }^{1219}$ Días más tarde, la CAABPA y la Cámara de Procesadores elevaron un comunicado en el que expresaron que "el paro de actividades de la flota fresquera, organizado y promovido por algunos de los gremios de la actividad maritima de Mar del Plata, beneficia exclusivamente a la flota de congeladores y factorías que continúan operando normalmente". Luego criticaron "la medida de fuerza arbitraria y discriminatoria en contra de la flota fresquera y de las plantas procesadoras en tierra". El documento llevaba la firma de Homero Cánepa quien añadió que "las causas invocadas para realizar el paro, que nunca fueron notificadas oficialmente a las Cámaras, han sido tergiversadas para convertirlas injustificadamente en un reclamo salarial".

...esta cámara no se niega a negociar los términos de nuevos convenios colectivos de trabajo, pero deben darse previamente dos condiciones indispensables: mantener la actividad normal de la flota fresquera y plantas en tierra, sin ningún tipo de medidas de fuerza; y que haya sido promulgada y reglamentada la Ley Federal de Pesca para que las empresas conozcan fehacientemente el nuevo modelo pesquero a implementar por la autoridad nacional de aplicación, lo cual es condición ineludible para poder definir el futuro de toda la industria pesquera. ${ }^{1220}$

"En el supuesto que se mantengan estas medidas injustificadas de acción directa, las cámaras se verán en la necesidad de plantear la declaración de ilegalidad de las medidas adoptadas, y las empresas a solicitar la declaración de crisis de la misma, adoptando las medidas que sean necesarias"1221. La Asociación de Embarcaciones de Pesca Costera, la Unión de Intereses Pesqueros Argentinos y la Sociedad de Patrones Pescadores adhirieron al documento firmado por Cánepa. La UCIPa través de un comunicado señaló que se quiere romper la unidad de todos los sectores logrando con el conflicto que Mar del Plata no pesque. Reclamaron que "se recupere la unidad de todos los sectores, priorizando la economía marplatense; salir a pescar lo que es nuestro, que hoy capturan los congeladores del sur; producir pescando (ello posibilitará discutir la distribución de la riqueza producida) y no mantener el conflicto en las actuales instancias, pues ello significará generar la pobreza, que no se puede distribuir". Por su parte UDIPA elevó un comunicado de similares características en el que argumentaba que "trasladando la crisis del recurso en sucesivos reclamos salariales, solamente estaremos acelerando la desaparición de algunas empresas argentinas que hoy se ven jaqueadas, favoreciendo así la agudización

\footnotetext{
${ }^{1219}$ L.C.,07/01/1998.

${ }^{1220}$ L.C.,04/01/1998

${ }^{1221}$ L.C.,04/01/1998.
} 
de la crisis social y la concentración de capital que algunos pretenden"1222. De este modo, los empresarios utilizaban el argumento de un consenso marplatense y la defensa del sistema fresquero para oponerse a los reclamos de los trabajadores. Así las cosas, la activación surgida en conjunto demostró su volatilidad cuando los trabajadores pretendieron hacer cumplir sus demandas particulares. Esto es lo que aparece en los periódicos como una "desviación" de los principios sostenidos durante la movilización conjunta a Buenos Aires. En este sentido, los reclamos se "des-marplatizan" y se tornan más clasistas, evidenciando las contradicciones de una alianza que se mantenía en oposición a un mal mayor pero se rompía cuando se discutían las condiciones salariales y otras reivindicaciones obreras.

Pero el desarrollo de la protesta no sólo expresó esta división "clasista", sino también provocó una nueva división horizontal a nivel gremial. Desde los comienzos de la propuesta del paro, el SOIP se manifestó contrario a la medida argumentando en el mismo sentido que el empresariado. Juan Luis Saravia, hermano de Abdul y secretario adjunto de la institución, sostuvo: "respetamos las diferentes posturas gremiales ya que cada gremio es autárquico en sus decisiones, por ello es que no vamos a avalar paro de ningún tipo, ya que sería netamente fresquero, dejándole el camino expedito a quienes nos están ocasionando el mayor perjuicio y ocasionando mayor daño a nuestros afiliados"1223. Esta postura fue criticada por el conjunto de los gremios y por trabajadores del SOIP opositores a la conducción gremial. Por otro lado, el SOMU nacional, contrariando la postura de la regional Mar del Plata, deslegitimó la medida de fuerza por no realizarse en consulta con la conducción nacional. Esta fue una de las tantas tensiones originadas entre la conducción de la entidad y su delegación local. Finalmente el paro fue levantado luego de veinte días, al obtener un aumento salarial para el conjunto de los trabajadores. Aunque hubo voces que expresaron su disconformidad con el acuerdo por no conquistarse los otros reclamos, esta vez la movilización de los obreros y obreros no se quedaba con las manos vacías.

\section{“No los une el amor...". Los orígenes de la Multisectorial}

La conformación de multisectoriales respondió, con las particularidades de cada región y rama económica, a una lógica nacional. Los primeros cortes de ruta en las provincias argentinas fueron llevados a cabo por multisectoriales que reunían distintos sectores sociales de las ciudades (Pereyra, 2008). Estaban conformadas por los afectados por la desestructuración de las economías locales y expresaban una reacción ante ese proceso. Por ejemplo, los cortes de 1996 en Cutral Có y Plaza Huincul y los de 1997 en Tartagal y General Mosconi fueron verdaderos cortes comunitarios donde confluyeron desocupados, comerciantes, pequeños empresarios, sindicatos y políticos locales. Por nuestra parte, en la pesca local, a mediados del año 1998 y a pesar de haberse sancionado la Ley Federal de Pesca, el problema en torno de la necesidad de reducir las capturas lejos estaba de haber sido resuelto. La evidencia del colapso de la merluza era cada vez más palpable. Había caído la biomasa general junto al tamaño de los peces y se estaban capturando juveniles. Por ello el conflicto sobre la cuotificación continuaba latente. La puja se realizaba a nivel empresarial, entre la CAPECA y las cámaras "Fresqueras" (CAABPA, Procesadores, UDIPA). Durante los meses previos, antes que desde el gobierno se tomara una decisión, se podían observar los diferentes posicionamientos frente a cuál debía ser el proceso de cuotificación.

1222 L.C., 10/01/1998

${ }^{1223}$ L.C.,03/01/1998. 
Recordemos que la disputa se manifestó en torno a la interpretación de la ley de pesca. Los fresqueros buscaban consolidar su posición a partir de considerarse quienes mayor empleo generaban, por lo que de implementarse un sistema de transición antes de cuotificar:

...debiera utilizarse como parámetro fundamental considerar para la distribución de las cuotas de capturas, la cantidad de mano de obra directa ocupada por la industria pesquera (buques, plantas procesadoras, frigoríficos, etcétera), ya que en el sector fresquero trabaja aproximadamente el 80 por ciento del total de personas que ocupa la industria pesquera del país. ${ }^{124}$

El argumento de mayor peso que esbozaban era el del desempleo:

En un momento en que la desocupación en la Argentina constituye una de las mayores preocupaciones del gobierno nacional y de los gobiernos provinciales, consideramos que debe preservarse el principio de minimizar el costo social de la cuotificación de las capturas, tratando de impedir la destrucción de los puestos de trabajo por falta de materia prima. ${ }^{1225}$

Argumentaban que por cada 10 mil toneladas que le redujesen a la flota fresquera se perderían 350 puestos de trabajo, mientras que sólo serían 70 en el caso de que la reducción se implementase sobre los congeladores. De este modo los fresqueros le hicieron llegar a los integrantes del CFP una propuesta de asignación de cuotas de pesca de merluza basados en los coeficientes del nivel de ocupación, por el cual al sector fresquero le correspondería la concesión de 234.444 toneladas anuales frente a las 65.856 que debería asignarse a los buques congeladores. ${ }^{1226}$ Así las cámaras empresariales fresqueras estimaron que para el año 1998, sobre una CMP de 300 mil toneladas de merluza, debería asignarse al sector fresquero el $78.04 \%$ y al de congeladores el $21.96 \% .{ }^{1227}$ En julio el CFP dispuso una veda de 20 días para fresqueros y 60 para congeladores. Mientras, continuaban los debates. Domingo Novero, ante la posibilidad de un nuevo cierre del caladero, expresó: "Estamos frente a un parate generalizado y la situación de los compañeros que trabajan en tierra va a ser terrible", al mismo tiempo que reiteraba quienes eran los culpables de la depredación: "Nosotros coincidimos totalmente con que los factoría no sólo depredan el recurso ictícola, sino que le quitan trabajo al obrero argentino" ${ }^{1228}$. La mayor preocupación del gremialista pasaba por saber cómo se resolvería el tema del cupo que fijaba entonces una CMP anual de merluza de 280 mil th. Ya se estaba cerca de alcanzar esa cifra. Por eso, y a fin de evitar el cierre de la fuente de trabajo, el dirigente inició "conversaciones con los empresarios para asignar un cupo extra a Mar del Plata de 40 a 50 mil toneladas más de pesca permitida de merluza"1229. De este modo los gremios volvían a acercarse a los empresarios. No los unía el amor, sino el espanto que implicaba la posibilidad de una nueva veda.

Sin embargo, el acontecimiento fundamental en la unidad de gremios y empresarios fue la designación de un funcionario. El nombramiento de Héctor Auguste, quien hasta el momento se había

\footnotetext{
${ }^{1224}$ L.C., $1 / 07 / 1998$

${ }^{1225}$ L.C., $1 / 07 / 1998$.

${ }^{1226}$ L.C., 4/07/1998.

${ }^{1227}$ En paralelo, y en el marco de los reveses que sufrían los buques procesadores, la secretaría de Industria resolvió excluir del registro industrial al procesamiento de productos del mar realizados en cualquier tipo de buques, incluso los factoría. Revista Redes N 101, año 1998, "Vigilia merlucera y padecimientos patagónicos".

${ }^{1228}$ E.A., $25 / 07 / 1998$.

${ }^{1229}$ E.A., 25/07/1998.
} 
desempeñado como presidente de CAPECA, en el cargo de Subsecretario de Pesca alentó una enconada crítica. Ni bien se conoció la noticia, un diario local publicó "El sector pesquero está listo para nuevas luchas" ${ }^{230}$. El cronista destacaba "A priori la parcialidad del nuevo subsecretario de Pesca inquieta a numerosos sectores de la actividad, sobre todo el fresquero, dado que Eduardo Auguste es el titular de la cámara que nuclea a los buques congeladores" ${ }^{1231}$. De inmediato se manifestaron contrarios a la designación todos los gremios pesqueros además de la CGT regional. Daniel Rodríguez expresó que en los últimos tiempos los sindicatos:

....han tenido un acercamiento bastante importante con la Secretaría de Agricultura, Ganadería, Pesca y Alimentación, con el Dr. Felipe Solá, y habíamos encuadrado de alguna manera actividades que nos permitían tener mayor optimismo. Pero ahora, lamentablemente, con este giro que ha pegado en estos últimos días, realmente hay preocupación en el sector. ${ }^{1232}$

En una nota enviada al presidente Menem los gremios pesqueros y la CGT destacaban que no era ético el nombramiento de un funcionario que representaba a una de las cámaras empresarias. Además, añadían que Auguste presidía la cámara que nucleaba a empresas de capitales mixtos que eran las que perjudicaron la pesca nacional. Y multiplicaban las críticas hacia los congeladores señalando que dicha flota se vio "ampliamente favorecida por los decretos promulgados por el Poder Ejecutivo Nacional (817/92), donde tenían libertad de contratar personal de origen extranjero y sin experiencia en la actividad pesquera (cédulas de empresas) y las ventajas de reembolsos y reintegros por exportaciones facilitados por el Ministerio de Economía" 1233 . A pesar de todas esas ventajas "el mayor logro obtenido por el pueblo argentino fue la desocupación de sus trabajadores y la depredación de nuestro mar, el cual ha llegado a los límites máximos de afección de su recurso". Por el contrario, las entidades gremiales se manifestaron a favor de "la necesidad de acordar una política pesquera que preserve el recurso $e$ incorpore a las capturas un mayor valor agregado para el desarrollo regional, como generador de empleo y de un mayor incremento en las exportaciones". Al mismo tiempo pedían la renuncia de Auguste, quien fue insultado y vapuleado por inspectores en su primera visita a Mar del Plata. También las organizaciones empresariales locales se sumaron al pedido de destitución. Por el lado de la UCIP, se solicitó la designación de "una persona sin compromisos", indicando que la figura de Auguste implicaba profundizar el proceso de concentración económica en el sector en desmedro de las empresas medianas y pequeñas, con la posibilidad de aumentar la desocupación y la falta de trabajo para la gente. En contraposición a la postura de fresqueros y trabajadores marplatenses, la CAPECA saludaba a Gumersindo Alonso, entonces secretario de la SAGPyA, por el nombramiento de Auguste: "como sector empresario representativo de la actividad pesquera ve con agrado la designación como subsecretario de Pesca de un dirigente gremial empresario con larga experiencia en la industria" ${ }^{1234}$.

Por su parte Auguste, ante los resultados de la campaña del INIDEP que indicaban se había alcanzado la CMP, lanzaba una serie de medidas tendientes a proteger el recurso entre las que se preveían dos vedas en el lapso de 12 meses que serían de 10 días para los fresqueros y de 30 para los congeladores.

${ }^{1230}$ L.C., 02/09/1998.

1231 L.C.,02/09/1998.

1232 L.C.,03/09/1998.

1233 L.C.,03/09/1998.

1234 L.C.,06/09/1998. 
Además, trascendió que el funcionario renovaría los acuerdos con la CEE. Los gremios locales y la CGT respondieron de inmediato convocando al "Encuentro Nacional en Defensa del Recurso Pesquero" donde se discutieron los cambios reclamados por el sector. Rodríguez afirmó:

...no vamos a permitir pagar una sola víctima más, como lo son los trabajadores que están padeciendo esta política porque se observa a extranjeros trabajando y los argentinos están desocupados. No se respeta la ley y marca una política negativa a los intereses del país y hay que rectificarla. ${ }^{1235}$

Sin embargo, las medidas restrictivas no eran suficientes y, por ello, Auguste anunció en diciembre la reducción de 120 mil toneladas para la captura de merluza (sobre las 420 mil capturadas en 1998) y la prohibición de que los buques congeladores (que no posean plantas en tierra) realicen su actividad sobre el paralelo 48 y dentro de las 180 millas marinas. Frente al anuncio de estas medidas, que soslayaban las peticiones de cuotificación según "el espíritu de la ley", los miembros de la CAABPA se mostraron disconformes: "No esperábamos esto, porque considero que el sector fresquero sigue permaneciendo en una situación de riesgo", comentó Pablo Otegui. Quien además consideró que "no tener un sistema de cuotificación como el que se propone en la ley, o en su defecto, que no se hayan tomado las medidas para que la flota fresquera pueda pescar en una zona donde opera la gran flota congeladora, es preocupante" 1236 . Con relación a esta decisión, la CAABPA y los Procesadores informaron que "después de 18 meses de reuniones, talleres y comisiones con autoridades pesqueras nacionales y provinciales, el Consejo Federal Pesquero decidió promover la desaparición de la Industria Pesquera Nacional".

...se han establecido cuotas de pesca arbitrarias y discriminatorias contra la flota pesquera fresquera, favoreciendo a la flota de buques congeladores, y desconociendo lo establecido en el artículo 27 de la Ley Federal de Pesca, otorgando 120.000 toneladas de captura de merluza hubbsi para el trabajo de 13.000 personas y 180.000 toneladas para los buques congeladores y factorías con sus 3.000 trabajadores.

Sentenciaron que con la implementación de estas medidas más de 5 mil personas perderán en forma inmediata sus puestos de trabajo y significará el certificado de defunción para la industria pesquera que "utiliza con mayor eficiencia" la materia prima que pescan nuestros buques y "elabora los productos con mayor valor agregado" que exporta nuestro país. Por último explicaron que:

...se favorece a quienes han destruido el caladero, al amparo de una política descabellada e irracional, que ha permitido el ingreso de una cantidad de buques pesqueros que supera holgadamente la capacidad real de nuestro caladero. Lamentablemente, y a juzgar por esta situación, se han confirmado nuestros temores respecto a la política de los nuevos funcionarios del sector pesquero nacional. $^{1237}$

Al mismo tiempo, distintos sectores unificaban sus críticas. El SOIP se declaró en estado de alerta y movilización. Darguibel expresó que: “...atento conocer las medidas del Consejo Federal Pesquero

${ }^{1235}$ L.C., 17/09/1998. La negrita pertenece a la fuente

${ }^{1236}$ L.C., 12/12/1998.

${ }^{1237}$ L.C., $17 / 12 / 1998$. 
que no ha tenido en cuenta, en ningún momento, a los trabajadores portuarios en general, el sindicato a [sic] decidido: $1^{\circ}$ ) Rechazar en todos sus términos la reducción de capturas". ${ }^{1238}$ El gremio:

...desconoce a los integrantes del Consejo Federal Pesquero como representantes de los trabajadores y del país, atento que con medidas como las del acta 14/98 y otras ya tomadas, están dilapidando no sólo el presente sino también el futuro de los trabajadores de la pesca y el recurso nacional.

CEDEPESCA también salió al cruce indicando que las medidas tomadas en la última reunión del CFP "son profundamente cuestionables tanto desde el punto de vista de la justeza como de su legalidad". La denuncia de la ONG afirmaba que "el Consejo transfirió el 16\% de las cuotas de merluza común de la flota pesquera a la congeladora -unas 40.000 toneladas- sin que para esto podamos encontrar una explicación plausible" 1239 . Finalmente, a principios de 1999 la SAGPyA sancionó la resolución 2/99 que, contradiciendo la ley de pesca, dictaba que todas las embarcaciones sin distinción de flota pescaría el 50\% menos de lo que había pescado en 1997. Tanto los empresarios "fresqueros", como los gremios y el gobierno municipal se opusieron a los términos de la reducción. Varias empresas marplatenses presentaron recursos de amparo. Por esta vía más de 30 empresas quedaron exceptuadas de cumplir con los límites establecidos por el Consejo Federal Pesquero. Homero Cánepa caracterizó de "absurda" la resolución de la SAGPyA: "es absurdo porque toman elementos que no figuran en la ley para fijar una cuotificación transitoria y además es una medida que tiene un claro destino de apoyo a la flota congeladora" $"$. Por su parte la UCIP exigió la separación Auguste de la subsecretaría "en resguardo de los intereses pesqueros nacionales". En un documento que llevaba la firma del presidente de la entidad, Raúl Lamacchia, se sostiene: "Con su actitud [Auguste] ha confirmado que vino a implementar politicas discriminatorias en perjuicio de los Fresqueros y la Pesca Costera, profundizando la concentración económica" ${ }^{1241}$. Finalmente la medida, que buscaba reducir las capturas perjudicando los intereses de los fresqueros marplatenses, fue bloqueada a través de un recurso de amparo presentado por la CAABPA y favorecido por el juez Jorge Sirochinsky, que levantó la limitación para la pesca de merluza por parte de buques fresqueros. Auguste declaró que se reservaba los derechos de iniciarle al juez un juicio político.

${ }^{1238}$ L.C., $20 / 12 / 1998$.

${ }^{1239}$ L.C., 18/12/1998.

${ }^{1240}$ L.C., 24/01/1999.

${ }^{1241}$ L.C.,01/02/1999. 


\section{La Multisectorial en acción: el "Barcazo"}

“...la dinámica resultante de una administración en retirada potencia el grado de conflicto social. Y la pesca es un claro ejemplo. Su historia en la Argentina no registra movilizaciones comparables a las que se produjeron en

las últimas semanas [...] Pero hoy, como entonces, el gran protagonismo lo tuvo Mar del Plata, con decenas de buques navegando hacia Buenos Aires, sus hombres manifestando a las puertas del Congreso Nacional y toda la ciudad aguardando expectante el pronunciamiento de los legisladores" Revista Redes, № 107, 1999.

En abril de 1999 la SAGPyA, con Ricardo Novo como secretario y Auguste como subsecretario de Pesca, afirmó que implementaría una veda a partir del 1 de junio, decisión que fue refrendada por el CFP. La medida fue inmediatamente rechazada por los "fresqueros" marplatenses y en el mes de mayo comenzaron las negociaciones para que sólo le sea aplicada a los congeladores. Los empresarios "fresqueros" junto a los gremios se reunieron en una asamblea y, con el apoyo de autoridades locales, legisladores provinciales y nacionales, rechazaron la medida. Acordaron elevar un reclamo ante las autoridades nacionales, pidiendo por la fijación de una cuota adicional para la captura de merluza hubbsi hasta diciembre que permitiera "evitar el caos social".

Rechazamos las medidas adoptadas por el Consejo Federal Pesquero según Acta 7/99 y exigimos su inmediata derogación. No debe cerrarse el caladero de merluza hubbsi por las graves consecuencias sociales que dicha medida traerá aparejada para los trabajadores, sus familias y a las empresas.

Finalizaba el mismo documento declarando a la ciudad de Mar del Plata en "estado de alerta y movilización permanente y en caso de que no sean rápidamente respondidos los puntos solicitados se dispondrán las medidas de acción directa que sean necesarias, convocando a la ciudadanía a apoyar esta resolución" "1242. Al día siguiente, el CFP respondió negativamente a los puntos exigidos en una reunión teñida "de gritos, discusiones y fuertes posturas de cada una de las partes"1243. Ante este rechazo, la Multisectorial en Defensa de la Pesca Argentina comenzó a organizar la movilización a la Capital para el 13 de mayo. Sin posibilidad de disputar dentro del CFP, se buscaba demostrar la fortaleza del sector apuntando directamente a presionar al ejecutivo nacional. Paralelamente, el intendente Elio Aprile se entrevistó con el gobernador Eduardo Duhalde, quién comprometió su apoyo a los fresqueros. Aprile declaró haber encontrado en el gobernador "una comprensión y una adhesión política absolutas" 1244 . En este contexto, la movilización planeada fue postergada a la espera de las gestiones iniciadas por Duhalde que, tras reunirse con Ricardo Novo, anunció la posibilidad de la firma de un acta acuerdo. El acta finalmente se rubricó con un contenido muy favorable a los reclamos de la convergencia marplatense. Se acordó que no se cerraría el caladero, los congeladores pescaran fuera del paralelo $48^{\circ} \mathrm{y}$ se realizará una parada biológica de 30 días, mientras que el INIDEP se haría cargo de estudiar las

\footnotetext{
${ }^{1242}$ Ámbito Financiero, 06/05/1999.

1243 E.A.,07/05/1999.

${ }^{1244}$ L.C., $12 / 05 / 1999$.
} 
condiciones del recurso merluza. Duhalde declaró "El viernes se va a firmar un acta-acuerdo en Mar del Plata. Todo lo que se pueda pescar va a ser para los fresqueros".

En caso de que haya crisis pesquera y que estemos obligados a cerrar el caladero, los primeros que deberán parar serán los congeladores y los últimos los fresqueros. Además, ya están dispuestas las partidas necesarias para paliar la crisis social que pueda surgir. Serán fondos nacionales. ${ }^{1245}$

Así la provincia de Buenos Aires se estructuraba como grupo unificado en defensa del sistema fresquero y el conflicto se volvía de carácter provincial, entre Buenos Aires y la Patagonia, al mismo tiempo que cruzaba horizontalmente las tensiones entre flota industrial. Finalmente, el acta se firmó el día 14 en el Concejo Deliberante local con la presencia de Eduardo Auguste y Sergio Lorusso. Más allá de eso, la Multisectorial se disponía a dar pelea por lo que consideraba una solución a mediano plazo como era la implementación de una Ley de Emergencia Pesquera. En respuesta el CEPA salió al cruce del acta por intermedio de una solicitada que tituló "Crisis Pesquera. Discriminación".

Nuestras empresas pesqueras integradas, con radicación principalmente en Mar del Plata y en el resto de los puertos del país, optaron por un modelo que incluyendo el anterior, asegura un alto nivel de ocupación de mano de obra, como lo demuestran nuestras compañías que ocupan sólo en Mar del Plata el 40\% de la mano de obra total, además de garantizar continuidad, calidad en el empleo, acceso a mejores mercados y empresas económicamente viables [...] Todo esto se logra con grandes inversiones, tecnología y el funcionamiento de las empresas dentro del marco de la ley. Aplicar el acuerdo firmado, es precarizar el trabajo del futuro, la discriminación a que pretende someternos, quiere remitirnos al pasado, en tecnología, seguridad y calidad de trabajo, comprometiendo la continuidad de las empresas pesqueras, nacionales e integradas y el futuro todo de la industria pesquera. ${ }^{1246}$

En el mismo diario, Fortunato declaraba:"Nosotros no estamos en contra del acuerdo, pero creemos que no es integrador y que tampoco va al fondo del problema", al mismo tiempo que indicaba: "No se trata de congeladores contra fresqueros, sino de argentinos contra extranjeros" y sostuvo que la solución a los reclamos pesqueros era aplicar la Ley Federal de Pesca. De este modo, el CEPA intenta explotar el conflicto desde la perspectiva flota nacional versus flota extranjera, procurando modificar la tensión entre fresqueros y congeladores. Era claro, como sucede con cualquier contienda, cada uno procuraba hacer ver su interés particular como el interés general.

Finalmente, tras la firma del acta acuerdo entre la comuna marplatense y los funcionarios de pesca, nacionales y provinciales, la veda de merluza le fue aplicada únicamente a los congeladores. La presión de los fresqueros, apoyados por el gobernador de la provincia, había logrado uno de sus objetivos. Entonces, un contrariado Eduardo Auguste expresó que "A partir de este acuerdo, la flota pesquera operará en el caladero en las condiciones habituales, suspendiéndose la veda prevista a partir del 1 de junio". Precisó que "para no cerrar el caladero, acordamos tomar medidas drásticas, como sacar del mismo a los congeladores y dejar esta parte para la flota fresquera, porque priorizamos la cuestión social antes que nada". El artículo primero del acta que fue elevada al Consejo Federal Pesquero señalaba

1245 L.C., 13/07/1999.

${ }^{1246}$ L.C., 16/05/1999. La negrita es de la fuente. 
que "a partir del 1 de junio de 1999 los buques congeladores y factoría podrán ejercer sus operaciones de pesca únicamente al sur del paralelo $48^{\circ}$ ", mientras que la flota fresquera "operará en el caladero en las condiciones habituales" (la negrita es de la fuente). Por último, el documento brindaba además el "apoyo político" de las partes firmantes "para la sanción definitiva de la ley de emergencia pesquera que obtuviera por unanimidad su media sanción en la Cámara de Senadores"1247.

Por supuesto, quienes reaccionar en oposición al acuerdo alcanzado en Mar del Plata fueron las cámaras de buques pesqueros congeladores y los gremios que representan a sus tripulantes. Mediante un comunicado reclamaron a los legisladores nacionales que no aprueben la Ley de Emergencia Pesquera y pidieron la renuncia del secretario de la SAGPyA, Ricardo Novo y de todos los funcionarios del área, incluido Eduardo Auguste. El documento se tituló "Señores Diputados: no compren pescado podrido" y denunció que de aplicarse la Ley de Emergencia Pesquera "quedarán en la calle más de 4.000 trabajadores y sus familias" "248. En caso de que no se atendieran sus reclamos los congeladores anunciaron que pondrían en marcha una serie de medidas de acción directa entre las que incluirían el regreso a puerto de la totalidad de los buques congeladores con el objeto de bloquear el ingreso de los buques de transporte de combustible. ${ }^{1249}$

De este modo, los grandes conflictos de intereses se volvían a hacer ostensibles. La Ley de Emergencia Pesquera se constituyó en un nuevo escenario de lucha entre la Multisectorial y el sector de congeladores y trabajadores vinculados a ese sistema. En la primera sesión de la Cámara de Diputados en la que se debía tratar se pasó para la semana siguiente debido a que, según los argumentos "oficiales" de los diputados justicialistas, necesitaban un tiempo mayor para revisar los contenidos. No obstante, Auguste señaló que las medidas acordadas en Mar del Plata y que estaban reflejadas en gran medida en la Ley de Emergencia entrarían en vigencia "de todas maneras" debido a que el acta-acuerdo sería convalidada por el CFP. A pesar de señalar que el acuerdo se pondría en marcha, el funcionario expresó no estar conforme y argumentó "Las generaciones futuras corren el riesgo de quedarse sin merluza" 1250 . Al contrario, los "fresqueros" mostraban su gratitud. El diario El Atlántico publicó una solicitada titulada "Crisis pesquera provocada por la flota de buques congeladores".

La industria pesquera nacional integrada por las flotas de buques pesqueros fresqueros, plantas procesadoras en tierra, sus miles de trabajadores y la ciudad de Mar del Plata, agradecen al señor gobernador y al señor intendente de esta ciudad su decidido apoyo, reflejado en el documento firmado en el Honorable Concejo Deliberante del Partido de Gral. Pueyrredón el día 14 de Mayo de 1999. ${ }^{1251}$

\footnotetext{
${ }^{1247}$ Ámbito Financiero, 17/05/1999.

${ }^{1248}$ L.C., 18/05/1999.

${ }^{1249}$ Nuestra investigación se centra en la Multisectorial en Defensa de la Pesca Argentina formada en la ciudad de Mar del Plata e integrada por lo que previamente denominamos "convergencia marplatense". Pero así como se produjo este entendimiento entre diferentes sectores y grupos sociales en la provincia de Buenos Aires, también la región patagónica produjo su propia Multisectorial. No nos dedicamos a estudiarla, pero al menos debemos señalar su existencia. La prensa de Mar del Plata no la menciona. Sólo hemos tomado nota de su aparición debido a que aparece en la prensa nacional, actuando en oposición a medidas para la pesca implementadas por el gobierno de La Alianza. La Nación, 06/06/2000, Franco Varise, "Pesca: sigue el descontento", en línea: http://www.lanacion.com.ar/19695-pesca-sigue-el-descontento.

${ }^{1250}$ L.C., $19 / 05 / 1999$.

${ }^{1251}$ Firmaban Homero Cánepa y adhería la Municipalidad de Gral. Pueyrredón, la Subsecretaría de Pesca de Buenos Aires, la CAABPA, la Cámara de Procesadores, la Asociación de Embarcaciones de Pesca Costera, la Cámara Argentina de Industriales del Pescado, UDIPA, Sociedad de Patrones Pescadores, UCIP, Centro de Patrones Fluviales de Pesca y de Cabotaje Marítimo (secc. Mar del Plata), SUPA, Asociación Argentina de Capitanes y Patrones de Pesca, SOMU, SICONARA, SOIP y CGT (regional Mar del Plata).
} 
Después, realizaban un pedido:

Solicitamos a los integrantes de la Honorable Cámara de Diputados de la Nación que el día 19 del corriente mes se de sanción definitiva al proyecto de ley de emergencia pesquera aprobado por unanimidad por el honorable Senado de la Nación el día 12 de Mayo de 1999. Asimismo, al Ing. Ricardo Novo y al Consejo Federal Pesquero que instrumenten de inmediato la resolución que ponga en vigencia lo establecido en el documento mencionado y que fuera firmado por el poder ejecutivo nacional. ${ }^{1252}$

En el mismo periódico Auguste, notablemente exasperado, salió al cruce de las cámaras marplatenses. "Que la Cámara de Mar del Plata se saque la careta" manifestó al endilgarle al sector que "pesca y hace lo que quiere". Señaló además que "No quieren inspectores a bordo, no quieren empleados en relación de dependencia... ésta es la situación de la Cámara de Mar del Plata. Después se van a lamentar los marplatenses cuando no tengan más merluza" ${ }^{1253}$ Pidió que los empresarios "no mientan" cuando dicen que no pescaron más: "Sí pescaron de más porque no se pueden haber pescado 125.000 toneladas hasta marzo de este año", dijo antes de acusarlos de haberse lanzado en "una carrera loca porque estaba el recurso de amparo". Insistió en que se estaba yendo "hacia un colapso" y recordó que los empresarios:

...pescaron un millón y medio, dos millones de toneladas de merluza y no decían "pobre gente" ni le daban aumento de sueldo [...] Al contrario -continuó- transformaron a todos en cooperativas y no quieren ni relación de dependencia ni aportes jubilatorios. No tienen nada porque si no llegan a 400 pesos no se pueden mantener pagando todo eso. ${ }^{1254}$

Finalmente, contrariando el acta firmada y para sorpresa de los "fresqueros", en la reunión del CFP la veda fue ratificada. Esto provocó gran indignación entre los integrantes de la Multisectorial. La entidad marplatense evaluó como un "atropelló incalificable" lo vivido por el hecho de que en horas de la tarde no los dejaron entrar al edificio donde estaba reunido el CFP y los controlaron con un cordón policial. Por esta razón, Sergio Lorusso representante de la provincia de Buenos Aires, renunció a su lugar dentro del organismo. Mientras que el Intendente Aprile aseguró sentirse "estafado por Auguste quien me merece el mayor de los desprecios por haberse comprometido en Mar del Plata a una cosa y dos días después haber votado en contra" ${ }^{\prime 1255}$. Este hecho fue el que volvió a estimular la realización de la protesta en Buenos Aires buscando la sanción de la Ley de Emergencia. Aprile dijo que en las últimas horas:

...me comuniqué con Federico Storani quien me aseguró que mañana los diputados votarán la ley, mientras el gobernador Duhalde, con quien también hable por teléfono comprometió el apoyo de los diputados que le responden de modo que los votos para que salga la ley estarían garantizados pero

\footnotetext{
${ }^{1252}$ E.A., 19/05/1999.

${ }^{1253}$ La negrita es de la fuente.

${ }^{1254}$ E.A., 19/05/1999.

${ }^{1255}$ El Día, 26/05/1999.
} 
hay que ver si después del feriado, se presenta la cantidad de legisladores como para dar quórum, por lo que debemos mantener la guardia alta. ${ }^{1256}$

Es así que el 26 de mayo partió una caravana por tierra hacia Capital Federal, integrada fundamentalmente por trabajadores de la pesca y del pescado, mientras que los barcos fresqueros se dirigieron por mar hacia el puerto de la ciudad de Buenos Aires. La rebelión de los pescadores marplatenses contra la medida de cerrar el caladero de merluza ordenada por el CFP, que fue nombrada con el título de "Barcazo", según La Capital "conmocionó al país". La movilización de casi un centenar de buques fresqueros amenazó con bloquear el puerto de Buenos Aires. La protesta incluyó la movilización de entre 2.500 (La Capital) o 4.000 personas (El Atlántico). ${ }^{1257}$

El día previo, la Multisectorial daba a conocer un documento bajo la denominación de "Carta abierta a los Diputados de la Nación". En él se plantean los fundamentos del reclamo por la Ley de Emergencia Pesquera que los legisladores debían votar en el Congreso y que ya contaba con media sanción del Senado. La misiva incluía entre sus puntos la aprobación de la mencionada ley bajo el argumento de que se trataba de "un reparador de lo graves perjuicios que nos han causado las reiteradas políticas pesqueras ajenas a la realidad del sector" ${ }^{258}$. El texto incluía la denuncia de la actitud de los gobiernos que permitieron la entrada al caladero nacional de buques congeladores, quienes instalaron un modelo pesquero eminentemente extractivo, el cual se volvió absolutamente regresivo sin agregar valor a los productos exportados. Además sostenía que el $80 \%$ del empleo en la actividad lo aporta el sistema fresquero, mientras que el restante $20 \%$ de la mano de obra la emplea la flota congeladora, pero la misma está integrada en un alto porcentaje por extranjeros. Por último enfatizaba: "Si decimos que todos pesquen el 50\% volvemos antieconómico el sistema para todos, por lo tanto hay que decidir qué modelo pesquero le conviene al país y crear los mecanismos para regresar a aquellos países de origen a aquellos barcos que no estén de acuerdo con ese modelo" ${ }^{1259}$. Respecto a la Ley de Emergencia sostenía que la norma permitía seguir pescando a quien menor esfuerzo ejerce sobre el recurso, es decir, a los buques fresqueros. Mientras tanto, el intendente Aprile señalaba que la protesta es "una cuestión de toda la ciudad" y sostenía que "estaré alli tantas veces como haya que estar, el domingo quedó claramente planteado que esto ya se ha convertido en una cuestión de ciudad, que es un problema nuestro". Vamos "a buscar la ley, que de no mediar mayores inconvenientes bien podría estar señalándose que va a estar aprobada, porque hay un compromiso de los presidentes de ambas bancadas". Y resaltó que "después de la estafa, la canallada a la que nos sometió el subsecretario Auguste, nosotros seguimos con la guardia muy alta y solamente vamos a estar en paz cuando la ley esté sancionada, promulgada y realmente en pleno ejercicio legal" ${ }^{1260}$. Por su parte, la concejala de la UCR Vilma Baragiola, elevó un proyecto de ordenanza para declarar en el ámbito del Partido de General Pueyrredón persona no grata al subsecretario de pesca de la Nación. La solicitud se basaba principalmente en "las actitudes de Auguste, que habiendo suscrito un acuerdo en esta ciudad con respecto a la explotación pesquera, quebrantándolo en el marco

\footnotetext{
${ }^{1256}$ El Día, 26/05/1999.

${ }^{1257}$ Distintas organizaciones locales expresaron su adhesión: la agrupación S.O.S. Pesca, el Sindicato Luz y Fuerza local, Federación Socialista Popular, entidades de taxistas marplatenses, Sindicato de Trabajadores Municipales, los Democristianos de Mar del Plata y la comisión de Pastoral Social de la Diócesis de la ciudad. Mientras tanto se organizó una misa en la parroquia de la Sagrada Familia pidiendo que la crisis pesquera fuera pasajera.

1258 L.C.,01/06/1999.

1259 L.C., 01/06/1999.

${ }^{1260}$ L.C.,01/06/1999.
} 
del Consejo Federal Pesquero". La UCIP convocó entre las 18.00 y las 18.10 a un apagón en apoyo al sector pesquero. La CGT informó que la actividad marítimo-portuaria realizaría una huelga de 24 horas, en tanto el resto de los gremios adherirían con un paro en los lugares de trabajo entre las 18 y las 18.10.Finalmente tuvo lugar la movilización hacia Buenos Aires y la manifestación frente al Congreso de la Nación. El titular de la CGT regional habló en la sesión de la comisión y expresó que "mi ciudad se encuentra al borde de un estallido social, que nadie quiere, a través de la desocupación de 20.000 trabajadores si no es sancionada esta ley de emergencia" ${ }^{1261}$. Al finalizar se levantó la veda de la merluza y al día siguiente la Ley de Emergencia fue aprobada. ${ }^{1262}$ El texto:

...declara la emergencia pesquera para la especie de merluza común -denominada hubbsi-, y obliga a los buques de la flota congeladora, de mayor tecnificación y generalmente de bandera extranjera, a realizar sus actividades por debajo del paralelo 48, es decir, en las costas de las provincias de Santa Cruz y Tierra del Fuego. ${ }^{1263}$

El Atlántico señalaba que "la decisión de no introducir modificaciones se tomó ante el poco tiempo del que disponen los diputados para mejorar la sanción del Senado, ante la presión de los pescadores marplatenses que amenazaron con instalarse en el puerto de Buenos Aires...". La ley, que fue interpretada por el CEPA como un "mamarracho jurídico", contó con la oposición de los representantes patagónicos, la CAPECA y CAPIP: "El proyecto es fuertemente criticado por los diputados santacruceños y fueguinos, ya que serán sus provincias las afectadas en mayor medida por la ley al obligar a los buques congeladores a pescar sobre las costas de sus territorios" ${ }^{1264}$. También se suspendió la asignación de cupos resultante del proceso de cuotificación hasta el 31 de diciembre de 1999.Al terminar la jornada el intendente Aprile lanzaba un fervoroso discurso:

...esto es un ejemplo más de que, cuando se lucha por algo justo como la dignidad de un pueblo, todo es posible y los marplatenses comprendieron que los problemas sociales son de todos [...] España resolvió gran parte de los problemas con su caladero, pescando en nuestro caladero. Y para toda esta crisis, la solución es trabajar por la renacionalización de la pesca. ${ }^{1265}$

\section{Conflictos al interior de la Multisectorial}

El regreso de los manifestantes fue recibido por numerosas personas instaladas a lo largo de la costa. En el recibimiento participó el obispo José María Arancedo que agradeció a Dios por "no abandonar a sus hijos" y reflejó seguidamente las "tres realidades que se conjugaron: una ciudad que ha expresado su identidad y pertenencia para escuchar el reclamo justo, la solidaridad que expresa la pertenencia de una comunidad y el trabajo, que sabemos es una expresión de la dignidad del hombre, un

1261 E.A., 02/06/1999.

1262 Sin embargo, a través del decreto presidencial que levantaba la veda, los grupos empresarios que contaban con buques congeladores podían seguir pescando si acreditaban la posesión de plantas en tierra.

1263 E.A., 02/06/1999.

${ }^{1264}$ E.A., 02/06/1999.

1265 L.C.,03/06/1999. 
derecho" $" 1266$. Sin embargo, la llegada de los trabajadores volvió a poner en evidencia las contradicciones al interior de la Multisectorial. Mientras los barcos regresaban de Buenos Aires, quienes oficiaban como voceros de la entidad anunciaron que la mejor forma de apoyar la Ley de Emergencia Pesquera era "trabajando". La experiencia de la última movilización semejante había enseñado que los trabajadores ya activados aprovechaban tal estado de situación para reclamar por sus reivindicaciones. Por ello, la conducción de la Multisectorial dio a conocer un documento dirigido a la comunidad pesquera:

A partir del arribo de la flota al puerto de Mar del Plata retoma sus tareas normales y habituales. Los buques que se encuentran en puerto a la espera de la flota podrán zarpar inmediatamente y el resto de las embarcaciones procederán a realizar el alistamiento para la zarpada a tareas de pesca [...] Decidimos que la mejor manera de apoyar la ley de emergencia pesquera es trabajando. Continuaremos con las gestiones necesarias para la inmediata promulgación de la ley recientemente sancionada que ha sido lograda con el esfuerzo de todos.

Además, en una conferencia de prensa, dieron las gracias por el apoyo comunitario. Dejaron en claro que se mantenían en estado de alerta permanente y adelantaron que pedirían una audiencia con el presidente Menem para explicarle la problemática pesquera y exigirle que, como se temía, no vetara la Ley de Emergencia sancionada por el Congreso. ${ }^{1267}$ Esta vez la conducción gremial, en particular la del SOMU, concordaba con los empresarios fresqueros. Conseguida la ley había que salir a pescar. Sin embargo existían disidencias entre los trabajadores y la conducción gremial e incluso entre los propios trabajadores. En contraposición al pedido de quienes encabezaban la Multisectorial, un amplio grupo de obreros y obreras se "autoconvocaron" y luego de una asamblea decidieron no volver al trabajo, no presentarse a embarcar y no salir a pescar, continuando con el paro. Había representantes de marineros, de trabajadores de tierra, así como también de conductores navales y capitanes. Citaron al secretario general de la CGT local y exigieron que el presidente Menem promulgara la ley aprobada por el Congreso. En los días posteriores realizaron distintas medidas de fuerza. De la asamblea en la sede del club Aldosivi participaron más de 500 trabajadores y trabajadoras que expresaron su desconfianza de la dirigencia gremial por "el apuro" para retornar a pescar. ${ }^{1268}$ A su vez, acordaron impedir la salida de buques y llamar a tierra a los que se hallaban pescando. La exigencia apuntaba a la aprobación definitiva de la Ley de Emergencia. En lo que concierne a los trabajadores en tierra se agregaba la denuncia de que sólo trabajaban aquellos que estaban en blanco, mientras que faltaba el pescado para los trabajadores de cooperativas y los que se desempeñaban en negro.

La continuidad del paro, producto de la decisión de un nutrido grupo de obreros y obreras demostrando la fuerza y legitimidad del reclamo, motivó a algunos dirigentes sindicales a rectificar su posición. Uno de ellos fue Novero, que lejos de enfrentar a quienes criticaron su accionar expresó: "si hemos cometido algún error pedimos disculpas, a partir de ahora, todos los gremios junto a la Multisectorial vamos a asegurarnos que no salgan al agua barcos de ninguna clase. Ni los nuestros, ni los amarillos. Vamos a ir al muelle a parar a los amarillos, si es necesario" ${ }^{1269}$.

${ }^{1266}$ L.C.,05/06/1999.

${ }^{1267}$ L.C.,05/06/1999.

1268 L.C., 06/06/1999.

${ }^{1269}$ E.A., 10/06/1999. 
En una nueva asamblea, los trabajadores eligieron "delegados de base" para que funcionaran como nexo entre obreros, la Multisectorial y el gobierno. En ese acto denunciaron presiones para salir a pescar por parte de algunos empresarios, al mismo tiempo que criticaron a las distintas dirigencias gremiales por mantener compromisos políticos con esos empresarios. De este modo, como producto de disidencias previas surgidas en el seno de los sindicatos, nuevos grupos comenzaron a generar procesos organizativos y de militancia a partir de los cuales buscaban diferenciarse de las dirigencias gremiales, construyendo una creciente oposición, sobre todo en el caso del SOIP. ${ }^{1270}$ Mientras tanto el paro continuaba. La dirigencia gremial planteaba la posibilidad de salir a pescar "en rebeldía", mientras que por el contrario un grupo numeroso de trabajadores y trabajadoras estaban decididos a sostener la medida de fuerza. El 23 de junio el Ejecutivo Nacional promulgó sin modificaciones la Ley de Emergencia Pesquera por lo que las embarcaciones fresqueras podían salir a pescar a partir de la madrugada del día siguiente, luego de una inactividad de 28 días. Además, fueron dispuestas una serie de medidas de acción social para los sectores más afectados por la crisis como la eximición de impuestos y el reparto de bolsas de comida. En este marco, la Multisectorial emitió un documento en el que consideraba que ya no existían impedimentos para que se volviera a pescar. El intendente Aprile expresó que "no podemos menos que celebrar". Cumplida la demanda de los marineros y capitanes, no así la de los trabajadores de las cooperativas de procesado de pescado, finalmente se levantó el paro.

Por otra parte, una de las consecuencias de este proceso, siendo los sectores que trabajan en tierra los más afectados ante la falta de pescado, fue que tanto el SOIP como el SUPA se retiraron de la Multisectorial en virtud de la falta de respuestas a sus reclamos. Aquellos que antiguamente habían estado más unidos a los fresqueros, jaqueados por una creciente oposición interna, a través de un comunicado firmado por Juan Saravia explicaban los motivos del abandono de la entidad, pues "a pesar del éxito obtenido en el Congreso Nacional en oportunidad del movimiento realizado para la descompresión de la crisis pesquera en la que hemos trabajado arduamente, hoy no se ven representados los intereses de los trabajadores del sector, en especial los trabajadores en tierra". Continuaba argumentando que el:

...compromiso formal del presidente de la Cámara de Procesadores como del intendente municipal, profesor Elio Blas Aprile, que una vez conseguida la Ley de Emergencia Pesquera se iba a regularizar el pseudo cooperativismo del puerto de Mar del Plata, tal cual lo han demostrado los trabajadores afectados por este sistema. Esto no sólo no se trató, sino que como la postura de nuestro gremio con respecto a la cuotificación no le sirve a sus intereses, de una manera u otra, evitan nuestra participación e intervención en dichos temas.

\footnotetext{
${ }^{1270}$ Desde nuestra óptica, sólo una mirada apresurada diría que se produjo una división entre bases y dirigencias. Esa división, polarizada por un eje institucional oculta más de lo que permite explicar. Lo cierto es que, críticos de la posición de las conducciones gremiales, en un contexto de crisis pesquera, comenzaron a gestarse cada vez de manera más organizada grupos opositores que fueron generando sus propios programas de acción para responder a la crisis. Para nosotros esos procesos deben entenderse como momentos de constitución de direcciones alternativas (lleguen o no a ocupar lugares institucionales dentro de los gremios), expresando la existencia de sectores con programas de acción distintos. El surgimiento y la potencia de estas alternativas será indicador de cambios y transformaciones en la propia subjetividad de la clase trabajadora. Con el tiempo, este proceso llevó en el caso del SOIP a cambiar la conducción gremial. Por el contrario, en el SOMU local, Novero y su grupo continuaron a la cabeza del sindicato sin que su liderazgo fuera cuestionado. Discutimos este aspecto en Colombo (2010).
} 
Además denunció como agravante que:

...muchos de los que integran la Multisectorial, que pelearon supuestamente por los 20.000 trabajadores de la ciudad de Mar del Plata afectados a esta crisis, hoy, conseguidos los objetivos que a ellos les interesaban, han empezado a trasladar los barcos al sur, significando esto no sólo un perjuicio a los 20.000 trabajadores que les preocupaban sino también a la provincia a la que dicen pertenecer, agravando aún más la desocupación y precarización laboral en Mar del Plata. ${ }^{1271}$

Mientras que en declaraciones a El Atlántico, Adrián Casariego (integrante de la CD del SOIP) multiplicaba las críticas al gobierno comunal señalando que "Aprile se borró del puerto, dejó de apoyar a la gente de trabajo que enfrenta el problema de las cooperativas truchas. Hoy está más preocupado por las cuestiones politicas y electoralistas". Para el dirigente gremial, los dueños de las plantas y barcos fresqueros utilizaron "nuevamente a la gente de trabajo para obtener beneficios personales y una vez que lo consiguen, se olvidan de la gente, de su hambre, su necesidad de trabajo, de un salario digno y estabilidad laboral". Explicó que el retiro del SOIP "se debió a la falta de interés de la parte empresaria para dar tratamiento a los asuntos laborales" ${ }^{1272}$. La percepción de estar siendo usados por los empresarios comenzó a expandirse en la subjetividad de los trabajadores y fue uno de los principales argumentos esgrimidos poco tiempo después, cuando obreros y obreras atacaron varias plantas pesqueras.

Daniel Rodríguez expresaba de manera muy gráfica la situación de la Multisectorial. Decía con relación a la partida de los dos gremios "estos contratiempos son riesgos previsibles, dado que en la Multisectorial están funcionando diversas instituciones que expresan diversos intereses; por lo tanto la posibilidad de controversia o puja de intereses sobre un mismo tema siempre estuvo presente".

...el objetivo principal en el nacimiento de la Multisectorial fue la posibilidad de amortiguar la crisis sin producir un quiebre en las relaciones laborales de miles de familias en el Puerto. Este primer objetivo se logró y también es cierto que a partir de ese objetivo, todos fuimos conscientes y lo dije en reiteradas oportunidades, que así como estaba en crisis el recurso por la merluza también estaba en crisis el sistema laboral portuario... Por tanto resulta imprescindible que una vez encaminado el tema del recurso también se encamine el tema laboral, que es un tema fundamental para miles de familias marplatenses $[\ldots]$ no he hablado todavía con los compañeros de ninguno de los dos gremios; pienso que tendrán sus razones para haber tomad[o] sus decisiones en estos momentos. Creo que todo es conversable y pienso que el espíritu que convocó a la Multisectorial es el de encontrar puntos en común para pelear también juntos objetivos en común [...] Ignoro los argumentos y circunstancias para provocar el alejamiento del SUPA y del SOIP de la Multisectorial; creo que hay que trabajar para revertir el tema. Sí digo que acá hay que producir un reacomodamiento en la explotación del recurso y demás, así como un reacomodamiento en el tema laboral... De lo que no estoy muy convencido es si ahora son los tiempos para producir ese reacomodamiento [...] Más allá de los tiempos adecuados para introducir cambios, está el convencimiento de todas las partes en avanzar hacia un reacomodamiento que elimine las condiciones laborales en negro. ${ }^{1273}$

\footnotetext{
${ }^{1271}$ L.C., 13/08/1999.

${ }^{1272}$ E.A., 19/08/1999.

${ }^{1273}$ L.C., $19 / 08 / 1999$.
} 


\section{El proyecto Mar del Plata 2000 o "De cómo permanecer juntos a pesar de todo"}

Las asperezas surgidas nuevamente entre trabajadores y empresarios fresqueros volvieron a subsumirse ante un problema mayor. Esto era el posible cierre del caladero. El 5 de noviembre Ricardo Novo informaba a las cámaras empresarias que se debía cerrar el caladero de merluza por haberse superado la captura máxima permitida. De inmediato, las cámaras y los gremios repudiaron la decisión e hicieron responsable a Novo por las consecuencias sociales que dicho cierre podría acarrear. Sergio Lorusso y el gobernador de la provincia de Buenos Aires, Carlos Ruckauf, se expresaron en contra del cierre y a favor de la pesca con buques fresqueros. Este último, al igual que antes lo había hecho Eduardo Duhalde, en una misiva dirigida a Novo sostuvo que "La explotación nacional del recurso pesquero se debe hacer a partir de darle prioridad absoluta a la pesca artesanal y a los buques que elaboran en tierra" ${ }^{274}$. Por su parte, mujeres de pescadores agrupadas en la organización no gubernamental SOS Pesca dialogaron con el presidente Carlos Menem, quien se comprometió a no cerrar el caladero. Ese mismo mes la Multisectorial se reunió en el palacio Municipal. Para entonces contaba nuevamente con la presencia del SOIP y el SUPA. Aprile presidió la reunión en la que se intentó generar nuevos consensos para responder a las medidas que provenían de la SAGPyA. Entre las iniciativas que se manejaron se trató la creación de un proyecto de pesca para el año 2000 que serviría como base para una nueva legislación más acorde con las necesidades de los actores del sector, sobre todo para tocar aquellos temas que "la comunidad" pesquera local consideraba prioritarios. Entre estos contenidos se ubicaba como prioridad la suspensión del cierre del caladero. Aprile dijo que se iba a "poner a la cabeza" de todos los reclamos. Con todo, el 23 de noviembre la SAGPyA suspendió hasta el 31 de diciembre la pesca de merluza común. La respuesta desde Mar del Plata fue la elaboración del proyecto pesquero Mar del Plata 2000. Aunque sin alcanzar una coincidencia unánime, durante la reunión en el municipio la mayoría de los sectores de la pesca local pudieron armonizaron criterios. El acuerdo sintetizaba las posiciones de la CAABPA, Procesadores y UDIPA, con algunos agregados de los gremios. Respecto al causante de la situación de crisis el documento cargaba nuevamente sobre los congeladores:

El desarrollo de esta pesquería en los últimos años, y fundamentalmente a partir de 1992, constituye el mejor ejemplo de lo que debe hacerse para diezmar un caladero. Un incremento descontrolado de la flota de buques congeladores, que originó una flota pesquera muy por encima de las posibilidades reales del caladero, con su secuela de sobrepesca y desaprovechamiento masivo de la materia prima capturada, originó la actual situación de crisis de este recurso, cercano al colapso de la especie. $^{1275}$

Como propuestas de corto plazo los firmantes exigían:

- Prórroga de la Ley $\mathrm{N}^{\circ} 25.109$ de Emergencia Pesquera hasta la recuperación total del caladero de merluza hubbsi. Este período no puede ser inferior a cuatro años. Esto significa mantener a la flota de buques congeladores pescando exclusivamente al Sur del paralelo $48^{\circ}$, cuando se trata de empresas con buques congeladores y plantas procesadoras en tierra, y al Este de la milla 200, en la

${ }^{1274}$ L.C., 13/11/1999.

${ }^{1275}$ Proyecto Pesquero 2000, Mar del Plata, año 1999. P. 1. 
denominada Zona Adyacente a la Zona Económica Exclusiva Argentina, para las empresas con buques congeladores sin plantas de procesamiento en tierra.

- La flota de buques congeladores deberá dar cumplimiento a lo establecido en la Ley $\mathrm{N}^{\circ}$ 25.109 en lo que respecta a la obligación de contar con plantas elaboradoras de harina de pescado a bordo de estos buques. De no contar con las mismas, deberán congelar la totalidad de los desperdicios de pescado que se producen durante el procesamiento a bordo y descargarlo en tierra para la elaboración de harina.

- Establecer un plan de manejo de la pesquería de merluza para la flota de buques fresqueros, mientras se mantenga la vigencia de la Ley. Esto significa determinar el alcance y fechas de los Paros Biológicos anuales, imprescindibles como una contribución adicional a la disminución del esfuerzo sobre esta especie.

- Los buques fresqueros, cuyos permisos de pesca fueron transferidos a algún buque congelador para permitir el ingreso de este a la Zona Económica Exclusiva Argentina, deberán dejar de operar hasta que los buques congeladores a los cuáles se le han transferido los permisos, salgan del caladero en forma definitiva. ${ }^{1276}$

Como propuesta de mediano y largo plazo se apuntaba directamente a reducir la presencia de buques congeladores en el mar argentino. Sin embargo, a pesar de las coincidencias macro, las diferencias entre empresarios y gremialistas aparecieron al momento de tratar las reivindicaciones de los trabajadores. Estos solicitaban la "imprescindible relación de dependencia" de todo el personal que trabaja en tierra. Y si bien se reconoció la relación de dependencia laboral con los embarcados, no sucedió lo mismo con la gente de las plantas y los estibadores, ya que desde el empresariado se argumentó la existencia de una ley que contempla al desarrollo de las cooperativas de trabajo. Este hecho queda claro en los puntos 5 y 6 del proyecto:

5) El personal embarcado en toda la flota pesquera trabajará en relación de dependencia.

6) El personal de tierra del sector pesquero, portuario, procesamiento e industrialización de los recursos ictícolas, deberán estar en relación de dependencia laboral y dar cumplimiento estricto a la legislación laboral y de seguridad social vigente, sin perjuicio del respeto a otras modalidades legales de contratación de servicios, contempladas en la legislación vigente. ${ }^{1277}$

El plan excluía, nuevamente, las pretensiones del CEPA. Por ello la entidad elaboró un documento aparte indicando que no estaban integrados a la Multisectorial. Comentaron que fueron invitados "pero con algunos condicionantes, y no a agenda abierta". El texto se tituló "Análisis de situación y propuesta para el relanzamiento de la actividad pesquera", el cual fue entregado al intendente Aprile. Señalaban cinco limitantes para la pesca: bajo stock de merluza hubbsi, sobreinversión en flota en relación con los recursos; altos costos internos de insumos y servicios; política fiscal y tributaria; aranceles que gravan las inversiones de capital que generan mano de obra; escasez del crédito y alto valor de los intereses bancarios. Como solución, las empresarios exigían que se fijase una política de promoción a la

\footnotetext{
${ }^{1276}$ Proyecto Pesquero 2000... P. 2 y 3.

${ }^{1277}$ Proyecto Pesquero 2000... P. 6. Firmaban el proyecto la Municipalidad del Partido de General Pueyrredón, la CAABPA, la Cámara Argentina de Procesadores de Pescado, Asociación de Embarcaciones de Pesca Costera, Cámara Argentina de Industriales de Pescado, UDIPA, UCIP, Centro de Patrones Fluviales de Pesca y Cabotaje Marítimo, SUPA, Asociación Argentina de Capitanes y Patrones de Pesca, SOMU, SICONARA, SOIP, Federación de Cooperativas de Trabajo de Actividades Portuarias, Navales, Pesqueras y Afines de la República Argentina y CGT regional Mar del Plata.
} 
producción y a las exportaciones pesqueras que contuviera: reintegro por las exportaciones; eliminación de impuestos distorsivos; reducción en el valor de las tasas que se pagan por los servicios; rebaja de aranceles para la importación de maquinarias y equipos y, por último; tasas preferenciales de créditos para las empresas.

En este contexto, la Multisectorial buscó conseguir la prórroga de la Ley de Emergencia que tenía vigencia hasta el 31 de diciembre. Finalmente, ya bajo el gobierno de La Alianza, el primero de enero el presidente Fernando De la Rúa decretó la continuidad de la emergencia. Se fijó en 24 mil toneladas la CMP de merluza para los fresqueros durante noventa días. Los congeladores sólo podrían operar al sur del paralelo 48. Ante el anuncio, el CEPA presentó sus quejas. Oscar Fortunato envió un comunicado a Antonio Berhongaray, nuevo titular de la SAGPyA, rechazando la resolución:

...es un error que los buques tangoneros o langostineros, los buques poteros, los palangreros y los que pescan vieira no podrán pescar ninguna de las especies que normalmente pescan al norte del paralelo 48, porque inicialmente son buques congeladores. Este punto demuestra claramente la intencionalidad y el preconcepto de discriminar al buque congelador independientemente de su empresa u origen, de su área de pesca y de su forma de operar. Se lo discrimina sólo por ser congelador. ${ }^{1278}$

Por el contrario el sector fresquero y costero se mostró satisfecho. Graciela Piergentilli dijo que "la verdad es que esperábamos que se hiciera algo, pero no imaginábamos una medida tan profunda como la que se tomó" y "estamos gratamente sorprendidos". Homero Cánepa consideró que las medidas adoptadas eran las adecuadas. ${ }^{1279}$ Al día siguiente, la Multisectorial brindó una conferencia de prensa encabezada por Aprile. Allí manifestaron su satisfacción por la declaración de la Emergencia Pesquera. Dijo el intendente en relación a la importancia de la Multisectorial: "Hemos formado una alianza por encima de las diferencias politicas, partidarias, económicas y sectoriales [...] cuyo fin es defender la pesca como generadora de mano de obra". Respecto a la emergencia declaró que "satisface plenamente a la Multisectorial por cuanto no refleja más que lo que nosotros planteamos como proyecto de política pesquera en el proyecto 'Pesca 2000', entregado a De la Rúa a fines del año pasado"1280. Sin embargo, a pesar del confinamiento que los relegaba al sur del paralelo 48, los buques congeladores marplatenses pudieron salir a pescar al norte de dicho paralelo a través de un recurso de amparo al que dio lugar un juez en Rawson. ${ }^{1281}$ Por lo tanto, las dos flotas continuaron operando sobre el Mar argentino, aunque por parte de los congeladores sólo lo continuaron haciéndolo las empresas que poseían, además de congeladores, plantas en tierra.

\footnotetext{
${ }^{1278}$ L.C., 05/01/2000.

${ }^{1279}$ L.C., 03/01/2000.

${ }^{1280}$ L.C., 04/01/2000.

${ }^{1281}$ Impulsada por los empresarios integrados marplatenses con el argumento de haber sido discriminados, los recursos de amparo se presentaron en un juzgado de Rawson, lo que según Darío Sócrate, se trató de una maniobra rara. Particularmente porque Rawson tiene como cámara de apelaciones la cámara de Comodoro Rivadavia, que en ese momento, de los tres jueces tenía sólo nombrados dos. Uno era favorable al amparo y otro no, con lo cual no se podía resolver, pero como los recursos de amparo funcionan con medidas de primera instancia finalmente tuvieron lugar. Entrevista del autor con Darío Sócrate op. cit...
} 


\section{Una crisis en espiral}

Las medidas para restringir la pesca, con marchas y contra marchas, no lograban reducir la actividad a niveles aceptables para la reproducción del recurso. En buena medida porque nunca terminaban de implementarse. Por ello, a pesar de estar en vigencia la Ley de Emergencia, el 9 de febrero de 2000 la SAGPyA decretó una nueva parada biológica para la pesca de merluza. A partir del día 15 los buques fresqueros no podrían pescar durante 30 días. La decisión se tomó porque en poco menos de un mes y medio se superaron las 24 mil toneladas de merluza fijadas para tres meses. Empresarios "fresqueros", funcionarios provinciales y gremialistas marplatenses nuevamente se mostraron disconformes con la medida. Después de una serie de reuniones volvía a recrearse la Multisectorial. E1 ahora subsecretario de Pesca de la provincia, Francisco Romano, expresó sus quejas por la medida que, según sus palabras, "afectará de lleno a Mar del Plata". También la CAABPA se mostraba disconforme al igual que los sindicatos. Domingo Novero expresó que si la parada biológica se lleva a cabo hay muchas empresas que van a quebrar y advirtió que "la desocupación crecerá hasta indices insospechados, incluso tengo gente que hace más de dos meses que no salen a pescar" 1282 . Después de varias reuniones y con el apoyo de Aprile, la Multisectorial decidió lanzar una ofensiva pidiendo que la veda no fuese tan rígida. Nuevamente Darío Sócrate señaló que "el municipio brindará total apoyo a la comunidad pesquera marplatense" sin importar que en el gobierno nacional haya un partido con el mismo color político "porque nuestro trabajo es representar a la gente de Mar del Plata"1283. Después de muchas idas y vueltas, el 19 de febrero representantes del gobierno nacional y de la Multisectorial, estos últimos encabezados por el propio Aprile, firmaron un acta de intención en la cual se estableció que a partir del 27 de febrero se levantaba la veda. El gobernador Ruckauf respaldó la decisión y manifestó su acuerdo con la carta de intención. Los puntos centrales del acuerdo apuntaron a ejecutar paradas escalonadas y una mayor planificación de la actividad. Finalmente, el 28 de febrero se levantó la veda de merluza y los barcos fresqueros salieron a pescar. La veda había sido prevista para 30 días. Sin embargo las gestiones entabladas por la Multisectorial posibilitaron achicar el margen a 12.

De este modo, la situación de fondo continuaba sin resolverse. A través de distintas argucias legales, gestiones y presiones políticas, las flotas pesqueras continuaban su actividad presionando sobre el recurso. El titular del INIDEP, Ramiro Sánchez, planteó un cuadro de situación alarmante en relación a la población de merluzas. En el año 1999 el máximo de captura era de 150 mil y se habían pescado 290 mil toneladas. La pesca máxima para el 2000 debía ser de 110 mil toneladas. Según el organismo no había salida: se debía suspender la pesca por un año. Novero, al salir de la reunión en que se conocían esos informes, expresó que "Es un desastre todo esto". Cayetano Arcidiácono, de la Asociación de Embarcaciones de Pesca Costera, dijo "Es un golpe mortal...". Novero era contundente "lo poco que haya de todas las especies, que lo pesquen los fresqueros argentinos. De una vez por todas se debe tomar la decisión política de decir no más a los congeladores". Respecto a la posible parada biológica señaló "Nosotros lo que queremos es trabajar. Ayuda social no hay, asi lo hizo saber el Gobierno nacional". Y anunció que entre todos los gremios "vamos a hacer un proyecto de ayuda para la gente y dárselo a la Provincia para que actúe. Pero esa no es la solución; la solución es poder trabajar". En abril Novero se reunió con Sócrate y le pidió una reunión urgente de la Multisectorial. El objetivo era comenzar "ya $a$

\footnotetext{
${ }^{1282}$ L.C., 11/02/2000.

${ }^{1283}$ L.C., $17 / 02 / 2000$.
} 
implementar un plan de lucha que desemboque con un paro y movilización de la ciudad el día 18, cuando se inicie la parada biológica". Ese día "tenemos que parar todos y de una vez por todas exigir que se arregle el tema de la pesca, porque si de acá a fin de año vamos a trabajar solamente dos meses, será insuficiente para Mar del Plata porque no puede estar parada durante tanto tiempo" ${ }^{1284}$.

Mientras tanto la SAGPyA fijó una nueva parada biológica para la pesca de merluza, mientras se conoció la resolución del paro decretado por los trabajadores. ${ }^{1285} \mathrm{Al}$ igual que en anteriores intentos de implementar restricciones las medidas generaron la reacción de "la comunidad" pesquera marplatense. Los gremios se declararon en estado de alerta y movilización. El SOIP acusó a las autoridades nacionales de utilizar a la industria pesquera como "moneda de canje" y convocó a los trabajadores a manifestar su disconformidad mediante su "presencia masiva en las calles". Carlos Darguibel expresaba una gran desazón al corroborar que:

...después de muchas reuniones, consultas, preguntas y respuestas con respecto a las mejores medidas a adoptar para la solución de la problemática pesquera que padece toda la ciudad de Mar del Plata y el resto del país, los responsables dictaminan resoluciones como la 145/2000 [...] Es entonces cuando nos damos cuenta que los trabajadores no les interesamos y que la industria pesquera argentina sigue siendo moneda de canje. ${ }^{1286}$

El texto también acusaba a los "funcionarios de turno" por "despilfarrar el recurso", contradiciendo "las proclamas del excelentísimo presidente de los argentinos, Fernando de la Rúa, cuando en sus discursos proclama que el Mar Argentino es para los argentinos". Por último, el sindicato consideró que "ante esta situación la única posibilidad que les queda a todos los trabajadores es manifestar su disconformidad con las medidas tomadas, mediante la presencia masiva en las calles de la ciudad para reclamar con dignidad la fuente de trabajo que nuestros funcionarios no supieron defender" ${ }^{2287}$. Por su parte, la CAABPA y la Cámara de Procesadores denunciaron que las últimas resoluciones ministeriales "son una clara señal de un perversa política pesquera que tiene como único objetivo la destrucción del modelo pesquero fresquero, basado en los buques fresqueros y las plantas procesadoras en tierra, dejando la actividad a merced de la flota congeladora con su mayor poder económico y de lobby" ${ }^{1288}$. Al día siguiente, gremios y empresarios realizaron una protesta en Mar del Plata. Y el 26 de abril, los trabajadores nucleados en el SOMU y los Conductores Navales resolvieron realizar un paro total de actividades en reclamo de una política nacional que protegiera el accionar de los buques fresqueros. Alrededor de 400 trabajadores reunidos en asamblea aprobaron un documento, posteriormente elevado al presidente de la Nación, en el que reclamaron:

- Expulsar definitivamente los buques congeladores y factorías que son los principales actores de la crisis del recurso;

- Garantizar la continuidad normal del trabajo para los buques fresqueros;

\footnotetext{
${ }^{1284}$ L.C., $06 / 04 / 2000$

${ }^{1285} \mathrm{El} 6$ de abril se dictó la veda para preservar la merluza por la cual los barcos pesqueros solo podrían salir a pescar entre el 1 de mayo y el 30 de noviembre en cuatro mareas. El total de merluza a capturar no debía superar las 35 mil toneladas divididas de la siguiente manera: flota costera, 3.500 toneladas; flota fresquera 24.000; flota tangonera, 1.500; flota congeladora 6.000. Esta última, debería permanecer 30 días en los muelles después de sus desembarques.

${ }^{1286}$ L.C. $21 / 04 / 2000$.

${ }^{1287}$ L.C. $21 / 04 / 2000$.

${ }^{1288}$ L.C. $23 / 04 / 2000$.
} 
- Aplicar la relación de dependencia de todo el personal involucrado en la actividad;

- Abonar al personal embarcado sin excepción los francos a promedio;

- Establecer el aumento del precio del pescado y los salarios.

El texto fue respaldado por la Multisectorial y también por Aprile, tras una movilización masiva desde la Manzana de los Circos (en el puerto de la ciudad) hasta el Palacio Municipal ubicado en el centro. Mientras se producía la reunión de la Multisectorial, trabajadores en las afueras de la comuna reclamaron con bombos, cánticos y cortes de tránsito la adhesión de la Multisectorial al paro dispuesto por el SOMU. Pero la falta de consenso sobre el paro fue palpable desde el comienzo de la reunión, cuando los distintos representantes de los sectores empresariales manifestaron sus posiciones con respecto a la propuesta. Días después en una nueva movilización, Aprile renovó su compromiso con el sector pesquero expresando que su lugar es "estar junto al pueblo y aqui me quedo hasta la última gota de lucha de todos ustedes" y sentenció que "hay que privilegiar a los fresqueros, los congeladores destruyeron el mar" ${ }^{1289}$. Los días siguientes se gastaron en la organización de una nueva movilización a Capital Federal.

En definitiva, el 10 de mayo se produjo la tercera marcha de quienes se consideraban como "la comunidad pesquera marplatense" (dejando fuera al CEPA) a la ciudad de Buenos Aires. Esta vez, siendo la movilización más numerosa según los datos de la prensa, más de 6 mil personas se congregaron en la Plaza de Mayo. Como respuesta el gobierno se comprometió a enviar un proyecto de ley al Congreso para declarar una vez más la emergencia pesquera. De esta forma se arribó a un principio de acuerdo. La normativa pretendía garantizar la continuidad de la fuente laboral de los trabajadores, al menos hasta fin de año e impedir la actividad de buques factorías extranjeros. Además, se comprometieron a revisar todos los permisos de pesca otorgados en la última década a los barcos congeladores. Tales decisiones fueron adoptadas tras negociaciones entre De la Rúa, Aprile y representantes de la Multisectorial. Durante la movilización de la Multisectorial se sumó una numerosa columna de la CGT "disidente" encabezada por Hugo Moyano. ${ }^{1290}$ Al terminar la reunión, Aprile indicó que con el nuevo proyecto de ley se podrá sacar a los congeladores fuera del paralelo 48, eliminar los barcos con permisos mal dados y castigar a quienes están depredando. Sobre la posibilidad de asignar subsidios informó que:

...empezaremos a conversar con el Ministerio del Interior que ya comprometió un millón de dólares con destino a una contención social en el puerto. Felipe Solá prometió la misma cantidad por parte de la Provincia. Los subsidios nacionales serán administrados por la Comuna y la Multisectorial. Buscaremos un mecanismo similar con la Provincia. ${ }^{1291}$

Producto de la experiencia previa, nuevamente se planteaba la cuestión de los trabajadores al regreso de la movilización. Consultado el intendente sobre si los marineros deberían levantar el paro Aprile respondió "Si levantan el paro, lo deben decidir ellos, pero creo que sí, que están dadas las condiciones para volver a pescar". Al día siguiente la Multisectorial expresó su satisfacción por el compromiso asumido por el presidente de enviar al Congreso una nueva ley de Emergencia. Empresarios y gremialistas se mostraron satisfechos con la movilización y el apoyo de las autoridades. No obstante, al

\footnotetext{
${ }^{1289}$ L.C.,29/04/2000.

${ }^{1290}$ La madre de Hugo Moyano trabajó como filetera, algo que insistentemente recuerda el líder camionero.

${ }^{1291}$ L.C., $11 / 05 / 2000$.
} 
día siguiente, también los congeladores se movilizaron y obtuvieron el compromiso por parte de Berhongaray de continuar con las tareas de pesca. De aquella movilización participaron los empresarios del CEPA. Esto motivó el desconcierto de la Multisectorial y acentuó las divisiones y enemistades dentro del empresariado pesquero marplatense. La campaña en contra de los buques congeladores y de las empresas que operaban con ellos se corporizó en la ciudad en una furia cada vez mayor hacia las firmas Solimeno, Moscuzza y Valastro. ${ }^{1292}$ Si previamente generaban antipatías dentro de los integrantes de la Multisectorial, ahora y tras haber participado de una movilización "pro-congelador", la antipatía trocaba en manifiesta hostilidad. Tal es así que el 28 de junio de 2000, en el marco de una manifestación de trabajadores, algunas de las plantas pesqueras de aquellos grupos empresarios fueron atacadas (desarrollamos este hecho en el capítulo siguiente). ${ }^{1293}$

\section{Nuevas tensiones dentro de la "convergencia"}

Suele cumplirse aquel postulado de que la historia se repite, pero no como tragedia sino como farsa. Al arribo de la movilización a la ciudad, los reclamos laborales de los trabajadores no obtuvieron respuesta. Por ello, los obreros marítimos y portuarios ratificaron el paro que venían cumpliendo. Las distintas asambleas que mantenían el SOMU, SUPA, la Asociación de Capitanes y Pilotos de Pesca, el Sindicato de Conductores Navales y el Centro de Patrones de Pesca decidieron continuar con la medida porque los empresarios, el pasado año y tras la aprobación de la Ley de Emergencia Pesquera "se habían comprometido a sentarse a dialogar y nunca lo hicieron" destacaron los referentes gremiales. En el documento elaborado por los sindicatos marítimos, además de los puntos compartidos con los empresarios, como la expulsión de los congeladores y continuidad normal de pesca, se especificaron otros tres: aplicación de la relación de dependencia de todo el personal involucrado en la actividad, abono al personal embarcado sin excepción de los francos promedio, aumento del precio de pescado pagado y de los salarios. Por su parte, los trabajadores del SUPA también decretaron el paro por tiempo indeterminado y exigieron el blanqueo de la actividad: "Queremos que la estiba sea respetada"1294. Nuevamente el SOIP se mantenía ajeno a la medida de fuerza.

Mientras tanto, entre el 17 y el 20 de mayo la Multisectorial y la SAGPyA acordaron los términos en que se continuaría la pesca. Después de algunas negociaciones, el día 20 de mayo en el Concejo Deliberante de la ciudad de Mar del Plata los representantes de la Multisectorial brindaron una conferencia de prensa. Aprile reconoció que en esta ocasión "se puso la camiseta" de "los fresqueros". Todos los oradores coincidieron en la satisfacción por el resultado de las cuatro jornadas de deliberaciones y remarcaron la predisposición de Antonio Berhongaray para destrabar el conflicto. Sócrate calificó como "muy satisfactorio el acuerdo logrado, que permitirá pescar la merluza hasta fin

\footnotetext{
1292 A comienzos del mes de junio la Multisectorial Pesquera dio a conocer un fuerte documento donde cuestionaba un acta acuerdo firmado entre el gobierno y el sector de los congeladores. Allí denunciaban la presencia de empresarios que "han operado permanentemente en contra de los intereses de la ciudad". Repudiaban específicamente el accionar "del señor" Oscar Fortunato y de las empresas asociadas a dicha entidad, quienes participaron de una movilización por los reclamos patagónicos y suscribieron un acta compromiso en forma conjunta con cámaras congeladoras. L.C.,06/06/2000.

${ }^{1293}$ Es interesante notar que también el grupo Barilari poseía buques congeladores, pero la conducción empresaria realizó esfuerzos por separarse de aquel grupo. En ese sentido, Francisco Barilari explicaba que convirtió en fresqueros a sus barcos congeladores para contribuir con la conservación del caladero y denunció un "lobby perverso y agresivo" que resulta "dañino para el puerto de Mar del Plata” por parte de las empresas con buques congeladores. L.C.,22/10/2000.

${ }^{1294}$ L.C., $13 / 05 / 2000$.
} 
de este año a la flota fresquera que genera trabajo en las plantas elaboradoras". Por su parte, Aprile expresó que mientras se gestó la resolución “en ningún momento se politizó partidariamente, porque se tuvo como objetivo el interés común de la gente. En segundo lugar funcionó como práctica la solidaridad porque actuamos como frente común, representando al sector más sufrido" ${ }^{\prime 1295}$.

Sin embargo, una vez más en las asambleas de los gremios pesqueros se decidió continuar con el paro hasta tanto los empresarios no dieran respuesta a los reclamos obreros. El 24 de mayo, Novero señaló "los empresarios algo van a tener que dar porque de esta manera nadie se mueve" ${ }^{1296}$. El día 26, reunidos en la sede de la CGT local, los gremios pesqueros acusaron a los empresarios nuevamente de haber "usado a los trabajadores" para asegurarse la captura de la merluza y luego haberlos "dejado tirados en la calle". José San Martín, nuevo titular de la central, manifestó su respaldo al reclamo de los trabajadores y expresó su deseo de que "no vuelva a repetirse la misma historia de tiempo, en la que los trabajadores son los que ponen la cara y los empresarios los que se quedan con toda la plata". Los gremios anunciaron su intención de "mantenernos unidos en el reclamo y no parar la medida de fuerza hasta tanto no estén satisfechos todos nuestros reclamos". Y expresaron su hastío respecto de que los empresarios no se sentaran a dialogar, apelando a la situación de la pesca: "Cuando el año pasado salió la Ley de Emergencia se comprometieron a conversar sobre todos estos temas y nunca más se habló". ${ }^{297}$

El 29 de mayo un grupo de trabajadores se movilizó a la sede de la CAABPA y comenzaron a atacarla. La respuesta del sector empresario no se dejó esperar. Presentaron una denuncia penal con el objetivo de "identificar responsables" de lo que calificaron como un "acto delictivo" y dieron a conocer un comunicado en el que acusaron a los manifestantes de estar "pagos por la flota congeladora". El texto recordaba que "ocho mil trabajadores, junto a empresarios de la pesca marplatense, estuvimos en Plaza de Mayo sin estropear un solo cantero y sin romper un solo vidrió, buscando garantizar la continuidad laboral". La cámara calificó de minúsculo al grupo de manifestantes y los definió como "patoteros". Por su parte el CEPA dio a conocer un comunicado en el que repudió las "acciones violentas de que fue objeto la Cámara de Armadores y Procesadores de Mar del Plata". Consideraba que el camino para lograr una solución "no es éste, sino el del diálogo, donde sepamos aceptar el consenso y el disenso de todos los sectores: gremiales, empresarios y oficial".

Durante los días siguientes la CAABPA continuó repudiando los hechos de violencia. Señalaron que estaban abiertos al diálogo pero sobre la base del trabajo. Respecto a los salarios del personal embarcado, expresaron que no eran salarios de hambre y que ante la situación nacional tendiente a rebajar los salarios, ellos no pidieron que se rebaje sino que todo siga igual. Ricardo Angeleri declaró que no encontró "motivos racionales" para los sucesos que tuvieron lugar frente a la sede de la Cámara, pero reconoció que:

...evidentemente hay mucha gente que se encuentra en estado de desesperación porque hace más de 45 días que no están saliendo a trabajar. Y es gente que no está habituada a estar en tierra, que generalmente se encuentra 24 a 25 días embarcada y cuyo ámbito de trabajo es el mar y son felices allí. A veces cuando están en un ámbito que no es el apropiado puede haber un comportamiento como el del día de ayer. ${ }^{1298}$

\footnotetext{
${ }^{1295}$ L.C., 21/05/2000.

${ }^{1296}$ L.C., $25 / 05 / 2000$.

${ }^{1297}$ L.C. $27 / 05 / 2000$.

${ }^{1298}$ L.C.,31/5/2000.
} 
Más allá de estas curiosas apreciaciones sobre el carácter de los trabajadores marítimos, después de aquellos hechos se creó una mesa de diálogo entre trabajadores y empresarios mediada por representantes de la Comuna, la cual no alcanzó mayores logros. Las demandas de cada sector iban por canales diferentes. Mientras el conflicto se agudizaba en términos de clase, la Multisectorial pesquera se quejaba de un convenio firmado por la SAGPyA con los congeladores, ${ }^{1299}$ a la vez que repudiaban al CEPA, argumentando que "han operado permanentemente en contra de los intereses de la ciudad". Al mismo tiempo, las divisiones horizontales se profundizaban. Mientras el SOMU local ratificaba el paro sin aceptar la propuesta de la CAABPA, denunciaba al SOMU nacional porque "apoya a los congeladores para seguir pescando y ahoga a nuestro paro, porque a ellos les conviene tener la flota de fresqueros sin salir" ${ }^{1300}$. El 26 de ese mismo mes los empresarios no se presentaron a una reunión en el Ministerio de Trabajo. Novero declaró que "nos vamos con bronca porque los empresarios no han estado en la reunión, y nosotros vinimos bastante optimistas pensando que hoy se iba a solucionar el problema". Para lograr una solución del conflicto los integrantes de la cámara deberían reconocer "algo mínimo entre los que pedimos y lo que nos ofrecen, para ellos no es nada y para nosotros es mucho". Los trabajadores se retiraron entre indignados y decepcionados. "Esta audiencia fracasó y es lamentable, porque la gente en Mar del Plata estaba muy optimista. No sé qué intereses defienden estos empresarios porque no hay vistas de que se solucione el conflicto", concluyó Novero. ${ }^{1301}$ Al día siguiente el dirigente señalaba "Esperaremos hasta el viernes a las 11, cuando se reanude la audiencia. Veremos cómo podremos contener a la gente que, lamentablemente como nosotros, se siente usada"1302. El día siguiente estuvo signado por la furia de los trabajadores en contra de algunas empresas pesqueras. Este hecho condensa distintos rasgos del período, con la particularidad de que ocurrieron todos el mismo día, al tiempo que presenta características distintivas y por ello presentamos un análisis específico en el capítulo siguiente.

\section{Recuperación de los stocks de merluza, nuevos vaivenes en la disputa fresqueros vs. congeladores y movimientos en la escena gremial}

Dentro de los aspectos más salientes de los conflictos que siguieron a los sucesos de junio (que analizamos en el capítulo siguiente) se destacaron, sobre la base de una incipiente recuperación de los stocks de merluza, la creación de un nuevo sindicato de pescadores en Mar del Plata y la conformación de una efímera Intersindical Marítima y Portuaria. Veamos cómo se produjeron esos procesos. Después de los hechos del 28 de junio, el SOMU alcanzó un acuerdo con la CAABPA. Los marineros, que exigían un piso de 30 pesos por franco compensatorio y un monto de 250 como fondo del SOMU, y los empresarios que se mantuvieron firmes en su postura de pagar 26 pesos el franco y 200 el fondo, llegaron a un arreglo parcial al conceder estos últimos 30 pesos del franco, pero fijar en 200 el fondo para el SOMU. Novero

${ }^{1299}$ El 2 de junio de 2000 la SAGPyA firmó un acuerdo con las empresas y sindicatos vinculados a buques congeladores, los cuáles desde días atrás realizaban protestas en Capital Federal. La medida se tomó luego de que los propietarios de buques aceptarán reprocesar el pescado en plantas habilitadas en tierra, mientras que el gobierno redujo a cinco días la obligación de amarre para sus buques. Se permitió a partir de entonces a los congeladores realizar tareas de pesca durante una misma marea, tanto dentro de la ZEE como en la Zona Adyacente, sin necesidad de tocar puerto entre una y otra fase. Previamente, los buques congeladores amenazaron, y se dirigieron, a pescar en la zona económica de las Islas Malvinas, lo que podría haber generado un grave conflicto diplomático.

${ }^{1300}$ L.C., 06/06/2000.

${ }^{1301}$ L.C. $27 / 06 / 2000$.

${ }^{1302}$ L.C., $28 / 06 / 2000$. 
consideró que "los empresarios parece que querían seguir dilatando las cosas, y por lo que vi creo que están desunidos en la Cámara. Pero en realidad lo que nos importa es que nosotros si estamos unidos". Con este convenio "se dignificó al trabajador y es una satisfacción para todos". Otros pescadores señalaron que si bien el acuerdo no se ajustó exactamente a sus expectativas, fue suficiente como para iniciar el camino de la conciliación. Dentro de los términos del entendimiento se lee:

...las partes dan por finalizada la situación de hecho ocurrida hasta la fecha, retrotrayéndose la situación de la misma al estado anterior a la iniciación del conflicto. Lo expuesto conlleva la inmediata normalización de las tareas y el compromiso empresario de no adoptar medidas disciplinarias ni persecutorias contra el personal alcanzado por el presente acuerdo [...] ambas partes se comprometen a mantener la paz social laboral por el término de un año, comprometiéndose a no adoptar medidas que alteren la misma debiendo comunicar previamente a esta autoridad administrativa laboral toda situación en tal sentido. ${ }^{1303}$

El 3 de julio el SOMU levantó el paro, aunque la flota continuó parada porque se prolongó el conflicto con los otros gremios marítimos. En este contexto surgió una disputa entre los marineros de la pesca costera afiliados al SOMU y la Asociación de Embarcaciones de Pesca Costera, lo que terminó por descomponer totalmente las relaciones del SOMU nacional con su sede local, provocando la separación de Domingo Novero del sindicato. El conflicto surgió a partir de que la conducción nacional del SOMU, sin consultar con la conducción local, firmó un nuevo convenio colectivo con la Asociación de Embarcaciones de Pesca Costera, el que afectó la situación de los marineros de dicha flota en Mar del Plata. Este nuevo convenio de trabajo fue rechazado por los marineros, quienes preferían mantenerse amparados por el viejo laudo de 1975. El convenio finalmente no fue homologado. Lo que si ocurrió fue el abandono de un Congreso General Extraordinario del SOMU realizado en Capital Federal por parte de Novero y su grupo. El dirigente se fue momentos antes de que se votara su expulsión del sindicato y, dando muestras de estar preparado para reaccionar a su exclusión, expresó que:

...me retiro con mis compañeros del SOMU y ahora vamos a formar nuestro sindicato de trabajadores de marinería de Mar del Plata, el que se va a llamar SIMAPE, Sindicato Marítimo de Pescadores $[\ldots]$ Ya tenemos más de mil doscientas firmas de compañeros adherentes [...] Queremos hacer un sindicato de Mar del Plata. ${ }^{1304}$

Del otro lado, Enrique Omar "El caballo" Suarez, líder del SOMU nacional, justificó la expulsión argumentando que las actitudes de Novero:

...fueron contrarias a las obligaciones que a éste le incumbían según las pautas estatutarias que rigen la actividad de esta organización. En base a ello y las anormalidades detectadas, como lo fue el cobro de aportes y contribuciones en forma directa, sin estar autorizado para ello, perjudicando así no sólo al gremio sino también a toda la comunidad marítima. ${ }^{1305}$

\footnotetext{
${ }^{1303}$ L.C., 02/07/2000.

${ }^{1304}$ L.C., 31/08/2000.

${ }^{1305}$ L.C., 08/09/2000.
} 
De este modo, tras la expulsión de Novero, alrededor de 1.200 trabajadores marineros pescadores de Mar del Plata conformaron un nuevo sindicato con la idea de representar específicamente a los pescadores locales (e inspectores de pesca), rompiendo con lo que veían como imposiciones de una conducción nacional poco proclive a atender las particularidades locales de los trabajadores pescadores. Reaccionando así contra una estructura gremial que, entre otras cuestiones, obligaba a concentrar el manejo de recursos financieros en la conducción nacional, la cual representaba también otras ramas de la economía como el transporte marítimo, el personal de buques petroleros y actualmente hasta los trabajadores del Casino de Buenos Aires. ${ }^{1306}$ Repetidamente Novero expresó ideas como: "Para saber lo que pasa en Mar del Plata nada mejor que estar en Mar del Plata" ${ }^{1307}$. El SIMAPE obtuvo la inscripción gremial y en el año 2007 consiguió la personería jurídica. El estatuto lo declara sindicato de primer grado pero restringe su incumbencia al ámbito de representación en Mar del Plata. Esta restricción geográfica remite a lo acordado con la conducción del SOMU, que aceptó que el SIMAPE obtuviera la personería gremial siempre y cuando "no saque los pies de Mar del Plata"1308. Al mismo tiempo, el SOMU continuó funcionando bajo una intervención nacional y, según algunas estimaciones, con el 30\% de su antigua afiliación. ${ }^{1309}$ De todos modos, la convivencia de los sindicatos sufrió diferentes vaivenes y las relaciones aún hoy presentan fuertes tensiones. ${ }^{1310}$

Por otra parte y volviendo al año 2000, en el mes de octubre un pedido de las provincias con litoral marítimo de la Patagonia generó el descontento de sindicatos y empresarios pesqueros marplatenses. El día 10 de ese mes el gobierno de Chubut, a instancias de Jorge Riobo, subsecretario provincial de pesca, solicitó ante el CFP un permiso para que los buques congeladores puedan operar al norte del paralelo 48, dentro de un corredor comprendido por la milla 170 y la 200. La solicitud despertó la inmediata oposición del subsecretario de Pesca bonaerense, Francisco Romano, quien interpretó el pedido como un ataque al sector fresquero. La solicitud fue rechazada por el CFP en base a los informes disponibles del INIDEP. Aunque el organismo decidió rever su posición en caso de que el instituto presente un nuevo estudio que no desaconseje la operación. Por su parte, desde las cámaras "fresqueras" cuestionaron el proyecto. Castro Arán manifestó su absoluto rechazo al planteo de Riobo y aseguró que "desde el mes de diciembre los congeladores están inventando cualquier excusa para poder subir al norte del 48" "1311.

Por otro lado, la experiencia previa en la Multisectorial y la extensión de los fracasos de la entidad en alcanzar soluciones de fondo para los trabajadores llevaron a que el conjunto de los sindicatos pesqueros (a excepción del SOMU) buscaran reconstruir, en la significativa fecha del 17 de octubre, una Intersindical Marítima y Portuaria. ${ }^{1312}$ Se buscaba la defensa del sistema fresquero pero desde una

\footnotetext{
${ }^{1306}$ Se atribuye a Omar Suarez la expresión “Todo lo que se mueve sobre el agua es mío". Diario El Clarín, 03/04/2011. Novero podría decirle que aquello no se cumplía con los marineros pescadores de Mar del Plata.

${ }^{1307}$ Revista Pesca y Puertos, 31/07/2006.

${ }^{1308}$ Entrevista del autor con Pablo Trueba, secretario adjunto del SIMAPE (Mar del Plata, 31/01/2011).

${ }^{1309}$ Entrevista del autor con Pablo Trueba... op cit.

${ }^{1310}$ El punto más alto de estas tensiones se produjo luego de que Néstor María, secretario de la delegación local del SOMU, sufriera una paliza. Tal situación se produjo en el contexto de negociaciones paritarias, momento que ponía sobre la mesa la fundamental cuestión acerca de cuál de los sindicatos aparecería rubricando el nuevo Convenio Colectivo de Trabajo. Entre los cinco hombres que atacaron a María se encontraba el tesorero del SIMAPE, Jorge Andrade. Pocos días después de este acontecimiento, el 3 de mayo de 2010 Andrade fue asesinado en un hecho que permanece aún sin ser aclarado y que albergó las sospechas -al menos en la prensa escrita- de estar vinculado al enfrentamiento gremial. Diario La Nación, 05/05/2010.

${ }^{1311}$ L.C., $11 / 10 / 2000$.

${ }^{1312} \mathrm{La}$ entidad se conformó con la presencia de Arturo Barrionuevo de SAON, Juan Carlos Ferreira del SUPA, Dante Onufrovich del Centro de Patrones de Pesca, José Benvenuto de la Asociación de Capitanes, Ricardo Alonso de la Asociación del Personal
} 
perspectiva obrera. Esto es, respetando las reivindicaciones de los trabajadores. Entre las razones de su formación los dirigentes expresaron que, ante la grave situación que atraviesan las actividades portuarias, marítima y pesquera "la actuación individual de los gremios provoca una atomización del esfuerzo de lucha, en busca de objetivos que nos son comunes". Por este motivo "no podemos menos que aunar estos esfuerzos para lograr el bienestar de los trabajadores [...] Sólo el trabajo en conjunto puede torcer esta realidad, pensada y desarrollada por intereses mezquinos, para los cuales el valor del trabajo es sólo una ecuación económica, sin alma y sin espiritu", sostenían en el documento fundacional. La lucha en común que emprendió la Intersindical se propuso como objetivos principales:

...la defensa de la industria nacional, la mano de obra argentina, la apertura de fuentes de trabajo, y la incondicional defensa de los recursos naturales argentinos. Y que éstos sean los factores de unión de todos nosotros, más allá de los legítimos derechos individuales de cada entidad gremial. ${ }^{1313}$

El mismo día de su conformación la Intersindical declaró el estado de alerta y movilización ante la "posibilidad de avance de la flota congeladora extranjera para operar por encima del Paralelo 48, utilizando para ello la creación de 'corredores' o impulsando 'proyectos de ley' que le permitan avanzar sobre aguas y especies protegidas contra la depredación de las grandes flotas pesqueras" ${ }^{1314}$. Pero así como la unidad empresaria no era más que una fracasada ilusión, tampoco podía alcanzarse una sostenida unidad gremial. No mucho duró el entendimiento intersindical. El SUPA y el SOIP pronto se declararon a favor de la creación de un corredor marítimo para los congeladores. Por ello abandonaron la Intersindical con el argumento de que no se los consultaba en las decisiones y denunciando el demasiado apego de los gremios con los intereses de la CAABPA. ${ }^{1315}$ Estos gremios estaban interesados en que las empresas del CEPA, que se habían comprometido a procesar el pescado dentro de sus plantas en tierra, pudieran desarrollar las tareas de pesca con sus congeladores.

Contra la posibilidad de la implementación del corredor la CAABPA emitió una solicitada $L a$ Capital con el ampuloso título "De espaldas al mar: el regreso de los saqueadores". Allí denunciaban el intento de los congeladores de obtener permisos para pescar merluza a través del Congreso, indicando que no pudieron conquistar esas intenciones a través del CFP. Señalaron al CEPA como mentor de esa ley y al Senador Sala (que antes elaboró la ley de Emergencia Pesquera) y a Eduardo Arnold, como los responsables políticos. Concluían criticando a Fortunato por una expresión que éste habría tenido días atrás, donde habría dicho “...me estoy preparando para pescar la última merluza del mar...”. Desde la CAABPA sostenían "Aquellos que pensamos que el recurso pesquero es un legado que debemos dejar en las mejores condiciones a quienes nos sucedan, estamos preparados para dar batalla sin tregua y no

de Dirección de Ferrocarriles y Puertos Argentinos, Juan Domingo Novero del SIMAPE, Edelmiro Gavilán del SICONARA y Carlos Darguibel del SOIP.

${ }^{1313}$ L.C., $21 / 10 / 2000$.

${ }^{1314}$ L.C., $20 / 10 / 2000$.

${ }^{1315}$ Después de su salida de la Intersindical, y con el propósito de contar con un espacio para la reflexión, el SOIP creó el Foro de Opinión y Análisis de la Actividad Pesquera (FOAAP). Este foro se constituyó como un organismo no gubernamental, sin fines de lucro. Estaba integrado por empresarios, trabajadores y profesionales comprometidos con la problemática de la pesca, siendo la intención del mismo "integrar a los organismos oficiales, organizaciones privadas y sindicales relacionadas con la actividad de la pesca en la Argentina”. Su funcionamiento no parece haber sido demasiado constante. 
permitir jamás que la triste frase anteriormente citada se convierta en realidad". Firmaban Castro Aran (secretario), Luis Caputo y Francisco Barilari (vicepresidentes) y Ricardo Angeleri (presidente). ${ }^{1316}$

El CEPA no dejó pasar el tiempo para responder públicamente las críticas en su contra. Aclararon que las empresas que integran la entidad "tienen grandes intereses en la actividad fresquera y también desarrollan actividad con buques congeladores" asegurando que "nunca hemos impulsado ninguna acción que menoscabe los derechos de ninguna actividad en el Mar Argentino". También señalaron que no son saqueadores sino "argentinos que hemos elegido el camino de la modernización de nuestras empresas, el camino de la generación de ocupación", al tiempo que remarcaban que "no somos la causa de los males de nadie y no aceptamos seguir siendo agredidos por la ira irresponsable como ya lo hemos sido, con actos de saqueo, incendio y vandalismo en nuestras fábricas durante el mes de julio pasado" 1317 . Con todo, de nuevo sindicatos y empresarios vinculados al sistema fresquero volvían a defender "su" sistema productivo, aunque ya no de manera conjunta, evidenciando el resquebrajamiento de la Multisectorial, pero no de los objetivos primarios comunes.

Poco después del enconado enfrentamiento empresarial una medida elaborada por el nuevo asesor de la Dirección de Pesca motivó un impensado entendimiento entre las cámaras pesqueras. Estas unificaron criterios cuando en diciembre, el ahora funcionario Ernesto Godelman, intentó reducir los cupos de merluza asignados a las flotas. La medida preveía además la aplicación de un arancel en calidad de derecho de extracción a cobrar a los armadores pesqueros, cuyo destino debía ser un fondo nacional pesquero. Criticando la resolución, los empresarios pesqueros marplatenses (ahora si todos en conjunto) elaboraron un documento que enviaron al presidente de la Nación, donde se consignó que ante las recientes medidas dispuestas por la Subsecretaría de Pesca se "favorece el accionar de las flotas operadas por empresas de capitales extranjeros, atentando contra los intereses productivos de la provincia de Buenos Aires y de Mar del Plata en particular". El documento llevaba las firmas de Luis Caputo, de la Cámara de Procesadores, Ricardo Angeleri, de la Cámara de Armadores, Oscar Fortunato, de CEPA y Miguel Constanzo de UDIPA. Señalaron que la medida "favorece el accionar de las flotas operadas por empresas de capitales extranjeros, accionar éste que es coincidente con la política de extranjerización del recurso calamar que está llevando adelante esta administración en su negociación con Japón". Y cuestionaron los nuevos cupos de merluza porque restringen su captura para la flota fresquera a un mínimo "incompatible con ninguna actividad empresaria económicamente rentable que ocupe mano de obra en tierra", ya que establece parámetros en cajones equivalentes a un viaje por mes y fija una cantidad de kilos por cajón (12 kilos máximo) de imposible cumplimiento por razones operativas.

Ante la reacción de los empresarios, el mismo De la Rúa declaró que revisaría las medidas.

He dado instrucciones para examinar las resoluciones cuestionadas y un informe completo para corregir los efectos negativos que afecten a la pesca, tanto de fresqueros como de congeladores [...] el tema pesca ha sido una gran preocupación a lo largo del año, porque la depredación del recurso y la

\footnotetext{
${ }^{1316}$ L.C.,22/10/2000. El 25 de octubre la CAABPA además denunciaba en una carta remitida a Rogelio Rieznik su oposición al corredor para congeladores, al mismo tiempo que criticaba la presencia de un ex funcionario del INIDEP en la dirección ejecutiva de CAPECA. "Indignación, no refleja acabadamente nuestro sentimiento al tomar conocimiento de que Bruno Prensky, biólogo hasta hace poco tiempo en la función pública es director ejecutivo de CAPECA, la misma persona que suscribió informes sobre recursos de nuestro mar y que permitieron, por ejemplo, la asignación de capturas de merluza negra a buques congeladores de empresas vinculadas a la cámara que hoy representa”. L.C.,26/10/2000.

${ }^{1317}$ L.C., 23/10/2000.
} 
casi extinción del caladero debido a la incuria de las anteriores autoridades, que dieron permisos de pesca sin límites, ha producido este efecto negativo tan grave para Mar del Plata, porque ha afectado el trabajo y la actividad pesquera. ${ }^{1318}$

Como "buena noticia" señaló que "los estudios muestran que el caladero está recuperándose, que aparecen las crías pequeñas de merluza, lo que vaticina la posibilidad de recuperarlo en un tiempo futuro". Señaló que ello fue posible porque "se mantienen los criterios de responsabilidad y prudencia en la pesca". Y concluyó que las resoluciones "si tienen gruesos errores, serán corregidas", reafirmando que "la pesca debe ser para los argentinos"1319. Por su parte, también la Intersindical expresó a través de un comunicado de prensa su profundo rechazo a las medidas adoptadas por la SAGPyA considerando que atentaban contra los puestos de trabajo. Finalmente, tras la reunión de un grupo de empresarios con el presidente De la Rúa, el gobierno nacional decidió dar marcha atrás con algunas de las medidas adoptadas, resolviendo suspender la aplicación de un nuevo sistema de captura. Además, se decidió no aplicar un tope en la cantidad de carga que debían contener los cajones y se pospuso la obligación del uso del sistema DEJUPA ${ }^{1320}$ y la exigencia de cargar un máximo de peso de pescado por cajón, junto con la aplicación de elevadas multas para quienes violaran estas disposiciones. De este modo, con una fugaz duración, caía la resolución $\mathrm{N}^{\circ} 965$. En su lugar, y tras la ofensiva de fresqueros, congeladores y gremios marplatenses, la SAGPyA sancionó la resolución 73/2001 que decidía diferentes concesiones. ${ }^{1321}$

Después de este hecho, y a diferencia de los gremios que no podían mantenerse unidos, los empresarios marplatenses volvían a profundizar sus lazos en un nuevo giro de su conflictiva relación. El 11 de enero la Cámara de Procesadores, la CAABPA, UDIPA y el CEPA se reunieron con Aprile para entregarle un extenso documento donde proponían una serie de medidas de aplicación inmediata para la continuidad de la actividad pesquera nacional y que más tarde elevaron a la autoridad del ramo. Entre las medidas económicas que pretendían se aplicasen en el corto plazo se encontraban: la declaración de emergencia económica pesquera, administración correcta de las distintas especies hubbsi, refinanciación de toda la deuda a no menos de 10 años con tasa de interés subsidiada, provisión de fondos frescos para recomponer el capital de trabajo, subsidio al personal afectado a toda la cadena del proceso pesquero, reducción de la alícuota del IVA, utilización de créditos fiscales y sociales que las empresas tengan en el Estado, reducción de derechos de importación de repuestos y accesorios para buques pesqueros $\mathrm{y}$ reducción de tasas por el servicio que brinda SENASA. En el plano provincial se insistió en la declaración del estado de emergencia económica pesquera, reintegro o reembolso provincial a productos pesqueros con destino al MERCOSUR, reducción en valores de peajes, apoyo del banco de la Provincia de Buenos Aires en créditos blandos, reducción de impuestos Inmobiliario Básico y Automotor, replanteo de la aplicación de la Guía de Tránsito, mejoramiento de puertos y readecuación de tarifas y derogación de una normativa de la Dirección General de Rentas. En el plano municipal se proponía la declaración de emergencia económica pesquera con reducción de tasas de seguridad, higiene, barrido, limpieza, alumbrado y del valor de los servicios de OSSE.

\footnotetext{
${ }^{1318}$ L.C.,02/01/2001.

${ }^{1319}$ L.C., 02/01/2001.

${ }^{1320}$ Instrumento de pesca selectiva para el sistema de arrastre.

${ }^{1321}$ El propio Rieznick reconocía que la derogación de la norma № 965 obedecía a los reclamos sectoriales. Entre otras cuestiones, la nueva normativa otorgaba un $30 \%$ más de cajones para ser pescados por la flota pesquera, a los que les permitía a su vez mayor kilaje.
} 
En resumen, las protestas dieron como resultado la resolución $\mathrm{N}^{\circ} 73$ de la SAGPyA, a través de la cual comenzó a darse cumplimiento a lo solicitado por los distintos actores de la pesca, intentando satisfacer las demandas de todos los sectores, política que se mostraba plausible por la recuperación de los stocks de merluza. Al respecto, el 28 de febrero Antonio Berhongaray anticipó que el pasado año "se duplicó la existencia de merluza común" en la ZEE y estimó que "a fines del año que viene estará totalmente recuperada". Dijo que "gracias a las fuertes medidas de control y regulación que dispusimos durante todo el año anterior, la captura máxima de merluza hubbsi (común) será este año de 210 mil toneladas" ${ }^{\prime 322}$. Al día siguiente, el funcionario anunció que el límite de pesca de la merluza común se elevó a "casi el doble" durante el año gracias a un aumento considerable de su reproducción y una mejora en las zonas de desove. También expresó que "Cuando asumi al frente de la Secretaría, en diciembre de 1999, encontré el mar colapsado y fue necesario llevar el límite de pesca a las 110 mil toneladas, cosa que trajo muchas dificultades, pero era necesario para no depredar la especie" ${ }^{\text {"1323. }}$.

Así se llegaba al fin de un ciclo de conflictividad. Podemos tomar como episodio que marca una nueva clave en la dinámica de la protesta la lucha que llevaron a cabo los marineros por mantener los salarios ajustados al nivel del dólar. En este caso, el nuevo escenario estaba dominado por la salida de la Convertibilidad en los comienzos del año 2002. Un marinero aseguraba que "Durante diez años no nos aumentaron [los salarios] y al estar el dólar uno a uno nosotros también perdimos. Ahora vienen las ganancias y nosotros queremos ser partícipes de las mismas". Ante las continuas reuniones fracasadas por la inasistencia de los empresarios, finalmente el 13 de marzo las tripulaciones de un centenar de barcos pesqueros, de fresqueros y congeladores, realizaron una asamblea en altamar. Debatieron a través de la radio y elaboraron un comunicado que enviaron a las patronales y a los sindicatos. El pedido principal remitía a cobrar según el valor dólar. Defendieron el interés común de todo el personal embarcado, advirtiendo que no se debía hacer diferenciación por sindicatos. En la última reunión de sindicatos y cámaras, éstas últimas ofrecieron un $15 \%$ de aumento salarial "en forma provisoria y a cuenta de cualquier tipo de reajuste que otorgue el gobierno nacional". Los gremios consideraron la propuesta "como insuficiente en razón de que los parámetros de la actividad indican como mínimo una base del 25\% como incremento a cuenta y de inicio de negociaciones". Por lo tanto, requirieron de la representación empresaria "una oferta del ya indicado porcentaje como incremento a cuenta y el compromiso de establecer en los próximos el ajuste de los valores de la producción pesquera". En este sentido, los tripulantes exigían que se respeten las actas firmadas en 1982, por lo que reclamaban "mantener el sistema de remuneración histórico". Los empresarios se presentaron a la audiencia e impidieron que participe Domingo Novero, quien ahora dirigía el SIMAPE. Allí pidieron que los gremios les ayudaran a conseguir más viajes para luego si mejorar la oferta salarial. Los representantes de los trabajadores no aceptaron esta iniciativa "porque sabemos que no van a cumplir como pasó en las distintas marchas a Buenos Aires, donde nos prometieron sentarse a hablar y nunca lo hicieron"1324. Finalmente, a fines de marzo los gremios marítimos conquistaron un aumento salarial del 50\% en todas las especies y productos. De este modo se cerraba el ciclo de conflictividad en la industria pesquera. Casi dos años después aflorarían nuevamente las protestas pero ya ajustadas a una dinámica diferente. A su vez, en los años 2007 y 2008 nuevamente los trabajadores ocuparon las calles del puerto. Una de las

${ }^{1322}$ L.C., 01/03/2001. Cabe recordar que durante el año 2000 sólo se permitió la captura de 110 mil toneladas.

${ }^{1323}$ L.C., 03/03/2001.

${ }^{1324}$ L.C., $14 / 03 / 2002$. 
diferencias principales de este nuevo ciclo fue la permanencia de la unidad de las cámaras pesqueras, las cuales, a pesar de sus diferencias, no volvieron a enfrentarse. 


\section{CAPÍTULO VII}

Las formas de la conflictividad. El "estallido" y la toma del SOIP

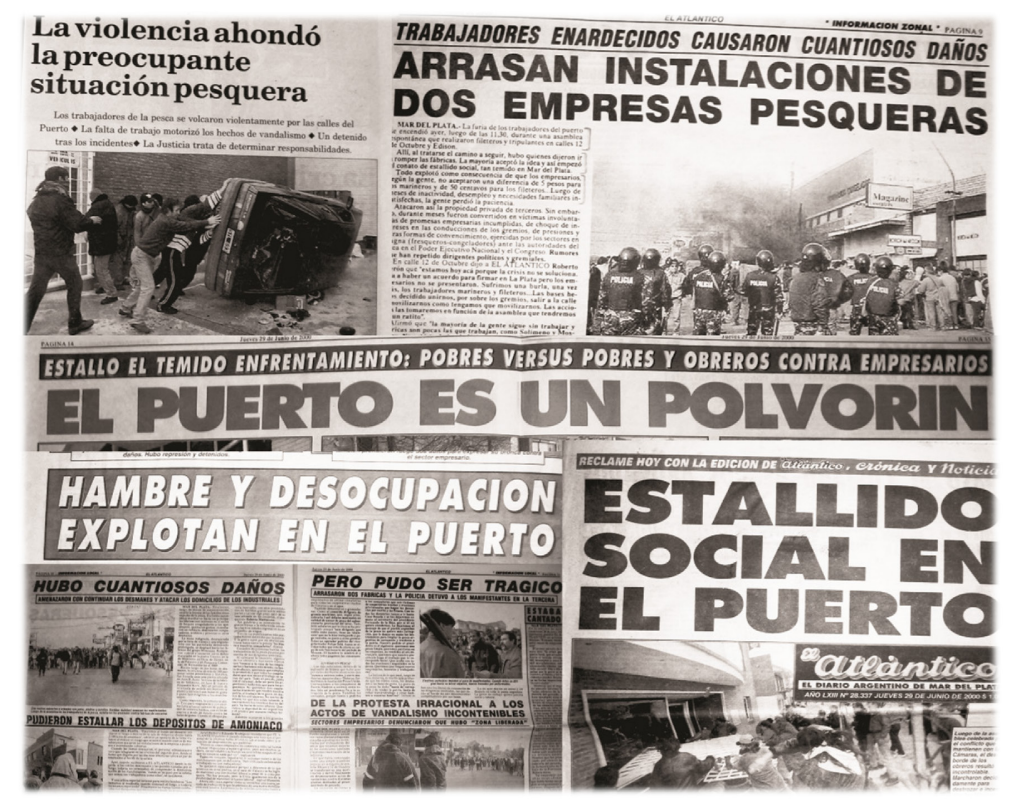




\section{Introducción}

En los dos capítulos precedentes, propusimos una periodización con la pretensión de narrar la dinámica de la conflictividad social en la industria pesquera marplatense. Esto es, buscamos dar sustento a los tres momentos en que se expresaron los antagonismos y contradicciones de un proceso de desarrollo pesquero que mutó en algunas de sus características esenciales. En el marco de una transformación de la industria pesquera, que corrió en paralelo al desarrollo de un modelo aperturista en lo económico, con el abandono estatal de los regímenes de promoción industrial y de una renovada vinculación de la Argentina con las potencias mundiales, se desplegaron entonces en la pesca marplatense aquellos episodios de beligerancia obrera junto con la participación de otros segmentos de la actividad. Conocida entonces la cronología de aquellos tres momentos, cada uno con sus ritmos y particularidades, buscamos ahora presentar un análisis de la conflictividad en la pesca marplatense a partir de la información que nos brinda una exhaustiva base de datos sobre las acciones de protesta desplegadas durante los años bajo estudio. Elaborada en base a los dos principales periódicos de la ciudad (La Capital y El Atlántico), hemos registrado para la industria pesquera marplatense entre los años 1989 y 2001 un total de 428 acciones de protesta. De ella intentamos construir determinados observables en torno a la dinámica conflictual destacando el ritmo de la conflictividad según cada año estudiado, los principales actores movilizados, las formas y el contenido de las demandas, la participación sindical en la convocatoria de acciones o la convocatoria por parte de otras instancias de organización gremial (como líneas internas, cuerpo de delegados, comisiones internas, etc.). El observable fundamental aquí es lo que otros autores han definido como hecho de rebelión (PIMSA). Esto es "todo hecho colectivo de protesta o de lucha, llevado a cabo por personificaciones de categorías económicas, sociales o politicas, dirigido contra alguna expresión del estado de cosas existente". Implique ello la movilización de cuerpos o solamente exprese antagonismo en el plano de las declaraciones. ${ }^{1325}$ Consideramos que la información empírica construida a partir de estos observables nos permite conocer cuáles fueron las reacciones de los principales actores de la escena pesquera marplatense en el escenario de un proceso particular de desarrollo pesquero. Pensamos que esas "reacciones" y "movimientos", al mismo tiempo que nos brindan información sobre los sujetos movilizados, sus enemigos, horizontes, formatos organizativos, etc., son tambiénuna puerta de entrada para conocer la evolución de una industria clave de la ciudad de Mar del Plata como es la pesca, pero no desde una mirada anclada solamente en una aislada especificidad de la economía, sino en sus manifestaciones sociales y en cómo afectaron las condiciones de vida y trabajo de las personas vinculadas a la pesca. Y si bien centramos el análisis en lo que puede considerarse un estudio de caso en la medida en que nos abocamos a la especificidad de una rama productiva en un territorio particular, somos optimistas respecto de que el conocimiento construido servirá también para pensar elementos de la beligerancia popular en la Argentina de la larga década del '90.

Además del análisis que resulta de procesar la base de datos incluimos en este capítulo una segunda parte, en la cual nos dedicamos a estudiar en profundidad dos acciones particulares que sucedieron el $28 \mathrm{y}$ 29 de junio del año 2000, en el momento más agudo de la escalada beligerante. Dedicamos un espacio particular a estudiar las formas y contenidos de esas dos protestas porque, desde nuestra mirada, aquellos episodios constituyen en una suerte de aleph de la dinámica conflictual de la pesca marplatense. En este

\footnotetext{
${ }^{1325}$ En nuestro caso, y a diferencia de la base de datos elaborada por el PIMSA, decidimos incluir también los hechos que expresan antagonismo en el plano de lo discursivo como declaraciones de alerta, emergencia, movilización.
} 
sentido, se trata de hechos que fascinan por ver en ellos una suerte de rito de pasaje colectivo hacia otra clave social, expresando una oportunidad de reinterpretar la cotidianeidad interpelada como excepción. Se trata de dos hechos que constituyen puntos, puntos dónde coinciden todos los puntos, acontecimientos que en su particularidad nos revelan de manera más completa y compleja las transformaciones ocurridas en la industria pesquera y la situación de los trabajadores. Además de dimensionar los perfiles de una cultura de protesta obrera y lo que se considera legítimo o ilegítimo a la hora del reclamar. Esos dos episodios fueron al ataque a diversas plantas pesqueras propiciado por un amplio grupo de trabajadores, donde participaron obreros y obreras del pescado (muchos de ellos desocupados, subocupados y/o trabajadores de cooperativas) junto con marineros. Presentando por la prensa comercial como un "estallido" que hundió sus raíces en el período más profundo de la crisis de la industria pesquera, buscamos no contentarnos con las apariencias que el hecho presentó, intentando a través de su análisis, penetrar en las relaciones subyacentes de aquel repertorio de acción colectiva. Asimismo, al día siguiente, se produjo la toma y ocupación de la sede gremial del SOIP por parte de corrientes opositoras a la conducción sindical. El acontecimiento lo consideramos central en la posterior derrota de la "tradicional" conducción peronista que encabezaba el gobierno sindical desde finales de la década del ' 60 y hasta ese momento no había sufrido derrotas electorales, aconteciendo la primera en el año 2002. 


\section{Primera Parte}

\section{El análisis de la conflictividad social}

Como veremos, la dinámica que presenta la conflictividad en la industria pesquera coincide en gran medida con las observaciones sobre protesta social a nivel nacional durante la década del '90. Tanto las interpretaciones generales como las diferentes bases de datos sobre conflictividad que hemos consultado muestran, a grandes rasgos, que frente a los estragos económico-sociales de la hiperinflación, producidos en los últimos años del gobierno de Alfonsín y los primeros del gobierno de Menem, surgía luego un período de estabilidad de la mano del llamado plan de Convertibilidad. Dicho momento mostró altos niveles de conflictividad. Luego, con la estabilidad que siguió a la implementación de la convertibilidad, los conflictos disminuyeron, al menos en los primeros años. Este período de baja en la conflictividad se mantiene hasta el año 1995, luego del cual comienzan a sentirse los efectos de la Crisis del Tequila, sumados a las consecuencias de la implementación de políticas neoliberales que impactaron especialmente en los niveles de empleo, arrojando a cada vez mayor parte de la población al flagelo del desempleo. En este contexto, el período que va desde el año 1997 hasta, al menos, las jornadas de diciembre de 2001, muestra un crecimiento constante de la protesta social. ${ }^{1326}$ Veamos qué sucede en la industria pesqueramarplatense. En el período que va de 1989 a 2001 hemos registrado un total de 428 acciones beligerantes. Esto quiere decir que en los 13 años bajo estudio las protestas alcanzaron el importante promedio de 1 cada 11 días. En su desarrollo anual la información de nuestra base de datos exhibe el siguiente resultado:

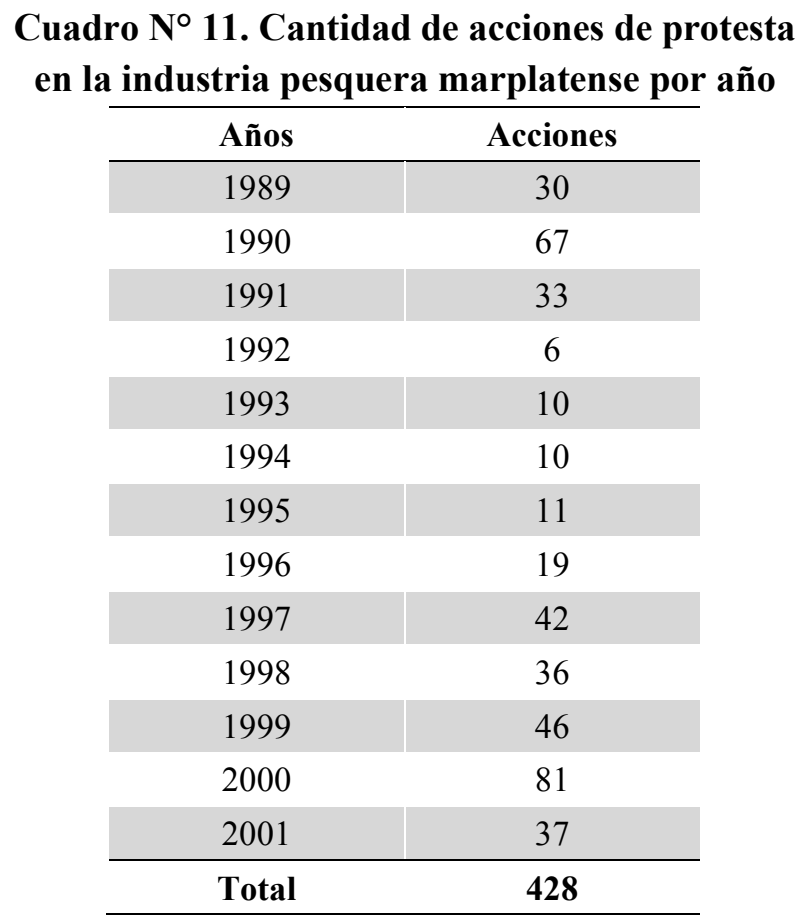

\footnotetext{
${ }^{1326}$ Las bases de datos disponibles son las elaboradas por el PIMSA, el GEPSAC, la encuestadora CISI y también la confeccionada por Adrián Piva. Cada una realizada con preguntas similares, pero también con puntos de partida diferentes, arriba a conclusiones particulares. Para un análisis crítico respecto a los aportes y límites de las distintas bases de datos ver Ghigliani (2009). Los criterios metodológicos que tuvimos en cuenta se especifican en el anexo II al final de este trabajo.
} 
Como podemos observar, el año 2000 es el que registra mayor cantidad de acciones (81), las que prácticamente duplican las 46 del año previo, el cual se ubica en el tercer puesto entre los años con mayor cantidad de conflictos. Ello nos habla de un año excepcional en extensión de la protesta. El segundo lugar lo ocupa el año 1990 con 67 acciones. De esta manera, el ciclo analizado empieza y termina con altos niveles de conflictividad, los mayores en la serie estudiada. Uno refiere al inicio (nunca total, dado que en buena medida la situación no es más que el desarrollo en profundidad de expresiones que venían desde la década del '80) de una serie de mutaciones en la industria pesquera que redundó en el quiebre y cierre de numerosas fábricas. El otro, ya en el año 2000, acontece durante el momento más agudo de la crisis en que desembocó aquel desarrollo pesquero, bajo un nuevo gobierno y prácticamente cerrando la "larga década del '90”. Elaborando una división en las tres etapas en que hemos periodizado la conflictividad en la industria pesquera, cada una con sus peculiaridades, se desprende que el período que va de 1989 a 1991 se caracteriza por una alta conflictividad (el nivel mínimo de 30 acciones sugiere para el período 1 acción cada 12 días), superando todos los años las 30 acciones de protesta. Aquellos años coinciden con la salida del alfonsinismo del poder, el ascenso de Menem y la experiencia hiperinflacionaria. Y, particularmente en la industria pesquera, con el proceso que llevó a la quiebra y el cierre de empresas. Luego, el año 1992 es el que presenta el menor índice de conflictividad de toda la serie con solamente 6 acciones. Los años siguientes (1993, 1994 y 1995) muestran cierta estabilidad en la cantidad de conflictos, rondando el número de diez. Es decir, que durante estos años se sucedieron menos de un conflicto por mes. En buena medida, la respuesta a esta baja en la conflictividad viene dada por los logros iniciales del plan de convertibilidad. Además, tras el cierre de empresas, muchos trabajadores se reincorporaron al mercado de trabajo vía cooperativas y los que no lo hicieron, todavía no ocuparon el escenario de la protesta, como si lo harán en el proceso siguiente. Es probable que pudieran conseguir trabajos a tiempo parcial o "changas", lo que les permitió subsistir. Fueron estos, por otra parte, los tiempos de mayor crecimiento de la industria pesquera, donde aún no explotó el antagonismo en el empresariado. El año 1996 muestra un incremento de la conflictividad social llegando a 19 hechos, los que se acrecientan en el año 1997, que suma la cantidad de 42 y nos indica el comienzo de la tercera etapa, también caracterizada por un desarrollo alto de la conflictividad. En la pesca es este el año que marca el pico de crecimiento de capturas y exportaciones y, conjuntamente, el comienzo de la crisis de la merluza. La merma en las capturas será padecida principalmente por los trabajadores cooperativizados que poco a poco fueron perdiendo posibilidades de trabajo, para terminar muchos de ellos, constituyendo la creciente masa de desocupados. Al mismo tiempo, la obligada reducción de las capturas, constituirá el trasfondo de la aguda disputa inter-empresaria. En 1998 los conflictos descienden a 36, para incrementarse hasta 46 en 1999 y llegar al pico de 81 en el duro año 2000. Los 37 conflictos que sucedieron en 2001 marcan un descenso importante respecto del año anterior, no obstante lo cual, dicha cantidad muestra que aún se mantenía la conflictividad en niveles elevados. En este último período y coincidiendo con la "crisis de la merluza", la cantidad de acciones registradas se incrementa, pues entre 1997 y 2001 se produjeron 242 acciones de protesta, alcanzando el número de un conflicto cada 7 días y medio. La beligerancia para el año 2002, aunque no aparece en esta serie, sabemos disminuyó, marcando el fin del ciclo analizado (Colombo y Nieto, 2009; Colombo, 2008).

Una segunda cuestión a atender es el tipo de acción implementado, lo cual se muestra en el siguiente cuadro. 


\section{Cuadro $N^{\circ} 12$. Tipo de acción y cantidad}

\begin{tabular}{cc}
\hline Tipo de acción & Cantidad \\
\hline Amenaza (de huelga o toma) & 2 \\
\hline Declaración estado de alerta & 71 \\
\hline Ataque a edificio & 3 \\
\hline Corte de calle o ruta & 27 \\
Asamblea & 31 \\
\hline Huelga & 48 \\
\hline Instalación de carpa & 12 \\
Manifestación & 87 \\
Movilización & 53 \\
\hline Olla popular & 10 \\
Paro patronal & 8 \\
\hline Permanencia en lugar de trabajo & 1 \\
\hline Piquete de obstrucción & 6 \\
\hline Toma & 62 \\
\hline Trabajo a reglamento & 3 \\
\hline Otros & 4 \\
\hline Total & $\mathbf{4 2 8}$ \\
\hline
\end{tabular}

El cuadro número 11 nos presenta información acerca del tipo de acción implementado y de su recurrencia. De 16 tipos de acciones que hemos agrupado, el más utilizado fue el recurso de la Manifestación, es decir, aquel que fácilmente permite volver pública una situación de insatisfacción. La manifestación puede darse sola, por ejemplo frente a una planta pesquera que despidió a sus trabajadores, o también puede (y suele hacerlo) acompañar otras medidas de protesta, apareciendo así asociada a una huelga o corte de calle. El segundo lugar lo ocupa una acción que asume el carácter de aviso y no implica la movilización de cuerpos. Esto es la declaración de Estado de Alerta en sus diversas variantes. La inclusión de este tipo de acción, que habla de la protesta en un nivel declarativo, pero que incluimos dado que contribuye a explicar la dinámica conflictual, incrementará el volumen total de participación de las conducciones gremiales en el escenario de la protesta, dado que son los gremios quienes generalmente lanzan estos avisos. Llamativamente, el tercer lugar lo ocupa la acción de Toma, mostrándonos que se trató de un recurso de importancia en la industria pesquera. El grueso de estas acciones estuvo dominado por las tomas de plantas en el contexto de cierre de empresas en los años 1989 y 1990. Más atrás aparece la Movilización y detrás de ella la Huelga. En este último caso, hay que tener en cuenta la particularidad de que muchas veces la huelga, de la que participan los sindicatos marítimos y pesqueros, obedece a convocatorias nacionales de la CGT y no es estrictamente una medida tomada en el seno de la actividad pesquera. Sin embargo, son incluidas dado que cuando participan los gremios de la actividad le imprimen contenidos propios a esa participación. Le sigue la Asamblea, que funciona como instancia organizativa, y sólo luego el Corte de calle ubicado en el sexto lugar dentro de los repertorios utilizados. Continúan la Instalación de Carpa, la colocación de Ollas populares, el Paro dispuesto por la Patronal, Piquetes, 


\section{Otros, Trabajo a Reglamento y Ataque a edificio, Amenaza de Huelga o Toma y Permanencia en el lugar de trabajo.}

En cuanto a las primeras interpretaciones que permite realizar la información precedente, podemos indicar que la Manifestación, que ocupa el primer lugar, es un recurso común a todos los actores del escenario pesquero. También lo son la Movilización y el Corte de Calle. Otros como la Asamblea, el Piquete de obstrucción o la Olla Popular no suelen ser recurrentes en cuanto recurso de los sectores empresarios, siendo utilizadas solamente por los trabajadores. Destacar la Manifestación significa que el mayor número de las acciones presentó un carácter demostrativo que buscaba exhibir públicamente una realidad padecida. Por otra parte, los casos de Olla popular, las Tomas, el Corte de calle y los Ataques a edificios nos hablan de un nivel de radicalidad en los repertorios que, en general, parece haber coincidido con la mayor desesperación de los trabajadores, particularmente de aquellos que se encontraban en situación de precariedad o desocupación. Advirtiendo que el sesgo de la fuente puede ser en esto decisivo, se observa que son pocas las acciones "tradicionales" e institucionales dentro de los repertorios, preponderandolos hechos beligerantes de tipo disruptivo, generalmente realizados por fuera del espacio fabril. En cuanto a las huelgas, hay que señalar que las producidas estrictamente en la industria fueron en su mayoría convocadas por marineros, siendo el SOIP bastante renuente a su convocatoria.

En la medida que nuestra observación no se reduce a la conflictividad desplegada solamente por los obreros sino que busca dar cuenta del conjunto de la dinámica conflictual en la industria pesquera, otro dato de interés lo arroja la división de acciones por sujeto que lo realizó, información que presentamos en su nivel máximo de agregación.

\section{Cuadro $\mathrm{N}^{\circ}$ 13. Cantidad de acciones por sujeto que lo efectuó}

\begin{tabular}{lr}
\hline Sujeto & Acciones \\
\hline Mediana burguesía* & 3 \\
Organizaciones ecologistas** & 1 \\
Pequeña burguesía*** & 16 \\
Sin determinar & 1 \\
Trabajadores y mediana burguesía & 4 \\
Trabajadores y pequeña burguesía & 7 \\
Trabajadores, pequeña burguesía y mediana burguesía & 3 \\
Trabajadores, pequeña burguesía, mediana burguesía y org. ecologistas & 1 \\
Trabajadores**** & 391 \\
Vecinos & 1 \\
\hline Total general & $\mathbf{4 2 8}$ \\
\hline *Empresarios fresqueros, comerciantes & \\
***areenpeace, Cedepesca & \\
***Dueños de lanchas amarillas & \\
***Trabajadores: marineros, de la industria del pescado, del hielo, estatales, estiba, capitanes, maquinistas, y \\
obreros navales.
\end{tabular}

Del análisis de la participación en las acciones según sujeto de la protesta puede verse como ampliamente destacan las acciones realizadas por los trabajadores de manera independiente, llegando a 
participar de 391 acciones. A veces convocadas por sus representantes gremiales, otras realizadas por fuera de las conducciones. También participan de episodios conjuntos con la mediana burguesía, pequeña burguesía, ambas, y con ellas y organizaciones ecologistas. Estas acciones conjuntas suman 15 participaciones. Solamente una acción no se pudo determinar. Las medidas de fuerza protagonizadas por la pequeña burguesía alcanzan el segundo lugar en participación, a una distancia importante, siendo 16 las acciones realizadas de forma autónoma. Mientras que 3 son los episodios de acción de fuerza realizados por la mediana burguesía. Escasas son las acciones llevadas a cabo por vecinos y organizaciones ecologistas. De todas estas acciones, si recortamos el universo de las realizadas por los obreros, trabajamos con un total de 407 acciones. ${ }^{1327}$ Un primer indicador de quienes participan de la protesta refiere a la condición de ocupación.

\section{Cuadro $N^{\circ}$ 14. Participación de los trabajadores en acciones de protesta por condición de ocupación}

\begin{tabular}{lc}
\hline Condición de ocupación & Acciones \\
\hline Ocupados & 222 \\
\hline Ocupados y desocupados & 26 \\
\hline Ocupados y desocupados recientes & 13 \\
\hline Ocupados, subocupados y desocupados & 8 \\
\hline Subocupados & 3 \\
\hline Subocupados y desocupados & 36 \\
\hline Desocupados & 41 \\
\hline Desocupados recientes & 43 \\
Familiares & 4 \\
\hline Jubilados & 2 \\
\hline Sin determinar & 9 \\
\hline Total general & $\mathbf{4 0 7}$ \\
\hline
\end{tabular}

Sin contar las acciones realizadas por familiares, jubilados y las no que pudimos determinar su condición, el universo total de acciones quedan reducidas a 392. En todo el ciclo, el 56,6\% de las acciones fueron realizadas por obreros ocupados, mientras que el 31,3\% de las acciones las protagonizaron trabajadores del ramo que padecían una situación de sub ocupación o desocupación. El $12,1 \%$ fue protagonizado por ambas categorías en conjunto. El análisis revela entonces una preponderancia de las acciones de los obreros ocupados. Aunque debemos tener en cuenta una diferencia sustancial en el contenido de estas acciones. Pues los hechos declarativos, como la enunciación de estados de alerta, por lo general lanzados por sindicatos, son contabilizados como acciones de los trabajadores ocupados (dado que las llevan a cabo los gremios que los representan) lo cual lleva a acrecentar el volumen de participación de estos. No constituye un dato menor que, por lo general, las acciones realizadas por las categorías que padecían mayores inconvenientes en su condición de ocupación protagonizaron hechos que siempre involucraron la movilización de cuerpos en disputa, siendo muy

\footnotetext{
${ }^{1327}$ Sumando las acciones realizadas por los trabajadores de manera independiente con otras personificaciones y una acción sin
} determinar. 
pocas las acciones netamente declarativas. Por otra parte, dentro del período estudiado la distribución de la acción beligerante por condición de ocupación se ve afectada por períodos. Así, si ponemos en observación el período I (1989-1991) tenemos que el 68,9\% de las acciones correspondieron a los ocupados, mientras que el $24,6 \%$ correspondieron a desocupados y desocupados recientes y el $6,5 \%$ a todas las categorías en conjunto. ${ }^{1328}$ Distintos porcentajes arroja el período III (1997-2001). ${ }^{1329}$ A los ocupados corresponden ahora el $47,9 \%$ de las acciones y el $39 \%$ a las restantes categorías, mientras que $13,1 \%$ fueron realizadas en conjunto. Si bien se mantiene la preponderancia de las acciones protagonizadas por los obreros ocupados, vemos cómo disminuye su peso hacia el final de la década. Con todo, el análisis registra que los obreros pertenecientes a la clase obrera "tradicional", es decir que trabajan bajo relación de dependencia y están amparados por sus sindicatos respectivos, tuvieron en la década -a pesar de todo- una fuerte participación en la dinámica conflictual.

Por otra parte, dado el desarrollo en extensión de relaciones laborales "precarias" dentro de la industria pesquera, una clave para visibilizar la protesta nos la aporta la mirada sobre la situación de registración de los trabajadores a la hora de protestar.

\section{Cuadro $\mathrm{N}^{\circ}$ 15. Participación de los trabajadores en la protesta según situación de registración}

\begin{tabular}{|lr}
\hline Situación de registración & Total \\
\hline Contratados & 6 \\
\hline Cooperativizados & 57 \\
Desocupados (No corresponde) & 41 \\
\hline Rel. de depen. y cooperativizados & 16 \\
Relación de dependencia & 212 \\
\hline Sin determinar & 25 \\
\hline Sin registración & 2 \\
\hline Familiares & 4 \\
\hline Jubilados & 2 \\
\hline Prov. relación de dependencia & 24 \\
\hline Prov. cooperativizados & 8 \\
\hline Prov. contratados & 10 \\
\hline Total general & $\mathbf{4 0 7}$ \\
\hline
\end{tabular}

Para evaluar la situación de registración debemos despejar las categorías de Desocupados (pues no corresponde la Registración), aquellas que no podemos determinar, junto a las acciones protagonizadas por familiares y jubilados. Siendo así, de las 407 acciones realizadas por trabajadores ocupados, quedan 335 episodios para mensurar. De ellos, 236 pertenecen a trabajadores bajo relación de dependencia (Relación de dependencia y Provenientes de relación de dependencia), es decir, el 70,4\% de las acciones. Cooperativizados, Provenientes de cooperativas, Contratados y Provenientes de contratados alcanzan un

${ }^{1328}$ Una acción quedó sin determinar y la otra fue llevada a cabo por familiares. Ninguna de ellas fue contabilizadas para sacar los porcentajes por condición de ocupación de las protestas.

${ }^{1329}$ Dejamos fuera del análisis trece acciones, ocho sin determinar, tres realizadas por familiares y dos por jubilados. 
total de 77 acciones, representando el $22,9 \%$ de los hechos, mientras que $6,7 \%$ de los episodios fueron protagonizados por todas las categorías en conjunto. De este modo, el resultado del análisis de la categorías de los sujetos trabajadores inmersos en la protesta arroja una preponderancia de los obreros ocupados que estuvieron en relación de dependencia, ya sea vía su participación en hechos que implicaron "poner el cuerpo" o vía la representación sindical que accionaba, a veces solamente con declaraciones, participando del escenario conflictual. Un resultado bastante sorprendente respecto de nuestros supuestos iniciales. También sorprende la participación de las conducciones gremiales en el escenario de la protesta, la cual supera a las acciones realizadas por otras instancias sindicales como cuerpo de delegados o comisiones internas y también líneas internas, incluyendo en ello la cuenta de las acciones realizadas por los desocupados. Veamos.

\section{Cuadro $N^{\circ}$ 16. Participación en la protesta según instancia que convocó}

\begin{tabular}{|l|c}
\hline Organización o instancia convocante & Acciones \\
\hline Comisión interna & 44 \\
\hline Conducción gremial & 217 \\
Cuerpo de delegados & 2 \\
\hline Línea interna & 84 \\
Sin organización formal & 18 \\
\hline Conducción gremial y gremial empresaria & 8 \\
Conducción gremial empresaria & 26 \\
\hline Familiares sin org. formal & 1 \\
\hline Jubilados & 2 \\
\hline ONG & 5 \\
\hline Vecinos & 1 \\
\hline Sin determinar & 20 \\
\hline Total general & $\mathbf{4 2 8}$ \\
\hline
\end{tabular}

Excluyendo las acciones Sin determinar, las realizas por la Conducción gremial empresaria, por Familiares, Jubilados, ONGs y Vecinos, los hechos protagonizados por trabajadores, cuya instancia que convoca pudimos efectivamente determinar, suman un total de 373 acciones. De ellas un $60,3 \%$ fueron convocadas por las distintas conducciones gremiales, mientras que las restantes se organizaron a instancias de comisiones internas, corrientes opositoras (líneas internas), cuerpos de delegados y sin organización formal (un 39,7\%). El resultado arroja nuevamente una preponderancia general de las acciones convocadas por las direcciones gremiales, aunque el número de acciones realizadas por fuera de ellas arroja un volumen para nada desdeñable.

Otra dimensión del análisis que interesa observar refiere a cuál de las sub-ramas de la industria pesquera fue la más movilizada ante el proceso de reestructuración producido durante la década del '90. Ello se vuelve observable en el siguiente cuadro. 


\section{Cuadro $\mathbf{N}^{\circ} 17$.}

\section{Cantidad de acciones según sub rama de la industria pesquera}

\begin{tabular}{l|r}
\hline Sub rama & Acciones \\
\hline Generales ciudad/nación & 33 \\
\hline Industria pesquera (general) & 59 \\
\hline Industria del pescado (general) & 105 \\
\hline Indus. del pescado (Filet) & 58 \\
\hline Indus. del pescado (Conserva) & 10 \\
\hline Indus. del pescado (Harina) & 1 \\
\hline Industria extractiva & 101 \\
\hline Indus. extractiva y estiba & 2 \\
\hline Indus. extractiva y naval & 2 \\
\hline Naval & 19 \\
\hline Estiba & 10 \\
\hline Estiba e Industria del Pescado & 1 \\
\hline Estado & 21 \\
\hline Hielo & 6 \\
\hline Total general & $\mathbf{4 2 8}$ \\
\hline
\end{tabular}

Suman 33 las acciones que responden al orden general de la ciudad o el país, donde se pueden contabilizar las huelgas generales convocadas por la CGT nacional o las medidas de acción de los comerciantes (y otras) de las que participan los actores de la industria pesquera, pero que no son exclusivas de ellos. 59 acciones abarcan al conjunto de la industria pesquera, es decir a los sectores sumados de la industria extractiva, la industria del pescado, la industria naval, la estiba, el hielo y el Estado vinculado al quehacer pesquero. 105 hechos responden al conjunto de la industria del pescado, 58 exclusivamente al filet, 10 a la conserva y solamente 1 a la harina. Vuelve a aparecer la industria del pescado en una acción conjunta con sectores de la estiba. En cuanto a lo específico de la industria del pescado, se observa un predominio notorio del sector filet por el de conserva y la harina. Por otro parte, 101 hechos corresponden a la industria extractiva, es decir, la que afecta a marineros. Además, está sub rama participa de 4 hechos en conjunto con la estiba (dos) y con la industria naval (también dos). Aparecen luego los organismos del Estado participando en 21 acciones, las que incluyen a empleados del INIDEP, del ex Mercado Nacional de Concentración Pesquera e Inspectores de pesca. Luego siguen la industria naval, la estiba y el hielo. Dejando de lado las acciones generales y las que implican al conjunto de la industria pesquera, podemos ver que la participación en acciones de conflicto de la industria del pescado supera a todas las demás con 175 acciones (contemplando sus subsectores y su participación en la protesta conjunta con la estiba). En segundo lugar aparece la industria extractiva participando en 105 acciones. Y, bastante más lejos, la participación de acciones de empleados estatales, así como también de la industria naval, la estiba y las fábricas de hielo. A grandes rasgos esto evidencia que el sector más movilizado durante la década del ' 90 corresponde a la industria del pescado y, en segundo lugar, a la industria extractiva. 
Otro clivaje de interés lo constituye el tipo de demanda dentro de la que se inscribe cada acción. Agrupadas, las demandas aparecidas tuvieron las siguientes características.

\section{Cuadro $N^{\circ}$ 18. Tipo de demanda y cantidad}

\begin{tabular}{lc}
\hline Tipo de demanda & Cantidad de acciones \\
\hline Asistencia social & 34 \\
\hline Ecológica & 15 \\
\hline Económica & 40 \\
\hline Político corporativa & 62 \\
\hline Laboral & 156 \\
\hline Salarial & 147 \\
Sindical & 70 \\
\hline Política & 88 \\
Sin clasificar & 32 \\
\hline Judicial & 2 \\
\hline Sin datos & 2 \\
\hline
\end{tabular}

En el conjunto de los años abarcados en este trabajo las demandas de contenido Laboral fueron las que mayor cantidad de veces se hicieron presentes (156). Muy de cerca siguen las demandas de contenido Salarial (147). Luego, con una frecuencia de apariciones alrededor de un 50\% menor que las anteriores, se ubican las demandas Políticas (88), Sindicales (70), Político Corporativas (62). Ya con 40 o menos apariciones se suceden las demandas Económicas (40), de Asistencia Social (34), Sin clasificar (32), Ecológicas (15). Y con dos (2) apariciones las demandas Judiciales (2) y Sin datos (2). En sí mismo no son demasiado interesantes las conclusiones que podemos extraer de esta información. Lo sugerente comienza con la desagregación de estas categorías. Una de las ideas fuerte al comenzar este trabajo fue que durante la década bajo estudió se vivió un retroceso en las condiciones de vida y trabajo de las clase trabajadora vinculada a la pesca, particularmente dentro de la industria de procesamiento de pescado, sometida a una fragmentación del mercado laboral. En ese contexto, las demandas principales debieron tener características defensivas. Es decir, moverse en el sentido de buscar no perder conquistas o recuperar lo que se iba perdiendo con el correr de la década. Pensamos que tanto por el contenido de las demandas laborales y salariales ese proceso queda visibilizado. 


\section{Cuadro $\mathrm{N}^{\circ}$ 19. Contenido de las demandas laborales y cantidad de apariciones}

\begin{tabular}{|lc}
\hline Demandas Laborales & $\begin{array}{c}\text { Cantidad de } \\
\text { Apariciones }\end{array}$ \\
\hline Conservar relación de dependencia & 8 \\
\hline Defensa fuente de trabajo & 34 \\
\hline Trabajo & 35 \\
\hline Denuncia trabajo en negro & 7 \\
\hline Empleo en blanco & 17 \\
\hline Erradicación de cooperativas & 23 \\
\hline Mejoras en las condiciones de trabajo & 5 \\
\hline Reincorporación de despedidos & 10 \\
\hline Reconocimiento vínculo laboral & 4 \\
\hline Actualización de escalafón & 2 \\
\hline Trabajar con obreros autónomos* & 6 \\
\hline Formar cooperativas de trabajo* & 1 \\
\hline Mayor presupuesto & 2 \\
\hline Rechazo CCT & 2 \\
\hline Total & 156 \\
\hline *Demandas patronales & \\
\hline
\end{tabular}

De las demandas que hemos agrupado como Laborales, podemos observar que la mayor recurrencia es para demandas de pedido de Trabajo, seguidas por la Defensa de fuente de trabajo, Erradicación de cooperativas, pedido de Empleo "en blanco", Reincorporación de trabajadores despedidos, Conservar relación de dependencia y Reconocimiento de vínculo laboral. Los contenidos de esas demandas en particular sugieren el retroceso padecido en las condiciones de trabajo y en el mercado de trabajo por los obreros y obreras. Muy por debajo de estos reclamos aparecen aquellas demandas como Mejoras en las condiciones de trabajo, Actualización de Escalafón y Mayor Presupuesto (para el caso de Organismos del Estado), que podrían indicar la búsqueda de una mejora para la población obrera. Pero esto, puede decirse, responde al contenido de las demandas que son específicamente laborales. Entonces veamos qué sucede con las demandas salariales.

Cuadro $\mathrm{N}^{\circ} 20$. Contenido de las demandas salariales y cantidad de apariciones

\begin{tabular}{lc}
\hline Demandas salariales & $\begin{array}{c}\text { Cantidad de } \\
\text { Apariciones }\end{array}$ \\
\hline Aumento salarial & 39 \\
Cobro indemnizaciones & 21 \\
Defensa del salario & 7 \\
Efectivizar incrementos salariales & 5 \\
Pago salarios atrasados & 73 \\
Aumento en el precio de Pescado* & 2 \\
\hline Total & 147 \\
\hline *Demanda patronal & \\
\hline
\end{tabular}


El cuadro previo nos sugiere que de un total de 147 demandas de tipo salarial, alrededor del 50\% (74) corresponden al reclamo del Pago de salarios atrasados. Si a ello le sumamos las demandas por Cobro de Indemnizaciones y Defensa del Salario, tenemos que 102 demandas nos muestran características de una etapa defensiva en el contenido de la lucha obrera. Mientras que 44 apariciones representan solicitudes por mejorar el salario de los trabajadores. Se aclara aún más la situación de los trabajadores y trabajadores cuando comparamos estos contenidos de las demandas salariales con los sujetos (obreros y obreras) que los llevaron a cabo.

\section{Cuadro $N^{\circ}$ 21. Participación en demandas salariales por organización que abarca al demandante}

\begin{tabular}{lc}
\hline Organización que los agrupa* & Cantidad \\
\hline SOMU & 43 \\
SOIP & 92 \\
Asociación de Procesadores de Pescado & 4 \\
ATE/UPCN & 11 \\
SAON & 26 \\
SICONARA & 8 \\
SUPA & 5 \\
STIHMPRA & 3 \\
Empleados de comercio & 13 \\
Centro de Capitanes y Patrones de Pesca & 17 \\
CGT & 12 \\
Asociación de Marineros Pescadores & 1 \\
Capitanes de Pesca Fluvial & 1 \\
Sin datos & 2 \\
\hline *Organización se entiende como ámbito que los agrupa.
\end{tabular}

No refiere a que haya convocado la conducción sindical. Éste puede haberlo hecho o no.

El cuadro precedente nos informa acerca de qué organización agrupaba al sujeto reclamante. Como vemos, los espacios donde se reclamó por salarios abarcaron al SOIP, SOMU y el SAON, para destacar a los tres principales. Si analizamos ahora el contenido de esas demandas, observaremos que los reclamos vinculados al ámbito del SOIP, mucho más recurrentes, sin embargo fueron los que proporcionalmente adquirieron un perfil más defensivo. 


\section{Cuadro $\mathrm{N}^{\circ} 22$. Contenidos de las demandas salariales en las organizaciones SAON, SOIP y SOMU}

\begin{tabular}{lccc}
\hline & SAON & SOIP & SOMU \\
\hline Aumento salarial & 17 & 19 & 26 \\
Pago salarios atrasados & 6 & 48 & 12 \\
Cobro indemnizaciones & 3 & 16 & 4 \\
Defensa del salario & - & 5 & 1 \\
Efectivizar incrementos salariales & - & 4 & - \\
\hline Total & $\mathbf{2 6}$ & $\mathbf{9 2}$ & $\mathbf{4 3}$ \\
\hline
\end{tabular}

A primera vista podemos apreciar cómo es el SOIP el ámbito dónde se producen la mayor cantidad de demandas de contenido salarial. No obstante, la mayor cantidad de acciones relacionadas con la búsqueda de aquel incremento se vincula con el pago de salarios atrasados, mientras que tanto en el SAON como el SOMU tienen primacía las demandas de aumento salarial. Éstas representan en el caso del SAON el 65\% y el 60\% para el SOMU, mientras que sólo alcanzan un $25 \%$ en el SOIP, agregando también en su caso la demanda por efectivizar incrementos salariales. Es decir, que las demandas dentro del ámbito de influencia del SOIP asumieron características de orden defensivo, mostrando una desigualdad con la situación imperante en otros gremios.

En lo referido a la participación general en hechos de protesta, tomando como muestra los dos sindicatos más importantes de la industria pesquera, el SOIP superó ampliamente a las acciones desarrolladas en el ámbito del SOMU. Mientras en espacios vinculados al SOIP las acciones que se registran suman un total de 211, en el ámbito de los marineros pescadores se alcanza el número de 118. ${ }^{1330}$ Mientras que en hechos producidos con independencia de otros gremios el SOIP muestra 165 acciones contra 52 del SOMU. En lo específico del SOIP, tomando en consideración el total de acciones en las que participó, y cruzando ese dato con la instancia que convocó, obtenemos que 102 hechos fueron llamados por la conducción gremial, 102 por instancias como comisiones internas, cuerpo de delegados, trabajadores sin organización formal o líneas internas y siete acciones que no se pudieron determinar. Esta paridad entre instancias de convocatoria entre la conducción sindical y las convocadas por fuera de ella resulta llamativa. Muy distinto es el caso del SOMU. 87 acciones fueron desarrolladas a instancias de la conducción gremial, solamente 22 por fuera de ella (y/o en oposición) y 9 acciones sin determinar. Se relaciona con ello una tradición de competencia gremial mucho más fuerte en el SOIP que en el SOMU. Asimismo, no deja de resultar vinculable el hecho de que la conducción de éste último sindicato permanece en su liderazgo (aunque luego conforme un sindicato propio, el SIMAPE), mientras que la del SOIP sale del ciclo perdiendo las elecciones.

\footnotetext{
${ }^{1330}$ En ambos casos contando la participación sindical en acciones conjuntas con otros gremios o en formaciones como la Multisectorial.
} 


\section{Cuadro $N^{\circ}$ 23. Participación de trabajadores del SOIP ${ }^{1331}$ en la protesta según condición de ocupación}

\begin{tabular}{lr}
\hline Condición de ocupación & Total \\
\hline Desocupados & 30 \\
Desocupados recientes & 23 \\
Ocupados & 81 \\
Ocupados y desocupados recientes & 6 \\
Sin determinar & 1 \\
Subocupados & 3 \\
Subocupados y desocupados & 29 \\
\hline Total general & $\mathbf{1 7 3}$ \\
\hline
\end{tabular}

Dentro de las 175 acciones que corresponden a la industria del pescado, el SOIP participó de 173 de ellas, algunas de las cuales fueron realizadas en conjunto con personificaciones de la pequeña y mediana burguesía. Mirando dentro de ellas, obtenemos que 1 no se pudo determinar, 81 fueron realizadas por trabajadores ocupados, 85 por categorías con "problemas" en su ocupación (subocupados, desocupados, desocupados recientes) y 6 en conjunto con trabajadores desocupados recientes. Es decir, que dentro de la esfera de incumbencia del SOIP la mayoría de las acciones se realizaron por sujetos que padecían una situación laboral precaria o que directamente estaban desocupados. A su vez, si solamente tomamos en consideración a los trabajadores y trabajadoras ocupados, quienes protagonizaron 81 hechos, tenemos que 61 de ellos fueron realizados por obreros bajo relación de dependencia (a instancias de la conducción sindical o por sus propios medios), 14 por trabajadores cooperativizados, una por personal sin registración y el resto no lo hemos podido determinar. A este dato, que indica una mayor presencia en la dinámica conflictual de los obreros "estables", sin embargo debe matizarse dado que las categorías sub ocupados y desocupados provienen en general de las cooperativas y son quienes tuvieron un destacado papel en la conflictividad. Asimismo, una notoria diferencia en la participación de la conducción sindical del SOIP se denota en los ciclos bajo análisis. Si en el primero la participación es notable, como también en el segundo, en el tercer período esa participación disminuye, creciendo las acciones realizadas por fuera de la conducción. Si de las 175 acciones de la industria del pescado, dejamos sólo aquellas de las que participan los trabajadores del SOIP de manera independiente y la procesamos según los tres momentos que establecimos como periodización, la proporción de participación de la dirección gremial en las medidas de protesta asciende al 72\% en el primer período (1989-1991), 70\% en el segundo período (1992-1996, recordemos dentro de un marco general de descenso de la conflictividad) y apenas un $10 \%$ en el tercer período (1997-2001). Esto muestra un agudo descenso del protagonismo de la conducción del SOIP en el escenario de la conflictividad, coincidiendo con la muerte de su máximo líder, el inicio de la

${ }^{1331}$ Por SOIP entendemos no el hecho de la participación de la conducción sindical sino la "representación" invocada por los trabajadores que desplegaron la acción. Esto es, si quienes protestan son desocupados, sub ocupados o cooperativizados, aún sin estar afiliados al sindicato, nosotros los consideramos pertenecientes al SOIP. Dejamos fuera aquí las acciones de las que participa el SOIP pero que afectaron al conjunto de la industria pesquera, por ejemplo la movilización de la Multisectorial. 
crisis de la pesca, en un proceso de "piqueterización" de la protesta en la industriay el cada vez mayor protagonismo de las corrientes opositoras que terminaron quedándose con el liderazgo del sindicato. ${ }^{1332}$

Hasta acá el análisis de la base de datos. En las conclusiones desarrollamos la interpretación de lo que ella muestra. Pero antes veamos los sucesos de dos días particulares dentro de la industria pesquera.

${ }^{1332}$ Insistimos en que estos porcentajes pueden estar ligeramente sobre representados dado que se excluye la participación del SOIP en protestas que abarcan al conjunto de la industria pesquera, pero a favor del ejercicio debemos decir que para los porcentajes del período previo también se excluyó la misma variable, al tiempo que lo propio, para los tres períodos, se hizo respecto de las corrientes opositoras. 


\section{Segunda Parte}

\section{"Dos días en la industria pesquera marplatense"}

\section{La fiera innominada}

"No bien una chispa de pasión, que brota de cualquiera de ellos, electriza a este montón de individuos, se produce súbitamente una especie de organización, algo así como una generación espontánea. La incoherencia se cambia en cohesión; el confuso rumor se convierte en voz clara y distinta y de pronto aquel millar de hombres que antes tenían distintos sentimientos y distintas ideas, no forman más que una sola bestia, una fiera innominada y monstruosa que marcha hacia su fin con una ferocidad irresistible" Eugenio Cuello Calón, La criminalidad anarquista.

Hacia mediados del año 2000 la "crisis de la merluza" se encontraba en uno de sus puntos más elevados. La merma en el ingreso de pescado a las plantas de procesado repercutía en la situación de los trabajadores de la industria pesquera, particularmente en aquellos que laboraban en una situación de precariedad. En paralelo, ya para estas alturas se habían producido tres movilizaciones de la "convergencia marplatense" a la ciudad de Buenos Aires buscando volcar la política pesquera en pos de un modelo de desarrollo "tradicional", asociado a la pesca con buques fresqueros. Eficaz en cuanto consiguió el cumplimiento de sus objetivos principales, esto fue la continuidad del flujo pesquero expresado en la sanción de la Ley de Emergencia Pesquera, el incumplimiento por tercera vez consecutiva de algunas de las reivindicaciones netamente obreras, en particular el incremento salarial (demandado por marineros), la reactivación del puerto y la relación de dependencia, dibujaron un escenario de agravios que tensionaba el clima social. En aquel contexto, un frío 28 de junio de 2000, las calles del puerto marplatense daban lugar al despliegue de todas esas tensiones cuando alrededor de 300 obreros y obreras, ${ }^{1333}$ entre los que se encontraban trabajadores de la pesca (marineros) y del pescado (fileter@s cooperativizados), luego de una asamblea, iniciaron una movilización por las calles del puerto. En el recorrido, cinco plantas de procesamiento de pescado fueron atacadas. El hecho fue retratado por distintos medios periodísticos locales. El Atlántico tituló su portada "Estallido Social en el Puerto" y en sus páginas se lee "Los empleados, algunos de ellos con décadas en la empresa, no recuerdan haber visto una protesta similar o al menos 'jamás con las consecuencias y la violencia acontecida ayer". ${ }^{1334}$ Para La Capital "La jornada de ayer (fue), una de las más violentas registradas en los últimos tiempos en Mar del Plata". ${ }^{1335}$ Un periodista de TV expresó "Conmoción en Mar del Plata, en el Puerto principalmente, hace más de 100 días que el conflicto se mantiene. No hay solución. Y hoy se produjo esta violentísima acción...". ${ }^{1336}$ Por su parte, el semanario Noticias y Protagonistas señaló que la jornada "será recordada

\footnotetext{
${ }^{1333}$ La cantidad de participantes es estimativa. Para la revista Puerto, la otra cara de la pesca fueron 200 y para los periódicos más de 300. Según las imágenes televisivas podríamos asegurar que se trataba de entre 400 y 500 personas.

${ }^{1334}$ E.A., 29/06/2000.

${ }^{1335}$ L.C. $29 / 06 / 2000$.

${ }^{1336}$ Imágenes de Canal 10 de Mar del Plata, 28/07/2000.
} 
por los marplatenses y el resto del país como un día histórico: el día en que entramos en la lamentable estadística de ser la segunda ciudad más violenta del país después de Neuquén". ${ }^{1337}$

Hoy prácticamente olvidados, estos eventos alentaron diferentes interpretaciones en los ámbitos periodísticos y gubernamentales. ${ }^{1338}$ La mirada más extendida definió al acontecimiento como un "estallido" y muchos de los discursos, para explicar sus causas, acudieron a la influencia de una "mano oculta" y a la presencia de "infiltrados". Otros calificaron a los manifestantes directamente como "vándalos" y "agentes irracionales". Lo cierto es que muchas de estas caracterizaciones "oficiales" también aparecen en otros episodios de beligerancia popular (Auyero, 2000; Cotarelo, 2003). Desde nuestra óptica, contrariamente de aquellas interpretaciones, creemos que estos episodios más que una "disfuncionalidad" expresan la existencia de un proceso de lo real y, de este modo, constituyen una oportunidad, una puerta de entrada que enuncia un determinado momento de los antagonismos sociales, así como refleja una cultura política y una tradición de lucha obrera en un contexto dominado por las transformaciones de la industria pesquera dentro de la Argentina que atravesó la "larga década del '90". Por eso aquellos episodios merecen un examen más atento, en la medida en que pueden constituir para nosotros un aleph, un punto en el que convergen todos los puntos. En principio se trata, cómo en todo hecho social, de no contentarnos con las apariencias, sino intentar penetrar en los sistemas de relaciones subyacentes. ¿Qué hay detrás del estallido? ¿Quiénes fueron los sujetos que lo protagonizaron? ¿Cuáles eran sus demandas y sus horizontes? ¿Quiénes sus enemigos? ¿Cuál fue el contexto? ¿Constituyó un episodio que modificó el territorio social donde ocurrió o fue sólo un estallido sin consecuencias? ¿Por qué una movilización más o menos habitual en las calles del puerto marplatense terminó convirtiéndose en un "día de furia"? Esta preocupación, que refiere a desentrañar los significados, mecanismos e impactos de la acción colectiva violenta en la industria pesquera asimismo pretende colaborar en la comprensión de episodios donde, como señala Auyero (2000), se produce la transición desde relaciones civiles más o menos pacíficas a períodos de rebelión y beligerancia. En este caso, se trata de mostrar cómo evoluciona el desarrollo de una convergencia social movilizada acudiendo a repertorios de acción "inciviles" y, al mismo tiempo, cómo se dirige la beligerancia hacia un enemigo delimitado. Además, hay que reflexionar en cuanto reflejan esos episodios el contenido de una política popular, donde en cierto modo se cuestiona un orden social instituido, emergiendo una violencia disidente. De ahí que consideremos inapropiado se recurra, para explicar estas acciones, a interpretaciones que pretenden ver en dichos episodios "estallidos" o "acontecimientos fenoménicos", procurando de esta manera ocultar, consciente o inconscientemente, todas sus raíces. Al contrario, aquí se busca "desmenuzar" el hecho para entenderlo en su complejidad. Precisamente, se trata de desarmar el "rompecabezas", reconocer sus partes y procurar rearmarlo. Pensamos que un hecho semejante no puede explicarse a partir de las "intenciones" iniciales de individuos o grupos, sino que esas intencionalidades devenidas en acciones, junto a causas subyacentes, se entremezclan, transformándose, y así dan forma al acontecimiento. Éste, finalmente, no obedece a ninguna planificación y mucho menos a una "dirección consciente". Aunque tampoco la imagen de lo "espontaneo" en sentido puro nos permite comprenderlo. El hecho es el producto de una trama donde la falta de trabajo, la crisis pesquera, las disputas de la burguesía, la acción de los funcionarios, el enfrentamiento de clase, la presencia del activismo, la cultura y tradición política obrera,

\footnotetext{
${ }^{1337}$ Noticias y protagonistas, 2/07/2000.

1338 Durante una protesta de trabajadores de la industria del pescado en el año 2008, en la cual se atacaron algunas fábricas pesqueras y se incendió un camión que transportaba pescado, un cronista de televisión afirmaba: "estos hechos, nunca vistos en el Puerto de Mar del Plata”.
} 
los conflictos entre trabajadores, la desesperación, los agravios y el recuerdo de promesas incumplidas, constituyen los determinantes que se entremezclan dando como resultado la ruptura de un código de conducta implícito, y es allí, finalmente, cuando los trabajadores se vuelven "vándalos".

\section{Emergentes de lo "incivil"}

“"Espero que no haya un estallido social', comentó el obispo cuando se le mencionó que no sólo la pesca está pasando por una difícil situación" José María Arancedo, obispo de Mar del Plata, abril de 2000.

Si consideramos el ciclo de conflictividad que acontece entre 1997 y el año 2001 son varios y heterogéneos lo momentos en que aparece en el horizonte de la protesta obrera el recurso a llevar adelante acciones de protesta de carácter "violento" o que discurren por fuera de los canales formales de la expresión de reclamos, manifestando un alto grado de incivilidad y donde siempre aparecen como agravios principales, por un lado la situación de hambre de los trabajadores de las cooperativas y, por otro, la negativa empresaria a dar curso a los reclamos de los marineros. Por esos días, estos últimos lograron mantener paros que se contaban por meses. La situación era diferente para los obreros de las plantas de procesado puesto que el SOIP mantuvo su determinación de continuar trabajando, mientras que por el lado de los obreros y obreras de las cooperativas el reclamo principal finalmente confluirá en el pedido de la obtención de un subsidio, una suerte de "garantía horaria" para el personal desempleado mientras duraran las vedas y la recesión en la industria. ${ }^{1339}$ La demanda daba cuenta de una serie de padecimientos y de una situación límite. De algún modo, ello aparece como mecanismo de legitimación de las acciones "violentas". En este sentido, los episodios del 28 de junio son más un resultado -expresado en sus niveles más altos- que una anormalidad.

En junio de 1999 representantes del SOIP se reunieron con ediles de todas las bancadas del Concejo Deliberante marplatense y le expusieron la gravedad de la situación pesquera:

...hace más de 15 días que no hay pescado, y por lo tanto no se cobra un peso. La más afligente es la situación de los trabajadores en negro de las seudocooperativas, ante las cuales no hay ningún reclamo y que son parte del sistema de los empresarios que, de esta manera se ahorran millones en aportes. El jueves hubo una reunión en el SOIP con más de 700 trabajadores y sus familias clamando por un poco de comida. Hay hambre, ya existen familias enteras que llevan más de un día sin comer, los chicos lloraban porque les dolían las tripas y es una situación que va para largo, y que puede explotar en cualquier momento. Hoy venimos a pedirles que nos ayuden,

\footnotetext{
${ }^{1339}$ Los trabajadores nunca recibieron el subsidio de \$500 pesos solicitado. La ayuda económica se manifestó en bolsones de comida, una tarjeta de compra por 20 pesos en un supermercado y un aporte en dinero dirigido al SOIP. En relación con esto último Luis Ronner, ex miembro del oficialismo y ahora integrante de la lista Granate opositora a la directiva del SOIP, denunció en diciembre de 1998 que: "los integrantes de la actual junta electoral están percibiendo subsidios de desempleo del gobierno, a razón de 56 pesos per cápita y por 3.500 compañeros. Pero, resulta que ninguno de ellos ha visto ni un centavo todavía, cuando estos fondos se estarían cobrando desde enero de este año. Suman unos dos millones de pesos, que no se sabe dónde están..." L.C.,16/12/1998. Respondiendo a esta denuncia, la directiva del SOIP señaló que la SAGPyA envió un subsidio de 190 mil pesos mensuales al SOIP destinado al personal cooperativizado, pero no era un subsidio para entregar directamente a los trabajadores sino que el objetivo fue implementarlo en un sistema de salud a través de la obra social. E.A.,17/12/1998.
} 
pero quizás mañana no los podamos contener y nos tengamos que poner a la cabeza de una movilización que llegue hasta acá o a un supermercado. ${ }^{1340}$

Ese mismo día, la dirigencia gremial pidió al poder político que interceda ante supermercados, almacenes, matarifes, empresas de transporte y estaciones de servicios. Solicitaron comida, querosén, pases de colectivos, etc. “... a fin de evitar un desborde social, en pocos días más serán varios miles los muertos de hambre que trabajan en tierra los productos de la pesca. Queremos evitar los desmanes y las situaciones incontrolables, los cortes de ruta y calles o la compulsiva petición en los mercados...". No hubo que esperar demasiado para que aquella advertencia finalmente se concretara. El 14 de febrero de 2000 los trabajadores cooperativizados y en negro de la industria pesquera marplatense resolvieron iniciar una serie de medidas de fuerza para reclamar al gobierno nacional el pago subsidios como mecanismo de contención social ante el cierre temporario del caladero. Así, a la realización de un corte de tránsito en la calle 12 de Octubre y Edison, se le sumó el anuncio de una movilización y manifestación frente al municipio. Al frente del reclamo, los dirigentes de la UOP acusaron a Antonio Berhongaray y al intendente Aprile de no tener en cuenta a los trabajadores a la hora de tomar decisiones. Rechazaban el pedido de aplicación de una veda escalonada, pues no les era de utilidad, porque en vez de "morirse de hambre de golpe" los llevaría sólo a hacerlo de a poco. Por eso insistían con la demanda del subsidio de 500 pesos por cada obrero que trabaja en negro. ${ }^{1341}$ La medida de fuerza se concretó el 21 de febrero. Frente a la Municipalidad anunciaron la instalación de una olla popular en rechazo a la firma del acta de intención efectuada por la Multisectorial y representantes del gobierno nacional. Mamerto Verón y María Dematteis, ambos dirigentes de la UOP, insistieron en que se les abone a los trabajadores desocupados una "garantía horaria" en forma de subsidio por el cese virtual y transitorio del empleo. ${ }^{1342}$ Días más tarde se realizó una sesión especial en el Concejo Deliberante para tratar la problemática pesquera. Los aspectos salientes de la reunión fueron la ausencia de los máximos referentes de la Multisectorial y de representantes del Ejecutivo Nacional, además del fuerte tenor crítico al rol del Estado. Allí habló Mamerto Verón, quien expuso una alarmante situación. Aclaró que el capital no tiene patria, cuestionó al SOIP y lo catalogó de menemista. Finalmente insistió en los reclamos por el aporte de un subsidio. Y al mismo tiempo advirtió: “...quiero dejar remarcado que es necesario ya una contención social de subsidio y asistencia social, no quiero que después salgan diciendo que son revoltosos los trabajadores o que no tienen paciencia, la paciencia se termina con el hambre" ${ }^{, 1343}$.

El 29 de mayo fueron los trabajadores marineros los que se movilizaron a la sede de la CAABPA. Según La Capital "Todo comenzó aproximadamente a las 14 frente al edificio ubicado en la calle Alem con la participación de aproximadamente trescientos trabajadores de la pesca que pretendian escrachar a los empresarios del sector por el incumplimiento del acuerdo alcanzado a principios de año con relación a las relaciones laborales" ${ }^{1344}$. Al no recibir respuesta, los trabajadores atacaron la sede empresaria arrojando piedras. Domingo Novero reconoció entonces que "La situación se salió se salió de

\footnotetext{
${ }^{1340}$ E.A., 12/06/1999. La negrita es de la fuente.

${ }^{1341}$ Explicaban: "Los que realmente tenemos problemas somos los trabajadores en negro. Los efectivos tienen una garantía de horario que establece que en caso de vedas o de poca pesca cobrarán igual el sueldo, y en algunos casos con bono. Nosotros de eso no tenemos nada". L.C.,15/02/2000.

${ }^{1342}$ L.C. $22 / 02 / 2000$.

${ }^{1343}$ Sesión del Honorable Concejo Deliberante, Mar del Plata, 23/02/2000.

${ }^{1344}$ L.C., 30/05/2000.
} 
control" y lamentó lo sucedido dado que "nuestra intención era protestar pacíficamente". Entonces era difícil contener a trabajadores que se sintieron usados. ${ }^{1345}$ En el mismo día en que la sede de la CAABPA fue atacada, un grupo de trabajadores de la industria del pescado tomaron la Delegación municipal del puerto. Allí denunciaron no sentirse amparados por el gremio que los agrupaba y pidieron trabajo en blanco para asegurarse cobertura social y jubilación. ${ }^{1346}$ Días después, trabajadores de tierra tomaron la sede de la Secretaría de Calidad de Vida de la Municipalidad. Según relató Mamerto Verón, las exigencias consistían en "que baje el intendente municipal a darnos una respuesta satisfactoria en cuanto al subsidio que desde hace seis meses se viene hablando y que se hagan las gestiones para que nos reintegren la luz y el gas que a muchos compañeros les han cortado porque no pueden pagar". ${ }^{1347}$

Por el lado de los gremios que se mantenían en huelga, algunos de ellos enfocaban a los empresarios congeladores como los principales responsables por la irresolución del conflicto. Para el SICONARA resultaba inexplicable y ridícula la presencia de empresarios relacionados al mismo tiempo con las flotas fresqueras y congeladoras en el seno de la CAABPA: "Son justamente estos grandes empresarios quienes tienen mayor incidencia en la entidad, situación que motiva el estancamiento y retroceso en la negociaciones", al mismo tiempo que condenaba "las respuestas evasivas e inconsistentes al reclamo de los trabajadores". La situación "atenta gravemente contra los intereses de una pequeña y mediana empresa, que no cuenta con los recursos grandes". Sostenían que los empresarios que poseen los dos tipos de flota estaban dilatando el conflicto porque igual podían pescar con los congeladores. ${ }^{1348} \mathrm{El}$ 13 de junio una manifestación de la UOP a la Municipalidad copó las calles aledañas y posteriormente se produjeron quemas de gomas en los accesos y roturas de vidrios del edificio. El reclamo continuaba siendo el subsidio de 500 pesos. Los incidentes se originaron cuando los trabajadores llegaron a la puerta del edificio comunal y les cerraron las puertas. Al no poder ingresar, quemaron gomas, ramas, plásticos y otros elementos. Dentro del Palacio Municipal se reforzaron las medidas de seguridad con personal policial y privado. Entonces los secretarios de gabinete Francisco Bowden y Carlos Brun presentaron una denuncia por daños (ventanales rotos, escalones removidos y quemaduras en las puertas) y obstrucción en la vía pública. ${ }^{1349}$ Estos fueron los antecedentes más inmediatos del "estallido", el cual no obstante se presentó de manera excepcional por las dimensiones que obtuvo y lo que condensó en la acción.

\section{El "estallido social"}

En el año 2000, tanto en las calles del puerto de Mar del Plata, como también en las de otros barrios, formaba parte de la rutina cotidiana la sucesión de periódicas protestas siendo más o menos habituales los cortes de tránsito, las asambleas de trabajadores, las movilizaciones y manifestaciones. En el puerto, minutos antes de realizarse otra asamblea, el dirigente de la UOP Mamerto Verón decía:

Estamos hoy acá porque la crisis no se soluciona. Iba a haber un acuerdo para firmar en La Plata pero los empresarios no se presentaron. Sufrimos una burla, una vez más, los trabajadores marineros y fileteros. Las bases hemos decidido unirnos, por sobre los gremios, salir a la calle y

\footnotetext{
${ }^{1345}$ L.C.,30/05/2000

1346 L.C.,30/05/2000.

${ }^{1347}$ L.C., $07 / 06 / 2000$.

1348 L.C., 11/06/2000.

${ }^{1349}$ L.C., $14 / 06 / 2000$.
} 
movilizarnos como tengamos que movilizarnos. Las acciones las tomaremos en función de la asamblea que tendremos en un ratito. La mayoría de la gente sigue sin trabajar y fábricas son pocas las que trabajan, como Solimeno y Moscuzza. No está trabajando Valastro. Si esto lo tenemos que profundizar, lo vamos a hacer y si tenemos que parar todas las plantas es lo que vamos a hacer. Lo decidiremos en conjunto las bases entre marineros, fileteros y todos los trabajadores de tierra. Hemos esperado demasiado y hacer pasar hambre a nuestras familias. Bueno, llegó el momento de sacar el conflicto a las calles para que triunfe nuestra causa. Entre las propuestas de los compañeros figura montar ollas populares frente a las mansiones de los empresarios pesqueros. Esto será debatido, si lo aceptamos entre todos es lo que haremos. Hoy es el comienzo de lo que tendríamos que haber hecho en un principio, unirnos entre todos... Pero, bueno, siempre los empresarios y los gremios ponen barreras para que las bases de la pesca no se unan. Ahora estamos rompiendo todas las barreras. Las bases rebasaron ya a las dirigencias, porque acá está en juego la comida y educación de nuestros hijos. ${ }^{1350}$

La intervención de Verón, previa a la movilización que terminó en el ataque a las fábricas, señala algunos aspectos clave respecto de la situación de los trabajadores. En primer lugar menciona un nuevo agravio, una nueva burla, cuando los empresarios volvieron a ausentarse en la reunión que el Ministerio de Trabajo llamó para tratar de llegar a un acuerdo entre las partes en conflicto. Además, el dirigente resalta la unidad de los trabajadores de tierra y los marineros por sobre la dirigencia gremial, la cual pasará a ser considerada como otro de los enemigos. También anunció la intención de provocar la detención del trabajo en todas las plantas pesqueras. De este modo, buscaba extender el paro que desarrollaban los marineros al personal de tierra. Es decir, se plantea la convocatoria a un paro declarado por "las bases" en oposición a la indeterminación de la conducción del SOIP. A su vez, manifiesta que existía una fuerte determinación respecto a las medidas para reclamar diciendo, por ejemplo, "movilizarnos como tengamos que movilizarnos". Dicha determinación se asentaba en que estaba en juego la comida y la educación de los hijos de los trabajadores del pescado. Este era en buena medida el clima con que se despertaba aquel día el puerto de Mar del Plata. Por su parte, Carlos Salé, marinero afiliado al SOMU, expresó: "Son las bases del SOMU, más la gente de tierra, que estamos acá tomando una medida de protesta, para que los empresarios que hacen lobby con los congeladores, permitan a los demás sentarse a conversar con nuestro gremio... No vamos a quedarnos sentados en nuestras casas esperando a que esto se resuelva para fin de año, vamos a salir a luchar. ${ }^{1351} \mathrm{En}$ su intervención aparece ya como el enemigo señalado, no el conjunto de los empresarios, sino particularizados en aquellos que disponen de buques congeladores.

El Atlántico continúa del siguiente modo su relato sobre los acontecimientos “...al tratarse el camino a seguir, hubo quienes dijeron ir a romper las fábricas. La mayoría aceptó la idea y así empezó el conato de estallido social, tan temido en Mar del Plata". ${ }^{1352}$ La cuestión, al parecer, no fue tan directa. A partir de imágenes televisivas podemos reconstruir el recorrido de los manifestantes y rescatar las expresiones que se escucharon durante su trayecto. Se destacan ocho ubicaciones. El punto A)Edison y 12 de Octubre. Allí se produjo la asamblea en la que decidieron marchar hacia las fábricas de procesado de pescado buscando extender el paro que realizaban los marineros a los trabajadores de tierra. Desde allí, y por la calle 12 de Octubre, llegaron al punto B) la primera fábrica atacada, perteneciente al grupo Giorno

${ }^{1350}$ E.A., 29/06/2000.

${ }^{1351}$ E.A., 29/06/2000.

${ }^{1352}$ E.A., 29/06/2000. 
en Ayolas 3075. Prendieron fuego la puerta y rompieron vidrios. Por la calle Pescadores llegaron al sitio C) Ortiz de Zárate 2950 donde se ubica la fábrica propiedad de Moscuzza. Allí rompieron vidrios, voltearon un auto, quemaron la puerta, destruyeron los vidrios de un camión de la empresa, discutieron con trabajadores que estaban trabajando en el interior de la planta y expusieron su bronca y sus demandas ante los medios de difusión que habían llegado al lugar. Por Ortiz de Zárate alcanzaron el punto D) la fábrica Pesquera Comercial, sita en Ortiz de Zárate 3645, perteneciente al grupo Solimeno. Allí rompieron vidrios, forzaron una puerta, prendieron fuego un auto. Continuaron por Ortiz de Zárate hasta la calle Don Orione 769 y llegaron al sitio F) la fábrica Cafiero y Polio, donde lanzaron algunas piedras, pero algunos de los manifestantes gritaron que "no", que ese era un empresario "chico" y continuaron su camino. Doblando por Don Orione, llegaron al lugar G) La planta de Solimeno ubicada en Irala y Don Orione, donde rompieron vidrios. A partir de aquí no pudimos rastrear por donde avanzaron hasta llegar al sitio H) en Juramento y Juan B. Justo, donde observaron que grupos policiales realizaban un cordón sobre la calle siguiente, es decir Alejandro Korn. Igualmente los trabajadores avanzaron hasta Korn, llegando al ítemI), donde alcanzaron a arrojar algunas piedras, pero fueron obligados por la presencia policial a retroceder hasta Juramento. Este embrollado recorrido se nos aclara mediante el siguiente gráfico. Las líneas representan el trayecto de los manifestantes por las calles portuarias. Por su parte, cada letra se corresponde con los puntos mencionados arriba. Salta a la vista que la particularidad de la concentración de las empresas en la zona portuaria favoreció el recorrido, que en total sumó 31 cuadras.

Gráfico III. Recorrido de la protesta del día 28 de junio de 2000

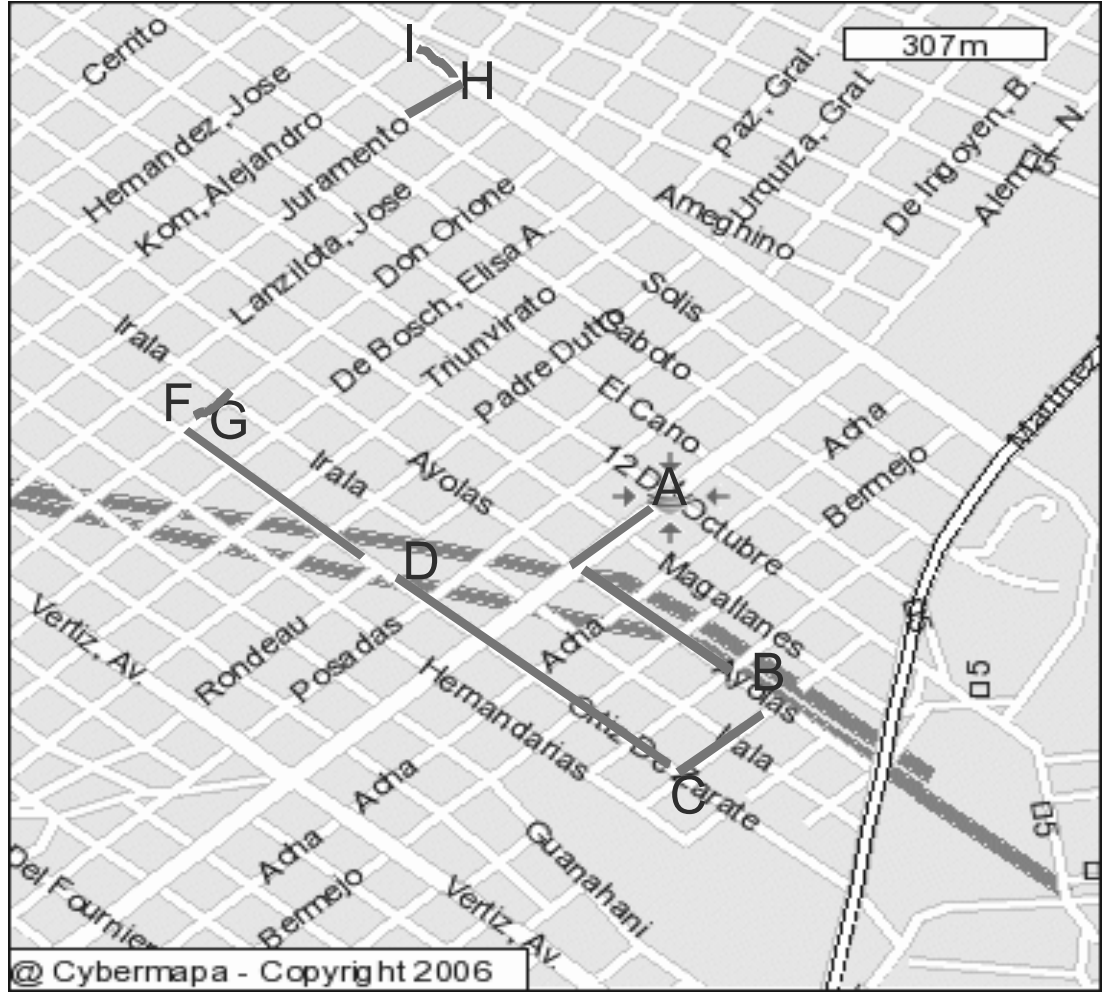

Elaboración propia en base al cruce de información deLa Capital, El Atlántico y las imágenes televisivas de Canal 10. 
Durante el trayecto se escucharon cánticos con el pedido de "paro general" o la expresión "el puerto no labura" con la cual se pretendía hacer extensiva la huelga de los marineros hacia los trabajadores de la industria que estaban bajo relación de dependencia. Las movilizaciones de obreros y obreras en huelga por las plantas pesqueras, buscando que aquellos trabajadores y trabajadoras que continuaban laborando acatasen la medida era una práctica con tradición en el SOIP. Desde la primera huelga general decretada en el gremio allá por el año 1942 existió este repertorio que la prensa de entonces denominó como "grupos de convencimiento". Más acá en el tiempo, ya en agosto de 1997 se produjo una movilización con estas características pero sin producir hechos de violencia material. ${ }^{1353}$ Volviendo a nuestro hecho, frente a una fábrica atacada se produjo una discusión entre manifestantes y empleados de la planta. Quienes protestaban acusaban de "traidores" a aquellos trabajadores que continuaban en su labor. Se escucha de parte de un manifestante: "Vos estas laburando y nosotros nos estamos cagando de hambre" e "Hijos de Puta, verceros, carneros, cornudos". Y una mujer declara ante el periodista de un canal de TV: "No hay trabajo. No tenemos más que darle de comer a nuestros hijos. La situación económica no da para más. Hay gente que está alquilando, que no tiene con que alquilar. La dejan en la calle... y estos [señalando a los empleados de Moscuzza] están trabajando cuando nosotros nos estamos muriendo de hambre". De este modo, queda en evidencia el conflicto y todo el drama existente entre los trabajadores de las cooperativas que demandaban soluciones a su situación y por ello pedían la solidaridad de los "estables" y estos últimos que continuaban laborando.

Las declaraciones realizadas ante el periodista de TV permiten reconstruir en parte también los sentimientos de la masa movilizada. El periodista pregunta a una mujer: “ ¿Se vislumbra una solución?” y ésta le responde: "No. No se vislumbra nada. Va pasando de una semana a la otra, de un día para otro... ya explotamos. Ya no damos más. Ya estamos indignados. No queríamos llegar a esto". Vuelve a intervenir la mujer que había hablado antes: "Nadie nos da una respuesta para seguir. Vamos a Municipalidad, Calidad de Vida también. Entonces basta, basta". Otro hombre dice: "Estamos cansados de tanto manoseo. Nuestros hijos se están muriendo de hambre. Nos están cortando el gas. Nos están cortando la luz. Todo. No tenemos absolutamente nada”. Una mujer, muy nerviosa, expresa: "¿Qué hacemos con nuestros hijos muriéndose de hambre? Y eso se lo digo al señor Aprile que usó a toda la gente para llevarla a no sé qué". ${ }^{1354}$

Mencionamos que durante la movilización los manifestantes pasaron por una fábrica de procesamiento, Cafiero y Polio, perteneciente a un empresario "fresquero". Ante el hecho de que algunos pocos arrojaron piedras, se escucharon voces diciendo "no che, a ese no" y el ataque se detuvo hasta llegar a otra fábrica, perteneciente al grupo económico Solimeno, la cual si fue atacada. Este hecho pone en evidencia dos cuestiones. La primera es que finalmente las fábricas atacadas fueron solamente las del CEPA y no las de los empresarios "fresqueros". La segunda, es que desde el mismo momento en que una fábrica "fresquera" sufrió un ataque, aunque frenado, se evidencia que para algunos manifestantes también era un blanco, si bien terminó primando la postura de aquellos que identificaron al enemigo en los "congeladores". Lo cierto es que para la reconstrucción a posteriori, y según declararon varios de los manifestantes, la intención primera de la movilización era concretizar un paro en el conjunto de la geografía fabril y no atacar las plantas. Dado que el SOMU mantenía la medida, por lo que los marineros se encontraban parados, la movilización se dispuso ampliar dicha situación a las plantas de procesado de

${ }^{1353}$ L.C., 15/08/1997.

${ }^{1354}$ La mujer hace referencia a las movilizaciones de la Multisectorial a Capital Federal. 
pescado, algunas de las cuales se encontraban laborando. Recordemos además que la conducción del SOIP se había negado sistemáticamente a convocar a un paro, argumentando las necesidades de trabajo de los obreros afiliados al sindicato. Pero ¿en qué momento una movilización que pretendía garantizar una medida de lucha trocó en un ataque a las plantas pesqueras? ¿Y por qué el ataque se dirigió sólo contra las empresas que integraban el CEPA?

En relación con esto último, hemos visto ya cómo "los congeladores" se construyeron en el enemigo de la "comunidad pesquera" marplatense. Toda la lucha previa, en particular de la Multisectorial, se encargó de enfocar a este segmento empresarial como el enemigo. En principio, ese enemigo era extranjero $y$, cuanto mucho, desempeñaba sus tareas de pesca en provincias del sur, alejadas de la "capital" de la pesca. Pero el hecho de que algunos empresarios con asiento en Mar del Plata operaban con congeladores los mostró como el enemigo dentro de la propia comunidad. Además, estos grupos empresarios -al menos Moscuzza y Solimeno- mantenían sus plantas en funcionamiento mientras se desarrollaba el paro de marineros y los trabajadores de las cooperativas denunciaban estar pasando hambre. El mismo día del ataque a las fábricas un manifestante afirmaba: “...acá está pasando esto con las fábricas, porque son los empresarios con congeladores, con factorías que están trabajando en el sur. Estos empresarios tienen congeladores les importa un bledo que toda la economía marplatense se caiga". ${ }^{1355}$ Mientras que otro hombre establece una diferencia entre empresas diciendo "acá hay empresas que quieren arreglar y se sienten amenazadas. Son una mafia los tres: Valastro, Moscuzza, son una mafia... Solimeno". Aparecían de este modo los empresarios "congeladores" como doblemente enemigos. Primero por poseer este tipo de buques, considerados depredatorios y que no brindaban mano de obra al personal argentino; y luego por tener parte de su flota radicada en el sur de la Argentina y desentenderse de la situación de la población marplatense.

En una entrevista con el dirigente Luis Verón, consultado por aquellos hechos de "violencia", nos contó un suceso previo vivido por los trabajadores, el cual incrementó el sentimiento anti empresarial que reinaba en la masa obrera, fomentado a su vez por las actitudes provocativas de un empresario pesquero.

Y estábamos en una plena asamblea, bueno... y un marinero conoció a un empresario que pasaba en un BMW en ese momento, que era Pedro Moscuzza. Uno de los marineros lo reconoce y bueno dice 'ahí va Pedro Moscuzza'. Bueno algunos lo miraron así, porque algunos lo conocían, otros no lo conocían... Entonces Moscuzza baja el vidrio del auto y le hace fuck you a la gente. Ahí lo agarraron, se le fueron encima y bueno... lo sacó la policía en su momento. Y entonces se hizo la asamblea y se resuelve de que... escrachar, hacer una movilización a estas empresas grandes para denunciarlas delante de la opinión pública y los medios, de que estas empresas grandes estaban extorsionando y eran las que se negaban a dar el reclamo de los marineros. ${ }^{1356}$

Es decir que en el marco de una convicción generalizada de que las empresas "grandes" eran las que no estaban dispuestas a dar satisfacción a la demanda de los trabajadores, mientras que al mismo tiempo seguían trabajando, surge un detonante cuando los obreros reunidos en asamblea sufren una burla. Asimismo, hubo otro episodio -quizás el más significativo- que motivó el ataque a esas empresas. Y fue el que habilitó las especulaciones acerca de "una mano negra" que orientó el sentido de los ataques. Este fue un documento que los manifestantes mostraron ante las cámaras de televisión, en el cual las tres

\footnotetext{
${ }^{1355}$ E.A., 29/07/2000.

${ }^{1356}$ Entrevista del autor con Luis Verón, militante de la UOP y futuro asesor del SOIP, 12/08/2006.
} 
empresas perjudicadas llamaban al conjunto de los integrantes de la CAABPA a no negociar con los obreros. Llamativamente, ese documento interno fue puesto al alcance de los manifestantes y, según nos contaron algunos trabajadores, el puerto había amanecido el día 27 "todo pegatinado y panfleteado" con dicho documento. Esta situación llevó a que desde las empresas perjudicadas denunciaran que "la policía permitió una zona liberada". ${ }^{1357}$ En ese sentido, la revista Puerto se pregunta:

¿Por qué contra CEPA? No es difícil dar una respuesta a esta pregunta. La lucha que ha desatado el intendente, junto con los gremios portuarios [...], la Cámara de Armadores y Procesadores, UDIPA, y junto con todos ellos los medios de comunicación locales más importantes, ha sembrado la semilla de la discordia que derivó en actos de violencia. Hipócritamente, todos se horrorizaron en la mañana del 29 de junio por los destrozos ocasionados a las empresas pesqueras, desatendiéndose por completo de lo que estaba ocurriendo, como si jamás se hubiese incitado, de una forma u otra, a que esto se llevara a cabo. Según los damnificados, el día de los incidentes una mano negra habría hecho circular una nota firmada por los tres empresarios -Solimeno, Valastro y Moscuzza-, en la que los comprometía directamente porque en ella pedían a la Cámara que no presentaran propuestas. Esta nota aclaraba que, antes de tomar alguna decisión, se les informara; pero al parecer esa parte fue recortada. Si esa nota llegó a manos de los embravecidos trabajadores, modificada, cabe preguntarse quién la sacó de la Cámara siendo este un escrito de circulación interna de los socios. Sin duda ha de ser una persona con acceso a los documentos y con una clara intencionalidad de perjudicar a estos armadores. De todas maneras la responsabilidad de las entidades antes mencionadas escapa a esta carta. En cada uno de sus discursos y manifestaciones públicas han dejado muy claro quiénes son sus enemigos. ${ }^{1358}$

Así, los editores de la revista ubican el origen del ataque en "la semilla de la discordia" instalada en la ciudad por los integrantes de la Multisectorial y los medios de comunicación, creando al CEPA como el enemigo. Al mismo tiempo que señalan la "malicia" de algún miembro de la cámara que no sólo hizo público un documento interno, sino que además lo modificó. Con todo, el 28 de junio de 2000 cinco plantas de procesado fueron perjudicadas. En la fábrica que la empresa Solimeno dispone en la intersección de las calles Juan B. Justo y Alejandro Korn una formación de Infantería Bonaerense bloqueó el paso de los manifestantes. Estos arrojaron algunas piedras contra la planta pesquera y los policías respondieron con balas de goma y gases lacrimógenos. Ante esto, quienes protestaban retrocedieron y utilizaron carteles publicitarios para cubrirse. Después de algunos minutos comenzaron a acercarse lentamente hasta encontrarse frente a frente con las fuerzas policiales. En ese momento se iniciaron discusiones. Un hombre grita a los efectivos policiales: “¿De qué lado están?”. Una mujer señala: "Tenemos gente herida. Somos trabajadores, no somos chorros" y sigue con insultos hacia la policía. Luego pregunta: “¿Cómo puede ser que nos hagan esto? Después de tanta hambre, de tanta miseria que hemos pasado". Otro manifestante explica: "llegamos al límite de lo que se puede aguantar". ${ }^{1359}$ Entre las intervenciones ante las cámaras de televisión, que son muchas y difíciles de reproducir, se destacan dos discursos. Por un lado, el reclamo a la policía para que no reprima a los trabajadores y, por otro, el llamado para que se movilice toda la ciudad. Un hombre expresa: "La policía no puede reprimir a los trabajadores. Hay que reprimir a los delincuentes. Tengo mi libreta de embarco

${ }^{1357}$ E.A., 29/06/2000.

${ }^{1358}$ Puerto, la otra cara de la pesca, Nro. 11, 2000.

${ }^{1359}$ E.A., 29/06/2000. 
(lo que constata que es marinero y la muestra a la cámara). No somos infiltrados. Somos gente de trabajo que queremos trabajar. Ellos (por los empresarios) no se quieren sentar ni a negociar". Otros dos hombres discuten con la policía: "Acá el problema no es con la policía. Acá el problema es con los empresarios". Un policía le responde "Hoy incendiaron todo". Uno de los manifestantes argumenta: “Ellos nos cagan de hambre hace dos meses ¿no es violencia eso?”. Y sigue: “QQuién empieza con la violencia primero? Ellos empiezan con la violencia, porque el hambre es violencia". Reunidos los manifestantes comienzan a aplaudir y cantan: "El puerto unido jamás será vencido". ${ }^{1360}$

En aquellos episodios una referencia central organizativa fue la UOP, junto con otros agrupamientos de la industria del pescado y también de los marineros. Es interesante ver entonces cuál era la intención de quien buscaba conducir aquel episodio. Respecto a la intencionalidad al atacar las fábricas Luis Verón dice:

Nunca tuvimos esa política de romper una fábrica o romper algo [...] tratamos de evitarlo, tratamos de parar a la gente, de que no pasara lo que pasó. Que fue que empezaron a agarrar piedras y empezaron a tirar piedras contra las empresas y ya después de ahí un poco que rebalsó todo, porque ya de ahí se fueron a Moscuzza... Va, fuimos, porque nunca nos abrimos nosotros del conflicto, también fuimos. ${ }^{1361}$

Es así como una de las organizaciones que pretendía dirigir las acciones se vio sobrepasada por la dinámica de la protesta, a la que terminó sumándose. Como resultado, tres manifestantes fueron detenidos y los obreros decidieron no desconcentrar hasta tanto la policía no los dejó en libertad. Finalmente, los trabajadores se dispersaron pero con la decisión de realizar otra asamblea para evaluar las medidas a seguir el día posterior. Los acontecimientos comenzaron con la asamblea aproximadamente a las 11.30 horas de la mañana y se prolongaron por varias horas. Además, las fuerzas policiales decidieron montar guardias permanentes en los domicilios de los industriales pesqueros debido a que entre los manifestantes se barajaba la posibilidad de realizar "escraches" en las casas de los empresarios. Según El Atlántico tras los incidentes el reacondicionamiento de las plantas pesqueras demandó una inversión superior al millón doscientos mil pesos. ${ }^{1362}$ Después de ocurrido "el estallido" distintas voces expresaron su acuerdo o desacuerdo con los hechos. Desde la SAGPyA, Antonio Berhongaray aseguró que los violentos incidentes que se registraron en Mar del Plata "no están enmarcados en las restricciones a la pesca que fueron dispuestos por el colapso de la merluza, sino por problemas laborales entre empleadores y empleados”. Puntualizó que el conflicto fue laboral y "entre los mismos integrantes de la multisectorial de esa ciudad". Contradiciendo en parte su argumentación, el secretario expresó que "el conflicto no se da entre sindicatos y empleadores sino a través de un tercer grupo, que son las cooperativas de trabajo, que están al margen de la multisectorial". Reconoció que las cooperativas "funcionan en forma bastante irregular. Hay que tener en cuenta que la mitad de los marplatenses dedicados a la pesca, trabajan en cooperativas en condiciones difíciles, como el empleo en negro". Después volvió a desligar responsabilidades y

\footnotetext{
${ }^{1360}$ Otra situación que se manifiesta es el llamado a la intervención de las centrales obreras: "Que la CGT y la CTA vengan acá. Si son tan combativos que vengan acá. Que los queremos ver acá”.

${ }^{1361}$ Entrevista a Luis Verón, op. cit.

${ }^{1362}$ E.A.,30/06/2000.
} 
sentenció que "El tema se ha generado por diferencias de criterios con respecto a las remuneraciones que se planteaban en algún momento entre sindicato y los empresarios". ${ }^{363}$

Las cámaras empresariales, antes enfrentadas, coincidieron en repudiar los hechos de violencia. ${ }^{1364}$ El CEPA emitió una solicitada en La Capital titulada "Estado de Indefensión". En ella declaraban que las empresas integradas se encuentran en un estado de indefensión que "tiene su origen en compromisos no cumplidos realizados por parte de la dirigencia empresarial pesquera local con el apoyo de varios funcionarios políticos locales y provinciales".

Nos sentimos víctimas sin causa de un accionar irresponsable e incapaz de los dirigentes empresariales pesqueros y de algunos funcionarios municipales, provinciales y nacionales en relación al manejo de esta crisis pesquera. Algunos dirigentes empresariales y sindicales nos han elegido como blanco de sus ataques y causa de sus males. Somos evidentemente su blanco, pero no somos la causa de sus males. Contra nuestra voluntad hemos sido marginados de toda negociación en el ámbito político y gremial. No estamos de acuerdo con el accionar de los siguientes funcionarios: El Sr. Francisco Romano, Subsecretario de Pesca de la Provincia de Buenos Aires; -El Lic. Darío Sócrate, Secretario de la Producción de la Municipalidad de Gral. Pueyrredón. No estamos de acuerdo con el accionar de algunos dirigentes empresariales que han hecho falsas promesas a los trabajadores de la Pesca para obtener su apoyo en el logro de objetivos empresariales. Frente al ataque organizado del que fueran objeto nuestros empleados, nuestras propiedades y nosotros mismos, renovamos nuestra posición de siempre: Diálogo entre todos, sin violencia ni exclusiones. Sr. Gobernador de la Provincia de Buenos Aires Dr. Carlos Ruckauf; Sr. Secretario de Agricultura, Ganadería, Pesca y Alimentación Dr. Antonio Berhongaray; Sr. Intendente del Partido de Gral. Pueyrredón Prof. Elio Aprile: Ustedes pueden y deben terminar con este estado de indefensión. Por favor, háganlo. Queremos trabajar. ${ }^{1365}$

Por su parte, tanto el SOMU como el Sindicato de Conductores Navales de la República Argentina responsabilizaron a los empresarios por lo sucedido, en la medida en que aquellos apostaron al fracaso de las negociaciones. Mientras que la CGT expresó su solidaridad con los trabajadores, comprometiendo la asistencia de la central para el día posterior. La conducción del SOIP reconoció como justos los reclamos, pero repudiaron el accionar para llevar a cabo los mismos.

\section{Imágenes construidas. La visión de los medios de difusión}

Los medios de difusión fueron los primeros que construyeron determinadas imágenes sobre los hechos -descartando otras posibles-, por lo cual son uno de nuestras principales referencias a la hora de analizar el día de furia. No resulta ocioso presentar cuáles fueron las principales interpretaciones de los

\footnotetext{
1363 L.C.,30/06/2000.

${ }^{1364}$ Darío Sócrate nos aseguró que "Esa situación sirvió para que el sector tomara conciencia de una sola cosa. Todos los reclamos son válidos. Las quemas de gomas y el ataque a las casas particulares de los empresarios no se soportan, de ninguno. Así sea del enemigo más acérrimo que se te pueda ocurrir". Asumió como un error propio no haber llamado a los empresarios para solidarizarse con ellos. Según sus apreciaciones, a partir de este momento los sectores empresariales tomaron conciencia de que la violencia se repudiaría siempre, más allá del motivo y de contra quien vaya dirigida. Entrevista del autor con Darío Sócrate... op. cit.

${ }^{1365}$ L.C., 1/06/2000. El énfasis es de la fuente.
} 
sucesos. El Atlántico, que se presentó a lo largo de su historia como un periódico ligado al "mundo popular", más cerca de "los intereses de la gente", fue el que a nuestro juicio realizó una lectura más comprehensiva de los sucesos. Dedicó seis páginas a los sucesos del 28 de junio de 2000. Señalaba que "la furia se encendió" tras una asamblea espontánea. La figura de lo espontáneo de la convocatoria y de las acciones aparece en otra nota que sostiene "En forma espontánea marcharon hacia las principales fábricas con intereses en el sector de buques congeladores...". No identificamos una linealidad de juicio en lo que respecta a las acciones. Más bien, podemos ver que está presente la idea de "estallido social" con dos tipos de significados. Uno se vincula a un "estallido" de algo que estaba en germen a partir de que no se solucionaba el conflicto entre trabajadores y empresarios. Este es el discurso principal. Remite a un acontecimiento, en cierto modo, esperable:

Luego de meses de inactividad, desempleo y necesidades familiares insatisfechas, la gente perdió la paciencia. Atacaron así la propiedad privada de terceros. Sin embargo, durante meses fueron convertidos en víctimas involuntarias de promesas empresarias incumplidas, de choque de intereses entre las conducciones de los gremios, de presiones y otras formas de convencimiento, ejercidas por los sectores en pugna (fresqueros-congeladores)...

Además se realiza una lectura sociopolítica de las consecuencias, llamativamente valorada de manera positiva:

La lectura de lo que pasó, luego de esta iniciativa, es mucho más profunda que los vidrios rotos, los desmanes y las balas de goma. La gente de la pesca ha dicho "basta de corrupción y de vender la patria, basta de robar nuestro trabajo y crear hambre a nuestras familias". Incluso se han roto los límites de contención de las dirigencias sindicales, las que están al borde de ser desconocidas completamente por sus bases. ${ }^{1366}$

También el titular de otra nota sugiere "Desocupación, reclamos, hambre... un coctel peligroso". En este sentido, los manifestantes aparecen como "víctimas involuntarias" que, en alguna medida, se ven obligados a adoptar tales medidas. En esta nota se transcriben algunas declaraciones de los trabajadores que están orientadas a criticar a los empresarios del CEPA (“...acá en la pesca hay tres personajes que traban todo, con nombre y apellido, son Moscuzza, Solimeno y Valastro...”) y también al gobierno (“...el gobierno está haciendo oídos sordos, acá se paga casi todo en negro, se evaden aportes previsionales y de todo. Es tiempo que el gobierno termine con esta corrupción en la pesca. De lo que pasa, es principal responsable..."). La contratapa sugiere con grandes letras "Hambre y desocupación explotan en el Puerto". En el sentido de lo anunciado del hecho, un texto firmado por Roberto Fava con el sugerente título "Estaba cantado", cita algunos párrafos de una nota publicada días antes, según la cual "la crisis pesquera local, que arrastra hacia el temido abismo del desempleo a unos 20 mil marplatenses, está alcanzando ribetes 'castaño oscuro'. Día a día se palpa que la gente se encuentra al límite y los incidentes pueden desatarse en forma imprevista e incontrolable". En la página siguiente se lee "Estaba escrito. Era tan seguro como que después de dos llega tres o que tras Nochebuena se celebra Navidad". Sin embargo, no es este el único sentido que el diario manifiesta. En una nota titulada "De la protesta irracional a los actos de vandalismo incontenibles" se lee: "Lo que había comenzado como una simple

${ }^{1366}$ E.A., $29 / 06 / 2000$. 
asamblea popular [...] se transformó en una movilización y derivó finalmente en desmesurados actos de vandalismo contra distintas plantas dedicadas al procesamiento de pescado". Se presenta de ésta manera la idea de vandalismo, de hechos sin justificación. Y en otro recuadro se resalta la violencia (" $L a$ violencia de los trabajadores portuarios causó graves daños"). Por último, se terminan explicando los hechos como consecuencia del modelo económico implementado y se responsabiliza a los dos partidos políticos mayoritarios de nuestro país. ${ }^{1367}$

Por su parte, La Capital, que pertenece a un grupo Multimedio del que es cara visible Florencio Aldrey Iglesias, dedicó tres páginas a nuestros episodios. El tono general es de condena y está presente desde la nota principal "La violencia ahondó la preocupante situación pesquera". Se coloca el foco de atención en la violencia y en quienes la ejercieron y no tanto en las causas que generaron el hecho. Ya previamente, en un editorial del día 15 de junio de 2000 refiriéndose a la protesta de los trabajadores y las trabajadoras del pescado, la dirección del periódico señalaba:

Lo que no es admisible es apelar a la violencia, muchas veces irracional, para alcanzar las metas que garanticen el ejercicio de los derechos sociales a la comunidad. Por ello lo ocurrido el martes frente al palacio municipal es reprochable, sin dejar de reconocer la situación muchas veces angustiante que, por ejemplo en este caso, expresaba un sector de obreros de la actividad pesquera, precisamente una de las más castigadas en nuestra región. Es que acudir a actos como los registrados por la crónica no solamente en sí mismo alcanzan soluciones, sino que por el contrario crea enfrentamientos que resquebrajan el cuerpo social. No es la manera ésta de peticionar, y excede en mucho el legítimo derecho de reunirse y peticionar ante las autoridades, para convertirse en un acto casi delictual. ${ }^{1368}$

Respecto del 28 de junio menciona a los trabajadores que "se volcaron violentamente a las calles" provocando "desbordes en la manifestación". Comparte la visión de lo espontáneo: "Los acontecimientos comenzaron a desarrollarse poco antes del mediodía, cuando un nutrido grupo de trabajadores embarcados y obreros de la industria pesquera se autoconvocó en la esquina...". Por otra parte, si bien se reconoce en el desempleo al motor de las acciones, de inmediato se utiliza el concepto de vandalismo ("La falta de trabajo motorizó los hechos de vandalismo"). Al momento de evaluar los hechos: "Las continuas desavenencias entre los distintos sectores de la pesca que determinaron una parálisis casi total de la actividad, tuvo su punto culminante con una serie de hechos irracionales". A pesar de presentarse como "irracionales" los hechos se vinculan con la precaria situación de los trabajadores ("La angustia que los trabajadores del pescado vienen viviendo desde hace casi tres meses explotó ayer...”). La voz de los protagonistas tiene menos espacio que en El Atlántico y, llamativamente, se menciona la existencia de manifestantes que no habrían estado de acuerdo con la metodología de protesta ("...en Edison y 12 de octubre, decidieron la recorrida que iban a realizar por distintas empresas, quemando gomas, lo que originó algunas discusiones entre distintos sectores, por la metodología de implementar la protesta"). También se alude a la ausencia de la dirigencia gremial. ${ }^{1369}$

El semanario Noticias y Protagonistas se ocupó del hecho en su editorial firmada por el periodista José Luis Jacobo bajo el título de "La tarde de los cristales rotos". Desde el comienzo de la nota se

${ }^{1367}$ E.A., 29/06/2000.

${ }^{1368}$ L.C., 15/06/2000. Editorial: "La violencia no puede ser una herramienta de presión".

${ }^{1369}$ L.C.,29/06/2000. 
apunta contra los empresarios fresqueros, sosteniendo que éstos habrían "preparado" el terreno para que "la violencia incontenible" se lanzara contra el CEPA. Para el autor de la nota, que no oculta su simpatía con los agredidos, dicho consejo está conformado por las "empresas que se han atrevido a ser eficientes, que tienen a su personal en blanco y concitan la envidia enfermiza de quienes controlan la Cámara de Armadores". Refiere al hecho como una: "demostración de poder mafioso que ampara el intendente Blas Aurelio Aprile". Cuando el autor menciona a los manifestantes, utiliza la noción de turba, la cual estaría dirigida por Domingo Novero. Sugiere: "En horas de la mañana del 27 ya se sabía que un sector de gente de trabajo, abandonada y empobrecida, iba a ser conducida como instrumento de destrucción hacia las empresas más representativas del sector congelador". Más adelante, en una variante periodística de la teoría de las masas manipulables -casi siempre presente en el sentido común mediático-, se sostiene: "un sufrido y sufriente conjunto de trabajadores desempleados [...] fueron conducidos por otro grupo, profesionales del escándalo social, los piquetes, los destrozos y la toma de propiedades ajenas, a una escalada de violencia sin precedentes en la ciudad". También se ocupa de denunciar el doble juego de algunos empresarios fresqueros, quienes tienen barcos pescando en el sur pero se muestran como empresarios con estrictos intereses en Mar del Plata. Al mismo tiempo, señala a los empresarios fresqueros como quienes operan de manera fraudulenta en la actividad: "Son los intereses que sustentan los que negrean a sus trabajadores, los que hacen a la mar a sabiendas de que no tienen permisos de pesca correspondientes y luego escudan su accionar fraudulento y clandestino en acusar, hostigar y violentar al otro". 1370

El último medio gráfico del que nos ocupamos es la revista Puerto, la otra cara de la Pesca, que en su número 1 tituló la columna en que se ocupó de nuestro hecho "Cuando el barro se subleva". Al momento de definir a los sujetos de la protesta sostuvo que se trataba de "un grupo de trabajadores $y$ algunos infiltrados". Sin embargo, la revista reconoce que la mayoría de los sujetos eran fileteros "en una penosa situación laboral" que "Con el paro de casi tres meses se vieron imposibilitados de conseguir medios simplemente para comer; debian pedir a los comercios de la zona un poco de arroz, verduras y pan, para poder así alimentar a sus hijos [...] Esta situación imposible de imaginar para quien nunca haya padecido hambre, es la que dio marco propicio para los desmanes". No obstante, si bien la situación de hambre aparece como el motor, la revista pretende enfatizar que “...sin duda hubo alguien que manejó los hilos para que estas personas materializaran en destrozos su indignación, principalmente sobre estas tres empresas...”. En este sentido, una nota aparte se pregunta por “¿Quién convocó?”. Después de criticar la idea de autoconvocados -que los diarios reproducen sin un tratamiento críticoseñala los nombres de los más representativos entre los obreros y menciona a tres integrantes de la UOP. Además denuncia la presencia de marineros en lo que era un reclamo de gente de tierra y la existencia de manifestantes a sueldo. Por último refuerza la idea de una "mano oculta" argumentando que "Es evidente que hubo una dirección, aunque ningún medio de comunicación-salvo Noticias y Protagonistas-se haya atrevido siquiera a sospecharlo". En la última nota titulada la "Desesperación de la gente es real" los editores señalan dos aspectos. Por un lado, el que enfatiza el título y que se vincula con la precaria situación de los trabajadores que participaron de la jornada de protesta. Se destaca: "Estas personas subocupadas realmente están pasando por una grave situación...". Por otro lado, de inmediato intentan quitar responsabilidad del sector empresario que la revista defiende: "Demás está decir que la culpa no la tienen los empresarios con buques congeladores. Ellos tienen derecho a modernizarse y a utilizar el

\footnotetext{
${ }^{1370}$ Noticias y Protagonistas, op. cit...
} 
sistema productivo que más les convenga: es el Estado el que debe ocuparse de quienes han quedado fuera del circuito laboral". El argumento resulta consistente ya que hay una gran ausencia estatal en la regulación de la pesca. No obstante, el punto débil es que en su énfasis crítico del Estado se ignora que los trabajadores de los que habla, más que quedar fuera del circuito laboral, están dentro, aunque en el peor lugar. Y es a través de su subocupación que los empresarios (fresqueros y congeladores) lograron regular las fluctuaciones tanto de la demanda como de los volúmenes de captura de pescado.

\section{Cuando los trabajadores se vuelven vándalos}

Analizamos este episodio de "ira obrera" procurando hallar una respuesta a la pregunta de ¿cuándo los trabajadores se vuelven "vándalos"? proponiéndonos discutir con aquellas imágenes que reproducen lo que Rudé definió como una lógica muerta, a partir de la cual se dan por sentadas, sin examinarlas, las cuestiones más importantes (Rudé, 1981). En primer lugar aquellos sucesos nos aportaron elementos para comprender algunas de las características fundamentales del modelo productivo sobre el que se sustentó la actividad pesquera en Mar del Plata. En este sentido, el colapso de la merluza producto de la sobreexplotación que sufrió el caladero aparece como dato ineludible funcionando como "la base" de la protesta obrera. Es así que a partir de la crisis desatada en 1997 y la obligatoria reducción de los volúmenes de captura, lo que hasta el momento era una división empresarial por tipo de flota, finalmente se transformó en una disputa abierta. Este enfrentamiento se convirtió en uno de los aspectos clave que pueden explicar de manera mediata el origen de la protesta "violenta", en la medida en que la alianza de la que participaron los empresarios "fresqueros", sectores de los trabajadores y la intendencia municipal fue delimitando a los "congeladores" como enemigos y al CEPA como uno de los antagonistas principales. En este sentido, aunque en una versión más radicalizada, los sucesos fueron una expresión más de aquel enfrentamiento. Asimismo, el día 28 de junio tuvo expresión el conflicto entre dos sectores clave de la actividad y que se encuentran en situaciones antitéticas. Como una ironía (o una consecuencia) de la historia, las "víctimas" fueron los grupos económicos más beneficiados, mientras que los "victimarios" fueron los trabajadores de las pseudo cooperativas, quienes quedaron ubicados en el peor lugar dentro del modelo productivo. Aquel día de furia fue el momento en que maduraron una serie de agravios experimentados por los trabajadores que padecían una situación angustiante y que, en lo inmediato, hacía más de dos meses que estaban parados. ${ }^{1371}$ Confluyó la angustia cotidiana de los trabajadores de las cooperativas y la desatención del gremio del SOIP de esta población obrera, junto a la "bronca" de los marineros ante la insistente negativa empresarial de llegar a un acuerdo salarial así como el padecimiento de desempleo. En algún sentido, los contenidos expresados en este episodio se asemejan a las puebladas, signadas dramáticamente por la acción de personas desesperadas. Eso es lo que el hecho tiene de "explosión", de desborde. Pero no se agota allí.

Prestando atención a la multitud movilizada vemos que no participaron ni del desarrollo de la protesta ni en su convocatoria los dirigentes de ninguno de los principales sindicatos. Esto no significa aceptar la imagen vulgar de "lo espontáneo" entendido como carente de toda organización, borrándose así

${ }^{1371}$ No está de más aclarar que la ciudad de Mar del Plata tenía los índices más altos de desempleo, con lo cual la canalización hacia otro tipo de ocupación de estos trabajadores se hacía imposible dentro del contexto de una profunda recesión que afectaba al conjunto de la economía argentina. 
uno de los elementos que permiten explicar el acontecimiento. ${ }^{1372}$ Fue la UOP la principal convocante, junto a otras agrupaciones vinculadas con sectores del peronismo y la izquierda (Corriente Clasista y Combativa, Movimiento Teresa Rodríguez y sectores del peronismo de izquierda). Sin embargo, trasladar el poder de convocatoria a la idea de una dirección "consciente de los fines" así como a una planificación previa presenta algunas dificultades debido a que los propios dirigentes de la UOP más que haber dirigido, parecen haberse sumado al ataque de las fábricas. Sin duda hubo convocantes y organizaciones que disputaban la conducción de la masa movilizada, organización elemental imprescindible para llevar adelante cualquier hecho colectivo, pero esas conducciones no pudieron elegir el fin, sino que más bien terminaron adecuándose a lo que el propio desarrollo de la protesta fue generando.

Una de las cuestiones de mayor interés que la protesta sacó a la luz se relaciona con las consecuencias que trajo aparejada la creación de las cooperativas, particularmente en cuanto mantuvo una división en el seno de los trabajadores. En la industria del pescado quedaron establecidos dos sectores: "los estables", que disfrutaban de distintos beneficios como vacaciones pagas, jubilación, garantía horaria, etc. y los "inestables", es decir, los obreros de las cooperativas que dependían de manera inmediata de la materia prima que ingresaba al puerto, no tenían garantía horaria, ni vacaciones, ni aportes jubilatorios. La permanencia de trabajadores "inestables", en cuanto garantizó la baja de los “costos del trabajo" constituyó, llamativamente, uno de los rasgos más estables del modelo pesquero. E1 día 28 se vio el conflicto entre ambos sectores cuando algunos obreros trabajaban normalmente, mientras que otros estaban sufriendo la falta de empleo. Esta situación repercutió en la unicidad y fortaleza del gremio y volvió difícil una acción común. Por la cantidad de acciones realizadas, fueron los obreros de las cooperativas el principal sujeto de la protesta. No obstante, este dato no debe llevarnos a interpretar que los obreros "estables" se volvieron "conservadores", mientras que los "inestables" fueron los más combativos. Esta imagen, que podría desprenderse de algunos datos como la supremacía en la cantidad de acciones de protesta realizadas por parte de los cooperativizados, la mayor presencia de la izquierda entre ellos y la radicalidad de sus acciones, debe ser matizada. Si prestamos atención a los contenidos de las demandas, se vuelve evidente la supremacía de un horizonte defensivo. La lucha fue por mantener el trabajo, exigir la jubilación y, finalmente, por la implementación de un subsidio de 500 pesos. La otra consigna, casi desaparecida en el propio desarrollo de protesta, la registración laboral en "blanco" de los cooperativizados, quedó relegada dando lugar al reclamo de subsidios. Difícil resultaba aquella exigencia en un contexto en que cada día había menos pescado. Por ello, no necesariamente debe asociarse radicalidad -disrupción- en las formas de la lucha con radicalidad en sus contenidos.

Cómo detonante del hecho en cuestión aparecen dos situaciones: la burla por parte de un empresario para con los trabajadores y la aparición de un documento donde, con la firma de las tres empresas que luego fueron atacadas, se conmina al conjunto de la cámara a no negociar con los obreros. El hecho devela el grado de enfrentamiento al que habían llegado los empresarios a partir de la publicidad de un documento de circulación interna. Esto demostró la presencia de una "mano oculta" que orientó el ataque hacia las plantas del CEPA. También resultó "sospechosa" la inacción policial mientras que eran atacadas las primeras fábricas. No obstante, si bien esta "mano oculta" sin duda existió, hay que matizar su capacidad para definir el hecho. Más que la clave de la explicación es un elemento más del rompecabezas. Las firmas que finalmente fueron blanco de los ataques habían sido construidas como enemigos durante un proceso previo cuando, como hemos demostrado, desde las primeras protestas se

\footnotetext{
${ }^{1372}$ No existe espontaneidad pura. Lo espontáneo es sólo una forma embrionaria de lo consciente (Gramsci, 1998).
} 
acusó a los “congeladores" como los culpables de la depredación y la falta de trabajo. El detonante fue la gota que rebalsó el vaso, pero éste se había llenado en el proceso previo.

Con respecto a la intervención de los medios de difusión, allí se trasluce el enfrentamiento empresarial. Tanto Noticias y Protagonistas cómo la revista Puerto, adoptaron una posición de defensa de las empresas atacadas y criticaron al sector empresario vinculado a los fresqueros así como al intendente de la ciudad. Para ellos, lo que termina explicando el hecho es la presencia de esa "mano oculta", ya que los grupos empresarios que fueron atacados no tenían "nada que ver" con los padecimientos de los trabajadores. En el mismo sentido, recurren a la presencia de infiltrados como agitadores, presuponiendo que los obreros "por sí solos" no hubieran atacado las fábricas. El señalamiento de la presencia de infiltrados, común a ciertos análisis de las protestas populares, se basa en el supuesto de que los "buenos trabajadores" (variante de los buenos pobres) no pueden cometer hechos de violencia. El argumento permite realizar una elusión. Esto es,posibilita excluir del análisis la violencia legal que el sistema desarrolla, sustentado en las propias relaciones sociales de desigualdad, descargando culpas en sujetos extraños al cuerpo social. Ello sin preguntarse el por qué los obreros, en una determinada coyuntura, salen colectivamente a quemar fábricas. Es decir, por qué se vuelve una opción adoptada por un conjunto. Por su parte, El Atlántico deja entrever una crítica a los empresarios congeladores. En la mayoría de las notas justifica (o al menos entiende) el accionar de los manifestantes que "perdieron la paciencia". Sin embargo, apela a la idea de vandalismo. La Capital, por su parte, introduce un dato del que no tenemos mayor comprobación y que se vincula con la posibilidad de que un grupo de trabajadores no estuvo de acuerdo con la metodología de protesta. De este modo, resta legitimidad al accionar de quienes atacaron las fábricas ya que no serían "todos los manifestantes". A su vez, es interesante la apelación a la "irracionalidad" de los hechos. Porque si algo no hubo, precisamente, fue irracionalidad. ${ }^{1373}$ Por un lado, las empresas atacadas eran para los obreros el enemigo. $\mathrm{Y}$ un enemigo que se fue construyendo con anterioridad. A esto se sumaron los detonantes. Al mismo tiempo, en términos instrumentales, para esta fracción de trabajadores el arma más apropiada para hacer oír sus reclamos no aparecía entre las opciones institucionales. Ya que ni los empresarios (que no los reconocían como trabajadores de sus empresas), ni el Estado (que no brindaba suficiente ayuda social), ni el sindicato (que no los representaba por no estar en relación de dependencia) brindaban algún tipo de solución. ${ }^{1374}$ De modo que lo que se presenta como un hecho irracional fue también un repertorio colectivo de protesta, conformado al calor de las propias acciones y que mostró cierta eficacia. Administrando, como diría Rudé, una "ruda pero eficaz justicia natural". Se trataba de población que ya no podía obtener sus medios de vida más imprescindibles dentro del marco jurídico vigente. Es en este sentido una protesta que se radicaliza, entre otros elementos, al no encontrar una salida institucional. El hecho cobró también un sentido moral en la medida en que buscó castigar a quiénes se consideró que maltrataron y se burlaron de los obreros.

Por último, posiblemente este hecho marca en toda su magnitud un cierto desplazamiento (siempre parcial) del sujeto de la protesta desde los trabajadores "estables" a los "inestables". Sin trabajo no hay manera que los trabajadores puedan garantizar una huelga. Por ello se pedía que convocaran a una medida

\footnotetext{
${ }^{1373}$ Ya Emile Durkheim, en su discusión con la escuela utilitarista, mencionó la utilidad de la furia. Una utilidad que no venía dada por una "acción racional respecto a fines", sino más bien, por la necesidad de una conciencia colectiva que se enfrentó a algún tipo de agravio, de expresarse y reunificar su cohesión. La furia no hace más que reconstituir el lazo social. Esto es, volver a dar cohesión y sentido a una identidad colectiva afectada (Durkheim, 1973 [1893]).

1374 Según Bonnet, respetar la convertibilidad exigía ajustes cada vez más severos que alejaban al Estado de la posibilidad de distribuir recursos (Bonnet, 2008).
} 
de fuerza fueran quienes aún mantenían la relación laboral. Asimismo, se emprendieron acciones eminentemente demostrativas que buscaban hacer visible una situación angustiante, expresaban ira y funcionaban a la vez como denuncia. En tanto todo conflicto parcial es la expresión singular de la lucha contra contradicciones más amplias y generales de la opresión (Cafassi, 2002), con independencia de lo que piensen los sujetos de lo que están haciendo, su éxito o fracaso, en tal sentido, no puede mecánicamente desprenderse del resultado inmediato, sino también de la autoconfianza lograda por la propia fuerza, del grado de extensión y solidaridad alcanzado, así como también de los legados organizativos. Estos sucesos influyeron sin duda, dos años más tarde, en el cambio de la conducción del SOIP, pasando algunos de los representantes de las protestas callejeras a formar parte de la dirección sindical. Además, los piquetes, el ataque a las fábricas, la toma y ocupación de la sede gremial se instalaron como un repertorio posible de acción colectiva. Estos repertorios se reiteraron durante el conflicto de los años 2007 y 2008.

\section{El "enemigo" dentro de la propia clase}

Como todo sindicato, la historia y evolución del SOIP también estuvo jalonada por batallas al interior de la propia clase trabajadora por la conducción de los trabajadores. El tránsito de las conducciones gremiales habla de la hegemonía anarquista al advenimiento del peronismo y el retorno anarquista luego del golpe de 1955. La vuelta del peronismo en 1969 y, por último, ya dentro de nuestro período de estudio, la victoria de una conducción trotskista. Además, aun sin llegar a ocupar la conducción sindical, otras tradiciones político ideológicas históricamente coexistieron en el sindicato de los trabajadores del pescado (socialistas, radicales, comunistas, peronistas de izquierda, etc.). Dentro de los instrumentos que los contendientes utilizaron para disputar la legitimidad de la conducción sindical se inscribió como una constante repetida a lo largo de la historia gremial la toma y ocupación de la sede sindical. Primero, en julio de 1966, los peronistas tomaron el sindicato durante el gobierno anarquista. Los fileteros y fileteras, entrenados en tomas de instalaciones fabriles, trasladaron el repertorio de acción a la ocupación de las instalaciones del SOIP. Entonces se trataba de denunciar la ilegitimidad de la conducción y forzar la intervención del Ministerio de Trabajo. Entre otros, aparecía en la toma un joven delegado de la Campagnola, Abdul Saravia. Si bien en el corto plazo la sede fue desalojada y devuelta a sus antiguos ocupantes, la medida logró desacreditar a la conducción anarquista allanando el camino de la intervención sindical (Nieto, 2012). Asimismo, en 1972 fue la oposición sindical peronista, encabeza por Corino Díaz, la encargada de llevar adelante una toma, ahora bajo la conducción de Saravia. ${ }^{1375}$ En esta

\footnotetext{
${ }^{1375}$ La ocupación se produjo el 3 de mayo de 1972 protagonizada por alrededor de 20 personas armadas. Durante la misma se efectuaron no menos de cinco disparos y se produjeron forcejeos entre representantes del oficialismo y la oposición que se negaba a salir. L.C.,04/05/1972. Una de los motivos principales surgía al no haber recibido ninguna respuesta tras varios meses de transcurrida su impugnación de las elecciones gremiales. Archivo DIPPBA, Mesa B, Factor gremial, Carpeta 57, Legajo 17, Folio 131, 03/05/1972. Según la prensa, se vivieron momentos de tensión cuando dirigentes oficialistas visiblemente irritados lanzaron un ultimátum a los ocupantes invitándolos a desalojar la sede gremial en una hora, de lo contrario ellos mismos se encargarían de la cuestión. Finalmente los ocupantes fueron desalojados por efectivos policiales. Tras el desalojo se detuvo a quince personas con tres armas de fuego. La intención de los ocupantes era denunciar a la comisión directiva. Además, ante la falta de definiciones respecto de la impugnación que existía en relación a los últimos comicios, querían promover un nuevo llamado a elecciones. Tras la toma emitieron un comunicado donde pedían el apoyo de los afiliados y justificaban su accionar tras los objetivos de "1) Terminar con la continuidad de una nefasta y fraudulenta dirección entregada de por vida al manoseo y provecho patronal; 2) Por la falta de atención total a los problemas de los trabajadores del gremio [...] 3) Acusamos de falta
} 
ocasión, el intento del grupo no se coronó con el éxito, no pudiendo socavar las bases del poder saravista. Varios años después, un 29 de junio de 2000, el día inmediatamente posterior al "día de furia", inscribiéndose en aquella tradición, trabajadores de cooperativas y desocupados, dónde emergía la UOP como principal instancia organizativa -sin el menoscabo de la presencia de otras corrientes político sindicales-, tomaron la sede sindical, en ese entonces bajo la conducción de Juan Carlos Darguibel, quien heredaba el liderazgo de Saravia. El proceso aconteció de un modo similar a su antecedente de 1966. En ese año el grupo de fileteros y fileteras nucleado en torno al STIA, que había salido fortalecido de un proceso de movilización durante todo el año 1965 -lo cual daba plafón para sostener una medida como la ocupación-, acometía la acción de toma. Mientras, el grupo dirigente del SOIP recibía un fuerte revés que no supo ni pudo revertir (Nieto, 2012). Ya en junio del año 2000, dentro de un proceso que incluyó numerosas movilizaciones protagonizadas por los trabajadores de las cooperativas, un grupo de manifestantes que se dirigía a exigir que el SOIP se plegara al paro que sostenían los marineros, procedió a la toma y ocupación de la sede sindical, denunciando la situación de acefalía gremial. Se buscó propiciar una intervención que efectivizara el llamado a elecciones gremiales. Recordemos que los comicios de 1998 se suspendieron y la directiva de la entidad se mantenía en la conducción bajo la figura de custodios de bienes. Si bien tras el hecho de la toma la sede fue devuelta a su antigua conducción, la medida potenció el liderazgo opositor y mostró como una alternativa de gobierno, más o menos real, a la fuerza opositora de izquierda, al tiempo que desnudaba la debilidad en que se mantenía sumida la conducción gremial. En este sentido, podemos ver cómo una fuerza social obrera fue "fabricando" una nueva conducción, en este caso representada en la UOP, aunque el proceso fue mayor e integró otras personificaciones excediendo las fronteras de esta agrupación. La nueva fuerza, mientras señalaba objetivos precisos y programas de acción, comenzó a cumplir papeles dirigentes antes de su llegada al poder gremial.

\section{La construcción del enemigo: "los burócratas"}

Dentro del sector de los trabajadores cooperativizados y desempleados existían en el puerto muchos militantes vinculados a diferentes agrupamientos y partidos de izquierda, así como militancia de tradición peronista opositora a la conducción gremial. En el contexto de movilizaciones del período de la crisis de la merluza, fueron estos los sujetos que aparecieron como activadores de las protestas, al mismo tiempo que pugnaban por darle una dirección al conflicto. A pesar de las diferencias y heterogeneidad de estas fuerzas opositoras al saravismo, todas las corrientes compartían un conjunto de críticas, las que ahora se emitían de manera más clara tras empezar a padecer de lleno las consecuencias del proceso de cooperativización en un contexto de retracción de las capturas de pescado. Además, no era un dato menor la muerte y ausencia del viejo líder del SOIP. Hemos visto ya como en la previa de los procesos electorales, y también en el transcurso de distintas acciones de protesta, se desplegaban numerosas críticas a la conducción gremial. Pero ahora, esas críticas poblaban la prensa y corrían parejas a la

grave e inconducta sindical, por no presentar ante la asamblea estatutaria el Inventario, Memoria y Balance [...] no haber rendido cuenta de los fondos sindicales y obra social [...]" y finalizaba caracterizando a la conducción gremial de "ENTREGADORES, VENDIDOS, OBSECUENTES, INOPERANTES Y VIVIDORES” al mismo tiempo que los acusaban de sostener en el sindicato "MATONES A SUELDO". Firmaba el documento la Comisión de Toma del SOIP. Archivo DIPPBA, Mesa B, Factor gremial, Carpeta 57, Legajo 17, Folio 133, 03/05/1972. 
participación de estos viejos antagonistas gremiales en las cada vez mayores acciones de protesta. Así, por ejemplo, el 9 de julio de 1997, día del primer corte de calle significativo de nuestro ciclo, los obreros denunciaban que "el SOIP no existe, son del mismo palo que el gobierno de Menem y negocian con él, con los grandes empresarios, siempre a espaldas de los trabajadores. Vendieron los convenios colectivos y están colaborando con la depredación". ${ }^{1376}$ Días más tarde declaraban respecto de la directiva sindical “...sigue sin aparecer, se lavó las manos en todo esto, crearon las cooperativas de trabajo, dejaron a la gente en la calle, nunca más se calentaron por el afiliado. Ellos colaboraron con los empresarios para quitarnos el derecho y la dignidad como trabajadores". ${ }^{1377}$ Las críticas se multiplicaron durante las primeras asambleas de enero de 1998 en las que el sindicato se declaró en contra del paro convocado por los marineros. Juan Luis Saravia se definía en contra delahuelga porque afectaría a la flota fresquera y su pretensión era garantizar un mínimo de ocupación para los obreros en relación de dependencia. Al mismo tiempo, señaló ser el blanco de pseudo organizaciones que "se dedican sistemáticamente a incentivar posturas ideológicas totalmente a contramano de las necesidades de la gente del pescado". ${ }^{1378}$ Por su parte Luis Verón, de la UOP, repudió la actitud de los dirigentes del SOIP y explicó que la conducción gremial no adhería al paro "porque tienen compromisos políticos (con dueños de barcos y plantas) y no pueden ir en contra de ellos". Días más tarde, desde el oficialismo gremial publicaron un comunicado en que insistían en su apoyó a los reclamos sindicales, pero decían "No" al paro. Y agregaban consideraciones que no tienen desperdicio.

....ante las continuas amenazas e infamias promovidas por las personas de siempre, eternos perdedores, les reiteramos que la agitación profesional marxista no tiene cabida en la gente de trabajo, cuya única preocupación, compartida con nuestra conducción, es que no falte el pan en su mesa $[\ldots]$ indudablemente, estos ideólogos del fracaso se olvidan que nuestra gente ya les ha dicho 'no' en tantas oportunidades que tendrían que haber aprendido quiénes son los representantes de las bases [...] Con la conciencia tranquila por haber defendido y protegido a nuestra gente y con la firme convicción de estar en la postura correcta, les decimos a nuestros afiliados que: ante la violencia, las amenazas, las agresiones, oponemos la razón, el diálogo y la honestidad, axiomas que han permitido a esta conducción ejercer el mandato durante más de 30 años. ${ }^{1379}$

Estas declaraciones fueron la respuesta a un volante elaborado por la Lista Celeste donde se realizaba un balance de la huelga portuaria, en el que se señalaba:

Todos los gremios que participaron consiguieron algo, menos el SOIP, porque estos pseudodirigentes se abrieron de la lucha cuando se declaró el paro. Una vez más estos traidores han demostrado que son agentes de las cámaras patronales, por eso se abrieron del frente de lucha, para no quedar mal con sus amos los patrones. Y por temor a que les corten las cometas. ${ }^{1380}$

De ésta manera, las líneas políticas iban delineando sectores enfrentados que, más allá del lenguaje y la adjetivación propia de la contienda gremial, de fondo expresaba no sólo diferencias político-

\footnotetext{
${ }^{1376}$ E.A., $10 / 07 / 1997$

${ }^{1377}$ L.C., $16 / 07 / 1997$.

1378 L.C.,03/01/1998.

1379 E.A., 16/01/1998.

${ }^{1380}$ Boletín de la Lista Celeste, febrero de 1998. El énfasis es de la fuente.
} 
ideológicas, sino además la tensión entre los intereses de los trabajadores en relación de dependencia y los cooperativizados. Este hecho se hacía evidente cuando los representantes del sector cooperativo buscaban participar de la vida político-institucional SOIP y la dirigencia los apartaba con el argumento de que no eran afiliados al gremio. Por ejemplo, la situación se plasmó durante la realización de una asamblea de memoria y balance del gremio en que se impidió el ingreso de los trabajadores cooperativizados. También las elecciones gremiales de 1998 tuvieron como eje estas disputas, debido a que según el estatuto del gremio los candidatos debían (actualmente sigue siendo así) poder demostrar que durante los dos últimos años han trabajado bajo relación de dependencia. Lo cual dejaba sin posibilidad de participar en elecciones al personal cooperativizado. Finalmente, como sabemos, aquellas elecciones fueron suspendidas. Ante esta suspensión, la vieja comisión directiva se mantuvo en la dirigencia del sindicato, pero sin tener el aval surgido del proceso electoral, lo que los dejaba en una situación de debilidad. Por ello, de inmediato los integrantes de la UOP instalaron la cuestión de la acefalía en el gremio. Al respecto, Patricia Comparada expresó que "vamos a proponer se nombre la comisión provisoria, ya que a nuestro entender, hoy por hoy, el gremio está acéfalo". Y se explayó diciendo que la "conducción habia perdido mandato entre la totalidad de los trabajadores y además finalizó el periodo que rige para Darguibel el 17 de julio pasado, por lo que para nosotros la conducción del gremio está acéfala y ahí pedimos un lugar". ${ }^{1381}$ En mayo del año 2000, el mismo día en que la sede de la CAABPA era atacada, los trabajadores de la industria tomaban la Delegación municipal del puerto. Allí denunciaron no sentirse amparados por el gremio que los agrupa. Dijeron: "Pedimos la participación inmediata del juez que tiene a su cargo la causa del SOIP porque están nombrados como meros veedores y los trabajadores no tenemos respuestas del gremio [...] Queremos que el juez lo intervenga y se lo entregue a los trabajadores, no a cuatro corruptos que hay hasta ahora". Señalaron a su vez que cuando golpearon las puertas del gremio, los dirigentes les señalaron que no podían hacer nada por ellos porque son seudocooperativizados. ${ }^{1382}$ Días más tarde, a través de un documento, la UOP criticó a "la dirección de nuestro gremio [que] constantemente se niega a representar nuestros reclamos por ello nos abocamos a la tarea de organizar a los trabajadores en negro". ${ }^{1383}$ Así como la UOP, también manifestaban el descontento con la directiva gremial los Trabajadores por la Reactivación del Puerto, organización que nucleaba a trabajadores cooperativizados, representados por Alberto Weingadt, Ana María Giampietro y Ramón González, quienes instalaron en el mes de junio del año 2000 una carpa en la sede de la CAABPA en señal de protesta, pidiendo la relación de dependencia, la condonación de las deudas previsionales y la jubilación. Desde la sede de la cámara empresarial Ramón González, antiguo candidato a secretario general del SOIP por la lista Verde, señaló que "hasta este momento no hemos recibido ningún tipo de apoyo gremial. Sólo fuimos acompañados por comerciantes u otros casos puntuales. Estamos peleando prácticamente solos, si bien nosotros apoyamos otros reclamos, pero lamentablemente por parte del SOIP no hay ningún tipo de apoyo". ${ }^{384}$ De este modo vemos crecer la disidencia respecto de la conducción gremial. Esa corriente opositora se constituyó principalmente en el sector de trabajadores cooperativizados y desocupados, quienes estatutariamente no participaban de la vida gremial. Al menos en el registro de la prensa escrita son inexistentes las críticas abiertas a la conducción gremial por parte del sector de trabajadores "estables".

${ }^{1381}$ L.C., 25/07/2000.

${ }^{1382}$ L.C., 30/05/2000 .

${ }^{1383}$ L.C., $13 / 06 / 2000$.

${ }^{1384}$ L.C., $06 / 07 / 2000$. 


\section{La toma y ocupación de la sede sindical}

Hemos visto que la toma y ocupación de la sede gremial era un repertorio de protesta conocido en la industria pesquera, acción mediante la cual se buscaba influir en la contienda gremial. Entonces, quienes acometieron la toma en la jornada del 29 de junio de 2000 apelaban a un repertorio con tradición en el SOIP. La medida de fuerza se llevó a cabo el día después del "estallido". Al día siguiente los trabajadores volvieron a realizar una asamblea en las calles del puerto, pero el marco había cambiado, ya que el "personal del Comando de Patrullas, como también de Infantería, la policía montada, helicópteros y bomberos estaban apostados en las zonas cercanas al lugar y luego acompañaron la marcha por las calles paralelas. Pero todo se registró con total normalidad, sin repetir los hechos violentos de anteayer, que preocuparon a mucha gente". ${ }^{1385}$ Después de un debate en asamblea los trabajadores de tierra en un grupo de 300 obreros encabezados por la UOP se movilizaron hacia la sede del SOIP para exigirle que adhiera al paro que mantenían los marineros. Una vez allí, desalojaron a los dirigentes que había dentro del lugar a empujones y se quedaron en el edificio gremial. En esa ocasión, solicitaron al Ministerio de Trabajo que avalara la comisión de base elegida en una asamblea y que convocara a elecciones dentro de 90 días y constituyeron una comisión provisoria como expresión de carácter más institucional del movimiento, que pretendió disputar la dirección del gremio al SOIP. María Dematteis, integrante de la UOP, expresó: "queremos formar una comisión provisoria para luego hacer el comicio con la participación de todos los sectores y que puedan votar todos los compañeros. Que se desarrollen dentro de un marco normal, no como hasta ahora, con fraude". ${ }^{1386}$ Días más tarde anunciaron la fijación de un "programa reivindicativo, que la dirección expulsada del SOIP se negó siempre a convalidar, lo que tuvo su expresión más siniestra en la negativa a sumarse a la huelga general indefinida de los trabajadores marítimos y del puerto". Entre los objetivos que pretendieron impulsar figuraron "la efectivización de todos los trabajadores cooperativizados, la actualización salarial y de garantía horaria, de 18 centavos el $\mathrm{kg}$ de filet y \$3 la hora para envasadoras y peones". Y recordaron que "en Mar del Plata somos 7 mil trabajadores del pescado, de los cuales 5 mil han estado proscriptos, como parias, en la relación laboral y la participación sindical, por la política de (la) dirección expulsada". ${ }^{1387}$ También pidieron el dictado de una amnistía que permitiera la afiliación de todos los trabajadores que desarrollaban sus labores bajo el régimen de las cooperativas a fin de realizar las elecciones y una auditoria en el gremio para concretar un inventario de bienes, recursos y destino de los gastos.

Desde el sector desalojado se produjo una respuesta. Carlos Darguibel durante una conferencia de prensa denunció la presencia de activistas en la toma de la sede gremial y dio plazo de un día para que se produzca el desalojo. En cuanto al reclamo de los ocupantes de que se llamara a elecciones, el dirigente explicó que "hace dos años que no podemos llamar a comicios, porque hay un recurso de amparo que nos lo impide", pero sentenció que de todas maneras ninguno de los activistas "puede participar, porque el estatuto se los prohibe". Además, Darguibel aclaró que las personas que tomaron el edificio no son mayoría en el sindicato y que muchas "ni siquiera" son trabajadores en tierra de la industria de la pesca: "Acá se metió gente de afuera: hay algunos de los que tomaron la Catedral, hay algunos de la CCC y hasta hay gente del SOMU". Mencionó también la participación de "un grupito" interno del SOIP entre

\footnotetext{
${ }^{1385}$ L.C.,30/06/2000.

${ }^{1386}$ L.C.,30/06/2000.

${ }^{1387}$ L.C., 02/07/2000.
} 
cuyos dirigentes señaló a "Comparada, Dematteis, los hermanos Verón, el Polaco Muñoz y otros muchachos". Dijo que "ninguno de ellos puede reclamar que el sindicato llame a elecciones ni mucho menos postularse, porque el estatuto dice que para poder ser candidato hay que estar trabajando efectivo y tener una antigüedad de dos años, y ninguno de ellos la tiene". En otro apartado, La Capital expresa "En cuanto a las diferencias internas que llevaron al Sindicato a esta situación de crisis, Darguibel relató que 'había un pequeño grupo que quería que fuéramos al paro, pero la asamblea entendió que tomar una medida de fuerza en este momento, en que no hay pescado, es beneficiar al empresario'. Según el convenio colectivo de trabajo firmado por el SOIP, el personal en relación de dependencia tiene un mínimo salarial garantizado (poco más de 300 pesos) que debe ser abonado por el empresario haya o no pescado para procesar". En relación con esto último, Darguibel expresó "Si nosotros hubiésemos ido al paro perderíamos ese jornal mínimo que tienen los compañeros". ${ }^{1388}$ De este modo queda ilustrada la opción de la dirección sindical que guío su política gremial en defensa de los intereses inmediatos de los trabajadores ocupados "estables".

En el balance de esta segunda jornada de protesta se evidencia el pasaje de un hecho que expresó la irá obrera, a otro dominado por una política positiva. Lo que se producía en ese pasaje era también un cambio de enemigo, concebido ahora al interior de la propia clase obrera de la industria del pescado. La "burocracia sindical" se constituyó en el antagonista, acusado de no plegarse al paro ni dar respuestas a las demandas de los trabajadores cooperativizados/desempleados. La organización político sindical que apareció dirigiendo las movilizaciones fue la UOP. La acción tendió a "recuperar" el sindicato como herramienta de los trabajadores para defender sus derechos y se convirtió en un hecho de singular importancia para la posterior victoria de la Lista Celeste en las elecciones del año 2002, que llevó como colaboradores de la lista a muchos de los activistas que participaron de la toma. De algún modo, la victoria en las elecciones puso en entredicho la división inserta en el gremio entre trabajadores "estables" e "inestables", constituyéndose en una búsqueda política por superar la fragmentación. La intención primordial de la nueva conducción fue la búsqueda de un mecanismo de reafiliación sindical de la masa obrera de la industria del pescado. Su éxito o fracaso forma parte de otro período y proceso histórico.

${ }^{1388}$ L.C.,30/06/2000. 


\section{Conclusiones}

En 1997 la propaganda presidencial se ufanaba del crecimiento de las exportaciones pesqueras que en aquel año superaban por primera vez los mil millones de dólares. Uno de los grandes carteles publicitarios anunciaba "Multiplicamos la explotación pesquera. Grandes transformaciones nacionales, presidencia Menem". La publicidad caía como un mal chiste en la comunidad pesquera que ya para esa altura se encontraba abrumada por el comienzo de la mayor crisis de la historia de la actividad, dada por la sobre explotación de los recursos pesqueros. ${ }^{1389}$ Aquel también fue el último año de crecimiento, le seguiría un vertiginoso descenso del nivel de capturas y un ciclo dominado por la conflictividad social abierta en el sector. En Mar del Plata estos procesos impactaron fuertemente en la industria pesquera, dando lugar a la crisis de finales de la década. En particular, cuando en el marco de una economía nacional en recesión y con menos ingreso de pescado a las plantas pesqueras, dio por resultado un proceso de expulsión de fuerza de trabajo.

A lo largo de esta tesis analizamos la conflictividad producida dentro de la industria pesquera en la larga década del '90 intentando examinar el proceso en diferentes niveles. En el capítulo Iintroducimos al lector en el conocimiento de las características básicas que le permitieran comprender las particularidades de la industria pesquera. De inmediato, presentamos un desarrollo histórico de la actividad narración durante la cual, luego de pasar revista rápidamente a los sucesos desde nuestro punto de vista más trascendentes de las décadas previas, enfatizamos en los clivajes fundamentales de la pesca en los años '90. Dentro de ellos, consideramos de importancia remarcar el carácter de una industria fundamentalmente extractiva y exportadora de commodities y, por tanto, expuesta a los vaivenes del mercado mundial. Situación que a pesar de proyectos en contrario se mantuvo inconmovible en gran medida porque los principales mercados de destino se inscribían en políticas amplias para recibir productos de escaso desarrollo industrial como pescado entero, $\mathrm{HG}$, filetes, bloques, etc., pero fueron reticentes respecto de los productos finales, dado que estos últimos competían con su propia producción. Por ello el tratamiento arancelario para con unos y otros productos era claramente discriminatorio. ${ }^{1390} \mathrm{~A}$ su vez, los sectores empresariales pesqueros vieron en ese desarrollo un modo de alcanzar beneficios, mientras el mercado interno para el consumo de pescado fue históricamente reducido.

La pesca industrial se desarrolló particularmente desde mediados de la década del '70, aunque sin el despliegue de un programa pesquero nacional que justificara la adopción de determinadas políticas y no de otras. Esta situación se evidenció en que recién en el año 1997 se sancionó una Ley Nacional de Pesca. Y tal medida se tomó ante la urgencia que emanaba de la cada vez más evidente sobre pesca y no como el resultado de una planificación u orientación del desarrollo pesquero. Tanto en la década del ' 80 como en la del '90 se produjeron acuerdos con potencias pesqueras extranjeras permitiéndoles ejercer la pesca en el caladero nacional. Los resultados de ambas iniciativas aún hoy generan polémica, pero el grueso de los analistas coincide en que no fueron satisfactorios desde el punto de vista de un posible desarrollo pesquero y la generación de puestos de trabajo. Sin embargo, pensamos que el desenvolvimiento de la

\footnotetext{
${ }^{1389}$ A la propaganda gráfica le siguió en junio de 1999 un spot televisivo que mostraba en imágenes un generoso lance de pesca ascendiendo a bordo. Un locutor en off señalaba que "por muchos años la captura no estuvo a la altura de nuestro litoral marítimo... pero hoy es de un millón y medio de toneladas y sigue a toda máquina". El corto publicitario concluía con un mensaje: "Diez años que cambiaron la historia. Presidencia de Menem". Simultáneamente, otros canales mostraban las movilizaciones motivadas por la crisis de la merluza y se sucedían los testimonios que alertaban sobre el colapso del recurso. Revista Redes, N 107, año 1999, "Diez años que cambiaron la historia”, p. 7.

${ }^{1390}$ Revista Redes, № 101, año 1998, ¿Es posible agregar valor?”, p. 24.
} 
rama no contribuye a pensar un caso "típico" de desindustrialización. Tal categoría, en todo caso, debe ser cuestionada. La pesca considerada por mucho tiempo por las políticas estatales vinculada a la agricultura más que a la industria, en realidad lo que padeció fue un proceso de reestructuración capitalista. Pues estamos ante el caso de una industria que cambia y crece en volúmenes de captura nunca experimentados. Y desde ahí consolida a nuevos sectores hegemónicos dentro de la actividad, sin que desaparezcan completamente otros actores más tradicionales. Al mismo tiempo, las condiciones impuestas por la convertibilidad, al igual que en otras industrias argentinas, hicieron que producto de la apertura externa, la mayor competencia y el abandono de los apoyos estatales, las empresas persiguieran mejorar sus ingresos vía la reducción del costo de la fuerza de trabajo, buscando incrementar la productividad y la intensificación del trabajo a través de diferentes vías, además de recurrir a la incorporación de tecnología y modernización de la flota y la diversificación vertical y horizontal.

En cuanto a la estructura de la flota pesquera argentina, aproximadamente hasta 1960 dominó la escena la flota costera. Entre 1963 y 1990 fueron los buques fresqueros con orientación a la pesca de merluza los que primaron en capturas y desembarques. A partir de 1990, los buques procesadores congeladores disputaron la hegemonía y comenzaron a hacerse cada vez más importantes en los volúmenes de captura. Esta trasformación en el tipo de flota también se visualizó en el modelo productivo pesquero y en la forma de las empresas hegemónicas del sector, que pasaron de ser relativamente pequeñas empresas con buques $\mathrm{y}$, en algunos casos plantas procesadoras, a verdaderos grupos económicos que desplegaron estrategias de integración vertical y horizontal, se asociaron con capitales extranjeros, ocuparon las ventas al mercado interno y un mayor lugar en las exportaciones. Por otra parte, nuestra investigación se centra en la "larga" década del "90. Sobre la base de la derrota de un proyecto pesquero con una perspectiva de mayor elaboración de los productos y desarrollo de empleo industrial, y en el marco de una crisis del Estado, la economía y las finanzas nacionales, la política pesquera buscó satisfacer la necesidad de producir ingresos de manera inmediata. El celo por la promoción de las exportaciones se basó fundamentalmente el desarrollo de un modelo netamente extractivo de "minería pesquera" buscando maximizar ganancias en el corto plazo. Esas ganancias no sólo fueron económicas, pues la promoción de las exportaciones donde se inscribieron los acuerdos con la CEE, también significaron en la cosmovisión menemista, una búsqueda de prestigio y fomento de relaciones con las principales potencias mundiales.

Las políticas implementadas en la pesca no fueron el resultado de una coalición previamente conformada que llegó al poder y aplicó un proyecto. De hecho, lo que pronto se evidenció fue la derrota de aquellos que pretendieron consolidar un tipo de desarrollo alternativo que, mal o bien, pretendía orientar la pesca hacia la agregación de valor de los productos manufacturados, una mayor relación con el mercado interno, la creación de puestos de trabajo, etc. Ese proyecto fue derrotado plenamente. Primero, por la orientación general de la política económica. Luego, por la propia sucesión de las políticas pesqueras. Estas estuvieron caracterizadas por el impulso de la apertura del mar argentino a flotas extranjeras, la profundización de la vocación extractiva con el incremento de capturas y volúmenes de exportación, el abandono de los regímenes de promoción industrial, el fomento de integración entre capitales nacionales y externos $y$, dentro de un marco de paridad cambiaria para una industria fuertemente exportadora, la garantía de abaratar los costos de la fuerza de trabajo. Mientras un conjunto de empresas se presentaron en quiebra, aquellas que sobrevivieron tuvieron que ajustarse a las nuevas definiciones de la política económica. Así, un sector empresario comenzó a consolidar su hegemonía vía la incorporación de tecnología y la integración horizontal y vertical. Los restantes actores sobrevivieron sobre la base de 
aprovechar las oportunidades de negocios que el sistema dejaba. Cuando como resultado del incremento del esfuerzo pesquero se hizo evidente la sobre pesca de la merluza, desde el gobierno se procedió a agilizar la sanción de la Ley de Pesca así como, a través de la implementación de sucesivas vedas, se buscó disminuir la presión de las flotas sobre los recursos. Esto motivó el despliegue de un escenario conflictual que dibujó diferentes antagonismos: entre los tipos de flota (fresqueros / congeladores), entre localidades (Mar del Plata / puertos del sur); entre capital y trabajo.

En el capítulo III vimos que el proceso de trabajo en las plantas de procesado de pescado conserva elementos del régimen de manufactura dada la importancia del trabajo con herramientas manuales, trasladándose los obreros al lugar de trabajo con sus propias herramientas y donde el factor subjetivo mantiene un valor nada desdeñable. En este sentido, la disgregación y desarticulación del trabajo encontró un límite en la medida en que la maquinaria resulta aún poco eficaz en su uso, desperdiciando parte de la materia prima que puede aprovechar una mano educada. Entonces, este "saber hacer" que conservan consigo los obreros y obreras implica un conocimiento particular que lo asemeja a un oficio y le otorga un valor específico a la persona que trabaja. Pero esto es solo una parte. Pues de todos modos las transformaciones ocurridas desde mediados de los setenta en el capitalismo a nivel global, pero también en la industria pesquera, perjudicaron a la fuerza de trabajo tanto en aspectos materiales como en el universo de las representaciones. Muy distinto es el valor de un filetero o filetera en un contexto en que "sobra" el pescado y es preciso procesarlo rápidamente, que en otro contexto dominado por el pasaje a una fase de contracción en la pesca. Además, la aparición de los buques congeladores dentro de la flota nacional, estos si utilizando máquinas, provocaron una competencia a los trabajadores manuales y en la medida en que aquellos crecieron en capturas, ello provocó una merma en el trabajo de los obreros y obreras de las plantas. A su vez, en el contexto de la flexibilización laboral, durante la década del noventa se dio lugar a un proceso de fragmentación del mercado de trabajo, con una consecuente degradación de las condiciones laborales de una parte significativa de la fuerza de trabajo de las plantas pesqueras, generando al menos dos estamentos entre los trabajadores: 1@s "estables" y 1@s "inestables". Cuando no lisa y llanamente el crecimiento de la desocupación en el sector, siendo la pesca una de las ramas de la economía marplatense más afectada por aquel fenómeno. Todo esto repercutió negativamente no sólo en las condiciones de vida y trabajo, sino también en las formas de organización y lucha obrera.

Si bien el filetero tradicionalmente fue una categoría laboral bien remunerada, las trayectorias laborales reflejan una situación muy diferente entre las décadas del '70 cuando se "estaba muy bien" y la década del "90 cuando "se está cada vez peor". La situación era diferente según el lugar que cada trabajador ocupaba en el mercado de trabajo, si se estaba bajo relación de dependencia o trabajando bajo el sistema cooperativo. Aunque a nivel general las remuneraciones se mantuvieron en niveles cercanos a la canasta básica considerada para la época en cifras apenas superiores a los 500 pesos, la aparición de la crisis de la merluza provocó que creciera la subocupación y la desocupación. Este período constituyó el momento más crítico para los trabajadores de la industria del pescado, transformados entonces en víctimas de la sobre explotación de los recursos pesqueros. La instauración de pseudo cooperativas de trabajo para el procesado de pescado, desplegadas fundamentalmente de la mano de la desregulación, no solamente cumplió un objetivo en pos de disminuir los costos de la fuerza de trabajo de manera inmediata. Sino que además repercutió negativamente en las relaciones políticas y organizativas de los trabajadores y trabajadoras de la industria del pescado. La existencia de un mercado de trabajo segmentado contribuyó a la desorganización de la clase obrera vinculada con el procesado, manteniendo a un segmento importante de la fuerza de trabajo dentro de una situación infra jurídica. En este sentido, la 
instauración de las cooperativas constituyó una derrota del poder de los trabajadores y del sindicato. Generó una división estructural entre un sector "estable" y otro "inestable" que dio lugar a renovados antagonismos dentro de la propia clase. Al mismo tiempo, afectó la capacidad organizativa de los trabajadores en cuanto disminuyó objetivamente la cantidad de afiliados al sindicato, generando la existencia de un contingente obrero no sindicalizado y presumiblemente desorganizado. De todos modos, la desorganización no fue completa, pues los obreros de las cooperativas recurrieron a formas organizativas "informales" para canalizar sus reclamos, al mismo tiempo que no perdieron la referencia de su pertenencia al sindicato del SOIP.

Por otra parte, en tanto el proceso hiperinflacionario representó el final de un modo de acumulación de capital, de una lógica de enfrentamiento entre las clases y de una determinada forma de Estado (Piva, 2007), la respuesta emprendida por la conducción del SOIP estuvo marcada por la tradición sindical en la que estaba habituada a desempeñarse en tiempos pretéritos. Esto fue el desarrollo de una estrategia centrada en la lucha salarial, la alianza con determinadas fracciones de la burguesía industrial, el fomento de una buena relación con determinadas agencias del Estado y la defensa de un viejo patrón de acumulación. Mientras desde el gobierno nacional se comenzaba a transitar el camino de salida de la crisis ligada a una reestructuración capitalista en estrecha articulación con el mercado mundial, se enterraba al mismo tiempo el proyecto que la conducción gremial, desde su influencia y peso en el sistema político había buscado desplegar. Insistimos que no se puede soslayar del análisis el hecho de que esta transformación implicó el pasaje de un capitalismo que hacía concesiones a los trabajadores, a otro donde eran los trabajadores los que, para mantener sus puestos de trabajo, debían realizar concesiones a la patronal. Ese proceso llevó a una mutación en la organización de la producción, redefiniendo los contornos de la propia clase obrera y, por ello, también de los sindicatos en cuanto mecanismos de representación. La metamorfosis impulsaba a su vez cambios en el modelo de desarrollo pesquero que enfrentaban al sindicato, junto a los otros sindicatos de la rama, a distintos desafíos. Se trataba de un proceso de crecimiento y expansión pesquera, con incidencia del capital extranjero, eliminación de apoyos y rescates estatales a las empresas, incorporación de tecnología (sobre todo a partir del arribo de buques congeladores) y todo ello en el marco de la paridad cambiara. Tal "modelo" generaba, como contrapartida, la reducción de la mano de obra y la búsqueda de flexibilidad laboral, tanto en las condiciones de contratación como en las normas de trabajo. Ante ello, el SOIP buscó en todo momento influir en el sistema político buscando alterar ese proceso, intentando regenerar un "modelo" de desarrollo pesquero más favorable o al menos ponerle límites al que se desarrollaba. En este aspecto, no hizo más que recibir derrotas. Es interesante notar que a pesar del apoyo al gobierno, Saravia fue un opositor bastante furibundo de la política pesquera desarrollada. Se opuso a la designación de los funcionarios para el área, al charteo, a los decretos de desregulación, al cierre del Mercado Concentrador, a la firma del convenio con la Unión Europea. Su gran esperanza había sido la de convertirse en un personaje influyente de la definición de la política pesquera vía el nombramiento de César Lerena en el ejecutivo pesquero, dada su amistad con el presidente Menem y su vinculación al Partido Justicialista. Sin embargo, su estrella como personaje influyente en el sistema político nunca llegó a brillar. La oposición que produjo en la política pesquera lo llevó a participar de varios hechos de acción directa contra situaciones puntuales así como a una búsqueda por generar bloques de oposición fomentando la unidad gremial a partir de la constitución de la Coordinadora de Gremios Marítimos y Portuarios y también buscando apoyo entre diferentes empresarios pesqueros. Sin embargo, no logró torcer el rumbo que adoptaba la nueva matriz de desarrollo pesquero y tuvo que enfrentarse a la decepción de padecer una derrota tras otra. Pero su crítica 
de la política pesquera estaba atravesada por su lealtad al gobierno, lo cual también le imponía algunos límites. Durante aquellos años el sindicato jamás convocó a una huelga realizada directamente contra la política pesquera. Si en 1986, tras los acuerdos Marco con Bulgaria y la URSS, el SOIP encabezaba la huelga general local contra su suscripción, en 1994, tras la puesta en marcha de los acuerdos con la CEE, se limitó a manifestar su inquietud y a sumarse al pedido de los gremios marítimos de que se labore con personal nacional. El gremio durante toda la década sólo participó de huelgas parciales por fábrica y, ya después de 1997, en huelgas convocadas en el contexto de la convergencia de empresarios y gremios que dio forma a la Multisectorial, ya tras el deceso de Saravia. Pero en el transcurso de los años el sindicato fue perdiendo su iniciativa dentro de la escena conflictual.

Lo curioso es que si bien bajo el liderazgo de Saravia, el SOIP acompañó y apoyó la gestión presidencial, no lo hizo tras una lógica participacionista "clásica" (esto es a cambio de beneficios organizacionales o de otro tipo). Según pensamos, la conducción sindical no llegó a advertir que el nuevo patrón de acumulación tenía uno de sus ejes en el incremento de la explotación de los trabajadores. En la mirada de su máximo dirigente, la reestructuración llevada a cabo por el presidente Menem se veía, en el mejor de los casos, como un período de transición. Confiado tal vez en que el liderazgo presidencial y las credenciales históricas del peronismo tarde o temprano lograrían el esperado crecimiento con desarrollo y distribución. Si otros sindicatos negociaron el proceso de implementación de reformas buscando obtener beneficios organizacionales (Murillo, 1997) no será esta la actitud del SOIP. Es decir que el participacionismo del gremio puede explicarse desde una lógica diferente centrada en la experiencia previa de militancia en el proyecto menemista, en las esperanzas que conllevó la victoria electoral y en la confianza de pertenecer al peronismo. No hubo por tanto negociaciones tendientes a obtener beneficios o prerrogativas a partir del cambio impulsado en la política pesquera, ni tampoco se produjo un proceso de concertación con concesiones. Los únicos beneficios de la conducción sindical parecían provenir de su vínculo con delegaciones locales y provinciales del Ministerio de Trabajo, lo cual servía para dirimir en su favor las cuestiones conflictivas que surgieran en procesos electorales y quizás obtener alguna ayuda económica vía el rescate de la obra social. Pero no mucho más.

En gran medida, consecuencia del despliegue de aquel "modelo" sin preocupación respecto de los "costos sociales" de la transformación, fue que los trabajadores y trabajadoras de la industria del pescado asistieron a un proceso cada vez mayor de fragmentación del mercado de trabajo con la formación de cooperativas y la generación de empleo precario. Lo que redundó en la pérdida de una gran masa de afiliados para la organización sindical. Ante aquellos cambios en la organización de la producción y su correlato en el intento por modificar la legislación laboral, tal como hicieron otros gremios, el SOIP buscó resistir protegiendo la legislación existente, defendiendo el convenio de 1975 y amparándose en la supervivencia de la ultraactividad. En este sentido, su actitud se corresponde con la de buena parte del sindicalismo local que reaccionó ante las transformaciones negociando la protección del empleo para un núcleo "duro" de trabajadores (Santella, 2012), aún a costa de la pérdida, por un lado, de intereses económicos como incrementos salariales y mejoras en las condiciones de trabajo y, por otro lado, de puestos de trabajo. El sindicato se limitó a buscar que los obreros y obreras pudieran cobrar las indemnizaciones, cuestión que no siempre se logró. Algunas voces hablan de la participación de la conducción del SOIP en el proceso privatizador, lo cual no podemos dejar de mencionar. No obstante, tales afirmaciones se contraponen, al menos, con el discurso y las gestiones de AbdulSaravia quien insistentemente criticó las cooperativas. 
En lo que respecta al convenio de 1975, éste fue sentido como una conquista de justicia por muchos trabajadores de la rama. Tal vez por ello, además de obviamente las condiciones laborales que disponía, pervivió en la memoria colectiva obrera y, por ello mismo, apareció de manera recurrente entre las demandas de quienes muchos años después luchaban por mejores condiciones laborales en la industria del pescado. De todos modos, resulta claro que él mismo se forjó en un contexto bien distinto del que acontecía en la década del '90, tanto en lo que refiere al patrón de acumulación capitalista, como en la forma de Estado y la propia realidad de la industria pesquera. Aquel convenio logró garantizar determinadas prerrogativas a los trabajadores como el pago de un salario mínimo por parte de la patronal, la fijación de las horas de ingreso y egreso de las plantas, la entrega de los equipos de trabajo, etc. En la larga década del '90, la defensa del convenio de 1975 fue una estrategia eficaz solo a medias. Pues, beneficiando a quienes estaban amparados por él, con la instauración de las cooperativas la burguesía pesquera pudo eludir sus cláusulas para un amplio grupo de trabajadores que ingresaban al circuito productivo desde diferentes condiciones de legalidad.

Por otra parte, para quienes día a día quedaban sin trabajo la respuesta gremial fue encabezar protestas buscando su reintegro al circuito productivo o, en su defecto, se abonen las indemnizaciones correspondientes, incluso fomentando denuncias en los Tribunales del trabajo. En relación a las cooperativas, con insistencia el sindicato denunció su formación y anclaje en el gremio. Pero aún a pesar de lo evidente de su existencia, no se ensayó ningún mecanismo de integración de estos trabajadores, ya sea en la confección de convenios diferentes, o en cuanto a su incorporación al gremio en la reforma de estatutos que les permitieran participar en la vida gremial. Todo este proceso llevó al sindicato a perder una parte importante de su nivel de afiliación, al mismo tiempo que poco a poco fue perdiendo el lugar central que ocupaba en la constelación de fuerzas dentro de la industria pesquera marplatense. Al terminar la década, el SOIP aparecía como un sindicato desguarnecido, ausente de muchas de las medidas de fuerza más importantes de la década, con la red de delegados que otrora fueran una de las principales herramientas de poder gremial en los lugares de trabajo francamente reducida. Dejaba su lugar de preeminencia al SOMU como principal gremio en el escenario de la conflictividad y en su capacidad de imponer condiciones a las patronales pesqueras. En paralelo, y cada vez menos subterráneamente, los trabajadores de las cooperativas se veían lanzados a un ciclo de lucha que los llevará a crecer no sólo en la cantidad de acciones de fuerza, sino también en la "radicalidad" que estas expresaban.

En cuanto los procesos electorales, con posterioridad a la intervención sindical que colaboró en correr a la vieja conducción anarquista del SOIP, las elecciones convocadas en 1969 arrojaron la victoria de un grupo de militantes peronistas liderados por Abdul Saravia. Desde allí, la principal oposición gremial a la conducción que se mantuvo durante la década del ' 70 surgió tras la escisión de la comisión directiva y estuvo liderada por Corino Díaz. También existieron diversas corrientes y agrupaciones de izquierda, quienes pudieron conformar una lista y presentarse a elecciones en 1973 pero, al menos desde el ámbito electoral, no pudieron ofrecer una competencia a la conducción. La posibilidad de una oposición más consistente conformada por corrientes de izquierda se logró tras el retorno democrático en el año 1984. Y si bien Saravia y su grupo fueron ratificados en el liderazgo gremial, la diferencia de votos fue bastante ajustada respecto de los alcanzados por la Lista Celeste. Luego de ello, las victorias del oficialismo fueron más holgadas. Ya en la década del '90, después de una buena elección de la Lista Verde la cual aglutinaba a peronistas críticos del "saravismo", todas las listas comenzaron un proceso de dispersión y pérdida de votos, afectadas por la consolidación de cooperativas que disminuían el caudal de afiliados. En ese contexto, sólo la lista oficial pudo mantenerse en 1994. Ésta fue la última elección de la 
década. En 1998, con la crisis pesquera desatada, la muerte de Saravia y el comienzo de la disgregación del oficialismo, las elecciones se suspendieron. Así, el SOIP asomó al final de los años '90 sin una conducción gremial legitimada electoralmente. Si por un lado el descenso en el nivel de afiliación perjudicaba a todas las listas, pero permitía al oficialismo mantenerse en el poder apoyado en los sectores de trabajadores todavía "estables"; por otro lado, el descrédito de su liderazgo no hacía más que crecer tras el deceso del líder y la incapacidad de dar respuestas ante la crisis. Desde allí, el crecimiento de una alternativa gremial comenzó a surgir, paradójicamente, entre los sectores cooperativizados. Quienes si bien no participaban de la vida gremial, mantenían como parte de su identidad el "ser filetero/a" y al SOIP como espacio de representación. Por ello, las agrupaciones y militantes más activos durante los años 1997-2001 apelaron a esa identidad, diseñando diferentes estrategias para mantener los vínculos con el sindicato. El sorprendente recambio dirigencial se produjo finalmente en el año 2002. Allí, tras más de 30 años de gobierno sindical y poniendo fin a la hegemonía peronista, la conducción "saravista" fue desplazada por una lista integrada por militantes de izquierda. En su desarrollo histórico la lista Celeste agrupó a peronistas enfrentados al oficialismo, comunistas y trabajadores "independientes". En el año 2002 hegemonizaban su conducción militantes trotskistas nucleados en el Partido Obrero. El resultado de esta elección, sin duda auspiciosa para las corrientes de izquierda que de este modo alcanzaban la cima de uno de los gremios industriales más importantes de la ciudad de Mar del Plata (aunque más no sea por tradición), alimentó un entusiasmo en los canales de difusión de la prensa partidaria, por ejemplo la del PO. Sin embargo, ese frenesí resultaba desmedido pues el triunfo de la Celeste señalaba más la disgregación de la lista oficial, su crisis y falta de liderazgo tras la muerte de Saravia, que una victoria sostenida a partir de una gran influencia dentro del gremio por parte de la nueva corriente sindical. La cual, sin embargo estuvo allí legitimando su fuerte actuación en la lucha y militancia sindical de finales de los '90, así como su tradicional participación en el gremio. Y supo aprovechar el momento electoral particular diseñando una estrategia creativa y novedosa para poder competir electoralmente. Esto fue el establecimiento de un acuerdo con determinados delegados y delegadas, obreros y obreras que trabajaban bajo relación de dependencia, llevándolos como candidatos pero asistidos por una mesa ejecutiva integrada por activistas vinculados al PO que, en calidad de asesores de cada secretaría, fueron quienes terminaron llevando adelante la política gremial. En aquel entonces, la segmentación del mercado de trabajo a raíz de la pervivencia de las cooperativas, así como las condiciones financieras de la obra social y la pérdida de representatividad del gremio en los últimos años, se presentaban como los principales desafíos a resolver en un contexto que exhibía mejoras para las posibilidades de la militancia sindical a raíz de transformaciones en la política nacional, reapareciendo por ejemplo las convenciones colectivas, mientras que en la industria pesquera se alteraban las condiciones de los últimos años de funcionamiento a partir de la implementación de la devaluación y otros cambios específicos del modelo pesquero.

Asimismo, señalamos en el capítulo IV elementos que permiten visualizar la conflictividad al interior de las plantas de procesado. Conflictos y tensiones que, en cuanto el proceso de subordinación del trabajo al capital nunca es absoluto, tuvieron lugar en la industria del pescado. De este modo, el ausentismo, la lucha por mejoras salariales, la resistencia a través del hurto de pescado, junto a otros mecanismos para combatir el despotismo patronal, continuaron existiendo durante la década del '90. Sin embargo, en contextos como los experimentados de fragmentación del mercado de trabajo, precarización de las condiciones laborales, creciente desocupación y crisis de la industria pesquera, todo ello sumado a la recesión de la economía nacional, hicieron que las reclamaciones al interior de las plantas mermaran y, en el escenario conflictual, tuvieran menor peso. Lo principal de la conflictividad surgía entonces en otro 
lado, en las calles, y la lucha, más que resistir la explotación, estuvo guiada por la búsqueda de garantizarla. Tanto a comienzos de la década, como hacia finales, la protesta de los trabajadores de la industria pesquera estuvo hegemonizada por la pretensión de reinsertarse en el circuito productivo. Primero ante el cierre de plantas, luego, ante la disminución en los volúmenes de pescado que ingresaba a las plantas en el contexto de la llamada crisis de la merluza. En este sentido, la protesta obrera adquirirá un marcado sesgo defensivo. Incluso, hacia finales de la década se impuso la lucha por un subsidio al trabajador desocupado. En este sentido, elaboramos una periodización que registra tres momentos en el ritmo y las características de la conflictividad en la industria pesquera. Un primer momento, de 1989 a 1991, donde a nivel nacional se produjeron los intentos gubernamentales por reducir la inflación, el acuerdo con oligopolios multinacionales de origen argentino para el manejo de la economía y la sanción de las leyes de Emergencia Económica y Reforma del Estado, lo que señalaba un nuevo rumbo de la economía argentina. Mientras, en la pesca se produjeron quiebras de empresas, a pesar de lo cual, la rama exhibió un crecimiento.Lo principal de los protestas fue la participación de obreros despedidos de plantas pesqueras ocupando sus instalaciones, reclamando por la reincorporación en el trabajo y el pago de las indemnizaciones. Además el SOIP, cuya conducción mantuvo un alto protagonismo en la escena conflictual, reclamará insistentemente las deudas del pago de obra social y cuota sindical. En paralelo, surgieron también las primeras movilizaciones de los desocupados del sector. Un segundo momento, que transcurre entre 1992 y 1996, contexto que vivió la estabilidad posterior a la convertibilidad, donde se redujeron, en gran medida, las acciones de protesta. Fueron años de crecimiento para la industria, lo cual se vincula además con que, tras la formación de las cooperativas y aunque en situación de precariedad, los obreros y obreras del pescado mantuvieron sus puestos de trabajo. Recién en 1997, cuando paradójicamente se alcanzaba un récord de exportaciones y comenzaba a conocerse en (y por) sus consecuencias prácticas la sobre pesca en el mar argentino, se reinició un ciclo de conflictividad que, en su espiral de contradicciones y movimientos, perduró hasta el año 2001.

A la protesta desarrollada por los obreros y obreras de las cooperativas y desocupados hay que sumar otro rasgo y sentido de la beligerancia en la pesca de aquellos años. Pues las derivas del "modelo" de desarrollo pesquero, que favoreció la operatoria de buques congeladores, la apertura del mar a flotas extranjeras y la vocación extractiva de la industria, motivó el surgimiento de la beligerancia en clave de cuestionar no ya dicho "modelo" en sí mismo, sino a partir de alguna de sus consecuencias. En particular, el fenómeno de la sobre pesca de los recursos marítimos, especialmente la merluza hubbsi. Salvo en lo que tuvo de conflicto ambiental, la realidad de la batalla estuvo dominada por que se garantice a los sectores pesqueros "tradicionales", entendiéndose por ello a la flota fresquera marplatense, sus volúmenes de pesca considerados "históricos". Es decir, 300 mil toneladas de merluza. Los momentos de activación coincidieron con medidas gubernamentales que, ante la evidencia de la sobre pesca, buscaban disminuir el esfuerzo pesquero en el caladero nacional. Este fue el sustrato de las batallas sostenidas por la Multisectorial en Defensa de la Pesca Argentina integrada por grupos empresarios fresqueros y sindicatos, acompañados por el gobierno municipal y el ejecutivo provincial. Éste nucleamiento identificó como enemigo a la flota congeladora, gran parte de la cual integraba empresas extranjeras o con participación de capitales extranjeros. En este momento las tensiones que permanecían larvadas entre grupos empresarios que operaban con diferentes tipos de flota se volcaron sobre la superficie, dando lugar a un fuerte combate. De este modo, el grupo de empresas marplatenses que adquirieron congeladores fueron apartadas del entendimiento patronal-obrero y poco a poco pasaron a constituirse en un enemigo interno. La construcción de este antagonista se conjugó, el 28 de junio del año 2000, con la manifestación 
de los sectores obreros que padecían la situación más precaria dentro de la industria y que, en aquel entonces, permanecían en condición de sub ocupación o directamente desocupados. Y en esa confluencia se produjo el ataque a las plantas pesqueras. En su excepcionalidad, el hecho se vuelve una estupenda puerta de entrada para conocer los procesos que afectaron a la industria pesquera a lo largo de una "larga" década. De allí que hayamos referido a él como un aleph. Pues además de lo antedicho, también mostró en su forma más extrema, la tensión existente en la industria del pescado generada a partir de la fragmentación del mercado de trabajo que siguió a las cooperativas. Recordemos que el acontecimiento tuvo lugar cuando se producía una movilización más o menos clásica conformada por "grupos de convencimiento" que buscaban hacer extensivo el paro decretado por los marineros a toda la industria. Allí pudo verse entonces la variedad de intereses de un grupo obrero "estable", que consideraba necesario continuar laborando, y aquellos "inestables" que no tenían trabajo. Tal separación se trasladaba al sindicato del SOIP el cual, alegando la defensa de los intereses de los trabajadores "estables", se negó a participar de la medida de fuerza lanzada por el SOMU. El día siguiente, el 29 de junio, mostrará un hito en tales tensiones, cuando los obreros y las obreras de las cooperativas tomen la sede sindical del SOIP buscando desplazar a la conducción. Lo cual ocurrirá dos años más tarde.

Por otra parte, debemos remarcar que los contenidos de la lucha llevada adelante por la Multisectorial se orientaron a discutir los efectos de la política pesquera, y a partir de ahí, buscar modificarla en algunos puntos (por ejemplo cuando se cuestionaron artículos de la Ley Federal de Pesca). Pero lejos estuvieron de cuestionar el fondo del "modelo" pesquero. La pelea buscó mantener un volumen de ingreso de pescado a puerto y la supervivencia del "modelo" fresquero. Y en este sentido, podemos decir, se mostró bastante eficaz. Logró que se plasmara en la sanción de la Ley de Emergencia Pesquera. Pero no se planteó un tratamiento industrial alternativo, ni el desarrollo de productos con mayor agregación de valor, ni se propuso modificar la vocación exportadora y orientar la oferta hacia el mercado interno, o cuestionar las condiciones laborales de la fuerza de trabajo. Éste último fue un contenido propuesto por los gremios en la discusión, pero nunca pasó de allí. Incluso el SOIP, crítico de las cooperativas, no protagonizó medidas de acción directa en contra de ellas. Y tampoco las protestas llevadas a cabo por los trabajadores cooperativizados, aunque en los sectores más "radicalizados" discursivamente aparecían como objetivo, pudieron instalar esa demanda plenamente, dado que entre los contenidos terminaron primando la reactivación del puerto y el pedido de subsidios. Con todo, pareciera que la última posibilidad de consolidar un "modelo" de desarrollo pesquero alternativo, cuanto menos postulado en las intenciones de sectores potencialmente capaces de llevarlo a cabo, fue desarticulado en los comienzos de la década del '90, tras la derrota del grupo que, en buena medida, representaban César Lerena y Abdul Saravia. 
La lectura principal que buscamos alentar es la que ligó las características de la protesta obrera -y el conjunto de la dinámica conflictual- con las consecuencias de un "modelo" pesquero sostenido sobre la base de la apertura externa, la vinculación subordinada con algunas potencias pesqueras, la consolidación de determinados agentes económicos, el incremento de la vocación extractiva y la precarización de la fuerza de trabajo. La ironía es que en un contexto de expansión de las capturas y volúmenes de exportaciones, sobre la base de un recurso de propiedad común, las políticas para la pesca terminaron, lejos de alentar procesos sostenidos de desarrollo, contribuyendo a la consolidación de ciertos grupos empresarios. Al contrario, las condiciones de trabajo de un sector de los trabajadores se retrotrajeron hasta la precariedad que mantenían los obreros y obreras en los comienzos de la actividad. De allí su involución. Las protestas del final del ciclo estudiado evidencian dos cuestiones importantes. Por un lado, la lucha por mantenerse en la actividad de los actores que se reconocían en un "modelo" de pesca más "tradicional", lo cual en buena medida consiguieron. Ello motivo la protesta marplatense como corporación económica, es decir, aglutinando intereses empresariales y obreros, sostenidos por el poder municipal, en contra de un enemigo externo (pero también interno). Pero esa lucha no expresó en sus contenidos la búsqueda por trasformar las condiciones laborales de los trabajadores y trabajadoras. Es así que tal supervivencia también se basó en la precarización de las condiciones de trabajo de un sector no menor de obreros y obreras de las plantas de procesado. Por otro lado, el combate social de los trabajadores terminó adquiriendo perfiles fundamentalmente defensivos, en particular para los representados por el SOIP. Esto nos habla de la consolidación de un "modelo" pesquero sobre la base de una "derrota" obrera y, así, muestra la realidad de un territorio social que en la balanza de poder entre las clases dejó a éstos en una situación de marcada desventaja. Los analistas deberán tener esto en cuenta cuando realicen análisis diagnósticos y prognósticos de la actividad. Los periodistas cuando informen de una nueva protesta. También los encargados de implementar políticas públicas cuando observen contradicciones entre las medidas tendientes a la "registración" de la mano de obra y su dificultad para implementarlas en determinadas ramas de la economía. Por último, los trabajadores, dirigentes sindicales y militantes deberán conocer las características de este proceso para saber dónde se encuentran parados y cómo orientar las estrategias de intervención si es que buscan modificar las cosas. 


\section{Anexo I}

\section{Aclaraciones metodológicas sobre los criterios de la base de datos}

\section{Definición de Hecho}

Entendemos por hecho de protesta en la industria pesquera a todo hecho colectivo de protesta o de lucha, llevado a cabo por actores de la industria pesquera, sean estos trabajadores, pequeños, medianos y grandes empresarios, dirigido contra alguna expresión del estado de cosas existente. Estos hechos generalmente implican la movilización de cuerpos para la acción (movilizaciones, manifestaciones, huelgas, etc.), pero también incluimos aquellos episodios dominados por batallas discursivas (declaraciones de estado de emergencia, de movilización, de alerta), las cuales señalan la existencia de una predisposición a la lucha. Lo que, desde nuestro punto de vista, ya constituye lucha.

\section{Acciones de Protesta}

\section{Acciones de baja intensidad}

Asamblea, Juntada de firmas, Fileteado de pescado en la calle, Limpieza de escuelas.

Declaración de: Estado de alerta, Estado de alerta y movilización, Estado de movilización permanente, Estado de asamblea, Estado de alerta y asamblea, Estado de sesión permanente, Estado de asamblea permanente.

Amenaza: Amenaza de paro, Amenaza de toma.

\section{Acciones de alta intensidad}

Acciones callejeras: Ataque a edificio patronal, Ataque a edifico público, Cacerolazos, Corte de calle, Corte de ruta, Instalación de carpa, Manifestación, Movilización, Olla popular, Piquete ${ }^{1391}$.

Acciones en espacios de trabajo: Quite de colaboración; Retención de tareas; Trabajo a reglamento. Huelgas: Huelga, Huelga de hambre, Huelga general, Huelga y apagón, Huelga parcial.

Paro Patronal.

Toma: Toma de buque, Toma de edificio público, Toma de edificio público (parcial) ${ }^{1392}$, Toma de edificio privado, Toma de planta, Toma de planta (parcial) ${ }^{1393}$, Toma sede sindical.

\section{Sujetos de la protesta}

Definidos según el ámbito de relaciones sociales donde se encuentren. Esto es trabajadores, burguesía, pequeña burguesía, gran burguesía, vecinos. ${ }^{1394}$

\footnotetext{
${ }^{1391}$ Como piquete mencionaremos aquella protesta de acción directa que busque de manera deliberada interrumpir y/trabar el "normal" funcionamiento de la producción pesquera. A diferencia de bases de datos para protestas nacionales o locales, no utilizaremos la noción de piquete para identificar un corte de calle. Por el contrario, la protesta estará vinculada a no permitir la salida de buques o a obstaculizar el funcionamiento de una planta pesquera.

${ }^{1392}$ Refiere a la toma u ocupación de un sector de la planta.

${ }^{1393}$ Refiere a la toma u ocupación de un sector de la planta.

1394 Por mediana burguesía entendemos a los empresarios dueños de buques fresqueros, con plantas en tierra. Por pequeña burguesía nos referimos a los dueños de pequeñas lanchas, dueños de fábricas fazoneras. Por gran burguesía tomamos a las empresas integradas que utilizan buques fresqueros y congeladores y están diversificados verticalmente.
} 


\section{Condición de Ocupación}

En el caso de los trabajadores asalariados se especifica su condición de ocupación (Ocupado, SubOcupado, Desocupado). En el caso de los trabajadores ocupados se agrega la situación de registración laboral. Esto es, trabajadores en relación de dependencia, trabajadores de cooperativas, trabajadores sin registración, contratados (en el caso de los empleados estatales). En el caso de los desocupados se diferencia entre desocupados recientes (por ejemplo, obreros y obreras de una fábrica que cerró) o simplemente desocupados, cuando esa condición se mantuvo por más tiempo. En este ámbito, también se incluyen las acciones realizadas por familiares. ${ }^{1395}$

En el caso de las declaraciones, generalmente realizadas por la conducción sindical, se relaciona a la condición de ocupación en función de las razones de la declaración y el tipo de demanda. Por ejemplo, cuando se realiza por defensa de fuente de trabajo, la medida se hace para defender a desocupados recientes. Entonces se considera la situación de estos últimos.

Sin organización formal remite a la activación de trabajadores que, no siendo impulsado por la conducción del sindicato, tampoco se le opone. Y, asimismo, no responde a la situación interna de una planta, ni tampoco es convocada por el cuerpo de delegados. Muchas veces funciona por la activación de militantes pero no aparece una línea interna clara y no necesariamente disputa con la conducción del gremio.

\section{Situación de registración}

Busca señalar la diferencia entre trabajadores en relación de dependencia, cooperativizados, trabajadoras "changa" o sin determinar

\section{Subrama de ocupación}

Naval; Hielo; Industria del pescado incluye: Industria del pescado (general), Filet, Conserva, Harina; Industria extractiva de pescado; Estiba; Estatales incluye: trabajadores del INIDEP y del Mercado Nacional de Concentración Pesquera.

Cuando aparece Industria Pesquera como sub rama es porque el conflicto abarca a todas, o la mayoría, de las subramas de conjunto.

Cuando se trata de un conflicto originado localmente aparecerá, en el lugar de sub rama, General Ciudad. Por ejemplo un paro de la CGT regional Mar del Plata, donde participan diferentes gremios de la industria pesquera.

Cuando se trata de un conflicto originado nacionalmente aparecerá, en el lugar de sub rama, General Nación. Por ejemplo un paro de la CGT, donde participan diferentes gremios de la industria pesquera.

General Ciudad/Nación cuando afecte tanto localmente como nacionalmente. Por ejemplo, un paro de la CGT nacional acompañado por medida de fuerza, como puede ser una movilización en Mar del Plata.

\footnotetext{
1395 De todos modos, hay que decir que definir criterios con fronteras demasiado rígidas tiene un fuerte nivel de arbitrariedad. Puesto que no es tan fácil, en ciertos casos, distinguir entre ocupados, subocupados, o desocupados.
} 


\section{Organización que los agrupa}

Dentro de la organización que los agrupa incluimos el Sindicato o Asociación Empresaria dentro de cuya órbita se encuentran los sujetos y organizaciones que convocan o participan del hecho conflictivo.

El criterio es que allí ubicamos la organización madre dentro de la que se incluyen organizaciones menores. Por ejemplo, para el caso concreto de los trabajadores vinculados a la Industria del Pescado, la organización de su órbita será siempre el SOIP. Esto a pesar de que en algunos episodios tengamos que los protagonistas son organizaciones como Autoconvocados o la UOP que representan a obreros desocupados, sub ocupados o cooperativizados que no participan, al menos no tienen el derecho estatutario de hacerlo, de la vida gremial del SOIP. Aún así, resulta evidente que tanto por el tipo de labor que realizaban, así como su identidad, e inclusive su influencia en la vida gremial (siempre que no reduzcamos la vida gremial a lo exclusivamente formal y normado) efectivamente los hace partícipes de la vida del SOIP.

\section{Organización o instancia que convoca}

Se refiere al tipo de organización que convoca, que en un caso puede ser el Sindicato o la Asociación Empresaria, pero también una Línea interna, Cuerpo de Delegados, Comisión Interna.

Interpretamos Comisión Interna en un sentido laxo. Por ejemplo, consideramos como Comisión Interna, tenga o no un lugar formal, cuando convoca el personal de planta de un espacio de trabajo. Comisión interna también se usa para desocupados recientes que protestan en calidad de ex miembros de una planta.

Desocupados es un caso atípico. Porque en general, salvo que se advierta especialmente, los desocupados pertenecen a la órbita del SOIP. Y en ese caso pueden protestar en calidad de Desocupados (sin organización formal que convoque) o anunciando ya una línea interna dentro del Sindicato. Cuando esto es así, se indicará Línea Interna.

\section{Demandas}

De un conjunto amplio de demandas, realizamos dos niveles de agregación. El primero refiere al carácter de las demandas. En ese sentido hemos reconocido nueve tipos de demandas y un espacio para aquellas acciones de las que no hemos podido recoger cuál era la demanda: Demanda Salarial, Demanda Laboral, Demanda Política, Demanda Sindical, Demanda Productiva, Demanda de justicia/judicial, Demanda Corporativa, Demanda de asistencia social, Demanda de salud, Sin datos. ${ }^{1396}$

Las demandas en un primer nivel de desagregación contienen las siguientes características:

- Demanda salarial: Aumento de salarios, Pago salarios atrasados, Cobro indemnizaciones, Efectivizar incrementos salariales, Defensa del salario, Rechazo CCT

\footnotetext{
${ }^{1396}$ Esta clasificación resulta bastante arbitraria ya que un tipo de demanda puede conllevar implícito el pedido de otra demanda. Por ejemplo, una demanda de carácter política por lo general apunta también (o cuanto menos puede hacerlo) a cumplir demandas salariales, productivas y corporativas. Como también una demanda de asistencia social, la que señala un nivel más urgente de necesidad, contiene también en sí misma una "politicidad" en la medida en que apunta obligar al Estado a hacerse cargo de un sector de la población perjudicado por la marcha del modelo económico. Con todas esas reservas, y varias más que se pueden realizar, sin embargo justifica la división tener una dimensión de la categoría de los reclamos, cuáles preponderaron, cuáles se mantuvieron constante. Ilumina algún más la cuestión un primer nivel de desagregación que presentamos a continuación.
} 
- Demanda laboral: Defensa fuente de trabajo, Reincorporación de trabajadores despedidos, Mejoras en las condiciones de trabajo, Actualización de escalafón, Conservar relación de dependencia, Denuncia trabajo en negro, Erradicación de cooperativas, Trabajo, Empleo en blanco, Reconocimiento de vínculo laboral, Embarcar sólo con CUIT (patronal), Formar cooperativas de trabajo (patronal).

- Demanda política: Proponer una medida de gobierno; Modificar una medida de gobierno; Rechazar una medida de gobierno; Rechazar política de gobierno; Rechazo accionar de Prefectura; Rechazar política económica; Rechazar política pesquera; Participación gremial en la política pesquera.

- Demanda sindical: Pago obra social, Pago aportes patronales, Defensa delegados, Reconocimiento delegado, Manejo bolsa de trabajo, Cumplimiento del CCT, Convocatoria a paritarias, Desvinculación de un capataz, Expresa solidaridad, Oposición a la conducción gremial, Oposición a la conducción gremial nacional, Apoyo a la conducción gremial, Incorporación al gremio, Efectivizar llamado a elecciones, Transparencia en reparto de comida, Solidaridad con medida de fuerza, Finalizar medida de fuerza.

- Demanda Productiva: Provisión de materia prima, Comenzar las tareas de pesca, Aumento en el precio del pescado pagado, Aumento en el precio del pescado, Reactivación del Puerto, Procesar pescado en tierra, Entrega de embarcaciones (patronal).

- Demanda de justicia/judicial: Celeridad de la justicia, Denuncia de estafa.

- Demanda corporativa: Oposición a congeladores, Oposición veda, Defensa fresqueros.

- Demanda de asistencia social: Subsidios, Bolsas de comida, Detener cortes de servicios.

- Demanda de salud: Salud en general, Sala de primeros auxilios

- Sin datos.

\section{Contra quien}

Contra quien refiere al antagonista de la acción, pero también al sujeto que resulta interpelado. En ocasiones puede interpelarse al gobierno, en cualquiera de sus instancias, sin considerarlo como el enemigo.

Las categorías agregadas son: Patronal empresa particular, Patronal empresa de conjunto, Gobierno (Local, Provincial, Nacional).

Por último se incluye el lugar de la acción, la cantidad de participantes y los resultados que arrojó. Esto último es, si las demandas fueron satisfechas o no. 


\section{Bibliografía}

\section{Industria pesquera y trabajadores}

A.A.V.V. (2011); Trabajadores militantes del puerto desaparecidos en Mar del Plata 1975 - 1983, Mar del Plata, Comisión Memoria Portuaria

Allen, Adriana (1999); "Sustentabilidad productiva: ajuste político-económico estructural y efectos ambientales. El caso de la industria pesquera marplatense", en A.A.V.V., Territorio, sociedad y desarrollo sustentable, Buenos Aires, Espacio Editorial.

Bertolotti, María et al (2002); "El sector pesquero del PGP”, en Gennero de Rearte, Ana y Carlos Ferraro (comp.); Mar del Plata Productiva: diagnóstico y elementos para una propuesta de desarrollo local, CEPAL, Estudios y perspectivas $\mathrm{N}^{\circ} 11$, Bs As, pp. 50 a 65.

Bertolotti, María et al (2001); "Algunas consideraciones preliminares sobre el estado del sector pesquero", INIDEP, Informe Técnico $\mathrm{N}^{\circ} 71$.

Bertolotti, María et al (2001b); “Actividad Pesquera. Incidencia relativa de la Provincia de Buenos Aires”, INIDEP, Informe Técnico $\mathrm{N}^{\circ} 70$.

Bertolotti, María et al (2001c); "Estimación de las remuneraciones promedio del personal contratado y de las cooperativas entre 1996 y 1997”, INIDEP Informe Técnico Nº1.

Bertolotti, María et al (1996); "Resultados preliminares del Censo Nacional Industrial Pesquero 1996. Provincia de Buenos Aires. Plantas instaladas en tierra", INTI-INIDEP.

Bertolotti, María y Emilio Manca (1986); "Procesamiento y comercialización de la anchoíta (Engraulis anchoíta) del Mar Argentino", en Revista de Investigación y Desarrollo Pesquero $N^{\circ}$ 5, INIDEP, Mar del Plata, Diciembre.

Bogo, Jorge (1994); "La regulación de la actividad pesquera: una propuesta de cambio de política", en Desarrollo Económico, vol. 33, № 132, enero-marzo.

Burijson, Viviana (2003);“La Actividad Pesquera en la República Argentina”, Buenos Aires, FREPLATA, Noviembre.

Carlone, Héctor (2004); "Elecciones en el SOIP. Un caso atípico de geografía electoral”, en Revista el Mensajero $\mathrm{N}^{\circ} 2$, UNMDP.

Cepparo, María Eugenia et al (2007); "El Acuerdo pesquero entre la Argentina y la Comunidad Económica Europea. Su impacto en la Patagonia Meridional. El caso de Puerto Deseado, Provincia de Santa Cruz, 1994-1999", en Magallania, vol. 35, Chile, pp. 37-53.

Cóccaro, José María et al (2000); “La minería pesquera ¿Argentina?”, en línea: http://elistas.egrupos.net/lista/encuentrohumboldt/archivo/indice/507/msg/543/, visitada el 02/12/2013

Copes, Parzibal (1999); "Una revisión crítica de las cuotas individuales como dispositivo en el manejo de pesquerías", en Comunidad Pesquera $\mathrm{N}^{\circ}$ 3, febrero, Mar del Plata.

Colombo, Guillermo (2011); "De "clasistas" a "burócratas": el devenir de una "traición". Acerca de la construcción moral del enemigo político en un sindicato de la industria del pescado (Mar del Plata - Argentina, 1997 - 2007)", en Revista Colombiana de Antropología, Instituto Colombiano de Antropología e Historia, Volumen 47 (I), enero - junio, Colombia, pp. 43 a 68.

Colombo, Guillermo (2010a); "De obreros a vándalos": Análisis de un 'estallido social' en el puerto de Mar del Plata, junio de 2000”, en Revista Historia Regional, № 28, ISP № 3, Villa Constitución, Argentina, pp. 121 a 144.

Colombo, Guillermo (2010b); “"Estos no solamente son burócratas'. Acerca de la moralidad en la construcción de antagonismos políticos en un sindicato marplatense", en Nuevo Topo. Revista de Historia y Pensamiento Crítico, Nro. 7, Buenos Aires, pp. 41 a 54. 
Colombo, Guillermo (2008); "Crisis de la merluza y protesta obrera. La dinámica de los enfrentamientos en el puerto marplatense", Tesina de Licenciatura, Universidad Nacional de Mar del Plata, Facultad de Humanidades, mimeo.

Colombo, Guillermo y AgustínNieto (2008); “Aproximación a las formas de la lucha obrera en la industria de la pesca, Mar del Plata 1997-2007”, en Labour Again. En línea: http://www.iisg.nl/labouragain/documents/colombo-nieto.pdf

Colombo, Guillermo y AgustínNieto (2006); "Bases sociales y económicas de la protesta. La industria de la pesca en Mar del Plata. De la convertibilidad a la devaluación (1991-2002)", en Actas de las XX Jornadas de la Asociación de Historia Económica, versión electrónica.

Cutuli, Romina (2012); "Del trabajo a la casa... Una mirada de género sobre las trabajadoras de la industria pesquera en tiempos de precarización laboral", Tesis de doctorado en Historia, Universidad Nacional de Mar del Plata, mimeo.

Ezpoz Espoz, Milcíadez (1999); Historia de la pesca argentina: hechos y vivencias, Mar del Plata, Fundación Atlántica.

Ezpoz Espoz, Milcíadez (1985); Introducción a la pesca Argentina, Mar del Plata, Fundación Atlántica.

Favero, Bettina y Gerardo Portela (2005); Más allá de la avenida Cincuentenario: el barrio del Puerto, 1920 - 1960, Mar del Plata, Suarez.

Feeny, David et al (1990); "Formas de propiedad y acceso a los recursos naturales", Instituto Nacional de Ecología, México. En línea: http://www2.inecc.gob.mx/publicaciones/gacetas/278/formas.html

Fermepin, Raúl y Juan Villemur (2004); 155 años de la pesca en el Mar Argentino (1821-1976), Mar del Plata, IPN.

Gennero de Rearte, Ana y Carlos Ferraro comp. (2002); "Mar del Plata Productiva: diagnóstico y elementos para una propuesta de desarrollo local", CEPAL, Estudios y perspectivas, $\mathrm{N}^{\circ} 11$, Bs As.

Genero de Rearte, Ana y otros (1998); "La capacidad innovativa de núcleos impulsores de firmas en entornos territoriales dinámicos: el caso de Mar del Plata", s/l., s/e.

Gennero de Rearte, Ana et al (1997); "Descentralización Productiva y Precarización Laboral: el caso de las cooperativas de fileteado de pescado", en Informe de Coyuntura, Centro de Estudios Bonaerense, Año 7, № 71, pág. 51 a 63.

Godelman, Ernesto et al (2004);“Propuesta para el ordenamiento de la pesquería de merluza en la argentina", en www.cedepesca.org.

Godelman, Ernesto (2001); “¿Crisis en la Pesca o Crisis en la merluza?”, en www.cedepesca.org.

Godelman, Ernesto (2000); "Análisis y comentarios del informe del Banco Mundial: situación pesquera”, en www.cedepesca.org.

Godelman, Ernesto (1999); "La Política de Subsidios Pesqueros de la Unión Europea, el Acuerdo en Materia de Pesca Marítima Entre la UE y la República Argentina, y sus Consecuencias en la Sustentabilidad de las Pesquerías del Atlántico Sudoeste, Particularmente en la de Merluza Argentina (Merluccius hubbsi)”, en www.cedepesca.org.

Holm, Paul (1998); “The global fish market, 1850-1995”, en Mercados globales: la internacionalización de la industria del transporte marítimo desde 1850, Sevilla, Universidad de Sevilla.

Ibáñez, José (1988); El Puerto que conocí (en la década del 40), Mar del Plata, Armedenho.

Idyll, Clarence (1983); El mar contra el hambre, Argentina, Corregidor.

Lázzaro, Silvia (1992); Estado, capital extranjero y sistema portuario argentino: (1880-1914), vol. I, Buenos Aires, Centro Editor de América Latina.

Lerena, César (2009); Malvinas: Biografia de una entrega: pesca, la moneda de cambio, Buenos Aires, Bouquet Editores.

Lerena, Cesar (1989); La industria Pesquera Argentina. Reafirmación o decadencia, Mar del Plata, Argentina, Editorial PREPOPE. 
Llosa, Macarena (2003); “La desvalorización y los conflictos de la pesca en el Mar Argentino. La situación en Patagonia”, Mendoza, Universidad Nacional de Cuyo. En línea: http://ffyl.uncu.edu.ar/IMG/pdf/pesca_en_Patagonia-LLosa.pdf, visitada el 02/12/2013.

Litovsky, Alejandro (2000); "La depredación de la merluza en la Argentina. Incentivos políticos y conservación de los recursos naturales", Universidad Torcuato Di Tella, Tesina de licenciatura en Relaciones Internacionales, mimeo.

Madaria, Edgardo (1999); "El sector pesquero argentino", Buenos Aires, Universidad Católica Argentina. En línea: http://www.uca.edu.ar/uca/common/grupo61/files/pesquero.pdf, visitada 02/12/2013.

Martin, Mariel (1998); "Las mujeres en el proceso de trabajo de la industria conservera en la ciudad de Mar del Plata. Generizando en la industria conservera (1940-1955)", en Temas de Mujeres. Perspectivas de Género, Centro de Estudios Históricos Interdisciplinarios sobre las Mujeres, FFyL-UNT, pp. 476 a 484.

Martin, Mariel (1994); "El rol de la mujer en la industria conservera del pescado de la ciudad de Mar del Plata de 1940-1955", en Actas del $2^{\circ}$ Congreso Nacional de Estudios del Trabajo, Buenos Aires.

Masid, Mirta y José Mateo (2008); "De la sustitución a la exportación. El sector pesquero argentino entre 1930 y 1965”, en Revista de Estudios Marítimos y Sociales, GESMar, Año 1, № 1.

Masid, Mirta (2005); "La expansión del sector pesquero argentino y el proceso de integración en el mercado exportador (1960-1980)", Rosario, ponencia presentada en las X Jornadas Interescuelas/Departamentos de Historia.

Mateo, José (2006); "Sembrando anzuelos para tiburones. Las demandas vitamínicas de la II Guerra Mundial y el desarrollo de la pesca comercial marítima en Argentina (1943-1952)", en Boletín del Instituto de Historia Argentina y Americana Dr. Emilio Ravignani, no 29, pp.119-150.

Mateo, José (2005); El período heroico de la pesca costera en Argentina (1940-1975). Universidad Nacional de Lanús.

Mateo, José (2004a); "Cosechando el mar en lanchas amarillas. La expansión de la pesca costera marplatense (1939 1963)”, en ANUARIO IEHS, n 19, pp. 305-335.

Mateo, José (2004b); “Gente que vive del mar. La génesis y el desarrollo de una sociedad marítima y una comunidad pescadora", en PROHISTORIA, no 8 , pp.59-86

Mateo, José (2004c); "El arte de vivir con fe. Pesca, religión y religiosidad en el puerto de Mar del Plata (1920-1950)", en Pasado y presente de la Mar del Plata social, Eudem, Mar del Plata, pp. 171-183.

Mateo, José (2003); "De espaldas al mar. La pesca y los pescadores en Argentina (siglos XIX y XX)”, Tesis doctoral, Universitat Pompeu Fabra, Barcelona.

Mateo, José; Nieto, Agustín y Guillermo Colombo (2010); "Precarización y fraude laboral en la industria pesquera marplatense. El caso de las 'cooperativas' de fileteado de pescado", Concurso Bicentenario de la Patria: Premio Juan Bialett Massé, Ministerio de Trabajo de la Provincia de Buenos Aires. En línea: http://www.trabajo.gba.gov.ar/informacion/masse/categoriaA/13_MATEO_Precarizacion_y fraude_laboral_en_la_i ndustria_pesquera_marplatense.pdf, visitada el 02/12/2013.

Mizrahi, Enrique (2001); "Evolución del proceso de desarrollo de la pesca en la Argentina", Consejo Federal de Inversiones.

Molina Carranza, Daniel (2004); “Accidentes náuticos en la actividad pesquera”, en Boletín del Centro Naval ํ 809, Sep-Dic., en línea: http://www.centronaval.org.ar/boletin/BCN809/809molinacarranza.pdf, visitada el $13 / 04 / 2013$.

Molinari, Irene (1998); "El mundo del trabajo: la vida de las obreras de la conserva en función de los tiempos de la fábrica. La sociabilidad en la fábrica, el hogar, el barrio, el tiempo libre en Mar del Plata, 1940/1983”, Anais Eletrônicos do III Encontro da ANPHLAC, Sao Paulo.

Molinari, Irene (1997); "Género y trabajo: el caso de las trabajadoras de la industria, los servicios y el comercio en Mar del Plata, 1940/1970”, Tesis de Maestría en Historia, Universidad Nacional de Mar del Plata, mimeo.

Nieto, Agustín (2012); "Entre anarquistas y peronistas. Organización sindical y experiencias obreras en la industria del pescado, Mar del Plata, 1942-1966”, Universidad Nacional de Mar del Plata, Tesis doctoral, mimeo. 
Nieto, Agustín (2010); “Amotinados. Ira obrera en la industria pesquera argentina, 1997-2007”, en Revista Lavboratorio, Bs. As./Mar del Plata, Instituto Gino Germani, pp. 63 a 92.

Nieto, Agustín y Guillermo Colombo (2009); "Lucha de calles en la industria del Pescado. Una interpretación del porqué de su regularidad (1997-2007)", en Revista Conflicto Social, año 2, № 1, junio, Instituto Gino Germani, UBA. En línea: http://www.iigg.fsoc.uba.ar/conflictosocial/revista/01/0108 nietocolombo.pdf

Nieto, Agustín (2005);“Lucha de calles en el Puerto de Mar del Plata. 28 y 29 de Junio de 2000”, Rosario, Ponencia, X Jornadas Interescuelas/Departamentos de Historia.

Pagani, Andrea y María Bertolotti (1991); "La actividad industrial pesquera: análisis intercensal 19821987, capacidad de producción por regiones y evolución de la incorporación tecnológica”, Mar del Plata, Frente Marítimo, vol. 9, sec. B, pp. 115 a 122.

Perrota, Bernardo (2008); La pesca comercial marplatense en el contexto socioeconómico argentino (19762001), Mar del Plata, Facultad de Humanidades, UNMDP, Tesina de Licenciatura en Historia, mimeo.

Pradas, Eduardo (2006); Un acercamiento a la problemática pesquera marplatense, Buenos Aires, ediciones El Mensajero.

Pradas, Eduardo (s/f); "La Unidad Obrera del Pescado", Mar del Plata, inédito.

Rodríguez, Alejandro et al (1999); "El sector pesquero marplatense. Una aproximación diagnóstica del actual y futuro escenario ante la emergencia de la Ley de Pesca", s/l, Instituto Nacional de Administración Pública.

Ruocco, Laura (2011); “Condiciones de trabajo de las mujeres obreras de la industria del pescado. Mar del Plata (1942-1956)”, en Cañete, Victoria et al, Los puertos y su gente. Pasado, presente y porvenir. La problemática portuaria desde las ciencias sociales, Mar del Plata, GESMar.

Ruocco, Laura (2009); "Mujeres obreras y sindicalismo anarquista. Dos paradigmas historiográficos (Mar del Plata, 1942”, en Revista de Historia Bonaerense, Instituto y Archivo Histórico Municipal de Morón, Año XVI, $\mathrm{N}^{\circ} 35$.

Ruocco, Laura (2008); "De las obreras de la conserva a las fileteras. Cambios y continuidades del trabajo femenino en la industria del pescado. Mar del Plata 1942-1975”, en Revista de Estudios Marítimos y Sociales, $\mathrm{N}^{\circ}$ 1, Mar del Plata.

Tomasone, Federico (2006); "El lugar de los obreros del SOIP en la Huelga General. Mar del Plata. Junio, Julio y Agosto de 1975”, Informe final de beca de estudiante avanzado, UNMDP, mimeo.

Valdez Goyeneche, Jorge (1974); La estructura pesquera argentina, Buenos Aires, EUDEBA.

Verazay, G. y Otero, H. (1986); "El estado actual de recurso merluza común (Merluccius hubbsi) y pautas para su manejo pesquero", Mar del Plata, Tercer Simposio Científico, 24 al 26 de noviembre.

Villalobos, Ruy de (S/f); "La valuación de recursos naturales extinguibles: el caso de la merluza en el mar continental argentino", en línea: biblioteca.clacso.edu.ar/ar/libros/ecología/Villalobos.pdf

Yurkievich, Gonzalo (2012); "Transformación estructural en la industria pesquera, conflictividad social y deterioro espacio-ambiental en el Puerto de Mar del Plata. 1991-2007", Tesis doctoral, UNMdP, mimeo.

\section{Historia de Mar del Plata}

Álvarez, Adriana y Daniel Reinoso (1999); Politica económica en Mar del Plata: 1946-1996, Mar del Plata, UCIP.

Böcker Zavaro, Rafael (2005); “Desarrollo, planificación estratégica y corporativismo local: El caso de Mar del Plata (Argentina)”, España, Tesis doctoral, Facultad de Ciencias económicas y Empresariales, Universidad Rovira i Virgili, mimeo.

Bozzi, Carlos (2005); Mar del Plata: ¿cien años de una ciudad sin futuro?, Mar del Plata, Argentina, Ediciones Suarez.

Lacabana, Miguel coord. (1997); Mar del Plata en transición. Mercado de trabajo local y estrategias familiares, Mar del Plata, UNMDP y Confederación Regional del Trabajo. 
Ladeiux, Juan (2013); "Entre un socialismo particular y un peronismo faccioso. Los actores y las prácticas políticas en Mar del Plata”; Tesis doctoral, Cap. IV, inédito. CEAL.

Pastoriza, Elisa (1993); Los trabajadores de Mar del Plata en vísperas del peronismo, Buenos Aires,

Sebreli, Juan (1970); Mar del Plata. El Ocio Represivo, Tiempo Contemporáneo, Bs. As.

Sangrilli, Carla (2009); "La normalización sindical en la transición democrática. El caso de la CGT Regional Mar del Plata", ponencia presentada en las IV Jornadas de Historia Política Bahía Blanca, julio, en línea: http://historiapolitica.com/datos/biblioteca/sangrilli_jiv.pdf.

Spadari, Oscar (2006); “¿Viejos o nuevos movimientos sociales? La experiencia socio-política de los participantes en los cortes de ruta en Mar del Plata 1997-2002”, Mar del Plata, Facultad de Humanidades, UNMDP, Tesina de Licenciatura en Historia, mimeo.

Torre, Juan Carlos y Elisa Pastoriza (2002); “La democratización del bienestar”, en Torre, Juan Carlos (dir.), Los años peronistas, Sudamericana, Buenos Aires.

\section{Protesta, beligerancia y conflictividad social}

A.A.V.V. (1999); A diez años de los saqueos en Rosario. Crisis Social, Medios y Violencia, Rosario, CECYT-CEHO-CEA-CU-UNR.

A.A.V.V. (2002); Qué son las asambleas populares, Buenos Aires, Peña Lillo y Ediciones Continente.

Acuña, Carlos (1995); "Política y economía en la Argentina de los noventa (o por qué el futuro ya no es lo que solía ser)", en América Latina Hoy № 12, diciembre, pp. 61 a 83.

Acuña, Carlos (1993); “Argentina. Hacia un Nuevo modelo", en Nueva Sociedad № 126, Julio - Agosto, pp. 11 a 24 .

Arias Bucciarelli, Mario; Favaro, Orieta y Graciela Iurno (1999); "Políticas de ajuste, protestas y resistencias. Las puebladas cutralquenses", en Favaro, Orieta (ed.), Neuquén. La construcción de un orden estatal, Neuquén, Cehepyc/Clacso-UNComahue.

Artese, Matías (2011); "Las acciones colectivas de protesta y el conflicto social en la Argentina de 1990. Apuntes sobre sus caracterizaciones", en Sociohistórica, Cuadernos del CISH, segundo semestre, pp. 107 a 129.

Astarita, Rolando (2002); "Interpretaciones alternativas sobre el 20 de diciembre en Argentina”, en Revista Argumentos, I, diciembre.

Aufgang, Lidia (1989);Las puebladas: dos casos de protesta social. Cipolleti y Casilda, Buenos Aires, Centro Editor de América Latina.

Auyero, Javier (2006); La zona gris: violencia colectiva y política partidaria en la Argentina contemporánea, Buenos Aires, Siglo Veintiuno Editores.

Auyero, Javier (2002); La protesta. Relatos de la beligerancia popular en la argentina democrática, Buenos Aires, Libros del Rojas-UBA.

Auyero, Javier (2001); La política de los pobres. Las prácticas clientelistas del peronismo, Buenos Aires, ediciones Manantial.

Auyero, Javier (2000); "El juez, la reina y el policía. Etnografía, narrativa y los sentidos de la protesta”, en Apuntes de Investigación del CECYP, Buenos Aires.

Auyero, Javier (2002b); "Los cambios en el repertorio de la protesta social en la Argentina", en Desarrollo Económico, vol. 42, $\mathrm{N}^{\circ} 166$, julio - septiembre, pp. 187 a 210.

Balbé, Beba y Balbé Beatriz(1991); "Acerca de los movimientos sociales y la lucha de clases", Buenos Aires, documentos de CICSO.

Battistini, Osvaldo (2004); El trabajo frente al espejo: continuidades y rupturas en los procesos de construcción identitaria de los trabajadores, Buenos Aires, Prometeo. 
Battistini, Osvaldo (2007); "Luchas sociales en crisis y estabilidad", en Villanueva, Ernesto y Astor Massetti (comp.), Movimientos sociales y acción colectiva en la Argentina de hoy, Buenos Aires, Prometeo.

Bialakowsky, Alberto; Costa, María y Mercedes Patrouilleau (2009); “Aportes a una teoría del cambio: gubernamentalidad, fuerzas productivas y praxis de sujetos colectivos en nueva época”, en Neffa, Julio; De la Garza Toledo, Enrique y Leticia Muñiz Terra (comp.), Trabajo, empleo, calificaciones, relaciones de trabajo e identidades laborales, Buenos Aires, CLACSO.

Calderón, Fernando (comp.) (1986); Los movimientos sociales ante la crisis, Buenos Aires, Universidad de Naciones Unidas-CLACSO-UNAM.

Cafassi, Emilio (2002); Olla a presión. Cacerolazos, piquetes y asambleas, sobre fuego argentino, Bs. As., Libros del Rojas.

Colectivo Situaciones (2002); 19 y 20 Apuntes para el nuevo protagonismo social, Buenos Aires, Ediciones de Mano en Mano.

Cotarelo, María Celia (2000);“"La protesta en la Argentina de los ‘90”, en Herramienta, № 12.

Cotarelo, María Celia (1999); "El motín de Santiago del Estero. Argentina, diciembre de 1993", en PIMSA, Doc. de Trabajo $\mathrm{N}^{\circ} 19$.

Dargoltz, Raúl (1994); El santiagueñazo. Gestión y crónica de una pueblada argentina, Buenos Aires, El despertador ediciones.

Delamata, Gabriela (2004); Los barrios desbordados. Las organizaciones de desocupados del Gran Buenos Aires, Bs. As., Eudeba-Libros del Rojas.

Delamata, Gabriela (2002); "De los 'estallidos' provinciales a la generalización de las protestas en Argentina”, en Revista Nueva Sociedad, ํ182.

Dinerstein, Ana (2001);"El poder de lo irrealizado. El (sic) en Argentina y el potencial subversivo de la mundialización", en OSAL.

Fajn, Gabriel et al (2003); Fábricas y Empresas Recuperadas: protesta social, autogestión y rupturas en la subjetividad, Bs. As., Centro Cultural de la Cooperación.

Farinetti, Marina (2007); "Viejas y nuevas luchas en un nuevo capítulo de la relación entre el sindicalismo y el peronismo", en Villanueva, Ernesto y Astor Massetti (comp.), Movimientos sociales y acción colectiva en la Argentina de hoy, Buenos Aires, Prometeo.

Fernández, Ana María et al (2008); Política y subjetividad: asambleas barriales y fábricas recuperadas, Buenos Aires, Biblos.

Fradkin, Raúl (2002); Cosecharás tu siembra, Buenos Aires, Prometeo.

Giarraca, Norma (2002); "La protesta agrorural en la Argentina", en Seone, José (Comp.) Movimientos Sociales y conflicto en América Latina, CLACSO-OSAL.

Iñigo Carrera, Nicolás (2007); "La lucha de los obreros y de los pobres en la Argentina del capital financiero", en Villanueva, Ernesto y Astor Massetti (comp.), Movimientos sociales y acción colectiva en la Argentina de hoy, Buenos Aires, Prometeo.

Iñigo Carrera, Nicolás (2000); “Fisonomía de las huelgas generales de la década de 1990 (1992-1999)”, en PIMSA 1999, Doc. de trabajo ${ }^{\circ} 21$.

Iñigo Carrera, Nicolás (1993);"Lucha democrática de la clase obrera argentina en las décadas de $1930 \mathrm{y}$ 1940", Critica de nuestro Tiempo $N^{\circ} 6$, Argentina.

Iñigo Carrera, Nicolás y María Celia Cotarelo (2005); “Algunos rasgos de la rebelión en Argentina 19932001", en PIMSA 2004, Doc. de trabajo n 49, pp. 125 a 138.

Iñigo Carrera, Nicolás y María Celia Cotarelo (2004); “La insurrección Espontánea. Argentina diciembre 2001. Descripción, periodización, conceptualización”, en PIMSA 2003, Doc. de trabajo n 43.

Iñigo Carrera, Nicolás y María Celia Cotarelo (2003); “¿Quién es el sujeto?, en Razón y Revolución $\mathrm{N}^{\circ} 10$, Buenos Aires, Invierno, pp. 24 a 32.

Iñigo Carrera, Nicolás y María Celia Cotarelo (2002); “¿Revuelta o Motín? Rosario y General Sarmiento, 1989”, en PIMSA 2001, Doc. de Trabajo n³2. 
Iñigo Carrera, Nicolás y María Celia Cotarelo (2001); “La protesta social en los '90. Aproximación a una periodización”, en PIMSA 2000, Doc. de Trabajo n 27.

Iñigo Carrera, Nicolás y María Celia Cotarelo (1999); "Los llamados 'cortes de ruta'. Argentina 19931997, en PIMSA 1998, Doc. de trabajo n 14.

Iñigo Carrera, Nicolás y María Celia Cotarelo (1998); "Revuelta, motín y huelga en la Argentina actual”, en PIMSA 1997, Doc. de trabajo ${ }^{\circ} 7$.

Jelin, Elizabeth et al (1987); Movimientos Sociales y democracia emergente, Buenos Aires, Centro Editor de América Latina.

Kindgard, Federico y Elizabeth Gómez(1999); “Los cortes de ruta en la provincia de Jujuy. Mayo/Junio de 1997”, en PIMSA 1998, documento de trabajo n 15.

Klachko, Paula (2000); "Cutral Có y Plaza Huincul. El primer corte de ruta (del 20 al 26 de junio de 1996). Cronología e hipótesis", en PIMSA 1999, documento de trabajo n 20.

Laufer, Ruben y Claudio Spiguel (1999); “Las “puebladas” argentinas a partir del 'santiagueñazo' de 1993. Tradición histórica y nuevas formas de lucha”, en López Maya, Margarita (ed.), Lucha popular, democracia, neoliberalismo: protesta popular en América Latina en los años de ajuste, Caracas, Nueva Sociedad.

Lobato, Mirta y Juan Suriano (2003); La protesta social en la Argentina, Buenos Aires, Fondo de Cultura Económica.

Lozano, Claudio (1995); “Los niveles de sindicalización”, en Realidad Económica № 133, Buenos Aires, pp. 2 a 12.

Lucita, Eduardo (2001); “Cortando rutas, abriendo nuevos senderos. Desocupados, ocupados, 'piqueteros', viejas y nuevas formas de lucha”, en Cuadernos del Sur, 31, Argentina, Editorial Tierra del Fuego, pp. 79 a 93.

McGuire, James (1997); "Peronism without Perón.Unions, Parties, and Democracy in Argentina", Stanford, University Prees.

Magnani, Esteban (2003); El cambio silencioso: Empresas y fábricas recuperadas por los trabajadores en la Argentina, Buenos Aires, Prometeo.

Massetti, Astor; Villanueva, Ernesto y Marcelo Gómez (Comp.) (2010); Movilizaciones, protestas e identidades políticas en la Argentina del Bicentenario, Buenos Aires, Nueva Trilce.

Massetti, Astor (2009); La década piquetera (1995-2005). Acción colectiva y protesta social de los movimientos territoriales urbanos, Buenos Aires, Nueva Trilce.

Massetti, Astor (2004); “¿Protesta o lucha de clases? La idea de 'conflictividad social’ en las teorías de los movimientos sociales”, en Laboratorio/n line, Revista de Estudios sobre Cambio Social, año IV, Nº15, 2004, en www.cátedras.fsoc.uba.ar/salvia/lavbo.htm.

Massetti, Astor (2004b); Piqueteros: acción de protesta e identidades colectivas, Buenos Aires, Editorial de las Ciencias.

Merklen, Denis (2005); Pobres ciudadanos: las clases populares en la era democrática, 1989-2003, Buenos Aires, Gorla.

Negri, Antonio y Guiseppe Cocco (2003); "El trabajo de la multitud y el éxodo constituyente, o el 'quilombo argentino"”, en Diálogo sobre la Globalización, la Multitud y la Experiencia Argentina, Paidós Ibérica.

Orlansky, Dora (1997); "Reforma del Estado, restructuración laboral y reconversión sindical. Argentina 1989-1995”, en Estudios Sociológicos, pp. 623-638.

Pereyra, Sebastián (2008); ¿La lucha es una sola? La movilización social entre la democratización y el neoliberalismo, Los Polvorines - Buenos Aires, Universidad Nacional de General Sarmiento - Biblioteca Nacional.

Pérez, Germán y Sebastián Pereyra (2008); La huella piquetera. Avatares de las organizaciones de desocupados después de 2001, La Plata, Ediciones Al Margen.

Pérez Álvarez, Gonzalo (2010); "Cambios en la estructura económica social y conflictos sociales en el noroeste del Chubut 1990 - 2005”, Tesis de Doctorado, FAHCE, UNLP, mimeo.

Pérez Álvarez, Gonzalo (2009); “Aunque parezca, la red no está vacía. Luchas de los obreros pesqueros del noreste de Chubut, 1990-2005”, en Revista de Estudios Marítimos y Sociales, № 2, Mar del Plata, pp. 171 a 183. 
Piva, Adrian (2006); "El desacople entre los ciclos del conflicto obrero y la acción de las cúpulas sindicales en Argentina (1989-2001)"; Estudios del Trabajo, N³1, 23 a 52.

Piva, Adrián (2001); “'La década perdida'. Tendencias de la conflictividad obrera frente a la ofensiva del capital (1989-2001)", en Cuadernos del Sur, $\mathrm{N}^{\circ}$ 31, Argentina, Ed. Tierra del Fuego.

Rebón, Julián (2005); Desobedeciendo al desempleo. La experiencia de las empresas recuperadas, Buenos Aires, Picaso - La Rosa Blindada.

Romero, Luis Alberto (2000); “Apogeo y decadencia de la política en las calles, 1969-1999”, en José Luis Romero y Luis Alberto Romero (directores): Buenos Aires, historia de cuatro siglos, 2da ed., Buenos Aires, Altamira.

Shuster, Federico et al (2006); "Transformaciones de la protesta social en la Argentina 1989-2003", Instituto Gino Germani, Doc. de trabajo ${ }^{\circ} 48$.

Stratta, Fernando y Marcelo Barrera (2009); El tizón encendido. Protesta social, conflicto y territorio en la Argentina de la posdictadura, Buenos Aires, El Colectivo.

Svampa, Maristella y Sebastián Pereyra (2003); Entre la ruta y el barrio. La experiencia de las organizaciones piqueteras, Buenos Aires, Biblos.

Viguera, Aníbal (2009); “Movimientos Sociales y Lucha de Clases”, en Revista Conflicto Social, Año 2, N 1 , junio.

Villanueva, Ernesto y Astor Massetti (comp.) (2008); Movimientos sociales y acción colectiva en la Argentina de hoy, Buenos Aires, Prometeo.

Zibechi, Raúl (2003); Genealogía de la Revuelta. Argentina: la sociedad en movimiento, La Plata, Letra Libre.

Proceso de trabajo, movimiento obrero, sindicatos.

Almeyra, Guillermo (1980); "La clase obrera en la Argentina actual”, en Coyoacán. Revista Marxista Latinoamericana, México, pp. 87.

Álvarez Rodríguez, Juan Fernando (2007); "La responsabilidad social en cooperativas de trabajo asociado en Bogotá. Una mirada desde su naturaleza empresarial y asociativa", en RULESCOOP, "Del diálogo a la puesta en práctica de soluciones estratégicas", Costa Rica, Universidad de Costa Rica.

Antunes, Ricardo (2000); "La metamorfosis en el mundo del trabajo", en Nomadas ํ 12, pp. 28 a 37.

Aquino, Cristián et al (1998); “Taylorismo, fordismo y posfordismo en la Argentina: ¿la consolidación del régimen de gran industria?", en Razón y Revolución $\mathrm{N}^{\circ} 4$, otoño.

Bendini, M. y N. Gallegos (2002); "Nuevas formas de intermediación en un mercado tradicional de trabajo agrario", en Revista Trabajo y Sociedad, Revista digital de la Universidad de Santiago del Estero, Argentina, $\mathrm{n}^{\circ} 4$, vol.III, marzo-abril.

Braverman, Harry (2007); "La degradación del trabajo en el siglo XX", en Revista Taller. Sociedad, cultura y política, No. 24. En línea: http://www.serviciosesenciales.com.ar/articulos/ladegradacion.pdf. Pág. visitada el 23/05/2013.

Braverman, Harry (1975); Trabajo y capitalismo monopolista. La degradación del trabajo en el siglo XX, México, Nuestro Tiempo.

Burawoy, Michael (1989); El consentimiento en la producción. Los cambios del proceso productivo en el capitalismo monopolista, España, MTySS, [1979].

Carri, Roberto (1967); Sindicatos y poder en la Argentina, Bs. As., Sudestada.

Chakrabarty, Dipesh (1997); "Sindicalismo en una cultura jerárquica: los trabajadores del yute de Calcuta, 1920-1950", Silvia Rivera Cusicanqui y Rossana Barragán (Comp.) Debates Post Coloniales: Una introducción a los Estudios de la Subalternidad. Sephis/Aruwiyiri/Historias, La Paz. 
Coriat, Benjamín (1997); El taller y el cronómetro. Ensayo sobre el taylorismo, el fordismo y la producción en masa, España, Siglo XXI, [1979].

Cotarelo, María Fernanda y Fabián Fernández (1997); "Lucha del movimiento obrero y crisis de la alianza peronista argentina, junio y julio de 1975 y marzo de 1976”, Documento de Trabajo No 6, PIMSA.

Del Campo, Hugo (1983); Sindicalismo y peronismo: los comienzos de un vínculo perdurable, Bs. As., CLACSO.

Delich, Francisco (1982);“Después del diluvio, la clase obrera”, en Rouquie, Alain (comp.), Argentina hoy, Buenos Aires, Siglo XXI.

Dicósimo, Daniel (2009); "Experiencias productivas, visión del mundo y unidad obrera. El proceso de trabajo como dimensión explicativa de los conflictos laborales", en H-industri@ 우 4, año 3, primer semestre.

Dicósimo, Daniel (2006); "Dirigentes sindicales, racionalización y conflictos durante la última dictadura militar", en línea: http://historiapolitica.com/datos/biblioteca/dicosimo.pdf

Donaire, Ricardo y Verónica Lascano (2001); "Movimiento obrero e hiperinflación", en PIMSA 2002, Doc. de trabajo $\mathrm{N}^{\circ} 36$, pp. 77 a 112.

Doyon, Louise (2006); Perón y los trabajadores. Los orígenes del sindicalismo peronista, 1943 - 1955, Bs As, Siglo XXI.

Ermida Uriarte, Oscar y Natalia Colotuzzo (2009); Descentralización, tercerización, subcontratación, OIT, Lima.

Etchemendy, Sebastian (2011); Models of economic liberalization: Business, Workers and Compensation in Latin America, Spain, and Portugal, Estados Unidos, Cambridge University Press.

Etchemendy, Sebastián y Ruth Collier (2007); "Golpeados pero de pie: Resurgimiento sindical y neocorporativismo segmentado en Argentina (2003-2007)", en Politics and Society, 35 (3).

Etchemendy, Sebastián y Vicente Palermo (1998); "Conflicto y concertación. Gobierno, congreso y organizaciones de interés en la reforma laboral del primer gobierno de Menem (1989-1995)", en Desarrollo Económico, vol. 37, № 145, (enero-marzo).

Falcón, Ricardo (1996); "La resistencia obrera a la dictadura militar (una reescritura de un texto contemporáneo a los acontecimientos)", en Quiroga, Hugo y Tcach, César (Comp.) A veinte años del golpe. Con memoria democrática. Buenos Aires, Homo Sapiens, pp. 136.

Farinetti, Marina (1999); “¿Qué queda del movimiento obrero? Las formas del reclamo laboral en la nueva democracia Argentina”, en Trabajo y Sociedad, $N^{\circ} 1$, Vol. I, Santiago del Estero, Argentina.

Fernández, Fabián (2000); "Las transformaciones en los procesos de trabajo en la industria argentina actual: algunas hipótesis e interrogantes", en PIMSA, Documento de Trabajo $\mathrm{N}^{\circ} 30$, disponible en http://www.pimsa.secyt.gov.ar/publicaciones/DT\%2030.pdf, visitada el 28 de marzo de 2013.

Fernández, Fabián (1999); "Cambios en el proceso de trabajo en la gran industria capitalista: una aproximación a partir del análisis de la industria automotriz argentina", en PIMSA 2000, Documento de Trabajo ${ }^{\circ}$ 22, disponible en http://www.pimsa.secyt.gov.ar/publicaciones/DT22.pdf, visitada el 28 de marzo de 2013.

Fernández, Arturo (comp.) (2002); Sindicatos, crisis y después, Buenos Aires, Biebel.

Fernández, Arturo (1997); Flexibilización laboral y crisis del sindicalismo, Buenos Aires, Espacio Editorial.

Fontela, Eduardo (2008); "SEUDOCOOPERATIVAS. Cooperativas que son pura apariencia", en Portalcoop, Argentina. (http://portalcoop.com.ar).

García Calavia, Miguel Angel (1999); “Trabajo y capital monopolista”. Veinticinco años después: Un texto clásico todavía vigente", en Cuadernos de Relaciones Laborales $\mathrm{N}^{\circ}$ 14, Serv. Publ. UCM, Madrid.

Gaudio, Ricardo y Héctor Domeniconi (1986); "Las primeras elecciones sindicales en la transición democrática”, en Desarrollo Económico, Vol.26, ํ103, Oct-Dic, pp. 423 a 454.

Ghigliani, Pablo (2009); "Acerca de los estudios cuantitativos sobre conflictos laborales en Argentina (1973-2009): reflexiones sobre sus premisas teórico-metodológicas”, en Revista Conflicto Social, Año 2, № 2 , Diciembre. 
Ghigliani, Pablo (2009); "Los dilemas de la democracia sindical: la Federación Gráfica Bonaerense 19661975”, en AA.VV., Relatos de las Luchas Obreras, Buenos Aires, Editorial del Subte.

Gómez, Marcelo (2009); "Un modelo de análisis para entender las transformaciones del sindicalismo durante los '90 en la Argentina",en Revista Conflicto Social, Año 2, № 2, Diciembre.

Herrera, María (2003); "La protesta como modo de participación cívica. Los nuevos formatos de la acción colectiva beligerante en Argentina y la apertura de un Ciclo de Protesta", trabajo presentadoen el $6^{\text {to }}$ Congreso Nacional de Ciencia Política, Sociedad Argentina de Análisis Político, San Luis, Noviembre.

Ibarlucía, Miguel (1997); "Las cooperativas de trabajo: un largo camino de obstáculos", en Trabajo y Seguridad Social, Buenos Aires, El Derecho.

Iñigo Carrera, Nicolás (2009); "La situación de la clase obrera en la Argentina del capital financiero", en Revista THEOMAI $\mathrm{N}^{\circ}$ 19, Primer Semestre, disponible en $\underline{\text { http://revista- }}$ theomai.unq.edu.ar/numero19/ArtCarrera.pdf, visitada el 29/03/2013.

Iñigo Carrera, Nicolás (2006); "La historia de los trabajadores", en Jorge Gelman (comp.), La historia económica argentina en la encrucijada. Balances y perspectivas, Buenos Aires, Prometeo, pp. 271-284.

Iñigo Carrera, Nicolás y Donaire, Ricardo (2003); “¿Qué interés se manifiesta en las centrales sindicales argentinas?", en PIMSA 2002, Doc. de Trabajo N 38, pp. 132 a 192.

Iñigo Carrera Nicolás y Jorge Podestá (1985); “Análisis de un relación de fuerzas sociales objetiva: caracterización de los grupos sociales fundamentales en la Argentina actual”, en CICSO, Doc. de Trabajo No 46.

James, Daniel (1990); Resistencia e Integración, Buenos Aires, Editorial Sudamericana.

Kabat, Marina (2009); "Los estudios sobre procesos de trabajo: ¿una respuesta al estancamiento de la historia de los trabajadores?", en Anuario $N^{o} 22$, Escuela de Historia, Revista Digital $N^{o} 1$, Facultad de Humanidades y Artes, UNR. En línea: http://web.rosario-conicet.gov.ar/ojs/index.php/Anuario/article/viewFile/50/74, visitada el 28/03/2013.

Kabat, Marina (2005); Del taller a la fábrica. Proceso de trabajo, industria y clase obrera en la rama del calzado (Buenos Aires 1870-1940), Ediciones RyR, Bs. As.

Kabat, Marina (2001); "Lo que vendrá. Una crítica a Braverman a propósito de Marx y la investigación empírica", en Razón y Revolución, $\mathrm{N}^{\mathrm{0}}$ 7, Buenos Aires.

Lobato, Mirta Zaida (2007); "Niveles y dimensiones de análisis en el mundo del trabajo: notas a partir de una experiencia de investigación", Anuario IEHS, N²2, pp. 401-422.

Lobato, Mirta y Juan Suriano (1996); "Historia del trabajo y de los trabajadores en la Argentina: aproximaciones a su historiografia”, en Panaia, Marta (Comp.); Trabajo y empleo un abordaje interdisciplinario, EUDEBA-PAITE, Bs. Aires.

Manzano, Virginia (2002); "Del ascenso social a la precarización. Un análisis sobre la producción de significados en torno al trabajo en el sector metalúrgico a fines de la década de 1990", en Cuadernos de Antropología Social $N^{o}$ 15, FFyL, pp. 71-90.

Manzano, Virginia (1996); "Reconversión productiva y lucha obrera en el interior de la fábrica: el caso de la industria metalúrgica”, en Razón y Revolución $\mathrm{N}^{\circ}$ 2, primavera.

Murillo, María Victoria (2008); Sindicalismo, coaliciones partidarias y reformas de mercado en América Latina, Buenos Aires, Siglo XXI.

Murillo, M. Victoria (2000); "Del populismo al neoliberalismo: Sindicatos y Reformas del Mercado en América Latina” en Desarrollo Económico, vol. 40, N 158.

Murillo, M. Victoria (1997); "La adaptación del sindicalismo argentino a las reformas del mercado en la primera presidencia de Menem” en Desarrollo Económico, vol. 37, №147.

Murillo, María Victoria (1996); "Los sindicatos frente a la reforma del Estado en Argentina y México" en Sociedad $\mathrm{N}^{\circ} 8,147-166$.

Neffa, Julio (coord.) (2008); La informalidad, la precariedad laboral y el empleo no registrado en la provincia de Buenos Aires, La Plata, Ministerio de Trabajo de la Provincia de Buenos Aires, CEIL Piette.

Neffa, Julio (1990); Proceso de trabajo y economía del tiempo. Ed. Hvmanitas. Bs. As. 
Palomino, Héctor (2005); "Los cambios en el mundo del trabajo y los dilemas sindicales", en Suriano, Juan (dir.) Dictadura y democracia (1976-2001), Buenos Aires, Sudamericana.

Pozzi, Pablo (1988); Oposición obrera a la dictadura. Buenos Aires, Contrapunto.

Ramírez Rojas, Manuel Álvaro y Diego AndrésGuevara Fletcher (2006); "Mercado de trabajo, subempleo, informalidad y precarización del empleo: los efectos de la globalización”, en Economía y Desarrollo, Vol. V., no. 1, pp., 96-131.

Santella, Agustín (2012); "Despotismo hegemónico y relaciones laborales en el sector automotriz argentino durante los años 90", en Trabajo y sociedad, $\mathrm{N}^{\circ} 19$.

Santella, Agustín (2006); “Trabajadores, peronismo y protesta en argentina. Una revisión desde 1970 al presente", en Revista Nuevo Topo, N², Abril-Mayo de 2006, pp. 30-50.

Schneider, Alejandro (2005); Los Compañeros: trabajadores, izquierda y peronismo en la Argentina, 19501973, Bs As, Imago Mundi.

Senén González, Santiago y Fabián Bosoer (1999); El sindicalismo en tiempos de Menem, Buenos Aires, Corregidor.

Sierra Álvarez, José (1990); El obrero soñado. Ensayo sobre el paternalismo industrial (Asturias, 18601917). Madrid, Siglo XXI.

Simonassi, Silvia (1996); "Productividad y disciplina en las fábricas metalúrgicas del Gran Rosario. Una mirada desde el periódico de la Asociación de Industriales Metalúrgicos de Rosario, 1974-1981", en Papeles de Trabajo, CESOR, UNR, Año 1, N 3, Rosario.

Suriano, Juan (2006);“Los dilemas actuales de la historia de los trabajadores”, en Jorge Gelman (comp.), La historia económica argentina en la encrucijada. Balances y perspectivas, Buenos Aires, Prometeo, pp. 285-306.

Svampa, Maristella (2007); "Profunda ruptura de lealtades. Los avatares del sindicalismo argentino", en Le Monde Diplomatique, Buenos Aires, enero.

Torre, Juan C. (1974); "La democracia sindical en la Argentina”, en Desarrollo Económico, Vol. 14, No. 55, (OctDic), pp. 531-543.

Walsh, Rodolfo (1994); ¿Quién mató a Rosendo?, Buenos Aires, Ediciones de la Flor.

\section{Política, economía y sociedad}

Asborno, Martín (1988), Grupos Económicos y Estado, Buenos Aires, CICSO.

Azpiazu, Daniel; Basualdo, Eduardo y Marín Schorr (2001); La industria argentina durante los años noventa: profundización y consolidación de los rasgos centrales de la dinámica sectorial post-sustitutiva, Buenos Aires, FLACSO.

Basualdo, Victoria (2006); “Complicidad patronal-militar en la última dictadura argentina. Los casos de Acindar, Astarsa, Dálmine Siderca, Ford, Ledesma y Mercedes Benz”, Engranajes, Buenos Aires, FETIA-CTA suplemento especial, marzo.

Basualdo, Eduardo (2006); "La reestructuración de la economía argentina durante las últimas décadas de la sustitución de importaciones a la valorización financiera", en Neoliberalismo y sectores dominantes. Tendencias globales y experiencias nacionales, pp. 123-177.

Basualdo, Eduardo (2003); "Las reformas estructurales y el Plan de Convertibilidad durante la década de los noventa. El auge y la crisis de la valorización financiera", en Realidad Económica, $\mathrm{N}^{\circ} 200$. En línea: http://www.iade.org.ar/modules/RealidadEconomica/

Basualdo, Eduardo (2000); Concentración y centralización del capital en la Argentina durante la década de los noventa: una aproximación a través de la reestructuración económica y el comportamiento de los grupos económicos y los capitales extranjeros, Buenos Aires, Universidad Nacional de Quilmes. 
Beccaria, Luis y Álvaro Orsatti (1989); "Precarización laboral y estructura productiva en la Argentina 1974-1988", en Marta Novick y otros (comps.), La precarización del empleo en la Argentina, CEAL/CLATCLACSO, Buenos Aires.

Beltrán, Gastón (2007); "La Acción Empresarial en el contexto de las reformas estructurales de las décadas de los ochenta y noventa en Argentina". Tesis de Doctorado en Ciencias Sociales, Universidad de Buenos Aires.

Bleichmar, Silvia (2006); No me hubiera gustado morir en los noventa, Bs. As., Taurus.

Boesner, Demetrio (1996); Relaciones internacionales de América Latina: breve historia, Caracas, Nueva Sociedad.

Bonnet, Alberto (2008); La hegemonía menemista: el neoconservadurismo en Argentina, 1989-2001, Buenos Aires, Prometeo.

Briner, María Agustina y Martín Schorr (2002); "Principales características e impactos de la extranjerización reciente de la economía argentina”, en Realidad Económica, № 189, Buenos Aires.

Calcagno, Alfredo y Eric Calcagno (2003); Argentina. Derrumbe neoliberal y proyecto nacional, Le Monde Diplomatique, Buenos Aires.

Castellani, Ana (2012); Recursos públicos e intereses privados. Ámbitos privilegiados de acumulación, Argentina 1966-2003, Buenos Aires, UNSAM EDITA.

Chudnovsky, Daniel y Andrés López (2001); La transnacionalización de la economía argentina, EUDEBA, Buenos Aires.

Fair, Hernán (2008); "La función del significante convertibilidad en la articulación discursiva de la identidad menemista”, en Question. Revista Especializada en Periodismo y Comunicación, Vol. 1, N 17, Facultad de Periodismo y Comunicación, UNLP. http://perio.unlp.edu.ar/ojs/index.php/question/article/viewArticle/508.

Gerchunoff, Pablo y Juan Carlos Torre (1996); "La política de liberalización económica en la administración Menem”, en Desarrollo Económico, vol. 36, N 143 (oct.-dic.), pp. 733 a 768.

Gervasoni, Carlos (2002); "Crisis política y crisis financiera en el Gobierno de la Alianza en la Argentina (1999-2001)", en Teresa Lozano Long Institute of Latin American Studies, The University of Texas at Austin, febrero.

Grigera, Juan (2011); "Desindustrialización, ¿agresión a la manufactura o reestructuración capitalista?”, en Bonnet, Alberto (ed.), El país invisible. Debates sobre la Argentina Reciente, Buenos Aires, Peña Lillo y Ediciones Continente, pp. 81 a 101.

Izaguirre, Inés y Aristizábal, Zulema (2000); “Las luchas obreras 1973-1976”.Avance de investigación, UBA/CONICET.

Jozami, Eduardo y Fabien Lefrancois (2004);Las empresas transnacionales en la Argentina, CENIT, Buenos Aires.

Kosacoff, Bernardo y Fernando Porta (1998); "La inversión extranjera directa en la industria manufacturera argentina. Tendencias y estrategias recientes". Doc. de Trabajo ํ77, CEPAL, Buenos Aires.

Martuccelli, Danilo y Svampa, Maristella (1997); La plaza vacía. Las transformaciones del peronismo, Buenos Aires, Editorial Losada S. A.

Matsushita, Hiroshi (1999); "Un análisis de las reformas obreras en la primera presidencia de Menem: la perspectiva de opción estratégica”, en Senén González, Santiago y Fabián Bosoer (1999); El sindicalismo en tiempos de Menem, Bs. As., Corregidor, pp. 165 a 193.

Navarro, Mario (1995); "Democracia y reformas estructurales: explicaciones de la tolerancia popular al ajuste económico", en Desarrollo Económico, vol. 35, № 139 (oct.-dic.), pp. 443 a 466.

Neffa, Julio (1998); Modos de Regulación, Regímenes de Acumulación y su crisis en Argentina (1880-1996). Una contribución a su estudio desde la Teoría de la Regulación, Buenos Aires, EUDEBA/PIETTE/Trabajo y Sociedad.

Novick, Marta et al (comps.) (1989); La precarización del empleo en la Argentina, CEAL/CLATCLACSO, Buenos Aires. 
Nun, José (1994); "Populismo, representación y menemismo", presentado en el First Viena Dialogue on Democracy, Depto. de Ciencia Política, Instituto de Altos Estudios.

Levitsky, Steven (2005); La transformación del justicialismo: del partido sindical al partido clientelista: 1933-1999, Siglo XXI, Buenos Aires.

Lindenboim, Javier (2004); "The Precariousness of Argentine Labor Relations in the 1990s", en Latin American Perspectives, v. 31, No4, pp. 21 a 31.

Llach, Juan (1997); Otro siglo, otra Argentina, Buenos Aires, Ariel.

Löbbe, Héctor (2009); La guerrilla fabril: clase obrera e izquierda en la Coordinadora de Zona Norte del Gran Buenos Aires: 1975-1976, Bs. As., CEICS-RyR.

Ostiguy, Pierre (1997); "Peronismo y antiperonismo: bases socioculturales de la identidad peronista en la Argentina", Bernal, Revista de Ciencias Sociales, № 6, UNQui.

O’Donnell, Guillermo (1977); “Estado y alianzas en la Argentina, 1956 - 1976”, en Desarrollo económico, № 16 (64), pp. 523 a 554.

Palermo, Vicente (1999); “¿Mejorar para empeorar? La dinámica política de las reformas estructurales argentinas”, en Torre, J.; Palermo, V. e I. Cherensky, Entre el Abismo y la Ilusión. Peronismo, democracia y Mercado, Buenos Aires, Grupo Editorial Norma.

Panigo, D. y E. Torija Zane (2004); "Una revisión de las crisis económicas argentinas desde la Teoría de la Regulación”, en Boyer, Robert y Julio Neffa, La economía argentina y su crisis (1976-2001): visiones institucionalistas y regulacionistas, Buenos Aires, Miño y Dávila editores/CEIL-PIETTE.

Peralta Ramos, Mónica (2006); La economía política argentina: poder y clases sociales (1930-2006), Buenos Aires, Fondo de Cultura Económica.

Portantiero, Juan Carlos (1973); "Economía y política en la crisis argentina (1958-1973)”, en Revista Mexicana de Sociología, N², México.

Restivo, Néstor y Raul Dellatorre (2005); El rodrigazo 30 años después. Un ajuste que cambió al país,Bs. As., Capital Intelectual.

Salvia, Agustín y Silvana Tissera (2000); "Heterogeneidad y precarización en los hogares asalariados en Argentina durante la década del 90", en Lindemboim, J. (comp.), Crisis y metamorfosis del Mercado de Trabajo, Parte I.

Sidicaro, Ricardo (2002); Los tres peronismos. Estado y poder económico 1946-1955/1973-1976/19891999, Buenos Aires, Siglo XXI.

Svampa, Maristella editora (2000); Desde abajo. La transformación de las identidades sociales, Bs. As., Biblos, $2^{\text {da }}$ edición.

Torre, Juan Carlos (1989); Los sindicatos en el gobierno1973-1975, Bs. As., CEAL.

Torre, Juan Carlos (2009); "Política y violencia en el movimiento obrero: a propósito de "la idea de la burocracia sindical' y sus efectos", en Schmucler, Héctor (comp.); Política, violencia, memoria. Génesis y circulación de las ideas en la Argentina de los años sesenta y setenta, La Plata, Ed. Al Margen, pp. 15-16.

Torre, Juan Carlos et. Al(1999); Entre el abismo y la ilusión: peronismo, democracia y mercado, Bs. As., Grupo Editorial Norma.

Viguera, Anibal (2000); La trama política de la apertura económica en la Argentina (1987-1996), FLACSO, México.

Vilas, Carlos (1974); La dominación imperialista en Argentina, Eudeba, Buenos Aires.

\section{Metodología, Teoría social e Historiografía}

Balbi, Fernando (2008); De leales, desleales y traidores. Valor moral y concepción de política en el peronismo. Buenos Aires, Antropofagia.

Bourdieu, Pierre (2007); Razones prácticas, Barcelona, Anagrama. 
Castel, Robert (1997); La metamorfosis de la cuestión social. Una crónica del salariado, Barcelona, Paidós.

Cooke, John W. (1964); “Apuntes para la militancia”, en línea: www.elortiba.org.

Durkheim, Emile (2008); De la división del Trabajo Social, Gorla, Bs. As. [1893].

Elley, Geoff y Keith Nield (2010); El futuro de la clase en la historia ¿Qué queda de lo social?, Valencia, PUV.

González, Horacio (2001); "Prólogo", en Carri, Roberto, Isidro Velazquez, formas prerevolucionarias de la violencia, Buenos Aires, Colihue.

Hardin, Garret (1956); "La tragedia de los comunes", en línea: http://www.uam.es/personal_pdi/ciencias/jonate/Eco_Rec/Intro/La tragedia_de_los_comunes.pdf, $02 / 12 / 2013$.

Foucault, Michel (1980); "Nietzsche, la genealogía, la historia”, en Microfísica del Poder, España, Las ediciones de la piqueta, pp. 7 a 29.

Franco, Marina y Florencia Levíncomp. (2007); Historia Reciente. Perspectivas y desafios para un campo en construcción, Buenos Aires, Paídos.

Gramsci, Antonio (1998); Antología, Siglo XXI, México.

Hyman, Richard (1978); El marxismo y la sociología del sindicalismo, México, Ed. Era.

Izaguirre, María Inés (1994a); Los desaparecidos: recuperación de una identidad expropiada. Buenos Aires, CEAL.

Izaguirre, María Inés (1994b); "Problemas metodológicos y construcción de observables en una investigación sobre luchas obreras", en La Clase Obrera De Alfonsín A Menem, compilado por Daniel Campione, Buenos Aires, CEAL.

Marin, Juan Carlos (1981); "La noción de polaridad en los procesos de formación y realización de poder", en cuadernos de CICSO.

Marx, Carlos (2003); El capital, Buenos Aires, Siglo XXI.

Marx, Carlos y Federico Engels (1988); Correspondencia; La Habana, Editora Política.

Offe, Claus y H. Wiesenthal (1980); "Dos lógicas de la acción colectiva”, en Cuadernos de Sociología n $n^{\circ}$, Carrera de Sociología, Universidad de Buenos Aires.

Perez Ledesma, Manuel (1994); "Cuando lleguen los días de cólera (movimientos sociales, teoría e historia)", en Zona Abierta, $\mathrm{N}^{\circ} 69$.

Rosanvallon, Pierre (1995); La nueva cuestión social: repensar el Estado providencia, Buenos Aires, Manantial.

Rudé, George (1981); Revuelta popular y conciencia de clase, España, Editorial Crítica.

Samaja, Juan (1996); El lado oscuro de la razón, Argentina, J.V.E Episteme.

Scott, Joan (1990); “El género: Una categoría útil para el análisis histórico”, en James y Amelang y Mary Nash (eds.), Historia y género: las mujeres en la Europa moderna y contemporánea, Alfons el Magnanim, Institució Valencina d Estudis i Investigació.

Tarrow, Sydney (1997); El poder en movimiento. Los movimientos sociales, la acción colectiva y la política, Madrid, Alianza Editorial.

Tilly, Charles (1986); The Contentious French, Harvard University Press, Cambridge.

Wacquant, Loic (2007); Los condenados de la ciudad. Guetos, perisferia y Estado, Argentina, Siglo XXI.

Weber, Max (1985); “¿Qué es la burocracia?”, Argentina, Siglo XX.

Womack, John (2007); Posición Estratégica y Fuerza obrera. Hacia una nueva historia de los movimientos obreros, Fondo de Cultura Económica, México, 2007.

\section{Artículos en revistas, diarios y portales de Internet}

Bonasso, Miguel (1999);“La década infame”, en Página 12. http://www.pagina12.com.ar/1999/99-07/99-0708/pag21.htm, visitada el 24/04/2013. 
Canelo, Paula (2010); “El marino que quería ser como Perón”, en Tiempo Argentino, 1 de Agosto, en línea: http://tiempo.infonews.com/notas/marino-que-queria-ser-como-peron.

Dadón, José (2003); “Argentina de espaldas al mar”, en Le Monde Diplomatique, El diplo, noviembre. En línea: http://www.ecologíamarina.com.ar/down/diplo.pdf

Garrone, Roberto (2009); "Causa Argenbel y Estrella de Mar: 23 años de injusticia”, en Revista Puerto, la otra cara de la pesca. En línea: revistapuerto.com.ar/RP_Nota_Imprimir.php?id=392, visitada el 04/12/2013.

Leyva Ramos, Miguel (2001); "Fileteros marplatenses", en Revista Puerto, la otra cara de la Pesca, 우 17, noviembre, p. 4 a 10.

Maturana, Roberto (S/fechar); "Cronología de la historia pesquera nacional y la responsabilidad de Felipe Solá", documento en línea en http://www.malvinense.com.ar/argentina_para_los_argentinos/pesca/cronologia_sola.htm, visitada el día $02 / 01 / 2012$.

Muleiro, Vicente (2000); "Saqueo en Alta Mar", Diario Clarín, 9 de abril.

Nahum, Guillermo (2003 ); "Fraude Laboral”, en revista Puerto, la otra cara de la pesca $\mathrm{N}^{\circ} 24$, Mayo, pp. 4 a 10.

Nahum, Guillermo (2003 ); ““Cooperativas Marplatenses”, en revista Puerto, la otra cara de la pesca $\mathrm{N}^{\circ}$ 25 , pp. 20 a 23.

Solari Yrigoyen, Hipólito (1994); “Acuerdo de Pesca. Discurso en la sesión del 22 de diciembre de 1993”, Buenos Aires, Archivo INIDEP, Mar del Plata.

Trotsky, León (1940); "Los sindicatos en la época del imperialismo", México, en línea: www.bolchevikes.com.ar

\section{Biografías y autobiografías}

Cerruti, Gabriela (1993); El jefe. Vida y obra de Carlos Saúl Menem, Bs. As., Planeta.

Corach, Carlos (2011); 18.885 días de política: visiones irreverentes de un país complicado, Buenos Aires, Sudamericana.

Santoro, Daniel (1994); El Hacedor. Una biografia política de Domingo Cavallo, Argentina, Planeta. 


\section{Fuentes}

\section{Repositorios documentales visitados}

Archivo de prensa Diario La Capital, Av. Marcelino Champagnat 2551, Mar del Plata Archivo de prensa del SOIP, 12 de Octubre 4445, Mar del Plata.

Archivo de prensa de la CAABPA, Av. Leandro Alem 650, Mar del Plata.

Archivo Municipal Roberto Barilli, Lamadrid 3870, Mar del Plata.

Archivo de la Comisión Provincial por la Memoria (ex DIPPBA), Calle $9 \mathrm{~N}^{\circ}$ 984, La Plata.

Tribunal del Trabajo N¹, Garay 1768, Mar del Plata, Provincia de Buenos Aires.

Biblioteca y Servicio de Documentación del Instituto Nacional de Investigación y Desarrollo Pesquero, Paseo Victoria Ocampo $\mathrm{N}^{\circ} 1$, Escollera Norte, Mar del Plata.

Museo del Hombre del Puerto, Padre Dutto 369, Mar del Plata.

Ministerio de Agricultura, Ganadería y Pesca de la Nación, Av. Paseo Colón 982, CABA.

Archivo del Consejo Federal Pesquero, Humberto Primo 133 5to Piso, CABA.

Archivo digital de Noticias de la industria pesquera marplatense Pescare.com.ar.

\section{Diarios}

Diario La Capital, Mar del Plata. Varios números entre enero de 1988 y marzo de 2002. Y diarios específicos de conflictos y temas pesqueros entre los años 1969 a 1987.

Diario El Atlántico, Mar del Plata. Varios números entre enero de 1988 y marzo de 2002

Diario El Clarín, Buenos Aires. Varios números.

Diario La Nación, Buenos Aires. Varios números.

Diario Ámbito Financiero, Buenos Aires, varios números.

Diario Hoy, La Plata, varios números.

Diario El Día, La Plata, varios números.

\section{Legislación}

Leyes

- Ley $N^{\circ} 17.500 / 67$

- Ley $N^{\circ} 20.136 / 73$

- Ley $N^{\circ} 20.094 / 73$

- Ley $N^{\circ} 20.337 / 73$

- Ley No 21.608/77

- Ley No 21.514/1976

- Ley No 21.382/1976

- Ley $N^{\circ} 21.673 / 77$

- Ley $N^{\circ} 22.260 / 80$

- Ley No 23.018/83

- Ley No 24.093/92

- Ley No 24.093/92

- Ley No 24.315/94

- Ley No 24.490/95 
- Ley $\mathrm{N}^{\circ} 25.877 / 97$

- Ley $\mathrm{N}^{\circ} 24.922 / 97$

- Ley $\mathrm{N}^{\circ} 25.109 / 99$

- Ley $\mathrm{N}^{\circ} 26.386 / 08$

\section{Decretos}

- Decreto $N^{\circ} 22.763 / 46$

- Decreto $N^{\circ} 440 / 71$

- Decreto $N^{\circ} 520 / 76$

- Decreto $\mathrm{N}^{\circ} 1533 / 82$

- Decreto $N^{\circ} 945 / 86$

- Decreto $N^{\circ} 1555 / 86$

- Decreto $N^{\circ} 20.489 / 91$

- Decreto No 817/92

- Decreto $N^{\circ} 2000 / 92$

- Decreto $N^{\circ} 2265 / 92$

- Decreto $N^{\circ} 1493 / 92$

- Decreto $N^{\circ} 2609 / 93$

\section{Resoluciones de la SAGPyA}

- Resolución $N^{\circ} 221 / 83$

- Resolución N 396/86

- Resolución N 946/88

\section{Audiencias públicas y sesiones del Honorable Concejo Deliberante, Mar del Plata}

- Audiencia pública día 29/08/1996

- Audiencia pública día 14/07/1997

- Audiencia pública día 10/9/98

- Audiencia pública día 04/5/99

- Audiencia pública día 26/8/99

- Audiencia pública día 23/02/2000

\section{Otras fuentes oficiales}

- "Convenio Colectivo de Trabajo para las ramas Conserva, Harina y Filet", 1975.

- "Informe Proceso de Trabajo - Industria del Pescado", Ministerio de Trabajo y Seguridad Social y P.I.A.C.C.T - O.I.T., 1986.

- "Acuerdo sobre las relaciones en materia de pesca Marítima entre la Argentina y la CEE", 1994.

- "Cooperativas sancionadas", Ministerio de Trabajo de la Nación, 2004.

\section{Revistas consultadas}

- Revista Puerto, la otra cara de la pesca. Varios números entre los años 1999 y 2009

- Revista Redes de la Industria Pesquera. Varios números entre los años 1988 y 2002

- Revista Tratados N 41, año X, Fundación Atlántica, 1994. 
- Revista Mercado N 956, julio de 1997.

- Revista Pesca y Puertos. Varios números.

- Semanario Noticias y protagonistas del día 2/07/2000.

\section{Fuentes audiovisuales}

- Imágenes televisivas en crudo, Canal 10 de Mar del Plata, varios días.

- Trabajadores del Pescado y Proyecto Audiovisual Comunitario Trabajo (2007), "Sin horario", Cortometraje, 28 minutos, idioma Español.

\section{Fuentes sindicales}

- "S/nombre", Lista Celeste, Comunicado, 02/07/1990.

- "Proyecto de la agrupación de la Lista Celeste a aplicarse en caso de llegar a la dirección del Sindicato", UOP-Lista Celeste, 1990.

- "Compañeros del S.O.I.P - Lista Celeste", Lista Celeste, Volante, S/fechar.

- "Por la Justicia Social", UOP-Lista Celeste, marzo 1990.

- "Convocatoria a Asamblea", AAVV, Volante, diciembre de 1997.

- "No hay que aflojar!!", Trabajadores del Pescado, volante, 4/1/98.

- "El que lucha decididamente... gana", UOP, Boletín, 1998.

- "S/nombrar", Lista Celeste, Boletín, febrero de 1998.

- “iAtenti, compañeros!”, Lista Celeste, volante, S/fechar.

- "Propuesta al encuentro nacional en defensa del recurso pesquero y su gente", CGT regional Mar del Plata, Documento, octubre de 1998.

- "Alerta compañeros: preparan una trampa contra la huelga", Partido Obrero, Regional Mar del Plata, Volante, 11/1/98.

- "Los trabajadores no somos convidado de piedra", Partido Obrero, Regional Mar del Plata, Volante, 1/6/99.

- "Viva la huelga general portuaria", Partido Obrero, Regional Mar del Plata, Volante, 3/1/98.

\section{Fuentes empresarias}

- Breve Síntesis informativa de la industria pesquera argentina, Informe, CAPECA, 1997.

- Boletín Informativo $N^{\circ}$ 9, CAPECA.

- Boletín Informativo $N^{\circ} 13$, CAPECA.

- Boletín Informativo $\mathrm{N}^{\circ} 16$, CAPECA.

- "Reflexiones sobre la grave situación de la pesca en la Argentina y su Desarrollo futuro", Informe, abril de 1999, CAPECA.

- "Análisis de la situación actual y propuestas para el futuro de la industria pesquera argentina", Informe, CAPECA, junio de 1996.

- "Reembolsos por puertos patagónicos", Informe, CAPECA, junio de 1996.

- "Comentarios y definiciones respecto del uso de buques congeladores en el mar argentino", Informe, CEPA, 1998.

- "S/título", Informe, CEPA, julio de 2000.

- "Situación de la Política pesquera", Informe, CEPA, febrero de 2001.

- "Análisis de situación y propuestas para el relanzamiento de la actividad pesquera", Informe, CEPA, noviembre de 1999. 
1999

- "Bases para un proyecto nacional pesquero y aspectos coyunturales", Informe, CEPA, mayo de

- "Proyecto de ley de emergencia y salvataje pesquero", Informe, CEPA, s/f.

- "Internacionalización de nuestro caladero", Informe, CEPA, abril de 1998.

\section{Fuentes de Organismos No Gubernamentales}

- "La situación de la pesca es demasiado grave", CEDEPESCA, Volante, 1999.

- "Identificación del perfil de la población objetivo vinculada a la captura y procesamiento de la merluza hubbsi”, Consultora de Investigación Social Independiente, Buenos Aires, 1999.

- "Proyecto Pesquero 2000”, Multisectorial en Defensa de la Pesca Argentina, Mar del Plata, 1999.

- "Informe de CasoUnión Fenosa en América Latina”, TPTEALT, Lima, 2008.

\section{Fuentes censales}

- "Relevamiento sobre la mano de obra ocupada. Sector pesquero de Mar del Plata", Fundación Atlántica-INIDEP, 1989-1990.

- "Censo de mano de obra ocupada y capacidad industrial instalada. Partido de General Pueyrredón”, Milciadez Espoz Espoz y otros, CITEP-INTI, Fundación Atlántica, 1996.

\section{Entrevistas realizadas por el autor}

- Elda Taborda, filetera, militante del Partido Comunista, Mar del Plata, 11/02/2011.

- Luis Verón, militante de la UOP y futuro asesor del SOIP, Mar del Plata, 12/08/2006.

- Darío Sócrate, gerente de la CAABPA y ex secretario de producción de la Comuna, Mar del Plata, $03 / 7 / 07$.

- Oscar Fortunato, gerente de CEPA y ex funcionario provincial y nacional del área pesquera, Mar del Plata, 23/04/2013.

- Ricardo el "Polaco" Muñoz, ex filetero y militante, Primera entrevista, Mar del Plata, abril 2009. Segunda entrevista, Mar del Plata, 05/06/2013.

- Carlos Darguibel, ex secretario general del SOIP, Mar del Plata, 18/02/12.

- Walter Flores, Técnico en Industria y Alimentación en orientación pesquera y capataz de la firma Di Constanzo, Mar del Plata, 07/06/2013.

- Gabriela, envasadora, Mar del Plata, 06/06/2013.

- Norma Mira, colaboradora de Abdul Saravia en el SOIP y militante del PJ, Mar del Plata, $06 / 12 / 2012$.

- "Cachito" Rodríguez, amigo y colaborador de Abdul Saravia, Mar del Plata, 06/02/2012.

- Amalia, filetera de cooperativa, Mar del Plata, marzo 2010.

- Ana, filetera de cooperativa, Mar del Plata, marzo 2010.

- Mariano, filetero y delegado de la empresa Centauro, Mar del Plata, abril 2011.

- "El negro", filetero en plantas clandestinas y cooperativas, Mar del Plata, marzo 2010.

- Alberto "Beto" Rosa, filetero y ex militante de la JTP, Mar del Plata, 02/02/2010.

- Daniel Di Bártolo, ex secretario de Prensa de la CGT local, Mar del Plata, 11/05/2012.

- Pablo Trueba, secretario adjunto del SIMAPE, Mar del Plata, 31/01/2011. 


\section{Entrevistas realizadas por terceros}

- Ana Mazzela, filetera, 60 años. Realizada por David Santos. Mar del Plata, 2009.

- Natividor Sosa, filetero, 59 años. Realizada por David Santos. Mar del Plata, 2009.

- Julio Lela (padre), filetero, 64 años. Realizada por David Santos. Mar del Plata, 2009.

- Julio Lela (hijo), filetero, 32 años. Realizada por David Santos. Mar del Plata, 2009.

- Mirta Canosa, envasadora y filetera, 53 años. Realizada por David Santos. Mar del Plata, 2009.

- Filetera. Realizada por Cristián Tibaldi. Mar del Plata, 2009.

- Sonia, envasadora, filetera y operaria de control de calidad. Realizada por María Schulze. Mar del Plata, 2009.

- Beatriz, filetera, 57 años. Realizada por Guillermina Laitano. Mar del Plata, 2009.

\section{Sentencias del Tribunal del Trabajo $\mathrm{N}^{\circ}$ 1, Mar del Plata, Provincia de Buenos Aires}

- "CAMPS ELVIRA RENEE contra DISPEZ S.R.L y Otro sobre cobro de haberes e indemnizaciones", Expediente $\mathrm{N}^{\circ} 33040,1993$.

- “GARCÍA Daniel Oreste c/ J.C.B. PRODUAR”, Expediente N 36.621, 1993.

- "ANDINO JOSE LUIS contra RODRIGUEZ OTTO ASMAN sobre Indemnización por despido", Expediente $\mathrm{N}^{\circ} 34921,1993$.

- "BAIZ GLORIA BLANCA contra PESQUERA DON ROMEO S.A. sobre Haberes e indemnizaciones", Expediente $\mathrm{N}^{\circ} 33607,1993$.

- "DIAZ CARMEN BEATRIZ contra TOMAR S.A. sobre Haberes y accidente de trabajo", Expediente $\mathrm{N}^{\circ} 34795,1993$.

- "TABOADA HÉCTOR EDUARDO contra TOMAR S.A. sobre Indemnización por incapacidad parcial y permanente", Expediente $\mathrm{N}^{\circ} 33402,1993$.

- "CHAVEZ ANGEL ADALBERTO contra RUA ANGEL ADOLFO sobre indemnización por despido", Expediente N 33446, 1993.

\section{Páginas web consultadas}

Organismos oficiales

http://infoleg.mecon.gov.ar

http://www.minagri.gob.ar

http://www.trabajo.gba.gov.ar

http://www.centronaval.org.ar

Organismos de investigación, no gubernamentales y universitarios

http://www.cfp.gob.ar

http://elistas.egrupos.net

http://www.cedepesca.org

http://www.uca.edu.ar

http://perio.unlp.edu.ar

http://www.uam.es

Medios gráficos, portales y revistas 
http://www.periodicotribuna.com.ar

http://www.lanacion.com.ar

http://www.iisg.nl/labouragain

http://www.iigg.fsoc.uba.ar

http://www.pescare.com.ar

http://www2.inecc.gob.mx

http://ffyl.uncu.edu.ar

http://historiapolitica.com

http://www.cátedras.fsoc.uba.ar

http://www.serviciosesenciales.com.ar

http://www.pimsa.secyt.gov.ar

http://revista-theomai.unq.edu.ar

http://web.rosario-conicet.gov.ar

http://www.pagina12.com.ar

http://www.bolchevikes.com.ar

http://tiempo.infonews.com

http://www.elortiba.org

http://www.iade.org.ar/modules/RealidadEconomica/

Páginas de empresas

www.solimenosa.com.ar

www.moscuzza.com

www.valastro.com.ar

www.barillari.com.ar

http://portalcoop.com.ar 